

\author{
Dirección Editorial: \\ Consejo de Redacción:
}

Editora Invitada

Secretaria de Edición:

Maquetación:

Traducción portugués:

Imagen portada:
Emma García Alonso

Ana Bailao, Rocío Bruquetas Galán, Emilio Cano Díaz, Ana Carrassón, Rafael Fort González, Silvia García Fernández-Villa, Marisa Gómez González, Ana Laborde Marqueze, Alfonso Muñoz Cosme

Elena García Gayo

Ma Concepción de Frutos Sanz

Ma Concepción de Frutos Sanz

Ana Bailao

Figura de Jesé en el rosetón del crucero norte de la Catedral de Cuenca. Giralte de Holanda, 1550. Autor imagen: Fernando Cortes Pizano

\section{ISSN: 1989-8568}

Esta publicación utiliza una licencia Reconocimiento-NoComercial-SinObraDerivada 3.0 Creative Commons Se permite compartir, copiar, distribuir y comunicar públicamente la obra con el reconocimiento expreso de su autoría y procedencia. No se permite un uso comercial de la obra original ni la generación de obras derivadas.

Esta revista utiliza Open Journal Systems, software libre de gestión y publicación de revistas desarrollando, soportado y libremente distribuido por el Public Knowledge Project bajo Licencia Pública General GNU.

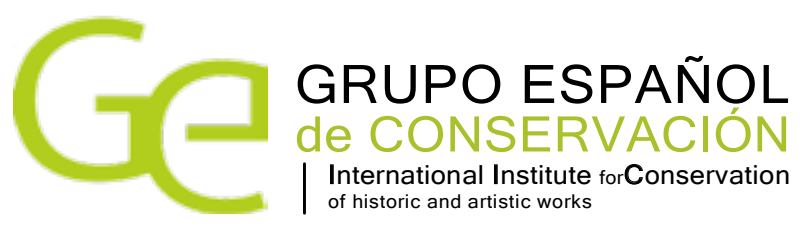

GE-conservación no se responsabiliza de la información contenida en los artículos ni se identifica necesariamente con ellas.

(c) La propiedad intelectual de los artículos pertenece a los autores, y los derechos de edición y publicación de este número son de Ge-conservación. Rogamos que en la difusión libre de los contenidos queden patentes los créditos de los autores y la procedencia.

El Grupo Español de Conservación es una asociación independiente afiliada a The International Institute for Conservation of Histtoric and Artistic Works, inscrita en el Registro Nacional de Asociaciones, Sección 1a, № 160.299. Sede: I.P.C.E. C/Greco, 428040 Madrid. Asociación Declarada de Utilidad Pública por Orden del Ministerio del Interior 3404/2009 (BOE 18-12-2009).

\section{Ge-conservación conservaçāol Conservation}

www. revista ge iic com

E-mail: revista@ge-iic.org www.ge-iic com

E-mail:administracion@ge-iic.org

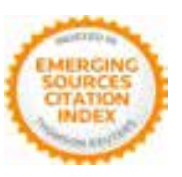




\section{Índice}

\section{Artículos}

Páginas

Revisión de la obra de Antonio Bisquert en la ciudad de Teruel a través de su análisis radiográfico y caracterización de materiales mediante SEM/EDX

Belén Díez Atienza, José Antonio Madrid García, Dolores Julia Yusá Marco

A Urna do Santíssimo - Metodologia analítica: "do mais subido e gemado" - artifícios para o douramento da talha

Maria da luz Nolasco Cardoso, Manuel A. Martins

Evaluación microbiológica de aire interior en tres Museos de la zona UNESCO $N^{\circ} 658$ Coro, Venezuela Patrimonio Mundial de la Humanidad

Yarubit Rojas, Francisco Yegres, José Araujo

Estudio de las pinturas murales de la sala del Mosaico de los Amores de la ciudad íbero-romana de Cástulo Irene Calabria Salvador, María Antonia Zalbidea Muñoz

Reflexiones sobre la necesidad de crear estudios superiores en conservación y restauración de vidrieras en España

Fernando Cortés Pizano

Análisis y comparación de las categorías e inventarios de la Ley de Patrimonio Histórico Español y las leyes de Patrimonio Cultural autonómicas del País Vasco y Canarias en el marco de la Convención de Granada Luis Miguel Sanz Rodriguez, Antonio Eduardo Humero Martín, Fernando Casqueiro Barreiro

Propuesta de plan de conservación preventiva para proyectos de muralismo urbano. El caso de Vigo, ciudad de color

Andrea Fernández Arcos

Aportación de nuevas metodologías multitécnica en el estudio y conservación de patrimonio numismático de procedencia subacuática

Carla Álvarez Romero, Antonio Doménech Carbó, Milagros Buendía Ortuño, Trinidad Pasíes Oviedo, María Teresa Doménech Carbó

La Pintura del techo del Teatro Vicó de Jumilla (Murcia). Estudio histórico y material

Sonia Santos Gómez, Margarita San Andrés Moya, Ruth Chércoles

\section{Suplemento: Arte urbano y museo. Competencias e (in)compatibilidades}

\section{Presentación}

Elena García Gayo (Coord.)

Prólogo

Susana Blas Brunel

Galerías, casas de subasta y Urban Art: evolución y paralelismos en las prácticas de arte independiente Rita Amor García. 
Arte urbano expuesto: procedencia y contenido

Elena Calderón Aláez

"Viral Mural", entre el muralismo y los espacios virtuales.

Carla Coluccio

El "espacio intermedio" del arte urbano

Elena García Gayo

Berlín: todo un paradigma en el pasado, presente y futuro del arte urbano

Sandra Gracia Melero

Identidad e imagen de la ciudad contemporánea: los museos de arte urbano

Laura Luque

(Des)localizaciones y contexto. La transición del arte urbano, desde la calle hasta su exhibición en centros de arte

Esteban Marín

La postura del artista ante los museos de arte urbano en el contexto latinoamericano

Ana Lizeth Mata Delgado

Arte público, ciencia y patrimonio en el entorno rural: el caso de Murales Conciencia

Diego Ortega, Juan Jesús Padilla

Museizar el arte urbano. Preguntas, relatos y complejos tras Street Art-Banksy \& Co

Jordi Pallarès

Repensando el arte público. New York City's Percent For Art Program

Sergio Pardo

Arte Urbano en colecciones públicas y privadas: intervenciones de artistas urbanos en el fondo de arte de la Universitat Politècnica de València

Mercedes Sánchez Pons

Museos de Arte Urbano. Estado de la cuestión

Rosa Senserrich-Espuñes, Elena García Gayo

Anexo: Entrevistas

Elena García Gayo, Sandra Gracia Melero, Rosa Senserrich-Espuñes, Carlota Santabárbara Morera, Jordi

Pallarès, Rosa M. Gasol

\section{Reseñas}

Modern Metals in Cultural Heritage: Understanding and Characterization

Ana Crespo Ibañez

Trading Paintings and Painters' Materials 1550 - 1800

Rocío Bruquetas Galán 
Artículos 


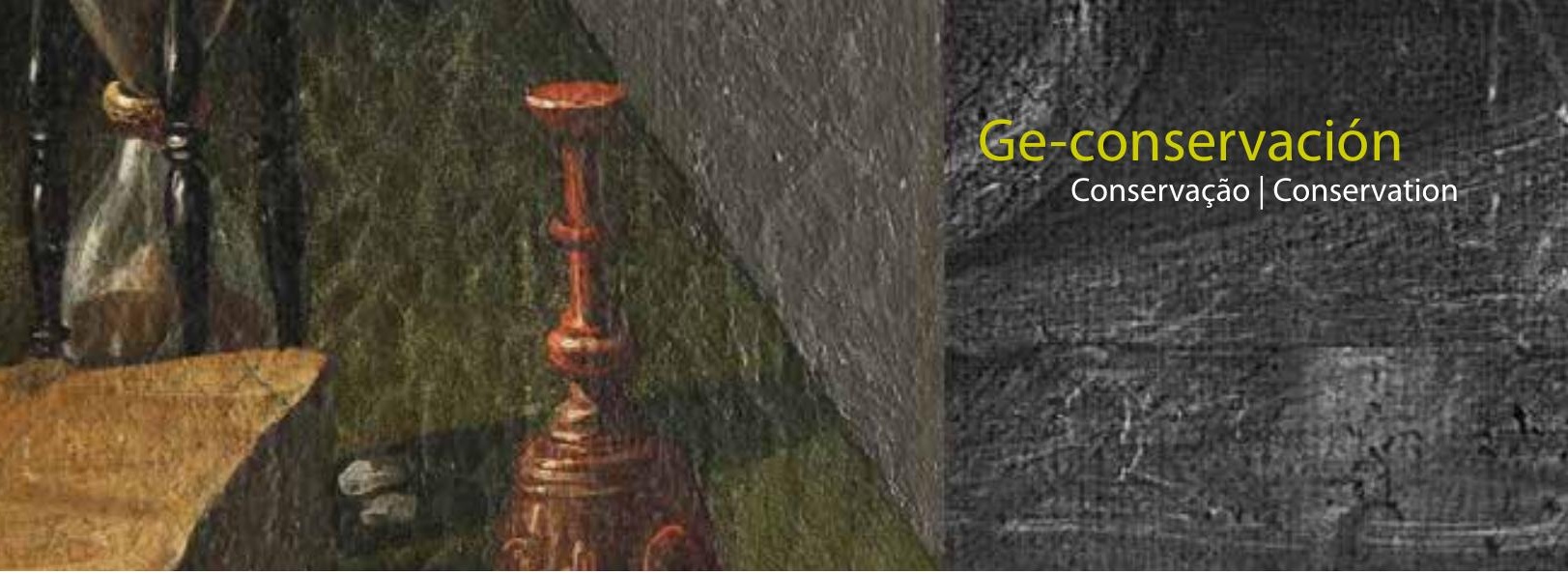

\title{
Revisión de la obra de Antonio Bisquert en la ciudad de Teruel a través de su análisis radiográfico y caracterización de materiales mediante SEM/EDX
}

\author{
Belén Díez Atienza, José Antonio Madrid García, Dolores Julia Yusá Marco
}

\begin{abstract}
Resumen: El presente trabajo de investigación, con un claro carácter interdisciplinar, se focaliza en un estudio donde se han combinado datos históricoartísticos junto a una extensa documentación radiográfica, más un amplio estudio estratigráfico y químico mediante Microscopía óptica y Microscopía electrónica de barrido. Todo ello sobre un conjunto de ocho lienzos de la producción artística del pintor Antonio Bisquert en la ciudad de Teruel.

Las obras analizadas en este artículo se encuentran localizadas tanto en el Museo de Arte Sacro de Teruel, como en diferentes iglesias de esa misma localidad. Tanto los resultados obtenidos de las imágenes radiográficas como los que ofrecen las pruebas analíticas conforman un compendio inédito de lo que se refleja en todo el proceso creativo y su génesis, revelando atribuciones contrastadas y el empleo de posteriores retoques considerados como no originales, que fueron ejecutados por una misma mano en una misma época. Todos estos datos generan un gran interés para el reconocimiento y puesta en valor de la obra de este olvidado pintor.
\end{abstract}

Palabras clave: Antonio Bisquert, Teruel, Museo de Arte Sacro, análisis radiográfico, SEM/EDX

\section{Review of the work of Antonio Bisquert carried out in the city of Teruel through radiographic analysis and characterization of materials by SEM / EDX}

Abstract: The present research work, with an interdisciplinary character, focuses on a study where historical-artistic data were combined with extensive radiographic documentation and extensive stratigraphic and chemical studies using optical microscopy and scanning electron microscopy. All this on a set of eight canvases of the artistic work’s Antonio Bisquert in the city of Teruel.

These works are located in the Museum of Sacred Art of Teruel and in different churches of this area. The results show a compendium of radiographic unpublished images, which reflects the entire creative process and the genesis of the works, revealing contrasted attributions and the use of subsequent retouchings considered not original, which were executed by the same hand at the same time. All these data generate a great interest for the recognition and the development of forgotten the artist's output.

Keyword: Antonio Bisquert, Teruel, Museum of Sacred Art, radiographic analyses, SEM/EDX

\section{Revisão do trabalho de Antonio Bisquert realizado na cidade de Teruel através de analise radiográfico e caracterização de materiais por SEM/EDX}

Resumo: O presente trabalho de pesquisa, com claro caráter interdisciplinar, enfoca um estudo em que dados histórico-artísticos foram combinados com extensa documentação radiográfica, além de um amplo estudo estratigráfico e químico utilizando microscopia ótica e microscopia eletrônica de varredura. Tudo isso num conjunto de oito telas da produção artística do pintor Antonio Bisquert na cidade de Teruel.

Obras que estão localizadas tanto no Museu de Arte Sacra de Teruel, como em diferentes igrejas da mesma cidade. Tanto os resultados obtidos a partir das imagens radiográficas quanto os oferecidos pelos testes analíticos formam um compêndio sem precedentes do que se reflete em todo o processo criativo e sua gênese, revelando atribuições contrastadas e o uso de retoques subsequentes considerados não originais, que foram executados pela mesma mão ao mesmo tempo. Todos esses dados geram um grande interesse pelo reconhecimento e valorização do trabalho desse pintor esquecido.

Palavras-chave: Antonio Bisquet, Teruel, Museo de Arte Sacro, análise radiográfico, SEM/EDX 


\section{Introducción}

Antonio Bisquert (Valencia, 1590-1596 / Teruel, 1646) fue un pintor muy significativo del barroco inscrito en la escuela valenciana, que desarrolló la mayor gran parte de su producción artística en la provincia de Teruel. A través del transcurso de esta investigación una de las primeras cosas con las que nos hemos encontrado es que se ha podido constatar que hasta la fecha no se ha llevado a cabo ningún trabajo riguroso y en profundidad sobre los aspectos más técnicos de su obra. Dato que sorprende, pues nos encontramos con el único pintor barroco que se encuentra representado en las tres provincias aragonesas y, dada su formación, también en el círculo valenciano. Como ya apuntan los autores Buil y Lozano, Bisquert es baluarte de la introducción de las maneras ribaltescas por toda esta región (Buil y Lozano 1995).

Además, a nivel técnico este estudio se presenta como una ocasión única, puesto que se aborda desde una perspectiva multidisciplinar un número muy significativo de obras producidas por la misma mano (Santa Úrsula y las once mil vírgenes con santa Rosa y santa Teresa, Santa Teresa escritora, San Joaquín con la virgen niña, El buen Pastor, San Juan Bautista, San Pantaleón médico, Inmaculada Concepción, Anuncio del ángel a los pastores). Esta oportunidad de poder comparar los resultados, e incluso cotejarlos, hace posible considerar la autoría de algunas de las obras examinadas. Siendo este hecho, la clara demostración de que las técnicas empleadas se convierten en complementarias, como ha sido en este caso la obtención de las radiografías y la caracterización química de los materiales empleados como pigmentos en la técnica de ejecución de esta obra pictórica. El conocimiento tanto de la génesis de la obra como de los materiales presentes facilita la localización y valoración de todas las evidencias de alteraciones, que son los aspectos que se han estudiado desde los mismos inicios de esta aplicación a lo largo de estos años (Burroughs 1938: 7-8; Mucchi y Bertuzzi 1983). Información que facilita la actuación de forma más eficaz en un posible proceso de intervención. En este sentido, el objetivo de este trabajo es poder asentar las bases para el posible reconocimiento de obras de este mismo pintor.

Por este motivo la selección de las obras estudiadas [tabla 1] se ha basado en la discusión de una producción que guarda características comunes, como por ejemplo en cuanto a su tamaño, siendo todas ellas de mediano o gran formato, o su localización en la ciudad de Teruel. El conjunto de obras estudiadas están en su mayoría firmadas o cuentan con una atribución a este autor basada en un discurso histórico artístico por comparativa con otras obras con las que guardan similitudes en sus características estéticas.

Tabla 1.- Ficha técnica de la relación de obras estudiadas.

\begin{tabular}{|c|c|c|c|c|}
\hline OBRA & AÑO & PROCEDENCIA & $\begin{array}{l}\text { DIMENSIONES } \\
(\mathrm{cm})\end{array}$ & FIRMA INSCRIPCIONES \\
\hline $\begin{array}{c}\text { Santa Úrsula y las once } \\
\text { mil vírgenes con santa } \\
\text { Rosa y santa Teresa }\end{array}$ & 1628 & $\begin{array}{c}\text { Catedral de Santa } \\
\text { María de Mediavilla, } \\
\text { Teruel }\end{array}$ & $206 \times 145 \times 2$ & Inscripción nombre y fecha \\
\hline Santa Teresa escritora & $1628-1631$ & $\begin{array}{c}\text { Iglesia San Martín, } \\
\text { Teruel }\end{array}$ & $194 \times 140 \times 2$ & $\begin{array}{l}\text { Inscripción nombre personaje } \\
\text { representado }\end{array}$ \\
\hline $\begin{array}{l}\text { San Joaquín con la } \\
\text { virgen niña }\end{array}$ & 1646 & $\begin{array}{c}\text { Iglesia de San Pedro, } \\
\text { Teruel }\end{array}$ & $163 \times 124 \times 3,30$ & Inscripción nombre y fecha \\
\hline El buen Pastor & $\begin{array}{l}\text { Segundo cuarto del } \\
\text { S.XVII }\end{array}$ & $\begin{array}{c}\text { Iglesia El Salvador, } \\
\text { Teruel }\end{array}$ & $154,5 \times 117 \times 3,30$ & Inscripción nombre \\
\hline San Juan Bautista & $\begin{array}{l}\text { Segundo cuarto del } \\
\text { S.XVII }\end{array}$ & $\begin{array}{c}\text { Iglesia de San Miguel, } \\
\text { Teruel }\end{array}$ & $186 \times 117$ & - \\
\hline $\begin{array}{c}\text { San Pantaleón médico } \\
\text { y mártir }\end{array}$ & $\begin{array}{l}\text { Segundo cuarto del } \\
\text { S.XVII }\end{array}$ & $\begin{array}{c}\text { Iglesia Inmaculada } \\
\text { Concepción, Cella, } \\
\text { Teruel }\end{array}$ & $157 \times 104 \times 2$ & $\begin{array}{c}\text { Firma con rúbrica Inscripción } \\
\text { santo }\end{array}$ \\
\hline $\begin{array}{l}\text { Inmaculada } \\
\text { Concepción }\end{array}$ & $\begin{array}{l}\text { Segundo cuarto del } \\
\text { S. XVII }\end{array}$ & $\begin{array}{c}\text { Iglesia de San Miguel, } \\
\text { Teruel }\end{array}$ & $160 \times 110$ & - \\
\hline $\begin{array}{c}\text { Anunciación del ángel } \\
\text { a los pastores }\end{array}$ & $\begin{array}{c}\text { Segundo cuarto del } \\
\text { S. XVII }\end{array}$ & Desconocida & $116 \times 167$ & Firma con rúbrica \\
\hline
\end{tabular}




\section{Metodología}

La metodología experimental empleada en este trabajo se compone de varias etapas interconectadas y ordenadas. En primer lugar, el estudio radiográfico de las obras, como paso previo para poder establecer los puntos de extracción de las muestras para su posterior análisis mediante técnicas microscópicas (LM y SEM/EDX). Así mismo, dentro de la primera etapa el objetivo del estudio radiográfico es poder reconocer la estructura interna de una obra, mostrando la información de las fases de evolución pictórica que ha sufrido y que han quedado ocultas, ya sea por la degradación de los barnices en superficie, o por los retoques que otra mano ha podido hacer a lo largo de estos últimos años.

A través de la imagen radiográfica se puede comprobar la técnica empleada por el pintor desvelando los diferentes estratos pictóricos desde la imprimación a la capa pictórica, o como hemos indicado las distintas pinceladas a la hora de ser aplicadas. También obtenemos información sobre la naturaleza de la tela empleada, o del soporte de madera, además de su constitución y posibles modificaciones. Todos estos datos ayudan a conocer las claves para determinar la escuela artística de pintura de la que procedía. Asimismo, este tipo de registros evidencian el estado de conservación de la obra. Pero uno de los aspectos más importantes que salen a la luz es la localización de cambios en la composición, retoques y modificaciones que pueden ser producto de otras manos y en épocas diferentes. Modificaciones y cambios causados por variados motivos, tanto de tipo histórico o simplemente estéticos, que se ocultan bajo su imagen visible (Madrid, 2014).

Hay datos ocultos en la obra, que forman parte de un proceso de expertización que otorga autenticidad a la obra y su firma. Esta fase experimental contó además del estudio radiográfico (RX) con otro de infrarrojos (IR) y fluorescencia ultravioleta (UV). Para ello se trasladó cada obra al Laboratorio de Documentación y Registro del Instituto Universitario de Restauración del Patrimonio (IRP) de la Universitat Politècnica de València (UPV). Esta instalación cuenta con un equipo de rayos $X$ modelo TRANSXPORTIX 50 de la empresa General Electric, con un tubo de rayos $\mathrm{X}$ de $3 \mathrm{~kW}$ y un foco de 2,3 con solo una filtración total de $2 \mathrm{~mm}$ de aluminio, que le permiten trabajar en voltajes muy bajos con un rango de 20-110 kV. Parámetros, o características, que convierten a este tipo de dispositivo en uno de los más adecuados para esta clase de estudio, donde el voltaje de penetración del haz de rayos $X$ es determinante a la hora de conseguir un registro con el contraste y nitidez deseados.

Además, como se viene haciendo en este laboratorio se han tomado las medidas de dosis integrada que se ha alcanzado en cada una de las distintas exposiciones, a través de un monitor de radiación de tipo de cámara de ionización, modelo Ram-lon de la empresa Lamse.
Medida que permite el mejor ajuste de los parámetros de voltaje e intensidad, para la obtención de la mejor imagen posible (Madrid, 2000; Madrid, 2006). Las radiografías de este trabajo se han fundamentado en la obtención de la superficie completa de cada una de obras, mediante un mosaico de placas individuales de $35 \times 45 \mathrm{~cm}$, procesadas a través de un digitalizador Agfa CR 30-X. Ya en los últimos años este laboratorio se ha ido especializando en la obtención de radiografías en soporte digital que no solo permite inmediatez en la obtención del registro, sino que ha perfilado un protocolo de trabajo para la obtención de radiografías de gran formato, experiencia que ha sido fundamental en este trabajo.

Como hemos expuesto, el proceso parte, tras las pruebas de ajuste (Madrid, 2006), de la obtención de las radiografías individuales para su montaje posterior en un solo registro. El estudio radiográfico completo ha empleado más de 255 exposiciones, recogidas en registro digital para la formación de esos mosaicos. Composiciones que han ido desde la más compleja integrada con 40 placas como es el caso de la obra de Santa Teresa escritora, frente a las 14 placas empleadas en Inmaculada Concepción. En relación con el rango de voltajes empleados, que han sido necesarios para atravesar cada una de las obras, podemos situar su punto más alto con $71 \mathrm{kV}$ como es el caso de San Joaquín con la virgen niña, o la pintura de San Juan Bautista, frente a los $46 \mathrm{kV}$ en el cuadro de la Anunciación del ángel a los pastores. Los demás parámetros utilizados en la obtención, como son la intensidad o el tiempo de exposición, se han mantenido constantes en casi todas las adquisiciones. Cabe señalar que la radiografía final en extensión de las obras estudiadas ha ocupado, en promedio en el caso del conjunto de lienzos, una superficie de $230 \mathrm{~cm}^{2}$, tamaño que hace inviable en muchos casos y motivos, como puede ser el económico, el estudio radiográfico en soporte analógico, pero que ya no son impedimento gracias al uso del soporte digital (Madrid. 2013).

Por otro lado, la identificación química de los materiales empleados por este pintor y los posibles añadidos posteriores permite averiguar la evolución de su producción artística y sus posibles influencias académicas, copias o rectificaciones introducidas. Desde el punto de vista de su conservación o restauración, se pueden establecer evidencias de las alteraciones que han sufrido. Para ello, se ha procedido con el estudio estratigráfico y de su composición química mediante técnicas microscópicas en el Servicio de Microscopía Electrónica de la UPV. Las muestras fueron preparadas como secciones transversales, utilizando una resina de poliéster para oclusiones transparentes Ferpol-1973 con acelerador incorporado, fabricada por Comercial Feroca, S.A. (Madrid, España), y distribuida por Agar Agar, S.L. (Pontevedra, España). Con la técnica de Microscopía óptica (LM) se consigue profundizar en el análisis morfológico y estratigráfico de las capas presentes en una micromuestra, obteniendo su número, grosor y color, además de la distribución de partículas de pigmento y sus cargas. 
Para ello se utilizó un microscopio óptico de la marca LEICA, modelo DMR2000, X5-X200, con sistema fotográfico digital acoplado. Seguidamente se recubren con carbono, para eliminar efectos de carga y de este modo, realizar la adquisición de imágenes mediante SEM/EDX que permite un segundo reconocimiento morfológico y estratigráfico, después se adquieren los espectros de rayos $X$ en áreas, o zonas puntuales de la muestra, que proporcionan información semicuantitativa acerca de su composición elemental, según el método ZAF de corrección del efecto matriz (Osete-Cortina 2010). Para ello, se utiliza un microscopio electrónico de barrido (SEM/EDX), marca JEOL y modelo JSM 6300 con sistema de microanálisis Link-Oxford-Isis, operando a $20 \mathrm{kV}$ de tensión de filamento, $2.10^{-9} \mathrm{~A}$ de intensidad de corriente y distancia de trabajo $15 \mathrm{~mm}$.

\section{Resultados y discusión}

\section{—Estudio radiográfico}

Se han logrado analizar 8 lienzos que ofrecen cada uno de ellos diferentes parámetros según sus características en composición química y formato. En la tabla 2 se exponen los datos técnicos empleados para la obtención en cada una de estas radiografías.
Como ya hemos indicado, el estudio radiográfico de todas estas obras se ha realizado mediante el protocolo de radiografías de gran formato diseñado en el laboratorio de inspección radiográfica para posibilitar una lectura sin ningún tipo de interrupción en la radiografía final (Madrid, 2013). El objetivo de este mosaico de imágenes radiográficas es presentar una imagen homogénea, tanto a nivel de contraste como de definición de toda su superficie.

En los primeros segundos de observación sobre de las radiografías, la mirada se dirige a aquellas regiones más dañadas y después nos lleva a los detalles más significativos que se concretan en la localización de esos cambios o modificaciones que han quedado ocultas bajo el original. Dentro del apartado de información relativo al estado de conservación de las pinturas [tabla 3] se ha tenido en cuenta que las obras Santa Úrsula y las once mil vírgenes con Santa Rosa [figura 1], San Juan Bautista y la Inmaculada Concepción se encuentran completamente enteladas. Factor que se ha tenido en cuenta no solo en el momento de ejecución de la radiografía, sino en momento de la interpretación de los resultados de estas pinturas.

Desde el punto de vista del estado de conservación del soporte, hay que señalar que algunas obras como San

Tabla 2.- Datos técnicos de las radiografías de RX en cada una de las obras estudiadas.

\begin{tabular}{|c|c|c|c|c|c|c|c|c|}
\hline Obra & $\begin{array}{l}\text { Área } \\
\text { (m2) }\end{array}$ & $\begin{array}{l}\text { Voltaje } \\
\text { (kV) }\end{array}$ & $\begin{array}{l}\text { Intensidad } \\
\quad(\mathrm{mA})\end{array}$ & $\begin{array}{l}\text { Distancia } \\
\text { al foco } \\
\text { (cm) }\end{array}$ & $\begin{array}{c}N^{\circ} \text { de } \\
\text { exposiciones } \\
\text { telemétricas }\end{array}$ & №placas & $\begin{array}{l}\text { Tiempo de } \\
\text { exposición } \\
\text { por placa } \\
\text { (seg) }\end{array}$ & $\begin{array}{c}\text { Dosis } \\
\text { Integrada } \\
(\mu \mathrm{Sv})\end{array}$ \\
\hline $\begin{array}{l}\text { Santa Úrsula y las } \\
\text { once mil vírgenes } \\
\text { con santa Rosa y } \\
\text { santa Teresa }\end{array}$ & 2,99 & 70 & 20 & 500 & 8 & 24 & 3 & $5,80 \pm 1.10$ \\
\hline $\begin{array}{l}\text { Santa Teresa } \\
\text { escritora }\end{array}$ & 2,97 & 58 & 20 & 500 & - & 40 & 3 & $10,8 \pm 2,7$ \\
\hline $\begin{array}{l}\text { San Joaquín con } \\
\text { la virgen ñiña }\end{array}$ & 2,02 & 71 & 20 & 480 & 6 & 18 & 3 & $4,9 \pm 0,5$ \\
\hline El buen Pastor & 1,80 & 59 & 20 & 420 & 6 & 18 & 3 & $6,3 \pm 0,3$ \\
\hline San Juan Bautista & 2,18 & 71 & 20 & 500 & 8 & 24 & 3 & $19,0 \pm 9,8$ \\
\hline $\begin{array}{l}\text { San Pantaleón } \\
\text { médico y mártir }\end{array}$ & 1,63 & 47 & 20 & 370 & 6 & 18 & 3 & $6,2 \pm 0,3$ \\
\hline $\begin{array}{l}\text { Inmaculada } \\
\text { Concepción }\end{array}$ & 176 & 72 & 20 & 440 & - & 14 & 3 & $21,8 \pm 8,9$ \\
\hline $\begin{array}{c}\text { Anunciación } \\
\text { del ángel a los } \\
\text { pastores }\end{array}$ & 2,52 & 46 & 20 & 440 & 8 & 24 & 3 & $6,4 \pm 1,9$ \\
\hline
\end{tabular}




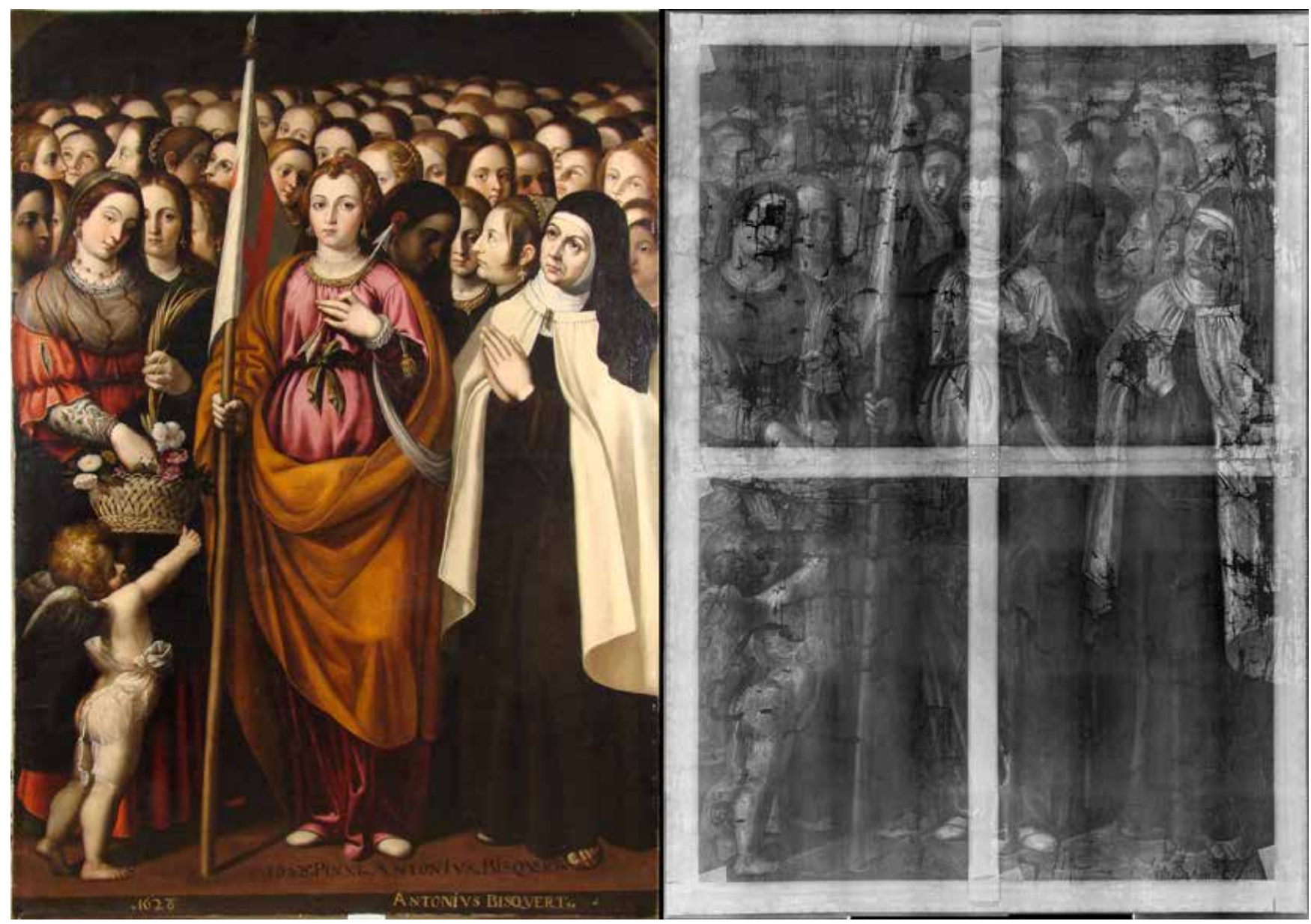

Figura 1.- Fotografía general anverso e imagen radiográfica de Santa Úrsula y las once mil vírgenes con santa Rosa y santa Teresa.

Joaquín con la virgen ñiña, San Pantaleón médico y mártir, o el Anuncio del ángel a los pastores, presentan sus bordes reforzados con otra tela para favorecer el tensado de las pinturas. En relación con el soporte la imagen radiográfica muestra que existe un completo aprovechamiento de las telas pues en algunos casos el uso de dos piezas se hace imprescindible para conseguir el formato demandado, puesto que el tamaño del ancho estaba limitado a 104 cm como presenta la obra de San Pantaleón médico y mártir. Información que permanecía oculta en esta obra debido a su reentealdo.

Estas intervenciones en el soporte han generado a lo largo de la historia material de las obras numerosas reintegraciones cromáticas, con la finalidad de ocultar desde pequeñas lagunas a otras de gran formato, así como la verdadera dimensión de algunos deterioros que se ocultan tras un repinte producto de una intervención posterior como son en la obra Inmaculada Concepción o en el caso de la Anunciación del ángel a los pastores [figura 2]. En la parte inferior de esta última se puede ver que la zona reintegrada, oculta parte del original.

Pero de lo que más se puede aprender, gracias a la lectura de los registros radiográficos, es de la técnica de ejecución del pintor Antonio Bisquert. En todas las radiografías obtenidas se muestra una gran maestría en la impresión de las pincelas, que sin dibujo previo aparente va construyendo cada una de las escenas presentadas en estas obras. La técnica de ejecución no está libre de cambios o modificaciones en la composición, considerados como arrepentimientos del pintor producidos a lo largo de la génesis de la obra.

Estos cambios son a veces pequeños, como el que podemos encontrar en la mano derecha de San Pantaleón médico y mártir [figura 3]. Mano que lleva una pluma, pero que en su imagen subyacente la radiografía muestra otro objeto. Este dato nos acerca a la hipótesis de que muy posiblemente la figura portaba inicialmente el atributo que le relacionaba con su martirio, como es la empuñadura del espadín con el que fue decapitado. Pero los cambios en esta obra no se limitan a este detalle, sino que se amplían a cambios en el sombrero que lleva consigo la figura y que originalmente era mucho más grande, el arrepentimiento a lo largo de su brazo izquierdo, o lo mismo en el caso del brazo derecho. Todas esas modificaciones se localizan en el contorno de la figura, a los que se suma algún pequeño cambio en su parte inferior. Además, en su origen, la figura del santo era más ancha y los pliegues de abajo de la capa no eran iguales. 

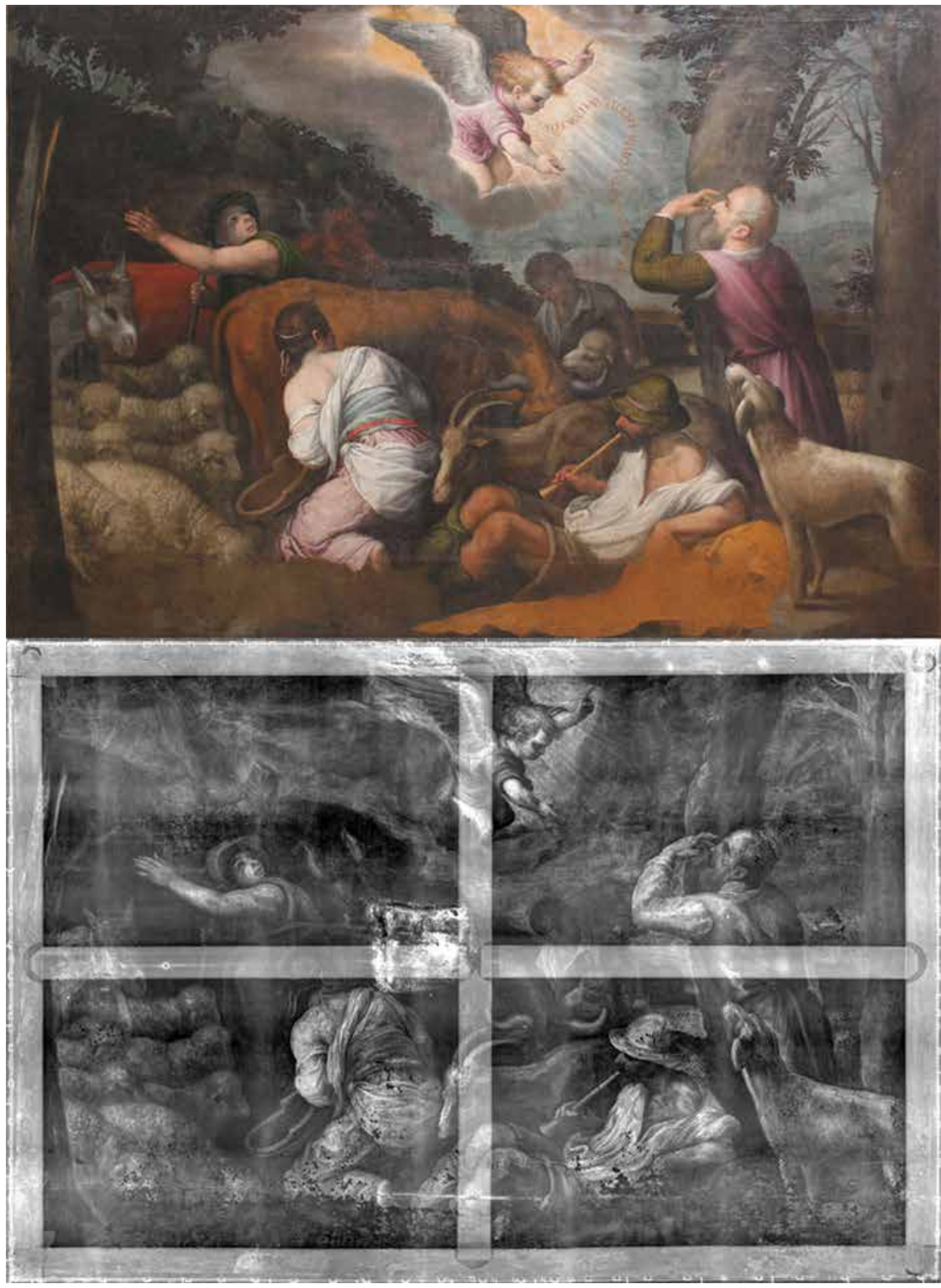

Figura 2.- Fotografía general anverso e imagen radiográfica de Anunciación del ángel a los pastores. 


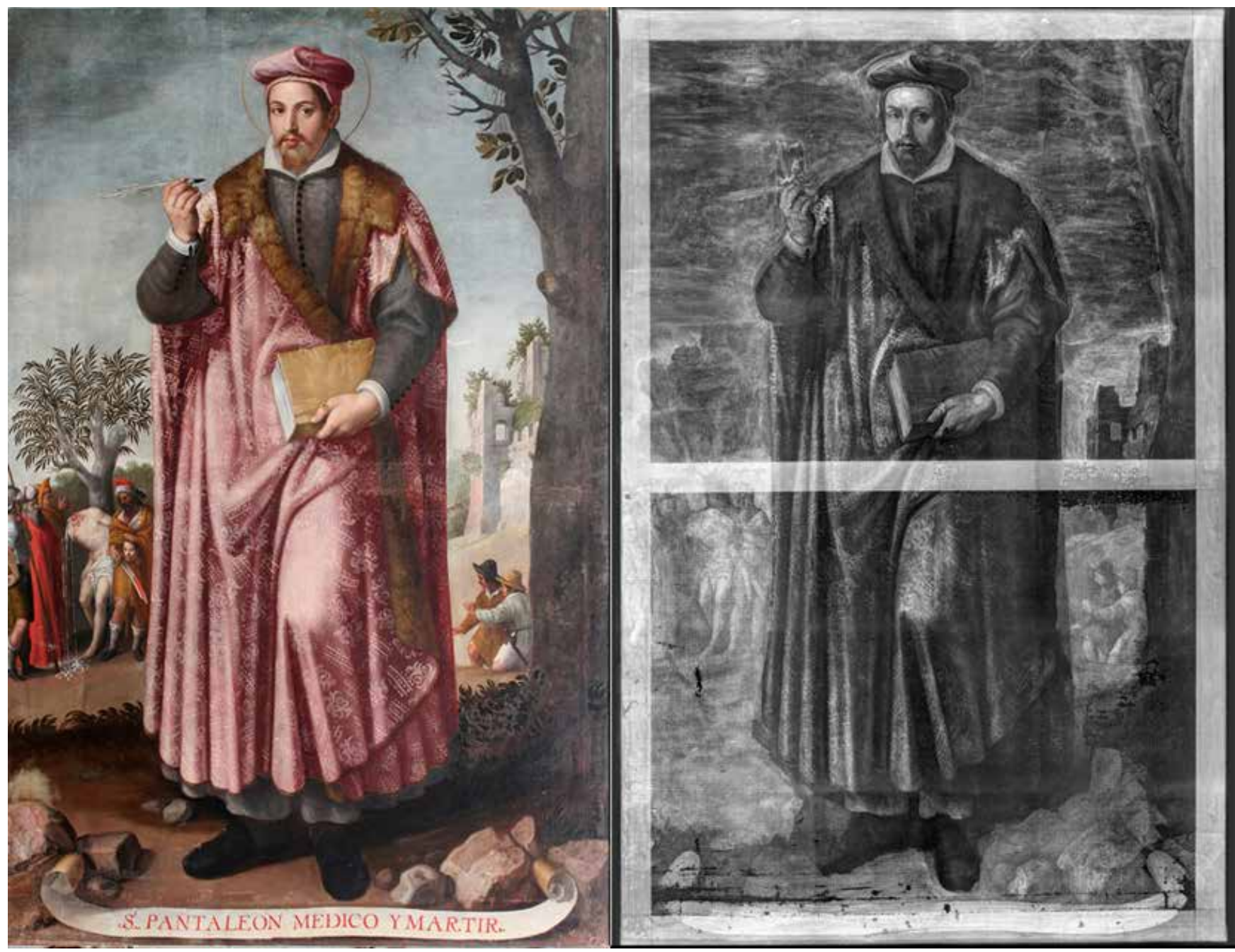

Figura 3.- Fotografía general anverso e imagen radiográfica de San Pantaleón médico y mártir.

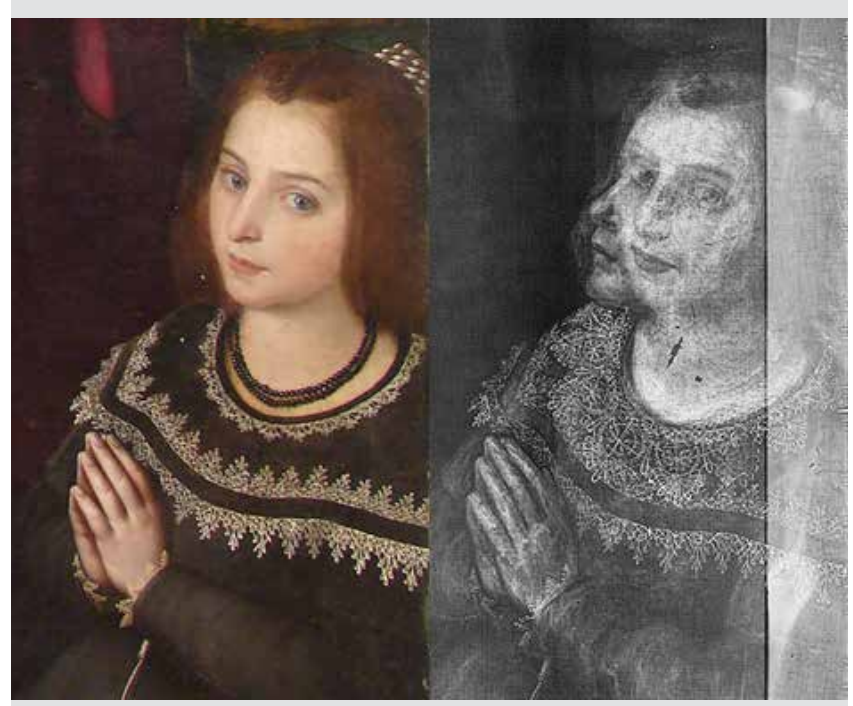

Figura 4.- Cambio de posición del rostro de la figura del donante en San Joaquín con la virgen ñiña.
Existen más modificaciones en la composición de las obras estudiadas que se han ido haciendo más interesantes, como ocurre en el caso de la obra de San Joaquín con la virgen ñiña, donde el pintor cambia la orientación tanto de la mirada como todo el rostro de imagen de figura situada en la parte inferior derecha de la composición y que actúa como donante [figura 4]. Antonio Bisquert, en esta obra, en la ejecución de esa figura parte de una posición con vista de perfil a una mirada más frontal, además de ocultar gran parte del excelente trabajo que efectúa en el bordado del vestido.

Los cambios se hacen muy numerosos en la obra del Buen Pastor [figura 5], como el que permite leer el título del cuadro encima de la inscripción de su nombre y que quedaba oculto, o diferencias en las zonas de la solapa del zurrón de la figura principal o los drapeados de su vestido, más un pequeño arrepentimiento tanto en su brazo derecho como en el contorno de la cabeza. También en este caso la figura del donante no está exenta de tener cambios y como desvela su registro radiográfico el cuello de su camisa es distinto a lo que vemos a simple vista. 

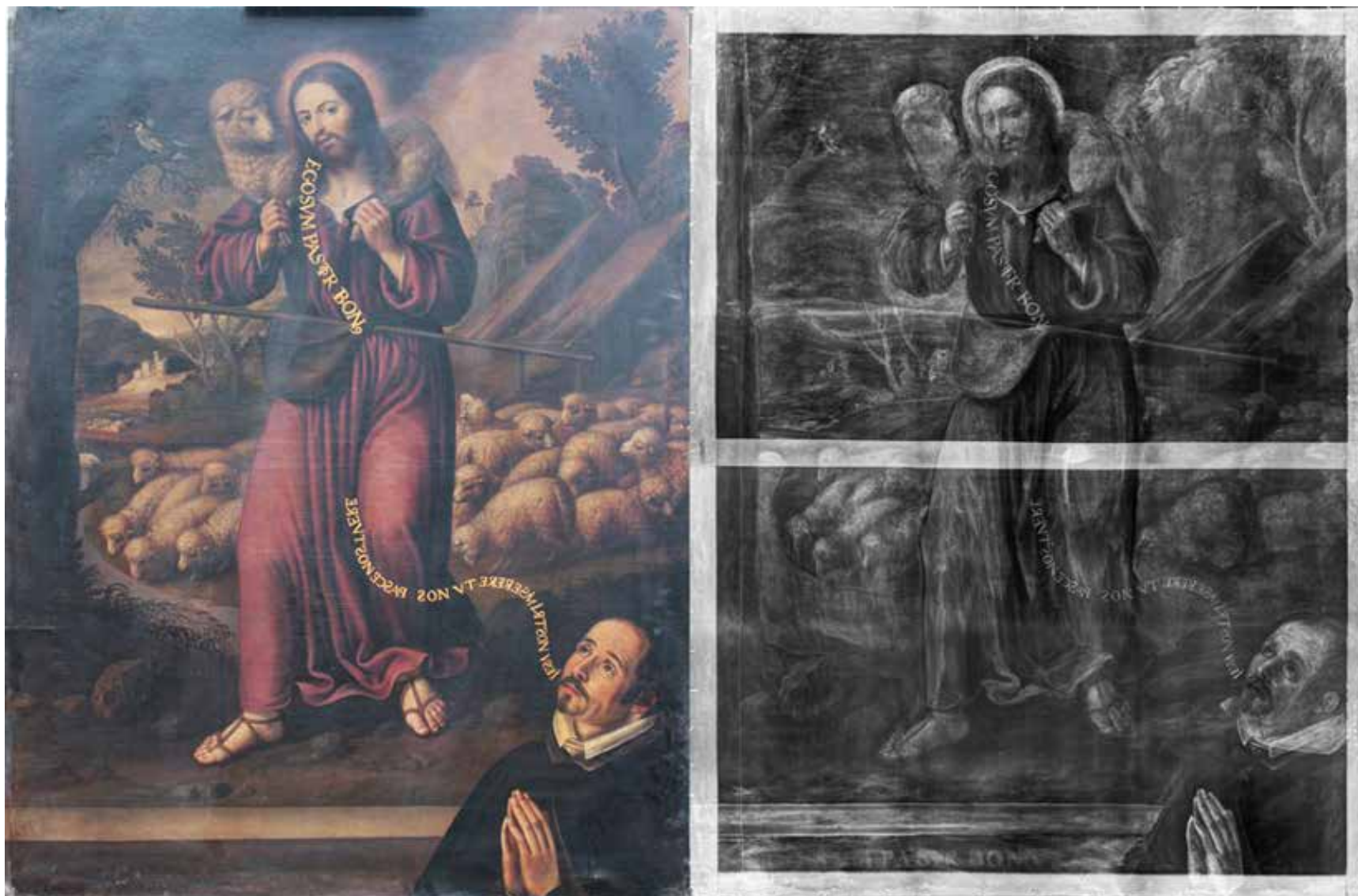

Figura 5.- Fotografía general anverso e imagen radiográfica de buen Pastor.

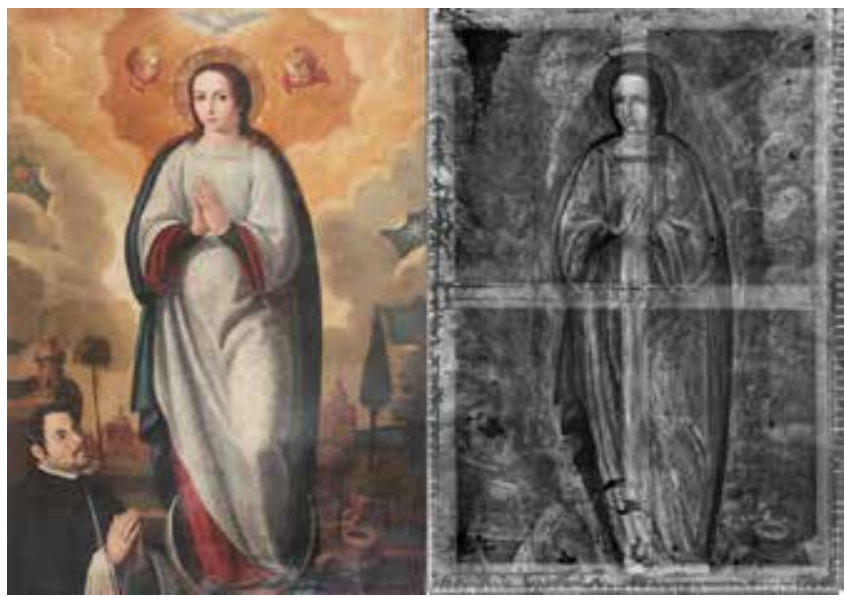

Figura 6.- Fotografía general anverso e imagen radiográfica de Inmaculada Concepción.

Siguiendo en el capítulo de pentimenti, o arrepentimientos, los más marcados se observan en la Inmaculada Concepción [figura 6], pues en la figura principal de la Virgen sus manos cambian completamente de posición y vemos que su doble túnica en un principio era solo una. Estos cambios fueron producidos muy posiblemente por la incorporación de la Luna bajo los pies de la Inmaculada, elemento indudablemente que incorpora después, puesto que no aparece ningún rastro de este en la capa que subyace y se hace visible en la radiografía. Esta incorporación va a

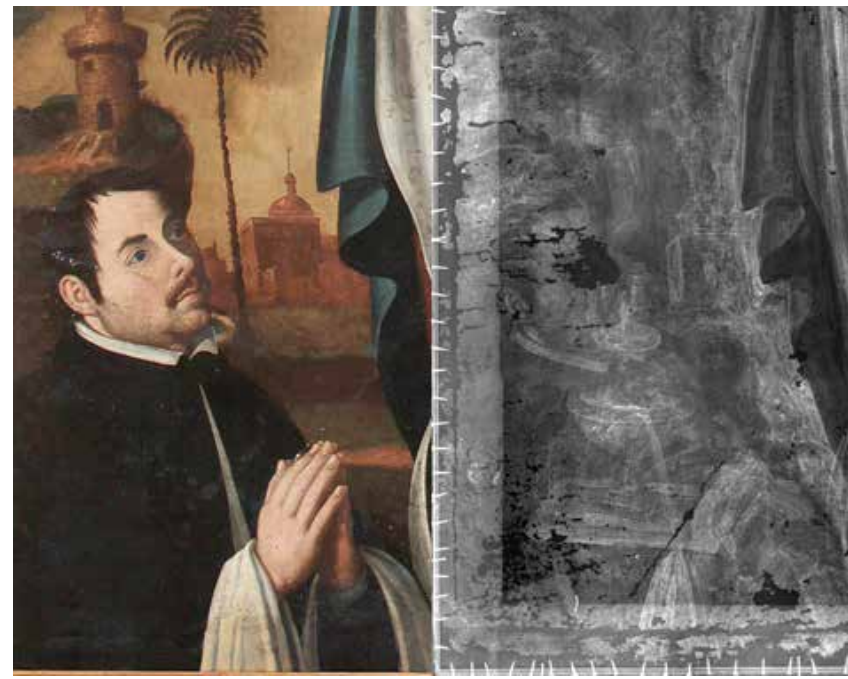

Figura 7.- Localización del elemento de la fuente de la sabiduría propio de la iconografía de las letanías de la Inmaculada Concepción.

obligar a Antonio Bisquert a rectificar parte del vestido en esa zona, además de hacer cambios en la posición de las piernas lo que deriva en modificaciones en el drapeado de la túnica.

La imagen de la Virgen también esconde variaciones en el rostro, más duro en su ejecución inicial, en la posición de las manos, y en el pendiente que portaba 

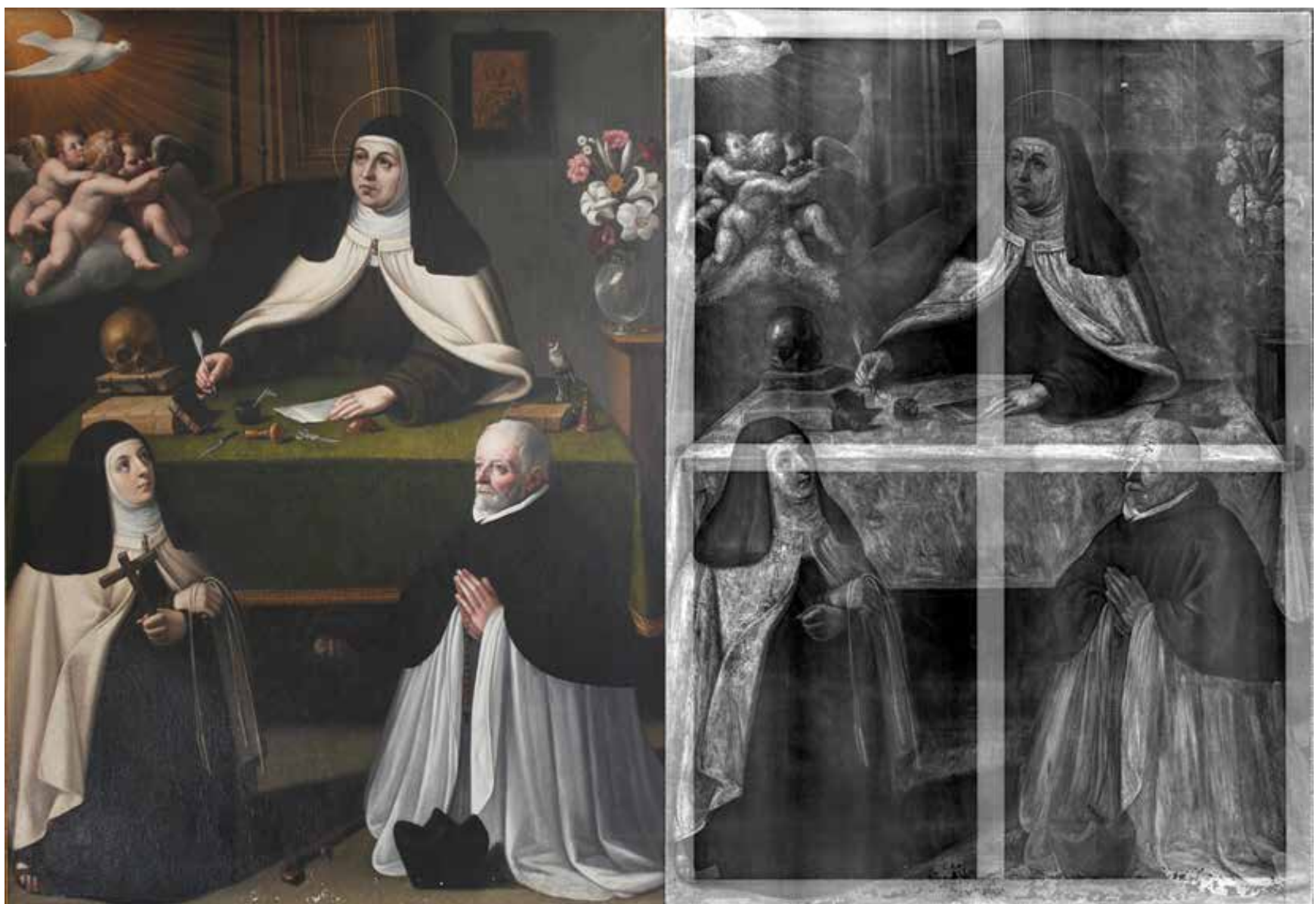

Figura 8.- Fotografía general anverso e imagen radiográfica de Santa Teresa escritora.

originalmente. Asimismo, el personaje que aparece en actitud de donante, en el lado izquierdo de la composición, posiblemente también se incorporara después. La radiografía revela que bajo el pecho de esta figura estaba situado otro de los elementos de las Letanías de la Virgen, la Fuente de Sabiduría [figura 7]. Este cambio iconográfico nos lleva a observar igualmente que los dos ángeles se pintan posteriormente, pues tampoco aparecen en la capa subyacente. Ángeles que no eran un motivo muy empleado en las representaciones más clásicas de esta iconografía.

Un rasgo singular dentro de conjunto de obras estudiadas es el referido a los objetos que se exhiben en su imagen visible, pero que en su radiografía se muestran no solo con intensidad diferente al resto de elementos de la obra, sino que además dejan entrever partes de la composición que subyace. Todas ellas las vamos a considerar superposiciones, que pueden responder a muchos motivos, pero la conclusión más probable es que Antonio Bisquert atendía así a las exigencias de la obra encargada. Exigencias y requerimientos, como es la inclusión de la figura del donante en sus obras, que nos muestran cómo estaba marcada su actividad artística antes de afianzar su taller. No podemos olvidar que Bisquert, pintor de origen valenciano, se tuvo que trasladar de la ciudad del Turia por la situación que atravesaba la pintura en aquella época a la ciudad de Teruel, con el afán de empatizar con esa nueva clientela e intentar así solucionar la carestía que sufría (Benito y Vallés, 1989: 158-159).

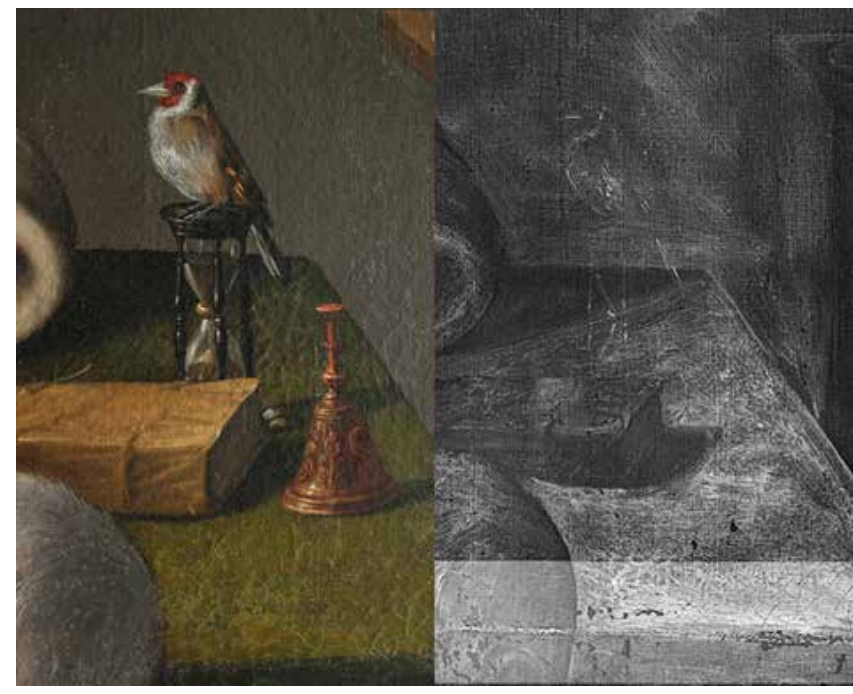

Figura 9.- Detalle de tres de los elementos que se desvanecen en la radiografía en la obra de Santa Teresa escritora, como es el jilguero, el reloj de arena o la campanilla. 
El caso más llamativo lo encontramos en la obra de Santa Teresa escritora [figura 8], donde los objetos que aparecen en la mesa como el cuchillo, el sello, las tijeras, la concha marina, la campanilla, el reloj de arena, o el más significativo de todos ellos, el jilguero, se aprecian en el rango visible, pero se difuminan en la imagen de la radiografía [figura 9]. Un caso también curioso, en esta misma obra, es lo que sucede en las figuras que están a los pies de la figura principal. En la radiografía se ve que discurre por encima del perfil de la mesa tanto el retrato de Sor Catharina como el de la figura masculina que está a la derecha de la composición. Esto apunta el orden en el que el pintor compuso la obra, primero preparó el motivo principal y luego construyó estas dos figuras. Otra obra donde encontramos estas superposiciones es en San Joaquín con la virgen ñiña donde nuevamente se ve bajo la paloma las líneas principales de la columna.

Otro dato relevante que proporciona el estudio radiográfico hace referencia a los elementos, $u$ objetos, que no se aprecian en este tipo de registro. Esto se debe fundamentalmente a la poca resistencia a la radiación por parte de los materiales empleados para su ejecución. Normalmente esto lo observamos en los elementos donde se ha empleado el color tierra, o verde, que en definitiva coinciden con el follaje de los árboles y sus ramas, algunos arbustos e incluso algunas piedras, como sucede en San Joaquín con la virgen ñiña [figura 10], El Buen Pastor, San Juan Bautista, San Pantaleón Médico y Mártir o la Anunciación del ángel a los pastores, siendo estos los más significativos. Y una mezcla entre superposición o elemento que se desvanecen debido a los pigmentos la podemos ver en la obra de la obra de Santa Teresa Escritora donde los fijadores empleados para sujetar en el cuello la capa que llevan encima del hábito durante la liturgia tanto de la figura de Santa Teresa como en el caso de Sor Catharina, además del rosario que muestra la figura masculina del lado derecho de la composición terminan por no apreciarse en la radiografía.

Pero de todos los estudios efectuados la obra que nos reservaba un gran secreto fue la que representa la figura de San Juan Bautista [figura 11]. En este lienzo la radiografía dejó al descubierto un personaje en la parte inferior derecha de la composición. El pintor decidió tapar finalmente esta figura, que se muestra prácticamente completa en su ejecución, a falta de las manos. En esta obra hay más cambios como ocurre en el manto que cubre la figura, que es muy distinto en su origen, la parte interna de la pierna izquierda o el cambio de posición en el dedo índice de la figura del Bautista, que quedan en un segundo término tras el descubrimiento de ese nuevo personaje.

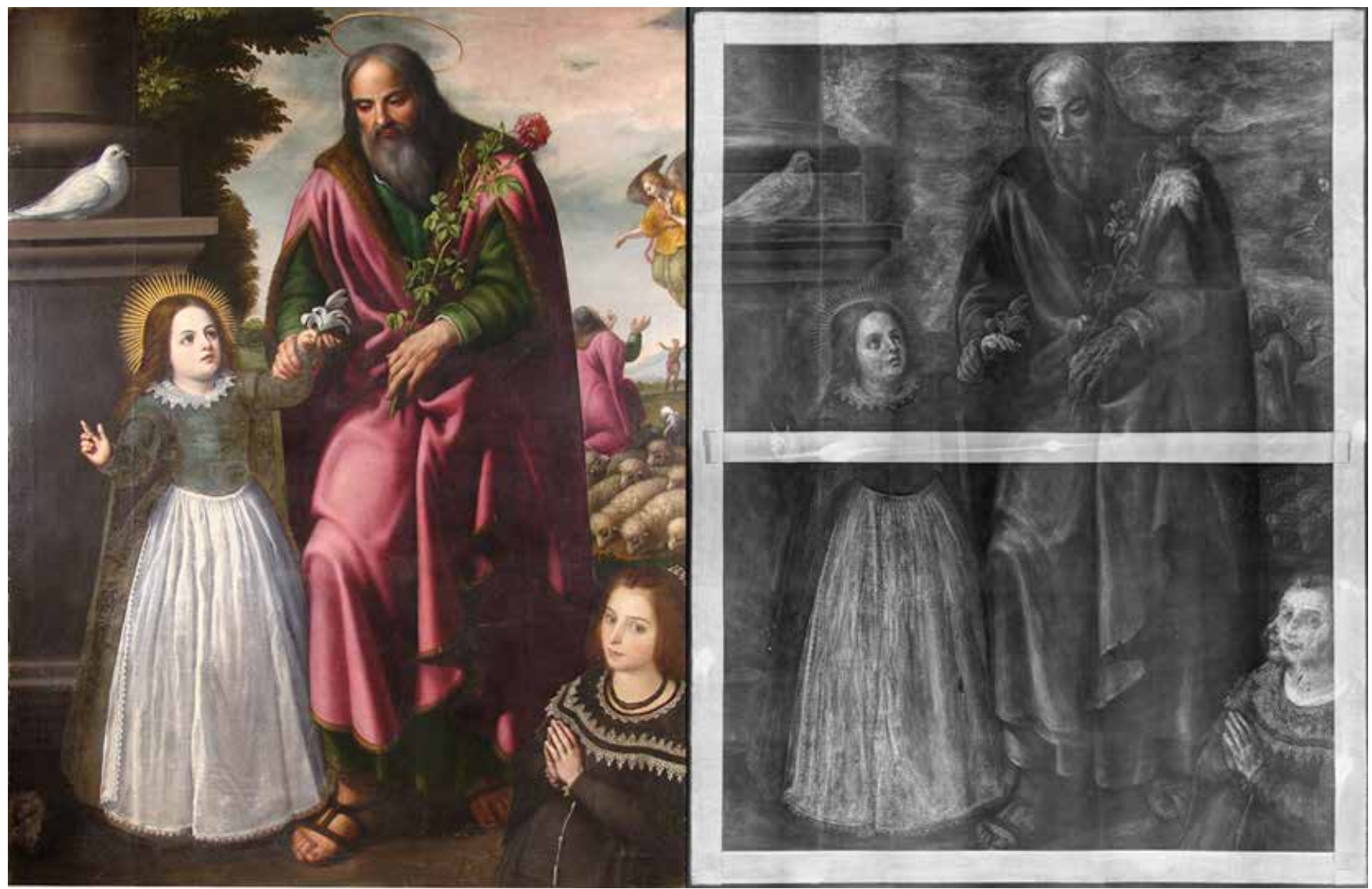

Figura 10.- Fotografía general anverso e imagen radiográfica de San Joaquín con la Virgen Niña. 


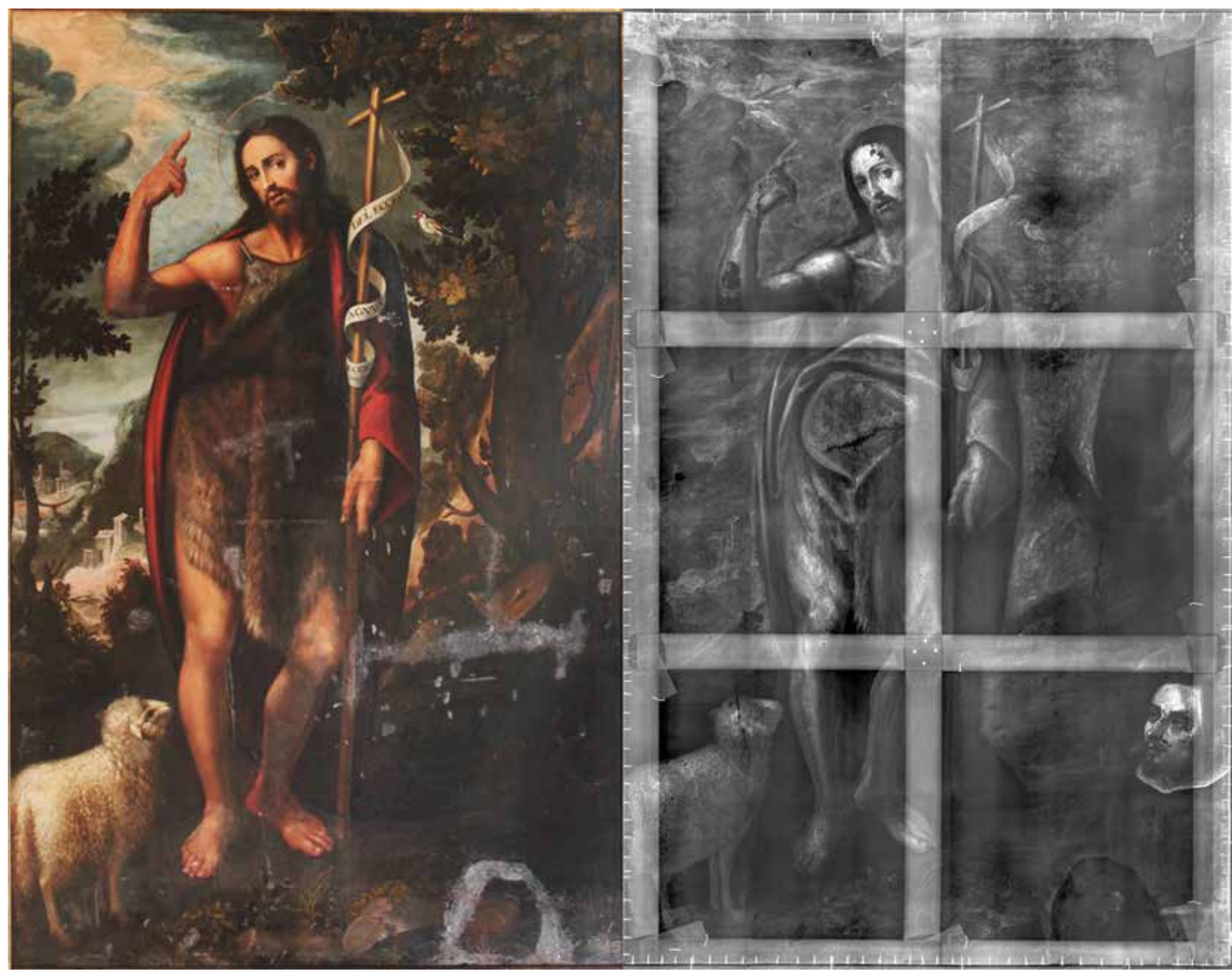

Figura 11.- Fotografía general anverso e imagen radiográfica de San Juan Bautista.

Tabla 3.- Resumen de las modificaciones encontradas mediante las imágenes radiográficas de las obras estudiadas.

\begin{tabular}{|c|c|c|c|c|c|c|c|}
\hline & 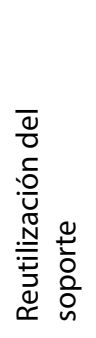 & 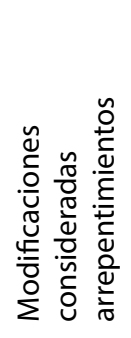 & 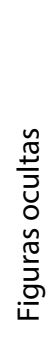 & 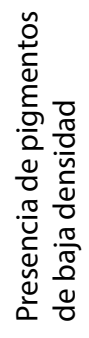 & 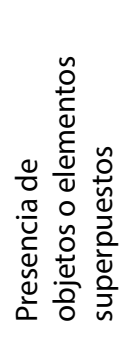 & 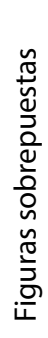 & 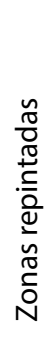 \\
\hline \multicolumn{8}{|c|}{$\begin{array}{l}\text { Santa Úrsula y las once mil vírgenes con } \\
\text { santa Rosa y santa Teresa }\end{array}$} \\
\hline \multicolumn{8}{|l|}{ Santa Teresa escritora } \\
\hline \multicolumn{8}{|l|}{ San Joaquín con la Virgen Niña } \\
\hline \multicolumn{8}{|l|}{ El buen Pastor } \\
\hline \multicolumn{8}{|l|}{ San Juan Bautista } \\
\hline \multicolumn{8}{|l|}{ San Pantaleón médico y mártir } \\
\hline \multicolumn{8}{|l|}{ Inmaculada Concepción } \\
\hline Anuncio del ángel a los pastores & & & & & & & \\
\hline
\end{tabular}




\section{Caracterización de materiales mediante SEM/EDX}

Como ya hemos indicado, este estudio radiográfico tan extenso y de estas características, realizado sobre un conjunto de obras elaboradas por la misma mano, ha permitido establecer una óptima estrategia de toma de muestras. Con cada una de ellas se ha obtenido la información de la composición de los pigmentos que constituyen la paleta de este artista $y$, además ha ofrecido una visión de las distintas capas que conforman la historia de cada una de estas obras. De esta forma los puntos de extracción de las diferentes muestras atendían a criterios como; zonas con posibles repintes, un mismo color en diferentes obras, o puntos que se situaban sobre partes ocultas.

En la siguiente [tabla 4] se presenta un resumen de la identificación química de los pigmentos más utilizados en estas obras y similares en todas ellas, correspondientes a los colores rojo, verde, magenta, carnación y azul. El análisis de las distintas secciones transversales de las obras estudiadas se obtiene mediante SEM/EDX. Dichos pigmentos, no solo son una constante en las obras caso de estudio, sino que están presentes en algunos de los elementos que se repiten, como es el caso del color rojo empleado en el jilguero. Así, en el color rojo se identifica bermellón (sulfuro de mercurio, $\mathrm{HgS}$ ) y tierra roja conteniendo hematita $\left(\mathrm{a}-\mathrm{Fe}_{2} \mathrm{O}_{3}\right)$; en el color verde se aprecia el uso de verde de malaquita, probablemente artificial $\left[2 \mathrm{CuCO}_{3}\right.$. $\mathrm{Cu}(\mathrm{OH})_{2}$, y en alguna obra, como en Santa Úrsula y las once mil vírgenes con santa Rosa y santa Teresa aparece el verdigrís $\left[\mathrm{Cu}\left(\mathrm{CH}_{3} \mathrm{COO}\right)_{2} \cdot \mathrm{H}_{2} \mathrm{O}\right]$ y tierra ocre con goetita (a-FeOOH); la tonalidad de color magenta es una mezcla de blanco de plomo $\left[2 \mathrm{PbCO}_{3} \cdot \mathrm{Pb}(\mathrm{OH})_{2}\right]$ y pigmentos rojos y azules, por un lado, minio $\left(\mathrm{Pb}_{3} \mathrm{O}_{4}\right)$ y tierra roja, y por otro, esmalte (vidrio potásico de color azul, de Co-Ni-Fe-As) o azurita $\left[2 \mathrm{CuCO}_{3} \cdot \mathrm{Cu}(\mathrm{OH})_{2}\right]$; la tonalidad de las carnaciones es obtenida con tierra roja con hematita mezclado con blanco de plomo; en el color azul utiliza esmalte en la mayoría de sus obras y también, en alguna emplea azurita.

Sin embargo, en el caso de San Joaquín con la Virgen Niña se produce cierto anacronismo pues se han identificado azul cobalto $\left(\mathrm{CoO} . \mathrm{Al}_{2} \mathrm{O}_{3}\right)$ (1803-1804) (Roy 2007) y azul de Prusia $\left[\mathrm{Fe}_{4}\left[\mathrm{Fe}(\mathrm{CN})_{6}\right]_{3}\right.$. $\left.\mathrm{xH}_{2} \mathrm{O}\right]$ (1704) (Berrie, 1997) que son dos pigmentos fabricados posteriormente a la fecha de datación de esta obra (1646). Este hecho se puede observar en los resultados obtenidos mediante SEM/EDX de la muestra SJ7 en la [figura 12], donde se identifican en la capa de preparación marrón (almagra) tierra ocre con goetita (a-FeOOH), blanco de plomo $\left[2 \mathrm{PbCO}_{3} \cdot \mathrm{Pb}(\mathrm{OH})_{2}\right], y$ sales solubles $\mathrm{NaCl}$ (Espectro 1); y en el estrato pictórico se identifica mayoritariamente blanco de plomo $\left[2 \mathrm{PbCO}_{3}\right.$. $\mathrm{Pb}(\mathrm{OH})_{2}$ ) y sílice $\left(\mathrm{SiO}_{2}\right)$ y como agentes pigmentantes azul cobalto $\left(\mathrm{CoO} . \mathrm{Al}_{2} \mathrm{O}_{3}\right)$ y azul de prusia (ferrocianuro férrico, $\left[\mathrm{KFe}\left[\mathrm{Fe}(\mathrm{CN})_{6}\right]_{3} \cdot \mathrm{xH}_{2} \mathrm{O}\right]$, más algunas partículas accesorias del pigmento ocre (espectro 3). Esto pudiera deberse, muy posiblemente, a alguna intervención de un retoque acometido en esta pintura.

Según el dato obtenido con los registros radiográficos respecto a la negativa apreciación de algunos elementos
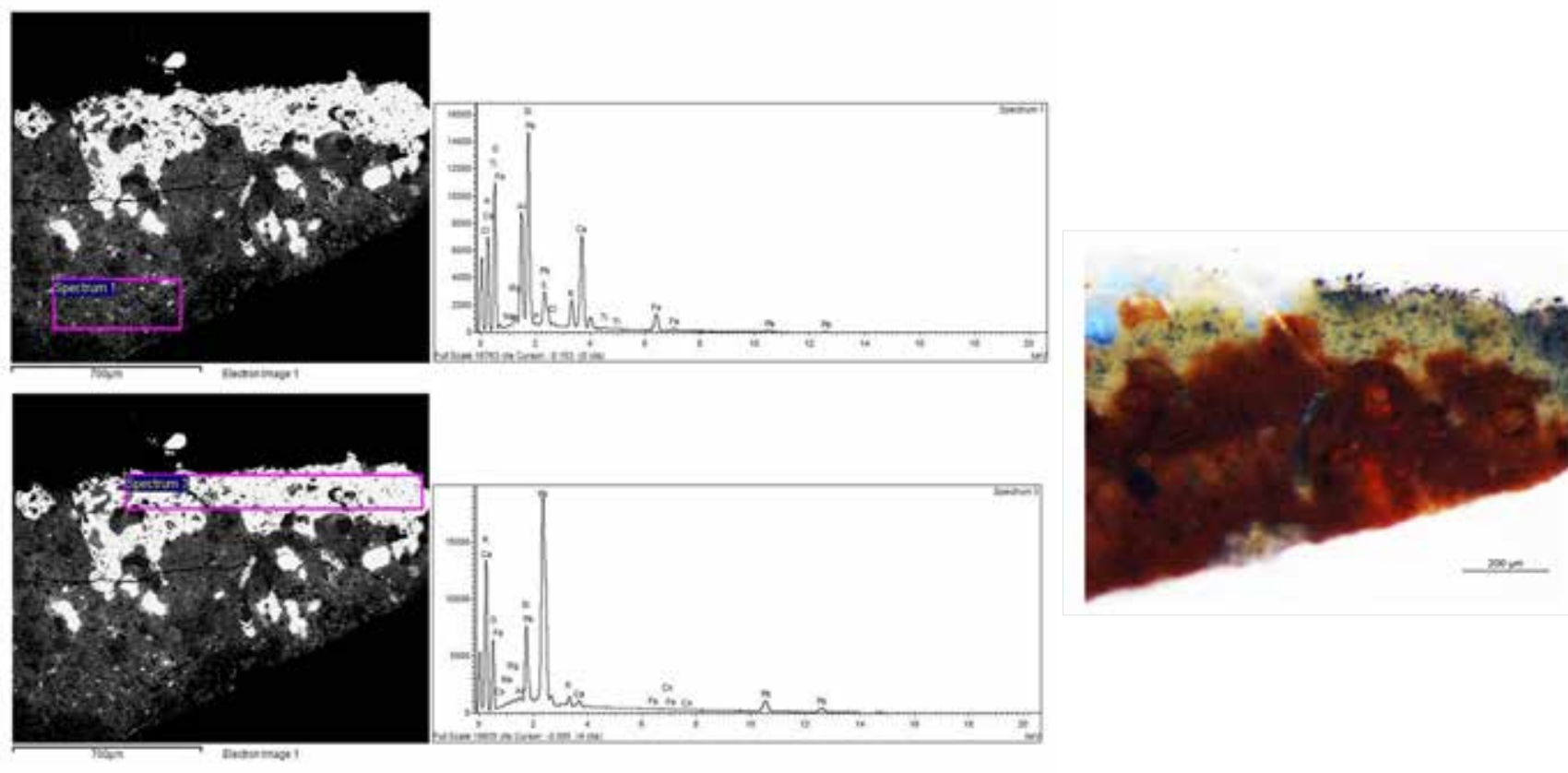

Figura 12.- Microfotografía de la muestra SJ7 a $63 \mathrm{X}$ e imagen de electrones retrodispersados y sus correspondientes espectros de rayos $X$. 

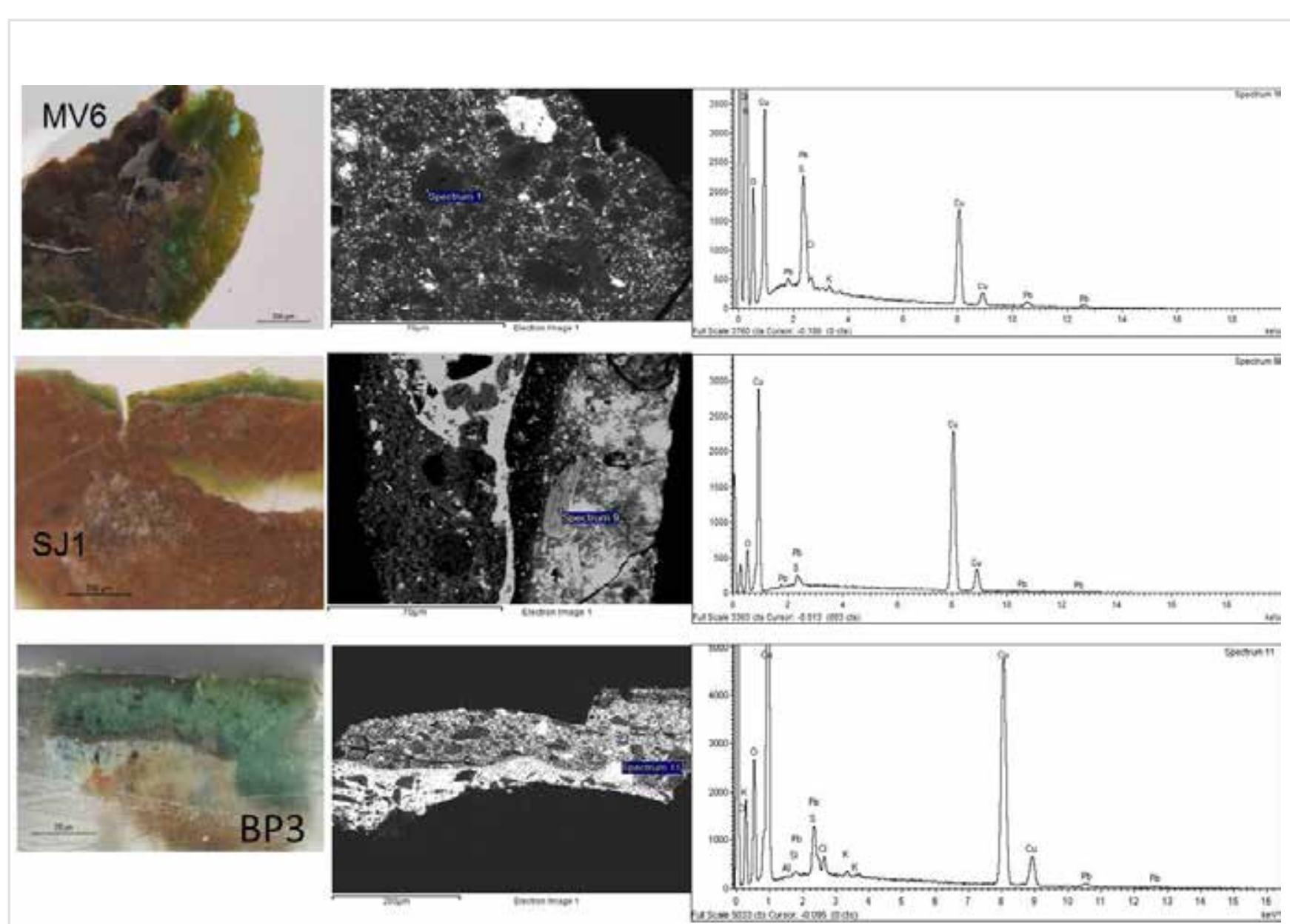

Figura 13.- Microfotografías de las muestras MV6, SJ1 y BP3 de tonalidad verde a $63 \mathrm{X}$ e imágenes de electrones retrodispersados y sus correspondientes espectros de rayos $\mathrm{X}$.

de la composición pudiera estar relacionado con la elaboración de los pigmentos empleados. Este hecho se produce en los objetos que implican tanto el color verde como el marrón. En los análisis por SEM/EDX de los pigmentos verdes se ha identificado cobre [figura 13], lo que sugiere que se pueda tratar de pigmentos como verdigrís (acetato de cobre) (Kühn, 1993) o verde de malaquita artificial (carbonato básico de cobre) (Gettens y West Fitzhugh, 1993) y ocre para los tonos marrón, esta composición química nos hace suponer su baja resistencia a la radiación $\mathrm{X}$ y, por lo tanto, se vuelven transparentes a ella.

Por otra parte, en estas obras las imprimaciones [tabla 4] se presentan coloreadas desde tonos rojizos propios de una preparación con almagra, como vemos en la obra Santa Úrsula y las once mil vírgenes con santa Rosa y santa Teresa, o bien, imprimación de color pardo de la mezcla del albayalde y ocre, como en la obra de Anunciación del ángel a los pastores e incluso, imprimaciones negruzcas con diferentes intensidades derivadas de la mezcla de sulfato de calcio, albayalde con pigmento tierra con magnetita y negro carbón animal que se encuentran en la obra de Inmaculada Concepción. Algunas están dispuestas, previo encolado, sobre un aparejo de yeso. El albayalde y el blanco de plomo actúan en todos los casos como componente principal en las mezclas heterogéneas que se dan en las preparaciones y aparece acompañado en cada caso por diferentes tipos de pigmento tierra roja o sombra, o en su defecto, por negro carbón animal $\left[\mathrm{C}, \mathrm{Ca}_{3}\left(\mathrm{PO}_{4}\right)_{2}, \mathrm{CaCO}_{3}\right]$. Este pigmento de plomo, es sabido que es perjudicial para la salud, como igualmente sucede con el rejalgar (en el que se identifica arsénico que es venenoso) encontrado en las obras San Pantaleón médico y mártir y el Anuncio del ángel a los pastores. La tierra almagra, o tierras rojas, es un pigmento que está muy presente en el suelo de la ciudad de Teruel, debido a que el enclave se asienta en distintos tipos de roca sedimentaria de tipo arcillas, yesos, calizas y margas. Estos suelos arcillosos presentan una textura fina, que pudo ser motivo del pronunciado uso de estos pigmentos en la producción pictórica estudiada de este pintor. En referencia a los grosores de los estratos pictóricos oscilan entre $380 \mu \mathrm{m}$ en el buen Pastor y aproximadamente 200 $\mu \mathrm{m}$ de las obras Santa Teresa escritora, San Juan Bautista o el Anuncio del ángel a los pastores. 
Tabla 4.- Resumen de la composición de pigmentos e imprimación mediante SEM/EDX en las obras estudiadas.

\begin{tabular}{|c|c|c|c|c|c|c|c|c|}
\hline \multirow{2}{*}{ OBRA } & \multirow{2}{*}{ FECHA } & \multicolumn{2}{|c|}{ IMPRIMACIÓN } & \multicolumn{5}{|c|}{ ESTRATO PICTÓRICO } \\
\hline & & COLOR & MATERIALES & ROJO & VERDE & MAGENTA & AZUL & CARNACIÓN \\
\hline $\begin{array}{l}\text { Santa Úrsula y las } \\
\text { once mil vírgenes } \\
\text { con santa Rosay } \\
\text { santa Teresa }\end{array}$ & 1628 & Almagra & $\begin{array}{l}\text { Tierra } \\
\text { sombra, } \\
\text { Albayalde }\end{array}$ & $\begin{array}{l}\text { Blanco } \\
\text { de plomo } \\
\text { Bermellón } \\
\text { Tierra } \\
\text { sombra }\end{array}$ & $\begin{array}{l}\text { Blanco } \\
\text { de plomo } \\
\text { Verdigris o } \\
\text { Verde de } \\
\text { malaquita, } \\
\text { Tierra ocre }\end{array}$ & $\begin{array}{l}\text { Blanco de } \\
\text { plomo, } \\
\text { Minio, } \\
\text { Azurita, } \\
\text { Negro hueso, } \\
\text { Tierra roja }\end{array}$ & & $\begin{array}{l}\text { Blanco de } \\
\text { plomo, Calcita, } \\
\text { Tierra ocre con } \\
\text { goetita }\end{array}$ \\
\hline $\begin{array}{l}\text { Santa Teresa } \\
\text { escritora }\end{array}$ & $\begin{array}{l}1628- \\
1630\end{array}$ & Marrón & $\begin{array}{l}\text { Albayalde, } \\
\text { Tierra roja }\end{array}$ & $\begin{array}{l}\text { Blanco } \\
\text { de plomo } \\
\text { Bermellon } \\
\text { Tierra roja }\end{array}$ & $\begin{array}{l}\text { Blanco de } \\
\text { plomo, } \\
\text { Verdigrís o } \\
\text { Verde de } \\
\text { malaquita, } \\
\text { Tierra roja }\end{array}$ & - & & $\begin{array}{l}\text { Blanco de } \\
\text { plomo, Minio }\end{array}$ \\
\hline $\begin{array}{l}\text { San Joaquín con la } \\
\text { virgen ñiña }\end{array}$ & 1646 & Almagra & $\begin{array}{l}\text { Tierra ocre, } \\
\text { Tierra } \\
\text { sombra, } \\
\text { Albayalde }\end{array}$ & - & $\begin{array}{l}\text { Blanco de } \\
\text { plomo, } \\
\text { Verdigrís o } \\
\text { Verde de } \\
\text { malaquita }\end{array}$ & $\begin{array}{l}\text { Tierra roja } \\
\text { con hematita }\end{array}$ & $\begin{array}{l}\text { Esmalte, } \\
\text { Azul } \\
\text { cobalto, } \\
\text { Azul de } \\
\text { Prusia }\end{array}$ & - \\
\hline El buen Pastor & $\begin{array}{l}\text { Segundo } \\
\text { cuarto } \\
\text { S.XVII }\end{array}$ & Marrón & $\begin{array}{l}\text { Calcita, } \\
\text { Albayalde, } \\
\text { Tierra roja }\end{array}$ & $\begin{array}{l}\text { Bermellón } \\
\text { Tierra roja }\end{array}$ & $\begin{array}{l}\text { Blanco de } \\
\text { plomo, } \\
\text { Verdigrís o } \\
\text { Verde de } \\
\text { malaquita }\end{array}$ & $\begin{array}{l}\text { Blanco de } \\
\text { plomo, Minio } \\
\text { Esmalte, } \\
\text { Tierra roja }\end{array}$ & $\begin{array}{l}\text { Esmalte } \\
\text { Azurita }\end{array}$ & $\begin{array}{l}\text { Blanco de } \\
\text { plomo, Tierra } \\
\text { enriquecida con } \\
\text { óxido de hierro }\end{array}$ \\
\hline San Juan Bautista & $\begin{array}{l}\text { Segundo } \\
\text { cuarto } \\
\text { S.XVII }\end{array}$ & Negruzca & $\begin{array}{l}\text { Sulfato } \\
\text { de calcio, } \\
\text { Albayalde, } \\
\text { Negro carbón } \\
\text { animal, Tierra } \\
\text { roja }\end{array}$ & $\begin{array}{l}\text { Bermellón } \\
\text { Tierra roja }\end{array}$ & $\begin{array}{l}\text { Blanco de } \\
\text { plomo, } \\
\text { Verdigrís o } \\
\text { Verde de } \\
\text { malaquita, } \\
\text { Tierra } \\
\text { roja con } \\
\text { magnetita }\end{array}$ & - & $\begin{array}{l}\text { Azul } \\
\text { ultramar, } \\
\text { Esmalte }\end{array}$ & $\begin{array}{l}\text { Blanco de } \\
\text { plomo, Tierra } \\
\text { roja con } \\
\text { hematita }\end{array}$ \\
\hline $\begin{array}{l}\text { San Pantaleón } \\
\text { medico y mártir }\end{array}$ & $\begin{array}{l}\text { Segundo } \\
\text { cuarto } \\
\text { S.XVII }\end{array}$ & Marrón & $\begin{array}{l}\text { Sulfato } \\
\text { de calcio, } \\
\text { Albayalde, } \\
\text { Tierra roja, } \\
\text { Rejalgar }\end{array}$ & $\begin{array}{l}\text { Bermellón } \\
\text { Tierra roja }\end{array}$ & $\begin{array}{l}\text { Blanco de } \\
\text { plomo, } \\
\text { Verdigrís o } \\
\text { Verde de } \\
\text { malaquita }\end{array}$ & $\begin{array}{l}\text { Tierra roja, } \\
\text { Blanco de } \\
\text { plomo, } \\
\text { Esmalte }\end{array}$ & Esmalte & \\
\hline $\begin{array}{l}\text { Inmaculada } \\
\text { Concepción }\end{array}$ & $\begin{array}{l}\text { Segundo } \\
\text { cuarto } \\
\text { S.XVII }\end{array}$ & Negruzca & $\begin{array}{l}\text { Sulfato } \\
\text { de calcio, } \\
\text { Albayalde, } \\
\text { Tierra con } \\
\text { magnetita, } \\
\text { Negro carbón } \\
\text { animal }\end{array}$ & Bermellón & $\begin{array}{l}\text { Verdigrís o } \\
\text { Verde de } \\
\text { malaquita }\end{array}$ & - & Esmalte & \\
\hline $\begin{array}{l}\text { Anunciación del } \\
\text { ángel a los pastores }\end{array}$ & $\begin{array}{l}\text { Segundo } \\
\text { cuarto } \\
\text { S.XVII }\end{array}$ & $\begin{array}{l}\text { Marrón } \\
\text { rojizo }\end{array}$ & $\begin{array}{l}\text { Albayalde, } \\
\text { Tierra ocre }\end{array}$ & Tierra roja & $\begin{array}{l}\text { Verdigrís o } \\
\text { Verde de } \\
\text { malaquita }\end{array}$ & $\begin{array}{l}\text { Blanco de } \\
\text { plomo, Tierra } \\
\text { roja }\end{array}$ & Esmalte & \\
\hline
\end{tabular}




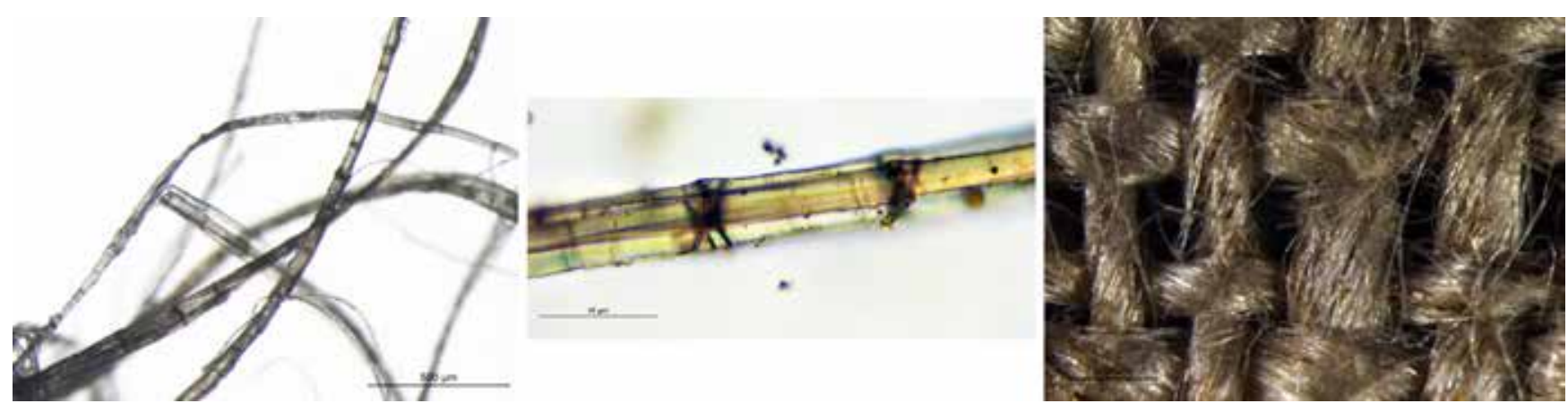

Figura 14.- Microfotografías de una muestra: de fibra MV8, luz transmitida polarizada, $\times 16-40 /$ de fibra BP5, luz transmitida polarizada, $\times 4-40 /$ del tejido del soporte MV8, luz incidente polarizada, $\times 8-25$

Respecto a la caracterización del soporte textil mediante el estudio morfológico de fibras [figura 14], se puede señalar que en todos los casos presentan nudos propios del lino o cáñamo. Y en cuanto a la caracterización del tejido del soporte, indicar que la torsión de los hilos es en Z y el tejido exhibe como ligamento tafetán, también denominado "a la plana".

\section{Conclusiones}

Gracias al protocolo utilizado en la obtención de radiografías de gran formato, se ha logrado aportar un amplio volumen documental inédito y de datos referenciados a través de las imágenes obtenidas. En ellas se ha podido no solo conocer el estado de conservación, el proceso creativo o la técnica de ejecución, sino que todo el conjunto de estas imágenes nos ayuda a comprender la forma de actuar de este pintor al quedar toda su gestualidad al descubierto. Resaltan datos como los numerosos arrepentimientos que muestra el pintor en su proceso de ejecución, así como aquellas figuras que han permanecido ocultas bajo la pintura hasta este momento $y$, sobre todo, los numerosos objetos que no están en el plano radiográfico debido a los añadidos a lo que Antonio Bisquert nos ha acostumbrado. La imagen radiográfica ha permitido mirar todo lo que el pintor fue imprimiendo desde el mismo momento del inicio de su proceso creativo en cada una de las obras. Al desvelar este proceso creativo se puede establecer una óptima estrategia de toma de muestras con la consiguiente identificación química de los pigmentos que constituyen la paleta de este artista, ofreciendo una visión de las distintas capas que conforman la historia de cada una de estas obras.

Por lo tanto, en virtud de la metodología experimental interdisciplinar aplicada en esta investigación sobre la producción artística (ocho obras pictóricas delimitadas a la ciudad de Teruel) del pintor Antonio Bisquert, se ha logrado valorar adecuadamente la relevancia de una obra que es indudablemente merecedora de un espacio significativo dentro de la historia del arte.

\section{Agradecimientos}

A la Diócesis de Teruel y Albarracín por asumir gastos de los traslados temporales de las obras a las instalaciones radiográficas de la Universitat Politècnica de València y depositar su confianza en el equipo de investigación.

Al Instituto de Estudios Turolenses por la concesión del XXXI Concurso de ayudas a la investigación, en 2014, "Estudios técnicos de la obra de Antonio Bisquert. Nuevas aportaciones."

Agradecer a la Dirección General de Patrimonio Cultural del Gobierno de Aragón por aceptar y reconocer estos estudios de interés, dando sus certificados de permisos temporales.

Por último, los autores desean agradecer a Dra. Sofía Vicente Palomino, Profesora titular de universidad y Especialista en Conservación - Restauración de Textiles, Departamento de Conservación y Restauración de Bienes Culturales, Instituto Universitario de Restauración de Patrimonio de la Universitat Politècnica de València por su asesoramiento en la identificación de tejidos y ligamentos; a D. Manuel Planes i Insausti su soporte técnico recibido en el Servicio de Microscopía Electrónica de la Universitat Politècnica de València; y para finalizar, a Marina Herriges por su ayuda en la redacción del resumen en Portugués.

\section{Referencias}

BENITO, F. y VALLÉS, V., (1989). "Un proceso a Ribalta en 1618". Academia. Boletín de la Real Academia de Bellas Artes de San Fernando, 69: 158-159.

BERRIE, B.H., (1997).“Prusian blue". En Artists'pigments. A handbook of their history and characteristics, West Fitzhugh, E. (Ed.). National Gallery of Art, Washington, Archetype Publications, London, 3: 191-218.

BUIL, C., y LOZANO, J. C., (1995). “El pintor Antonio Bisquert”. En El pintor Antonio Bisquert, 1596-1646. Teruel: Instituto de Estudios Turolenses de la Excelentísima Diputación Provincial, 52. 
BURROUGHS, A. (1938). Art criticism from a laboratory. Boston: Brown and Company.

GETTENS, R. J. y WEST FITZHUGH, E., (1993). "Malachite and Green Verditer". En Artists' pigments. A handbook of their history and characteristics, Roy, A. (Ed.). National Gallery of Art, Washington, Archetype Publications, London, 2: 183-202.

KÜHN, H., (1993). "Verdigris and Copper Resinate". En Artists” pigments. A handbook of their history and characteristics, Roy, A. (Ed.). National Gallery of Art, Washington, Archetype Publications, London, 2: 131-158.

MADRID, J. A., (2000). Metodología para la mejora del contraste en el análisis radiográfico aplicado a la conservación y restauración de obras de arte. Valencia: Universitat Politècnica de València.

MADRID, J. A., (2006). Aplicación de la técnica radiográfica en la conservación y Restauración de bienes culturales. Valencia: Universitat Politècnica de València.

MADRID, J. A., (2013). “Use of telemetry X-ray techniques in largesize pictorial works". Ge-conservación, n5: 101-109.

MADRID, J. A., (2014). “Dos décadas de inspección radiográfica en España: retrospectiva y horizontes en un contexto de cambio tecnológico". Intervención. Revista Internacional de Conservación, Restauración y Museología, Escuela Nacional de Conservación, Restauración y Museografía-INAH, 10: 85-93.

MUCCHI, L., y BERTUZZI, A., (1983). Nella profondità dei dipinti. La radiografia nell 'indagine pittorica. Milan: Ed. Electa.

OSETE-CORTINA, L., DOMÉNECH-CARBÓ, M. T., YUSÁ-MARCO, D. J., AHMADI, H., (2010). "Multimethod analysis of Iranian Ilkhanate ceramics from the Takht-e Soleyman palace", en Analytical Bioanalytical Chemistry, 397:319-329.

ROY, A., (2007). "Cobalt blue". En Artists' pigments. A handbook of their history and characteristics, Berrie, B. (Ed.). Oxford University Press, National Gallery of Art, Washington, 4: 151-178.

\section{Autor/es}

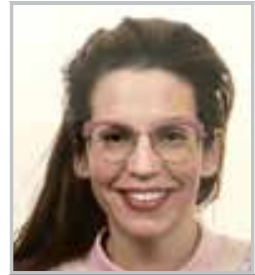

\section{Belén Díez Atienza}

bediat@unizar.es

Conservadora y restauradora en el Obispado de Teruel y Albarracín

Doctora en Conservación y Restauración de Bienes Culturales en la Universitat Politècnica de València con la tesis doctoral Estudio técnico de la producción pictórica de Antonio Bisquert en Teruel. Conservadora y restauradora en el Obispado de Teruel y Albarracín y técnico supervisor del Museo de Arte Sacro de Teruel.
Como profesora asociada imparte docencia en el Grado de Bellas Artes de la Facultad de Ciencias Sociales y Humanas de Teruel. Profesional en activo ha trabajado en numerosas responsabilidades de restauración de bienes culturales en proyectos de recuperación de bienes eclesiásticos en retablística, pintura sobre tabla y madera. .

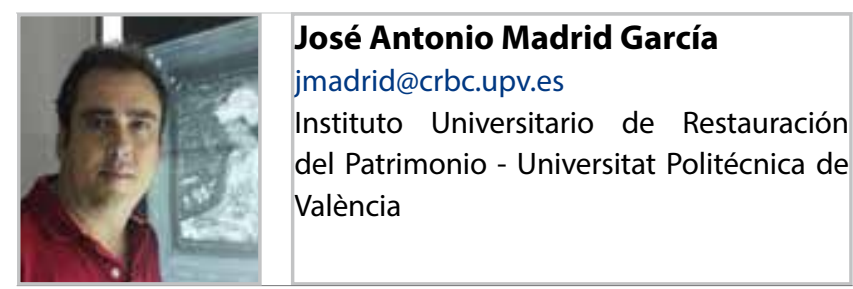

Doctor en Conservación y Restauración de Bienes Culturales en la Universitat Politècnica de València. Profesor Titular de Universidad, en el Departamento de Conservación y Restauración de Bienes Culturales, de la Facultad de Bellas Artes y responsable del Laboratorio de Documentación y Registro en el Instituto Universitario de Restauración del Patrimonio de la Universitat Politècnica de València.

Como profesor imparte docencia tanto en el Grado de Conservación y Restauración de Bienes Culturales como en el Master Oficial de Conservación y Restauración de Bienes Culturales. Dentro de su docencia imparte asignaturas relacionadas con la teoría de la conservación y Restauración de Bienes Culturales, la aplicación del análisis radiográfico o los sistemas de gestión y catalogación en relación con los Bienes Culturales. Ha dirigido un gran número de trabajos final de grado y así como varias tesis doctorales. Supervisor Responsable de la Instalación Radioactiva asociada al Instituto Universitario de Restauración del Patrimonio de la Universitat Politècnica de València, ha dirigido su línea de investigación a la realización de radiografías de gran formato de obras bidimensionales y tridimensionales.

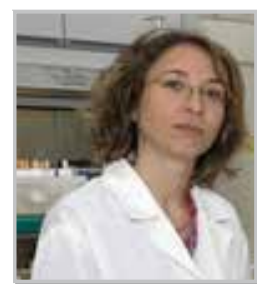

\section{Dolores Julia Yusá Marco}

doyumar@crbc.upv.es

Instituto Universitario de Restauración del Patrimonio - Universitat Politécnica de València

Doctora en Química por la Universitat de València. Profesora Titular de Universidad en el Departamento de Conservación y Restauración de Bienes Culturales, de la Facultad de Bellas Artes de la Universitat Politècnica de València (UPV). Investigadora miembro del Instituto Universitario de Restauración del Patrimonio (UPV). Como profesora imparte docencia tanto en el Grado de Conservación y Restauración de Bienes Culturales como en el Master Oficial de Conservación y Restauración de Bienes Culturales. Sus asignaturas versan sobre la caracterización química de los materiales integrantes del Patrimonio, tanto a nivel de química básica como a nivel de técnicas analíticas instrumentales avanzadas. Ha dirigido un gran número de 
trabajos final de master y de grado, y varias tesis doctorales. Lidera una línea de investigación basada en el desarrollo de metodologías de análisis y control para la caracterización química y de las propiedades mecánicas y dimensionales de obra textil, en la que ha desarrollado diversos proyectos de investigación en los que ha sido investigador principal. También, destacaremos su colaboración como investigadora en otras líneas de diferentes áreas de la Conservación y Restauración de Bienes Culturales. Los resultados obtenidos han sido publicados en revistas científicas de elevado índice de impacto, así como en congresos nacionales e internacionales.

\author{
Artículo enviado el 03/10/2018 \\ Artículo aceptado el 21/08/2019
}




\section{Introdução}

A Urna do Santíssimo (Thesaurus, 2004: 195) do Museu de Aveiro/Santa Joana, com número de inventário 129/M, representa um sacrário em forma de urna ou de arca, poligonal, seccionada e com uma tampa articulada, com fechadura e chave, no qual se conserva, num cálice, a hóstia consagrada, simbolismo do corpo de Cristo na Quinta-feira Santa, momento em que se comemora a Última Ceia e, a partir do qual, se institui a Eucaristia. A Urna corresponde à tipologia de objeto litúrgico, de utilização restrita (uma vez por ano), circunscrita à adoração do Santíssimo Sacramento, de Quinta para Sexta-feira Santa. O exemplar em análise do Museu de Aveiro, Santa Joana (MA/SJ), obra de arte do século XVIII, em madeira entalhada, dourada e policromada, produz um efeito cenográfico acentuado devido à incidência da luz na folha de ouro, sendo este efeito, também, característico do tempo Barroco, tal como ilustra a figura 1a. Esta peça esteve durante décadas num depósito que reporta ao período de constituição do Museu Regional de Aveiro [figura 1b].

Associando ao material o espiritual, esta peça é, como tal, evocativa da realidade de um lugar não visível -
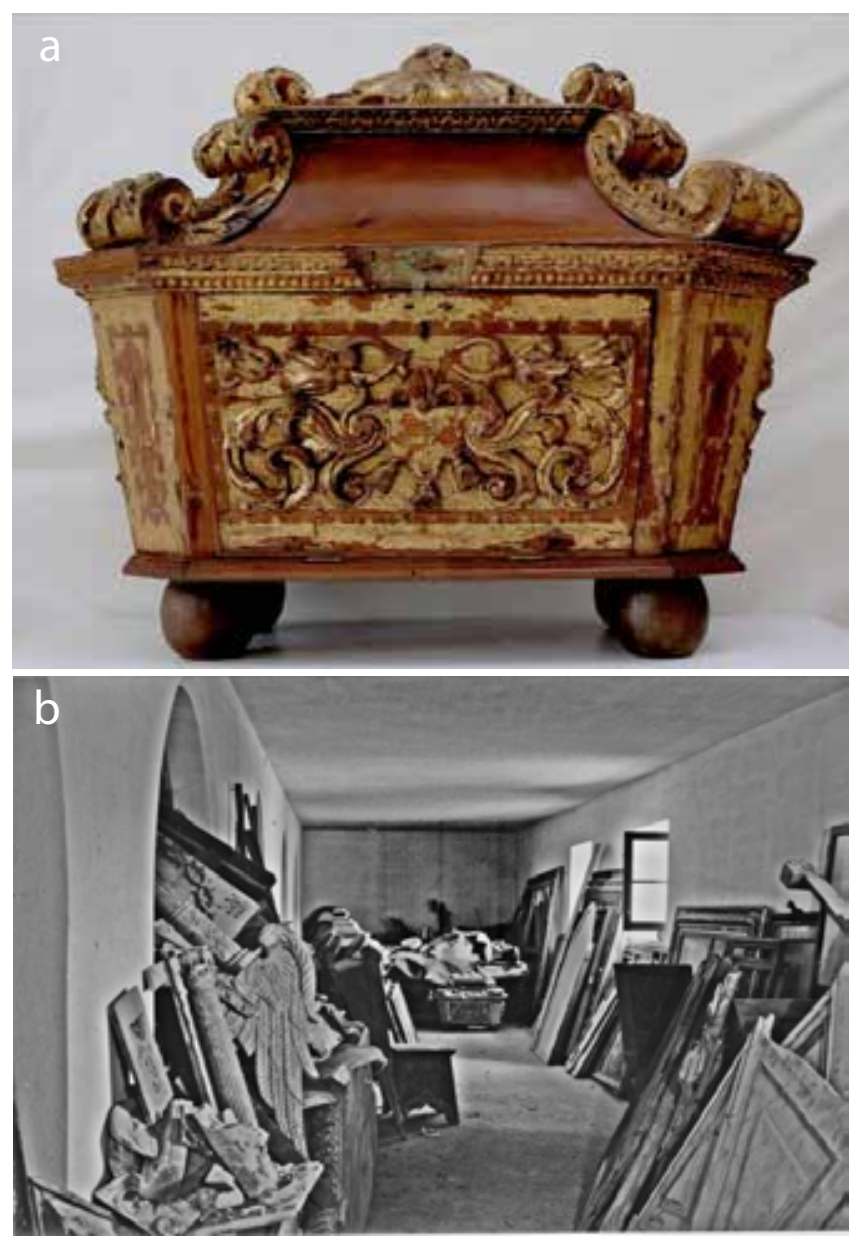

Figura 1.- a) Urna do Santíssimo, século XVIII, n. ${ }^{\circ}$ inv. ${ }^{\circ}$ 129/M; madeira entalhada, dourada e policromada. Coleção do Museu de Aveiro / Santa Joana. (Fonte: própria); b) Depósito de peças em talha. Década de 1980. (Fonte: Arquivo do MA). um sepulcro - que está além (para lá da vida), e aquém (do lado de cá) da proximidade dos sentidos. É a materialização do invisível (Freedberg 1992: 214-224). A Urna do Santíssimo, esculpida em madeira, materializa uma imagem icónica que pelo efeito luminoso da folha de ouro nos é revelada. Esta dialética da imagem e dos seus recursos/efeitos intrínsecos traduzidos em signos, presentes e/ou ausentes na imagem, remetem para o pensamento dissertado por Régis Debray no seu livro intitulado Vie et Mort de l'ímage: "The image here has its light in-built. It reveals itself. With its source in itself, it becomes in our eyes its own cause. Spinozist definition of God or substance." (Debray 1992: 382).

A peça revela-se ela mesma, e a sua leitura visual é tida como imagem substituta da presença de um corpo, ou, ainda, é entendida como imagem-objeto que repõe a ausência de uma presença divina (Debray 1992) e que o douramento aurifulgente revela ainda mais. Como tal, a Urna do Santíssimo costuma ser solenemente exposta à adoração dos fiéis durante os três dias finais da Semana Santa, em altar preparado para o efeito, sendo retirada dessa exposição no Sábado de Aleluia. A sua colocação em local destacado acontece simultaneamente com a evolução formal e espacial do retábulo português (Lameira 2005: 33) que passou a ser estruturado segundo um grande pórtico em cuja parte central, a partir de 1680, "recebe o trono para a exposição solene do Santíssimo Sacramento, caraterística e particularismo nacional por excelência, que só Portugal conhece. (...) Era o altar-trono." (Reinaldo dos Santos 1960: 103).

No topo da escadaria que desenha o Trono Eucarístico, colocada no corpo central do retábulo-mor da Igreja, seria exposta a Urna do Santíssimo.

\section{Descrição: morfologia da peça}

A Urna do Santíssimo assume, no caso presente, a forma de uma caixa poligonal, como se de um recetáculo multiangular se tratasse, com tampa e base de nível por forma a permitir a sua colocação sobre um suporte plano, na horizontalidade, mas elevado, para exposição e leitura frontal.

Importa referir, que o local idealmente pensado para estas Urnas do Santíssimo correspondia ao cimo do trono eucarístico, no altar-mor, seguindo a morfologia da peça a sua específica função: a de um recetáculo evocativo da morte, exposto, visível e resplandecente, mas não acessível, logo, algo distante na relação com o crente. A tampa é, por norma, piramidal e ostenta como elemento de fecho uma figura simbólica esculpida. No caso em estudo, a tampa tem em destaque uma composição floral que remata com elementos em voluta; o fecho poderia ser um segmento de frontão ou um elemento figurativo, sendo o mais comum a representação do Agnus Dei ou Cordeiro Pascal [figura 2].

Existem vários exemplos de Urnas do Santíssimo com tipologias e dimensões diversas, dependendo a qualidade 


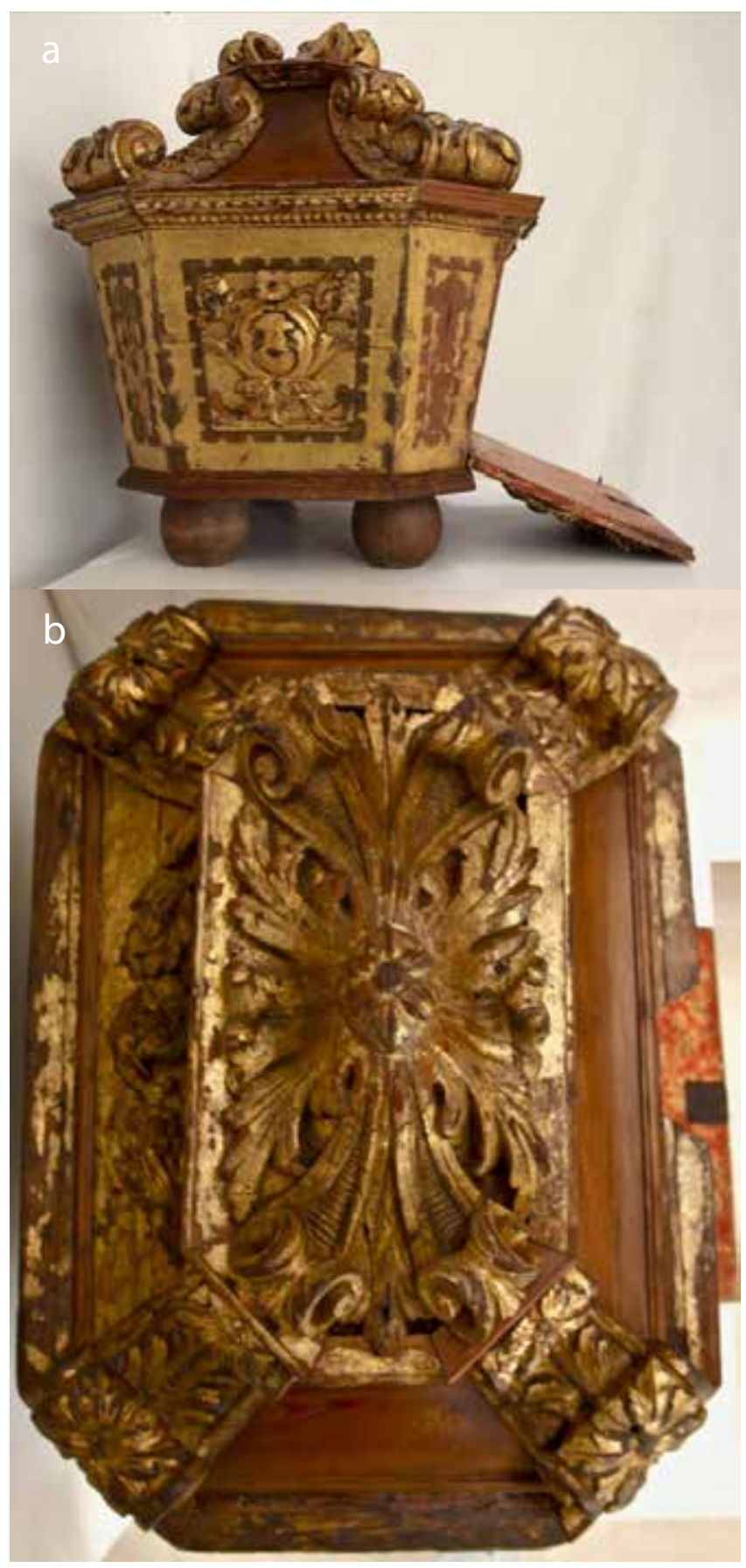

Figura 2.- a) Urna do Santíssimo: tampa piramidal, elementos em voluta com motivos fitomórficos. Porta frontal articulável. (Fonte: própria); b) Detalhe da tampa oitavada com os painéis trapezoidais do fecho. Composição floral entalhada e dourada. (Fonte: própria)

do recetáculo do valor da encomenda, do local para o qual era destinado e da escala do ostensório e/ou do cálice que neste era guardado e, por vezes, exposto. Ainda que não se conheça quem tenha executado o risco ou o projeto da Urna do Santíssimo, pertença do Museu de Aveiro, Santa Joana, sabe-se que os modelos migravam a partir da circulação de croquis, de modelos e de gravuras (Seruya et. al 2002: 148) para a execução de peças idênticas, quer fossem esculpidas pelo entalhe da madeira, ou modeladas e cinzeladas em prata e/ou em outros materiais.
No que reporta à proveniência da Urna do Santíssimo do Museu de Aveiro, consultamos fontes documentais que se encontram no Museu de Aveiro, conforme consta dos inventários de 1922 e 1942. Encontramos mais dados a partir dos Livros de Inventário de todos os bens e alfaias pertencentes à Confraria do Santíssimo Sacramento da Freguesia da Vera Cruz de Aveiro, da Junta Paroquial da Freguesia da Vera Cruz, para o ano de 1836 [1] acessíveis na base de dados de leitura virtual do Arquivo Distrital de Aveiro, da Direção Geral do Livro, dos Arquivos e das Bibliotecas e que se passa a descrever:

"existência na Sacristia do Reverendo Párocho de Vera Cruz de uma cápsula de páo, com sua talha dourada, e que tem a porta na frente" (...) "existência de uma outra cápsula de páo, com uma talha dourada, e que tem a porta de lado" (...). (pt/ adavr/dio/issavr 12/006)

A descrição destas duas cápsulas, denominação antiga da alfaia litúrgica que reporta à Urna do Santíssimo, no Livro de Inventário do Santíssimo Sacramento, manuscrito, exigiu o cruzamento com outra documentação, tal como uma série de inventários produzidos em 1910-1911-19131916, provenientes do Arquivo Corrente do Ministério das Finanças. Nestes documentos são enumerados, listados e denominados os bens arrolados após a $1^{\text {a }}$ República, (os bens das Igrejas seculares e de Ordens Monásticas), transferidos por força legal no âmbito da Lei da Separação do Estado das Igrejas, publicada em 20 de abril de 1911 e, que no contexto de Aveiro, foram objeto de cedência ao, nesse caso criado, Museu Regional de Aveiro (1911-12). Decorre, em parte pelos motivos expostos anteriormente, que o trabalho de inventário de bens artísticos e/ou patrimoniais é um processo "em aberto" e em continuum, porque envolve uma miríade de fatores orientadores de cariz social, económico, político, histórico e artístico, sendo o trabalho de estudo e análise laboratorial dos materiais um dos fatores determinantes para a identificação conceptual, e de origem da cultura material. Neste sentido e, após a análise dos documentos acima citados, excluímos a proveniência da peça por análise comparativa com o exemplar existente na sacristia da Igreja da Vera Cruz. Está em aberto a confirmação do exemplar constante dos inventários de 1922 e de 1942 que reportam ao Convento das Carmelitas de Aveiro e ao Mosteiro de Jesus de Aveiro.

\section{Técnicas de construção e decoração}

Os pigmentos vermelhos são predominantes no interior da peça e têm aliados a si uma técnica específica de aplicação, a do estofado/esgrafitado, que neste caso consiste num tratamento cromático de tom vermelho sobre ouro, patente na imagem do interior da porta [figura 3a].

Distingue-se, na Urna do Santíssimo em análise, o detalhe do seu interior policromado segundo um desenho aberto a vermelho sobre folha de ouro [2], visível quando estamos próximos da peça e, quando em exposição, fruímos da 
possibilidade de ver o seu interior, através do rebatimento frontal de uma das faces maiores da caixa [figura 3b]. Esta face, movível, corresponde ao painel dianteiro do corpo da urna. A ampla zona policromada, com ouro subjacente ao desenho padronizado de motivos florais, produz um efeito decorativo que é obtido pela técnica do estofado, a qual permite imitar um tecido sedoso e brilhante, em que o amarelo do ouro implícito e parcialmente visível alterna sob o efeito vibrante do pigmento vermelho.

A esta técnica se associa uma outra, a do esgrafito, particularmente distinta pela ilusão ótica e tátil conseguida pela raspagem da tinta, de modo a deixar a folha metálica à vista, formando um padrão texturado. A técnica de estofo, tal como a de esgrafito, integram o leque das diversas técnicas decorativas que, na Idade Moderna catalisaram a evolução de um formulário artístico caraterístico da talha dourada, policromada e estofada a nível nacional, e ao qual daremos atenção ao longo do presente estudo.

A técnica de esgrafito, atrás enunciada, consiste na aplicação de uma camada pictórica opaca ou transparente sobre ouro polido, seguida da incisão ou remoção da
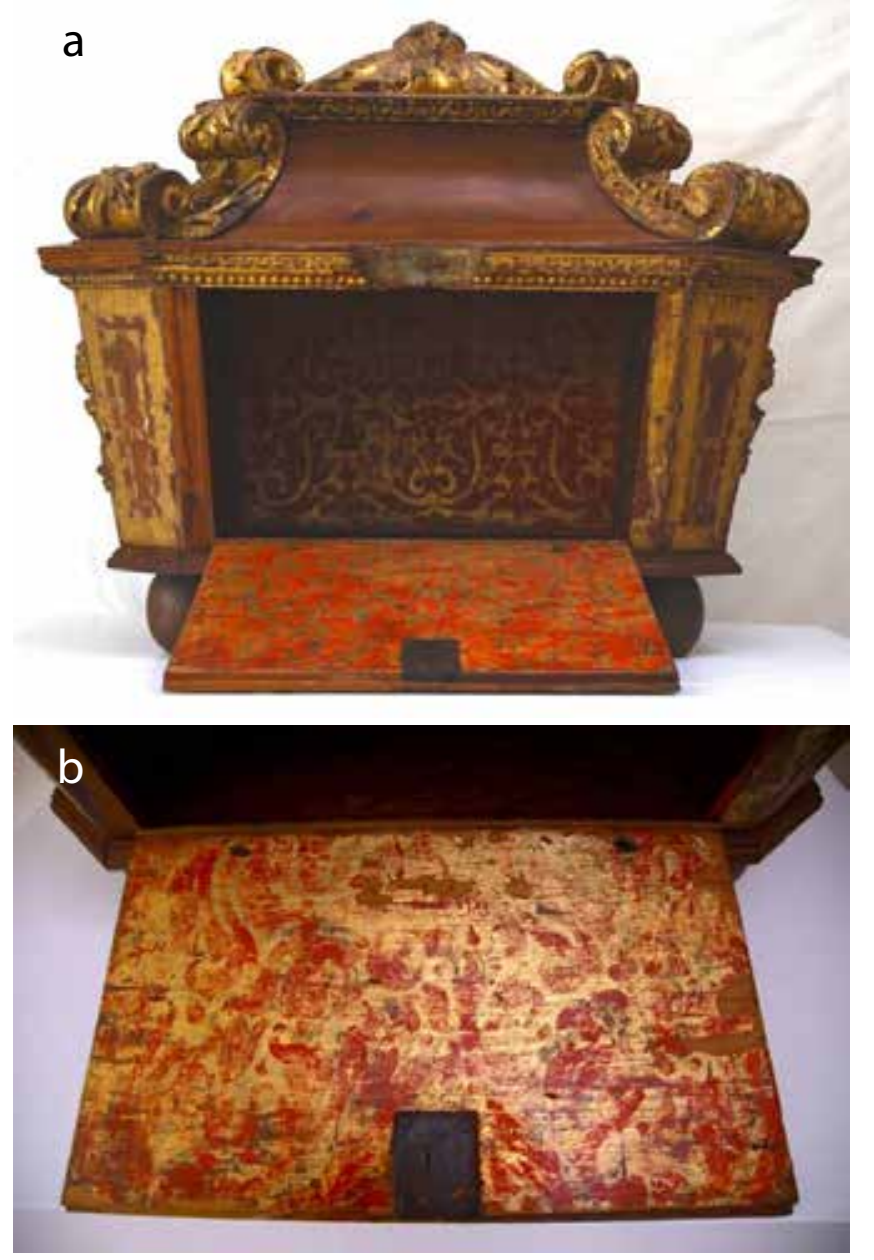

Figura 3.- a) Alçado principal e vista interior da Urna do Santíssimo. Detalhe do interior policromado, estofado e esgrafitado. (Fonte: própria); b) Painel dianteiro do corpo da urna, com fechadura; abre rebatendo através de duas dobradiças. (Fonte: própria) camada de cor [3] sob ação de um instrumento de ponta fina. A remoção da policromia permite o reaparecimento de ouro que subjaz à camada pictórica, que o reveste, e o delinear de motivos decorativos que neste caso são de inspiração vegetalista e floral. A equipa de investigação que elaborou um estudo comparativo em Portugal, Espanha e Bélgica das técnicas, alterações e conservação da escultura policromada religiosa dos séculos XVII e XVIII, documenta detalhadamente os procedimentos das várias práticas artísticas usadas à época, tal como a do esgrafito, referida no texto. Nas Atas do Congresso Internacional de Lisboa, "Policromia" (Seruya et al 2002) é referido, ainda, e no que reporta aos "décors" (Ibidem 2002: 144) pela equipa portuguesa de investigadores, nomeadamente por, Isabel Ribeiro, Alexandrina Barreiro, Paula Romão e Agnès Le Gac, que este método dito "à sgraffito" nasce em Itália no século $\mathrm{XV}$, tendo migrado para os Países-Baixos meridionais nos finais de quinhentos, tendo sido amplamente usado nas oficinas de Anvers e de Malines. Este sistema decorativo, tido como um método tradicional de decoração policroma, seria abandonado nestes territórios a Norte durante os séculos XVII e XVIII, mas, contrariamente, manter-se-ia na Península Ibérica onde se continuaria a expandir de modo excecional durante todo o período barroco (Ibidem 2002: 144 -145).

Do ponto de vista da sua conceção e suporte a Urna é constituída por várias peças que uma vez unidas formam o conjunto em forma de cápsula fechada. O elemento de fecho, a tampa, apresenta no interior um espaço escavado de forma côncava que mantém a cor natural da madeira, onde se podem ver as marcas das goivas utilizadas. Esta concavidade confere maior leveza e homogeneidade ao elemento de fecho; tem como remate um tabuleiro plano, oitavado, que segue o desenho do corpo da caixa composto por nove painéis oblíquos, estáveis e bem conservados.

A estrutura da Urna é fixa através de samblagens simples a topo e a meia esquadria, reforçadas por pregos de ferro sem qualquer tipo de encaixe ou de cola [figura 4a]. Caso particular para os quatro cantos da tampa onde existe um rasgo em $V$, de modo a receber os painéis côncavos da tampa, que por sua vez, têm samblagem à meia esquadria. Entre os oito elementos da Urna é visível um material têxtil, que aparentemente corresponde a uma matéria orgânica de cânhamo ou linho, à qual não fizemos quaisquer exames, e que serve para reforçar as uniões e para reparar as fendas. Os elementos de talha foram fixos á estrutura por meio de pregos (originalmente eram poucos, tal como refere o relatório realizado pela equipa responsável pela intervenção de restauro, em 2002, no I.P.C.R.) [figura 4b].

Foram construídos a partir de uma única peça de madeira (elemento a elemento), o topo da tampa, o painel traseiro, a porta, as ilhargas, os lados menores e o fundo do corpo, assim como alguns elementos decorativos. O remate superior, os quatro cantos, o painel da tampa e alguns elementos de talha foram construídos a partir de mais de uma peça (por partes unidas). 

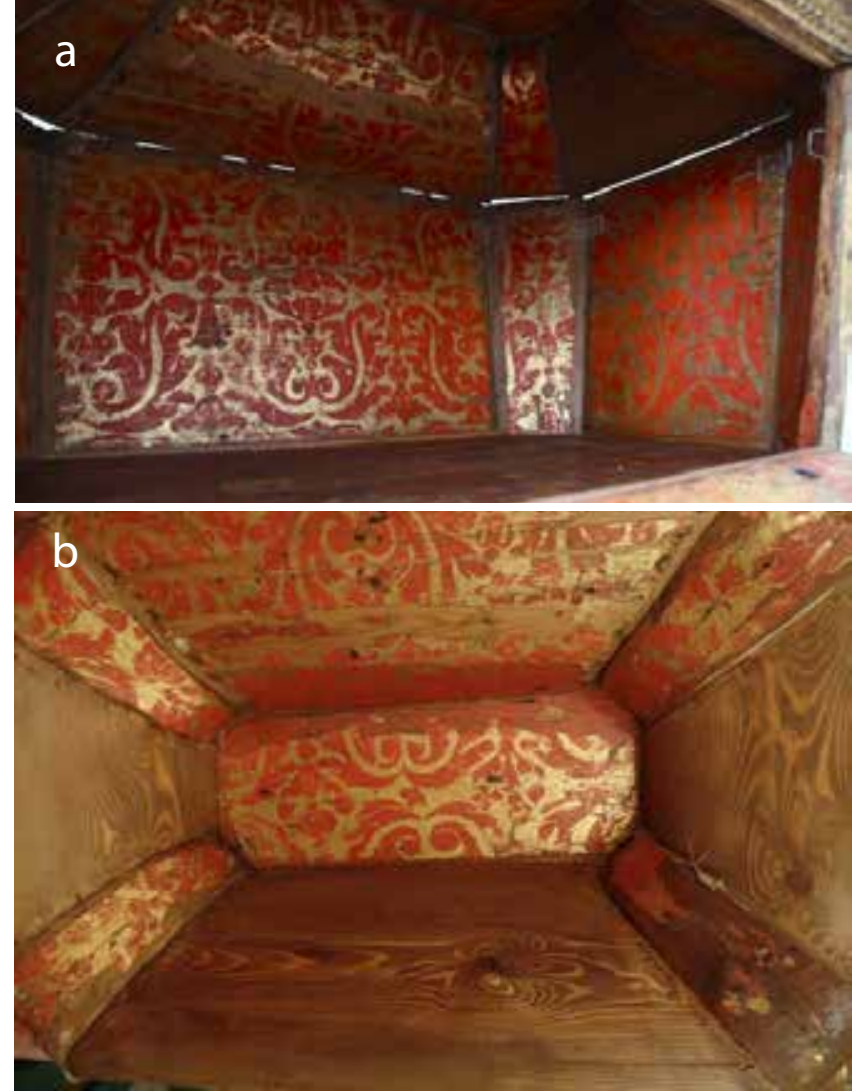

Figura 4.- a) Corpo central da urna, com samblagens simples a topo e a meia esquadria. (Fonte: própria); b) Interior da tampa oitavada, painéis côncavos trapezoidais e samblagens. (Fonte: própria)

Os pés da Urna são constituídos por quatro esferas de madeira maciça torneadas, fixas por vários pregos colocados de forma equidistante nos quatro extremos do tabuleiro inferior. Do ponto de vista da composição, as esferas dotam de autonomia e leveza o conjunto integrado (corpo e tampa), e imprimem maior sustentabilidade e equilíbrio à peça. No entanto, e de acordo com o relatório do I.P.C.R. (Abreu 2002: 103), as dúvidas acerca destas "esferas" consistem no seguinte:

“ (...) Existem ainda grandes dúvidas sobre a originalidade dos pés. Não só por serem de uma essência de madeira diferente do resto da Urna, mas também porque não apresentam qualquer tipo de decoração, o que choca com o resto da peça que se apresenta decorada. Não se pode concluir nada se os pregos se encontram ou não sobre a policromia do fundo, pois esta é uma área que apresenta grandes lacunas, no entanto são visíveis os pregos (apesar de os pés, com exceção de um, se encontrarem separados do fundo) que foram colocados arbitrariamente. (...) " (Relatório do I.P.C.R. 2002:103).

\section{Materiais de suporte, sua caracterização e conservação}

Uma particularidade, no que reporta à estrutura da respetiva Urna do Santíssimo, é que às "esferas" (pés) de madeira maciça, foi retirado um fragmento de madeira na vertical, em "cunha", talvez com o objetivo de evitar o aparecimento de fendas devidas aos movimentos naturais de retração vs. expansão da madeira (higroscopia das madeiras). Igualmente peculiar é o desenho escavado no interior do tabuleiro superior, que contrapõe ao da base, e que sustenta a tampa piramidal, em madeira, entalhada e dourada. Este remata com uma composição floral, em folhagem de acanto, e uma pinha esculpida ao centro. A fixação aos painéis trapezoidais da tampa é obtida através de pregos (não originais) provocando, do ponto de vista da conservação, alterações físicas graves: grande número de fendas profundas, no sentido do veio da madeira, e ainda, em zonas onde existem elementos metálicos. Estas fissuras são uma resposta da madeira face ao aumento de volume provocado pela oxidação dos metais. Verificou-se ainda, um ligeiro empeno do painel trapezoidal de suporte à composição de remate da tampa, forçado a manter uma forma côncava quando fixo à estrutura.

No relatório do I.P.C.R. (Ibidem 2002: 103) é justificado este empeno pelo movimento natural da madeira, os de retração vs. expansão, que de modo quase natural reajustaram o painel à sua forma original.

A Urna apresenta graves problemas de conservação visíveis na camada preparatória, no douramento e na policromia. Estes problemas de conservação remetem-nos para as ancestrais técnicas do "aparelhar" [4] da talha (Alves 1989: 188), sendo este "aparelhar" o momento prévio à aplicação da camada de policromia, que iria cobrir as partes visíveis e decoradas da peça. O aparelhar consistia na aplicação de várias mãos de gesso antecedida da encolagem (cola animal ou vegetal; cola de alhos). Sobre a cola destacamos os ensinamentos sistematizados por Natália FerreiraAlves sobre as técnicas utilizadas na execução da talha e douramento incluindo referencias ao "Tratado da Arte da pintura. Simetria e perspectiva" de Filipe-Nunes (1615; 1982: 100-101) plasmadas em contratos de douramento de retábulos contendo indicações precisas sobre a encolagem e sobre a cola de alho ou "alhada" (Ferreira-Alves 1989: 202). Vários investigadores afirmam que muitas peças de madeira entalhada, dourada e policromada, seriam cobertas por uma camada preparatória à base de colofónia (pez - louro - breu, resina) (Seruya et. al 2002: 129). A questão da aplicação ou não da encolagem ou, tal como é denominada na Bélgica de um bouche-pores ou de uma aguacola em Espanha, antes da camada de preparação sobre a madeira, é algo ainda não sistemático nem metodologicamente consentâneo para todos os casos relacionados com a escultura em madeira, com vista a ser dourada e/ou policromada (Ibidem 2002: 130). As preparações com base em gesso (carbonato de cálcio) e cola animal para cobrir, impermeabilizar e homogeneizar as madeiras variam de acordo com as zonas geográficas, com os centros de produção artística, com as matérias em uso, com o período temporal, entre outros fatores (Ibidem 2002: 130-135). No caso em análise podemos destacar, acerca do tratamento da policromia e do douramento, o que no relatório de restauro do I.P.C.R (456/AL/98/MOB 123: 2), era então referido: 
"A Urna foi dourada com folha de ouro, segundo a técnica húmida, que faz com que a superfície final tenha um aspeto metálico brilhante. Como a Urna do Santíssimo é do século XVIII, os artesãos nesta altura regiam-se por receitas existentes em tratados, optou-se pela apresentação de uma receita de douramento segundo a técnica húmida, existente no Tratado de Filipe Nunes do século XVII, que de seguida se expõe:

"Para Acentar Ouro em Pedra, Pao e Vidro, e Couro": "(...) O ouro burnido se faz assi. Depois de estar o pao encolado lhe day hûa mão de gesso comum, e seja ao modo de lavadura delgado, e se na cola lhe botardes hûa cabeça de alhos serve para que não falte, depois lhe day três ou quatro mãos de gesso mate, o qual se faz assi. Tomase o gesso comu, e depois de moydo e peneirado se bota em hua panella chea de agoa clara, e cada dia se lhe muda e se bate duas ou tres vezes, e aos dez dias fica gesso mate então tiray e sequay, e uzay delle. Depois de dardes estas mãos que digo, lhe dareis duas de bollo comum, e depois outras duas de bollo fino, e sejão todas estas mãos dadas com cola quente, depois de enxuto quando quereis dourar molhareis muito bem, e sobre o molhado com agoa clara acentay o ouro, e depois de seco burni com o bornidor, que se faz de pederneira muito lizo e ficará o ouro muito fermoso. (...)" (Relatório do I.P.C.R., 1998-2002: 2); (Nunes, Philippe, Fac-simile da ed. $1615,1982, \mathrm{p:}$ 125).

A camada de preparação geralmente aplicada sobre uma camada de cola animal (encolagem) era, tal como é registado por Beatriz Coelho, conservadora-restauradora, uma matéria identificada, por norma, da seguinte forma:

"branca e constituída por cola animal e carga, distribuída, especialmente em obras eruditas, por duas camadas: a primeira, mais próxima ao suporte, servindo também para corrigir alguma imperfeição da talha e ainda apresentando impurezas." (Coelho 2002: 248).

No caso da Urna os dourados são constituídos, tanto no interior como no exterior, pelo bolus e folha de ouro colocados sobre a preparação. O bolus, dito bolus arménio, é a matéria de que é feita a camada aplicada sobre a preparação branca antes da aplicação da folha metálica, neste caso, folha de ouro. $\mathrm{O}$ bolus pode ter colorações distintas de acordo com o País, o Território e a Oficina, podendo ser amarelo, ocre, laranja, vermelho e castanho (Garcia 2002: 238).

\section{Análise elementar para caraterização do ouro e policromia}

A caraterização dos elementos decorativos da peça, a talha dourada do exterior assim como o conjunto dourado e de cor vermelha do interior, foi realizada por microscopia eletrónica de varrimento (SEM) associada com análise elementar por espectroscopia de Raios X por dispersão de energia (EDX).
A utilização destas técnicas permite obter uma análise morfológica detalhada da superfície assim como uma análise química local. Uma característica das técnicas de microscopia eletrónica de varrimento é a utilização de um feixe de eletrões que vai "varrer" a superfície da amostra. Como resultado da interação entre o feixe de eletrões e os átomos da superfície, vários tipos de sinais são produzidos, como é o caso dos eletrões secundários e emissão de raios $X$. Os eletrões secundários resultam de interações inelásticas entre os eletrões do feixe e eletrões nas bandas de valência e de condução. Dada a relativamente baixa energia destes eletrões, estes são originados a uma profundidade de apenas alguns nanómetros abaixo a superfície da amostra pelo que a informação obtida pela análise destes eletrões é essencialmente topográfica. Por sua vez, a análise da emissão de raios $X$ permite obter uma informação composicional. O perfil de energias da radiação emitida (isto é, os valores em energia de raios $X$ emitidos que chegam ao detetor) é resultado de transições eletrónicas nos átomos e características de cada elemento químico, pelo que podem ser inequivocamente atribuídas a cada elemento presente na amostra. Associando assim à informação morfológica é possível obter informação composicional pontual e local que em conjunto com o processo de "varrimento" permite obter informação espacial dos elementos presentes na amostra.

Através da análise dos cortes estratigráficos das amostras obtivemos informação estratigráfica das várias camadas constituintes do processo de douramento aplicado sobre o suporte de madeira. Na Figura 5 apresenta-se em detalhe um corte estratigráfico da região correspondente à talha dourada decorativa presente no exterior da peça, de baixo para cima: a camada de preparação e o boles; a camada da folha dourada e finalmente a camada relativa à cola de montagem utilizada na preparação das peças para análise. A utilização das técnicas de microscopia eletrónica em conjunto com as técnicas de análise de EDX permitem construir uma imagem de "mapa" elementar em que a informação topográfica é complementada pela informação composicional da amostra [Figura 5b]. Desta forma e analisando a região correspondente à folha dourada (cujo elemento principal é o ouro) e comparando com a imagem de microscopia eletrónica [Figura 5a], podemos estimar uma espessura tipicamente micrométrica $(7.5 \pm 1.5 \mu \mathrm{m})$ da folha, apesar de este valor poder estar majorado se admitirmos algum arrastamento desta camada, como resultado do processo de corte. A análise da folha de ouro por EDX-SEM [Figura 5d], permitiu identificar a presença de uma liga de ouro de elevada pureza (cerca de $87 \%$ ), com uma presença minoritária de prata e cobre [Tabela 1].

A camada de preparação e o bolo arménio, matérias utilizadas para permitir a aplicação da folha de ouro, foram também objeto de análise elementar [Figura 5c], o que permitiu identificar alguns dos seus constituintes, maioritariamente: alumínio, silício com traços de ferro, o potássio, o titânio, o cálcio e o magnésio [Tabela 2]. 

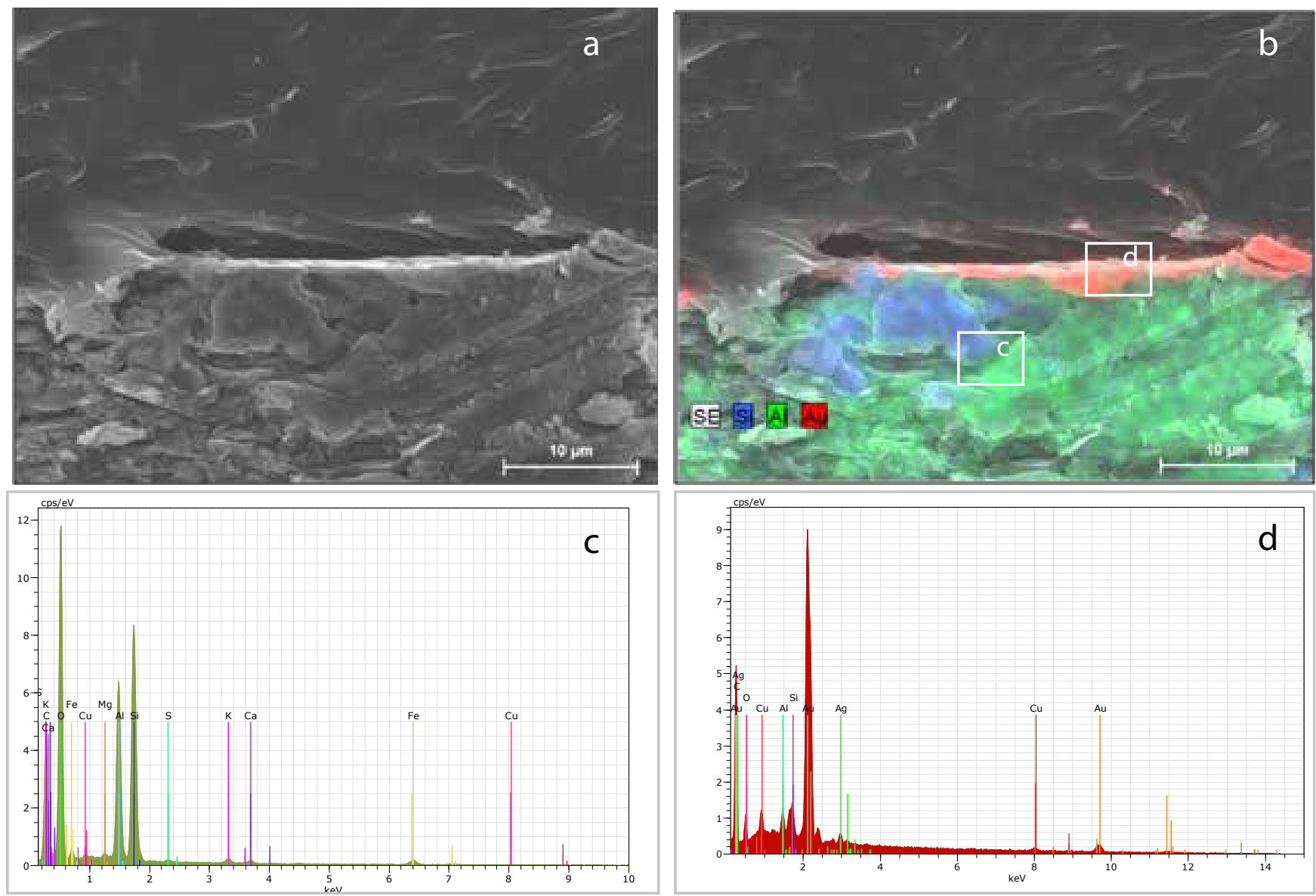

Figura 5.- a) Imagem de SEM de uma secção em corte transversal da talha dourada; b) Mapa de composição onde se identifica a folha dourada e a zona do "bolo" utilizado na fixação da folha de ouro; c) e d) espectros de EDX das regiões assinaladas.

Tabela 1.- Quantificação dos elementos presentes na região correspondente à folha de ouro na parte exterior da urna.

\section{Elemento (símbolo químico) Percentagem (\%) Erro (\%)}

\begin{tabular}{r|c|c}
\hline Ouro $(\mathrm{Au})$ & 87.67 & 4.76 \\
\hline Alumínio $(\mathrm{Al})$ & 0.66 & 0.13 \\
\hline Silício $(\mathrm{Si})$ & 0.86 & 0.14 \\
\hline Cobre $(\mathrm{Cu})$ & 7.65 & 0.64 \\
\hline Prata $(\mathrm{Ag})$ & 3.17 & 0.27 \\
\hline
\end{tabular}

Tabela 2.- Quantificação dos elementos presentes na região correspondente à zona do "bolo"

\section{Elemento (símbolo químico) Percentagem (\%) Erro (\%)}

\begin{tabular}{r|c|c}
\hline Silício $(\mathrm{Si})$ & 54.66 & 3.72 \\
\hline Alumínio $(\mathrm{Al})$ & 30.54 & 2.35 \\
\hline Magnésio $(\mathrm{Mg})$ & 1.08 & 0.18 \\
\hline Cobre $(\mathrm{Cu})$ & 1.74 & 0.28 \\
\hline Potássio $(\mathrm{K})$ & 1.99 & 0.20 \\
\hline Cálcio $(\mathrm{Ca})$ & 1.26 & 0.17 \\
\hline Enxofre $(\mathrm{S})$ & 0.86 & 0.15
\end{tabular}

Uma particularidade inconfundível da Urna do Santíssimo é a utilização de técnicas de decoração distintas na parte exterior e na parte interior da peça. Enquanto no exterior destaca-se a utilização da técnica de douramento sobre a superfície de madeira, a parte interior da Urna caracteriza-se pela decoração de cor vermelha sobre uma superfície dourada. A presença destas duas regiões é claramente distinguível quando analisamos por SEM uma zona de interface entre estes dois elementos [Figura 6a]. Na figura é evidente uma zona mais granular, do meio da figura para o canto inferior direito, e uma zona em que é possível observar estruturas semelhantes a finas folhas de material sobre uma superfície fibrosa, do meio da figura para o canto superior esquerdo. O "mapeamento" e respetiva análise elementar realizadas por EDX, permitemnos identificar estas duas regiões [Figura 6b] como zonas onde predomina o elemento mercúrio [Figura $6 d$ ] e zonas onde o elemento ouro é predominante [Figura 6c], respetivamente. As estruturas observadas, assim como as composições obtidas por EDX para as distintas regiões são compatíveis com a utilização de uma técnica de esgrafito, e na remoção da camada de cor, com o reaparecimento de uma camada de folha de ouro que surge assim exposta com poucos sinais de manuseamento. Na camada de cor vermelha, a presença dos elementos mercúrio e enxofre permitem- 
nos identificar o pigmento como sendo um sulfureto de mercúrio, matéria-prima a partir da qual o pigmento sintético era obtido. Sendo este pigmento sensível à luz, a camada de vermelhão colocada sobre a preparação mantém-se bem conservada, pelo facto de ter sido aplicada no interior da urna. A análise da pureza da folha de ouro, presente na decoração da parte interior da urna, obtida por análise de SEM-EDX, permitiu-nos identificar a presença de uma liga de ouro de elevada pureza, cerca de $82 \%$, com a presença de uma percentagem elevada de Ferro (cerca de $11 \%$ ) e elementos minoritários de Cobre, Titânio e Mercúrio [Tabela 3].

A comparação das composições das camadas de folha de ouro, presentes na parte exterior e na parte interior da Urna, permitem-nos estimar uma pureza de ouro que oscilava entre 19,68 e 20,88 quilates. O quilate é, pois, uma medida de pureza do metal, e não de peso. As diferenças observadas entre a percentagem de ouro presente no exterior da peça, cerca de $87 \%$ e os cerca de $82 \%$ de ouro presentes na preparação interior, poderão não corresponder à aplicação de materiais de diferentes graus de pureza, mas sim, como consequência do processo de remoção da policromia,
Tabela 3.- Quantificação dos elementos presentes na região correspondente à folha de ouro na parte interior da urna.

\section{Elemento (símbolo químico) Percentagem (\%) Erro (\%)}

\begin{tabular}{r|c|c}
\hline Ouro $(\mathrm{Au})$ & 81.87 & 4.89 \\
\hline Ferro $(\mathrm{Fe})$ & 10.79 & 0.57 \\
\hline Cobre $(\mathrm{Cu})$ & 3.43 & 0.30 \\
\hline Mercúrio $(\mathrm{Hg})$ & 2.62 & 0.36 \\
\hline Titânio $(\mathrm{Ti})$ & 1.30 & 0.17 \\
\hline
\end{tabular}

típico da técnica de esgrafito, processo este que poderá resultar na contaminação da camada de ouro com elementos da camada de pigmento, como é o caso do mercúrio e ferro.

Importou aqui esclarecer o significado de alguns termos técnicos ligados à aplicação do ouro nos mais diversos elementos de madeira entalhada e cuja evolução semântica nos foi exigido confirmar. Estes termos técnicos são na investigação em história de arte, essenciais à interpretação da documentação dos séculos XVII e XVIII
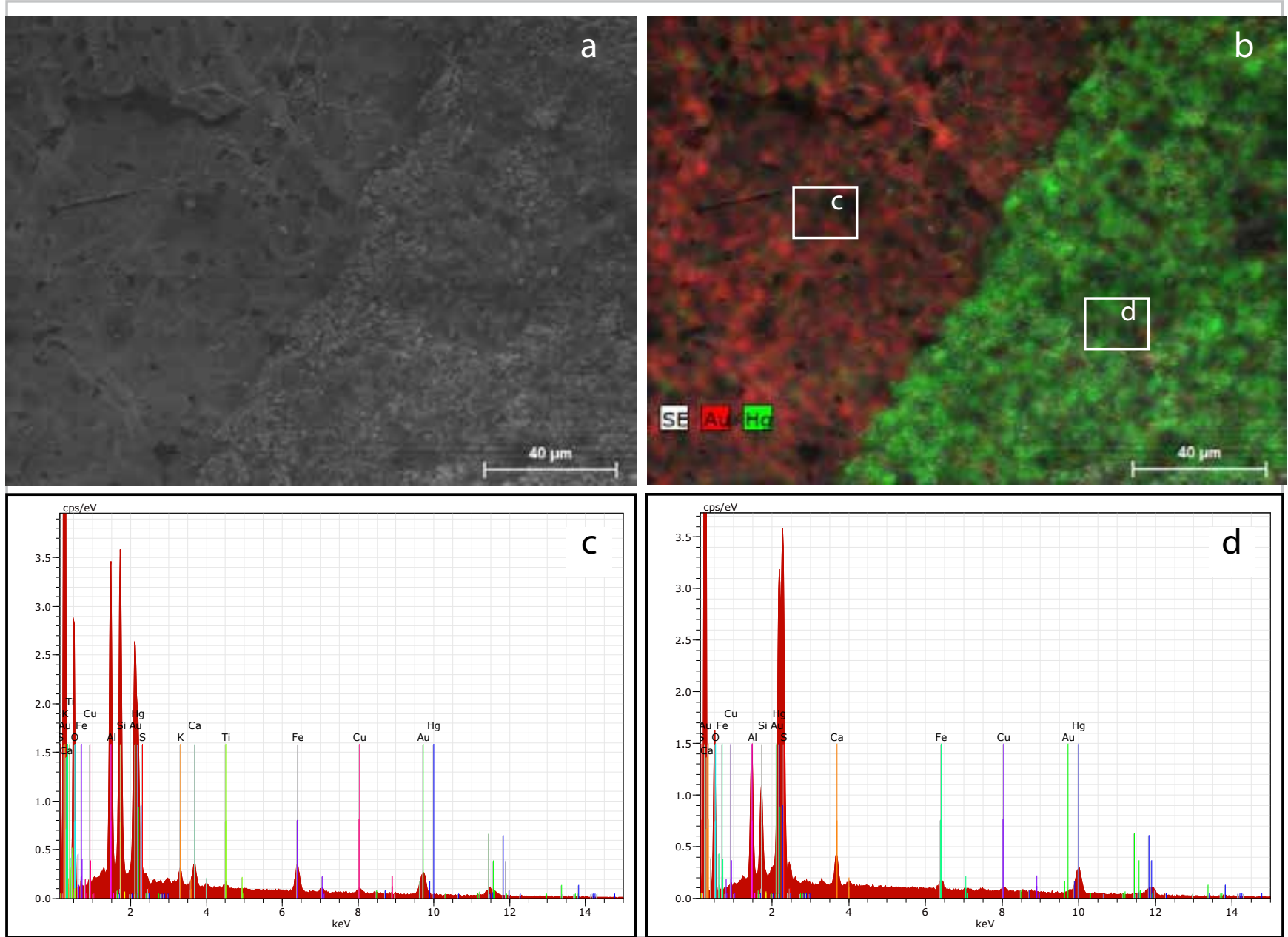

Figura 6.- a) Imagem de SEM que mostra em detalhe a interface entre a zona dourada e a região pintada de cor vermelha; $b$ ) Mapa de composição identificando as regiões onde predomina o elemento ouro (de cor vermelha) e o elemento mercúrio (de cor verde); c) e d) espectros de EDX das regiões assinaladas. 
respeitantes a contratos de douramento proveniente de encomendas que gravitavam, na sua essência, em torno da Igreja.

\section{As técnicas de caracterização:}

Microscópio eletrónico de varrimento (SEM) analítico e de alta resolução, de emissão Schottky (SE), da marca Hitachi, modelo SU-70, associado ao microscópio eletrónico encontra-se um sistema de microanálise por espectrometria de dispersão de energias de raios-X (EDX), marca Bruker, modelo QUANTAX 400.

A amostragem foi realizada utilizando um pequeno extrator tubular manual de diâmetro inferior a $2 \mathrm{~mm}$, em zonas pouco visíveis da peça e/ou que apresentavam algum dano. As amostras foram posteriormente fixas a suportes específicos de SEM utilizando fita-cola condutora de carbono. As amostras vistas em corte estratigráfico foram embebidas em cola termoplástica e posteriormente seccionadas transversalmente com uma lâmina de corte, de forma a expor a secção da região desejada para a análise.

\section{Conclusão}

A utilização de técnicas avançadas de caracterização de materiais, como as técnicas de Microscopia eletrónica de varrimento e de espetroscopia de raios $X$ por dispersão de energia (SEM-EDX), permitiram, não só uma análise morfológica detalhada das técnicas decorativas presentes na Urna do Santíssimo, mas também uma análise local composicional da folha de ouro, das camadas de preparação e de pigmentos inorgânicos presentes na peça. A elevada pureza da folha de ouro utilizada na preparação da talha dourada exterior da Urna, justifica a expressão "do mais subido e gemado" que correspondia, também, a uma cor dourada intensa da folha de ouro aplicada. Para o caso em concreto fica a faltar o documento contratual. No entanto, este resultado confirma o que na expressão "do mais subido e gemado", muito comummente aplicada nos contratos de obra estabelecidos nos séculos XVII e XVIII, era deveras demandado, especificações acerca da qualidade exigida ao ouro a aplicar na obra de talha. No caso dos elementos decorativos presentes no interior da peça, a análise morfológica e composicional, permitiu a identificação de um processo de remoção da policromia, típico da técnica de esgrafito, assim como identificar o pigmento inorgânico de cor vermelha como sendo sulfureto de mercúrio.

\section{Agradecimentos}

CICECO - Instituto de Materiais de Aveiro, Departamento de Física da Universidade de Aveiro
Ana Violeta Girão, Investigadora do Departamento de Engenharia de Materiais e Cerâmica

DGPC - Laboratório José de Figueiredo, Conservação e Restauro Câmara Municipal de Aveiro, DCT, Museu de Aveiro / Santa Joana

\section{Notações}

[1] Junta Paroquial da Freguesia da Vera Cruz de Aveiro, Livros de Inventário de todos os bens e alfaias pertencentes à Confraria do Santíssimo Sacramento, Documento manuscrito, fl. 8 (1836). https://digitarq.adavr.arquivos.pt/details?id=1290114 (consulta:4/10/2018)

[2] Técnica registada no relatório de Restauro do I.P.C.R. (2002), c/ n. 456 / Guia 34/98, Restauro: AL/98, Proc. MOB (Mobiliário), $\mathrm{n}^{\circ} .123$.

[3] Em "Policromia", Atas do Congresso Internacional, Lisboa, 29, 30 e 31 de Outubro de 2002.

[4]Natália Marinho Alves (1989). “A Arte da Talha...,' Vol. I, p:188

\section{Referências Bibliográficas}

ABREU, P.C. et. al (1998-2002). “Relatório do Exame e Tratamento de Mobiliário no IPCR". Documentação no Instituto Português de Conservação e Restauro, MOB 123, Restauro AL98, Lisboa: IPCR

AGUIAR, A. (1954). "Mobiliário Português do Século XVIII (Achega para o seu estudo) ". Revista Ocidente, vol. XLVIII, Lisboa: Tipografia da Editorial Império Lda.

FERREIRA-ALVES, N. M. F. (1989). A Arte da Talha no Porto na Época Barroca (Artistas e Clientela. Matérias e Técnica). Volumes I e II. Arquivo Histórico. Porto: Câmara Municipal do Porto.

BIDARRA, A; COROADO, J.; ROCHA, F. (2009). “Gold leaf analysis of three baroque altarpieces from Porto', Archeo Science, Revue d'Archéométrie 33: 417-422, https://doi.org/10.4000/ archeosciences. 2552

BIDARRA, A., COROADO, J., ROCHA, F. (2010). “Contributos para o estudo da folha de ouro de retábulos Barrocos por microscopia ótica e eletrónica", Ge-Conservación, 1: 83-191.

BIDARRA, A; BUZANICH, G.; COROADO, J.; ROCHA, F. (2018). "Estudo tecnológico e composicional da folha de ouro de retábulos barrocos - bases para uma metodologia de investigação", Conservar Património, 29 41-50, https://doi. org/10.14568/cp2016035.

BIGELOW, D. et. al (1991). Gilded wood: conservation and history. Connecticut: Sount View Press, ISBN: 0-932087-21-3 
BRANDÃO, D. de P. (1984). Obra de talha dourada, ensamblagem e pintura na cidade e diocese do Porto. Documentação I, SÉCULOS XV A XVII, S/E, Porto.

CRUZ, P., GIRAULT, C., FERRÃO, D., (2002). "Relatório da disciplina de Seminário I da ESCR", ano letivo [98/99], Relatório de Estágio, IFROA, Maio/Julho [2001]., Relatório de Estágio, Julho /Setembro [2002], Lisboa: IPCR. DARQUECERETTI, E.; FELDER, E.; AUCOUTURIER, M., (2011). "Foil and leaf gilding on cultural artifacts; forming and adhe $\neg$ sion", Revista Matéria 16(1) 540-559, https://doi. org/10.1590/ $\underline{\mathrm{S} 1517-70762011000100002 .}$

DEBRAY, R. (1992). Vie et Mort de I'Image. Une histoire du regard en Occident. Paris: Gallimard. ISBN 9782072095665

GOLDSTEIN, J. I. (1975). Electron and ion microprobe analysis, em GOLDSTEIN, J. I., \& YAKOWITZ, H. (eds). Practical Scanning Electron Microscopy. Springer, Boston, 49-94, https://doi. org/10.1007/978-1-4613-4422-3 3 .

FERRÃO, B. (1990). Mobiliário Português, 4 vol., Porto: Lello e Irmão.

FERREIRA, S. MURTA, E. SANDU, I. C. A; PEREIRA, M. C. (2014). "Os púlpitos da Igreja de Nossa Senhora da Pena, em Lisboa: um estudo histórico, estilístico, técnico e material", Conservar Património 19 5-20, https://doi.org/10.14568/ cp2013009.

FREEDBERG, D. (1992). El Poder de Las Imagenes. Estudios sobre la Historia y la teoria de la Repuesta (v. Castelhana), Madrid: Ediciones Cátedra

GONZÁLEZ-ALONSO MARTíNEZ, E. (1997). Tratado del Dorado, Plateado y Su Policromía. Tecnología, Conservación y Restauración, Universidad Politécnica de Valencia, Valencia

GUEDES, N.C. et. al (2004). Thesaurus, Vocabulário de Objetos do Culto Católico, Vila Viçosa: Universidade Católica Portuguesa, Instituto de Coordenação de Investigação Científica, Mediateca Intercultural.

LAMEIRA, F. (2005). O Retábulo em Portugal, das origens ao declínio, Algarve; Évora: Departamento de História, Arqueologia e Património da Universidade do Algarve e Centro de História da Universidade de Évora.

LAMEIRA, F.; SERRÃO, V. (2003). “O retábulo proto-barroco da capela do antigo Paço Real Salvaterra de Magos (c. 1666) e os seus autores". Atas do II Congresso Internacional. Porto: Universidade do Porto, 215-226.

LE GAC, A. (2009). Le retable majeur de la Sé Velha de Coimbra et la polychromie dans le diocèse de Coimbra à l'époque baroque. Aspects techniques et esthétiques, tese de doutoramento, vol. 1, Universidade Nova de Lisboa, Lisboa.

MACTAGgART, P.; MACTAGgART, A. (2005). Practical Gilding, Archetype Publications, London
MARTINS, F. S. (1991). "Trono eucarístico do retábulo português: Origem, função, forma e simbolismo", Atas I Congresso do Barroco, [1989], Porto: Reitoria da Universidade, 17-58.

NICHOLSON, E. D. (1976). "The ancient craft of gold beating", Gold Bulletin 12(4) 161-166, https://doi.org/10.1007/ BF03215119.

SANDU, I; MURTA, E.; FERREIRA, S.; PEREIRA, M.; CANDEIAS, A.; MIRÃO, J.; MIGUEL, C.; PABA, F. (2014). "More than gold - an inter $\neg$ disciplinary, complementary study of gilding materials and techniques in Baroque altarpieces from Portugal", ECR - Estudos de Conservação e Restauro 6 13-37, https:// doi. org/10.7559/ecr.6.7522

SANDU, I.; PABA, F.; MURTA, E.; PEREIRA, M.; RIBEIRO, C. (2014) "Travelling beneath the gold surface - Part I: study and characterization of laboratory reconstructions of Portuguese seventeenth and eighteenth centuries ground and bole layers', e-conservation journal 2 94-115, https://doi. org/10.18236/ econs2.201413

SANTOS, R. dos. (1960). Arte Barroca, História del Arte Português, Barcelona: Labor, 103.

SMITH, R. C. (1962). A Talha em Portugal. Lisboa: Livros Horizonte.

SMITH, R. C. (1950). "The Portuguese Wood carved Retable,1600-1750", Belas Artes, 2. a série, n. 2, Lisboa: Academia Nacional de Belas Artes, 16-57.

SERUYA, A. I. et. al (2002). "Policromia: a escultura policromada religiosa dos séculos XVII e XVIII: estudo comparativo das técnicas, alterações e conservação em Portugal, Espanha e Bélgica". Atas do Congresso internacional. [29, 30 e 31 de outubro], Lisboa: Instituto Português de Conservação e Restauro.

TELES, L. (1900). A Arte de Dourar, 3.a edição revista e aumentada, Lisboa: Typographia do Commercio.

\section{Referências a documentos de arquivo}

Arquivos Nacionais/Torre do Tombo, Inventário do Património Cultural Móvel, inventário coletivo dos registos paroquiais, vol.1 [1993]. Lisboa, Secretaria do Estado da Cultura, ISBN 972 - 8107-08-0.

Arquivo da Paróquia da Vera Cruz (1836). Inventário de alfaias, títulos, papéis e objectos pertencentes à confraria do santíssimo sacramento da freguesia da vera cruz, Liv. 1, fl- 3/40, Arquivo Distrital de Aveiro, dio/issavr12/006 Inventário 1836/1856-08.(pt/adavr/dio/issavr12/006) https://digitarq.adavr.arquivos.pt/details?id=1290114 (consulta:4/10/2018) 


\section{Autor/es}

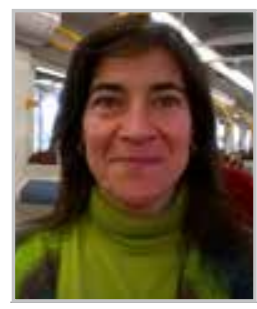

\section{Maria da Luz Nolasco}

mlnolasco@cm-aveiro.pt

Conservadora do Museu de Aveiro / Santa

Joana

Es Conservadora del Museo de Aveiro/Santa Joana, responsable por la colección de Talla, inventario y estudio; Tiene la coordinación de los Servicios Educativos do MA / SJ (2019). Doctoranda em Artes dos Media en la Universidad Lusófona de Porto (2017/2019). Posgraduación em Cultura Inmaterial en la Universidade Lusófona, Lisboa (2012/13). Graduación en Estudio en Economía y Gestión de la Ciudad por la Faculdad de Economía de la Universidad de Porto (2008/9). Estudio especial em Museografía en la Academia Domus, Milano, Itália (2004). Mestre en Estudios de Museos (Master in Arts), Universidad de Leicester, Reino Unido (1992/1993). Licenciatura em Beaux Arts / Design e Cinografía por la Facultad de Bellas Artes de Lisboa, Universidad Clásica (1986).

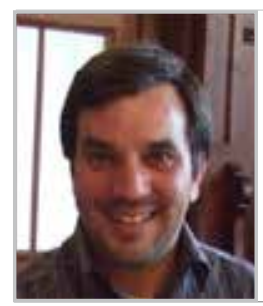

\section{Manuel A. Martins}

mamartins@ua.pt

CICECO - Aveiro Institute of Materials, Department of Physics, University of Aveiro, Campus de Santiago, 3810-193 Aveiro, Portugal

Doctor em Química por la Universidad de Aveiro, Portugal (2011), con Máster en Ciencia y Ingeniería de Materiales (2004) y graduación en Química Analítica (2000). Es investigador posdoctorado en el Instituto de Materiales de Aveiro (CICECO - Universidad de Aveiro). Ha participado en proyectos de investigación $\mathrm{I}+\mathrm{D}+\mathrm{I}$ en el desarrollo y caracterización de materiales particularmente en la utilización de técnicas de microscopia electrónica e de fuerza atómica. Actualmente colabora con el Museo de Aveiro para el estudio del patrimonio de piezas en talla dorada.

Artículo enviado el 14/12/2018 Artículo aceptado el 18/06/2019 


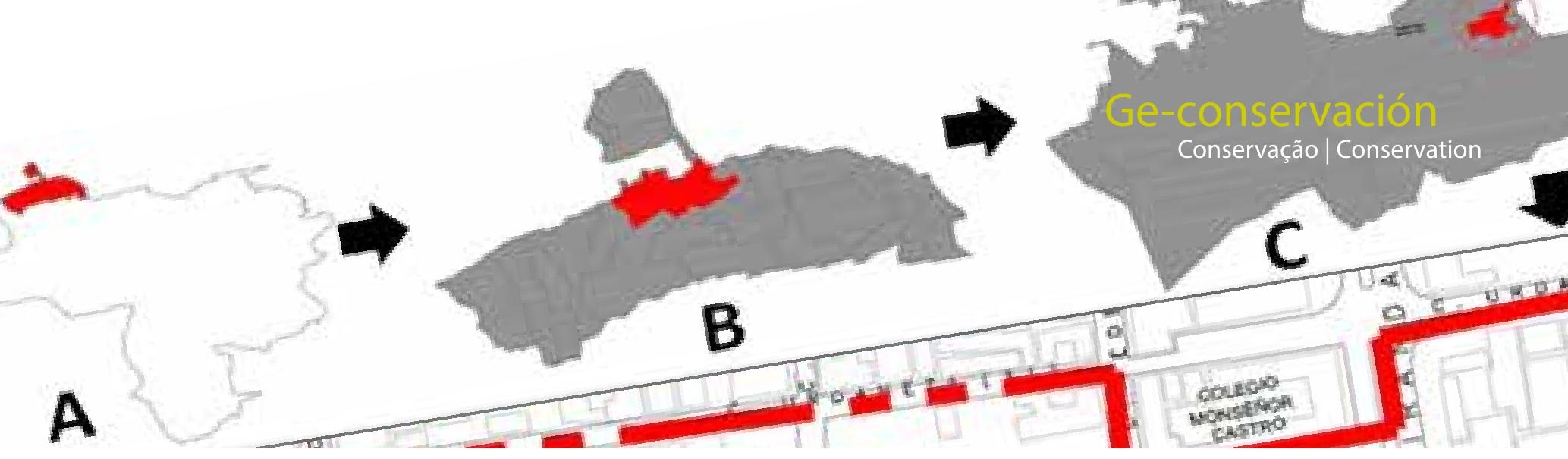

\title{
Evaluación microbiológica de aire interior en tres Museos de la zona UNESCO $N^{\circ} 658$ Coro, Venezuela Patrimonio Mundial de la Humanidad
}

\author{
Yarubit Rojas, Francisco Yegres, José Araujo
}

\begin{abstract}
Resumen: Se realizó un estudio con el objetivo de caracterizar la calidad del aire interior en tres museos ubicados dentro de la zona UNESCO N ${ }^{\circ} 658$ Patrimonio Cultural Mundial de la Humanidad. Se evaluó Humedad Relativa HR medida en $\%$ y temperatura medida ${ }^{\circ} \mathrm{C}$, se recuperaron bacterias y hongos del aire por el método de sedimentación por gravedad, se caracterizó bacterias por el método Gram e identificó hongos por microcultivo. Se determinó una correlación inversa entre la HR y la Temperatura. Se caracterizaron, Streptococos $\mathrm{G}(+)$, Cocos aislados $\mathrm{G}(+)$, Cocos aislados G(-), Streptococos G(+), Stafilococos G(+), Bacilos G(+), Bacilos G(-), Filamentos G(+). Aspergillus sp., Mucor sp., Penicillium sp. La UFC/m3 de bacterias fue ligeramente mayor que la de los hongos. Todos los museos presentaron valores microbianos para el aire, entre medio y alto según la clasificación propuesta por la OMS.
\end{abstract}

Palabras clave: Microbiología del aire, UNESCO, Museos, Humedad Relativa

\section{Microbiological evaluation of indoor air in three Museums of the UNESCO No. 658 zone. Coro, Venezuela World Heritage of Humanity}

Abstract: A study was carried out with the aim of characterizing indoor air quality in three museums located within the UNESCO 658 World Heritage Area. Relative Humidity HR measured in\% and measured temperature ${ }^{\circ} \mathrm{C}$ was evaluated, bacteria and fungi were recovered from the air by gravity sedimentation method, bacteria were characterized by the Gram method and identified fungi by microculture. An inverse correlation between $\mathrm{RH}$ and Temperature was determined. Were caracterizaed Streptococci $\mathrm{G}(+)$, Staphylococci G (+), G (+) Bacillus G (+), Bacillus G (-), Filaments G (+) 5\%. Aspergillus sp., Mucor sp., Penicillium sp. The UFC / m3 of bacteria was slightly higher than that of the fungi. All the museums presented microbial values for air, between medium and high according to the classification proposed by the WHO

Keyword: Air Microbiology, UNESCO, Museums, Relative Humidity

\section{Avaliação microbiológica do ar interior em três Museus da zona UNESCO Nº 658 Coro, Venezuela Património Mundial da Humanidade}

Resumo: Realizou-se um estudo com o objetivo de caracterizar a qualidade do ar interno em três museus localizados na zona da UNESCO N..$^{\circ}$ 658, Património Cultural Mundial da Humanidade. Avaliou-se a humidade relativa HR medida em \% e a temperatura medida ${ }^{\circ} \mathrm{C}$, recuperaram-se bactérias e fungos do ar pelo método de sedimentação por gravidade, caracterizaram-se bactérias pelo método Gram e identificaram-se fungos por microcultura. Determinou-se uma correlação inversa entre a HR e a Temperatura. Caracterizaram-se Streptococos $\mathrm{G}(+)$, Cocos aislados $\mathrm{G}(+)$, Cocos aislados $\mathrm{G}(-)$, Streptococos $\mathrm{G}(+)$, Stafilococos $\mathrm{G}(+)$, Bacilos $\mathrm{G}(+)$, Bacilos $\mathrm{G}(-)$, Filamentos G(+). Aspergillus sp., Mucor sp., Penicillium sp. A UFC/m3 de bactérias foi ligeiramente maior que a dos fungos. Todos os museus apresentaram valores microbianos para o ar, entre médio e alto segundo a classificação proposta pela OMS.

Palavras-chave: Microbiologia do ar, UNESCO, Museus, Humidade Relativa 


\section{Introducción}

La ciencia en los museos es un campo de interés mundial que cada día cobra mayor auge e importancia tanto desde la perspectiva clásica de los museos así como los nuevos aportes que trae la nueva museología. El principal organismo que concentra a los museólogos a nivel mundial, es el Consejo Internacional de Museos (ICOM), asociado a la UNESCO (MPPC, 2005), y este ha desarrollado diversas directrices relacionadas con la operación de los museos, que incluyen el estudio, seguimiento y control de las condiciones ambientales del aire interior como base para la conservación preventiva en el museo para el mantenimiento de la condiciones favorables de las colecciones el espacio museístico y el público que interactúa con estos espacios (Antomarchi, y De Guichen, 1989; Michalski, 2006).

El estudio y control de las condiciones ambientales presentes en museos, galerías, casas patrimoniales, iglesias (AENOR, 2012), archivos, bibliotecas, jardines parques naturales (Rojas et al., 2015) o cualquier depósito destinado a atesorar el patrimonio histórico, constituye hoy en día uno de los elementos más importantes a tener en cuenta en la conservación preventiva de tan preciado legado (Alcántara, 2002; Cassar, 2013). La prevalencia de condiciones ambientales inadecuadas junto a la presencia de elevadas concentraciones microbianas en dichos museos, ha despertado la atención de varios grupos de investigadores y especialistas en el área de conservación de bienes patrimoniales, debido al riesgo que estos implican tanto para la salud humana como para la integridad del patrimonio en ellos se resguarda (Valentin, 2003; 2007; Herráez 2014).

La atmósfera de las salas de exposición de los museos y los almacenes que albergan obras de arte presentan concentraciones variables de agentes químicos y microbiológicos que es necesario medir y controlar (Valentin, 2015). Es por ello, que es de interés el estudio del aire exterior e interior donde es posible encontrar diversos tipos de partículas de diferente origen, forma y tamaño suspendidas en el aire; ellas constituyen el aerosol atmosférico (Araujo et al., 2013).

Los países tropicales presentan por lo general valores altos de humedad relativa y temperatura, generando condiciones climáticas que favorecen el incremento bacterias, y esporas de hongos (Florian, 2000 a, b). Venezuela es un país con clima tropical donde la humedad relativa y las temperaturas diurnas y nocturnas presentan variaciones permanentes, es por ello que el control de estos elementos es, de importancia para preservar los objetos y las colecciones El presente estudio se realizó con el fin de caracterizar y evaluar las condiciones del aire interior de tres museos que se encuentran dentro de la zona UNESCO Nº 658 (Reyes, 2016) como parte del plan de evaluación y corrección de las condiciones sanitarias, ecológicas y ambientales de una zona de interés turístico para la región.

\section{Materiales y Métodos}

\section{—Delimitación de la zona de Estudio}

La zona de estudio se encuentra ubicada en la ciudad de Santa Ana de Coro del Estado Falcón-Venezuela, con una poligonal constituida por 25 manzanas, que poseen una superficie de 25.28 hectáreas [figura 1], en ella se encuentran diversas edificaciones protegidas por la legislación mundial, nacional y regional, designada como Patrimonio Cultural Mundial de la Humanidad $N^{\circ}$ 658 por la UNESCO (Reyes 2016; UNESCO, 1993, 1994) y Patrimonio Histórico y artístico de la Nación Venezolana (Gaceta, 1995, 1996). Esta área junto a la Vela de Coro y las diversas zonas de influencia constituye una zona de atractivo turístico mundial, (PLINCODE 2005, Araujo et al., 2013). Cabe destacar que esta zona incluye a Coro y su puerto de la Vela, pero en el estudio solo se desarrolló en la poligonal constituida en la ciudad de Coro.

\section{- Estaciones de Muestreo}

Se aplicó un programa de seguimiento considerando los criterios propuestos por Herráez (2014). Para la determinación de las estaciones de muestreo se aplicó la normativa UNE 171330-2 (AENOR, 2014) la cual determina que el número mínimo de estaciones de muestreo según la siguiente fórmula:

$$
P=0,15 \times \sqrt{ } S \text {, donde } P: n .^{\circ} \text { de puntos } / S \text { : superficie }
$$

Se realizaron muestreos en un periodo de tres meses, con tres muestreos semanales interdiarios, hasta completar cada mes, de igual manera en ese mismo periodo se tomaron los datos climáticos, estos muestreos fueron realizados en la estación de verano en los meses de enero, febrero y marzo durante el día (Herráez, 2014).

\section{- Humedad Relativa y Temperatura}

La Humedad relativa (HR) en (\%) y la Temperatura (T) en $\left(C^{\circ}\right)$ fueron medidas utilizando el equipo de medición puntual termohigrómetro electrónico según la norma (AENOR, UNE-EN 15758:2011) aplicando el método descrito en la norma por Herráez, (2014).

\section{- Recuperación de Microorganismos del Aire / Medios de Cultivo}

El muestreo aerobiológico del aire se realizó atendiendo las recomendaciones de las Normas 


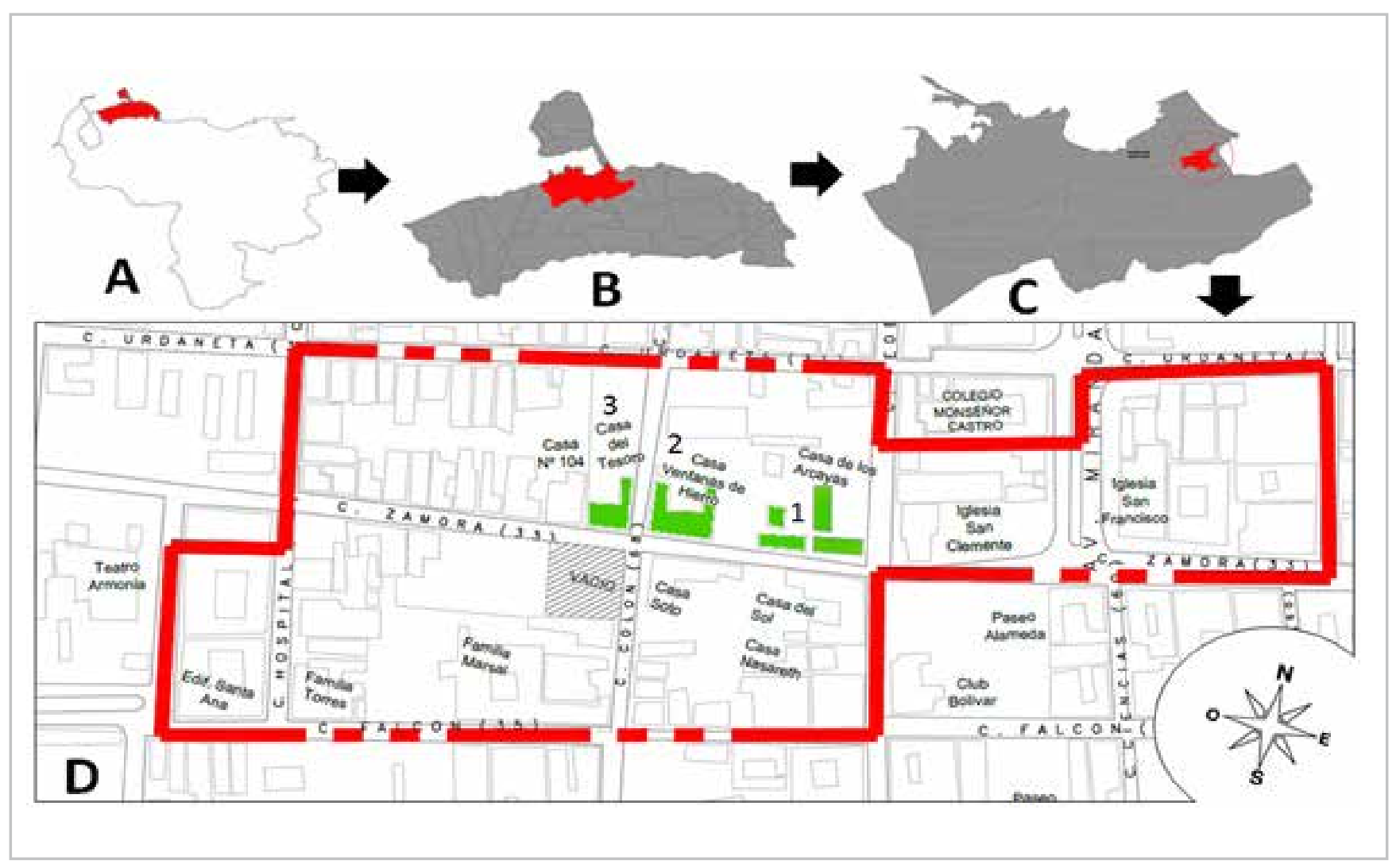

Figura 1.- Situación Geográfica de la Zona UNESCO N 658, Pratimonio Cultural Mundial de la Humanidad, Coro, Venezuela. A) Situación Nacional del Estado Falcón, B) Situación Regional del Municipio Miranda, C) Situación Ciudad Santa Ana de Coro, D) Situación de la Zona, línea en color rojo Poligonal de zona UNESCO, color verde: 1) Casa de los Arcaya (Museo J. M. Cruxent); 2) Casa Ventanas de Hierro (Museo Casa de las Ventanas de Hierro); 3) Casa del Tesoro o Monumento "Casa del Obispo Talavera" (Museo Guadalupano).

Internacionales ICOM para el Estudio de la Calidad del aire en museos (Antomarchi, y De Guichen, 1989; INSHT 1989), aplicando el método gravimétrico de sedimentación el cual consiste en tomar placas de Petri con medios previamente preparados para hongos y bacterias, someterlas al contacto con un flujo de aíre, durante un periodo de 10 minutos a una altura de un metro y medio (Araujo et al., 2013; Rojas et al., 2015). Para la recuperación y promoción del crecimiento de los diversos microorganismos del aire se prepararon medios de cultivos selectivos previo a la toma de muestra. Para bacterias se utilizó Agar Nutritivo (AN) el cual se preparó a una concentración que contenía peptona $5.0 \mathrm{~g}$, extracto de carne $3.0 \mathrm{~g}$, y agar bacteriológico $15.0 \mathrm{~g}$, ajustado a un $\mathrm{pH} 6.8 \pm 0.2$.

Para la caracterización e identificación de las especies fúngicas se prepararon los medios Agar Sabouraud (AS) preparado a una concentración de $40 \mathrm{~g}$ de dextrosa, $5 \mathrm{~g}$ de peptona, $5 \mathrm{~g}$ de digerido pancreático de tejido animal, $15 \mathrm{~g}$ de agar bacteriológico $15 \mathrm{~g}$ para un $1 \mathrm{~L}$ de agua destilada, mas dihidroestreptomicina como antibiótico a una concentración de $0,4 \mathrm{~g} / \mathrm{L}, \mathrm{pH} 5.6 \pm 0.2$ a $25{ }^{\circ} \mathrm{C}$. Todos los medios fueron esterilizados por calor húmedo en autoclave a 15 Libras de presión o 1,1 atm de sobresaturación a $120^{\circ} \mathrm{C}$ (Araujo et al., 2013).

\section{-Cuantificación delUFC/m3 debacterias y hongos miceliales}

Se cuantificó aplicando la fórmula descrita por Kolwzan et al., (2006).

$$
X=\frac{a \cdot 5 \cdot 10^{4}}{\pi \cdot r^{2} \cdot t}
$$

$\mathrm{X}$ - número de microorganismos en el aire (UFC/m3); a - el número de colonias en la placa de Petri; $r^{2}$-la superficie de la placa de Petri $\left(\mathrm{cm}^{2}\right)$; $\mathrm{t}$ - tiempo de exposición (minutos).

La unidades fueron determinadas como unidades formadoras de colonias por metro cubico UFC $/ \mathrm{m} 3$, los datos obtenidos se codificaron en tablas de contingencia para su posterior análisis estadístico y comparación con normas propuestas para determinación de la calidad.

\section{- Aislamiento y Caracterización de hongos y bacterias re- cuperados del aire interior de los museos}

Previamente las placas recuperadas de los muestreos fueron incubadas a $30-37{ }^{\circ} \mathrm{C}$ en tiempos de 3-5 días para hongos y de 1-2 días para bacterias; Transcurrido el tiempo para el crecimiento de las diversas especies fúngicas, y bacterianas se procedió a asilar cada colonia 
crecida en placas de Agar Nutritivo (AN) y Agar Saboraud (AS) nuevamente con el fin de observar posteriormente las características en placa de Petri. Para ello las bacterias fueron sembradas por el método de rayado en triple estría y los hongos por punción en el centro de la placa y fueron incubadas con las mismas condiciones previamente descritas (Schlegel, 1997). Los hongos y bacterias aislados a partir de colonias recuperadas del aire interior de los museos, fueron evaluadas mediante las características macroscópicas tomando en cuenta el número de colonia, su tamaño y el color, forma, borde, superficie, elevación, consistencia, opacidad (Kerr, 1998).

\section{- Identificación de hongos y morfotinción de bacterias}

Para la determinación de las características microscópicas los hongos fueron aislados aplicando el método de aislamiento por microcultivo de Riddell, (Casas, 1994). Para la identificación los diversos cuerpos fructíferos fueron evaluados según las características morfológicas propuestas por Lacaz (1998). La caracterización de las bacterias se logró identificando su morfología mediante la observación microscópica con muestras que previamente fueron tratadas mediante la técnica de diferencial de Gram para bacterias (Rojas et al., 2015).

\section{— Determinación de calidad de aire interior}

Los resultados fueron evaluados según los criterios sugeridos por la ICOM sobre contaminantes ambientales y las recomendaciones de la norma (Antomarchi, y De Guichen, G, 1989). Los datos obtenidos fueron contrastados con la normativa Internacional actualizada por el SIAQ-CIBTaskGroupTG 42 (2004) para la clasificación de concentración de bacterias y hongos presentes en el aire interior (CEC, 1993).

\section{- Análisis Estadístico}

Todos los datos obtenidos fueron evaluados por un estadístico para el análisis de la varianza aplicando el modelo de Duncan con un $95 \%$ de confianza $(p<0,05)$ para evaluar la significancia de las variables de estudio (ILSTRUP, 1990).

\section{Resultados}

Los resultados obtenidos cumplen los criterios propuestos por la ICOM y las normativas técnicas para museos Venezolanos (MPPC, 2005; Alcántara, 2002). Los espacios definidos tienen como criterios de interés, la evaluación de los espacios administrativos, lugares de mayor afluencia y estancia dentro del museo, evaluación del patio o traspatio de edificación colonial, para un total de 17 estaciones de muestreo.
Los diversos museos presentaron variaciones climáticas medidas de Humedad Relativa HR con un porcentaje de saturación global promediada en $60,1 \%$ y una temperatura promedio de $32,7^{\circ} \mathrm{C}$ [Gráfico 1]. Las variaciones internas dentro de cada museo evaluado muestran que el museo JM Cruxent presente en el Balcón de los Arcaya poseía una temperatura promedio de $32,43{ }^{\circ} \mathrm{C}$ con un rango inferior de $30,80^{\circ} \mathrm{C}$ y un nivel máximo de $33,50^{\circ} \mathrm{C}$, el museo de las Ventanas de Hierro presentó una temperatura promedio de $32,79^{\circ} \mathrm{C}$ con un nivel mínimo de $31,90^{\circ} \mathrm{C}$ y un máximo de $34,40^{\circ} \mathrm{C}$, por último el Museo Guadalupano presentó un promedio interno de 32,96 con límite inferior de 32,40 y máximo de 33,50 [Gráfico 1].

El análisis de la varianza mostró diferencias significativas entre los tres museos lo que indica que existe una variación térmica en el aire interior de los diferentes recintos. Por su parte el Balcón de los Arcaya presenta la temperatura más baja y de igual manera su límite térmico inferior es el más bajo. El promedio global del estudio [Gráfico 1] fue de $61,7 \%$ de humedad relativa (HR), con una variación de la HR interna en cada museo, el Museo Guadalupano (60,75\%) y el Museo Ventanas de Hierro $(61,00 \%)$ estadísticamente similares, mientras que el Balcón de los Arcaya (Museo JM Cruxent) mostró una variante con una HR más alta de (63,20\%). Al evaluar los datos mediante la regresión lineal de temperatura y humedad relativa [Gráfico 1] se encontró que los datos arrojaron que la HR es función inversa de la temperatura ( $\mathrm{T})$.

Gráfico 2 muestra que las bacterias se encontraron entre los niveles intermedio, alto, y muy alto según la clasificación propuesta por la (CEC, 1993). Siendo el nivel alto quien presentó mayor frecuencia el museo JM Cruxent presente en el Balcón de los Arcaya oscilo entre los niveles intermedio y alto mientras que el museo casa de las Ventanas de Hierro presentó valores de concentración de microorganismos entre alto y muy alto, de igual manera el valor más alto se representa para el área CV5 de este museo que presentó $2123 \mathrm{UFC/m3.} \mathrm{EI}$ museo Guadalupano presentó valores clasificados como intermedio y alto presentando el valor más bajo con 356 UFC/m3. Los datos obtenidos para los hongos mostraron que estos variaron dentro los niveles intermedio y alto para los tres museos evaluados pero estos valores no superaron a los encontrados para bacterias.

La evaluación de los resultados de niveles de concentración de bacterias y hongos (UFC/ m3) del aire interior mediante el análisis estadístico aplicado mostró tres grupos [Gráfico 2] para el caso de las bacterias y uno para el caso de los hongos. Es decir un grupo (A) Museo Guadalupano; (A-B) Museo Casa de las Ventanas de hierro; (C) Museo JM Cruxent lo que muestra un comportamiento propio para cada espacio en las condiciones y tiempo evaluadas. Por otro lado los hongos solo mostraron un grupo (A) que incluye a los tres museos evaluados, mostrando que no existieron diferencias significativas al comparar los museos para la concentración de las especies fúngicas presentes en estos espacios. 


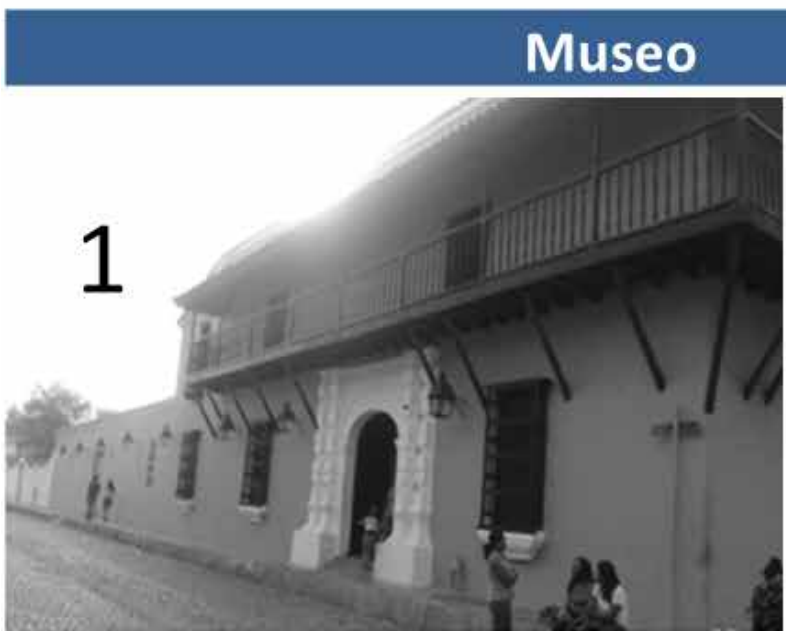

Area

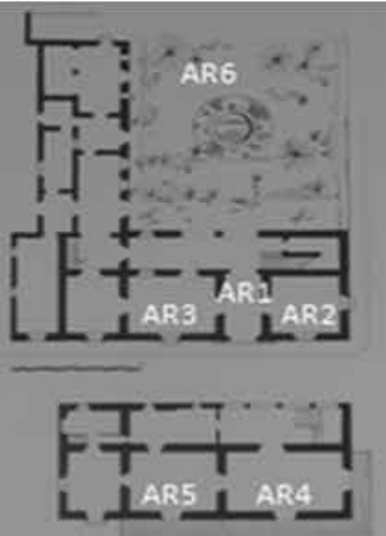

\begin{tabular}{l|l|l} 
AR1 & 67,2 & 32,7
\end{tabular}

\begin{tabular}{l|l|l} 
AR2 & 62,9 & 32,1
\end{tabular}

\begin{tabular}{l|l|l} 
AR3 62,6 & 32,3
\end{tabular}

\begin{tabular}{l|l|l} 
AR4 63,7 & 31,8
\end{tabular}

\begin{tabular}{l|l|l} 
AR5 & 62,6 & 32,6
\end{tabular}

\begin{tabular}{l|l|l} 
AR6 60,2 & 33,0
\end{tabular}

$63,20^{(a)} \quad 32,42^{(a)}$
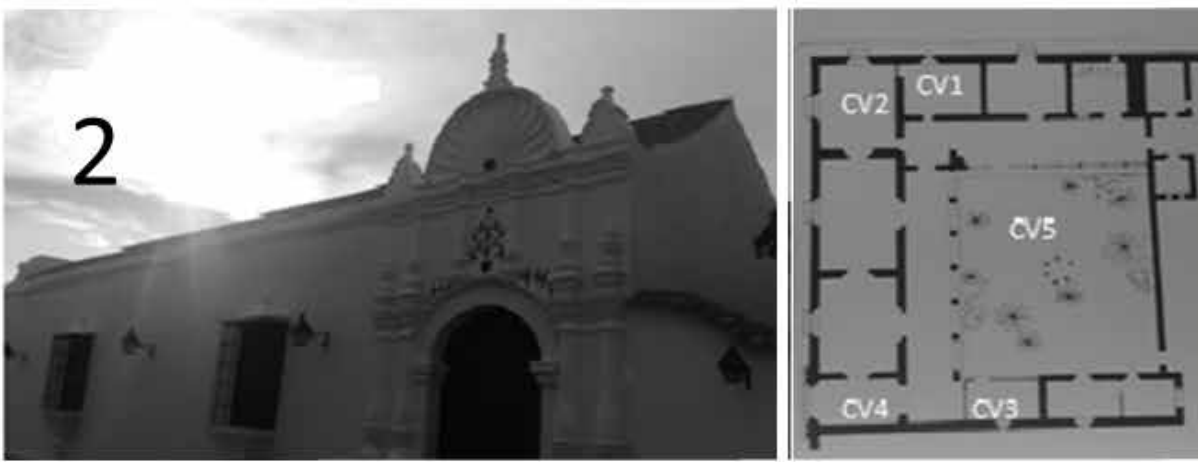

\begin{tabular}{|c|c|c|}
\hline CV1 & 61,5 & 32,6 \\
\hline CV2 & 61,5 & 32,7 \\
\hline CV3 & 61,2 & 32,5 \\
\hline CV4 & 61,4 & 33,4 \\
\hline CV5 & 59,4 & 32,8 \\
\hline & $61,00^{(b)}$ & $32,80^{(b)}$ \\
\hline
\end{tabular}
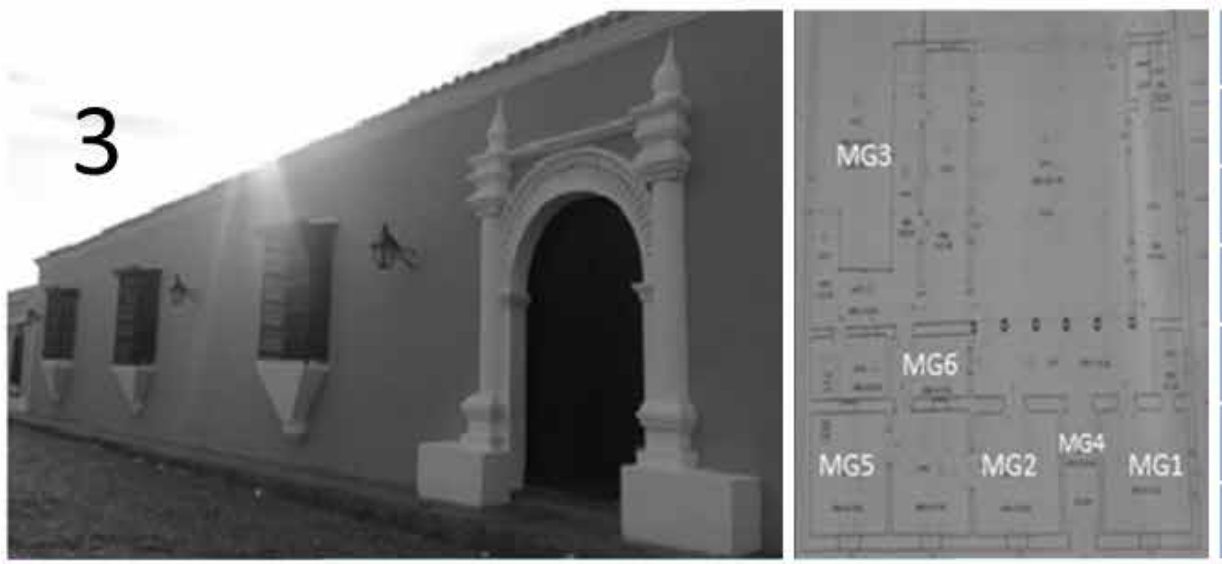

\begin{tabular}{|c|c|c|} 
MG1 & 60,3 & 33,0 \\
\hline MG2 & 60,4 & 32,9 \\
\hline MG3 & 60,2 & 32,9 \\
\hline MG4 & 62,2 & 33,0 \\
\hline MG5 & 60,7 & 33,0 \\
\hline MG6 & 60,7 & 33,0 \\
\hline & $60,75^{(\text {(b) }}$ & 32,97 (c) \\
\hline
\end{tabular}

Promedio Global

$\begin{array}{ll}61,7 & 32,7\end{array}$

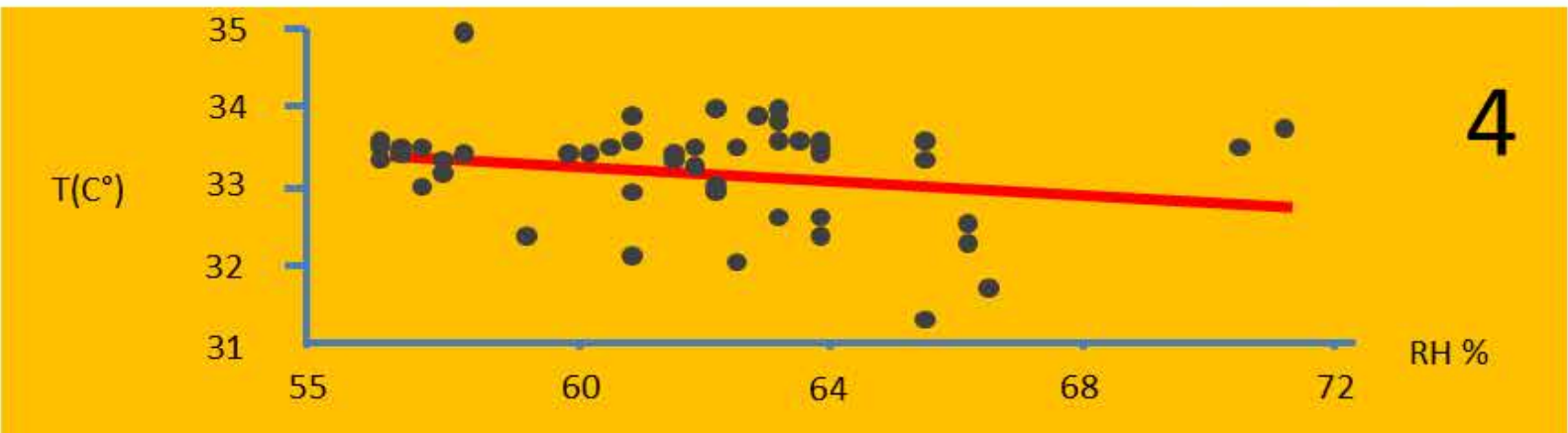

Gráfico 1.- Fachada de museos y planta con estaciones de muestreo determinadas, 1) BALCÓN DE LOS ARCAYA: AR1-Entrada; AR2-SALA 2; AR3-SALA 3; AR4-SALA 1; AR5-SALA 4; AR6-PATIO. 2) CASA DE LAS VENTANA DE HIERRO: CV1-ALCOBA SECUNDARIA; CV2-ALCOBA PRINCIPAL; CV3-CAPILLA; CV4-ENTRADA; CV5-PATIO. 3) MUSEO GUADALUPANO: MG1-SALA DE ESTAR; MG2DORMITORIO; MG3-TRASPATIO; MG4-ENTRADA; MG5-DESPACHO; MG6-OFICINA. Las letras distintas (a), (b), (c) indican diferencias significativas $(p<0,05)$ en análisis de varianza 4$)$ Temperatura $T\left(C^{\circ}\right)$ vs Humedad relativa HR\%. 


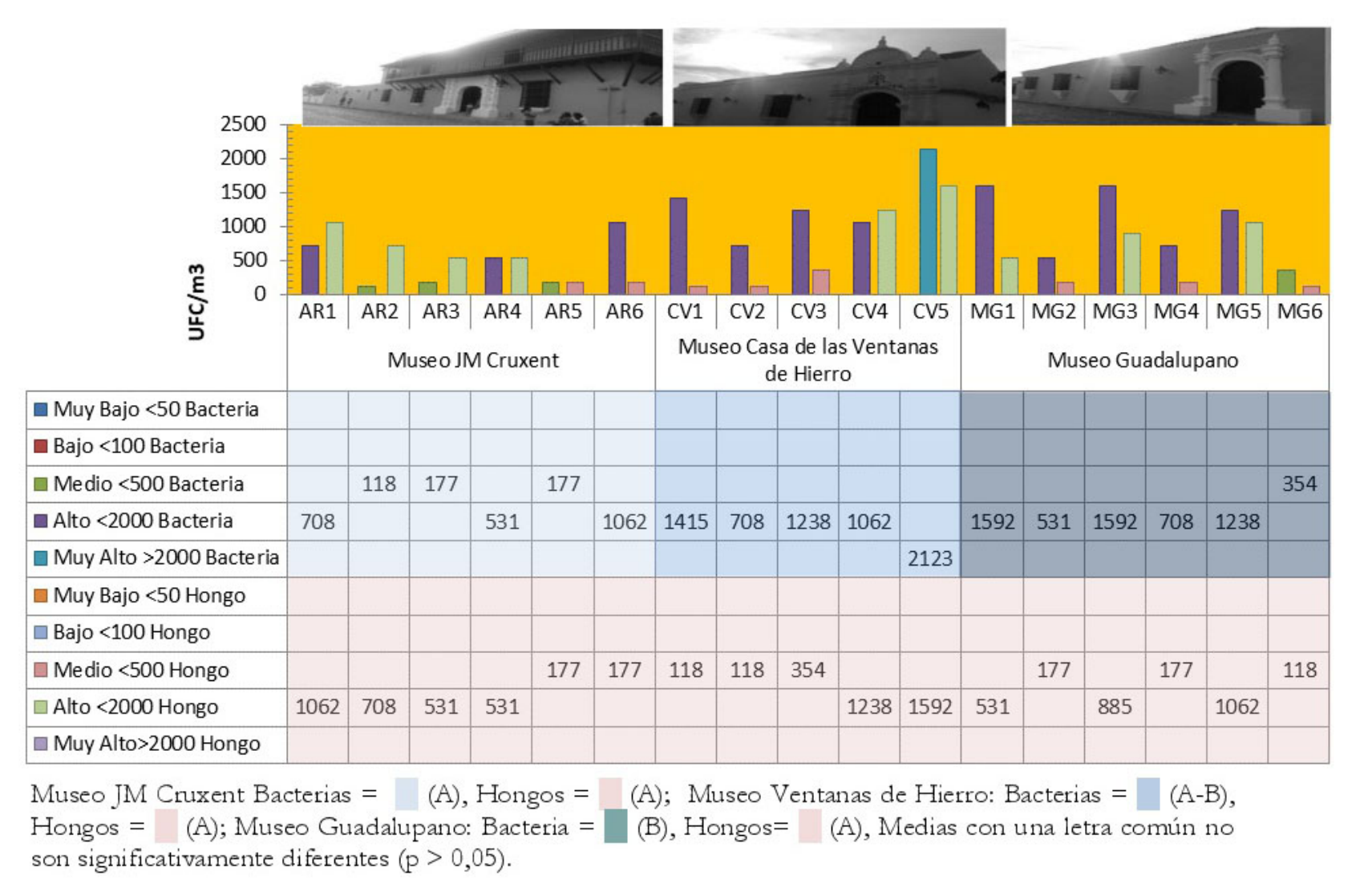

Gráfico 2.- Promedio aritmético de niveles de concentración de bacterias y hongos (UFC/m3) del aire interior tres museos en la zona UNESCO Nº58 Coro, Venezuela, según (CEC, 1993).

\begin{tabular}{|c|c|c|c|c|c|c|}
\hline \multirow{2}{*}{ Museo /Área } & \multirow{2}{*}{ Micromorfologia } & \multicolumn{4}{|c|}{ Macromorfologia } & \multirow[b]{2}{*}{$\mathrm{N}^{\circ} /$ (Total) } \\
\hline & & Color & Forma & Borde & Elevación & \\
\hline AR1 & Aspergillus sp. & Blanco & Redonda & entero & elevado & (6) \\
\hline $\begin{array}{c}\text { AR2, AR5, AR6, CV2, } \\
\text { CV3 }\end{array}$ & Aspergillus niger & Negro & Redonda & entero & elevado & $4+1+1+4+5 /(15)$ \\
\hline AR3 & Aspergillus clavatus & Gris & Redonda & entero & elevado & (3) \\
\hline AR4, CV1, MG6 & Aspergillus flavus & Verde & Redonda & entero & elevado & $3+2+6 /(11)$ \\
\hline CV4 & Aspergillus orizae & Blanco & Redonda & entero & algodonoso & (1) \\
\hline CV5 & Aspergillus terreus & Marrón & Redonda & entero & elevado & (6) \\
\hline MG1, MG2, MG3, MG4 & Mucor sp. & Blanco & Redonda & entero & elevado & $3+1+5+1 /(10)$ \\
\hline MG5 & Penicillium sp. & Blanco & Irregular & entero & elevado & $(6)$ \\
\hline AR1 & Filamentos $G(+)$ & Blanco & Redondo & entero & plano & (4) \\
\hline AR2, MG3, MG4, MG6 & $\operatorname{Cocos} G(-)$ & Beige & Redondo & entero & plano & $1+9+4+2(16)$ \\
\hline AR3, AR4, CV5, MG1 & $\operatorname{Cocos} G(+)$ & Beige & Redondo & entero & plano & $1+4+12+9(26)$ \\
\hline AR5, AR6, CV4 & Bacilos G(+) & Blanco & Redondo & entero & plano & $1+6+6(13)$ \\
\hline CV1 & Cocobacilo G(-) & Beige & Redondo & entero & plano & (8) \\
\hline $\mathrm{CV} 2$ & Bacilos G(-) & Blanco & Redondo & entero & plano & (4) \\
\hline CV3 & Streptococos $G(+)$ & Beige & Redondo & entero & plano & (7) \\
\hline MG2, MG5 & Stafilococos $G(+)$ & Beige & Redondo & entero & plano & $3+7(11)$ \\
\hline
\end{tabular}

Tabla 1.- Identificación fúngica y caracterización bacteriana, del aire interior de tres museos ubicados en la zona UNESCO de la Ciudad de Coro patrimonio Cultural de la Humanidad. 
La [tabla 1] muestra ocho cepas de hongos, de las cuales 6 son del género Aspergillus con 5 especies para un total de 25 asilados, presentes el Museo JM Cuxent y el Museo Casa de las Ventanas de Hierro, 10 aislados de Mucor sp. y 6 de Penicillum sp. en el Museo Guadalupano. Se recuperaron 9 cepas de bacterias con caracteres distintos, de las cuales los Cocos $G(+)$ con (26) aislados fueron la mayor proporción.

\section{Discusión}

Los datos obtenidos presentan el primer estudio que evalúa la calidad del aire interior de tres museos ubicados en el área declarada como patrimonio cultural de la humanidad N 658 por la UNESCO y Patrimonio Histórico y artístico de la Nación, evaluando la correlación de los datos asociados a la aerobiología y los datos climáticos. De esta manera los microorganismos se presentan como bioindicadores de las condiciones de los museos y funcionan como un primer registro de la situación de la colecciones frente a la variabilidad y dinámica de estos en edificios que posee una arquitectura colonial Europea y que además no se encuentran climatizados con equipos de aire acondicionado. La importancia que reviste un espacio designado a nivel mundial por la UNESCO como patrimonio cultural de la humanidad debe ser objeto de estudio puesto que el espacio es un lugar prístino para el desarrollo de la actividad turística mundial y atractivo para el desarrollo de actividades artísticas y recreacionales.

El análisis global [Gráfico 1] mostró una humedad relativa $60,1 \%$ y una temperatura promedio de $32,7{ }^{\circ} \mathrm{C}$ en el aire interior de los museos evaluados, estos valores son considerados altos y son un factor que incrementa la sensibilidad para hongos y bacterias al ser contrastadas con las normativas técnicas para museos Venezolanos (MPPC, 2005).

Sin embargo otros estudios como el realizado en un museo en Chile mostró que la humedad obtenida fue inferior con $59 \%$ a una temperatura de $15{ }^{\circ} \mathrm{C}$ propio del país Austral donde se considera dentro de los límites permisibles (Nitiu et al., 2016). De igual manera un estudio realizado en Cuba muestra humedades relativas más altas $76 \%$ a 28 $\mathrm{C}^{\circ}$ en épocas de lluvia y humedades un grado mayor que la reportada en este estudio en épocas secas $61 \%$ a $21^{\circ} \mathrm{C}$ (García, 2016).

Cabe notar que Venezuela tiene dos estaciones distintas invierno que va de Mayo a Noviembre y verano que va de Diciembre a Abril, sin embargo se caracteriza por tener una variabilidad en su humedad relativa y la temperatura diurna y nocturna, los datos obtenidos, son solo para una evaluación realizada durante el día en el aire interior de los recintos evaluados en época de verano en el que cada museo presento una variación térmica propia pero dentro de los límites establecidos por la norma nacional venezolana (MPPC, 2005).
Otros estudios realizados en el aire exterior del área de estudio muestran que el la humedad relativa puede variar entre un $60 \%$ a un $40 \%$ pero esta evaluación se realizó en un periodo de invierno de mayo a julio (Yunis et al., 2015, 2014) la contrastación con la información climática medida por una estación climática nacional cercana al estudio, muestra que la temperatura exterior fue menor para los meses de enero $(27,5)$, febrero $(27,8)$ y marzo $(28,8)$ y la humedad relativa del aire exterior es mucho mayor para estos meses evaluados en enero (69\%), febrero $(68,5 \%)$ y marzo (67\%) (INAMEH, 2015). Esto muestra que estos recintos generan una temperatura mayor en su interior y una humedad relativa menor [Gráfico 1] que varía de forma inversa y proporcional en comparación con el aire exterior.

El análisis global muestra que las bacterias estuvieron dentro de la clasificación de alto y muy alto mientras que los hongos dentro de la clasificación medio y alta al compararse con el índice de referencia mundial (CEC, 1993). Por su parte el Museo JM Cruxent de dos plantas [Gráfico 1,2] presentó la humedad relativa más alta al compararla con las demás edificaciones de una sola planta y en este, la carga bacteriana fue menor y la carga fúngica fue alta (CEC, 1993). Los museos de una sola planta [Gráfico $1,2]$ como el Museo de las ventanas de hierro y el museo Guadalupano se comportaron con una dinámica similar ya que en ambos, la humedad relativa fue menor que el museo de dos plantas, y ambos presentaron mayor concentración de bacterias que de hongos, con excepción de sus patios o traspatios al compararse con el índice de referencia (CEC, 1993). Los datos obtenidos son contrastable con la teoría propuesta por los museos venezolanos, ya que en los espacios con mayor humedad relativa, encontramos mayor carga de hongos como el museo Cruxent, mientras que en espacios donde la humedad relativa fue menor la carga bacteriana fue mayor como en los otros dos museos evaluados (MPPC, 2005).

Los resultados [Gráfico 1,2] mostraron que cada diseño estructural de la vivienda colonial proporciona una dinámica propia y un microclima diferente en cada recinto evaluado. Los espacios evaluados mostraron que en el área de los patios y traspatio la humedad relativa es menor y la temperatura es mayor, esto es consistente con la teoría de la utilidad del patio en las viviendas coloniales como un dispositivo bioclimático (Giraldo, 2014), sin embargo estos fueron los espacios que presentaron mayor cantidad de bacterias y hongos al evaluar los museos, esto puede ser posible ya que en estos espacios hay mayor corriente de aire proveniente del exterior donde las cargas tanto de bacterias como de hongos es alta (Rojas et al., 2015; Yunis et al.; 2015, 2014; Araujo et al., 2013).

Las bacterias Gram negativas (-) más frecuentes fueron los cocos Gram (-), este tipo de microorganismos ha sido reportados en el aire exterior (Rojas et al., 2015, Yunis et al., 2015, 2014; Araujo et al., 2013) y en el aire interior en espacios como archivos (Escalona et al., 2013). De igual manera se encontraron diversos Bacilos y cocobacilos 
Gram negativos en el aire que posiblemente pueden depositarse sobre las obras de arte y generar biodeterioro (MPPC, 2005).

Las bacterias Gram positivas (+) predominantes fueron, filamentos, bacilos, streptococos y stafilococos como también reportan otros estudios (Gaüzère, 2016; MPPC, 2005). Se ha determinado que los filamentos pueden estar presente en obras de arte en capas pictóricas y superficies de obras, generando biodeterioro, así como la presencia de bacillus produciendo biodeterioro en obras de arte de madera (Rojas et al., 2014; MPPC, 2005), también se considera que la presencia de streptococos y stafilococos en bioaerosoles es producto de la actividad antrópica (Araujo et al., 2013) y se puede encontrar sobre superficie formando biopelículas en edificios históricos coloniales (Araujo et al., 2017), además de que pueden causar biodeterioro sobre diversas obras de arte.

Reportamos la presencia de Aspergillus como género dominante dentro del grupo de hongos evaluados y 5 de sus especies en viviendas de construcción colonial, y que a la fecha tienen su puesta en valor como museos dentro la poligonal de una zona protegida como patrimonio cultural de la humanidad UNESCO N 658.

El género Aspergillus comprende unas doscientas especies con gran cantidad de variedades, y con una distribución cosmopolita en la naturaleza. Puede adaptarse a un amplio espectro de condiciones ambientales y poseen conidios resistentes a la variación de la temperatura, lo cual le proporcionan un buen mecanismo para su dispersión, además puede producir biodeterioro por su capacidad carbonoclástica y poder transformar una gran variedad de compuestos orgánicos e inorgánicos (Araujo et al., 2016 a, b). Es común encontrarlo tanto en el aire exterior (Araujo et al., 2013) como en el aire interior, en edificaciones históricas (Araujo et al., 2017), archivos (Escalona et al., 2013), salas, industrias, museos (MPPC, 2005), objetos de interés histórico y obras de arte (Nitiu et al., 2016; Gaüzère, 2016; Rojas et al., 2014).

Las 5 especies identificadas $A$. niger; $A$. clavatus; $A$. flavus; $A$. orizae; $A$. terreus en el aire interior de los museos evaluados también han sido reportadas en el aire de museos, bibliotecas y diversas colecciones artísticas, biológicas, momias y obras de arte (Nitiu et al., 2016; Gaüzère; 2016; Skóra, 2015; Rojas et al., 2014; Escalona et al., 2013; MPPC, 2005).

Desde el punto de vista de salud pública las especies encontradas $A$. niger y $A$. flavus se ha reportado que pueden producir aspergilosis pulmonar como patógenos oportunistas; por su parte $A$. clavatus es ocasionalmente patógeno, $A$. orizae es utilizado para producir a partir del arroz el sake y el shochu y A. terreus se encuentra en todos los tipos de suelos y es útil para la producción de medicamentos (Abarca 2000; Kozakiewicz 1989). De igual manera reportamos la presencia de Mucor sp. y Penicillium $s p$. las cuales pueden ser consideradas como especies patógenas oportunistas que pueden producir problemas en humanos cuando las condiciones son propicias para esto (Knutsen, 2002; Escalona et al., 2013).

Los registros de la diversidad microbiana encontrada mostraron que el método de identificación de microorganismos es útil para conocer si el ambiente donde se encuentra la obra, es el más propicio y si las corrientes de aire interior donde están estas obras, son las más idóneas para evitar el biodeterioro (Rojas et al., 2014).

\section{Conclusión}

Se realizó el primer estudio que evalúa la calidad del aire interior de tres museos ubicados en el área declarada como patrimonio cultural de la humanidad $N^{\circ} 658$ por la UNESCO para conocer la situación de la colecciones frente a la variabilidad y dinámica del aire en tres museos de arquitectura colonial Europea. La información climática muestra que los resultados de bacterias se clasificaron como altos y muy altos para bacterias mientras que los hongos oscilaron dentro de la clasificación media y alta para hongos, con humedades relativas superiores a $60 \%$ propicias para el crecimiento tanto de hongos como de bacterias. Cada recinto evaluado presentó una dinámica propia y un microclima, así mismo los patios y traspatios son dispositivos bioclimáticos que permiten el recambio del aire pero que a su vez son el punto de entrada del aumento de la carga microbiana en las viviendas coloniales proveniente del aire exterior. Se encontraron bacterias Gram (+) con predominancia de filamentos, bacilos, streptococos y stafilococos, las bacterias Gram Negativas (-) encontradas fueron cocos, bacilos y cocobacilos. EI principal género de hongos encontrado fue Aspergillus con representación de 5 de sus especies, $A$. niger; $A$. clavatus; $A$. flavus; $A$. orizae; $A$. terreus en el aire interior de los museos evaluados, el método de identificación de microorganismos fue útil para la toma de decisiones en la que se propone colocar deshumificadores y controladores de temperatura en los diversos museos estudiados, para evaluar y controlar la humedad relativa en estos recintos, se sugiere la apertura periódica de ventanas para propiciar un recambio de las corrientes internas, junto a un programa de control del aire más periódico con el fin de resguardar las diversas colecciones y evitar su biodeterioro.

\section{Bibliografía}

AENOR (2012). Conservación del patrimonio cultural. Clima interior. Parte 1: Recomendaciones para la calefacción de iglesias, capillas y otros lugares de culto. UNE-EN 15759-1. Madrid.

AENOR (2011). Conservación del patrimonio cultural. Procedimientos e instrumentos para la medición de las temperaturas del aire y de las superficies de los objetos UNE-EN 15758:2011. Madrid. 
AENOR (2014). Calidad ambiental en interiores. Parte 2: Procedimientos de inspección de calidad ambiental interior. UNE 171330-2:2014. Madrid.

ALCÁNTARA, R. (2002). Standards in preventive conservation: meanings and applications (pp. 7-8). ICCROM.

ANTOMARCHI, C., \& GUICHEN, G. D. (1987). "Pour une nouvelle approche des normes climatiques dans les musées. In ICOM committee for conservation: 8th triennial meeting, Sydney, Australia, 6-11 September, 1987. Preprints (Vol. 3, pp. 847-851). Getty Conservation Institute.

ARAUJO, J., ROJAS, Y., \& YEGRES, F. (2013). "Evaluación aeromicrobiológica en la costa del puerto de La Vela de Coro, patrimonio cultural de la humanidad". Multiciencias, 13(4).

ARAUJO, J., ROJAS, Y., YEGRES, F., et al. (2017). "Evaluación microbiológica ambiental en el edificio de la vieja Cárcel". Hechos Microbiol. 8 (1-2); 1-8

ARAUJO, J., YEGRES, F., BARRETO, G., et al. (2016). a. "Biocatalizadores fúngicos hidrocarbonoclásticos del genero Aspergillus para la descontaminación de agua con Hidrocarburos Policíclicos Aromáticos (HPAs)". Revista Cubana de Química, 28(2), 703-735.

ARAUJO-BLANCO, J., ROJAS, Y., DEPOOL, B., etal. (2016). “Microanálisis de una cepa de Aspergillus niger biocatalizadora de hidrocarburos policíclicos aromáticos HPA". Acta Microscopica, 25(2).

CASAS RINCÓN, G. (1994). Micología general. Ediciones de la Universidad Central de Venezuela (UCV), Caracas.

CASSAR, M. (2013). Environmental management: guidelines for museums and galleries. Routledge.

COMMISSION OF THE EUROPEAN COMMUNITIES (CEC) (1993): Biological Particles in Indoor Environments. European Concerted Action, Indoor Air Quality and Its Impact on Man, COST Project 613, Report N. 12, EUR 14988 EN, Luxembourg. Disponible en: http:// www.inive.org/medias/ECA/ECA Report12.pdf.

ESCALONA VW, SILVA, R, MONTIEL DE MORALES, M. (2013) Aeromicología de la colección general en la biblioteca "Dr. Ramiro Antonio Finol Ortega" de la facultad Experimental de Ciencias de la Universidad del Zulia, tesis de grado.

FLORIAN M.L.E. (2002) a. Fungal Facts. Solving fungal problems in heritage collections. Archetype Publications Ltd. London.

FLORIAN, M.L.E. (2002) b. “The four components of biodetrioration and of preservation of our collective memory". International Symposium a Choice and Strategies for Preservation of a Collective Memory. Dobbiaco, Toblach, Italy.

GACETA MUNICIPAL (1996). Municipio Miranda Edición Extraordinaria, Ordenanza de Zonificación Arquitectura y Construcción para el Centro Histórico de Coro I, IX N7. p.p. 24.
GACETA OFICIAL DE LA REPÚBLICA DE VENEZUELA (1995) No.33.024, Comité de Patrimonio Mundial. Julio XVII.

GARCÍA, J. C. R. (2016). “Evaluación aeromicrobiológica del depósito del Centro de Documentación del Museo Nacional de la Música de Cuba". Ge-conservación №. 9, p. 117. Disponible en: <https://ge-iic.com/ojs/index.php/revista/article/view/289>.

GAÜZĖRE, C., MOLETTA-DENAT, M., BLANQUART, H., et al (2014). "Stability of airborne microbes in the L ouvre M useum over time". Indoor air, 24(1), 29-40.

GIRALDO, J.D.C. (2014).“"El cielo en la casa. Casas de patios, sol y lluvia en el Valle de Aburrá". Cuadernos de Vivienda y Urbanismo, 7(13).

HERRÁEZ, J. A. (2014). Manual de seguimiento y análisis de condiciones ambientales. plan nacional de conservación prevenfiva. Ministerio de Educación, Cultura y Deporte, España.

ILSTRUP, D. M. (1990). Statistical methods in microbiology. Clinical microbiology reviews, 3(3), 219-226.

INAMEH, (2015) “Instituto Nacional de Meteorología e Hidrología”, Venezuela Boletín Climático, Caracas.

INSHT (1989). Calidad del aire interior: riesgos microbiológicos en los sistemas de ventilación/ climatización. NTP 313. Madrid: Ministerio de Trabajo y Asuntos Sociales.

KERR, J. THOMAS (1998). Introductory microbiology: Laboratory manual, Georgia: University of Georgia.

KOLWZAN, B., ADAMIAK, W., GRABAS, K., et al. (2006). Introduction to environmental microbiology. Oficyna Wydawnicza Politechniki Wroc1awskiej, Wroc1aw.

KOZAKIEWICZ, Z. (1989). "Aspergillus species on stored products" Mycological Papers. 161:1-188.

LACAZ, C. D. S., PORTO, E., HEINS-VACCARI, E., et al. (1998). Guia de identificaçäo fungos, actinomicetos, algas de interesse médico. Sarvier

MICHALSKI, S. (2006). "Preservación de las colecciones", Cómo administrar un museo: manual práctico. París: ICOM, pp. 51-90.

MPPC, (2005). Manual de normativas técnicas para museos, Ministerio de la Cultura. Venezuela.

NITIU, D. S., MALLO, A., SAPARRAT, M., et al. (2016). "Survey of the state of conservation of the Mylodon listai (XenarthraMylodontidae) skin fragment from the Pleistocene of Argentina kept at the Museum of La Plata (Argentina)". Ge-conservación, No10, p. 44-53, dic. 2016. ISSN 1989-8568. Disponible en: < https:// ge-iic.com/ojs/index.php/revista/article/view/367>

PLINCODE (2005). "Plan Integral de conservación y desarrollo de Coro, La Vela y sus áreas de Influencia", Estudio Arquitectónico y Urbanístico Ministerio de la Cultura, Instituto de patrimonio Cultural. Caracas: Venezuela p.p.38. 
REYES-LOVERA A.M. (2016). “Coro y su Puerto La Vela: patrimonio mundial de la humanidad". Consciencia y Diálogo. Año 6, № 6, Enero-Diciembre, pp. 167-182.

ROJAS YARUBIT, ARAUJO JOSÉ, NOROÑO YOSENIA, (2014). "Métodos de Microanálisis aplicados a obras de arte pictóricas", Revista Interdisciplinaria de Ciencias y Artes, Bacoa ISSN: 2343-5542. Año IV. Vol. 4. Nº 7. Enero - Junio, p.p. $80-95$.

ROJAS, Y., JORDÁN, M., YEGRES, F., et al. (2015). “Caracterización microbiológica del suelo, agua y aire en el humedal Quebrada de Guaranao", Paraguaná, estado Falcón. Revista de la Universidad del Zulia, 4(9).

SCHLEGEL, H. G., \& ZABOROSCH, C. (1997). Microbiología general. Barcelona: Omega.

SIAQ-CIB Task Group TG 42. (2004). "Performance criteria of buildings for health and comfort".68p.CIB number 292. Disponible en: www.isiaq.org/docs/TG42-report.pdf

SKÓRA, J., GUTAROWSKA, B., PIELECH-PRZYBYLSKA, K., S. et al. (2015). "Assessment of microbiological contamination in the work environments of museums, archives and libraries". Aerobiologia, 31(3), 389-401.

UNESCO (1993). Convention Concerning the Protection of the World Cultural and Natural Heritage, Colombia: Cartagena 70:611.

UNESCO, VON DROSTER, Bernd (1994). "Comunicación WHC/74/230/426/IvH Inscripción de Coro y su Puerto" en Decimoséptima reunión del Comité de Patrimonio Mundial, $\mathrm{N}^{\circ} 658$, 28:1.

VALENTÍN V, MURO C, MONTERO J. (2015). “Métodos y Técnicas para Evaluar la Calidad del Aire en Museo: Museo Nacional Centro de Arte Reina Sofía". Ed. CARS - IIC Grupo Español pp. 63-81.

VALENTIN, N. (2003). "Microbial contamination in museum collections: organic materials". Molecular biology and cultural heritage, 85-91.

VALENTíN, N. (2007). Microbial contamination in archives and museums: health hazards and preventive Strategies using air ventilation Systems. The Getty Conservation Institute.

YUNIS S, ARAUJO J, DIAZ A. (2014). "Calidad microbiológica del aire exterior en la zona UNESCO de la ciudad de Coro. Estado Falcón". 109. En V Congreso Venezolano de Diversidad Biológica, Zulia, Ministerio para el poder popular de Ciencia y Tecnología, 109.

YUNIS S, DÍAZ A, ARAUJO J. (2015) "Calidad del aire exterior utilizando bacterias y hongos miceliales como bioindicadores en el patrimonio cultural de la humanidad (UNESCO) de la ciudad de Coro; estado Falcón, Venezuela". Universidad Nacional Experimental Francisco de Miranda, tesis de grado para optar al título de licenciado en Ciencias Ambientales. 112.

\section{Autor/es}

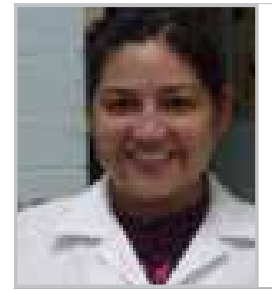

\section{Yarubit Rojas}

yarupichu@gmail.com

UNEFM (Universidad Nacional Experimental Francisco de Miranda)

La Profesora Yarubit Rojas es Licenciada en Ciencias Ambientales y Abogada, con maestría en Museología y especialización en microscopía y microanálisis. Docente del Programa de Licenciatura en Conservación y Restauración, del Bien mueble Cultural Universidad Nacional Experimental Francisco de Miranda UNEFM, Fue Becaria de la Unidad de Microscopía Electrónica y Microanálisis de la UNEFM y actual coordinadora del laboratorio de Biología, Química y Física aplicada a la Conservación y Restauración de la UNEFM, Ganadora del Premio en Ciencia y Tecnología 2014 a la mejor investigación científica. Trabaja en estudios de Microbiología y Calidad del Aire en Museos, Casas patrimoniales, Jardines y ambientes naturales, así como en el microanálisis valoración, tasación y peritaje de obras de arte desde el 2010. Posee numerosos antecedentes en Reuniones y Publicaciones en distintos ámbitos científicos nacionales e internacionales. Pertenece al comité evaluador de diversas revistas científicas.

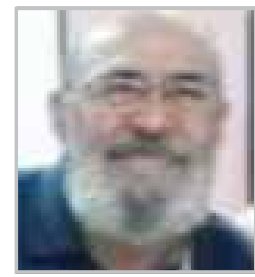

\section{Francisco Yegres}

fyegres@gmail.com

Director de laboratorio LIADSA UNEFM

(Universidad Nacional Experimental

Francisco de Miranda)

El Profesor Francisco Yegres es Biólogo, reconocido como micólogo de gran experiencia internacional en Francia, Brasil, Italia, Japón, Colombia y Venezuela entre otros países, Doctor en Ciencias de la Salud. Conferencista Internacional junto a su esposa y también Investigadora la Dr. Nicole Richard de Yegres. Posee más de 200 publicaciones científicas y paracientíficas. Tutor de tesis de pregrado y postgrado en las áreas de las Ciencias de la Salud (Medicina, Enfermería, Gerontología, Medicina Veterinaria), Ingeniería Química, Agronómica e Industrial, y en las ciencias Ambientales, Biología y Química, Conservación y Restauración. Creador de la maestría en Micología de la UNEFM. La especie Cladiophialophora yegresii fue reconocida en su honor. Ganador de diversos premios en Ciencia y Tecnología así como distinciones, regionales, nacionales, presidenciales e internacionales. Director de laboratorio LIADSA UNEFM. Investigador PEIl y activo desde el año 77 hasta la fecha. 


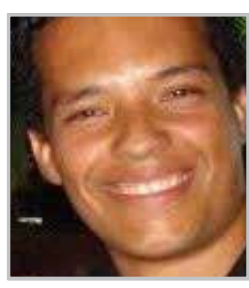

\section{José Araujo}

jaab19@gmail.com

UNEFM (Universidad Nacional Experimental

Francisco de Miranda)

El Profesor Francisco Yegres es Biólogo, reconocido como micólogo de gran experiencia internacional en Francia, Brasil, Italia, Japón, Colombia y Venezuela entre otros países, Doctor en Ciencias de la Salud. Conferencista Internacional junto a su esposa y también Investigadora la Dr. Nicole Richard de Yegres. Posee más de 200 publicaciones científicas y paracientíficas. Tutor de tesis de pregrado y postgrado en las áreas de las Ciencias de la Salud (Medicina, Enfermería, Gerontología, Medicina Veterinaria), Ingeniería Química, Agronómica e Industrial, y en las ciencias Ambientales, Biología y Química, Conservación y Restauración. Creador de la maestría en Micología de la UNEFM. La especie Cladiophialophora yegresii fue reconocida en su honor. Ganador de diversos premios en Ciencia y Tecnología así como distinciones, regionales, nacionales, presidenciales e internacionales. Director de laboratorio LIADSA UNEFM. Investigador PEll y activo desde el año 77 hasta la fecha.

Artículo enviado el 01/12/2017 Artículo aceptado el 21/08/2019 


\section{Descripción del proyecto de investigación: Cástulo siglo XXI y FORVM MMX}

Desde que este yacimiento se declaró Conjunto Arqueológico en 2011 por la Consejería de Cultura de la Junta de Andalucía (Decreto 261/2011, de 26 de julio), cuenta con un proyecto integral denominado Cástulo Siglo $X X I$. En este proyecto se planteó realizar la investigación de algunas zonas concretas de la ciudad de Cástulo a través de la excavación del mismo (foro romano, puerta norte, cisternas de agua, zona ibérica, castillo de Santa Eufemia y puerto fluvial). De manera que, dentro de este marco general, surgió un primer proyecto denominado FORVM $M M X^{\prime}$, que tuvo lugar entre 2011 y 2014, y cuyo objetivo fue encontrar el foro romano de la ciudad.

El devenir de los hallazgos cambió mucho el planteamiento inicial del proyecto Cástulo siglo XXI y también de FORVM $M M X$ pues, en lugar de encontrar el foro, se hallaron tres importantes edificaciones en el centro monumental de la urbe:

- Los restos de la primera de estas tres edificaciones corresponden a un inmueble de carácter público (de culto imperial a Domiciano) en el que se han recuperado pavimentos musivarios, entre ellos el Mosaico de los Amores (Calabria 2013: 40; López 2014), y pinturas murales de una gran calidad (Jiménez 2014).

- La segunda de ellas tiene que ver con otro gran espacio público, en el cual se han documentado evidencias de una comunidad judía que revela, por primera vez, datos de ocupación de este pueblo en Cástulo (Ceprián y Soto 2014: 83-87).

- Y por último, un tercer edificio de culto paleocristiano, documentado por las investigaciones arqueológicas en torno al siglo IV d.n.e. y donde se halló una patena de vidrio para el culto litúrgico con la representación de Cristo en Majestad que además, es de una de las patenas más antiguas conservadas en la Península Ibérica (Expósito et al.: 2017).

Desde 2014 hasta la actualidad se vienen realizando trabajos de excavación en otras áreas, con nuevos hallazgos de importante calado en la secuencia histórica de este yacimiento arqueológico, como la torre púnica al noroeste (Soto et al. 2017) o los restos de un importante monumento romano situado sobre la muralla ibérica al noreste de la ciudad (Barba 2014: 135; Barba et al. 2015).

\section{Aproximación histórica a la ciudad}

La ciudad de Cástulo se sitúa en el valle del Alto Guadalquivir. Elevada sobre una meseta confinada al sur por el río Guadalimar (uno de los afluentes más importantes del río Guadalquivir) y al oeste por el arroyo San Ambrosio [figura 1].

Ubicada en un enclave geográfico privilegiado desde el punto de vista agrícola y ganadero, pero sobre todo por su riqueza minera que permitiría mantener un rico comercio por vía fluvial a través del Guadalimar (entonces

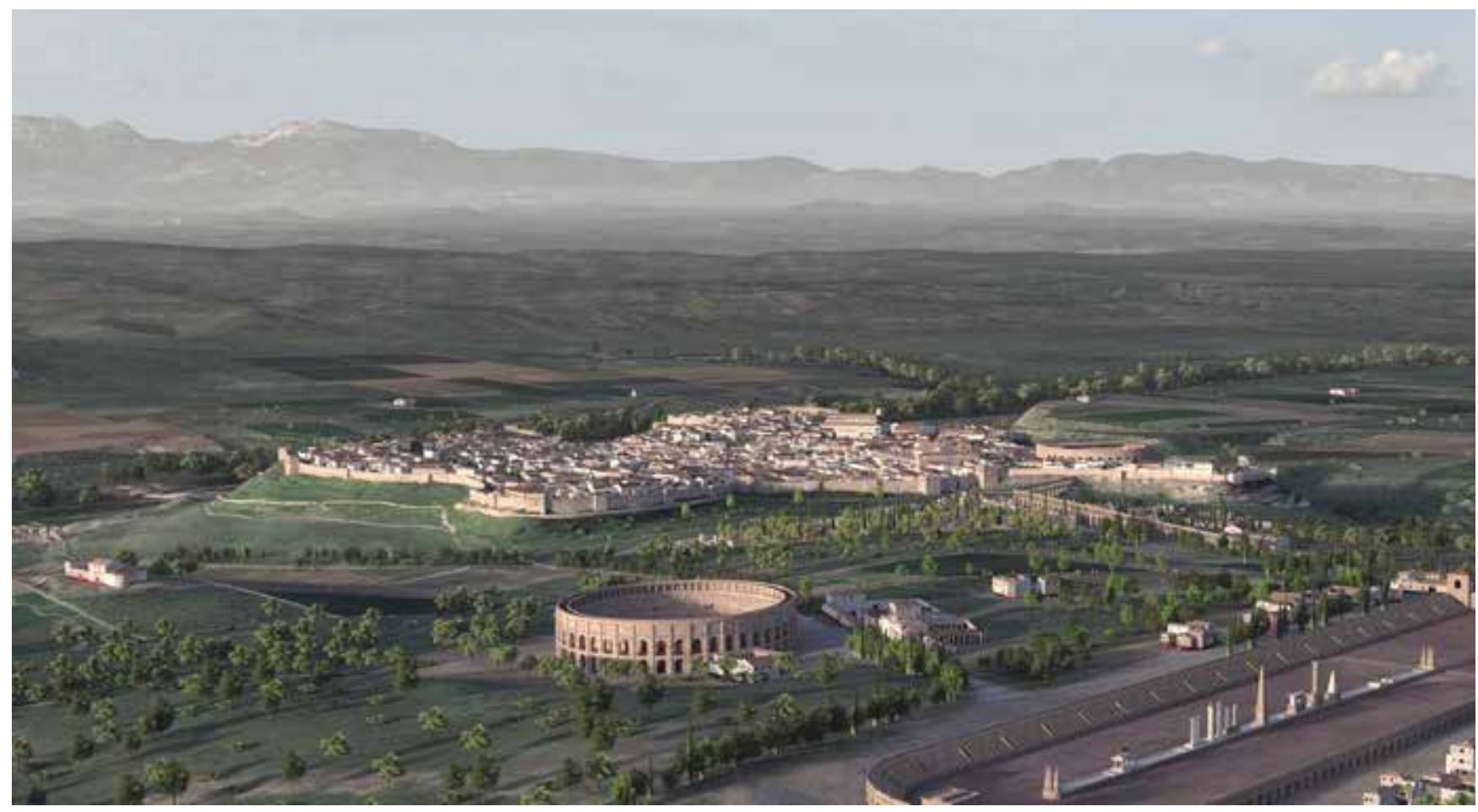

Figura 1.- Reconstrucción 3D de la ciudad romana de Cástulo vista desde la zona norte. Autor: Francisco Arias de Haro. 
navegable) y por su amplia red de caminos (Blázquez y García-Gelabert 1983: 1).

La plata, el plomo, el cobre, la anglesita y el hierro eran metales abundantes en las explotaciones mineras de Sierra Morena (Blázquez y García-Gelabert 1983: 1), lo cual atrajo desde la antigüedad a otros pueblos del Mediterráneo. Sus primeros colonos fueron griegos y fenicios con el fin de propiciar un comercio con los íberos, autóctonos de la zona, respetando la legitimidad territorial de éstos.

Estas tierras han tenido una ocupación ininterrumpida desde el siglo IX a.n.e. hasta el siglo XVI d.n.e. Aunque el máximo esplendor viene dado por la ocupación ibero-romana, convirtiéndose en capital de la provincia de la Oretania y motivo, más tarde, de litigios entre cartagineses y romanos durante la Segunda Guerra Púnica (218-201 a.C.), en la cual los cartagineses, con Aníbal Barca al frente, fueron derrotados por las tropas de Publio Cornelio Escipión, conocido como el Africano (Castro s.f.: 47-69).

Estrabón o Tito Livio citaban la ciudad de Cástulo a menudo en sus escritos, junto a ciudades de la talla de Hispalis (Sevilla) y Córduba (Córdoba):

"El Betis, a lo largo de sus orillas, está densamente poblado y es navegable corriente arriba casi mil doscientos estadios (más de doscientos kilómetros) desde el mar hasta Córduba y lugares situados un poco más al interior [...] Así pues, hasta Hispalis la navegación se efectúa en embarcaciones de tamaño considerable [...] hasta Córduba en lanchas fluviales hechas hoy día con maderos ensamblados [...] Más arriba de Cástulo el río (actual río Guadalimar) deja de ser navegable". (Estrabón, Geographica III, 2, 3. Traducido por María José Meana (1992: 51).

"Cástulo, fuerte y célebre ciudad de Hispania, estrechamente unida a los cartagineses hasta el punto de que la esposa de Aníbal era de allí (la princesa íbera Himilce), pasó sin embargo a los romanos." (Tito Livio, Ab urbe condita XXIV, 41,4. Traducido por José Antonio Villar Vidal (1993: 359).

Es a partir del siglo III cuando comienza, en Cástulo, una crisis económica que se prolongará y declinará hasta siglo V (Blázquez y García-Gelabert 1994: 527-540). Con los Visigodos, la ciudad aún sigue conservando importancia siendo sede episcopal, aunque pronto, la sede se trasladará a Baeza comenzando así la decadencia de esta ciudad (Blázquez y García-Gelabert 1994: 545). Durante la conquista musulmana (a partir del siglo VIII), Quastuluna nombre de Cástulo adquirido bajo el mandato árabe- sigue funcionando como núcleo urbano por un corto periodo de tiempo, hasta la sublevación muladí contra Córdoba (en el siglo IX) (Blázquez y García-Gelabert 1994: 545-546). La ciudad de Cástulo sobrevive a pesar de todo este periodo de inestabilidad, y después de este tiempo pasa a llamarse Cazlona. En etapas posteriores (entre los siglos XIII y XV), poco se conoce del lugar pues no existen testimonios escritos ni demasiados vestigios que atestigüen su ocupación. La ciudad desaparece definitivamente hacia los siglos XV y XVI cuando es usada como cantera para abastecer de materiales a las ciudades emergentes de la zona (Blázquez y García-Gelabert 1994: 547-549).

\section{Justificación y objetivos del trabajo}

La estancia del Mosaico de los Amores fue descubierta en 2011, junto a un conjunto de pintura parietal de gran calidad y de grandes dimensiones, correspondiente al muro norte de esta sala. El director de los mencionados proyectos y del Conjunto Arqueológico, Marcelo Castro, aclara que estos estucos del revestimiento de la pared norte corresponden al muro de cabecera del edificio y se encuentran tumbados, en modo de derrumbe, sobre el pavimento musivario, habiéndose conservado en esa posición hasta la cornisa del techo, por lo que se ha podido estimar su altura y la decoración que presenta [figura 2a y 2b] (Castro 2014 b: 127-129).

Posteriormente han ido apareciendo una gran cantidad de estucos conforme se ha ido excavando la estancia, en los años 2012 y 2013, aunque uno de los lienzos más interesantes para su estudio es el del muro norte, por las características que comenta Castro.

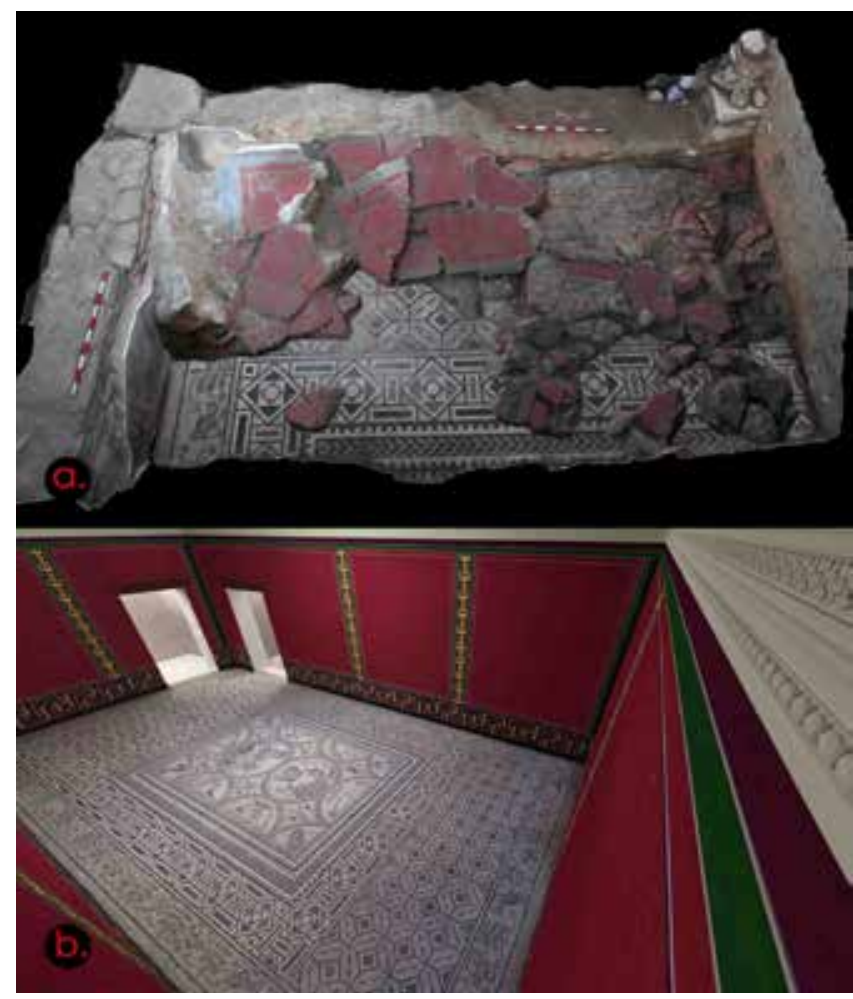

Figura 2.- a) Fragmentos de pintura mural hallados, en posición de derrumbe, en la zona de la pared norte de la sala del Mosaico de los Amores. b) Reconstrucción 3D de la sala del Mosaico de los Amores vista desde el ángulo noreste. Autor: Francisco Arias de Haro. 
Uno de los objetivos establecidos por el Proyecto Cástulo Siglo XXI a medio plazo, es formalizar la puesta en valor del sitio arqueológico. Se pretende musealizar la zona de titularidad pública con los itinerarios e hitos. Uno de los puntos principales en el recorrido es la estancia del Mosaico de los Amores, de manera que se hace necesario el estudio y puesta en valor de su conjunto mural dada la calidad artística, y la excepcionalidad de su estado de conservación.

El ICOMOS (Consejo Internacional de Monumentos y Sitios Histórico-Artísticos), define los principios generales para la preservación, conservación y restauración de pinturas murales. Entre éstos criterios defendidos encontramos que "Las pinturas murales son una parte integrante de los monumentos y lugares de valor patrimonial y deben ser preservadas in situ..." (ICOMOS 2003: 1).

En 2013, aprovechando el nuevo proyecto para la instalación de una cubierta provisional para esta sala, se realizó una investigación sobre los revestimientos murales del muro norte (Calabria 2013) con el fin de idear una propuesta que contemplase una solución expositiva viable in situ y así contribuir a la conservación de estas pinturas murales devolviendo parte de "legibilidad" al conjunto.

En el presente artículo, el objetivo principal es poner de manifiesto que, previo a cualquier propuesta de intervención, es esencial realizar un estudio para conocer las tipologías estilísticas, la técnica de ejecución, la resistencia mecánica y las características tanto de la argamasa como de la pintura mural. Los datos arqueométricos obtenidos facilitan información muy valiosa para llevar a cabo futuras intervenciones y tratamientos de restauración.

En este sentido, este estudio es determinante para caracterizar la técnica de ejecución y estilística de estas pinturas murales, profundizando, sobre todo, en la identificación de la forma en la que se aplicaron los pigmentos rojos con el propósito de poner al servicio de la comunidad investigadora y científica los datos y las conclusiones obtenidas.

\section{Metodología}

En este artículo se presentan los resultados obtenidos en el estudio analítico llevado a cabo por los autores que se sustenta y amplía los datos obtenidos en la investigación previa desarrollada en colaboración con la UPV. Como todo estudio científico, inicialmente se respalda en el análisis de fuentes documentales clásicas y las recomendaciones técnicas que éstas hacen, para así cotejarlas con los materiales que los muralistas romanos emplearon en la ejecución de los revestimientos de la pared norte de la sala del Mosaico de los Amores. Además, el estudio y la observación de los morteros y la técnica pictórica se ha llevado a cabo con nuevos análisis de MO y MEST. EI Microscopio Óptico utilizado ha sido Leica ${ }^{\circledR}$ DM 750 y el microscopio estereoscópico Leica ${ }^{\circledR}$ S8 APO, ambos con sistema de adquisición de imágenes Leica Microsystems ${ }^{\circledast}$ (Servicio de Análisis del Departamento de Conservación y Restauración de la Universitat Politècnica de València -UPV-).

Se han observado y analizado las micromuestras por medio de Microscopía Electrónica de Barrido con detector de Rayos X (SEM-EDX) con el fin de complementar y profundizar ciertos aspectos que resultan de interés. Estas muestras han sido metalizadas con oro paladio y no se han englobado en resina de poliéster para conseguir una mejor conductividad que favorezca la obtención de resultados de los análisis. El microscopio utilizado ha sido el S4800 (Hitachi) con cañón de emisión de campo (FEG) con una resolución de $1.4 \mathrm{~nm}$ a $1 \mathrm{KV}$. Este equipo dispone de detector retrodispersado, detector de RX Broker, detector de transmitida, el programa QUANTAX 400 para realizar microanálisis y cinco ejes motorizados. Además para este estudio se ha utilizado la herramienta mapping, resultando muy útil ya que determina los elementos por áreas generando un mapeo cuantitativo de elementos detectados en una superficie generando una imagen cartográfica. Dichos estudios se han llevado a cabo gracias a la colaboración del técnico de laboratorio E. Navarro Raga, miembro perteneciente al Servei Central de Suport a la Investigació Experimental (SCSIE) de la Universitat de València (UV).

\section{La técnica mural a través de los textos clásicos}

Sobre la preparación de la pintura mural han sido muchos los eruditos que han aportado sus ideas: Vitrubio, Catón, Plinio, Columela, Paladio y Faventino (Olmos 2006: 28). Aunque hay que hacer especial mención al trabajo de Vitrubio (Los diez libros de la Arquitectura VII, 3)2, pues el tratadista, realiza una descripción detallada de cómo elaborar el revestimiento mural y los materiales que se deben emplear para la confección del mismo, apuntando recomendaciones precisas a la hora de acometer algunas tareas (Vitrubio, Los Diez libros de Arquitectura.Traducido por José Luís Oliver 1995: 267-269). Otro autor clásico a tener en cuenta es Plinio "el Viejo". Éste, aunque más escueto en detalles cuando describe la técnica de ejecución, se centra en la descripción de ciertos pigmentos más empleados en la época (Plinio el Viejo, Textos de Historia del Arte XXXVI: 29-52, Traducido por Ma Esperanza Torrego (1987: 85-88).

Estos dos autores clásicos recomendaban la aplicación de un número determinado de estratos preparatorios. Modelos paradigmáticos que, se entiende, eran secundados a lo largo y ancho de todo el Imperio Romano. Vitrubio (Los diez libros de la Arquitectura, VII, 3. Traducido por José Luís Oliver (1995: 268) nombra siete capas preparatorias, que además han sido encontradas en la Casa de Lívia y Villa Farnesina en Roma, (Ling 1991: 199). Plinio (Adam 2002: 236) recomienda el uso de cinco capas. Pero los datos arqueométricos que nos ofrecen las excavaciones arqueológicas, concluyen que en la mayor 
parte de las pinturas murales halladas no se siguen los patrones clásicos en la preparación del revestimiento mural, sino que normalmente se componen de tres capas, incluso dos o en ocasiones cinco estratos (Olmos 2006: 31). Esto nos hace pensar que los artesanos muralistas trabajaban, sujetos a la condición de tener que nivelar correctamente la preparación de la pintura mural sobre el paramento más que a la preocupación de seguir modelos paradigmáticos dictados por los eruditos.

\section{Las pinturas murales de la estancia del Mosaico de los Amores}

\section{a) Estudio estilístico}

El muro norte de esta estancia cuenta con $6,15 \mathrm{~m}$ de ancho por 3,80 m de alto (Castro 2014 b: 127; Calabria 2013: 83), con un friso de casi 20 centímetros de altura [figura 3]. Se conoce la altura porque se recuperaron todos los fragmentos desde la base hasta la cornisa.

Como se puede apreciar, el estilo compositivo de estas pinturas murales tiene un patrón muy conocido en el mundo romano: esquema tripartito (Abad 1982: 146; Fernández 1997-98: 198; Adam 2002: 238; Mora et al. 2001: 118-121; Cantarella y Jacobelli 2013: 79). Este esquema

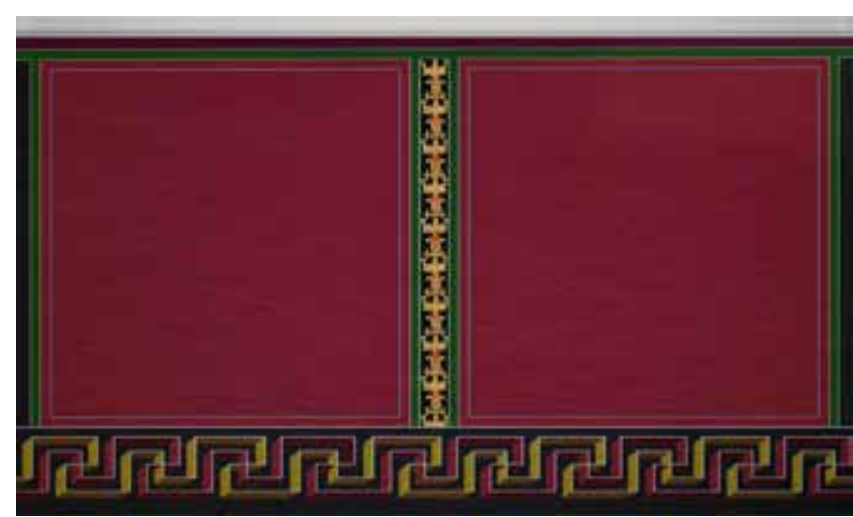

Figura 4.- Reconstrucción de la decoración de la pared norte. Autor: Francisco Arias de Haro.

tiene una distribución espacial realizada horizontalmente [figura 4] en cuya parte inferior se encuentra el zócalo corrido con cruces gamadas que se entrelazan unas con otras creando una ilusión de profundidad.

La parte central está compuesta por dos paños rojos divididos mediante una cenefa. Este tipo de decoración dividida por franjas es muy habitual en la práctica mural romana. Dicha cenefa está decorada con una cadena de candelabros (Abad 1982: 518) que recuerdan a motivos

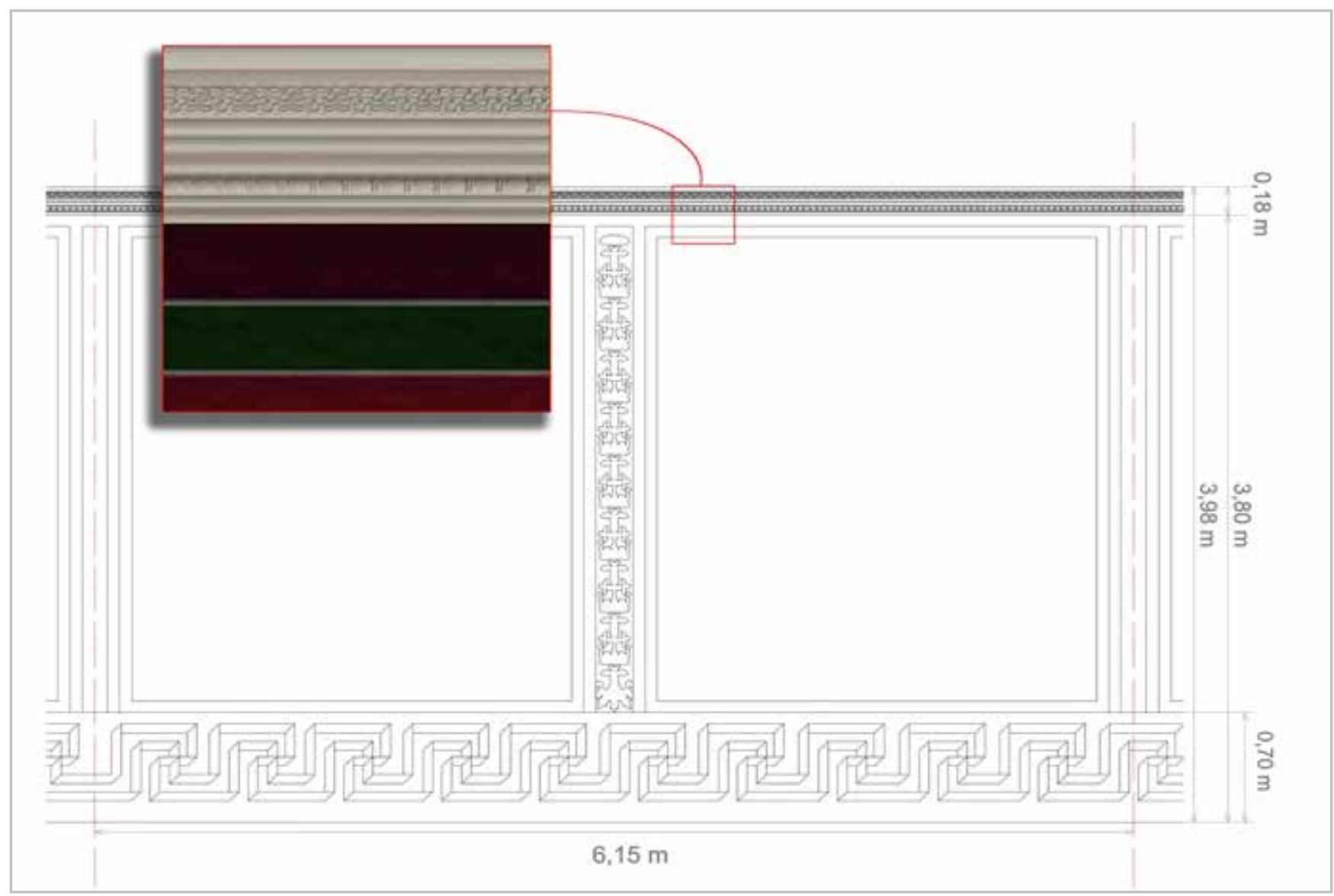

Figura 3.- Dibujo esquemático y medidas de la pared norte de la sala del Mosaico de los Amores. Autor: Irene Marta Calabria Salvador. 
vegetales con perfiles y terminaciones en forma de cisne [figura 5a]. Las superficies monocromas rojas quedan delimitadas por franjas verdes con trazos lineales más finos de color blanco.

En la zona superior se encontraba la cornisa con una decoración vegetal elaborada con tréboles de tres hojas que van alternando su posición [figura 5b]. Según un reciente estudio (López et al. 2016: 163) estas cornisas tienen una matriz de cal y se han encontrado restos de policromía ocre y roja (óxidos de hierro y plomo). Es excepcional encontrar la cornisa en las excavaciones (Fernández 1998), pues este friso es un elemento difícil de recuperar ya que se suele perder en el momento del derrumbe del edificio.

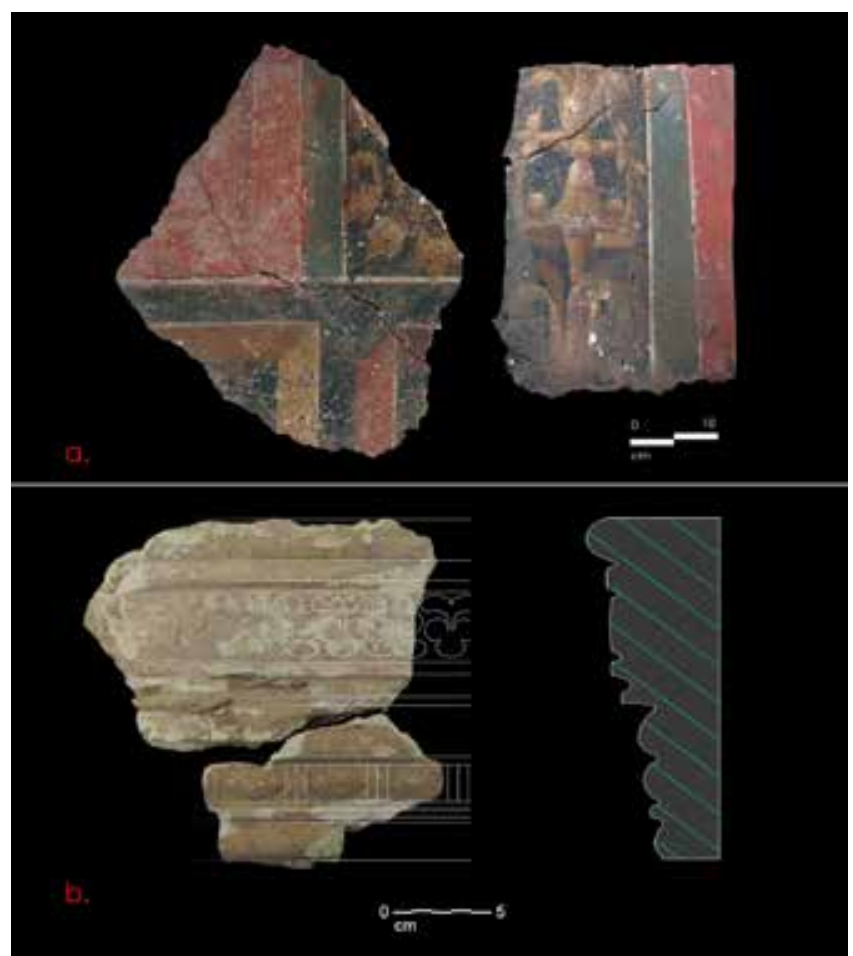

Figura 5.- . a) Fragmentos de la cenefa central donde se muestra parte de la decoración de la cenefa central. / b) Fragmento de la cornisa recuperada completa, dibujo lineal y sección de la misma. Autor: Irene Marta Calabria Salvador.

Se aprecia que la pintura de la sala del Mosaico de los Amores es una combinación de dos estilos pompeyanos (Rostovtzeff 1919: 149), entre el Estilo III (denominado ornamental) correspondiente a la primera mitad del siglo I d.n.e., y el Estilo IV (considerado teatral) desarrollado a partir de la segunda mitad del siglo I d.n.e. (Mostalac 1992: 16-21). Aunque la observación del estrato pictórico en el que se percibe un predominio de la decoración, denota una evolución del Estilo III al Estilo IV. Un estudio interesante para profundizar en los detalles estilísticos de las pinturas murales de estilos III y IV, es el realizado por Antonio Mostalac y Carmen Guiral (1990: 155-174). En él se estudian los paralelos más significativos de la península ibérica encuadrados en estos estilos: Emporiae (Ampurias), Baetulo (Badalona), Celsa (Velilla de Ebro), Caesaraugusta (Zaragoza), Tiermes, Uxama (Osma), Valentia (Valencia), Vic, Bilbilis (Calatayud), Calagurris (Calahorra) y Arcobriga (Monreal de Ariza).

La clasificación dentro de los Estilos III y IV, proporciona datos cronológicos coincidentes con la investigación arqueológica llevada a cabo en esta área de excavación del edificio público, al que pertenecen las pinturas. Los datos arqueométricos reflejan que este edificio, muy posiblemente, se construyó a lo largo del siglo I d.n.e. y, según las hipótesis, fue destruido a finales de esta centuria a causa de la orden de Damnatio Memoriae aplicada después del asesinato del emperador romano Domiciano (81-96 d.n.e.) (Castro 2014 b: 128). Este suceso refuerza los hallazgos arqueológicos y constatan que el edificio nunca llegó a terminarse, y por ende, a utilizarse. Esto explicaría el buen estado de conservación en el que se encuentran los paramentos murales y también el pavimento musivario.

\section{b) Técnica de ejecución}

Como se ha comentado anteriormente, pocas pinturas murales presentan siete estratos preparatorios, la gran mayoría se componen de tres estratos (Garate 2002: 83), a veces, incluso se reducen a dos (Olmos 2006: 31). Por otro lado, en la Hispania romana observamos casos de empleo de cuatro estratos, como en la Casa del Teatro de Mérida (Badajoz) y en Itálica (Sevilla), según Olmos (2006: 35). En las pinturas murales de la sala del Mosaico de los Amores, se han encontrado entre tres y cuatro estratos de mortero preparatorio [figura 6].

\section{Estudio estratigráfico}

El estudio estratigráfico realizado sobre las pinturas murales ubicadas en el muro norte de la sala del Mosaico de los Amores, nos revela la existencia de tres-cuatro estratos o capas bien definidas en la mayor parte de los fragmentos [figura 6]. Olmos (2006: 35) hace referencia a que en Cástulo se han encontrado pinturas murales de cinco capas, y según López et al. (2015 a: 171; 2016: 162) se reconocen cuatro capas.

El nombrado arriccio se encuentra en el primer estrato de nivelación. Se reconoce gracias a la huella del reverso (en muchos casos dispuesta en espiga) para conseguir que el mortero se agarre lo mejor posible a la pared [figura 7a]. Otro detalle que indica que se trata del primer estrato, es que además presenta un mayor número de impurezas y de clastos de gran tamaño. También se perciben pequeños orificios que debieron estar rellenos de broza y que no se ha conservado a causa de su naturaleza orgánica [figura 7b]. Sin embargo, la forma de estos restos vegetales permanece bien definida y conservada gracias a la carbonatación de la argamasa [figura 7c]. 

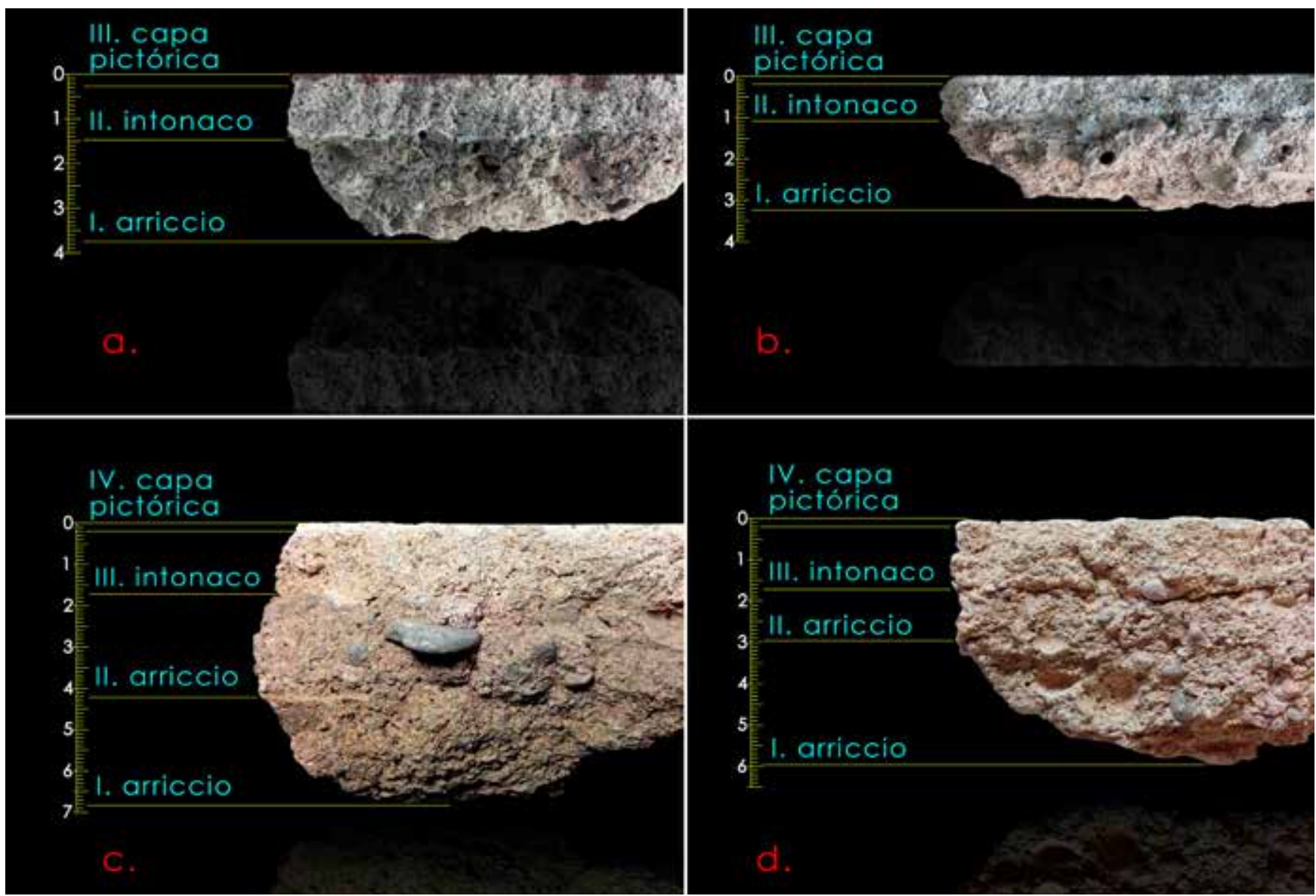

Figura 6.- Estudio estratigráfico de cuatro fragmentos de pintura mural de la sala del Mosaico de los Amores. Autor: Calabria, I. M. En las imágenes a y b se observan 3 estratos preparatorios mientras que en las imágenes c. y d., se aprecian cuatro capas.

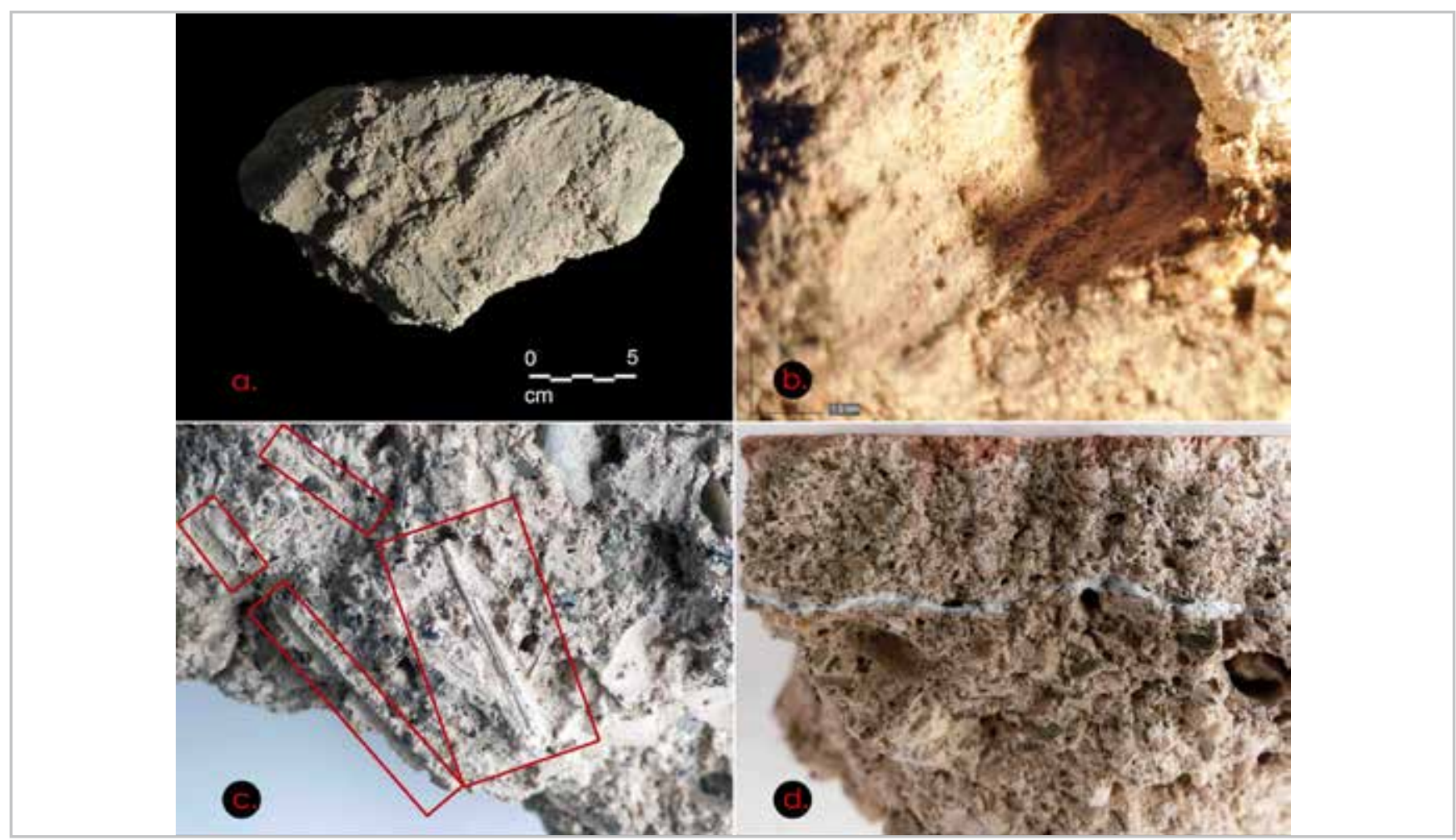

Figura 7.- a) Reverso de uno de los fragmentos de pintura parietal donde se observa la posible huella del agarre a la pared. También se aprecia la tosquedad de esta primera capa de mortero. b) Imagen tomada mediante microscopía óptica. Se aprecia la impronta de broza en el mortero. c) Zonas donde se observa la forma de la broza gracias a la carbonatación del mortero. d) Detalle de una fina capa de lechada de cal. 
La broza tenía un importante papel en la elaboración de la argamasa, ya que le aporta resistencia mecánica gracias a su función reguladora del agua en el proceso de fraguado dando elasticidad a la mezcla (Sickels 1981: 7-20; Zalbidea 2004: ss.pp.; Zalbidea et al. 2010: 506).

Este estrato, que denominamos estrato de nivelación o arriccio, se encuentra duplicado en diferentes muestras, por ello se determina que las capas de preparación de la estancia del Mosaico de los Amores oscilan entre tres y cuatro capas o estratos dependiendo de la zona analizada [figura 6].

Sobre el estrato de arriccio encontramos el intonaco. Se trata de un mortero preparatorio con un árido de gran similitud en la granulometría al anterior estrato pero sin impurezas de tipo clastos. Además entre el primer y segundo estrato se puede observar una fina lechada de cal en algunas de las muestras analizadas [figura 7d].

El último estrato (enlucido) es el pictórico, denominado también capa pictórica. Se compone de una fina capa de cal que engloba los pigmentos aplicados por el pictor parietarius o pictor imaginarius (Olmos 2006: 24; Adam 2002: 242; Guiral 2014: 106)³ sobre el estrato aún en fresco y que, en la mayoría de ocasiones, era acabado con algunos retoques en seco (Garate 2002: 81) con aglutinantes orgánicos (Adam 2002: 240) y/o agua de cal.

\section{Componentes del mortero: análisis}

Conocemos la composición de la argamasa de mortero por el estudio realizado tanto con MO, MEST como al SEMEDX. En líneas generales el mortero de la sala del Mosaico de los Amores es un mortero de aspecto rosáceo en el cual se incorporan clastos de tonalidad gris oscuro con forma de elipse. Como se ha nombrado anteriormente, dependiendo del fragmento estudiado, encontramos 3 o 4 estratos de argamasa, pero se percibe que ésta es frágil y tiene poca resistencia mecánica, ya que se fragmenta al presionarla ligeramente. Esta debilidad, probablemente derive de la dosificación entre árido-ligante [3: 1] (Calabria 2013: 84) y con un porcentaje inferior de óxido de calcio que posteriormente se transformó en carbonato.

Otra característica a tener en cuenta es el elevado porcentaje de superficie ocupado por poros y áridos, valorado a través de la observación con el MO y MEST. Estos poros, en los morteros de cal, pueden originarse en los procesos de hidratación lenta (Cazalla, 2002: 139) del óxido de magnesio presente como contaminante en algunas cales. Aunque también, los poros, aparecen como bolsas de aire, lo que indica mezclas relativamente húmedas de mortero que ha sido aplicado sin esfuerzo específico de presión con la llana durante la aplicación (Weber et al. 2009).

La observación determina que no existen fracturas y grietas por contracción debido al endurecimiento rápido como sí se ha determinado en el estudio realizado por Ergenç et al. (2018), en La Casa de los Grifos.

Los últimos análisis realizados al SEM-EDX, determinan que este mortero está constituido por carbonato de calcio y magnesio con cantidades moderadas de compuestos silíceos o aluminosos. Interesante es el resultado obtenido en el microanálisis, que muestra en diferentes zonas analizadas que el porcentaje de calcio en relación a otros elementos es de un $7-8 \%$ en las capas interiores (2-3) y que aumenta al doble (16-17\%) en la capas exteriores. Estos porcentajes influyen en el proceso de carbonatación de la cal. Hay que tener en cuenta que la suma de estos dos elementos ( $\mathrm{Mg}$ y $\mathrm{Fe}$ ) es de un $5 \%$, al que se le debe de agregar otro $5 \%$ de otros materiales localizados como el $\mathrm{Si}$ y el Al e impurezas como el P y K.

Además, la presencia de estos materiales secundarios (no sólo $\mathrm{Mg}$ y $\mathrm{Fe}$, sino de $\mathrm{Si}$ y $\mathrm{Al}$ ), influyen en la tonalidad del mismo mortero reduciendo su blancura y generando este aspecto rosáceo.

\section{Estudio de la capa pictórica}

Se conoce la composición de ciertos pigmentos pertenecientes a decoraciones parietales en varias salas del mismo edificio gracias a los primeros análisis realizados para el proyecto FORVM MMX por Domènech et al. (2012, 2013 a, 2013 b), Arcos et al. (2015 b) y López et al. (2015 $a, 2015$ b, 2016). En éstos, Domènech distingue la lechada de cal como pigmento blanco, pensamos que se refiere al hidróxido de calcio, el cual, una vez carbonatado se transforma en carbonato de calcio. Como pigmento negro, principalmente se detectan tierras rojizas mezcladas con negro carbón. Para los ocres se usa tierra ocre amarilla rica en óxido de hierro, en los rojos se detecta el uso del carbonato de plomo y se aprecia el empleo copioso de hematita. Las sombras se elaboran con tierra natural y óxido de hierro. Algunos verdes se obtienen a partir del uso de azul egipcio (Domènech et al. 2013 b; Arcos et al. 2015 a) y los verdes oscuros a partir de carbonato cálcico y particulado de óxido de hierro. Sobre los pigmentos verdes en las pinturas murales de la Hispania romana encontramos estudios científicos interesantes (Domènech et al. 2013 a; Edrein et al. 2001; Duran et al., 2010), especialmente el de las pinturas murales del Alcázar de Sevilla por centrarse en los verdes (Pérez-Rodríguez et al. 2015).

Es curioso observar la combinación de pigmentos rojos (Ergenç et al. 2018), con los que trabajaban los pictor parietarius en estas pinturas. De hecho los óxidos de hierro seguramente serían materiales adquiridos de extracción local o cercana al sitio. Domènech (2012: 112) nombra el uso "... de óxido/sulfuro de plomo", en la muestra. Al igual que López et al. (2016: 165), en una de las muestras de tonalidad roja, detecta la presencia de óxido de plomo (minio) en una capa superpuesta a otra capa de óxidos de hierro. En la última analítica realizada para este estudio, se 
verifica que los pigmentos se han trabajado de esta forma específica, por capas independientes y no mezclados como habitualmente se ha certificado (Zarzalejos et al. 2014; Domènech 2012).

El estudio y la observación de diferentes muestras con diferentes tipos de análisis, han permitido verificar la técnica pictórica utilizada para la ejecución de la pintura de la estancia del Mosaico de los Amores, de tal modo que el proceso de aplicación de este estrato de color rosado, se ha conseguido con la aplicación a pincel de un enjalbegado coloreado con tierras rojas (mayoritariamente óxidos de hierro) sobre el que se aplicaron diferentes tonalidades; una de ellas un rojo compuesto de plomo (minio) [figura $8 \mathrm{c}]$. El minio es tetraóxido de plomo $\left[\mathrm{Pb}_{3} \mathrm{O}_{4}\right]$ y se conoce con varias denominaciones, cerusa usta (Eastaugh et al. 2004:97), minio de plomo, azarcón (Baez y San Andrés 2003: 155-172), siricum (Toubert 2006: 208) o rojo Saturno (Doerner 2001: 63). Era obtenido por calentamiento del blanco de plomo (Ergenç et al. 2018), y constituía uno de los pocos pigmentos rojos brillantes que se encontraba en el comercio, pero su tonalidad es anaranjada, muy distinto al carmín. Por ello es totalmente lógico encontrar un estrato inferior en el que se introduzcan óxidos de

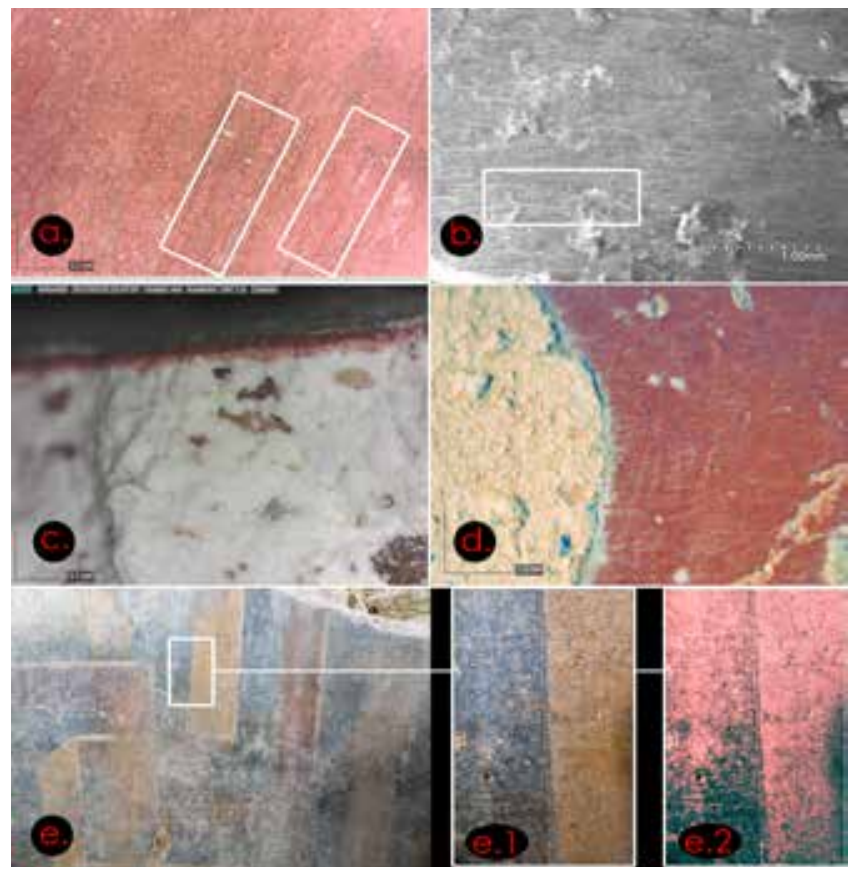

Figura 8.- En las imágenes a y b se observa la huella del pincel para la aplicación de los pigmentos. c) Fotografía tomada mediante microscopía óptica de la sección transversal donde se aprecia la capa de minio superpuesto a las tierras ricas en óxido de hierro. d) Imagen tomada mediante microscopía óptica que muestra la técnica de aplicación de la capa blanca (al seco) sobre fondo rojo (al fresco). e) Zócalo inferior con zona marcada en rojo donde se observa el detalle de una de las técnicas de encaje previo utilizadas en este paramento mural. e.1) Detalle del encaje previo mediante línea incisa. e.2) Imagen editada mediante software Image J de procesamiento de imagen digital, en la cual se aprecia, con mayor definición, el trazo inciso. hierro que potenciarán la tonalidad rojiza del minio en detrimento de su matiz anaranjado [figura $8 \mathrm{c}$ ] y protegerán al minio del contacto directo con el estrato de carbonato de calcio (rico en álcalis). Las cualidades que distinguen a los óxidos férricos son a tener en cuenta: facilidad de preparación, gran permanencia a la luz, buena capacidad de cubrimiento, además su abundancia en la naturaleza les hace formar parte del grupo de pigmentos rojos de precio bajo (Toschi et al. 2013: 295).

El minio, a diferencia de los óxidos de hierro, no tiene estabilidad a la luz, acelera el secado del aceite (como tantos pigmentos derivados del plomo o de metales), además es inestable en algunos medios como los álcalis. En este estudio, se ha comprobado que el cambio de coloración entre los dos pigmentos rojos detectado a través de la observación de la muestra con MO y MEST, se pierde cuando éstos son englobados en resina de poliéster para hacer estratigrafías y poder trabajar las muestras.

En la figura 8a y figura 8b se observa con claridad la huella del pincel utilizado en la aplicación de este pigmento. Además anteriormente se ha comentado que el trabajo era realizado por estratos, lo cual permite apreciar el pigmento rojo bajo otras coloraciones en las imágenes [figura $8 \mathrm{~d}$ ].

Se ha comprobado la presencia del plomo en el estrato superior a través del análisis de muestras al SEM-EDX, en el que no se detecta (ni si quiera con la herramienta mapping) la presencia del plomo mezclado con tierras ricas en óxido de hierro que contiene el segundo estrato de color rojo, ni tan sólo de pequeñas trazas cuando la muestra es colocada transversalmente. En cambio, en los análisis realizados en la superficie de la muestra, el plomo se detecta con normalidad [figuras 9 y 10].

La presencia del óxido de hierro detectada en las muestras analizadas, no es tan abundante como la detectada en los análisis realizados por Domènech (2012), pero es curioso cómo en el análisis FTIR de la muestra CS 9, nombra: “... capa mayoritariamente constituida por tierra rica en óxido de hierro con presencia de óxido/carbonato de plomo". Esta presencia de carbonato de plomo, determina que el minio presente en la muestra, puede haber sido extraído por tostación del blanco de plomo a $480^{\circ} \mathrm{C}$ durante $3 \mathrm{~h}$ (Sif Dagmar et al. 2014: 534-545).

La obtención del minio por tostación del blanco de plomo, es una opción bastante sencilla y habitual en la época, lo detectan en la La Casa de los Grifos (Ergenç et al. 2018). Aunque también, el compuesto a base de plomo hubiese podido ser extraído de las minas explotadas en esta zona minera de Sierra Morena según cuenta Jiménez (2014: 94) y Eastaugh, et al. (2004: 392). Sobre la extracción del minio y su refinación en la capital del imperio nos habla Plinio el Viejo. El erudito menciona la extracción de este mineral en Sisapo (un antiguo municipio romano situado dentro de la región prerromana de la Oretania, de la cual Cástulo fue su capital y que actualmente se corresponde con la 


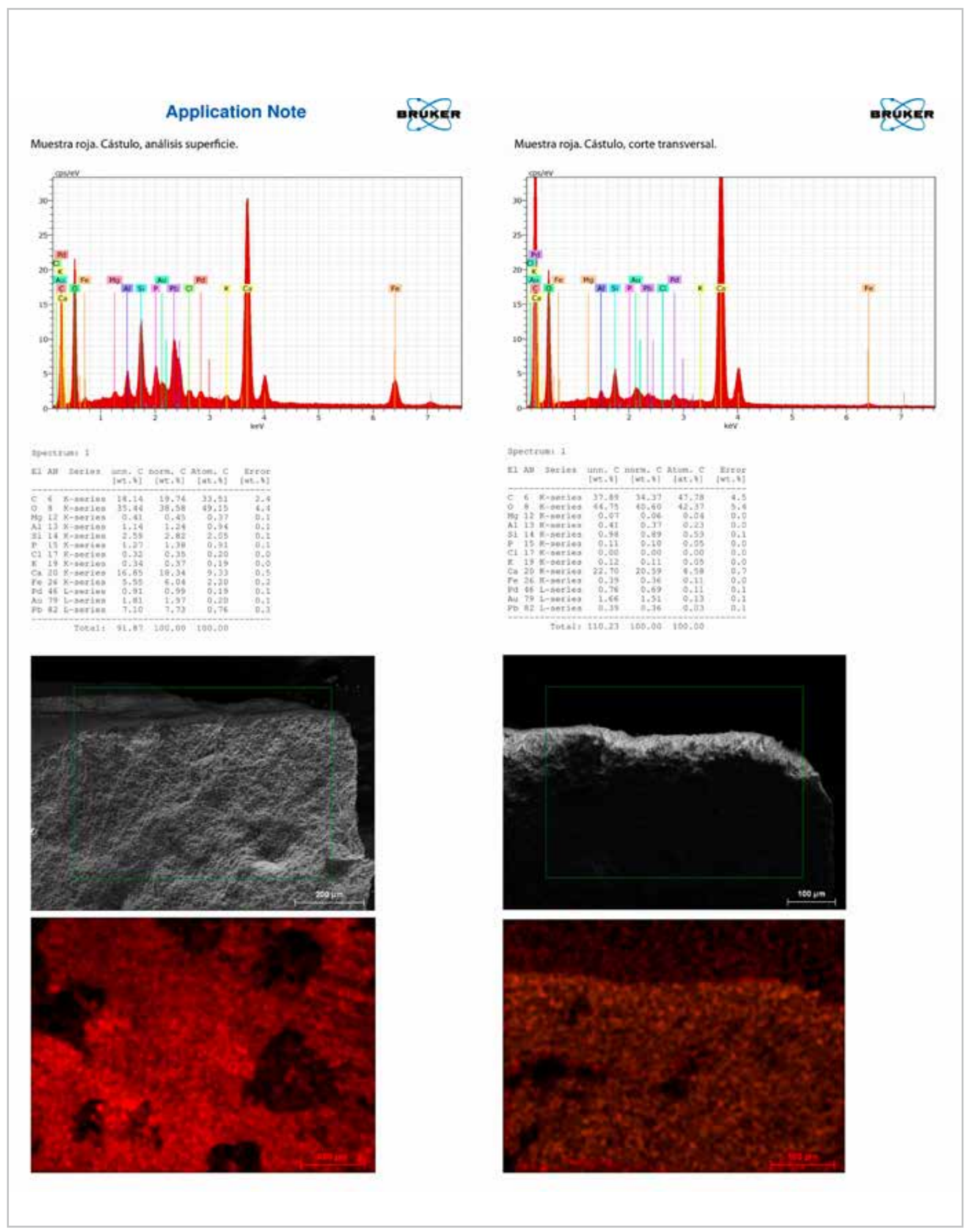

Figura 9.- En las imágenes se observan los espectros obtenidos a través de microanálisis de dos muestras, además de las imágenes en alta resolución y el mapping de ambas. A la izquierda el espectro del análisis, fotografía y mapping que se ha realizado a la muestra sobre la superficie pictórica. A la derecha el espectro del análisis, fotografía y mapping que se ha realizado con la muestra colocada lateralmente de forma que se ha estudiado en transversalidad. Ambas muestras no han sido englobadas en resina de poliéster, pero sí se metalizaron con oro paladio para mejorar la conductividad de éstas y así obtener un correcto resultado en el microanálisis. 


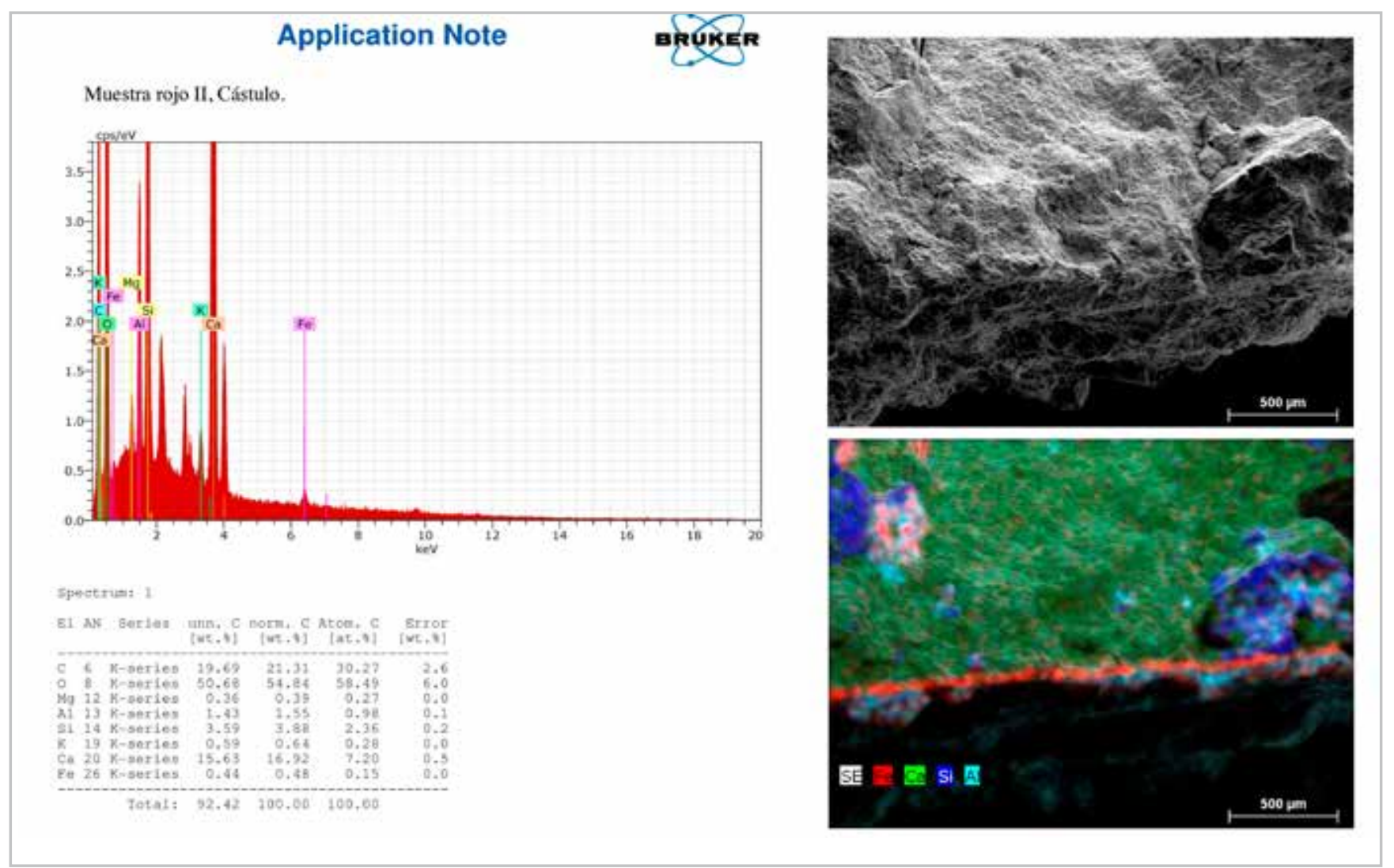

Figura 10.- En las imágenes se observan el espectro obtenido a través de microanálisis de la muestra (rojo II), además la imagen y el mapping de la misma. A la izquierda el análisis, a la derecha la fotografía de la muestra en la parte superior y en la inferior el mapping, en el que se aprecia la concentración de óxido de hierro debido a la posición de muestra estudiada transversalmente. La muestra no se ha englobado en resina de poliéster, pero sí se metalizó con oro paladio para mejorar su conductividad.

aldea de La Bienvenida, en Ciudad Real) en su Naturalis Historia (XXXIII, 40, 118. trad. Rackman: 89): "El minio más conocido es el de la región sisaponense, en la Baetica, mina que es propiedad del pueblo romano. Nada se vigila con más cuidado; no está permitido refinarlo en plaza, sino que se envía a Roma, en bruto y bajo sello, [...] En los yacimientos de minio sisaponenses las vetas están compuestas sólo de tierra de minio, sin plata".

Otro detalle que da gran calidad a estas pinturas son las tonalidades conseguidas a través del uso de azul egipcio (Domènech et al. 2013b; Arcos et al. 2015). Este pigmento era muy apreciado y codiciado en la antigüedad pues se trata del primer pigmento conseguido artificialmente a base de minerales de cobre. Tuvo una gran importancia en Egipto y durante la época romana, su uso se extendió por los países de la cuenca mediterránea, siendo uno de los pigmentos más utilizados en aquel período de la historia. Su presencia es habitual en los yacimientos arqueológicos de aquella época y ha sido objeto de numerosos estudios (Agnoli et al. 2003; Eastaugh, et al. 2004: 153; PagesCamagna et al. 2010; Clementi et al. 2011; Duran et al. 2010; Piovesan et al. 2011, Domènech et al. 2013 b; Arcos 2015 a).

En los fragmentos observados, se aprecia cómo los pigmentos se aplicaban sobre la última capa de cal (en el enlucido) aún fresca, ésta al fraguar crea una red cristalina que atrapa las partículas de pigmento (Zalbidea 2004). Esta técnica, según Abad Casal (1982: 152-153) conocida como buen fresco, es la utilizada para la ejecución pictórica de la sala del Mosaico de los Amores y también identificada por (Weber et al. 2009) en varios sitios arqueológicos y por Ergenç et al. (2018), en La casa de los grifos. Aunque también se reconocen trazos y acabados posteriores con la técnica del fresco seco o medio fresco (Zalbidea 2004). Los acabados a seco, se aplican una vez carbonatado el enlucido, sobre el que se emplean los pigmentos disueltos en hidróxido de calcio "... formando un ligero relieve sobre el fondo..." (Adam 2002: 240) [figura 8d]. Cabe mencionar que, en otras muchas pinturas murales del Imperio Romano, se ha podido documentar el uso de la técnica al temple (normalmente a la caseína) para retoques (Abad 1982: 153).

Si observamos detenidamente el dibujo de las cruces gamadas del zócalo inferior, se percibe el trazo del encaje previo mediante incisión [figuras 8e, 8e.1, 8e.2]. Sin embargo no se aprecia este trazo en el resto de pintura parietal, es posible que en el resto de la composición se empleara un encaje mediante dibujos preparatorios aplicados a mano alzada, mediante encaje a cordel o incluso cabría la posibilidad de que hubiesen realizado una sinopia de forma muy somera. La sinopia es el encaje realizado a pincel, directamente sobre el muro o sobre 
el estrato del arriccio, mediante una pálida línea con pigmentos ocres o rojizos mezclados con tierras ricas en óxidos de hierro. De aquí la presencia del estrato compuesto estas tierras ricas en óxido de hierro en las diferentes muestras analizadas. Según Perusini (1989: 173) en algunos frescos de Pompeya se ha encontrado el uso de la sinopia sobre el arriccio, a veces cubierta por una fina y semitransparente capa de intonacchino (refiriéndose a un fino enlucido). Además, para realizar los trazos de líneas rectas era común usar la técnica del encaje a cordel (Adam 2002: 240) cuya similitud con la Battitura dei fili empleada en el medioevo refuerza la teoría de que la técnica empleada por los muralistas medievales tuviera su origen en época romana.

No se observan líneas de interrupción de la capa pictórica correspondientes a las jornadas de trabajo ${ }^{4}$. Esto se debe a la realización de 'empalmes invisibles' aprovechando los límites de las bandas horizontales del esquema tripartito. Este detalle nos hacer ver una vez más la gran maestría de los artesanos que trabajaban en la decoración del muro (Adam 2002: 239) que usan, de forma generalizada, los procesos de pulido para hacer invisibles las uniones de los morteros aplicados en diferentes jornadas de trabajo.

Jean Pierre Adam (2002: 240) afirma que la sensación de pulido de la superficie ha dado lugar a numerosas suposiciones por parte de los estudiosos de la técnica romana. Un ejemplo de ello es la suposición por otros autores del uso de la encáustica, ceras, aceites u otros materiales como explica Zalbidea (2014: 51). Pero, según Adam, no se ha llegado a demostrar su uso e incluso advierte de la incompatibilidad de estos materiales con el medio alcalino del soporte mural. En efecto, el acabado pulido tan deseado en época romana, podía conseguirse gracias a la presencia en la última capa de cal grasa, aunque autores como Mora (2001: 104-115) interpretan del texto de Vitrubio, que según el tratadista romano se debía añadir al mortero caolín para facilitar este pulido. Sea esta teoría inexacta o correcta, lo cierto es que sobre el acabado pulido de las pinturas murales romanas abundan teorías antagónicas, y no se han llegado a establecer una conclusiones definitivas.

\section{Conclusiones}

Todas las propuestas de restauración y puesta en valor de una obra deben ir acompañadas de un estudio previo pormenorizado. Este estudio es significativo para conocer adecuadamente la pintura mural de la sala del Mosaico de los Amores y así determinar su resistencia mecánica y composición tanto estratigráfica como matérica. Sin determinar estos parámetros será difícil poder proyectar una restauración rigurosa, efectiva y con garantías de durabilidad. En este sentido, las pinturas murales de Cástulo cuentan con estudios que resultan de interés para un futuro tratamiento, es el caso de los ensayos de bioconsolidación realizados por la Universidad de
Granada (Calero et al. 2015; 2016). Desafortunadamente, en muchos casos, también existe un desconocimiento de los materiales constitutivos de la pintura mural, lo cual lleva en ocasiones a intervenciones inadecuadas. Dei et al. (1998) presentan un estudio donde se muestra cómo en varias pinturas murales restauradas se determinó, $a$ posteriori, que se había producido un deterioro de los pigmentos verdes a causa de la aplicación inadecuada de carbonato de amonio e hidróxido de bario, lo cual terminó provocando una degradación de la azurita que se convertiría en paratacamita e hidróxido de cobre; esto indujo a un notable cambio de tonalidad de vede a marrón. Otro ejemplo similar es el de una pintura mural del siglo XVI ubicada en la iglesia de Santa María de Lemoniz (País Vasco). En la restauración de 1991 se realizaron análisis a algunos de los pigmentos más significativos y también a la composición del mortero, determinando que el yeso era el material que más predominaba en la argamasa. Sin embargo, tras la aparición de una mancha verde muy extendida y un ennegrecimiento y amarilleamiento generalizado, así como algunos cambios de color en zonas puntuales de la pintura mural, se realizó un estudio en el año 2006 (Pérez et al.) para determinar las causas de esta alteración. En dicho estudio se detecta que el yeso del mortero se convirtió en anhidrita a causa de la aparición de ácido oxálico que eliminó el calcio del yeso y dejó sulfatos libres que reaccionaron con la malaquita y la degradaron. Todo apunta que este deterioro fue causado por una intervención inadecuada en la restauración de 1991, ya que esta degradación se produjo en los 14 años sucesivos a dicha intervención.

De este modo, este estudio amplía el conocimiento sobre la técnica pictórica y el estilo de la pintura mural de la sala del Mosaico de los Amores, para ello, ha sido imprescindible la revisión de las recomendaciones técnicas que dan los textos clásicos. Una vez estudiados, éstos han sido cotejados con los análisis realizados a las muestras de los revestimientos murales (análisis $\mathrm{MO}$, MEST y SEM-EDX). Los resultados obtenidos han sido determinantes y clarificadores para certificar que la transmisión del conocimiento se realizaba a través de la difusión de los textos antiguos. La difusión de estos textos, es patente por la repetición de recetas que se detectan en varios de ellos, pero con múltiples teorías que generan conclusiones antagónicas, como se ha demostrado en el estudio estratigráfico realizado a las capas preparatorias de mortero. En el que se detecta el uso de 3 y 4 capas de guarnecido a diferencia de los estratos recomendados en los textos de Plinio y Vitrubio, los cuales ratifican la existencia de 5 (según Plinio) y 7 (según Vitrubio), mientras que autores como Olmos aseguran que en la Hispania romana se observan un uso amplio de 2 ó 3 estratos de preparación. El motivo de encontrar diferentes estratos preparatorios en Cástulo, depende de la zona del muro de donde provengan las muestras analizadas, y seguramente tenga que ver con la destreza práctica de los tectorii (según Plinio) para conseguir una correcta nivelación del paramento a través de diferentes estratos. 
Se ha determinado la composición mineralógica de la argamasa. También se ha detectado el uso de la broza (cebada según Plinio) para favorecer la resistencia mecánica final del mortero, y que la última capa tiene un grosor de 1-2 milímetros y se encuentra, a menudo, constituida mayoritariamente por aglomerante (hidróxido de calcio carbonatado). Partiendo de esta base, se pueden utilizar morteros de restauración más respetuosos y similares a las argamasas originales Por otro lado, el estudio estilístico del esquema tripartito ha permitido clasificar las pinturas de la sala del Mosaico de los Amores como pinturas pertenecientes estilísticamente al estilo pompeyano, entre los Estilos III y IV. Este resultado ha sido determinante en la resolución de los datos cronológicos que han permitido ser cotejados con los datos obtenidos por las investigaciones arqueológicas, comprobando que se trata de cronologías coincidentes.

El estudio de la capa pictórica, ha resultado especialmente interesante por la técnica y el empleo de los tonos rojos. Se ha detectado presencia de pigmentos compuestos mayoritariamente de óxido de hierro (en forma de hematita) y óxido de plomo (minio), aplicados en capas bien diferenciadas (en la inferior las tierras ricas en óxido de hierro y en la superior el minio. La razón por la cual se usan pigmentos en capas diferenciadas era bien conocida por los pictor parietarius; y es que el minio es un pigmento inestable en medios alcalinos, por tanto, era una buena solución el empleo de otro pigmento mineral estable, aplicado como base para amortiguar la alcalinidad de la cal y que, además, era más económico y sencillo de adquirir. La presencia de óxido férrico en la capa interna, afirma la tesis defendida en el texto por la que se determina el uso de la sinopia para realizar los encajes previos aplicados directamente sobre el enlucido. También se ha comprobado que el modo de aplicación del pigmento minio, se ha realizado mediante pincel gracias a la observación de las muestras a través de MO y MEST, ya que en esta observación se aprecia como el minio se extiende sobre una capa de enjalbegado rica en óxidos de hierro, que aportan color y que al ser aplicada con llana generan una sensación de brillo debido al pulido realizado con ésta. Sobre esta capa de rojo minio, se identifica que se han aplicado sucesivas capas de color, combinando así acabados en seco con pintura a la cal o medio fresco.

Estos datos se han podido diagnosticar gracias al estudio óptico (MO y MEST) realizado con muestras no englobadas en resina, ya que se ha evidenciado que el uso de la resina de poliéster penetra en la estructura cristalina del pigmento impidiendo hacer ver este cambio de tonalidad $y$, por consiguiente, evita detectar este cambio de dolor y su posterior estudio. Los datos derivados de esta observación, se corroboraron con el uso de la herramienta mapping del SEM-EDX que detecta y analiza los elementos por áreas generando un mapeo cuantitativo de los mismos generando una imagen cartográfica que ha sido determinante para confirmar el estudio anterior y a teoría derivada de éste.
Otros datos que hablan de la gran calidad de estas pinturas parietales son la presencia del pigmento azul egipcio tan codiciado en la antigüedad, así como la pericia con la que trabajaban los muralistas al hacer invisible las uniones correspondientes a las jornadas de trabajo, posiblemente utilizando técnicas como el aprovechamiento de las franjas horizontales de la tripartición y con el pulido posterior de éstas.

Como vemos, todos los datos presentados son determinantes para conocer a fondo las pinturas de la sala del Mosaico de los Amores y para definir, de manera rigurosa y exhaustiva, la metodología de trabajo a la hora de su restauración y futuras propuestas de reubicación del conjunto mural in situ.

Se abren nuevas líneas de investigación hacia el origen de los materiales compositivos, a partir de las analíticas donde se han identificado elementos distintivos de los minerales empleados como pigmentos. Estos elementos pueden definir las explotaciones mineras de procedencia de los pigmentos, lo cual permitiría relacionar así vías de comercio de estos materiales, además de poder establecer relaciones entre otras pinturas encontradas en Cástulo. Este sería el caso de los óxidos de hierro y el minio estudiados en este texto.

\section{Agradecimientos}

Especial mención y agradecimientos merece Marcelo Castro, director del Conjunto Arqueológico y de los Proyectos Cástulo siglo XXI y FORVM MMX, que nos ha facilitado el acceso a los materiales y ha ofrecido siempre facilidades para llevar a cabo este estudio. También queremos agradecer a Francisco Arias de Haro, coordinador del Conjunto Arqueológico, que igualmente ha estado siempre a disposición de cualquier consulta y nos ha facilitado mucha documentación gráfica y 3D. Yolanda Jiménez Morillas, arqueóloga en el Proyecto FORVM MMX que recuperó la sala del Mosaico de los Amores, con la cual hemos mantenido fructíferas discusiones. Así como a Laura Osete Cortina, profesora asociada al Departamento de Conservación y Restauración de Bienes Culturales de la Universidad Politécnica de Valencia que ha llevado a cabo los análisis físico-químicos de las muestras analizadas.

"Por último agradecer su disponibilidad a Enrique Navarro Raga, técnico de laboratorio perteneciente al Servei Central de Suport a la Investigació Experimental (SCSIE) de la Universitat de València (UV).

\section{Notas}

[1] En líneas generales, el proyecto de investigación Cástulo siglo $X X I$ y, por consiguiente, FORVM MMX surgen de la iniciativa del Instituto Universitario de Investigación en Arqueología Ibérica (entonces reconocido como Centro Andaluz de Arqueología 
Ibérica) de la Universidad de Jaén y en colaboración con el Conjunto Arqueológico de Cástulo, que promueve el Ayuntamiento de Linares y es financiado por la Consejería de Economía, Innovación y Ciencia y Empleo de la Junta de Andalucía junto con la Diputación Provincial (Castro 2013; 2014).

[2] Cabe señalar que se han localizado numerosos transcripciones de las recomendaciones de Vitrubio cuya interpretación varía según el autor que traduzca los textos. Encontramos que José Ortiz y Sanz, en su traducción del año 1787 de Los diez libros de la Arquitectura (2008: 171-176), utiliza el término Jaharrado para traducir la palabra stucco. Mientras que, en una traducción más actual, José Luís Oliver (1995: 267-269) comienza a utilizar el término enlucido y habla de éste mediante la aplicación del material que él interpreta como 'yeso'.

[3] "[...] el pintor decorador, podía ser parietarius, en cuyo caso realizaba los tintes de fondo, los paneles o los decorados [...] de tema repetitivo. [...]. Finalmente, el verdadero maestro era el imaginarius, al cual se confiaba la realización de las escenas gráficas" (Adam 2002: 242).

[4] Esta apreciación inicial es forzosamente contrastable en un futuro. Ya que, en el momento en el que se realizó este examen visual, la pintura mural aún no se había sometido a ninguna operación delimpiezay, en algunaszonas, quedaban concreciones calcáreas de tamaño considerable que impedían apreciar el dibujo subyacente. Actualmente se están interviniendo muchos fragmentos de murales de la sala y otras zonas del yacimiento por la Universidad de Granada (López 2016). Así que posiblemente se obtendrán datos concluyentes sobre las jornadas de trabajo.

\section{Bibliografía}

ABAD CASAL, L. (1982). "Aspectos técnicos de la pintura mural romana en España. En Lvcentvm I,: 135-171.

ADAM, J. P. (2002). "La Construcción Romana: materiales y técnicas", 2a ed. Editorial de los Oficios. León.

AGNOLI, F., CALLIARI, I. y MAZZOCCHIN G. A. (2007). "Use of differents Spectroscopic Techniques in the Analysis of Roman Age Wall Paintings". En Annali di Chimica, 97: Società Chimica Italiana.

ARCOS VON HAARTMAN, M. E. (2015 a). "El azul egipcio en la pintura de Cástulo (Jaén)". En Anuario San Telmo.

ARCOS VON HAARTMAN, M. E., DOMÈNECH CARBÓ, M. T., OSETE CORTINA, L. Y DOMÈNENCH CARBÓ A. (2015 b). “Análisis científico e intervención sobre las pinturas murales de Cástulo (Linares, Jaén)". En Estudio y Conservación del Patrimonio Cultural. Actas. Málaga, 127-130.

BARBA COLMENERO, V. (2014). “Un león en la muralla de Cástulo”. En 7Esquinas. n 6: 135-136.

BARBA, V., FERNÁNDEZ, A. y JIMÉNEZ, Y. (2015). “La muralla de
Cástulo y la Puerta de los Leones". En Jaén, tierra ibera: 40 años de investigación (Arturo Ruíz y Manuel Molinos, eds.). Universidad de Jaén: 305-322.

BLÁZQUEZ MARTÍNEZ, J. M. y GARCÍA-GELABERT, M. P. (1983). "Cástulo, una importante ciudad oretano-romana". En Revista de Arqueología 31: 16-26.

BLÁZQUEZ MARTíNEZ, J. M. y GARCÍA-GELABERT, M. P. (1994). Cástulo, ciudad íbero-romana. Ediciones Istmo. Madrid.

CALABRIA SALVADOR, I. M. (2013). "Las pinturas murales de la ciudad íbero-romana de Cástulo, Linares (Jaén): estudio técnico y propuesta de diferentes sistemas de anclaje para su musealización". UPV. Valencia.

CALERO CASTILLO, A. I., LÓPEZ MARTÍNEZ, A., GARCÍA BUENO, A., MEDINA FLÓREZ, V. J. Y GONZÁLEZ MUÑOZ, M. T. (2015). “Ensayos de bioconsolidación en los revestimientos murales del Conjunto Arqueológico de Castvlo, Linares (Jaén)". En Estudio y conservación del Patrimonio Cultural. Actas. Málaga, 135-137.

CALERO CASTILLO, A. I., LÓPEZ MARTÍNEZ, A., GARCÍA BUENO, A., GONZÁLEZ MUÑOZ,M. T. Y MEDINA FLÓREZ, V. J. (2016). “Ensayos de consolidación en los revestimientos murales del Conjunto Arqueológico de Cástulo (Linares, Jaén)". En Ge-conservación. 3143.

CANTARELLA, E. y JACOBELLI, L. (2013). “Pompei è viva”. Feltrinelli Editore, Milano.

CASTRO LÓPEZ, M. (s.f.). "Proyecto general de conocimiento: Conjunto Arqueológico de Cástulo". [Informe técnico inédito].

CASTRO LÓPEZ, M. (2013). “El proyecto FORVM MMX (Cástulo, Linares): Conjunto arqueológico de Cástulo, Consejería de cultura y Deporte, Junta de Andalucía. Instituto Universitario de Investigación en Arqueología Ibérica, Universidad de Jaén". [Informe técnico inédito], Universidad de Jaén.

CASTRO LÓPEZ, M. (2014). “Introducción: Forvm MMX nos ha reunido". En 7Esquinas. n 6, 2014: 7-9.

CASTRO LÓPEZ, M. (2014b). “Avatares constructivos de la sala del mosaico de los Amores". En 7Esquinas. n 6: 127-129.

CAZALLA VÁZQUEZ, O. (2002). “Morteros de cal. Aplicación en el Patrimonio Histórico". Facultad de Ciencias de la Universidad de Granada.

CEPRIÁN DEL CASTILLO, B. y SOTO CIVANTOS, M. (2014). "Excavaciones en el área 1: Arquitectura y devenir histórico del centro de la ciudad romana". En 7Esquinas. n 6: 73-87.

CLEMENTI, C., CIOCAN, V., VAGNINI, M., DOHERTY, B., TABASSO, M. L., CUNTI, C., BRUNETTI, B. G. y MILIANI, C. (2011). "Non- invasive and microdestructive investigation of the Domus Aurea Wall painting decoration". En Analytical an Bioanalytical Chemistry, 401, 1815-1826. 
DEI, L., AHLE, A., BAGLIONI, P., DINI, D. y FERRONI, E. (1998). “Green Degradation Products of Azurite in Wall Paintings: Identification and Conservation Treatment". En Studies in Conservation, Vol. 43, $n^{\circ} 2:, 80-88$.

DOERNER, M. (2001). Los materiales de pintura y su empleo en el arte. Editorial Reverté, 2005, Madrid. DOMÈNECH

CARBÓ, M. T. (2012). Informe Analítico: pinturas murales de Cástulo. [Informe analítico inédito]. Instituto de Restauración del Patrimonio. Universidad Politécnica de Valencia, Valencia.

DOMĖNECH CARBÓ, M. T., DOMĖNECH CARBÓ, A., LÓPEZ LÓPEZ, F., VALLE ALGARRA, F. M., OSETE CORTINA, L., ARCOS-VON HAARTMAN, E. (2013 a). "Analytical characterization of the roman wall paintings of the archaeological site of Cástulo (Spain)". http://elcher.webs.upv.es/webreports.php?idx=1 [consulta: 20/08/2019].

DOMÈNECH CARBÓ, M. T., DOMĖNECH CARBÓ, A., LÓPEZ LÓPEZ, F., VALLE ALGARRA, F. M., OSETE CORTINA L., ARCOS-VON HAARTMAN, E. (2013 b). "Electrochemical Characterization of Egyptian Blue Pigment in Wall Paintings Using the Voltammetry of Microparticles Methodology", Electroanalysis: 2621-2630.

DURAN, A., JIMENEZ DE HARO, M. C., PEREZ-RODRÍGUEZ, J. L., FRANQUELO, M. L., HERRERA, L. K. y JUSTO, A. (2010). "Determination of pigments and binder in Pompeian wall paintings using synchrotron radiation-high-resolution X-ray powder diffraction and conventional spectroscopychromatography". En Archeometry, 52, 286-307.

EASTAUGH, N., WALSH V., CHAPLIN T. y SIDDALL R. (2004): Pigment Compendium. A Dictionary of Historial Pigments. Elsevier, Oxford.

EDREIN, M. C., FELIU, M. J., FERNANDEZ-LORENZO, C. y MARIN, J. (2001). "Spectroscopic study of Egiptian blue mixed with other pigments". En Analytica Chimica Acta., 434, 331-345.

ERGENÇ, D., LA RUSSA, M. F., RUFFOLO, S. A., FORT, R. y SÁNCHEZ MONTES, A. L. (2018). "Characterization of the Wall paintings in La Casa de los Grifos of Roman city Complutum", En The European Physical Journal Plus, New Challenges in the Scientific Applications to Cultural Heritage. Eds. M. Fedi, L., Liccioli, et al. 133: 355. https:// doi.org/10.1140/epjp/i2018-12223-7 [consulta: 4/9/2019].

EXPÓSITO MANGAS, D., CASTRO LÓPEZ, M., ARIAS DE HARO, F., PEDROSA LUQUE, J. M., CEPRIÁN DEL CASTILLO, B. (2017). “A large glass dishfrom Cástulo (Linares-Jaén, Spain) whit an engraved representation of Christ in Maesty". En International Association for the History of Glass. Annales du 20e Congrès, 2016, Suiza. [Capítulo de libro inédito].

FERNÁNDEZ DÍAZ, A. (1997-98). “Estudio de las pinturas murales de la villa romana de la Huerta del Paturro en Portmán". En Anales de Prehistoria y Arqueología, vols. 13-14: 181-218.

GARATE ROJAS, I. (2002). Las artes de la cal. Ministerio de Cultura. Instituto de Conservación y Restauración de Bienes Culturales, Madrid.
GUIRAL PELEGRÍN, C. (1994). "Técnicas analíticas aplicadas a la pintura romana". En A distancia, no 1, 43-50.

GUIRAL PELEGRÍN, C. (2014). “Decoración pintada en la Hispania romana: artesanos y talleres". En Anejos de Aespa LXXI: Artífices idóneos. Artesanos, talleres y manufacturas en Hispania. Reunión científica, Mérida (Badajoz, España), 105-125.

JIMÉNEZ MORILLAS, Y. (2014). "El posible edificio del culto imperial. Una reflexión forzosamente penúltima". En 7Esquinas. n० 6: 89-103.

LING, R., (1991): Roman painting. Cambridge University Press, Cambridge.

LÓPEZ MARTíNEZ, T. (2015 a). "Las pinturas murales del Conjunto Arqueológico de Cástulo. Problemática de conservación y metodología de intervención". En Arqueología y Territorio, 12: 165-175.

LÓPEZ MARTÍNEZ, T., CALERO CASTILLO, A. I., GARCÍA BUENO, A. Y MEDINA FLÓREZ, V. (2015 b). Póster. "Metodología de intervención en las pinturas murales del Conjunto Arqueológico de Cástulo, Linares (Jaén)". En Conservação e Restauro, 2015: 108.

LÓPEZ MARTÍNEZ, T., LÓPEZ CRUZ, O., GARCÍA BUENO, A., CALERO-CASTILLO, A. I. y MEDINA LÓPEZ, V. (2016). “Las pinturas murales de Castvlo. Primeras aportaciones a la caracterización de materiales y técnicas de ejecución". En Lvcentvm, xxxv: 155-170.

LÓPEZ MONTEAGUDO (2014). "El mosaico de los 'Amores' de Cástulo". En 7Esquinas. n 6: 117-125.

MORA, P., MORA, L. y PHILIPPOT, P. (2001). “La Conservazione delle pitture murali". $2^{\text {a }}$ ed. Bologna.

MOSTALAC CARRILLO, A. (1992). “La pintura romana en España. Estado de la cuestión". En Anuario del Departamento de Historia y Teoría del Arte, UAM, vol. IV: 9-22.

MOSTALAC CARRILLO, A. y GUIRAL PELEGRÍN, C. (1990). "Preliminares sobre el repertorio ornamental del III y IV estilos pompeyanos en la pintura romana de España". En Itálica: Cuadernos de trabajo de la Escuela Española de Historia y Arqueología en Roma, no 18: 155-173.

OLMOS BENLLOCH, P. (2006). “Preparación pintura mural en el mundo romano". En Ex Novo III: Revista d'història ihumanitats, $\mathrm{n}^{\circ}$ 3: 23-40.

PAGES-CAMAGNA, S., LAVAL, E., VIGEARS, D. y DURAN, A. (2010). "Non-destructiva and in situ analysis of Egyptian wall paintings by X-ray diffraction and X-ray fluorescence portable systems. En Applied Physics, 100, 671-681.

PÉREZ-ALONSO, M., CASTRO, K. y MADARIAGA J. M. (2006). "Investigation of degradation mechanisms by portable Raman spectroscopy and thermodynamic speciation: The wall paintings of Santa María Lemoniz (Basque Country, North of Spain)". En Analytica Chimica Acta 571: 121-128. 
PÉREZ RODRÍGUEZ, J. L., JIMÉNEZ DE HARO, M. C., SIGÜENZA, B.y MARTÍNEZ-BLANES, J. M. (2015). " Green pigments of Roman mural paintings from Seville Alcazar". En Applied Clay Science 116117: 211-219.

PERUSINI, G. (1989): “Il Restauro dei Dipinti e delle Sculture Lignee: storia, teorie e tecniche". Udine.

PIOVESAN, R., SIDDALL, R., MAZZOLI, C. y NODARI, L. (2011). “The Temple of Venus (Pompeii): a study of the pigments and paintings techniques". En Archaeological Science 38, 2633-2643.

ROSTOVTZEFF, M. (1919). "Ancient Decorative Wall-Paintings". En Journal of Hellenic Studies, 39: 144- 163.

SIF DAGMAR, D., SAN ANDRÉS MOYA, M. (2004). “Litargirio y masicote. Terminología, propiedades y usos. Reproducción a escala de laboratorio de algunos de sus procesos de obtención". En XV Congreso de Conservación y Restauración de bienes culturales: 534-545.

SICKELS, L. B. (1981): “Organic Additives in Mortars, Ediburgh Architecture Resarch (EAR)", 8: 7-20.

SOTO CIVANTOS, M., EXPÓSITO MANGAS, D., CEPRIÁNDEL CASTILLO, B., LÓPEZ RODRÍGUEZ, M. P. (2017). “Material romano republicano procedente del Santuario de Torre Alta. Cástulo (Linares, Jaén)". En Congreso Internacional de Arqueología: Cultura Material Romana en la Hispania Republicana. Lezuza (Albacete), 22-24 abril 2016. [Capítulo de libro inédito].

TOSCHI, F., PALADINI A., COLOSI, F., CAFARELLI, P., VALENTINI, V., FALCOIERI, M., GALIARDI, S. y SANTORO P. (2013). "A multitechnique approach for the characterization of Roman mural paintings". En Applied Surface Science 284: 291-296.

TOUBERT, P. (2006). “Europa en su primer crecimiento, de Carlomagno al año mil". Publicacions de la Universidad de Valencia, 2006: 208.

WEBER J., WALTER P. y ZIMMERMANN N. (2009). "Microscopic techniques to study Roman renders and mural paintings from various sites". En Materials Characterization 60: 586-593.

ZALBIDEA MUÑOZ, M. A. (2004). “Cómo hacer una pintura mural: un fresco". [Recurso CD]. UPV, Valencia.

ZALBIDEA MUÑOZ, M. A. y SAN MARÍN ARMIJO, A. (2010). “El uso de la pintura a la cal: ventajas e inconvenientes de su aplicación (con aditivos como la caseína y el aceite) sobre morteros tradicionales". En Arche, Intituto de Restauración de Patrimonio (IRP), UPV, Valencia.

ZALBIDEA MUÑOZ, M. A. (2014). “Els vernissos artístics. Revisió i evolució". UPV, Valencia.

ZARZALEJOS PRIETO, M., GUIRAL PELEGRÍN, C., MANSILLA PLAZA, L., PALERO FERNÁNDEZ, F. J., ESBRÍ VÍCTOR. J. M., (2014). "Caracterización de pigmentos rojos en las pinturas de Sisapo (Ciudad Real), Taf. CLXXIX, Abb. 1-3". En Antike Wandmalereien aus Pergamon, in: N. Zimmermann (Hrsg.), Antike Malerei zwischen Lokalstil und Zeitstil. Akten des XI. Internationalen Kolloquiums der AIPMA (Association Internationale pour la Peinture Murale Antique, Wien), 13-17. September 2010 in Ephesos 165-176.

\section{Fuentes Clásicas}

ESTRABÓN, Geographica, Libros III-IV. Ma José Meana (trad.) (1992). Madrid, editorial Gredos.

PLINIO EL VIEJO, Naturalis Historia, XXXIII: Mineralogía y metalurgia del oro, plata y mercurio. H. Rackham (trad.) (1968), Loeb Classical Library, Cambridge.

PLINIO EL VIEJO, Naturalis Historia, XXXV: Mineralogía, usos de la tierra, pigmentos, discusión sobre el arte de la pintura, y el uso del sulfuro. H. Rackham (trad.) (1968). Loeb Classical Library. Cambridge.

PLINIO EL VIEJO, Textos de Historia del Arte, XXXVI. Ma Esperanza Torrego (trad.) (1988). Visor, Madrid.

TITO LIVIO, Ab Urbe condita, Libros XXI-XXV. José Antonio Villar Vidal (trad.) (1993). Editorial Gredos, Madrid.

VITRUBIO, Los diez libros de Arquitectura. José Luis Oliver Domingo (trad.) (1995). Editorial Alianza. Madrid.

VITRUBIO, Los diez libros de la Architectura de M. Vitruvio Polión. José Ortiz y Sanz (trad.) (1987). Imprenta real, Madrid. Edición: 2008. Ediciones Akal. Madrid.

\section{Cartas internacionales}

ICOMOS, Comité Español del Consejo Internacional de Monumentos y Sitios. Principios para la Preservación, conservación y Restauración de las Pinturas Murales.

\section{Leyes}

DECRETO 261/2011, de 26 de julio, por el que se crea el Conjunto Arqueológico de Cástulo, en Linares (Jaén).

\section{Autor/es}

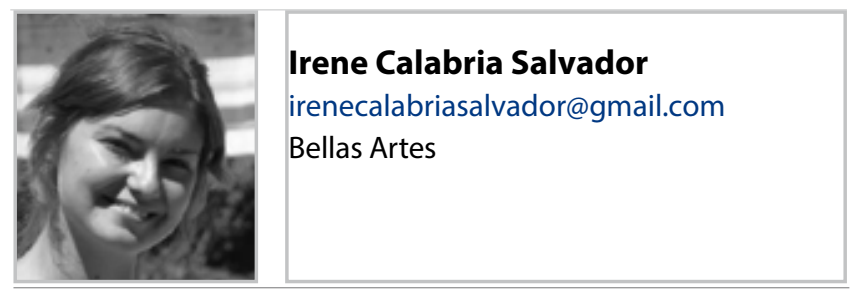

Licenciada en Bellas Artes por la Universidad de Granada (2010) con itinerario curricular en Conservación \& Restauración de Bienes Culturales. Asimismo realizó un Máster en Conservación \& Restauración de BB. CC. en la Universidad Politécnica de Valencia 
(2013) con especialidad en material pétreo, cerámico, mural, cerámico, óseo y metálico; habiendo también intervenido otras obras como escultura de madera policromada. Con el objetivo de profundizar en la materia y conocer otras realidades laborales ha trabajado, a través del Programa de Aprendizaje Permanente 'Leonardo Da Vinci', en Italia para la Soprintendenza per i Beni Archeologici della Toscana, realizando labores de conservación y restauración en el Museo Archeologico Nazionale di Firenze o el Museo dell'Accademia Etrusca e della città di Cortona. Su actividad profesional se desarrolla desde el año 2013 trabajando sobre todo en el ámbito arqueológico, tanto en proyectos de excavación como en intervenciones de urgencia, estudio diagnóstico e intervención de material en laboratorio. Todos estos trabajos llevados a cabo para la Universidad de Jaén, Diputación Provincial de Jaén o la Consejería de Cultura de la Junta de Andalucía. En la trayectoria profesional destaca el trabajo, que desde el 2013 se viene llevando a cabo, para los proyectos de investigación Forum MMX y Cástulo siglo XXI, con las labores de intervención de urgencia in situ y los tratamientos llevados a cabo en el laboratorio, durante las diferentes campañas de excavación. También destaca el trabajo realizado para la Consejería de Cultura de la Junta de Andalucía a cerca del estudio diagnóstico de la colección de titularidad estatal que formarà parte del Museo Ibero de Jaén.

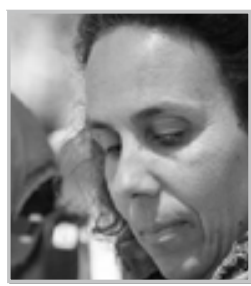

\section{María Antonia Zalbidea Muñoz}

manzalmu@crbc.upv.es

Universidad Politécnica de Valencia

Profesor titular de universidad politécnica de valencia, ha dirigido tres Tesis Doctorales. Ha participado en distintos proyectos de investigación y contratos $\mathrm{I}+\mathrm{D}+\mathrm{I}$ relacionados con sus área de especialización como: “La restauración de la decoración pictórica del Teatro Leal de la Laguna" (2007-08). "La restauración de las pinturas murales exteriores de la Galería Dorada del Palacio Ducal de Gandía" (2009-10). "El proyecto de restauración de las pinturas murales de Palomino en la bóveda de la Real Parroquia de los Santos Juanes de Valencia" (2004-2010). "La restauración de los frescos y decoración ornamental de la Iglesia de San Pedro y San Nicolás de Valencia". También colabora en proyectos internacionales como; "Diversidad cultural y desarrollo turístico, social y ambientalmente sostenible del muralismo uruguayo contemporáneo - Los drones como herramienta de catalogación científica en patrimonio cultural", financiado por el Ministerio de Educación y Cultura de Uruguay, "Restauración y diseño de un nuevo esquema de uso y disfrute social del mural Alegoría al trabajo de Felipe Seade" y "Función social del muralismo uruguayo del siglo xx como vehículo y modelo de activación patrimonial sustentable. Descentralización-identidad y memoria". El último proyecto de investigación en el que ha participado es Movilidad y transferencia artística en el Mediterráneo medieval, 1187-1388: artistas, objetos y modelos -MAGISTRI MEDITERRANEI (Universidad Autónoma de Cataluña). Actualmente en la actualidad co-dirige (junto a Inés Domingo Sanz de la Universidad de Barcelona) el proceso de investigación de otra Tesis Doctoral, relacionada con la conservación del arte rupestre levantino.
Artículo enviado el 09/05/2019 Artículo aceptado el 02/10/2019 


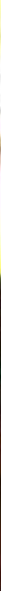

\title{
Reflexiones sobre la necesidad de crear estudios superiores en conservación y restauración de vidrieras en España
}

\author{
Fernando Cortés Pizano
}

Resumen: El presente artículo intenta poner de manifiesto la gran necesidad que existe en España de crear estudios superiores en conservación y restauración de vidrieras, así como la importancia que desempeñaría el aprendizaje y dominio del oficio tradicional de vidriero en dichos estudios. En efecto, las habilidades manuales y aspectos técnicos empleados tanto en la creación como en la conservación y restauración de vidrieras están íntimamente relacionados, hasta el punto de que sería difícil entender los unos sin los otros en la formación de futuros conservadores-restauradores. Es pues de la mayor importancia que cualquier intento de crear unos estudios superiores en esta disciplina no descuide la importancia de este aspecto.

Palabras clave: vidrieras, vidrieros, conservación, restauración, oficio, tradición, estudios superiores

\section{Reflections on the need to create higher studies in conservation and restoration of stained glass in Spain}

Abstract: This article tries to highlight the great need that exists in Spain to create higher education studies on stained glass conservation and restoration, as well as the importance that the learning and mastering the traditional glazier's crafts would play in these studies. Indeed, the manual skills and technical aspects used both in the creation and in the conservation and restoration of stained glass windows are intimately related, to the extent that it would be difficult to understand one without the other in the training of future conservators-restorers. It is therefore of the greatest importance that any attempt to create higher education studies on this discipline do not neglect the importance of this aspect.

Keyword: stained glass, glaziers, conservation, restoration, craft, tradition, higher education

\section{Reflexões sobre a necessidade de criar estudos superiores em conservação e restauro de vitrais na Espanha}

Resumo: Este artigo tenta destacar a grande necessidade existente na Espanha de criar estudos superiores em conservação e restauro de vitrais, bem como a importância que a aprendizagem e o domínio do trabalho do vidreiro tradicional teriam nesses estudos. De facto, as habilidades manuais e os aspetos técnicos usados, tanto na criação quanto na conservação e restauro de vitrais, estão intimamente relacionados, a ponto de que seria difícil entender uns sem os outros na formação de futuros conservadores-restauradores. Portanto, é da maior importância que qualquer tentativa de criar ensino superior nesta disciplina não negligencie a importância deste aspeto.

Palavras-chave: vitrais, vidreiros, conservação, restauro, comércio, tradição, ensino superior 


\section{La sorprendente supervivencia de un arte frágil}

Las vidrieras tradicionales, esa combinación única y magistral de vidrios planos sustentados por perfiles de plomo soldados con estaño, existen desde hace más de mil años y siguen fascinando a cada nueva generación. Sus orígenes están estrechamente vinculados a la arquitectura cristiana de la Alta Edad Media en Europa, con muy posibles influencias del arte islámico. Estas obras han pasado por una gran diversidad de estilos y vicisitudes, habiendo conocido una época de esplendor entre los siglos XII y XVI, una etapa de relativa decadencia y pérdida de oficio en los siglos XVII y XVIII, una recuperación a partir de mediados del siglo XIX, seguida de un periodo de experimentación con nuevas técnicas y materiales desde finales del siglo XIX y finalmente, a partir de la Segunda Guerra Mundial, una segunda etapa de renovación que perdura hasta nuestros días.

Sin embargo, y a pesar de los maravillosos conjuntos de vidrieras conservados en infinidad de edificios repartidos por todo el mundo, el porcentaje de obras que ha llegado hasta nosotros es tan solo una parte pequeña comparada con todas aquellas que han ido desapareciendo a lo largo de los siglos. Y el motivo es bien sencillo. Las vidrieras, funcionando durante años o siglos como hermosas barreras divisorias (de entre 2 y $4 \mathrm{~mm}$ de espesor) entre el exterior y el interior de la gran mayoría de nuestros edificios históricos, son sin duda uno de sus elementos más frágiles y vulnerables. Diversos agentes destructores de la naturaleza (seísmos, incendios, viento, granizo, agua de condensación, microorganismos, etc.), o factores humanos (guerras, iconoclastia, vandalismo, restauraciones poco respetuosas, falta de mantenimiento o cambios de gusto, por mencionar unos pocos), o generalmente una combinación de ambos, han sido tradicionalmente los principales responsables de su progresivo deterioro y desaparición.

Teniendo en cuenta todos estos posibles factores y los mil años de historia que contemplan a este arte, hoy día sigue sorprendiendo que unos materiales tan frágiles hayan podido llegar hasta nosotros, si bien de forma más o menos fragmentaria, habiendo logrado a su vez reinventarse a lo largo de los siglos. En efecto, el arte de la vidriera sigue vivo y además parece gozar de buena salud, a juzgar por la gran cantidad de personas que en la actualidad se dedican a esta especialidad, ya sea como profesionales o como aficionados, como creadores o como conservadoresrestauradores, o más frecuentemente practicando ambas especialidades. Así pues, el hecho de que muchas de las vidrieras más antiguas hayan sobrevivido y podamos seguir admirándolas en la actualidad, es en gran parte también el resultado de siglos de mantenimiento y restauración, con mayor o menor destreza, respeto y cuidado según el periodo histórico o las personas a su cargo [Figura 1].

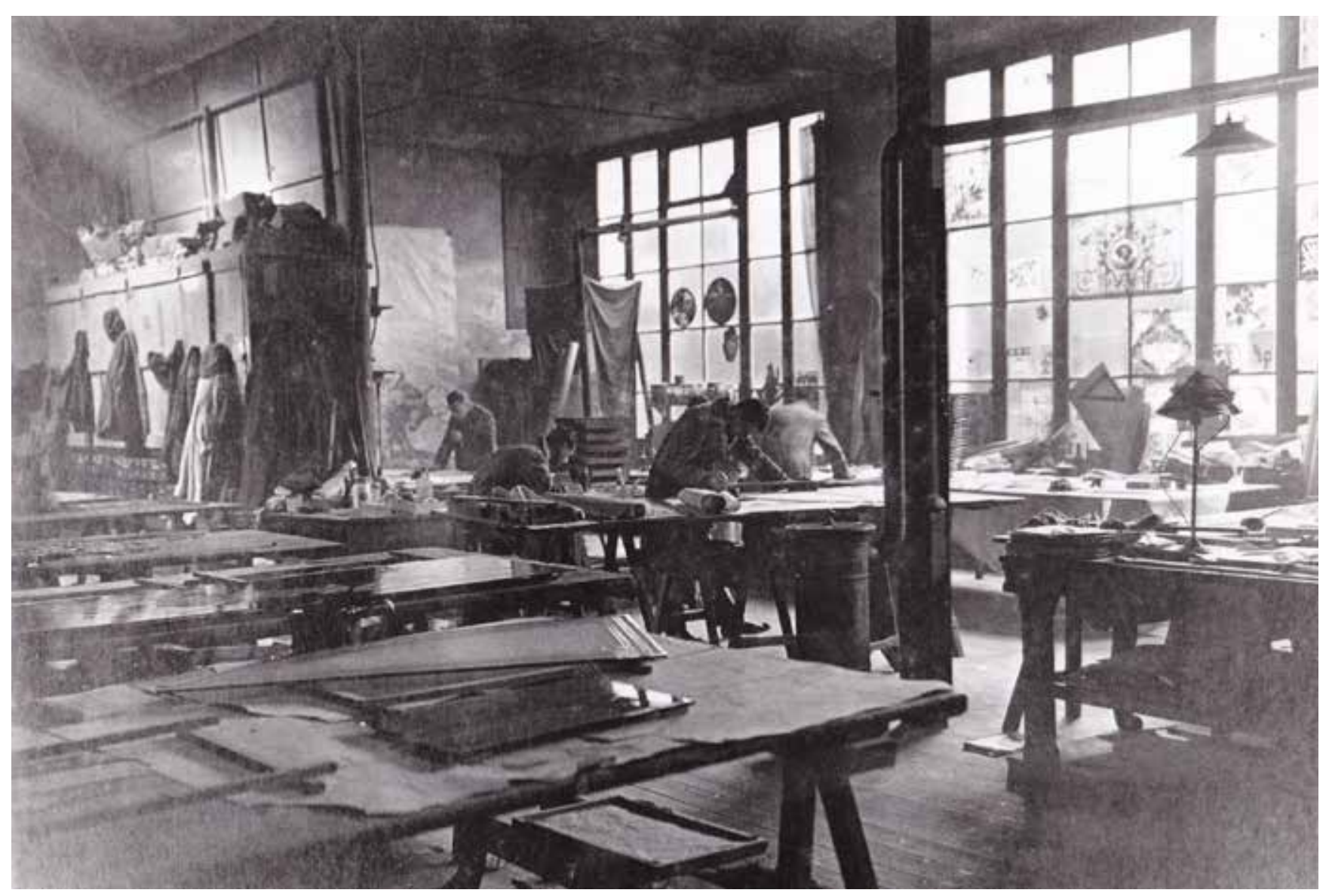

Figura 1.- Fotografía del taller de vidrieras Casa Rigalt i Granell de Barcelona, realizada entre 1920 y 1930 . Imagen del Archivo del Museu del Disseny de Barcelona. Ref. ES ES MDB 3-401-02-02-01-RIG-0607-001 


\section{El carácter funcional o utilitario de las vidrieras y su relación con el edificio}

Las vidrieras cuentan con una ventaja que les ha ayudado en cierta manera a garantizar su supervivencia: su carácter funcional o utilitario. Estas obras son, como ya hemos visto, la piel exterior del edificio y no hemos de olvidar que su principal función es de tipo práctico: cerrar un vano para así impedir el paso de elementos externos (viento, agua, aves, etc.) y garantizar un cierto aislamiento térmico y acústico. Las otras funciones de este arte, sin duda más conocidas, son realmente secundarias desde un punto de vista práctico, como veremos a continuación. Nos referimos a aquellas que le confieren su merecida admiración, como son su carácter estético, decorativo, simbólico, religioso, etc.

Es precisamente su condición de bien inmueble con carácter funcional y utilitario la que convierte en prioritaria la reparación de las vidrieras. Es fácil deducir que, si una vidriera no funciona correctamente como cerramiento, peligra la trasmisión de sus valores estéticos o didácticos. En este sentido, cualquier daño estructural considerable en la obra, como la perdida de vidrios o la rotura o abombamiento de la red de plomo, ha de ser frenado y reparado lo antes posible a fin de evitar el deterioro progresivo de la vidriera o de los paneles afectados y poder garantizar la estanqueidad e iluminación del edificio. Asimismo, no menos importante, una vidriera en mal estado puede presentar un riesgo considerable para la seguridad de las personas y de aquellas otras obras de arte o del mobiliario en sus proximidades. Es por estos motivos que la recuperación de una posible lectura artística o iconográfica interrumpida pasa necesariamente a ocupar un segundo lugar en las prioridades a la hora de plantearnos cualquier intervención sobre este tipo de obras.

Por otro lado, es lógico deducir de todo lo dicho hasta ahora que la conservación y restauración de vidrieras existe desde los mismos orígenes de este arte y que lógicamente han sido y son los mismos artistas vidrieros quienes, casi de forma exclusiva, han estado cualificados para llevar a cabo estas necesarias tareas de mantenimiento o reparación. Esta situación no es exclusiva de las vidrieras y la podemos observar también en otras profesiones u oficios, y de forma más evidente en aquellos aplicados a la arquitectura tradicional, como son los herreros, carpinteros, ceramistas, plomeros, canteros o albañiles, por poner unos cuantos ejemplos. $Y$ es por ese motivo que estos oficios, tan presentes en la mayoría de nuestros edificios históricos, han logrado pervivir, en mejores o peores condiciones, hasta la actualidad. Sin embargo, cuando se descuidan estas tareas de mantenimiento es cuando empezamos a observar un deterioro progresivo en los materiales constructivos o decorativos del edificio, mientras que poco a poco se van perdiendo los oficios asociados a su conservación. Es un hecho constatado que en aquellos periodos en los que el arte de la vidriera gozaba de buena salud y los vidrieros dominaban su oficio, las intervenciones de mantenimiento o de restauración que se realizaban eran frecuentes, respetuosas y de mejor calidad. Por el contrario, en aquellas épocas en las que la vidriera no era tan valorada, su demanda y práctica cayó en desuso y las operaciones de mantenimiento o restauración sencillamente no se llevaron a cabo o fueron más espaciadas o de peor calidad, siendo a menudo practicadas por profesionales de otras especialidades más o menos afines [Figura 2].

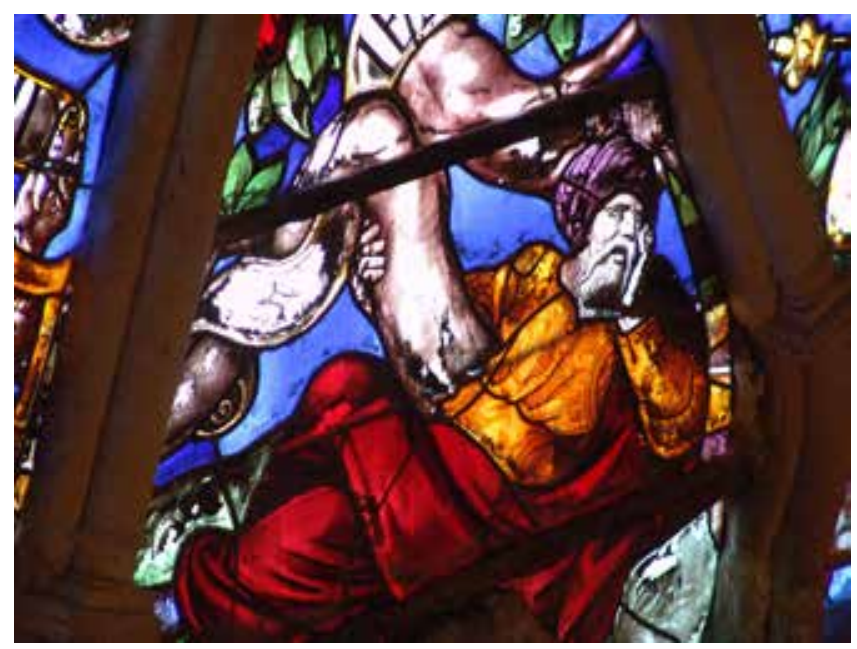

Figura 2.- Figura de Jesé en el rosetón del crucero norte de la Catedral de Cuenca. Giralte de Holanda, 1550. Autor imagen: Fernando Cortes Pizano.

\section{Las consecuencias de la ausencia de una cultura vidriera}

Así pues, si bien el carácter funcional de la vidriera es lo que en gran parte ha mantenido vivo el oficio, este hecho no ha ido lamentablemente acompañado siempre de una apreciación y valoración generalizada de este arte, como ha sucedido en otros países europeos. $Y$ aquí radica en mi opinión el problema principal del abandono y la falta de atención hacia las vidrieras en muchos de nuestros edificios: no existe un conocimiento, y consecuentemente una apreciación, de la cultura vidriera a nivel social, cultural o educativo. Esta falta de valoración se ve reflejada en su escasa divulgación, en su falta de presencia en los museos o en exposiciones, en su ausencia de los programas de investigación y difusión, o en proyectos de intervención, en planes de estudio en conservación y restauración, etc. A esta circunstancia hemos de añadir el hecho de que tradicionalmente las vidrieras han sido percibidas $y$ clasificadas con la cuestionable etiqueta de artes menores, aplicadas o artesanías, lo cual a menudo ha actuado lógicamente en su detrimento.

Por otro lado, el arte y el oficio de la vidriera abarcan un campo muy amplio de conocimientos y destrezas 


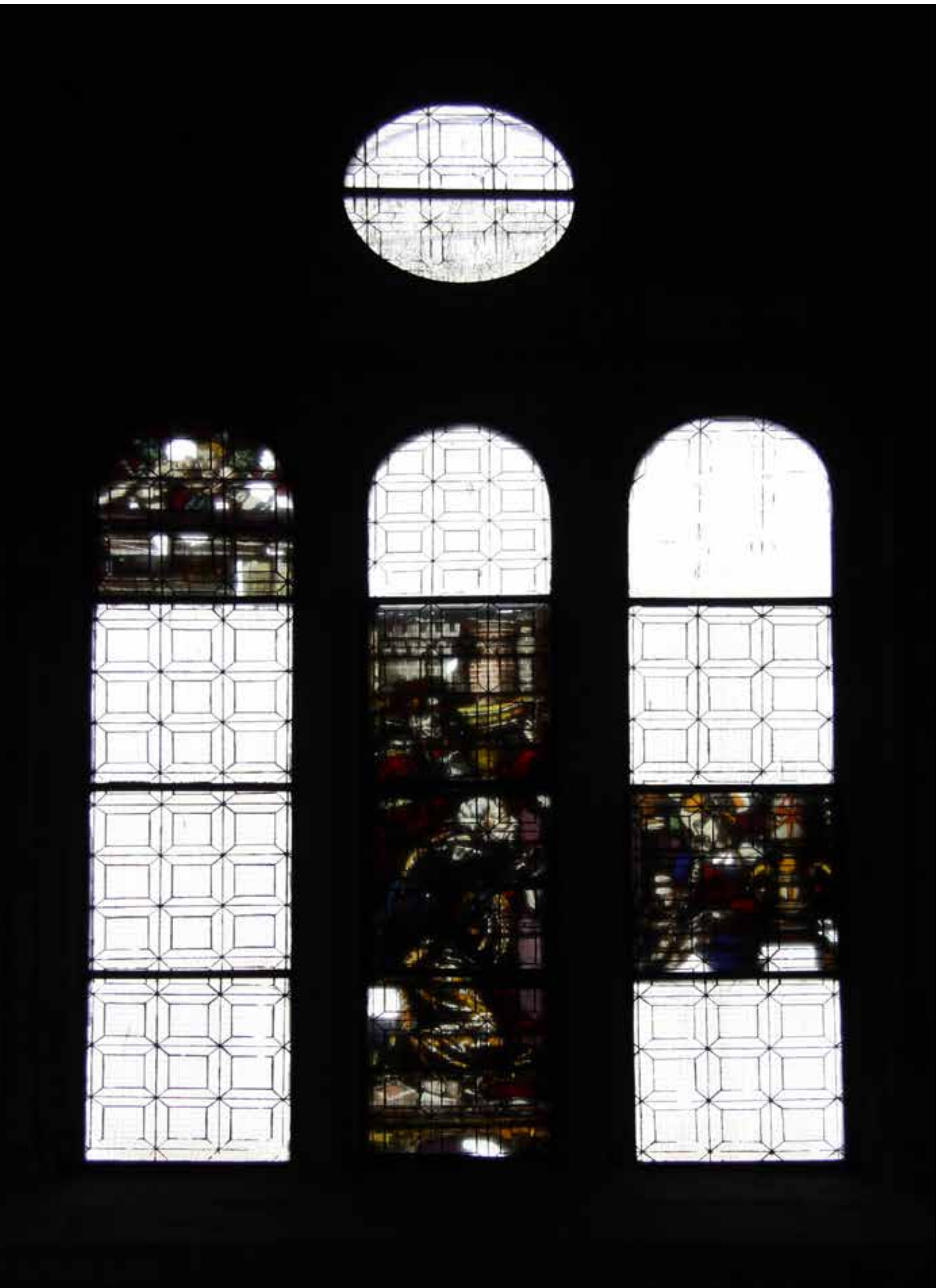

Figura 3.- Restos de una vidriera del siglo XVI en la Iglesia San Esteban, en Salamanca. Autor imagen: Fernando Cortes Pizano. 
que incluyen varias disciplinas técnicas, artesanales y artísticas, cuyo dominio suele requerir de muchos años de aprendizaje, trabajo y perfeccionamiento. La dificultad y el tiempo de aprendizaje de los aspectos técnicos de este oficio, han obstaculizado sin duda una mayor difusión de esta profesión y su inclusión en programas de estudio. Por otro lado, los vidrieros se enorgullecen, no sin motivos justificados, de su profesión y de los años de aprendizaje y perfeccionamiento invertidos en la misma. Esta característica se refleja en el hecho de que tradicionalmente el grado de maestro vidriero solo se alcanzaba después de muchos años de duro trabajo y esfuerzo. En cierta manera, esto ha propiciado que los vidrieros sean a menudo vistos, no sin motivos, como un colectivo bastante cerrado, con tendencia al secretismo y poco dado a compartir y divulgar sus conocimientos, ya sea mediante la enseñanza, publicaciones, charlas, etc. [Figura 3].

\section{Sobre las competencias de los diferentes profesionales involucrados en este oficio}

Al plantearnos el futuro de nuestra profesión, no podemos caer en el error de convertir la conservación y restauración de vidrieras en una profesión en la cual los conservadores-restauradores no especializados en este campo dirigen el trabajo de los vidrieros, mientras que estos pasan a desarrollar una tarea auxiliar o de apoyo en el trabajo de los primeros. En mi opinión este enfoque, en ocasiones sugerido, es totalmente erróneo ya que ignora el problema de base: la urgente necesidad de crear estudios superiores en esta especialidad. En efecto, una de las principales críticas que durante años he observado por parte de un sector de los conservadores-restauradores titulados es que los vidrieros no deberían restaurar las vidrieras "sin supervisión", ya que no tienen ni la formación ni los criterios necesarios para esta labor. Estos a menudo sugieren que los proyectos de conservación y restauración en vidrieras deberían estar dirigidos por un conservador-restaurador, quedando los vidrieros subordinados a los primeros para ejecutar la parte manual de la intervención, la cual los primeros no dominan. Los vidrieros por su parte rechazan claramente esta propuesta en base a la carencia de conocimientos necesarios de su oficio y de los materiales de las vidrieras por parte de los primeros. En realidad, los argumentos de ambas partes tienen lógica y sentido, todo depende de cómo los miremos. Si lo pensamos objetivamente, esta situación es comparable en cierta manera a la de los conservadoresrestauradores cuando reivindican su papel frente al del arquitecto encargado de proyectos integrales. $Y$ ya que se ha mencionado a los arquitectos, y para complicar más el panorama expuesto, es importante mencionar que estos, a menudo, tienen también su opinión sobre cómo se deben conservar y restaurar las distintas obras del edifico, entre ellas lógicamente las vidrieras.

Es evidente que es necesario salir de este ciclo vicioso que sin duda no ayuda a resolver la cuestión del estancamiento de las vidrieras. La solución no es sencilla y pasa por buscar puntos comunes de entendimiento y aprender a escucharnos los unos a los otros, manteniendo una actitud dialogante, abierta y sin prejuicios y dejando de lado nuestros egos e ideas preconcebidas. Para ello, lo que a menudo realmente se echa de menos es la ocasión de poder reunirnos todas las partes involucradas en la conservación y restauración de las vidrieras para poder tratar estos temas, buscando soluciones consensuadas que garanticen una adecuada conservación y restauración de este valioso patrimonio [Figura 4].

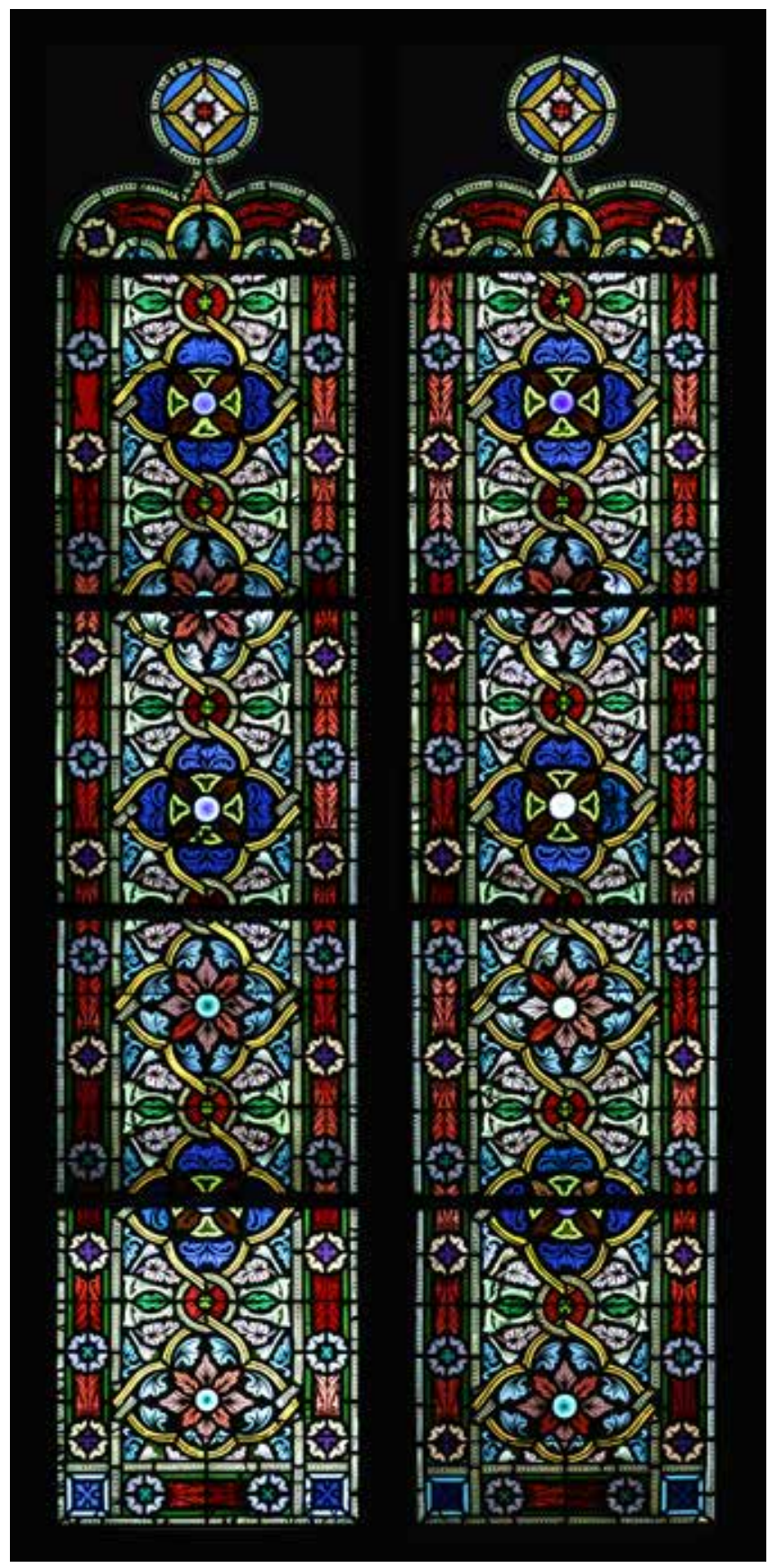

Figura 4.- Vidriera de finales del siglo XIX en la fachada principal de la Catedral de Barcelona. Casa Rigalt i Granell. Autor imagen: Fernando Cortes Pizano. 


\section{La urgente necesidad de crear estudios superiores en conservación y restauración de vidrieras}

Tal y como ya hemos apuntado más arriba, no podemos seguir ignorando o aplazando la urgente necesidad de crear, lo antes posible, estudios superiores en esta especialidad, como en su día sucedió con las especialidades de pintura, escultura, documentos, material arqueológico o textil. Pudiera parecer una tarea complicada, pero en aquellos países donde el arte de la vidriera ha sido tradicionalmente más valorado y respetado si han logrado crear estudios universitarios en esta especialidad, situándola a la misma altura que las otras especialidades. Es por ejemplo el caso de las Universidades de Amberes, en Bélgica ${ }^{1}$ y de Erfurt, en Alemania ${ }^{2}$, pioneras desde hace varias décadas en estudios universitarios en conservación y restauración de vidrieras. En el caso de Amberes, los estudios consisten en 3 años de grado y un último año de máster. Asimismo, la Universidad de York, en Inglaterra ${ }^{3}$ también oferta desde 2008 un máster en esta especialidad.

Aparte de los mencionados estudios superiores, también existen diversas asociaciones $\mathrm{u}$ organizaciones especializadas en vidrieras. Tal vez el ejemplo más destacado y conocido sea el del CVMA (Corpus Vitrearum Medii (Aevi) ${ }^{4}$, organización internacional creada en los años cincuenta del siglo pasado y dedicada inicialmente al estudio e inventario de las vidrieras más antiguas. Desde los años ochenta se constituyó en cada país miembro un grupo técnico dedicado al estudio sobre aspectos científicos y de conservación-restauración de las vidrieras. Parte importante de su trabajo, desarrollado conjuntamente con el Comité Científico Internacional para la Conservación de Vidrieras de ICOMOS$^{5}$, ha consistido en la organización de reuniones técnicas bianuales y en la redacción de unas Líneas directrices sobre la conservación-

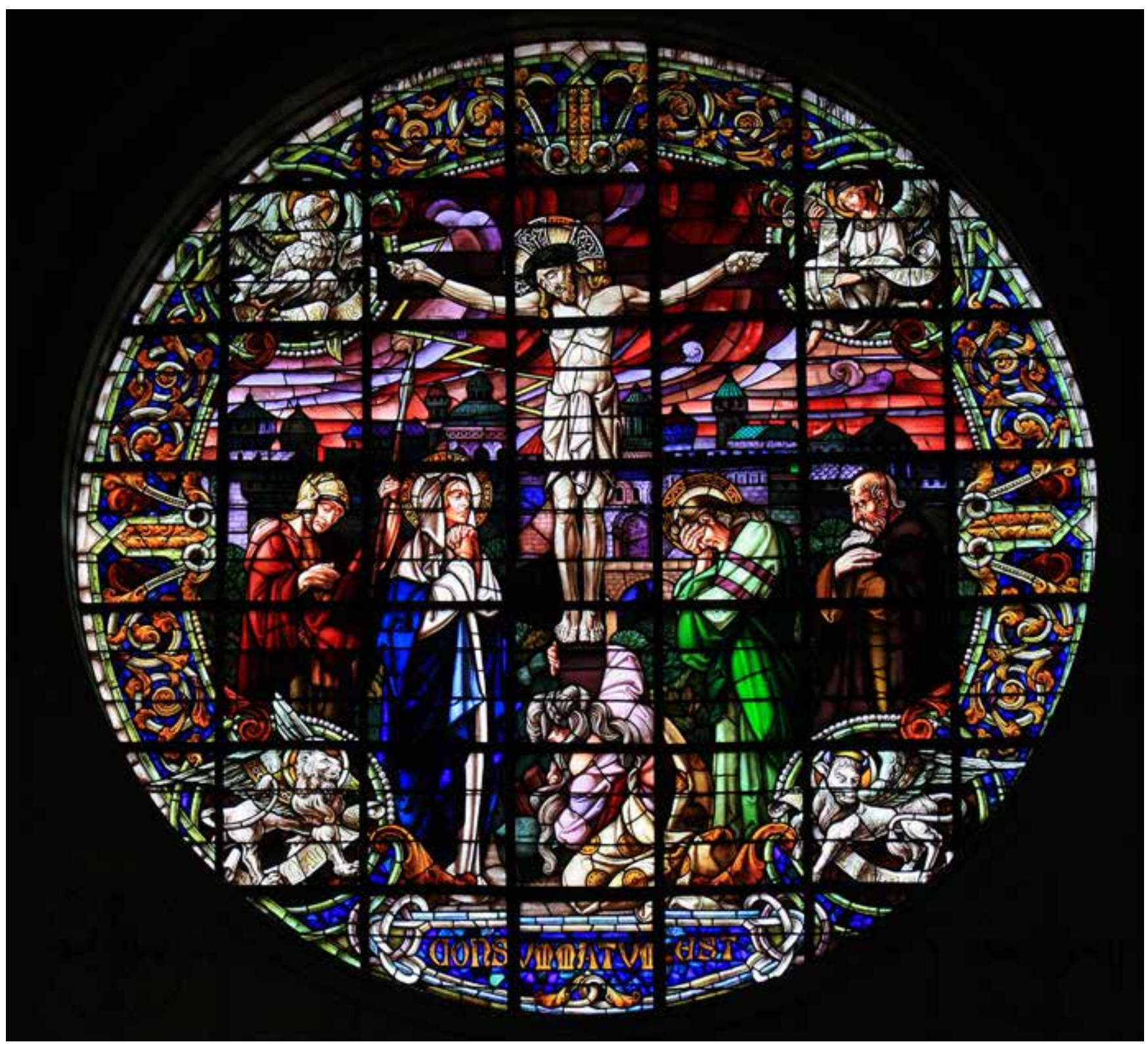

Figura 5.- Vidriera de la Casa Maumejean en la Iglesia del Sagrado Corazón de Jesús, Gijón. Autor imagen: Fernando Cortes Pizano. 
restauración de vidrieras en las reuniones de Ámsterdam en 1989 y Núremberg $2004^{6}$.

Sin embargo, desde las instituciones públicas nunca se ha visto realmente la necesidad o urgencia de crear estudios universitarios en esta especialidad ya que, con mejor o peor técnica o criterio, las vidrieras tradicionalmente las han restaurado los vidrieros. El problema, sin embargo, consiste en que la conservación-restauración de vidrieras es un campo bastante desconocido donde no existen estudios específicos y como consecuencia no resulta sencillo controlar, juzgar o valorar la calidad de las intervenciones realizadas. A menudo, para profesionales de otras disciplinas, pareciera no existir una metodología, normas o criterios específicos para estas intervenciones, ya que en ocasiones los métodos empleados y los resultados obtenidos pueden diferir de aquellos a los que están acostumbrados muchos conservadores-restauradores. En este sentido, no hemos de olvidarnos que las vidrieras, en su particular relación con el edifico y la luz, son un medio que presenta unas peculiaridades que las hace diferentes a otros soportes, y cuya conservación y restauración a menudo exige soluciones diferentes y no por ello menos válidas. En cualquier caso, la realidad es que desde hace ya varias décadas sí existen criterios, normas, estudios superiores e infinidad de publicaciones científicas en esta especialidad, y la gran mayoría de los conservadoresrestauradores de vidrieras conocen y aplican los conceptos de reversibilidad, mínima intervención, discernimiento de las nuevas intervenciones, compatibilidad de los materiales, documentación de la intervención, etc. [Figura 5].

\section{Posibles vías para el establecimiento de estudios superiores}

Después de todos los datos expuestos hasta ahora, bebería resultar evidente la urgente necesidad de crear estudios superiores en esta especialidad en España. Por lo que respecta a las posibilidades prácticas de cómo crear dichos estudios, estos podrían llevarse a cabo bien mediante el establecimiento de una especialidad de vidrieras, equiparable a las ya existentes de pintura, escultura, etc. en las actuales escuelas de restauración, o bien, en su defecto,

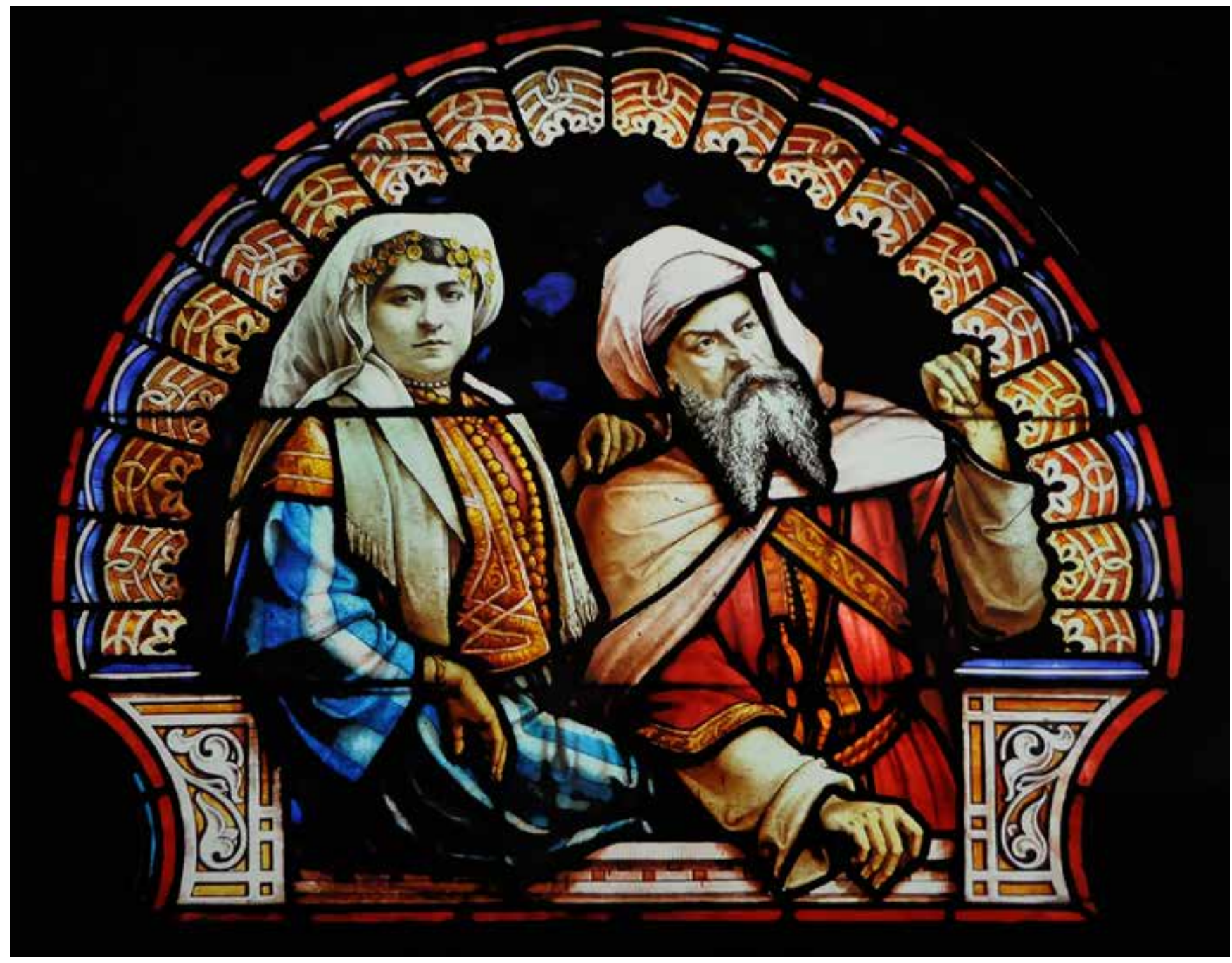

Figura 6.- Procedencia de la imagen: El Blog de Joaquín Medina: http://elblogdejoaquinmedina.blogspot.com/2018/01/diegoperez-director-de-cultura-recibe.html?spref $=\mathrm{fb} \& \mathrm{~m}=1$ 
a través de unas asignaturas sobre esta especialidad en los estudios de conservación-restauración en la Universidad. Sin embargo, personalmente no me parece que el cursar una o unas asignaturas en la Universidad sea la solución para formar especialistas en este campo. En mi opinión, tal y como están en la actualidad configurados los planes de estudios, el crear una especialidad de vidrieras sería sin duda la opción más recomendable para formar profesionales en esta especialidad.

Como ya hemos apuntado anteriormente, estos estudios no deberían descuidar la gran importancia que el aprendizaje de los aspectos artesanales y de oficio desempeñan en la conservación y restauración de vidrieras. Esto significa que el plan de estudios diseñado debería incluir, junto con el resto de asignaturas comunes en los estudios de conservación-restauración, un porcentaje razonable de horas taller. Durante estas clases prácticas se enseñaría el oficio de vidriero, tanto en el taller como en edificios con vidrieras, para así, de esta manera, poder ir introduciendo gradualmente al alumnado en intervenciones de conservación y restauración.

En la actualidad existe una tendencia generalizada a hacer desaparecer las especialidades en favor de un título único en conservación-restauración, relegando las especialidades a la realización de un futuro máster. Esta opción, de llegar a ponerse en práctica, me parecería realmente lamentable, especialmente para el futuro de las vidrieras. Sin embargo, paralelamente, la profesión de los conservadores-restauradores se encuentra en la actualidad en una etapa muy interesante de cambios y exigencias, con un objetivo común muy importante que es el reconocimiento y la regulación de la profesión. Es por ello que estoy personalmente convencido de que es este el momento adecuado para aprovechar el creciente interés en esta especialidad y luchar por la creación de estos estudios.

Como vemos, el laberinto de una futura formación en conservación-restauración de vidrieras históricas no es fácil de recorrer. A pesar de todo es necesario cambiar este panorama y empezar a trabajar codo con codo, conservadores-restauradores, vidrieros, arquitectos e instituciones públicas; proponiendo soluciones viables para que este patrimonio tan frágil y complejo sea debidamente conservado para nuestro disfrute y el de las futuras generaciones. [Figura 6].

\section{Conclusiones}

El patrimonio vidriero de España es indiscutiblemente uno de los más importantes de Europa. Sin embargo, su riqueza y calidad contrasta con la escasa atención y difusión que recibe y a menudo, lamentablemente, con su estado de conservación. La inexistencia de una cultura vidriera en nuestro país está en la base del problema y tiene como resultado la ausencia de estudios específicos sobre esta especialidad y por tanto de conservadores-restauradores especializados. Una de las principales medidas a adoptar es sin duda la creación de estudios superiores universitarios en este campo. Es absolutamente necesario que las autoridades competentes sean conscientes de este problema y que se pongan las medidas necesarias para buscar soluciones.

\section{Notas}

[1] Sobre los estudios en Conservación y Restauración de vidrieras en la Universidad de Amberes en Bélgica: https:// www.uantwerpen.be/nl/studeren/opleidingsaanbod/ bachelor-conservatie-restauratie/profiel/. Consulta: Junio 2019.

[2] Sobre los estudios en Conservación y Restauración de vidrieras en la Universidad de Erfurt, en Alemania: https:// www.fh-erfurt.de/kr/en/studium/studienschwerpunkte/ glasmalerei-und-objekte-aus-glas/?Size $=1$. Consulta: Junio 2019.

[3]. Sobre los estudios en Conservación y Restauración de vidrieras en la Universidad de York, en el Reino Unido: https://www.york.ac.uk/study/postgraduate-taught/ courses/ma-stained-glass-conservation-heritagemanagement/. Consulta: Junio 2019.

[4] Corpus Vitrearum Medii Aevi: http://www. corpusvitrearum.org/. Consulta: Junio 2019.

[5] International Scientific Committee for the Conservation of Stained Glass: http://sgc.Irmh.fr/?Ing=en. Consulta: Junio $\underline{2019}$.

[6] Líneas directrices sobre la conservación-restauración de vidrieras (Núremberg 2004): http://decorativasartesgeiic. blogspot.com/2012/03/. Consulta: Junio 2019.

[7] La Asociación Profesional de Conservadores Restauradores de España (ACRE) ha venido desarrollando un papel importantísimo durante los últimos años en la defensa y reconocimiento de la profesión de los Conservadores-Restauradores.

\section{Bibliografía}

DOCUMENTO DE PAVÍA (1997). "Preservación del Patrimonio Cultural: Hacia un perfil europeo del Conservador-Restaurador". Pavía 18 al 22 de octubre de 1997. http://www.icomos.es/ wp-content/uploads/2017/05/22.documento-pavia1997.pdf. Consulta: Junio 2019.

DOCUMENTO DE VIENA (1998). Conferencia Europea. "Un marco de competencia para conservadores-Restauradores en Europa", Viena 30 de Diciembre al 1 de Noviembre de 1998. http://www.iaph.es/ revistaph/index.php/revistaph/article/view/1177 
DECLARACIÓN DE BOLONIA (1999). “Espacio Europeo de Enseñanza Superior Declaración conjunta de los ministros europeos de enseñanza", Bolonia 19 de Junio de 1999. http:// www.peri.net.ni/pdf/01/Declaraci.pdf. Consulta: Junio 2019.

ENcoRE (2001). "Clarification of conservation/restoration education at university level or recognised equivalent", 3a Asamblea General, Munich, Junio de 2001. http://www.encoreedu.org/ENCoRE-documents/cp.pdf. Consulta: Junio 2019.

E.C.C.O. (2002). “Directrices Profesionales de ECCO. La profesión y su código ético". Bruselas 1 de marzo de 2002. https://ge-iic.com/ files/Cartasydocumentos/2002 directrices \%20profesionales de ecco la profesion y su codigo etico.pdf. Consulta: Junio 2019.

E.C.C.O. (2004). "Competencias necesarias para acceder a la profesión de conservador-restaurador", Bruselas 2 de Abril de 2004. https://asociacion-acre.org/el-conservador-restaurador/ marco-competencias-acceder-la-profesion/. Consulta: Junio 2019.

CAEN, J. (2015). Conservation-Restoration Education in Europe in General, and at the University of Antwerp in Particular, en "Glass is More", 19 de Marzo de 2015:http://www.glassismore.com/ core/content.php?\&option=viewitem\&id=42\&rd=955\&le $=120$. Consulta: Junio 2019.

\section{Autor/es}

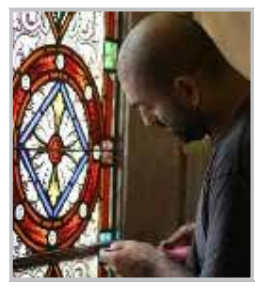

\section{Fernando Cortés Pizano}

fcpcrv@gmail.com

The Cathedral Studios, Canterbury, Reino

Unido (https://www.thecathedralstudios. $\mathrm{com} /$ )

Estudié la carrera de Historia del Arte en la Universidad Complutense de Madrid entre 1984 y 1989 y posteriormente Conservación y Restauración, con especialidad de Vidrieras, en la Real Academia de Bellas Artes de Amberes en Bélgica entre 1994 y 1998, obteniendo el grado de Master. Desde entonces me ha dedicado completamente a la Conservación y Restauración de Vidrieras y mi campo de trabajo abarca tanto la intervencion directa como la docencia, la investigacion, la dirección técnica y el asesoramiento en diferentes proyectos. Desde Enero de 2015 trabajo como restaurador de vidrieras en la Catedral de Canterbury, en Inglaterra.

* La información y opiniones contenidas en el presente artículo son responsabilidad exclusiva de su autor y no reflejan necesariamente las de la empresa donde este trabaja en el momento de su publicación. 


\title{
Análisis y comparación de las categorías e inventarios de la Ley de Patrimonio Histórico Español y las leyes de Patrimonio Cultural autonómicas del País Vasco y Canarias en el marco de la Convención de Granada
}

\author{
Luis Miguel Sanz Rodriguez, Antonio Eduardo Humero Martín, Fernando Casqueiro Barreiro
}

\begin{abstract}
Resumen: La Convención para la Salvaguarda del Patrimonio Arquitectónico de Europa, aprobada en 1985, constituye el núcleo doctrinal de la protección y conservación del Patrimonio Arquitectónico a nivel internacional. España ratifica la Convención en el año 1989, tras la aprobación de la Ley 16/1985 del Patrimonio Histórico Español con la que se adapta al marco jurídico internacional. En el contexto del estado autonómico, desde los años 90 todas las Comunidades Autónomas han aprobado gradualmente sus propias leyes de Patrimonio Cultural. El presente estudio analiza la ley estatal y las recién aprobadas leyes autonómicas del País Vasco y Canarias, centrado en dos aspectos en los que la Convención marca unas directrices: la definición de Patrimonio Arquitectónico y la identificación de los bienes objeto de protección.
\end{abstract}

Palabras clave: patrimonio arquitectónico, protección, legislación española, Convención de Granada

\section{Analysis and comparison of the categories and inventories of the Spanish Historical Heritage Law and the autonomous Cultural Heritage laws of the Basque County and Canary Islands in the framework of the Granada Convention}

\begin{abstract}
The Convention for the Protection of the Architectural Heritage of Europe, adopted in 1985, constitutes the doctrinal core of the protection and conservation of the Architectural Heritage at an international level. Spain ratifies the Convention in 1989, after the approval of Law 16/1985 of the Spanish Historical Heritage adhering to the international legal framework. In the context of the autonomous state, since the 1990s all the Autonomous Communities have gradually adopted their own Cultural Heritage laws. The present study analyses the State's law and the Autonomous laws of the Basque Country and Canary Islands, focusing on two of the aspects in which the Convention sets guidelines: the definition of Architectural Heritage and the identification of the assets subject to protection.
\end{abstract}

Keyword: architectural heritage, protection, Spanish legislation, Granada Convention

Análise e comparação das categorias e inventários da Lei de Património Histórico Espanhol e das leis de Património Cultural autónomo dos Países Bascos e Canários no âmbito da Convenção de Granada

Resumo: A Convenção para a Salvaguarda do Património Arquitetónico da Europa, aprovada em 1985, constitui o núcleo doutrinário da proteção e conservação do Património Arquitetónico a nível internacional. A Espanha ratifica a Convenção em 1989, após a aprovação da Lei 16/1985 sobre o Património Histórico Espanhol, com a qual se adapta ao quadro jurídico internacional. No contexto do estado autónomo, desde os anos 90, todas as comunidades autónomas passaram gradualmente as suas próprias leis de Património Cultural. $O$ presente estudo analisa a lei estadual e as leis autónomas recentemente aprovadas do País Basco e das Ilhas Canárias, concentrando-se em dois aspetos nos quais a Convenção estabelece diretrizes: a definição de Património Arquitetónico e a identificação dos bens sujeitos à proteção.

Palavras-chave: património arquitetónico, proteção, legislação espanhola, Convenção de Granada 


\section{Introducción}

La normativa internacional en materia de patrimonio cultural se ha desarrollado intensamente a lo largo del siglo $X X$ y del XXI. Aunque no se trata de un listado exhaustivo de los documentos existentes a nivel internacional, en el cuadro que se adjunta en la página siguiente[Tabla 1] se resumen los principales documentos y convenios internacionales relacionados con la protección y salvaguarda del patrimonio arquitectónico y cultural que se han considerado relevantes para el presente estudio.

La Convención para la Salvaguarda del Patrimonio Arquitectónico de Europa, más conocida como Convención de Granada, fue aprobada por el Consejo de Europa en 1985 y fija las directrices a las que deben adecuarse las leyes nacionales de tutela del Patrimonio Histórico y Cultural de los países firmantes para recoger en las mismas los principios de la «conservación integrada».

La Convención, que constituye el núcleo doctrinal de la protección y conservación a nivel internacional, pretende, partiendo de un régimen de protección, integrar el Patrimonio Arquitectónico en el sistema socioeconómico actual, de modo que sea al mismo tiempo testimonio del pasado y un motor de desarrollo de las regiones.

Para ello, cada Estado signatario debe identificar los bienes a proteger elaborando inventarios nacionales y desarrollar procedimientos legales de protección de acuerdo con los criterios establecidos en la Convención. España ratifica la Convención en el año 1989, tras la aprobación de la Ley 16/1985 del Patrimonio Histórico Español, que desarrolla la disposición en materia de patrimonio contenida en el artículo 46 de la Constitución y con la que España se adapta al marco jurídico internacional.

Este artículo toma como referencia fundamental la Convención de Granada por dos motivos: 1) la legislación española, de ámbito estatal, vigente hoy en día sigue siendo la misma que cuando se ratificó dicha convención, a pesar de que España haya suscrito nuevos convenios; 2) dicha convención se refiere específicamente al patrimonio arquitectónico y sentó las bases fundamentales sobre identificación y categorización de los bienes culturales inmuebles, que son objeto de estudio en este artículo.

No obstante, el estudio también tiene en cuenta los documentos y convenios publicados tras la promulgación de la Convención de Granada. Entre ellos, cabe destacar la importancia de la Carta de Cracovia del año 2000, circunscrita a Europa, sobre los principios para la conservación y restauración del patrimonio construido. Mantiene el espíritu de la Carta de Venecia de 1964 y actualiza al tiempo presente, tras los cambios producidos en cuarenta años, los criterios en el ámbitojurídico, cultural y tecnológico, para mejorar las medidas de salvaguardia del patrimonio, ofreciendo definiciones terminológicas para el entendimiento común y considerando el paisaje y el territorio como integrantes de la ciudad histórica. (Rivera Blanco, 2005: 405).

Adicionalmente, el marco jurídico-constitucional español se basa en un Estado descentralizado que se configura a través de las distintas autonomías que lo componen, de forma que todo el derecho sustantivo sobre el patrimonio cultural se estructura en torno a la dicotomía existente entre el Patrimonio Histórico Español, y los "Patrimonios Autonómicos", diferenciados, pero a la vez insertos en el primero (Azpeitia, 2016). En base al artículo 148.1 de la Constitución, que otorga competencias a las Comunidades Autónomas en «el patrimonio monumental de interés para la Comunidad Autónoma», desde los años 90 todas han promulgado gradualmente sus propias leyes de Patrimonio.

Por ello, para el presente estudio, además de la ley española de ámbito estatal y la Convención de Granada en la esfera internacional, se han seleccionado las dos leyes autonómicas de publicación más reciente:

- La Ley 11/2019, de 25 de abril, de Patrimonio Cultural de Canarias, que sustituye a la Ley 4/1999, de 15 de marzo, de Patrimonio Histórico de Canarias.

- La ley 6/2019, de 9 de mayo, de Patrimonio Cultural Vasco que sustituye a la Ley 7/1990, de 3 de julio, del Patrimonio Cultural Vasco. El País Vasco fue pionero en esta materia, siendo de las primeras comunidades autónomas en promulgar su propia ley.

Esta elección se ha tomado teniendo en cuenta que las dos leyes elegidas son las leyes autonómicas de segunda generación más actuales, ya que han sido promulgadas en 2019, por lo que se estudiará, dentro de los aspectos analizados, la potencial influencia de los documentos internacionales con relevancia en el ámbito de identificación y categorización de bienes posteriores a la Convención de Granada [1].

\section{Dispositivo experimental}

El presente estudio se centra en dos de los aspectos de la Convención de Granada y, sigue un análisis comparativo de las leyes citadas con el objetivo de: 1) detectar las principales similitudes y diferencias; 2) analizar su alineación con los preceptos de la Convención de Granada; 3) estudiar la influencia de los textos legislativos más recientes; 4) concluir sobre las implicaciones de la coexistencia de leyes estatales y autonómicas en materia de conservación del patrimonio arquitectónico. Los aspectos de la Convención de Granada estudiados son:

- La definición de Patrimonio Arquitectónico

- La identificación de los bienes objeto de protección 
Tabla 1.- Documentos y convenios internacionales

\begin{tabular}{|c|c|c|c|c|}
\hline Año & $\begin{array}{l}\text { Documentos } \\
\text { y convenios } \\
\text { internacionales }\end{array}$ & $\begin{array}{l}\text { Organismo } \\
\text { relacionado }\end{array}$ & Detalle & Relevancia \\
\hline 1964 & Carta de Venecia & $\begin{array}{l}\text { Expertos } \\
\text { internacionales }\end{array}$ & $\begin{array}{l}\text { Carta Internacional para la } \\
\text { Conservación y Restauración de } \\
\text { Monumentos y Sitios (II Congreso } \\
\text { Internacional de Arquitectos y } \\
\text { Técnicos en Monumentos Históricos). }\end{array}$ & $\begin{array}{l}\text { Supone la base fundamental de futuros documentos } \\
\text { internacionales sobre conservación y restauración. } \\
\text { ICOMOS fue fundado en 1965, como resultado de la } \\
\text { Carta de Venecia de } 1964 \text {. }\end{array}$ \\
\hline 1972 & $\begin{array}{l}\text { Convención de } \\
\text { París }\end{array}$ & UNESCO & $\begin{array}{l}\text { Convención sobre la Protección } \\
\text { del Patrimonio Mundial, Cultural y } \\
\text { Natural. }\end{array}$ & $\begin{array}{l}\text { Se crea un Comité intergubernamental de protección } \\
\text { del patrimonio cultural y natural y el Fondo para } \\
\text { protección del patrimonio mundial cultural y natural. }\end{array}$ \\
\hline 1976 & $\begin{array}{l}\text { Recomendación } \\
\text { de Varsovia y } \\
\text { Nairobi }\end{array}$ & UNESCO & $\begin{array}{l}\text { Recomendación sobre la salvaguarda } \\
\text { de los conjuntos históricos o } \\
\text { tradicionales. }\end{array}$ & $\begin{array}{l}\text { Define el conjunto histórico o tradicional, que sentará } \\
\text { las bases para la futura definición de paisaje urbano } \\
\text { histórico. }\end{array}$ \\
\hline 1985 & $\begin{array}{l}\text { Convención de } \\
\text { Granada }\end{array}$ & $\begin{array}{l}\text { Consejo de } \\
\text { Europa }\end{array}$ & $\begin{array}{l}\text { Convención para la Salvaguarda del } \\
\text { Patrimonio Arquitectónico de Europa. }\end{array}$ & $\begin{array}{l}\text { Marco fundamental en materia de Patrimonio } \\
\text { Arquitectónico en Europa, detallando la relevancia de } \\
\text { la identificación y categorización de bienes objeto de } \\
\text { protección. }\end{array}$ \\
\hline $\begin{array}{l}1986- \\
1987\end{array}$ & $\begin{array}{l}\text { Carta de Toledo } \\
\text { y Carta de } \\
\text { Washington }\end{array}$ & ICOMOS & $\begin{array}{l}\text { Carta Internacional para la } \\
\text { conservación de Ciudades Históricas } \\
\text { y Áreas Urbanas Históricas (ratificada } \\
\text { en VIII Asamblea General de ICOMOS). }\end{array}$ & $\begin{array}{l}\text { Complementaria de la Carta de Venecia de } 1964 \text {. } \\
\text { Incorporan un enfoque sistémico, entendiendo la } \\
\text { ciudad en su totalidad como una entidad histórica y } \\
\text { como una construcción social y dinámica que requiere } \\
\text { políticas coherentes de desarrollo económico y social } \\
\text { (Azkarate, Azpeitia, 2016: 310). }\end{array}$ \\
\hline 2000 & $\begin{array}{l}\text { Carta de } \\
\text { Cracovia }\end{array}$ & $\begin{array}{l}\text { Expertos } \\
\text { internacionales }\end{array}$ & $\begin{array}{l}\text { Principios para la conservación } \\
\text { y restauración del Patrimonio } \\
\text { construido. }\end{array}$ & $\begin{array}{l}\text { Actualización de la Carta de Venecia en base a los } \\
\text { avances internacionales en materia de conservación } \\
\text { del Patrimonio arquitectónico. Tiene como objetivo la } \\
\text { conservación del patrimonio arquitectónico, urbano y } \\
\text { paisajístico. }\end{array}$ \\
\hline 2000 & $\begin{array}{l}\text { Convenio } \\
\text { europeo del } \\
\text { paisaje }\end{array}$ & $\begin{array}{l}\text { Consejo de } \\
\text { Europa }\end{array}$ & $\begin{array}{l}\text { Convenio europeo que pretende } \\
\text { promover la protección, gestión y } \\
\text { ordenación de los paisajes europeos. }\end{array}$ & $\begin{array}{l}\text { Los conceptos de Patrimonio Cultural y Natural por } \\
\text { primera vez se fusionan en una visión integral del } \\
\text { paisaje. Ratificado por España en 2007. No obstante, } \\
\text { el Comité del Patrimonio Mundial (1992) adoptó } \\
\text { las Directrices Prácticas para la aplicación de la } \\
\text { Convención del Patrimonio Mundial, introduciendo ya } \\
\text { una nueva categoría de "Paisajes Culturales" (Azkarate, } \\
\text { Azpeitia, 2016: 310). }\end{array}$ \\
\hline 2003 & $\begin{array}{l}\text { Carta de Nizhny } \\
\text { Tagil }\end{array}$ & $\begin{array}{l}\text { Comité } \\
\text { Internacional } \\
\text { para la } \\
\text { Conservación } \\
\text { del Patrimonio } \\
\text { Industrial }\end{array}$ & Carta sobre el Patrimonio Industrial & $\begin{array}{l}\text { Basada en el espíritu de la Carta de Venecia, pone de } \\
\text { relieve la importancia del patrimonio industrial. }\end{array}$ \\
\hline 2005 & $\begin{array}{l}\text { Convenio de } \\
\text { Faro }\end{array}$ & $\begin{array}{l}\text { Consejo de } \\
\text { Europa }\end{array}$ & $\begin{array}{l}\text { Convenio sobre el valor del } \\
\text { patrimonio cultural para la sociedad }\end{array}$ & $\begin{array}{l}\text { Exige la creación de un marco que coloque el } \\
\text { patrimonio cultural en el centro de la atención social } \\
\text { y fortalezca el acceso público y la participación en el } \\
\text { patrimonio cultural. Ratificado por España en } 2018 \text {. }\end{array}$ \\
\hline 2005 & $\begin{array}{l}\text { Memorándum } \\
\text { de Viena }\end{array}$ & $\begin{array}{l}\text { UNESCO- } \\
\text { ICOMOS }\end{array}$ & $\begin{array}{l}\text { Patrimonio Mundial y la Arquitectura } \\
\text { Contemporánea. Gestión del Paisaje } \\
\text { Histórico Urbano. }\end{array}$ & $\begin{array}{l}\text { Aparece el concepto de Paisaje Urbano Histórico } \\
\text { (la definición fue redactada definitivamente en } \\
\text { 2010). Hace referencia explícita a la arquitectura } \\
\text { contemporánea. }\end{array}$ \\
\hline 2008 & $\begin{array}{l}\text { Carta de } \\
\text { Itinerarios } \\
\text { Culturales }\end{array}$ & ICOMOS & Carta de Itinerarios Culturales & $\begin{array}{l}\text { Destaca el reconocimiento de los Itinerarios Culturales } \\
\text { como nueva categoría patrimonial. }\end{array}$ \\
\hline 2011 & $\begin{array}{l}\text { Recomendación } \\
\text { de París }\end{array}$ & UNESCO & $\begin{array}{l}\text { Recomendación sobre el Paisaje } \\
\text { Urbano Histórico }\end{array}$ & $\begin{array}{l}\text { Se concluye la definición de Paisaje Urbano Histórico } \\
\text { que incluye su medio urbanizado tanto histórico como } \\
\text { contemporáneo }\end{array}$ \\
\hline 2018 & $\begin{array}{l}\text { Declaración de } \\
\text { Davos }\end{array}$ & $\begin{array}{l}\text { Consejo de } \\
\text { Europa y } \\
\text { Convenio } \\
\text { Cultural } \\
\text { Europeo }\end{array}$ & $\begin{array}{l}\text { Hacia una Baukultur de alta calidad } \\
\text { para Europa. Consejo de Europa, } \\
\text { Participan asimismo UNESCO, } \\
\text { ICCROM, ICOMOS, Comisión Europea, } \\
\text { Consejo de Arquitectos de Europa, } \\
\text { Consejo de Europa de Urbanistas y } \\
\text { Europa Nostra. }\end{array}$ & $\begin{array}{l}\text { El concepto de Baukultur que como aspecto de } \\
\text { identidad cultural y diversidad abarca de manera } \\
\text { integral todas las actividades humanas que cambian el } \\
\text { entorno construido }\end{array}$ \\
\hline
\end{tabular}


Las leyes objeto del presente estudio están concebidas para la protección de todo el patrimonio cultural, mientras que el ámbito de aplicación de la Convención de Granada es el patrimonio arquitectónico. Por ello, el análisis se circunscribirá a dicho ámbito.

\section{—Definición del patrimonio arquitectónico}

En la tabla 2 se muestran las diversas categorías, con el máximo grado de protección, en que se clasifican los bienes inmuebles que constituyen el patrimonio arquitectónico según cada una de las leyes estudiadas. [Tabla 2]

\section{- Identificación de los bienes objeto de protección}

El artículo segundo de la Convención de Granada establece la obligatoriedad, por parte de los Estados firmantes, de realizar un inventario de los bienes inmuebles susceptibles de protección con el fin de identificarlos para hacer efectiva dicha protección. Con esa finalidad las leyes estudiadas establecen:

- La ley 16/1985 de Patrimonio Histórico Español establece dos inventarios:

- El Registro General de Bienes de Interés Cultural, donde se incluyen bienes tanto muebles como inmuebles con un mayor grado de protección.

- El Inventario General contiene los bienes muebles de singular relevancia no declarados de interés cultural.

-La Ley 6/2019, de 9 de mayo, de Patrimonio Cultural Vasco establece dos inventarios:

- El Registro de la CAPV del Patrimonio Cultural Vasco, en el que se inscribirán los bienes de protección especial y de protección media.

- El Registro de la CAPV de Bienes Culturales de Protección Básica que incluye los bienes inmuebles

Tabla 2.- Categorías de bienes inmuebles y valores a proteger

\begin{tabular}{|c|c|c|c|}
\hline Convención de Granada & Ley $16 / 1985$ Estatal & Ley $11 / 2019$ de Canarias & Ley 6/2019 País Vasco \\
\hline \multicolumn{4}{|c|}{ CATEGORÍAS DE BIENES INMUEBLES [2] } \\
\hline $\begin{array}{c}\text { Monumento } \\
\text { Conjunto arquitectónico } \\
\text { Sitio }\end{array}$ & $\begin{array}{c}\text { Monumento } \\
\text { Conjunto Histórico } \\
\text { Sitio Histórico } \\
\text { Jardín Histórico }\end{array}$ & $\begin{array}{c}\text { Monumento } \\
\text { Conjunto Histórico } \\
\text { Sitio Histórico } \\
\text { Jardín Histórico } \\
\text { Paisaje cultural }\end{array}$ & $\begin{array}{c}\text { Monumento } \\
\text { Conjunto monumental } \\
\text { Espacio cultural } \\
\text { Jardín Histórico } \\
\text { - } \\
\text { Itinerario cultural }\end{array}$ \\
\hline \multicolumn{4}{|c|}{ VALOR O INTERÉS } \\
\hline $\begin{array}{c}\text { Histórico } \\
\text { Arqueológico } \\
\text { Artístico } \\
\text { Científico } \\
\text { Social } \\
\text { Técnico }\end{array}$ & $\begin{array}{c}\text { Histórico } \\
\text { Arqueológico } \\
\text { Artístico } \\
\text { Científico } \\
\text { - } \\
\text { Técnico } \\
\text { Paleontológico } \\
\text { Etnográfico }\end{array}$ & $\begin{array}{c}\text { Histórico } \\
\text { Arqueológico } \\
\text { Artístico } \\
\text { Científico } \\
\text { - } \\
\text { Técnico } \\
\text { - } \\
\text { Etnográfico } \\
\text { Industrial } \\
\text { Arquitectónico } \\
\text { - } \\
\text { - } \\
\text { Paisajístico } \\
\text { Otra naturaleza cultural }\end{array}$ & $\begin{array}{c}\text { Histórico } \\
\text { Arqueológico } \\
\text { Artístico } \\
\text { Científico } \\
\text { - } \\
\text { Paleontológico } \\
\text {-- } \\
\text { Industrial } \\
\text { Arquitectónico } \\
\text { Etnológico } \\
\text { Antropológico } \\
\text { Paisajístico } \\
\text { Otra naturaleza cultural }\end{array}$ \\
\hline
\end{tabular}


de los catálogos del planeamiento urbanístico municipal (salvo en el caso de aquellos bienes que estén incluidos en el Registro de la CAPV del Patrimonio Cultural Vasco).

-La Ley 11/2019, de 25 de abril, de Patrimonio Cultural de Canarias crea tres inventarios, en alguno de los cuales deberán incluirse los bienes integrantes del patrimonio cultural de Canarias para su protección:

- Registro de Bienes de Interés Cultural.

- Catálogo insular de bienes patrimoniales culturales.

- Catálogo municipal de bienes patrimoniales culturales.

En cuanto al acceso a los inventarios, las leyes autonómicas establecen claramente en su articulado que la información contenida en los mismos será accesible a los ciudadanos, aunque establezca determinadas limitaciones derivadas de la seguridad y el orden público, la intimidad de las personas o los secretos comerciales y científicos. En cambio, la ley estatal y sus reales decretos de desarrollo
(Real Decreto 111/1986 y Real Decreto 64/1994) estipulan la información, así como el régimen de visitas fijado en el artículo 13.2 de la Ley 16/1985, que debe quedar reflejada en el Registro General y fijan que «será preciso el consentimiento expreso del titular para la consulta pública de la situación jurídica y el valor de los bienes inscritos y su ubicación en el caso de bienes muebles». De esta limitación, se deriva que el resto de información contenida en el Registro General y relevante desde un punto de vista cultural debería ser accesible.

Consultadas las webs de cada uno de los organismos competentes que gestionan los inventarios de Bienes de Interés Cultural, se ha elaborado el cuadro que se adjunta a continuación [Tabla 3], en el que se resume la información disponible en la red de cada uno de los inventarios estudiados.

Cabe destacar que la web del Ministerio de Cultura facilita la fecha del BOE de la declaración, pero no adjunta el decreto de declaración. Asimismo, los Bienes de Interés

Tabla 3.- Información disponible en webs públicas

\begin{tabular}{|c|c|c|}
\hline $\begin{array}{c}\text { Registro General de Bienes de Interés } \\
\text { Cultural (Estatal) }\end{array}$ & $\begin{array}{c}\text { Registro de Bienes de Interés Cultural } \\
\text { de Canarias }\end{array}$ & $\begin{array}{c}\text { Registro de la CAPV del Patrimonio } \\
\text { Cultural Vasco }\end{array}$ \\
\hline \multicolumn{3}{|c|}{ INFORMACIÓN DISPONIBLE A TRAVÉS DE LAS RESPECTIVAS PÁGINAS WEB } \\
\hline $\begin{array}{c}\text { Localización } \\
\text { Comunidad Autónoma }\end{array}$ & Localización & Localización \\
\hline Provincia & Isla & Provincia \\
\hline Municipio & Municipio & Municipio \\
\hline Categoría & Categoría & Categoría \\
\hline Fecha de declaración & - & - \\
\hline Fecha Boletín Declaración & - & - \\
\hline- & Decreto de declaración & Decreto de declaración \\
\hline Código & - & - \\
\hline Registro & - & - \\
\hline Matiz & - & - \\
\hline- & Breve descripción & Breve descripción \\
\hline- & Fotografía & Fotografía \\
\hline- & - & Periodo general \\
\hline- & - & Siglo \\
\hline- & - & Estilo \\
\hline- & - & Grado de protección \\
\hline- & - & No ficha \\
\hline- & - & Tipología \\
\hline
\end{tabular}


Cultural cuentan con un código donde los dos primeros dígitos indican el tipo de bien y los siete siguientes son el código identificativo del mismo.

\section{Discusión de resultados}

Del análisis comparativo desarrollado se deduce que si bien la legislación española, tanto a nivel nacional como autonómico, cumple los preceptos recogidos por la Convención de Granada y las actualizaciones incorporadas por otros documentos dentro de los aspectos analizados, se han observado diferencias relevantes que ponen de manifiesto un tratamiento sustancialmente distinto desde las autonomías y desde el gobierno central de aspectos relativos a la identificación e inventariado del patrimonio arquitectónico.

\section{—Definición del patrimonio arquitectónico}

Como se recoge en el epígrafe anterior [Tabla 2], las tres leyes analizadas recogen los valores contenidos en la Convención, pero las leyes autonómicas amplían su alcance para recoger nuevos valores, asumiéndose así que el concepto mismo de patrimonio está en permanente construcción y que los elementos que lo configuran forman un conjunto susceptible de modificación y abierto a nuevas incorporaciones. Muestra de ello es la inclusión de:

- El valor industrial como parte del patrimonio cultural, referente a los procesos y a la tecnología, cuya definición, catalogación y protección se recoge en la Carta de Nizhny Tagil sobre Patrimonio Industrial de 2003.

- El valor paisajístico como incorporación de las directrices recogidas en el Convenio Europeo del Paisaje del 2000.

- El valor arquitectónico, ya recogido en la ley canaria anterior y que en el caso de la ley vasca se incorpora en su última versión, pero se elimina el valor urbanístico que aparecía en su predecesora.

Asimismo, en ambas leyes autonómicas, después de la especificación de valores que debe tener el patrimonio cultural para ser digno de protección, se añade «cualquier otra naturaleza cultural» previendo la evolución del concepto de patrimonio, pero implicando también, dada la vaguedad en su redacción, que los verdaderos valores dignos de protección queden potencialmente diluidos y que los bienes más importantes no sean objeto de la suficiente protección.

Por otro lado, se observa una especialización en los valores a proteger, al no hacerse referencia al valor social de la Convención de Granada, pero sí a otros más específicos como el valor paleontológico, etnográfico, etnológico y antropológico.

En cuanto a las categorías, si bien puede considerarse que se ajustan a lo establecido internacionalmente, aunque la nomenclatura y definición no sea exactamente la misma, es importante hacer varias consideraciones:

- En la definición de Monumento, la redacción dada en la ley estatal y la canaria es prácticamente idéntica, mientras que la del País Vasco, aunque incluya lo establecido en las otras dos, es más genérica y abierta como ocurría también en su predecesora, la ley 7/1990, de 3 de julio, del Patrimonio Cultural Vasco en la que un monumento podía ser tanto un bien mueble como inmueble.

- En cuanto al Jardín Histórico, hay que destacar que esta categoría no existe en la Convención de Granada con esta nomenclatura, si bien el concepto recogido en las leyes estudiadas se ajusta al de Sitio de la Convención. Como en el caso anterior, la ley estatal y la de Canarias es muy similar añadiendo esta última el valor artístico, mientras que la ley vasca es muy ambigua en su definición.

- En referencia al concepto de Conjunto Histórico/ Monumental, las tres leyes recogen la misma idea, en este caso de manera mucho más clara que en los casos anteriores y cabe destacar cómo la ley del País Vasco ha clarificado la definición respecto a la ley anterior en la que un conjunto monumental podía estar integrado por bienes muebles o inmuebles.

-Dado que las leyes españolas, tanto estatal como autonómicas, adaptan el concepto de Sitio de la Convención a la categoría de Jardín Histórico, la idea de Sitio Histórico recogido en la legislación española está vinculada a acontecimientos del pasado, tradiciones o creaciones culturales más que al patrimonio arquitectónico.

- Por último, es importante citar la aparición de nuevas categorías en las leyes autonómicas de patrimonio, que, si bien no se circunscriben al ámbito arquitectónico, demuestran el avance producido a lo largo del tiempo en la propia definición de patrimonio cultural para su mejor comprensión y estudio. Muestra de ello, la ley del País Vasco contempla el Itinerario Cultural, concepto recogido en la Carta de Itinerarios Culturales de ICOMOS ratificada en 2008 y la ley canaria incluye tanto el sitio industrial como el paisaje cultural, recogido en el Convenio Europeo del Paisaje del 2000. No obstante, debe garantizarse que las definiciones de las nuevas categorías queden perfectamente perfiladas (Amoedo-Souto, 2017: 91;140), dado que un enunciado generalista y difuso, como el dado para los Paisajes Urbanos Históricos en el Memorándum de Viena o la Recomendación de París de 2011, puede conducir, imperceptiblemente, a una desregulación de los criterios de protección y conservación del patrimonio urbano (Azkarate, Azpeitia, 2016: 324). 


\section{Identificación de los bienes objeto de protección}

En los inventarios creados por cada una de las leyes, si bien cumplen el mandato de la Convención, se observa una gran diferencia en el nivel de información proporcionada por la ley estatal y las leyes autonómicas. La información proporcionada por el Registro General del Ministerio de Cultura no supone un verdadero valor añadido para el ciudadano de a pie, al no incluir ni una breve descripción, ni el Decreto de declaración que podría proporcionar esa información. Además, únicamente recoge los Bienes de Interés Cultural. De esta manera, los bienes que no tengan un interés especialmente notable no quedan inscritos en el inventario nacional, aunque posteriormente estén en los Catálogos de los municipios. Esto es así a pesar de que, como se apuntó en el epígrafe anterior, no existe una limitación legal que impida que, a nivel nacional, la información relacionada con los valores por los que un bien es digno de protección no pueda ser accesible para los ciudadanos a través de la red (datos recogidos en la declaración de Bien de Interés Cultural tal como establece el Real Decreto 111/1986).

Por otra parte, el desarrollo de las leyes autonómicas ha hecho que la declaración de los bienes merecedores de protección y, por tanto, su catalogación, la hagan fundamentalmente las Comunidades Autónomas (Alegre Ávila, 1991: 618). No obstante, deben trasladar al Registro General las inscripciones y restantes anotaciones registrales a efectos de constancia general (Real Decreto $111,1986)$.

De las leyes estudiadas, el inventario más completo que puede consultarse a través de la red es el del Departamento de Cultura y Política Lingüística del País Vasco que además de la localización y una descripción, incorpora el grado de protección, estilo etc. No obstante, en la web de la Consejería de Turismo, Cultura y Deportes de Canarias, al igual que en la del País Vasco, se puede descargar el decreto de declaración del bien, a través del cual se tiene acceso tanto a la información histórica del bien como a su delimitación geográfica.

Además, en ninguno de los tres casos, se ha conseguido obtener una tabla que resuma el número de bienes y su categorización en los inventarios del Estado y de cada Comunidad Autónoma, lo que permitiría tener un orden de magnitud del patrimonio arquitectónico existente. No obstante, a través del Anuario de Estadísticas Culturales 2018 del Ministerio de Cultura, se sabe que en el año 2017 el número de bienes inmuebles inscritos como Bienes de Interés Cultural (BIC) ascendió a 17.579, lo que supone un aumento del $0,7 \%$ respecto a 2016. De ellos, 1.894 fueron bienes incoados y 15.685 bienes declarados (MCD, 2018). Por otro lado, hay que destacar el hecho de que a pesar de que cada Comunidad Autónoma establezca sus propias categorías, el Registro General dependiente del Ministerio de Cultura se convierte en una única base de datos en la que quedan recogidos todos los Bienes de
Interés Cultural de España y en la que se les asigna un código de acuerdo a las categorías establecidas en la ley $16 / 1985$, por lo que la multiplicidad de categorías a nivel autonómico supone un impedimento a la hora de generar una base de datos global del patrimonio cultural español.

\section{Conclusiones}

Las principales conclusiones del presente estudio pueden resumirse en los siguientes epígrafes:

\section{-Cumplimiento de convenios internacionales}

-La legislación española se ajusta a la normativa jurídica internacional en materia de categorización e inventariado de los bienes inmuebles pertenecientes al patrimonio arquitectónico.

-El desarrollo de las leyes autonómicas de protección del patrimonio supone que la política en esta materia ha dejado de ser meramente estatal y por tanto unificada y unitaria, como demuestra la existencia de distintas categorías de protección que establecen cada una.

\section{- La evolución del concepto de patrimonio y la definición de nuevas categorías}

- A medida que se promulgan nuevas leyes como resultado de la evolución del concepto de patrimonio cultural recogido en diversos documentos y convenios internacionales, aparecen nuevas categorías cada vez más amplias en su concepción. Si bien la aparición de nuevas figuras de patrimonio cultural supone un avance en la comprensión del pasado, el hecho de que sean cada vez más amplias y con definiciones difusas y generalistas en su concepción puede llegar a poner en riesgo la protección del patrimonio arquitectónico.

-Al estudiarse las leyes autonómicas de aprobación más reciente, se observa una especialización cada vez mayor en los valores $y$, por lo tanto, en los tipos de patrimonio a proteger. Esta especialización, si bien es positiva para conseguir un mayor conocimiento del patrimonio arquitectónico, puede desembocar en una banalización del propio concepto. En definitiva, las leyes estudiadas tienen como principal objetivo proteger lo más relevante y sobresaliente de nuestra cultura.

\section{- Inventarios y acceso público a la información}

- El contenido y formato de la información disponible en los medios de difusión oficiales (páginas web) no están normalizados, aunque es de naturaleza y alcance similar en las dos leyes autonómicas estudiadas. Sin embargo, 
el hecho de que no haya una comunicación directa desde el Ministerio de Cultura a las distintas consejerías responsables de los inventarios autonómicos no facilita el acceso a los ciudadanos. Sería conveniente y, sin duda, haría más fácil el acceso a esta valiosa información el que los contenidos del Ministerio y las distintas Consejerías fuera de la misma naturaleza y alcance, así como que existiera una mutua redirección de las búsquedas, desde el Ministerio hacia las Consejerías y viceversa.

- La catalogación de los Bienes de Interés Cultural y la gestión de los inventarios por parte de las Comunidades Autónomas facilita que estos estén actualizados y sean más accesibles a los ciudadanos por su mayor proximidad, sin embargo, la multiplicidad de categorías puede acabar llevando el sistema a una ineficiencia indeseable.

- Coexistencia de acuerdos supranacionales, leyes estatales y autonómicas en materia de protección del patrimonio

-La coexistencia de categorías estatales y autonómicas, sumadas a las definidas internacionalmente por los convenios y cartas, puede no redundar en una mejora de la protección del patrimonio arquitectónico, a pesar de que todas ellas tengan un mismo núcleo doctrinal. Por ello, sería deseable aclarar los ámbitos de competencias. Ese "núcleo doctrinal" parece bien definido y de forma precisa y flexible en los acuerdos internacionales. Las "categorías y criterios de valor" podrían estar definidos en la legislación nacional y ser matizadas autonómicamente si fuese necesario. Las Comunidades Autónomas seguirían siendo las responsables de la catalogación y gestión de los inventarios, dado que esa gestión descentralizada y cercana al ciudadano se ha demostrado mucho más atenta y eficaz. Con ello, no se plantea una recentralización, sino una simplificación y optimización de los recursos intelectuales y financieros disponibles para una mejor protección del patrimonio arquitectónico.

\section{Notas}

[1] El presente estudio forma parte de un trabajo más amplio que incluye el análisis pormenorizado de todas las leyes autonómicas en materia de Patrimonio Cultural.

[2] Solo se han incluido las categorías de bienes relacionados con el patrimonio arquitectónico.

\section{Bibliografía}

- Artículos

AZPEITIA SANTANDER, A. (2016) "Patrimonio y cultura. EI concepto de patrimonio cultural en la normativa vasca" Revista de la Facultad de Ciencias Sociales y Jurídicas de Elche, Volumen 1 Número 11: 369-389

AZKARATE, A y AZPEITIA, A. (2016) “Paisajes Urbanos Históricos. ¿Paradigma o subterfugio?" Alla ricerca di un passato complesso Contributi in onore di Gian Pietro Brogiolo per il suo settantesimo compleanno. 219-238

AMOEDO-SOUTO, C. (2017) "La ley 5/2016, de 4 de mayo, de patrimonio cultural de Galicia: una ley de baja calidad para un nuevo ciclo de desarrollismo" Revista Patrimonio Cultural y Derecho, número 21: 91-146

-Congresos

ALEGRE ÁVILA, J.M. (1991). “El ordenamiento estatal del Patrimonio Histórico Español: Principios y bases de su Régimen Jurídico" Seminario de Derecho Administrativo, Cantabria: Universidad de Cantabria.

RIVERA BLANCO, J. (2005). “Nuevas tendencias de la restauración monumental. De la Carta de Venecia a la Carta de Cracovia". En 2 Seminário A Intervenção no Património. Práticas de Conservação e Reabilitação, realizado na Faculdade de Engenharia da Universidade do Porto. Volume: 1.

\section{-Legislación}

BOE (1982) Instrumento de aceptación de 18 de marzo de 1982, de la Convención sobre la Protección del Patrimonio Mundial, Cultural y Natural, hecha en París el 23 de noviembre de 1972. Núm. 156, 17883-17887. https://www.boe.es/boe/ dias/1982/07/01/pdfs/A17883-17887.pdf

BOE (1985) Ley 16/1985, de 25 de junio, del Patrimonio Histórico Español. Núm. 155, 20342-20352. https://www.boe.es/boe/ dias/1985/06/29/pdfs/A20342-20352.pdf

BOE (1986) Real Decreto 111/1986, de 10 de enero, de desarrollo parcial de la Ley 16/1985, de 25 de junio de Patrimonio Histórico Español. Núm. 24, 3815-3831 https://www.boe.es/boe/ dias/1986/01/28/pdfs/A03815-03831.pdf

BOE (1989) Instrumento de Ratificación del Convenio para la Salvaguarda del Patrimonio Arquitectónico de Europa, hecho en Granada el 3 de octubre de 1985. Núm. 155, 20472-20475. https:// www.boe.es/boe/dias/1989/06/30/pdfs/A20472-20475.pdf

BOE (1994) Real Decreto 64/1994, de 21 de enero, por el que se modifica el Real Decreto 111/1986, de 10 de enero, de desarrollo parcial de la Ley $16 / 1985$, de 25 de junio, del Patrimonio Histórico Español. Núm. 52, 6780-6785 https://www.boe.es/ boe/dias/1994/03/02/pdfs/A06780-06785.pdf

BOE (2012) Ley 7/1990, de 3 de julio, de Patrimonio Cultural Vasco. Núm. 51, 17498-17526. https://www.boe.es/buscar/ pdf/2012/BOE-A-2012-2861-consolidado.pdf 
BOE (2008) Instrumento de Ratificación del Convenio Europeo del Paisaje, hecho en Florencia el 20 de octubre de 2000. Núm. 31, 6259-6263. https://www.boe.es/boe/dias/2008/02/05/pdfs/ A06259-06263.pdf

BOE (2019) Ley 11/2019, de 25 de abril, de Patrimonio Cultural de Canarias. Núm. 140, 61264- 61338. https://www.boe.es/boe/ dias/2019/06/12/pdfs/BOE-A-2019-8707.pdf

BOE (2019) Ley 6/2019, de 9 de mayo, de Patrimonio Cultural Vasco. Núm. 128, 56452- 56492 https://www.boe.es/eli/es$\mathrm{pv} / \mathrm{l} / 2019 / 05 / 09 / 6 /$ dof/spa/pdf

-Cartas, recomendaciones internacionales y otros documentos de referencia

CONSEJO DE EUROPA (2005) Convenio sobre el valor del patrimonio cultural para la sociedad. Conocido generalmente como Convenio de Faro. https://rm.coe.int/16806a18d3

ICOMOS (1987): Carta internacional sobre la salvaguarda de las ciudades históricas. Conocida generalmente como Carta de Washington. http://www.international.icomos.org/towns sp.htm

TICCIH (2003): Carta de Nizhny Tagil sobre el Patrimonio Industrial. $\quad$ https://www.icomos.org/18thapril/2006/nizhnytagil-charter-sp.pdf

UNESCO (1976): Recomendación sobre la salvaguarda de los conjuntos históricos o tradicionales y su papel en la vida contemporánea. Conocida generalmente como Recomendación de Nairobi. http://portal.unesco.org/es/ev.php$\underline{R L} I D=13133 \&$ URL DO=DO TOPIC\&URL SECTION=201.html

UNESCO (2000) Principios para la conservación y restauración del patrimonio construido. Conocidos generalmente como Carta de Cracovia. https://en.unesco.org/sites/default/files/ guatemala carta cracovia 2000 spa orof.pdf

UNESCO (2005) Memorándum de Viena sobre el Patrimonio Mundial y la Arquitectura Contemporánea. Gestión del Paisaje Histórico Urbano. http://whc.unesco.org/archive/2005/whc0515ga-inf7e.pdfICOMOS (2008) Carta de Itinerarios Culturales. https://www.icomos.org/images/DOCUMENTS/Charters/ culturalroutes sp.pdf

UNESCO (2011) RECOMENDACIÓN SOBRE EL PAISAJE URBANO HISTÓRICO. Conocida generalmente como Recomendación de París. https://whc.unesco.org/uploads/activities/documents/ activity-638-100.pdf

MINISTERIO DE EDUCACIÓN, CULTURA Y DEPORTE (2018) Anuario de Estadísticas Culturales. http://www.culturaydeporte. gob.es/dam/jcr:f818fa71-6313-468b-9db1-6a44d4fbd461/ principales-resultados-2018.pdf

\section{Autor/es}

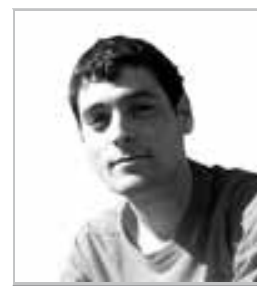

\section{Luis Miguel Sanz Rodriguez}

Im.sanz@alumnos.upm.es

Escuela Técnica Superior de Arquitectura de Madrid (ETSAM), Universidad Politécnica de Madrid (UPM), España

Arquitecto por la Escuela Técnica Superior de Arquitectura (ETSAM) de la Universidad Politécnica de Madrid (UPM), España. Actualmente, se encuentra desarrollando el doctorado en la Universidad Politécnica de Madrid en el ámbito de la protección del patrimonio arquitectónico desde una perspectiva legislativa. Desde marzo de 2015, su experiencia profesional se ha desarrollado en el estudio de arquitectura PRODIARQ Gelabert y Asociados centrado especialmente en el campo de la rehabilitación de edificios y en informes periciales. Desde 2014 participa de forma activa en un proyecto de investigación sobre vivienda colectiva del arquitecto Mies van der Rohe, dentro del grupo de investigación ARKRIT de la Escuela Técnica Superior de Arquitectura de Madrid, Universidad Politécnica de Madrid.

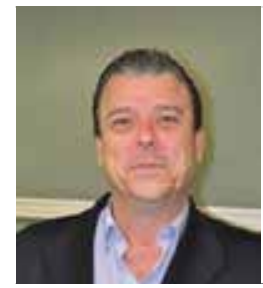

Antonio Eduardo Humero Martín

a.humero@upm.es

Escuela Técnica Superior de Arquitectura de Madrid (ETSAM), Universidad Politécnica de Madrid (UPM), España

Dr. Arquitecto desde el año 1997. Profesor Titular de la Universidad Politécnica de Madrid. Departamento de Construcción y Tecnología Arquitectónicas de la Escuela Técnica Superior de Arquitectura de Madrid. Director de diversos másteres, cursos de especialización y de la Cátedra Universidad-Empresa de Valoraciones de la Universidad Politécnica de Madrid, durante seis años. Investigador de los grupos de investigación «Regulación y Análisis Económico del Proceso Edificatorio» y «Técnicas Innovadoras y Sostenibles en la Edificación» del Área de Conocimiento de Construcciones Arquitectónicas de la Universidad Politécnica de Madrid. Autor de más de 100 publicaciones, en revistas indexadas, libros de autoría propia y compartida, capítulos de libros y contribuciones a congresos internacionales y nacionales, en editoriales de reconocido prestigio: Thomson Reuters Aranzadi, Dykinson, Wolters Kluwer, etc. Director de más de 100 proyectos de investigación de la Universidad Politécnica de Madrid, pertenecientes a las especialidades de patología edificatoria y responsabilidades en la construcción, urbanismo y ordenación del territorio y valoraciones expropiatorias y urbanísticas. Director de más de 10 tesis doctorales. Profesor invitado en universidades e instituciones oficiales y privadas de ámbito nacional e internacional (Argentina, Chile, Colombia, Panamá, etc.). Miembro de tribunales de oposición de ámbito nacional y local y de comisiones evaluadoras y científicas. 


Fernando Casqueiro Barreiro
fernando.casqueiro@upm.es
Escuela Técnica Superior de Arquitectura de
Madrid (ETSAM), Universidad Politécnica de
Madrid (UPM), España

Arquitecto y doctor por la ETSAM-UPM. Premio Extraordinario de Tesis Doctorales por la UPM, en 2002. Ha compatibilizado su actividad profesional con la académica y la investigadora. La mayor parte de su actividad profesional la ha desarrollado mediante encargos obtenidos en concursos públicos, internacionales, nacionales y restringidos (ganador en 33 ocasiones). Su obra ha sido expuesta en Santiago de Compostela, Stuttgart, París, Oporto, Zurich y Madrid.Es Profesor de "Proyectos Arquitectónicos" en la ETSAM_UPM desde 1991 hasta la actualidad.Miembro fundador del Grupo Consolidado de Investigación AKRIT (http://arkrit.dpaetsam.com/) y director de varios proyectos de investigación financiados por el Departamento de Proyectos de la ETSAM y por el Ministerio de Ciencia e Investigación. Autor de más de 40 artículos especializados y de divulgación. Autor de los libros: El Pabellón de Cristal de Madrid, Adenda a Arquitectura y Verdad, La Estación Marítima de Denia, Canon de Centros Escolares del Siglo XX.

Artículo enviado el 03/03/2019 Artículo aceptado el 07/11/2019 


\title{
Propuesta de plan de conservación preventiva para proyectos de muralismo urbano. El caso de Vigo, ciudad de color
}

\author{
Andrea Fernández Arcos
}

\begin{abstract}
Resumen: Son numerosas las ciudades que se están dejando subyugar por el cambio en su fisionomía que proporcionan los grandes murales urbanos, y también algunas empiezan a conocer los problemas que plantea su conservación. En 2015 el Ayuntamiento de Vigo se sumó a esta tendencia con el objetivo de transformar el feísmo urbanístico en un museo al aire libre.

Este estudio pretende analizar los problemas de conservación a los que se enfrentan estas obras por su ubicación y por las particulares condiciones ambientales de la ciudad, pero también desde la óptica de los nuevos materiales con los que han sido creadas y la perspectiva de conservación que sus autores tienen sobre ellas, con el fin de crear un plan de conservación preventiva que facilite su preservación.
\end{abstract}

Palabras clave: pintura mural, arte urbano, conservación, conservación preventiva, patrimonio cultural

\section{Proposal for a preventive conservation plan for urban mural projects. The case of vigo, city of color}

Abstract: Many cities are being subjugated by the change in their physiognomy provided by large urban murals and some are beginning to understand the problems posed by their conservation. In 2015, Vigo City Council joined this trend with the aim of transforming urban feism into an open-air museum.

This study aims to analyze the conservation problems faced by these works due to their location and the particular environmental conditions of the city, but also from the perspective of the new materials with which they have been created and the conservation perspective that their authors have on them, in order to create a preventive conservation plan that facilitates their preservation.

Keyword: mural painting, street art, conservation, preventive conservation, cultural heritage

\section{Proposta de plano de conservação preventiva para projetos de muralismo urbano: 0 caso da cidade de Vigo}

Resumo: Muitas cidades estão a ser subjugadas por uma mudança fisionómica proporcionada pelos grandes murais urbanos, e algumas também começam a conhecer os problemas colocados na sua conservação. Em 2015, a Câmara Municipal de Vigo aderiu a esta tendência com o objetivo de transformar o urbanismo num museu ao ar livre.

Este estudo tem como objetivo analisar os problemas de conservação que estas obras enfrentam devido à sua localização e às condições ambientais particulares da cidade, mas também a perspetiva dos novos materiais com os quais foram criadas e a perspetiva da conservação que os seus autores têm sobre elas, a fim de se criar um plano de conservação preventiva que facilite a sua preservação.

Palavras-chave: pintura mural, arte urbana, conservação, conservação preventiva, património cultural 


\section{Introducción}

En 2015 el Ayuntamiento de Vigo promovió la creación de un museo al aire libre compuesto por pinturas murales, con gran acogida por parte de los ciudadanos. Este texto pretende diseñar una estrategia de trabajo que facilite su preservación.

Para los conservadores restauradores no resulta novedoso realizar un plan de conservación preventiva para un grupo heterogéneo de obras como éste. Lo que sí se considera una particularidad de este estudio es que pretende crear un plan para un conjunto de obras de distintos artistas, con sus particularidades, repartidas al aire libre en un área de $109 \mathrm{~km}^{2}$ aproximadamente.

Si el planteamiento es exitoso, esta propuesta permitirá mejorar la conservación de los murales pertenecientes al proyecto Vigo. Ciudad de color, optimizando la inversión de recursos públicos. Además, las pautas de trabajo podrán ser extrapolables a otros conjuntos murales, cada vez más presentes en las ciudades.

\section{Objetivos}

El principal objetivo de este trabajo es diseñar un plan de conservación preventiva para el conjunto de murales pertenecientes al proyecto Vigo. Ciudad de color. También pretende conocer el contexto en que han sido creados los murales, determinar los factores de alteración decisivos para su conservación, conocer las expectativas de conservación que tienen los distintos actores vinculados al proyecto y reflexionar sobre el papel de los conservadores restauradores en la conservación de este tipo de conjuntos.

\section{Vigo. Ciudad de color}

El proyecto surgió con la aparición en 2014 de un nuevo solar en la Calle del Príncipe. Los ciudadanos expresaron un especial malestar al quedar expuesta una llamativa medianera en una de las vías que más turistas recibe todos los días. Para paliar el daño visual desde el Ayuntamiento se tomó la decisión de taparla con una enorme lona pintada con la obra "Fiestra" del surrealista gallego Lugrís.

La acogida entre los ciudadanos fue extraordinaria, aunque finalmente se construyó un edificio en el solar y la lona fue retirada; pero la gran aceptación convirtió este primer mural en el detonante de un nuevo proyecto. En agosto de 2014 la prensa recogía que "La iniciativa costó 20.000 euros y se repetirá en más de cien medianeras repartidas por toda la ciudad, incluidas las parroquias (...) con el fin de embellecer la ciudad" (Atlántico Diario 2014).

Este mural supuso el primer paso de Vigo. Ciudad de color, que tendría como objetivo mejorar el paisaje urbano con graffiti y otras especialidades pictóricas, según se indica en su propia web [1]. Abel Caballero, alcalde de la ciudad, aseguró que así se conseguirían recuperar "(...) zonas afeadas por un urbanismo nefasto, haciendo concursos y otras iniciativas con pintores muralistas" (Pastoriza 2014).

Esta desafortunada planificación de la urbe a la que se refería el alcalde tiene como uno de sus máximos exponentes las medianeras de los edificios. Lo habitual es que estas medianeras se encuentren sin remates estéticos dejando el material de construcción a la vista, o bien tapadas tan sólo con cemento, con pintura plana, con chapa metálica, espuma de poliuretano o tela asfáltica.

Hasta ahora algunas de ellas habían sido utilizadas como soporte publicitario e incluso como soporte de intervenciones artísticas. $Y$ ya hay un buen número de ciudades que, como Vigo, se han sumado a esta misma iniciativa.

Estamos pues, ante una fórmula no original en la propuesta, pero si en la cantidad de obras en una misma ciudad, puesto que el propio alcalde ha anunciado la voluntad de convertir Vigo en la ciudad europea con mayor número de murales (Méndez 2017).

En la web diseñada por el ayuntamiento para dar difusión a este proyecto se explican sus objetivos: además de promover el street art, esta iniciativa pretende la creación de un museo al aire libre mediante la transformación del feísmo urbano en arte "(...) gestionando actividades y actuaciones culturales complementarias, convirtiendo la participación ciudadana en un pilar del cambio artístico de la ciudad".

El principal objetivo de Vigo. Ciudad de color era paliar la estética desagradable causada por algunos inmuebles, pero con el tiempo se han sumado otros: se trata de un proyecto integrador, puesto que han sido incluidos barrios de distinta condición, del centro o periféricos. Tanto es así que los vecinos del barrio de Ribadavia solicitaron un mural al Ayuntamiento tras una etapa de mejora de infraestructuras. El Ayuntamiento accedió, creando un mural sobre una medianera descubierta tras la demolición de una infravivienda (Ponce 2019).

Vigo. Ciudad de color pretende también atraer a artistas reconocidos así como respaldar a artistas de la ciudad, ya sean pintores consolidados (incluso en otros ámbitos, como pintura de caballete) o nuevos valores. $Y$ hay que destacar que se ha convertido en un nuevo atractivo turístico para la ciudad.

De este modo, en 2015 se realizaron 14 murales, otros 14 en 2016, 15 en 2017 y 15 en la edición de 2018. Hasta 2018 se pintaron 58 murales repartidos por toda la ciudad y su creación ha supuesto ya un total de 1.049.626,23€ procedentes del erario público [2]. Para el año 2019 se anunció en la prensa la creación de 14 nuevos murales por un importe de $280.176 €$ (Prego 2018). 
El Ayuntamiento ha desarrollado otras actividades alrededor de esta iniciativa, como talleres artísticos o actuaciones musicales (Ponce 2018).

En resumen, es un proyecto muy ambicioso que pretende un gran impacto sobre los ciudadanos y que implica un gran volumen presupuestario.

\section{Antecedentes}

Las pintadas en las paredes, que en un principio se percibían como un acto de vandalismo, han adquirido nuevos valores para la sociedad, evolucionando en distintas las expresiones artísticas sobre todo tipo de soportes urbanos.

Algunos autores han reflexionado ya sobre la necesidad de conservación del arte urbano, como Mata Delgado (2013), Ciancabilla (2015), o Sánchez Pons et al. (2015). Chatzidakis (2018:99) sitúa el origen de este interés en Reino Unido, señalando a la sociedad como su detonante y en nuestro país hay que destacar necesariamente el intenso trabajo que el Grupo de Trabajo de Arte Urbano del Ge-IIC, creado en 2015 , viene desarrollando en los últimos años.

Inicialmente el arte urbano no nacía con pretensión de permanencia: la irregularidad y clandestinidad de su factura lo ligaba de forma indisoluble a un carácter efímero y por el riesgo de ser descubiertos durante su realización, de formato normalmente pequeño. Nada que ver con las grandes medianeras que necesitan de cierta infraestructura para ser pintadas, como es este el caso. Sin embargo en términos de conservación presentan numerosos puntos en común, como los materiales empleados o los riesgos a los que se ven expuestos.

Luque Rodrigo investiga cómo segestionala perdurabilidad de aquellas obras encargadas por las instituciones públicas (2015:13). En el caso de Vigo veremos que el punto de partida es la voluntad del propio ayuntamiento.

\section{Descripción material}

En Vigo. Ciudad de color tanto artistas como espacios fueron elegidos por una Comisión técnica creada para cada una de las fases del proyecto. En esta comisión, nombrada por la Concejalía de Patrimonio Histórico, estarían representadas las asociaciones culturales de la ciudad y técnicos municipales especializados en la conservación de patrimonio histórico, además de expertos en arte urbano.

En cuanto a los espacios, esta Comisión debía tener en cuenta ciertos factores relativos al impacto visual del mural y otros vinculados a la conservación, como la seguridad estructural o estanqueidad del muro (Concejalía de Patrimonio Histórico 2014).
Cada una de las superficies propuestas fueron estudiadas por técnicos municipales, que emitieron un informe sobre seguridad, conservación, impermeabilidad y otras cuestiones técnicas.

Con objeto de mejorar la conservación de los murales, el Ayuntamiento de Vigo solicitó un nuevo estudio en 2017. Fueron analizados entonces diversos aspectos de interés y se tomaron medidas tales como visitas a las viviendas vinculadas para localizar posibles humedades y actuar en consecuencia. También se limpiaron las fachadas y se les aplicó fungicida.

El informe señala la necesidad de aplicar una imprimación sobre los elementos metálicos presentes en algunas fachadas. Además, todas las superficies de las medianeras debían ser pintadas con un tipo de pintura determinado. Una vez pintados los murales fueron protegidos con una capa de barniz. El objetivo era aportar una protección para "prevenir un menor ensuciamiento, un mejor envejecimiento y por tanto una mayor duración de los mismos" (Sánchez de Haz 2017:16). En este proyecto se incluye la aplicación de barniz protector a los murales realizados en las fases anteriores.

En cuanto a los materiales empleados para pintar, son muy dispares. En la mayoría de ocasiones se han usado pinturas no diseñadas específicamente para la creación artística; en su lugar, los artistas han utilizado diversos materiales diseñados inicialmente con fin decorativo o industrial. Por este motivo es imprescindible que el plan de conservación preventiva incorpore una ficha que identifique y describa todos los materiales presentes en cada uno de los murales.

Por señalar tan sólo algunos ejemplos de entre los más de 60 artistas participantes hasta este momento, indicaremos que Alejandro Fernández, creador del mural de O Calvario, explica que para su obra empleó tanto spray como pintura al agua para exteriores. Gonzalo Alonso por su parte usó acrílicos para su mural de la calle Zaragoza 55. El artista Popay usó colores en spray para el mural de la Avenida Atlántida; Elara Elvira y Ana Santiso utilizaron, en su última creación, una pintura plástica para interior y exterior con fungicida en su composición y Magalhaes se atrevió con la materia de carga en su mural de Abeleira Menéndez.

\section{Conservación}

Dado que el proceso de deterioro continúa avanzando se sugiere la elaboración de un plan de conservación preventiva desde la óptica del profesional de conservación restauración de bienes culturales.

El Grupo de Trabajo del Ge-IIC propone la consideración del arte urbano como Bien Cultural Común, BIComún, dada la dificultad de encontrar un encaje legal apropiado que facilite la adopción de medidas para su conservación. Efectivamente, la figura jurídica que otorga el máximo nivel de protección es el Bien de Interés Cultural, BIC, y 
su definición no abarca este tipo de manifestaciones. El BiComún por su parte, es una propuesta reciente que tiene como fin designar a un patrimonio que merece ser conservado como consecuencia de una reflexión colectiva de la sociedad (Masaguer y Vázquez 2014:156).

En el programa redactado por la Concejalía de Patrimonio Histórico de Vigo (2014) se señala como objetivo "conseguir que la ciudadanía se involucre en la conservación y estética de las zonas de goce de todos y del patrimonio", por lo que parece oportuno extender al muralismo esta cobertura. Por tanto, de forma previa al desarrollo del diseño del plan de conservación sería necesario constatar la existencia de esta identificación por parte de los diferentes actores implicados.

Este tipo de obras se multiplican en ciudades de todo el mundo $y$, hayan sido hechas o no con los permisos necesarios, frecuentemente son bien acogidas gracias a una serie de valores que la sociedad percibe en ellas (estético, turístico, social...). En el plano turístico, por ejemplo, los murales de Vigo tienen un mapa-guía específico para su visita y se han creado una web y perfiles para difusión en distintas redes sociales.

En definitiva, es un arte sobre el que se percibe un deseo social de conservación pero que está destinado a ser disfrutado fuera del controlado ambiente del museo, lo que supone un gran reto para los profesionales encargados de su cuidado. A este reto los profesionales responden con nuevos estudios y propuestas dirigidos a solventar la problemática específica que se plantea. Uno de los primeros pasos en este sentido ha sido el desarrollo de un código deontológico de trabajo específico: los profesionales de la conservación restauración han adoptado de forma tácita el propuesto porE.C.C.O. para el desempeño de su trabajo. Por las características particulares que envuelven al arte urbano, el Grupo de Trabajo del Ge-IIC para este campo ha considerado necesario crear un código propio que oriente a los profesionales que trabajen con este tipo de bien (2016:188-192). Esta normativa, como su homóloga de ECCO, es un conjunto de artículos que recoge los principios generales para la aplicación del Código (arts. 1-23) y las obligaciones del autor, propietario o guardián legal (arts. 24-27).

\section{-Perspectivas de conservación}

Buena parte de los artistas participantes en este proyecto comparten el deseo de conservación de las obras, como la pintora Elisa González, quien mostró su disgusto a través de la prensa al saber que su obra quedaría oculta tras la construcción de un edificio en el solar adyacente (Sotelino 2018).

Existen excepciones como Gonzalo Alonso, quien confía en que su mural no vaya a ser afectado por actos vandálicos y cree que, tras una estimación de unos 20 años de vida, "está bien que se deshaga y se pudra porque el arte ha de ser efímero" (Rodríguez 2015). Esta disparidad de pareceres obliga a que el plan de conservación preventiva tenga en cuenta también la opinión de cada creador. Y finalmente, como se ha visto, la Administración tiene la voluntad de que los murales duren en el tiempo, así lo ha expresado el alcalde de la ciudad [3] y como consecuencia se tomaron algunas medidas con este fin (descritas en el apartado 5).

\section{—Agentes de alteración}

A pesar de la amplitud geográfica en la que están distribuidos los murales, éstos están expuestos a una serie de agentes y/o riesgos comunes de sobra estudiados por los profesionales de la conservación restauración, por lo que tan sólo se describirán brevemente.

El plan de conservación preventiva debe conocer tanto estos agentes como aquellos que de forma específica pongan en riesgo cada mural y debe evaluar su efecto periódicamente con el fin de establecer diagnósticos y planes de actuación.

\section{a) Factores intrínsecos}

Dentro de los factores intrínsecos recogeremos aquellos que están directamente vinculados a la creación de las obras.

\section{Soporte}

En este apartado se incluyen los riesgos inherentes a la construcción como morteros, humedades e incluso debilidades estructurales del inmueble. Como soporte debe incluirse no sólo el muro, sino también otros elementos presentes en la fachada (puertas, ventanas, tuberías, rejillas...) con su propio deterioro y amenazas de conservación (manipulación, uso...). Será preciso realizar un mapa de identificación de zonas sujetas a riesgo potencial, sobre las que hacer especial vigilancia (tuberías, posibles desprendimientos...).

En el mural Kraken, realizado por el artista Delio Rodríguez en el año 2017 apreciamos ya la aparición de unas manchas blancas que, con la observación realizada desde la distancia, parecen eflorescencias.

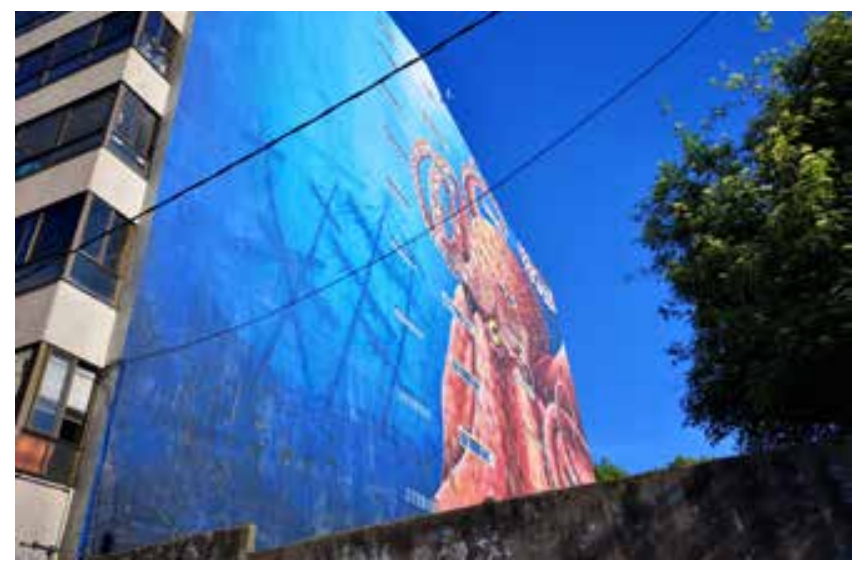

Figura 1.- Manchas blanquecinas en la esquina inferior izquierda del mural Kraken. A. Fernández 


\section{Técnica}

Los materiales y técnicas empleados son de gran importancia para la conservación. El uso de materiales de escasa durabilidad, en mal estado o el uso de técnica inadecuada/incompatible con los materiales del soporte pueden dar como resultado un variado número de alteraciones, al margen de la interacción con el resto de factores que puedan afectar a la conservación del mural. Un ejemplo de ello es el mural Verne, en donde ya hay grandes áreas de pintura levantada, con la incompatibilidad de materiales entre pintura y capa de soporte como causa probable [figura 2].

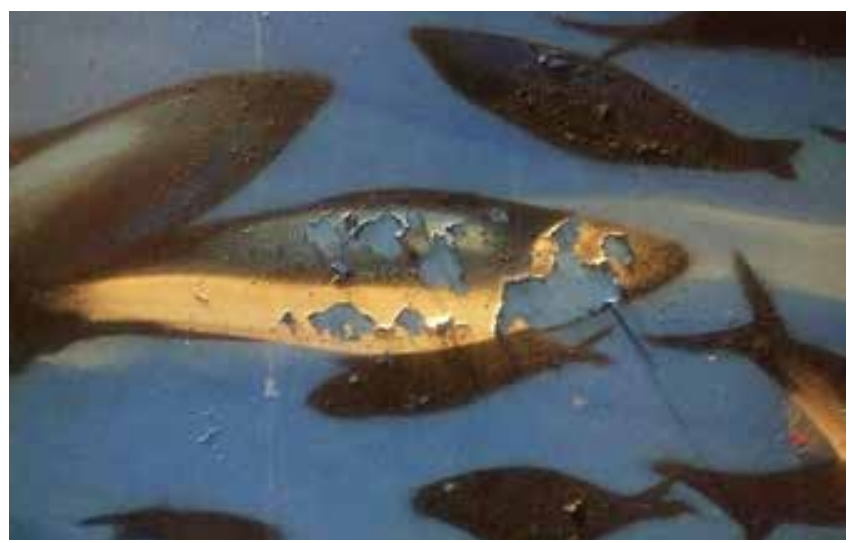

Figura 2.- Levantamiento de película pictórica en el mural de Verne. A. Fernández

\section{b) Factores extrínsecos}

Los factores extrínsecos son aquellos ajenos a la obra que inciden directa o indirectamente en su conservación. Parte de los parámetros que se evaluarán en este apartado son consecuencia del clima de la ciudad, por ello parece necesaria una pequeña descripción de las circunstancias climáticas de Vigo. El clima de esta ciudad es de tipo oceánico, lo que implica una abundante pluviometría en los meses de otoño e invierno y una temperatura en general suave, que oscila entre $5^{\circ} \mathrm{C}$ y $10^{\circ} \mathrm{C}$ en invierno, y $25^{\circ} \mathrm{C}$ y $30^{\circ} \mathrm{C}$, en verano.

\section{Humedad}

Vigo es una zona con una media de precipitaciones al año de $1303 \mathrm{~mm}$. Además del agua de lluvia que impactará directamente sobre la pintura con mayor o menor fuerza, hay que tener en cuenta la humedad ambiental y el agua procedente de la propia estructura del inmueble (tuberías interiores o exteriores en mal estado, sistemas de desagüe en mal estado o insuficientes) que afecten a la obra por capilaridad o incluso por escorrentía.

\section{Temperatura}

La temperatura se verá condicionada por dos factores fundamentales: por una parte, la temperatura ambiental, que en Vigo es por lo general suave; por otra parte, hay que tener en cuenta la temperatura que puede alcanzar la superficie del mural a causa de la incidencia de la radiación solar. Esta incidencia dependerá a su vez de varias circunstancias: la variación según el momento del día y la época del año, y la orientación de la medianera.

\section{Luz.}

La principal exposición de los murales es, lógicamente, de luz solar. Los valores máximos de insolación en el hemisferio norte son en junio y julio y la menor exposición ocurre de diciembre a enero. Pero además hay que tener en cuenta la climatología para determinar el grado de insolación. El clima de Vigo, extensivo a todas las Rías Baixas, implica una atmósfera más limpia y con menos nubes, lo que supone un aumento de la radiación, significativamente mayor que en otras urbes de Galicia (Pettazzi y Salsón 2011:21). También es necesario tener en cuenta la luz artificial de las farolas, especialmente cuando el foco de iluminación está próximo a la superficie del mural y por tanto la incidencia y su efecto es mayor.

\section{Biodeterioro.}

El biodeterioro es la alteración indeseada e irreversible de los materiales causada por organismos o microorganismos. En el caso de los murales de Vigo el principal problema para la conservación tiene variado origen:

1. Animal. En este sentido es posible determinar un daño más acusado por mamíferos en las zonas bajas de los murales y por aves en las zonas altas. En ambos casos el principal problema será la deposición de excrementos/ orines en la superficie. También hay que tener en consideración el biodeterioro por insectos, especialmente a través de la deposición de excrementos.

2. Vegetal. Muchos de los murales están en contacto directo con zonas en las que crecen plantas creando un riesgo de invasión, como ya ocurre en el mural Sea Walls for Oceans [figura 3]. Pero los murales también pueden verse afectados por otros agentes vegetales causantes de biodeterioro, como musgos, líquenes... Tanto su ubicación exterior como las irregularidades de la superficie son factores propicios para el asentamiento vegetal de distinta entidad.

\section{Contaminación.}

Vigo es una ciudad industrial. En el estudio ambiental sobre Pontevedra entre 2004-2017 se concluye que las emisiones contaminantes han dismiuido debido a los efectos de la crisis. Aún así destaca la presencia de contaminantes: flúor, cloruro de hidrógeno, ácido sulfúrico, formaldehídos, sulfuro de hidrógeno, metano y compuestos orgánicos volátiles (Consellería de Medio Ambiente, Territorio e Vivenda, 2017:16). El estudio también apunta a los incendios forestales como causa de la elevada cifra de CO en 2017 (Consellería de Medio Ambiente, Territorio e 


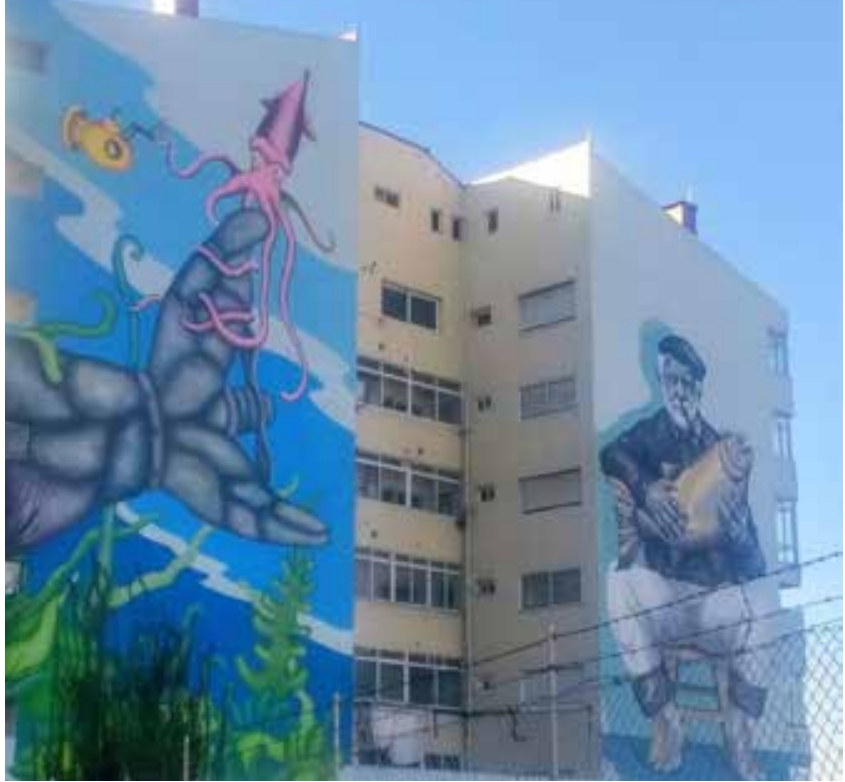

Figura 3.- Mural Sea Walls for Oceans e invasión de la pintura por enredaderas. A. Fernández

Vivenda, 2017:228). Por supuesto también hay que tener en consideración la alta densidad del tráfico como origen de la contaminación ambiental y el impacto que tendrá en murales especialmente expuestos, como el mural del túnel de Beiramar hecho por Lidia Cao. La contaminación unida a la lluvia puede provocar lluvia ácida. El pH de la lluvia se controla de forma habitual y el valor medio para Vigo en el último informe oficial disponible es de 6,6 (Consellería de Medio Ambiente, Territorio e Vivenda, 2017:184).

\section{Viento.}

La importancia del viento radica especialmente en que vaya acompañado de lluvia o partículas sólidas, pudiendo entonces tener un efecto más agresivo sobre las pinturas. Incluso puede facilitar la alteración provocada por aerosoles marinos, especialmente en las fachadas más expuestas. El mural de Lula Goce, todavía íntegro, es uno de los que corre riesgo de verse alterado por la erosión propiciada por el viento, como podemos ver en una fachada próxima y de orientación análoga [figura 4].

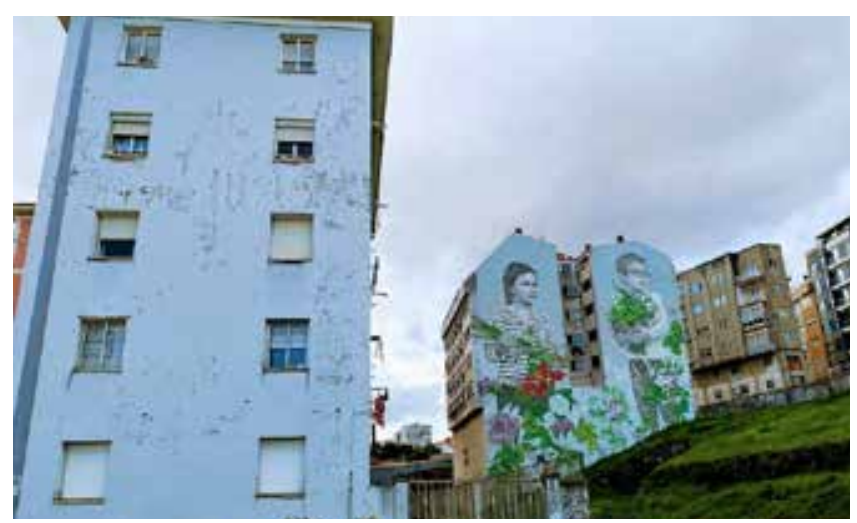

Figura 4.- Mural de Lula Goce en segundo plano y fachada con idéntica orientación y exposición a factores ambientales, en primer plano. A. Fernández

\section{Factor antrópico.}

El daño causado por el ser humano sobre los murales tiene dos posibles orígenes: un daño consciente o el daño inconsciente por acción u omisión. Como actos vandálicos encontramos chicles adheridos, pegatinas o arañazos, y sobre tdo graffitis o grafismos localizados fundamentalmente a metro y medio del suelo, es decir, a una altura cómoda para generar el daño. En la prensa local se hacen eco periódicamente de los graffitis de mayor tamaño (Faro de Vigo 2019) y en general se pasa por alto el gran número de pequeñas pintadas existentes. También hay daño antrópico inconsciente, como los roces casuales. Por ejemplo, en el mural del parque infantil de Navia de Proyecto Ewa, en el que el mural acaba en un banco ampliamente usado y por tanto el roce con la pintura es habitual [figura 5].

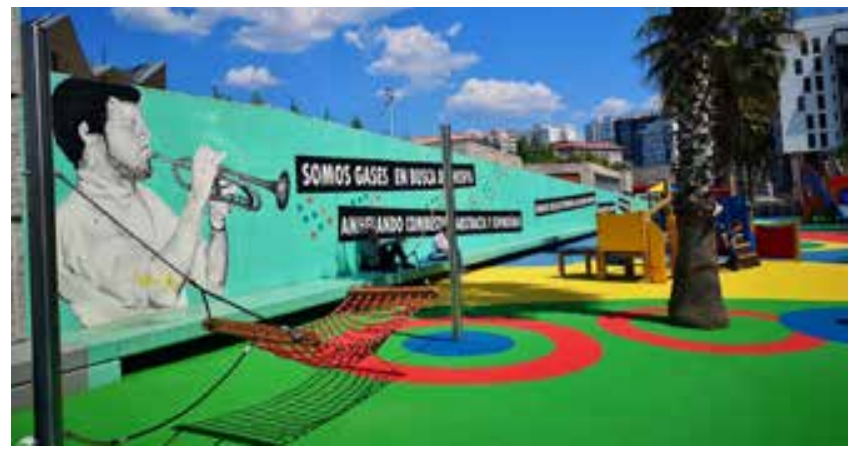

Figura 5.- Ciudadanos apoyados sobre el mural de Proxecto Ewa. A. Fernández

En esta sección podríamos incluir los roces realizados sin querer por automóviles, como en el mural Mulleres da conserva de Beiramar 177 [figura 6].

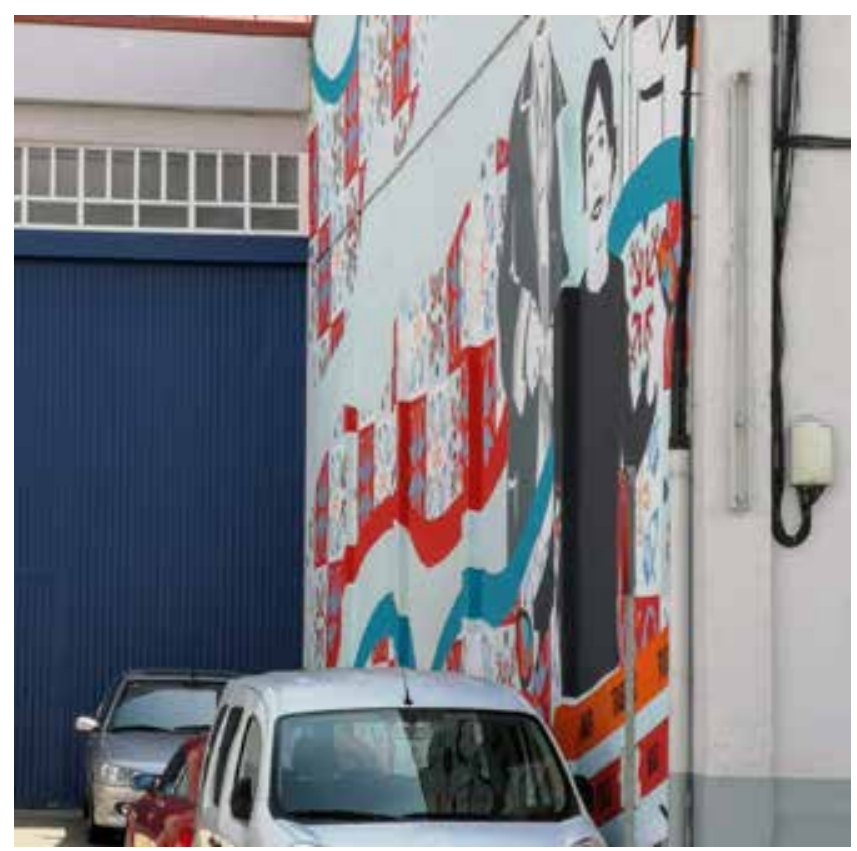

Figura 6.- Coches aparcados junto al mural Mulleres da conserva. A. Fernández 
VIII. Vibraciones.

Vigo no es una ciudad de especial riesgo sísmico. En cambio, sí cabe esperar riesgo derivado de vibraciones transmitidas desde el suelo en aquellas zonas afectadas por una gran densidad de tráfico, especialmente cuando éste es más pesado, de tipo industrial.

\section{Valoración del estado de conservación y diagnóstico}

El número, tamaño y dispersión de las obras obligan a adoptar una metodología específica de trabajo que facilite tanto la toma de datos como su análisis y la determinación de la urgencia a la hora de tomar medidas. Por ello se propone un sistema de recogida de información mediante tablas[3].

Para daños presentes en los murales, se empleará la Tabla 1 que determina la extensión y gravedad del daño sobre el mural. En la Tabla 2 se recoge en cambio la probabilidad de que aparezca un daño todavía no presente y su gravedad una vez aparezca.

Se usará otra tabla para valorar la urgencia con que los daños detectados deban ser intervenidos. El modelo que se propone [Tabla 3] ofrece 3 posibilidades: sin necesidad de intervención, intervención inmediata o necesidad de intervención no inmediata, programable en el tiempo. De este modo se podrá facilitar la organización de las intervenciones y optimizar los recursos. No hay que olvidar que los murales están dispersos en una gran área y que pueden necesitar una importante infraestructura para abordar su intervención, en caso de que sea necesaria.

Finalmente, una tabla con datos básicos de cada mural [Tabla 4] recogerá las medidas de impacto o riesgo de daño de los distintos agentes señalados en el apartado 5.2.

Tabla 1.- Impacto de daño

\begin{tabular}{|c|c|c|c|c|}
\hline DAÑO EXISTENTE & Leve (1) & Medio (2) & Alto (3) & Mry allo (4) \\
\hline Extensión / Impacto & & & & \\
\hline $\begin{array}{c}\text { Extension 0-10\% } \\
\text { Baja (1) }\end{array}$ & $\begin{array}{c}1+1 \\
2\end{array}$ & $\begin{array}{c}1+2 \\
3\end{array}$ & $\begin{array}{c}1+3 \\
4\end{array}$ & $\begin{array}{c}1+4 \\
5\end{array}$ \\
\hline $\begin{array}{l}\text { Extensión } 10-25 \% \\
\quad \text { Media (2) }\end{array}$ & $\begin{array}{c}2+1 \\
3\end{array}$ & $\begin{array}{c}2+2 \\
4\end{array}$ & $\begin{array}{c}2+3 \\
5\end{array}$ & $\begin{array}{c}2+4 \\
6\end{array}$ \\
\hline $\begin{array}{c}\text { Extensión } 25-50 \% \\
\text { Alta (3) }\end{array}$ & $\begin{array}{c}3+1 \\
4\end{array}$ & $\begin{array}{c}3+2 \\
5\end{array}$ & $\begin{array}{c}3+3 \\
6\end{array}$ & $\begin{array}{c}3+4 \\
7\end{array}$ \\
\hline $\begin{array}{c}\text { Extensión } 50-100 \% \\
\text { Mry alta (4) }\end{array}$ & $\begin{array}{c}4+1 \\
5\end{array}$ & $\begin{array}{c}4+2 \\
6\end{array}$ & $\begin{array}{c}4+3 \\
7\end{array}$ & $\begin{array}{c}4+4 \\
8\end{array}$ \\
\hline & Categoria 4 & Categoria 3 & Categoria 2 & Categońa 1 \\
\hline
\end{tabular}

Tabla 2.- Riesgo de aparición de daño

\begin{tabular}{|c|c|c|c|c|}
\hline DAÑO PROBABLE & Leve (1) & Medio (2) & Alto (3) & Muy allo (4) \\
\hline Probabilidad / Impacto & & & & \\
\hline $\begin{array}{c}\text { Improbable que se produzca } \\
\text { Fesgo bajo (1) }\end{array}$ & $\begin{array}{c}1+1 \\
2\end{array}$ & $\begin{array}{c}1+2 \\
3\end{array}$ & $\begin{array}{c}1+3 \\
4\end{array}$ & $\begin{array}{c}1+4 \\
5\end{array}$ \\
\hline $\begin{array}{l}\text { Es posible que se produzca } \\
\text { Fesgo medio (2) }\end{array}$ & $\begin{array}{c}2+1 \\
3\end{array}$ & $\begin{array}{c}2+2 \\
4\end{array}$ & $\begin{array}{c}2+3 \\
5\end{array}$ & $\begin{array}{c}2+4 \\
6\end{array}$ \\
\hline $\begin{array}{c}\text { Muy probable que se produzca } \\
\text { Fiesgo allo (3) }\end{array}$ & $\begin{array}{c}3+1 \\
4\end{array}$ & $\begin{array}{c}3+2 \\
5\end{array}$ & $\begin{array}{c}3+3 \\
6\end{array}$ & $\begin{array}{c}3+4 \\
7\end{array}$ \\
\hline $\begin{array}{l}\text { Seguro que se produce, } \\
\text { incluso con inmediatez } \\
\text { Fesgo muy allo (4) }\end{array}$ & $\begin{array}{c}4+1 \\
5\end{array}$ & $\begin{array}{c}4+2 \\
6\end{array}$ & $\begin{array}{c}4+3 \\
7\end{array}$ & $\begin{array}{c}4+4 \\
8\end{array}$ \\
\hline & Categoria 4 & Categoría 3 & Categoria 2 & Categoria 1 \\
\hline
\end{tabular}


Tabla 3.- Urgencia de intervención

\begin{tabular}{|c|l|l|l|}
\hline \multicolumn{1}{|c|}{ URGencia } & \multicolumn{1}{|c|}{$\mathbf{0}$} & \multicolumn{1}{c|}{$\mathbf{1}$} \\
\hline $\begin{array}{l}\text { Urgencia de la intervención con la que debe } \\
\text { ser afrontada una alteración }\end{array}$ & $\begin{array}{l}\text { No precisa } \\
\text { intervención }\end{array}$ & $\begin{array}{l}\text { Precisa intervención } \\
\text { pero no es urgente }\end{array}$ & $\begin{array}{l}\text { Precisa } \\
\text { intervención } \\
\text { inmediata }\end{array}$ \\
\hline
\end{tabular}

Tabla 4.- Recolección de datos

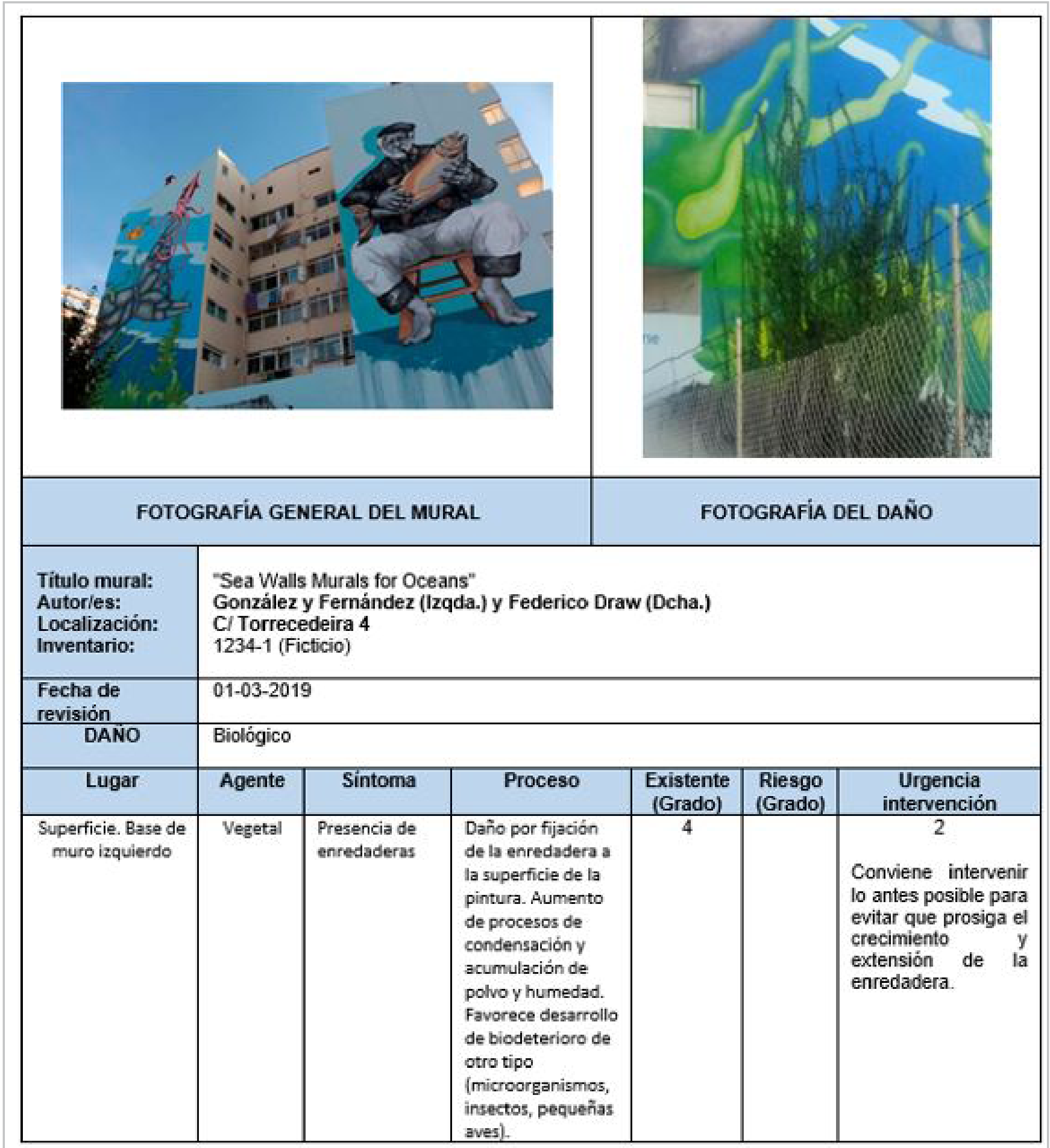


Se recomienda evaluar anualmente la incidencia de todos los agentes señalados. De este modo se podrán establecer diagnósticos singularizados de daños o de riesgo de aparición de los mismos y, en consecuencia, determinar los tratamientos necesarios y el orden de prioridad para su aplicación.

\section{Otras medidas}

La preocupación por la conservación preventiva no es nueva. En el año 2000 el ICCROM animó a centrar las acciones sobre el patrimonio cultural en la prevención de los riesgos como una forma más eficaz y sostenible de gestión del patrimonio, y así lo recoge la Resolución de la Reunión de Vantaa. Este proyecto se realiza inspirado en esas directrices.

Este plan consta de dos apartados: uno dedicado a las medidas previas a la ejecución de los murales y otro para los ya pintados.

\section{a. Medidas para obras que van a ser realizadas}

Esta fase cuenta con la ventaja de poder influir en la toma de decisiones que puedan favorecer la conservación del mural a ejecutar. Las medidas serían las siguientes:

1. Inclusión de un profesional de conservación restauración en el Comité de selección de superficies, con el fin de señalar las más problemáticas en términos de conservación.

2. Propuesta y ejecución de medidas de conservación preventiva para cada una de las superficies elegidas.

3. Oferta de asesoramiento de técnicas y materiales, para el/los artistas que lo deseen.

\section{b. Plan de conservación preventiva para murales ejecutados.}

1. Documentación. La recogida de información relativa a los murales es de gran importancia, especialemente teniendo en cuenta que en algunos casos el deterioro y la pérdida del mural serán inevitables y la documentación será todo el legado que quede tras su desaparición. En este sentido se proponen las siguientes medidas:
a. Asignación de un número de inventario.
b. Elaboración de ficha documental de cada obra. Para este fin se propone el uso del Modelo de registro elaborado por el Grupo de Trabajo de Arte Urbano del Ge-IIC (Úbeda 2016:175-176).
c. Creación de una base de datos que recoja toda la información de cada mural, para facilitar su gestión.

2. Revisión anual de cada uno de los murales con las tablas propuestas en el apartado 7.

3. Posteriormente, se tomarán medidas apropiadas para las incidencias detectadas. Éstas serán realizadas por profesionales de la conservación restauración en el ámbito de su competencia o bien serán sugeridas a la administración para que pueda proceder a su encargo. Por ejemplo:

a. Medidas a realizar profesionales de la conservación restauración tras la detección del problema:

i. Eliminación vegetación invasora sobre los murales.

ii. Tratamiento de daños causados por humedad.

b. Medidas a desarrollar por otros profesionales, con la supervisión del responsable del plan:

i. Prevención de asentamiento de vegetación invasora en solar adyacente.

ii. Mejora del sistema de evacuación del agua de lluvia en el túnel de Beiramar, para evitar que forme charcos y ascienda por capilaridad en el mural, como sucede en la actualidad.

4. Se propone contar con la colaboración activa de la sociedad en la vigilancia de los murales. Se considera oportuno contar con un colaborador en el propio inmueble (podría tratarse de un representante de la comunidad de vecinos o de la asociación vecinal) que dé aviso en caso de incidencias.

5. Plan de calidad. Como todo proyecto que se pretenda mantener en el tiempo, el propio plan necesitará una evaluación periódica de calidad que permita detectar fallos, aplicar de medidas correctivas e implantar mejoras.

Es preciso señalar que muchas soluciones de conservación que se propongan deberán pasar por un comité multidisciplinar del Ayuntamiento que valore la compatibilidad de las propuestas con otras necesidades/ usos del entorno.

\section{Conclusiones}

Vigo, como otras muchas ciudades a nivel mundial, se ha dejado seducir por la estética y el diálogo con la sociedad que establecen los murales. El gran número de medianeras que afeaban la ciudad ha resultado ser la excusa perfecta y el lienzo ideal para este proyecto, que ya consta de más de 70 obras.

En este caso existe un especial interés de la administración y la sociedad por su preservación; sin embargo, los murales de Vigo. Ciudad de color no están protegidos por las leyes de patrimonio, nacionales o autonómicas. Estaríamos ante uno de esos elementos que podrían ser englobados bajo la denominación de BIComún.

Este plan pretende proteger los murales creados hasta ahora y todos aquellos que se incorporen en futuras fases. Está basado en la asunción de un código ético específico, así como en el uso de una metodología concreta de trabajo que facilita la recogida de datos relativos al estado de conservación, facilitando la evaluación de riesgos y 
prioridades y permitiendo una adopción razonada de decisiones.

Los factores decisivos para la conservación de los murales mantienen algunas similitudes con los que afectan a otro tipo de bienes en entornos mejor conocidos. Sin embargo, en nuestro caso, algunos de los parámetros no son en absoluto manipulables (temperatura, humedad, por ejemplo), lo que obliga a un trabajo alternativo que permita, a pesar de las dificultades, retrasar o disminuir sus consecuencias.

Otra ventaja de este sistema es que optimiza el uso de las infraestructuras necesarias, tanto para revisión como para intervención y lógicamente ello redundará en un mejor empleo de los recursos disponibles.

Este sistema de recolección de información, sostenido en el tiempo, facilitará también conocer la evolución de muchos materiales empleados en la actualidad para la creación, pero de los que todavía carecemos de información suficiente, permitiendo mejorar el pronóstico de conservación de estas obras en el futuro.

Es preciso destacarquees desdela conservación restauración de bienes culturales que se pueden dar las soluciones apropiadas a los retos que supone la conservación de estos murales. Por ello, conviene avanzar en las líneas de investigación recientemente abiertas en este campo.

\section{Notas}

[1] Url del proyecto Vigo. Cidade de cor: http://ciudaddecolor.vigo. org/

[2] En 2015 se invirtieron $230.000 €, 224.000 €$ en $2016,297.043,71$ $€$ en 2017 y $298.582,52 €$ en 2018 , según se desprende de en las licitaciones de los expedientes, 8185-307, 8521-307, 8845-307 que se pueden consultar a través de la web del ayuntamiento www.vigo.org

[3] En declaraciones recogidas por el mismo artículo de Sotelino, el Alcalde de Vigo indicaba que los murales recibirían "un tratamiento especial para garantizar su durabilidad y preservarlos así en buen estado de conservación durante al menos 100 años".

[4] Para el diseño de las tablas se han tomado como referencia las tablas propuestas por Carrera (2018) para la elaboración de planes de conservación preventiva en yacimientos arqueológicos, por la similitud de diversos parámetros como exposición a factores ambientales no controlables, dispersión geográfica, etc. Éstas tienen a su vez su base en el sistema de evaluación de riesgos diseñado por Culubret et al. (2008:28-29), que lógicamente también se ha tenido en consideración. Así, las asignaciones numéricas funcionan del mismo modo que aquellas: se asignan valores de 1 a 4 según si el riesgo de aparición o la gravedad del daño es leve (1), media (2), alta (3) o muy alta (4), y los posibles resultados de las sumas oscilan entre 2 y 8 . Se genera así la posibilidad de agrupar daños en 4 categorías, siendo la categoría 1 la que indica la mayor gravedad y 4 , la que menos.

\section{Bibliografía}

CARRERA RAMÍREZ, F. (2018): Conservación preventiva de yacimientos arqueológicos: ¿empezamos? VI Congreso GEIIC. 20-22 Septiembre 2018. Vitoria, 376-384.

CHATZIKADIS, M. (2018): Preventive conservation and monitoring of Street art, graffiti, and public murals: education and training as an effective tool. En Actas VI Congreso Ge-IIC. pp. 99-106 Madrid, 2018. Disponible en <https://www.ge-iic.com/2018/10/03/actasdel-vi-congreso-del-geiic/ > [Consulta: 8 de febrero 2019]

CIANCABILLA, LUCA (2015): The sight gallery: salvaguardia e conservazione della pittura murale urbana contemporanea a Bologna. Bolonia, Bolonia University Press.

CONCELLERÍA DE PATRIMONIO HISTÓRICO (2014): Programa para arrumbar medianeiras e outros elementos verticais con incidencia sobre a vía pública, e demais espazos libres que conforman a paisaxe urbana. Vigo, Concello de Vigo. Disponible en vigo.org

CONSELLERÍA DE MEDIO AMBIENTE, TERRITORIO E VIVENDA (2017): Informe anual da calidade do aire de Galicia 2017. Santiago de Compostela, Xunta de Galicia.

CULUBRET WORMS, B., Hernández Azcutia, M., Hidalgo Cámara, E., Martínez de Marañón Yanguas, M. y Rallo Gruss, C. (2008): Guía para un plan de protección de colecciones ante emergencias. Madrid, Ministerio de Cultura.

GARCÍA GAYO, E. (2015): "Introducción". Mural Street Art Conservation. Observatorio del Arte Urbano no 1 pp. 4-5. <https:// issuu.com/observatoriodearteurbano/docs/mural 1> [Consulta: 8 de enero 2019]

GRUPO DE ARTE URBANO (2016): "Anexo I. Propuesta de código deontológico para la conservación y restauración de arte urbano" en Ge-Conservación no 10. Monográfico Arte Urbano. Conservación y Restauración de Intervenciones Contemporáneas. pp. 188-192 <http://observatoriodearteurbano.org/wordpress/wp-content/ uploads $/ 2017 / 01 / \mathrm{Ge}$-conservacio\%CC\%81n-N\%C2\%BA10Suplemeto-Arte-Urbano.pdf> [Consulta: 3 de abril de 2019]

LUQUE RODRIGO, L. (2015). "Arte urbano para la ciudadanía: conservación colectiva".MuralStreetArtConservation.Observatoriodel ArteUrbanon ${ }^{\circ} 1$ p. $13<$ https://issuu.com/observatoriodearteurbano/ docs/mural 1> [Consulta: 8 de enero 2019]

MASAGUER OTERO, M. y VÁZQUEZ VEIGA, A. (2014): "BIComun: un experimento en el espacio público" Tejuelo: Didáctica de la Lengua y la Literatura. Educación, n 19, págs. 154-158. < $\underline{\text { https:// }}$ dialnet.unirioja.es/servlet/articulo?codigo $=4725343>$ [Consulta: 1 de marzo 2019]

MATA DELGADO A. L. (2013) “Conservando el street art \& grafiti, la pertinencia de su conservación y la problemática material derivada de su técnica de manufactura". Memorias del X Foro Académico ECRO, México, 2013. Documento electrónico disponible en http:// www.ecro.edu. $\mathrm{mx} /$ memorias $\mathrm{x}$ foro.html 
MÉNDEZ, ÓSCAR (2017): “Vigo llegará a las 100 medianeras en un lustro y aspira a ser la urbe con más murales de Europa" en Faro de Vigo, 12 de julio. <https://www.farodevigo.es/granvigo/2017/07/12/vigo-llegara-100-medianeras-lustro/1714993. html>[Consulta: 14 de abril 2019]

PASTORIZA, JAVIER (2014): “La calle Príncipe estrenará el primer mural en un edificio con la réplica de "Fiestra" de Lugrís" en Faro de Vigo, 22 de agosto. <https://www.farodevigo. es/gran-vigo/2014/08/22/calle-principe-estrenara-primermural/1079661.html> [Consulta: 30 de noviembre 2018]

PETTAZZI, A. Y SALSÓN CASADO, S. (2011): Atlas de radiación solar de Galicia. Santiago de Compostela, Ed. Xunta de Galicia. $<$ https://www.meteogalicia.gal/datosred/infoweb/meteo/ docs/publicacions/libros/Atlas Radiacion Solar Galicia.pdf> [Consulta: 16 de abril 2019]

PONCE, CARLOS (2018): "El arte llega a los colegios" en Faro de Vigo, 30 de diciembre. <https://www.farodevigo.es/granvigo/2018/12/30/arte-llega-colegios/2025295.html> [Consulta: 31 de diciembre 2018]

PONCE, CARLOS (2019): “Un mural en una medianera relanzará el "olvidado" barrio vigués de Ribadavia" en Faro de Vigo, 6 de enero. <https://www.farodevigo.es/gran-vigo/2019/01/06/ mural-medianera-relanzara-olvidado-barrio/2028210.html> [Consulta: 7 de enero 2019]

PREGO, CARLOS (2018): "El museo urbano fija a Vigo en el mapa del 'street art'" en Faro de Vigo, 30 de diciembre. $<$ https://www.farodevigo.es/gran-vigo/2018/12/30/museourbano-fija-vigo-mapa/2025294.html> [Consulta: 30 de diciembre 2018]

REDACCIÓN ATLÁNTICO DIARIO (2014): “Príncipe presume ya de su gigantesco mural de Lugrís" en Atlántico Diario, 2 de septiembre. https://www.atlantico.net/articulo/vigo/principepresume-gigantesco-mural-lugris/20140907002612434005. html> [Consulta: 30 de noviembre 2018]

REDACCIÓN FARO DE VIGO (2019): “Las pintadas vuelven a cebarse con uno de los murales de Vigo" en Faro de Vigo, 3 de enero. <https://www.farodevigo.es/gran-vigo/2019/01/03/ pintadas-vandalicas-ceban-gran-mural/2026422.html> [Consulta: 3 de enero 2019]

RODRÍGUEZ, A. (2015): “Un colorista paisaje urbano alegra la calle" en Faro de Vigo, 11 de noviembre. <https://www. farodevigo.es/especiales/arte-urbano/2015/11/coloristapaisaje-urbano-alegra-calle-n861 2 24639.html> [Consulta: 10 de enero 2019]

SÁNCHEZ DE HAZ, B. (2017) "Las actuaciones preparatorias orientadas al desarrollo del $3^{a}$ programa para el pintado de medianeras y otros elementos verticales con incidencia sobre la vía pública" Disponible en http://www.vigo.org/csv empleando el código de verificación 2DE34-D2B88-4EAC4-842BE. [Consulta: 7 de febrero 2018]
SÁNCHEZ PONS, M., SHANK, W. Y FUSTER LÓPEZ, L. (2015): Conservation Issues in Modern and Contemporary Murals. Cambridge Scholars Publishing

SOTELINO, BEGOÑA (2018): "Por mi enfermedad respiratoria, el mural es símbolo del esfuerzo" en La Voz de Galicia, 24 de marzo. <https://www.lavozdegalicia.es/noticia/vigo/vigo/2018/03/24/ exposiciones-formacion-enfermedad-respiratoria-mural-simboloesfuerzo/0003 201803V24C12991.htm> [Consulta: 7 de enero 2018]

ÚBEDA GARCÍA, M. (2016). Propuesta de un modelo de registro para el análisis y documentación de obras de arte urbano. GeConservacióN, , 169-179. Consultado de https://ge-iic.com/ojs/ index.php/revista/article/view/410 [Consulta: 3 de abril de 2019]

\section{Autor/es}

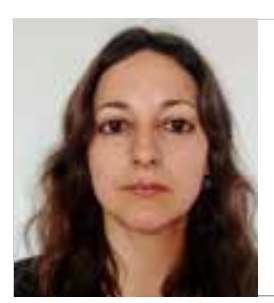

\section{Andrea Fernández Arcos}

andreafarcos@gmail.com ESCRBBCCG

Andrea Fernández Arcos: Titulada en la especialidad de pintura por la Escuela Superior de Conservación y Restauración de Bienes Culturales de Galicia (2003), Máster en Conservación, Restauración y Exposición de Bienes Culturales por la Universidad Complutense de Madrid (2009) y Postgrado en Gestión, Preservación y Difusión de Archivos Fotográficos por la Universitat Autónoma de Barcelona (2014).

Desarrolló su trabajo en instituciones como el Museo Nacional Thyssen-Bornemisza (2004-5), Museo Nacional del Prado (2005-8) o el Museo del Traje-CIPE entre otros (2010-13). Desde 2013 pertenece al Departamento de Conservación y Restauración de Bienes Pictóricos de la Escuela Superior de Conservación y Restauración de Bienes Culturales de Galicia, donde actualmente desempeña el cargo de vicedirección.
Artículo enviado el 06/09/2019 Artículo aceptado el 11/10/2019 


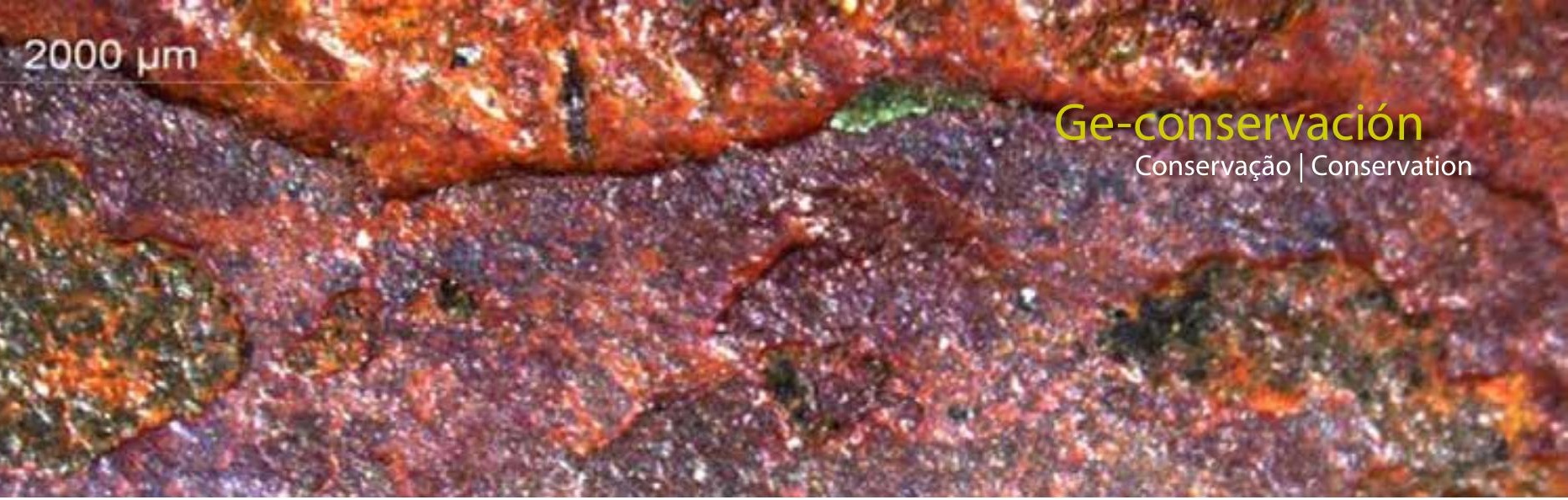

\title{
Aportación de nuevas metodologías multitécnica en el estudio y conservación de patrimonio numismático de procedencia subacuática
}

\author{
Carla Álvarez Romero, Antonio Doménech Carbó, Milagros Buendía Ortuño, Trinidad Pasíes \\ Oviedo, María Teresa Doménech Carbó
}

\begin{abstract}
Resumen: Este trabajo presenta un estudio del estado de conservación de monedas con base de cobre procedente del Museo Nacional de Arqueología Subacuática. La metodología multitécnica incluye instrumentación convencional como microscopía óptica, espectroscopia FTIR y técnicas avanzadas nanoinvasivas como voltamperometría de micropartículas y haz de iones focalizados-FESEM-EDX. Así se ha podido identificar el tipo de aleación, productos de corrosión, depósitos superficiales y antiguas intervenciones. Cabe señalar la identificación de mecanismos de alteración atípicos como la formación de complejos carboxilados de iones metálicos generados en los procesos electroquímicos de corrosión del metal o aleación y los materiales lipídicos fijados en la superficie de la moneda cuando esta estuvo en circulación y que gracias a su carácter hidrófobo se han conservado en el ambiente subacuático en el que las monedas han permanecido durante siglos. Estos hallazgos han resultado de gran utilidad para establecer los tratamientos más idóneos de conservación de estas piezas.
\end{abstract}

Palabras clave: numismática, microscopía óptica, espectroscopia FTIR, voltamperometría de micropartículas inmovilizadas, microscopía electrónica de barrido de emisión de campo con haz de iones focalizados, productos de corrosión, depósitos superficiales, antiguas intervenciones.

\section{Contribution of new multi-technical methodologies in the study and conservation of numismatic heritage of underwater origin}

\begin{abstract}
This paper presents a study of the conservation status of copper-based coins from the National Museum of Underwater Archaeology. The multitechnical methodology includes conventional instrumentation such as optical microscopy, FTIR spectroscopy and advanced non-invasive techniques such as microparticle voltamperometry and focused ion beam -FESEM-EDX. Thus it has been possible to identify the type of alloy, corrosion products, surface deposits and old interventions. It should be noted the identification of atypical alteration mechanisms such as the formation of carboxylated complexes of metal ions generated in the electrochemical processes of corrosion of the metal or alloy and the lipid materials fixed on the surface of the coin when it was in circulation and that, due to its hydrophobic character have been preserved in the underwater environment in which the coins have remained for centuries. These findings have been very useful to establish the most suitable conservation treatments for these pieces.
\end{abstract}

Keyword: numismatics, optical microscopy, FTIR spectroscopy, immobilized microparticle voltamperometry, scanning electron emission field microscopy with focused ion beam, corrosion products, surface deposits, old interventions

\section{Contribuição de novas metodologias multitécnicas no estudo e conservação do património numismático de procedência subaquática}

Resumo: Este artigo apresenta um estudo do estado de conservação de moedas à base de cobre provenientes do Museu Nacional de Arqueologia Subaquática. A metodologia multitécnica inclui instrumentação convencional, como microscopia ótica, espectroscopia FTIR e técnicas avançadas de não invasivas, como voltamperometria de micropartículas e feixe de iões focado - FESEM-EDX. Assim, foi possível identificar o tipo de liga, produtos de corrosão, depósitos superficiais e intervenções antigas. Deve-se destacar a identificação de mecanismos atípicos de alteração, como a formação de complexos carboxílicos de iões metálicos gerados nos processos eletroquímicos 
de corrosão do metal ou liga e os materiais lipídicos fixados na superfície da moeda quando ela estava em circulação e que, devido ao seu caráter hidrofóbico, foi preservado no ambiente subaquático em que as moedas permaneceram por séculos. Estas descobertas foram muito úteis para estabelecer os tratamentos de conservação mais adequados para essas peças.

Palavras-chave: numismática, microscopia ótica, espectroscopia FTIR, voltamperometria de micropartículas imobilizadas, microscopia de campo de emissão de eletrões de varrimento com feixe de íões focado, produtos de corrosão, depósitos superficiais, intervenções antigas

\section{Introducción}

Las piezas numismáticas constituyen un importante porcentaje de las colecciones de numerosos museos y del patrimonio metálico en general, además, se tratan de vestigios arqueológicos e históricos fundamentales para el estudio de diferentes aspectos de las sociedades pasadas llegando a proporcionar información, tan diversa que abarca desde la composición de las aleaciones o las técnicas empleadas para su fabricación hasta, por ejemplo, las relaciones comerciales existentes entre las diferentes ciudades en un determinado momento histórico (Álvarez Romero et al., 2016: 157).

Es en el siglo XVIII cuando comienzan a realizarse las primeras investigaciones combinando los estudios físico-químicos con los estudios arqueológicos, aunque no será hasta 1958 cuando el término de arqueometría quede acuñado gracias al Laboratorio de Investigación de Arqueología y de Historia del Arte de la Universidad de Oxford con la fundación de la revista Archaeometry (Aitken, 1961, 1970; Doménech-Carbó y Osete-Cortina, 2016: 3). En paralelo, y debido al aumento que se estaba produciendo de las colecciones de los museos más importantes del momento, comienzan a realizarse estudios sobre los procesos de deterioro de los bienes culturales, sus productos de alteración, los parámetros necesarios para su óptima conservación y el estudio de nuevas técnicas y materiales empleadas para la conservación-restauración, naciendo, de esta manera la llamada ciencia de la conservación (De Tagle, 2008: 31).

En este contexto, el empleo de estrategias multitécnica y multidisciplinares aplicadas al estudio del patrimonio ha aumentado considerablemente en los últimos años, quedando patentes los beneficios de emplearlas y la gran aportación que pueden realizar al estudio de los objetos patrimoniales.

Para el desarrollo de este trabajo se ha empleado la microscopía óptica, la voltamperometría de micropartículas inmovilizadas (VIMP), la espectroscopia infrarroja por transformada de Fourier (FTIR) y la microscopía electrónica de barrido de emisión de campo con haz de iones focalizados y microanálisis de rayos $X$ (FIB-FESEM-EDX). Dichas técnicas complementarias, han proporcionado información de las muestras de diferente naturaleza.

Las técnicas microscópicas aportan información morfológica, topográfica y textural de los objetos metálicos mediante el examen directo (DoménechCarbó et al., 2009: 23-24; Prous y del Egido, 2008: 68; Dillmann et al., 2013: 62). A través de la microscopía óptica se han podido obtener imágenes aumentadas de las piezas numismáticas e información preliminar sobre la superficie de las monedas debido a la gran diferencia tonal que exhiben los productos de corrosión del cobre y los depósitos exógenos, siendo posible realizar una primera identificación aproximativa por colores.

La voltamperometría de micropartículas inmovilizadas (VIMP) es una técnica electroquímica basada en las respuestas voltamperométricas que se producen cuando un sólido poco soluble (muestra de metal a analizar) y fijado en un electrodo inerte de grafito mediante abrasión, se sumerge en un electrolito adecuado dispuesto en la celda de un analizador voltamperométrico (DoménechCarbó, 2015: 63; Doménech-Carbó y Osete-Cortina, 2016: 86) y proporciona información sobre determinados productos de corrosión, depósitos exógenos y a su vez sobre la composición de la aleación empleada.

Por otro lado, la espectroscopia infrarroja por transformada de Fourier (FTIR) se basa en la interacción que se produce entre la radiación electromagnética infrarroja y las moléculas que componen la muestra analizada. Estas transiciones a modos vibracionales específicos son características de dichos grupos de átomos o grupos funcionales, y tienen lugar a valores de longitud de onda (o número de onda, $\mathrm{cm}^{-1}$ ) específicos pudiendo, de esta manera, caracterizar las diferentes moléculas que componen la muestra (García Rodríguez et al., 2010: 45-46). Esta técnica es ampliamente usada en los análisis de patrimonio cultural, ya que proporciona información analítica relativa tanto a materiales orgánicos como inorgánicos (Doménech-Carbó y Osete-Cortina, 2016: 63-66). Gracias a esta técnica, además de poder identificar los depósitos superficiales y los productos de corrosión presentes en las monedas de carácter inorgánico, se ha podido realizar la caracterización de diferentes productos orgánicos empleados en antiguas intervenciones de las piezas. 
La microscopía electrónica de barrido de emisión de campo con haz de iones focalizados y microanálisis de rayos $X$ (FIB-FESEM-EDX) permite obtener imágenes de gran resolución y profundidad de campo, realizar secciones transversales o trincheras gracias a la columna de iones de $\mathrm{Ga}^{+}$focalizados, que al interactuar con las muestras permite romper los enlaces químicos e ionizar los átomos de una manera controlada, y se puede obtener la composición elemental de la muestra analizada de forma cualitativa y cuantitativa gracias al microanálisis de rayos X (Álvarez Romero y Doménech Carbó, 2016 y 2017). Esta técnica analítica ya se ha empleado para el análisis de diferentes colecciones numismáticas (Doménech-Carbó et al., 2017; Álvarez-Romero et al., 2017; DoménechCarbó et al., 2019) quedando patente su capacidad para obtener información tanto de las capas más superficiales de las monedas compuestas, mayoritariamente, por productos de corrosión de los metales empleados en la fabricación de las piezas, depósitos exógenos y, como se presenta en este estudio, productos empleados en antiguas intervenciones.

\section{Objeto de estudio}

La selección de monedas de la colección numismática del Museo Nacional de Arqueología Subacuática (MNAS) consta de dieciséis monedas acuñadas en diversos momentos históricos y recuperadas en varios yacimientos subacuáticos. Todas las monedas de la selección fueron fabricadas en distintas aleaciones de cobre, lo que, unido a su procedencia, presenta depósitos exógenos y productos de corrosión característicos.

La documentación de las monedas comenzó con la consulta en Domus *(sistema informatizado de documentación y gestión museográfica) de la información relativa a cada una de las monedas; y sólo tres de las monedas (1, 6 y 16) habían recibido algún tipo de tratamiento conservativorestaurativo según dichas fichas.

La tabla 1 resume las principales características de las monedas del Museo Nacional de Arqueología Subacuática. Se identifican las piezas numismáticas estudiadas aportando datos como el yacimiento del que proceden, el emisor, la cronología, la denominación de valor, la ceca, los tipos y leyendas de anverso y reverso, datos técnicos como el peso y las dimensiones del módulo y si las piezas han sido sometidas a algún tipo de intervención conservativa-restaurativa según la documentación consultada. La figura 1 muestra las fotografías de anverso y reverso de cada una de las monedas estudiadas.

\section{Metodología analítica}

Los análisis realizados en la selección de monedas del MNAS han sido llevados a cabo en el Laboratorio de
Análisis Físico-Químico y Medioambiental de Obras de Arte (LAFQYM) del Instituto Universitario de Restauración del Patrimonio (IRP) de la Universitat Politècnica de València (UPV), el Servicio de Microscopía Electrónica de la UPV y en el departamento de Química Analítica de la Universitat de València (UV).

Para realizar la caracterización morfológica de las monedas y los productos de corrosión presentes en dichas piezas se ha empleado un microscopio óptico estereoscópico Leica S8APO (10x-80x). Los objetos numismáticos se observaron y fotografiaron digitalmente con una cámara Leica Digital FireWire Camera (DFC), controlada mediante un software Leica Application Suite (LAS). No fue necesaria la toma de muestra, ya que las monedas pudieron ser observadas directamente sin realizar ningún tipo de montaje.

Los experimentos voltamperométricos se realizaron a 298K con un potenciostato $\mathrm{CH} 1660 \mathrm{C}$ (Cambria Scientific, Llwynhendy, Llanelli, Reino Unido) con una celda electroquímica de tres electrodos: electrodo de referencia $\mathrm{Ag} / \mathrm{AgCl}$ (3 $\mathrm{M} \mathrm{NaCl}$ ), electrodo auxiliar de platino y electrodo de trabajo de grafito parafinado comercial de la marca Faber Castell, HB de $2 \mathrm{~mm}$ de diámetro sobre el que se depositaron por abrasión micropartículas de las capas de corrosión de las monedas. Como electrolito se empleó un tampón acético/acetato (Panreac) a 0,25 $\mathrm{M}$ y un $\mathrm{pH}$ de 4,75 sin desoxigenación para así poder emplear las mismas condiciones en el análisis de todas las muestras.

Los espectros de absorción IR fueron obtenidos en modo FTIR-ATR (reflectancia total atenuada) mediante un espectrómetro Vertex70 con un accesorio de reflectancia total atenuada (ATR) MKII Golden Gate. EI sistema de detección utilizado incluye un dispositivo con recubrimiento para estabilización de temperatura FR-DTGS (fast recovery deuterated triglycine sulphate). Las muestras son depositadas en la ventana de análisis pulverizadas y posteriormente se obtienen los espectros de cada una de ellas. Cada espectro se adquirió con un total de 32 scans o barridos y una resolución de $4 \mathrm{~cm}^{-1}$ y se procesaron con el software OPUS/IR 7.2. La toma de muestras se realizó bajo el microscopio óptico, donde se seleccionó la zona más interesante para el análisis, y mediante bisturí se obtuvieron las partículas, del orden de $\mu \mathrm{g}$, que posteriormente se depositaron en la cámara portamuestras del instrumento para proceder a su análisis.

Los análisis realizados mediante microscopía electrónica de barrido de emisión de campo con haz de iones focalizados y microanálisis de rayos $X$ se han llevado a cado con un equipo FESEM-FIB-EDX Zeiss (Orsay Physics Kleindiek Oxford Instruments) modelo AURIGA Compact que dispone de una columna FIB que opera a $30 \mathrm{kV}$ con corrientes de intensidad de $500 \mu \mathrm{A}$ y $20 \mathrm{nA}$, fino y grueso, respectivamente, para generar sendos haces de 
Tabla 1.- Principales características de las monedas analizadas y pertenecientes al Museo Nacional de Arqueología Subacuática

\begin{tabular}{|c|c|c|c|c|c|c|c|c|}
\hline Ref. & Pecio & Emisor & Cronología & Anverso & Reverso & Peso (g) & $\begin{array}{l}\text { Módulo } \\
\text { (mm) }\end{array}$ & Tratada \\
\hline 1 & $\begin{array}{c}\text { Puerto de Mazarrón, } \\
\text { Mazarrón }\end{array}$ & & Desconocida & Frustra & Frustra & 5,86 & 22,45 & \\
\hline 2 & $\begin{array}{c}\text { Puerto de Mazarrón, } \\
\text { Mazarrón }\end{array}$ & & Desconocida & $\begin{array}{c}\text { Cabeza } \\
\text { masculina a } \\
\text { derechas }\end{array}$ & Frustra & 3,91 & 20,13 & $x$ \\
\hline 3 & $\begin{array}{c}\text { Puerto de Mazarrón, } \\
\text { Mazarrón }\end{array}$ & & Desconocida & Frustra & Frustra & 1,77 & 17,38 & $\mathrm{x}$ \\
\hline 4 & $\begin{array}{l}\text { Puerto de Mazarrón, } \\
\text { Mazarrón }\end{array}$ & & Desconocida & Frustra & Frustra & 2,08 & 17,77 & $x$ \\
\hline 5 & $\begin{array}{c}\text { Puerto de Mazarrón, } \\
\text { Mazarrón }\end{array}$ & & Desconocida & Frustra & Frustra & 0,81 & 15,87 & $\mathrm{x}$ \\
\hline 6 & Escombreras, Cartagena & & Desconocida & Frustra & Frustra & 25,25 & 35,95 & \\
\hline 7 & $\begin{array}{l}\text { Puerto de Mazarrón, } \\
\text { Mazarrón }\end{array}$ & & Fenicia & Frustra & Frustra & 14,08 & 27,17 & $\mathrm{x}$ \\
\hline 8 & Escombreras, Cartagena & & 150-101 a.C. & Espiga de trigo & $\begin{array}{l}\text { ILIPENSE } \\
\text { Pez a } \\
\text { derechas } \\
\text { con leyenda } \\
\text { abajo entre } \\
\text { líneas }\end{array}$ & 9,57 & 27,03 & $\mathrm{x}$ \\
\hline 9 & Isla del Fraile, Águilas & & Romana & Frustra & Frustra & 1,44 & 13,26 & $x$ \\
\hline 10 & Isla del Fraile, Águilas & & Romana & Frustra & Frustra & 1,44 & 13,26 & $\mathrm{x}$ \\
\hline 11 & Isla del Fraile, Águilas & & Romana & Frustra & Frustra & 1,02 & 14,14 & $\mathrm{x}$ \\
\hline 12 & Isla del Fraile, Águilas & & Romana & Frustra & Frustra & 1,94 & 13,84 & $x$ \\
\hline 13 & $\begin{array}{l}\text { El Mojón, San Pedro del } \\
\text { Pinatar }\end{array}$ & & $301-400$ & $\begin{array}{l}\text { Cabeza } \\
\text { masculina a } \\
\text { derechas }\end{array}$ & Frustra & 4,16 & 21,71 & $\mathrm{x}$ \\
\hline 14 & $\begin{array}{c}\text { El Mojón, San Pedro del } \\
\text { Pinatar }\end{array}$ & Constancio II & $324-361$ & $\begin{array}{c}\text { D] N } \\
\text { CONST(ANT) } \\
\text { IUS P F AUG } \\
\\
\text { Busto a } \\
\text { derechas con } \\
\text { ínfula }\end{array}$ & $\begin{array}{c}\text { (SPEREI } \\
\text { PVBLI) CE } \\
\text { Alegoría } \\
\text { de pie con } \\
\text { una bola } \\
\text { en la mano } \\
\text { izquierda y } \\
\text { una lanza. }\end{array}$ & 0,87 & 16,10 & $\mathrm{X}$ \\
\hline 15 & La Azohía, Cartagena & Felipe III & 1603 & Frustra & $\begin{array}{l}\text { Resello } \\
\text { redondo con } \\
\text { marca "VIII" }\end{array}$ & 6,14 & 24,50 & $x$ \\
\hline 16 & $\begin{array}{l}\text { Playa de la Isla, } \\
\text { Mazarrón }\end{array}$ & $\begin{array}{l}\text { Gobierno } \\
\text { Provisional }\end{array}$ & $1851-1900$ & $\begin{array}{c}\text { Figura } \\
\text { femenina } \\
\text { sentada dentro } \\
\text { de gráfila de } \\
\text { puntos }\end{array}$ & $\begin{array}{l}\text { León } \\
\text { sosteniendo } \\
\text { escudo sobre } \\
\text { gráfila de } \\
\text { puntos }\end{array}$ & 3,92 & 24,74 & \\
\hline
\end{tabular}




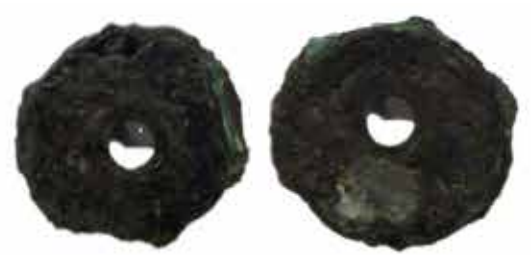

A)
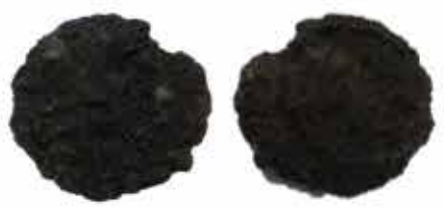

D)
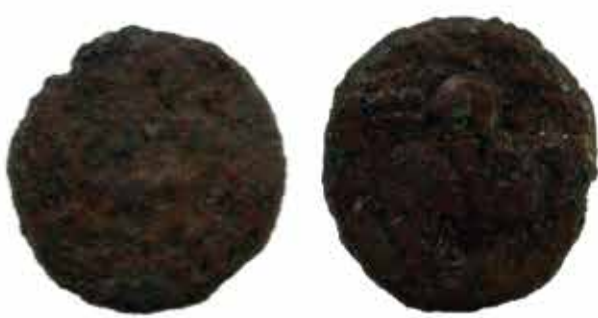

G)

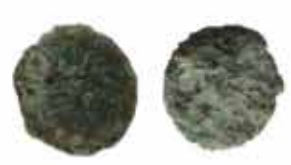

J)
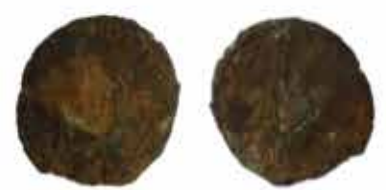

N)

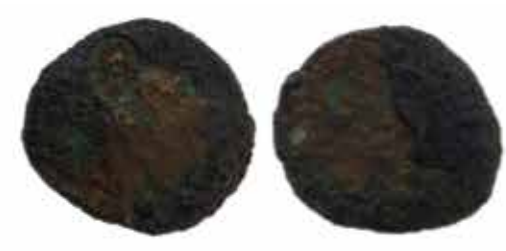

B)

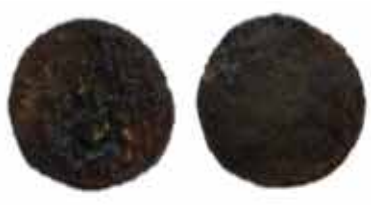

C)
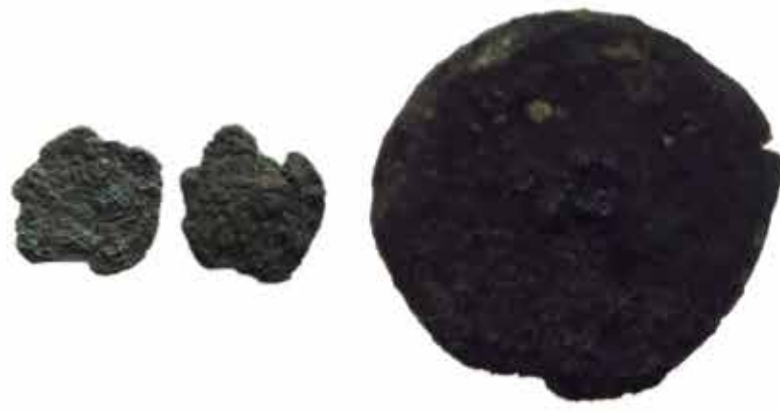

E)

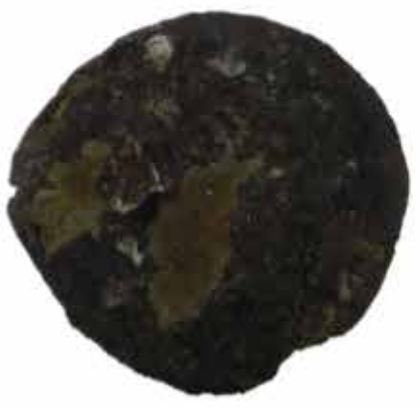

F)

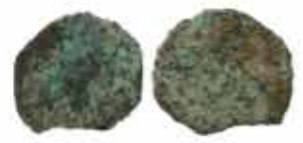

H)

I)

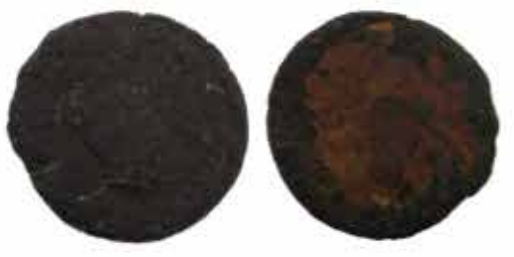

L)

M)

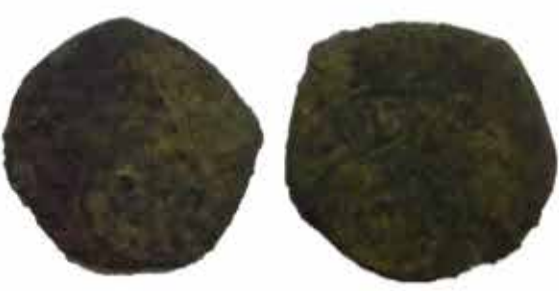

N)

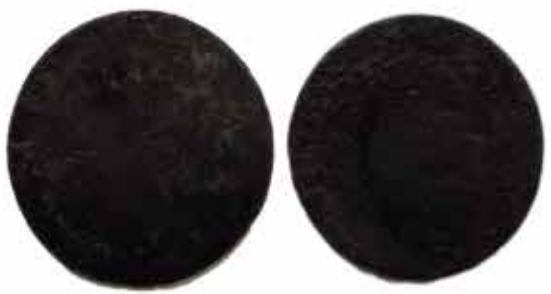

O) 
iones $\mathrm{Ga}^{+}$. Las imágenes en electrones secundarios se han obtenido aplicando un voltaje de $3 \mathrm{kV}$ en la fuente de electrones. Los elementos presentes en las muestras se han obtenido mediante un sistema EDX Oxford-X Max controlado por un software Aztec, operando a $20 \mathrm{kV}$ y con el detector situado a 6-7 $\mathrm{mm}$ de la superficie de la muestra y con el diámetro mínimo del haz, $<5 \mathrm{~nm}$ a $30 \mathrm{kV}$. Las piezas numismáticas fueron insertadas directamente en la cámara de alto vacío del microscopio sin necesidad de ningún tipo de preparación, ya que al ser metálicas poseen una buena conductividad eléctrica y no se producen efectos de acumulación de carga. El montaje de la moneda en el portamuestras se realiza con cinta de carbono de doble cara, asegurándose de que una vez insertadas en la cámara de vacío cuando se realizan los movimientos en las direcciones " $x$ ", " $y$ " $y$ " $z$ ", no se produzcan movimientos de la pieza.

\section{Resultados y discusión}

\section{-Caracterización micromorfológica}

\section{Microscopía óptica}

Con las microfotografías obtenidas a partir del microscopio óptico se ha podido hacer una aproximación visual y preliminar de los elementos que componen la capa más superficial de las monedas. En ellas se pueden observar tanto depósitos exógenos adheridos como los productos de corrosión característicos de las aleaciones empleadas para la realización de los cospeles que posteriormente fueron acuñados, que, en este caso, todas fueron realizadas en aleaciones de base cobre. El examen microscópico permite conocer, de manera no invasiva, la morfología microcristalina que presentan las capas más superficiales de las monedas y sus productos de corrosión.

\section{-Óxidos de cobre}

Los óxidos de cobre son productos de corrosión que se encuentran con frecuencia en los objetos metálicos fabricados con cobre y suelen formar pátinas estables y protectoras. Los más comunes son la cuprita y la tenorita. La cuprita $\left(\mathrm{Cu}_{2} \mathrm{O}\right)$ es un óxido cuproso (I) de color rojo, rojo-anaranjado e incluso morado, ya que varía de color en función de las impurezas y el tamaño de las partículas que la componen. Normalmente conforma la primera capa o capa más interna de corrosión (Díaz Martínez y García Alonso, 2011: 14-17; Scott, 1997; 2002). En las monedas 2, $3,7,13$ y 14 se puede observar el óxido cuproso, aunque es principalmente en la moneda 13 [figura 2A] donde se puede apreciar una mayor concentración de esta pátina de color rojizo. La tenorita (CuO) es un óxido cúprico (II) de color negro. Su formación se inicia a partir de la cuprita en un proceso secundario (Díaz Martínez y García Alonso, 2011: 17; Scott, 1997; 2002). La mayoría de las monedas estudiadas presentan esta pátina, pero es en la moneda 8 [figura 2B] donde mejor se puede apreciar y diferenciar.
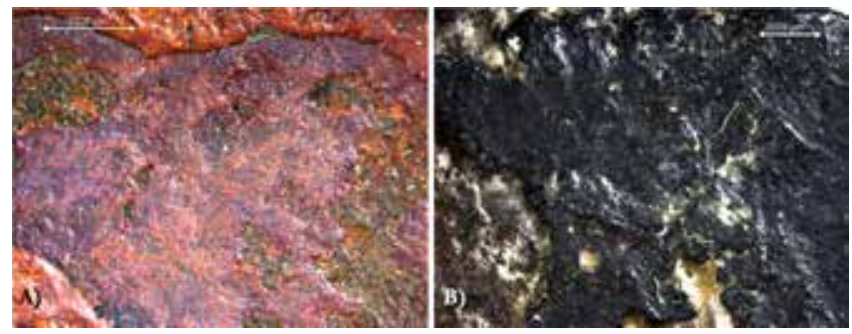

Figura 2.- Microfotografías del anverso de las monedas A) 13 (X16) y B) 8 (X10).

\section{-Cloruros e hidroxicloruros de cobre}

Los cloruros e hidroxicloruros de cobre son productos de corrosión muy inestables y suponen uno de los mayores problemas para la estabilidad de las piezas. Tienen un color verde variable y no es posible realizar una diferenciación entre ellos, a no ser que se recurra a técnicas analíticas más avanzadas, ya que muchos de ellos como los trihidroxicloruros de cobre atacamita, paratacamita o clinoatacamita, son minerales polimorfos que comparten fórmula química (Díaz Martínez y García Alonso, 2011: 24-25; Scott, 2000; 2002). En la figura 3 se pueden apreciar dos microfotografías donde están presentes estos productos de corrosión correspondientes a las monedas 3 [figura 3.A] y 9 [figura 3.B], aunque se han podido identificar en la mayoría de las monedas salvo en las piezas 8, 13 y 16 (está última intervenida según la documentación del Museo mediante electrólisis y sesquicarbonato de sodio, lo que podría explicar el por qué no se han encontrado cloruros).

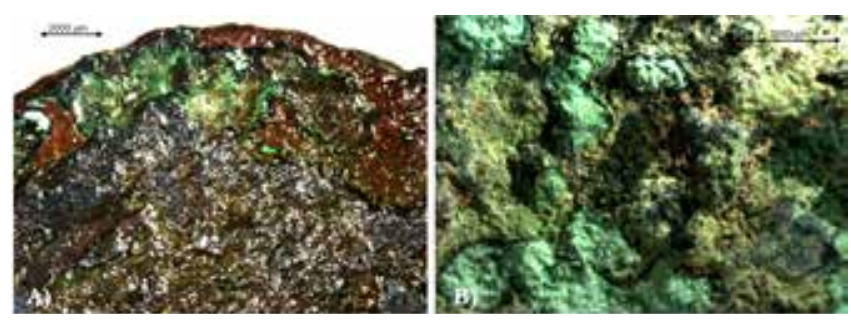

Figura 3.- Microfotografías del anverso de las monedas A) 3 (X10) y B) 9 (X16).

\section{-Elementos exógenos}

Además de los productos de corrosión procedentes de la alteración de la aleación de cobre con la que fueron fabricadas las monedas, la microscopía óptica permite reconocer distintos materiales exógenos que se han depositado o adherido a la superficie original de las piezas. En la microfotografía correspondiente a la moneda 12 [figura 4A] se pueden observar depósitos de materia de color marrón que podrían asociarse a minerales silíceos y arcillosos procedentes del lecho marino donde la moneda 
estuvo hasta que se recuperó y que posteriormente han sido caracterizados gracias a la espectroscopia FTIR (monedas 1 y 6-16). En las fotografías también se pueden apreciar las evidencias que han dejado los diferentes tratamientos aplicados en las monedas, como sucede en la fotografía de la moneda 16 [figura 4B], donde se observa cómo toda la superficie de la moneda se encuentra recubierta de una película de naturaleza orgánica y aspecto translúcido brillante.

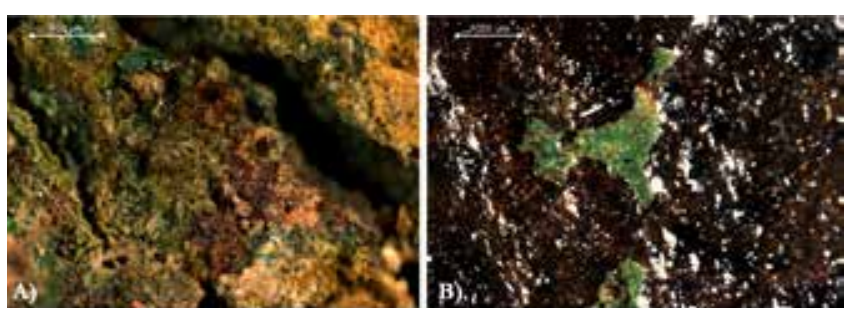

Figura 4.- Microfotografías del anverso de las monedas A) 12 (X50) y B) 16 (X25).

\section{-Identificación de productos de corrosión y consolidantes utilizados en intervenciones previas}

\section{VIMP}

Gracias a los análisis realizados mediante VIMP se ha podido identificar la presencia de cuprita, tenorita, atacamita, sales de $\mathrm{Pb}, \mathrm{HgS}$ y $\mathrm{CdS}$.

En la figura 5 se pueden observar, a título de ejemplo, diferentes voltamperogramas obtenidos para las muestras de las monedas analizadas. En la figura 5.A, se muestra el voltamperograma correspondiente a la moneda 1, se puede distinguir un pico catódico a - $-0,25 \mathrm{~V}$, que puede atribuirse a la reducción de atacamita a cobre metálico. La intensa señal catódica a $-0,95 \mathrm{~V}$ corresponde a la reducción de tenorita a cobre metálico, que acompaña a la reducción de cuprita. Esta señal conjunta aparece en las monedas 1-5, 7, 9-12 y 15, lo que indica que en estas piezas se pueden encontrar los dos óxidos de cobre,
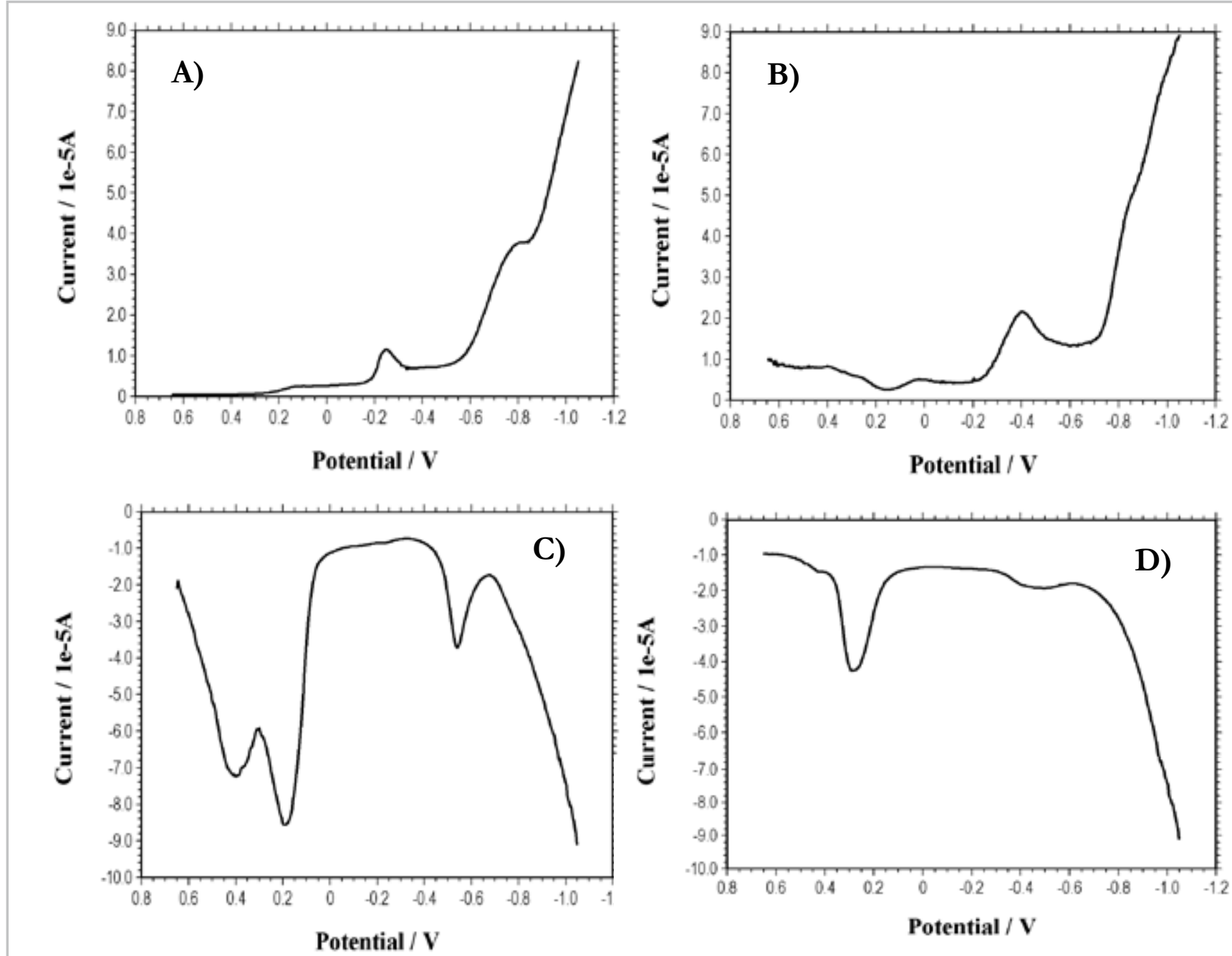

Figura 5.- Voltamperogramas de onda cuadrada de las muestras tomadas en las monedas del Museo Nacional de Arqueología Subacuática: A) 1; B y C) 8 y D) 4 
mientras que en las monedas 6, 8, 13 y 14 únicamente se puede observar la señal de cuprita a $0,10 \mathrm{~V}$. Por último, también es destacable que en alguna de las piezas se han podido encontrar peculiaridades, como en la moneda 8 [figura 5.B y 5.C], donde se analizó una región de color amarillo y cuyos voltamperogramas muestran un perfil catódico con la señal de atacamita a -0,25V acompañada de un pico más elevado a $-0,35 \mathrm{~V}$ y aparecen picos anódicos intensos a -0,35 y -0,20V, que podría asociarse a sulfuro de cadmio (SCd) (Ortiz-Miranda et al., 2016), o en la moneda 4 [figura 5.D], donde las señales anódicas a 0,20V y 0,45V apuntan a la presencia de sulfuro de mercurio ( $\mathrm{HgS})$ (Doménech-Carbó et al., 2012). Estos depósitos exógenos poco comunes pueden estar asociados a la intensa actividad minera de la zona costera donde se encuentran los pecios donde fueron halladas las monedas.

\section{Espectroscopia FTIR}

La tabla 2 resume el conjunto de compuestos identificados mediante espectroscopia FTIR en la colección de monedas procedente del Museo Nacional de Arqueología Subacuática.

Dentro de los compuestos inorgánicos se han podido reconocer tres tipos de carbonatos, dos carbonatos de calcio, y un carbonato de plomo. Los carbonatos de calcio identificados han sido el aragonito y la calcita (Gunasekaran et al., 2006. Estos dos compuestos comparten la misma fórmula química $\mathrm{CaCO}_{3^{\prime}}$ pero se pueden diferenciar debido a que el sistema en el que cristalizan es diferente (el aragonito en el sistema ortorrómbico y la calcita en el sistema hexagonal (Hurlbut y Klein, 1992: 316) y a que las bandas IR que emiten también son diferentes, gracias a lo cual es posible su discriminación mediante FTIR. La calcita se encuentra en la naturaleza con mayor facilidad, puede encontrarse en rocas calizas, en margas o areniscas y formarse por la evaporación de aguas calcáreas (Hurlbut y Klein, 1992: 319), por eso es común que en las muestras analizadas se hayan podido formar depósitos de este compuesto. Por otro lado, el aragonito es mucho menos corriente que la calcita y menos estable (Hurlbut y Klein, 1992: 325). Su formación se produce en condiciones físico-químicas muy determinadas: en entornos marinos cálidos con temperaturas medias por encima de $6 \pm 3^{\circ} \mathrm{C}$ y condiciones adecuadas de salinidad donde puede verse favorecida la formación de aragonito biológico y abiológico frente a la formación de calcita (Sánchez-Beristain et al., 2016), por ejemplo, las conchas de los organismos marinos están compuestas de aragonito. El último carbonato identificado es un carbonato de plomo, la hidrocerusita $\left(2 \mathrm{PbCO}_{3} \cdot \mathrm{Pb}(\mathrm{OH})_{2}\right)$, concretamente en las muestras extraídas de las monedas 1 y 5, ambas halladas en el pecio de Puerto de Mazarrón, Murcia. Esto indica que, posiblemente, la aleación empleada para la fabricación de estas dos monedas contuviera, en mayor o menor proporción, plomo. Otros de los compuestos inorgánicos identificados en muchas de las muestras son los minerales silíceos y arcillosos los cuales es posible que procedan del lecho marino donde han estado depositadas las piezas hasta su recuperación. Los trihidroxicloruros de cobre como la atacamita y la clinoatacamita $\left(\mathrm{Cu}_{2} \mathrm{Cl}(\mathrm{OH})_{3}\right)$ son los productos de corrosión de cobre que con mayor frecuencia aparecen en los análisis de las muestras. Ambos comparten la misma formula química, pero es posible diferenciarlos tanto por el sistema en el que cristalizan, la atacamita en el sistema ortorrómbico y la clinoatacamita en el sistema monoclínico (Scott, 2000: 41; Scott, 2002: 124), como por la posición de las bandas IR, aunque es muy común que ambos compuestos coexistan y se encuentren los dos en una misma muestra. El último compuesto identificado del grupo de los inorgánicos es la whewellita, un oxalato de calcio monohidrato $\left(\mathrm{CaC}_{2} \mathrm{O}_{4} \cdot \mathrm{H}_{2} \mathrm{O}\right)$ formado debido a la degradación de la materia orgánica presente en la superficie de la moneda (Salvadó et al., 2009) o procesos biogenéticos propios del medio subacuático (Carati et al., 2003; Toffolo et al., 2019).

Los compuestos orgánicos identificados se pueden dividir en dos grupos: a) la materia orgánica que se depositó en la superficie de la moneda de manera natural y debido al uso que se ha realizado de las piezas cuando estuvieron en circulación y b) los productos relacionados con las intervenciones conservativo-restaurativas realizados en las monedas. Dentro del primer grupo se pueden incluir los complejos metálicos de tipo carboxilatos de $\mathrm{Pb}$ y $\mathrm{Cu}$, identificados en las monedas 1-6, 8 y 10, los cuales han podido formarse al combinarse los iones $\mathrm{Cu}(\mathrm{II})$ o $\mathrm{Pb}$ (II) liberados durante los procesos de corrosión electroquímica de la moneda y los ácidos grasos de cadena larga liberados mediante procesos hidrolíticos a partir de la película lipídica formada en la superficie de la moneda mientras estuvo en circulación. El segundo grupo lo constituyen la cera microcristalina y la resina acrílica, posiblemente Paraloid B72 ${ }^{\circ}$ (Derrick et al., 1999), procedentes de los procesos de conservación-restauración sufridos por las monedas, ya que estos productos son empleados con frecuencia en tratamientos de protección de objetos de cobre y bronce (Balbo et al., 2012; Álvarez Romero, 2013, 2014 y 2015). Como es posible observar en la tabla 3 en las monedas 1-6, $8,10,13$ y 16 se han identificado estos productos, por lo que, aunque en las fichas DOMUS únicamente conste que tres de las piezas de la colección han sido intervenidas, gracias a los análisis realizados se ha podido determinar que más monedas de las indicadas han sido tratadas. Por último, se ha podido determinar la presencia de materia lipídica (1, $5,13,15$ y 16) y materia orgánica inespecífica (monedas 7 , $9,10,14$ y 15), las cuales podrían estar relacionadas, bien con estos tratamientos o bien con la manipulación de las monedas realizada durante su vida útil o una vez que han sido recuperadas.

La tabla 3 resume los compuestos inorgánicos y orgánicos identificados en cada una de las muestras analizadas de la colección numismática. Además, se ha procedido a realizar una aproximación semicuantitativa en función de la intensidad de las bandas que presentaba cada uno de los compuestos identificados en los espectros. 
Tabla 2.- Compuestos con las correspondientes bandas IR y su asignación identificados en las monedas de la colección del Museo Nacional de Arqueología Subacuática

\begin{tabular}{|c|c|c|}
\hline Compuesto & Posición de la banda $\left(\mathrm{cm}^{-1}\right)$ & Asignación \\
\hline \multirow{3}{*}{$\begin{array}{l}\text { ARAGONITO } \\
\qquad\left(\mathrm{CaCO}_{3}\right)\end{array}$} & 1473 & Tensión $v_{3}$ \\
\hline & 858,843 & Tensión $\boldsymbol{v}_{2}$ \\
\hline & 712,700 & Tensión $v_{4}$ \\
\hline \multirow{3}{*}{$\begin{array}{l}\text { CALCITA } \\
\left(\mathrm{CaCO}_{3}\right)\end{array}$} & 1422 & Tensión $v_{3}$ \\
\hline & 876,848 & Tensión $v_{2}$ \\
\hline & 712 & Tensión $v_{4}$ \\
\hline \multirow{4}{*}{$\begin{array}{l}\text { HIDROCERUSITA } \\
\left(2 \mathrm{PbCO}_{3} \cdot \mathrm{Pb}(\mathrm{OH})_{2}\right)\end{array}$} & 3510,3402 & Tensión $\mathrm{OH}$ \\
\hline & 1400 & Tensión $v_{3}$ \\
\hline & 1043 & Tensión $v_{1}$ \\
\hline & 682 & Tensión $v_{4}$ \\
\hline \multirow{3}{*}{$\begin{array}{l}\text { MINERALES SILÍCEOS Y } \\
\text { ARCILLOSOS }\end{array}$} & 3694,3621 & Tensión $\mathrm{OH}$ \\
\hline & $1129,1020,1005,911$ & Tensión $\mathrm{SiO}$ grupo $\mathrm{SiO}_{4}$ \\
\hline & 793,753 & Doblete ot $z$ \\
\hline $\begin{array}{c}\text { CUPRITA }\left(\mathrm{Cu}_{2} \mathrm{O}\right) \\
\text { TENORITA }(\mathrm{CuO})\end{array}$ & $650-500$ & Tensión \\
\hline \multirow{2}{*}{$\begin{array}{c}\text { ATACAMITA } \\
\left(\mathrm{Cu} \mathbf{u}_{2} \mathrm{Cl}(\mathrm{OH})_{3}\right) \\
\end{array}$} & $3438,3357,3330$ & Tensión $\mathrm{OH}$ \\
\hline & $950,890,845$ & Deformación $\mathrm{OH}$ \\
\hline \multirow{2}{*}{$\begin{array}{l}\text { CLINOATACAMITA } \\
\left(\mathrm{Cu}_{2} \mathrm{Cl}(\mathrm{OH})_{3}\right)\end{array}$} & $3444,3359,3310$ & Tensión $\mathrm{OH}$ \\
\hline & $921,904,891,863,827$ & Deformación $\mathrm{OH}$ \\
\hline \multirow{2}{*}{$\begin{array}{l}\text { WHEWELLITA } \\
\left(\mathrm{CaC}_{2} \mathrm{O}_{4} \cdot \mathrm{H}_{2} \mathrm{O}\right)\end{array}$} & 1643 & $\begin{array}{c}\text { Tensión asimétrica - } \\
\mathrm{COO}\end{array}$ \\
\hline & 1322 & $\begin{array}{c}\text { Tensión simétrica - } \\
\mathrm{COO}\end{array}$ \\
\hline \multirow{5}{*}{ CARBOXILATOS Pb } & $2955,2919,2849$ & $\begin{array}{l}\text { Tensión CH grupos } \\
\text { metilenos y metilos }\end{array}$ \\
\hline & 1540,1513 & $\begin{array}{c}\text { Tensión asimétrica } \\
\mathrm{COO}^{-}\end{array}$ \\
\hline & 1472,1462 & Flexión $\mathrm{CH}_{2}$ \\
\hline & 1419 & $\begin{array}{c}\text { Tensión simétrica } \\
\mathrm{COO}^{-}\end{array}$ \\
\hline & $1350-1180$ & Deformación $\mathrm{CH}_{2}$ \\
\hline \multirow{3}{*}{ CARBOXILATOS Cu } & 1585 & $\begin{array}{c}\text { Tensión asimétrica } \\
\mathrm{COO}^{-}\end{array}$ \\
\hline & 1411 & $\begin{array}{c}\text { Tensión simétrica } \\
\mathrm{COO}^{-}\end{array}$ \\
\hline & 1470 & Deformación $\mathrm{CH}_{2}$ \\
\hline \multirow{2}{*}{$\begin{array}{l}\text { MATERIA ORGÁNICA } \\
\text { INESPECÍFICA }\end{array}$} & $2950-20$ & $\begin{array}{c}\text { Tensión asimétrica } \mathrm{CH}_{2} \\
\mathrm{y} \mathrm{CH} \mathrm{H}_{3}\end{array}$ \\
\hline & $2855-35$ & $\begin{array}{l}\text { Tensión simétrica } \mathrm{CH}_{2} \mathrm{y} \\
\mathrm{CH}_{3}\end{array}$ \\
\hline \multirow{3}{*}{ CERA MICROCRIS'TALINA } & $2951,2915,2845$ & Tensión C-H \\
\hline & $1471,1462,1372$ & Flexión C-H \\
\hline & 728,719 & Torsión C-H \\
\hline \multirow{5}{*}{ MATERIA LIPÍDICA } & $2948,2920,2850$ & Tensión C-H \\
\hline & 1738,1704 & Tensión $C=0$ \\
\hline & $1472,1468,1379$ & Flexión C-H \\
\hline & 1178 & Tensión $\mathrm{C}-\mathrm{O}$ \\
\hline & 736,727 & Torsión C-H \\
\hline \multirow{4}{*}{ RESINA ACRÍLICA } & $2964,2929,2829$ & Tensión C-H \\
\hline & 1716 & Tensión $C=0$ \\
\hline & $1465,1440,1380,1359$ & Flexión C-H \\
\hline & $\begin{array}{c}1247,1228,1151,1130,1022, \\
963\end{array}$ & Tensión C-O \\
\hline
\end{tabular}


Tabla 3.- Compuestos identificados en las muestras analizadas y clasificación semicuantitativa de cada uno de ellos mediante la leyenda: $\mathrm{x}$ bandas débiles, $\mathrm{xx}$ bandas moderadas y $\mathrm{xxx}$ bandas muy intensas

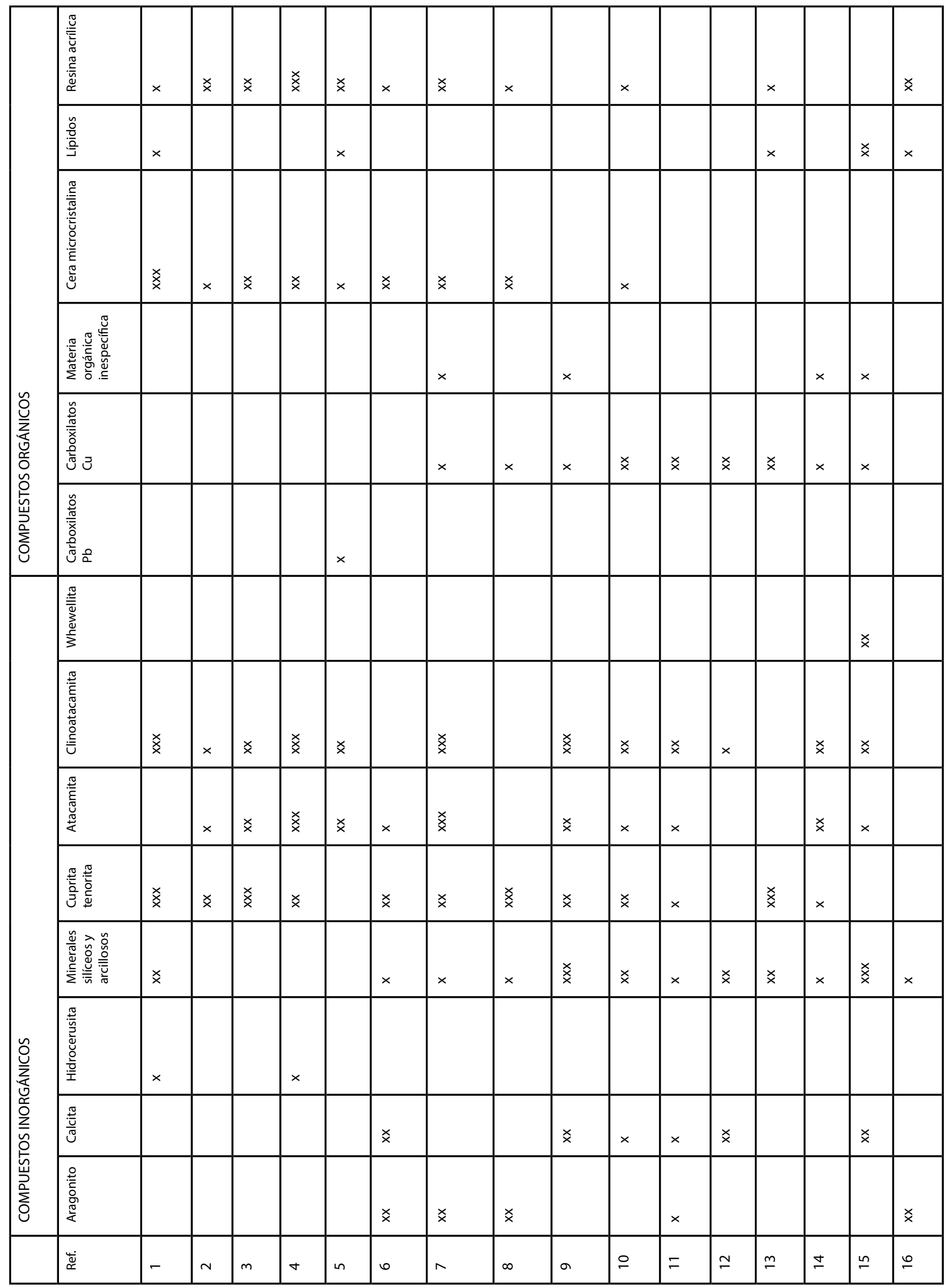




\section{FESEM-EDX}

Debido al delicado estado de conservación de la mayoría de las monedas que conforman la colección, únicamente se pudieron analizar mediante FIB-FESEM-EDX las dos monedas que presentaban un buen estado de conservación y una gran cohesión. En el resto de las monedas se desestimó este análisis ya que las muestras han de ser adheridas al portamuestras mediante cinta adhesiva que podría producir su fragmentación dada su fragilidad.

En la figura 6.A se puede observar la trinchera realizada en la moneda 7 . Se puede apreciar una capa superficial de unos $2 \mu \mathrm{m}$ de espesor correspondiente a la película protectora aplicada durante los tratamientos conservativosrestaurativos que se habrían realizado en la pieza tras su hallazgo. Esta película se ha caracterizado como una resina acrílica mediante los análisis de FTIR que recubre toda la moneda. El microanálisis de rayos $X$ ha permitido detectar $\mathrm{C}, \mathrm{O}$, Sn y $\mathrm{Pb}$ en esta capa acrílica. La presencia de $\mathrm{Sn}$ y $\mathrm{Pb}$ en esta zona se asocia a una migración de estos elementos hacia el exterior con posible formación de complejos metálicos carboxilados. Por debajo de esta primera capa, y con un espesor de unos $4 \mu \mathrm{m}$, es apreciable la capa de corrosión, donde se pueden observar microporos, microfisuras y zonas donde se ha producido la infiltración del material sintético empleado para actuar de capa protectora y consolidante. En esta zona se han identificado elementos exógenos a la moneda como $\mathrm{C}, \mathrm{O}, \mathrm{Si}, \mathrm{P}$ y $\mathrm{Cl}$. El núcleo metálico de la moneda es inapreciable, por lo que se puede deducir que se encontraría a más profundidad que la que posee la trinchera realizada, aunque si es posible deducir que esta moneda se realizó con una aleación de $\mathrm{Cu}$, $\mathrm{Sn}$ y Pb, ya que son los elementos identificados en la capa de corrosión accesible con la trinchera.

La figura 6.B muestra la trinchera realizada en la moneda 15. Como se puede observar en la imagen la muestra presenta una capa superficial que correspondería a la capa corrosión, en la que mediante EDX se ha identificado $\mathrm{C}, \mathrm{O}, \mathrm{Mg}, \mathrm{Al}, \mathrm{Si}, \mathrm{P}$, $\mathrm{Cl}, \mathrm{K}$, Ca y Fe. Son perceptibles, a unos $2 \mu \mathrm{m}$ de profundidad, numerosas microfisuras, por donde han podido penetrar elementos químicos exógenos a la moneda hacia el interior. El núcleo metálico de la pieza no es perceptible, ya que se encontraría a mayor profundidad de la obtenida con la trinchera. Debido a la condición de bien cultural del objeto no ha sido posible profundizar más, pero en la zona más profunda de la trinchera únicamente se ha podido identificar $\mathrm{Cu}$, por lo que esta moneda se habría fabricado en este metal principalmente.

\section{Conclusiones}

La aproximación multitécnica puesta a punto permite realizar estudios exhaustivos de colecciones numismáticas y conocer diferentes aspectos de su naturaleza y de la historia corrosiva, deposicional y conservativa-restaurativa que han sufrido las piezas de un modo micro y nanoinvasivo.

Gracias a los resultados obtenidos se ha podido realizar una aproximación a la composición de la capa más superficial de monedas de procedencia subacuática. Se han podido identificar tanto compuestos inorgánicos y orgánicos de naturaleza endógena y exógena, como pueden ser los productos de corrosión del cobre, los carbonatos de calcio, la materia lipídica depositada cuando la moneda estuvo en circulación o la resina acrílica y las ceras utilizadas en intervenciones de conservación-restauración anteriores. Además, se ha podido establecer que muchas de las monedas de las cuales no había documentación sobre los tratamientos recibidos en el Museo han sido intervenidas ya que muestran bandas características de los productos empleados para estos fines. Esto será de gran utilidad para establecer el tratamiento de conservación más adecuado en el futuro.

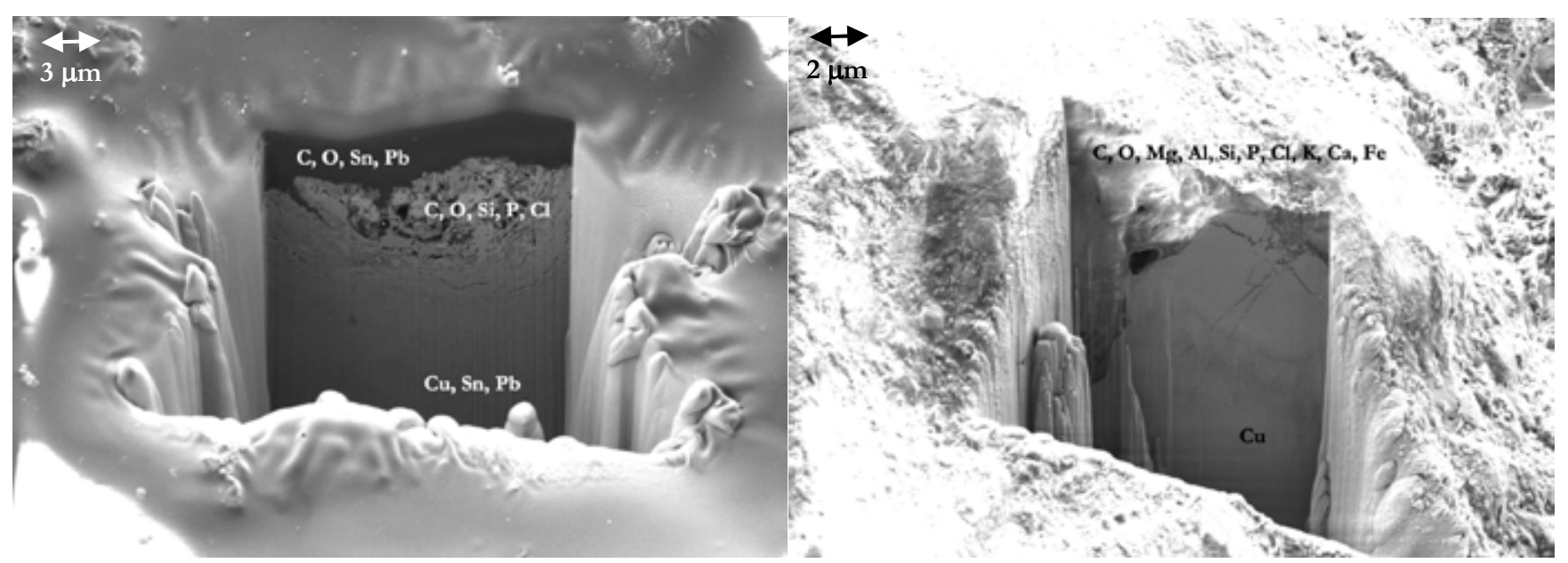

Figura 6.- . Imágenes obtenidas mediante FIB-FESEM de las microtrincheras realizadas en las monedas A) 7 y B) 15 . Puede apreciarse la diferencia textural en las capas más externas de las trincheras donde se observan productos de corrosión y productos de intervenciones previas y el facetado del metal de la región más profunda. 


\section{Agradecimientos}

La presente investigación está financiada con los proyectos I+D: CTQ2017-85317-C2-1-P y CTQ2014-53736-C3 cofinanciado por el Ministerio de Ciencia, Innovación y Universidades, el Fondo Europeo de Desarrollo Regional (ERDF) y la Agencia Estatal de Investigación (AEI). Los autores agradecen al Museo Nacional de Arqueología Subacuática, a la Dirección General de Bienes Culturales de la Comunidad Autónoma de la Región de Murcia y la colaboración de Manuel Planes, José Luis Moya y Alicia Nuez, técnicos del Servicio de Microscopía Electrónica de la Universitat Politècnica de València.

\section{Bibliografía}

AITKEN, M. J. (1961): Physics and Archaeology. New York, Interscience.

AITKEN, M. J. (1970): "Publication of Archaeometry", Antiquity, 44, 173: 60.

ÁLVAREZ ROMERO, C. (2013, 2014 Y 2015): “La conservación de objetos metálicos", Arché: Publicación del Instituto Universitario de Restauración del Patrimonio de la UPV, 8, 9 y 10: 219-232.

ÁLVAREZ ROMERO, C; DOMÉNECH CARBÓ, M.T., MARTÍNEZ BAZÁN, M.L.; PASÍES OVIEDO, T.; BUENDÍA ORTUÑO, M.; DOMÉNECH CARBÓ, A. (2016): "Aportación de las técnicas de microscopía electrónica y nanoelectroquímicas al estudio histórico de una colección numismática" en Emerge 2016. Jornadas de Investigación Emergente en Conservación y Restauración de Patrimonio, 157-164.

ÁLVAREZ-ROMERO, C; DOMÉNECH CARBÓ, M.T. (2016 y 2017): "Aplicación de la técnica de microscopía electrónica de barrido de emisión de campo con haz de iones focalizados-microanálisis de rayos $\mathrm{X}$ a colecciones numismáticas", Arché. Publicación del Instituto Universitario de Restauración del Patrimonio de la UPV, 11 y 12: 65-70.

ÁLVAREZ ROMERO, C.; DOMÉNECH CARBÓ, A.; DOMÉNECH CARBÓ, M.T.; PASÍES OVIEDO, T.; BUENDÍAORTUÑO, M. (2017): “Estudio arqueométrico de maravedís de Felipe IV (1660-1664)", Sagvntvm, Papeles del Laboratorio de Arqueología de Valencia, 49: 235-239.

BALBO, A.; CHIAVARI, C.; MARTINI, C.; MONTICELLI, C. (2012): "Effectiveness of corrosion inhibitor films for the conservation of bronzes and gilded bronzes", Corrosion Science, 59: 204-212.

CARIATI, F.; RAMPAZZI, L.; TONIOLO, L.; POZZI, A. (2003): “Calcium oxalate films on Stone surfaces: experimental assessment of the chemical formation" Studies in Conservation, 45: 180-188.

DE TAGLE, A. (2008): "El papel de las ciencias en la preservación del patrimonio cultural. La situación de Europa" Bienes culturales: revista del Instituto del Patrimonio Histórico Español, 8: 27-36.

DERRICK, M.R.; STULIK, D.C.; LANDRY, J.M. (1999): Infrared Spectroscopy in Conservation Science. Los Angeles: The Getty Conservation
DÍAZ MARTÍNEZ, S.; GARCÍA ALONSO, E. (2011): Técnicas metodológicas aplicadas a la conservación-restauración del patrimonio metálico. Ministerio de Cultura, Madrid.

DILLMANN, P.; WATKINSON, D.; ANGELINI, E.; ADRIAENS, A. (Eds.) (2013): Corrosion and Conservation of Cultural Heritage Metallic Artefacts. European Federation of Corrosion Publications, Cambridge, England.

DOMÉNECH-CARBÓ, A.; DOMÉNECH-CARBÓ, M.T.; COSTA, V. (2009): Electrochemical methods in archaeometry, conservation and restauration, in Scholz, F. (Ed.) Monographs in electrochemistry. Springer, Berlin.

DOMÉNECH CARBÓ, M.T.; VÁZQUEZ DE AGREDOS-PASCUAL, M.L.; OSETE-CORTINA, L.; DOMÉNECH-CARBÓ, A.; GUASCH-FERRE, N.; MANZANILLA, L.R.; VIDAL-LORENZO, C. (2012): “Characterization of prehispanic cosmetics found in a burial of the ancient city of Teotihuacan (Mexico)", Journal of Archaeological Science, 39: 10431062.

DOMÉNECH-CARBÓ, A. (2015): "Aportaciones recientes de la Voltamperometría de micropartículas a la conservación y restauración de bienes culturales" en Proceedings of the Second European Conference on electrochemical methods applied to the conservation of artworks, Doménech-Carbó, A; Doménech-Carbó, M.T. (Eds.). Universitat Politècnica de València, Valencia.

DOMÉNECH-CARBÓ, M.T.; OSETE-CORTINA, L. (2016): "Another beauty of analytical chemistry: chemical analysis of inorganic pigments of art and archaeological objects" ChemTexts, 2: 14.

DOMÉNECH-CARBÓ, A.; DOMÉNECH-CARBÓ, M. T.; ÁLVAREZROMERO, C.; MONTOYA, N.; PASÍES-OVIEDO, T.; BUENDÍA-ORTUÑO, M. (2017): "Electrochemical characterization of coinage techniques the 17th century: The maravedís case", Electroanalysis, 29: 20082018.

DOMÉNECH-CARBÓ, M.T.; ÁLVAREZ-ROMERO, C.; DOMÉNECHCARBÓ, A.; OSETE-CORTINA, L.; MARTÍNEZ-BAZÁN, M.L. (2019): "Microchemical Surface analysis of historic copper-based coins by the combined use of FIB-FESEM-EDX, OM, FTIR spectroscopy and solid-state electrochemical techniques" Microchemical Journal, 148: 573-581.

GARCÍA RODRIGUEZ, M.A.; CHÉRCOLES ASENSIO, R.; SANZ RODRÍGUEZ, E. (2010): “Métodos analíticos desarrollados en el IPCE para el estudio de bienes culturales basados en la Espectroscopia Infrarroja por Transformada de Fourier y Técnicas Cromatográficas" en del Egido, M.; Juanes, D. (Coords.) (2010): La Ciencia y el Arte II. Ciencias experimentales y conservación del Patrimonio Histórico. Ministerio de Cultura, Madrid.

GUNASEKARAN, S.; ANBALAGAN, G.; PANDI, S. (2006): "Raman and infrared spectra of carbonates of calcite structure", Journal of Raman Spectroscopy, 37: 892-899.

HURLBUT, C.S.; KLEIN, C. (1992): Manual de mineralogía de Dana. Barcelona: Editorial Reverté, S.A. 
ORTIZ-MIRANDA, A.S.; DOMÉNECH-CARBÓ, A.; DOMÉNECHCARBÓ, M.T.; OSETE-CORTINA, L.; VALLE-ALGARRA, F.M.; BOLÍVARGALIANO, F.; MARTÍN-SÁNCHEZ, I.; LÓPEZ-MIRAS, M.M. (2016): "Electrochemical characterization of biodeterioration of paint films containing cadmium yellow pigment", Journal of Solid State Electrochemistry, 20: 3287-3302.

PROUS, S.; DEL EGIDO, M. (2008): La Ciencia y el Arte. Ciencias experimentales y conservación del Patrimonio Histórico. Instituto del Patrimonio Histórico Español, Ministerio de Cultura, España.

SALVADÓ, N.; BUTÍ, S.; NICHOLSON, J.; EMERICH, H.; LABRADOR, A.; PRADELL, T. (2009): "Identification of reaction compounds in micrometric layers from gothic paintings using combined SR-XRD and SR-FTIR", Talanta, 79: 419-428.

SÁNCHEZ-BERISTAIN， F.; GARCÍA-BERRERA， P.; CALVILLOCANADELL, L. (2016): "Mares calcíticos y aragoníticos: efectos en organismos formadores de arrecifes a través del tiempo", TIP Revista Especializada en Ciencias Químico-Biológicas, 19, 1: 45-53.

SCOTT, D.A. (1997): "Copper compounds in metals and colorants: Oxides and hydroxides" in Studies in Conservation, 42, 2: 93-100.

SCOTT, D.A. (2000):"A review of copper chlorides and related salts in bronze corrosion and painting pigments", Studies of Conservation, 45: 39-53.

SCOTT, D.A. (2002): Copper and Bronze in Art. Corrosion, colorants, conservation. Los Angeles, California: Getty Publications.

TOFFOLO, M.B.; REGEV, L.; DUBERNET, S.; LEFRAIS, Y.; BOARETTO, E. (2019): "FTIR-Based Crystallinity Assessment of Aragonite-Calcite Mixtures in Archaeological Lime Binders Altered by Diagenesis", Minerals, 9, 121.

\section{Autor/es}

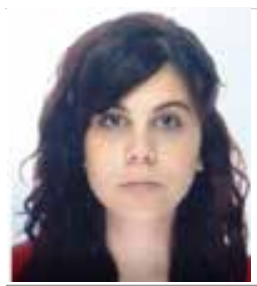

\section{Carla Álvarez Romero}

carla.alvarez.romero@gmail.com Instituto de Restauración del Patrimonio, Universitat Politècnica de València

Licenciada en Historia con la intensificación en Arqueología y Prehistoria por la Universidad Autónoma de Madrid en 2012. En 2014 acaba sus estudios de postgrado realizando el Máster de Conservación y Restauración de Bienes Culturales en la Universitat Politècnica de València (UPV) y desde 2015 se encuentra realizando el Doctorado, inscrito en el programa de Conservación y Restauración de Bienes Culturales de la UPV con un contrato predoctoral para la formación de doctores del Ministerio de Economía y Competitividad. Sus investigaciones están centradas en el estudio arqueométrico y ciencia de la conservación de objetos arqueológicos, colaborando con instituciones españolas como el Museu de Prehistoria de València y el Museo Nacional de Arqueología Subacuática, e instituciones extranjeras como el Museo Nacional en Cracovia, Polonia, donde realizó una estancia de investigación. El desarrollo de esta actividad ha dado lugar a la publicación de cinco artículos en revistas indexadas, dos artículos en revistas no indexadas y cinco publicaciones en congresos, así como a la participación en congresos de ámbito nacional e internacional. También ha colaborado en tareas docentes en el Departamento de Conservación y Restauración de Bienes Culturales de la UPV durante varios cursos académicos.

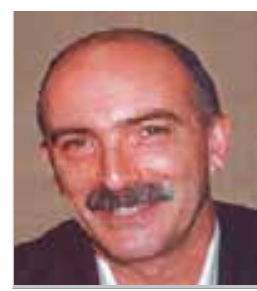

\section{Antonio Doménech Carbó}

antonio.domenech@uv.es

Departamento de Química Analítica,

Universitat de València

Doctorado en Ciencias Químicas por la Universitat de València. Estudi General en 1989, desde 1980 ha sido catedrático de Bachillerato compaginando este trabajo con el de profesor asociado desde 1993 hasta 2001 en que pasa a profesor titular y posteriormente, en 2010 catedrático de Análisis Químico en el Departamento de Química Analítica de la Universitat de València. En su trayectoria académica universitaria que supera los 25 años ha publicado cerca de 300 artículos, la mayoría de ellos en revistas indexadas y ha escrito varios libros por invitación para las editoriales Springer y Taylor and Francis sobre análisis electroquímico de bienes culturales. Es topical editor de la revista Journal of Solid State Electrochemistry y miembro del editorial board de la revista didáctica ChemTexts. Ha dirigido 7 tesis doctorales y numerosos proyectos de investigación competitivos de ámbito regional y nacional.

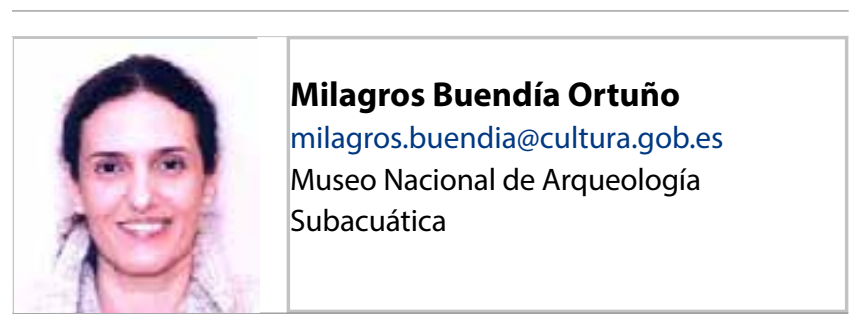

Doctora en Conservación y Restauración de Bienes Culturales por la Universitat Politècnica de València. Desde su licenciatura en 1996, amplía su formación en conservación de materiales arqueológicos con distintas estancias tanto en España como en el extranjero (Italia, Rusia o Guatemala). Su actividad profesional se ha centrado en la conservación y restauración de material arqueológico y ha desempeñado su trabajo para empresas privadas, organismos e instituciones públicas y en diversos museos como el Museu de Prehistòria de València y los Museos Arqueológicos de Murcia, Lorca, Jumilla, Mula o Sagunto. Desde 2003 es conservadora-restauradora del Museo Nacional de Arqueología Subacuática de Cartagena, y de su trayectoria en el centro destacan la participación en el Proyecto Museográfico (2006-2008) del museo en su nueva sede, la implementación del Programa de Conservación en intervenciones arqueológicas subacuáticas (2007-2011 Bajo de la Campana, Mazarrón, Punta de Algas), la aplicación del programa de conservación preventiva 
de elementos de la exposición permanente y colección de reserva y la conservación y restauración del conjunto monetario de la Fragata Nuestra Señora de las Mercedes. Ha participado como docente en cursos, Máster y Posgrados sobre conservación de patrimonio arqueológico en España y Guatemala. Es autora de artículos sobre la conservación de materiales arqueológicos de procedencia subacuática publicados en revistas especializadas, así como ponencias en diversos congresos y jornadas. Su labor de investigación se centra, desde 2007, en el marfil de procedencia subacuática, las defensas de elefante del pecio fenicio del Bajo de la Campana, San Javier (Murcia).

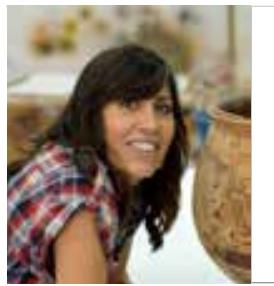

\section{Trinidad Pasíes Oviedo}

trini.pasies@dival.es

Museu de Prehistòria de València

Restauradora del Museo de Prehistoria de Valencia e investigadora dentro del Servicio de Investigación Prehistórica de la Diputación de Valencia desde 2005. Licenciada en BBAA con la especialidad de restauración en 1992. Amplía su formación con estancias en centros internacionales de Italia, Guatemala, Francia, Turquía o Grecia. Se doctora en 2004 y presenta su tesis doctoral sobre la conservación de mosaicos romanos, publicada por la Universidad Politécnica de Valencia (UPV). Ha dirigido numerosas actuaciones de conservación y restauración arqueológica y ha colaborado con distintas instituciones nacionales e internacionales en proyectos de intervención. Relevante es su labor docente en cursos de especialización desde 1996, y entre 2017 y 2019 como profesora asociada del Dpto de Conservación y Restauración de la UPV. Su labor de investigación se refleja en numerosas publicaciones, impartiendo conferencias y como investigadora de proyectos I+D+i.

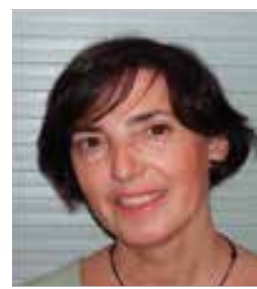

\section{María Teresa Doménech Carbó}

tdomenec@crbc.upv.es

Instituto de Restauración del Patrimonio,

Universitat Politècnica de València

General en 1989, desde 1984 hasta 1990 ha sido profesora agregada y catedrática de Bachillerato y desde 1990 es profesora de Análisis Químico de Patrimonio Cultural en la Universitat Politécnica de València (UPV) alcanzando la condición de catedrática en 1999, desde 2005 hasta 2016 ha dirigido el Instituto Universitario de Restauración del Patrimonio de la UPV (IRP). En su trayectoria académica universitaria que supera los 25 años ha publicado cerca de 200 artículos, la mayoría de ellos en revistas indexadas y ha escrito dos libros por invitación para las editoriales Springer y Síntesis sobre análisis químico de bienes culturales. También ha dirigido 19 tesis doctorales cuatro de las cuales han recibido Premios Extraordinarios a nivel Nacional y de la UPV y durante su mandato en el IRP ha dirigido la edición de la revista Arché del IRP. Ha coordinado sucesivos programas de doctorado ofertados por el Departamento de Conservación y Restauración de Bienes Culturales de la UPV. Finalmente cabe destacar que ha dirigido numerosos proyectos de investigación competitivos de ámbito regional, nacional y de la Comisión Europea y ha participado y dirigido un número muy elevado de convenios y contratos de I+D.

Artículo enviado el 04/09/2019 Artículo aceptado el 08/10/2019 


\title{
La Pintura del techo del Teatro Vicó de Jumilla (Murcia). Estudio histórico y material
}

\author{
Sonia Santos Gómez, Margarita San Andrés Moya, Ruth Chércoles
}

Resumen: Las representaciones teatrales constituyeron uno de los ejes de la vida social de la España decimonónica, por lo que durante el siglo XIX se construyeron numerosos inmuebles que necesitaron, asimismo, de mobiliario, enseres $y$ pinturas que configuraran un ambiente suntuoso. Muchas de estas pinturas fueron realizadas al temple de cola sobre lienzo. Un ejemplo de lo citado es la pintura del techo del teatro Vico de la ciudad de Jumilla en Murcia (España) (ca. 1883). Su estudio microanalítico ha revelado los materiales y la metodología de trabajo aplicados en su ejecución, característicos de la pintura decorativa del siglo XIX. Se ha constatado el uso de ciertos pigmentos producidos por la industria moderna europea, acompañados de otros más tradicionales, que entran dentro de la categoría de los pigmentos históricos. Asimismo, resulta destacable la identificación de carbonato cálcico, en forma de creta, en las preparaciones y en la capa pictórica.

Palabras clave: Pintura decorativa, pintura al temple, pigmentos artísticos, carbonato cálcico, creta, microscopía óptica, SEM-EDX

\section{The painting of the ceiling of the Theater Vico Jumilla (Murcia). Historical and material study}

Abstract: The theatrical representations were one of the axes of social life of 19th century in Spain, so during that century were built many buildings that also needed furniture, furnishings and paintings that set a sumptuous atmosphere. Many of these paintings were made in queue on canvas tempera. An example of this is the ceiling painting of the Vico theater in the city of Jumilla in Murcia (Spain) (ca. 1883). Its microanalytical study has revealed the materials and work methodology applied in his execution, which are characteristic of 19th century decorative painting. The use of certain pigments produced by modern European industry, accompanied by more traditional ones, which fall within the category of historical pigments, has been confirmed. Likewise, the identification of calcium carbonate, in the preparations and in the pictorial layer is noteworthy.

Keyword: Decorative painting, tempera painting, artistic pigments, calcium carbonate, chalk, optical microscopy, SEM-EDX

\section{A pintura do teto do Teatro Vicó de Jumilla (Murcia). Estudo histórico e material}

Resumo: As representações teatrais constituíram um dos eixos da vida social da Espanha oitocentista, de modo que durante o século XIX foram construídos inúmeros edifícios que precisavam de móveis, equipamentos e pinturas que configuravam um ambiente suntuoso. Muitas destas pinturas foram realizadas a têmpera de cola sobre tela. Um exemplo disso é a pintura no teto do teatro Vico, na cidade de Jumilla, em Múrcia (Espanha) (ca. 1883). O seu estudo micro analítico revelou os materiais e a metodologia de trabalho aplicados na sua execução, característicos da pintura decorativa do século XIX. Constatou-se o uso de certos pigmentos produzidos pela indústria moderna europeia, acompanhados de outros mais tradicionais, que se enquadram na categoria de pigmentos históricos. Da mesma forma, destaca-se a identificação do carbonato de cálcio, nas preparações e na camada pictórica.

Palavras-chave: Tinta decorativa, tinta a têmpera, pigmentos artísticos, carbonato de cálcio, cré, microscopia ótica, SEM-EDX 


\section{Introducción}

A lo largo de la historia, la pintura al temple sobre lienzo ha tenido diversas utilidades, como cubrir los altares en época de Cuaresma, decorar doseles de cama, túmulos, monumentos de Semana Santa, y paredes de las casas. Normalmente se utilizaba cola animal como aglutinante (aunque a veces también se empleaba huevo) y, si se aplicaba una capa de preparación, ésta solía ser de cola, habitualmente mezclada con yeso en el caso de España (Santos 2017).

Algunos de estos usos decorativos tienen ejemplos significativos en palacetes y casas principales de burguesía y nobleza, así como en otros edificios emblemáticos para el esparcimiento y encuentro social de la España decimonónica. Es el caso de teatros, casinos y otros centros socio-culturales, cuyas estancias eran decoradas con enseres, mobiliario y pinturas; todo ello con el objetivo de conferir a estas estancias un ambiente suntuoso.

Estos temples que iban a estar fijos solían ser adheridos al muro, con lo que la obra adquiere el carácter de pintura mural. Hilaire Hiler, en su tratado The Painter's Pocket-Book of Methods and Materials (primera ed. 1937), denomina la pintura adherida a los muros como Marouflage e indica fue muy popular en el siglo XIX. (Hiler 1970: 157-158). Como ejemplos de estos temples, pueden citarse el de la bóveda del Salón de Plenos del Senado Antiguo, del siglo XIX o el techo del patio de butacas del Teatro Calderón de Motril, tradicionalmente atribuida a Francisco Muros y ejecutada poco antes del otoño de 1881.

Aunque efectivamente la técnica del temple sobre lienzo ha sido empleada como pintura decorativa en paredes, también se ha utilizado el óleo en pintura decorativa de grandes dimensiones, denominada comúnmente como de gran formato (Calvo:2002: 84-85). Existen múltiples ejemplos y pueden citarse como tales las pinturas murales del salón de Comisiones del Palacio de la Diputación Provincial de Ciudad Real (óleo sobre lienzo adherido a techo), de Ángel Andrade.

La razón de la amplia demanda de pinturas de carácter decorativo estaba junstificada por la existencia de una clase media influyente y deseosa de asistir a todo tipo de actos sociales y culturales, entre los que destacaban las respresentaciones teatrales. En el caso de España, esta circunstancia coincidió con la importante renovación que los teatros experimentaron a lo largo del siglo XIX. Las casas o corrales de comedias que tuvieron su época de esplendor durante los siglos XVI y XVII, en general, habían llegado al siglo XIX con importantes signos de degradación, lo que planteó la necesidad de su renovación o de abordar la construcción de otros nuevos que permitieran la representación de las obras de teatro apoyándose en escenografías más novedosas. Todo ello propició la construcción de numerosos teatros. Algunos ejemplos importantes son el teatro Real (1850) y el teatro Lara (1879), ambos en Madrid, el Gran teatro del Liceo de Barcelona (1847), el teatro Arriaga de Bilbao (1890), el teatro Calderón de Valladolid (1864), el teatro Romea de Murcia (1862) y el teatro Vicó de Jumilla (1883). Puesto que una de las salas más importantes de un teatro es el propio salón de actos en el que se va a llevar a cabo la representación, es lógico que el techo fuera ricamente decorado a base de molduras, lámparas y otro tipo de elementos ornamentales, entre los que destacan las pinturas de grandes dimensiones que cubren gran parte de ese espacio.

En estos entornos, los temples a la cola sobre lienzo se emplearon frecuentemente como pinturas decorativas en paredes y techos. Estas pinturas al temple en general son obras con carácter más estable, menos efímero que el que presentan otros temples, como los ejecutados en los teatros para ser utilizados como telones y pintura de escenografías en general, que tenían una mayor movilidad, debido a su uso $y$, por tanto, se deterioraban con mayor rapidez.

Tanto la pintura de carácter decorativo relacionada con la construcción de estos grandes edificios de carácter público, como la vinculada al arte escénico tuvieron gran demanda y su realización llegó a ser considerado un verdadero oficio, altamente valorado durante la segunda mitad del siglo XIX (García 2013: 313-359). Prueba de la importancia del arte escénico es su introducción en los programas formativos asociados a la educación de los pintores de ese siglo, llegando incluso a constituir una especialización (Catalán 2003: 113).

Las pinturas de escenografías presentaban formatos de grandes dimensiones, lo que obligaba a que fueran ejecutadas en amplísimos talleres $y$, en algunos casos, se pintaran extendidas en el suelo, de modo que el propio pintor se desplazaba sobre su superficie durante su realización (Arola 1920: 42-43; Moynet 1999: 119-120). Estos talleres podían estar integrados en los llamados almacenes de decoraciones que, en ocasiones, estaban ubicados en el propio teatro.

La pintura del techo del patio de butacas del teatro Vicó de la ciudad de Jumilla en Murcia (España) constituye un ejemplo de este tipo de obras. Este teatro fue inaugurado el 14 de agosto de 1883 y en su construcción intervinieron los arquitectos Juan J. Belmonte, que realizó los planos de la cimentación, y Justo Millán Espinosa, que diseñó los correspondientes al levantamiento del edificio. El 8 de septiembre de 1890, fue bautizado como "Teatro Vicó", en honor al actor y empresario Antonio Vicó Pintos.

Esta pintura, junto a otras decoraciones del teatro, fue encargada al pintor catalán Manuel Sanmiguel, que inició su actividad en la provincia de Murcia a partir de 1868. Sanmiguel se formó en el taller del pintor francés Felix Cagé, que llegó a ser Director de Pintura del Teatro del Liceo de Barcelona y autor de muchas de las pinturas que lo decoran (Radigales i Babi 1998: 114); además, pintó numerosas obras del Teatro Romea de Murcia (Muñoz 2018: 311-314). Respecto a la obra que nos ocupa, en el Libro de Actas 
Capitulares de los años 1883 a 1885, tomo 21, fols. 34 v. a 36 v se indica que, en la sesión de 9 de abril de 1883, y bajo la presidencia de D. Rafael Soriano Palencia, el Ayuntamiento de Jumilla (Murcia) contrata con el escenógrafo Sanmiguel la pintura del techo y decoraciones de su teatro Vico (Aragoneses, 1964). En este contrato se indica lo siguiente:

[...] Dicho señor se compromete con el Ayuntamiento, a pintar con arreglo al arte, el cielo raso sobre lienzo para colocarlo en el teatro de esta villa, [...] telón de boca y embocadura del escenario y las decoraciones siguientes: Dos decoraciones cerradas, una de carácter rico y otra de carácter medio del día, una de plaza o calle, otra de selva larga, otra de jardín, otra de cárcel, una de salón regio, una de sala corta, otra de Casa Blanca, y una de marina. Total diez decoraciones con sus correspondientes telones [...] el Ayuntamiento se compromete a entregar ó pagar a D. Manuel Sanmiguel, la cantidad de cincuenta y cinco mil reales siendo también de cuenta del Municipio, el importe del lienzo necesario para dichos decorados y la madera necesaria y construcción de ella para los bastidores y pago de los portes de todo ello desde Murcia a esta villa.

Respecto al lugar de ejecución de la pintura, es posible que Manuel Sanmiguel la realizara en el propio edificio del teatro, evitando de esta manera gastos en alquiler de espacios y desplazamiento. Esta suposición se apoya en un documento de 1889 que hace referencia al Teatro Romea de Murcia, y en el que se menciona a Sanmiguel realizando la pintura del telón de boca que tenía encargada para éste y pidiendo permiso para pintar otras obras en ese mismo lugar. Según figura en dicho documento, si le fuera concedida esta gracia, el autor correspondería pintando de manera gratuita nuevas decoraciones o restaurando otras, siempre y cuando se le suministrara el material para ello (Aragoneses, 1964). Por tanto, no puede descartarse que actuara de manera similar en el Teatro Vicó de Jumilla.

Representa una alegoría de la Música, de acuerdo al gusto de la época por el mundo clásico [Figura 1]. En la escena central, entre nubes, aparece la musa Eutherpe rodeada por siete figuras femeninas que portan distintos instrumentos musicales. En torno a ellas, se disponen tres amorcillos. Alrededor de esta escena central, se encuentran otras dos figuras femeninas que representan las alegorías de la Tragedia y la Comedia, Melpómene y Talía, además de los retratos de varias actrices (Matilde Díez, Rita Luna y Teodora Lamadrid) y dramaturgos (Calderón de la Barca, Fernández Caballero y Ricardo Calvo y José Echegaray); entre estas imágenes aparecen representadas hornacinas. En la parte inferior se hallan los retratos de los actores Julián Romea e Isidoro Maiquez. Enmarcando el conjunto de las representaciones indicadas, se encuentran una serie de figuras femeninas, que portan guirnaldas y se disponen alternativamente con una serie de cartelas en las que aparecen escritos los títulos de diferentes obras literarias y nombres de escritores. La pintura ha sido realizada para ser observada a cierta distancia, con ásperas transiciones de luces y sombras, tal y como se puede apreciar en el detalle de la figura $1 c$.

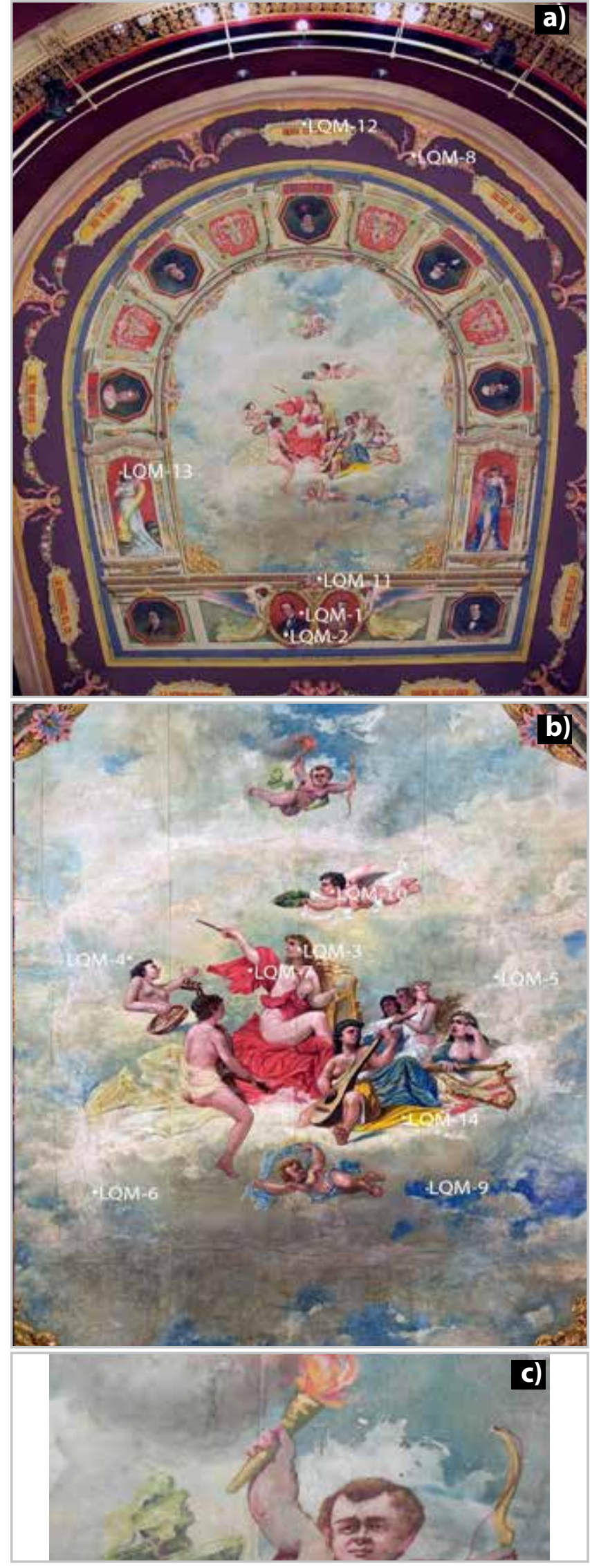

Figura 1.- a) Vista general de la pintura que decora el techo del patio de butacas del teatro Vicó de Jumilla (Murcia), b) Motivo central de la pintura. Autor de la pintura M. Sanmiguel (ca. 1884). En ambas imágenes se indican las zonas de toma de muestra. c) Detalle de uno de los amorcillos (Eros). 
La obra se inscribe en un rectángulo de 10,52 x 9,45m, Según se observa en la figura 2 , está configurada mediante la unión de diversos fragmentos de lienzo. Las líneas continuas indican que se trata de trozos de tela independientes, y las discontinuas representan costuras a punto de sábana que unen los fragmentos. El lienzo está adherido directamente al techo, sin bastidor, y el adhesivo utilizado se encuentra distribuido en toda la superficie del reverso.

Probablemente la naturaleza de los morteros y la estructura arquitectónica subyacentes hayan influido sobre el estado de conservación de la obra, aunque por el momento no se dispone de datos sobre la naturaleza de estos elementos.

Según Hilaire Hiller, este tipo de pintura sobre lienzo adherida al muro (no especifica si se trata de temple $u$ óleo) era normalmente encolada con una pasta de harina y ajo o también posteriormente con blanco de plomo con aceite. Después, el lienzo sería presionado con rodillos, desde el centro hacia los extremos a fin de conseguir una buena adherencia. (Hiler 1970: 157-158).

Dentro del proyecto integral de conservación y restauración del teatro Vicó, iniciado en mayo de 2008, fue abordada la restauración de esta pintura (De La Hoz, 2011) y en este contexto fueron llevados a cabo los análisis con el objetivo de realizar un estudio detallado de los materiales utilizados en su ejecución y su forma de aplicación. Las técnicas de análisis utilizadas y la interpretación de los resultados obtenidos, apoyadas en la consulta de documentación de la época sobre la metodología de trabajo más habitual empleada sobre este tipo de obras han hecho posible determinar la estratificación de la pintura e identificar los pigmentos utilizados, algunos de los cuales se encuentran dentro de los desarrollados por la industria química del siglo XIX. Asimismo, los resultados presentados en este artículo han ampliado el conocimiento de la técnica de trabajo aplicada en la ejecución de las pinturas al temple de cola sobre lienzo de carácter decorativo en la España del siglo XIX.

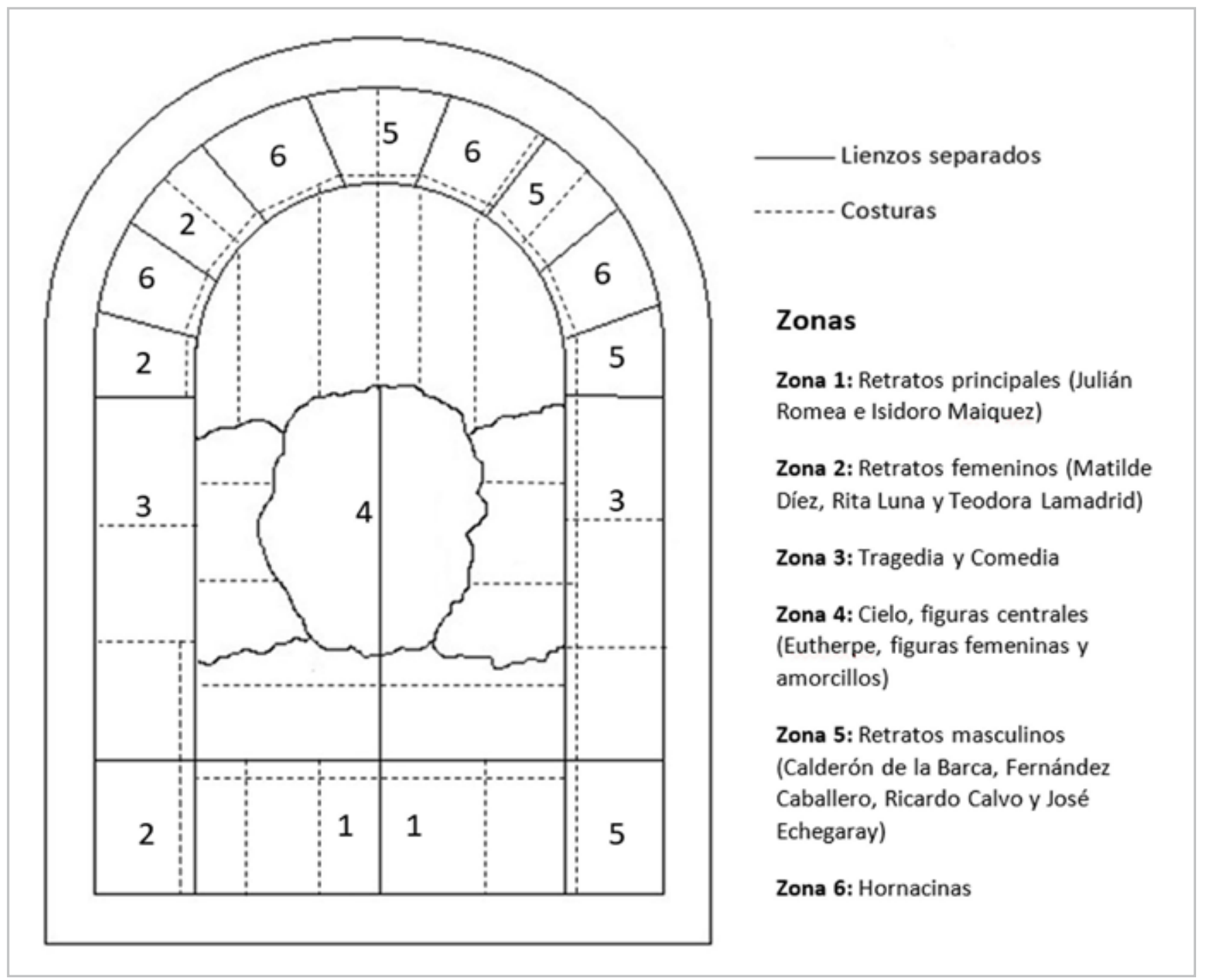

Figura 2.- Disposición de los distintos paños que constituyen la pintura. Las líneas contínuas marcan la separación entre lienzos independientes; las discontínuas indican las costuras de unión de los paños que consituyen el lienzo de la escena central. 


\section{Materiales y Métodos de análisis}

\section{-Muestras}

Se han estudiado un total de catorce muestras, que incluyen doce de pintura, una del soporte (lienzo) y otra del adhesivo de unión del soporte al techo. Dentro del conjunto de muestras pictóricas, tres de ellas corresponden a zonas repintadas. En la Tabla 1 se indica la relación de muestras, su ubicación en la obra y la referencia asignada. Las zonas en las que han sido tomadas las muestras correspondientes a la capa pictórica están indicadas en la figura 1.

Tabla 1.- Muestras estudiadas (referencia y zona de toma de muestra) ${ }^{*}, * *$

\begin{tabular}{|l|l|l|}
\hline Muestra & Referencia & Ubicación en el cuadro la pintura \\
\hline 1 & LQM-1 & Rojo fondo retrato de Julián Romea \\
\hline 2 & LQM-2 & Azul chaqueta Julián Romea \\
\hline 3 & LQM-3 & Encarnación (repinte) cara figura Eutherpe \\
\hline 4 & LQM-4 & Azul-verdoso, zona de cielo escena central \\
\hline 5 & LQM-5 & Adhesivo de unión de los lienzos al techo \\
\hline 6 & LQM-6 & Soporte (tela) \\
\hline 7 & LQM-7 & Rojo manto figura Eutherpe \\
\hline 8 & LQM-8 & $\begin{array}{l}\text { Encarnación (testigo de limpieza), figura } \\
\text { portando guirnalda (parte superior de la pintura) }\end{array}$ \\
\hline 9 & LQM-9 & Azul cielo (repinte), escena central \\
\hline 10 & LQM-10 & $\begin{array}{l}\text { Encarnación cara, figura amorcillo portando } \\
\text { corona }\end{array}$ \\
\hline 11 & LQM-11 & $\begin{array}{l}\text { Marrón (preparación?), representación moldura } \\
\text { (parte inferior de la pintura) }\end{array}$ \\
\hline 12 & LQM-12 & Rojo cartela (repinte, zona superior de la pintura) \\
\hline 13 & LQM-13 & $\begin{array}{l}\text { Verde testigo de limpieza, cabeza figura de } \\
\text { Melpómene }\end{array}$ \\
\hline 14 & LQM-14 & \begin{tabular}{l} 
Paño amarillo, figura femenina portando laúd \\
\hline
\end{tabular} \\
\hline
\end{tabular}

* Todas las muestras fueron proporcionadas por la empresa Lorquimur.

**No es posible completar los datos respecto al muro (si se trata de una estructura encamonada, cañizo, o mixta), ni de sí los morteros subyacentes que reciben el encolado, aunque sea muy interesante para la futura conservación de esta pintura ya que los autores del estudio no han tenido un acceso a la obra de esta naturaleza.

\section{—Métodos de análisis}

Las fibras han sido identificadas mediante microscopia óptica, observando la morfología de su plano longitudinal previa tinción con reactivo Herzberg (mezcla de disoluciones de cloruro de cinc y yoduro potásico/yodo).

Las muestras de pintura han sido observadas primeramente con un microscopio esteresoscopico modelo Leica MZ125 con iluminador de luz fluorescente y cámara digital Leica DC150. Después, han sido incluidas en resina acrílica polimerizable Résine Mécaprex KM-U, para su estudio por técnicas microscópicas. El estudio mediante microscopía óptica (MO) ha sido llevado a cabo con un microscopio petrográfico Olympus BX51 y el análisis morfológico y elemental ha sido realizado mediante SEM(BSE)-EDX con el empleo de un microscopio electrónico de barrido JEOL JSM 6400 que presenta $20 \mathrm{kV}$ de voltaje de aceleración. Este equipo incorpora un espectrómetro de dispersión de energía LINK eXL con una resolución de 138 eV a 5.39 keV.

El análisis de los materiales organicos, es decir, del aglutinante de las capas de pintura y del adhesivo de fijación de las telas al techo ha sido realizado mediante técnicas de tinción específica, utilizando Fuchsina ácida y rectivo de Lugol, que se prepara disolviendo $20 \mathrm{~g}$ de yoduro potásico en $100 \mathrm{~mL}$ de agua y añadiendo a esta disolución $10 \mathrm{~g}$ de yodo. Además, en el caso del primero también se ha empleado croamatografía de gases-espectrometría de masas (GC-MS), utilizando un equipo GCMS-QP5050, marca SHIMADZU).

\section{Resultados y discusión}

En las muestras referenciadas como LQM-1 (rojo fondo retrato de Julián Romea), LQM-2 (azul chaqueta Julián Romea), LQM7 (rojo manto figura Eutherpe), LQM-8 (encarnación de figura portando guirnalda en la parte superior de la pintura) y LQM14 (paño amarillo, figura femenina portando laúd), se observa que la pintura parece haber sido aplicada directamente sobre el lienzo e impregna totalmente el tejido. Los estratos pictóricos presentan grosores irregulares, característica que tiene relación con la morfología ondulada de la superficie del soporte, producida por el entrecruzamiento de la trama y la urdimbre. El análisis de las fibras ha constatado que, en ambos casos, se trata de algodón [Figura 3].
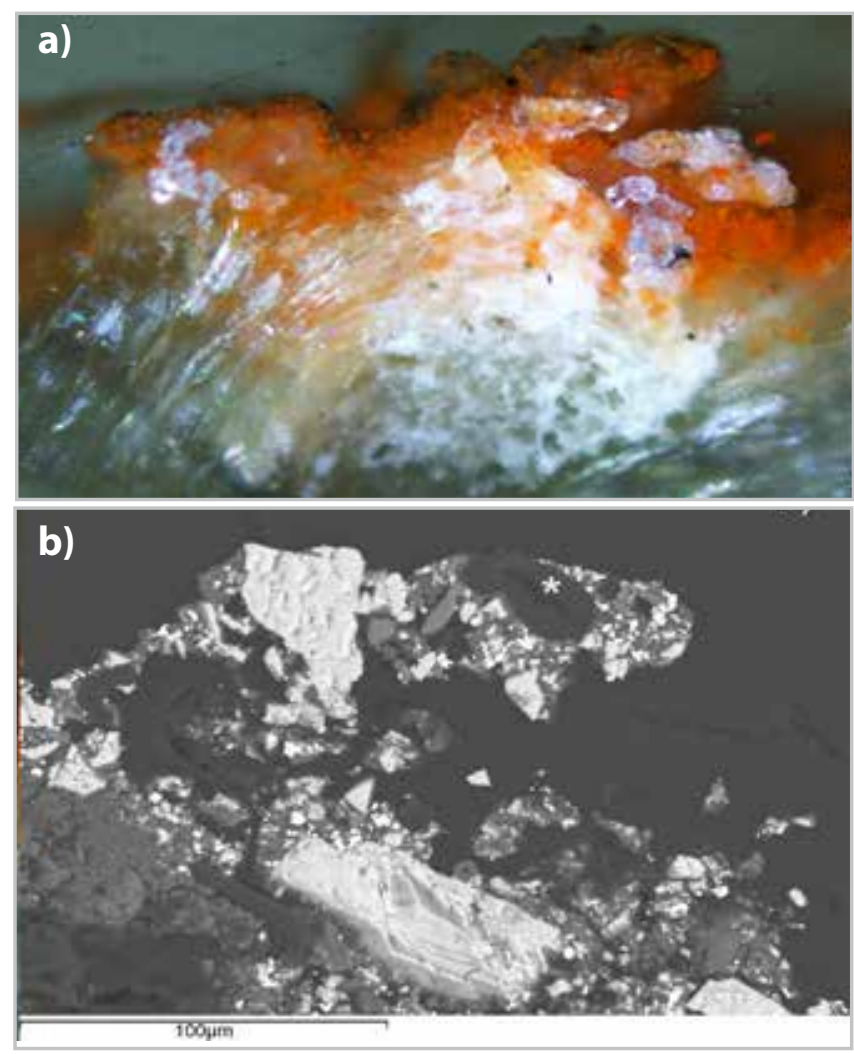

Figura 3.- Muestra LQM-1. Corte transversal: a) Observación por MO (100X); b) Observación por SEM(BSE): detalle de la capa pictórica en la que se aprecia la forma arriñonada del la seccion transversal de una fibra de algodón (señalada con un asterisco) embebida en la pintura. 
En solo cuatro de las muetras estudiadas resulta muy evidente la existencia de una capa de preparación de color blanco. Tres corresponden a zonas claras: LQM-4 (cielo), LQM-10 (encarnación) y LQM-3 (repinte de una encarnación) y la cuarta (LQM-9) corresponde a una zona más oscura del cielo. En el resto de las muestras no se aprecia claramente una capa de preparación y parece que la pintura haya sido aplicada directamente sobre el lienzo.

Esta singularidad lleva a pensar que en las zonas más relevantes de la pintura, donde se habría pretendido conseguir una pintura más luminosa se consideró oportuno aplicar una preparación de color blanco. Con esta capa previa, la pincelada discurre con mayor fluidez y, además, se limita la absorción de la capa pictórica por parte del soporte. De esta manera, se reduce además el influjo del color del lienzo en la visualización de la pintura.

Los estudios realizados por $\mathrm{MO}$ constatan que, en el caso de las muestras LQM-4, LQM-9 y LQM-10, la capa de preparación es una mezcla que contiene, además de partículas blancas, otras de color rojo-anaranjado y negro [Fig.4]. Las observaciones de las muestras en SEM (BSE), así como los análisis elementales realizados por EDX indican la presencia de calcio (Ca) como elemento mayoritario, destacándose la presencia de microfósiles y, además, otros elementos como son plomo $(\mathrm{Pb})$, en las partículas de color naranja, y fósforo $(\mathrm{P})$ y calcio (Ca) en algunas de color negro, así como carbono (C) en otras que también presentan este color. [Figuras 4 y5]

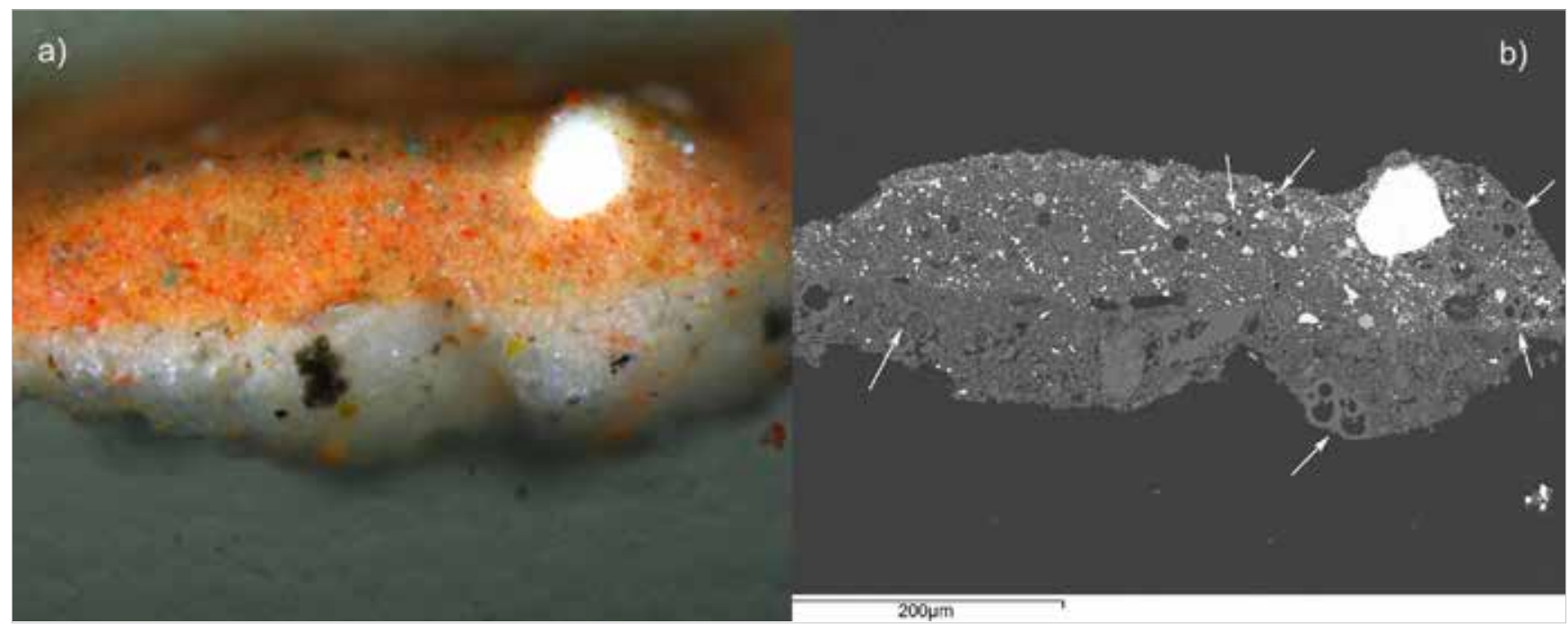

Figura 4.- Muestra LQM- 10. Corte transversal: a) Observación por MO (100X); b) Observación por SEM (BSE). Las flechas señalan la presencia de microfósiles.

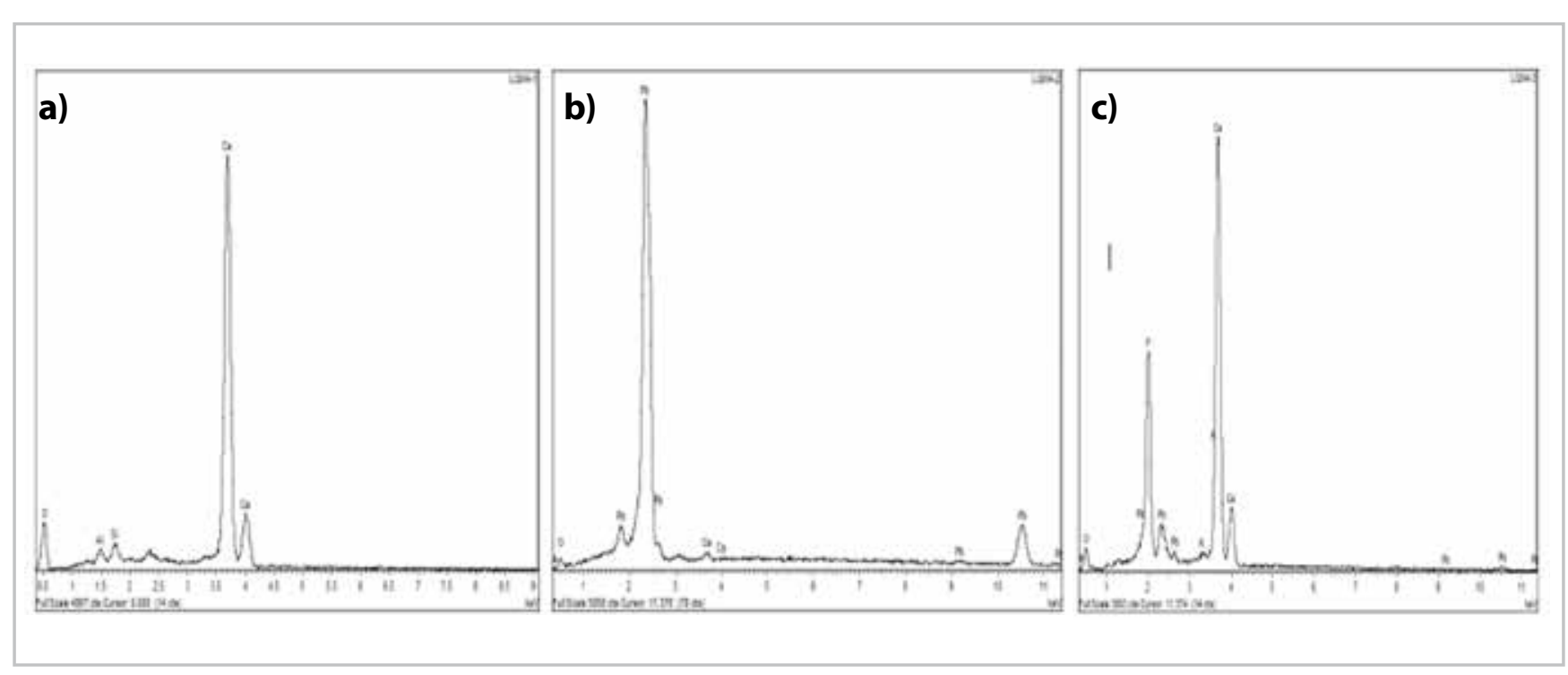

Figura 5.- Muestra LQM-10. Microanálisis por EDX correspndientes a la capa de preparación: a) análisis de zona; b) análisis de partículas de color naranja; c) análisis de partículas negras. 
Atendiendo a estos resultados, la composición de la capa de preparación en las muestras que la presenta es carbonato cálcico de origen orgánico (creta), mezclada con un pigmento de plomo, probablemente minio y dos tipos de pigmento negro, negro carbón y negro de huesos.

En la muestra LQM-3, que corresponde a una zona donde visulamente fue identificado un repinte de acuerdo a las indicaciones de Lorquimur, la empresa que suministró las muestras para su análisis, se ha observado una capa de preparación constituida únicamente por carbonato cálcico. En ella no se observan microfósiles, como ocurría en el caso de la capa de preparación de las muestras correspondientes a la capa pictórica original, lo que contribuiría a diferenciar las preparaciones [Figura 6]. Este repinte, al igual que el que correponde a la zona de extracción de la muestra referenciada como LQM-12 (rojo cartela, repinte), podría tener su origen en alguna intervención anterior destinada a adecentar la decoración en algún momento de la historia de la obra.

La técnica pictórica frecuentemente asociada a este tipo de pintura es el temple a la cola, que se caracteriza por su rigidez. Esta peculiaridad, unida a las grandes dimensiones de estas obras y a la manipulación a la que se veían sometidas durante su ejecución, transporte y colocación en su ubicación definitiva, podía dar lugar a pérdidas de pintura si las capas eran muy gruesas y no impregnaban convenientemente el soporte.

En el caso de la pintura objeto de estudio, se observa esa penetración en el soporte y la delgadez de la pintura e, incluso, la ausencia de preparación en la mayoría de las muestras estudiadas durante los exámenes microscópicos.

El uso del carbonato cálcico en la capa de preparación puede tener relación con la existencia de numerosos tratados foráneos en los que se menciona este material y el frecuente trasiego de artífices por la Europa del siglo XIX. A este respecto recuérdese el origen francés de la propia formación artística de Sanmiguel. Estas circunstancias, sin duda, pudieron favorecer ese "contagio" de materiales y metodologías pictóricas (Bellanger 1899: 230-231) [1].

De la transmisión entre países de metodologías pictóricas y uso de materiales dan fe algunos textos, como el titulado Técnica del arte de la pintura o Libro de la pintura (1959), de José Manaut Viglieti, que describe en detalle el proceso de preparación de los temples sobre lienzo. Dentro de sus indicaciones, este autor señala la posibilidad de utilizar tierra blanca (carbonato cálcico?), en lugar de yeso, posiblemente por ese intercambio de conocimientos con otros países (Manaut 1959: 161-162).

Como se ha indicado, algunos tratados se refieren a ese empleo de carbonato cálcico en preparaciones y como pigmento en pintura al temple sobre lienzo, Pueden citarse, por ejemplo, el de Du Puy Du Grez, Traité sur la peinture pour en apprendre la theorie \& le perfectionner dans la pratique (1699) (Du Puy 1700: 239), el de AntoineJoseph Pernety, titulado Dictionnaire protatif de peinture, sculpture et gravure (1757), (Pernety 1757: xxx. xxii-xxxvi) o el de Watin, en $L^{\prime}$ art du Peinture, Doreur, Vernisseur (1772) (Watin 1793: 109). Igualmente, existen textos del siglo XIX y posteriores en los que se menciona el uso del carbonato cálcico (Vernon-Smith 2013). Su uso como pigmento en una técnica como es el temple a la cola se fundamenta en que este aglutinante mantiene el poder cubriente del carbonato.

Por otra parte, en cuanto a la presencia de carbonato cálcido en la capa pictórica de algunas de las muestras estudiadas, no debe descartarse la posibilidad de que haya sido utilizado como carga de pigmentos más costosos, como el blanco de plomo. Es bien conocido que este último era comercializado con diversas calidades y

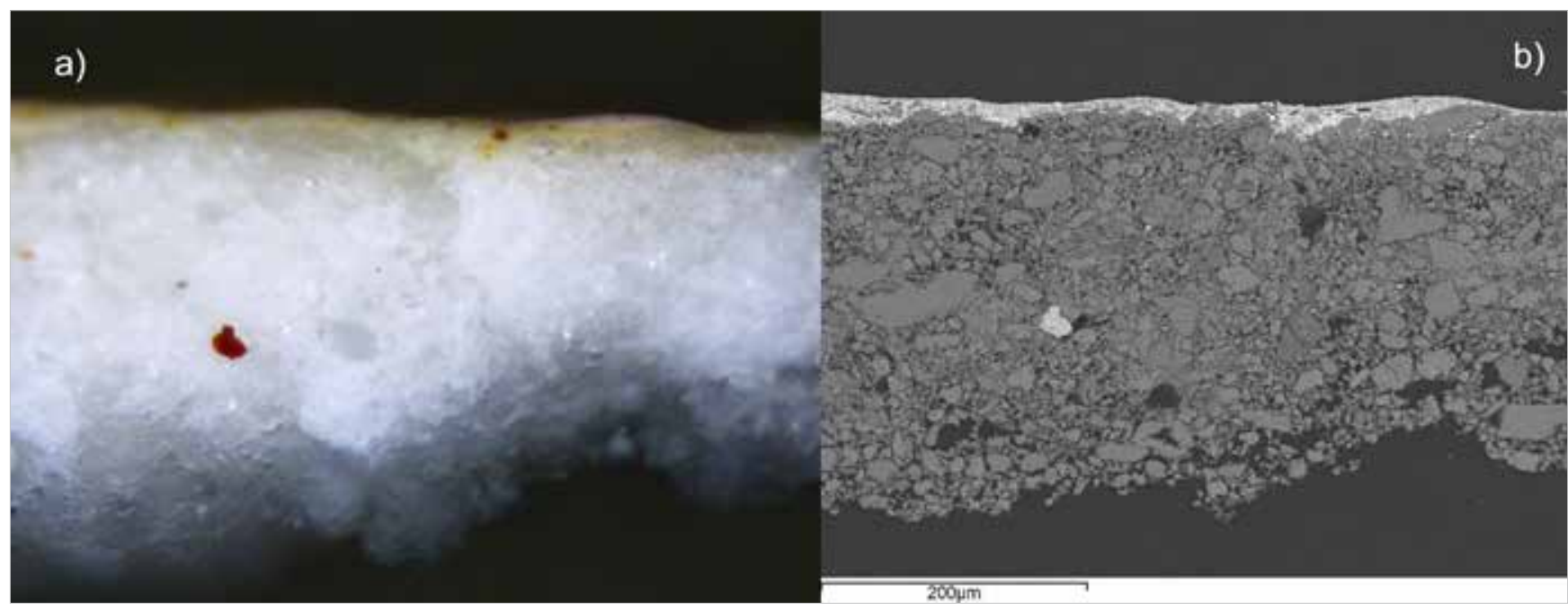

Figura 6.- Muestra LQM- 3. Corte transversal: a) Observación por MO (100X); b) Observación por SEM (BSE). 
precios. En la versión más económica de este pigmento, el carbonato cálcico figuraba como carga. Hay que indicar que, además de este carbonato, también ha sido identificada la presencia de yeso en la capa pictórica de algunas muestras; este es el caso de LQM-10, LQM-13 y LQM-14, de lo que se deduce que este último material también pudo haber sido utilizado como carga.

Con repsecto a la capa pictórica, lo primero que hay que indicar es la amplia gama de colores utilizada (blanco, amarillo, azul, verde, rojo, naranja, negro), obtenidos todos ellos por mezcla de pigmentos y aplicados en general en una única capa. En la Tabla 2 se recogen los resultados de los microanálisis realizados por EDX sobre los distintos pigmentos y cargas presentes en la pintura. Dentro de éstos, algunos son tradicionales, y tienen una amplia trayectoria de uso en pintura artística y otros son más modernos, estando en algunos casos su fecha de producción y comercialización dentro de la primera mitad del sigo XIX.

Se han identificado pigmentos tradicionales como son blanco de plomo, bermellón, minio, negro de huesos, negro carbón y tierras (San Andrés, Sancho, de la Roja 2010) y, además, carbonato cálcico y yeso, a los que ya se ha hecho referencia anteriormente. Tambien se han detectado otros pigmentos más modernos cuya producción y comercialización están estrechamente relacionadas con el nacimiento de la Química moderna (San Andrés 2010). En orden cronológico, el primero que hay que mencionar es el azul de Prusia, ferrocianuro férrico, cuya fecha de síntesis se sitúa entre 1704 y 1706, y es debida a Diesbach y Dippel. Fue comercializado poco después, en 1708 y fue inmediatamente aceptado en pintura artística (Berrie 1997). Otro de los pigmentos identificados es el amarillo Turner, también conocido como Patent Yellow, oxicloruro de plomo, sintetizado por el químico y farmacéutico británico Carl Wilhelm Scheele en 1770. Este producto de color amarillo, Ilama la atención del industrial Turner, a quien debe su nombre y que en 1781 patenta su procedimiento de obtención (Russell 2000: 165). Es mencionado por el fabricante de colores George Fields que indica que puede ser utilizado en la técnica al óleo y al temple, pero advierte que se puede alterar bajo la acción de la luz y de la contaminación (Fields, 1841: 144) razón por la cual, su uso queda relegado a pintura decorativa. En relación a esta recomendación, es posible que esta sea la razón de las escasas referencias que existen a la identificación de este pigmento en pintura artística (Pisareva, 2005).

El blanco de bario, químicamente es un sulfato de bario, que puede ser de origen natural o sintético. El primero procede de la barita, mineral de la misma composión del pigmento, y su uso se remonta a la antigüedad. Pero es a raíz de su obtenión com producto sintético, cuando se intensifica su empleo como pigmento. El descubrimiento de su método de obtención se situa a finales del sglo XVIII y principios del XIX (Eastaugh, Walsh, Chaplin, Siddall 2004: 40-41).

Otro pigmento amarillo que ha sido identificado es el amarillo de cromo,), cuya síntesis está relacionada con el descubrimiento del cromo) como elemento químico y el estudio de sus propiedades y derivados. El cromato de plomo(II) fue obtenido en torno a 1800, y en 1804 los químicos franceses Berthollet y Vauquelin sugieren su uso como pigmento. Hay que esperar a 1816 año en el que el fabricante de pigmentos inglés Bollman inicia su producción, pero no es hasta 1831 cuando el industrial Andreas Kurtz de Manchester logra su introducción en el mercado (Russell 2000:164).

El pigmento verde identificado es un pigmento de cobre (Cu) y arsénico (As) de origen sintético. Podria tratarse de Verde Schweinfurt, acetato arsenito de cobre (II) o bien del verde Scheele. Respecto al primero, también conocido como verde de Paris y verde esmeralda, fueron varios los protagonistas responsables de su síntesis y comercialización. Uno de ellos fue Wilhelm Sattler, fabricante de pinturas de Schweinfurt (Alemania), que en colaboración con el farmacéutico Friedrich Russ lo comercializa en 1814 bajo el nombre de verde Schweinfurt. Otra posibilidad es que se trate del verde Scheele. pigmento sintetizado en 1775, por Scheele y que responde a la composición del arsenito de cobre(II).

Tabla 2.-Pigmentos y cargas identificados. Resultados microanálisis EDX.

\begin{tabular}{|l|l|l|}
\hline Pigmento & $\begin{array}{l}\text { Análisis } \\
\text { elemental } \\
\text { (SEM - EDX) }\end{array}$ & Formula química \\
\hline $\begin{array}{l}\text { Amarillo de } \\
\text { Cromo }\end{array}$ & $\mathrm{Cr}, \mathrm{Pb}$ & $\left(\mathrm{PbCrO}_{4}\right)$ \\
\hline $\begin{array}{l}\text { Amarillo de } \\
\text { Turner }\end{array}$ & $\mathrm{Cl}, \mathrm{Pb}$ & $\left(\mathrm{PbCl}_{2.5-7} \mathrm{PbO}\right)$ \\
\hline Azul de Prusia & $\mathrm{Fe}$ & $\mathrm{Fe}_{4}\left[\mathrm{Fe}(\mathrm{CN})_{6}\right]_{3}$ \\
\hline $\begin{array}{l}\text { Blanco de } \\
\text { bario }\end{array}$ & $\mathrm{S}, \mathrm{Ba}$ & $\mathrm{BaSO}_{4}$ \\
\hline Bermellón & $\mathrm{S}, \mathrm{Hg}$ & $\mathrm{HgS}$ \\
\hline $\begin{array}{l}\text { Blanco } \\
\text { de plomo } \\
\text { (albayalde) }\end{array}$ & $\mathrm{Pb}$ & {$\left[\mathrm{Pb}_{3}\left(\mathrm{CO}_{3}\right)_{2}(\mathrm{OH})_{2}\right]$} \\
\hline $\begin{array}{l}\text { Carbonato } \\
\text { cálcico }\end{array}$ & $\mathrm{Ca}$ & $\mathrm{CaCO}_{3}$ \\
\hline Minio & $\mathrm{Pb}$ & $\mathrm{Pb}_{3} \mathrm{O}_{4}$ \\
\hline $\begin{array}{l}\text { Negro de } \\
\text { huesos }\end{array}$ & $\mathrm{Ca}, \mathrm{P}$ & $\mathrm{Ca}_{3}\left(\mathrm{PO}_{4}\right)_{2}$ \\
\hline Negro carbón & $\mathrm{C}$ & $\mathrm{C}$ \\
\hline Tierra & $\mathrm{Si}, \mathrm{Al}, \mathrm{Fe}, \mathrm{Mn}$ & $\mathrm{aSiO}_{2} \cdot \mathrm{bAl}_{2} \mathrm{O}_{3} \cdot \mathrm{CNa}_{2} \mathrm{O} \cdot \mathrm{dMnOx} \cdot \mathrm{eFe} \mathrm{O}_{3}$ \\
\hline $\begin{array}{l}\text { Verde } \\
\text { Schweinfurt }\end{array}$ & $\mathrm{As}, \mathrm{Cu}$ & {$\left[\mathrm{Cu}_{4}\left(\mathrm{C}_{2} \mathrm{H}_{3} \mathrm{O}_{2}\right)\left(\mathrm{AsO}_{2}\right)_{2}\right]$} \\
\hline Verde Scheel & $\mathrm{As}, \mathrm{Cu}$ & {$\left[\mathrm{Cu}_{2}\left(\mathrm{HAsO}_{3}\right)_{2}\right]$} \\
\hline Yeso & $\mathrm{Ca}, \mathrm{S}$ & $\mathrm{CaSO}_{4} \cdot 2 \mathrm{H}_{2} \mathrm{O}$ \\
\hline
\end{tabular}


Algunos de los pigmentos referidos pueden ser observados en la figura 4, correspondiente a la muestra LQM- 10. En esta última se han identificado los siguientes pigmentos: blanco de plomo, barita, minio, bermellón y verde de Schweinfurt o verde Scheel. También se han detectado algunas partículas de yeso. En la figura 7 se muestran algunos de los resultados de los microanálisis realizados sobre la capa de pintura de esta muestra.
En cuanto al estudio de los materiales orgánicos utilizados como adhesivo de fijación del lienzo al techo del teatro y de los aglutinantes de las capas pictóricas, en una primera etapa, se han utilizado técnicas de tinción específicas (reactivos Lugol y Fuchina ácida). La muestra de adhesivo (LQM-5) ha dado resultado positivo con el reacivo Lugol, adquiriendo una coloración azulviolacea característia de la presencia de almidón. Asimismo, la tinción con fuschina ácida ha resultado positiva en todas las muestras, exceptuando la capa pintórica del repinte (Figura 8).

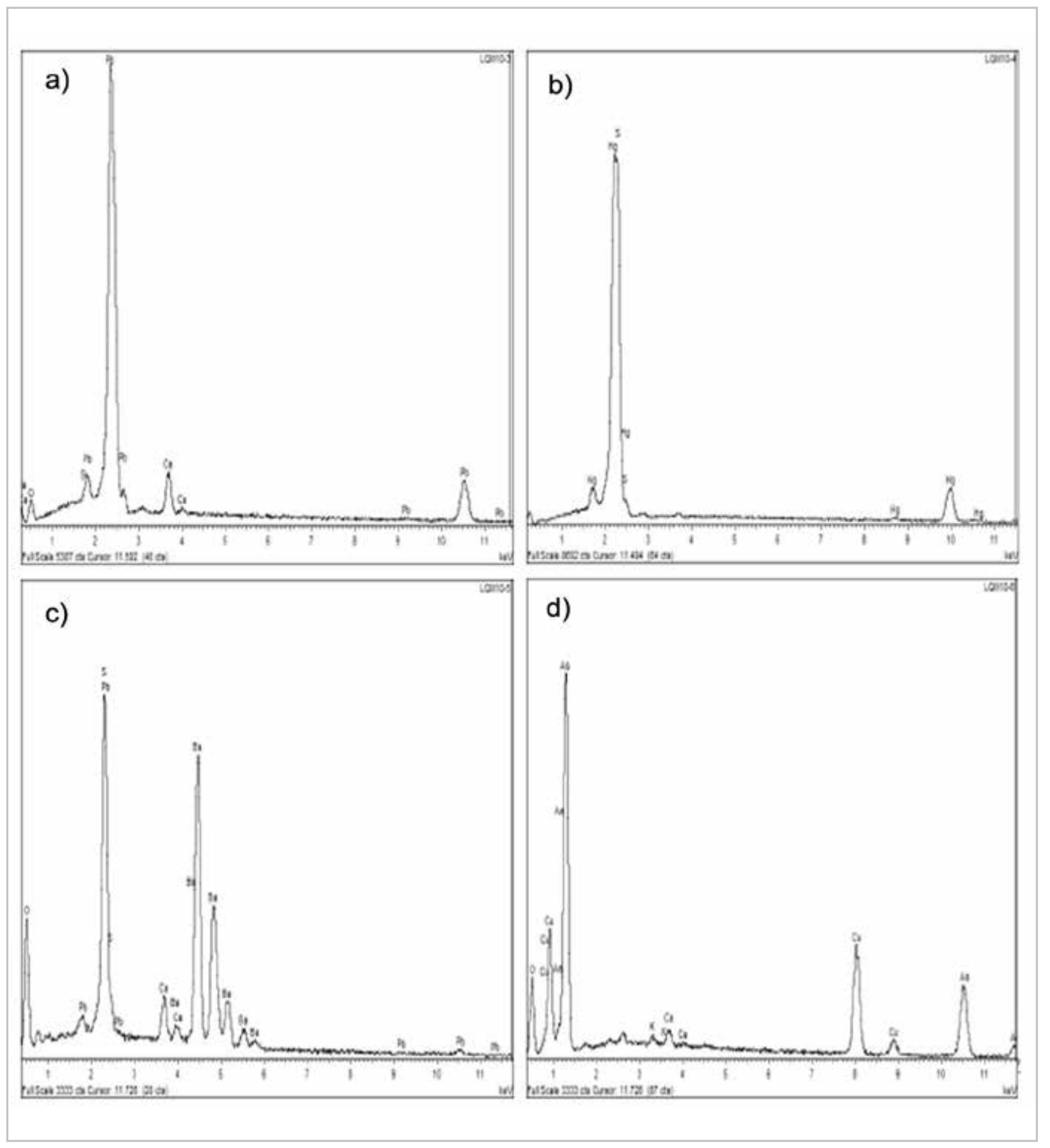

Figura 7.-Muestra LQM-10. Microanálisis por EDX correspondientes a la capa pictórica de color rojo anaranjado: a) partículas blanco de plomo; b) grano de bermellón; c) área con barita mezclada con pigmento de plomo y creta; d) verde con As y Cu. 


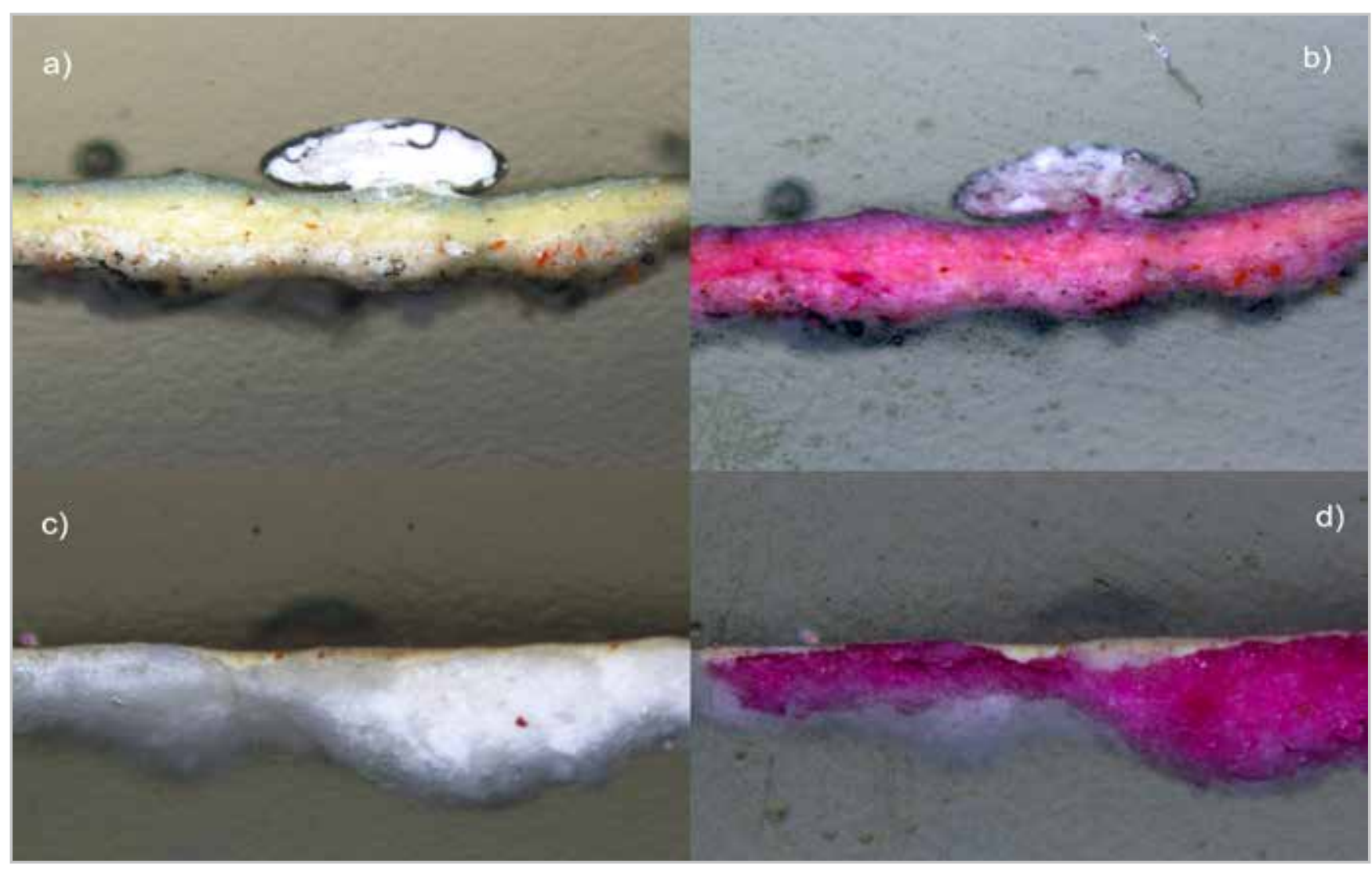

Figura 8.-Observación por MO de la muestra LQM-4 (50X): (a) antes (b) después de la tinción con fuschina ácida. Los resultados son positivos en todas las capas (preparación y capa pictórica). Muestra LQM-3 (50X) correspondiente a un repinte (c) antes y (d) después de la tinción con fuschina ácida con resultado positivo en la tinción de la capa de preparación unicamente.

Los ensayos de tinción para el estudio del aglutinante con fuschina ácida han sido positivos si se exceptúa la capa pictórica del repinte, como se puede apreciar en la Figura 8.

El resultado negativo en la tinción con fuchina de la muestra de repinte podría llevar a pensar en la presencia de un aceite secante en esta capa. Sin embargo, los análisis realizados mediante GCMS no han permitido confirmar la presencia de este tipo de aglutinante. Según se recoge en la tabla 3 y en las figuras 9 y 10.

Tabla 3.- Resultados de los análisis GC-MS

\begin{tabular}{|c|c|c|c|c|c|c|}
\hline Muestra & $n^{\circ}$ pico & $\begin{array}{c}\mathrm{t}_{1} \\
\text { (minutos) }\end{array}$ & $\mathrm{m} / \mathrm{z}$ & $\begin{array}{l}\text { Especie } \\
\text { quimica }\end{array}$ & area pico (9) & Relación P/S \\
\hline \multirow{2}{*}{ LQM-3 } & 1 & 11,902 & $74,87,143$ & $\mathbf{P}$ & 39,60 & \multirow{2}{*}{0,65} \\
\hline & 6 & 14.573 & $74,87,143$ & E & 60,40 & \\
\hline \multirow{2}{*}{ LQM-9 } & 1 & 11,925 & $74,87,143$ & $P$ & 40,12 & \multirow{2}{*}{0,67} \\
\hline & 6 & 14.595 & $74,87,143$ & $\mathrm{E}$ & 58,88 & \\
\hline \multirow{2}{*}{ LQM-12 } & 1 & 11,911 & $74,87,143$ & $P$ & 41,03 & \multirow{2}{*}{0,69} \\
\hline & 6 & 14.581 & $74,87,143$ & E & 58,97 & \\
\hline
\end{tabular}

P: ácido palmítico

E: ácido esteárico

tr: tiempo de retención

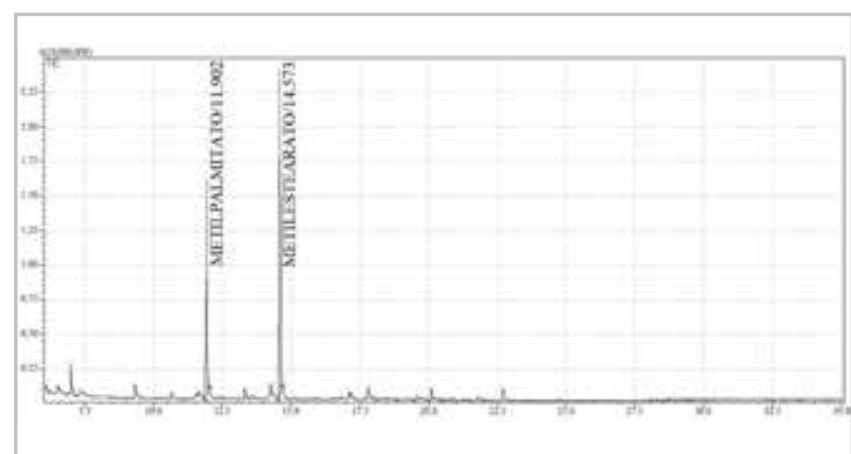

Figura 9.-Muestra LQM-3. Cromatograma correspondiente al aglutinante de la capa pictórica.

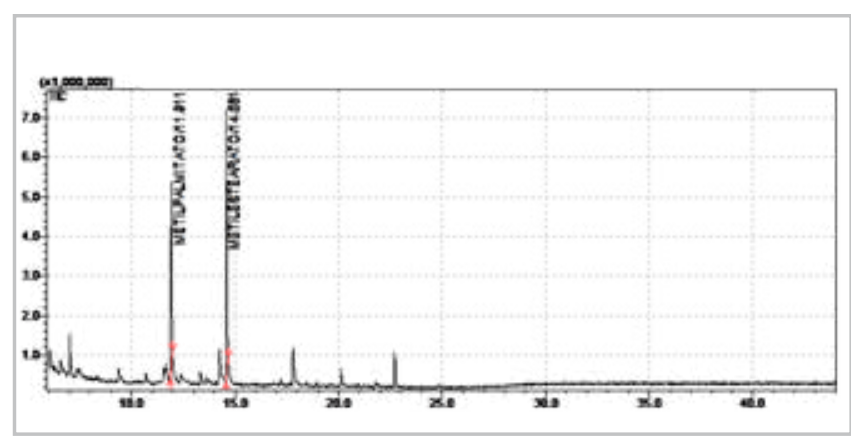

Figura 10.-Muestra LQM 12. Cromatograma correspondiente al aglutinante de la capa pictórica. 
En todos los casos, se han detectado los esteres metílicos de los acidos palmítico y esteárico, lo que nos indica la prsencia de una grasa (la cola animal contiene grasa), pero no relacionada con aceites secantes, puesto que la relación $\mathrm{P} / \mathrm{S}$ es muy inferior a la que corresponderia a una aceite secante [2]. Además, la ausencia del pico correspondiente al éster metílico del ácido azeláico, igualmente confirma que no existe un aceite secante ya que este ácido se forma durante el proceso de secado de este tipo de aceites

El cromatograma y las características de los picos identificados [Figura 10] indican que no se trata de un aceite secante.

A partir del conjunto de los resultados obtenidos, se puede interpretar que la técnica pictórica utilizada para pintar la obra es un temple. Probablemente se trate de un aglutinante protéico en el caso de la pintura original mientras que, en lo que respecta a los repintes, podría tratarse de una goma.

\section{Conclusiones}

El estudio analítico de la pintura del techo del teatro Vicó de Jumilla ha contribuido al conocimiento de los materiales y técnica de trabajo empleados en las pinturas al temple sobre lienzo del siglo XIX. Se ha constatado que en algunas zonas la capa pictórica impregna profundamente el soporte textil y que no se aprecia preparación en un gran número de muestras; de esta manera se limitarían las pérdidas de pintura, durante el proceso de ejecución y su colocación en su emplazamiento definitivo.

En las zonas en las que existe preparación ha sido identificado carbonato cálcico de origen natural (creta) como componente mayoritario. Este también también ha sido detectado en la capa pictórica. La existencia de preparación puede tener relación con la intención de dar luminosodad a la pintura y minimizar el efecto del color del soporte.

Por otra parte, se apunta hacia el empleo de cola animal como aglutinante, tanto en la capa pictórica como en la preparación, manteniendo así una técnica tradicional para este tipo de trabajos.

En la relación de pigmentos utilizados, destaca el uso de numerosos pigmentos modernos, sintetizados $y$ comercializados algunos en el siglo XVIII, como el azul de Prusia y el amarillo Turner, y otros en el siglo XIX, como el blanco de bario, amarillo de cromo y verdes de arseniato de cobre, Schweinfurt o Scheele. Con esto se desmuestra que Sanmiguel utilizó en la ejecución de esta obra pigmentos artísticos novedosos.

\section{Agradecimientos}

Esta investigación ha sido financiada por el contrato de investigación firmado con la empresa Lorquimur al amparo del Art. 83 de la L.R.U, y a quienes las autoras agradecen la información suministrada. Tambien agradecen el soporte económico del Proyecto TopHeritage-CM (S2018/NMT-43724) y el apoyo del el CNME (Centro Nacional de Microscopía Electrónica) de la Universidad Complutense de Madrid. Los análisis de cromatografía de gases-espectrometría de masas han sido realizados en el Laboratorio de Materiales del Instituto de Patrimonio Cultural del España (IPCE) con el equipo SHIMAZU QP5050A El.

\section{Notas}

[1] Por ejemplo, Camilo Bellanger, en su obra traducida del francés en 1899 Manual de pintura al alcance de todo el mundo se refiere a la mezcla de yeso y carbonato cálcico con cola de pescado en las preparaciones de los lienzos (si bien el ejemplo se refiere a la pintura al óleo).

[2] Por ejemplo en el caso del aceite de linaza: $\mathrm{P} / \mathrm{S} \sim 1,4-2,0$.

\section{Bibliografía}

ARAGONESES, J. (1964). Pintura decorativa en Murcia. Siglos XIX y $X X$. Murcia: Diputación Provincial de Murcia.

AROLA, F. (1920). Escenografía. Barcelona: Calpe.

BELLANGER, C. (1899). Manual de pintura al alcance de todo el mundo. (trad. franc. By E. Zamacois). París. Garnier Hermanos, Libreros-Editores

BERRIE, B. H. (1997). "Prussian Blue". En Artists'Pigments, A Handbook of their History and Characteristics, E.W. Fitzhug (ed.). Vol. 3. Oxford: Oxford University Press, pp.191-217.

CALVO, A. (2002). Conservación y restauración de pintura sobre lienzo, Barcelona: Ediciones del Serbal.

CATALÁN, M. S. (2003). La escenografía de los dramas románticos españoles (1834-1850). Zaragoza: Prensas Universitarias de Zaragoza. Zaragoza.

DE LA HOZ, J., CAÑADAS, P., PÉREZ, J, DE LA HOZ, L, CAÑADAS, M. (2011). "Restauración de Cubiertas y Fachadas. Teatro Vicó. Jumilla". En XXII Jornadas de Patrimonio Cultural de las Region de Murcia, Melgares, J. A., Collado, P. E., Bascuñana, J. A (coord..). Murcia. Ed. Tres Fronteras. Consejería de Cultura y Turismo, pp. 259-274.

DU PUY DU GREZ, B. (1700). Traité sur la peinture pour en apprendre la theorie \& le perfectonnerdans la pratique, (1 a ed. de 1699, París). París : Florentin et Pierre Delaulne.

EASTAUGH, N, WALSH, V, CHAPLIN, T, SIDDALL, R. (2004). Pigment Compendium. A dictionary of Historical Pigments. Oxford: Elsevier Butterworth-Heinemann. 
FIELD, G. (1841): Chromatography or a Treatise on Colours and Pigments: and of their Powers in Painting (new edition improved), Tilt and Bogue, London.

GARCÍA,M. (2013). "Oficios del pintor en el siglo XIX" en María del Carmen Lacarra (Coord.): Arte del siglo XIX, Zaragoza: Institución Fernando el Católico.

HILER, H. (1970). The Painter's Pocket-Book of Methods and Materials. London: Faber \& Faber, 1975.

MANAUT, J. (1959). Técnica del arte de la pintura o Libro de la pintura. Madrid: Dossat.

MOYNET, M. J. (1999). Elteatro pordentro; maquinariay decoraciones. ( $1^{\text {a }}$ ed. 1873 vers. esp. de Cecilio Navarro de 1885. Primera ed. facs.). Madrid: Asociación de Directores de Escena de España.

MUÑOZ, A. (2018). La conservación de bienes culturales en Murcia en el S XIX.Tesis Doctoral. Universidad de Murcia. Escuela Internacional de Doctorado. Disponible en: https://digitum. um.es/.../Amparo\%20Muñoz\%20Fernández\%20Tesis\%20 Doctoral.pdf [Consulta: 24-07-2019].

PERNETY, A. J. (1757). Dictionnaire protatif de peinture, sculpture et gravure. París: Libraire, Quai des Augustins, à SainteGenevieve, $\&$ à S Jean dans le Désert.

PISAREVA, S. (2005). Some Occurrences of Patent Yellow, Studies in Conservation, 50, pp. 33-36.

RADIGALES Y BABI, J. (1998). Els orígens del gran teatre del Liceu (1837-1847). Barcelona: Publicacions de I’Abadia de Montserrat.

RUSSELL, C. A. (ed.) (2000). Chemistry, Society and Environment. A New History of the British Chemical Industry, England: The Royal Society of Chemistry.

SAN ANDRÉS, M., SANCHO, N., DE LA ROJA, J. M. (2010). "Alquimia. Pigmentos y Colorantes Históricos", Anales de Química, 106, pp.58-65.

SAN ANDRÉS, M. (2010). "Química Moderna y Producción de Nuevos Pigmentos". En Fatto d'Arquimia. Historia $e$ identificación de pigmentos artificiales en las técnicas pictóricas. Madrid: Secretaría General Técnica. Subdirección General de Publicaciones, Información y Documentación (Ministerio de Cultura), Madrid, pp.27-54.

SANTOS, S. (2017). “Las sargas y otros modos de temple: estudio comparativo experimental", revista ph, 92, pp. 192-209.

VERNON-SMITH, H. (2013). "The changing practice of scenic painters in England". En Setting the scene, Costaras, N, Young, (eds.). Plymouth: Archetype Publications, pp. 92-98.

WATIN, J. F. (1793). L' art du Peinture, Doreur, Vernisseur, (first ed. 1772). Quatrieme édition. París:ChezL`Auteur, rue Sainte-Apolline.

\section{Autor/es}

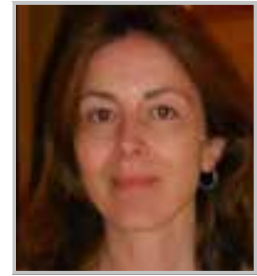

\section{Sonia Santos Gómez}

soniasantos@ucm.es

Facultad de Bellas Artes. UCM

Doctora por la Universidad Complutense de Madrid con la tesis doctoral: Las preparaciones de yeso en la pintura sobre tabla de la Escuela Española. Ha desarrollado una triple labor como docente, investigadora y profesional en el ámbito de la conservación de bienes culturales. Desarrolla su labor docente en la Facultad de Bellas Artes de la Universidad Complutense de Madrid. En el campo de la conservación-restauración, ha trabajado en diferentes instituciones, entre las que se encuentran Patrimonio nacional, obispados, ministerios y museos. Ha desarrollado su actividad investigadora a través de diferentes proyectos de investigación financiados. Fruto de todo ello son la publicación de libros, artículos y participación con ponencias en congresos: Santos, S. (2015), El yeso: Su elaboración y empleo en la pintura y dorado de retablos, Almería: Círculo Rojo; Santos, S., (2017), La Conservación del Arte Contemporáneo: Criterios y metodologías de actuación en obras configuradas con nuevos materiales, Oviedo, ed. Trea; Santos, S., San Andrés, M. (2004): "La pintura de sargas" Archivo Español de Arte, CSIC, t. LXXVII, no 305, Enero-Marzo 2004, 59-74.; Santos, S. (2019): Nuevas aportaciones sobre la temática y utilidad de la pintura de sargas, Goya, 369, pp. 294-305.

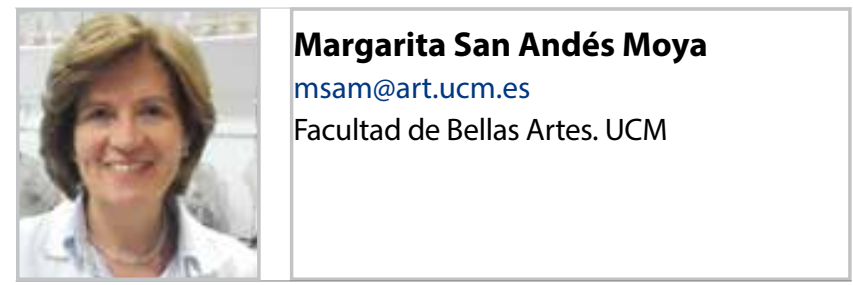

Dra. en Ciencias Químicas por la UCM y Profesora Titular (acreditada a Cátedra) del Departamento de Pintura y ConservaciónRestauración de la Facultad de Bellas Artes. Su actividad docente e investigadora se centra en la aplicación de las ciencias experimentales en el estudio material del patrimonio cultural, su conservación y restauración. Es coautora de 150 publicaciones y 5 patentes. Ha participado en 20 Proyectos de investigación, en 12 como Investigadora Principal. Es Directora del Grupo de Investigación UCM "Técnicas de Documentación, Conservación y Restauración del Patrimonio". Es Directora del Laboratorio de Materiales de la Facultad de Bellas Artes, certificado bajo norma ISO 9001:2015 e integrado en la Red de Laboratorios e Infraestructuras de la Comunidad de Madrid (Lab 397). Ha dirigido 10 Tesis Doctorales. Desde el 2011 es miembro electo representante del nodo de Universidades de la Comisión Ejecutiva de la Red de Excelencia TechnoHeritage. Ha sido Vicerrectora de Extensión Universitaria y Secretaria Académica de la Facultad de Bellas Artes de la UCM. Actualmente es Vicerrectora de Investigación y Transferencia de la UCM 


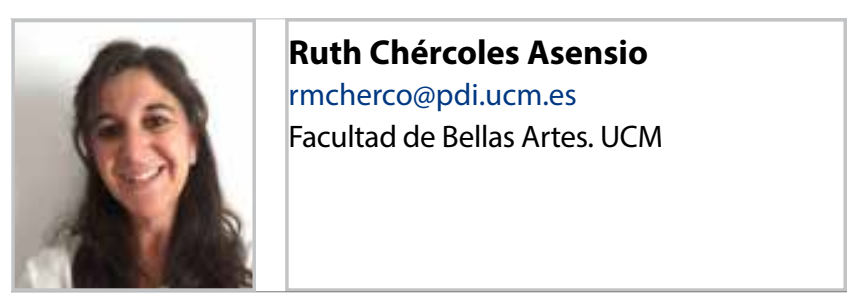

Licenciada en CC. Químicas y Doctora en Bellas Artes de la UCM, Master de Restauración y Rehabilitación de Patrimonio Histórico de la Universidad de Alcalá de Henares. Profesora en el Grado de Conservación y Restauración de la Facultad de Bellas Artes de la UCM y Responsable de Calidad del laboratorio de materiales de la Facultad de Bellas Artes de la UCM, incluido dentro de la Red de laboratorios e Infraestructuras de la Comunidad Autónoma de Madrid. Su actividad investigadora, docente y profesional está vinculada a la Conservación y Restauración del Patrimonio Cultura desde hace 13 años, especializandose en el estudio de propiedades, comportamiento y técnicas de análisis aplicadas a materiales del patrimonio cultural. Su labor investigadora en los últimos años se centra en la caracterización de polímeros utilizados en conservación y restauración y el estudio de su comportamiento físico y químico aplicando ensayos de envejecimiento artificial.

Artículo enviado el 25/07/2019 Artículo aceptado el 05/12/2019 
Suplemento: Arte urbano y museo. Competencias e (in)compatibilidades 


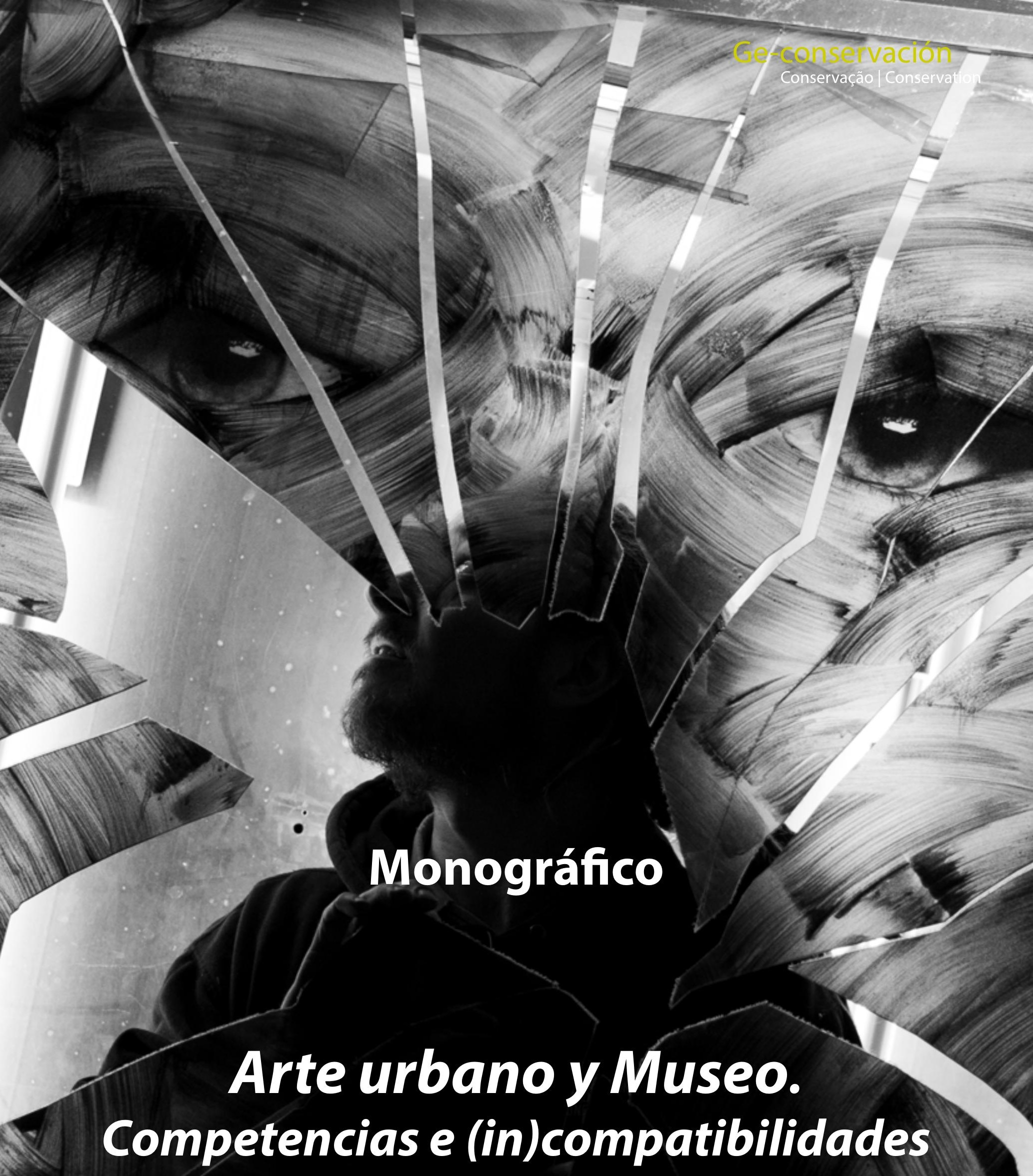

\section{Arte urbano y Museo.}




\section{Índice}

Páginas

\section{Suplemento: Arte urbano y museo. Competencias e (in)compatibilidades}

\section{Presentación}

Elena García Gayo (Coord.)

\section{Prólogo}

Susana Blas Brunel

Galerías, casas de subasta y urban art: evolución y paralelismos en las prácticas de arte independiente

Rita Amor García.

Arte urbano expuesto: procedencia y contenido

Elena Calderón Aláez

"Viral Mural", entre el muralismo y los espacios virtuales.

Carla Coluccio

El "espacio intermedio" del arte urbano

Elena García Gayo

Berlín: todo un paradigma en el pasado, presente y futuro del arte urbano.

Sandra Gracia Melero

Identidad e imagen de la ciudad contemporánea: los museos de arte urbano

Laura Luque

(Des)localizaciones y contexto. La transición del arte urbano, desde la calle hasta su exhibición en centros de arte

Esteban Marín

La postura del artista ante los museos de arte urbano en el contexto latinoamericano

Ana Lizeth Mata Delgado

Arte público, ciencia y patrimonio en el entorno rural: el caso de Murales Conciencia

Diego Ortega, Juan Jesús Padilla

Museizar el arte urbano. Preguntas, relatos y complejos tras Street Art-Banksy \& Co

Jordi Pallarès

Repensando el arte público. New York City's Percent For Art Program

Sergio Pardo

Arte Urbano en colecciones públicas y privadas: intervenciones de artistas urbanos en el fondo de arte de la Universitat Politècnica de València

Mercedes Sánchez Pons

Museos de Arte Urbano. Estado de la cuestión

Rosa Senserrich-Espuñes, Elena García Gayo 
hipervisibilidad y "descaro" en la alianza con instituciones, marcas comerciales, negocios inmobiliarios y procesos de turistización de las ciudades, es el fenómeno que, en mi opinión, con toda su crudeza revela más claramente la colaboración generalizada entre la cultura y el poder económico. El arte urbano al menos inventa continuos modos de subversión de esas paradojas escondidas en las artes tradicionales (las bellas artes, la literatura, la ópera o el teatro) detrás del prestigio de la tradición.

\section{Un cambio de paradigma que excede el arte urbano}

Me atrevería a decir que "el arte urbano", en todo su caos y heterogeneidad (acogiendo lo legal, lo ilegal, lo público, lo privado, lo amateur y lo profesional), es de las pocas expresiones artísticas que pone en jaque al museo y a la institución y les hace plantearse su propia esencia. La confrontación entre lo viejo y lo nuevo no solo dice a los centros de arte urbano "lo que les falta para devenir museo", también revela a la institución tradicional "lo que le ha dejado de funcionar" y que sí consigue hacer el arte urbano, por ejemplo, la conexión con el público joven y en concreto con los nativos digitales, que serán la audiencia del futuro.

Porque no nos engañemos, el problema de la "musealización" del arte urbano no estriba en que es obra efímera (cualidad ya resuelta desde hace tiempo en la museografía para el caso de las artes vivas, presentadas de diversas maneras: con documentación, con vestigios, con un aparato discursivo adecuado, etc.), o en la dificultad de trabajar con el muralismo (desarrollado ampliamente por los museos de Historia Antigua y por la arqueología). La novedad que aporta el arte urbano es que ni sus obras ni sus autores se dejan adaptar tan fácilmente a las fórmulas existentes con las que trabajan tanto las instituciones de arte contemporáneo como la Academia que regula los discursos que legitiman la creación.

Quizás la dificultad estriba en cómo acomodar al "relato" existente una práctica heterogénea que pervierte tantas cosas: el concepto de estilo, de técnica, de movimientos artísticos..., en definitiva: que trastoca la rígida idea de tiempo consolidada por el arte de los museos: un modelo occidental, paternalista, patriarcal, racista, machista y colonial, centrado en la historia de los objetos y en sus discursos asociados, con el que el arte urbano tiene poco que ver en su heterodoxia. De esta divergencia puede surgir la asociación con la circularidad, lo outsider, lo ancestral, y sus lazos con el arte popular, el diseño, la música, la artesanía y la marginalidad. Esta disonancia es responsable en buena medida de las dificultades y reticencias que encuentran tanto el Museo como la Academia para absorberlo; de ahí que resulte admirable la energía salvaje que a pesar de todo siguen atesorando estas obras.

\section{Virtualización, recesión económica y vida tecnológica}

Otro aspecto que se transparenta de diferentes maneras en los ensayos que vamos a leer es el papel crucial que juega internet en la construcción de estas prácticas urbanas, no solo para su difusión, también para su propia elaboración y procesos. Y en ese sentido me gustaría señalar el año 2008 como una fecha de encrucijada en la que confluyeron razones tecnológicas, políticas y económicas que propusieron un nuevo panorama. Considero que, al igual que 1989 fue un año clave en la contemporaneidad por confluir en él dos elementos que cambiaron nuestro mundo: el nacimiento de la web y la caída del muro de Berlín (abandonando nuestros destinos al neoliberalismo más radical), 2008 fue otra "fecha llave", pues también en esta ocasión se combinan transformaciones económicas y de modos de vida, e innovaciones técnicas cruciales. 2008 es el año de la Gran Recesión mundial y de la depresión económica española, y también la fecha en la que el usuario incorpora a su cotidianidad las redes sociales, que permiten compartir imágenes y pensamiento libremente y con el tiempo crear hábitos, conocimiento y memoria. Esta confluencia tecnológica y económica coincide con la explosión del arte urbano. No por casualidad, en 2008 se produce también uno de los grandes eventos de legitimación institucional de este movimiento: la exposición "Street Art" en el museo Tate Modern de Londres en 2008; la primera exposición temporal de este carácter realizada en un museo público.

La crisis económica, la burbuja inmobiliaria y las políticas de austeridad (que propiciarán el empobrecimiento y la pérdida de derechos sociales de la población), y el uso cotidiano de las tecnologías por parte de productores y receptores (artistas y audiencia) transformaron el modo de sentir y de producir cultura, y es el público de este nuevo contexto con el que los museos del futuro deben trabajar. Hablamos de una audiencia interesada por la imagen en movimiento, por la cultura visual en sentido amplio y que practica un "curioso" activismo en el que el consumo y la crítica al sistema conviven. Una audiencia que concebirá los museos de forma tecnológica y presencial como ya hacen los niños con sus juegos (virtuales y reales) sin el menor problema.

Quizá si el público joven conecta con el arte urbano, mientras el arte clásico se esconde en su torre, no es por la superficialidad y la incoherencia de lo urbano, sino porque "el arte urbano" vive con fluidez las paradojas de nuestra sociedad esquizofrénica que compagina hedonismo y protesta, activismo y pragmatismo, virtualidad y presencia, y a la que hay que buscarle las grietas como tan bien hace el arte urbano en su "asalto a los museos" y en "saltarse la Academia".

\section{Susana Blas Brunel}

Comisaria e historiadora de arte contemporáneo 

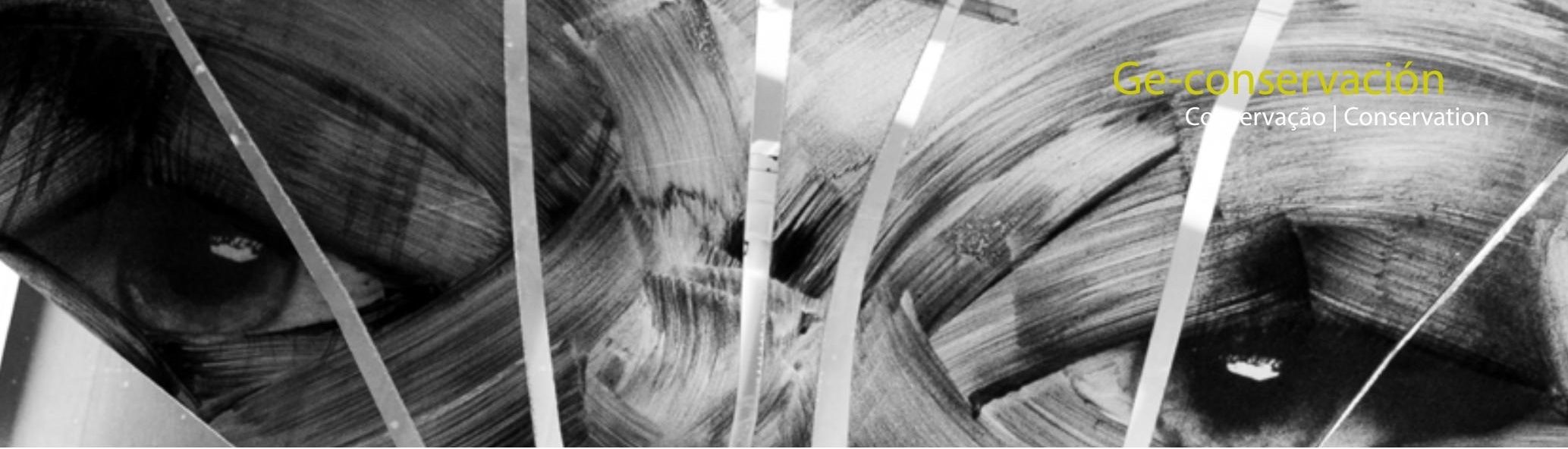

\title{
Galerías, casas de subasta y Urban Art: evolución y paralelismos en las prácticas de arte independiente
}

\author{
Rita Lucía Amor García
}

Resumen: Con la expansión de las prácticas de arte público independiente y su reconocimiento como arte accesible y cercano al público, sus formas se introdujeron y expandieron en entornos tradicionales como las galerías. Con ello, el mercado del arte tomó una importante posición al aceptar dentro de su repertorio obras vinculadas al grafiti y al Street Art (arte urbano). Este arte de origen independiente encontrado actualmente en sectores institucionalizados es lo que se conoce internacionalmente como Urban Art.

A efectos históricos, el nacimiento, evolución y traspaso de fronteras entre las prácticas en espacio público y su inclusión en la galería, son hechos cercanos entre sí y relativamente recientes. Aun así, mucho ha ocurrido desde la celebración de las primeras exposiciones en los años 70 del siglo XX hasta la actualidad. Este artículo hará un recorrido de ese periodo, presentando cómo ha repercutido la inclusión de obras de escritores de grafiti y artistas urbanos dentro del mercado del arte y con ello, en su conservación.

Palabras clave: subasta, arte urbano, grafiti, Urban Art, galerías, arte público independiente, mercado, arte

\section{Art Galleries, auction houses and urban art: evolution and parallelisms in independent art practices}

Abstract: With the expansion of independent public art practices and their recognition as accessible and acceptable to the public, their forms were introduced and expanded into traditional environments such as galleries and auction houses. Consequently, specialists, gallerists and auctioneers recognised the commercial potential of these works, and accepted graffiti and street art within the contemporary art market repertoire. This originally independent art currently found in the private sector is what is known internationally as "Urban Art".

Historically, the birth, evolution and crossing of borders of practices from public spaces to their inclusion in galleries are relatively recent events. However, much has occurred from the first exhibitions of the 1970s to the present day. This article will look at everything that has happened since then, showing how the inclusion of works by graffiti writers and street artists in the commercial art market has influenced the art and its conservation.

Key words: auction, street art, graffiti, urban art, galleries, independent public art, art-market

\section{Introducción}

Desde las primeras muestras de grafiti en el metro de Nueva York a finales de los 60 y principios de los 70 del siglo XX (Castleman, 1982: X), seguida de su rápida expansión en otros soportes de la ciudad y la ampliación de fronteras en la exposición y accesibilidad de éste junto al arte urbano en los 80 (Schacter, 2013: 16), los movimientos de arte independiente han tomado posesión del espacio público como el lugar y soporte donde estas formas de arte se crean, desarrollan, exponen y conviven.
El arte localizado en estos entornos se denomina arte público independiente (Abarca Sanchis, 2010: 39-44) y está liderado por los movimientos del grafiti y el street art o arte urbano [1]. Ambas formas con estilos paralelos el uno del otro, han empleado el espacio público como lienzo en blanco, un perfecto soporte para exponer gratuitamente conceptos y formas a los diferentes públicos. En cualquier caso, la relación de sus trabajos con el público puede variar dependiendo de la accesibilidad a la obra, la intencionalidad del artista, el interés del público o simplemente, el mensaje expuesto y su vinculación al entorno. 
El empleo de la calle de forma libre por los artistas no supone la limitación de su práctica artística en un único entorno. Al igual que los artistas emplean cualquier soporte o parte del mobiliario urbano en el espacio público, participan en eventos organizados vinculados al grafiti como Meeting of Styles (festival celebrado internacionalmente y centrado en el grafiti mural desde 1997) (Gerullis, 2013: 5-7), u otros eventos con escritores de grafiti y artistas urbanos como The Wynwood Walls en Miami (Wynwood Walls, 2019), Upfest en Bristol (Upfest, 2019) o Nuart en Stavanger y Aberdeen (Nuart, 2019); sus fronteras también se expanden abarcando espacios privados. Es de este modo como artistas vinculados al grafiti y el arte urbano hacen uso, al igual que otros artistas contemporáneos, de espacios más tradicionales o institucionalizados, y sectores comerciales, para exponer su obra. [figuras 1y 2]

\section{Primeras exposiciones en galerías}

Entre los años 70 y 80 del siglo $X X$, y al mismo tiempo que el grafiti se desarrollaba en Nueva York y se expandía por EEUU y Europa, se celebraron las primeras exposiciones vinculadas con el movimiento y sus practicantes. En algunos casos promovidas por asociaciones relacionadas

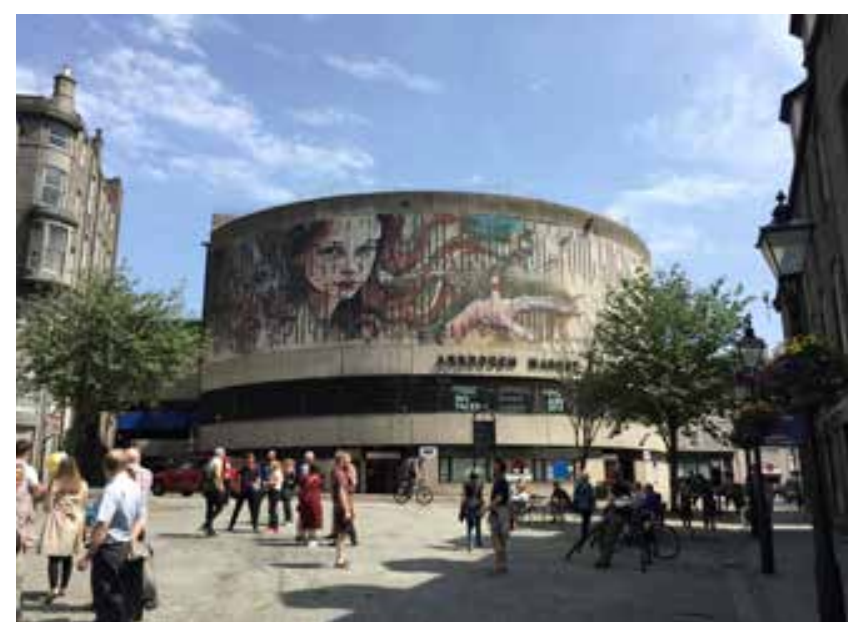

Figura 1. Intervención de Herakut en Nuart, Aberdeen, edición 2017.

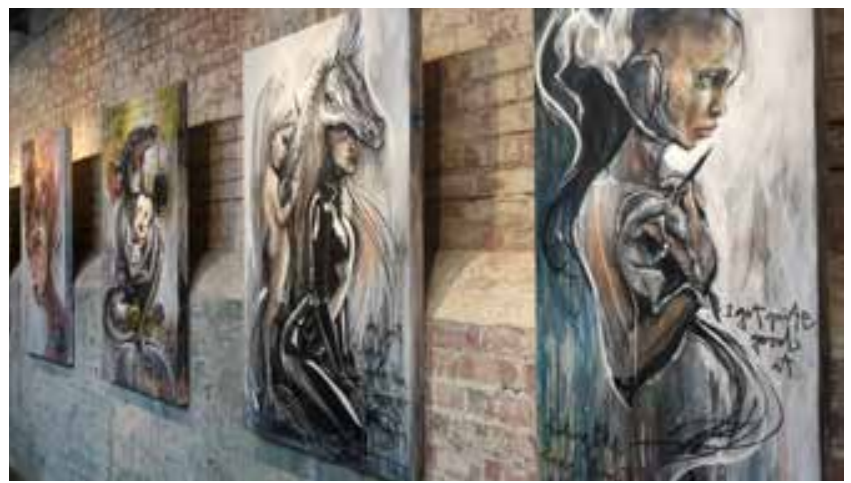

Figura 2. Exposición de Herakut en StolenSpace Gallery, Londres, 2017. con los escritores de grafiti y en otros casos, por galeristas externos que apreciaban lo que estaba sucediendo en las calles de Nueva York.

Por un lado, la organización de asociaciones de escritores de grafiti como United Graffiti Artists (UGA) y Nation of Graffiti Artists (NOGA), surgidas en 1972 y 1974 respectivamente, ayudó en la entrada a escritores de grafiti en círculos artísticos convencionales. Los objetivos de estas asociaciones eran: descriminalizar la práctica, ayudar a aquellos practicantes en entornos de exclusión social, fomentar la práctica artística entre los mismos y proveer un medio en el que dar a conocer sus obras al público. Todo ello mediante la organización de grupos, eventos y medios de difusión. En general, agrupaban a escritores que habían mostrado su potencial artístico en las calles, al mismo tiempo que los ayudaban en su producción en otros entornos, como los estudios de artista.

Por otro lado, fuera de esas asociaciones con fines creativos y de difusión, también se organizaron exposiciones que contaban con escritores de grafiti y otros artistas independientes que no trabajaban directamente con asociaciones. La primera exposición que reunía escritores de grafiti es la Razor Gallery del SoHo en septiembre de 1973, seguida de la Detective Show en 1978, una exposición al exterior de artistas procedentes de prácticas callejeras (Lewisohn, 2009: 15). Pero no fue hasta 1981 cuando se realizó otra exposición con el título Street Art, organizada por el Washington Project of the Arts, como otro intento de reunir "artistas trabajando puramente en el entorno urbano e ignorados por la institución del arte" (Lewisohn, 2009: 93). Y, la exposición, Post-graffiti en 1983, que presentaba a artistas trabajando "más allá del grafiti" (Janis y Neumann, 1983) incluyendo a Keith Haring que, aunque externo al grafiti (Gablik, 1982), sus intervenciones en el espacio público y el metro de Nueva York se consideran precursoras del arte urbano que conocemos hoy en día (Lewisohn, 2019: 94-96) [figura 3].

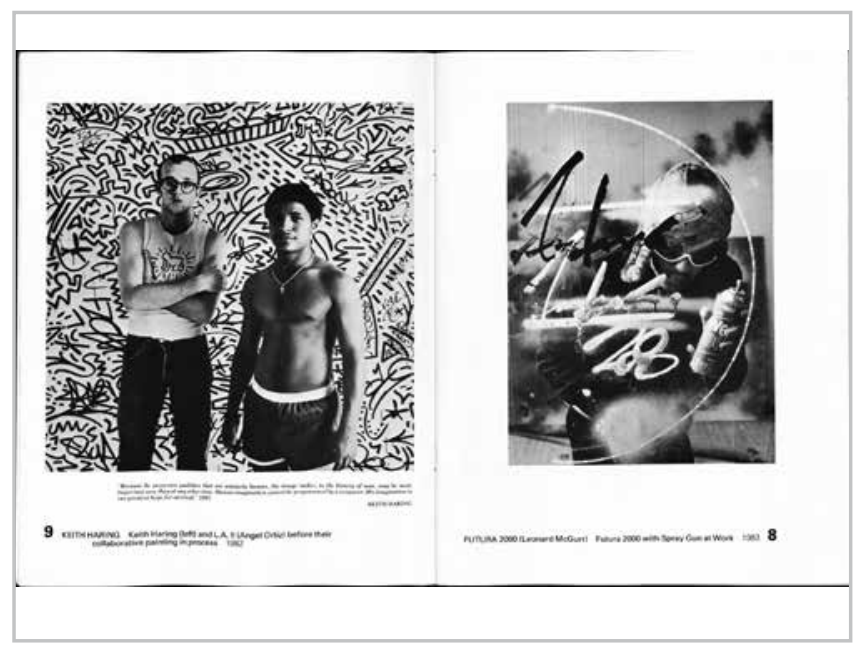

Figura 3. Catálogo de exposición Post-graffiti. 
De este modo fue como el mundo del arte abrió camino a algunos artistas que, con una corta carrera a nivel temporal -pero completa a nivel práctico en el grafiti generalmente-, buscaban nuevas maneras en la difusión de su arte. Ellos encontraron su forma de expresión plástica y utilizaron lo aprendido en las calles, y lo que consideraban su marca (su estilo), para forjarse una profesión como artistas. Al mismo tiempo, estos eventos aportaban a los artistas cierto reconocimiento y seguridad en su trabajo, lo cual no ocurría siempre al intervenir en la calle. Al mismo tiempo, la participación en exposiciones, grupos de trabajo, así como encargos decorativos, resultaba un buen medio para sufragar y continuar su práctica artística, lo cual sigue vigente hoy en día.

Respecto al público, el interés, en un principio minoritario, fue expandiéndose poco a poco, desde un entorno cercano a sus practicantes, hacia un público más general. Y lo mismo para los galeristas y coleccionistas que veían el potencial de los escritores de grafiti y artistas. Un claro ejemplo de ésto fue Martin Wong, apasionado de esas formas de arte independiente surgidas en Nueva York, el cual recogió material sobre grafiti durante toda su vida y donó a los fondos del Museum of the City of New York en 1994 (McCormick y Corcoran, 2003: 7). Esta donación de fondos se considera la inclusión más importante de grafiti en un museo hasta la fecha. La colección fue expuesta en 2014 en el mismo museo en la exposición City as Canvas (Museum of the City of New York, 2014).

De este modo, el interés del público y el apoyo recibido por algunos artistas, fue notablemente importante en la futura consideración de sus obras, y con ello, la expansión en otros sectores expositivos.

\section{Expansión del grafiti y el arte urbano, y el surgimiento del Urban Art}

A pesar de mantenerse en el radar de ciertos especialistas, no fue hasta los años 90 cuando el arte público independiente realmente despertó interés en círculos más generales. Fue cuando las formas de arte público que recordaban al grafiti pero que mostraban diferencias en estilo y una diversidad notable en los mensajes se expandió internacionalmente. Después de muchos intentos en el uso de terminología para identificar estas formas, como post-graffiti (Abarca Sanchis, 2010: 54-56; Waclawek, 2011: 7,12,29; García Pardo, 2015: 52-54), el término street art a nivel internacional y arte urbano en España, se empleó para designar esas muestras de arte alternativo en el entorno público (Schacter, 2013: 16) que no fueran grafiti.

Entre el arte urbano y el grafiti siempre ha existido cierta vinculación, y aun hoy en día hay confusión a la hora de diferenciar ambos movimientos. Esto es generalmente debido a que muchos de los artistas urbanos comenzaron inicialmente a explorar el entorno público como escritores de grafiti (Waclawek, 2011:7), pero expandieron sus fronteras más allá de la práctica posteriormente. No obstante, hay que entender que la terminología puede variar debido a la cercanía en el tiempo, pero en parámetros generales ayuda a la diferenciación de ambos movimientos, mostrando adecuación y respeto a los artistas acorde a los principios establecidos en cada manifestación, y con ello, también con los términos o vinculaciones que cada artista decide o asume para exponer su arte en el espacio público.

El interés generado por el público está, en gran medida, provocado por especialistas y amantes de estas formas de arte alternativo y generalmente subversivo, lo cual ayudó directamente a la inclusión del grafiti y el arte urbano en el museo. Las primeras exposiciones de carácter temporal, intentaron explicar lo que estaba ocurriendo en la calle, resaltando los mensajes y la nueva dinámica de conceptos que se exponía al recuperar el espacio urbano como lugar para la muestra de arte puramente público, y donde cualquier persona podía ser partícipe del arte que se encontraba. Pero, al mismo tiempo, mientras fuentes documentales como el vídeo y la fotografía resultaban muy convenientes para exponer tales realidades en el entorno del museo, las obras expuestas dentro de éste combinaban el uso de la práctica mural con obras en caballete, láminas y esculturas, entre otras.

Uno de los eventos más importantes relacionados con este hecho fue la exposición Street Art en el museo Tate Modern de Londres en 2008. Street Art fue la primera exposición temporal de esta índole realizada en un museo público. Comisionada por el especialista en grafiti y arte urbano, Cedar Lewisohn, la exposición hacía una retrospectiva de las prácticas independientes a nivel histórico y formal, mostrando obras de artistas ya reconocidos en los movimientos, junto a obras de gran influencia para escritores de grafiti y artistas urbanos. Al mismo tiempo que en el interior del museo se exhibían obras en soporte móvil, la fachada principal del edificio mostraba las obras murales de cinco artistas internacionales: Blu, Faile, JR, Nunca, Os Gemeos y Sixeart (Tate Modern, 2008ab). Además, como guiño a la importancia de la exposición en el panorama artístico del momento, entre 2008 y 2009 , el grafiti como movimiento y el nombre de escritores originarios de éste, como Taki 183, Blade, Seen y Lee Quiñones, fueron introducidos dentro de la línea temporal de movimientos del arte moderno y contemporáneo diseñada por Sara Fanelli. [figuras 4 y 5]

El siguiente evento, mayor en obra y en artistas participantes, fue la exposición Art In The Streets en el Museum of Contemporary Art de Los Angeles (MoCA) en 2011. Esta exposición fue comisionada por el director del museo Jeffrey Deitch junto a los especialistas Roger Gastman y Aaron Rosepor. En ésta, el recinto de exposiciones The Geffen Contemporary at MoCA en 


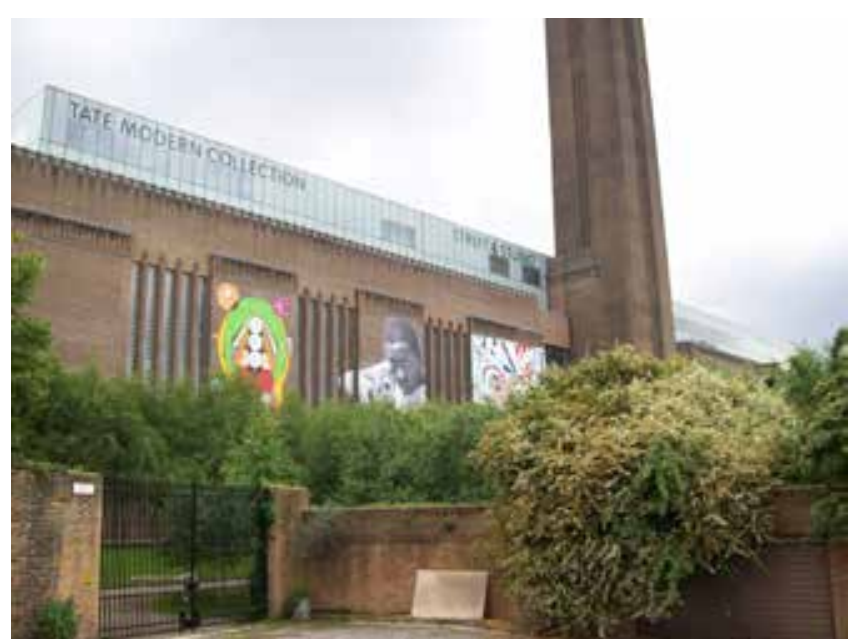

Figura 4. Fotografía de las intervenciones en la fachada de la Tate Modern, Mayo 2008.

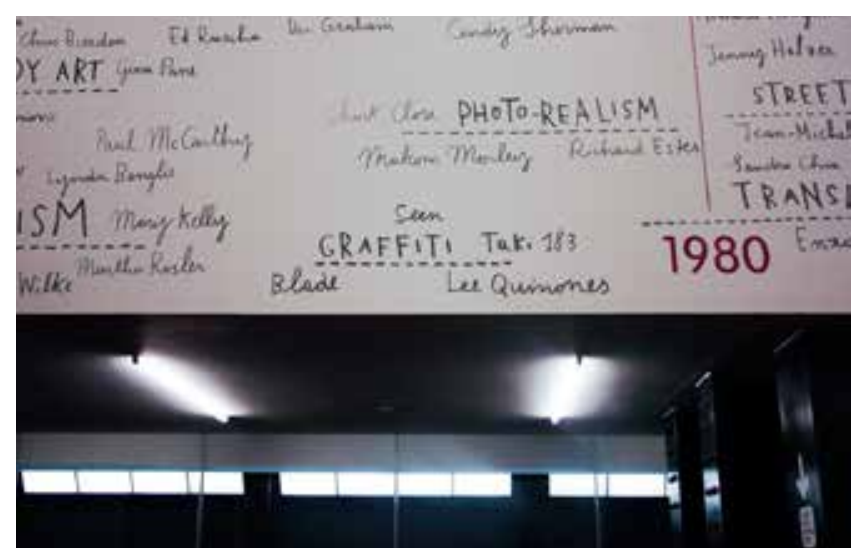

Figura 5. Fotografía de la línea temporal de Sara Fanelli, detalle grafiti.

Downtown Los Angeles reunió a un total de cincuenta escritores de grafiti, artistas urbanos y fotógrafos (MoCA, 2011).

Otras exposiciones han seguido muy de cerca estos eventos en otros entornos, con gran magnitud y público interesado en los mismos, más allá de los museos públicos. En la actualidad son muchas las galerías especializadas, casas de subasta, ferias de arte y festivales, así como museos, los que ofrecen en su catálogo obras que se vinculan o recuerdan al grafiti y el arte urbano, pero ies correcto usar estos términos para obras realizadas específicamente para el sector privado? En parámetros generales, la diversidad de las obras con otros estilos artísticos, y específicamente, la necesidad de separar la terminología de las obras de arte público independiente de aquellas obras realizadas para sectores más comerciales, han producido el uso de términos diferenciados en cada caso. Del mismo modo que existe una diferenciación entre el grafiti y arte urbano como movimientos independientes uno del otro, también ha surgido una diferenciación terminológica en aquellas obras que aunque vinculadas a estos movimientos, se presentan fuera del espacio público. Es de este modo como el relativamente reciente término Urban art ha entrado dentro de la dinámica. Este término se emplea principalmente para identificar obras procedentes o que recuerdan al grafiti y arte urbano, o que generalmente, aunque no siempre, son realizadas por escritores de grafiti y artistas urbanos para la galería, y que en cualquier caso son accesibles exclusivamente en sectores privados (Lewisohn, 2011: 13; Young, 2014: 9).

Como consecuencia a la inclusión y expansión de obras vinculadas a prácticas de arte independiente dentro del espacio museístico, otros eventos similares han ocurrido en los últimos años. Uno de los eventos expositivos con mayor magnitud en la organización y exposición de obras del Urban art ha sido Beyond the Streets. La primera exposición vinculada a este título fue celebrada en Los Angeles en 2018, seguida por otra en Nueva York en 2019. Ambas comisionadas por Roger Gastman, esta tipología de evento reúne obras y artistas emblemáticas del grafiti, arte urbano y más allá, en casi 9300 metros cuadrados de suelo expositivos con más de ciento cincuenta artistas participantes en su segunda edición (Beyond the Streets, 2019) [figura 6].

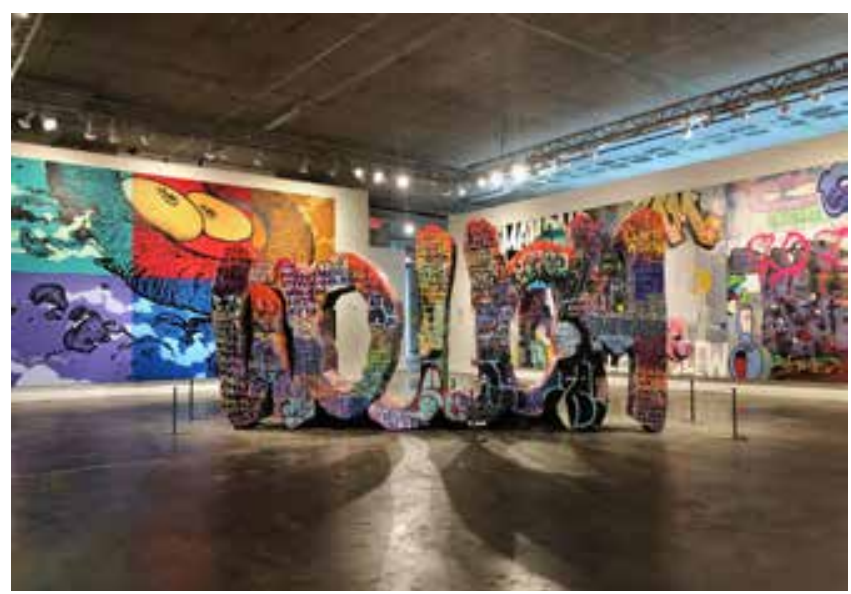

Figura 6. Exposición Beyond the Streets, en Nueva York, 2019.

\section{El artista independiente en el sector privado}

La introducción de estas formas de arte, o de los propios escritores de grafiti y artistas urbanos en tales espacios, no significa la pérdida de identidad de sus obras "libres" en entornos "normalizados" o "pseudo-institucionalizados", sino que se trata de otras obras estéticamente muy similares, pero que conceptualmente suelen mostrar diferencias. A pesar de que muchos galeristas especializados en el Urban Art animan a los artistas independientes a trasladar su arte público al sector galerístico sin limitaciones, el mercado del arte o simplemente el entorno privado puede cambiar singularmente el concepto inicial de la obra.

En muchos casos, artistas que trabajan en el espacio público libremente y en la galería, hacen distinción de su obra en cada entorno empleando diferente terminología como Wow123 - Graffiti writer/Nersatil Artist - (Genesius, 2017), o Conor Harrington - Inside/Outside - (Harrington, 
2019) entre muchos otros. El entorno de exposición supone un condicionante importante para aquellos artistas que trabajan el concepto de su obra y defienden la libertad de expresión en el espacio público, y las formas originales del grafiti y el arte urbano. En general, muchos de estos artistas hacen cambios no solo en las imágenes empleadas, sino también distinción en los mensajes expuestos o simplemente empleando una intencionalidad diferente, ya que al mismo tiempo que, en el espacio público, el espectador encuentra la obra sin una intención directa de encontrarla; en la galería, el espectador tiene una intención directa de encontrar la obra de un cierto artista. Por todo ello, la relación entre la obra y el público cambia en el momento que el entorno es diferente, y con ello el artista adapta estos parámetros en cada caso. [figura 7].

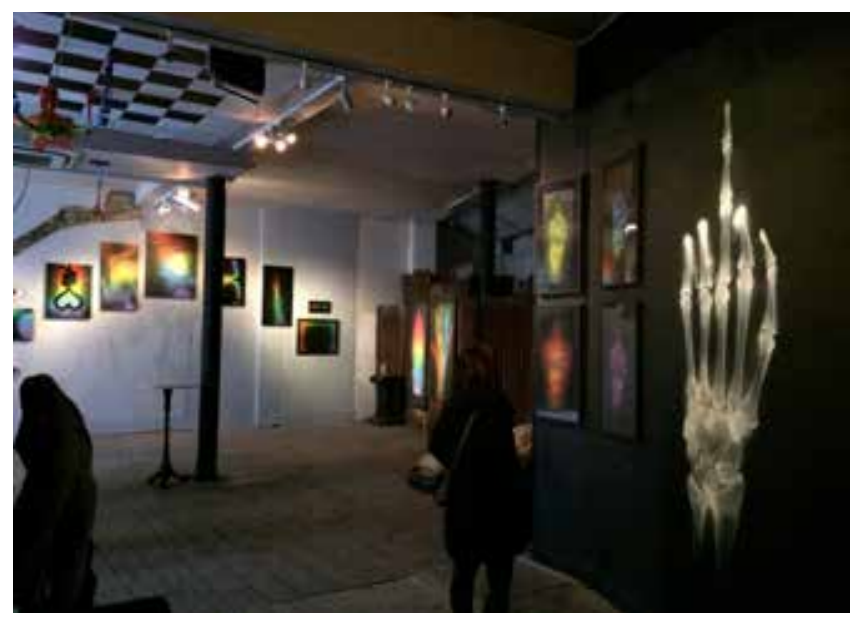

Figura 7. Exposición de Shok1 en Londres, 2013.

Respecto a la opinión de los artistas sobre su participación en exposiciones y la venta de sus obras, existen muchas diferencias y posturas. Por un lado, aquellos que focalizan su carrera en la producción artística, se presentan más abiertos a la introducción de sus obras en el mercado del arte, aceptando y defendiendo la necesidad de emplear la galería y la calle como dos espacios diferenciados. Así pues, artistas como JonOne han subrayado la importancia de tener una galería que los represente o muestre interés por su obra y señala que las galerías "intentan maximizar el potencial" de los artistas (Boujnah y Gabaret, 2015a). No obstante, y por otro lado, otros artistas como C215, reniegan parcialmente de esa necesidad, ofreciendo sus trabajos a la venta en sus propias páginas web, mostrando galerías actualizadas y abiertas a todos (Boujnah y Gabaret, 2015b).

\section{Las casas de subasta y los artistas}

Con la aceptación de obras alternativas dentro del entorno comercial, y el incremento tanto entre seguidores como en la demanda por poseer obras de ciertos artistas, las casas de subasta se introdujeron como partícipes en este intercambio. A pesar de que no hay un evento particular donde se pueda señalar el inicio de las casas de subasta tratando obras relativas al Urban art, algunas de las primeras subastas públicas con obras relacionadas datan de 2005 (Sotheby's, 2019a).

Así, la introducción del Urban Art en casas de subastas fue paulatina, con la presencia de obras puntuales en ciertas subastas mezcladas con obras de arte contemporáneo, o subastas de colecciones de arte de coleccionistas específicos. Gracias al notable interés revelado en la última década, la venta de este tipo de obras en casas de subasta ha creado mayor atención y crecimiento, no solo incluyendo obras del Urban Art dentro de este sector, sino también creando eventos específicos para la venta de las mismas. Como ocurrió con Against the Wall, dentro de la subasta Contemporary Curated celebrada en noviembre 2018, que contó con nueve trabajos donados por artistas del Urban Art, y cuyos beneficios fueron a la organización sin ánimo de lucro Movember (Sotheby's, 2018); o también, y más reciente, Banksy / Online, celebrada en septiembre de 2019, la primera venta online de impresiones exclusivamente del artista (Sotheby's, 2019b).

Igualmente y en consecuencia al incremento de interés, en la actualidad, casas de subasta como Christie's, Phillips y Sotheby's ya incluyen las obras de cierta manera vinculadas $a$ artistas alternativos o que recuerdan al grafiti y arte urbano dentro de sus departamentos de arte de posguerra, arte del siglo XX y arte contemporáneo (Christie's, 2019; Phillips, 2019a; Sotheby's, 2019c) mientras que otras las presentan independientemente con el término urban art (Chiswick Auctions, 2019; Art Curial, 2019).

Respecto a la participación de los artistas en estos eventos, su presencia es en general anecdótica y son muchos los que tras producir de forma libre en el espacio público ven la compra-venta de obras en entornos extremadamente privatizados como algo contraproducente o simplemente basado en un círculo ficticio externo a la idea romántica del arte para el deleite. Un ejemplo es Blek Le Rat, quien menciona en una entrevista para Street Art À la Française, que el incremento de los precios en las subastas es algo ficticio y en muchas ocasiones realizado de forma fortuita y algo picaresca (Boujnah y Gabaret, 2015a).

Paralelamente a las subastas de obras en papel, lienzo o esculturas y directamente realizadas bajos las expectativas del Urban Art, también existen casos de subastas de obras del grafiti y arte urbano, originalmente realizadas en el entorno público. Esto, en algunos casos, ha enfrentado notablemente el uso y la explotación de las mismas con la intención primera de las obras, la exposición y acceso libre.

El artista que ha despertado mayor revuelo en estas subastas ha sido Banksy, aunque no de forma directa. En su caso, la fama que existe detrás de su anonimato y el carácter de sus obras ha influenciado notablemente también en la venta de las intervenciones que realiza en el espacio abierto. En Reino Unido, donde ha ocurrido la mayoría de estas situaciones, se establece como lícito la compra-venta de 
obras localizadas en el espacio urbano, sin necesidad de un permiso del artista. Específicamente, la legislación señala que el dueño del edificio donde se encuentra una obra realizada sin contrato o comisión, posee los derechos de compraventa de la misma (Laker Legal, 2013). Por lo que, aunque la propiedad intelectual la posea el artista (Reino Unido, 2017), este siempre quedará en segundo lugar en esos casos, y todas aquellas obras realizadas con o sin permiso explícito sobre tales espacios, quedan al amparo del propietario.

Esto ha favorecido la venta de obras en soporte mural o esculturas, no solo por casas de subasta sino también por empresas privadas que han superpuesto el valor económico de las obras sobre cualquiera de los otros valores (artístico, histórico, social, antropológico) que las mismas pudieran tener en el espacio para las que fueron creadas. El estamento de empresas que fomentan este tipo de acciones se basa en salvar, restaurar y vender las obras para evitar el vandalismo y multas, como apunta The Sincura Group (Baxter, 2019). En general, Banksy no ha mostrado un posicionamiento reaccionario directo respecto a estas situaciones [2], pero sí que ha apoyado casos muy puntuales donde la compraventa de sus obras en el espacio público podían suponer un beneficio para la comunidad o propietarios en situaciones delicadas, como la venta de Mobile Lovers para salvar un club juvenil en Bristol (The Telegraph, 2014).

Otro caso a destacar sobre la relación de artistas independientes y casas de subasta es Stik. Este artista británico ha mostrado un gran interés y apoyo en la venta de sus obras en estos entornos, sean realizadas para su venta en sectores privados o en casos donde la obra, originalmente realizada en el espacio público de forma libre, termina en la casa de subasta y posteriormente en sectores privados, siempre y cuando los beneficios se destinen a causas sociales. Las subastas de las obras del segundo caso suelen estar apoyadas por el artista y por asociaciones con fines benéficos, como es el ejemplo de las subastas organizadas en diciembre 2016 y diciembre 2018 por Phillips Auctions, donde las obras fueron autentificadas por el artista y sus ventas aprobadas por él mismo. Los beneficios obtenidos fueron directamente a las asociaciones locales, como la subasta de la obra Magpie cuyos beneficios fueron a parar a Magpie Social Centre en Bristol (Phillips, 2019b); o la subasta de un fragmento de la obra Big Mother, cuyos beneficios fueron destinados a Artification Charity, un programa gratuito para la promoción del arte entre los residentes de Charles Hocking House en el barrio de Acton en Londres (Phillips, 2019c) [figuras 8 y 9].

No obstante, Stik ha sufrido también la apropiación de algunas de sus obras en el espacio urbano, como un caso en Hackney, Londres (Stik, 2019a), así como la aparición de dichas obras en casas de subastas, sin su aprobación (Hackney Citizen, 2019). En cualquier caso, el artista ha promovido la recuperación de tales obras, y en otros casos ha establecido acciones extremas para evitar la desaparición y venta no autorizada de las mismas, como en el caso de Gdansk, Polonia (Stik, 2019b).

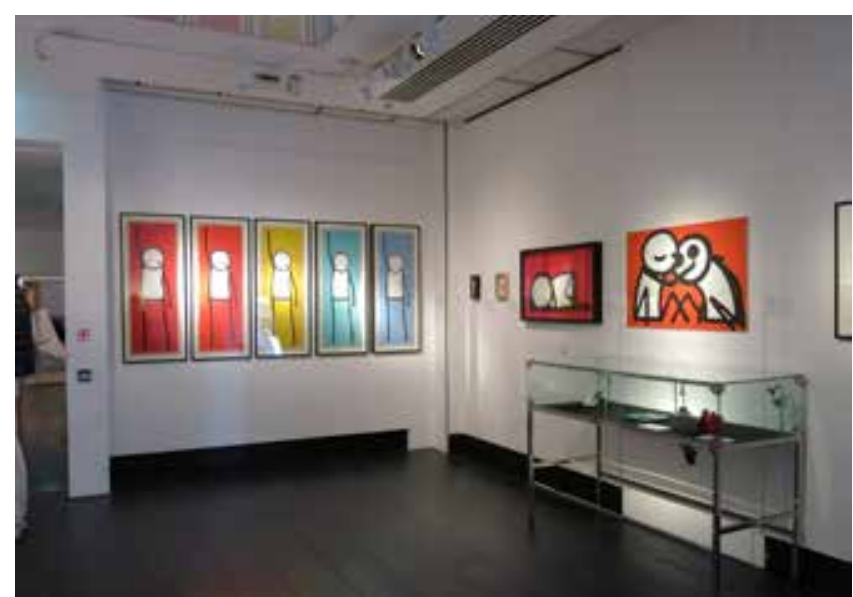

Figura 8. Obras de Stik en la subasta Prints and Multiples en Christie's, Londres, 2019.

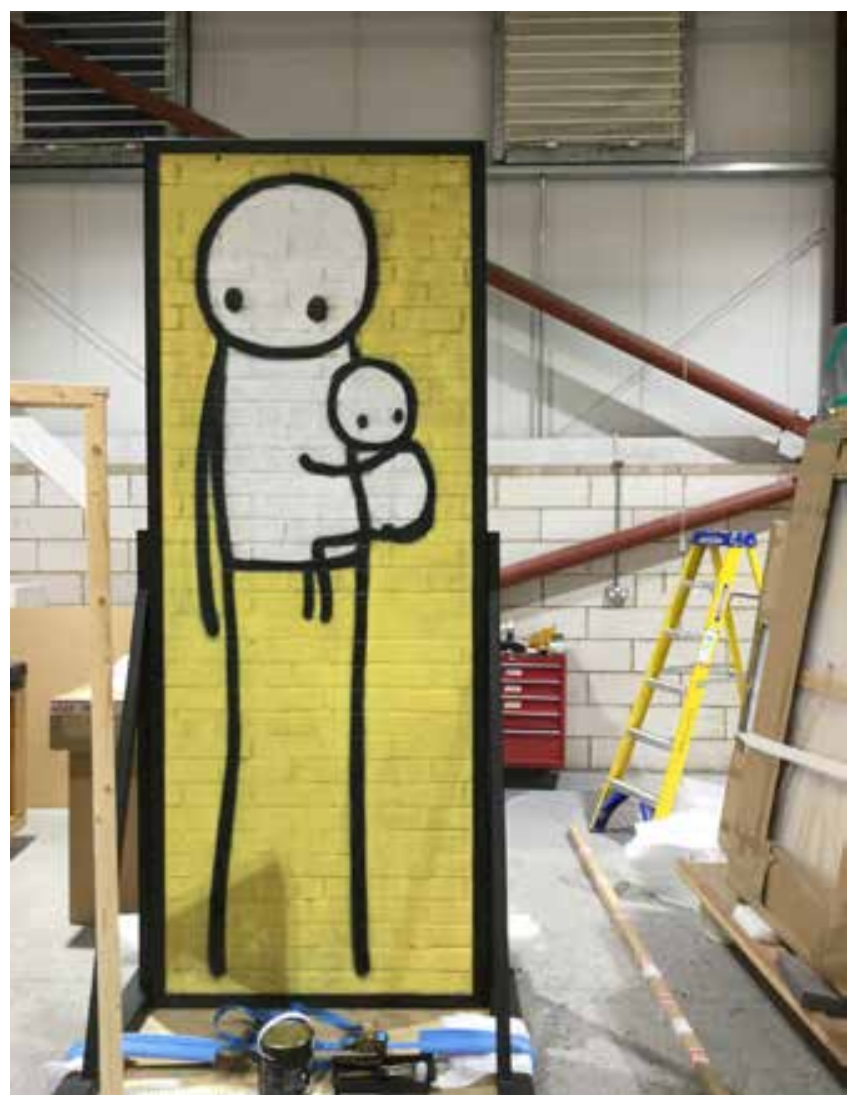

Figura 9. Big Mother de Stik, previamente a la subasta en Phillips, 2018.

\section{Conclusiones}

La inclusión de manifestaciones de arte público independiente dentro de entornos institucionalizados o incluso dentro del mercado del arte, resulta positivo para los artistas y para el público. Esto ha generado un mayor interés y seguimiento en artistas procedentes de sectores menos reconocidos y que han trabajado para la recuperación del entorno urbano como lugar de trabajo, exposición y para el arte (realmente) público; y el empleo de la crítica desde una perspectiva más alternativa y menos esperada. 
No obstante, las diferencias conceptuales y creativas de los artistas vinculados a movimientos independientes y sus obras, al ser introducidos en el sector comercial, varían notablemente. Por ello, es importante establecer una diferenciación terminológica entre las obras realizadas para fines comerciales y las relacionadas por movimientos independientes o por artistas. El empleo del término Urban Art mantiene una separación entre lo que está hecho para la venta y lo que simplemente está hecho para el disfrute sin comisiones o influencias externas (arte público independiente). Al mismo tiempo, la introducción de artistas originalmente vinculados al grafiti y arte urbano dentro de los sectores comerciales supone un punto positivo para los artistas y sus obras, ya que favorece la continuidad de la producción dentro y fuera del sector galerístico. Asimismo permite, en parámetros generales, establecer diferencias entre las obras y ampliar conceptos y posibilidades; y también, refuerza la identidad libre de las obras realizadas en el espacio urbano, ampliando las fronteras de cierto público focalizado anteriormente solo en sectores comerciales o institucionalizados.

Con la expansión de obras de artistas vinculados al grafiti y arte urbano dentro del mercado del arte, se han dado ciertas situaciones que confunden el arte para uso comercial y el simplemente hecho para el disfrute en el entorno público. Esto ocurre promovido por un interés puramente especulativo, donde los límites que se establecen gracias a la identificación terminológica y a las diferencias entre los espacios de trabajo se sobrepasan sin seguir una ética correcta, obviando los valores, conceptos e identidades originalmente mostradas por los artistas. Por ello, aquellas obras que no fueron realizadas para un sector privatizado, no deberían terminar en tales espacios sin el consentimiento del artista y de la comunidad, ya que el valor económico nunca debe anteponerse al establecimiento de un procedimiento ético o moral consensuado por todas las partes interesadas o vinculadas a la obra.

Por otro lado, y para concluir, es importante subrayar que el incremento en la producción en sectores más comerciales implica la necesidad de establecer patrones de conservación que en cualquier caso pueden ser aplicados en entornos privados pero también en entornos públicos. Pese a que los factores de degradación en las obras pueden variar dependiendo si la obra se encuentra en espacio abierto o en entorno pseudo controlado, la producción y materiales empleados por los artistas en ambos entornos se asemeja y, en muchos casos, incluso, puede ser idéntica. Esto es inherentemente positivo para los especialistas en conservación que han trabajado e investigado en el establecimiento de mecanismos de conservación sobre técnicas empleadas en el grafiti y arte urbano. Desde una postura positiva, se valora como favorable la demanda comercial de obras del Urban Art ya que implica un mayor interés e inversión por desarrollar tales mecanismos en cualquier campo. Con ello, se espera que las propuestas de investigación y las posibilidades de conservación, actualmente escasas en producción, aumenten notablemente en los próximos años.

\section{Notas}

[1] Street Art es la acepción inglesa original para expresar formas de arte independiente en el espacio público que van más allá del empleo del nombre y de los soportes de la ciudad como generalmente hace el grafiti. El término en español para esta forma de expresión es arte urbano, término que no debe confundirse con Urban art (vinculado al sector comercial).

[2] La plataforma Pest Control (Pest Control, 2019) de Banksy, ofrece un servicio de autentificación de obras realizadas para el disfrute privado, como impresiones en papel y pinturas sobre lienzo. El artista ofrece este servicio como medio para evitar fraudes, pero éste no se ofrece para casos de obras extraídas del entorno urbano, las cuales no son comúnmente autentificadas.

\section{Bibliografía}

ABARCA SANCHIS, F.J. (2010). El postgraffiti, su escenario y sus raíces: graffiti, punk, skate y contrapublicidad. Tesis doctoral. Madrid: Universidad Complutense de Madrid. http://eprints.ucm. es/11419/ [Consulta: 29 de agosto de 2019]

BAXTER, A (2019). The controversial Banksy Book. http:// banksybook.com/ [Consulta: 26 de agosto de 2019]

BOUJNAH, S; GABARET, J. (2015a) Street Art À la Française, Episodio 4 "Wall Street Art".

BOUJNAH, S.; GABARET, J. (2015b) Street Art À la Française, Episodio 5 "The Art of Marketing".

CASTLEMAN, C.(1982). Getting Up. Subway Graffiti in New York. Massachusetts: The MIT Press.

GABLIK, S.(1982). "Report From New York: The Graffiti Question". En Art in America Magazine, archives. https://www. artinamericamagazine.com/news-features/magazines/from-thearchives-report-from-new-york-the-graffiti-question/ [Consulta: 29 de Agosto de 2019]

GARCIAPARDO,B.(2015).GrafitiyPostgrafitien laciudaddeValencia: una perspectiva crítica. Tesis doctoral. Valencia: Universidad de Valencia. http://roderic.uv.es/handle/10550/45854 [Consulta: 26 de agosto de 2019]

GENESIUS, M. (2017). Markus Genesius, Wow 123. http://markusgenesius.com/ [Consulta: 13 de marzo de 2017]

GERULLIS, M.(2013). Meeting of Styles, Volume 1. Berlin: From Here to Fame.

HACKNEY CITIZEN (2019). "Stik's community mural 'finally' back in Poland after long tug-of-war with London gallery". En 
Hackney Citizen, June 21, 2019. https://www.hackneycitizen. co.uk/2019/06/21/stik-community-mural-back-poland/ [Consulta: 26 de agosto de 2019]

HARRINGTON, C.(2019). Conor Harrington - Works. http://www. conorharrington.com/[Consulta: 29 de agosto de 2019]

JANIS, S. y NEUMANN, D. (1983). Post-graffiti: exhibition by postgraffiti artists, opening Thursday December 1-31st, at Sidney Janis Gallery, New York, 1983. Nueva York: The Gallery.

LAKER LEGAL (2013). "Banksy graffiti, Intellectual Property \& who owns what?". En Laker Legal Solicitors Blog. http://www. lakerlegal.co.uk/banksy-graffiti-intellectual-property-who-ownswhat/ [Consulta: 26 de agosto de 2019]

LEWISOHN, C. (2009). Street Art. The Graffiti Revolution. Londres: Tate Publishing.

LEWISOHN, C. (2011). Abstract graffiti. Londres: Merrell.

McCORMICK, C. y CORCORAN, S. (2013). City as Canvas: New York City Graffiti from the Martin Wong Collection: New York City Graffiti and the Martin Wong Collection. Nueva York: Skira Rizzoli.

MOCA (2016). "Art in the Streets". En MoCA website. https://www. moca.org/exhibition/art-in-the-streets [Consulta: 26 de agosto de 2019]

MUSEUM OF THE CITY OF NEW YORK (2014). "City as Canvas. February 4 - September 21, 2014". En Museum of the City of New York, Exhibitions. http://www.mcny.org/exhibition/city-canvas [Consulta: 26 de agosto de 2019]

NUART (2019). Nuart Festival. http://www.nuartfestival.no/home [Consulta: 29 de agosto de 2019]

PEST CONTROL (2019). Pest Control Handling Services http:// pestcontroloffice.com/ [Consulta: 26 de agosto de 2019]

PHILLIPS (2019a). "20th Century and Contemporary Art", En Phillips Auctions, Departments. https://www.phillips.com/ departments/department?DepartmentName=Contemporary [Consulta: 26 de agosto de 2019]

PHILLIPS (2019b). "Stik, Magpie, 2009. Lot 90" En Phillips - London Auction 8 December 2016. https://www.phillips.com/detail/stik/ UK010816/90 [Consulta: 26 de agosto de 2019]

PHILLIPS (2019c). "Stik, Big Mother, 2014. Lot 14" En Phillips London Auction 5 December 2018. https://www.phillips.com/ detail/stik/UK010818/14 [Consulta: 26 de agosto de 2019]

Reino Unido (2017). "Copyright, Designs and Patents Act 1988". En Acts of Parliment, 15 de noviembre de 1998 [versión actualizada 10/7/2017], chapter 48, article 11.

SCHACTER, R. (2013). The World Atlas of Street Art and Graffiti. Londres: Aurum Press.
SOTHEBYS (2018). "Contemporary Curated". En Sotheby's auctions, results. http://www.sothebys.com/en/auctions/2018/ contemporary-curated-I18027.html?locale=en [Consulta: 26 de agosto de 2019]

SOTHEBYS (2019a). "Banksy, Untitled (Mother and Child), Lot 408". En Sothebys Auctions, Contemporary Art, E-catalogue 2005. https://www.sothebys.com/en/auctions/ecatalogue/2005/ contemporary-art-w05709/lot.408.html [Consulta: 26 de agosto de 2019]

SOTHEBYS (2019b) "Banksy | Online". En Sothebys Auctions, Upcoming.<https://www.sothebys.com/en/auctions/2019/ banksy-online-sale-I19357.html?locale=en [Consulta: 29 de agosto de 2019]

SOTHEBYS (2019c). "Contemporary Art". En Sotheby's auctions, Departments. https://www.sothebys.com/en/departments/ contemporary-art?locale=en [Consulta: 26 de agosto de 2019]

STIK (2019a). "Stolen $£ 30,000$ Stik Sculptures Returned to Community". En Stik website. http://stik.org/news [Consulta: 26 de agosto de 2019]

STIK (2019b). "STIK Deletes Remains of Missing Artwork". En Youtube, Stik Stik channel. https://www.youtube.com/ watch?v=G0oRvx-n1n0 [Consulta: 26 de agosto de 2019]

TATE MODERN (2008a). "Street Art Exhibition". En Tate website. https://www.tate.org.uk/whats-on/tate-modern/exhibition/ street-art [Consulta: 29 de agosto de 2019]

TATE MODERN (2008b). "Street Art Exhibition, Press Releases". En Tate website. https://www.tate.org.uk/press/press-releases/ street-art-tate-modern [Consulta: 29 de agosto de 2019]

THE TELEGRAPH (2014). "Banksy artwork saves youth club as it sells for $£ 400 k "$. En The Telegraph, Culture, Art - 24 August 2014. https://www.telegraph.co.uk/culture/art/11059481/Banksyartwork-saves-youth-club-as-it-sells-for-400k.html [Consulta: 29 de agosto de 2019]

UPFEST (2019). Upfest 2016. Europe's largest Street Art and Graffiti Festival. http://www.upfest.co.uk/[Consulta: 29 de agosto de 2019]

WACLAWEK, Anna. (2011). Graffiti and Street Art. Londres: Thames and Hudson.

WYNWOOD WALLS (2019). The Wynwood Walls' website. http:// www.thewynwoodwalls.com/ [Consulta: 29 de agosto de 2019]

YOUNG, A. (2014). Street Art, Public City. Law, Crime and the Urban Imagination. Oxon: Routledge. 


\section{Autor/es}

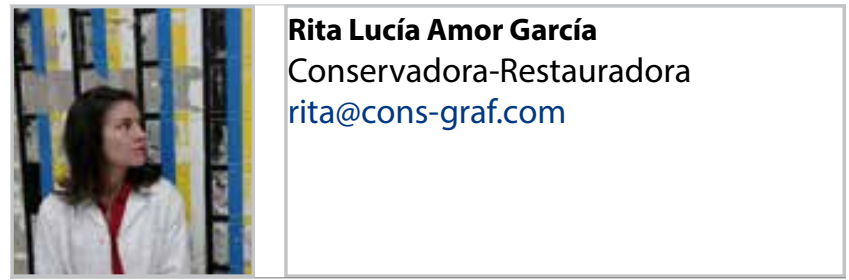

Es Doctora en Ciencia y Restauración del Patrimonio Histórico-Artístico. Trabaja en Londres como conservadora especialista en arte contemporáneo y urban art, y como técnica de exposiciones. Es también licenciada en Bellas Artes y posgraduada en Conservación y Restauración de Bienes Culturales, ambos por la Universitat Politècnica de València (UPV).

Desde 2010, combina el trabajo en restauración con la investigación en la aplicación de mecanismos de conservación sobre arte público independiente y Urban Art. Al mismo tiempo, ha trabajado en diferentes proyectos de investigación en conservación de pintura mural, ha participado en conferencias y simposios internacionales en diferentes ciudades Europeas, y cuenta con publicaciones en español e inglés relativas al estudio, conservación y difusión del grafiti y el arte urbano y, desde 2014, ha colaborado activamente durante el proceso creativo con las artistas Patricia Gómez y Ma Jesús González, además de hacer entrevistas a artistas vinculados al grafiti y arte urbano, como parte de su investigación. Es miembro del grupo de trabajo de Arte Urbano del GE-IIC por la defensa de buenas prácticas en la preservación de arte urbano.

En los últimos años, ha trabajado en programas educativos y de difusión del patrimonio británico dentro de instituciones públicas como la Royal Academy of Arts y los Royal Museums Greenwich. Actualmente trabaja en el sector privado en conservación, preservación y en la preparación de exposiciones a nivel internacional. 

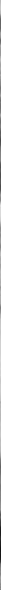

\title{
Arte urbano expuesto: procedencia, contenido e implicación
}

\author{
Elena Calderón Aláez
}

\begin{abstract}
Resumen: Análisis de dos exhibiciones de gran formato llevadas a cabo en los últimos años, dedicadas a exponer graffiti y arte urbano. Los dos casos de estudio serán: The Haus (Berlín, 2017) y Banksy: Genius or Vandal? (Madrid, 2019). Exhibiciones efímeras o itinerantes, no autorizadas o comisariadas por los propios artistas, gratuitas o privadas. Dos propuestas muy diferentes, que exponen obras de muy diversas tipologías y formatos, pero siempre englobadas bajo el título de "graffiti" o "arte urbano". En un museo tradicional, el contenido de su colección es lo que define su tipología. En este caso en nuestra clasificación, las exposiciones no son definidas o clasificadas atendiendo al contenido de la colección (materiales, soportes, técnicas, formatos), sino a la procedencia de las piezas expuestas (expoliadas del espacio público, vendidas por el propio artista, parte de colecciones privadas, creadas ex profeso (in situ o en taller, por los propios artistas...) Todas estas exhibiciones muestran un mismo tipo de expresiones artísticas provenientes del espacio público, pero cada una de ellas ha sabido exponerlo de un modo muy diferente. Analizaremos cuál es el más correcto o adecuado, atendiendo a las características del propio arte y sobre todo, a la opinión de los artistas.
\end{abstract}

Palabras clave: Banksy, The Haus, graffiti, no autorizado, arte urbano, exposición, procedencia, implicación

\section{Urban art exposed: provenance, content and implication}

Abstract: Analysis of two large-scale exhibitions in recent years, dedicated to graffiti and urban art. The two case studies will be: The Haus (Berlin, 2017) and Banksy: Genius or Vandal? (Madrid, 2019). These were ephemeral exhibitions, itinerant, unauthorized, curated by the artists, free, private ... Two very different approaches, which exhibited works of very different types and formats, but always under the title of "graffiti" or "urban art." In a traditional museum, the content of its collection is what defines its typology. In this case, in our classification, the exhibitions were not defined or classified according to the content of the collection: materials, media, techniques, formats; but to the origin of the exhibited pieces: pillaged from public space, sold by the artists themselves, part of private collections, created ex profeso (in situ or in workshop) by the artists themselves ...) All of these exhibitions show similar types of artistic expressions from the public space, but each one of them has exposed it in a very different way. We will analyze which are the most correct or adequate, taking into account the characteristics of the art itself and especially the opinion of the artists.

Key words: Banksy, The Haus, graffiti, unauthorized, street art, exhibition, provenance, implication

\section{Introducción}

En caso de que se quisiera llevar el arte urbano a los museos, ¿cuáles serían las condiciones, metodologías y factores más adecuados o correctos, teniendo en cuenta los principios fundamentales o características de este tipo de arte?

El arte urbano, para considerarse como tal, debe ser público e independiente y debe provenir del contexto de la "calle". Las técnicas y materiales empleados no son en este aspecto tan importantes, ya que hoy en día no todo se reduce al spray, plantillas (stencils) o paste-up. Además, debemos tener en cuenta que no toda la obra de los artistas urbanos se reduce al trabajo de calle, sino que también mucha parte de su producción es obra de estudio y por tanto el contexto o entorno (del que siempre se hace hincapié en las obras públicas) desaparece.

La situación ideal para llevar a cabo una exposición de estas características sería:

- Si el artista sigue vivo, ante todo, lo más importante sería contar al menos con la aprobación de éste.

- Residencia artística de larga duración en caso de que 
el artista no fuese nativo de esa localidad (contrario al denominado artista "paracaidista", que desconoce totalmente el contexto en el que trabaja y que reside en el lugar por un periodo de tiempo muy limitado).

- Creada por los propios artistas (artista-curator) o por un profesional en el ámbito indicado.

- Precio de la entrada gratuito, para que sea pública y totalmente accesible a toda la población.

- Que trabaje o tenga algún tipo de conexión con el contexto o el entorno de ese mismo lugar.

Todos estos puntos parecen bastante obvios, aun así, desgraciadamente no siempre se cumplen. Por otro lado, encontramos otros aspectos en los que aún existe debate, como los enumerados a continuación:

- ¿Cuál debería ser la duración más adecuada para las obras?, ¿es ideal que su vida sea efímera, como las de The Haus, y que todas las piezas sean destruidas al finalizar?, ¿se debería guardar algún testimonio para la posteridad?

- El tipo de obras, los materiales y técnicas empleadas no son juzgadas por ser unas más usadas que otras en el ámbito callejero, pero sí deberían jugar con el entorno y el contexto del lugar de exhibición.

- En cuanto a la ubicación y el diseño, ¿da igual si son expuestas en pequeñas galerías o en grandes pabellones?, ¿ubicadas tanto en el centro como en las afueras de la ciudad?, ¿itinerantes?, ¿únicas?

- Sobre la procedencia de estas piezas, ¿qué sería lo más adecuado?, ¿y para quién?, ¿deberían ser piezas expoliadas del espacio público, vendidas por el propio artista, parte de colecciones privadas, creadas ex profeso (in situ o en taller) por los propios artistas...?

Se espera que una exposición de arte, y más de este tipo, siempre genere algún tipo de conflicto o discusión. Hay muchas voces que piensan que exhibiciones como éstas "domestican" el arte urbano, que la subversión de este tipo de arte desaparece, que el arte urbano se contradice al introducirse en un entorno "limpio" como es una sala de exposiciones.

Se entiende que la emoción que este arte transmite, emana del hecho de que en su hábitat natural, la calle, entra de forma espontánea en comunicación con su entorno, se involucra con lo dado, lo ataca, lo mira con ironía, se burla de las cosas. En resumen, el Street Art prospera y evoluciona en resistencia con su propio entorno (incluso en su forma legal como un trabajo comisariado). Esta sensación es algo que se pierde en el museo, pero éste no es un problema nuevo en el mundo del arte. Las imágenes de un altar medieval también se descontextualizan de forma radical cuando son retiradas de una iglesia. En este caso no ahondaremos en la cuestión de si es lícito exponer en interior obras inicialmente destinadas al exterior, ya que el origen de las obras seleccionadas para estas exposiciones, aunque es muy diferente entre ambas, no ha sido en ningún momento la calle, sino que los artistas escogidos son artista urbanos, muralistas o escritores de graffiti.
Por ello, debemos tener en cuenta que algunos de los artistas en cuestión tienen también una práctica en interior, y que estas dos prácticas pueden ser del todo compatibles.

En este artículo se revisarán distintos formatos que pueden ser útiles a la hora de exponer este tipo de obras de "interior" a través de dos exposiciones muy diferentes entre sí, una como ejemplo de buena práctica y otra como ejemplo de algo que creemos debería cambiar en el mundo del arte. No contar con el consentimiento del artista es algo que no se debería permitir, pero tal y como veremos a continuación, en la exposición dedicada a Banksy, esto no es algo que preocupe a coleccionistas o curators que creen firmemente que, habiendo adquirido las obras, tienen todo el derecho de exponerlas cómo y cuándo les plazca.

\section{The Haus}

The Haus, Berlin Art Bang (Berlín, 2017) es la exhibición escogida en este artículo para ejemplificar un buen uso o práctica de la labor curatorial en el denominado arte urbano o de obras realizadas por grafiteros/artistas urbanos. Esto se debe a que fueron los propios artistas los que organizaron la muestra y la entrada era totalmente gratuita, por tanto, accesible a todo el público. Un total de ciento sesenta y cinco artistas internacionales participaron en este gran proyecto ubicado en un banco en desuso de Berlín (en el número 68 de Nürnberger Straße, en la zona conocida como Ku'Damm, avenida de Kurfürstendamm) que iba a ser demolido en pocos meses. El resultado fue la intervención de ciento ocho habitaciones en un edificio de cinco pisos (10.000 metros cuadrados) que contó con el trabajo de creadores provenientes de más de veinte países diferentes. El proyecto comenzó en enero del 2017 y la exposición estuvo abierta al público durante ocho semanas, entre los meses de abril y mayo, hasta que en junio del 2017 se clausuró antes de su demolición.

Definitivamente, la riqueza en la diversidad de materiales, formatos y contenidos, hicieron deThe Haus una exposición única que supuso un antesy un después para los entusiastas tanto del graffiti como del arte urbano y del arte actual en general. Una exposición sólo accesible por un periodo de tiempo limitado que atrajo un total de setenta y ocho mil visitantes, amantes del arte urbano, que viajaron a la capital alemana exclusivamente para no perderse una de las exhibiciones más revolucionarias de los últimos años. La responsabilidad de esta exposición recayó en un trío de creadores alemanes, activos en la escena artística urbana de Berlín durante los últimos 20 años: Kimo von Rekowski, Jörn Reiners y Marco Bollenbach, (sus alias: Kimo, Jörni y Bolle) que en conjunto forman el grupo Die Dixons. Juntos han dedicado toda su vida a pintar murales en las fachadas de la capital alemana y en otras ciudades del mundo. Además, son propietarios de la 
empresa profesional de pintura de letreros Xi-Design, que originó este proyecto. Por este motivo, tienen múltiples contactos con empresas de construcción, marcas de materiales, proveedores de pintura y pintores comerciales altamente cualificados. A raíz de este proyecto, juntos, se hacen llamar los Hausmeister (TheHaus Web). Este grupo de creadores comenzaron invitando a unos cincuenta artistas amigos, de su círculo más cercano, y en pocos días la lista de espera de artistas que deseaban tener un hueco en la exposición llegaba a los cien.

Tal vez, lo más interesante de este proyecto, aparte de la entrada gratuita, la gran implicación de cada uno de los artistas con el proyecto y la gran diversidad de propuestas, es la idea de temporalidad. Y esta idea, a su vez, proviene del concepto de trabajar en el espacio público. "Esto es lo que pasa en la calle, la obra a veces desaparece rápidamente y a veces permanece" subraya Kimo (Tuñas, 2017: s.p.).

Desde que se inició el proyecto se conocía su fecha de desaparición y caducidad, es por lo que los organizadores creen que ha tenido tanta popularidad. Cada día las colas eran infinitas, recibiendo un total de milquinientas visitas diarias para poder acceder al edificio [figura 1], ya que no más de doscientas personas podían visitar la muestra simultáneamente.

En poco tiempo, todo lo creado desapareció por completo, y convirtió la visita en única e irrepetible. "The Haus es una galería temporal y eso también tiene un impacto en la afluencia: las colas que hay en la entrada son de dos a seis horas de espera, porque esto va a desaparecer" (Tuñas, 2017: s.p.), dicen dos de los artistas invitados, Amanda Arrou-tea y Guillermo S. Quintana.

Posiblemente, debido a la naturaleza efímera de este proyecto, se podría creer en un principio que las instalacionesno serían de unaalta calidad oque suejecución sería simplemente abocetada y poco comprometida. Sin embargo, todas y cada una de las intervenciones sorprendieron gratamente por su sofisticación conceptual, destreza técnica, atención a los detalles y la originalidad

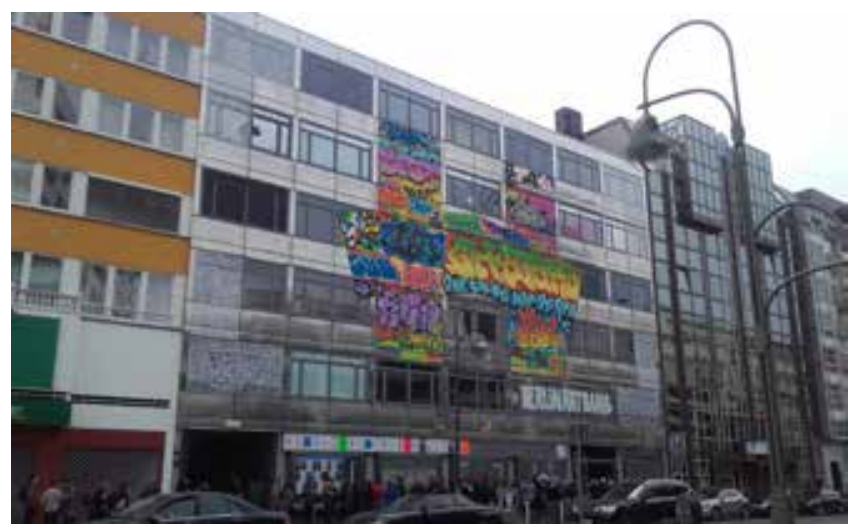

Figura 1.- Interminables colas para acceder a la exhibición de The Haus, Berlín. 6 de mayo de 2017. Fotografía de Rebeca Villanueva. de los entornos en los que el espectador se podía sentir totalmente inmerso en cada una de las habitaciones. En The Haus, se pudo apreciar todo tipo de propuestas artísticas, desde esculturas de gran tamaño, video instalaciones, graffiti, stencils, yarn bombing, fotografía, ilustración, hasta realidad aumentada. La idea no importaba, decían los creadores, "mientras fuese algo guay" (Ilovegraffiti.de Web, 2017: s.p.). Kimo explicó en uno de los tours realizados, que los conceptos de cada una de las habitaciones no están de ningún modo comisariados, simplemente pidieron algo que fuese "muy muy guay" a los artistas invitados (Rojo, 2017: s.p.).

Es cierto que algunos de los temas como: la violencia, sexualidad, trata de personas, entre otros, se repetían, pero en general cada artista plasmaba su propia visión. "No queremos problemas, ni odio, ni tonterías. Eslóganes como 'Fuck Trump' no. No queríamos este tipo de cosas. Que cada uno de ellos lo enfocase desde un punto de vista político, habría sido genial, pero era complicado, tratándose de ciento sesenta y cinco artistas en total, que sus trabajos no entrasen en conflicto. Buscábamos en todo momento llevar a cabo un proyecto familiar, nuestro objetivo era que la gente viera lo que podemos hacer, lo profesional que puede llegar a ser el arte urbano de alta calidad. Todavía se pueden hacer grandes cosas sin tener que dañar a otra gente" (Lindsay, 2017: s.p.).

En una visita guiada de dos horas por el edificio de la mano de algunos de los propios artistas, explicaban cada una de las habitaciones (10€ por persona). Uno de los detalles más curiosos y siguiendo múltiples ejemplos de la capital alemana, es que el uso de teléfonos móviles para realizar fotografías estaba totalmente prohibido y al comenzar el tour, pedían depositar los dispositivos móviles en pequeñas bolsitas grises. De este modo invitaban a disfrutar de la experiencia y olvidarse de sacar un selfie en cada una de las diferentes habitaciones. Su lema era: "At the end only the memory remains" (Estilo Palma Web, 2017: s.p.). Esta "zona sin teléfono" se creó, según expresó Kimo, para que el público "vuelva a las raíces. Use sus ojos, sentimientos y emociones, permanezca en las habitaciones. Retroceda, mire nuevamente, tóquelo. Deje de mirar las cosas a través de su teléfono o en Internet. Experiméntelo usted mismo y concéntrese en el momento" (Lindsay, 2017: s.p.). Además, con este sistema conseguían que las visitas fuesen más dinámicas y claramente tenía un punto de vista económico, pues si se deseaba tener un recuerdo del proyecto, el único modo era invertir en el catálogo creado para la muestra. De este modo, los artistas sacaban algún beneficio aparte, claro está, de donaciones o propinas de los visitantes. Este catálogo tuvo tanto éxito que se agotó en varias ocasiones, teniendo que imprimir hasta cuatro ediciones. Kimo cuenta que todo este proyecto fue posible gracias a que la inmobiliaria Pandion AG, ya que se necesitó a algún responsable que pagase el alquiler del edificio hasta que éste fuese totalmente desmantelado para transformarse en viviendas de superlujo. [figura 2] 


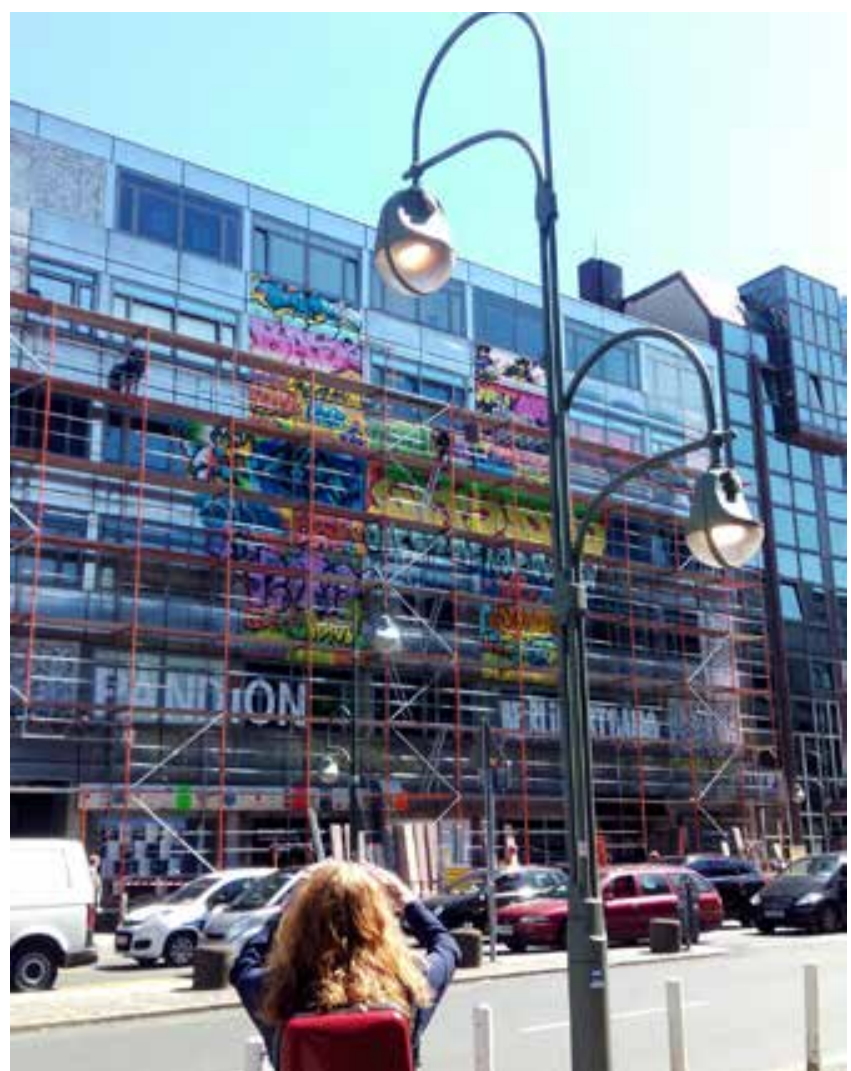

Figura 2.-La fachada, con los andamios ya colocados para su desmantelamiento, exhibe un gran grafitti de colores y la inscripción con el nombre de la inmobiliaria Pandion, Berlín. 1 de junio de 2017. Fotografía propia.

"El acuerdo fue genial para ambas partes: ellos tienen una historia que contar a sus futuros inquilinos y para nosotros era perfecto disponer de un edificio vacío en esta zona comercial de Berlín para llenarlo de Street Art". "Nos sirve para dignificar el Street Art. Nuestro arte también tiene un lugar en el centro de Berlín", añade (Tuñas, 2017: s.p.). "Recibimos las llaves de The HAUS el octubre pasado, preparamos un plan en noviembre y llamamos a todas las personas que sabíamos que serían capaces de hacer un buen trabajo. Todos somos amigos y confiamos los unos en los otros. Esto es un proyecto familiar" dice Kimo (Tuñas, 2017: s.p.).

Los artistas trabajaron desde mediados de enero hasta el 9 de marzo. Dormían, comían y construían juntos casi sin descanso. "Les dimos algunas reglas" dijo Kimo (Lindsay, 2017: s.p.). Pudimos disfrutar de un total de ciento ocho habitaciones del banco en desuso intervenidas por artistas de la talla de: 1UP, El Bocho, Klebebande, Emess, Honsar, HRVB + Vidam + Dxtr from The Weird, One Truth, Herakut, Telmomiel y Base23. Arrou-tea (una de las artistas españolas de la muestra) contó que para ella The Haus fue "algo maravilloso, me está abriendo muchas puertas. Es una familia, es una oportunidad de enseñar mi trabajo, de poder hacerme un huequecillo aquí en Berlín, de crearte una familia. Todos los artistas, los compañeros, nos apoyamos. Es maravilloso, The Haus es un punto de partida" (Tuñas, 2017: s.p.).
Fueron propuestas, que consiguieron cautivar a los visitantes, tan diversas como la del Señor Schnu que llenó las paredes de su habitación con $200 \mathrm{~kg}$ de yogur para alimentar $400 \mathrm{~kg}$ de musgo, cubriendo casi la totalidad del cuarto para criticar la doble moral del primer mundo hacia el cuidado del planeta. Colectivos alemanes tan importantes en la escena del graffiti como 1UP o Rocco und seine Brüder, en los que destaca la pintura en trenes, también tuvieron su espacio, incluso llegaron a robar un fragmento de una de las vías ferroviarias en desuso de Berlín para exponerla en su habitación junto con vídeo del proceso de extracción de la pieza.

Algo que también hizo muy interesante este proyecto fue que absolutamente todo eran donaciones de empresas solidarias. Los materiales de construcción empleados fueron aportados por una empresa de construcción local. La cerveza que se consumió por Berliner Pilsner. Un hotel de cuatro estrellas alojó a todos los artistas durante el período del proyecto, de forma gratuita. Según Kimo, “Esto no fue una broma de marketing. Queríamos respeto por los artistas, para que eligiesen lo que querían decir. Es por eso que a nadie se le pagó y nada está a la venta" (Lindsay, 2017: s.p.). Kimo dijo que "The Haus siempre ha sido nuestro objetivo final: un espacio en el que reunir a nuestra gente, demostrar toda nuestra experiencia y crear algo grande desde el corazón, y no del bolsillo de un cliente" (Tuñas, 2017: s.p.).

Parece que de algún modo lo consiguieron y es que, aunque no deje de tratarse de un negocio más, han atendido siempre a las necesidades de los artistas dándoles a todos la misma oportunidad y han conseguido transformar un edificio bancario en una iniciativa artística.

Muy al contrario de lo que ocurrió, como veremos a continuación, en la exposición de Banksy en Madrid, ya que la propia exhibición se convirtió en un negocio redondo.

\section{Banksy}

La exposición titulada "BANKSY: Genius or Vandal?" (Madrid, diciembre 2018 - mayo 2019), ha sido la primera gran muestra en España sobre el artista británico. Albergada en el ESPACIO 5.1 de IFEMA, mostraba un total de setenta obras originales cedidas por coleccionistas privados internacionales.

"Una impresionante instalación audiovisual envolvente especialmente creada para esta muestra dará la bienvenida al visitante, desvelando pistas sobre el misterioso artista, destacando sus piezas más importantes y enmarcando su insólita trayectoria, no exenta de polémica". (BANKSY: Genius or Vandal? Web oficial). Así es como vendían la exposición, ya que, de algún modo, tenía que justificar el desorbitado precio de la entrada. [figura 3]

Alexander Nachkebiya, comisario responsable de la exposición, decía: "Queremos que cada visitante de esta 


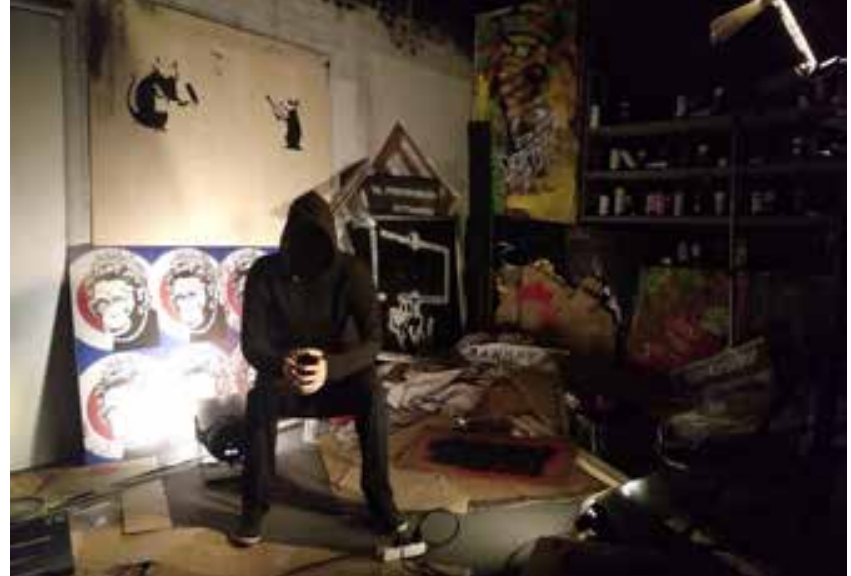

Figura 3. Ejemplo de instalación dentro de la exposición simulando la grabación del documental de Banksy: Exit Through The Gift Shop. Madrid, 8 abril de 2019. Fotografía propia.

exposición pueda resolver por sí mismo quién es realmente Banksy: ¿un genio o un gamberro?, ¿un provocador o un rebelde?". (CORES, 2017: s.p.).

Organizada por las empresas IQ Art Management y Sold Out, llegó como exposición itinerante tras haber pasado con gran éxito por las ciudades de Moscú y San Petersburgo, donde fue visitada por más de quinientas mil personas.

En la web oficial de esta exposición de Madrid se indicaba que: "Esta muestra, como todas las dedicadas a Banksy anteriormente, no está autorizada por el artista, que busca defender su anonimato y su independencia del sistema". (BANKSY: Genius or Vandal? Web oficial). [figura 4]

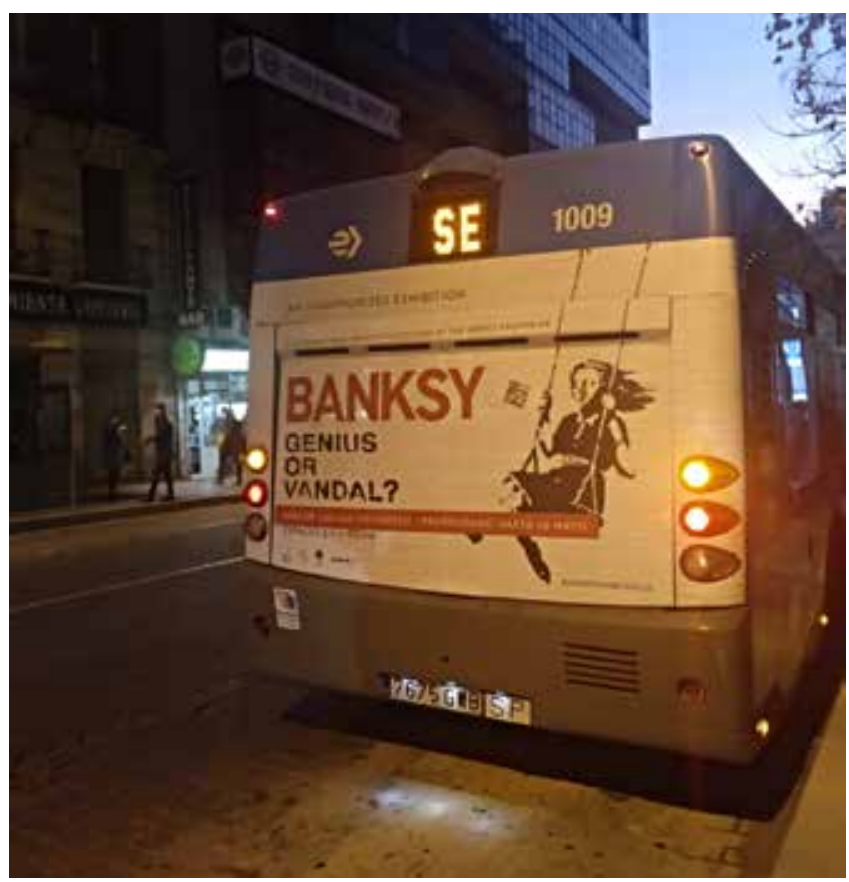

Figura 4. Publicidad de la exhibición de Bansky en el transporte público de Madrid. En la letra pequeña podemos observar que se indica en inglés: "an unauthorized exhibition". Madrid, 9 de marzo de 2019. Fotografía propia.
BANKSY: Genius or Vandal?, ésta es la cuestión principal que nos plantean sus organizadores. Para nosotros, tiene fácil respuesta. Todo el que diga que Banksy es más vándalo que genio debería visualizar su último documental The Man Who Stole Banksy (2018). En el documental queda clarísimo cómo cualquier acción que realice este artista, por mínima que sea, consigue cambiar el entorno en el que la pieza se ubica, casi de forma radical.

Se ha llegado a un punto en el que carece absolutamente de importancia el contenido de sus stencils. Ahora lo que importa es que Banksy ha intervenido en un lugar concreto y en sus últimas piezas se ha podido ver cómo todos estos lugares están elegidos a conciencia. Las intervenciones realizadas en el muro de Palestina y posteriormente la construcción de su hotel con vistas al muro, que había intervenido, han supuesto un gran cambio en su entorno y comunidad local, cosa que cualquier otra intervención con mayor contenido o trasfondo de cualquier otro artista no habría conseguido. Banksy, por tanto, ha dejado de ser el genio del contenido político y la reivindicación, para pasar a ser el genio del marketing y las redes sociales (del mainstream).

Esta exposición de Madrid, al mostrar únicamente láminas o piezas "de estudio", sólo se centra en ese contenido "político" o "reivindicativo" de las obras obviando totalmente la conexión entre la pieza y su entorno/ contexto. Conexión que sí encontramos en sus obras callejeras y por tanto, quedando muy lejos la idea que hace único a este artista. Pero esta cuestión de si se trata de un genio o un vándalo, queda obsoleta. La cuestión que verdaderamente interesa en esta muestra es: ¿se trata de arte ó es un negocio? El precio de la muestra era de 14,90 € más gastos de gestión. Niños (hasta 12 años): $7,90 €$ más gastos de gestión. Lo cual se traduce en 16,40 $€$ y $9,40 €$, respectivamente. La muestra exhibía un total de setenta obras (veintiocho obras originales y cuarenta y cinco piezas de edición limitada, que Banksy realizó en su estudio), de las cuales únicamente una es un arranque de pared. El resto son serigrafías numeradas (de tiradas larguísimas, algunas de quinientos ejemplares) que carecen de interés. Cuando llega a nuestros oídos la existencia de una exposición dedicada a un artista urbano se deduce que se van a encontrar piezas arrancadas de la calle y expuestas en un espacio cerrado. En este caso ni eso. Por ello, incluso el comisario Nachkebiya, sentía la necesidad de aclarar que: "Todo lo que hay aquí lo ha hecho Banksy con sus manos". (Pulido, 2018: s.p.)

El valor global de todas las piezas expuestas en la muestra era de 15 millones de libras. La más cara, Stop Esso, era la única obra que sí provenía del arranque de un muro del espacio público y cuyo precio es de 1,7 millones de libras [figura 5].

Se sabe que Banksy también tiene una parte de obras creadas en estudio, de tipo gráfico, y que son ideadas para exponer en interior (láminas, serigrafías...), pero 


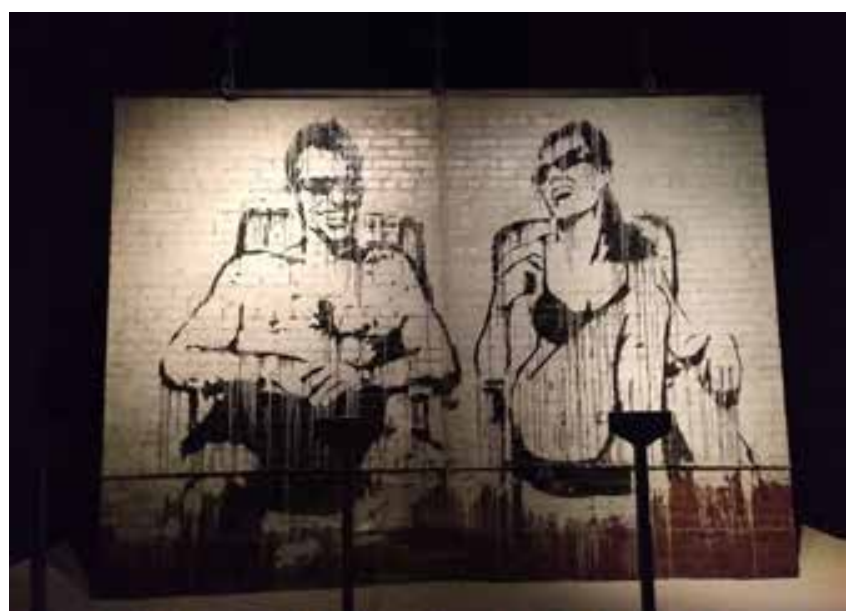

Figura 5. Stop Esso es la obra más cara de la exposición (427 por 366 centímetros), un muro cuyo precio es de 1,7 millones. Madrid, 9 de abril de 2019. Fotografía propia.

está claro que no es lo que más atrae en el caso de ir a visitar una exposición de una figura del arte urbano de su talla mediática. Resultaba curioso que la exhibición careciese de catálogo, pero este detalle hacía darse cuenta de que la propia exposición era en sí misma un catálogo sin más, sin ningún interés más que simples láminas acompañadas de una explicación de la audioguía, disponible a través de la descarga de una app. Un buen título para la muestra habría sido: "Entrada por la tienda de regalos", haciendo un guiño a su primer documental y remarcando que lo más interesante, en este caso, de la exhibición, fue la tienda ubicada a la salida del recinto, repleta de vulgar merchandising [figura 6].

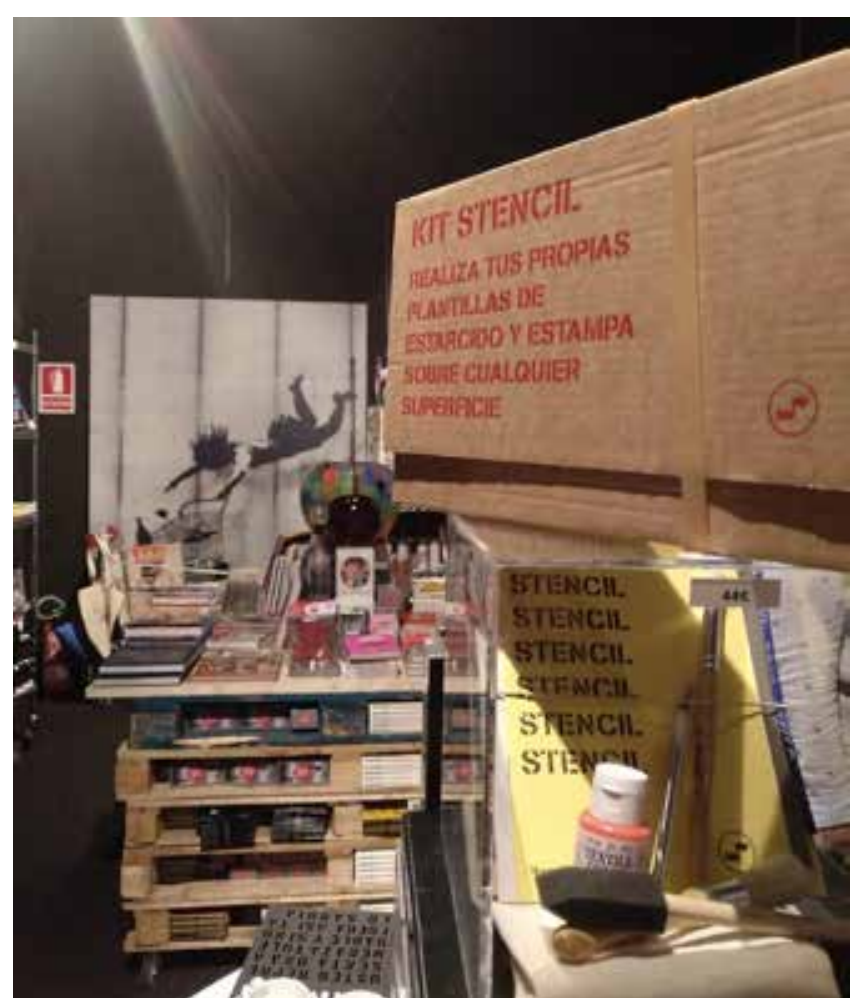

Figura 6. Ejemplo del merchandising que la tienda de la exposición ofrecía. Madrid, 9 de abril de 2019. Fotografía propia.
Las preguntas inmediatas que surgen acerca de esta exposición son ¿quién la organiza?, ¿qué relación tienen con la figura de Banksy? y por tanto ¿qué grado de implicación tiene el artista en todo esto?. La realizaron en conjunto dos empresas: IQ Art Management y Sold Out, especializadas en eventos culturales. Esta última ha celebrado exposiciones de gran tirón popular sobre David Bowie, Björk, Harry Potter o Juego de Tronos. En los últimos veinte años, Sold Out ha organizado algunos de los proyectos de entretenimiento más importantes que se han realizado en nuestro país, desde conciertos hasta obras de teatro, pasando por exposiciones, festivales y eventos corporativos. Sold Out trabaja habitualmente organizando giras y espectáculos internacionales. El pasado 17 de noviembre estrenó, también en ESPACIO 5.1, Jurassic World: The Exhibition, la exposición oficial de la exitosa saga cinematográfica (Sold out Web Oficial).

Según Rafael Giménez, socio director de Sold Out, "vimos esta exposición en Rusia hace un año. Hay tres de Banksy en el mercado, pero nos gustó ésta porque está muy bien montada y tiene obras singulares" (Pulido, 2019. S.p). Tal vez en el montaje audiovisual se pueda coincidir, pero desconocemos a qué se refería exactamente con el término "obras singulares", siendo todas ellas tiradas de serigrafías, excepto un único arranque de un mural original.

Curiosamente, el director general de IQ Art Management, Alexander Nachkebiya, es además productor y comisario de la exposición de Banksy junto con Andrew Lilley, propietario de la Lilley Fine Art/Contemporary Art Trader Gallery (Galería de Irlanda del Norte que había cedido la mayoría de las obras que se podían ver en la exposición).

En la página web oficial se especificaba que algunas de las obras estarían a la venta "incluyendo obras originales, esculturas, instalaciones, vídeos y fotografías. Las piezas, procedentes de colecciones privadas y con la colaboración de Lilley Fine Art/Contemporary Art Trader Gallery, se exhibian en España por primera vez" (BANKSY: Genius or Vandal? Web oficial).

El hecho de que algunas obras estuviesen a la venta dejaba entrever que ésto, más que de arte, se trataba de un completo negocio, por lo que el comisario de la exposición se vio obligado a aclarar que "Todo está a la venta, excepto el amor" (Pulido, 2019: s.p).

La localización elegida fue en ESPACIO 5.1, el nuevo recinto para grandes exposiciones en IFEMA [figura 7]. Este espacio se ha creado con la idea de albergar de forma regular grandes exposiciones internacionales. Se trata de una carpa permanente de $5.000 \mathrm{~m}^{2}$ anexa al edificio principal de IFEMA, pero con una entrada independiente.

En este espacio se tiene prevista la programación de dos exposiciones al año, blockbusters y títulos internacionales para todos los públicos y de temática variada, "que ofrecerán nuevas experiencias al visitante, prestando 


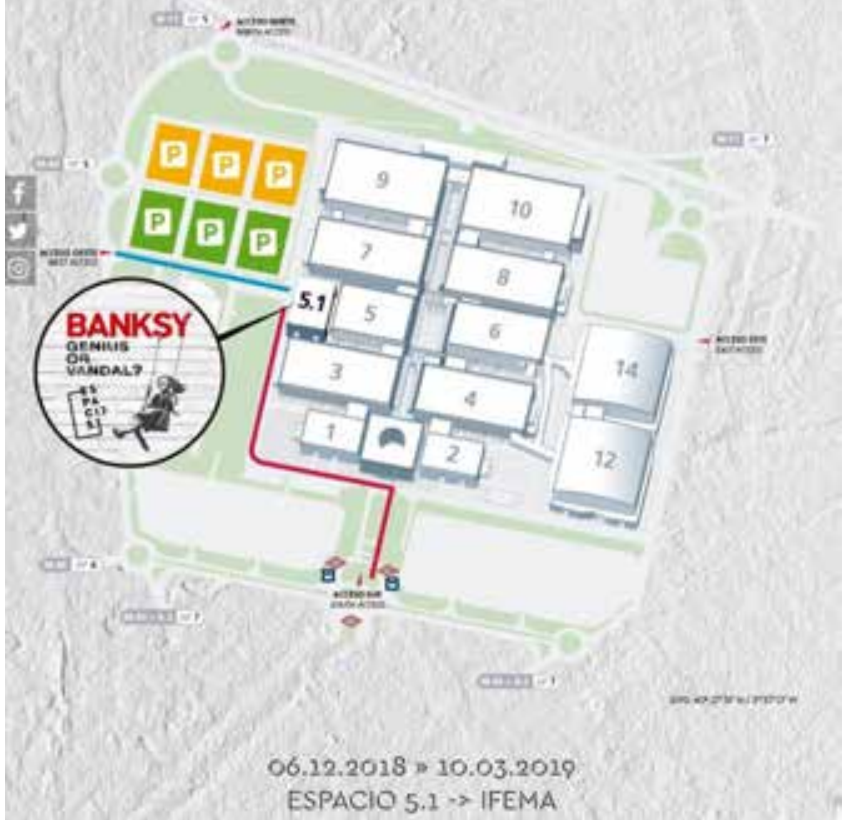

Figura 7. : Captura de pantalla, mapa de la localización de la exposición de Banksy en el Recinto ferial de Ifema, Madrid. Disponible en: https://www.banksyexhibition.es/la-exposicion/ [Consulta: 22/08/2019].

una especial atención a la inmersividad y a las nuevas tecnologías audiovisuales" (Espacio 5.1 Web Oficial).

Encontrar críticas negativas acerca de la exposición es una tarea complicada. Todas las opiniones son positivas y muy superficiales. Lo único de lo que el público se ha quejado es del excesivo precio de la entrada.

Únicamente un artículo en castellano habla de que la exposición pretende plantear un dilema a los visitantes, pero la polémica se queda en la puerta: "Dicen proponer el debate entre el público acerca de si Banksy es, como el nombre de la exposición muestra, un genio o un vándalo. Sin embargo, más allá de este título, no hay nada en las instalaciones que incentive dicho debate. Se limitan a exponer las obras junto a textos que alaban la figura del artista urbano" (Serrano, 2018, s.p.). Pero por otro lado afirma que:"De no ser por el excesivo precio, la exposición sería ciertamente recomendable". Ya que la exposición según él "ofrece un diseño y unas instalaciones francamente impresionantes" (Serrano, 2018: s.p.).

En ninguna de las opiniones aportadas acerca de la muestra se tiene en cuenta que esta exposición en ningún momento fue autorizada por el propio artista. Por tanto, lo importante sería saber qué piensa realmente el propio Banksy acerca de que sus obras sean utilizadas como excusa para que dos empresas privadas, coleccionistas y comisarios, entre otros, se beneficien económicamente. De hecho, la muestra tuvo tanto éxito en nuestro país que fue prorrogada dos meses más (de marzo a mayo del 2019).

Una exposición de arte urbano debería ser como mínimo gratis, ya que lo más interesante de este tipo de arte es que está ubicado en la calle para que sea accesible a cualquier público. Este es un principio con el que Banksy está muy de acuerdo y así lo hace saber en sus comunicados.

En su página web oficial (Banksy web oficial) Banksy se encarga de dejar bien claro cuáles de sus exhibiciones son autorizadas y cuáles no [figuras 8 y 9]. Él mismo las clasifica como "Reales" (las exposiciones que él mismo ha comisariado) o "Falsas" (en las que no ha participado en absoluto). Desde hace unos años (primera en 2016, en Estambul) se han realizado un sin fin de exposiciones no autorizadas del artista urbano Banksy en distintos países alrededor del mundo. En estas exposiciones se suele indicar que no han sido autorizadas por el artista (pero siempre en la letra pequeña) por lo que los no expertos en el ámbito del arte urbano o la galería, no siempre se percatan de este hecho (algo importantísimo a la hora de evaluar si este tipo de exhibiciones que abarcan el denominado "arte urbano", son más o menos adecuadas en cuanto al contexto de creación, adquisición de las obras e implicación del artista en ellas).

En sus descripciones, algunas de estas exposiciones, también señalan que no han sido en ningún momento ni autorizadas ni comisariadas con la ayuda del artista. Por ejemplo, en la exposición de Amsterdam en el MOCO museum se explicaba: "The 'Laugh Now' exhibition is not authorised by Banksy, nor was it curated in collaboration with the artist" (Michaut, 2019: s.p.).

Además, al lado de cada una de las exposiciones se especifica cuál es el precio de entrada de su visita, haciendo ver que las sí comisariadas por él siempre han sido totalmente gratuitas (a excepción del parque de atracciones de Dismaland por el que se cobraba un precio de 3 libras por la entrada al recinto). Los precios de las entradas a las exposiciones no autorizadas oscilan entre los 6 dólares en la de Estambul hasta los 49 dólares de la que tuvo lugar en Miami.

En la exposición de Moscú el propio comisario Alexander Nachkebiya decía: "creo que el precio de la entrada es muy justo. Hemos tratado de no sobrepasarnos con ello, era un factor muy importante para nosotros" (PYATAKOV, 2018, s.p.).

Banksy advirtió en una ocasión, en su cuenta de Instagram oficial, que él únicamente cobraría la entrada para ver su arte si hubiese una "fairground wheel" (noria). $Y$ parece que lo ha cumplido hasta el momento, ya que sólo lo hizo en el caso del parque de atracciones. Durante los pocos meses en los que se ha redactado este artículo la lista de exposiciones no autorizadas ha crecido con otras tres ciudades europeas (Lisboa, Sicilia y Gotemburgo). En total han sido diecisiete exposiciones no autorizadas desde 2016. Desde las que tuvieron lugar en Estambul y Antwerp hasta lo que llevamos de año 2019.

El tipo de obras que se exhiben en estas exposiciones son en su mayoría de tipo "indoor" (tal y como se menciona 

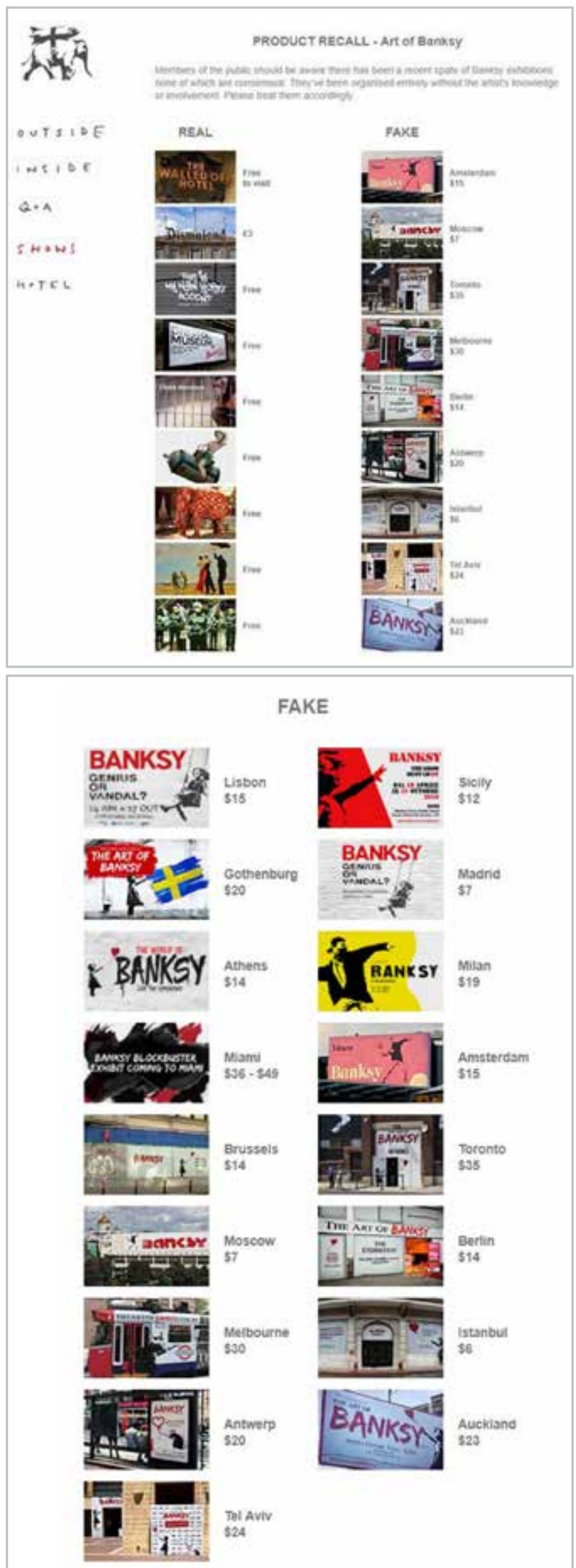

Figuras 8 y 9.- Captura de pantalla de la clasificación en su página web oficial de las exposiciones "reales" y "falsas". BANKSY WEB OFICIAL. Disponible en: http://www.banksy.co.uk/ [Consulta: 23/08/2019]. en todas las descripciones en cada una de las páginas web oficiales de dichas exposiciones), como sucedió en la de Madrid.

Lo importante en este caso, para grandes exhibiciones como éstas, es vender el nombre del artista. $Y$ en este caso concreto, Banksy es únicamente conocido por sus piezas de arte urbano. Por tanto, el público lo que busca ver en este tipo de muestras son piezas de tipo arte urbano y no simples láminas de algunos de sus stencils. Su mensaje no llega de igual manera en la calle que dentro de una galería. De alguna forma, estas exposiciones tienen que justificar la muestra $y$, por ello, en casi todas la descripción es la misma: aquí podrán disfrutar de "las piezas de interior de Banksy, trabajos únicos y originales en lienzo, madera, papel... que han sido hasta el momento exhibidos en menor medida".

Pero también es cierto que la obra callejera de Banksy representa menos de la mitad de sus trabajos. El resto son óleos, acrílicos, esculturas e instalaciones. Su mercado, en general, podría clasificarse en cuatro partes:

-Serigrafías (prints). Hay aproximadamente sesenta motivos que han sido serigrafiados en ediciones desde diez a mil ejemplares por motivo.

-Los múltiples. Son originales, acabados a mano y están hechos en series de hasta veinticinco piezas. Todos firmados y numerados por Banksy.

-Originales (unique piece), pueden ser tanto óleos o acrílicos como esculturas. Hay aproximadamente setecientad piezas únicas.

-Obras "callejeras" "urbanas". Los propios propietarios de los edificios, cuyas paredes han sido pintadas, deciden vender estas obras. Este submercado no está apoyado por Banksy y su oficina Pest Control Office no emite certificados de autenticidad.

También hay un mercado en lo que se llama Ephemera. Son los catálogos de las exhibiciones, pósteres $u$ otros items relacionados con Banksy, pero no tienen edición limitada ni firma. Es decir, en pocas ocasiones se exponen obras "arrancadas de la calle" de fachadas, paredes, muros, etc, y únicamente se exhiben piezas móviles y de pequeño tamaño creadas para ser exhibidas en interior (esculturas, lienzos, láminas, etc).

Esto es lo que escribe en su blog un visitante a la exposición de Banksy en el MOCO (Amsterdam), en el cual explica con sentimientos encontrados la relación de obras exhibidas: " $A$ medida que voy entrado a la exposición me van asaltando las dudas (...) Sin embargo, me sorprende gratamente descubrir que la gran mayoría de los trabajos en la exhibición no provienen de muros arrancados o de simples fotografías. Éstas son obras originales que van desde esculturas hasta pinturas sobre lienzo e instalaciones. Esta exposición no está autorizada, pero no me da la sensación de que con ella se haya destrozado el trabajo 
de Banksy; sin embargo, un sentimiento amargo persiste ... " (Michaut, 2019: s.p.). Por tanto, sabemos que Banksy está al tanto de todas estas exposiciones que se realizan a su costa y hace poco hizo saber de forma pública que no se muestra conforme con éstas. El pasado año (2018) se hizo viral una captura de pantalla [figura 10] de una de las conversaciones que el propio artista (o quien quiera que se encargue de las redes sociales de éste) mantuvo con una persona anónima sobre la exposición que se había inaugurado recientemente en la Casa Central de los Artistas de Moscú (Rusia), de la cual éste no tenía constancia hasta el momento. Mostró su descontento al respecto, porque además el precio de la entrada incluía una visita guiada que oscilaba entre los $7 €$ y los $18 €$. Entonces colgó en su Instagram una captura de la conversación:

-"He visto esto y he pensado en ti.

BANKSY-Eres muy divertido. ¿Qué demonios es eso?

- Una exhibición de tu trabajo en Moscú. Están cobrando 20 libras de entrada. LOL.

B- Me gustaría poder encontrarlo divertido. ¿Qué es lo contrario de $L O L$ ?

- Creo que es LOL.

$B$ - ¿Sabes que no tiene nada que ver conmigo verdad? Yo no cobro a la gente por ver mi arte...

- Ellos lo han hecho parecer auténtico. Creo que deberías hacer algo. ¿No puedes enviar una nota de prensa?

$B$ - No estoy seguro de ser la persona indicada para quejarme de la gente que sube imágenes sin pedir permiso. - No tío. Esto es el principio, es un timo. Tienes que hacer algo.

B-No sabría por dónde empezar.

- ¿Subiendo una captura de pantalla de esta conversación? B-LOL".

La publicación se hizo viral a las pocas horas de publicarse y cuenta con más de trescientos sesenta mil "me gusta" y más de siete mil comentarios.

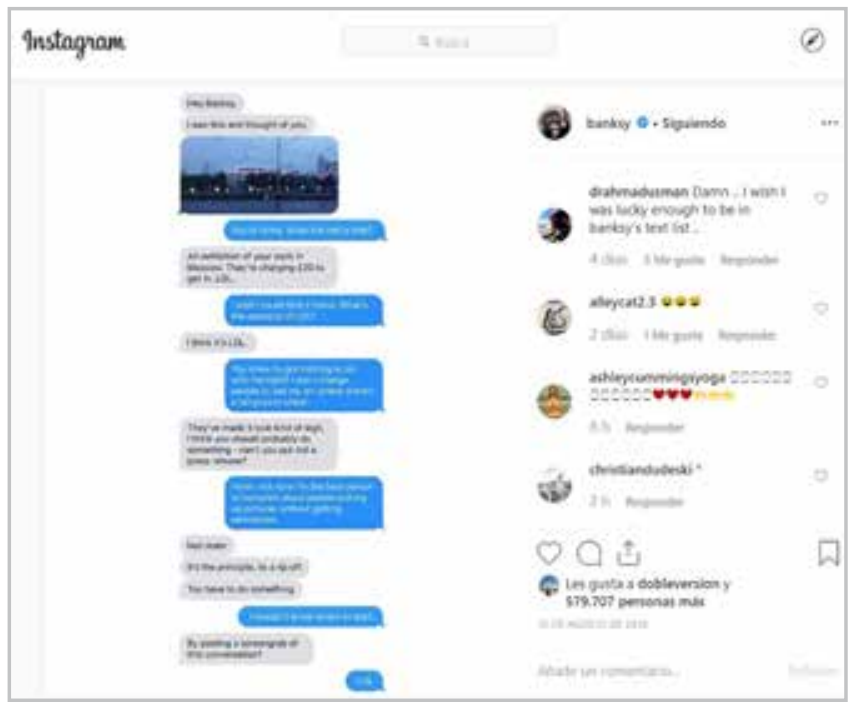

Figura 10.- Captura de pantalla de la conversación de la conversación, que Banksy publicó en su propia página oficial. Disponible en: https://www.instagram.com/banksy/?hl=es-la [Consulta: 25/08/2019].
En la conversación Banksy cuestionó su propio modus operandi, ya que él tampoco se considera como la "mejor persona para quejarse de los que suben imágenes sin tener permiso". Elena Bukhmak, una portavoz de la exposición de Moscú, tomó esta conversación como una señal de que no estaba criticando el espectáculo, a pesar de sus otros comentarios en contra. "Desde nuestro punto de vista, de esta manera, él mostró indirectamente la aprobación de nuestra exposición y está demostrando que éste también es un evento importante para él", dijo Bukhmak (Balmforth, 2018: s.p.).

Decenas de personas respondieron a la publicación de Banksy acusando a los organizadores de la exposición de Moscú de comportamiento poco ético y robo.

Respondiendo a las críticas del post, Nachkebiya dijo que Banksy nunca admite exposiciones en las que no esté directamente involucrado y generalmente emite comunicados de prensa que denuncian tales eventos.

"Creo que el hecho de que lo hiciera de una manera irónica es, en cierta medida, un reconocimiento de nuestro éxito y hace ver que fue un evento grande e importante, incluso en la carrera de Banksy", dijo Nachkebiya (Pyatakov, 2018: s.p.).

El organizador agregó: "Es realmente divertido cuando todos me preguntan acerca de la confirmación por parte de Banksy. Es decir, ¿cómo es posible obtener la confirmación de Banksy?" (Pyatakov, 2018: s.p.).

La institución rusa señaló, a través de la misma red social, que todas las obras son propiedad de coleccionistas y galerías de arte contemporáneo privadas. Apuntan que en ningún momento presentaron el evento como algo autorizado por Banksy, aun así, no tuvieron intención de retirar las piezas ya que "los propietarios tienen el derecho de exponer las obras que realizó el artista".

Además de esta clasificación entre reales y falsas, Banksy deja bien claro en su página web oficial el trato que estas exposiciones deben tener por parte del público y lo acompaña con una imagen muy ilustrativa [figura 11] que además se complementa a la perfección con su origen en el contexto urbano.

"Los miembros del público deben saber que ha habido una serie reciente de exhibiciones de Banksy, ninguna de las cuales han sido consensuadas. Han sido organizados en su totalidad sin el conocimiento o participación del artista. Por favor, trátelas en consecuencia" (Banksy Web oficial).

A la salida de la muestra, parte del personal entrega una Tablet donde se puede votar si se considera a Banksy un genio o un vándalo, pero en este caso, como bien indica Pulido en su artículo, la pregunta ideal sería "¿arte o negocio?" (Pulido, 2018: s.p.). Se podría decir que Banksy, siendo uno de los líderes en contra del sistema capitalista (hecho que parece muy alejado del espíritu de esta 


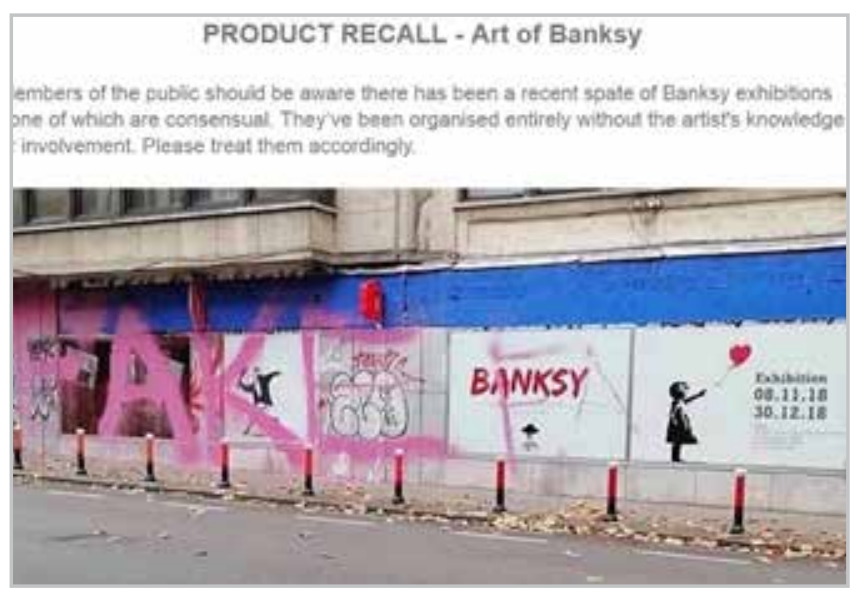

Figura 11.: En la imagen se puede ver un graffiti de gran tamaño en el que se puede leer la palabra FAKE (falso en inglés) tachando parte del advertising (publicidad) de una de sus exhibiciones no autorizadas en Bélgica. BANKSY WEB OFICIAL. Disponible en: http://www.banksy.co.uk/ [Consulta: 23/08/2019].

exposición), se ha convertido en una"víctima" de su propio éxito. $\mathrm{O}$ tal vez se trata de un juego más, que además le aporta una publicidad desmedida. Sin embargo, sólo el artista debe ser el que tome las decisiones, al menos en casos como estos, en los que una exposición se refiere directamente a su carrera.

\section{Conclusiones}

Por tanto, lo que diferencia principalmente al formato de estas dos exhibiciones no es el precio de su entrada sino el grado de implicación que tienen cada uno de los artistas con sus piezas exhibidas.

Curiosamente estos datos son inversamente proporcionales. A mayor precio de la entrada (Banksy, Genius or vandal?, Madrid 2018-2019) menor o ninguna implicación; este es el caso de la exhibición de Banksy en Madrid. Por el contrario, cuanto menor es el precio de entrada (en el caso de The Haus, gratuito), la implicación de los artistas es mucho mayor. Como ya se vio, The Haus, era un espacio en el que cada uno de los artistas y colectivos participaron activamente creando, diseñando, dirigiendo y guiando las visitas en primera persona.

La ubicación de cada una de estas exposiciones también es un factor interesante a tener en cuenta. Ya que la de Berlín se situaba en el centro de la ciudad (pero no en una zona alternativa donde se puede encontrar mayor número de graffiti, sino en las más comerciales) mientras que la segunda se situaba en una zona alejada del centro, en la periferia, en grandes recintos de exposiciones, sin nada en común con áreas alternativas de graffiti.

La idea de temporalidad es algo que también las diferencia, mientras que la de The Haus era totalmente efímera, sin posibilidad ninguna de conservar alguna obra para el futuro, la de Banksy era una exposición itinerante con obras que aún están disponibles e incluso a la venta y ni siquiera son únicas ya que son, en su mayoría, serigrafías de largas tiradas.

Entonces para que una exposición de arte urbano sea realmente "buena"/"correcta", ¿debe ser de naturaleza efímera?. Tal vez sí, ya que la temporalidad de las obras realizadas en el espacio público es lo que atrae a estos artistas a trabajar en ellas. Debe ser gratuita y por lo tanto, pública y accesible para todo posible espectador. Y además, cuanta mayor sea la implicación del artista con el proyecto, más satisfactorio y "real" será el resultado final.

Se puede resumir que, mientras que la exposición de Banksy era: privada, con un precio de entrada desorbitado, comisariada por individuos que no tenían absolutamente nada que ver con el mundo del arte urbano o el graffiti, itinerante y con obras de "interior" (cómo era el caso de las serigrafías).

Que intentaba atraer al público a través del reclamo del "Street Art", del uso de lo "vandálico" y de la supuesta increíble puesta en escena audiovisual. Además de estar ubicada en un espacio sin personalidad en las afueras de la ciudad y de que hayan tenido lugar repetidas ediciones de la misma en diferentes ciudades alrededor del mundo.

En contraposición, la exposición de The Haus fue algo que pasará a formar parte de la historia del arte urbano y graffiti en Berlín. Situada en un edificio icónico de la ciudad, en pleno centro neurálgico de la capital, comisariada, dirigida y administrada por los propios artistas urbanos y grafiteros, con trabajos en relación con su entorno, su contexto. Además de ser totalmente gratuita, accesible para todos los públicos, con una gran variedad de propuestas artísticas, soportes, materiales y efímera.

El que sea efímera y todas las obras hayan sido destruidas al finalizar la exposición no quiere decir que sea mejor ni peor que otras, pero sí que juega y le aporta un toque romántico, que acerca más toda la muestra a la verdadera naturaleza de los trabajos creados en la calle.

Hay que destacar que, en ambas muestras, aunque tanto en una como en otra los artistas son conocidos por ser artistas urbanos y grafiteros, que realizan obras públicas, ninguna de las obras seleccionadas eran piezas ya existentes previamente, extraídas o expoliadas, de la calle. El reclamo en ambas ha sido el arte urbano y una vez más "lo vandálico", pero se ha tratado más de un trabajo de estudio (de piezas "de interior"); en el caso de Banksy, en lo que se refiere al gran número de serigrafías expuestas, $y$ en el caso de The Haus por ser obras creadas ex profeso para la muestra (ya sea por tratarse de obra gráfica, esculturas, graffiti, murales o incluso arranque de mobiliario urbano). Quedando en ambos casos desdibujada la idea romántica y antisistema de la pureza, la frescura y la inmediatez que desprende el primigenio arte urbano. 


\section{Bibliografía}

\section{The Haus:}

ESTILO PALMA WEB. (2017) "Temporary Art: The Haus (Berlin III)". Mallorca Magazine [13 de mayo de 2017] s.p. Disponible en: https://www.estilopalma.com/2017/05/temporary-art-hausberlin-iii/[Consulta: 21/08/2019]

ILOVEGRAFFITI.DE WEB. "170 Artists Invade a Giant Empty Bank Building in Berlin - THE HAUS [PREVIEW]". [2017] s.p. Disponible en: https://ilovegraffiti.de/blog/2017/02/13/100-artists-invadea-5-storey-bank-building-in-berlin-the-haus-preview/ [Consulta: 21/08/2019]

LINDSAY. (2017) "165 Street Artists Took Over an Abandoned Building in Berlin, and the Results Are Wild" [23 de abril de 2017] s.p. Disponible en: https://www.vice.com/en us/article/3d9vg8/165street-artists-abandoned-building-berlin [Consulta: 21/08/2019]

ROJO. (2017) "ROCKING "THE HAUS": A 5-FLOOR BERLIN BANK IS TRANSFORMED BY ARTISTS" [16 de marzo de 2017] s.p. Disponible en: https://www.brooklynstreetart.com/2017/03/16/rocking-thehaus-a-5-floor-berlin-bank-is-transformed-by-artists/ [Consulta: 21/08/2019]

THEHAUS WEB OFICIAL. Disponible en https://www.thehaus.de/ [Consulta: 21/08/2019]

TUÑAS, OLALLA. (2017) "165 artistas llenan de arte un viejo banco de Berlín condenado a la demolición" [17 de mayo de 2017] s.p. Disponible en: https://www.traveler.es/viajes-urbanos/articulos/ the-haus-165-artistas-banco-berlin/10641 [Consulta: 21/08/2019]

\section{Banksy:}

BALMFORTH (2018) "Banksy calls out Moscow gallery for showing his art without approval" [16 de Agosto del 2018] s.p. Disponible en: https://www.reuters.com/article/us-art-banksy-moscow/ banksy-calls-out-moscow-gallery-for-showing-his-art-withoutapproval-idUSKBN1L11TU [Consulta: 23/08/2019]

BANKSY: Genius or Vandal? WEB OFICIAL. Disponible: https://www. banksyexhibition.es/la-exposicion/ [Consulta: 22/08/2019]

BANKSY WEB OFICIAL. Disponible en: http://www.banksy.co.uk/ [Consulta: 23/08/2019]

CORES NANI F. (2018) “La obra del misterioso e irreverente Banksy se exhibe en España por primera vez en la muestra 'Genius or Vandal?" Periódico 20 minutos. [5 de diciembre de 2018] s.p. Disponible en: https://www.20minutos.es/noticia/3508148/0/banksy-geniusor-vandal-primera-exposicion-espana-arte-urbano/ [Consulta: 22/08/2019]

ESPACIO 5.1 WEB OFICIAL. Disponible en: https://www. espacio5punto1.es/espacio-5-1/ [Consulta: 23/08/2019]

MICHAUT, CHRISTOPHER. "The Writing on the Wall. Banksy's
Unauthorized Exhibition"[30 de Enero del 2019] s.p. Disponible en: http://www.dailyartmagazine.com/banksys-unauthorizedexhibition/ [Consulta: 23/08/2019]

PYATAKOV, SERGEY. "Banksy lashes out at 'unauthorized' Moscow exhibition of his work" [16 de Agosto del 2018] Disponible en: https://www.rt.com/news/436129-banksy-moscow-exhibitionsuccess/ [Consulta: 23/08/2019]

PULIDO, NATIVIDAD: “¿Por qué lo llaman arte cuando quiere decir negocio?" Periódico ABC cultura [11 de diciembre de 2018] s.p. Disponible en: https://www.abc.es/cultura/arte/abci-llamanarte-cuando-quiere-decir-negocio-201812070215 noticia.html [Consulta: 22/08/2019]

SERRANO, MIGUEL. "Banksy. Genius or vandal?» El grafitero que se creyó Robin Hood". [19 de diciembre del 2018]. Disponible en: https://eldebatedehoy.es/cultura/banksy-genius-or-vandal/ [Consulta: 23/08/2019]

SOLD OUT WEB OFICIAL. Disponible en: http://www.soldout. es/ [Consulta: 22/08/2019]

\section{Autor/es}

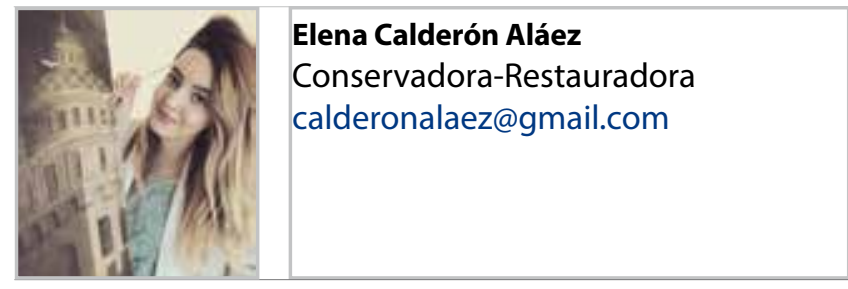

Conservadora Restauradora. Investigadora independiente.

Es Graduada en Conservación y Restauración del Patrimonio Cultural por la Universidad Complutense de Madrid. Ha sido miembro activo del grupo ST.A.CO (Street Art Conservators del TEl de Atenas) durante su beca Erasmus en Grecia (curso 2014-2015). TFG sobre conservación y restauración de obras del artista Eltono en Madrid. En el año 2017 finalizó sus estudios de Máster en Conservación y Exhibición de Arte Contemporáneo en la UPV de Bilbao. TFM sobre Artistas Urbanos intervencionistas/ apropiacionistas en España. Actualmente forma parte de la comunidad de Street Art Cities, donde documenta murales de ciudades como Bilbao, Estocolmo, Reykjavík y Maribor. 

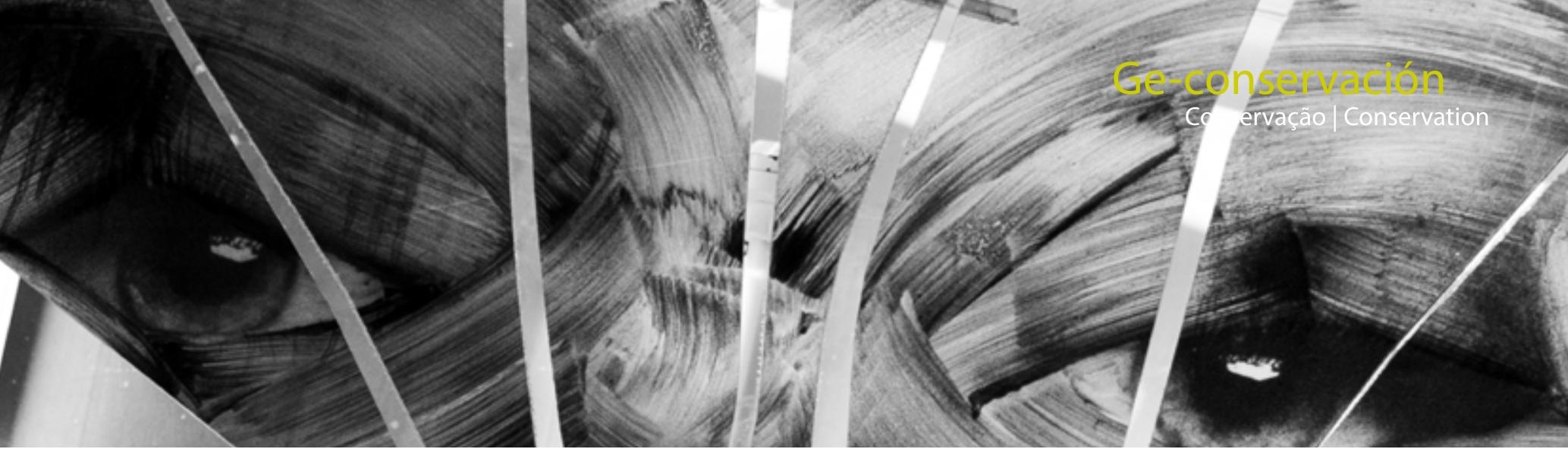

\section{"Viral Mural", entre el muralismo y los espacios virtuales}

\section{Carla Coluccio}

Resumen: La muestra "Viral Mural" desarrollada en Buenos Aires combinó el arte del muralismo con los espacios virtuales, poniendo el foco en el fenómeno de la viralización como manifestación contemporánea, en la medida en que estas obras se infiltran en las redes sociales, logrando una difusión más amplia y su consolidación en el imaginario de la sociedad. De ahí que la relación entre el "dentro y fuera" tuviera límites borrosos y abriera debates en torno a la descontextualización de los murales. En el presente trabajo se reunirán algunos de los principales interrogantes generados por el espíritu de la muestra. De la misma forma, se intentará abordar la investigación desde las redes utilizándolas como fuentes de documentación para el campo de la conservación. Por último, se postularán a estos aspectos, como elementos necesarios capaces de aportar datos valiosos para el estudio del arte en el espacio público.

Palabras clave: arte urbano, viralización, viral mural, descontextualización, conservación, efímero

\section{"Viral Mural", between muralism and virtual spaces}

Abstract: The exhibition "Viral Mural," developed in Buenos Aires, combined the art of muralism with virtual spaces, focusing on the phenomenon of "viralization" as a contemporary manifestation, to the extent that these works infiltrate social networks achieving wider diffusion and consolidation in society. The relationship between "inside and outside" had blurred boundaries and opened debates about the decontextualization of murals. In this paper, some of the main questions generated by the exhibition will be explored. In the same way, we will approach the subject from a variety of social media, using them as sources of documentation in the field of conservation. Finally, these findings will be postulated as part of contemporary culture, perhaps still neglected, and as necessary elements capable of providing valuable data for the study of art in public space.

Key words: urban art, viralization, viral mural, decontextualization, conservation, ephemeral

\section{Introducción: objetivos, metodología}

Existen hoy numerosas propuestas artísticas -intra y extra institucionales- que exploran la potencialidad de las creaciones del arte mural en tanto producciones contextuales: site-specific, abiertas y efímeras, entre otras. Éstas integran recursos provenientes del muralismo, el graffiti, el stencil o los carteles callejeros.

Su diversidad da cuenta de su experimentalismo y de la complejidad que va adquiriendo el movimiento de arte urbano a medida en que se va desarrollando.
El arte urbano es un concepto heterogéneo que se compone de varias influencias como el punk, el skate, la cultura popular, el graffiti y el arte contemporáneo. El término comenzó a utilizarse en los años 80; y como señala el autor Carlo McCormick: "el arte urbano actual es demasiado multifacético e internacional como para reducirlo a una única línea de actuación. Si el graffiti trata de la creación de signos para algunos pocos, el arte urbano ha estado más interesado en transformar esos signos y cambiarlos de múltiples formas" (McCormick, 2011:24). Entre los meses de enero y mayo del año 2019, se llevó a cabo en el Centro Cultural Recoleta [1] de la Ciudad 
de Buenos Aires la muestra "Viral Mural", reuniendo a un grupo de artistas, consagrados y emergentes, provenientes del arte urbano local e internacional, con el objetivo de que produjeran creaciones similares a las que habitualmente desarrollan en las calles pero dentro de un espacio cerrado, en un ámbito institucionalizado. Allí se puso de manifiesto una multiplicidad de relaciones entre los artistas y sus soportes expresivos por medio de la creatividad y la innovación tecnológica. Se analizará, en consecuencia, si esta muestra desarrolló la propuesta de un nuevo tipo de percepción espacial híbrida donde el componente destacado está en lo virtual y el fragmentado en lo físico, o bien, otra menos radical, que caracteriza a los espacios públicos como nudos complejos donde existe una mayor relación espacial con su entorno.

Los objetivos de esta investigación se enfocarán en esa exploración de la vinculación entre el muralismo y sus conexiones con las redes sociales y otras plataformas digitales de circulación viral de contenidos. También se abordarán las relaciones entre los ciudadanos y la vitalidad de los espacios públicos y cómo esa realidad compuesta por lo presencial y lo virtual puede romper la estructura rígida de una exposición cerrada (como por ejemplo, la de un centro cultural).

Aquí se han empleado textos científicos, se han realizado entrevistas a los artistas y se han utilizado las redes sociales para analizar el impacto de la viralización del arte mural. Abriendo un debate orientado hacia las nuevas formas de su exposición, así como también hacia la imperiosa necesidad de su documentación como fuente fundamental para el campo de la conservación.

\section{"Viral Mural"}

Desde los inicio del siglo XX el arte invade las calles con la intención de escapar de los museos y vincularse con la gente. Mientras que algunas vertientes artísticas poseen una lógica más bien institucional, que sólo cobra sentido en el interior de un sistema formal cerrado y específico, la creación mural posee un carácter más bien comunicativo, que busca atrapar las miradas de las personas y transformar su experiencia urbana.

El Centro Cultural Recoleta, con la exhibición colectiva "Viral Mural", puso foco en los muros de las ciudades como superficies de expresión pública e invitó al visitante a embarcarse en un recorrido en el que arte y praxis vital se imbrican a propuestas artísticas que plantean materiales alternativos para la creación con recursos no ortodoxos y soportes no habituales. La exposición combina el muralismo y los espacios virtuales como "muros" de Facebook y observa el fenómeno de la viralización como manifestación contemporánea en la medida en que estas obras se convierten en vehículos de reclamo y opinión que se infiltran en redes sociales, memes, tuits y acciones virales. La muestra, curada por Rodrigo Alonso [2] y con el diseño de montaje de Daniel Fischer, brindó la participación de artistas provenientes de la pintura, el tatuaje, el dibujo o el graffiti reuniendo obras de una diversidad de soportes, técnicas y estilos: figuración, abstracción, afiche, stencil (tantas variantes expresivas como artísticas). Para seleccionarlos, el curador realizó una investigación exhaustiva, combinando muralistas conocidos y unders a modo de representación de lo que está ocurriendo a nivel mundial con el movimiento de arte urbano.

Los jóvenes artistas elegidos fueron Drë (Chile), Elliot Tupac (Perú), TEC (Argentina/Brasil), Les.soeurs.chevalme (Francia), María Noel Silvera (Uruguay) y Nuria Mora (España) quienes ocuparon las principales salas del Centro Cultural Recoleta y los patios del edificio,reflexionando sobre los usos y las posibilidades del espacio público junto a los artistas argentinos Unidos Crew, Ale Giorgga, Fluorencia, Elisa Estrada, Pum Pum, Cristhian Riffel, Cabaio, Lu Yorlano, Lacast, Valeria Calvo, Doma y Malen Pinta.

Con respecto al diseño de la exposición y al guión curatorial, no hay un hilo conductor: más allá del soporte, cada artista realizó el trabajo dentro de la línea de lo que hace habitualmente. Hay que resaltar que muchos de los murales están ubicados en espacios que fueron utilizados para conciertos, talleres, clases abiertas y conferencias, como parte del contexto de un acontecimiento artístico o pedagógico en función de las otras actividades que ofreció el Centro. Las intervenciones ocuparon los espacios cubiertos como las salas Cronopios, J y C del C. C. Recoleta, mixtos como Espacio Clave 13/17 y al aire libre como espacio Hip-Hop, Patio del Aljibe o Pasaje de los Tilos.

Esta muestra fue pensada para espacios que poseen un contexto bien diferente al de la calle, su relación con las redes sociales surge de ese muro que invita a que la gente se exprese públicamente de cualquier forma, mediante textos políticos, lúdicos e incluso intimistas. El Comisario asegura que la relación entre el fuera y dentro fue un problema que se planteó desde el principio. Por tal razón centró la muestra en el concepto de mural, sumó respuestas y debates abiertos en función de la temática planteada.

La bienvenida de la propuesta artística tuvo presencia desde la fachada del histórico edificio diseñado por los artistas y arquitectos Clorindo Testa, Jacques Bedel y Luis Benedit [3]. El viejo tono rosado que lo caracterizó desde que fue inaugurado en 1980 fue pintado con colores estridentes (amarillo, violeta, verde y fucsia) por el artista Yaia, con la obra "Amor de verano", dedicada a la potencia del amor y la diversidad de sus formas. Amor como parte del ser, como construcción de la mente, depósito de fuerza, inexorable destino, desafío y realidad [figura 1]. Pero hay que destacar que la intervención de la fachada (que fue efímera, como la muestra misma) actuó como una marquesina, como un flyer publicitario, una "muestra" 
de la muestra que el visitante encontraría en su interior, sin el espíritu de espontaneidad que caracterizaría a esta misma obra en cualquier otro muro de una calle cualquiera.

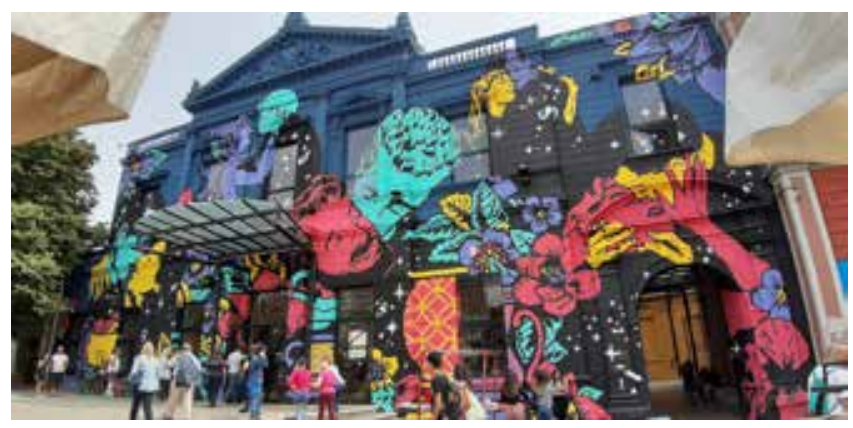

Figura 1.- Intervención de la fachada del Centro Cultural Recoleta por el artista Yaia

Ingresando a las salas se pudo observar cómo cada pieza se destacó por alguna particularidad: la obra de Les Soeurs Cheval Ilamó la atención por su reflexión sobre el colonialismo, la obra de Cabaio ha desarrollado un estilo elaborado símil al collage, en el que trabajó con capas y la inclusión de imágenes cuidadosamente seleccionadas reflejando una manera de expresar más personal e intuitiva: composiciones coloridas, repetición de figuras geométricas, utilización de elementos figurativos y la inclusión de caligrafía, lo que conlleva a obras caracterizadas por el uso de la técnica stencil [figura 2]

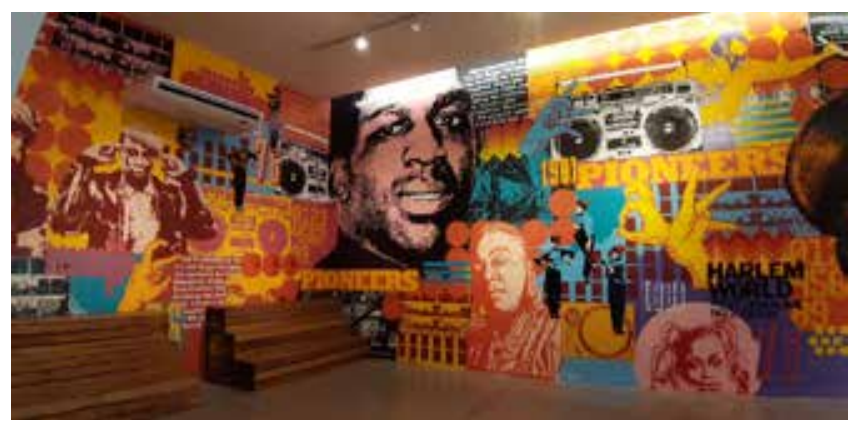

Figura 2.- Esta obra de Cabaio integra múltiples referencias a la historia del hip-hop.

Dentro del recorrido de la muestra se destacó la la participación del colectivo Unidos Crew, que intervinieron un vagón de tren con aerosoles [figura 3]. La propuesta curatorial presentaba un paralelismo con los trenes de Nueva York como lienzo, mezclando así la exhibición del arte y la transgresión, dos características importantes del graffiti. Los trenes ofrecían, además, la ventaja de ser objetos en movimiento que permitían una viralización local de la obra que luego se replicó en las calles y muros. En la exhibición, los espectadores podían subir y hacerse un selfie e interactuar a la entrada del metro con el video del artista Jorge Macci y compartir su experiencia a través del ciberespacio [figura 4].

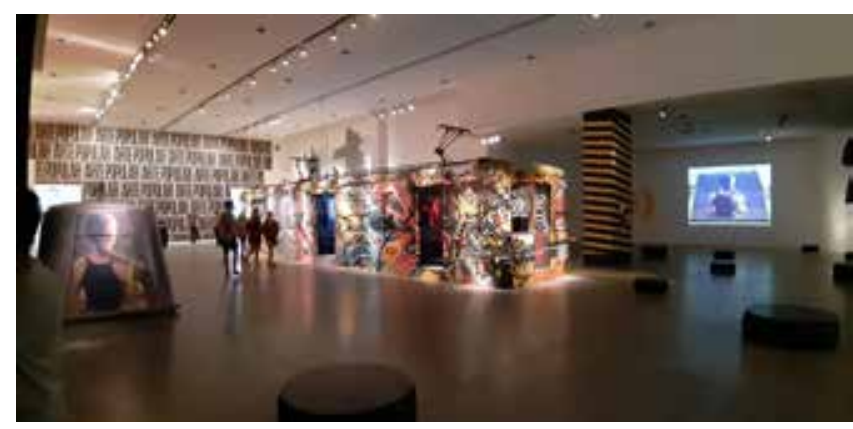

Figura 3.- Vagón pintado por los escritores de Unidos Crew y, de fondo, los carteles con la leyenda "arte popular"

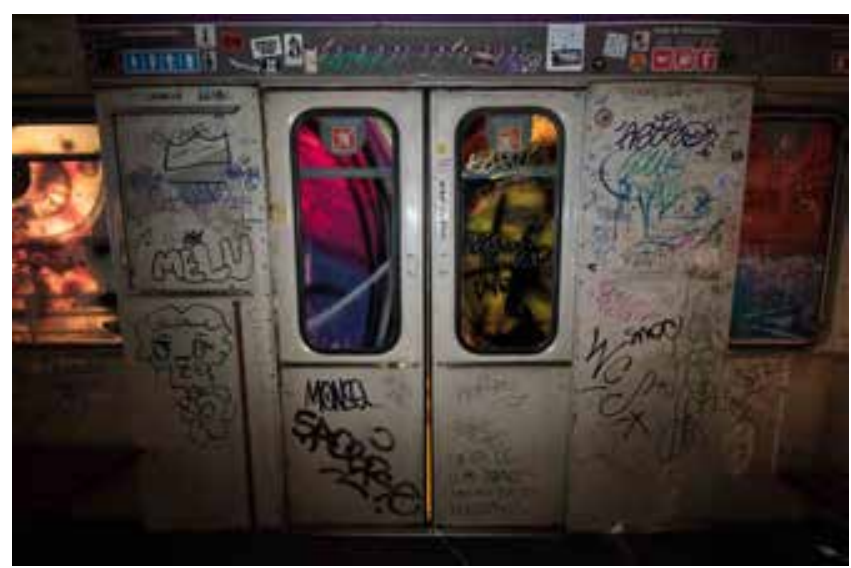

Figura 4.- IAcción artística de Unidos Crew en el interior del vagón. Foto de Guillermo Coluccio.

La exploración con distintos medios artísticos persistió en una sala a oscuras cómodamente dispuesta con colchones en el suelo en el que el público se sumerge en un mundo de recopilación, acumulación y acopio de videos, cada uno, un universo imaginado diferente que tienen en común la búsqueda de nuevas formas de pensar el videoarte [figuras 5 y 6 ]. A estas expresiones se le suman las de Elisa Strada y María Noel Silvera, que intervienen muros digitales y analógicos, expandiendo el campo.

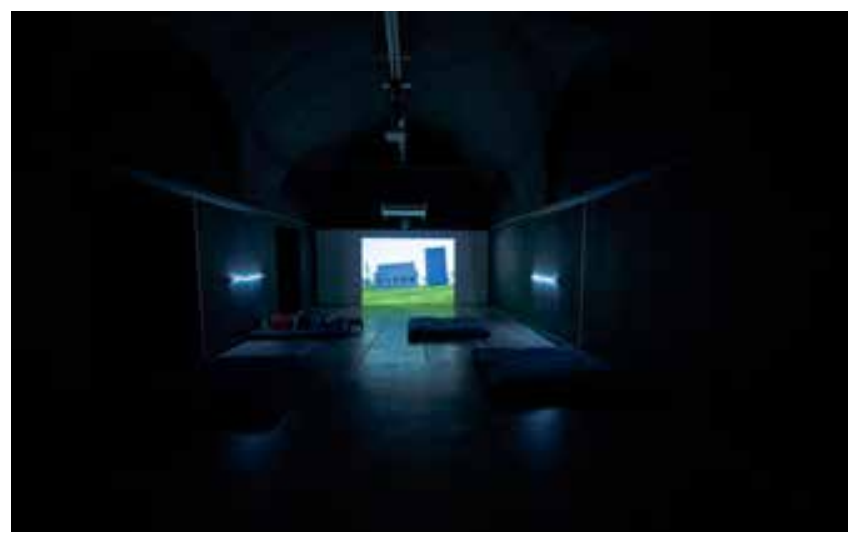

Figura 5.- Intervenciones en el espacio con muros digitales. Foto de Guillermo Coluccio. 


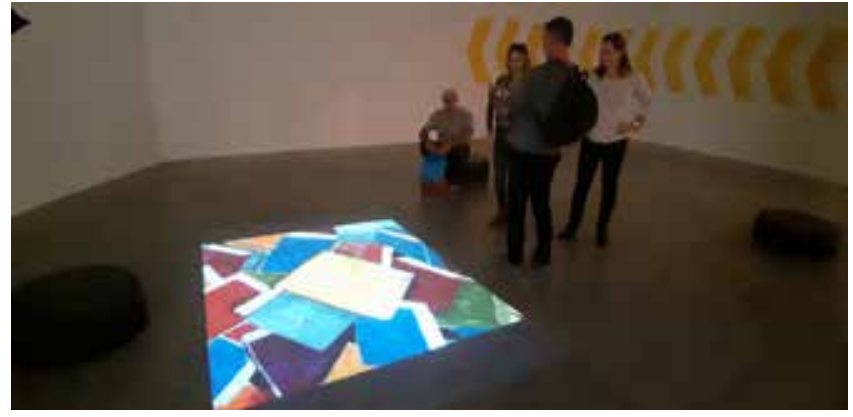

Figura 6.- Proyección de video arte.

Elliot Tupac propone al espectador una nueva manera de relacionarse con el arte y con la vida, provocar una nueva conciencia del espacio cotidiano a través del juego y de la reflexión, pidiéndole que asuma una actitud activa, y que se convierta en coautor de la obra, que mute y logre alguna transformación en su vida cotidiana [figura 7]. Que el hombre rehabite su espacio, lo cambie, lo resignifique, comprenda o simplemente rehaga, pero que después de esta experiencia, no quede intacto.

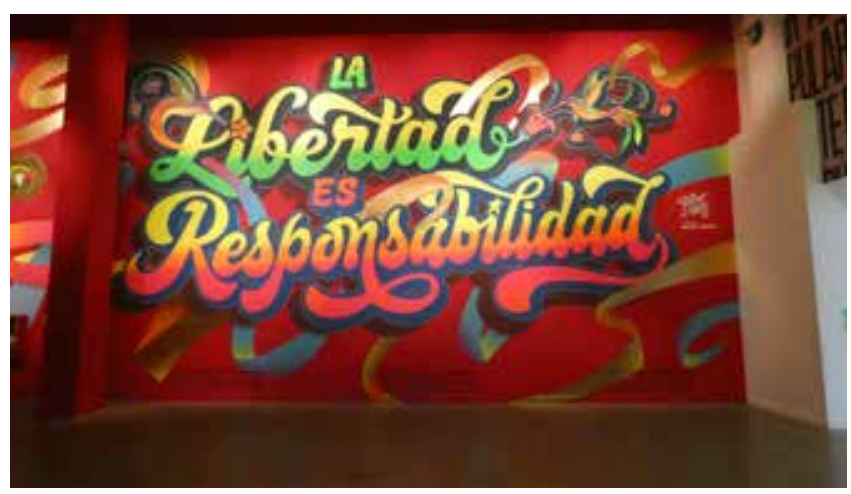

Figura 7.- El artista peruano Elliot Tupac con su mural “La Libertad es Responsabilidad".

Otro de los grandes exponentes del arte urbano es el artista comprometido con temas sociales TEC. A través de sus expresiones, capta determinadas formas de resistencia de lo cotidiano, sintetizando y pluralizando el discurso de la calle en su trazo. Participó con una instalación audiovisual creada exclusivamente para este espacio con relatos del argentino Matías Barzola, reconocido narrador de historias que en esta ocasión expuso una pelota de fútbol hecha de dólares, una manera de relatar los vaivenes de la moneda a través del juego, la alegría y el lamento con un elemento intrínseco de unión con la historia contemporánea argentina.

El recorrido ofreció la convivencia de diferentes artistas, una perspectiva en cuanto a las tendencias actuales, la combinación del uso de técnicas tradicionales junto con la producción y realización de obras digitales (de libre e infinita interactividad por parte de los usuarios en la web). El objetivo fue llamar la atención de todo aquel que pasara por el lugar: ¿cuáles son los lugares menos sospechados para sorprender al ciudadano con arte? Los artistas son capaces de tomar un muro, sí, pero también de dotar de personalidad a un cesto de basura, o de fosforescencia al alterar el negro profundo de una pared, y de cargar espacios de intensos y vibrantes colores, como la obra de Fluorencia.

De esta manera, la visita al Centro Cultural Recoleta invitó a los concurrentes a repensar el arte, a preguntarse acerca de qué es lo que hace que una obra sea arte, qué es lo que le otorga su estatus, cuál es su relación con la vida cotidiana; pero, además: con qué materiales y técnicas se puede hacer arte y qué puede utilizarse como soporte (material o virtual) y en qué espacios se puede encontrar. Todo este camino se ve reflejado en muchas de las obras de la muestra donde los muralistas manifiestan críticas al sub-sistema artístico, a la manipulación, al comercio. Hablan también como huella, en contra del olvido y a favor de un mayor compromiso con la realidad histórica. Seleccionan hechos de la realidad para así encontrar el intersticio que les permita contraponer al espectador común con la reflexión, muchas veces a través de una acción lúdica.

Estas son algunas de las manifestaciones que presentó "Viral Mural" como muestra participativa, gestando una construcción del público más compleja que al invitarlo a asumir un rol activo frente a diferentes ámbitos, lecturas, recorridos, simbologías y medios, para generar en ellos consciencia del cambio de su propia experiencia estética.

\section{Artistas urbanos, la relación entre "el dentro y fuera"}

El Centro Cultural Recoleta es cuna de las vanguardias en Buenos Aires. Es un espacio abierto a la diversidad y propulsor del arte. Multifacético, ha nutrido a muchas generaciones de jóvenes artistas emergentes con su estímulo. La década de los 80 lo definió como pionero en cuanto a su propuesta cultural, mientras la recuperación de la democracia se acercaba y, con ella, toda la fuerza de la expresión silenciada. Pero, como dicen los porteños, el Recoleta es, ante todo, un espacio público, complejo y expansivo.

La propuesta que planteó Alonso con "Viral Mural" fue trabajar sobre un espacio cerrado e institucional, frente a la toma del espacio público abierto. Un concepto dedicado por completo al arte urbano que implicó hacer "dentro" lo que se concibe "fuera" y hacerlo al alcance de todos, transmitiendo contenidos y recibiendo el beneplácito del ciudadano que se nutre y lo retroalimenta de acciones que representan la diversidad cultural. [figura 8].

Se brindó un escenario para la comprensión del arte urbano en sus diferentes expresiones que invitaba a compartir, reflexionar, cuestionar y disfrutar las 


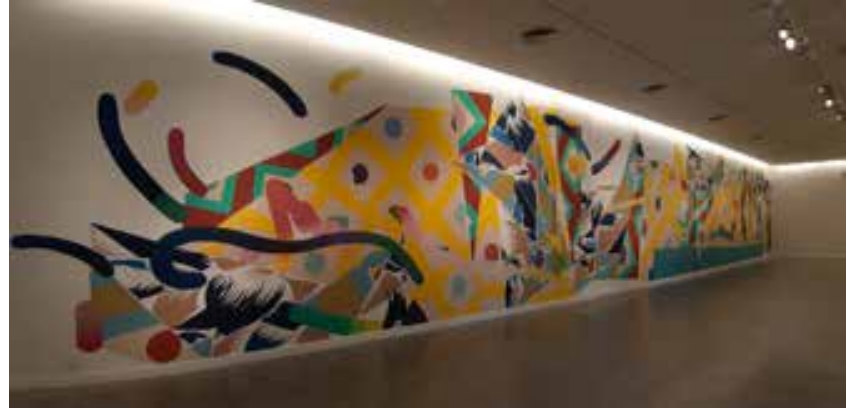

Figura 8.- El colorido mural de la española Nuria Mora inunda una de las paredes del Recoleta.

diferentes propuestas de los artistas. Los distintos espacios expositivos no estuvieron separados, sino que se integraron en un recorrido conceptual, siendo los murales, también escenario de otras actividades (workshops, performances, conferencias, presentaciones de música hip hop) que acompañaron la experiencia.

La fusión con arquerías coloniales, tuberías de aire acondicionado, ventanas triangulares en diálogo con las aberturas originales del viejo convento, integró lo nuevo a lo viejo, sin perder el respeto por el pasado y sin tener que subordinar el uno al otro, de este modo se exaltaron ambos léxicos. En los espacios exteriores, alrededor de los árboles y plantas en convivencia, se instalaron cestos de basura que fueron intervenidos por los artistas, rodeados por escaleras de hormigón, pasarelas y marquesinas metálicas, dando origen a los patios del Tilo [figura 9]. De este modo, la articulación no buscó suavizar los contrastes estilísticos, sino que, por el contrario, destacó las características respectivas de cada muralista. De este modo, el conjunto se expresó en diseños, volúmenes, espacios, texturas y colores diferentes.

Frente a esta propuesta curatorial, se les preguntó a los diferentes artistas participantes si sentían algún tipo de encasillamiento por el medio en que trabajan, la calle. El $100 \%$ respondió que sí, aunque ellos primero se proclaman "artistas", para luego crear sentido de pertenencia con el contexto en el que interactúan, por lo cual el medio queda relativizado ante posibles mutaciones de estilo.

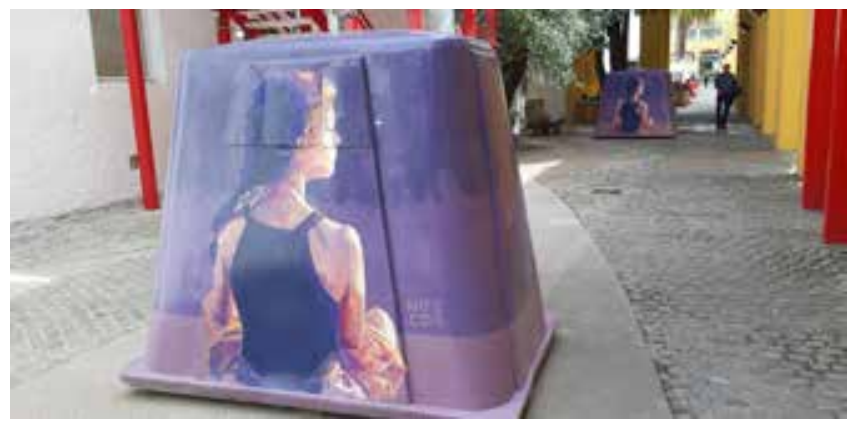

Figura 9.- Papeleras de reciclaje pintadas por el artista uruguayo Noe Cor.
Cabe destacar que hoy los artistas urbanos tienen un rol más amplio e íntegro, no solamente se expresan en las calles, sino que son gestores y productores de un trabajo mediado por la investigación y el diálogo interdisciplinar con otros saberes como la sociología, ecología, música, danza y teatro, entre otros, que trasciende las técnicas y el oficio. Desde el circuito del movimiento urbano se ha alegado la falta de reconocimiento a los artistas que vienen de la calle, cuando en muchos casos tienen una elevada calidad conceptual y/o plástica.

También se indagó acerca de las posibilidades de que el arte urbano se ensamble en un lugar cerrado. Las opiniones fueron dispares. Un $48 \%$ de los artistas respondió que tal vez se desvirtúa la esencia de estas manifestaciones, pero el $52 \%$ restante consideró a la propuesta del curador interesante y posibilitadora para que los murales consiguieran implicar a la ciudadanía en su entorno, generar identidad e integrarse mejor en el imaginario colectivo de la ciudad y su arte. Los artistas resaltaron la importancia de derribar el mito que condena al arte urbano como $100 \%$ vandálico.

Las instituciones han ido asimilando paulatinamente al arte urbano, limitando su esencia a causa de sus convencionalidades, a las que apenas una minoría puede acceder. Pero "Viral Mural", al emplazarse en un centro cultural de puertas abiertas a la comunidad, con entrada gratuita, se diferencia de las paredes blancas y la rigurosa estructura del museo como institución.

En primer lugar, un museo y un centro cultural no son instituciones análogas; sus diferencias afectan a la producción artística y a las condiciones y estándares de su difusión. Pero ambas actúan como legitimadoras que deciden hacia dónde debe dirigirse la mirada del espectador. Se trata, pues, de un proceso de exclusión que siempre ha suscitado tensiones y enfrentamientos entre los artistas y las instituciones. Más aún tratándose de los muralistas, quienes a través de la amplitud que les brinda la calle intentan hacer llegar sus producciones a una totalidad que abarca no solamente a quienes son habituales visitantes de instituciones cerradas sino también a todos aquellos que son ajenos a ellas. Pero los hechos indican que la difusión alcanzada por el arte urbano en los últimos años a través de la creación de museos especializados en varias ciudades del mundo ha generado un alto impacto social y mediático. Su patrimonialización en instituciones ya es una realidad ineludible que se replica cada vez más.

Hoy en día, la legitimidad de cualquier obra nace del reconocimiento del público masificado y en este contexto, las aspiraciones anti-institucionales del arte urbano mantienen un precario equilibrio con la necesidad de propagación inherente a toda práctica artística. El soporte digital, en este caso, ha aportado en el campo de las artes plásticas no sólo nuevas posibilidades formales y expresivas, sino también nuevos canales de difusión de la 
obra. Es importante analizar, entonces, desde qué ángulos y polaridades diferentes confluyen o se contraponen.

\section{Del muro a las redes}

Es indudable que Internet representa uno de los mayores factores de cambio de la sociedad. En las últimas décadas hemos sido testigos de la expansión de las comunicaciones inalámbricas. Teléfonos móviles, smartphones, PDA's, tablets y un sin fin de nuevos dispositivos han emergido ofreciendo a los usuarios la promesa de la comunicación ubicua. Comunicarse en cualquier momento y desde cualquier lugar se ha convertido en una realidad diaria. El surgimiento de la comunicación interactiva caracterizada por la capacidad para enviar mensajes en tiempo real o en un momento concreto ha viralizado la comunicación.

Las plataformas digitales, y especialmente las redes sociales, se han constituido como espacios para crear y compartir información, conocimiento, procesos y proyectos colaborativos capaces de ser trasladados de la esfera digital al espacio físico y viceversa. Estas nuevas formas de comunicación han establecido espacios híbridos, puntos de encuentro entre los planos digitales y físicos expositivos que pueden favorecer los procesos de innovación de carácter tecnológico pero también social. Ni la gestión cultural, ni las formas de producciones artísticas y consumo cultural pueden permanecer al margen de estos cambios.

Dicho esto, es evidente que no podemos pensar en los espacios expositivos sin tener en cuenta las potencialidades de estas tecnologías, en cómo se usan y cómo pueden aportar valor añadido. Deberíamos empezar a hablar de un nuevo tipo de espacio, un espacio híbrido, donde la tecnología pueda llegar a catalizar dinámicas de hibridación entre actividades que tradicionalmente no están conectadas o se encuentran alojadas en otros espacios privados, como en este caso un centro cultural.

En el arte urbano sucede algo similar. Los murales irrumpen en el espacio público relacionándose con los espectadores desde su cotidianidad, mimetizándose con el entorno, pero a la vez modificándolo. El espacio virtual, al igual que el espacio público geográfico, admite un uso social y colectivo de apropiaciones múltiples y ambos se modifican e interrelacionan entre sí, pues el cambio técnico en los medios y procesos de comunicación social ha rediseñado los escenarios urbanos, los espacios públicos y privados, y las prácticas sociales de comunicación. Este nuevo paradigma, denominado auto comunicación de masas (Castells, 2009), combina dos aspectos cruciales: un potencial alcance global en la comunicación, sea quien sea el emisor; y una nueva forma de comunicar masivamente, en la cual las categorías de emisor y receptor se difuminan notablemente. La viralización del arte urbano es un claro ejemplo de la necesidad de los ciudadanos de una aproximación diferente a las obras contemporáneas, cada vez más complejas y cambiantes. En primer lugar, la comprensión de que lo real y lo virtual ya no son mundos separados, sino totalmente imbricados. Este nuevo poder proviene de la evolución, democratización y extensión en el uso de las tecnologías de la información, que otorgan nuevas capacidades a las personas (Rheingold, 2002: 25).

Se toma el caso de la artista Elisa Strada que se sumerge en las calles para recolectar carteles, avisos y propagandas de créditos hipotecarios, deliverys de helados y volantes publicitarios para construir con ellos una intervención desbordante: "La enamorada del muro". Una pared en la que los fragmentos repetitivos y obsesivos sobre el color se despliegan por los casi $40 \mathrm{~m} 2$ de pared en el centro cultural. Pensado como un lienzo comunitario, como los posteos públicos en las redes sociales, las paredes reflejan las voces de una comunidad [figura 10].

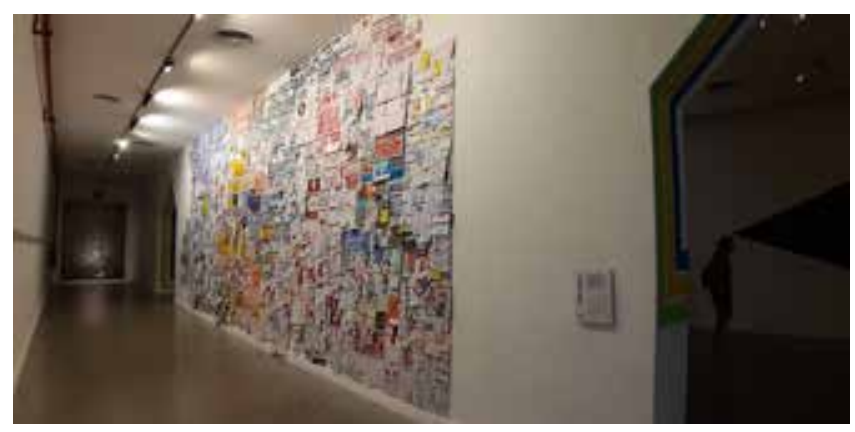

Figura 10.- El mural “La enamorada del muro” de Elisa Strada.

El objetivo de Strada fue potenciar el efecto de sus creaciones ya que sumó a las interacciones presenciales, las experiencias de lo virtual. Concibió su producción sabiendo que posteriormente los espectadores la publicarían en la web, por lo que el registro de la obra y su posterior divulgación se vuelven parte de la obra misma. La legitimidad de la obra nace del conocimiento y reconocimiento de su esencia artística por parte de un público y de su disfrute en la experiencia artística. Como lo plantea Lefebvre en tres dimensiones profundamente interrelacionadas: lo percibido, lo concebido y lo vivido. Estos aspectos son las prácticas espaciales, las representaciones del espacio y los espacios de representación (Lefebvre: 1991). Este espacio expositivo es un elemento simbólico y subjetivo que se interrelaciona con la vida efectiva de las personas que se desarrollan en estas redes sociales, construyen un lenguaje performativo establecido colectivamente, que puede trascender los límites de las tecnologías de la información y desplegarse en otros ámbitos. Nos planteamos: ¿qué supone utilizar el lenguaje de las redes sociales en espacio expositivos?, ¿qué implica este lenguaje?.Esta obra invitaba a los espectadores a postear "un hashtag" en servicios tales como Twitter, FriendFeed o identi.ca, con caracteres formados por una o varias palabras concatenadas y precedidas por una almohadilla (\#). Por ejemplo, el fin de semana fui a la muestra Viral mural en el Recoleta. \#AmoLosMurales. Posteriormente, un usuario podrá buscar la cadena \# AmoLosMurales y este mensaje estará presente 
en los resultados de la búsqueda junto con otros mensajes con el mismo hashtag. Los hashtags, asimismo, también se muestran en algunas páginas web de trendingtopics tales como la propia página de inicio de Twitter. En ocasiones, un hashtag pasa a convertirse en un fenómeno de Internet a pequeña escala. El proceso es el siguiente: creación de un hashtag a raíz de un tema emergente, su popularización a lo largo de unos días y su desaparición.

En cambio en la red social Facebook, solamente está disponible en su versión "Me gusta". Este hecho remite a la facilidad de participación y opinión que ofrece el mecanismo de la página que, con un simple clic permite valorar una publicación o fotografía. Otros amigos o usuarios podrán reutilizar el contexto en sus muros de la experiencia del usuario, interactuar y llevar a cabo prácticas de apropiación o de resistencia.

Los ejemplos propuestos a lo largo de la muestra desde el ámbito del lenguaje, indicaban un aspecto clave al emplear mensajes que para su comprensión es necesario un entendimiento de las diferentes redes sociales, proponiendo un espacio híbrido virtual-urbano. En este espacio, el conocimiento de las dinámicas y códigos que vertebran la interacción social en Internet tienen el mismo peso que las convenciones relacionales a nivel presencial. Se impone, por tanto, un conocimiento social dual online-offline para la descodificación de las prácticas realizadas. Como dice el sociólogo Manuel Castells “... la conexión entre lo virtual y lo presencial (no diría lo real, porque la realidad es virtual y presencial a la vez) la establecemos nosotros. No hay dos sociedades, hay dos formas de relación y actividad social en nosotros mismos. Somos nosotros los que tenemos que buscar la mejor forma de acomodarlas y adecuarlas" (Castells: 2008). La conexión entre estas dos dimensiones funciona como una vidriera de alto alcance con las redes sociales. Los espectadores vuelven a transitar la doble experiencia: la de observar en el centro cultural y luego subir una fotografía o un comentario en una red social. La teórica Susana Darín indica que la identidad es una necesidad individual y colectiva, caracterizada por ser afectiva, cognitiva y activa. Las formas de vinculación varían, en primer lugar, una vez que se viraliza un contenido, ya no le pertenece al centro ni al curador ni al artista (Darín 2015:15). El contenido ya puede ser modificado por los usuarios, entonces ¿cuál es el verdadero producto del arte?

Podría pensarse como una consecuencia natural de la misma dinámica actual de globalización las relaciones de poder que se generan en la tensión de una escena donde los artistas/productores no serían los únicos agentes mediadores de la obra y el público: la práctica actual de presentación fotográfica, documentación, circulación, recepción y negociación de las imágenes del arte urbano en Internet conduce a una reconfiguración de lo global y lo local, y por lo tanto, a las nuevas normas y relaciones de poder. Tanto fotógrafos como bloggers y administradores de páginas de Facebook se auto posicionan, y están posicionados, como creadores de opinión (Glaser, 2015: 6). Sitios y páginas existentes institucionalizan una especie de canon y configuran la escena. Podría parecer que el arte urbano tiene una vocación por alcanzar una esfera de difusión lo más extensa posible, aunque cabe preguntarse si esa vocación es la del artista, la del usuario o la de ambos. En muchos casos nunca podremos conocer el mural original y sin embargo podremos ver no una sino múltiples imágenes de los murales urbanos, circulando, a través de todo tipo de dispositivos: impresos, digitales, merchandising, etc. Desde los distintos puntos del globo llegan miles de imágenes, algo que realmente parece abrumador.

También la viralidad se relaciona con los números de seguidores en las redes sociales, la identificación, hoy día, se logra "cuando las comunidades empiezan a defender el patrimonio propio" (Pérez Simón 2015: 70), es decir, que la ciudadanía se identificará con el arte urbano cuando comience a defenderlo, lo que ya ha empezado a suceder. Por lo tanto, la viralidad depende del contenido que guste a la gente y que lo compartirá, y generalmente es algo que emociona, pequeñas acciones que se salen fuera de lo común de todos los días. Los llamados "influenciadores", son los primeros usuarios que están dispuestos a compartir sus opiniones con respecto del acto artístico, generando una conversación proactiva en las distintas redes sociales.

El espectador forma parte activa en la construcción tanto de las obras de arte como de las piezas de comunicación de la muestra. Estos efectos atraviesan un proceso de ida y vuelta, tomando otras dimensiones, disparando y generando efectos en las redes sociales. Entendida esta intervención tanto en lo que respecta a la participación y experimentación, como en la difusión y compartición posterior, se puede afirmar que se nutre del arte al tiempo que lo nutre. Está retroalimentación se convierte en un fenómeno de la postmodernidad.

\section{Reflexiones finales}

El arte es una herramienta eficaz y poderosa para la transformación social de las comunidades en las que incide. En todas las épocas y culturas, el arte siempre ha dialogado interdisciplinariamente con la ciencia, los avances tecnológicos y materiales. El siglo XXI ha impreso un cambio decisivo al permitir que las tecnologías digitales modifiquen radicalmente la forma en que nos relacionamos y organizamos con el entorno, donde lo digital es tan relevante como lo físico.

La incorporación de las redes sociales ha planteado una revolución al generar una comunicación interactiva y participativa a través del feedback. "Los usuarios actuales de la web proponen servicios, intercambian información, hacen comentarios, se implican, participan. (...) Estos internautas en plena mutación ya no se contentan con navegar, con surfear. Actúan" (Pisanti, Piotet, 2009:14). 
Tanto los artistas como el público que replican sus publicaciones son webactores y se diferencian de los primeros usuarios de la web (los internautas) por su papel activo en la construcción de la viralización; generando un vastísimo caudal de información y por ende de contenidos. En "Viral Mural", particularmente, se pudo observar cómo las propuestas expositivas incrementaron el interés de visitantes cada vez más diversos y propiciaron el impacto cultural de los montajes usando lecturas del patrimonio cultural novedosas para una ciudad como Buenos Aires.

Desde hace una década, el arte urbano es un paradigma de la hibridación en la cultura visual global, un género post-posmoderno que se define más por la práctica en tiempo real que por cualquier sentido de post-fotográfica, post-internet y post-media, intencionalmente efímera pero ahora documentada casi obsesivamente con fotografía digital para la web, apropiando y combinando constantemente imágenes, estilos y técnicas de todas las fuentes posibles (Irvine, 2012: 235).

La propuesta del curador Alonso permaneció abierta por apenas tres meses, un período de tiempo preacordado con los autores de las obras efímeras que allí se expusieron. La viralización perseguida por esta muestra radicó en que, a través de las redes y otros medios digitales, se lograse una difusión más amplia para que las obras, que ya no existen, puedan ser experimentadas únicamente a través de los formatos digitales como un "exhibidor permanente".

De esta manera, en la escena del arte urbano contemporáneo, la importancia del archivo y de la circulación de las imágenes, que por su carácter efímero, tienen contada vida física, preocupa e interesa a un amplio abanico de actores sociales como académicos, curadores, conservadores, entre otros. Esta multiplicación de imágenes, genera desde el campo de la conservación del patrimonio cultural un nuevo debate. Los aspectos particulares del arte urbano nos demuestran que es necesario construir nuevas herramientas metodológicasy lenguajes específicos desde el campo de la conservación. Una de las preocupaciones actuales es encontrar formas adecuadas de documentación y archivo, resultando muchas veces el único testimonio de la existencia de los murales. Pero hay que tener en cuenta que se puede llegar a desvirtuar una perfecta documentación fotográfica si no se aportan datos suficientes o se pasan por alto detalles fundamentales, que en el momento pueden resultar demasiado evidentes, pero que si no se mencionan, pasado un tiempo, las obras no podrán situarse en su contexto histórico.

En ese sentido con las redes sociales, se puede entender este movimiento global como una dinámica inmersa en el gran flujo que Groys describe para las tendencias contemporáneas del arte como fluido: "El arte tradicional produce objetos de arte; el arte contemporáneo produce información sobre acontecimientos de arte [...]. El arte fluido actual está mejor documentado que nunca, y la documentación se preserva y distribuye mejor que las obras de arte tradicionales" (Groys, 2016: 12-14).

Para culminar con este eje de análisis, el objetivo de esta investigación fue acercar ideas a investigadores sobre los espacios híbridos del arte urbano, estableciendo que el trabajo de campo tradicional no es la única forma de obtener datos del valor de los murales, ya que como se comentó, mucho de lo que acontece en relación a la producción, circulación y apreciación del arte urbano, se produce en y para las redes. Es entonces allí mismo donde debemos estar presentes para obtener información de primera mano; y en dónde se está intentando innovar sobre la forma de archivar ese material, de citarlo apropiadamente y de clasificarlo para su posterior uso y análisis, estableciendo el desafío de la construcción de un nuevo conocimiento que se está desarrollando.

\section{Notas}

[1]. Centro Cultural Recoleta ubicado en la calle Junín 1930 en el barrio porteño de Recoleta, Buenos Aires.

[2]. Rodrigo Alonso es Licenciado en Artes de la Universidad de Buenos Aires (UBA), Argentina, especializado en arte contemporáneo y nuevos medios (new media). Profesor de la Universidad de Buenos Aires (UBA), Universidad del Salvador (USal) y del Instituto Universitario Nacional del Arte (IUNA), Buenos Aires, Argentina. Profesor y miembro del Comité Asesor del Máster en Comisariado y Prácticas Culturales en Arte y Nuevos Medios, Media Centre d'Art i Disseny (MECAD), Barcelona, España. Profesor invitado en importantes universidades, congresos y foros internacionales en América Latina y Europa.

[3].ClorindoTesta,(Nápoles 1923-Buenos Aires 2013).Arquitecto, urbanista, pintor, artista conceptual. Luis Benedit, (Buenos Aires 1937 - 2011). Fue un artista plástico y arquitecto argentino. Jacques Bedel nació en Buenos Aires el 7 de agosto de 1947. Es escultor, pintor, diseñador y arquitecto argentino egresado de la Facultad de Arquitectura y Urbanismo de la Universidad de Buenos Aires.

\section{Bibliografía}

CASTELLS, M. (2004). La sociedad Red: Una visión global. Madrid. Alianza Editorial.

CASTELLS, M. (2008). “Citilab demuestra que es posible cambiar la realidad con el poder de la imaginación y de las ideas", Citilab de Cornellá, Barcelona. http://es.citilab.eu/actualidad/opinion/ citilab-demuestra-que-es-posible-cambiar-la-realidad-con-elpoder-de-la-imaginaci [Consulta: 09/06/2019].

CASTELLS, M. (2009). Comunicación y Poder. Madrid. Alianza Editorial. 
DARIN, S. (2015). "Conservación del Patrimonio y la Identidad en la Sociedad del Conocimiento: el rol de la Universidad". Revista Publicando 2. pp.3-24.

GLASER, K. (2015). The Place to Be for Street Art Nowadays is no Longer the Street, it's the Internet., en P. Soares Neves y D. de FreitasSimóes (Eds), Street Art \& Urban Creativity. Scientific Journal. Methodologies For Research, 1 (1). 102. http://www.urbancreativity. org/uploadas/1/0/7/2/10727553/journal2015 v1 n1 web final. pdf [Consulta: 03/05/2019].

GROYS, B. (2016). Arte en flujo. Buenos Aires. Caja Negra. pp.12-14.

ICOM,https://icom.museum/es/actividades/normas-y-directrices/ definicion-del-museo/ [Consulta: 30/07/2019].

IRVINE, M. (2012) The Work on the Street: Street Art and Visual Cultura. en B. Sandywell e I. Heywood (Eds), The Handbook of Visual Culture (235-278). London \& New York. Berg.

LEFEBVRE, H. (1991).The Production of space. Oxford. Blackwell.

McCORMICK, C. (2011). "The Writing on the wall" en Jeffrey Deitch, Roger Gastman y Aaron Rose eds., Art in the Streets, 1 sted. New York, SkriraRizzoli, p.24.

RHEINGOLD, H. (2002). Multitudes Inteligentes. La próxima revolución social. Gedisa. p.25.

PÉREZ SIMÓN, S. (2015), https://www.academia. edu/11065709/Antropolog\%C3\%ADa e identidad. Reflexiones interdisciplinarias sobre los procesos de construcci\%C3\%B3n identitaria en el siglo XXI, p.70. [Consulta: 22/04/2019].

PISANI F, PIOTET, D. (2009) La alquimia de las multitudes: cómo la web está cambiando el mundo. Barcelona. Editorial Paidós.

\section{Autor/es}

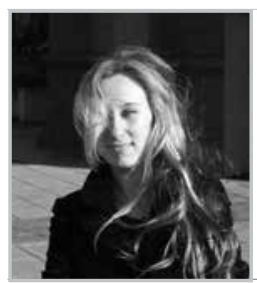

\section{Carla Coluccio}

Conservadora-Restauradora

carlacoluccio@hotmail.com

Licenciada en Conservación y Restauración de Bienes Culturales por la Universidad Nacional de las Artes de Argentina. Posgrado en Gestión Cultural de la Fundación Ortega y Gasset. Especialista en conservación de escultura policromada. Maestranda en conservación y restauración de bienes culturales en la Universidad Nacional de Gral. San Martín. Desde 2016, en la actividad como docente, desempeña funciones de jefatura de trabajos prácticos en Nivel III de la Universidad Nacional de las Artes. Ha asistido a varios cursos de perfeccionamiento dictados por renombrados especialistas nacionales e internacionales. Laboralmente, ha participado de numerosas restauraciones entre las que destacan, en diferentes etapas, las concernientes al Teatro Colón, La Basílica de la Merced, el ex Instituto Biológico Nacional ubicados en la ciudad Autónoma de Buenos Aires. Actualmente es restauradora en el área de Coordinación, Recuperación y Conservación del Patrimonio Cultural, dependiente del Ministerio de Hacienda y Finanzas Públicas de la República Argentina. Desde el 2017 participa en proyectos de gestión y difusión del acervo cultural de la Legislatura de la Ciudad Autónoma de Buenos Aires. Miembro del Grupo de Arte Urbano del Grupo Español del International Institute of Conservation. Con trayectoria en el ámbito académico, investigaciones, publicaciones y participación en congresos nacionales e internacionales. 

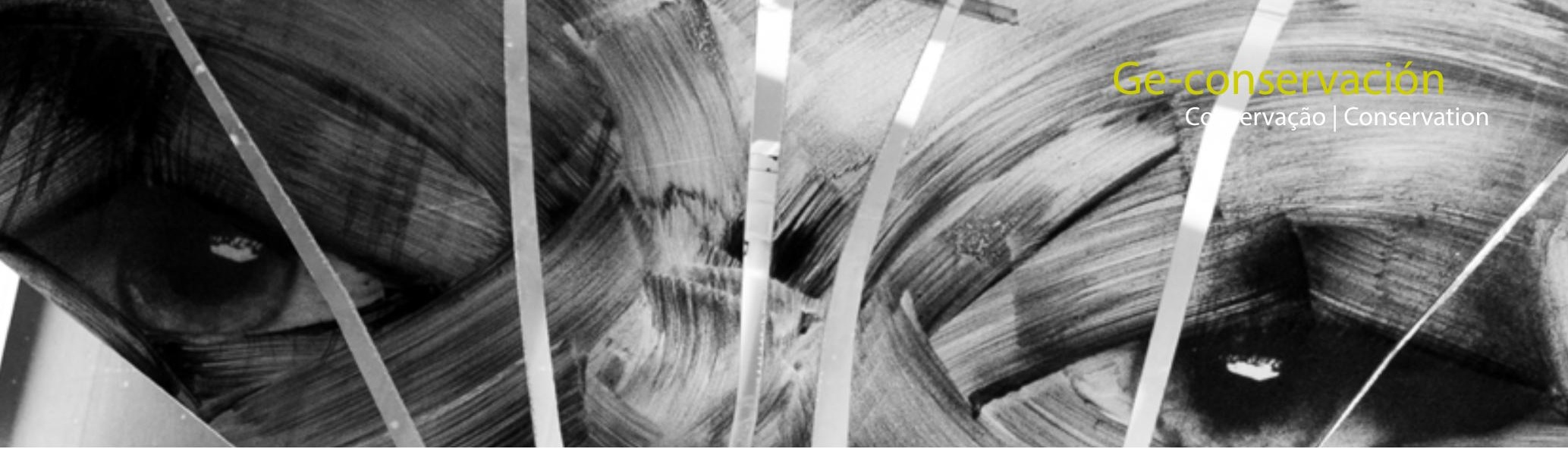

\section{El espacio intermedio del arte urbano}

\section{Elena García Gayo}

Resumen: El análisis de manifestaciones artísticas en el espacio público hace necesario ordenar el panorama. Se conocen con la etiqueta generalista de "graffiti" $y$ "arte urbano" aunque estas dos fórmulas definen manifestaciones diferentes que solo tienen en común el espacio. Después de cincuenta años de existencia del graffiti (escribo mi nombre incansablemente) y algunos menos del arte urbano (interpreto y/o decoro el contexto), han sido asumidos por las instituciones y el mercado del arte, haciendo desaparecer las diferencias que los separaban, por más que en el ámbito académico estén ampliamente documentadas. Finalmente, el mercado del arte y la administración pública se han dado la mano apropiándose e intercambiando a voluntad ambas etiquetas "arte urbano" y "graffiti" que han resultado reapropiadas vaciando su contenido. Esto ha llevado a la creación de "museos de arte urbano", unos productos híbridos que pervierten tanto el primer concepto (museo) como el segundo (arte urbano). Para este estudio se propone un espacio imaginario común, el espacio intermedio, que ofrece la posibilidad de compartir propuestas artísticas. El único límite lo marca el uso de su particular terminología.

Palabras clave: street art, intermediate space, graffiti, urban art, muralism, creativity, conservation-restoration

\section{The Intermediate Space of Street Art}

Abstract: The analysis of artistic manifestations in public space makes it necessary to order the phenomena. They are known by the generalist label of "graffiti" and "urban art" although these two formulas define different manifestations that have only their location in common. Over the past fifty years, graffiti (I write my name tirelessly) and urban art (I interpret and/or decorate the environment) have been assimilated by cultural institutions and the art market, making the differences that separated them disappear, more so than in the academic fields in which they are widely documented. Finally, the art market and the public officials have agreed to appropriate and exchange at will the labels "urban art" and "graffiti" and by appropriating them, emptying them of meaningful content. This has led to the creation of urban art museums, hybrid products that pervert both the first concept (museum) and the second (urban art). For this study a common imaginary space is proposed, the intermediate space, which offers the possibility of sharing authentic artistic productions. The only limit is the necessary use of accurate and appropriate terminology.

Key words: street art intermediate space, graffiti, urban art, muralism, creativity, conservation-restoration

\section{Introducción}

Los diferentes usos artísticos del espacio público en el siglo XX han influido en la puesta en escena de lo que se conoce ahora como arte urbano [1] (Ulrich, 2015; Gayo, 2018a) y todos juntos establecen una herencia cultural de origen diverso, desde la que proviene de la crítica social de finales de los sesenta - el cuestionamiento competitivo y uso comercial del espacio público por algunos sectores del graffiti- hasta las fórmulas musealizadas más convencionales de exponer extramuros de los museos. En este punto de vista se significan dos tipos diferentes de intervenciones, las subvencionadas e institucionales, que son las que se reconocen como arte público y otras pequeñas y alternativas que toman el espacio de forma ilegal, que son las que se definen como graffiti y arte urbano. La fórmula legal subvencionada integra obras que sirven al fomento de intereses locales, casi siempre el turismo, y se articulan como exposiciones urbanas en pro del bien común y de la visibilidad institucional. En estas propuestas se intenta contar con artistas de reconocido prestigio que llegan a protagonizar la imagen de la propia iniciativa. En los casos mencionados, todos buscan la máxima visibilidad y llegar al mayor número 
de personas posible. Es innegable que en esta carrera ha ganado la batalla la fórmula ilegal, que finalmente ha conseguido filtrarse hasta llegar a las instituciones [figura1]

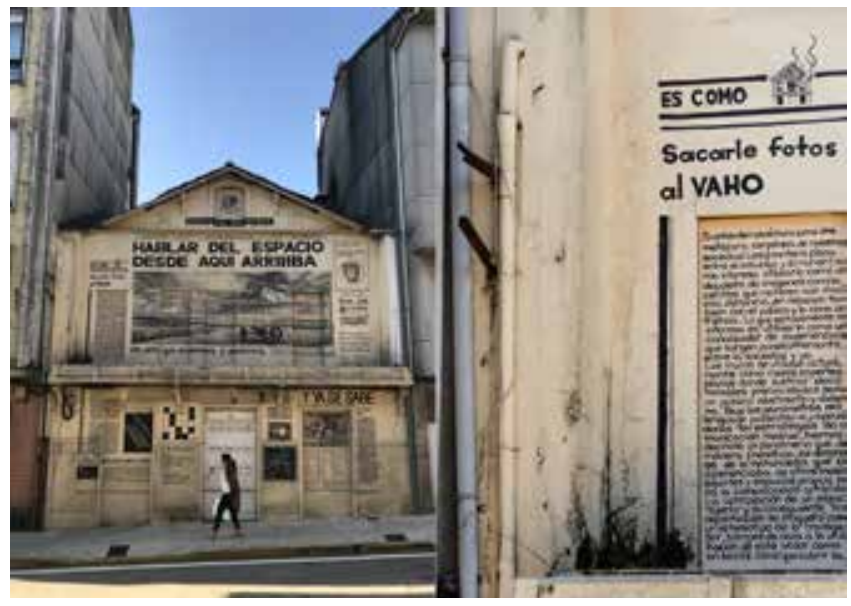

Figura 1.- Daniel Muñoz, alias San. Festival, Desordes Creativas. Ordes 2019. "JERGA", una pieza site specific que habla sobre las manifestaciones artísticas en el espacio público. "Hablar del espacio desde aquí arriba es como sacarle fotos al vaho, un acto que envenena y purifica: Entre lo crudo y lo calcinado..."

Aunque en este ascenso por capilaridad aún no hay lugar para la recompensa ni reconocimiento artístico, los artistas obtienen una gran repercusión posterior en el mercado del arte especializado y en galerías, es decir, aunque no llegan a ser admitidos en el ámbito público dedicado a preservar el patrimonio cultural, el mercado del arte se deja influir por esta esperanza. Sus obras no se disimulan en el espacio sino que alteran el propio contexto en el que se sitúan, del que se adueñan, y en el que se muestran como una piel vulnerable que recubre visualmente la arquitectura. La calidad efímera es una pantalla que evita el compromiso de conservación, que tantos quebraderos de cabeza da a las instituciones. Las obras que se generan no llegan a tener la consideración de obras de arte, pero consiguen ser el foco de atención mediática a través de la prensa. La ciudad es un campo de acción en el que los artistas experimentan muchas prácticas diferentes. Se puede decir que el arte de la calle se ha incorporado al arte público como una manifestación artística diferente que ha generado la necesidad de cubrir un espacio vital propio.

Por otra parte, el ámbito administrativo público también está cambiando y la muestra es el proyecto Percent for Art Program, que vio la luz en 1983 y sigue avanzando como un programa de arte público del Department of Cultural Affairs del Ayuntamiento de Nueva York, consigue desde la selección de obras y las temáticas elegidas, de máximo interés público, una relación de cercanía con los barrios donde se sitúan (ver artículo de Sergio Pardo López).

Parece que la variable de todos los proyectos artísticos urbanos es la manera de entender lo que significa trabajar en un entorno urbano, algo que resultó perfectamente descrito en la documentación generada para la exposición sobre arte y espacio público del Centro Atlántico de Arte Contemporáneo de Las Palmas de Gran Canaria, en la que Ramón Parramón (2009) describe como imprescindible la necesidad de establecer unos mecanismos de negociación y de mediación donde el trabajo artístico y la relación con el lugar y el espacio social puedan encontrarse y extraer elementos de interés, basados en una relación recíproca. También identifica el resultado obtenido con un servicio público, dónde hay un beneficio colectivo generado por el intercambio de conocimientos. Reconoce la actividad artística como un campo de batalla en el que, finaliza, "los nuevos centros de producción de arte no pueden eludir su participación" (Parramón 2009). No podría ser una descripción más acertada del espacio intermedio en el que desarrollar la actividad artística urbana.

En este texto, a continuación, se compararán varias iniciativas con la intención de extraer unas directrices que ayuden a definir fórmulas de exposición que fluyan de su propia esencia. Como novedad, en este nuevo rango artístico urbano, se observa que se acude a los artistas, fundamentalmente, porque son reconocidos y valorados por los mass media, que no es sinónimo de valor artístico.

No se entrará a definir ni analizar lo que es un museo ya que está desarrollado en varios artículos de este mismo monográfico y resultaría reiterativo (ver artículo de Diego Ortega y Juan Jesús Padilla). Sólo mencionar que la dificultad para actualizar la definición de museo por parte el ICOM [2] aparece, de cara a la opinión pública, como una necesidad de anclar las instituciones al pasado sin permitir su avance, algo que tampoco facilitaría la apertura y crítica hacia esta institución desde los planteamientos de las tendencias artísticas urbanas actuales, algo que establecería una interesante relación.

\section{Metodología}

El presente trabajo se basa en más de setenta entrevistas a artistas con actividad en el espacio público, gestores de grandes eventos y personas involucradas en el estudio y difusión de la expresión artística en entorno urbano [3] (Capel, 1975:265-301), además de en la consulta de bibliografía especializada en cada una de las materias involucradas. Se identificarán nexos de unión entre diferentes manifestaciones artísticas desarrolladas en el espacio público, fundamentalmente las que han usurpado la etiqueta "arte urbano" cuando su denominación pública no está sujeta a las mismas reglas y forma parte del muralismo contemporáneo o a intervenciones artísticas actuales. Se parte de un planteamiento transversal, que busca planificar la mejor manera de exponer arte en el espacio público y que tiene que ver con las buenas prácticas en Conservación- 
Restauración, en las que se considera fundamental tener en cuenta la opinión y percepción del artista [4]. El hilo conductor del análisis se inscribe en un espacio intermedio imaginario que permite una relación sin fricciones y desde el cual se pueden analizar las diferentes influencias sobre las obras de arte desarrolladas en la calle teniendo en cuenta la motivación - que define su razón de ser-, el proceso creativo - que se sitúa entre la idea y la motivación de cada obra de arte urbano-, y por último, sus posibilidades de permanencia.

Se definirán los espacios intermedios como:

1. Espacio intermedio para la creatividad,

2. para la comunicación,

3. público y privado, regulados,

4. colaborativo,

5. entre lo efímero y lo perdurable.

\section{Espacio intermedio para la creatividad}

Es un espacio tan material como temporal, que tiene que ver con el instante de creación de una obra y que se presta a muchas combinaciones, tal y como se verá a lo largo de esta exposición. En el caso del graffiti y el arte urbano, su soporte es de una variedad infinita, aunque la máxima visibilidad es de las medianeras de edificios. El espacio público conquistado por el graffiti es el que más encajaría en esta definición, porque, como afirmaba Juan Antonio Ramírez (1992:197-207) "¿no será el arte verdadero una cosa clandestina? Los graffiti neoyorkinos desde luego si lo son". Y siendo simples capas de pintura, ¿por qué resultan siempre tan perseguidos? [figura 2]

El graffiti actual, heredero del de los setenta, viene también del mundo adolescente, dónde hay una necesidad de reafirmación personal y única del ego. Representa a una voz exenta de ideología política. Con el tiempo, los propios writers han revolucionado la expresión artística urbana y

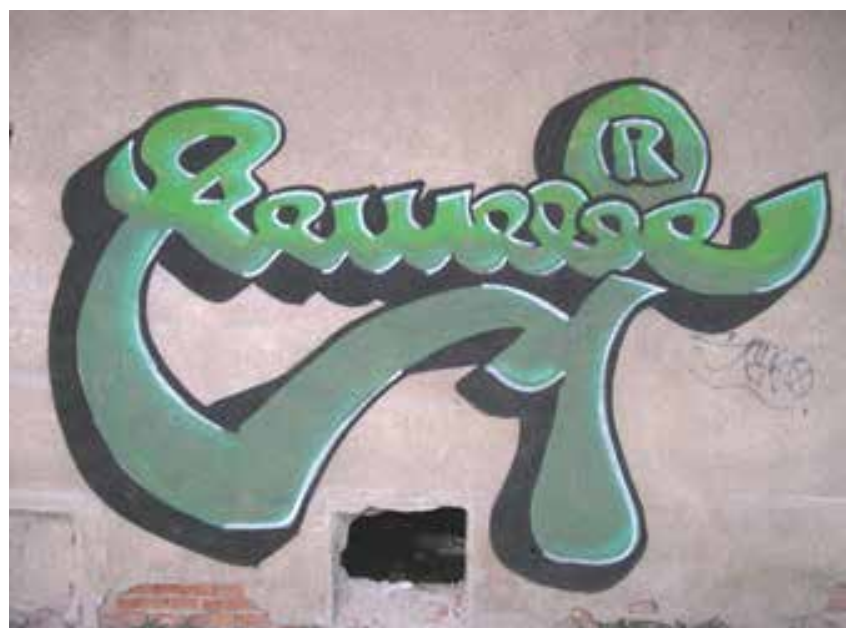

Figura 2.- Pieza en grosor de estilo flechero. Autóctono madrileño. Remebe. Loeches. Madrid. 2005. han conseguido contagiar a más artistas con su forma de transitar el mundo. Es una necesidad de expresión innata en el ser humano, que se realiza sin esperar nada a cambio y con la única ambición de dejarse ver y abrirse al mundo (Craig Castleman, entrevista anexo). Los Hall of Fame, espacios de máxima afluencia de escritores en cada ciudad, son el centro de reunión de cada círculo social del graffiti y constituyen unos espacios expositivos imprevistos. En ese viaje personal de conquista por la ciudad se descubren de forma intuitiva los espacios de mayor visibilidad y sorpresa. Esta particularidad resultará aumentada por el espíritu crítico de las obras y los planteamientos de los artistas activistas.

Por su parte, el arte urbano utiliza el espacio público como espacio de creación, exposición y difusión al mismo tiempo, es decir, las obras site specific se crean en un espacio y lugar concretos. Son obras en contexto y realizadas para la sorpresa. Sirva como ejemplo la acera tallada del escultor Ken Hiratsuka que empieza sus "fósiles del momento" en 1983, año en el que talla la primera línea interminable en la esquina de Prince con Broadway, en Nueva York. Aquellas primeras obras continúan hoy en la calle. Han sido erosionadas por el paso del tiempo y el roce de millones de pisadas, sus improntas estarán unidas para siempre a la historia material de un pavimento que sin esta obra no tendría un significado sentimental tan especial. [figura 3].

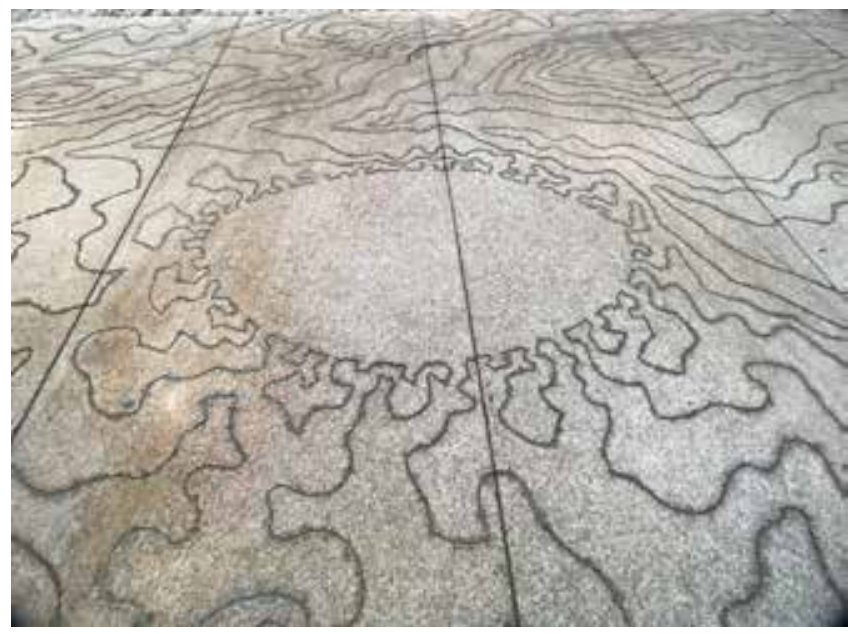

Figura 3.- Obra de Ken Hiratsuka en Nueva York. Foto de Jaime Rojo. Brooklyn Street Art

En este caso, el espacio urbano es también un espacio intermedio de vital importancia, porque para un artista la calle da sentido y vida a su producción. Al llegar a la galería las obras expuestas son el resultado de esa experiencia (Nuria Mora, entrevista anexo). Las obras que se exponen en los llamados "museos de arte urbano" -a las que sería más apropiado llamar arte actual- son la consecuencia de la experiencia de trabajar en la calle con el contexto, que consigue transformar y formar a la persona como artista. Como resultado, las obras de galería 
son la conclusión de un trabajo intelectual que finaliza en una obra "enmarcada". Esto sucede con todas las obras artísticas, tengan la forma que tengan, pero el interés del arte en el espacio público es que, aunque se intervenga en la calle, no es trasladable, puesto que lo que viaja a la galería es la experiencia transformada del artista. Es la esencia y conclusiones del artista, las que se enmarcan dentro de los espacios expositivos. En esta práctica, según San (entrevista en anexo) están "todos los elementos que se conjugan en una pieza" y hablan del propio proceso. Aluden a lo que interviene en la mirada, de la historia, de la construcción, del lenguaje. "El proceso, que serían las pautas a seguir: el orden que intentas controlar en el pensamiento, el ciclo que sigue una idea; todos esos conductos por los que transito mentalmente, intento provocarlos y que la gente pase por lo mismo que he pasado yo".

Dentro del proceso creativo puede haber tantas conclusiones y recursos como sea posible imaginar. Las obras así ejecutadas —entre la calle y la galería- pueden verse alteradas o no. En el caso de la obra de Vermibus, eminentemente activista y urbano, no podría existir la segunda parte sin la primera, aunque, en este caso concreto, las obras no cambian en el traslado pero no se entenderán sin conocer el contexto original del que emergen (Gayo, 2018b).

El resultado final es una interpretación del funcionamiento imperfecto del sistema. No puede afirmarse que la parte que se expone sea arte urbano, porque no lo es, aunque es evidente que todos los pasos del proceso creativo que lo han provocado sí lo son. Esto quedó muy bien expresado con la obra de SUSO33 I-legal, de 2013, en la cual su famosa plasta estaba pintada sobre un panel y apoyada en un muro de la calle, debajo escribió "Ilegal". Al separar el panel quedaba fuera la "i" y dentro del panel se leía "legal" y fue esta parte recortada la que se expuso de una forma coherente en una sala de exposiciones. De esto se deduce que el arte urbano no podrá ser nunca expuesto en un museo sin resultar alterado, aunque puede llegar a ofrecer una visión diferente e interesante relacionada con los elementos que lo rodean. Las obras de la calle que se exponen en museos y galerías tendrán que ser siempre consideradas como arte urbano sustraído, trasladado o apropiado, si esa posibilidad no ha sido prevista y justificada intelectualmente por el artista.

\section{Espacio intermedio para la comunicación entre el artista y el espectador}

El espacio urbano para la comunicación se definiría como aquel en el que se desarrollan los procesos y se construyen tipologías artísticas diferentes (pintura, escultura, mural, instalaciones...). El espacio entre la obra y el espectador es aquel que tiene en cuenta este diálogo a través de las obras. Su interacción puede definir el tipo de espectador, clasificándolo, por ejemplo, en testigo, invitado, enemigo, protagonista o coproductor (Matewecki, 2014).
Hay que resaltar que la clasificación del espectador elegida no es gratuita, sino que ayudará a detectar aspectos importantes que definirán cómo es la relación entre éste, la obra y el contexto; algo que en el arte urbano y el graffiti es importante. El espectador del graffiti es el espectadorenemigo, si no es bien recibido, ya que va dirigido preferentemente a sus iguales y sólo es entendido por ellos. En el arte urbano, por el contrario, se comunica con el entorno y en sus obras hay implícita una relación con los vecinos, el barrio o la ciudad que se podría llegar a medir y valorar. Si los elementos que se conjugan en las piezas están hablando de lo que interviene en la mirada, lo que procede de la historia, de la construcción o del lenguaje, será el proceso lo que marcará las pautas a seguir en el viaje inverso del espectador para descifrar la obra y lo que le convertirá en espectador protagonista, si fuera el caso.

Se tendría que definir también cúal es el papel de los artistas, que tampoco se libran de clasificaciones. Suzanne Lazy (1995) los clasifica en experimentados, informados, analistas y activistas; y estos últimos también pueden ser los herederos de las inquietudes políticas generadas a finales de los años sesenta y principios de los setenta (Aznar, Iñigo, 2007). Estas definiciones no deben tomarse como compartimentos estancos, ya que cuando se habla de arte y de expresión en medio urbano los límites se pueden difuminar. Por ejemplo, desde el punto de vista de Vermibus, "la obra es principalmente una comunicación unilateral, por lo que no considero que la obra en sí misma sea una conversación con el público, sino más bien con la industria. Mi obra es una respuesta a su mensaje" (ver entrevista Vermibus en anexo).

\section{Espacio intermedio musealizado}

Desde las instituciones lo que se promueve es la presentación pública de espacios para la promoción local cuyo ejemplo son los murales de los ochenta, muchos de ellos mediante financiación del Fondo Europeo de Desarrollo Regional (FEDER) y cuyo objetivo era embellecer las ciudades. En este caso, el espectador es un invitado y a la vez un observador, y los espacios se ceden con espíritu de ser obras de arte listas para observarse a distancia, con esa distancia que marca la línea museal de "no pasar","no tocar". De ahí viene la tradición más cercana en el tiempo de los museos al aire libre, porque son los museos los que salen a la calle a mostrar sus obras. Estos espacios cedidos al arte por los ayuntamientos acusan en su iniciativa un cierto fracaso de las instituciones, ya que se identifica la necesidad de salir al exterior con una solución para solventar la insuficiencia de público en el interior y un deseo de atraer visitantes de un nivel cultural medio. Porque el rigor científico y la didáctica de las colecciones expuestas no son suficientemente eficaces para llenar los pequeños museos locales que se dedican a preservar colecciones de todo tipo. Un ejemplo fallido es el caso del Museo de Escultura al Aire Libre del Paseo de la Castellana de Madrid, poco conocido y visitado. Ahora, el arte debe ser 


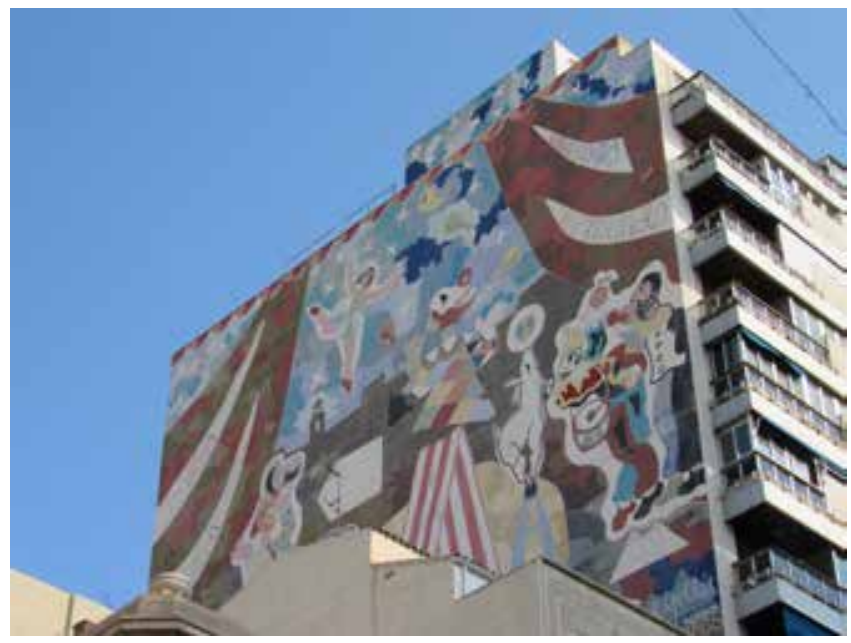

Figura 4.- Mural de Ripollés en Castellón. Foto de Mayte Pastor Vals

espectáculo y es eso lo que se quiere ofrecer a los visitantes. El arte en la calle se ofreció en el pasado como reclamo turístico dentro de iniciativas como el Museo al Aire Libre de Castellón, en el que la buena calidad de los materiales utilizados en los años ochenta permitió a las obras llegar a nuestros días en buenas condiciones [figura 4].

Calvo Serraller (1983) describe el Museo Abierto de Fuengirola como "Arte Urbano" en un artículo en el que enumera las características que debe tener un museo al aire libre. En su descripción la principal es el criterio de rigurosa selección de los bocetos y, por tanto, de los artistas, cuyas obras murales se ejecutan por pintores profesionales supervisados por los artistas. En segundo lugar, la versatilidad de los soportes que, en principio, parecían facilitar el traslado de las obras, pero con el tiempo ha sido algo imposible de realizar, ya que se utilizaron planchas de fibrocemento, polvo de amianto, de elevada y reconocida toxicidad. Y la tercera de las cualidades enumerada como importante, es la participación del pueblo de Fuengirola en un rol que se podría describir como de espectador-testigo, ya que su colaboración se queda en la financiación de los proyectos a través del ayuntamiento.

En 1994 y según el artículo de Paz Bernal (1994) de la mano de los artistas José Antonio García Álvarez, Fernando Álamo y Manuel Padorno se interviene en las medianeras del paseo de las Canteras de Las Palmas de Gran Canaria para celebrar el fin de las obras de acondicionamiento y modernización de las instalaciones de esa primera línea de playa. El hilo conductor es un poema de Tomás Morales que se planteó como un juego de color. Un usuario imaginario vería al ir a la playa las medianeras ejecutadas con colores fríos y a la vuelta las de colores cálidos. Eran conscientes de que se trataba de pintura efímera, de la que solo queda una medianera de Manuel Padorno y muy repintada a lo largo del tiempo, aunque se han respetado las líneas originales. Los artistas hablaban de salir a la calle para darse a conocer a un público más amplio y no quedarse en el círculo de los que podían conocerlos en las galerías. La ejecución, igual que en Fuengirola, la llevaban a cabo pintores de fachadas, usando las plantillas que se les facilitaba y bajo supervisión de los artistas.

El Museo de Pintura al Aire Libre de Candás, en Asturias (Vaquero, 1980), es diferente a los anteriores ejemplos, porque está profundamente vinculado al espacio y a su población. Comprometidos desde los inicios con la memoria histórica de la localidad, desde 1979, van adaptando la expresión artística local al paso de los años bajo la mirada de los artistas invitados. Señalar que en sus inicios fue una iniciativa privada que, tras varias etapas y desapariciones, se retomó asumida por el ayuntamiento.

\section{Espacio intermedio virtual}

Este espacio es el que da visibilidad a todo un colectivo de artistas que ha nacido con Internet y cuya formación está ligada a las nuevas tecnologías. A diferencia de los planteamientos institucionales, el aspecto en el que el arte en el espacio público es más libre es en el que se comparte sin esperar la presencia de un observador especializado. La sorpresa se valora como un descubrimiento íntimo y una experiencia personal única. A este instante le sigue el análisis de lo representado y la posibilidad de descubrir más datos sobre la obra y su autor, con la experiencia vivida del contexto, que es un añadido. Es lo más parecido a entrar materialmente en una obra. En la era tecnológica los espectadores-colaboradores se convierten también en intérpretes de lo que ven y participan de su difusión. Martha Cooper se pregunta "ise podría imaginar qué pasaría con el llamado arte urbano si Facebook o Instagram desaparecieran?". Y ella misma se contesta "todo desaparecería" (ver entrevista en anexo). En este entorno la experiencia sólo la vive una persona, pero es a la vez compartida por muchas.

Por otra parte, el graffiti y el arte urbano se han abierto al uso de soportes virtuales donde resultan manipulados y reutilizados, su calidad efímera es nula, porque en la red se convierten en obras inmortales. Las reglas las marca la demanda de internautas y la voluntad del artista desaparece en una apropiación, aparentemente, sin reglas. Todo en favor de una visibilidad artística sin límites. El espacio tecnológico, la tecnosfera, es un nuevo soporte del que ya no se podrán desligar pero, como comenta Sixe Paredes (entrevista en nexo) "aunque desaparezca la materia original, la imagen de tu obra en Internet existe y te pertenece". Spok va más allá, menciona Internet como el soporte real del arte urbano (entrevista en anexo).

\section{Espacio público y privado regulados}

El espacio intermedio regulado es el que se sitúa en el límite entre lo público y lo privado, donde está la fina capa de enlucido de las medianeras. Se podría definir como la parte visible de un espacio privado. Una capa que es susceptible 
de tener una utilidad social gracias a su visibilidad pública, aunque no está exenta de convenciones. Querer agradar, ser complaciente, se refleja en los temas elegidos de muchos murales que llegan a ser descritos como enlucidos meramente decorativos, que no tienen nada que ver con el contexto en el que se sitúan y no llegan a crear ningún vínculo afectivo con su entorno. Aquí se mencionan fundamentalmente obras murales, por cantidad, pero existe una gran variedad de soportes callejeros como OPIS, MUPIS, marquesinas y vallas, entre otros, que sirven como soportes artísticos y que forman parte de ese espacio intermedio entre lo público y privado.

Tal y como sucede con las obras colgadas en una sala de un museo, todas y cada una de ellas, están esperando a ser descubiertas y que alguna mirada se deposite conscientemente a desgranar su contenido. En ese punto, la mirada muta en deseo y posesión de la idea, con la cual, las obras adquieren un nuevo significado. No se puede dejar de lado la asociación mental del arte en el espacio público con el coleccionismo, que siempre va unido al poder político, el mercado, la cultura y la dominación, a fin de cuentas (Yvars, 2005:314). El coleccionista de arte urbano puede ser también objeto de clasificación, desde sociológica y económica a psicoanalítica, lo que puede ser buen material de estudio.

\section{Espacios controlados}

La administración no promueve espacios para la libre expresión. Es decir, espacios que resulten alternativos a las salas de exposiciones y que estén situados en el espacio público, en los que pueda haber una expresión artística realmente independiente y no fiscalizada. El muro "Por la Paz" (1982) promovido por el alcalde Enrique Tierno Galván, en la plaza del Carmen de Madrid, quiso serlo, pero nunca lo consiguió. Su parte baja, se anunciaba como un espacio para la libre expresión de ideas de los madrileños, aunque su diseño resulta pobre y es casi más valioso como documento histórico. "Un espacio para decir lo que uno piensa, con la coherencia de lo permitido" decía la nota de prensa de su presentación [5].

\section{Espacio intermedio para un graffiti y arte urbano "utópicos"}

La convergencia de los destinos del graffiti y arte urbano son evidentes en un tiempo de publicidad salvaje. Las modas calan en la sociedad adueñándose de símbolos generacionales y las marcas de ropa lo compran todo. " $L a$ notoriedad frente a una comunidad y también la búsqueda de un sentimiento de podery un respeto social descansan ahora en la exposición a través de los medios y en la participación en la industria-mercado" (Fernando Figueroa, entrevista en anexo)

Dondi (1961-1998) artista y escritor de graffiti, fue uno de esos ejemplos, que experimentó el cambio. De pionero del graffiti del metro de Nueva York a exponer en los Países Bajos y Alemania, con obras en varios museos europeos. Una de sus piezas ha sido finalmente subastada en Artnet, en 2017 y adjudicada por 240.000 USD. Esto es algo que siempre se había intentado desde las galerías como lo demuestra la experiencia de Lee Quiñones (Puerto Rico 1960) de los Fab5 con su salto al mercado del arte internacional. A Lee se le atribuye uno de los primeros trenes enteros pintados, en el Nueva York de los años 70 - aunque fueran realmente CAINE, MAD 103 y FLAME ONE los primeros (Castleman 1982:36-40) - y pasó, igual que Dondi, a pintar en la galería Medusa de Roma en 1979. "Si algo ha cambiado en el grafiti es la aparición del mercado del arte" (Martha Cooper entrevista anexo).

Diez años después, en España, Juan Carlos Argüello Garzo, Muelle, (Madrid 1965-1995), era el reclamo de la modernidad en ARCO 89, en la galería Estiarte. Otro de los principales representantes españoles de esta corriente multidisciplinar que va de la calle a la galería es SUSO33, que se inicia en el graffiti y reúne en su trayectoria toda una experiencia de tránsito de la calle a la galería a través de la experimentación en multitud de medios (entrevista en anexo).

Esa penetración en el sistema del arte marcará definitivamente a las nuevas generaciones, hasta tal punto de que "el mercado, unido a los certámenes institucionales, conseguirán finalmente dividir el grafiti en dos: uno legal, domesticado, y otro ilegal" (Fernando Figueroa, entrevista en anexo). Al mismo tiempo y como respuesta se prevé una intensificación dentro del graffiti, al que vuelven muchos de los artistas como una manera de recuperar su identidad y para mantener su vigencia dentro del propio colectivo. En este punto de inflexión, quizá, se pueda empezar a relacionar estas dos manifestaciones artísticas autogestionadas como graffiti y arte urbano "utópicos" para diferenciarlas del graffiti y el arte urbano institucionalizado, ya que en esta definición idealista nunca podrán llegar ser reconocidos sus valores sin que exista un riesgo de perder su razón de ser.

\section{Espacio intermedio para un nuevo arte público}

Sin querer entrar en mayores descripciones que se escaparían del objetivo del presente artículo por la amplitud del espacio necesario, el término arte público está en proceso de modernización y de permanente actualidad por el debate político que suscita. El arte en el espacio público viene de finales del siglo diecinueve, cuando se convocó el primer congreso (Abreu, 2010:17-29) [6] en el que sus objetos artísticos eran mayoritariamente monumentos institucionales. Lo cierto es que el arte público de finales del siglo veinte en España se nutrió con el 1\% cultural, obligado por la ley de Patrimonio Histórico, dedicado a obras públicas y que sembró el paisaje nacional de esculturas que muchas veces eran ejecutadas por los ingenieros y arquitectos que intervenían en los proyectos.

Las instituciones entienden la manifestación artística en el espacio público como actos festivos y conmemorativos de 
acercamiento intergeneracional y la marca "arte urbano" consigue fácilmente la visibilidad mediática perseguida, aunque una institución sólo pueda llevar a cabo arte público porque se rige por las siguientes premisas:

a) Su instalación en el espacio urbano debe autorizarse. b) Las obras deben registrarse, aunque sean efímeras, porque se subvencionan con dinero público. c) Sus autores deben gozar de reconocimiento, puesto que deben cobrar un servicio. d) Las obras son, la mayoría, de lectura fácil, o muestran varios niveles de expresión, porque el público es muy variado. e) Están respaldadas por la utilidad pública de su entorno o por asociaciones locales que pueden hacer uso de esas instalaciones mejoradas.

Conforme a esa voluntad de promoción artística y cultural, es evidente que los artistas, conocidos como "artistas urbanos", en estos casos, ejecutan obras de carácter público, aunque la administración ceda sus competencias a entidades privadas para llevar a cabo murales monumentales. La etiqueta es más publicitaria que real. Algunas instituciones ceden también sus funciones de comisariado a galerías, asociaciones y empresas privadas a las que subvencionan. En estos casos se invierte el sentido de lo público convirtiendo el territorio en un espacio privado para unos fines de promoción indefinida. Se evita, así, cualquier tipo de responsabilidad posterior y no existe la necesidad de registro, tutela ni reconocimiento de los artistas que han generado unas obras efímeras de disfrute público. Las obras se ejecutan con materiales que van a sobrevivir una media de siete a diez años, en el mejor de los casos, y no se crea ninguna vinculación institucional con ellos. Por otra parte, las instituciones siempre van a resultar beneficiadas por el interés mediático que despiertan estos artistas en otros países.

Tal y como se puede ver en muchas de las entrevistas del anexo, los artistas se plantean estas intervenciones subvencionadas de forma diferente a como las abordarían de una forma independiente o para una galería. Los espacios que se ofrecen van siempre más allá de cualquier expectativa, porque son espacios públicos a los que no tendrían acceso de otra manera sin asumir una importante multa y la ventaja que supone contar con todos los medios necesarios.

Existe, pues, un doble rasero para considerar el acceso a algunos muros, ya que la mayoría de ellos se liberan para ser pintados por un objetivo de visibilidad y con un proyecto justificado y aprobado por la institución que los promueve. Según el criterio de San (entrevista en anexo) "Uno de los pilares más importantes de mis obras es sobre la regularización de mi trabajo. Del arte público y de cómo se pueden mantener unos patrones para que esa insolencia, rebeldía, un poco adolescente, y su espontaneidad, representada en algunas de mis obras, no se pierda. De cómo una de esas obras insolentes puede llegar a ser inaugurada por el presidente de una comunidad autónoma. Incluir toda esa fricción, ese conflicto que genera, forma parte de mi trabajo". [figuras 5 y 6 ]
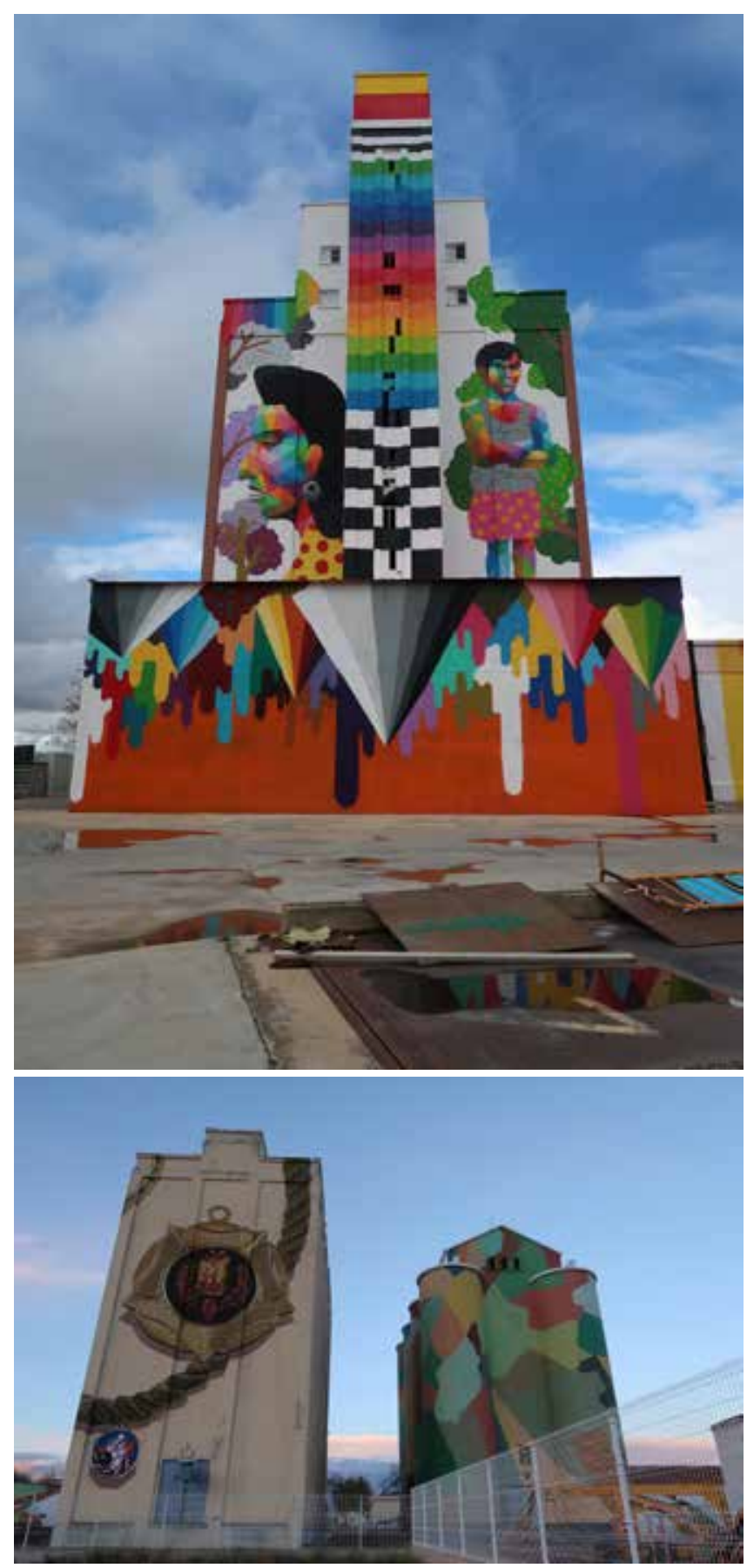

Figura 5 y 6.- Izquierda: Proyecto Titanes. Silo de Calzada de Calatrava. Okuda. Ink and Movement. Derecha: silos de Manzanares durante el proceso: San y Spok y Equipo plástico: Nuria Mora, ElTono, Sixe. Nano 4814

La "España vacíada" ha dejado un buen número de iniciativas que se pueden referenciar con la seguridad de que hay muchas más, alguna de ellas ha sido analizada en artículos de este mismo monográfico. Sólo mencionar las que han podido tener una mayor repercusión mediática: Fanzara, Cambre, Carballo, Ordes, El Provencio, Campo de Criptana, Castrogonzalo, Penelles, Romangordo, Fresnedilla de la Oliva, Tubilla del Lago, La Bañeza, Tudela, Villangómez y una de las últimas, las famosas intervenciones en los silos de la provincia de Ciudad Real localizados en Calzada de Calatrava, Corral de Calatrava, La Solana, Herencia, 
Malagón, Manzanares y Porzuna. Este es un mínimo listado de pequeños municipios y aldeas cuyos muros han sido utilizados como soportes artísticos, algunos de ellos con la esperanza de recuperar su visibilidad y no desaparecer. Al mismo tiempo, se deja notar la penetración en temas artísticos urbanos por parte de las políticas institucionales en las que se sitúa el foco en pequeños municipios, aunque no existan proyectos estables que perfilen la posibilidad de promoción e investigación con los que apoyar a los artistas.

La diferencia en algunos de estos casos es también evidente cuando los vecinos, a través de asociaciones locales, se convierten en espectadores-colaboradores con proyectos de desarrollo local, como es el caso de Fanzara, ya que esto garantiza el éxito de la iniciativa. Se facilitan encuentros en pequeñas localidades que de otra manera serían imposibles. Se mezclan talleres con espectáculos musicales que cambian la visión del mundo de muchas personas que nunca han salido de los límites de sus municipios. En estas iniciativas tan enriquecedoras como ilusionantes se da alojamiento a los artistas y algunas veces las familias mantienen unos lazos de continuidad con ellos.

Todas las propuestas son válidas, siempre que no se denominen arte urbano y se empiecen a utilizar etiquetas propias como ha sido el caso de Parees Fest de Oviedo, Asalto de Zaragoza (entrevistas en anexo) y Murales Conciencia de Bailén (con artículo en este monográfico) son buenos ejemplos de esta corrección en la terminología y una pequeña muestra de las posibilidades.

\section{Espacio intermedio colaborativo: festivales y gestión cultural. El camino de lo institucional a lo procomún}

Es el espacio que se mueve entre lo institucional y lo asociativo haciendo visibles a sus promotores. Espacios de colaboración que se dan normalmente fuera de las instituciones y muy pocas veces dentro de ellas, aunque son propuestas subvencionadas que incluyen al espectador y que bajo esa clasificación mencionada al principio resulta ser el coproductor de las iniciativas. La imposibilidad de realizar estas propuestas íntegramente desde la administración está marcada por el ritmo necesario para realizar los ajustes que van surgiendo dentro de la propia dinámica de las propuestas (Sánchez, 2003).

Ese camino iniciado por el arte en espacios públicos en el siglo XXI tiene su inspiración en el movimiento digital open source, basado en la idea de compartir el conocimiento de forma abierta para conseguir un método colaborativo y empoderamiento social. En 2009, con el premio nobel de economía a Elinor Ostrom y la demostración de la posibilidad de desarrollo a partir de recursos compartidos y el fomento de bienes comunes, se empieza también a entender el espacio público de otra manera.

Algunas experiencias pasadas de museo en la calle - aún en la memoria-, son las que han hecho más fácil la aceptación de un buen número de artistas para recuperar esa actividad. Procedían de una situación de subsistencia - basada en la gratuidad de sus producciones-creada por la crisis económica, que resultó agudizada en el ámbito cultural y dejó a muchos artistas sin salidas profesionales porque el sistema no era capaz de asumirlos. Las exigencias de las galerías y ferias de arte siempre han sido un filtro que no todos han estado dispuestos a pasar para ganarse la vida, aunque siempre se termine aceptando, tal y como reconoce Okuda (entrevista en anexo).

Por otra parte, la sociedad necesita recomponerse y recuperar la protección cultural perdida en los años de profunda crisis económica y beneficios sociales, desde 20072008, en los que se llegó a hablar del "arte boicot", desde el que se declinarían invitaciones a no participar en muestras "por amor al arte" y sin medios. La alternativa estaba en la calle, representada por una legión de artistas que de forma autodidacta salían a conquistar lo que se les negaba, un espacio vital, y se formaron en la ejecución de obras en formatos murales monumentales. Artistas con el respaldo de ser en un elevado porcentaje titulados superiores, los más numerosos en Bellas Artes, Diseño y Arquitectura (Gayo, 2011). Esto ha unido a dos sectores necesitados, uno de un medio de vida y otro de visibilidad; con esta alianza se ha dado luz a diferentes proyectos que se han abordado desde muchos puntos de vista dando lugar a festivales, concursos, "museos", proyectos artísticos que se desarrollan a través de residencias, culturales, asociativos y un largo etcétera. Alguno de ellos representado en entrevista en el anexo de este monográfico por sus gestores y comisarios.

Los artistas tampoco son todos iguales y sus propuestas van desde las meramente decorativas a las activistas y solo algunas se consideran obras con interés artístico. En ese universo urbano, la falta de jerarquías y de críticos profesionales formados y especializados - dispuestos a crear opinión, que ayude a ordenar la escena, hace que aumente la confusión a la hora de valorar las obras que se encargan. “Los gestores culturales actúan como comisarios y son parciales", suplen lo que debería ser un criterio objetivo de coleccion pública, situación que lejos de aclarar el panorama artístico actual, lo ensombrece (Nuria Mora, entrevista en anexo).

Como se ha apuntado, en las intervenciones de este espacio intermedio, en el que hay asociado un proyecto local y también hay obras de un elevado nivel artístico que, si no llegan a identificarse con el territorio, quedarán en el olvido y se convertirán en invisibles. Su degradación será bien recibida y los muros acabarán repintados. No quedará nada más que el agradecimiento de su calidad efímera.

\section{Espacios entre lo efímero y lo perdurable}

El espacio intermedio desde la conservación, un espacio temporal entre lo efímero y lo perdurable, es necesariamente interdisciplinar. Se podría definir como el punto máximo de deterioro que el artista está dispuesto a aceptar en su obra 
antes de que desaparezca. Dejarlas envejecer hasta ese punto - los materiales usados en expresiones artísticas callejeras son muy degradables y su conservación no se puede garantizar - y alargarles un poco más la vida. A muchos artistas les gusta ver la degradación de sus obras porque aprecian un cierto romanticismo en este deterioro, aunque hay un punto en el que dejan de entenderse y ese es el que hay que evitar si se quiere frenar su envejecimiento. Se puede conseguir que una obra se degrade lo más lentamente posible hasta que ya no exista la generación que la creó o cuando deje de estar en el punto de mira de su entorno y caiga en el olvido. Veremos algunos ejemplos, en cuanto a la posibilidad de seguimiento.

Si se decide desde el proceso creativo que las obras tienen que ser perdurables en el tiempo, esto requieren materiales y técnicas concretas con las que deben contar los artista en la ejecución. Estas propuestas tienen un espacio de intercambio que puede ir desde el juego intelectual al material, ya que se decide la paulatina degradación de los materiales con una doble simbología y la posibilidad de crear varios registros en una misma representación, tal y como lo ha contemplado Gonzalo Borondo en VitoriaGasteiz. Las dos intervenciones diferentes, superpuestas, en el mural "Lore Beltza" llevado a cabo en el marco del VI Congreso del GE-IIC en 2018, hablan sobre esto. La obra perdurable fue ejecutada con una preparación previa y silicatos, sobre la que se realizó una segunda intervención, final, experimental, en la que se aplicó una capa final efímera. Esto permite que el artista tenga dos registros diferentes de una misma obra. La capa efímera se irá perdiendo con el tiempo y dejará a la vista la capa original al silicato (Gayo, 2019) [figuras 7 y 8]

Las intervenciones de restauración dirigidas a alargar la vida de las obras, ya sean meramente preventivas o más intervencionistas, juegan un papel importante porque actúan como marcador de su reconocimiento por la sociedad. Este reconocimiento llega a formar parte de ellas y puede alterar su percepción futura si hay una tutela del estado que antes no existía o si llegan a reconocerse como obras de arte de especial relevancia, porque, tal situación no estaba prevista por el artista y pudiera interferir en su concepto y significado. En algunos casos su institucionalización tendrá que ser evaluada con respecto a otros valores contenidos en la propia obra. [figura 9]

Por otra parte, el mural realizado por ESCIF para el Institut Valencià d'Art Modern (IVAM) es una obra que surge de una residencia artística para la zona exterior del museo que se ha ofrecido públicamente al seguimiento de su proceso de degradación, puesto que es una obra efímera. Según menciona el museo, el artista se había basado en un trabajo de campo previo que duró seis meses, en los que se entrevistó con diferentes agentes de la zona para construir un archivo de símbolos y mensajes con los que estructurar el proyecto (IVAM, 2017).
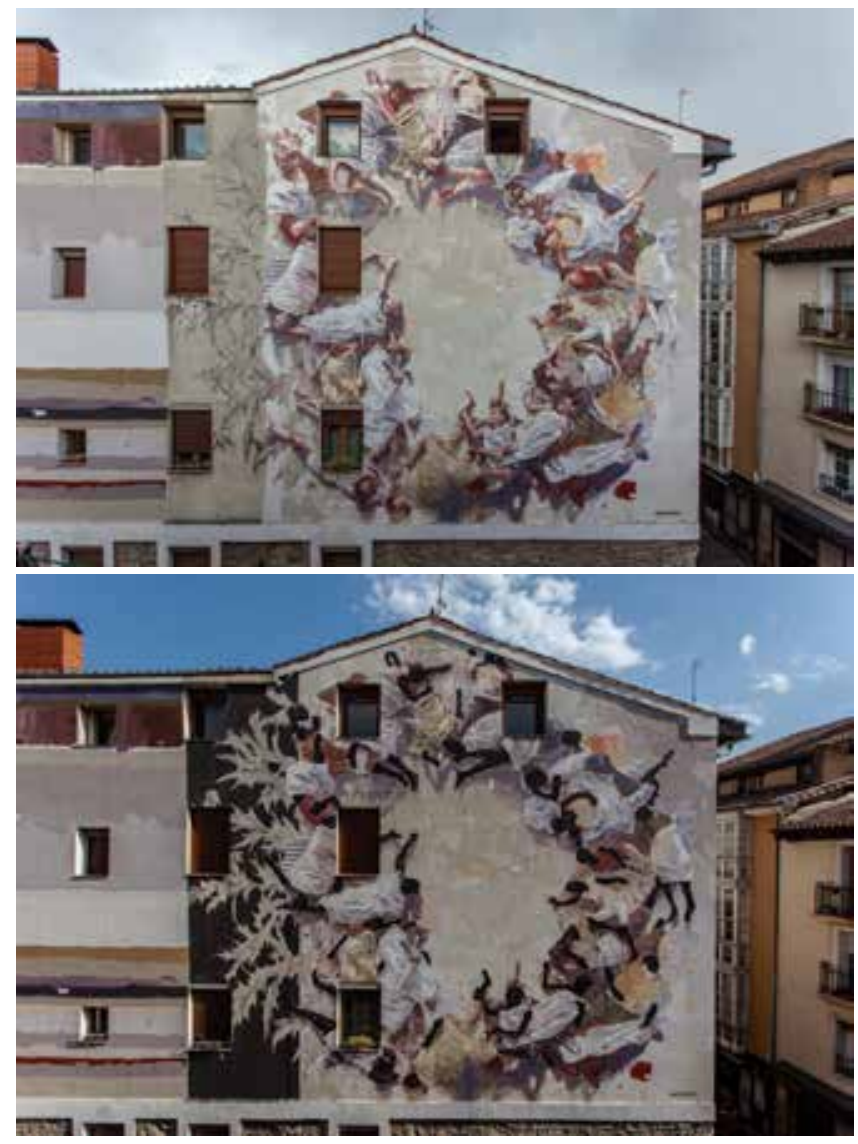

Figura 7 y 8.- "Lore Beltza". Obra de Gonzalo Borondo en Vitoria. Capa efímera experimental sobre silicatos. Fotos de Vincent Cornelli

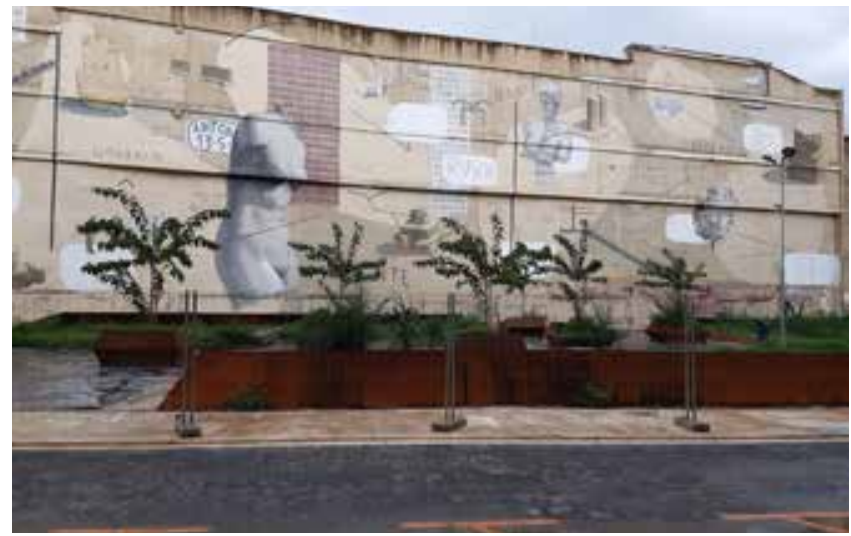

Figura 9.- IVAM produeix. Primera intervención exterior del IVAM (2017) en lo que hoy es el pati obert del museo. Fragmento del mural de ESCIF. Foto de Juan Antonio del Campo

Finalmente, la obra de SUSO33 en el exterior del Centro Atlántico de Arte Moderno (CAAM) que en 2009 formó parte de una exposición temporal de producción propia, con comisarios externos que han dejado muestra en su catálogo [7]. Esta obra que ha desaparecido recientemente por la esperada edificación en el solar en el que estaba, diez años después de su creación, fue objeto de un seguimiento fotográfico por parte del Centro Atlántico de Arte Moderno hasta cerrar su círculo vital (CAAM, 2009). [figura10] 


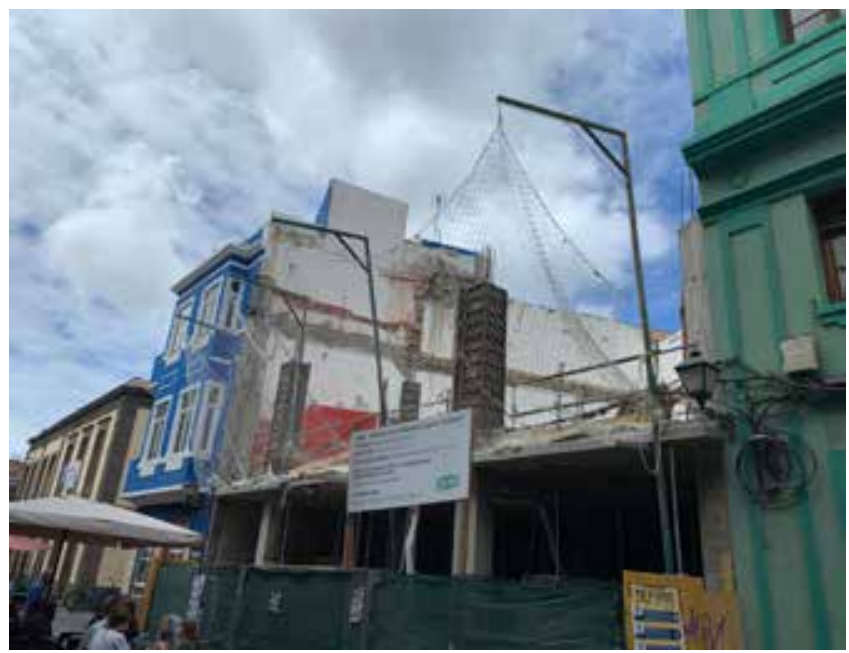

Figura 10.- Imagen izquierda la obra de Suso33 en las afueras del CAAM en 2009. Imagen derecha en 2019. Fotos de el CAAM

En estas tres obras se decidió que su faceta efímera fuera más o menos larga y también en los tres casos existe un seguimiento de su proceso de degradación.

El éxito de una obra de arte radica en su reconocimiento, sea de la naturaleza que sea y venga de donde venga. Cuando se solicita la conservación material de alguna de ellas, lo que se puede intentar es ralentizar su carácter efímero y las obras son mantenidas en su contexto con el consentimiento del artista. Esto es significativo cuando las obras encierran unas claves valiosas para la sociedad y por eso solo unas cuantas se asumen como patrimonio. En el tipo de obras artísticas por y para el espacio urbano, este proceso no debe alterar su titularidad y existirá un compromiso de servicio público para acceder a su contemplación.

\section{Conclusión}

El análisis de la relación entre museo y arte urbano suele provocar un error en el uso de la terminología y constituye una provocación intencionada por parte de las galerías, que usan ambos términos como nombres propios vacíos de contenido. La unión de estos conceptos tan diferentes constituye un contrasentido que no es posible justificar en un análisis en profundidad desde ninguno de los dos puntos de vista. A los museos se les supone un rigor científico, orden, sistema, pero sobre todo un reconocimiento y el catálogo de su colección. El muralismo contemporáneo se asocia a la idea de un pseudo arte urbano que es aceptado por las instituciones por su valor ornamental, que mantiene frescura en sus producciones y se asocia a futuro, novedad, intuición, pasión, rebeldía, espíritu crítico, independencia y sobre todo libertad, aunque sea el reflejo de una libertad perdida.

Para dar ese paso, las instituciones han trasladado el concepto musealizado de obras de la calle de los ochenta al siglo XXI, aprovechando la necesidad de profesionalización de los artistas y convirtiéndolos en muralistas para conseguir objetivos de promoción local y visibilidad. Por su parte, las galerías, situadas en el mercado del arte, aprovechan cualquier opción susceptible de ser mediática y útil desde el punto de vista comercial. El arte urbano aparece en estos museos y bajo esta terminología como un Disney World del arte, diseñado en el más puro estilo callejero. Todo esto, resulta ser lícito e incluso enriquecedor, aunque, necesitado de una estructura capaz de soportar la responsabilidad de contenidos. Por parte de la administración está pendiente la creación de una terminología propia y asumir un comisariado profesional que lleve a cabo el registro y acceso público digital de las obras, teniendo en cuenta que han sido subvencionadas con dinero público y el espacio para el que han sido encargadas.

Las diferencias de terminología no implican que los museos y centros de arte contemporáneo no puedan comunicar el resultado de todo este proceso performativo, sino que deben encontrar un procedimiento adecuado que no interfiera en las posibilidades de evolución del arte urbano, que seguirá persiguiendo, por su sendero particular, la utopía.

\section{Notas}

[1] Ulrich Blanché establece una diferencia entre arte urbano y street art, el primero se realiza con permiso y el segundo no. Elena G. Gayo en un "glosario básico" defiende una cuestión meramente idiomática e identifica un pequeño matiz de cercanía, en cuanto a actuar en la calle, street, o en la urbe, ciudad, es decir, que al analizar esta diferencia se subraya la relación de la obra y el artista con el entorno y el contexto, que será más o menos amplio, pero esto no afecta a la motivación.

[2] El artículo de Peio H. Riaño en el diario El País “Problemas para definir el museo del futuro" del 20 de agosto de 2019, menciona las palabras: inclusión, transparencia, dignidad, justicia, igualdad y bienestar para que se incluyan en la nueva definición de museo. Así como, el énfasis de la propuesta en el trabajo de los profesionales "de" museos y no de los profesionales "en" los museos. Términos, todos ellos, que no parece que puedan llegar a ser aceptados en la reunión de Kioto de 2019. https://elpais. com/cultura/2019/08/18/actualidad/1566148405 711078.html [última consulta 02-11-2019]

[3]. El enfoque de "lo rural" y "lo urbano" es una realidad cambiante que depende históricamente de la situación social en la que se quiera definir un entorno concreto y depende de muchos factores, tales como el grado de complejidad de la población o las diferencias de desarrollo y oportunidades económicas y sociales. Desde el punto de vista de la cultura, los medios de comunicación de masas contribuyen a impregnar todo el espacio homogeneizando el sentido de población y convirtiendo, según Lefebvre (1971:5), a toda la sociedad en urbana. 
[4] Además de las entrevistas publicadas en el anexo de este monográfico, se han tenido en cuenta las realizadas en vídeo a artistas internacionales y gestores como Jorge Rodríguez Gerada (gestor y artista de Avant Garde, Tudela) Jasper Wong y Jeff Gress de (Pow! Wow! Hawaii), Matthew Ortiz (Wooden Wave), Ron English, Set Globepainter, Inti, y un buen número de artistas cuya trayectoria se ha seguido desde 2010 y que no se publican en esta ocasión.

[5] El Muro por La Paz fue diseñado por el Servicio de Patrimonio del Ayuntamiento de Madrid y ejecutado por Ramón Polo. Plaza del Carmen. ABC Madrid 7-12-1982 pág. 38. Al ser una propuesta institucional nunca consiguió la acogida deseada.

[6] En 1898 se celebró en Bruselas el primer Congrès International de l'Art Public, al que siguieron otros cinco congresos internacionales con el mismo lema, que propiciaron la fundación en 1905 del Institut International de l'Art Public, cuyo órgano de expresión fue la revista editada desde 1907 a 1912.

[7] Exposición: Distorsiones, documentos, naderías y relatos. Las Palmas de Gran Canaria. Centro Atlántico de Arte Moderno (CAAM), 2009.

\section{Bibliografía}

ABREU, J.G. (2010) El concepto de arte público. Sus orígenes y significado actual. En Actas del Congreso internacional de críticos de arte 2009: Arte Público Hoy. Valladolid, ACYLCA, p. 17-29.

AZNAR Y. IÑIGO, M. (2007) Arte, política y activismo. Textos de la Universidad Complutense de Madrid.

http://webs.ucm.es/info/artepltk/textos/texto aznar inigo. html [02-11-2019]

BERNAL P. (1994) “Canteras viva, Atlántico sonoro”. Canarias7 Las Palmas de Gran Canaria. 8 de mayo de 1994

BLANCHÉ, U. (2015) Qu'est-ce que le Street art ? Essai et discussion des définitions. Cahiers de Narratologie [en linea] https://journals.openedition.org/narratologie/7397\#ftn15 [0211-2019]

CAAM (2009). Distorsiones, documentos, naderías y relatos. La Palmas de Gran Canaria: Centro Atlántico de Arte Moderno (CAAM)

CALVO SERRALLER, F.(1983) Fuengirola pone en su museo abierto de pintura al aire libre. La iniciativa forma parte de un plan municipal. El País 18-01-1983. https://elpais.com/ diario/1983/01/18/cultura/411692412 850215.html [02-112019]

CAPEL, H. (1975) La definición de lo urbano. Estudios Geográficos n¹38-139. Pág: 265-301
CASTLEMAN, C. (2012) Getting up. Hacerse ver. Capitán Swing

GARCÍA GAYO, E. (2011) ¿Se debe conservar el arte urbano basado en la premisa de: "piensa, crea, actúa y olvida"? en: Conservación de Arte Contemporáneo, 12 Jornada. MNCARS. GE-IIC. Madrid.

GARCÍA GAYO, E. (2018a:) Arte urbano. Herencia cultural. En VI Congreso del GEIIC. ¿Y después? Control y mantenimiento del Patrimonio Cultural, una opción sostenible / coord. por International Institute for Conservation of Historic and Artistic Works. págs. 306-313. Vitoria-Gasteiz.

GARCÍA GAYO, E. (2018b) Vermibus, de la calle al estudio y la galería. 19a Jornada de Conservación de Arte Contemporáneo. MNCARS, GEIIC. [Disponible en video] https://www.youtube. com/watch?v=wbTYuUIPBP0 (English subtitles) [02-11-2019]

GARCÍA GAYO, E. (2019). Murales urbanos. Una sucesión de capas de pintura perdurables y efímeras. 20a Jornada. MNCARS. GE-I/C. Madrid (pendiente de publicación)

GARSAN, C. (2017) En primera persona: así es el mural de Escif en el IVAM explicado por su autor. valenciaplaza.com (9-92017)

NATALIA MATEWECKI. (2014) Las figuras de espectador en el arte contemporáneo. Instituto de Historia del Arte Argentino y Americano. Facultad de BBAA. Universidad Nacional de La Plata. Boletín de Arte. Año 14, no 14.

LAZY, S (1995) Debate territory: toward a critical languaje for Public Art. Seatle. Washington. Buy Press.

LEFEBVRE, H: (1971:5) La ville et I'urbain. Espaces et sociétés. París

IVAM (2017) Inauguración de la intervención de Escif en el solar del IVAM. Actividades. https://www.ivam.es/es/actividades/ inauguracion-de-la-intervencion-de-escif-en-el-solar-delivam/ [02-11-2019]

PARRAMÓN, R. (2009). Arte y espacio público. ¿Campo de acción o campo de batalla? ¿Producto o servicio? Murría, Alicia (Dir.) Catálogo de la exposición: Distorsiones, documentos, naderías y relatos. La Palmas de Gran Canaria: Centro Atlántico de Arte Moderno (CAAM), 2009. http://ramonparramon.net/artey-espacio-publico-campo-de-accion-o-campo-de-batallaproducto-o-servicio/ [02-11-2019]

RAMÍREZ J.A. (1992: 197-207) Arte y arquitectura en la época del capitalismo triunfante. Visor

SÁNCHEZ.J.A. Coord. (2003). Nuevos espacios para el arte, en Práctica artística y políticas culturales: algunas propuestas desde la universidad. Universidad de Murcia. Campus digital: https://www.um.es/campusdigital/Libros/textoCompleto/ poliCultural/05asanchez.pdf [02-11-2019]

VAQUERO, J. M. (1980) Creado en Candás (Asturias) un 
museo al aire libre. El País. 7-nov-1980 https://elpais.com/ diario/1980/11/07/cultura/342399611 850215.html [02-112019]

YVARS. J.F. (2005) El espacio intermedio. Apreciaciones sobre el arte moderno. Debolsillo

\section{Autor/es}

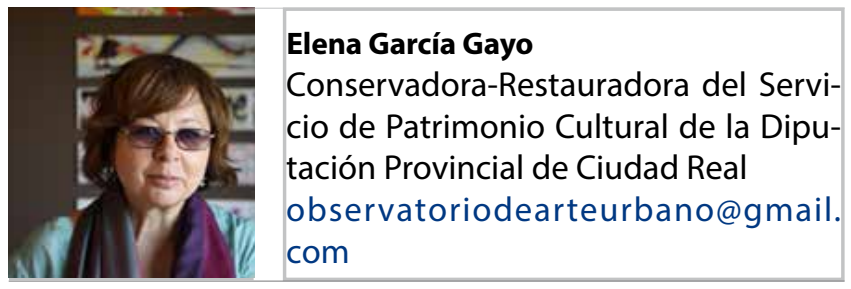

Elena García Gayo es titulada en Conservación Restauración de Bienes Culturales por la ESCRBC de Madrid. ConservadoraRestauradora del Servicio de Patrimonio Cultural de la Diputación Provincial de Ciudad Real. Paralelamente, es coordinadora de los grupos de trabajo, y del de Arte Urbano, del grupo español del International Institute for Conservation, GEIIC, desde 2015. Colabora con la Comisión de Seguimiento del Plan Nacional de Conservación del Patrimonio Cultural del siglo XX en representación del GEIIC. Crea y administra el Observatorio de Arte Urbano. Dirige y edita la revista digital especializada Mural Street Art Conservation. Coordinó el primer monográfico anexo al n¹0, Arte Urbano: Conservación y Restauración de intervenciones contemporáneas, publicado en la revista digital ge-conservación, en 2016.

http://observatoriodearteurbano.org

https://independent.academia.edu/EGayo 

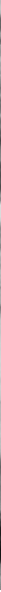

\title{
Berlín: todo un paradigma en el pasado, presente y futuro del arte urbano
}

\author{
Sandra Gracia Melero
}

Resumen: Desde el muro de Berlín y la East Side Gallery, al Urban Nation. Una historia política con perspectiva comercial. Berlín ha sido siempre un referente en arte urbano a nivel mundial. La zona ocupada por los EE. UU, el Berlín Oeste, fue en los ochenta un hervidero de subculturas de las que surgieron escritores de graffiti que usaron el muro como lienzo. Tras su caída en el 1989, estas manifestaciones callejeras se fueron extendiendo y desde finales de los noventa hasta nuestros días el graffiti, el arte urbano y el muralismo han ido mutando y siguen formando parte del ambiente contracultural berlinés. Enmarcado en este contexto, en el año 2017 abrió sus puertas el Urban Nation Museum, un claro ejemplo de que la musealización del arte urbano supone un grandísimo reto, ya que se trata de un oxímoron con respecto a sus valores, códigos y medios de difusión propios, que difieren del arte tradicional.

Palabras clave: grafiti, arte urbano, muralismo, berlín, muro de berlín, east side gallery, urban nation museum

\section{Berlin: a paradigm in the past, present and future of urban art}

Abstract: From the Berlin Wall and the East Side Gallery, to the Urban Nation. A political history with a commercial perspective. Berlin has always been a reference in urban art worldwide. The area occupied by the USA, West Berlin, was in the eighties a hotbed of subcultures from which graffiti writers emerged who used the wall as their canvas. After its fall in 1989, these street manifestations spread throughout the city and from the end of the nineties until today graffiti, urban art and muralism have been mutating and continue to be part of Berlin countercultural environment. Framed in this context, in 2017 the Urban Nation Museum opened its doors, a clear example that the museumization of urban art is a great challenge, since it is an oxymoron with respect to its values, codes and media which differ from traditional art.

Key words: graffiti, street art, muralism, berlin, berlin wall, east side gallery, urban nation museum

\section{Introducción}

Las calles de Berlín han sido desde los años 80 un lienzo en "blanco" para los escritores de grafiti de todo el mundo. Los acontecimientos históricos sucedidos durante la Guerra Fría y la represión sufrida por sus habitantes fueron en gran parte el detonante de la inclusión del graffiti y el arte urbano en sus calles. Y es que ha sido Berlín, pese a su aparente corta historia, el reflejo de las pulsiones políticas más importantes de la época contemporánea. Antes de concluir la Segunda Guerra Mundial, Alemania era un país estratégico en Europa, siendo considerada peligrosa para las potencias aliadas por su tejido industrial y su marcado nacionalismo. Berlín estaba dividida en cuatro sectores: uno de corte comunista, el soviético, y los tres que correspondían a los aliados, el estadounidense, el británico y el francés. En 1949, la división en dos de la ciudad, y por extensión de Alemania, quedó patente con la creación de la República Federal de Alemania (RFA) por parte de los aliados, en el sector occidental, y de la República Democrática Alemana (RDA) por parte de los soviéticos, en el sector oriental (Garzón, 2013: 85-91). 


\section{El Muro de Berlín provoca la reivindicación y frescura de las primeras intervenciones urbanas}

Tras algo más de diez años de la creación de ambos sectores, el desarrollo económico de la zona occidental hizo que la población de la parte soviética se trasladara allí masivamente en busca de más oportunidades. Frente a esto, la RDA sorprendió a la población durante la noche del 12 de agosto de 1961, comenzando a construir un muro provisional en forma de alambrada, de más de 155 kilómetros de largo, para evitar así el éxodo de población. A los pocos días se hicieron oficiales las intenciones soviéticas, anunciando públicamente la construcción de un "muro antifascista como medida para asegurar la paz" (Garzón, 2013: 118), sustituyendo las alambradas por muros de ladrillo, piedra y hormigón, y erigiendo torres de vigilancia, custodiado todo ello por la policía fronteriza de la RDA. A esta fase inicial de la construcción se la conoce como la primera generación del muro, ya que posteriormente se iría ampliando y modernizado. Primero con la segunda generación, que incorporó vías paralelas para las patrullas; posteriormente una tercera generación, a partir de 1968, incluyendo planchas de hormigón industrial; y finalmente con la sustitución progresiva en la cuarta generación en 1967, por los definitivos bloques de hormigón. Todo esto llegó a ser una mezcla heterogénea con varias fases que incluían algunos sectores del muro y diversos puestos de control, que tenían forma de torres para centinela y pasos entre los muros interiores y exteriores, lo que facilitaba una vigilancia a pie con perros patrulla. La estación de tren Friedrichstrasse fue el único punto de tránsito entre las dos zonas, existiendo un pabellón donde se llevaban a cabo los trámites burocráticos necesarios para pasar de un lado a otro del muro. Hoy en día este espacio todavía se conserva y alberga, además de la estación ferroviaria en uso, el Tränenpalast, un museo que recuerda la historia del lugar (Ibidem) [figura 1].

La división que provocó el muro en la sociedad berlinesa es un hecho indiscutible. La repentina adaptación que tuvieron

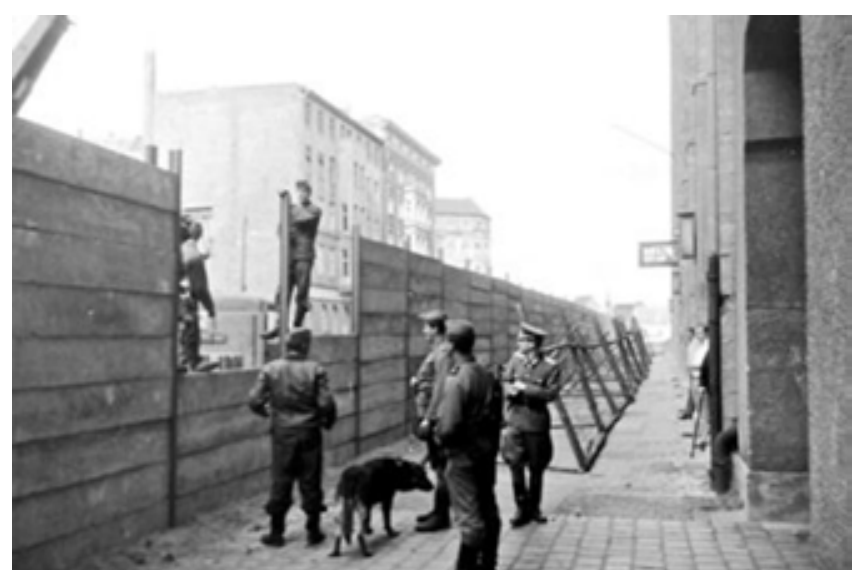

Figura 1. Fase inicial de la construcción del Muro de Berlín (Fuente: Berkeley News, disponible en https://news.berkeley.edu, imagen Creative Commons). que realizar al nuevo medio supuso un coste personal y profesional difícil de asumir y de integrar en su día a día. Esta brecha de hormigón dividió, además de a familiares y amigos, líneas ferroviarias, cursos de ríos e incluso accesos y fachadas de viviendas. Al final de la construcción, el muro llegó a medir 156 kilómetros, con alrededor de 130.000 bloques de hormigón de 3,60 metros de alto por 1,20 metros de ancho (Pinto, 2015: 63-64).

Nada más se erigió el muro, la población plasmó su repulsa en él mediante pintadas, aprovechándose así del anonimato y el gran alcance que les otorgaba este medio. Si bien el graffiti no tiene porqué estar necesariamente unido al activismo político (aunque implícitamente exista por ser una apropiación del espacio público sin el permiso de quienes gestionan ese lugar), se puede afirmar que en el caso del muro de Berlín surgió como repulsa y respuesta a la situación política imperante; el fin era claramente activista y reivindicativo [1]. Pese a existir mucha rumorología sobre el número de escritores de graffiti que, tras ser descubiertos por los VoPos [2], "desaparecieron" después de ser arrestados, oficialmente solo se registró una detención por este motivo (Kimvall, 2015: 87; Pinto, 2015: 64).

Durante esta primera década, las intervenciones realizadas en el muro se limitaban a mensajes políticos ejecutados de forma apresurada, generalmente con un solo color y in ningún tipo de intención estética. Esto difiere de los murales que se ejecutarán durante los años 80 , posiblemente porque en este momento la vigilancia y el control era mucho más estricto. Además de esto, cabe destacar que las secciones del muro de las primeras generaciones, como se mencionaba anteriormente, se conformaban con materiales más heterogéneos e irregulares (ladrillos, madera, hormigón), por lo que la superficie sobre la que pintar no debía ser la más adecuada para realizar piezas más elaboradas.

La zona ocupada por los EEUU, concretamente el barrio de Kreuzberg, fue en los ochenta todo un hervidero de subculturas, proliferando sobre todo la música y el estilo punk, así como grupos pertenecientes a corrientes políticas anarquistas. Este barrio, además se encontraba muy próximo a los muros represores que fraccionaban la ciudad alemana. Berlín era el epicentro de la contracultura. Sus habitantes resultaron influenciados por la película Style Wars de Tony Silver y Henry Chalfant y libros como Subway Art, también de Chalfant y Martha Cooper, que mostraban a escritores de graffiti de ciudades como NY y que actuaron como catalizadores de esta libre forma de plasmar ideas políticas, su rabia ante la opresión, se "dejaba ver" en los muros exteriores de la brecha que dividía su ciudad [figura 2].

Sin embargo, fue a partir de los años ochenta cuando las pintadas en el muro comenzaron a ser más elaboradas, claro ejemplo de ello fue el Running Man que Jonathan Borofsky pintó en 1982, una figura sencilla blanca y contorneada en negro de un hombre angustiado huyendo, su autorretrato [figura 3]. Este fue realizado con la ayuda de un proyector que trasladaba la imagen desde el museo al muro y dos 


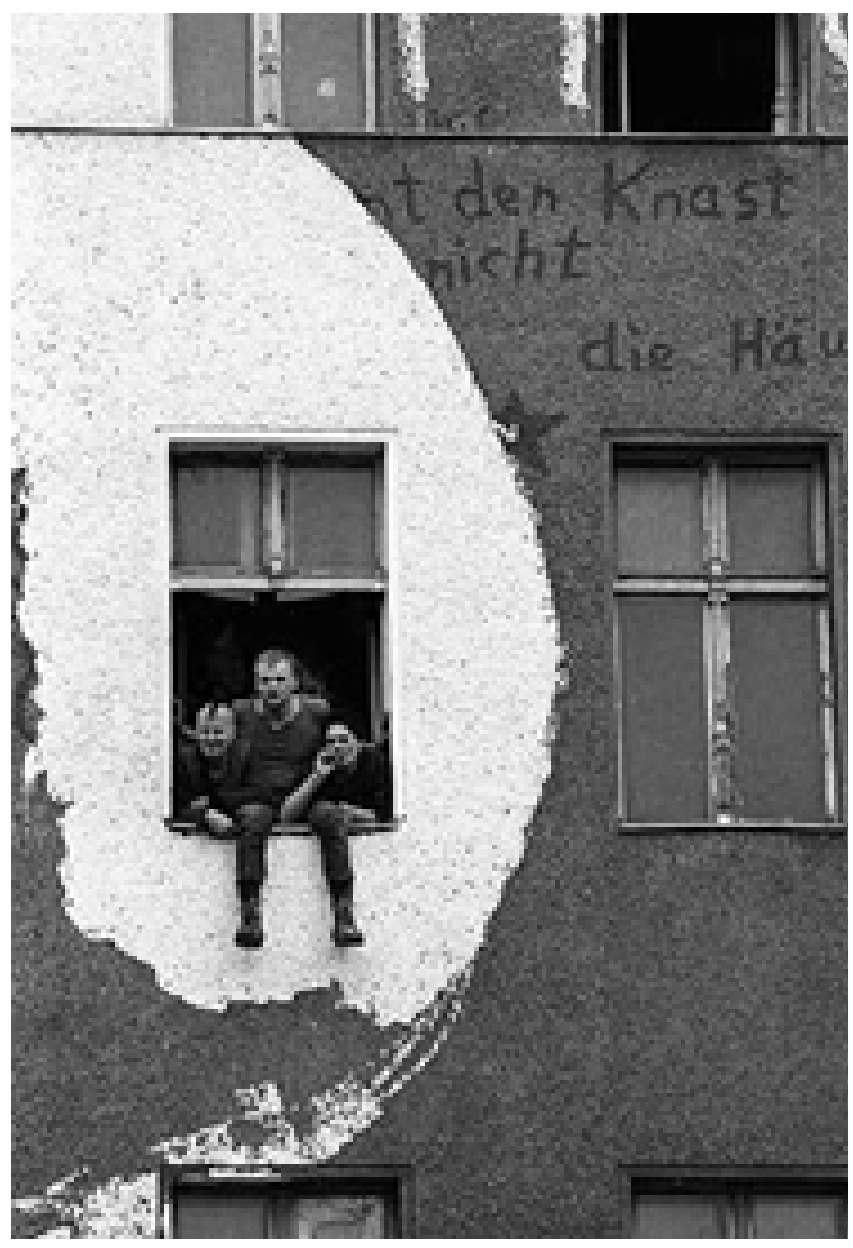

Figura 2. Okupas en el bloque Oranienstr, número 198 con esquina Besetza (Fuente: Archivo Umbruch, Autor: Manfred Kraft).

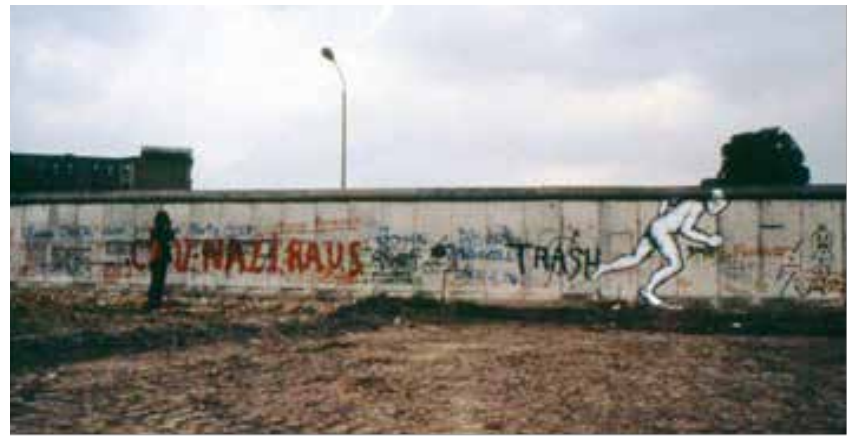

Figura 3. A la derecha de la imagen, el Runnin Man de Jonathan Borofsky. Fotografía tomada por el artista en 1982 (Fuente: Archivo de Jonathan Borofsky).

asistentes, siendo sorprendidos durante el proceso por los patrulleros británicos que, haciendo la vista gorda, les dejaron continuar. Además de esto, pintó en otra sección del muro las palabras "KARMA: What you think and do comes back to you" y un pequeño rubí rojo de cartón en el lugar donde se encontraban las antiguas cámaras de tortura de la Gestapo. Esta intervención fue realizada por el artista como consecuencia de su participación en la exposición colectiva Zeitgeist, celebrada en el Martin-Gropius-Bau, museo situado en el Berlín occidental (barrio de Kreuzberg) (Calvocoressi, 1983: 120) [3]. Pero los muros cambiaban (y cambian) constantemente, y al año siguiente añadieron de forma anónima al Running Man un bocadillo en el que se podía leer "Ick stand uff Berlin", un dicho popular que se podría traducir como "Estoy parado en Berlín" (Stahl, 2009).

Dentro de este grupo de primeros escritores y artistas que intervinieron en el Muro de Berlín, podemos tomar como ejemplo al francés Thierry Noir. Además de ser uno de los pocos artistas que ha logrado permanecer en él desde 1984 hasta la actualidad, es una muestra clara del proceder de aquel momento. Comenzó realizando piezas más elaboradas, con más elementos, pero pronto vio que permaneciendo tanto tiempo pintando llamaba demasiado la atención de los agentes de la Stasi y de los transeúntes (Noir, s.f.). Por ello, pasó a realizar obras más sencillas y rápidas de ejecutar, más efectistas. Su iconografía más conocida es la de esta segunda época, con personajes que despliega por largas extensiones de muro, usando tricromías o cuatricromías de colores vibrantes y contrastados, todos ellos perfilados en negro. Noir lo denominada "arte kilométrico"y "pintura industrial", otorgándole ese sentido de continuidad y de producción seriada y acercándose a la estética del Pop Art o del Nouveau Réalisme (Puyol, 2014) [figura 4]. También trabajó con otros artistas in situ, sobre todo con Christophe Bouchet, e hizo guiños a la obra de Marcel Duchamp, colocando un urinario

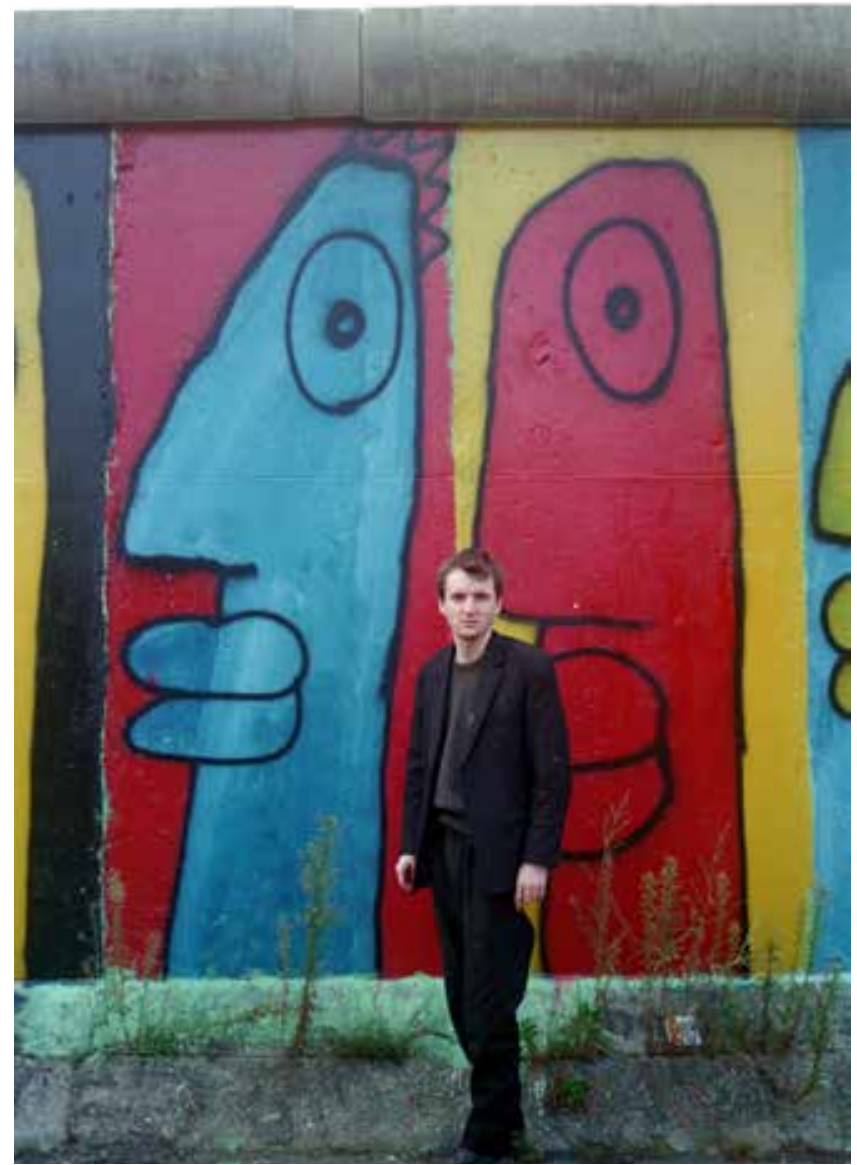

Figura 4. Thierry Noir en 1986 frente a una de sus obras en el Muro de Berlín (Fuente: Archivo de Thierry Noir). 
y un lavabo en el muro. Cabe mencionar su colaboración con el cineasta Wim Wenders, apareciendo en la película The Wings of Desire subido a una escalera y pintando el Muro en la zona de Walsemarstresse. Paradójicamente, esta sección del muro, tal y como apostilla el propio Noir, se conserva en la actualidad en un patio privado de Madison Avenue de Nueva York y la escalera en la colección permanente del Museo Wende en Culver City (California) (Noir, s.f.). En la actualidad, Thierry Noir sigue realizando obras con sus emblemáticos perfiles coloristas en el barrio de Kreuzberg, aunque ahora en su atélier y en otros formatos como esculturas o lienzos.

El fenómeno del Muro de Berlín como lienzo, para los escritores y los artistas, se extendió por todo el mundo y en algunos momentos de su historia guardó una relación muy estrecha con el estilo de graffiti que se estaba viendo en el metro de Nueva York. Si la película Style Wars, mencionada anteriormente, se estrenaba en 1983, ese mismo año, el graffitero ZEPHYR realizaba una pieza con marcada estética neoyorkina, en la que se podía leer "Style", quizás incluyendo un cierto toque irónico por la naturaleza política del soporte. Era de esperar que las conexiones con la ciudad americana fueran especialmente prolíficas, ya que el propio barrio de Kreuzberg era el ocupado por EE. UU. Además, la participación directa de escritores y artistas americanos fue dilatada.

Interesante fue la exposición titulada Stadtsichten, celebrada en 1986 en la nGbK, una galería berlinesa que posee una filosofía cooperativa. En ella, y durante cuatro semanas, cinco artistas de Berlín invitaban a cinco artistas de Nueva York para trabajar en un proyecto en el que el espacio expositivo fue la misma ciudad. La idea desarrollaba el hecho de que las obras se veían determinadas por el cambio y la adaptación que los artistas americanos debían hacer al nuevo medio urbano. Entre ellos destacan el artista neoyorkino John Fekner, que colaboró con el escritor DAZE realizando una intervención en el muro en la que se podía leer "BETON PUZZLE" (rompecabezas de hormigón), o Peter Mönnig, que construyó un trozo de muro al lado del original (nGbK, 1986).

Un mes más tarde de la citada exposición, el también artista neoyorkino y gran referente para el arte urbano a nivel mundial, Keith Haring, fue invitado por Rainer Hildebrandt, fundador del Museo Checkpoint Charlie, a Berlín a pintar en el muro. La organización había preparado 300 metros en la zona de Checkpoint Charlie para la intervención de Haring, aplicando un fondo amarillo y cubriendo otros murales anteriores, entre ellos uno de Thierry Noir [4]. El mural incluyó, sobre el fondo amarillo, grandes figuras con los pies y las manos entrelazadas, buscando la unidad entre las personas que se debían enfrentar a la situación política, todo ello en rojo y negro para crear con el fondo, los colores de la bandera alemana (Public Delivery, s.f.; Pugh, 2015).

Tras la caída del muro en 1989, estos mismos activistas conquistaban el este de la ciudad, hasta ahora repleto de muros grises y vírgenes. Graffitis, stikers, stencils, tags, collages... el "bombardeo" fue masivo, y barrios como Friedrichshain, Mitte o Prenzlauer Berg, se llenaron de graffiti y consignas políticas. Un claro ejemplo es el sticker de Tower, pegatinas que fueron apareciendo por toda la ciudad con esta palabra, que incluía la silueta de la torre de televisión comunista. Esta hacía alusión a los rascacielos de las grandes ciudades que estaban erigidos respondiendo a los egos de los empresarios y que el espacio urbano debería diseñarse o constituirse por la mayoría de los ciudadanos y no por una minoría (Arms, 2011).

Contemporáneamente, asistimos a un hecho relevante, ¿qué pasó con los 156 kilómetros de muro? Unos 40.000 bloques de hormigón (de los 130.000 aprox. que lo componían) fueron utilizados para reparar la autopista que une Berlín con el Mar Báltico y el resto de fragmentos, fueron donados o adquiridos por instituciones como el Newsmuseum de Washington, el Parlamento Europeo en Bruselas, el Museo Imperial de Guerra de Londres y, en otros lugares más variopintos como los jardines del Vaticano, los baños masculinos del Hotel - Casino Main Street Station de Las Vegas o los pedazos para vender a los turistas.

El muro debía desaparecer, al menos en gran medida, ya que había sido el símbolo principal represivo de aquel momento aunque el despiece y el reparto masivo pueda resultar a los ojos ortodoxos del conservador-restaurador una pérdida. Pese a esto, cabe destacar que se refleja un cierto interés de la sociedad por conservarlo (aunque a su manera, a modo de fetiche), seguramente teniendo en este caso mucha más importancia la carga simbólica y su valor como documento histórico, que como vestigio de lo que ha sido para la historia del graffiti y del arte urbano.

\section{East Side Gallery: memoria y re-interpretación del Muro de Berlín}

Actualmente, el tramo más largo conservado in situ es el East Side Gallery con 1,3 kilómetros de extensión. De junio a noviembre de 1990, un total de 118 artistas de 21 nacionalidades fueron invitados a intervenir, celebrando la libertad que había conseguido la ciudad. Estas intervenciones se realizaron en la cara sur oriental del muro, a lo largo de Mühlenstraße, que se sitúa entre Kreuzberg y Friedrichshain. Esto fue el germen de la posterior denominación, en noviembre de 1991 por parte del Senado de Berlín, de la East Side Gallery como un monumento oficial de la ciudad con la descripción de "galería al aire libre" (Heinsohn, 2015: 127).

Posteriormente, en 1996, se fundó la Verein Künstlerinitiative East Side Gallery (Asociación de artistas de la East Side Gallery), con el fin de preservar y conservar los murales que en ella se encontraban. En el año 2000, se llevó a cabo una intervención de "restauración", algunos de los artistas que había pintado en el muro con anterioridad, repintaron treinta y tres murales de la East Side Gallery, tratándose 
por tanto de una reintegración ilusionista con materiales difícilmente reversibles (Künstlerinitiative East Side Gallery, 2013).

Esta galería al aire libre está gestionada por el distrito de Friedrichshain, que a su vez se encuentra bajo el dominio de la alcaldía de la ciudad, teniendo por tanto el Senado cierta influencia pero muy poco margen de maniobra con respecto a la conservación, mantenimiento y la otorgación de permisos de construcción que afecten a la zona. Muta continuamente, y no goza precisamente de supervisión y conservación bajo criterios y objetivos claros por parte de las instituciones. Claro ejemplo de ello, es el derribo en 2006 de 44 metros de muro para permitir el atraque de los barcos en el edificio O2 World (Caldas, 2015: 21) o el polémico repintado de cien murales de la galería, algunos basándose en el mural anterior (reconstrucción) y otros sustituyendo los existentes por otros de nueva creación, en 2009. En este último caso, fueron ochenta y cinco los artistas que participaron, imprimando previamente el soporte mural, pintando posteriormente y finalizando con la aplicación de una capa de protección anti-graffiti, todo ello con un coste de dos millones de euros (Künstlerinitiative East Side Gallery, 2013).

Sin embargo, la acción de los ciudadanos y de los turistas realizando pintadas y tags sobre los murales no cesó, incluso en 2012 se propuso colocar cámaras de seguridad para controlar y evitar nuevos daños, continuando así con el deseo de conservar los murales realizados. Finalmente parece que esto no ha llegado a llevarse a cabo.

\section{Reinterpretación del muro. El paso del tiempo y el recuerdo}

Publicitándose como la "galería al aire libre más grande del mundo", cuenta con una página web en la que se recoge su historia, incluye un listado con los artistas que han participado en los murales que actualmente pueden verse, aportan información sobre la asociación, animan a la participación de los ciudadanos por medio de donativos (aquí incluyen una fotografía de una persona eliminando graffitis de los murales) y publicitan la venta de su catálogo, además de sus visitas guiadas con artistas (Künstlerinitiative East Side Gallery, s.f.). La comunicación e información proporcionada in situ junto a los murales, se realiza a través de placas de pie. Los datos que muestran son los mismos en todos los casos, el rótulo principal es "Berliner Mauer / East Side Gallery" y luego incluye los años en los que se pintaron los murales actuales, los créditos de organización, además de una advertencia de que no se puede pintar sobre ellos. En este sentido se comprueba cómo no existe una información individualizada de cada mural ni de cada artista. Además de esto, existen una serie de columnas informativas, una al final de Warschauer Strasse, con datos básicos sobre la East Side Gallery, además de otras diseminadas por el resto de la ciudad aunque, la mayoría de ellas, se encuentran en mal estado, con una gran cantidad de pintadas que impiden su lectura. También se puede obtener información a través aplicaciones móviles, actualmente se encuentran disponibles dos para iOs y una para Android, que aportan datos individualizados sobre los murales, aunque todas ellas están creadas por desarrolladores independientes y ajenos a la gestión del espacio.

Tras analizar lo anterior, se puede afirmar que la East Side Gallery es una reinterpretación de lo que realmente fue el Muro de Berlín, los murales y las intervenciones son postcaída; poco queda de lo que fue en realidad, ya no se habla de graffiti o de street art, se trata de murales comisionados. Transformado en un lugar meramente turístico, todavía invita a la reflexión, la interacción y al cambio constante y conserva su carácter pacifista [figura 5].

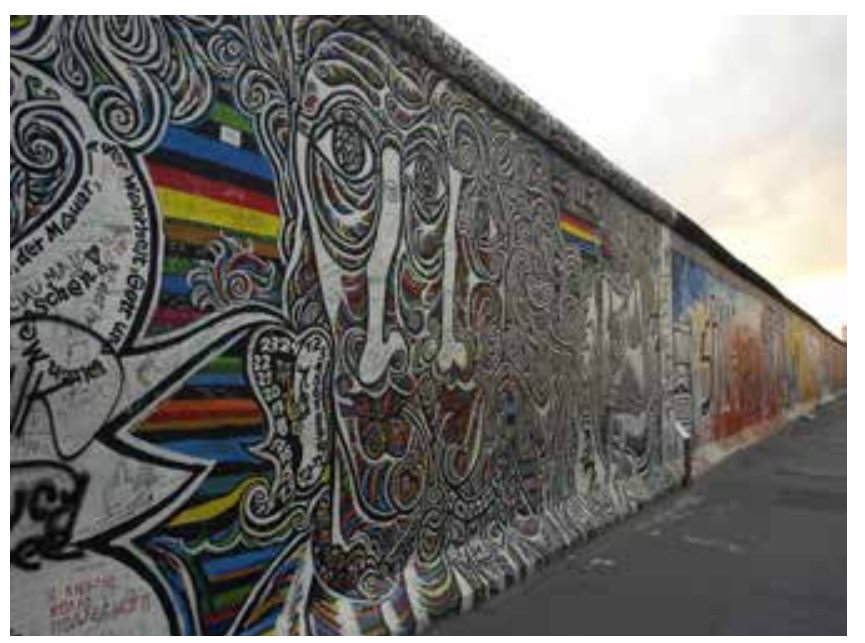

Figura 5. Vista de la East Side Gallery.

En mayo de 2018, tras largas negociaciones por parte de la Asociación de Artistas de la East Side Gallery, con el artista Kani Alavi a la cabeza, se consiguió el reconocimiento como patrimonio perteneciente o dependiente de la Fundación del Muro de Berlín. Con esto, parece que deja de correr peligro con respecto a lo apetecible del terreno por parte de las grandes constructoras. Además, se prevé que exista una gran aportación económica por parte de la fundación para el total de los fragmentos del muro en Berlín (se habla de una inversión de hasta 15 millones de euros). Esto supondrá un gran cambio para la East Side Gallery, Alavi afirma que se ampliarían las zonas peatonales, se instalarían barreras entre el público y el muro y se colocarán placas o cartelas explicativas. Concluye diciendo que la East Side Gallery va a poder dar la "impresión de ser un museo" (Mas, 2018).

\section{La escena vibrante del graffiti, el arte urbano y el muralismo berlinés en la actualidad}

La respuesta contracultural sucedida en los 80 , ha hecho que la ciudad de Berlín sea un paradigma del graffiti y el arte urbano en el mundo. Los alquileres en la zona oriental de la ciudad, resultaban especialmente asequibles para 
los jóvenes, concentrándose en la zona una gran cantidad de artistas y creativos que terminarán abriendo tiendas independientes, pequeñas galerías o editoriales jóvenes (Jakob, 2017: 13), todo ello contribuyendo a la creación de un interesante y excitante tejido cultural. Esto ha propiciado a su vez la existencia de una atrayente demanda formativa relacionada con el arte y el diseño, siendo una ciudad que invita a los jóvenes talentos a desarrollar su formación y carrera profesional.

En los barrios de Mitte, Kreuzberg, Friedrichshain o Prenzlauer Ber, se puede disfrutar de un ambiente cultural muy rico y callejero, en el que los residentes comparten, interactúan y participan en el espacio público. Un claro ejemplo de ello, es el desarrollo del graffiti y del arte urbano en esta ciudad. La armonía, el orden, el control o lo monótono, no suelen ser adjetivos que definan las calles de estos barrios berlineses, donde se extienden las acciones artísticas ilegales que buscan reivindicar y criticar al sistema, rediseñar el espacio urbano o responder a los más estrictos códigos del graffiti.

A partir de los 2000 y hasta la actualidad, ha sido una de las ciudades pioneras en aprovechar el interés que suscitaba el graffiti, el arte urbano y el muralismo, sucediéndose una gran cantidad de festivales, con obras ahora comisionadas y legales, que han transformado sus calles y sus edificios. Artistas como Roa, Blu, Ash o JR, comparten medio con arte urbano ilegal, como las Little Lucy de El Bocho [figura 6], las modelos de XOOOOX, los OPIS con su luz vibrante de Vermibus, los muñecos de Prost, las impresiones de FLOCKE o de Bifido, o las huellas dejadas por los graffiteros que intervienen en los emblemáticos vagones amarillos de la red ferroviaria berlinesa.

Muchos han sido, y serán, los festivales de "arte urbano" celebrados en la ciudad de Berlín, algunos de reciente formación como el Berlin Mural Fest, que contó en su primera edición en 2018 con artistas como El Bocho, Klebebande o Ben Wagin. Para la edición de este año 2019, ya se han anunciado varios pesos pesados del panorama

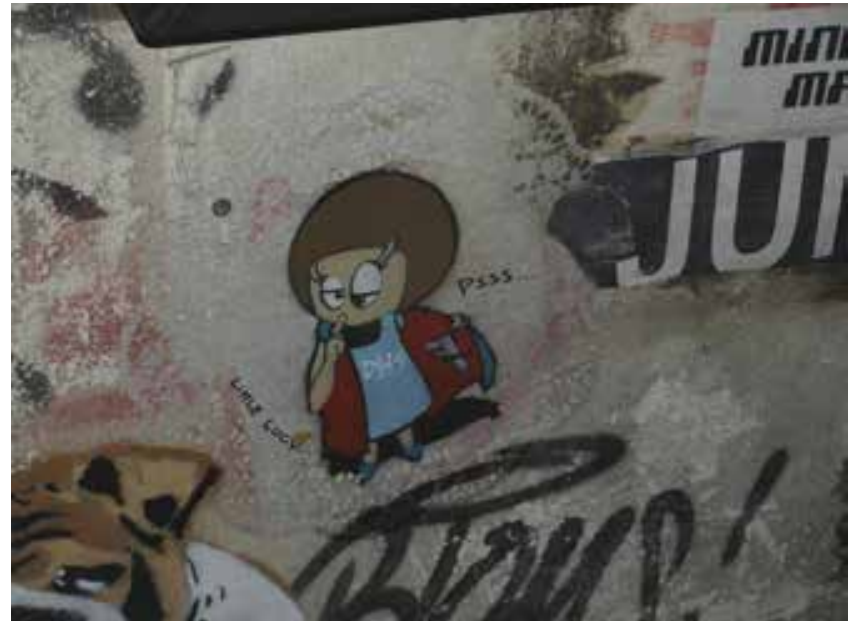

Figura 6. Little Lucy de El Bocho. internacional como Okuda San Miguel, Aryz o Pichiavo. Además, este festival ofrece actividades complementarias como eventos de música hip-hop, visitas guiadas nocturnas o una aplicación móvil para geolocalizar los murales y las intervenciones (Berlin Mural Fest, s.f.).

Otro con más recorrido es el Yard 5 Festival \& Graffiti Sport Jam (vinculado a la tienda Yard5 Graffiti Shop) que, desde 2014, lleva celebrando diversas ediciones. En él, se invita a artistas y escritores nacionales e internacionales y animan a los visitantes a que ellos mismos también intervengan en murales y paneles de madera. También incluyen, como suele ser lo habitual, otras actividades como música en vivo o batallas de beatboxs (Streetartbln, s.f.).

El uso de pegatinas y vinilos en las calles también es una práctica que se extiende por Berlín. A finales de los años 90, surgió una gran afición por coleccionar e intercambiar estas stickers. La famosa pegatina de "Hello my name is" (Hola, mi nombre es) que incluía un espacio en blanco para escribir tu nombre, fue realmente un diseño realizado por una empresa americana a finales de los años cincuenta, para ser pegada en la ropa durante reuniones y conferencias (Couvreux Alijarte 2016: 163) y que a partir del año 2000 fue muy utilizada por los grafiteros para extender sus tags rápidamente por la ciudad. La tendencia de los stickers fue tal, que en 2008 se abrió en Berlín el Hatch Sticker Museum que, pese a autodenominarse museo de las pegatinas, se trata realmente de una tienda que cuenta con un amplio catálogo para su venta (Hatch Kingdom, s.f.).

Los gasfiteros y artistas que intervienen en la ciudad de forma ilegal, interactúan con los ciudadanos sin nada que filtre sus obras: ni galeristas, ni comisarios, ni instituciones culturales. Tienden a crear una vibrante y desenfadada escena artística y cultural. La más reciente escena de festivales y murales comisionados, supone una pérdida de frescura notable, aunque también permite el desarrollo de grandes murales más complejos, que necesitan de una infraestructura específica y que sin los permisos oportunos difícilmente podrían llevarse a cabo. Por esta cuestión, y en muchas ocasiones por la necesidad de recibir una remuneración por sus actuaciones, muchos artistas urbanos han dado el paso de la ilegalidad a la legalidad, aunque en algunas ocasiones no haya sido fácil.

\section{Excepciones que crean patrones para el movimiento autogestionado.}

En Berlín encontramos un caso realmente relevante en este sentido, el gran mural del artista Blu, que realizó en 2008 en el barrio de Kreuzberg. Este mural, que se divide en dos partes, ocupa las medianeras de dos edificios diferentes [figura 7]. Mostraba, en primer lugar, un torso de un personaje blanco delineado en negro, que portaba dos relojes de oro unidos por una cadena. En el segundo, dos personajes enmascarados, también en blanco y con delineado en negro, intentan quitarse las máscaras mientras uno forma con sus 
dedos la letra "W" (refiriéndose al oeste de la ciudad) y el otro forma la letra "E" (haciendo alusión al este). Esta obra se encontraba concretamente en un descampado en Cuvry Str $y$, en 2014, solar que fue adquirido por un empresario que lo iba a utilizar para construir un edificio de apartamentos. Este constructor, sabiendo la importancia que tenía el mural, aprovechó la coyuntura y publicitó estas nuevas viviendas con la promesa de que iban a tener vistas privilegiadas al famoso mural de Blu. El artista, al enterarse de la noticia, llamó a su equipo y, colocando una grúa en mitad de la noche, tapó con pintura negra los dos muros, dejando a la ciudad de Berlín sin uno de sus más emblemáticos murales (Escorial, s.f.).

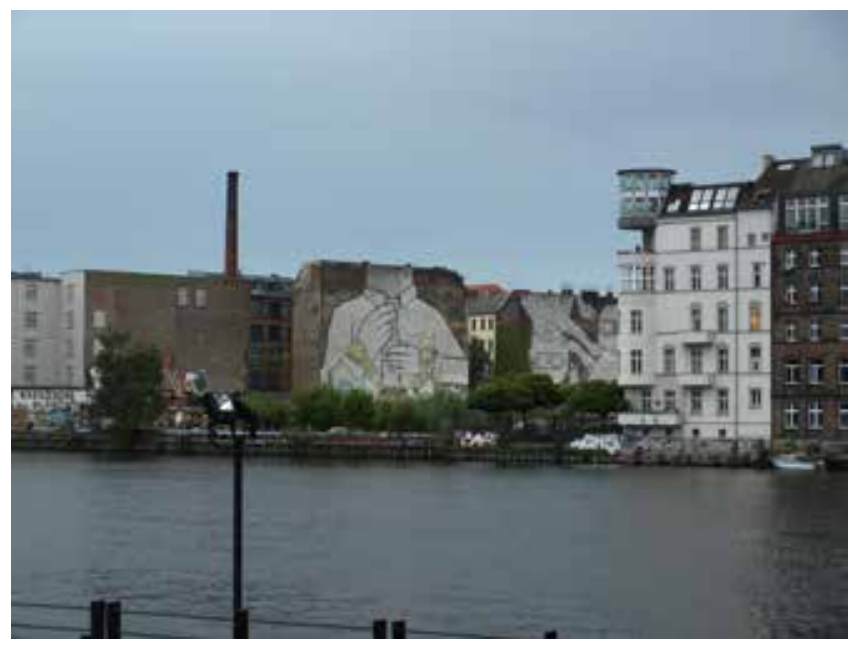

Figura 7. Mural de Blu en Cuvry Str, actualmente cubierto con pintura negra. Fotografía tomada en mayo de 2014.

\section{"Arte urbano" indoor: el Urban Nation Museum}

Además de galerías de arte, que suelen contar con obras de artistas urbanos como es el caso de la Urban Spree o la BC Gallery, Berlín cuenta con el que se denomina como el primer museo de "arte urbano" del mundo.

En septiembre de 2017 abre sus puertas Urban Nation Museum for Urban Contemporary Art en la ciudad de Berlín. Se encuentra ubicado en el edificio Wilhelminian que estaba originalmente en la calle Bülowstrasse, ligeramente desplazado del centro turístico de la ciudad, en el barrio de Schöneberg. Su entrada es gratuita y en su web promete trasladar la calle al interior del museo, conectando a los artistas, creativos y público interesado y despertando el interés de los visitantes, promoviendo el talento y documentando el patrimonio cultural.

Bajo la dirección de Yasha Young [5], el museo está respaldado por la fundación Gewobag y el espacio está diseñado por los arquitectos del grupo GRAFT (Urban Nation Museum for Urban Contemporary Art, (s.f.). Los muros exteriores del edificio son utilizados como soporte de manera periódica por artistas invitados, algo que le da visibilidad y protagonismo en el barrio. Además, se suelen suceder las intervenciones en las calles aledañas al museo (aunque en este caso se trata igualmente de obras legales y comisionadas) y posee una colección que va engrosando con adquisiciones y donaciones de artistas vinculados al arte urbano y al arte actual [figura 8].

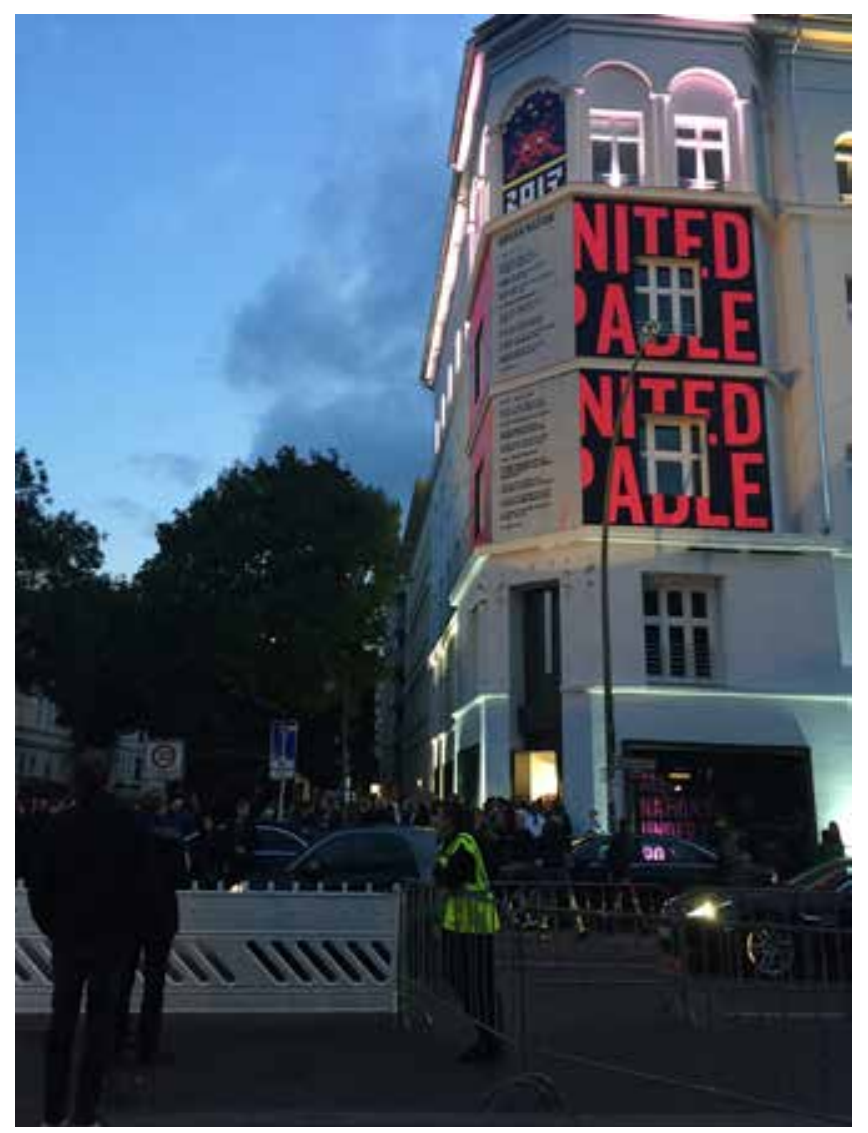

Figura 8. Urban Nation Museum for Urban Contemporary Art.

El espacio interior se asemeja al de una galería de arte. Las obras, de muy diversos artistas, se exponen bajo un criterio estético y sin aparente discurso científico. Siempre se trata de exposiciones temporales que se prolongan en el tiempo, sin existir un calendario claro o una línea discursiva concreta. Las obras más predominantes suelen ser cuadros, aunque también se incluyen algunas esculturas o instalaciones en las zonas centrales. Como recursos informativos, se pueden encontrar cartelas individualizadas para cada obra, con sus datos básicos, aunque no hay muchos textos de apoyo a la comprensión, como podrían ser vinilos o paneles explicativos de la exposición. Existe la posibilidad de realizar visitas guiadas, esta vez de pago, tanto del museo como del barrio de Schöneberg, para conocer las intervenciones artísticas [figura 9]. El edificio alberga a su vez la biblioteca especializada en graffiti, arte urbano y muralismo inspirada y llevada a cabo con el apoyo de Martha Cooper, que funciona como un centro de documentación. Esta nació con una colección de libros, revistas y otros objetos de la propia fotógrafa neoyorkina y ha ido aumentando sus fondos con adquisiciones y donaciones de artistas, actualmente depende del historiador del arte Christian Omodeo (Le Grand Jeu, s.f.). 


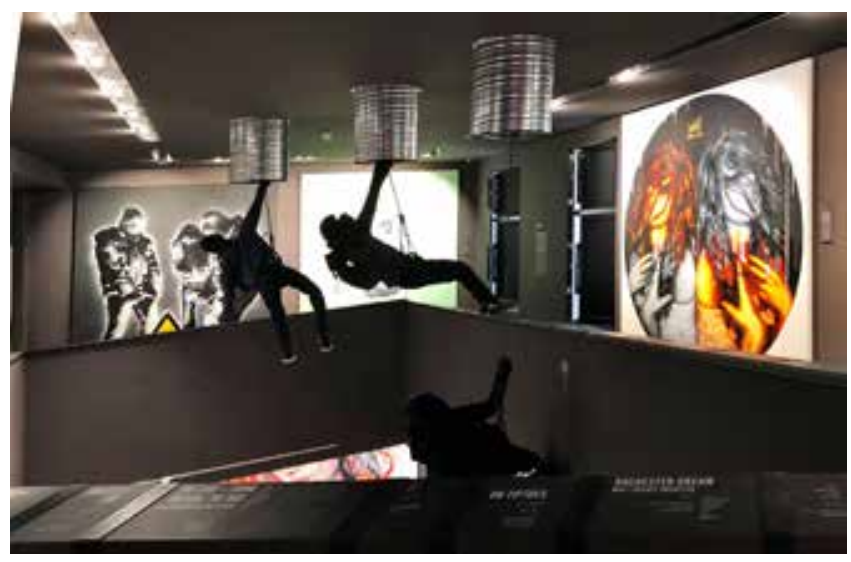

Figura 9. Interior del Urban Nation Museum for Urban Contemporary Art.

El museo también ofrece a artistas emergentes un programa de residencias becadas de tres a seis meses, bajo la tutorización profesional de Yasha Young y el apoyo económico de la Fundación Berliner Leben. Los artistas pueden ser del ámbito urbano o del arte actual, y deberán pertenecer a algún estado miembro de la Unión Europea y tener su residencia fuera de Berlín. Disponen de todo el edificio para alojarse y tener su estudio, aprovechando así las posibilidades y las sinergias que les pueda aportar la ciudad. Desde el Urban Nation apuntan, que Berlín está sufriendo una gran gentrificación en el centro de la ciudad, haciendo en muchas ocasiones poco asequibles los alquileres de viviendas y de estudios, por lo que esto es una oportunidad para los artistas que quieran centrarse en desarrollar su creatividad.

Dentro de las prioridades que posee la Berliner Leben para financiar las iniciativas artísticas de los residentes, se encuentran el apoyo de proyectos vinculados a la localidad y a la zona donde se ubica la residencia/museo, el contar con un compromiso social y el hacer partícipes a los ciudadanos y vecinos, el apoyo a la diversidad social, a la igualdad, y que cuenten con ideas que destaquen por su originalidad, calidad artística y que miren al presente y al futuro de la sociedad urbana. Para ello, cuentan con una beca de 1.900 euros al mes, de los cuales 1.000 corresponderían al pago de la estancia, 300 euros para materiales, 100 euros para el transporte en Berlín y sus alrededores y el sobrante, 500 euros, para costear el resto de gastos. El proceso de selección se realiza mediante un jurado rotativo, siendo su decisión definitiva y sin posibilidad de comunicar a los aspirantes el razonamiento de sus decisiones. Una de las condiciones de participación es la de ceder al final de la estancia una obra a la Fundación Berliner Leber, además de ser obligatoria la asistencia a todos los actos y eventos tanto de la misma, como del museo [6] (Urban Nation Museum for Urban Contemporary Art, s.f.).

Más interés guardan los proyectos relacionados con el arte urbano y el arte actual, que gestionan desde la organización del Urban Nation y que, generalmente, se encuentran bajo el comisariado de su directora Yasha Young [figura 10]. Un ejemplo de ello es el Project M en el que con más trayectoria que el propio museo (desde 2013), realizan colaboraciones con artistas para que intervengan en el mismo edificio o en otras partes de la ciudad. Algo similar es el denominado One Wall, en el que se realizan grandes murales en los edificios de Berlín, o acciones como la reciente Urban Nation Biennale 2019 que, bajo el título "Robots and relics: unmanned" (Robots y reliquias: no tripulados), concentra a veinticinco artistas que trabajan conjuntamente en crear un gran distrito artístico con instalaciones, esculturas interactivas y actuaciones en vivo, para concienciar del diseño urbano desde un punto de vista tecnológico y sostenible (Ibidem.).

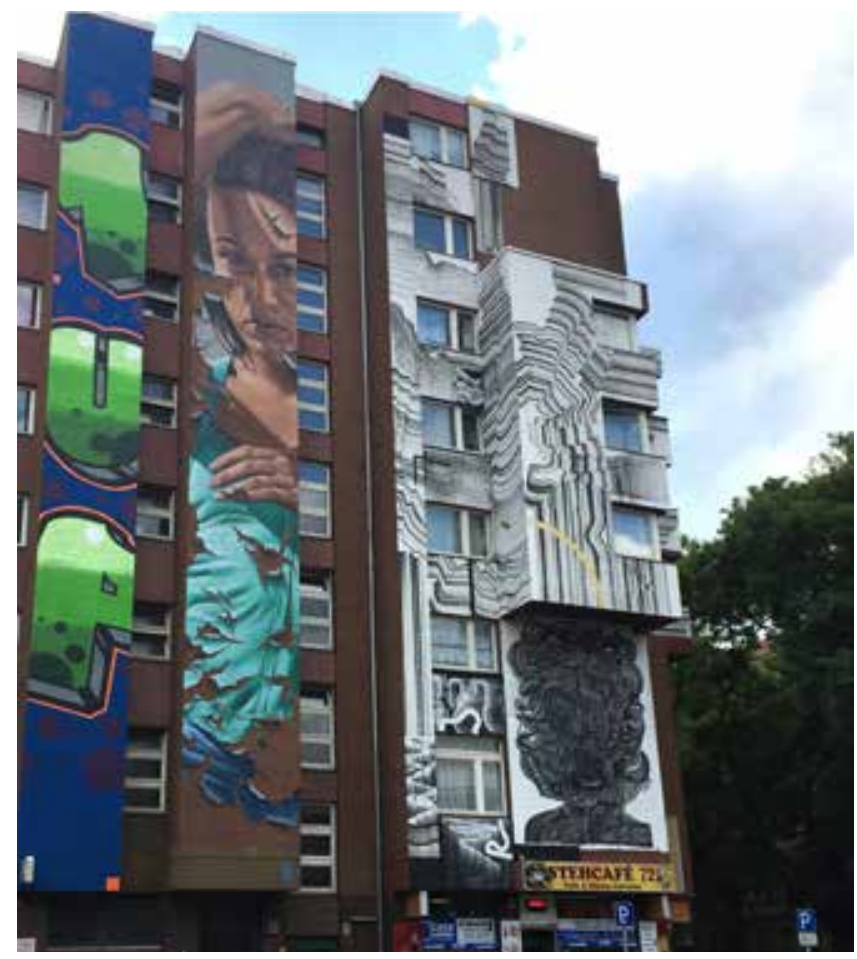

Figura 10. Las intervenciones murales en los alrededores del Urban Nation Museum for Urban Contemporary Art resultan frecuentemente renovadas.

Para analizar el alcance y el calado que posee el Urban Nation, el ICOM en su definición de museo (pese a que se encuentra actualmente en prueba de reformulación) hace especial hincapié en que deben ser instituciones sin fines lucrativos que, entre otras cosas, adquieran, conserven, investiguen, comuniquen y expongan el patrimonio (ICOM, s.f.), la de La Stiftung Preußischer Kulturbesitz (Fundación de Patrimonio Cultural Prusiano), entidad financiada por el Estado y de la que dependen gran parte de los museos de Berlín, que establece los objetivos de sus museos nacionales en: "Cultivar, aumentar y promocionar sus colecciones para el público en general. Actualizar, hacer accesible y preservar para el futuro. Crear contenido científico de sus colecciones a través de la investigación. Desarrollar documentación y publicaciones. Centrarse en los valores sensoriales y contenidos intelectuales de sus colecciones para organizar exposiciones y eventos adecuados. Usar sus colecciones como base para futuras actividades centradas en la mediación del arte y la cultura. Proporcionar conocimiento 
y experiencia a nivel nacional e internacional" (Stiftung Preußischer Kulturbesitz, s.f.).

Aplicando ambas definiciones a las funciones realizadas por esta institución, se puede constatar que cumple con los objetivos de adquirir y exponer obras, así como de organizar eventos y actividades basados en sus colecciones o en sus artistas colaboradores. Por otro lado, en las instituciones museísticas, resulta especialmente importante el ámbito de la investigación, el de crear un discurso científico y generar documentación y publicaciones en relación a sus exposiciones y su colección, algo que en este caso no resulta un punto clave en la organización y gestión del museo.

\section{Conclusiones}

Se constata a lo largo de la historia que, la violencia, la represión y las tensiones políticas, suelen generar una interesante respuesta social, cultural y artística y, sin duda, este es el caso de Berlín, una ciudad cambiante, vibrante e inspiradora.

El Muro de Berlín, siempre será una muestra y un documento histórico de gran valor, que merece la pena ser conservado (al menos en parte) como muestra de una época convulsa de nuestra historia más reciente. Además de su valor histórico, las intervenciones artísticas y el graffiti que se realizaron, y que son una fiel muestra de las realidades que sufrieron los berlineses en las últimas décadas del siglo XX, deberían ser valoradas y conservadas. Esto no siempre ha sido así, se conservan pocos fragmentos originales del Muro, y mucho menos in situ.

Lugares como la East Side Gallery, se han rendido a las corrientes turísticas y han sufrido una transformación constante, en muchas ocasiones sin un criterio conservativo ni estético claro. Recientemente, con la inclusión de este espacio en la Fundación del Muro de Berlín, se prevén una serie de cambios que, pretenden mejorar el deficiente estado y la falta de información que se aporta en el lugar.

Sin duda, lo que hace a Berlín una ciudad especialmente valiosa, en lo que ámbito cultural se refiere, es su vida urbana. Sus calles están repletas de graffiti, arte urbano y muralismo, que hacen de ella todo un referente en estos campos; para muchos artistas, escritores e investigadores, toda una meca del arte. En las dos últimas décadas, estas manifestaciones han ganado en popularidad, lo que ha supuesto en muchas ocasiones, la merma de su frescura, espontaneidad y calidad, debido al efecto llamada y a la facilidad de acceso.

En los últimos años, han tomado fuerza los denominados "museos de arte urbano", utilizando una definición (la de museo) que ha estado siempre ligada a un tipo de arte con un reconocimiento consolidado y que implica una serie de requisitos, difíciles de cumplir para este tipo de lugares. Parece que se trata de una fórmula para poner en valor y elevar el arte urbano a un estatus que, supone un oxímoron con respecto a sus valores, códigos y medios de difusión propios. Quizás no sea arte urbano lo que albergan, quizás sea simplemente arte actual realizado por artistas que provienen de la experiencia del arte urbano. Quizás, no se deberían llamar museo, porque su funcionamiento se identifica fielmente con las galerías. Grandes galerías de arte para el consumo.

\section{Notas}

[1] Este carácter reivindicativo no existía en el graffiti neoyorquino de los años 70, que por lo general buscaba el "bombardear" y estar presente en toda la ciudad; una cuestión de ego más que de activismo político (Figueroa, 2014).

[2] Así es como se les llamaba comúnmente a los soldados del oeste.

[3] Información obtenida del testimonio que brinda Jonathan Borofsky en la entrevista incluida como anexo en este monográfico.

[4] Este hecho provocó el enfado de Thierry Noir, que acudió a hablar con Haring al enterarse por la prensa de lo sucedido. Haring se disculpó con él afirmando que "in New York you can get killed for that" (en Nueva York me podrías haber matado por esto) (Noir s.f.).

[5] Yasha Young posee una dilatada experiencia en el mundo del mercado del arte, siendo galerista desde 2001 a 2013, de la Strychnin Gallery con sede en Nueva York, Londres y Berlín. También ha sido comisaria de una gran número de exposiciones en grandes instituciones y cofundadora y directora del Blooom, programa de la Art Fair de Colonia.

[6] Actualmente se encuentran en la residencia Sibomania, Sara Bernabucci, Nadine Baldow, Bifidobacterias, Liviu Bulea, Faisal Hussain, Aniete Ekanem, Alexis Fidetzis, Alexandros Simopoulos y Sebastian Wandl. En la edición anterior (2018) participaron LUDO, Hera y Akut Von Herakut, WES 21 y Onur, Snik, Vendible, Louis Massai, Li-Hill, Mia Florentine White, Quintessenz, NESPOON y DOT DOT DOT (Urban Nation Museum for Urban Contemporary Art s.f.).

\section{Bibliografía}

ARMS, S., (2011). The Heritage Of Berlin Street Art And Graffiti Scene, https://www.smashingmagazine.com/2011/07/theheritage-of-berlin-street-art-and-graffiti-scene/\#comments-theheritage-of-berlin-street-art-and-graffiti-scene , [Último acceso: 30 de agosto 2019].

BERLIN MURAL FEST (s.f.). https://berlinmuralfest.de/, [Último acceso: 30 agosto 2019].

CALDAS, R., (2015). Gallery, Interpretation and Communication of Uncomfortable Heritage: the East Side, Cottbus: BT University Cottbus-Senftenberg. 
CALVOCORESSI, R., (1983). 'Zeitgeist' en el Martin-Gropius-Bau. Berlina. The Burlington Magazine, p. 120.

COUVREAUX ALIJARTE, N., (2016). La Biblia del graffitero: una teoría constructiva para la generación que tomará el relevo, Granada: Universidad de Granada.

ESCORIAL, M., (s.f.). http://www.berlinamateurs.com/desapariciondel-graffiti-de-blu-en-berlin/, [Último acceso: 30 agosto 2019].

FIGUEROA SAAVEDRA, F., (2014). El grafiti de firma: Un recorrido histórico-social por el grafiti de ayer y hoy. Madrid: Minobitia.

GARZÓN, D., (2013). El Muro de Berlín. Final de una época histórica. Madrid: Marcial Pons. Ediciones de Historia.

HATCH KINGDOM, (s.f.). http://hatchkingdom.com/, [Último acceso: 30 agosto 2019].

HEINSOHN, B., (2015). Critical Voices from Underground: Street Art and Urban Art Transformation in Berlin. En: Envisioning Social Justice in Contemporary German Culture. Rochester: Camden House, pp. 119-141.

ICOM, (s.f.). https://icom.museum/es/actividades/normas-ydirectrices/definicion-del-museo/, [Último acceso: 10 agosto 2019].

JAKOB, K., (2017). Street Art in Berlin: Version 8.0. Berlín: Jaron Verlag $\mathrm{GmbH}$.

KÜNSTLERINITIATIVE EAST SIDE GALLERY, (2013). http://www. eastsidegallery-berlin.de/, [Último acceso: agosto 2019].

KÜNSTLERINITIATIVE EAST SIDE GALLERY, (s.f.). http://www. eastsidegallery-berlin.com/ [Último acceso: 23 agosto 2019].

KIMVALL, J., (2015). The Rise, Fall, and Aftermath of the Berlin Wall Graffiti. En: G-Word: Virtuosity and Violation, Negotiating and Transforming Graffiti. Arsta: Dokument Press, pp. 81-104.

LE GRAND JEU, (s.f.). https://www.legrandj.eu/veso portfolio/ marthacooperlibrary/ [Último acceso: 28 agosto 2019].

PUYOL, A., (2014). Del desafío pictórico a la generación de un símbolo: Thierry Noir, pionero de la acción artística sobre el Muro de Berlín. Asociación Aragonesa de Críticos de Arte, Issue 28.

MAS, A., (2018). https://www.eldiario.es/cultura/arte/East-SideGallery-Berlin-gentrificacion_0_845865702.html, [Último acceso: agosto 2019].

NGBK, A. D. L. G., (1986). https://archiv.ngbk.de/projekte/ stadtsichten-berlin-new-york-exchange-i/ [Último acceso: 15 agosto 2019].

NOIR, T., (s.f.). https://thierrynoir.com/berlin-wall/photo-history/ [Último acceso: 20 agosto 2019].
PINTO, S., (2015). The wall is dead, short live graffiti and street art! Graffiti, street art and the Berlin Wall's heritage. Lisboa, Authors and Editors, pp. 62-72.

PUBLIC DELIVERY, (s.f.). https://publicdelivery.org/keith-haringberlin-wall/, [Último acceso: 15 agosto 2019].

PUGH, E., (2015). Graffiti and the Critical Power of Urban Space: Gordon Matta-Clark's Made in America and Keith Haring's Berlin Wall Mural. The Art/History Resistance. Special issue, 18(2), pp. 1-15.

STAHL, J., (2009). Graffiti und andere Kunst an der / mit der / über die / neben der / Berliner Mauer., https://www.burg-halle.de/ jstahl/ texte/mauer09.html, [último acceso: agosto 2019].

STIFTUNG PREUßISCHER KULTURBESITZ, (s.f.). http://www. preussischer-kulturbesitz.de/ueber-uns.html, [Último acceso: 10 agosto 2019].

STREETARTBLN, (s.f.). https://www.streetartbln.com/heat-wave-inberlin-it-gets-hotter/, [Último acceso: 30 agosto 2019].

URBAN NATION MUSEUM FOR URBAN CONTEMPORARY ART, (s.f.). https://urban-nation.com/, [Último acceso: agosto 2019].

\section{Autor/es}

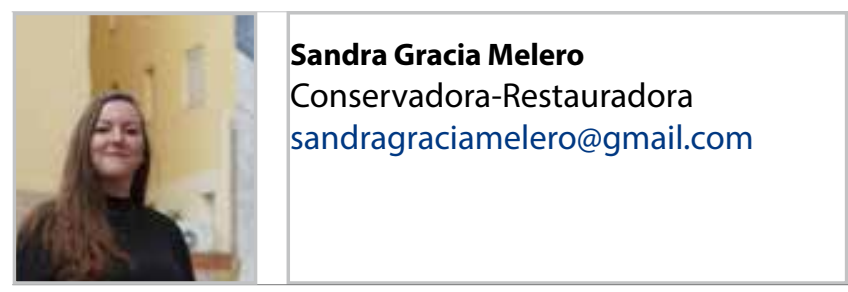

Titulada en Conservación Restauración de Bienes Culturales por la Escuela Superior de Conservación y Restauración de Bienes Culturales de Aragón, realiza una estancia en la Scuola di Belle Arti Lorenzo en Viterbo (Italia). Graduada en Historia del Arte por la Universidad de Zaragoza, realiza prácticas en el IAACC Pablo Serrano. Máster en Estudios Avanzados en Historia del Arte, con estancia de investigación en técnicas pictóricas de arte contemporáneo italiano en Roma. Presenta y publica los resultados de dicha investigación en las II Jornadas de Jóvenes Investigadores de Aragón. Vicepresidenta de la Asociación de Alumnos y Ex-alumnos de la ESCRBCA (ACYRA), desde la que organiza cursos y conferencias. Integrante del equipo de Arte Urbano del Grupo Español del International Institute for Conservation of Historic and Artistic Works (GEIIC) desde 2017. Obtiene una beca de Gestión Cultural en la Sede del Instituto Cervantes de Madrid en 2019, colaborando en la organización de exposiciones multidisciplinares y en la celebración de jornadas y ciclos de conferencias científicas e históricas de los diferentes centros del IC del mundo. Desde 2011 ejerce como conservadora restauradora por cuenta propia y ajena. 

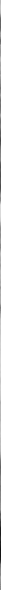

\title{
Identidad e imagen de la ciudad contemporánea: los museos de arte urbano
}

\author{
Laura Luque Rodrigo
}

Resumen: Como indica la Unesco, somos identidad, entre otras cosas, porque somos memoria. Con frecuencia identificamos la identidad con el monumento, con lo antiguo, pero, ¿qué pasa con lo contemporáneo? Es evidente que buena parte de la sociedad, aún en el siglo $\mathrm{XXI}$, no se identifica con el arte de los últimos siglos. A pesar de ello, el arte que está en la calle genera reacciones en la sociedad. Algunos problemas de la ciudad contemporánea han generado soluciones institucionales, ciudadanas y artísticas como la creación de museos. El arte urbano, en muchos casos se ha convertido en el eje vertebrador de estas propuestas que pretenden dotar a las ciudades históricas de una imagen renovada, más actual, de cara al turismo e incluso con el objetivo de crear nuevas identidades para la población local. ¿Tienen realmente este efecto en las ciudades? ¿Consiguen implicar a la ciudadanía? ¿Generan ciudades más resilientes?

Palabras clave: arte urbano, arte público, identidad, museos, ciudad, contemporáneo, arte actual, graffiti

\section{Identity and image of the contemporary city: the urban art museums}

Abstract: As Unesco indicates, we are identity, among other things, because we are memory. We identify the term identity frequently with the monument, with the old heritage, but what about the contemporary? It is evident that a good part of society, even in the 21 st century, does not identify with the art of the last centuries. Despite this, the art that is on the street generates reactions in society. Some problems of the contemporary city have generated institutional, citizen and artistic solutions such as the creation of museums. Street Art, in many cases, has become the backbone of these proposals that aim to provide historic cities with a renewed, more up-to-date image for tourism and even create new identities for the local population. Do they really have this effect in the cities? Do they get to involve citizens? Do they generate more resilient cities?.

Key words: urban art, public art, identity, museums, city, contemporary, current art, graffiti

\section{Introducción: objetivos, metodología y fuentes de la investigación}

Este estudio tiene como objetivo analizar hasta qué punto el arte urbano -sin entrar a valorar si el término es adecuado o no, ya que no es el objetivo de este texto-, crea identidad en la población y, sobre todo, cómo participan de ello los museos que están apareciendo en Europa, dedicados al arte urbano. Se pretende conocer si sus objetivos están relacionados con la población local o con el turismo y si tienen que ver con la identidad de la ciudadanía o con la idea institucional de crear una imagen renovada de las urbes. Para ello, se han empleado desde textos científicos y normativas internacionales, al método de la entrevista. Además, se han usado otros recursos hemerográficos y se han empleado las redes sociales como forma de conocer la opinión de al menos, una parte de la ciudadanía. No se trata de un texto del que se pueda extraer una solución definitiva, sino que abre un debate y aporta datos para ello, tanto cuantitativos como cualitativos.

\section{Imagen e identidad: conceptos}

"La identidad supone un reconocimiento y apropiación de la memoria histórica, del pasado. Un pasado que 
puede ser reconstruido o reinventado, pero que es conocido y apropiado por todos" (Molano, 2007: 84).

El concepto de identidad, asociado a nuestro patrimonio histórico-artístico, ha sido definido por la UNESCO como algo relacionado con la memoria, que comienza a forjarse desde el propio nacimiento y que no solo se asocia a lo inmóvil (González Sáez, s.f.). Si leemos la definición que la RAE (Web) proporciona para identidad, conseguiremos entender en conjunto el concepto: "2. $f$. Conjunto de rasgos propios de un individuo o de una colectividad que los caracterizan frente a los demás. 3. f. Conciencia que una persona tiene de ser ella misma y distinta a las demás". Por tanto, la identidad es algo que caracteriza a una colectividad frente a las demás, al mismo tiempo que permite a cada individuo ser uno mismo. En definitiva, la identidad es aquello que nos permite ser quienes somos, y nos facilita el reconocernos como parte de un grupo. De ahí que, la UNESCO, insista en el hecho de no asociar la identidad únicamente con lo inmóvil, es decir, que este conjunto de rasgos que nos define como personas y como parte de una sociedad, no viene dado únicamente por nuestro patrimonio monumental, sino que tiene mucho que ver con lo inmaterial: nuestras peculiaridades en el habla, expresiones, gastronomía, fiestas, canciones tradicionales, etc. La globalización, en gran medida, ha homogeneizado nuestras sociedades, haciendo que en parte se pierdan o se igualen cada vez más todas estas costumbres, lo que crea en las comunidades efectos negativos, como el desarraigo. No obstante, aún hoy, quien emigra entiende perfectamente el concepto de identidad, pues cuando en un país extranjero, se escucha una expresión propia de la localidad de origen, los efectos en la persona se hacen patentes tanto en su psique como en su propio organismo. Al fin y al cabo, es la dimensión humana la que da sentido a las ciudades, no tanto sus elementos inertes. En cualquier caso, la identidad es un constructo social por lo que no es inalterable en el tiempo (Agudo Torrico, 1999: 41-42), además, no implica necesariamente homogeneidad, sino que cabe la pluriculturalidad.

Darin (2015: 15), indica que la identidad es una necesidad individual y colectiva, caracterizada por ser afectiva, cognitiva y activa. Hernando Gonzalo (2009), explica cómo la realidad en que vivimos es tan compleja, que los mecanismos que activan la identidad permiten al ser humano sobrevivir sin ser consciente de su pequeñez. Es por ello, porque la identidad implica esas funciones sensibles e inteligibles, así como la eliminación de la ansiedad de la propia existencia, que "cuando se pretende destruir una sociedad, se ataca su cultura, su estilo de vida, su identidad, es decir, se destruye su patrimonio" (Sousa Macias, 2018: 165). De ahí la importancia que la ONU, a través de la UNESCO, otorga a la protección del patrimonio, especialmente en casos de conflictos armados. Nuestra Ley del Patrimonio Histórico Español de 1985, como ya hiciera la de 1933 recoge también la necesidad de proteger el patrimonio, precisamente como manifestación de una identidad cultural.
No obstante, como ya se ha advertido, tendemos a una identidad cada vez más individualizada que implica "un correlativo aumento de la ansiedad. (...) De ahí que quepa esperar que la importancia del Patrimonio se incrementa en proporción directa a la intensificación de los rasgos de individualidad como definidores de la identidad postmoderna" (Hernando Gonzalo, 2009: 97).

Debe tenerse en cuenta además que un individuo a lo largo de su vida puede formar parte de varias comunidades (Romero de Tejada y Picatoste, 2002: 11-23), hecho que cada vez se produce más en nuestras sociedades, por lo que la identidad se vuelve un fenómeno cada vez más complejo a la vez que más necesario, para evitar el desarraigo y promover la cohesión de una sociedad heterogénea y plural, pues aunque la identidad sea una construcción social que se basa en la diferencia, en la alteridad y el contraste cultural (Marcos Arévalo, 2004: 933), debe tender cada vez más al entendimiento del otro, el respeto y la aceptación. La identidad cultural, la pertenencia al grupo, que tan necesaria es, no debe suponer el rechazo a lo diferente, sino todo lo contrario.

Por tanto, debemos preguntarnos no sólo qué papel juega nuestro patrimonio en nuestra sociedad contemporánea en cuanto a la construcción de la identidad a la par que, de valores de respeto e igualdad, sino cómo integrar las manifestaciones artísticas actuales y cómo renovar nuestros museos al respecto de las múltiples subjetividades que conforman nuestras comunidades: "Hay que entender la identidad de forma crítica, distinta de la manera en que tradicionalmente se expresa. Pensarla así permite entenderla como algo cerrado, es decir, la identidad se construye por el Otro, el espacio humano abierto desde aquí permite mostrar que es éste el que recibe al Otro, es lugar de acogida en el que se puede construir identidad" (Aguilar Rocha, 2017: 100).

\section{Ciudad contemporánea e identidad}

Nuestras ciudades están compuestas por una amalgama de acciones humanas sobre el paisaje, que se superponen en el tiempo, eliminando o manteniendo aquellos elementos que, subjetivamente, la colectividad considera susceptibles de olvidar o de conservar. Aquellos elementos que se conservan contraen un valor simbólico que puede venir dado por distintos motivos, ya sean puramente históricoartísticos, religiosos o de cualquier otro tipo. Pueden incluso, perder estos elementos sus valores iniciales, y continuar siendo reconocidos por la comunidad como elementos a conservar por su significación. Estos valores subjetivos, desarrollados ampliamente por Riegl (1903), no hacen sino definir el concepto de identidad. La colectividad convierte algunos de sus elementos en monumentos, mementos, es decir, recuerdos del pasado, otorgándoles nuevos valores que quizá, no tuvieron al ser creados. Pero ¿cómo se integran estos recuerdos en nuestras ciudades? El equipamiento de nuestras urbes se ha ido adaptando, 
junto al urbanismo, a las nuevas necesidades que presenta la sociedad actual, generando al mismo tiempo nuevos conflictos y problemas. En todo esto, se insertan los monumentos, en lo que llamamos centros históricos. Así, dentro de una misma ciudad, podemos distinguir entre ciudades históricas, concepto ampliamente definido y ciudades contemporáneas, peor definida, pero el término aparece tanto en textos científicos como en documentos internacionales como la Carta de Cracovia (2000) (Luque Rodrigo, 2018).

¿Qué sucede por tanto con los símbolos que crean identidad en las ciudades contemporáneas? Podríamos pensar que, en estas zonas, se crean nuevos símbolos, asociados obviamente a la contemporaneidad, pero no siempre sucede así, pues, en definitiva, el ser humano tiende a mirar al pasado y por tanto busca aquellos elementos que contienen el valor de la historia. Es evidente además que, a pesar de estar ya en pleno siglo $\mathrm{XXI}$, el arte contemporáneo, incluso de inicios del siglo $X X$, sigue generando rechazo en buena parte de la población, al menos conscientemente. Es decir, de forma intencionada, pocas personas se declaran identificadas con obras, especialmente plásticas, de un pasado ya no tan reciente. ¿Por qué iba una persona del siglo XXI a identificarse mejor con una obra del barroco que con una de su mismo tiempo? Posiblemente haya una cuestión educacional, y los historiadores del arte y humanistas en general, nos hayamos dedicado más a hacer entender el pasado más remoto, que nuestro propio presente. Sin duda, conocer y entender el pasado es fundamental para entender el presente y poder construir el futuro, pero si el relato termina siglos atrás, en algo se ha fallado (Luque Rodrigo, 2019).

En cualquier caso, esta tendencia disminuye en lo referente a las ciudades y su equipamiento. A fuerza de costumbre, puesto que las calles son ante todo democráticas (todo el mundo las transita) y vividas (no están hechas para ser contempladas como una escultura, sino que en ellas transcurre la vida y las relaciones personales), la arquitectura, el urbanismo, los monumentos urbanos que componen las vías, sí han logrado integrarse mejor en el imaginario colectivo: "en todas las épocas, el patrimonio arquitectónico-urbanístico está presente en la memoria colectiva, aunque sea de manera inconsciente. Referencia necesaria para la construcción de la identidad social e individual" (Venturini, 2004: 159).

Aun así, con bastante frecuencia se producen intensos debates en torno a nuevos edificios que parte de la población considera "demasiado modernos" para un lugar concreto o como no, en torno a todo lo que tienen que ver con el arte urbano, que es el tema que centra este texto. Así, con asiduidad leemos noticias que nos hacen saber que tal comunidad de vecinos se ha levantado en pie de guerra contra cierta obra colocada en sus fachadas, sea espontánea o encargada. ¿Quiere esto decir que el llamado arte urbano no genera identidad?
Antes de nada, debemos dejar claros algunos conceptos relacionados con el arte urbano, que será el término empleado en este texto para referirnos a cualquier tipo de obra situada en la calle, sea espontánea (sin permiso) o por encargo, excepto para los monumentos urbanos, que se definen como aquellos elementos escultóricos colocados por la municipalidad en plazas, parques y calles, para homenajear a algún personaje histórico generalmente, con unas características muy concretas creadas sobre todo a partir del siglo XIX. Si bien no hay consenso en el tema, ni entre los expertos ni entre los propios artistas, con frecuencia se ha venido utilizando arte urbano como un término más amplio que graffiti, puesto que incluye no sólo este tipo de creación artísticas, sino cualquiera que pueda ser realizada en el espacio urbano. Por otro lado, se ha distinguido entre graffiti (vandálico, realizado con espray, que puede ser figurativo, pero que sobre todo son tags, firmas e incluso sticking) y el muralismo, realizado con cualquier otra técnica pictórica, generalmente preparando el muro, figurativo y por encargo. Por otro parte, se viene usando el término arte público, en sustitución de arte urbano, para distinguir aquel que está realizado por encargo y el que no [1].

\section{Arte urbano y ciudadanía}

Talego (2012), explica que las nuevas generaciones de jóvenes deben identificarse con un patrimonio heredado, en el que deben reconocerse, aunque les resulten extraños, por ello, según el autor, el graffiti es un signo que les da sentido de pertenencia en las megalópolis. El autor, define el graffiti como patrimonio inmaterial y va más allá al expresar que "la oficialidad intenta incorporarlos y les ofrece murales y premios. No importa, otros grafiteros vienen detrás reformulando códigos y redefiniendo su singularidad cultural y geográfica" (Talego, 2012: 37).

En tan breve texto encontramos claves importantes, en primer lugar ¿el graffiti y por ende el arte urbano, genera identidad? y ¿en quiénes? Por otro lado, ¿qué tipo de patrimonio es? En respuesta a la primera cuestión, en las siguientes líneas se tratará de mostrar que sí es capaz de crear identidad. En cuanto a la segunda cuestión, tal vez sí debamos entender estas manifestaciones, surgidas con vocación efímera, como una manifestación inmaterial, a pesar de su materialidad, y de su artisticidad en algunos casos, si bien es una cuestión compleja ya que no aparece recogido en la legislación. Por último, el planteamiento de Talego sobre la institucionalización del graffiti es absolutamente pertinente, pues, como se planteará más adelante, al institucionalizar y musealizar estas obras, tal vez estamos provocando que pierdan esa identidad y dejen de fomentar el reconocimiento de los grupos sociales que los crean. El tipo de patrimonio en el que incluyamos al arte urbano será significativo al respecto, puesto que, en un museo dedicado a manifestaciones inmateriales, no se musealiza el producto, sino los objetos que sirven a ello, es decir, no se recrea en el museo una fiesta, sino 
que se muestran materiales u objetos que la conforman, como podrían ser farolillos, ninots, o cabezudos que ya se usaron. Igualmente, si entendemos el graffiti como patrimonio inmaterial, no se musealizarían obras, sino que se contaría su historia, se mostraría material fotográfico o videográfico, y por qué no, botes de espray. Tal vez así, lograrían identificarse con el arte urbano grupos sociales que aún no lo hacen, sin que pierda su razón de ser.

$Y$ es que, son muchos los grupos que aún muestran rechazo por el graffiti, identificándolo con vandalismo, aunque cada vez más la población parece diferenciar entre lo que considera reprobable (las firmas) y lo que considera manifestaciones artísticas (obras figurativas), -quizá la génesis del problema sea, volviendo al inicio de este texto, la supuesta mayor identificación con la figuración barroca que con la abstracción contemporánea-. No obstante, no es cuestión de este trabajo hablar del rechazo, sino de todo lo contrario. Son muchos los ejemplos de lugares que han integrado perfectamente el arte público y el muralismo como parte de sus localidades, los pueblos de Córdoba como La Victoria; Fanzara; el Barrio del Oeste de Salamanca; el Barrio de San Cristóbal de Madrid; Lisboa, etc.

Un ejemplo paradigmático sería el Muro de Berlín, convertido en un auténtico símbolo para la ciudad y que un movimiento ciudadano consiguió salvar cuando se pretendió destruir para construir un hotel en 2013 (Efe, 2013: s.p.). Todo ello institucionalizado, pero con arraigo en la población, puesto que conocen los efectos positivos de estas manifestaciones en sus localidades, tanto por atraer visitantes, como por la experiencia que viven con los artistas, que mejora no sólo la economía de la zona sino la autoestima en el conjunto de la población. Estas iniciativas consiguen lo que se ha venido a llamar por Lerner (2005), acupuntura social. No obstante, en ocasiones al partir estas iniciativas de instituciones alejadas de la sociedad, pueden generar rechazo e incluso gentrificación, como ha sucedido en cierto modo en Málaga.

Algunos ejemplos de cómo el arte urbano genera identidad, los encontramos en los siguientes casos, entre otros:

-En 2016, el mural de Boa Mistura "Porque sueño no estoy loco", pintado cuatro años antes en el marco del Festival Asalto, en Zaragoza, se disponía a ser destruido. Conscientes de que la ciudadanía zaragozana lo consideraba ya un símbolo de la ciudad, se repartieron trozos del muro, ante las largas colas que se formaron (Amatriain, 2016: s.p. / Asalto Web).

-En 2017, el cantante Raphael, contó para el videoclip de Infinitos Bailes, con la presencia del artista urbano Belin. Tanto el cantante como el artista plástico son naturales de Linares (Jaén) y son símbolos de la ciudad para su población, en un caso identificado con una generación adulta, aunque sabiendo captar la atención de los jóvenes y en el otro caso, a la inversa, representante de una generación más joven, pero con la aceptación y el cariño de los más mayores (Linares 28, 2017: s.p). [figura 1]

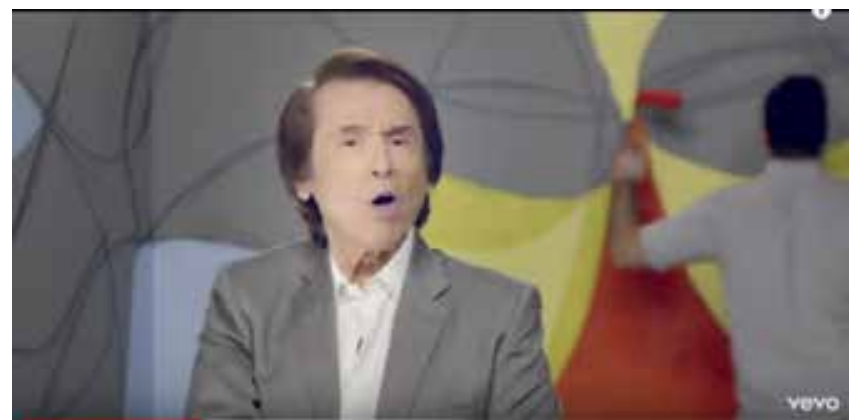

Figura 1.- Fotograma del Videoclip Infinitos Bailes, con Raphael cantando y Belin al fondo pintando. Captura de pantalla de Youtube https://www.youtube.com/watch?v=rF YiH1y0FQ

- En 2019, el cartel oficial de la Semana Santa de Málaga, presentaba un palio pasando ante un muro con un graffiti. El autor, José Antonio Jiménez Muñoz, confesaba que había hecho un cartel arriesgado que se acercaba a la realidad de Málaga, tras crear una gran polémica y el rechazo de una parte de los cofrades malagueños (Escalera, 2019: s.p.). El asunto llegó a tal punto que Diario Sur realizó una encuesta preguntando si gustaba o no el cartel, ganando el No por un $81 \%$, más de 7000 personas participaron en la encuesta (Diario Sur, Web). [figura 2]

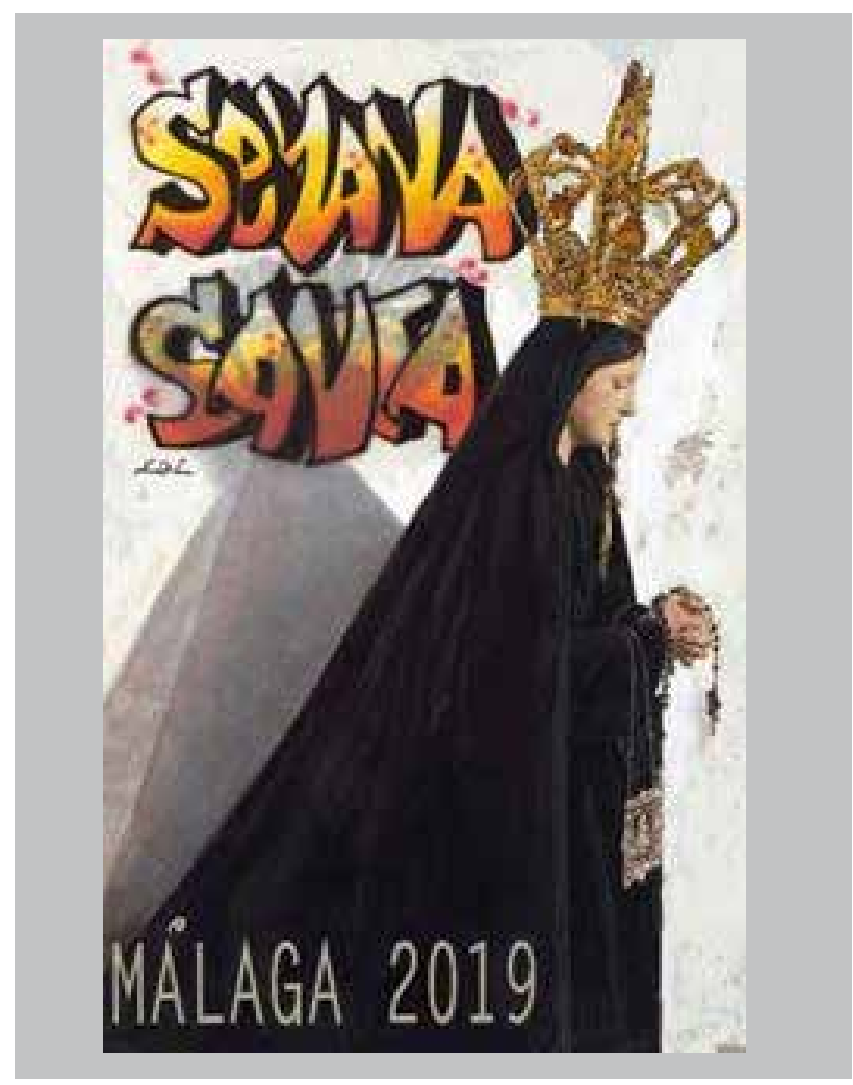

Figura 2.- Cartel de Semana Santa de Málaga 2019. Extraído del Facebook del artista https://www.facebook.com/photo.php?fbid $=813950118959791 \&$ set $=\mathrm{t} .100000891603412 \&$ type $=3 \&$ theater $]$. 
- En 2019, en un lienzo de la muralla de Córdoba, en un lugar emblemático y turístico, aparecieron unas caras, aparentemente talladas, aunque realizadas con escayola y adheridas al muro. Si bien se desconoce aún el autor, rápidamente se asoció al Hombre del Río, una obra que apareció también de forma espontánea en el Guadalquivir a su paso por la ciudad califal, en 2006, obra de Rafael Cornejo y Francisco Marcos. Como sucediera entonces, las autoridades retiraron las caras con diligencia, ante el aplauso de parte de la población, pero también ante la petición de un vasto número de personas, que reclamaban que se quedaran donde habían aparecido (Marzo, 2019: s.p.). [figura 3]
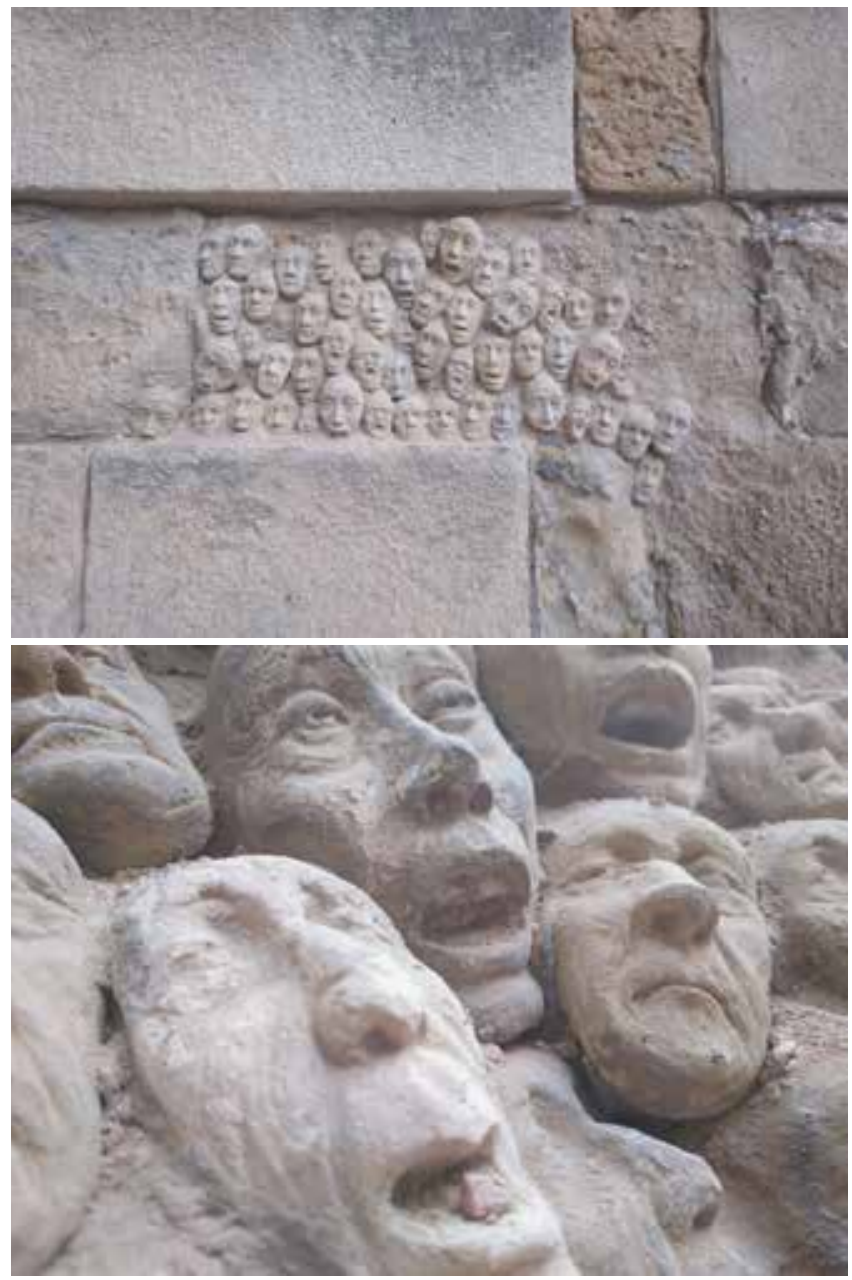

Figura 3.- Caras en la muralla de la Puerta de Almodóvar, Córdoba.

Estos ejemplos han sido elegidos porque representan cuatro formas de mostrar la identidad de un sector de la población con el arte urbano. En el primer caso, el mural de Boa Mistura se convirtió en un objeto fetiche. La ciudad pudo aceptar perder la obra, pero necesitó llevarse un trozo de él, convertirse en pequeños coleccionistas de un pedazo de algo, que quedaba descontextualizado y destruido. De alguna forma, cada persona que se llevó un trocito del muro pasaba a conformar parte de un grupo que, uniéndose, podría recuperar el todo, de manera que ese sentido de pertenencia aparece con respecto al grupo social y al mismo tiempo en relación a la propia ciudad. La apropiación del hábitat no se produce ya únicamente al pasearla y vivirla, sino al poseer parte de uno de sus elementos integradores.

En el segundo caso, el de Raphael y Belin, ambos personajes son símbolos de la ciudad que cuentan con un auténtico fenómeno fan a su alrededor. El cantante es un icono de la ciudad, que lleva su nombre por todo el mundo, lo que le ha valido no sólo el cariño de la localidad, sino contar con un museo a su persona. Por otro lado, la ciudad saca pecho y se enorgullece de ser la cuna de Belin, el graffitero al que antes multaban por actos vandálicos en los muros de Linares, ahora, como artista urbano, lleva su nombre por todo el mundo. Así, dos generaciones se unen en un vídeo y este acto se reproduce en cada concierto del artista, en las pantallas de fondo.

En tercer lugar, el caso del cartel de Semana Santa es paradigmático de una realidad. La ciudad histórica se enfrenta a la ciudad contemporánea, la tradición popular, en este caso concreto de Málaga, se ve cara a cara con la cultura institucional, en un duelo entre la identidad y la imagen. La fiesta de la Semana Santa, aunque multitudinariamente turística en ciudades como Sevilla o Málaga, sigue teniendo una gran raigambre popular, la ciudad entera se identifica con ella, no sólo por fervor religioso, sino porque es un icono, un acto social de encuentros y reencuentros, una catarsis donde vivir la calle. Sin embargo, en el caso de Málaga encontramos el contrapunto de forma muy clara, aunque no es la única ciudad española y del mundo que trabaja en estas lides, renovar la imagen de la ciudad mediante lo contemporáneo. Pero ¿se identifica la población con esa nueva imagen o es algo de cara al exterior?

Son muchas las voces críticas, incluso dentro del mundo de la cultura, por los efectos negativos que conlleva todo esto, gentrificación, turistificación, elitización del centro histórico. Así, Rogelio López Cuenca junto a Elo Vega, crearon en 2017 la iniciativa Málaga 2026, arropados por la Casa Invisible y el MNCARS, que supone una crítica al equipamiento cultural, en lo que aparece también el arte urbano institucionalizado, y que invita a pensar en otra ciudad (Málaga 2026, web). Podríamos pensar que de alguna forma, el cartel legitima estas prácticas culturales alejadas de la población local las asume ya como propias de la ciudad. El autor, Jiménez Muñoz, en diversas entrevistas, señalaba cómo pretendía acercar la Semana Santa a la realidad de la ciudad, y es cierto que los tronos pasan ante un graffiti. Sin embargo, se creó cierta polémica puesto que en los foros cofrades hubo rechazo.

Pero ¿Por qué se produce dicho rechazo? ¿Es porque la gente se opone a este modelo de ciudad? Quizá, más probablemente, sea por la eterna lucha entre tradición y modernidad. Aún parece que ambos mundos no se pueden mezclar, que durante las fiestas tradicionales 
debemos volvernos barrocos, para ser contemporáneos ya está "La Noche en Blanco", como si tuviéramos distintas personalidades a lo Dr. Jekyll y Mr. Hyde. En cualquier caso, el autor, a su vez, es muestra de otra parte de la población, aquella que ya integra ambos parámetros, que se identifica tanto con una cosa como con la otra.

Por último, el 21 de junio de 2019, aparecieron en Córdoba, más de cincuenta caras de escayola, con pigmento que simulaba el color del sillar del muro al que se adhirieron con un adhesivo bicomponente [2], a parte de la muralla situada junto a la Puerta de Almodóvar. El día 24 ya estaban siendo retiradas por el Ayuntamiento, sin embargo, durante el fin de semana que perduraron, se generó un intenso debate en las calles de la ciudad $y$ en redes sociales, donde mucha gente mostraba su indignación y rechazo, pero otro grupo de igual envergadura pedía que se dejaran, pues "les gustaba", a pesar de tratarse de un delito contra el patrimonio y el posible daño causado al muro. La noticia salió en los telediarios del día y el fenómeno fue tal que, durante esos tres días, hubo colas para realizar una fotografía a la obra e incluso, hubo personas que extrajeron algunas de las caras, arrancándolas sin cuidado.

Este acontecimiento nos deja varias lecturas. Por un lado, cómo la ciudadanía, o parte de ella, atendiendo simplemente a un criterio de gusto personal, puede identificarse rápidamente con el arte urbano, asimilado como arte actual, aunque sea ilegal. Por otro lado, la experiencia anterior del Hombre del Río, nos enseña cómo un movimiento ciudadano puede generar que una obra vandálica sobre un monumento logre su legitimidad y sea conservada por las instituciones. Además, este hecho abre el debate de la propiedad. ¿Puede la gente arrancar la obra y llevarse parte de ella sin más? ¿No sería también esto un delito? $\mathrm{O}$ ¿nos encontramos ante el hecho de que por ser un acto vandálico todo vale?
Leer las conversaciones producidas en Facebook sobre este tema, es interesante, pues había quien pedía que se quedaran y si alguien le respondía que era vandalismo, la contra respuesta era: "vale, pero me gusta, que lo dejen". El propio Diario Córdoba, en su entrada a esta red social donde copiaba el enlace a la noticia, escribía "¿Arte o vandalismo?", animando así el debate. Los alegatos en contra se centraban en el daño al monumento o incluso se dudaba de su artisticidad ("arte, dudo. Vandalismo puro"), en cuanto a los alegatos a favor, se reproducen algunos a continuación: "Para mí es arte, arte callejero del bueno. Porque me impacta, me llama la atención, me provoca y para colmo lo he sentido integrado en ese todo (...)". "Si todo lo vandálico fuera así, estaríamos llenos de obras de arte". "Un artista sin ninguna duda, sería perfecto que lo dejaran me encanta y me parece una manera de atraer más turismo un aplauso para el artista" [3] [figura 4]

Estos comentarios dan buena cuenta de distintas ideas: la relación del gusto con el aspecto sensible y la aceptación de la obra en gran medida por su integración con el entorno (una obra que no se integra con el entorno, sea por encargo o espontánea, suele producir rechazo, de ahí el éxito del arte relacional); la supuesta necesidad, en una ciudad como Córdoba, de atraer más turismo a través de más obras de arte (que generó debate en sí con respuestas como: "la muralla en sí ya es arte, el turista que quiera ver arte que se vaya al museo Julio Romero (...)" o "Córdoba ya tiene demasiado turismo, como para dejar este acto vandálico como atracción") - se genera un debate similar al malagueño-. En un lugar intermedio: quienes lo reconocían como arte, pero situado en el lugar incorrecto. Se debe señalar también un comentario que decía "Prefiero esto, antes que los grafitis", es decir, se acepta el relieve, pero se rechaza el graffiti, siendo en todo caso el mismo tipo de expresión artística, variando tan sólo los materiales, quizá porque se asocie con más frecuencia a lo vandálico el empleo de la pintura en aerosol.
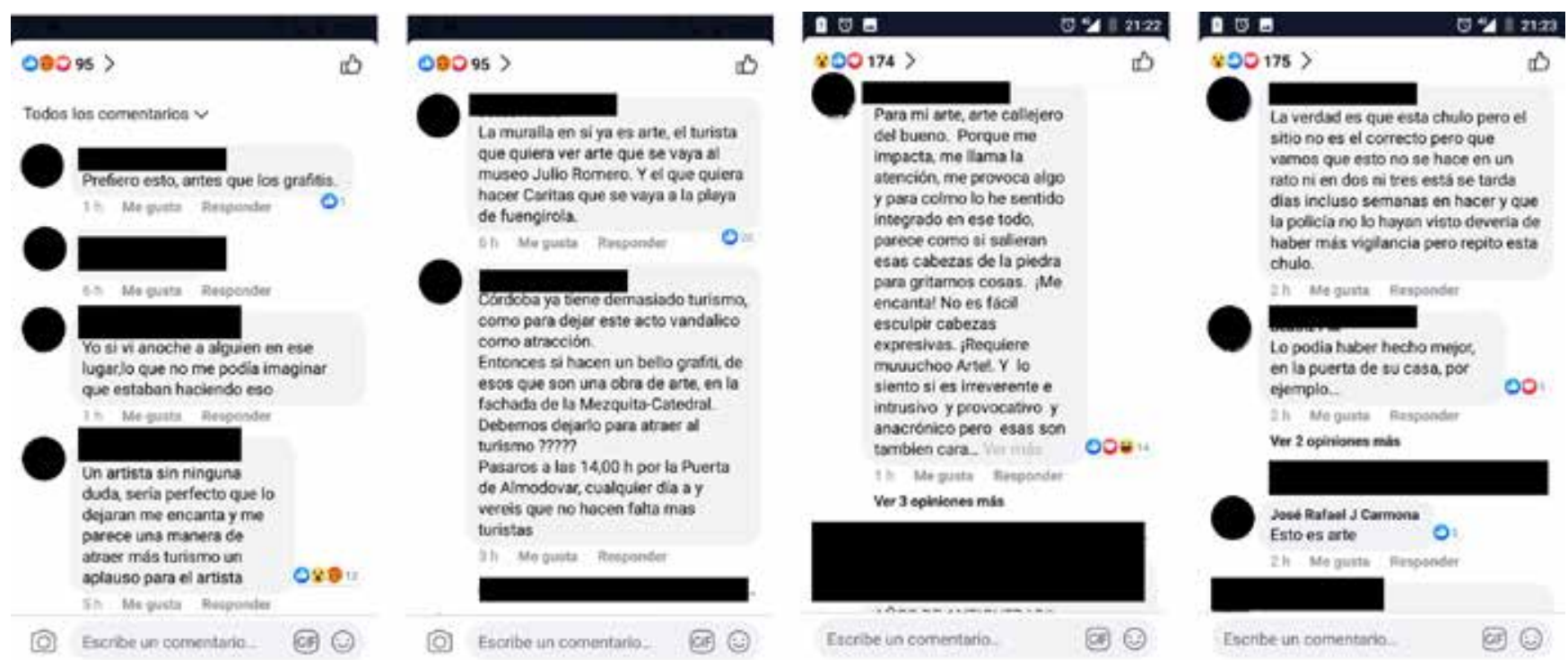

Figura 4.- Captura de pantalla del Facebook de Cordópolis y Diario Córdoba, en la entrada a la noticia sobre las caras. 
En definitiva, con estos ejemplos se puede comprobar cómo el arte urbano puede generar identidad a través de distintos procesos y medios, y dar como resultado la conservación o no de las obras, pero hay que reconocer que sí generan sentimiento de cohesión social a través del reconocimiento, aunque también el debate y muchas críticas.

\section{Museos de arte urbano ¿para quién y para qué?}

“El museo es una institución sin fines lucrativos, permanente, al servicio de la sociedad y de su desarrollo, abierta al público, que adquiere, conserva, investiga, comunica y expone el patrimonio material e inmaterial de la humanidad y su medio ambiente con fines de educación, estudio y recreo" (ICOM Web). Esta definición, ahora en revisión por el ICOM [4], contiene las funciones principales de los museos, por un lado, es fundamental su labor de conservación y por otro de comunicación. No obstante, los museos son algo más, son entidades capaces de generar identidad (Sierra Salcedo, 2016: 391), de hecho, los primeros surgen durante los nacionalismos, en busca precisamente de crear una identidad nacional, diferenciada del resto. El museo legitima, además, prácticas culturales "que en muchos casos acaban siendo desvirtuadas, simplificadas o mitificadas en exceso" (Camps, 2011: 172). ¿Estarían los museos de arte urbano, que están surgiendo en Europa en los últimos años, legitimando esta práctica artística, a la par que la desvirtúa y mitifica?

Lo cierto es que los museos, por muchos llamados "cementerios de obras de arte", no hacen sino recoger obras que se encuentran descontextualizadas, pensemos en las palas de altar, en las pinturas murales del románico en el Museo de Cataluña, y en otros tantos ejemplos. Las obras musealizadas pierden su uso original. Por lo tanto, cabría preguntarse ¿puede un museo contener arte urbano? ¿Si no está en las calles puede llamarse urbano? En cualquier caso, parece que pierden su significación original, al no estar en la calle dejan de ser obras democráticas -que serán contempladas por todo tipo de público, vaya o no a museos-, especialmente si se cobra entrada.

Al margen de esta cuestión, la realidad es que en los últimos años han surgido en ciudades como Berlín o Ámsterdam, entre otras muchas, museos de arte urbano que están logrando, al menos, éxito mediático. ¿Para quién o para qué surgen estos museos? Lo cierto es que la creación de estos espacios está vinculada a esa búsqueda del Efecto Guggenheim, crear espacios que generen una nueva imagen de las ciudades, más contemporánea, nuevos focos turísticos, la espectacularidad, a costa, en muchos casos, de la homogeneización de las ciudades y su consiguiente pérdida de identidad, pues el skyline de todas acaba siendo muy similar. No hay más que ver dónde se sitúa el MoCo, en el Museumplein de Ámsterdam, entre el Rijksmuseum y el Museo Van Gogh, es decir, en pleno núcleo turístico y museal. ¿Es esto una elitización del arte urbano o una provocación? [figura5]

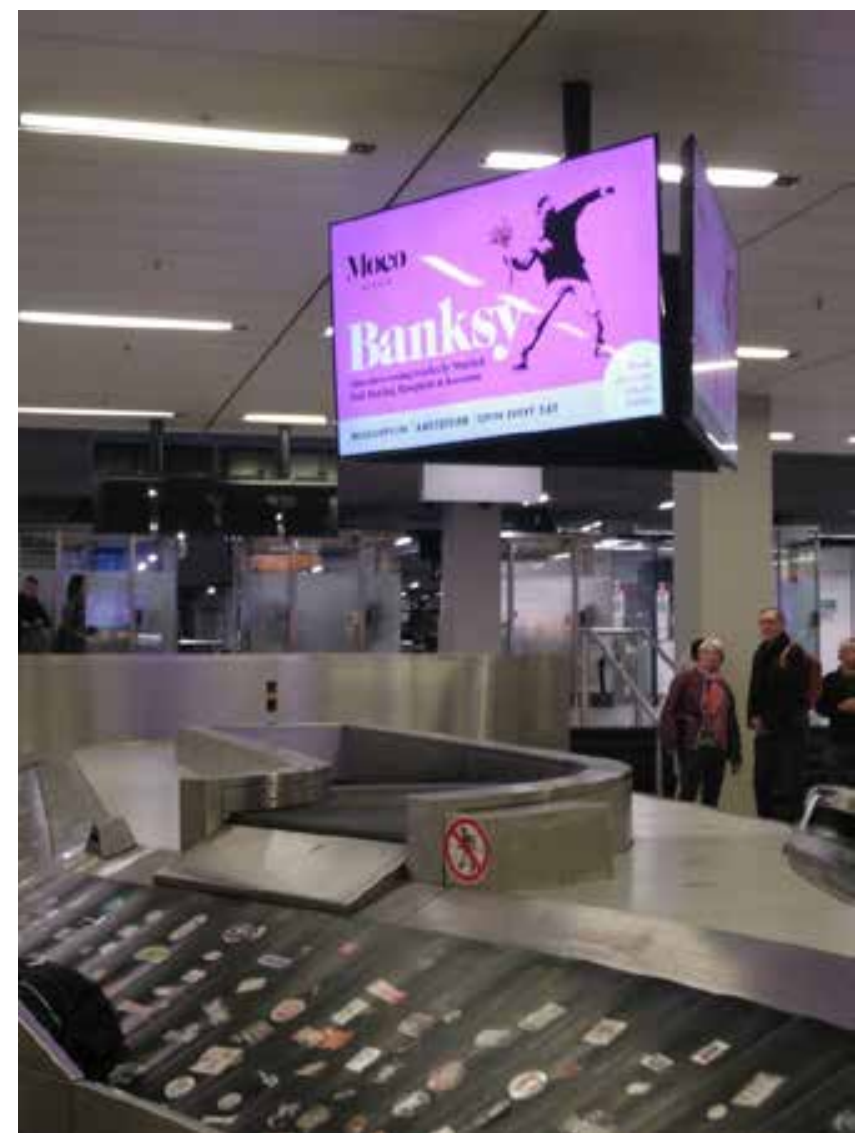

Figura 5.- Publicidad sobre el MoCo a la llegada del Aeropuerto de Ámsterdam. Enero de 2019.

¿Están por tanto estos museos creando nuevas identidades en las poblaciones? ¿O sólo crean imagen? Hay que valorar "en qué medida el desarrollo de una oferta patrimonial va a contribuir a mejorar la calidad de vida de la población" (Miró i Alaix, 1997: 34) y preguntarse ¿de quién es el patrimonio? Para Tunbridge (2006: 93) la respuesta suele ser "una cuestión de identidad cultural". Pero, puesto que "la política de patrimonio tiene impactos económicos directos (creación de empleos, generación de ingresos) e inducidos (desarrollo de sectores vinculados a la industria cultural, tales como la producción audiovisual)" (Lisocka-] aegermann, 2004: 13), puede conllevar la invención de patrimonio e identidades.

Se ha enviado a varios de estos museos una encuesta a través de Google Formularios, a la que han respondido tan sólo dos: Street Art Museum [5] Amsterdam y el MAU de Turín. Se les ha preguntado si ¿creen que su museo aporta a la ciudad algo nuevo con lo que identificarse?, a lo que ambos han respondido que sí; ¿creen que los habitantes de su ciudad sienten como propio el museo? Con un $100 \%$ de respuestas afirmativas; ¿el museo recibe más visitas de extranjeroso delocales? Ambos responden que extranjeros, lo que claramente contrasta con la respuesta anterior, pues si los habitantes se identifican con el museo y lo sienten como propio, sería lógico que la programación estuviese pensada más para un público local que extranjero y así se dejase notar en las cifras. Por ello, la siguiente pregunta era si hacen actividades para atraer a la población local, siendo 
la respuesta también afirmativa; a la pregunta ¿cree que su museo contribuye a mejorar la oferta cultural de su ciudad? También ambos respondieron que sí; ¿cree que su museo contribuye a modernizar la imagen de su ciudad al mostrarla más actual? 100\% sí; en la pregunta ¿cree que la gente se identifica con el arte urbano? Ambos creen que sí, que no prefieren el arte tradicional, si bien esta pregunta contrasta con las cifras de visitas a museos dedicados a otras etapas artísticas, por ejemplo, en Ámsterdam el MoCo recibe 404.404 visitas frente a los más de dos millones del Rijksmuseum o el Museo Van Gogh (Ámsterdam Web).

Se les preguntó también si ¿creen que puede llamarse urbano a obras de arte que se muestran dentro de un lugar cerrado? Donde se pierde la unanimidad. Esta pregunta va ligada a la siguiente ¿cree que el arte urbano, especialmente el graffiti, queda descontextualizado al sacarlo de las calles? Sin embargo, aquí el 100\% respondió que sí; por último, ¿cree que los museos de arte urbano deben estar conectados con los demás monumentos y museos de la ciudad o es preferible que se emplacen en lugares distintos para llevar la cultura a más rincones de la ciudad? La respuesta a esta pregunta en ningún caso fue afirmativa, en un caso se respondió que es indiferente y en otro que sí deben estar en un lugar diferenciado.

En cualquier caso, debe tenerse en cuenta que ambas instituciones se corresponden con los llamados "museos al aire libre", ninguno de los museos "cerrados" ha querido responder. Ambos museos están insertos en un entorno donde existía el arte urbano e implican a la gente del barrio. El Street Art Museum, señala que trabajan en documentar la escena del graffiti y destinarán actividades a la población local, al mismo tiempo que a través de su director, Peter Coolen, que trabaja el graffiti desde hace tres décadas, tienen aceptación, según señalan, dentro de la propia comunidad artística. Apuntan además que una de las formas de llevar el arte urbano al museo, pasa por contextos industriales, pues el muro blanco no funciona bien. Además, su ubicación se aleja del núcleo turístico, lo que permite dispersar la congregación de turistas.

\section{Conclusiones}

En definitiva, debemos pensar que ciertamente el "arte urbano", que genera identidad, es susceptible de ser estudiado como otras manifestaciones artísticas, en su contexto; sin embargo, su exposición es distinta, pues si pierde su función, podríamos provocar su muerte. Además, cuando se trate de artistas vivos, sin duda habría que contar con su opinión. Por otro lado, debe tenerse en cuenta que existen museos de arte urbano de distinto tipo en su propia génesis. Así, pueden estar creados por los propios artistas o comunidades o por instituciones, en cada caso funcionarán de una forma u otra y se dirigirán a un público u otro. No es lo mismo exhibir obras de artistas creadas para otro tipo de exposición, que dejar los muros para que sean intervenidos y mostrar obras arrancas dentro, sin permiso de los autores; esto no debería pasar por alto a los visitantes y la población.

Tal vez, se debería tomar nota de la exposición Arte en la Calle Madrid 2000 - 2018 (Conde Duque, Web), donde no se muestran obras, sino información sobre ellas, de manera que permite conocerlas mejor e invita a visitarlas en las calles. Otra opción sería mostrar el arte urbano, como ya se propuso anteriormente, de la manera que se construyen los museos etnológicos, manteniendo así viva la tradición, "el ser entorno protector de los objetos como trasuntos de un patrimonio vivo, sucesión de un 'continuum" (Zubiaur Carreño, 1999: 287). Según Pérez Simón (2015: 70), la identificación, hoy día, se da "cuando las comunidades empiezan a defender el patrimonio propio", es decir, que la ciudadanía se identificará con el arte urbano cuando comience a defenderlo, lo que ya ha empezado a suceder como se ha mostrado, pero no tanto por su inclusión en los circuitos artísticos. También Castaneira (2017: 1206) defiende la necesidad de la participación, pues al fin y al cabo es la sociedad "la causante de otorgar valor al patrimonio. De otra manera, esos vestigios culturales sólo serían restos carentes de historia y simbolismo".

Por todo ello, "no existiría identidad cultural sin memoria" (Cepeda Ortega, 2018: 254), es decir, es la sociedad quien debe considerar, en este caso, al arte urbano, como parte de su patrimonio, y será labor de los expertos el hacerlo entendible y activar la experiencia patrimonial (Muriel, 2018: 96). ¿Cómo realizar esa activación? Desde luego, posiblemente no pase por crear museos que buscan la espectacularidad del propio inmueble, orientado a los visitantes y mostrando obras arrancadas o que no forman parte del arte urbano como tal. Quizá la clave sea orientarse más a mostrar los procesos, la historia, los artistas locales e invitar a visitar los muros. En cualquier caso, parece un fenómeno imparable, pero no en todas las ciudades tiene que haber un museo de arte urbano, abierto o cerrado, como no tienen por qué haber una noria como la de Londres en todos los skylines. Los profesionales de la historia del arte y la conservación del patrimonio, así como otras disciplinas como la antropología o el derecho, deben trabajar como intermediarios, de manera que tanto los artistas como las sociedades sientan como propias las iniciativas relacionadas con el arte urbano, teniendo en cuenta que si la creación parte de la institución, se pierde buena parte de la propia identidad intrínseca del arte urbano y deberemos Ilamarlo arte público o muralismo.

Volviendo a las funciones del museo, debemos preguntarnos qué conservar con respecto al arte urbano ¿las obras o los procesos vivos? Si optamos por lo primero, redefiniremos la propia creación urbana arrebatándole su sentido inicial, sin embargo, optar por lo segundo podría no sólo mejorar la relación entre institución y artistas, sino también cómo comunicar esto a la sociedad, para que pueda generarse un sentimiento de pertenencia real y no impostado. 


\section{Notas}

[1]. Sobre este tema, leer el texto de Elena García Gayo en este mismo monográfico.

[2]. El día 24, durante la retirada, se pudieron comprobar dichos datos en conversaciones con la restauradora, el arquitecto municipal y el arquitecto de la Junta de Andalucía.

[3]. Es una pequeña selección de comentarios extraídos de las entradas de Facebook del Diario Córdoba sobre la noticia, entre el 22 y el 24 de junio.

[4]. En Kioto en septiembre de 2019, durante la XXV Conferencia General del ICOM, se iba a generar la nueva definición, si bien ha quedado aplazado.

[5]. El nombre oficial será anunciado dentro de poco.

\section{Bibliografía}

AGUILAR ROCHA, I.S. (2017). "La ciudad contemporánea: identidad y patrimonio". En $V$ Congreso Internacional Cidades Creativas, Janeiro: Facultade de Letras da Universidade do Porto, 97-105.

AMATRIAIN, A. (2016). "Llévate un pedazo del mural de Boa Mistura", Heraldo de Zaragoza [18 de febrero de 2016], s.p. Disponible en https://www.heraldo.es/noticias/aragon/ zaragoza/2016/02/18/festival-asalto-reparte-pedazos-del-muralboa-mistura-entre-todos-los-zaragozanos-771725-2261126.html [Consulta: 23/07/2019].

AMSTERDAM WEB. https://amsterdam.org/en/facts-and-figures. php [Consulta: 23/07/2019].

ASALTO. http://www.festivalasalto.com/adios-al-mural-de-boamistura/ [Consulta: 23/07/2019].

CAMPS, R.R. (2011). "El museo como instrumento de legitimación en la construcción de identidades", Educación Artística Revista de Investigación, 2: 170-174.

CASTANEIRA, E. (2017). "Cidade: construção identitária". En V Congreso Internacional Cidades Creativas, Janeiro: Facultade de Letras da Universidade do Porto, 1191-1208.

CEPEDA ORTEGA, J. (2018). “Una aproximación al concepto de identidad cultural a partir de experiencias: el patrimonio y la educación", Tabanque, 31: 244-262.

CONDE DUQUE WEB. https://www.condeduquemadrid.es/ actividades/exposicion-arte-en-la-calle-madrid-2000-2018 [Consulta: 24/07/2019].

DARIN, S.B. (2015). “Conservación del Patrimonio y la Identidad en la Sociedad del Conocimiento: el rol de la Universidad", Revista Publicando, 2: 3-24.
DIARIO SUR WEB. https://www.youtube.com/watch?v=rF YiH1y0FQ [Consulta: 24/07/2019].

EFE. (2013). "Las protestas masivas evitan que un constructor alemán tire partes del muro de Berlín", $A B C$ [4 de marzo de 2013], s.p. Disponible en https://www.abc.es/internacional/20130304/abciconstructor-muro-berlin-renuncia-protestas-201303040930. html [Consulta: 24/07/2019].

ESCALERA, A. (2019). "No he hecho el cartel para que guste a todo el mundo; he huido de lo manido", Diario Sur [12 de enero de 2019], s.p. Disponible en: https://www.diariosur.es/semanasanta/cartel-guste-mundo-20190112233154-nt.html [Consulta: 23/07/2019].

GONZÁLEZ SÁEZ, O.J. (s.f.). "La formación de la identidad cultural. Una mirada desde una escuela asociada a la UNESCO", http://www.unesco.org/new/fileadmin/MULTIMEDIA/FIELD/ Havana/pdf/laformaciondelaidentidadcultura.pdf [Consulta: 22/07/2019].

HERNANDO GONZALO, A. (2009). "'EI Patrimonio: entre la memoria y la identidad de la Modernidad", PH 70: 88-97.

ICOM Web. https://icom.museum/es/actividades/normas-ydirectrices/definicion-del-museo/[Consulta: 24/07/2019].

LERNER, J. (2005). Acupuntura Urbana. Barcelona: Institut d'Arquitectura Avançada de Catalunya.

LINARES 28. (2017). "Raphael y Belin se unen gracias a los 'Infinitos Bailes"', Linares 28 [3 de junio de 2017], s.p. Disponible en https:// www.linares28.es/2017/06/03/raphael-belin-se-unen-graciaslos-infinitos-bailes/ [Consulta: 22/07/2019].

LISOCKA-JAEGERMANN, B. (2004). "Patrimonio cultural, identidad y territorio: problemas de investigación", Espacio y desarrollo, 16: 9-25.

LUQUE RODRIGO, L. (2018). "La ciudad contemporánea: problemas y tendencias. Perspectivas institucionales, sociales y artísticas", SÉMATA, Ciencias Sociais e Humanidades, 30: 377-398.

LUQUE RODRIGO, L. (2019). "Reflexiones sobre arte urbano y educación: de lo académico a lo colectivo", Mural Street Art Conservation, 8: 7-9. Observatorio de Arte Urbano

MÁLAGA 2026. http://malaga2026.net/[Consulta: 24/07/2019].

MARCOS ARÉVALO, J. (2004). "La tradición, el patrimonio y la identidad", Revista de estudios extremeños, 3: 925-956.

MARZO, I. (2019). "Buscan al autor de las caras de la Puerta de Almodóvar", Diario Córdoba [22 de junio de 2016]: s.p. Disponible en https://www.diariocordoba.com/noticias/cordobalocal/ buscan-autor-caras-puerta-almodovar 1308724.html [Consulta: 22/07/2019].

MIRÓ I ALAIX, M. (1997). "Interpretación, identidad y territorio. Una reflexión sobre el uso social del patrimonio", PH 18: 33-37. 
MOLANO, O.L. (2007) "Identidad cultural un concepto que evoluciona", Opera, 7: 69-84.

MURIEL, D. (2018). Identidady patrimonio. Manual (desdela sociología) para entendery gestionar el patrimonio cultural. S.C.: Lulú.

PÉREZ SIMÓN, S. (2015). “Patrimonio e identidad: una exploración de las múltiples caras del patrimonio". En Antropología e Identidad. Reflexiones interdisciplinarias sobre los procesos de construcción identitaria en el siglo XXI. Valladolid: Fundación para la Investigación y Formación en Interculturalidad y Educación para el Desarrollo: 6576.

RIEGL, A. (1903). El culto moderno a los monumentos: caracteres y origen. Ed. Madrid:Visor, 1987.

ROMERO DE TEJADA Y PICATOSTE, P. (2002). "Identidad cultural y museos. Una visión comparada", Museo, 6: 11-23.

SIERRA SALCEDO, I.A. (2016). "Museos e identidad: espacios en juego". En Deconstruir la alteridad desde la didáctica de las ciencias sociales: educar para una ciudadanía global. Las Palmas de Gran Canaria: Universidad de Las Palmas de Gran Canaria: 391-397.

SOUSA MACÍAS, C. (2018). “¿Se destruye patrimonio o identidad cultural?", PH 93: 165-166.

TALEGO, F. (2012). "Grafitis: huellas de un patrimonio inmaterial urbano", mus-A Revista de los museos de Andalucía, 13: 36-37.

TORRICO AGUDO, J. (1999). "Cultura, patrimonio etnológico e identidad", PH 29: 36-45.

TUNBRIDGE, J.E. (2006). “¿De quién es el patrimonio? Conflicto, cultura e identidad", $\mathrm{PH}$ 58: 93.

RAE. https://dle.rae.es/srv/search?m=30\&w=identidad [Consulta: 22/07/2019].

ZUBIAUR CARREÑO, F.J. (1999). “El Museo al servicio de la memoria e identidad colectivas", Cuadernos de etnología y etnografía de Navarra, 73: $281-288$.

VENTURINI, E.J. (2004). "Centros urbanos, patrimonio e identidad ciudadana en el mundo de la globalización", Estudios, 15: 157-168.

\section{Autor/es}

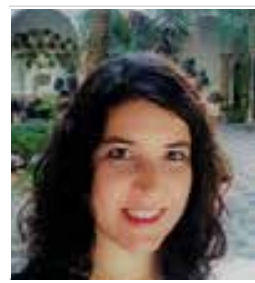

\section{Laura Luque Rodrigo}

Universidad de Jaén

Iluque@ujaen.es

Doctora en Historia del Arte por la Universidad de Jaén, es actualmente profesora en la misma universidad. Ha trabajado en inventarios artísticos institucionales. Ha participado en diversos proyectos relacionados con el arte contemporáneo, publicado múltiples artículos en revistas científicas y capítulos de libro; catálogos de exposiciones y libros. Ha participado en una treintena de congresos nacionales e internacionales, e impartido conferencias en diversas instituciones nacionales e internacionales. Realizó una estancia de investigación en la Pontificia Università Gregoriana de Roma y una estancia docente en la Universidad de Siena; recibió un premio de emprendimiento. Es miembro del comité científico de varias revistas y es miembro del Grupo de Arte Urbano ligado al GEIIC. Pertenece al grupo Arquitecto Vandelvira (HUM 573). Además ha coordinado una veintena de actividades divulgativas, como cursos, ciclos de conferencias, mesas redondas, etc 
Este baile de nombres y definiciones intenta huir del término "arte urbano" a toda costa, ya sea por encontrarlo erróneo, insuficiente o carente de valor (comercial). Del mismo modo, algunos proyectos abrazan el término arte urbano y lo integran en su discurso, como es el caso de los denominados "museos"; otros huyen de esta definición y lo relacionan con nuevos espacios y oportunidades. Los casos de los espacios como "Urban Nation Museum"(Berlín) de el "Museo de Arte Urbano Contemporáneo", futuro museo de Street Art en Ámsterdam o el nuevo Centro de Arte Urbano B-Murals en Barcelona, son los ejemplos más notables, y hacen suyo sin pudor el término arte urbano, aún no conteniendo ninguno de ellos arte urbano en absoluto, aunque sí puedan promoverlo o coleccionar obras realizadas por artistas urbanos.

Los artistas se ven frecuentemente atrapados en estas categorías que no les definen en absoluto. Las etiquetas como la de "artista urbano" son bidimensionales, planas e incapaces de mostrar la totalidad de la producción artística del sujeto.

Un cuadro pintado por un artista urbano es un cuadro pintado por un artista urbano y no una obra de arte urbano. $Y$ no hay nada de malo en ello. Del mismo modo que no hay, por lo general, seres bidimensionales y no existe una única definición, que se suele quedar corta para hablar de cualquier individuo, así, los llamados artistas urbanos escapan de las categorías únicas para hacer gala de una multidisciplinariedad elogiable. Es por ello, que el término "museo de arte urbano" en sí mismo suele ser erróneo por definición y estos centros están repletos de cuadros y obras de estudio de artistas urbanos y/o piezas robadas y arrancadas del espacio público. En ambos casos, no se trata de arte urbano, ya sea por el tipo de pieza, dónde y para qué fue producida o por ser arrancada de su contexto para ser expuesta. ¿Significa eso que el arte urbano no puede ser exhibido en museos o centros de arte? El arte urbano que se extrae del contexto para el que se produjo (espacio público) y se exhibe en un museo se asemeja más a la taxidermia, a la cabeza del león abatido y expuesto a la vista como trofeo. Eso no significa que no se pueda disfrutar de los otros aspectos de la producción de un artista. Que no se pueda valorar la producción de estudio, cuadros, instalaciones, etc. de estos mismos artistas, pero no se pueden reconocer en su totalidad y se tendrá una visión parcial, con una de sus líneas de trabajo, sin la que se desarrolla en el espacio público. Guste o no, estos artistas llevan años moviéndose entre la calle, el estudio, los centros de exhibición y venta de arte. A los consumidores, gestores y comisarios, les toca empezar a presentar a estos artistas en su totalidad y hacerles tomar el lugar que tienen y la denominación correcta de cada una de sus facetas. Apoyar, para mostrar y promover el disfrute de todos los aspectos que conforman la producción del artista, debería ser una prioridad. Valorar a un artista solamente por su trabajo en el espacio público es despreciar el resto de su producción y discurso para caer en un elitismo cultural, que también existe en el arte urbano.

\section{Entre la calle y el centro de arte: Proyecto $12+1$}

En Junio de 2015 se inicia el proyecto $12+1$ en Sant Feliu de Llobregat y unos meses después lo haría en L'Hospitalet de Llobregat. Actualmente también se realiza en Barcelona y Sant Vicenç dels Horts. El proyecto $12+1$, que nace con la idea de mostrar las diferentes facetas de artistas jóvenes y en su mayoría considerados "urbanos" y cómo se mueven, entre la calle, el estudio y los centros expositivos. Cuenta entre sus filas con escritores de grafiti, ilustradores, diseñadores, artistas visuales y un sinfín de corrientes, técnicas y estilos. Aun así, al desarrollar parcialmente su trabajo en el espacio público, todos ellos son catalogados (erróneamente) dentro del arte urbano.

El proyecto fue diseñado no sólo para mostrar varias facetas del trabajo de los artistas si no que se abordó de una manera no invasiva con el entorno y abrazando la efimeridad de este tipo de intervenciones murales. Para llevarlo a cabo, que no se necesitaban muros sobre los que realizar murales con los que mostrar a los artistas. Solo era necesario contar con un solo espacio en el que cada artista pudiera intervenir. Un muro en el que crear una nueva obra, cada vez, eliminando así la anterior de manera continuada. Esto permite un comisariado y el beneplácito de la administración sobre el proyecto (que no supervisa las obras). Se establece una programación estable que muestre la cantidad de corrientes artísticas que pueblan las calles hoy en día. Cada edición tiene una duración a largo plazo, varios meses, y cuenta con varios participantes. Se cierra con una exposición colectiva en un centro de exposiciones cercano al muro que ha servido de soporte durante todo el año.

Esta metodología es especialmente relevante en el espacio de L'Hospitalet de Llobregat, donde se sitúa el km2 más densamente poblado de Europa (Longás,2019) en un entorno degradado en vías de ser gentrificado, debido a la apertura de la nueva línea de Metro que va al aeropuerto de Barcelona.

Es un proyecto que se autolimita y permite intervenir el espacio sin colonizarlo y mediante el arte, actuando en una zona en riesgo y generando, a su vez, una programación cultural estable que era esperada por vecinos y artistas, para usar el espacio en idénticas condiciones para todos ellos [4] [figuras1 y 2].

Es en la segunda parte del proyecto en la que se centra el presente análisis y en cómo sucede la transición de estos artistas al Centre d'Art Tecla Sala en Hospitalet de Llobregat al final de cada edición.

Este centro se sitúa a escasos 150 metros de la zona donde están los murales y el equipamiento artístico de referencia. Con programa educativo propio, cuenta con cientos de metros para realizar exposiciones y con el capital humano y el presupuesto necesario. 


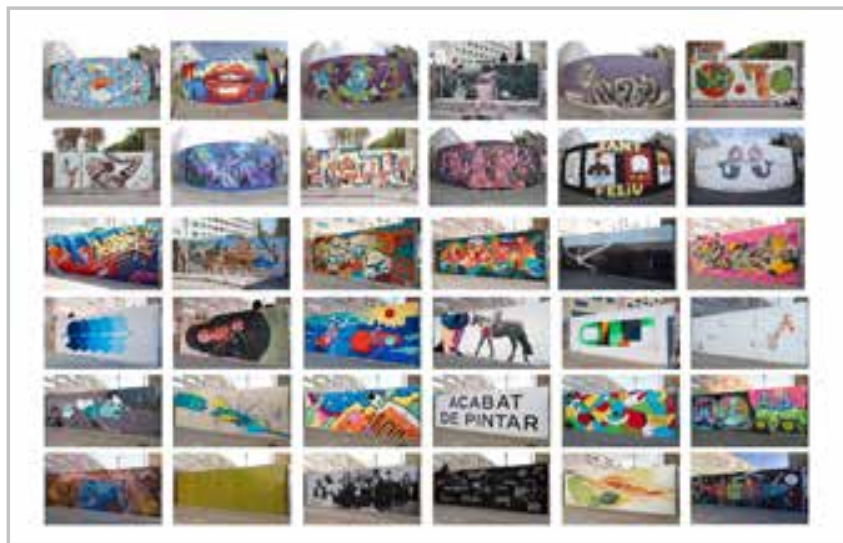

Figura 1.- Murales del proyecto $12+1$ Sant Feliu de Llobregat. 2015-2018. Foto: Alex Miró]

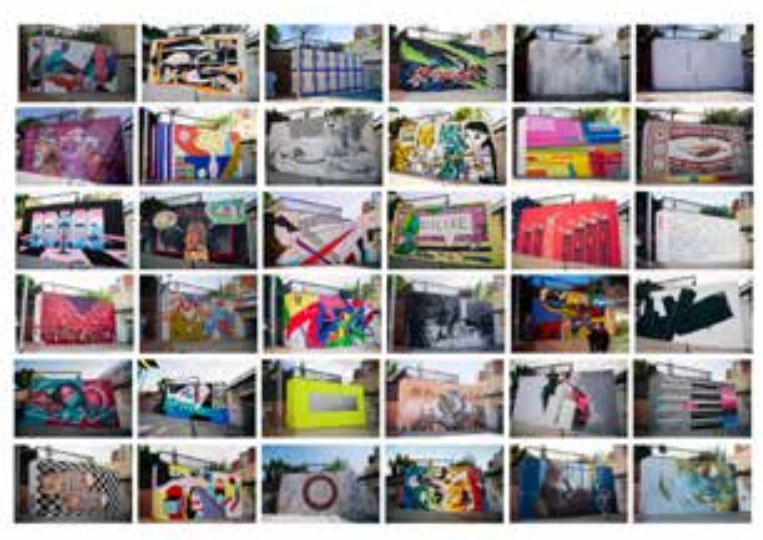

Figura 2.- Murales del proyecto $12+1$ L'Hospitalet de Llobregat 2015-2018. Foto: Clara Antón]

El Centro de Arte Contemporáneo Tecla Sala cuenta con una programación estable y de calidad, pero que prácticamente ningún vecino visita. Con una población superior a las 150.000 personas, pese a ser gratuito, el centro no supera habitualmente los 5 visitantes diarios si se excluyen las visitas concertadas con escuelas de la ciudad. Esta desconexión absoluta con el entorno que rodea al centro, a pesar de tener una programación de calidad, aunque esté anticuada, tiene una dirección artística en la que raramente se cuenta con exposiciones individuales con artistas que no sean contemporáneos, catalanes, hombres y mayores de cincuenta años [5]. Esto suponía un reto al que enfrentarse, al proponer que precisamente ese era el espacio idóneo para exponer los proyecto. Desde el inicio se creyó firmemente, que si no había representación de estas nuevas corrientes artísticas en el centro se debía proponer un proyecto que lo ayudase a avanzar en esa dirección para explorar nuevos caminos y reencontrarse con una ciudadanía más interesada en este tipo de exposiciones [6].

Muchos de los participantes del proyecto demostraban una dilatada carrera y han realizado exposiciones y murales por todo el mundo gozando de reconocimiento y apreciación. Artistas como Cinta Vidal, Medianeras Murales, Sue975, Etnik, Zurik o Mohammed L'Ghacham, han participado en estas exposiciones con un total de noventa y seis artistas locales e internacionales.

\section{Sucesión de pasos}

Se planteaban las primeras preguntas que afectan a la propia esencia de las obras. ¿Cómo se podría trasladar fielmente un proyecto de murales en el espacio público a un espacio tan elitista como es un centro de arte contemporáneo? ¿Cómo se puede trasladar la frescura y el "salirse de lo establecido" del arte urbano?

Es precisamente esa falta de rigor lo que hacía a estos artistas tan interesantes y lo que llevó a plantear la mejor manera de mostrar sus trabajos. En el caso de las exposiciones que retroalimentan este proyecto, las obras se dividieron en dos partes muy diferenciadas: una documental y otra con obra de estudio.

En la parte documental, que nunca ocupó más de un 25\% del espacio total, se mostraron textos e información para situar al público, así como las fotos de las intervenciones murales de los artistas participantes en orden cronológico. Estas fotografías estaban vinculadas a una aplicación de realidad aumentada que mostraba el vídeo individual del proceso de creación de cada una de las obras. La realidad aumentada permitía huir de las pantallas y los proyectores, así como, medir el número de reproducciones y hacer al público partícipe de la experiencia de ver al artista realizar su obra en el espacio público. Esta parte de la exposición se situó al inicio para contextualizar el proyecto, el espacio y a los artistas. [figuras 3 y 4 ]

Para la segunda parte de la exposición, se encontró una dificultad añadida. No sólo había que trasladar el carácter urbano de estos artistas a un espacio expositivo, sino que las diferentes líneas de trabajo, estilos y estéticas eran opuestas entre sí. Esto presentaba inconvenientes para encontrar un nexo común que uniera las piezas y dificultó

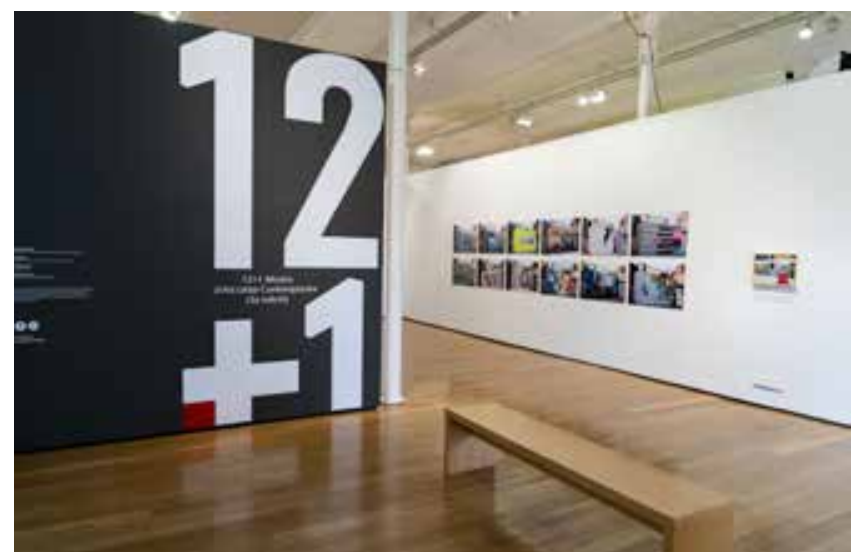

Figura 3.- Exposición 12+ Centro de Arte Tecla Sala, 2019. Foto, Clara Antón 


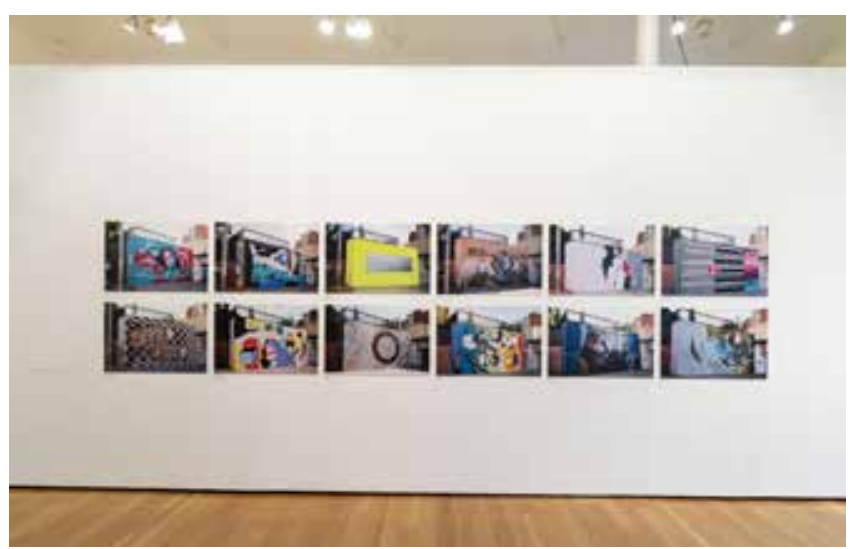

Figura 4.- Exposición 12+ Centro de Arte Tecla Sala, 2019.Foto, Clara Antón

la presentación y distribución de las obras. Tras un par de intentos fallidos, se llegó a la conclusión de que el único nexo que unía a estos artistas era un punto de vista desde el eclecticismo, porque a pesar de ser tan distintos todos eran considerados "artistas urbanos". Así que, la característica principal del proyecto fue la variedad de propuestas y el contraste que existe entre ellas, lo que las separaba, también las unía, si se situaban en un determinado orden.

Para realizar el proyecto expositivo se utilizó la metodología de la primera fase del proyecto y no se clasificaron por estilos o corrientes estéticas, sino que fueron intercalados para generar el máximo contraste posible entre ellos.

De igual modo, el desagrado manifiesto y la resistencia de los centros expositivos, ayudaron a explorar nuevas fórmulas para romper ligeramente el concepto de "caja blanca" donde se realizaba la exposición, para adaptarla a lo que los artistas querían mostrar. Esto sucedió de una forma gradual, al ir virando hacia una especie de "exposición de exposiciones" donde, al igual que en el espacio público, cada artista contaba con los mismos metros lineales y tenía total libertad para desarrollar su propuesta dentro de la propuesta general.

El criterio inicial fue mutando con el paso de los años hasta llegar a tener auténticas instalaciones, mucho más escultóricas, creadas para acompañar a las piezas de estudio. Además, estas instalaciones se diseñaron para ese espacio específico y siempre teniendo en cuenta el contexto - un centro de arte contemporáneo- y hasta a los "vecinos" de exposición.

Conforme se realizaban más exposiciones, se observó que al extrapolar algunos de los códigos de las intervenciones desde el espacio público - para adaptarse al lugar- se facilitaba también la transmisión de parte de las emociones vividas a un contexto totalmente diferente. Se transitaba por una línea intermedia en la que los artistas, para mostrar sus obras de estudio, intervienen también en el contexto, y esto se asemejaba a su manera de trabajar en la calle sin tener la necesidad de trasladar, literalmente, su trabajo pintado - un mural o una pieza de grafiti - $\mathrm{a}$ la sala de exposiciones con el consiguiente arranque. [Figuras 5 y 6 ]

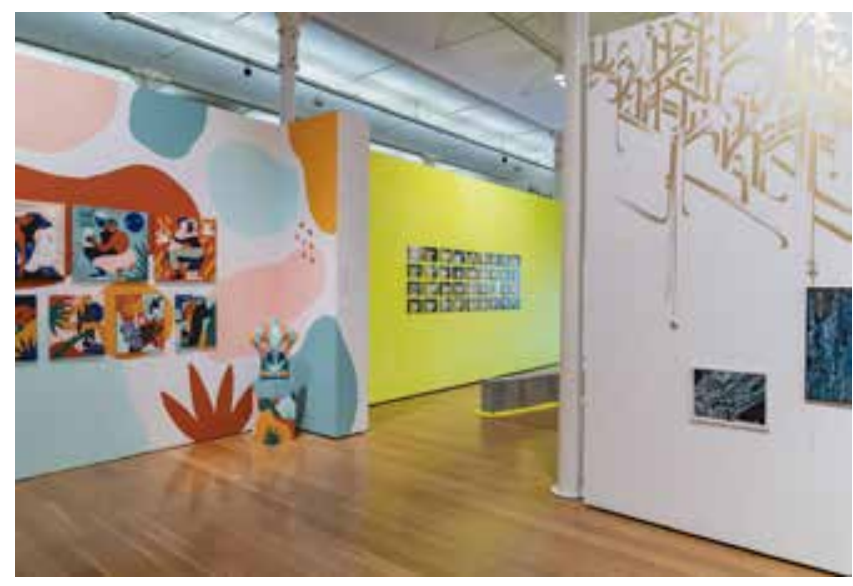

Figura 5.- Exposición $12+$ Centro de Arte Tecla Sala, 2019. Instalaciones de Perriné Honoré, Sue975 y Asu de izquierda a derecha. Foto: Clara Antón

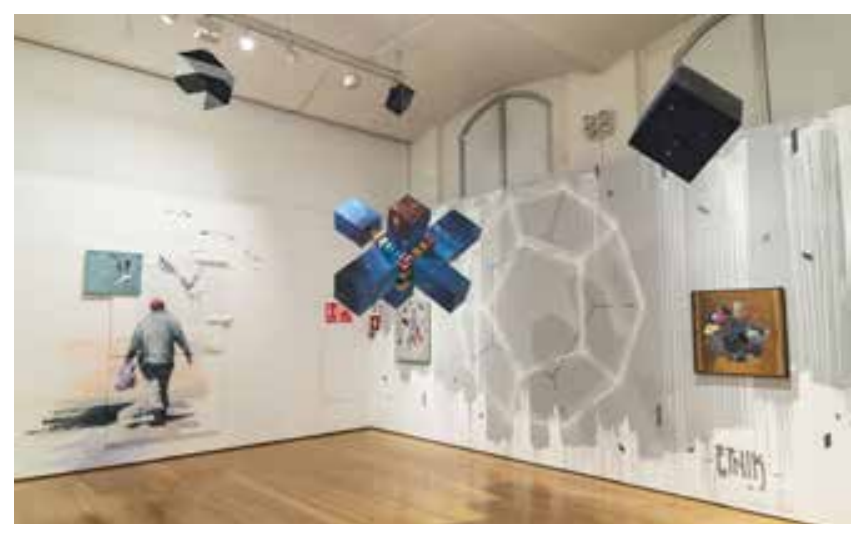

Figura 6.- Exposición 12+ Centro de Arte Tecla Sala, 2019. Instalaciones de Udane y Etnik de izquierda a Derecha. Foto: Clara Antón

Evidentemente esto es un camino que se ha ido trazando con la experiencia y que se perfecciona con cada nueva muestra, pero actualmente esta fórmula es la que mejor resultados ha dado y ha creado un alto grado de consenso entre artistas, público y la Fundación. No caer en lo redundante y fácil es sumamente complicado a veces y en este tipo de centros nadie intervenía las paredes blancas desde hacía años, si no era la primera vez.

¿Será que ante un muro en blanco es imposible resistirse? En este caso resultaba ser tan necesario que sin salirse de la línea marcada, sin manchar las paredes, habría sido mejor no hacer nada.

La posibilidad de intervenir el espacio en su totalidad se ha convertido en una condición indispensable, hasta el punto de rechazar la posibilidad de exponer en espacios municipales en los que haya que ceñirse a los muros en lanco y a los hilos de colgar. 
El resultado después de tres exposiciones en un Centro de Arte Contemporáneo es muy positivo, con una media de asistencia superior a la habitual, especialmente entre vecinos y residentes de la ciudad que, tras establecer un vínculo previo con una obra o con un artista, han querido conocer más sobre las otras facetas del autor.

\section{Murales y traslados: Mural Ciudad de las Rosas, Sant Feliu de Llobregat.}

El proyecto Kaligrafics funciona desde el año 1994 como colectivo de escritores de grafiti, no formal, y en 1999 se constituye como asociación sin ánimo de lucro. La sede de la entidad, se encuentra en el casal de jóvenes de la ciudad desde su constitución, un punto neurálgico de las actividades culturales del municipio. Como entidad, Kaligrafics es la más antigua en funcionamiento de toda Cataluña, está vinculada al "graffiti" y el hip-hop, que continúa gozando de un buen estado de salud y tiene nuevos miembros, más jóvenes que los miembros de la primera junta directiva.

\section{“Ciudad de las rosas" de Esteban Marín.}

En 2009 se realizó este gran mural institucional. Un encargo que en su momento fue un primer trabajo remunerado para el artista, con la ayuda que esto supone para poder desarrollar en el futuro más y mejores proyectos, y es un mural que no ha envejecido bien con los años. Surge de una propuesta del Ayuntamiento de Sant Feliu de Llobregat en 2008 por el derribo de un edificio que dejaría descubierta la fachada del Casal de Jóvenes de la ciudad. La idea era la de representar a través del tema elegido a la ciudad de Sant Feliu, que es conocida como la ciudad de las rosas por su tradición en el cultivo de esta flor, y que durante la guerra civil cambió su nombre a Rosas del Llobregat. Hay que tener en cuenta, que la ciudad nunca había tenido un mural de este tipo ni de estas dimensiones, por lo que se pensó en hacer algo muy característico. Esto resultó ser un acierto y llevó a la realización posterior de propuestas mucho más arriesgadas, en parte, gracias a esa primera gran obra, que fue "la ciudad de las rosas" ejecutada por varios artistas, en colaboración. [figura 7]

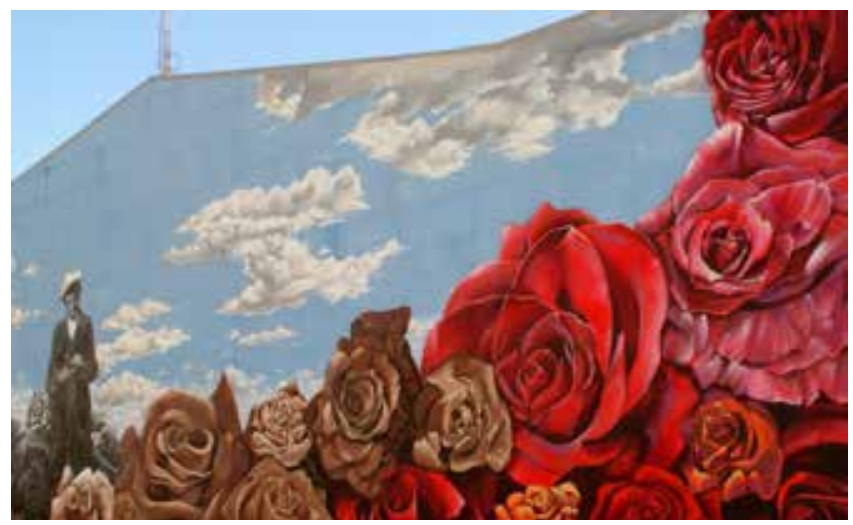

Figura 7.- Foto del mural "ciudad de las rosas"
El mural fue realizado sobre un conjunto de placas de fibrocemento instaladas en una subestructura metálica que cubría toda la fachada. Se pintó con aerosol y pintura de exterior, y con un barnizado de protección y el hecho de que no estuviese muy expuesto al sol ayudó a que se conservase en bastante buen estado durante años.

En 2016 el ayuntamiento decidió derribar el edificio para hacer un nuevo y más grande Casal de Jóvenes. Al ser un mural muy icónico y querido por la ciudad se realizó un pequeño estudio para desmontarlo y volver a instalarlo en otra localización. Esto fue posible gracias a que las placas de fibrocemento estaban unidas a la estructura con pequeños remaches fácilmente extraíbles. Aun así, durante el desmontaje alguna placa sufrió daños, especialmente durante su almacenaje y traslado al almacén municipal. El daño más común era la rotura de alguna de las esquinas al encontrarse el agujero del remache muy cercano al borde y debilitando la placa. Estas piezas tienen un tamaño máximo de dos metros de largo por sesenta centímetros de altura y son fácilmente apilables para su almacenaje. [figura 8]

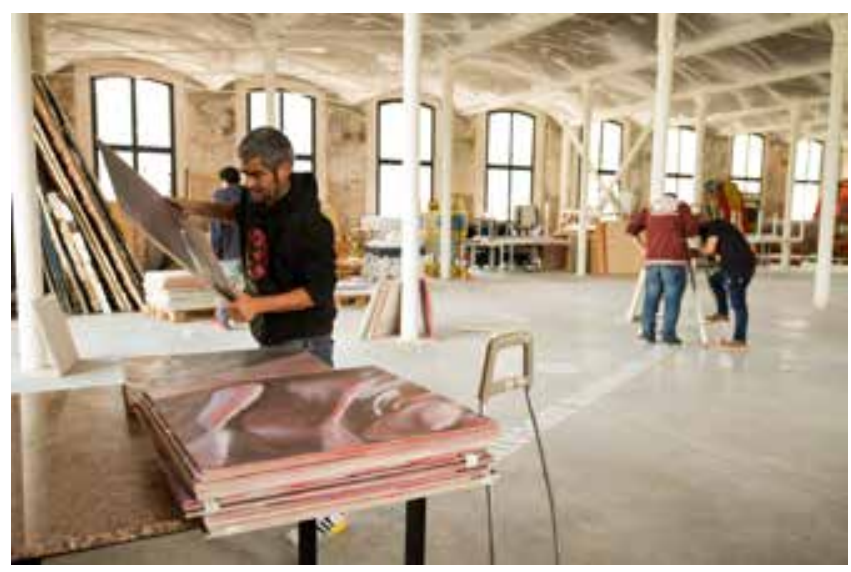

Figura 8.- Desmontaje y almacenamiento del mural. Foto, Alex Miró

En enero de 2018 uno de los autores del mural, el escritor de grafiti conocido como Treze muere a la edad de 31 años en Barcelona [7]. Algunos meses después se finaliza la construcción del nuevo edificio en el que no se dispone del mismo espacio para volver a colocar el mural, ya que la composición de la fachada ha cambiado completamente.

Durante los meses previos a la finalización del nuevo edificio se plantearon diferentes espacios para reubicar la obra, con el añadido que suponía el significado especial que le daba la muerte de uno de sus autores y debido a la presión por parte de la ciudadanía para su recuperación. Encontrar un espacio con las características adecuadas era una tarea complicada debido a la superficie de $200 \mathrm{~m}^{2}$ que tenía la obra. Se decidió colocar sólo la parte principal del mural que representaba a Pere Dot, el principal impulsor de la tradición de la rosa como imagen de la ciudad y que fue pintada por el artista Treze [8]. Pese a las reticencias iniciales de los autores - a la 
modificación de la disposición de las piezas que componen la obra - se consideró que era preferible esta solución, si ello permitía finalmente su exhibición pública. La propiedad intelectual de la obra pertenecía a los autores, pero no la propiedad del soporte que era del ayuntamiento.

Tras varias propuestas, que no conseguían consenso, la administración decidió unilateralmente su ubicación y por lo tanto su futuro. Al inaugurar el nuevo edificio saltan todas las alarmas, 8 de las placas que formaban la obra habían sido montadas y expuestas como decoración en las escaleras del edificio, sin consulta previa ni consentimiento expreso de los artistas. Al mismo tiempo, se notificó que algunas de las piezas serían utilizadas para decorar otros espacios y despachos de técnicos y políticos municipales, algo que ya había sido descartado cuando se empezaron a seleccionar las piezas. Tras la sorpresa inicial se informó de la decisión de denunciar la modificación de la obra por exponerse de forma fragmentada y sin consentimiento de los poseedores de la propiedad intelectual. Actualmente, la situación se encuentra en un punto muerto, en el que las piezas no pueden ser recolocadas sin consentimiento expreso, a riesgo de entrar en una dinámica de acciones judiciales que decidan una solución legal. Como única respuesta se ha llegado al bloqueo del proyecto por parte de la administración y a la imposibilidad de volver a colocar la parte principal del mural en homenaje a la ciudad y al autor fallecido.

Este ejemplo tan cercano ilustra bastante bien los riesgos del desmontaje y reubicación de piezas realizadas en el espacio público, muchas veces sin permiso de los autores, aunque en este caso existiera una buena predisposición por parte del artista.

La utilización por parte de las instituciones, ya sean museos privados o administraciones públicas, de este tipo de obras puede ser objeto de faltas contra la propiedad intelectual, que siempre pertenece al artista. No sólo eso, sino que, no hay que olvidar que es precisamente el riesgo de que estas obras sean arrancadas y reubicadas lo que puede dotar a esos fragmentos de un valor económico específico del que antes carecían. Poder mercantilizar y comerciar las piezas situadas en el espacio público - se realicen o no con permiso- es uno de los grandes problemas derivados de la proliferación de exposiciones en galerías, centros de arte y museos. Es evidente la dificultad para comercializar algo que no se puede vender como un producto tradicional y en el mercado, por este motivo, se observa la necesidad de encontrar soluciones de compromiso que faciliten la especulación artística y económica de esos bienes. La tendencia de llenar nuestras ciudades con intervenciones mastodónticas crea otra clase de mercado en el que el efecto revalorizador sobre ese espacio se utiliza como catalizador para reclasificar otros bienes —inmuebles — que sí pueden ser vendidos.

Probablemente muchos artistas se negarían a llevar a cabo obras desmontables si fueran conscientes de que sus fragmentos pueden llegar a ser separados sin su permiso, ya que lo que se lleva a cabo es una obra desmontable cuyos paneles por separado no tienen entidad propia como obra artística. En este caso la reubicación no se hizo de manera ilegal ni fue a parar a un museo donde se cobra entrada, pero fue una maniobra cuestionable y sin un criterio ético por parte de la administración. Ejemplos de malas prácticas, hay varios y muy mediáticos, con obras de Banksy (Chazan, 2019) o de Space Invaders (Sutton, 2017) son sobradamente conocidos. La realidad obliga a actuar con la máxima cautela en este tipo de procesos y empuja a la creación de modelos contractuales que reflejen los derechos de integridad material e intelectual de las obra.

\section{Conclusiones}

Con estos ejemplos recientes se pretende ilustrar tanto la correcta exposición de obras generadas por artistas con el perfil de "artistas urbanos", así como los peligros de la especulación y reubicación de obras que no han sido creadas para ser alejadas del espacio público, y mucho menos para ser obras decorativas y "de despacho". Ambas situaciones - exposición y reubicación de piezas- se dan cada vez con mayor frecuencia, tanto de forma acordada como ilícita y se ha convertido en una parte importante de todo lo que rodea al arte urbano y a sus movimientos derivados o paralelos.

La irrupción de las instituciones públicas en el "arte urbano" supone un riesgo altísimo y probablemente la deformación $y$, por lo tanto, la muerte de lo que ha hecho tan interesante este movimiento en las últimas décadas. Asimismo, los proyectos independientes y los artistas contribuyen a la asimilación por parte de las administraciones del arte urbano dentro de proyectos museísticos que alimentan una burbuja difícilmente sostenible y que ha dejado de ser interesante para muchos de los agentes involucrados desde sus inicios.

\section{Notas}

[1] Artmosphere, Biennale es la Bienal rusa que se celebran por primera vez en 2014 y 2016 . Actualmente ha cambiado el nombre de Bienal de Street Art por el de Bienal de Street Wave, en respuesta a la opinión de que el arte callejero pertenece a la calle y, por lo tanto, no puede ser transferido y presentado adecuadamente en un espacio como es una galería. http://2018. artmossphere.com/ [consúlta: 30/08/19]

[2] CALLELIBRE, es un festival de estética urbana que muestra y fomenta a través de intervenciones artísticas el diálogo entre el público y los artistas. Las perspectivas culturales, las opiniones personales y artísticas se expresan libremente. https://www. callelibre.at/about [consúlta:30/08/19]

[3] Urvanity art, declaración de intenciones en favor de medios expositivos a través de los que explicar propuestas urbanas 
https://urvanity-art.com/manifiesto/ [consúlta: 30/08/19]

[4] Montana world blog, L'Hospitalet ofrece más información sobre el proyecto http://www.mtn-world.com/es/blog/tag/ lhospitalet-de-Ilobregat/ [consúlta: 30/08/19]

[5] Laura L. Ruiz, 07/02/2017, “'Contorno urbano', el muro de las reivindicaciones 'street art' en Barcelona" El Asombrario. https:// elasombrario.com/contorno-urbano-street-art-barcelona/ [consúlta 03/11/19]

[6] La colaboración con la dirección del centro no resultó fácil, negándose a mostrar obra de estudio de los artistas participantes y ofreciendo como alternativa mostrar solamente las fotos de los murales pintados en el proyecto, argumentando que las obras de estudio no podían ser expuestas por "su baja calidad artística". Durante el montaje del segundo año, fueron arrancadas varias piezas de la pared dos días antes de la inauguración. El público que quería visitar la muestra era invitado a entrar por una puerta trasera. Esto es sólo un ejemplos de la resistencia ofrecida por este centro de arte contemporáneo para exponer obras de "artistas urbanos". Situaciones similares se han dado en centros de exposiciones municipales en otras localidades. La resistencia a abrir la puerta a los artistas ha sido siempre una tónica general. A pesar de las malas experiencias se han conseguido comisariar nueve exposiciones en espacios institucionales en los últimos cuatro años.

[7] Relación de exposiciones individuales en el Centro de Arte Tecla Sala desde el 2014: Joaquim Chancho, 1943. Josep Maria Alcover, 1950. Gervasio Sánchez, 1959. Jiménez Balaguer, 19282015. Margarita Andreu, 1953-2013. Jaume Pitarch, 1963. Lluís Lleó, 1961. Pepe Espaliú, 1955-1993. Jaume Pitarch, 1963. Lluís Hortalà, 1959. Eugenio Ampudia, 1958.

En las exposiciones colectivas también predominan los hombres así como en las exposiciones individuales organizadas por el festival de videoarte LOOP.

[8] Montana World Blog, 29/01/18, "La belleza de la vida, Treze para siempre" "En su silenciosa batalla de casi cuatro años contra el cáncer, Treze, exprimió su potencial viajando a gran cantidad de ciudades por todo el mundo. Una lucha ejemplar que siempre trató de llevar con discreción para no alarmar a sus allegados". https://www.mtn-world.com/es/blog/2018/01/29/the-beautyof-life-treze-forever/ [consúlta: 03/11/19]

\section{Bibliografia}

CHAZAN, D. ( 26/01/19), "Banksy painting stolen from Bataclan" Telegraph, news. https://www.telegraph.co.uk/ news/2019/01/26/banksy-painting-stolen-bataclan/ [consúlta 07/09/19]

LONGÁS, H. (27/02/16) Menos de un kilómetro cuadrado para 43.000 vecinos. El País, A fondo. https://elpais.com/ elpais/2016/02/23/media/1456224524 967983.html [consúlta 08/09/19]
SUTTON, B. (07/07/2017), “Vigilantes Posing as City Workers Steal Street Art in Paris" Hyperalergic, In brief. https://hyperallergic. com/394562/vigilantes-posing-as-city-workers-steal-street-artin-paris/ [consúlta 07/09/19]

\section{Autor/es}

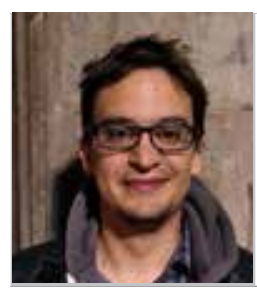

\section{Esteban Marín}

Contorno Urbano, project@contornourbano.com

Empieza a pintar graffiti en el año 2000 y se vincula al tejido asociativo del Baix Llobregat, ocupando desde entonces diferentes cargos en asociaciones de arte urbano en Sant Feliu, Cornellà y L'Hospitalet de Llobregat. El arte urbano despierta su interés para formarse como artista y realiza durante los siguientes años sus estudios en diseño gráfico e ilustración. En 2009 realiza su primer mural de gran formato y desarrolla su carrera artística. En 2015 funda el proyecto Contorno Urbano, que en 2017 se constituye como Fundación sin ánimo de lucro, en la cual ejerce de presidente y comisario desde sus inicios. 

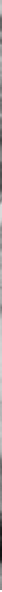

\title{
La postura del artista ante los museos de arte urbano en el contexto latinoamericano
}

\author{
Ana Lizeth Mata Delgado
}

Resumen: Cuando se utiliza el término "museo", se asume que es un lugar cuyo objetivo es conservar, investigar y difundir el patrimonio cultural representativo de una sociedad. Por lo tanto, se entiende que la función del museo es positiva. Por el contrario, cuando hablamos de "museos de arte urbano" las percepciones de su naturaleza son muy diferentes, tanto por parte de los artistas como del público. A priori, se genera una crítica sobre la relevancia de su existencia, así como su misión, visión, función de esta tipología de espacio y el efecto que tendrá en la propia creación artística. Desde la gestión de espacios museísticos enfocados y realizados ex profeso para exponer, difundir, investigar e incluso conservar el arte urbano, han surgido diversas posiciones en este sentido, ya que limitar las intervenciones urbanas en el contexto museístico es aparentemente contradictorio con el propio sentido del arte urbano, a menudo transgresor, que reivindica el espacio público en toda la extensión de la palabra. No obstante, la inclusión del mismo en estos entornos abre nuevas posibilidades para la percepción de sus formas artísticas y muestra una nueva valoración de las mismas dentro de nuevos contextos. se centra en la evolución del arte urbano en el contexto de América Latina y su traspaso a los museos. Además se expondrá la opinión de diversos artistas al respecto de la creación de museos de arte urbano, utilizando para ello la entrevista como herramienta.

Palabras clave: entrevista, opinión del artista, arte urbano, contexto, museo

\section{The artist's opinion towards street art museums inside the Latin American context}

Abstract: When the term 'museum' is used, it is assumed to be a place whose purpose is to conserve, research and disseminate the cultural heritage representative of a society. It is therefore understood that the function of the museum is positive. On the contrary, when we speak of 'street art museums' the perceptions of their nature are very different, both on the part of the artists and the public. A priori, a critique is generated about the relevance of their existence, as well as their mission, vision, function of this typology of space and the effect it will have on the artistic creation itself. From the management of museum spaces focused and created specifically to exhibit, disseminate, investigate and even conserve street art, different positions have emerged in this sense, since limiting urban interventions in the museum context is apparently contradictory with the very meaning of street art, often transgressor, which vindicates public space to the full extent of the word. However, its inclusion in these environments opens up new possibilities for the perception of its artistic forms and shows a new appreciation of them within new contexts. This article focuses on the evolution of public art in the context of Latin America, and its transfer to museums. In addition, the street artists' vision of the creation of street art museums will be presented, using an interview methodology.

Key words: Interview, artist's opinion, street art, context, museum.

\section{Introducción}

Generalmente, los museos se entienden como espacios adecuados y diseñados ex profeso para albergar patrimonio cultural y obras de arte. Por ello, la identidad y función del museo se asume de manera positiva, dado que promoverá la difusión, exhibición, investigación y conservación de las obras que conformen su colección.

En términos generales, el espacio museístico se concibe como un sitio cerrado y controlado, el cual ofrece todas las condiciones idóneas en términos medioambientales (humedad, temperatura, luz, etc.), así como respecto a la seguridad y su contexto, todo ello para la correcta conservación y difusión de los bienes que alberga permanente o temporalmente [1].

Sin embargo, cuando se trata de museos de arte urbano, el panorama y la percepción son muy distintas, tanto por los artistas como por el público. Inicialmente, al plantear el tema se genera una resistencia, una crítica sobre la pertinencia de su existencia, se discute sobre la misión, visión y función que 
tendrá el formato museo sobre las producciones artísticas urbanas, puesto que supone una descontextualización de las mismas. Al mismo tiempo, al insertarse estas creaciones en un discurso curatorial, pierden la alternativa de la transgresión del espacio público y la visión de las calles se traslada a un lugar específico.

Consecuentemente, y como se ha expuesto en varios artículos de este monográfico, la creación de espacios museísticos enfocados y diseñados para arte urbano, ha producido el surgimiento de diversas posturas al respecto. Por un lado, acotar las intervenciones urbanas en un contexto museable puede resultar contradictorio con la práctica libre, transgresora y callejera que reclama el arte público independiente. No obstante, y por otro lado, se abren nuevas posibilidades para los artistas, lo que da paso a una nueva valoración del arte en el espacio público dentro de nuevos contextos de exhibición. Esto crea un debate dual sobre los posibles efectos positivos y negativos de la musealización.

A partir de esta unión y la doble polaridad creada entre la figura del museo como contenedor de patrimonio cultural y la creación artística urbana, como arte actual independiente, este artículo tiene como objetivo analizar todos los ángulos posibles y establecer de qué manera confluyen o se contraponen las obras y las fórmulas de exhibición. Para ello, se ha considerado fundamental revisar el contexto histórico y los hechos que han generado la situación actual, y dualidad en opinión, así como conocer la opinión de los artistas en este tema, además de la postura que mantienen otros agentes relacionados con la cultura. De esta manera y previamente a exponer el proceso de la entrevista a artista y gestores, así como resultados obtenidos de la misma, a continuación se realiza una exposición histórica breve de los hechos más destacables en el entendimiento actual del arte en el espacio público en México.

\section{Revisión de los antecedentes del arte urbano en el contexto latinoamericano}

El arte urbano emerge con la intención de apropiarse de las calles, de tomar el espacio público como un foro dónde desarrollar diversas expresiones artísticas; esto le otorga el carácter transgresor y activista ante otro tipo de expresiones, de igual manera lo pone en tensión con la sociedad.

En el caso de México, una de las primeras propuestas de llevar el arte a las calles tiene sus antecedentes desde el ámbito institucional con en el Movimiento Muralista Mexicano, gestado en 1921 gracias a José Vasconcelos, Secretario de Educación Pública que promovió la creación de un nuevo arte para pueblo. Igualmente, la figura del Dr. Atl (1875-1964) es fundamental en los inicios del muralismo mexicano, pues se considera el precursor ideológico y defensor de estas nuevas expresiones artísticas. El Muralismo Mexicano fue por tanto, un movimiento artístico y social que instaba a pintarfuera de los museos, llevando el arte al espacio público a través de obras murales de grandes dimensiones, que se insertaron en la arquitectura de diversos espacios, como edificios gubernamentales, escuelas públicas y mercados, y que promovía, a su vez, el vínculo de la educación y el arte con la intención de que las temáticas de la mayoría de estas obras reflejaran una identidad nacional:

"En sus inicios, la pintura mural fue un movimiento vanguardista. El manifiesto publicado por los muralistas de 1923 pertenece a la tradición de las vanguardias occidentales. En este punto conviene distinguir las diferencias entre el muralismo mexicano y las vanguardias europeas" (Mandel, 2007:42).

Estas expresiones de Arte Público Mural dieron paso a una nueva manera de concebir el arte, tanto en términos de creación como de apropiación y arraigo por parte de la sociedad.

Con la revisión de estos antecedentes y para comprender el contexto dentro del cual se inserta la postura del artista urbano actual, es oportuno subrayar otro de los acontecimientos ocurridos en México en la segunda mitad del s. XX que dieron paso a nuevas expresiones artísticas callejeras, se trata de la "Matanza de Tlatelolco" acaecida el 2 de octubre de 1968 en la Plaza de las Tres Culturas al norte de la Ciudad de México. Este fue uno de los episodios más crueles, criticables y a su vez semillero de expresiones artísticas subversivas, vinculado a las revueltas estudiantiles acontecidas en el mismo año. Si bien este episodio no fue exclusivo de México, si lo fue en tanto el impacto que tuvo para la creación del arte público actual.

La matanza de estudiantes tuvo su antecedente meses antes en donde la policía capitalina, entonces conocida como Cuerpo de Granaderos intervino para calmar una riña estudiantil, haciéndolo con lujo de violencia y atentando contra los estudiantes. Eso derivó en una serie de marchas y manifestaciones en inicio organizadas por parte de los estudiantes de Universidad Nacional Autónoma de México (UNAM) y del Instituto Politécnico Nacional (IPN), pero este movimiento que fue creciendo no solo por parte de los estudiantes, sino por otros movimientos sociales que estaban en contra de la represión gubernamental y policial.

Para la tarde del 2 de octubre se había convocado a una nueva marcha que iniciaría en la Plaza de las Tres Culturas en Tlatelolco, en esa ocasión los soldados rodearon el sitio y los estudiantes decidieron dar por cancelada la marcha justo para evitar conatos de violencia, no obstante inició una brutal balacera en contra de los manifestantes lo que generó caos y pánico entre los asistentes. A la fecha no hay claridad cuántas personas murieron ni fueron heridas, sin embargo, ese acontecimiento marcó de manera tajante la historia contemporánea del país y de su arte.

Es interesante y fundamental comprender cómo las diversas expresiones artísticas generadas en ese momento 
y derivadas de estas manifestaciones, no tenían ninguna intención de trascender ni de conservarse, ahora son consideradas material de estudio para la historia del arte, la sociología y la política, ya que muchas de estas obras forman parte de colecciones de museos y archivos especializados generando discursos curatoriales dentro del espacio museístico. El cambio de vocación que han sufrido ha dado cuenta de la historia contemporánea mexicana y su impacto en el actual arte urbano local.

Francisco Reyes Palma, en su artículo“La resistencia blanda y la mediación como obra" (Reyes, 2004:127), se refiere a este momento de la historia mexicana describiendo esta etapa activista desarrollada durante la década de 1968:

"la euforia participativa del 68 cuando por primera vez, artistas de posturasideológicas y tendencias encontradas, en particular los militantes del realismo social y los rupturistas, actuaron de manera conjunta en un mural colectivo sobre la estructura metálica que cubría la estatua dinamitada de Miguel Alemán, en la Ciudad Universitaria, misma que este presidente edificó, con su efigie monumental como centro, antes de concluir su mandato. Lo que unificaba a los artistas era el alto grado de tozudez y autoritarismo criminal de otro presidente, Gustavo Díaz Ordaz, quien ordenó la toma, con lujo de violencia, de las instalaciones universitarias por parte del ejército que destruyó el mural. Poco después sobrevino el asesinato a mansalva de estudiantes en la Plaza de Tlatelolco" (Reyes 2004:127).

El movimiento estudiantil del '68 dio paso a una serie de creaciones artísticas tanto individuales como grupales, que a su vez dieron origen a un nuevo imaginario del arte público y generaron imágenes icónicas para el México contemporáneo, que se continúan empleando en las manifestaciones actuales debido a su iconicidad. Es la llamada gráfica del '68, conformada por consignas políticas, grabados, panfletos y folletos:

"La bayoneta, el gorila, la paloma ensangrentada, el candado en la boca, la madre atemorizada, la imagen presidencial ridiculizada y otras representaciones contra la represión fueron símbolos principales desde los primeros días de lucha" (Aquino 2011:39). Todos estos grabados son ahora considerados material de archivo fundamentales para la historia contemporánea mexicana; aunque, no en todos los casos se conservan los materiales originales, sino fotocopias, registros gráficos, fotografías y audiovisuales.

De este movimiento social nacieron también en la misma época los llamados "Grupos", diversos colectivos artísticos de participación social, cuya presencia en las calles fue objeto de una dinámica activa con perspectiva social, era en la calle donde todo pasaba, el mejor sitio para socializar a través del arte y hacer partícipe al público. Algunos de estos colectivos fueron el Grupo Suma, No Grupo, Proceso Pentágono, Tetraedro y Tepito Arte Acá; todos ellos marcaron un nuevo horizonte en la perspectiva de la intervención urbana a partir, no sólo de obras pintadas en el muro, sino de acciones diversas bajo un contexto urbano que reforzaba el significado de todo lo representado. Estos grupos "se postulaban bajo una plataforma de ideas estéticas no tradicionales o al margen del circuito establecido de producción y circulación del arte" (Espinosa y Zúñiga, 2002: 55). De cierta manera, estos "Grupos", hacían frente "al estancamiento del medio artístico de los años setenta, y asumían en la experimentación plástica un medio de aprendizaje alternativo y renovador" (Vázquez 2006: 194).

Para ejemplificar algunos casos de la apropiación de la calle y su impacto en el ámbito artístico urbano a nivel histórico es interesante revisar el caso de Tepito Arte Acá, bajo la tutela del Maestro Daniel Manrique (1939-2010), precursor del colectivo. El Mtro. Manrique fue un luchador social que desde sus inicios hasta sus últimos días siempre promovió el arte urbano libre y social, colaborando de la mano de la gente de su barrio no solo creando obras, sino generando espacios para la producción artística urbana.

"Mi nombre es Daniel Manrique Arias, pertenezco a la comunidad del barrio de Tepito y soy iniciador del movimiento 'Arte-Acá' pintando murales en la calle, o lo que ahora se llama arte urbano. Chance y se acuerde un cacho de nosotros, pues a usted fue al que primero le llegamos con este cuete [2], y nos dijo que era muy importante el planteamiento que hacíamos, sobre todo por la importancia que encierra en cuanto a la trascendencia de la cultura popular, y que nos deseaba la mejor de las suertes y que tambor [3] lo hiciéramos hasta sus últimas consecuencias, ¿cuáles serán?... quién sabe, pero el movimiento 'Arte Acá' continúa, 'ái la llevamos." [4].

Por su parte, Tepito Arte Acá, fue uno de los grupos más prolíficos y conocidos en la escena urbana, primordialmente en el centro de la Ciudad de México, y cuyo trabajo ha sido reconocido a nivel mundial; de hecho, actualmente se están generando diversos proyectos de difusión y conservación de las obras de este grupo.

"Tepito Arte Acá, fundado por Daniel Manrique y Francisco Zenteno Bujaidar en 1973 había establecido un fuerte vínculo con organizaciones vecinales del barrio céntrico de la Ciudad de México. Había mucha cercanía en el trabajo de Arte Acá con el espíritu que animaba a los colectivos chicanos que por esa época trabajaban el tema de la identidad en comunidades marginales del sur de los Estados Unidos (aunque habría que señalar que el contacto directo de los artistas mexicanos con los chicanos por aquellos años fue excepcional)" (Vázquez 2007:194).

El vínculo del arte en la calle con la gente es un recurso para la interiorización de este tipo de expresiones callejeras, como expone García:

"Los collages, los ready made, el arte en la calle, el arte ecológico urbano, los murales y carteles son algunos de los caminos explorados para trascender la soledad elitista del arte por el arte" (García, 1979:20). 
Al contemplar casos como este, se entiende que estas manifestaciones de arte en el espacio público no tendrían sentido dentro de un contexto arquitectónico museístico, pues al eliminar su contexto, desaparece aquello que le da sentido y perspectiva al barrio mismo [figuras 1 y 2 ].

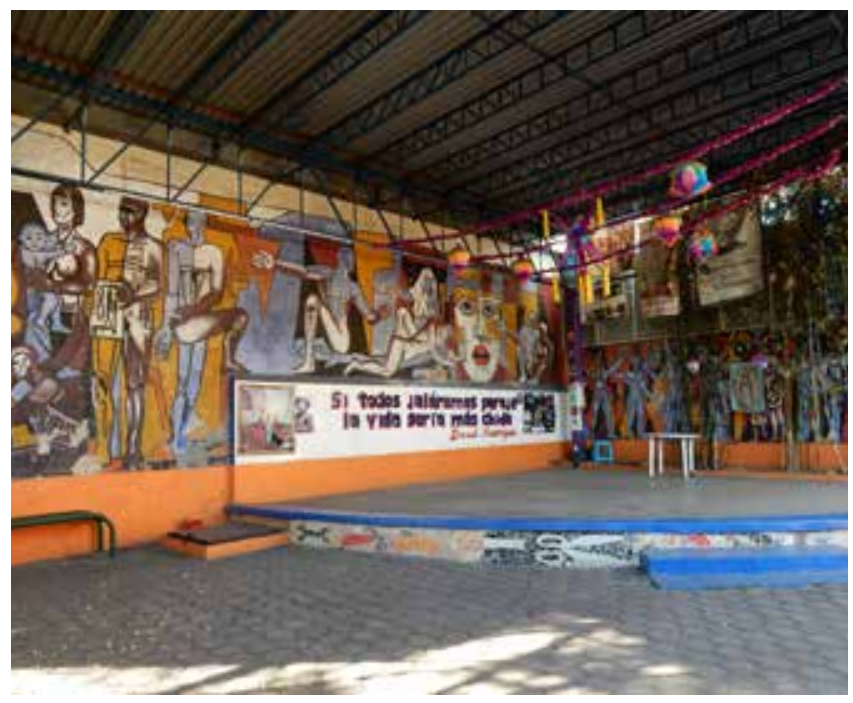

Figura 1.- Martes de arte, Tepito Arte Acá.

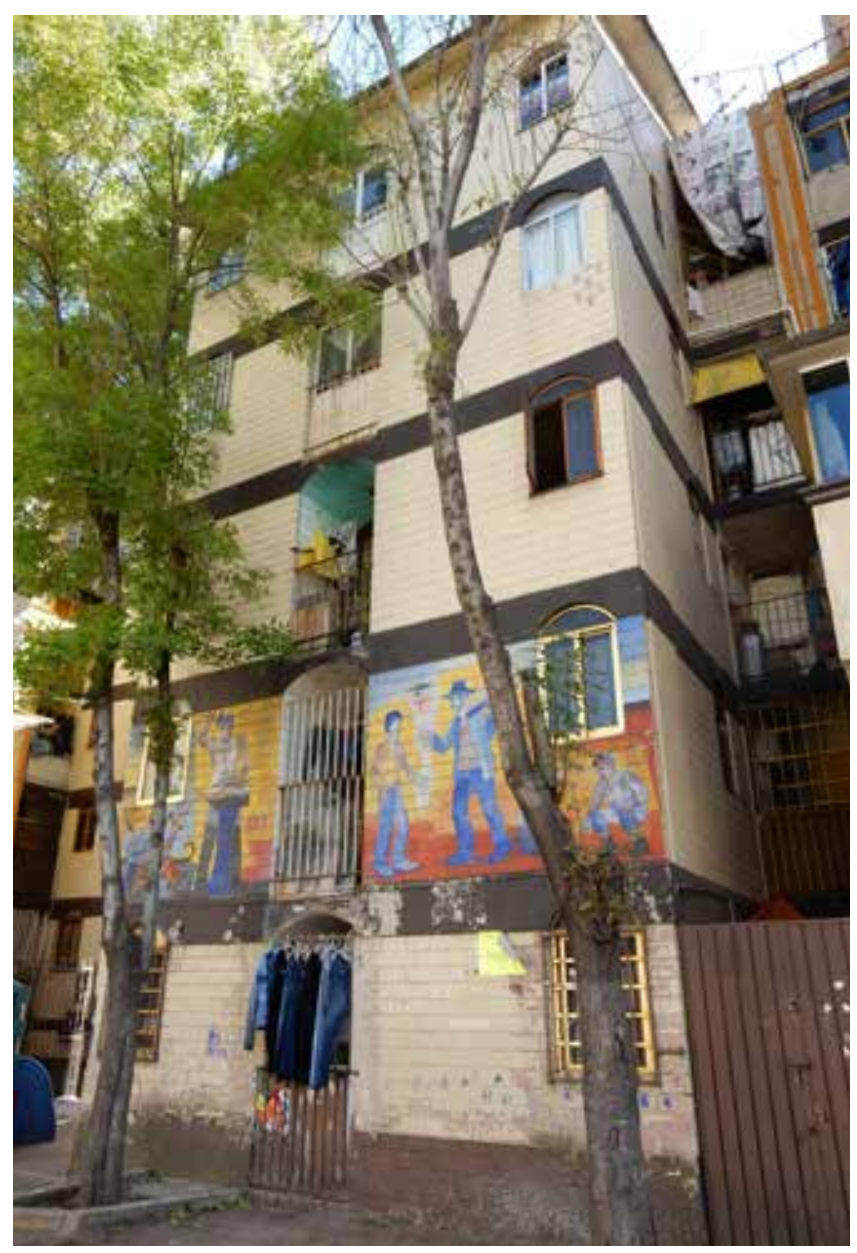

Figura 2.- Los oficios, Tepito Arte Acá
En la Ciudad de México, el contexto de la década de los noventa planteó una manera distinta de establecer la práctica del Arte Público.

"[...] en varios puntos de la ciudad, se pintaron varias bardas lo que causó curiosidad en los jóvenes principalmente y asombro en los adultos con respecto a la belleza que este arte callejero podía manifestar" (Fajardo 2018:36).

\section{¿A cielo abierto o en cubo blanco?}

Como se ha comentado en el apartado anterior, aun no se ha logrado un consenso universal sobre si es viable musealizar el arte urbano y las motivaciones que derivan en ello, por tanto es importante contemplar diversas opiniones al respecto.

"Llegar a un concepto único es muy complejo, cada quien va construyendo una idea de los trabajos fijados y abandonados en la urbe, según su propia experiencia. hay un punto de coincidencia y es su carácter extrainstitucional e ilegal, ya que la mayoría lo hace fuera de la ley. En general, hay una percepción de que el arte en la calle busca tener un contacto directamente con la sociedad y ofrece otras alternativas a los museos, galerías y demás espacios establecidos del arte" (Montessoro 2016:55 y 57).

Esta reflexión de Montessoro, es interesante dado que plantea al arte urbano como la alternativa a los museos y/o galerías, es un arte para y por la calle. Es importante por tanto, comprender la relación que se establece entre el espectador y la obra, y a su vez, cómo cambia la manera en que se vinculan si se encuentran en el contexto del museo, en vez de en la calle, a fin de ser congruentes en la manera en que el arte urbano se tendría que exhibir, si se llegara a esa conclusión. Por tanto, el tipo de museo que ha emergido en los últimos años, ha puesto en tensión el binomio arte urbano-calle.

Es imprescindible estudiar los diversos contextos en los que se desarrollan este tipo de iniciativas museísticas, y curatoriales, y es importante analizar qué le da sentido a estos museos y a las obras expuestas. Aunque actualmente en diversas partes del mundo el término museos de arte urbano proliferan cada vez más, es necesario comprender y analizar el discurso que manejan y la manera en que se plantea su misión y cuál es su visión social. De esa larga lista que se ha generado sobre museos de arte urbano, son muy pocos los que se sitúan en el contexto latinoamericano, por el momento, solo el Museo de Valparaíso, de Chile, tiene la connotación de "museo" [figuras 3, 4, 5].

Es importante mencionar que existen zonas y ciudades con amplia trayectoria y vocación por el arte urbano; por ejemplo, en México este arte ha tenido una gran recepción y si bien en todos los estados del país se producen este tipo de expresiones, existen ciudades que destacan en el tema, por mencionar algunas: Tijuana, Ciudad Juárez, Guadalajara, Monterrey, Oaxaca, Campeche, Playa del Carmen y 
evidentemente la Ciudad de México [figuras 6 y 7]. Pero, ¿se les podría aplicar a estas zonas el término de "Museos a Cielo Abierto"? Dicho concepto designa aquellos sitios de la ciudad donde el arte forma parte del espacio urbano, por lo que podría relacionarse en cierta manera con una integración plástica, aunque no se trata sólo de integrar lo plástico con la arquitectura, sino con la ciudad misma. Incluso hay espacios en los que el público local o visitante puede recurrir a mapas y guías que lo lleven por la ciudad, descubriendo los espacios intervenidos por los artistas [figura 8].
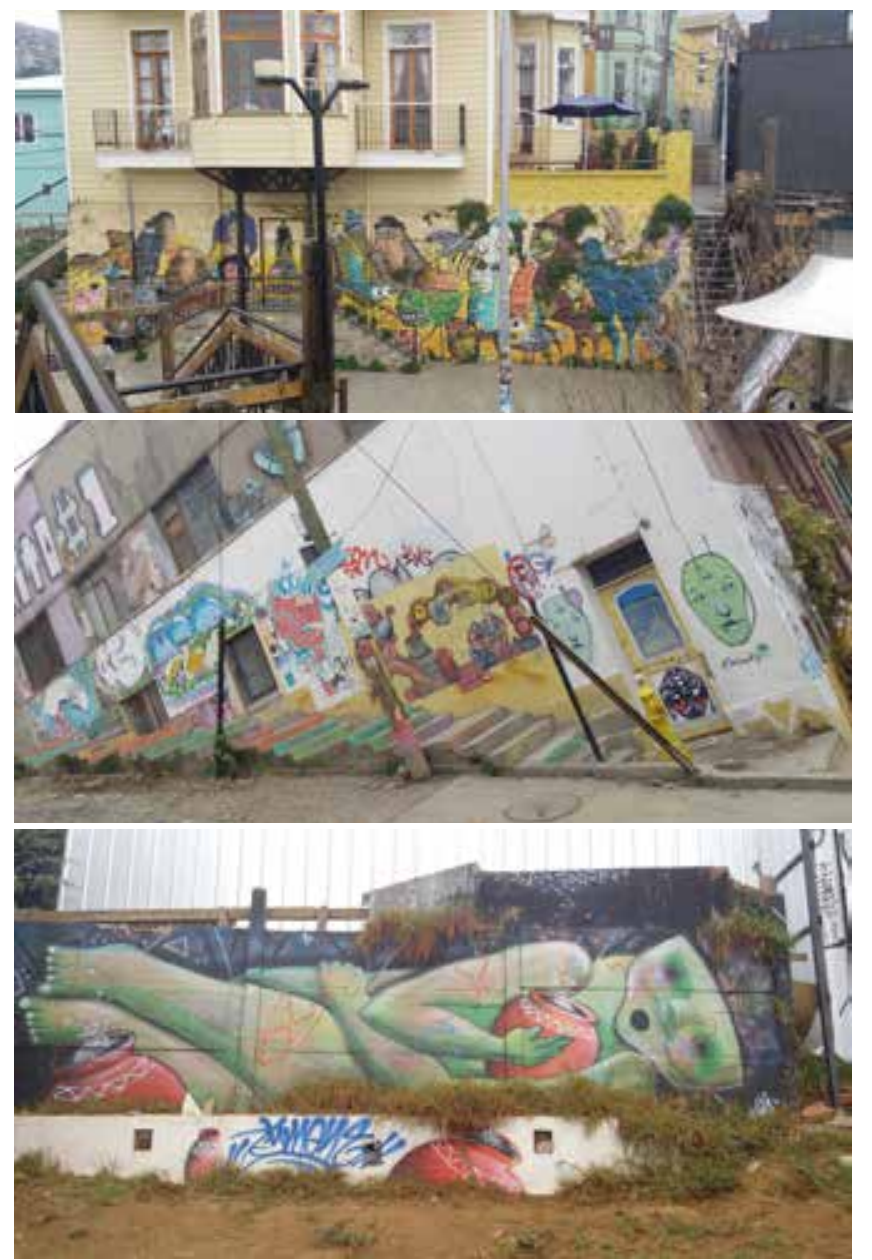

Figuras 3, 4, 5.- Museo a cielo abierto de Valparaíso, Chile.

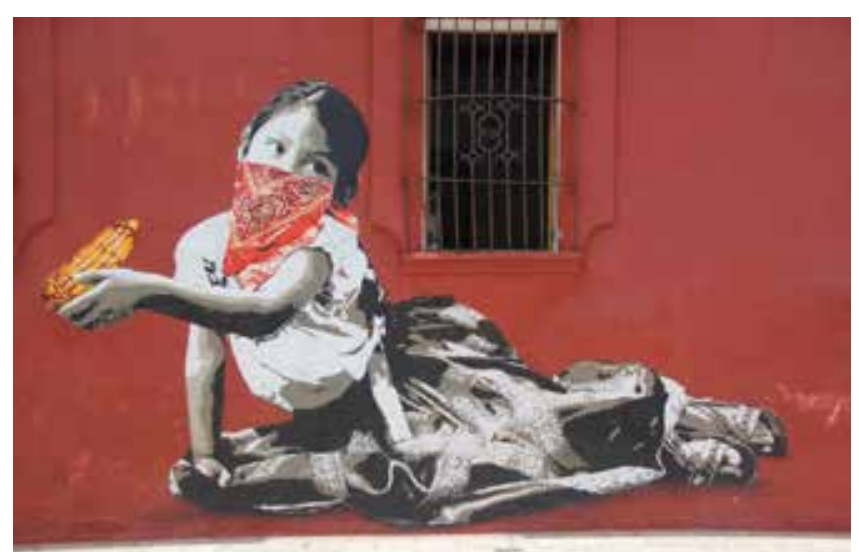

Figura 6.- Arte urbano de Lapiztola, Oaxaca México. Fotografía Yareli Jáidar Benavides

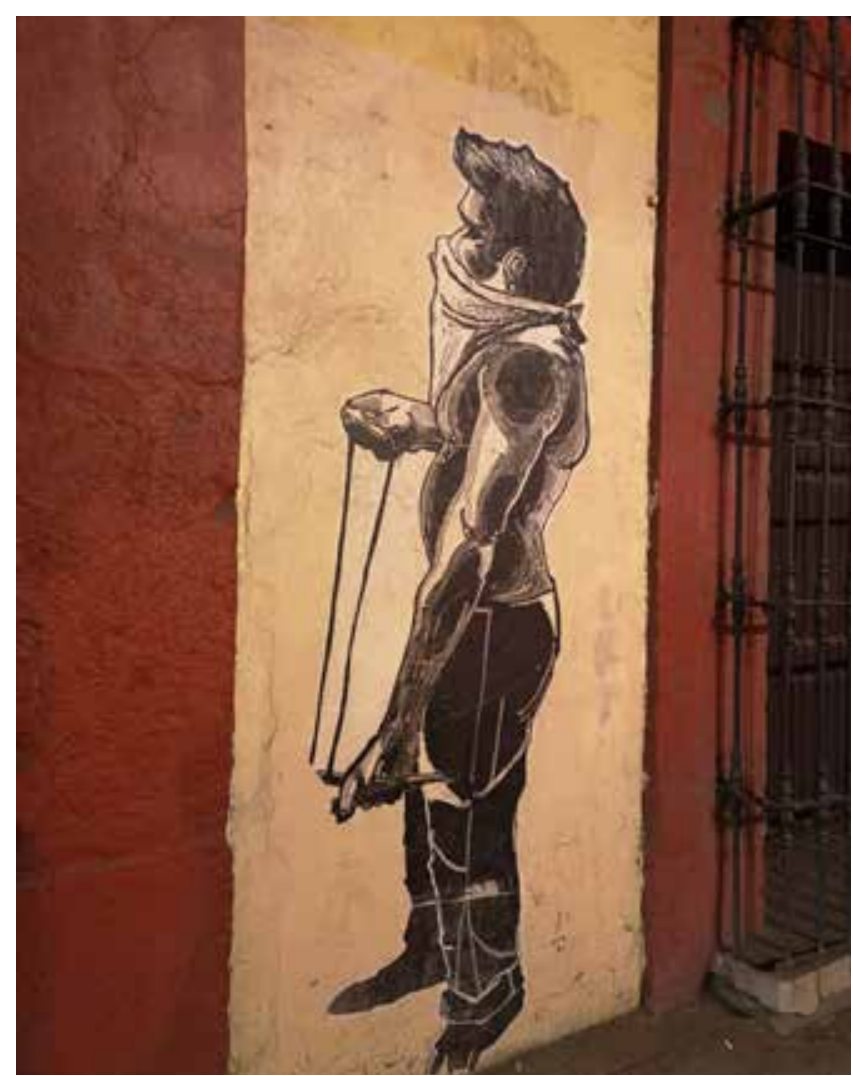

Figura 7.- Arte urbano oaxaqueño, Oaxaca México.

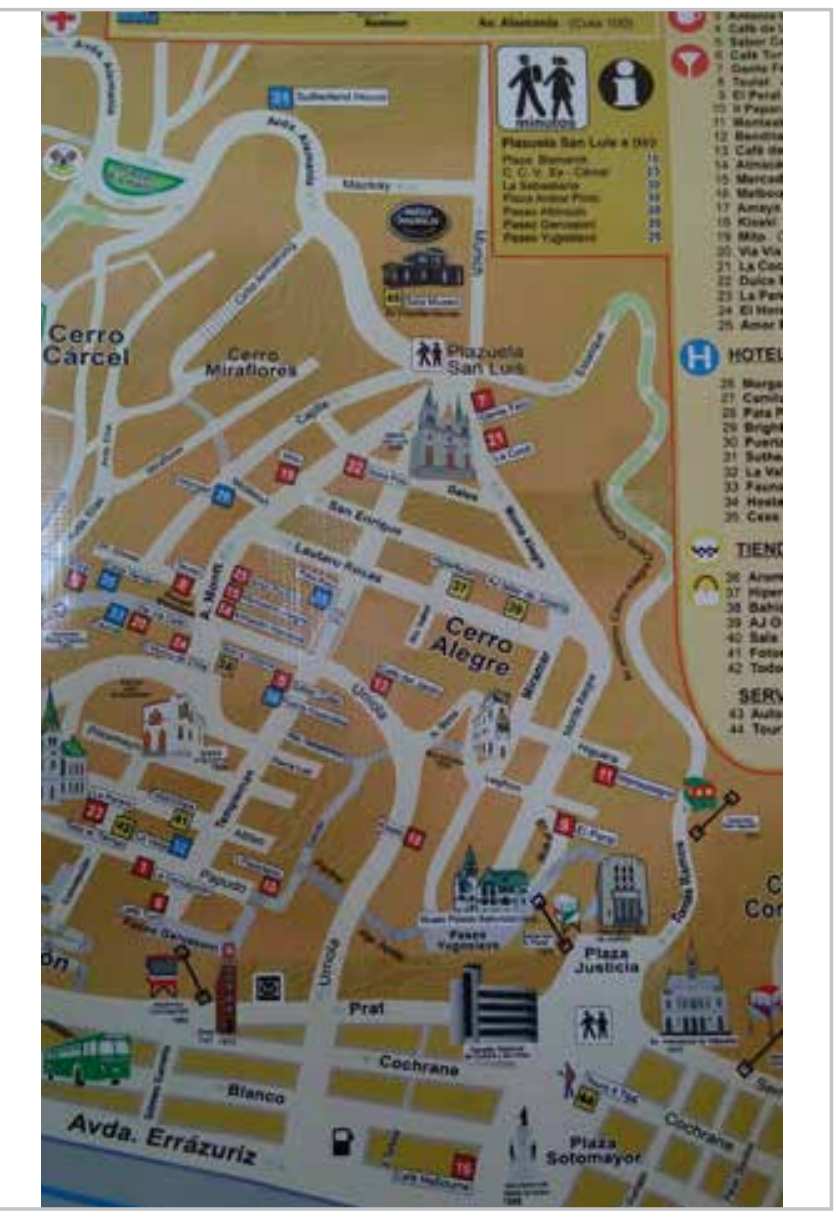

Figura 8.- Mapa que muestra la ubicación del Cerro Alegre de Valparaíso, Chile. 
Estos espacios, los llamados "Museos a Cielo Abierto", contemplan dentro de sus objetivos y dinámicas de interacción, el contexto, el espacio, la comunidad y primordialmente al espectador que visitará y caminará el espacio urbano en donde se insertan las obras. Si bien, en inicio toda la producción artística urbana que se encuentre en las ciudades podría considerarse un museo a cielo abierto, es verdad que requiere tener un discurso curatorial o al menos una guía, acorde a las propuestas artísticas realizadas por los artistas, para poder llamarse "museo", inclusive aunque en algunos casos pudieron incluir el diálogo con los habitantes de las ciudades o barrios donde se llevó a cabo la obra.

\section{La entrevista a artistas urbanos: metodología y formatos}

La entrevista es una herramienta fundamental para recolectar información de manera directa, y en la conservación de arte contemporáneo, es una alternativa sustantiva para adentrarse en la comprensión de las obras. Como expone Mikel Rotaeche:

“Una herramienta irreemplazable para poder completar esta investigación, previa a cualquier intervención, es la entrevista a los artistas. [...] A diferencia del arte tradicional, en el arte contemporáneo se puede recurrir a la fuente más fiable de información sobre los materiales y las técnicas usadas en la creación de una obra, es decir, el artista o en su defecto a sus asistentes" (Rotaeche 2011:178).

De manera similar, la entrevista se puede aplicar al arte urbano, ya que en muchas ocasiones estas permiten acceder a información que no está explicitada en la bibliografía o es carente en otras fuentes documentales.

Existen diversos modelos de entrevistas, cada uno con diversas características dependiendo del contexto, el tipo de obra, la accesibilidad al artista, entre otros; lo que a su vez deriva en diversos modelos para desarrollarla, sin embargo, el más básico y accesible es sin duda el cuestionario:

“El antecedente más claro de la entrevista como herramienta de trabajo es el cuestionario técnico. Este tipo de cuestionario, que iba dirigido al artista, era una relación de preguntas sobre materiales, técnicas pictóricas o escultóricas y modo de exposición de las obras de arte. Las respuestas eran consideradas como una fuente documental de información técnica" (Rotaeche 2011:179).

Para esta investigación y con el objetivo de acceder directamente a la opinión de los creadores, se empleó una metodología basada en el diálogo, con cuestiones enfocadas a recabar y sistematizar sus posturas frente a las posibilidades de estos nuevos espacios de exhibición de reciente creación y que cada vez están más extendidos en el contexto internacional.
Los artistas entrevistados hasta el momento para esta investigación se encuentran dentro del contexto de la América Latina, principalmente México y Colombia. Sin embargo, se pretende extrapolar este ámbito a fin de contar con diversas miradas sobre un tema común. Así pues, el modelo usado en este estudio será aplicable en otros contextos geográficos, enriqueciendo el estudio y obteniendo una visión más global y completa sobre el tema. Es importante señalar, que dentro del contexto latinoamericano, el concepto de museo de arte urbano aún no está extendido ni apropiado como está sucediendo en Europa. De este modo, la producción artística urbana en este área está más vinculada a la identidad, derivada de la resistencia y lucha social; muchas de las obras surgen a partir de manifestaciones populares, con el objetivo de llevar el arte a la calle en aras del vínculo social, en donde la política y el arte se conjugan de una manera orgánica.

"[...] de una gran importancia, es el contenido, tanto del corte macro-político como poético-afectivo, y eso también se debe a la tormentosa historia del continente y a la necesidad de buscar nuevos mitos colectivos. A esta mezcla contribuyó también el [...] fenómeno: universitario y popular, que alimenta el amalgama socio-cultural que se expresa a través de las inscripciones y las imágenes urbanas" (Koziol 2014:10).

La información obtenida resulta imprescindible para comprender qué conlleva la exhibición de obras en exposiciones permanentes, temporales y/o rutas guiadas a través de las ciudades, que también están funcionando como verdaderos museos abiertos. Ello derivará en una reflexión respecto a la pertinencia de difundir, apreciar y conservar el arte urbano como un objeto museable y estático dentro de un contexto expositivo.

Tras evaluar de manera general la problemática de los museos de arte urbano y su impacto en la percepción del mismo por parte del público, se valoró la importancia de que los artistas generadores de este tipo de arte expusieran su perspectiva. Esta consideración resulta imprescindible y fundamental para esta investigación, pues serán ellos quienes formarán parte de estas nuevas colecciones y acervos culturales en diversos museos, ya sean espacios cerrados o abiertos, que implican una lógica de percepción y apropiación distinta por parte del espectador que requiere de unas reglas que deben ser asumidas desde el proceso creativo de las obras.

Además de contar la opinión de un grupo de artistas, también consideró importante contactar con gestores culturales, dado que son estos los que plantean las diversas propuestas curatoriales que determinan las exhibiciones.

La estructuración de la entrevista tanto a artistas como gestores culturales se hizo a partir de un formato de cuestionario que podía ser editado por el artista, basado en seis preguntas abiertas, a fin de que tuvieran plena libertad de expresión. Cabe señalar que se les dio la alternativa 
de poner, o no, su nombre o su seudónimo a fin de establecer un vínculo de respeto a su identidad. Algunos artistas no tuvieron inconveniente en proporcionar sus datos personales completos (nombre y seudónimo), sin embargo, otros prefirieron el anonimato; por tanto, para evitar polemizar, la información vertida en las entrevistas, se maneja a través del anonimato, dando así un parámetro general a todos los participantes. Las entrevistas fueron enviadas vía correo electrónico, la mayoría respondió a través de este medio; en otros casos las respuestas se recibieron por notas de voz, las cuales fueron transcritas para tener un archivo completo y con el mismo tipo de registro.Estas alternativas de diálogo resultan válidas, toda vez que se recupera la información por cualquier vía, como se expone:

“En 1999 el INCCA publica el manual: Guide to good practice: artist interview. En éste se establecen los puntos de partida para construir un canal de comunicación directo con el artista. El manual se estructura en varias situaciones distintas de interacción con el artista: Por carta (cuando el artista no está accesible), por teléfono (cuando el artista es accesible pero no en persona), trabajando con el artista, conversación cara a cara, entrevista corta o extendida, entrevista extendida, entrevista bajo presión (en situaciones de trabajo complicadas), otros medios de comunicación con el artista" (Rotaeche 2011:181).

En este caso, se conjuga el binomio de entrevista directa o corta mediante otros medios de comunicación alternativos con el artista, de este modo además se resolvió el problema de la ubicación geográfica en varios casos.

Por último, complementariamente a la entrevista -como ya se ha expuesto- fue necesario hacer una revisión de los hechos históricos que influyeron en la evolución y entendimiento del arte de la calle, las expresiones muralistas en México, y su influencia en el posterior arte urbano.

Tabla 1.-

\section{Resultados de las entrevistas}

Una vez recopilada la información a través de las entrevistas, se revisaron cuáles podrían resultar más interesantes a efectos de documentación del presente artículo. Las respuestas se han explicitado a manera de gráficos, de porcentaje, a fin de que sea más sencilla su lectura. Es importante mencionar que este artículo presenta un avance de resultados dado que es una investigación que continúa en marcha y se espera la colaboración de más artistas. A la fecha de publicar este artículo se tienen diez entrevistas de las cuales hay todo tipo de respuestas, abiertas y cerradas, a favor y en contra de la figura del museo. Tabla 1.

Las respuestas a las preguntas propuestas proporcionan un corolario que si bien no se genera desde la unanimidad, sí revela la postura de este grupo de artistas encuestados y que podría ser extrapolable a otros contextos. Respecto a las respuestas, a la primera pregunta, ¿Conoces alguno de los museos de Arte urbano/Street Art que han surgido a últimas fechas en diversas ciudades del mundo? [Gráfico 1] la opinión más común fue que no sabían de la existencia de museos, quizá tenga que ver con que la mayoría de estos museos se están generando en el contexto europeo y no en el latinoamericano.

\section{Gráfico1.-}

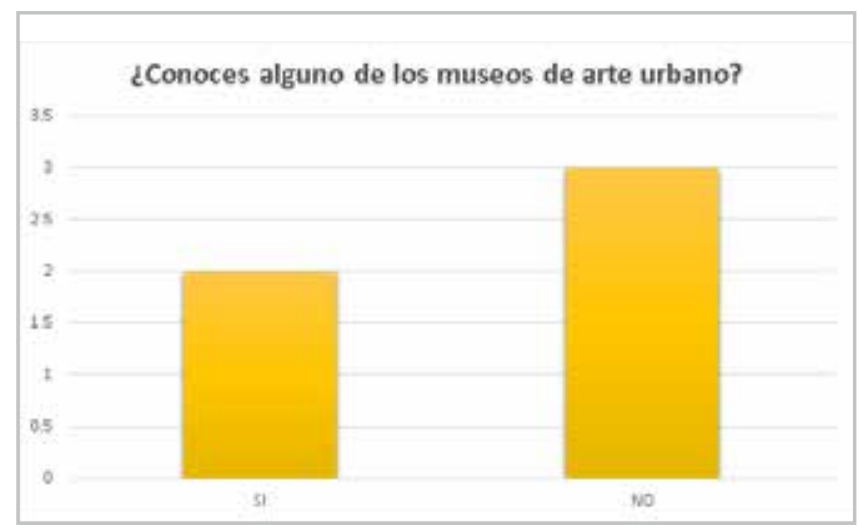

Proyecto URBARTE Conservación, diagnóstico y registro de Arte Urbano y Graffiti en México. “Los museos y los creadores de arte urbano y/o Street Art"

1. ¿Conoces alguno de los museos de Arte urbano y/o Street Art que han surgido a últimas fechas en diversas ciudades del mundo?

2. ¿Qué características consideras que tendría que tener un museo de este tipo para poder exhibir arte de este tipo?

3. ¿Consideras viable que este tipo de obras se muestre dentro de un espacio cerrado o es la calle la única alternativa de exhibición?

4. Desde tu perspectiva los museos de Street Art y/o arte urbano ¿enriquecen o demeritan la escena?

5. Alguna obra (s) tuya ha sido expuesta en alguna exhibición y/o museo dedicado al arte urbano y/o Street Art? De ser positiva la respuesta favor de agregar datos (exhibición y/o museo, título de las obras, año, técnica).

6. Finalmente, ¿museo especializado o exhibición temporal dentro de un museo?

Nombre y/o seudónimo:

Colectivo o crew: 
Solo un par de artistas respondieron que sí conocían el caso de Berlín y el de París. Sin embargo, otras respuestas hacen énfasis en el desconocimiento de la figura de los museos de arte urbano:

"A decir verdad no sabía de la existencia de museos de arte urbano en otros países, pero sí por ejemplo de la expo que se lleva a cabo en el Fotomuseo de Cuatro Caminos [5]. También sé de galerías al aire libre como Wynwood o la Central de Abastos [6], ubicada en nuestra bella ciudad (CDMX), pero de museos, entendido como espacio cerrado no tenía conocimiento".

Es interesante porque ni la Central de Abastos, ni el Fotomuseo de Cuatro Caminos, se han erigido como espacios museísticos especializados en arte urbano, no obstante, la Central de Abastos es el mercado más grande de la ciudad, el segundo mayor centro comercial de la ciudad después de la Bolsa Mexicana de Valores; y si bien ha sido intervenido por colectivos con arte urbano con el proyecto "Central de muros" no se considera un museo. Por su parte, el Foro Cuatro Caminos expuso recientemente la exposición "Ilegal" donde se llevó a cabo una división entre lo legal y lo ilegal, explicando las motivaciones de cada uno y creando obras de artistas ilegales como SILER al interior del museo [figuras 9 y 10 ].

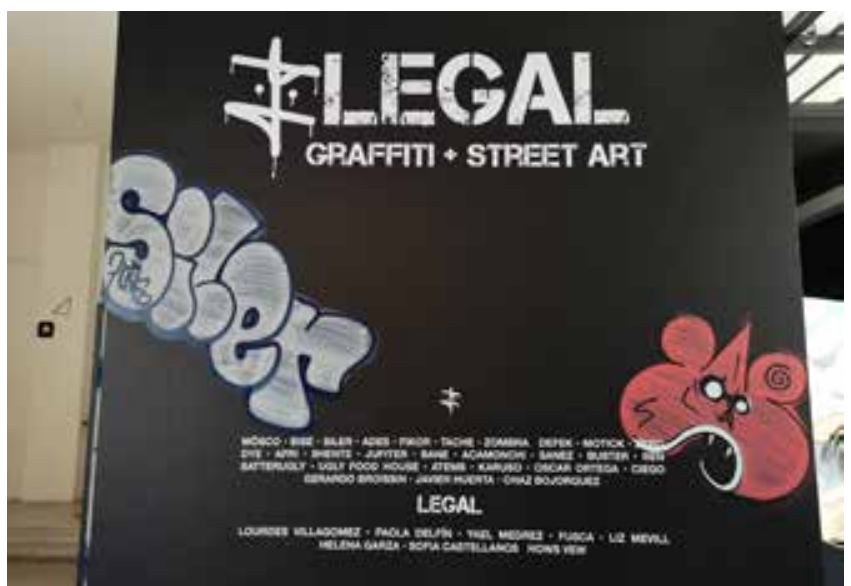

Figura 9. Inicio de la exposición ILEGAL en el Foto Museo Cuatro Caminos, Naucalpan de Juárez, México. En la cédula inicial se aprecia la división entre los artistas ilegales y legales presentes en la muestra.

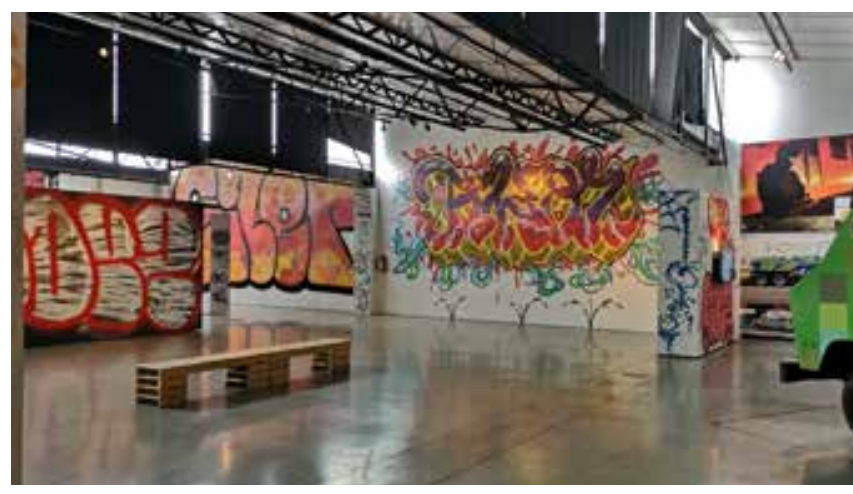

Figura 10. Exposición ILEGAL en el Foto Museo Cuatro Caminos, Naucalpan de Juárez, México.
En relación a la pregunta ¿Qué características consideras que tendría que tener un museo de arte urbano? [Gráfico 2].

\section{Gráfico 2}

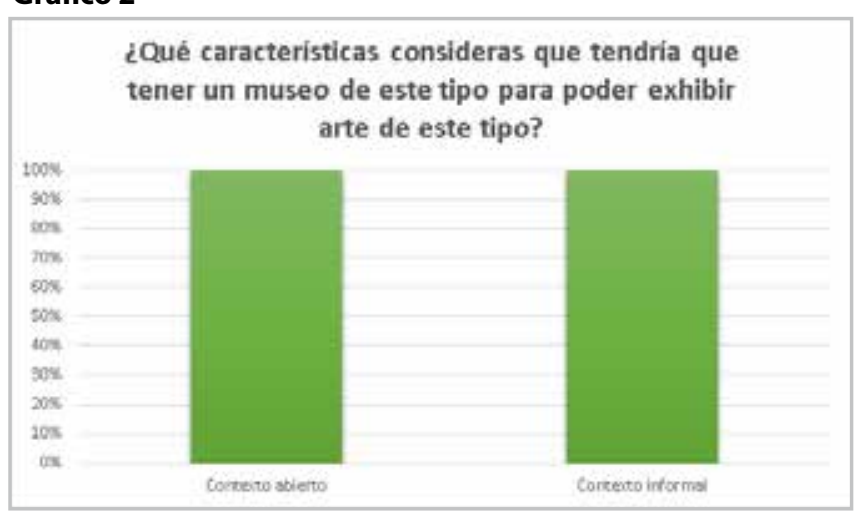

Las respuestas mostraron la tendencia a que se debe dejar de lado la formalidad del museo como lo tenemos entendido y que la exhibición en el exterior es fundamental. Una de las respuestas más relevantes, por la clara división que hace entre arte urbano y muralismo y por el hecho de evidenciar que puede ser beneficioso explicar el arte urbano, fue que no es el museo el formato más adecuado, como expuso uno de los artistas entrevistados:

"Considero que no hay museo que tenga las características necesarias para exhibir dichas expresiones, porque el museo como espacio es ya una delimitación categórica dentro/fuera, [...] divisiones que no existen en las calles o, por lo menos, las distinciones son más tenues, además de que acciones como el plasmar tu tag en lugares peligrosos o físicamente difíciles de alcanzar, en un museo, carecen completamente de sentido. Creo que la intención es buena al tratar de explicar el fenómeno, sin embargo, no creo que sea el medio adecuado. Creo yo que el muralismo es, de las "artes" urbanas que me son familiares, la que mejor se podría adaptar para exhibirse en un museo".

Respecto al cuestionamiento en torno al espacio cerrado o abierto a partir de la pregunta ¿Consideras viable que este tipo de obras se muestre dentro de un espacio cerrado o es la calle es la única alternativa de exhibición? [Gráfico 3]

\section{Gráfico 3}

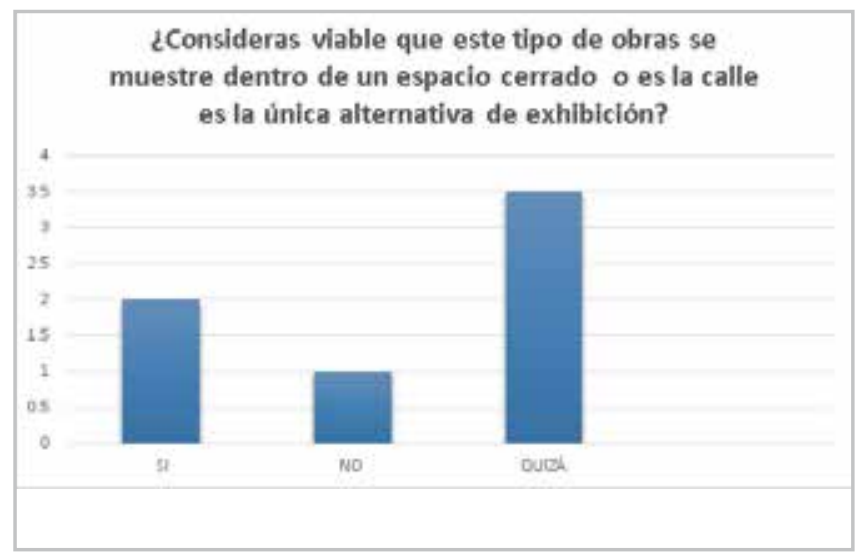


el resultado comienza a variar un poco la tendencia, sobre todo en relación a la validación del arte urbano como una expresión artística no vandálica, aunado a que le dará difusión al trabajo artístico y generará documentación histórica. En este caso la perspectiva varía de acuerdo a la consecuencia, aparentemente positiva derivada de la existencia del museo.

Sobre si los museos enriquecen o demeritan la escena [Gráfico 4] en la pregunta número cuatro: Desde tu perspectiva los museos de Street Art y/o arte urbano ¿enriquecen o demeritan la escena? las respuestas vuelven a polarizarse, pues la mayoría no acaban de determinar aún si la enriquecen o si la representan de manera injusta, como expresa uno de los artistas

\section{Gráfico 4}

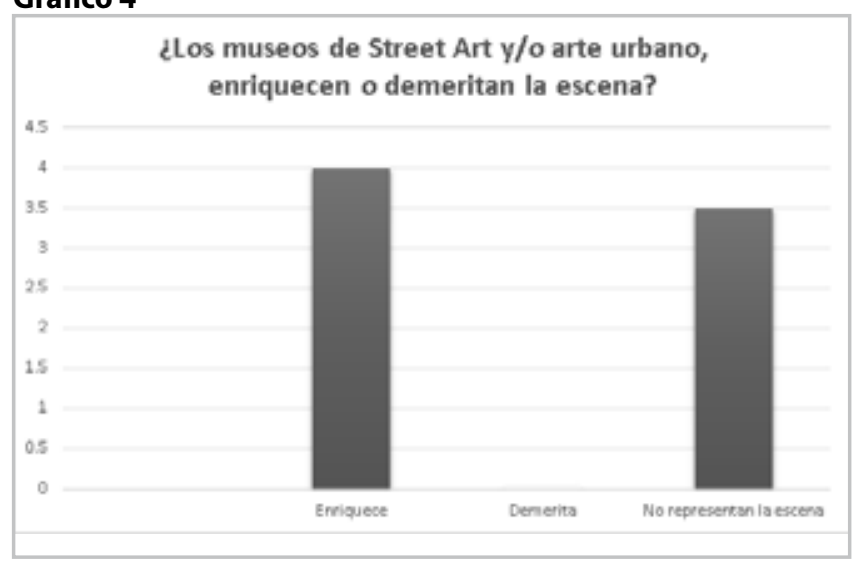

"Me parece que no representan la escena de manera justa, pero, hasta ahí, me parece que entre otras cosas, es un intento de mercantilizar, de cosificar la escena, de convertirla en recursos. Creo que el proceso de selección y curaduría que el museo implica, merma la democratización y el acceso a los espacios de exhibición del cual gozan las expresiones urbanas. Desde mi punto de vista, la exhibición en museos, más allá de enriquecer o demeritar la escena, la descontextualizan y la resignifican, la adaptan a parámetros de exhibición de otro tipo de expresiones. Creo que estas acciones centralizan el acceso a expresiones culturales, por qué exhibir una pieza en un museo, en una zona turística y de alto índice de desarrollo humano, cuando lo puedes hacer en un muro de la periferia sin acceso a expresiones culturales".

El insertar las obras dentro de un discurso curatorial y cosificar el arte urbano, es uno de los puntos en contra para validar la figura del museo; como explica Montessoro "el arte urbano, es una alternativa a la figura de los museos y las galerías" (2016, 55-57).

En cuanto a la exhibición de sus obras dentro de este tipo de contextos a través del cuestionamiento: Alguna obra (s) tuya ha sido expuesta en alguna exhibición y/o museo dedicado al arte urbano/Street Art? De ser positiva la respuesta favor de agregar datos (exhibición y/o museo, título de las obras, año, técnica), [Gráfico 5] la mayoría indica que no han sido exhibidas en museos de arte urbano especializados, sin embargo, dos de las respuestas coinciden en que sí se han expuesto en otros contextos como galerías o exposiciones colectivas dentro de museos de otro tipo, no especializados en arte urbano.

\section{Gráfico 5}

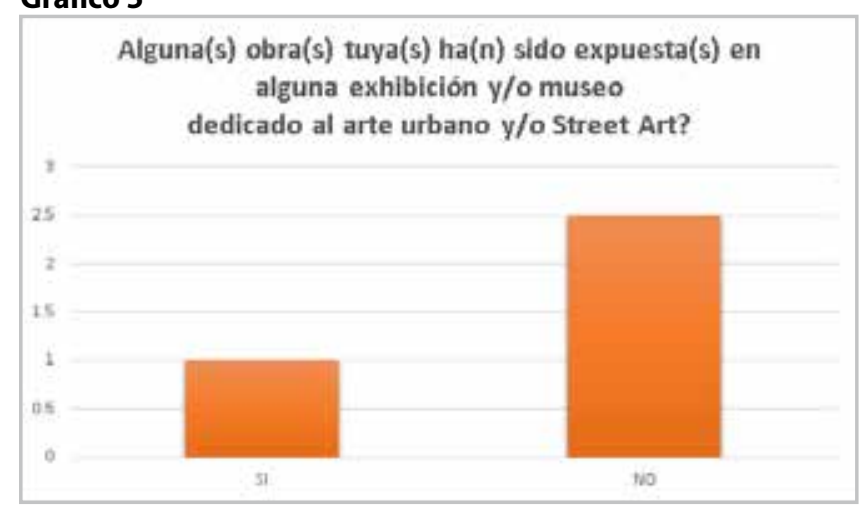

Finalmente, la pregunta enfocada a la existencia de los museos de arte urbano, ¿Museo especializado o exhibición temporal dentro de un museo? [Gráfico 6], obtuvo respuestas significativamente enfocadas a que la calle es el espacio adecuado para su exhibición, aunque algunos no descartan la posibilidad de que coexistan ambas alternativas.

\section{Gráfico 6}

¿Museo especializado o exhibición temporal dentro de un museo?

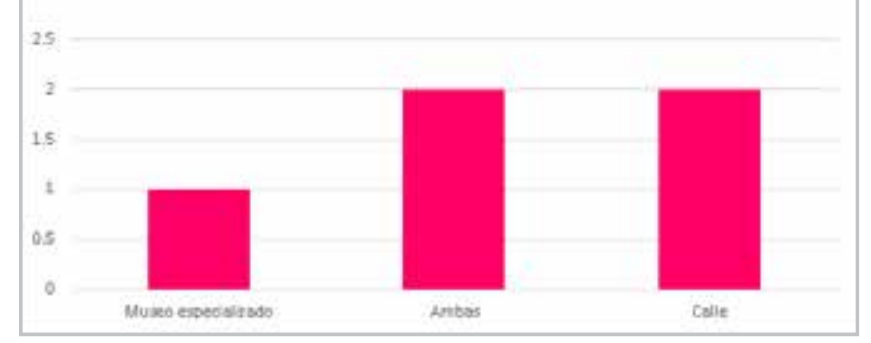

Lo que reflejan estas respuestas, es que difícilmente la figura de museo como espacio cerrado será aceptado, pues es la calle su contexto natural. Si se considera la diversidad de términos planteada al inicio como parte de su problemática es válida la perspectiva de Sergio Raúl Arroyo:

"el grafiti lleva implícita una convocatoria a la que, de una u otra, todos están invitados: el indiferente; el transeúnte que circula por una arteria citadina y mira perplejo una intervención; el activista o el colectivo que forma redes para grafitear en diferentes lugares y ponen en marcha rutas enteras dentro de un extenso mapa, propiciando una peculiar retroalimentación, transmitiendo mensajes entre generaciones e individuos de todo tipo. “Ojo: la búsqueda consiste en garantizar más la permanencia de una idea que de una obra" (Arroyo 2015:21 y 23). 
Esta reflexión sobre la permanencia de la idea, del concepto, es de suma importancia, ya que será importante considerar qué es lo que se busca conservar o hacer trascender en los museos enfocados al arte urbano, si la idea o las obras. Resulta evidente que este tipo de expresiones artísticas no buscan necesariamente trascender materialmente, sino conceptualmente, como lo han hecho durante décadas, incluso siglos, en distintos contextos.

\section{Conclusiones}

Es evidente que este tipo de expresiones artísticas nacieron por y para la calle, que circunscribirse al contexto de museo no es una alternativa viable a menos que se garantice un espacio urbano como contexto y se respete su forma libre y transgresora, situación que se complica al tener que ceñirse a un discurso curatorial derivado del museo en el que ambos, comisario y museo, deben convertirse en cómplices y mediadores del artista. Por tanto, al entrar dentro del espacio físico o conceptual del museo tradicional, retoman su esquema limitante, la conquista libre del espacio público y el vínculo directo con el espectador quedan relegados al hacerlo desde el objetivo institucional, a no ser que llegue a ser reformulado, se abra, y llegue a contemplar la transgresión como fórmula expresiva.

Los museos de arte urbano, hasta el momento, se han presentado como nuevos y alternativos espacios para exhibir este tipo de arte, sin embargo, no han logrado vincularse de manera positiva, ni legitimar este tipo de expresiones artísticas. Al menos, no con una gran parte del gremio que considera esto como una cosificación del arte urbano y un proceso relacionado con la mercantilización del arte más que como una práctica que pueda legitimar el movimiento.

De las entrevistas realizadas se desprende que no existe interés por los museos enfocados al arte urbano. Dependerá del contexto en donde se ubique el artista y el propio museo, si bien es cierto que la existencia de museos de arte urbano ofrece una perspectiva distinta a este tipo de obras y les otorga un reconocimiento y legibilidad social diferentes, las obras se descontextualizan de su principal referencia, la calle. Es fundamental considerar la opinión de los artistas respecto a la existencia de estos museos. Inclusive aquellas obras comisariadas derivadas de festivales, buscan en su mayoría respetar la práctica callejera, libre y abierta, quedando ante la mirada de la gente que convive con ellas, lo que no resulta así cuando están en un espacio cerrado, como es un museo.

Aún es pronto para saber hasta dónde y cuántos museos de arte urbano surgirán, lo que será interesante evaluar es cuántos permanecerán en el futuro, además de evaluar si esto generará un cambio positivo en la percepción del arte urbano o si, por el contrario, se abrirá el concepto de museo a intervenciones artísticas que admitan la crítica de la propia institución y sus reglas, retomando algunos de las características que le dan sentido y origen a este tipo de expresiones artísticas.

\section{Referencias}

[1] El ICOM propone (2017) la definición de museo como: "una institución, sin fines lucrativos, permanente, al servicio de la sociedad y de su desarrollo, abierta al público, que adquiere conserva, comunica y expone el patrimonio material e inmaterial de la humanidad y su medio ambiente, con el fin de educación, estudio y recreo" ICOM, https://icom.museum/es/news/the-challenge-ofrevising-the-museum-definition/ [consulta: 26/05/2019].

[2] En la jerga popular mexicana el término "cuete" hace referencia al tema tratado o en su caso al problema que nos ocupa.

[3] En la jerga popular mexicana el término "tambor" hace referencia al término también.

[4] La Redacción. "La muerte de Daniel Manrique, cofundador de Tepito Arte Acá en Revista Proceso https://www.proceso.com. $\mathrm{mx} / 103003 /$ la-muerte-de-daniel-manrique-cofundador-de-tepitoarte-aca [consulta: 29/05/19].

[5] El Foto Museo Cuatro Caminos es un espacio educativo referente de la cultura visual en México, donde la imagen es un detonador de experiencias y diálogo entre artistas, fotógrafos, creadores, investigadores, académicos y público en general. Somos un proyecto cultural al servicio de la sociedad y su desarrollo. https:// www.fotomuseo.mx/nosotros [consulta 08/10/2019].

[6] Central de Muros es el nombre de la iniciativa que Itze González e Irma Macedo del colectivo We Do Things propusieron para que este espacio público se transformará no solo en aspecto, sino en "cómo se siente" su ambiente.

Su deseo es que con estas intervenciones visuales se logren diálogos, cuestionamientos, interacciones y nuevas perspectivas en la comunidad. "No estamos descubriendo el agua tibia: el arte es apapachón, purifica el alma", dice Irma. https://www.elfinanciero. com.mx/sibarita/central-de-abasto-el-arte-que-esta-en-todaspartes [consulta 08/10/2019].

\section{Bibliografía}

AQUINO, A. (2011). Imágenes épicas en el México contemporáneo. De la gráfica al graffiti. 1968-2011, INBA, CENIDIAP, CONACULTA, México.

ARROYO, S. y D. ARROYO. CODEX. Una aproximación al grafiti de la Ciudad de México, CONACULTA-TURNER, México.

GARCÍA, N. (1979). La producción simbólica. Teoría y método en sociología del arte, SIGLO VEINTIUNO EDITORES, México.

ESPINOSA, C. y A. ZUÑIGA. (2002). La perra brava: arte crisis y políticas culturales. Periodismo cultural y otros textos de los años 70 a los 90, UNAM, México.

FAJARDO, E. (2018). "El grafiti en México" en Graffiti DF, Broissin, México. 
KOZIOŁ, K. (2014). No estamos pintados en la pared. El arte urbano como representación de la identidad latinoamericana. Universidad Jaguelónica de Cracovia, Cracovia.

MANDEL, C. (2007). “Muralismo mexicano: arte público / identidad / memoria colectiva" en Artes Visuales Revista ESCENA 30 (61), Costa Rica.

MONTESSORO, F. (2016). Stickers DF, Universidad Iberoamericana, México.

PALMER, R. (2013). Arte callejero en Chile, Ocholibros, Chile.

PAÚL, A., (2016-2017), M.I.A.U.El museo que cambió a Fanzara, Universidad Jauteme, Inédito.

REYES, F. (2004). “La resistencia blanda y la mediación como obra”. En Tercer Simposio Internacional sobre Teoría del Arte Contemporáneo. Resistencia, Ciudad de México: Patronato de Arte Contemporáneo.

ROTAECHE, M., (2011). Conservación y restauración de materiales contemporáneos y nuevas tecnologías, Madrid: Editorial Síntesis.

VÁZQUEZ, A. (2007). “Los Grupos: una reconsideración” en La era de la discrepancia. Arte y cultura visual en México 1968 - 1997, UNAM, México.

Entrevistas realizadas a: Colectivo Lapiztola, Flavio Montessoro, Alter Os, Museo Mutante [México] y a PDV Crew [Colombia].

\section{Autor/es}

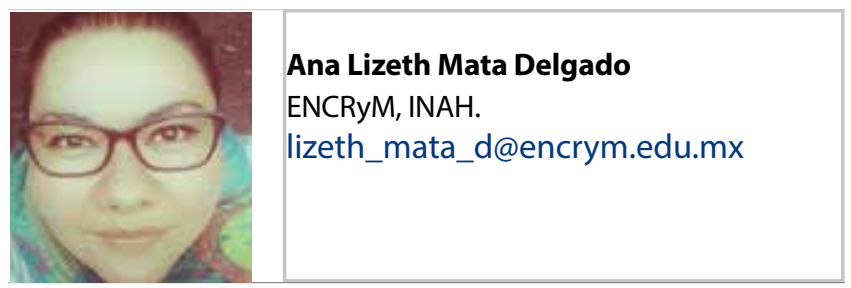

Licenciadaen Restauración porla Escuela Nacional deConservación, Restauración y Museografía del Instituto Nacional de Antropología e Historia, Secretaría de Cultura y Maestra en Historia del Arte con especialidad en Arte Contemporáneo por la Universidad Nacional Autónoma de México. Docente investigador titular del Seminario Taller de Restauración de Arte Moderno y Contemporáneo en la ENCRyM, INAH. Coordinadora del Proyecto de Registro, Diagnóstico y Conservación de Arte Urbano en la Ciudad de México desde 2011. Organizadora de los encuentros Conservando el Street \& Graffiti (2013) y el Encuentro Internacional de Arte Urbano URBARTE (2016 y 2018). Participante en VINCULARTE 2015. Miembro del Grupo de Arte Urbano del Grupo Español del International Institute of Conservation Autora de diversos artículos relacionados con el Arte Urbano, por mencionar algunos títulos: Conservando el Street Arty el Graffiti. ¿Se queda o se va? La disyuntiva ante la conservación del arte urbano. La estética de la resistencia en el arte urbano, entre la política y el arte. 
que se encarga de plantear las nuevas perspectivas y potencialidades de un museo, lo concibe como un lugar democratizado, inclusivo y polifónico para el diálogo, crítico sobre el pasado y el futuro, que reconoce y aborda los conflictos y desafíos del presente, mantiene los artefactos y objetos que le han sido confiados por la sociedad, salvaguarda la diversidad de la memoria para las generaciones futuras, y garantiza la igualdad de derechos y el acceso al patrimonio para todas las personas. Asimismo, los museos no deben tener ánimo de lucro y se les exige ser participativos, transparentes y trabajadores activos en la recopilación, preservación, investigación, interpretación y exhibición del mundo, y deben tener como principal objetivo contribuir a la dignidad humana y la justicia social, la igualdad global y el bienestar planetario. De acuerdo con esto, a partir de ahora se decide apostar por conceptos como la inclusión, para dar visibilidad a la diversidad de la sociedad y poder atender las necesidades de todos los públicos. Otras nociones importantes son la de transparencia, dignidad, justicia, igualdad y bienestar, apuntalando el papel crucial que los profesionales de los museos tienen en la sociedad a la que se dirigen. Sin duda, se trata de toda una declaración de intenciones que pretende transformar por completo la concepción tradicional de dicho término y comprometerse con las necesidades e intereses del nuevo público, al menos en los próximos años, hasta que la propia evolución de la humanidad en su conjunto demande nuevos planteamientos y necesidades.

Ante tal coyuntura, el proyecto Murales Conciencia, desarrollado desde el Ayuntamiento de Bailén gracias a la concesión de una ayuda para el Fomento de la Cultura Científica, Tecnológica y de la Innovación por parte de la Fundación Española para la Ciencia y la Tecnología (FECYT), ha permitido materializar un museo en abierto, entendido este como un espacio público patrimonial, democrático e inclusivo que cuenta con los artefactos artísticos necesarios para establecer una interacción recíproca con la ciudadanía, tanto de forma física como a través de recursos tecnológicos y plataformas digitales. El proyecto muestra la necesidad de traspasar las fronteras establecidas y entender los museos como entes diáfanos y componentes fundamentales en los procesos de "hacer ciudad", mediante la generación de artefactos de carácter artístico (Remesar 2019: 9) que propicien una interrelación entre el patrimonio local y la comunicación social de la ciencia, y que potencian el cuidado, mantenimiento y mejora de los ámbitos de vida compartidos por la comunidad.

\section{Ciencia, arte público, patrimonio y turismo en un contexto rural}

Bailén, localidad de la provincia de Jaén con una población de 17.820 habitantes (según los datos registrados en el Instituto Nacional de Estadística, en su censo de 2018), Ilegó a ser el primer productor de España de cerámica estructural, alcanzando alrededor de un 30\% de la producción nacional (Cárdenas y Agudo 2012). La denominada crisis del ladrillo supuso para este municipio un varapalo socioeconómico que le llevó a superar el 35\% de desempleo y a perder un millar de habitantes en una década (2). En este contexto de emergencia social y económica, Bailén fue contando con multitud de infraestructuras urbanas degradadas o abandonadas, que invitaban a plantear acciones para su mejora o mantenimiento. El aprovechamiento de estos espacios para la generación de nuevos artefactos culturales con utilidades inmediatas y cercanas (Martos y García 2014: 123), podría ser utilizado para recuperar una estética identitaria, que confiriese a los habitantes del municipio un sentimiento de pertenencia a través del establecimiento de un nuevo vínculo social. Además, constituirse en otro recurso turístico que, en línea con proyectos similares instaurados en el territorio, generase un impacto socioeconómico real en la vida del municipio. En este sentido, el arte es una herramienta eficaz para la aplicación de diversos procesos como la cohesión del grupo, la transformación y la participación ciudadana, ya que incide directamente en el desarrollo comunitario y social y en el bienestar de los sujetos (Serrano-Martínez 2016: 25), pese a la inicial "necesidad de desarrollar procesos de regeneración más centrados en las personas y no tanto en el entorno físico" (Remesar, 2019: 28) [figura 1].

El proyecto Murales Conciencia se puede enmarcar en el ámbito de la definición que Remesar realizó sobre el arte público (2010) cuando se refiere al "conjunto de las intervenciones estéticas que, interviniendo sobre el territorio, desencadenan mecanismos sociales e individuales de apropiación del espacio que contribuyen a co-producir el sentido del lugar". Los elementos patrimoniales con los que contaba la localidad, como monumentos, edificios históricos o el Museo de la Batalla de Bailén, se ven complementados por otros nuevos que no solo generan una dinamización cultural alternativa en

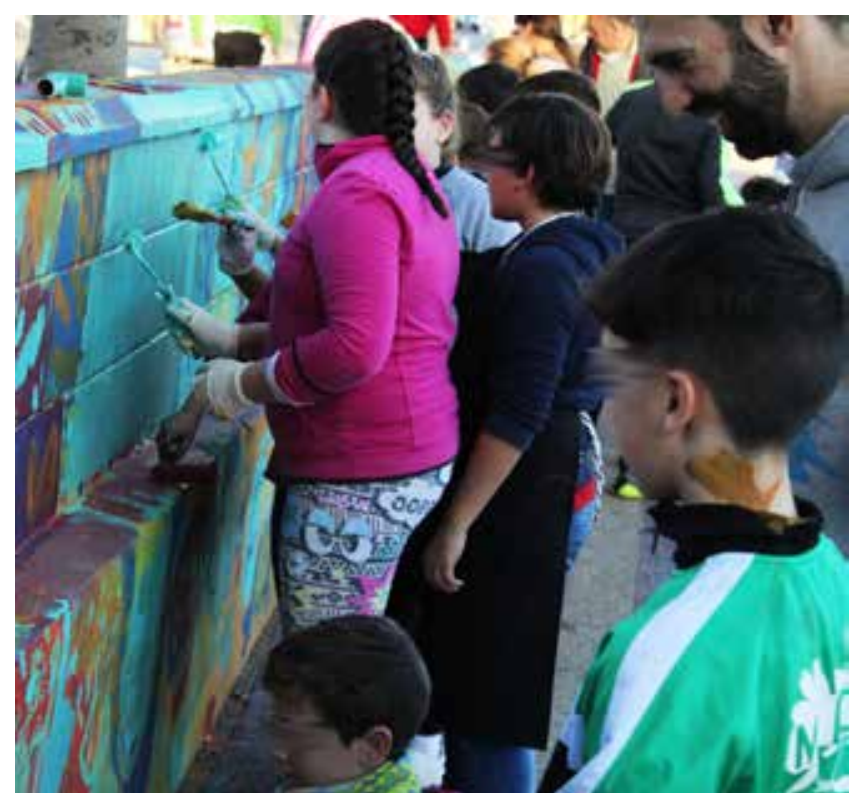

Figura 1.- Proceso de creación de la acción Simbiosis, a cargo de Boa Mistura, con la participación de más de 600 personas. 
el municipio, sino que además se constituyen como un nuevo recurso que se puede abordar desde la perspectiva del turismo cultural, en la misma línea de otros proyectos llevados a cabo con éxito, como, las rutas del Niño de las Pinturas en Granada, Madrid Street Art Project en Madrid, las de Belin en Linares (Jaén), o Festivales como ASALTO en Zaragoza, MIAU Fanzara (Castellón) o MAUS en Málaga, por citar solo algunos ejemplos (García y García 2016: 133; Ortega-Alonso 2018: 190).

Silberberg (1995) se refirió al turismo cultural como "las visitas realizadas por personas de fuera de la comunidad receptora, que están motivadas total o parcialmente, por el interés histórico, artístico, científico, además de las costumbres y modos de vida que puede brindar una comunidad, región, grupooinstitución".Más recientemente, en la Conferencia de la Organización Mundial del Turismo (OMT) y la Unesco, celebrada en Turquía en diciembre de 2018, una de las conclusiones alcanzadas se refiere a las políticas y estrategias de turismo cultural, indicándose que "deben considerar las perspectivas e intereses de las comunidades locales, que también pueden ayudar a los organismos de gobernanza a hallar un equilibrio entre el desarrollo del turismo y la conservación y salvaguarda del patrimonio." Ambas perspectivas inciden en la necesidad de involucrar a la comunidad en lo que le es propio.

En una sociedad de consumo como la actual, en la que los productos artísticos que llegan al ciudadano medio en general, y rural en particular, están muy influenciados tanto geográficamente (por su carácter descentralizado) como económicamente - por la enorme influencia de los mass media en la construcción de una cultura de consumo, la mayoría de las veces "de usar y tirar"—, se torna necesario que los organismos públicos e instituciones los contrarresten, preservando y fomentando el patrimonio y la cultura, mediante el desarrollo de estrategias y acciones que garanticen una alternativa viable y de suficiente calidad para garantizar su perdurabilidad. Como afirma Bauman (2010), con la aparición de estos mercados de consumo, los agentes y administradores deben ocupar un papel neutral sobre el consumo de la cultura y el comportamiento humano "normativamente regulado" hacia los administrados (sociedad), asignándole a la educación un papel fundamental. Así pues, el espacio público debe entenderse como un bien colectivo, donde el sentido de pertenencia de la comunidad y el diálogo con el mismo lo instaura como lugar significativo, con capacidad para estimular los intercambios dialécticos y dialógicos entre todas las partes implicadas (Visconti, Sherry, Borghini y Anderson 2010: 511).

Murales Conciencia ha resultado ser un revulsivo que no solo ha conseguido acercar la ciencia a toda clase de públicos, sino que además, ha aportado valor estético, cultural, patrimonial y turístico a la localidad. Así pues, el proyecto surge con la intención de crear espacios agradables y prósperos para sus habitantes y visitantes, documentando los procesos de creación de los murales y la interacción entre artistas y ciudadanía. En connivencia con los propietarios de los edificios objeto de las intervenciones pictóricas, se han plasmado en murales diversas temáticas relacionadas directa o indirectamente con la ciencia (Ortega-Alonso 2018: 189) [figura 2]

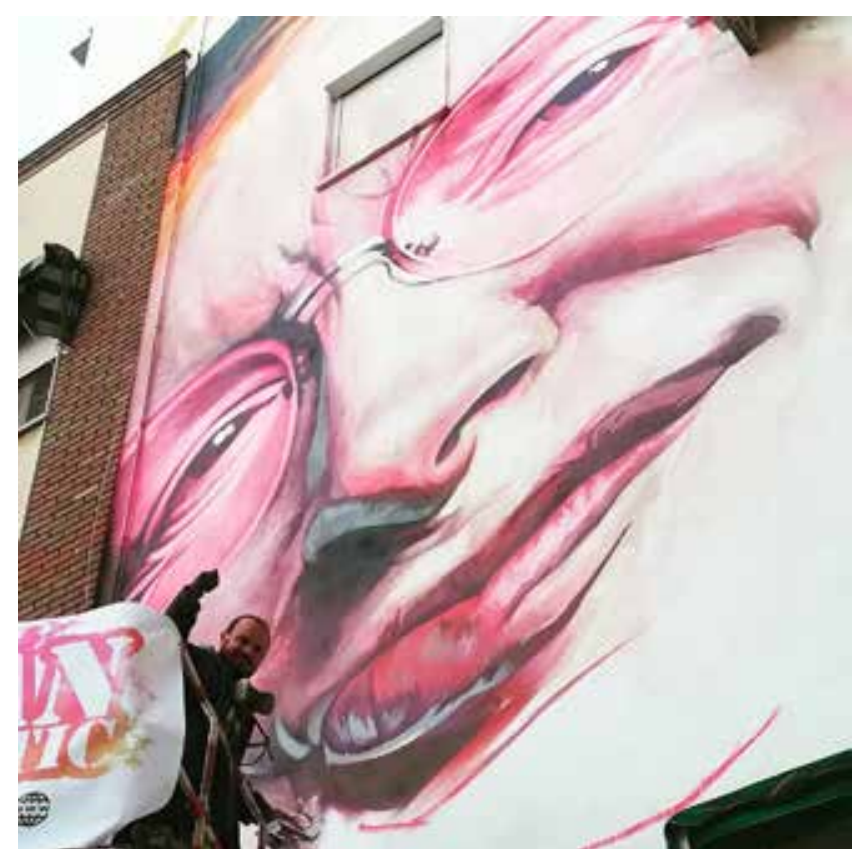

Figura 2.- Adrián Pérez "Manomatic" ejecutando Hawking y la universalidad del AOVE.

El carácter público de la pintura mural en el contexto urbano de una sociedad como la actual, tan expuesta a tecnologías que nos interconectan —la mayoría de índole audiovisual e interactiva-, permite difundir cualquier tipo de expresión artística a todos los confines del mundo, con independencia de (o incluso gracias a) su localización, y proyecta culturalmente estas intervenciones como lugares que visitar. El proyecto Murales Conciencia ha conseguido transformar estéticamente la localidad de Bailén (Jaén), dotándola de un nuevo recurso inexistente hasta el momento. La unión de elementos de carácter artístico (pintura mural), con una sólida apuesta por la comunicación social de la ciencia, ha convertido la localidad en un ecosistema museístico de divulgación innovadora, utilizando elementos tecnológicos de geolocalización, promoción y difusión por la red de Internet.

Nos encontramos ante un proyecto de innovación social que promueve la interacción entre diversas formas de conocimiento, y la resolución colectiva e inclusiva de problemas que incluyen a sus protagonistas a través de metodologías participativas, generando bienes colectivos y comunes, así como una movilización distinta de los actores de la sociedad (Lora y Rocha 2016: 176). Pero ¿por qué ciencia? Es ésta una pregunta que frecuentemente se ha planteado durante los procesos de ejecución de las diferentes intervenciones artísticas. En este punto, cabe recordar los objetivos específicos del proyecto 
Murales Conciencia, recogidos en la memoria técnica de la Convocatoria 2017 de ayudas para el Fomento de la Cultura Científica, Tecnológica y de la Innovación, los cuales son:

-Aportar conocimiento sobre aspectos científicos concretos que son comunes, y que son vistos como muy abstractos y alejados de la sociedad.

- Impulsar la localidad de Bailén a través de la realización de recorridos artísticos con la ciencia como protagonista, por medios electrónicos e impresos, configurando un nuevo atractivo turístico al municipio.

-Creación de actividades paralelas al certamen, que impulsen sectores locales como la hostelería o el comercio (conferencias, talleres, simposios...)

-Establecer vínculos y sinergias con municipios y ciudades que ya cuentan con recorridos y oferta turística específica en torno al arte público, así como con otras entidades relacionadas con el mundo de la divulgación científica.

-Promover y difundir el evento a través de la plataforma Exploria Ciencia, tras convenio firmado con la Fundación Descubre. En esta plataforma aparecerán los siguientes aspectos:

-Presentación de los artistas y de los proyectos de divulgación científica que trabajarán.

-Procesos de creación de las obras.

-Información de carácter científico con las temáticas abordadas.

-Promoción y difusión a través de redes sociales e internet.

Desde el año 2002, la FECYT recoge bianualmente el análisis y los resultados de la Encuesta de Percepción Social de la Ciencia y la Tecnología en España, cuyo fin es "profundizar en el conocimiento de las relaciones entre ciencia, tecnología y sociedad y analizar la percepción de la ciudadanía sobre los avances científicos y tecnológicos, y sobre la capacidad de éstos para la mejora de la calidad de vida de la población". Los datos que arroja la última encuesta (2018) indican que el interés suscitado por los temas científicos y tecnológicos de la sociedad española se sitúa en torno al $16,3 \%$, en una tendencia ascendente que, sin embargo, parece haberse estancado en los últimos años. En cuanto a la alfabetización científica general, se considera que el nivel de educación científico-técnico es bajo, o al menos más bajo de lo que se desearía, ya que el $40,6 \%$ de las personas encuestadas lo califica así, frente al $12,6 \%$ que lo considera muy alto $(1,6 \%)$ o alto $(10,9 \%)$. La búsqueda del incremento del interés de la ciudadanía en ámbitos científico-técnicos responde a una de las razones que justifican esta necesidad. En palabras de Toharia
(2010): "Cuando se difunde ese tipo de cultura científica, cuando se educa a toda la población de manera informal y atendiendo más a sus curiosidades e inquietudes que a una mera formación erudita y sistemática, se está contribuyendo a incrementar el nivel medio de la educación científica global, hoy por hoy bajo mínimos."

Otra de las razones se encuentra en la reivindicación de la innovación disruptiva (Christensen, Raynor y Mcdonald 2015: 4) que supone incluir algo tan, a priori, ajeno a la cotidianidad de lo rural como puede ser el conocimiento científico. A través de expresiones artísticas que generan nuevos recursos visuales, y vinculan lo que es propio de la identidad colectiva de un pueblo con cuestiones de relevancia para la sociedad, se consiguen crear nuevas identidades que encuentran de este modo los canales adecuados para su comunicación social [figura 3].

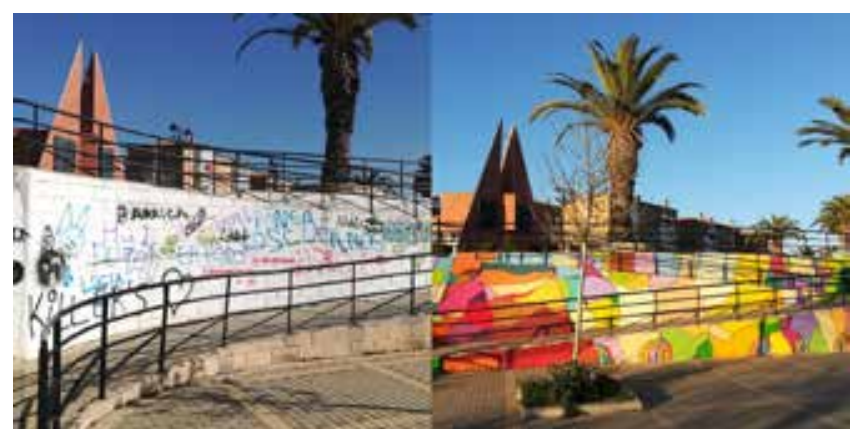

Figura 3.- Vista del antes y el después de la intervención Bosque de neuronas de Ramón Pérez Sendra.

Si bien la previsión inicial del proyecto era la de realizar quince murales, la idiosincrasia de los espacios y el presupuesto disponible supusieron la reducción de este número hasta un total de nueve, tal y como puede verse en el recorrido museístico virtual (3). Como contrapartida, los artistas han podido abordar obras de un tamaño muy superior al inicialmente previsto, con el consiguiente impacto que causa su monumentalidad, al estar ubicadas en espacios públicos como paredes medianeras, accesos a plazas o muros que, en algunos casos, llevaban más de medio siglo sin haber sido siquiera pintados con pintura de exteriores.

\section{Los Murales Conciencia}

Comoya seha mencionado, uno de los factores diferenciales de Murales Conciencia, más allá de ser una colección de arte público, reside en su musealización virtual, que permite la interacción del público con las obras artísticas, el registro audiovisual de los procesos de creación de las mismas [4] y una apuesta por la comunicación social de la ciencia a través de descripciones textuales y audiodescritas, así como enlaces a contenidos en la red de internet. Esta tarea, por tanto, se materializa desde el espectro físico pero también a través del uso de herramientas digitales. 
Dicho museo virtual está incluido dentro de la plataforma Exploria Ciencia, de la Fundación Descubre, una institución privada y sin ánimo de lucro impulsada por la Consejería de Conocimiento, Investigación y Universidad de la Junta de Andalucía, cuyo compromiso institucional reside en comunicar ciencia a la sociedad. La plataforma permite, de forma sencilla e intuitiva, navegar por una panorámica en $360^{\circ}$ de cada uno de los murales, conocer más sobre quién los hizo, cómo, cuándo, por qué y para qué. La distribución, en los puntos de interés turístico y cultural de la localidad, de dípticos impresos informativos sobre la ubicación geográfica de los murales y su vinculación a la plataforma digital a través del uso de códigos QR, permiten la interacción entre la ruta urbana y el museo virtual [figura 4].
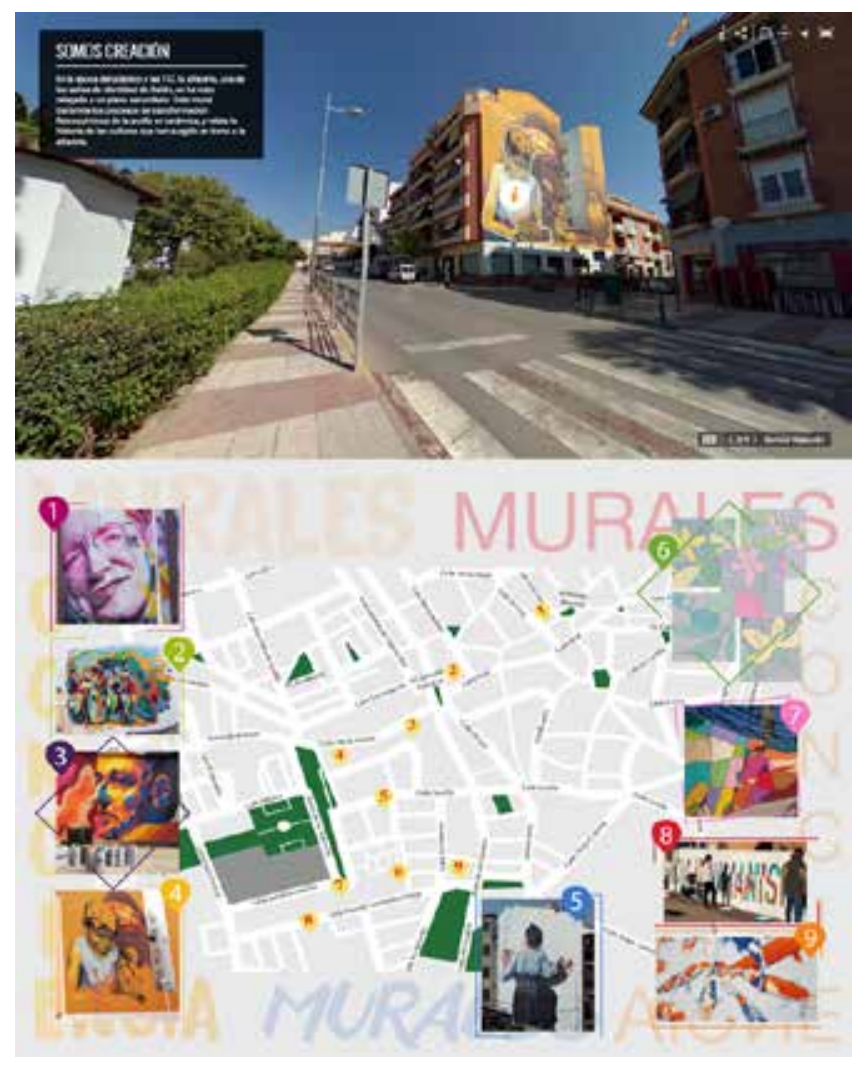

Figura 4.- Vista del museo virtual Murales Conciencia en plataforma Explora Ciencia. Fundación Descubre. (Abajo): Plano con la ubicación de los murales para su recorrido en Bailén. Ilustración de los autores.

Este artículo no estaría completo sin describir cada una de las temáticas científicas de las obras que componen los Murales Conciencia. Los artistas partían de una propuesta inicial formulada por los responsables del proyecto, y condicionada por aspectos como el conocimiento de los espacios y lugares del municipio, el contexto de las intervenciones o el interés por temáticas concretas que dotaran al itinerario de mayor riqueza patrimonial y científica. En este sentido, los artistas desarrollaron una investigación propia de procesos, en ocasiones, cercanos a los de la ilustración científica, mediante documentación basada en bibliografía o a través de la investigación directa, de carácter tanto metodológico como epistemológico y gnoseológico. Sin coartar en ningún caso a los autores en su libertad creadora o su lenguaje expresivo, éstos acumularon grandes conocimientos que propiciaron resultados artísticos personales y fundamentados en el ámbito del encargo (Ortega-Alonso 2019: 61).

\section{La Rendición de Bailén}

La vida bailenense gira en torno a la plaza General Castaños, como espacio público y de encuentro. Además, como su propio nombre indica, se trata de una plaza ligada a la Batalla de Bailén, hecho histórico que ha dado al municipio una fama internacional y que la ha situado en los libros de Historia. Debido precisamente a su singularidad,el proyecto Murales Conciencia inició su andadura en este lugar, uno de los puntos neurálgicos de la ciudad. Esta intervención de Ramón Pérez Sendra es una reinterpretación de la obra del pintor romántico Casado del Alisal, que plasmó en un lienzo la primera derrota de Napoleón en campo abierto, tomando como referencia La Rendición de Breda de Velázquez. El mural hace referencia a este hecho, pero además, a la teoría y la percepción del color: en la retina del ojo existen millones de células especializadas en detectar las longitudes de onda procedentes de nuestro entorno. Estas células fotorreceptoras, los conos y los bastones, recogen parte del espectro de la luz y, gracias al efecto fotoeléctrico, lo transforman en impulsos eléctricos, que son enviados al cerebro a través de los nervios ópticos, para crear la sensación del color.

\section{Los peces del Vivero}

La memoria social también es patrimonio. Durante más de tres generaciones, el estanque emplazado en el jardín del Parque D. Eduardo Carvajal (conocido popularmente como El Vivero) contó con una estimable población de carpas japonesas Cyprinus carpio koi, y fue protagonista del esparcimiento familiar bailenense. Antes de la llegada de la revolución tecnológica, este espacio era uno de los más frecuentados por las familias en días no lectivos, porque en él los niños podían jugar y pasear sin peligro, así como observar y dar de comer a estos peces de gran tamaño y colores llamativos. Por tanto, el valor patrimonial de este mural es inmaterial, y reside en el recuerdo de los habitantes de Bailén, pero la obra también aprovecha para tratar un tema de especial relevancia en la actualidad y que es uno de los principales causantes de pérdida de biodiversidad: las especies exóticas invasoras y su incidencia en los ecosistemas.

La existencia de una pared medianera construida en (y sin ser pintada desde) la década de los 60, justo enfrente del estanque, y la transformación continua de la localidad, ha convertido esta zona en un lugar de paso obligado para viandantes y escolares. El mural fue concebido por uno de 
los autores de este texto, Diego Ortega-Alonso, y para su ejecución contó con la colaboración de Ramón Pérez Sendra.

\section{Somos creación}

La cerámica es una de las señas de identidad de Bailén. Desde tiempos inmemoriales este municipio ha sido un pueblo alfarero. Desgraciadamente, en la época del plástico y las nuevas tecnologías la cerámica se ha visto relegada a un segundo término y los conocimientos heredados de generación en generación por este oficio, corren el peligro de la desaparición. En este sentido, Murales Conciencia apuesta por difundir conceptos físicos y químicos tomando como ángulo de referencia el proceso de producción cerámico. Este se encuentra repleto de gestos técnicos que transforman naturalmente el mineral de la arcilla extraído de los cerros bailenenses para crear recipientes funcionales de cerámica, tales como platos, vasos, cazuelas, orzas, cántaros, macetas, etc., que forman parte de nuestra vida cotidiana. La fabricación cerámica es capaz de unir por sí misma patrimonio y ciencia y se constituye como una de las señas de humanidad más características desde el periodo neolítico. La capacidad de generar recipientes duraderos que permitían almacenar y cocinar una serie determinada de productos revolucionaría, a partir de entonces, el modo de vivir de las comunidades humanas. La generación de excedentes y la sedentarización estuvieron íntimamente relacionados con la gestación de un nuevo producto y su proceso de manufactura. Tanto es así que prácticamente la mitología de todas las culturas recoge la creación de piezas cerámicas como sinónimo de divinidad. Numerosas leyendas centran el origen del mundo y del ser humano en el barro y también coinciden en situar a sus artífices como dioses que modelan el mundo a su imagen y semejanza. De forma paralela, el traspaso inmaterial de saberes técnicos de generación en generación ha propiciado la instauración de un sistema de transformación físico-químico fundamentado en el valor de la experiencia. Obra de Raúl Ruiz “El Niño de las Pinturas", su ejecución tuvo lugar aprovechando el contexto de la III Feria Internacional de Cerámica Artística de la Ciudad de Bailén, CERAMIBA 2018, y el V Congreso de la Asociación Española de Ciudades de la Cerámica.

\section{Simbiosis}

Más de seiscientas personas pertenecientes a centros educativos, asociaciones locales y colectivos en riesgo de exclusión social, participaron en la creación de este mural colaborativo de casi sesenta metros de largo, coordinado por el colectivo madrileño Boa Mistura. El resultado fue la confección de una frase del escultor Pablo Serrano, que habla de la necesidad de unir ciencia y arte, y no entenderlas como disciplinas separadas por barreras que en realidad, no existen, lo que supone una declaración de intenciones para el proyecto Murales Conciencia. El tema tiene que ver con utilizar la ciencia, el arte y el patrimonio urbano para despertar una conciencia cívica de respeto por lo que es de todos, en un espacio público marginal que se encontraba muy degradado y que, gracias a esta intervención, ha sido recuperado para su uso y disfrute. Así pues, este mural ha sido realizado por varios colectivos que abarcan desde niños/as y jóvenes, hasta padres y madres, personas mayores, entidades del movimiento asociativo, profesorado o personas con discapacidad [figura 1].

\section{Hawking y la universalidad del AOVE}

¿Qué tiene que ver Stephen Hawking con Bailén? Se trata de una pregunta recurrente que se suele plantear cuando se visualiza por primera vez este mural ubicado en la Plaza de Prim. Con la elección de uno de los grandes científicos de la historia de la humanidad, Adrián Pérez "Manomatic" podía cumplir con cada uno de los criterios que hacen de Murales Conciencia un proyecto singular. En primer lugar, en este mashup artístico ha inmortalizado a uno de los padres

Tabla 1.- :Relación de entidades y personas involucradas en la ejecución colectiva del mural Simbiosis.

\begin{tabular}{|l|c|}
\hline COLEGIOS/ENTIDADES & TOTAL \\
\hline CEPr 19 DE JULIO (todo el alumnado) & 70 \\
\hline CEPr GENERAL CASTAÑOS / CEIP PEDRO CORCHADO (50 alumnos/colegio) & 100 \\
\hline COLEGIO SAGRADO CORAZÓN (6॰ y ESO) & 100 \\
\hline CEIP VIRGEN DE ZOCUECA (50), IES MEDINA RIVILLA (50) & 100 \\
\hline $\begin{array}{l}\text { PerSOnaS CON disCapacidad intelectual y familias: TALLER OCUPACIONAL (20 personas), Asoc. AFAMP (30 personas), } \\
\text { CLUB DEPORTIVO ALI-UP (25 perSOnas) }\end{array}$ & 75 \\
\hline ALUMNADO, AMPA Y PROFESORADO CONSERVATORIO REINA SOFÍA DE BAILÉN & 150 \\
\hline CENTRO DE DÍA DE MAYORES DE BAILÉN & 15 \\
\hline total participantes & 610 \\
\hline
\end{tabular}


del conocimiento de las Teorías del Universo que exploran lo que somos y de dónde venimos, en el mismo año de su muerte (2018). En segunda instancia, se refuerza la necesidad de difundir que la inclusión en nuestra sociedad es posible y debe ser una realidad, si se prestan los apoyos necesarios. Por último, con el guiño al olivar en el estampado de aceitunas de la camisa de Hawking, su autor pone de relieve que el aceite de oliva, una seña de identidad gastronómica de la provincia de Jaén, es un producto universal que nos pertenece a todos. Porque, recordemos, este mural se encuentra ubicado en un espacio en el que la gastronomía (mercado de abastos) y la cuestión social e inclusiva (Centro de Servicios Sociales de Bailén) encuentran gracias a la intervención de Manomatic, la unión perfecta a través de esta visión tan innovadora de Stephen Hawking [figura 2].

\section{Topo-grafías}

La topografía ha sido siempre una disciplina científica y técnica esencial para erigir monumentos enigmáticos de la antigüedad, aunque también ha servido a los geógrafos para conocer las propiedades y naturaleza del territorio que ha sido ocupado por las comunidades humanas. De igual modo, era imprescindible en el arte de la guerra. Por estas razones, el espacio elegido para llevar a cabo la realización de un mural ligado a la importancia de la medición, fueron las paredes y el ventanal de la terraza del Museo de la Batalla de Bailén. El conocimiento del territorio supone obtener ventaja en cualquier ámbito que tenga la pretensión de realizar alguna actividad en él. Lógicamente, en los conflictos bélicos el dominio del paisaje ha jugado tradicionalmente un papel fundamental a la hora de decantar la victoria hacia uno de los bandos enfrentados. Desde el punto de vista histórico, la idiosincrasia orográfica de Bailén y el conocimiento de ésta por parte del General Reding fue determinante para vencer por primera vez en campo abierto a la grande armée de Napoleón. La posición sobreelevada de la línea de artillería española acabó rompiendo en dos la división central gala sin causar un número de bajas numerosas entre sus soldados. Al igual que lo sucedido en las Termópilas, Zama, o las Navas de Tolosa, las tropas españolas, menores en formación y número, consiguieron desorganizar al ejército más poderoso del mundo de ese momento. El mural realizado por Ramón Pérez Sendra es una reinterpretación personal del mapa topográfico de la época. En el centro aparece esbozado el Bailén de 1808 sobre una gama cromática de curvas de nivel. A la izquierda se representa al general Reding, principal estratega sobre el campo del bando español y buen conocedor del medio geográfico. A la derecha se muestra al general Dupont, el máximo dirigente de los regimientos franceses obligado a capitular.

\section{Reforestando}

Esta intervención artística de alrededor de $300 \mathrm{~m}^{2}$, ha transformado por completo una plaza absolutamente degradada de la localidad y la ha reconvertido en un lugar de paseo, esparcimiento y contemplación. "Reforestando" es un proyecto de Doa Ocampo, que nace con la voluntad de recuperar espacios a través de temáticas vegetales relacionadas con el entorno donde se ubican. En Bailén son cinco las especies escogidas: el olivo, el clavel silvestre, la coscoja, la lavanda y el paloduz. Todas ellas están ligadas al municipio de diversas maneras: algunas, por ser plantas de cultivo tan importante para la economía local como el olivar; otras como el paloduz, cuya presencia en las cuencas de los ríos Rumblar y Guadiel ha implicado su consumo por parte de varias generaciones y alude a la memoria colectiva local; el resto, por tratarse de especies ligadas al ecosistema mediterráneo y a la flora de Sierra Morena. Las especies de flora autóctona representadas en este mural están estéticamente vinculadas a la ilustración botánica, utilizando colores planos de gamas frías y líneas que perfilan las sinuosas formas de la vegetación elegida por su autora.

\section{Bosque de neuronas}

Ramón Pérez Sendra aborda la intervención de un espacio de rampas sumamente degradado que conduce desde el Paseo de las Palmeras (uno de los puntos neurálgicos de la localidad) hasta un área vinculada a un parque infantil, muy próxima a las intervenciones de Doa Ocampo y la obra colectiva coordinada por Boa Mistura. La perspectiva de las rampas, con el Paseo de las Palmeras y el Monumento a la Batalla de Bailén de fondo, permite al autor la creación de una anamorfosis en la que los motivos pictóricos y el paisaje coinciden desde un determinado punto de vista, y unen su temática con el lugar, a través de una intrincada maraña de células nerviosas y colores, de la mezcla del paisaje y la composición del mural, donde las raíces de las palmeras son dendritas, y viceversa, en el 85 aniversario del fallecimiento de Santiago Ramón y Cajal [figura 3].

\section{Cántaros comunicantes}

Desde la época romana, los recipientes cerámicos se utilizaban para lograr el equilibrio de los líquidos contenidos en vasos comunicantes. La presión atmosférica y la gravedad son constantes en cada recipiente, por lo que la presión hidrostática es siempre la misma, sin influir su geometría ni el tipo de líquido. Esta es la base a través de la cual el muralista jiennense José Fernández Ríos construye un trampantojo que enlaza directamente con el contexto histórico y el patrimonio inmaterial de la localidad, a través de la figura de una mujer y su cántaro, que evoca al papel crucial que tuvieron las aguadoras en el desarrollo de la Batalla de Bailén y que Benito Pérez Galdós reflejase en una de sus obras dedicada a este suceso:

“Es verdad que de Bailén salían en bandadas multitud de mujeres con cántaros de agua para refrescarnos; pero de este socorro apenas podía participar una pequeña parte 
de la tropa, porque los que estaban en el frente no tenían tiempo para ello. Más de una vez aquellas valerosas mujeres se expusieron al fuego, penetrando en los sitios de mayor peligro, y llevando sus alcarrazas a los artilleros del centro. En los puntos de mayor peligro, y donde era preciso estar con el arma en el puño constantemente, nos disputábamos un chorro de agua con atropellada brutalidad: rompíanse los cántaros al choque de veinte manos que los querían coger, caía el agua al suelo, y la tierra, más sedienta aún que los hombres, se la chupaba en un segundo." (Pérez Galdós, Benito: «Bailén». Episodios Nacionales, 1.a Serie, IV episodio)

\section{Consideraciones finales}

Murales Conciencia es un proyecto singular que se alinea con la nueva definición de museo propuesta por el sector más progresista del ICOM. De acuerdo con esta, no importaría tanto el continente como el contenido y la relación que este último tenga con las personas que entran en contacto con él. Más allá de la percepción propia que se tenga de las obras que conforman el proyecto, y atendiendo principalmente a diversos condicionantes contextuales y sensoriales, los murales se encargan de narrar discursos científicos que parten de valores patrimoniales intrínsecos a la sociedad bailenense. Se trata esta de una singularidad que ha propiciado el nacimiento de un sentimiento de apropiación y arraigo en un entorno plenamente rural.

Existen datos que permiten comenzar a apreciar el potencial turístico que la configuración de una ruta física y virtual de arte público puede llegar a generar. La repercusión en el flujo turístico, y la percepción y valoración pública del proyecto, desde un punto de vista cualitativo y cuantitativo, ha propiciado unos resultados reflejados en los mecanismos de evaluación de impacto del proyecto y en el interés que este ha suscitado tanto en la población como en los diferentes eventos en los que ha sido presentado.

Tabla 1.- Herramientas, acciones, indicadores y resultados de los mecanismos de evaluación de impacto del proyecto Murales Conciencia.

\begin{tabular}{|c|c|}
\hline HERRAMIENTA/ACCIÓN & INDICADOR \\
\hline Murales colaborativos & $\begin{array}{l}\text { Simbiosis de Boa Mistura. } 610 \text { participantes de diferentes perfiles sociales (Datos desglosados en Tabla 1). } \\
\text { Mural colaborativo (exhibición) en Encuentro Guadalinfo de Punta Umbría, Huelva (más de } 800 \text { dinamizadores de } \\
\text { Centros Guadalinfo pudieron verlo, más de } 8000 \text { visualizaciones en Facebook). } \\
\text { Debido a que todos los murales se han realizado en el entorno urbano, es prácticamente imposible contabilizar el } \\
\text { número de personas que han podido asistir directamente a sus procesos de creación o visitarlos in situ. Nos remitimos } \\
\text { al censo de la localidad de } 2018 \text { ( } 17820 \text { habitantes) para dar una cifra referencial. } \\
\text { Número de visitantes que ha recibido el Museo de la Batalla de Bailén en } 2019 \text { (enero-octubre): 12000, nacionales } \\
\text { e internacionales. Aunque no podamos asegurar que hayan realizado la ruta diseñada al completo, sí podemos } \\
\text { certificar que han podido observar el mural Topo-grafías. }\end{array}$ \\
\hline $\begin{array}{l}\text { Participación en congresos, } \\
\text { jornadas, conferencias... }\end{array}$ & $\begin{array}{l}\text { V Congreso de la Asociación Española de Ciudades de la Cerámica. Bailén, Jaén (Junio 2018). Creación de mural } \\
\text { adscrito al programa del congreso. } \\
30^{\circ} \text { Encuentro de APECV (Asociación de Profesores de Expresión y Comunicación Visual) y } 3^{\circ} \text { Congreso de la RIAEA } \\
\text { (Red Iberoamericana de Educación Artística). Coimbra, Portugal (Junio-julio 2018). Participación con comunicación } \\
\text { oral. } 200 \text { asistentes aprox. } \\
\text { Jornadas Murales Conciencia. } 5 \text { conferencias y } 1 \text { mesa redonda. Museo de la Batalla de Bailén. (Enero 2019). No de } \\
\text { asistentes/conferencias: } 60 \text { personas (en su mayoría, alumnos del Máster de Investigación y Educación Estética y del } \\
\text { Máster de Patrimonio de la Universidad de Jaén, y también personas interesadas de la localidad y de alrededores). } \\
\text { Participación en debate abierto del grupo de arte urbano del GElIC: Museos de arte urbano: competencias y } \\
\text { posibilidades. 20a Jornada de Conservación de Arte Contemporáneo del Museo Nacional Centro de Arte Reina Sofía: } \\
40 \text { personas aprox. (Marzo 2019). } \\
\text { Congreso de Comunicación Social de la Ciencia. Universidad de Burgos, Asociación Española de Comunicación } \\
\text { Científica (Octubre 2019). Comunicación Flash oral. }\end{array}$ \\
\hline $\begin{array}{l}\text { e-mailing especializados a } \\
\text { los prescriptores y actores } \\
\text { seleccionados }\end{array}$ & $\begin{array}{l}\text { № de destinatarios de la lista de distribución de contactos del ayuntamiento: } 33 \text { medios de comunicación. } \\
\text { Lista de comunicación de la Red Guadalinfo. }\end{array}$ \\
\hline $\begin{array}{l}\text { Video-clips en canales de } \\
\text { divulgación virtuales }\end{array}$ & $\begin{array}{l}9 \text { videoclips (uno por cada mural ejecutado). } \\
\text { Visualizaciones totales Youtube: } 2329 . \\
\text { Videoclips en Instagram: } 9 . \\
\text { Visualizaciones totales: } 603 \text {. } \\
\text { (Se reflejan los datos de las publicaciones propias del proyecto, si bien los datos de visualizaciones son muy superiores } \\
\text { en los perfiles sociales profesionales de los artistas participantes). }\end{array}$ \\
\hline
\end{tabular}



turístico para promoción y difusión del proyecto (a través de difusión en vídeos,

El proyecto Murales Conciencia se integra dentro del paquete turístico de la en estos eventos

Integración de recorrido virtual en Google My Maps
Ferias y muestras del sector cartelería y folletos) localidad que se promociona

Feria de los Pueblos de Jaén (Marzo de 2018 y 2019) En torno a 15000 visitantes cada edición.

Tierra Adentro. Jaén (Noviembre de 2018). En torno a 20000 visitantes.

FITUR 2018 En torno a 70000 visitantes.

FITUR 2019 En torno a 60000 visitantes.

( $N$ o de encuentros mantenidos y contactos generados: 12. Contactos con empresas turísticas provinciales. 20 Contactos con empresas turísticas autonómicas. 100 Contactos con empresas turísticas nacionales e internacionales).

https://www.google.com/maps/d/u/1/edit?hl=es\&mid=1vPTZvlf3SNf3sH9UaamNORg0WCJ80YGU\&ll=38.09404309 537841\%2C-3.779163516671815\&z=17 [última consulta:2-11-2019]

\begin{tabular}{|c|c|}
\hline Portales web & $\begin{array}{l}\text { No de visitas a portal Ayuntamiento en el primer trimestre de 2018: } \\
\text { Enero (Visitas } 14.525 \text { | Número de páginas visualizadas 42.908). } \\
\text { Febrero (Visitas } 14.510 \text { | Número de páginas visualizadas 45.266). } \\
\text { Marzo (Visitas } 16.501 \text { | Número de páginas visualizadas 49.233). } \\
\text { En cuanto a la web del Museo de la Batalla de Bailén, donde también se encuentra ubicado el link a la exposición } \\
\text { virtual, los datos estadísticos del primer trimestre de } 2019 \text { han sido los siguientes: } \\
\text { Enero - (Visitantes - } 2157 \text { | Páginas visitadas : 4000) } \\
\text { Febrero - (Visitantes - } 1787 \text { | Páginas visitadas : 3533) } \\
\text { Marzo - (Visitantes - } 1634 \text { | Páginas visitadas : 4512) }\end{array}$ \\
\hline $\begin{array}{l}\text { Notas de prensa/apariciones } \\
\text { en medios }\end{array}$ & $\begin{array}{l}\text { No de notas de prensa/comunicaciones: } \\
\text { Artículos en Diario Ideal: } 2 \text { (uno de ellos, portada del diario en su edición impresa). Volumen de público de los medios } \\
\text { que publican: Diario Ideal. } \\
\text { Artículo en Diario Jaén: } 1 \text { ( } 66000 \text { lectores según Estudio General de Medios 2013). https://www.diariojaen.es/ } \\
\text { provincia/bailen/murales-conciencia-impulsa-el-arte-urbano-IA5453749 [última consulta:2-11-2019] } \\
\text { Los datos facilitados por el medio Bailén Diario, son de } 39836 \text { sesiones en su página en } 2018 . \\
\text { Los datos de alcance de la Red Guadalinfo, que se ha realizado numerosas acciones de promoción y difusión del } \\
\text { proyecto (como ya se ha indicado anteriormente) pueden consultarse aquí http://consorciofernandodelosrios.es/ } \\
\text { descargas/Informe_POA_2018.pdf [última consulta:2-11-2019] } \\
\text { Artículos en blog de Guadalinfo: } 2 \\
\text { Nota de prensa de FECYT } \\
1 \text { entrevista en Radio Municipal de Bailén. } \\
1 \text { aparición en las noticias autonómicas de Canal Sur Televisión (septiembre 2019). } \\
1 \text { reportaje en el programa Andalucía Directo, de Canal Sur Televisión (Octubre 2019). }\end{array}$ \\
\hline Perfiles sociales & $\begin{array}{l}\text { Cuenta en Instagram } \\
\text { Página Facebook. }\end{array}$ \\
\hline $\begin{array}{l}\text { Acciones de Divulgación de } \\
\text { la Fundación Descubre* }\end{array}$ & $\begin{array}{l}\text { Datos recabados por la fundación sobre el nº de visitas al portal EXPLORIA CIENCIA en 2018: } 487 . \\
\text { *(Datos facilitados por la Fundación Descubre }\end{array}$ \\
\hline $\begin{array}{l}\text { Publicaciones en revistas } \\
\text { especializadas }\end{array}$ & Artículo “Murales Conciencia”. Locvber, Revista Científica de Patrimonio (2018), Vol 2: 187-194.ISSN: 2603-5847. \\
\hline
\end{tabular}


No obstante, la adscripción de pertenencia por parte de la mayoría de un colectivo social, permite divulgar ciencia y que se entienda el patrimonio material e inmaterial como algo de dominio público, que merece ser conocido, conservado y promovido por el conjunto de la sociedad. La creación de esta colección museográfica en la calle ha favorecido el surgimiento de una conciencia colectiva que reivindica la necesidad de mantener, proteger y preservar el espacio público, promoviendo la gestación de una nueva realidad urbana democratizadora y responsable con su medio. El desarraigo individualista impuesto por la modernidad (Hernando 2012) ha empezado a romperse gracias a la creación de obras que hablan de lo que une a la comunidad.

La ejecución de algunos de los murales se realizó coincidiendo con importantes eventos celebrados en la localidad, como la Recreación de la Batalla de Bailén 2017, con alrededor de 4500 visitantes, o la Feria Internacional de Cerámica Artística CERAMIBA 2018 y el V Congreso Nacional de Ciudades de la Cerámica (3600 visitantes entre ambos eventos). Sólo en estas dos actividades, el municipio bailenense recibió más de 8000 visitantes de fuera de la localidad que pudieron ver los procesos de creación de los murales y, por tanto, la transformación de la ciudad.

¿Podría ser Murales Conciencia un referente o método marco para actuar en otros municipios? No necesariamente, pero sí puede servir como ejemplo para un mundo rural cada vez más desarraigado, que intenta hacer frente a crisis de identidad que condicionan su propia existencia. Un punto de partida podría ser empezar a plantear enfoques innovadores que garanticen una adaptación sostenible y sensible a los cambios asociados a la crisis económica de la última década, que han supuesto una fuerte contracción de la población rural (Pinilla y Sáez 2017). Si estas líneas sirven, al menos como reflexión, habremos cumplido con creces los objetivos planteados cuando este proyecto, ahora materializado, empezó a forjarse como idea. En nuestro caso la clave reside en recordar y potenciar de dónde venimos para proyectar un presente prometedor que vaticine un futuro sostenible. Los museos tienen una misión crucial en esta tarea y Murales Conciencia empieza a cumplirla.

\section{Notas}

[1] Tal y como Rosa Gasol, Restauradora de la Diputació de Barcelona, expuso de forma clara durante la reunión paralela a la $20^{a}$ jornada de Conservación de Arte Contemporáneo celebrada en el Reina Sofía en febrero de 2019.

[2] DONAIRE, G (2012). Los ladrillos se amontonan en Bailén. El País. Fecha de última consulta: 23/08/2019 https://elpais.com/ ccaa/2012/06/16/andalucia/1339865809 126996.html [última consulta:2-11-2019]
[3] FUNDACIÓN DESCUBRE (2019). Murales Conciencia. Exploria Ciencia. Fecha de última consulta: 23/08/2019 https:// fundaciondescubre.es/recursos/murales-conciencia/ [última consulta:2-11-2019]

[4] ORTEGA-ALONSO, D (2019). Lista de reproducción de vídeos del proyecto Murales Conciencia. Canal Youtube del Centro Guadalinfo de Bailén. Fecha de última consulta: 28/08/2019 https://www.youtube.com/playlist?list=PLX3qa9QSsW56aWlcQWjPrZSM62b-pG6- [última consulta:2-11-2019]

\section{Bibliografía}

BAUMAN, Z. (2010) Mundo-consumo: ética del individuo en la aldea global. Editorial Paidós Mexicana.

CÁRDENAS, A., AGUDO, J. A. (2012). La Edad del Barro. Granada: Port-Royal.

CHRISTENSEN, C. M., RAYNOR, M. E., MCDONALD R. (2015) “What is disruptive innovation." Harvard Business Review 93.12 : 44-53.

FUNDACIÓN ESPAÑOLA PARA LA CIENCIA Y LA TECNOLOGÍA (2018). "Percepción Social de la Ciencia y la Tecnología en España". Recuperado de: https://icono.fecyt.es/sites/default/ files/filepublicaciones/18/epscyt2018 informe 0.pdf [última consulta:2-11-2019]

GARCÍA, J., GARCÍA. M. R. (2016). “El turismo cultural en Málaga: Una apuesta por los museos." International journal of scientific management and tourism 2.3: 121-135.

HERNÁNDEZ, F. (1993): "Evolución del concepto de Museo." Revista General de Información y Documentación 2.1:85-97.

HERNANDO, A. (2012): La fantasía de la individualidad. Sobre la construcción sociohistórica del sujeto moderno. Buenos Aires: Katz editorial.

ICOM (2019): "Definición de Museo". Recuperado de: https://icom. museum/es/actividades/normas-y-directrices/definicion-delmuseo/ [última consulta:2-11-2019]

LORA, P., ROCHA, D. (2016). "Promoción de la innovación social a través de la utilización de metodologías participativas en la gestión del conocimiento". Equidad y Desarrollo, (25): 159-178.

MARTOS, E., y GARCÍA, A. E. M. (2014). "Artefactos culturales y alfabetización en la era digital: discusiones conceptuales y praxis educativa". Teoría de la educación. Revista Interuniversitaria, 26 (1 (en-jun), 119-135.

ORTEGA-ALONSO, D. (2018). "Murales Conciencia". Locvber, Vol 2: 187-194

ORTEGA-ALONSO, D. (2019). “Personalidad artística en ilustración científica: Un estudio de caso." Tercio Creciente, 15, págs. 55-72. 
PÉREZ GALDÓS, B. (2014): Episodios Nacionales (todas las series, con índice activo). E-artnow.

PINILLA, V., SÁEZ, L. A. (2017). “La despoblación rural en España: génesis de un problema y políticas innovadoras". CEDDAR, Zaragoza.

REMESAR, A. (2000). “@rte contra el pueblo. Tensiones entre la democracia y el arte público." Publicacions de la Universitat de Barcelona. Monografías socioambientales 24

REMESAR, A. (2019). “Del arte público al post-muralismo. Políticas de decoro urbano en procesos de Regeneración Urbana." On the W@terfront. Public Art. Urban Design. Civic Participation. Urban Regeneration, 61(1), 3-65.

SERRANO-MARTÍNEZ, C. (2016). “El arte urbano como instrumento de empoderamiento y visibilización. El Festival de Asalto." Comunitania: revista internacional de trabajo social y ciencias sociales, 11, 9-26.

SILBERBERG, T. (1995). "Cultural Tourism and business opportunities for museums and heritage sites". Tourism Management, Vol.16, no. 5: 361-365.

TOHARIA, M. (2010). "Políticas de comunicación universitaria y divulgación científica." La Cuestión Universitaria 6: 95-102.

VISCONTI, L. M., SHERRY JR, J. F., BORGHINI, S., ANDERSON, L. (2010). "Street art, sweet art? Reclaiming the "public" in public place". Journal of consumer research, 37(3), 511-529.

\section{Referencias web}

Fundación Española para la Ciencia y la Tecnología. Informe de resultados de Percepción Social de la Ciencia y la Tecnología (2018). Referencia web: https://icono.fecyt.es/informes-ypublicaciones/percepcion-social-de-la-ciencia-y-la-tecnologiaen-espana [última consulta 24-10-2019]

Conferencia OMT/UNESCO: El turismo cultural mantiene las comunidades y el patrimonio vivo. Referencia web: http:// www2.unwto.org/es/press-release/2018-12-05/conferenciaomtunesco-el-turismo-cultural-mantiene-las-comunidades-y-elpat [última consulta 24-10-2019]

Ruta virtual de Murales Conciencia en la plataforma Explora Ciencia, de la Fundación Descubre. Referencia web: https:// idescubre.fundaciondescubre.es/exploria-ciencia/muralesconciencia/ [última consulta 24-10-2019]

Ruta virtual de Murales Conciencia en página web del Ayuntamiento de Bailén. Referencia web: http://www.ayto-bailen. com/index.php/component/content/article/95-news/2781murales-conciencia [última consulta 24-10-2019]

Museo de la Batalla de Bailén. Referencia web: http:// museobatalladebailen.es [última consulta 24-10-2019]

\section{Autor/es}

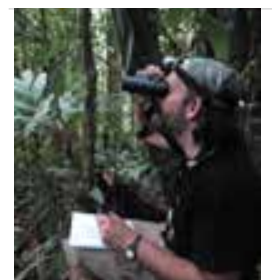

\section{Diego Ortega-Alonso}

Universidad de Jaén

info@diegortegalonso.com

Licenciado en Bellas Artes por la Universidad de Granada. Máster en Investigación y Educación Estética y Doctorando en Patrimonio por la Universidad de Jaén. Sus líneas de trabajo se extienden en torno a temas como la investigación en artes, la divulgación de la ciencia a través del arte, la ilustración científica, la innovación social o la inclusión de las personas con discapacidad intelectual y colectivos en riesgo de exclusión social. Agente de Innovación del Ayuntamiento de Bailén en la Red Guadalinfo, es responsable e investigador principal del proyecto Murales Conciencia, financiado por FECYT.

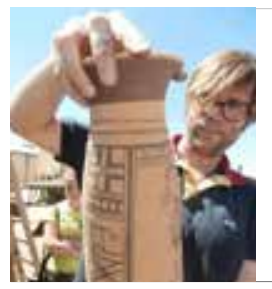

\section{Juan Jesús Padilla Fernández}

Patrimonio del Ayuntamiento de Bailén juanjpad@ucm.es / jjpadilla@ayto-bailen.com

Doctor internacional en Historia y Arqueología por la Universidad Complutense de Madrid con la calificación de Cum Laude. Actualmente gestiona y dirige el área de Patrimonio del Ayuntamiento de Bailén, así como el Museo de dicha localidad, centrado en recordar la célebre Batalla de Bailén. Desde esta posición, ha promovido múltiples actuaciones de carácter cultural que han ayudado a enriquecer y fomentar el patrimonio material e inmaterial de este municipio jiennense. Uno de ellos es precisamente Murales Conciencia, financiado por FECYT. 

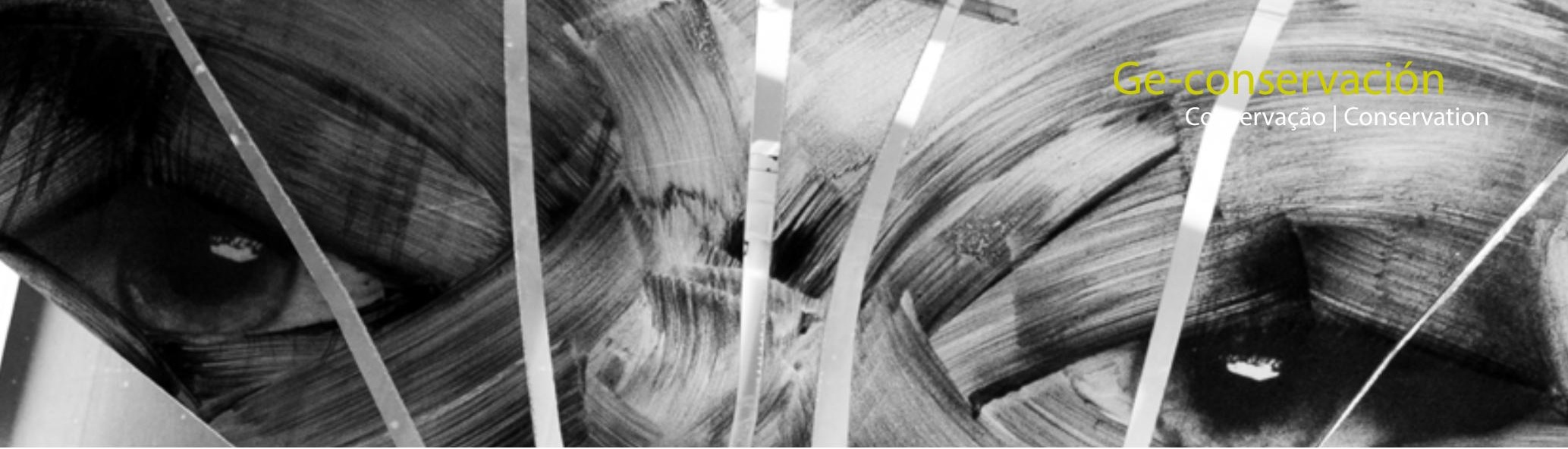

\title{
Musealizar el Arte Urbano. Preguntas, relatos y complejos tras Street Art-Banksy\&Co
}

\author{
Jordi Pallarès
}

Resumen: Probablemente sea todo un reto musealizar un fenómeno artístico tan presente en el siglo XXI como es el Arte Urbano. El proyecto Street Art-Banksy\&CO marcó en 2016 un hito incómodo en Bolonia al respecto, poniendo sobre la mesa cuestiones delicadas que aún hoy posicionan a artistas y a comisarios de toda Europa. Reacio y con reservas, el sector del arte contemporáneo empieza a incluirlo en sus respectivos espacios y colecciones, beneficiándose del mercado sin dejar de observarlo con el mismo intrusismo que el de los artistas urbanos cuando otros intervienen las calles.

Sin olvidar intereses económicos, autorías e ilegalidades, siguen existiendo lagunas sobre cómo se debe abordar el Arte Urbano indoor con cierta profundidad y cuál es el relato a construir desde la institución. Trampas y malas prácticas museísticas que siguen desarrollándose a nivel internacional.

Palabras clave: arte urbano, museo, comisario, artista urbano, espacio público, práctica artística, mediación

\section{Bringing street art into the museum. Questions, narratives and complexes after Street Art- Banksy\&Co}

Abstract: It is a challenge to present in a museum an artistic phenomenon as unique as Urban Art in the $21^{\text {st }}$ Century. The project Street Art-Banksy \& CO in Bologna in 2016 marked an uncomfortable milestone in this regard, putting on the table delicate issues that still challenge artists and curators all over Europe. Reluctantly and with reservations, the contemporary art establishment began to include Urban Art it in their respective spaces and collections, benefiting from its popularity while observing it with the same feeling of intrusion as that felt by urban artists when others intervene in the streets.

In terms of economic interests, authorships and legalities, there still exists a challenge in determining how Urban Art should be presented indoors and avoiding poor museum practices as art institutions continue to develop Urban Art exhibitions.

Key words: street art, museum, curator, street artist, public space, artistic practice, cultural mediation

\section{Introducción}

No debería ser nada nuevo que a una práctica artística contracultural, subversiva y urbana en muchos sentidos se le dé visibilidad en un museo como lugar institucional que legitima lo que es y no es arte. Otro lugar público del propio espacio de la ciudad en el que el propio público -hoy más activo, si cabe - actúa en tanto que prosumer contemporáneo (Fontdevila 2015: 15). Con unos códigos preestablecidos de actuación, se trata de un lugar del que se esperan puentes e interpelación con la ciudadanía por parte de profesionales especializados que dilucidan y ordenan las prácticas artísticas y en el que la puesta en escena de las mismas no deja de ser una convención social más que, paradójicamente, tiende a autorreferenciarse y a ser poco empática con el Otro.

Pensemos, por ejemplo, en la revisión del punk que comisarió Andrew Bolton para el MET de Nueva York, "Punk: Chaos to Couture" en 2013. Un enfoque estético centrado, sobre todo, en la moda para un fenómeno que ha generado cientos de tendencias e imágenes desde que surgió a finales de los setenta. Más cercano al arte contemporáneo y con su espíritu más vivo fue "Punk. Sus 
rastros en la creación contemporánea". Un proyecto de David G. Torres en 2015 que, sin pretender exhibir lo que fue el movimiento, exploró quizá lo más interesante de este: su legado. Ambas revisiones serían ejemplos de cómo grandes instituciones museísticas —el MET de Nueva York por un lado, y la extraordinaria coproducción entre el MACBA, el CA2M, el ARTIUM, el Museo Universitario del Chopo y la propia Ciudad de México por otro, museos públicos todos dependientes de distintas instituciones gubernamentales y universitarias en sus respectivos países - asumen dar visibilidad a un movimiento contracultural cuyo uno de sus lemas fue No Future. Como corriente, el punk arroyó más de lo pretendido con unos mensajes antisociales que, como todo fenómeno contracultural, acabaron fagocitados por la industria cultural del momento. Más allá de cierta rebeldía contra el sistema respecto a la situación política y social de sus respectivos contextos, la música, la moda y las distintas expresiones de este y otros movimientos subculturales terminaron necesitando de una estructura capitalista para difundir sus propios mensajes y productos en determinados canales. La lógica de estos procesos no exime a ninguno de sus protagonistas de cierta responsabilidad: los que gestionan lo público, las empresas privadas que pueden lucrarse con ello, y los que producen de manera alternativa y precaria material que cuestiona ese sistema. Contradicciones propias de movimientos que surgen a contracorriente pero que recurren a lo oficial y establecido para definir su identidad, provocando y sintiendo a la vez la recepción de esa provocación en la esfera pública. Una cuestión que no debería afectar el legado de su actitud vital pues el empoderamiento del DIY "háztelo tú mismo" va mucho más allá.

Entre las actividades programadas alrededor del proyecto de 2016, se organizaron en el MACBA seminarios y debates con profesionales de variados perfiles partiendo de la premisa de que "el punk ejemplifica una actitud hecha de rabia, inconformismo e incorrección, pero también de contradicciones e incerteza" [1]. Al igual que el Hip-Hop y retomando las palabras de Eloy Fernández Porta en los seminarios antes mencionados, el punk podría definirse como una subcultura que se construye con tensiones que reflejan y reelaboran elementos de la cultura dominante. Tensiones que suelen ser percibidas como paradójicas en el sentido filosófico y contradictorias en el sentido moral pero que forman parte de su propia dinámica. Esos"sentimientos encontrados" formaron parte de un debate que reflejaba una voluntad de transmitir las trampas propias del estudio y la aproximación académica e institucional de algo que surge con la intención de ser lo contrario. Una visión no siempre aceptada por parte de aquellos y aquellas que lo practican pues algunos de ellos consideran que la parte experiencial de lo vivido en primera persona es fundamental para poder hablar de ello. Cierta razón no les falta, aunque también es ciertamente recomendable la perspectiva de no estar inmerso en un tema para poder abordarlo, y nada desdeñable subestimar la mirada cenital y transdisciplinar que pueden aportar ciertos estudios académicos y culturales al respecto. De ahí la importancia de contextualizar y analizar lo testimonial y lo documental en base a un necesario trabajo de campo. Precisamente, esa perversión en abordar lo popular desde cierta autoridad intelectual está conectada con un elemento clave en lo museístico: la mediación.

\section{Mediar con lo público: retos museísticos y curatoriales}

Si entendemos la mediación como la posibilidad de realizar y sostener una tensión persistente entre el arte y la sociedad (Fontdevila 2018: 186), como una forma de acompañar e implicar al espectador en un discurso a construir, esta acaba siendo fundamental para abordar fenómenos que surgen como disruptivos en el espacio y la esfera públicas. Lejos de la visión paternalista y colonialista de la estructura museo, existen nuevas maneras de entender este espacio como lugar público y la práctica curatorial como un proceso en el que cambian las relaciones de poder en la propia práctica artística por la necesidad de tener presente al público como un ente heterogéneo y transformador. Ese romper barreras con la ciudadanía es debido en gran parte a las profundas reflexiones que la práctica del arte público (no del arte urbano) estableció en su momento con respecto a los tradicionales espacios de exhibición (Baldini 2016: 108). No en vano, artistas y comisarios son ciudadanos y, como tales, contribuyen en un proceso colaborativo a reforzar la misión pública del museo (Fontdevila 2014: 3). El no perder de vista la ciudad y la ciudadanía en determinados perfiles suele aportar miradas cuando menos interesantes (Pallarès 2017: 13), y estos son (o deberían ser) bienvenidos en determinadas prácticas artísticas urbanas en las que la autoría intelectual y la legal no siempre están resueltas. La reivindicación y asunción de una intervención ilegal firmada y la propiedad material de la misma son dos cuestiones distintas que deberían poder ser debatidas en ese otro lugar público que un museo institucional representa en el contexto de la ciudad y lo urbano. No el de cualquier ciudad, sino en un escenario local con su propia historia donde lo sociopolítico retumba directamente sobre lo cultural y donde piden conectarse con lo ocurrido en otros contextos parecidos. De ahí la importancia de potenciar y reflejar este tipo de experiencias en y desde el museo para con lo que se ha venido llamando cultura popular o baja cultura. Contrariamente a lo que muchos artistas y comisarios piensan, no se trata de prácticas colaborativas, pero sí de procesos en los que el público juega un importante e ineludible papel.

Desde la pedagogía crítica, insertada ya entrado el siglo XXI desde la disidencia en ciertos Departamentos de Educación y Acción Cultural de museos (DEAC) y en determinados agentes culturales, se desea que dichos museos sean un escenario para el debate alrededor de los posibles modos de producir cultura (Fontdevila 2014: 13). Y ese debate pasa más por formular preguntas (a veces incómodas para una institución o la ideología del correspondiente gobierno que la apoya, para los profesionales involucrados que se ven expuestos o para el propio espectador que busca 
la satisfacción de reconocerse en el saber) y propiciar la producción de conocimiento, que por elaborar verdades (absolutas) y sentencias que se empeñen en explicar las cosas desde una sola óptica. "El espectador no accede a la cultura en el momento en que se libera de la política cultural, más bien el poder del público aumenta en el momento en que se le reconoce como un mediador más capaz de que su "aventura intelectual" se traduzca y tenga impacto en la configuración de la política cultural" (Fontdevila 2014: 15).

\section{Street Art-Banksy \& CO: el comisario como vándalo}

Las preguntas formuladas por G. Torres en la exposición o las que se verbalizaron en el debate sobre el movimiento desde el MACBA [2] pretendían dar visibilidad a lo que el público puede y debe poder contribuir a formular. Algo tan básico como construir y compartir discurso. Esa honestidad resulta imprescindible a veces para que esa inevitable perversión no resulte ni se proyecte ingenua y pueda, a la vez, conectar con la estructura profunda de todos aquellos y aquellas (coetáneos o no con el movimiento) interesados en ver y compartir lo que se ha hecho. [figura 1]

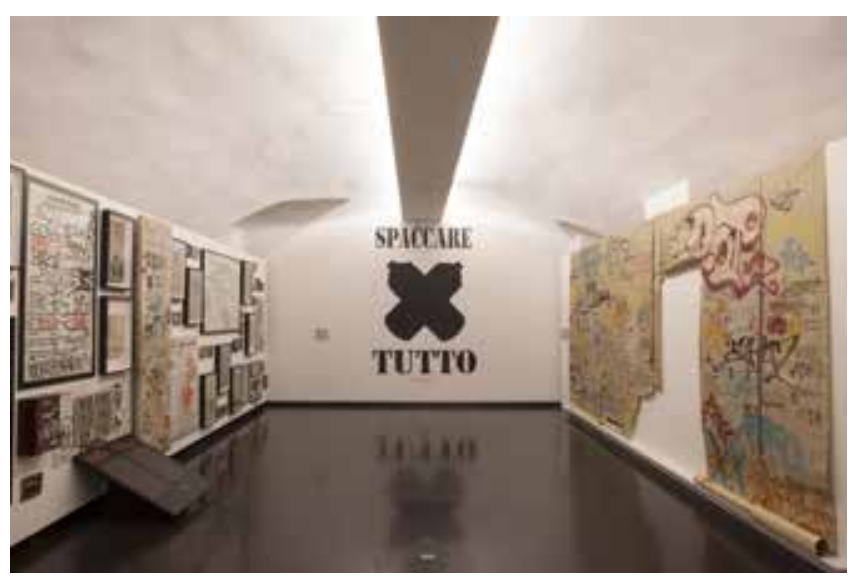

Figura 1.- Fragmento de SABC, 2016. Foto: Le Grand Jeu

Street Art-Banksy \& CO. L'arte allo stato urbano (SABC) fue un proyecto expositivo co-comisariado por Christian Omodeo, Luca Ciancabilla y Sean Corcoran en 2016, surgido de una propuesta del propio Ciancabilla a Fabio Roversi-Monaco - presidente de la fundación de la cual depende el museo-con el objetivo de reflexionar sobre la protección, conservación y musealización de este tipo de prácticas artísticas. De hecho, SABC se planteó mostrar las incomodidades y contradicciones de un fenómeno mediático y ya mercantilizado como es el "Arte Urbano", a la vez que las corresponsabilidades acerca de cómo hay que explicar a la ciudadanía una práctica artística con ya más de cuarenta años de historia. Durante el proyecto, Christian Omodeo comentó en varias ocasiones sus propias expectativas y cómo afrontar el reto de llevar el arte urbano al museo [3]. Sin pretender valorar si la polémica con Blu eclipsó en su momento el verdadero ejercicio curatorial, SABC fue, probablemente, uno de los primeros proyectos curatoriales indoor en abordar temas incómodos, pero imprescindibles, en el arte urbano. Muchos son ya los museos que han trabajado, de una $u$ otra manera, este tema en su programación, pero pocos son los que han dado visibilidad a esas trampas, en un relato honesto y atrevido sobre cómo llevar el graffiti y el arte urbano al cubo blanco. El propio Omodeo comenta los riesgos de trabajar en espacios cerrados y la necesidad de reflexionar sobre ello: "We need to design new rules for bringing urban art into museum space" (Omodeo 2019: 94). De ahí el concepto del comisario como vándalo. Un personaje que "desde dentro" subvierte los planteamientos institucionales y museísticos, intentando modificar esa mirada colonizante y condescendiente para con esas otras prácticas artísticas que se desarrollan presencialmente en la ciudad. Lejos de la visión complaciente y prepotente de determinados perfiles, probablemente este "ejercicio vandálico" debería formar parte de la práctica curatorial como acción que cuestiona y da visibilidad a determinados procesos identitarios y creativos susceptibles y meritorios de un discurso institucional que los contemple. Validarlos y contextualizarlos por parte de sus distintos protagonistas presupone reconocer esas otras maneras de proceder que conviven, crecen y se empoderan en ese complejo pero necesario equilibrio entre el contradiscurso y la mirada oficial. Una visión que no solo afecta a aquellos que operan y gestionan en centros culturales municipales $u$ otros espacios, sino también a los propios artistas pues, en cierto modo, sienten usurpada esa condición de vándalo o enfant terrible. Para muchos de ellos, el simple hecho de "venir del graffiti" pone ya en valor cualquiera de sus intervenciones en la ciudad. Un mérito adquirido que justifica sus acciones en el espacio público con respecto a otros u otras que no hayan pasado por ahí. "Esta respuesta, lícita y mayoritaria, usa el recurso - llamémosle - urbano como un soporte de exhibición, como una manera de hacerse un dossier de artista (autopromoción), con códigos más o menos crípticos y autorreferenciales" (Morilla 2019: 27). Una manera de autolegitimarse frente a ese otro perfil de artista con otro bagaje formativo. Por lo tanto, "being a vandal is not just about rule breaking. (...) You have to find new rules for working with museums" (Omodeo 2019: 95). Respecto a la reacción radical y unilateral de Blu, ¿acaso no podrían considerarse vandálicos los planteamientos del proyecto expositivo con respecto a la institución que lo acogió?¿Por qué a los artistas hay que pedirles permiso para todo cuando ellos suelen operar en el espacio público a su antojo? Esa y otras contradicciones no dejan de ser propias del espacio público a pesar de haber cierta resistencia, cuando hay ocasión, a que surjan como parte del conflicto en el contexto del engranaje oficial. En el fondo, se trata de "bloccare il meccanismo!" [4] Como colectivo activista presente en la escena boloñesa, Wu Ming fueron invitados por el equipo curatorial de SABC a participar en el debate escrito como otro lugar de discusión (ver entrevista en anexo), rechazando finalmente la invitación tras la decisión de Blu. Según ellos, las contradicciones del proyecto son explícitas en la propia paradoja expositiva y en cómo la musealización de aquello que surge libre en la ciudad es en 
beneficio privado de los que se autodenominan salvadores del arte urbano (Wu Ming 2016). Argumentos quizá también contradictorios pues niegan la posibilidad de que la institución museística (en Italia siempre financiada por dinero privado) —desde un lugar legitimado y con profesionales sobre el tema- cree un debate abierto sobre la autoría y el destino de un fenómeno susceptible de patrimonializarse y que pide a gritos formar parte de la industria del arte con el permiso de los mismos artistas urbanos. Encargados de publicar el comunicado de Blu, Wu Ming propiciaron un debate en el que la participación contraria a esa decisión no era bienvenida $y$, como consecuencia, la negociación fue imposible de darse ante tan radicales disyuntivas.

Participantes en SABC y como contrapunto a todo ello, los artistas Cuoghi e Corsello comentaron en su momento: "Sappiamo che vi piace tanto lo stereotipo dello streetpittore che fa i disegni figurativi con argomenti sociali, ma in strada ci sono delle differenze" (Marsala 2016 ). Se trata de una crítica a las intervenciones disfrazadas de proyectos sociales que tanto gustan a los políticos, que tanto proliferan en el espacio urbano y que tan poco aportan a la sociedad. Una crítica dirigida a quienes las hacen posibles, o sea, artistas, gestores, comisarios e instituciones que, una vez en la calle, acaban siendo complacientes en lugar de crear debate y transformación. En la misma entrevista, ambos artistas ponen en evidencia las constantes contradicciones de un determinado perfil de artista urbano que preserva y se apropia del propio espacio de la ciudad criticando, sin más, lo oficial al mismo tiempo que se aprovecha de la institución y de la iniciativa privada cuando la ocasión lo merece. Hoy, las polémicas piezas de Blu permanecen en el Palazzo Pepoli como una donación a la ciudad de Bolonia a cambio de evitar su comercialización y permitiendo el acceso gratuito a la ciudadanía. Ante todo esto, ¿qué están aportando realmente determinados combates y posturas radicales, si la propia práctica artística es incapaz de reflexionar sobre su propia sostenibilidad en el espacio público de la ciudad? ¿Por qué esas y otras obvias paradojas no se aprovechan y comparten para reflexionar por parte de unos y otros sobre los caminos del arte urbano hoy? [figura 2].

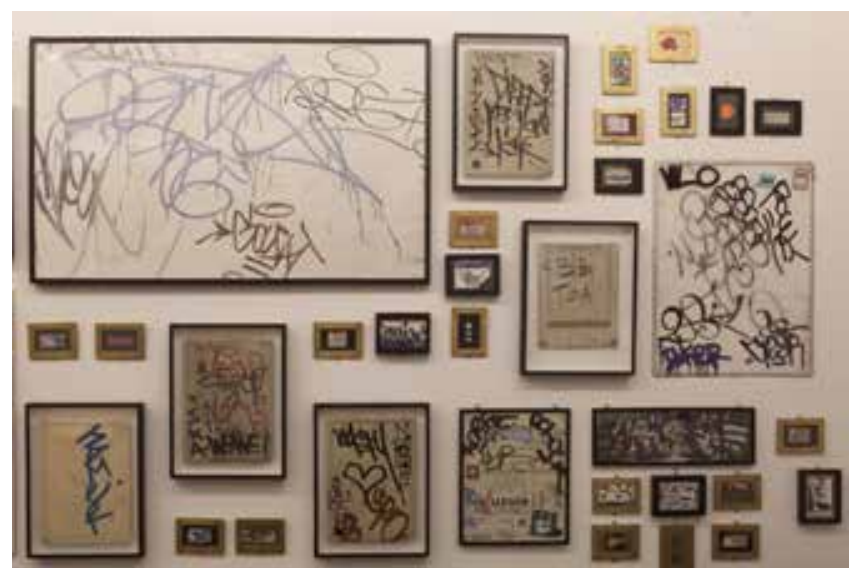

Figura 2.- Fragmento de SABC, 2016. Foto: Le Grand Jeu.
Es discutible y difícilmente evaluable si SABC consiguió sus objetivos en el público visitante, como también es complejo discernir sobre si gran parte de este no iba condicionado por el revuelo mediático de la exhibición de las piezas de Blu tras la reacción iconoclasta del artista al privar a la ciudadanía de sus trabajos outdoor. En cualquier caso, no son pocos los museos que han exhibido piezas de calle - la mayoría procedentes de colecciones privadas - sin crear apenas debate al respecto y sin que este hecho haya generado nada extraordinario en el colectivo de artistas urbanos del lugar (una comunidad no organizada ni mucho menos homogénea). Aún pudiendo desaparecer el espíritu subversivo de estas prácticas, la institucionalización de las mismas no presupone privarlas de ese valor. Del mismo modo, su ilegalidad tampoco las convierte en rebeldes (Baldini 2016: 108). De hecho, la subversividad de muchas manifestaciones viene dada paradójicamente desde su legalidad, desde su representación y acción en escenarios y contextos propios de metanarrativas visuales (4). Las visiones historicistas y formales en las que solo se informa y pone en valor las obras de los artistas urbanos no son ni subversivas ni "útiles". Desde el museo es necesario y lícito poder reflexionar sobre este fenómeno con respecto a la propia evolución de las ciudades, la ciudadanía y en el contexto del propio arte contemporáneo. Sin embargo, ¿por qué al Arte Urbano no se le permite ser un instrumento para transformar la visión hegemónica de ese otro espacio público de la ciudad y de las políticas culturales municipales a las que pertenece? En un momento de gran privatización del espacio público urbano, ese sería un interesante planteamiento curatorial para las prácticas artísticas que ahí se desarrollan. "We need to educate the art institutions about our rules and not just play by their rules" (Omodeo 2019: 95). De acuerdo con esta premisa y contrariamente a lo que algunos autores como Mazzucchelli sustentan, uno de los logros de SABC fue el hecho de crear debate entre todo el sector del arte urbano internacional frente a un relato incómodo que provocó peculiares solidaridades contra el sistema entre determinados puristas y adeptos al Street Art movilizados por la difusión y el calado de ciertos mensajes populistas y mediáticos en las redes sociales. "Only a few have understood that the exhibition was also proposing to destroy the 'critical' approaches towards street art of the past, before starting to build new ones" (Omodeo 2019: 95). No es casual, pues, que haya sido a partir de este proyecto cuando se ha empezado a hablar de derechos de autor, conservación, propiedad intelectual y buenas prácticas entre el sector. Más allá de intentos y aproximaciones históricas por exhibir el graffiti en espacios indoor [5], las contradicciones parecen seguir siendo palpables, poniendo en ocasiones en evidencia determinadas posturas. "In questo senso, mi sembra che il modo in cui viene presentato il lavoro degli street artist sia una caricatura: una mitología romántica dell'artista" [6]. Existen, pues, procesos lógicos para quienes desean (o parecen desear) entrar en el mercado del arte para profesionalizar su práctica y así poder subsistir, sin necesidad de sentirse prostituido ni vendido al sistema. Negarse a ello y al sistema que lo engloba supone no asumir ciertas 
paradojas y ralentizar (o no facilitar) el reconocimiento del propio sector del arte contemporáneo [7]. Precisamente, en el uso y apropiación de lo público, la misma condición de residentes autoasignada por parte de muchos artistas urbanos presupone la existencia de intrusos en contextos que acaban convirtiéndose en xenófobos artísticamente hablando. De ahí que la "lucha" sea más efectiva, inteligente e interesante desde "dentro" porque, al final, como dicen Cuoghi e Corsello- "Ios graffiti no pertenecen a la izquierda ni a los centros sociales" (Marsala, 2016). La práctica artística, muy a pesar de muchos y a muchas, no es exclusiva del artista. Entendiendo esta como un proceso comunicativo y transformador que va desde su gestación (con o sin agentes participativos), pasando por su producción, puesta en escena y mediación, hasta la recepción y devolución por parte del espectador, son varios sus protagonistas.

\section{La opinión de los profesionales}

Dadas las diversas repercusiones en el sector y pasados tres años de SABC, se ha enviado una batería de preguntas a perfiles diversos de profesionales de España e Italia (países representativos de la escena internacional del Street Art) para completar los objetivos de este artículo. Galeristas, comisarios, gestores y, cómo no, creadores en activo respecto a la práctica artística en la calle a los que se les pidió reflexionar, desde su experiencia, sobre las siguientes cuestiones: la existencia de museos de arte urbano y el papel de la institución al respecto; maneras de abordar proyectos de arte urbano indoor, con especial atención al concepto de lo efímero y al de autoría; y la ciudad como museo, sus límites y el impacto en la ciudadanía. Se trata de entrevistas a través de correo electrónico a Antonella Di Lullo, E1000, el colectivo FARE ALA, Sergio García Bayón, Jaume Gómez y Greg Jager; todas ellas situadas en el anexo de este monográfico y en una recopilación referenciada a este artículo.

\section{Respecto a los emergentes museos de arte urbano}

Antonella Di Lullo (entrevista en anexo) cuenta su experiencia en la transformación de un festival como el Outdoor de Roma y la necesidad latente de confrontación de los artistas con espacios cerrados. Sergio García Bayón y Greg Jager (entrevistados en anexo), por otro lado, constatan la paradoja y la evolución de un arte que nace para ser efímero y lejos de cualquier institución con respecto a los objetivos básicos del museo como ente que surge para conservar, adquirir, investigar, transmitir información y exhibir lo producido en un determinado período histórico. " $E$ ' fisiologico che una sottocultura prima o poi emerga e si confronti con la società" añade Greg Jager en su entrevista anexa-. Más allá de contradicciones, la mayoría de profesionales coinciden a priori en la importancia de cómo va a llevarse a cabo y cuáles serán los acuerdos con los artistas en ese proceso museístico. Un proceso que deja muchas cuestiones abiertas sobre cómo afrontarlo. En cualquier caso y como E1000 apunta en su entrevista anexa, "pueden existir museos con trabajos de artistas que desarrollen su trabajo en la calle pero el $50 \%$ de la esencia del arte urbano sigue dándose en el entorno donde se desenvuelve. De ahí la imposibilidad de crearle un nuevo espacio porque ya dispone de él". Esa imposibilidad de crear otros espacios para las prácticas artísticas urbanas parece reforzar su sentido político como "cavallo di troia che facilita la mutazione urbana dettata dalle politiche capitaliste, sécuritaire e di controllo" —en palabras de FARE ALA en su entrevista anexa-. Aun así, y más allá de sus resultados, se trata de acciones públicas y las instituciones - como gestoras de lo público y al servicio de lo público- deben apoyar y facilitar todo tipo de procesos creativos y curatoriales con el riesgo y derecho, a su vez, a ser cuestionadas.

Probablemente, solo así puedan ofrecer contenidos interesantes a la ciudadanía. Ese proceso de musealización debería ser lógico y natural pues — como opina Gómez en su entrevista- hay más artistas, más venta, más galerías, más "consumo", más público expectante de obra y más espacios de exhibición que nunca en la difusión de este fenómeno. De ahí que esa aceptación global del graffiti y el arte urbano conlleve —-según García Bayón en su entrevista - una implicación en profundidad de las propias instituciones públicas para acercarlos a la ciudadanía. Pero, la historia más reciente nos demuestra que las instituciones son, a priori, reticentes y reacias a integrar ese tipo de prácticas. Digamos que "necesitan su tiempo" para digerirlo y exhibirlo como tal. Eso ha provocado y favorecido que iniciativas privadas próximas a las prácticas referidas especulen y generen con sus propias colecciones, fondos que nutren muchos de esos nuevos museos. ¿Cuál es, pues, el camino? Privado o público, el museo debe trabajar —según De Lullo- en dos direcciones aparentemente divergentes: por un lado, haciéndose preguntas sobre su propia historia y evolución, valorando el trabajo de numerosos fotógrafos, cámaras y algunos artistas que supieron documentar lo que estaba sucediendo; por otro, los museos deben tener la capacidad de promocionar y financiar proyectos, intentando entender hacia dónde va este movimiento. "Non ponendosi come statico contenitore, ma sottolineando e promuovendo la dinamicità di questo contenuto". Apuntes todos interesantes para unos fondos museísticos que aún hoy siguen resistiéndose a incorporar piezas susceptibles de polémicas respecto a su autoría y procedencia pues sigue habiendo dudas "se l'attenzione dello storico debba concentrarsi sull'opera e sul rapporto che essa intrattiene con il suo contesto di creazione o, piuttosto, sul gesto stesso dell'artista" (Omodeo 2016: 15). En cualquiera de los casos, quizá su recontextualización no presuponga perder su fuerza subversiva sino recuperarla (Baldini 2016: 110) porque, al final, siempre serán representaciones - como sugiere E1000 en su entrevista- de algo que sucede en otra esfera. 


\section{Abordar lo efímero y la autoría en espacios indoor}

En la práctica del graffiti como ocio grupal vinculado a colectivos (crews) y comunidades, la firma y el estilo personal han sido siempre requisitos básicos para desmarcarse y enorgullecerse a título personal. Aun así, muchos creadores que han desarrollado su obra en el llamado postgraffiti han jugado con el concepto de autoría, creando discursos metalingüísticos que han cuestionado la propia identidad.

Legales, alegales o de tipo ético, se trata de temas suficientemente complejos como para ser ignorados en un espacio expositivo. Paradójicamente, ocurre algo parecido con la documentación fotográfica, pues editoriales, guías turísticas y otras empresas acaban lucrándose de las imágenes tomadas de obras ilegales realizadas en la calle. En ambos casos, trabajos que suelen realizarse sin ningún tipo de permiso en los que la autoría se reclama y reivindica. Un debate sobre el que especialistas en legislación de muchos países se pronuncian ya que no se trata tan sólo de reconocer o cuestionar la propiedad intelectual y/o material de una determinada intervención ilegal en la calle, sino de las consecuencias legales, económicas, éticas y políticas de haber intervenido sobre otra intervención con intención y sin permiso alguno del artista ni del propietario del inmueble que la acoge [8]. En cierto modo, se reproduce el eterno juego callejero del "tú pintas algo que a mí no me gusta o donde a mí no me gusta y yo te lo piso o saboteo". Una acción vandálica bastante común, aunque no por ello bien vista entre quienes llevan pintando y escribiendo en las calles de cualquier ciudad que, hasta hace poco, importaba tan solo a quienes la ejercían y recibían. En cualquier caso, la legislación para lo realizado ilegalmente en el espacio público y privado de la calle no parece ser la misma cuando trasciende a otros niveles de la esfera pública, ni mucho menos cuando lo intervenido se exhibe en un museo o espacio expositivo. $Y$ es que la ley sigue mostrándose obsoleta para la existencia y mercantilización de lo que hoy se conoce como arte urbano. Porque, al final, ¿el interés de unos y otros por aquello realizado ilegalmente se demuestra y es proporcional al beneficio que se pueda sacar de todo ello? Una reflexión que ya surgió tras lo sucedido con Blu en $S A B C$.

Otro tema clave para trabajar en espacios expositivos - sean o no museos- es el concepto de durabilidad respecto a lo que en la calle se exhibe. Algo en lo que no todos los artistas urbanos y profesionales del sector coinciden, pero que es implícito a la práctica del graffiti, más allá de su romántica intención de permanencia. Gómez comenta (entrevista en anexo) que "gran parte de los formatos en los que se presentan obras de graffiti y arte urbano en los museos son apropiables y no especialmente efímeros. Además, como piezas museables, compradas, tasadas y exhibidas con medidas de seguridad hacia el gran público, están proyectadas con una clara voluntad no efímera". En cualquiera de los casos, se trata de otro tema complejo de abordar dado que — según sigue apuntando Gómez- "en el momento de plantearse una exposición, tanto artistas urbanos como escritores de graffiti necesitan romper los marcos e intervenirlos como algo clave e innato para ellos". Muchas de las veces, esa necesidad de ir más allá les eclipsa de cierta autorreflexión sobre lo que supone producir y exhibir un trabajo en un contexto muy distinto al de la calle. De nuevo, la contradicción surge cuando artistas urbanos pretenden realizar arte urbano dentro del cubo blanco o comisarios e instituciones les piden que lo hagan, pues en muchas de las ocasiones caen en la trampa de reproducir, sin más, la misma estrategia que en la calle o, en el peor de los casos, se exhiben en directo para que el público ajeno a esta práctica artística "vea lo que hacen cuando actúan en la ciudad". Una situación perversa muy propiciada por instituciones $\mathrm{y} / \mathrm{o}$ festivales que adultera la esencia subversiva del graffiti y el arte urbano, en lugar de propiciarla dando visibilidad a lo que el museo, quizá, pretende domesticar. Esa podría ser una mala práctica de llevar a cabo lo efímero en espacios indoor, pero no siempre es así. Sin olvidar la musealización del amplio abanico de prácticas artísticas conceptuales en los años setenta, el carácter efímero de estos lenguajes presenta ciertas ventajas - comenta Gómez - a la vez que inconvenientes respecto al hecho de intervenir, interior o exteriormente, los recintos de los museos de arte contemporáneo. Un proyecto que merece ser mencionado al respecto es el de la Tate Modern. Comisariado por Cedar Lewisohn en 2008, el museo londinense produjo intervenciones en su fachada a cargo de artistas internacionales como Blu, el colectivo Faile, JR, Nunca, Os Gemeos y Sixe, en lugar de exhibir en sus salas producción alguna de este tipo de práctica artística. Más allá de eventos puntuales como las proyecciones de Graffiti Research Lab, el proyecto "salió", además, del museo con The Street Art Walking Tour. Unos itinerarios urbanos site-specific a cargo de 3TTMan, Spok, Nano4814, Eltono y Nuria Mora.

\section{La ciudad como museo}

Las ciudades son entes que se transforman constantemente gracias (o a pesar) de sus ciudadanos y ciudadanas. Privatizándose a marchas forzadas, nos sigue impresionando y afectando lo que ahí ocurre. De ahí la urgente reconquista de lo público para un uso igualitario. Esa concepción ha permitido la bienvenida al arte urbano, democratizándolo sobremanera hasta el punto de poder ser invasivo e insostenible por cantidad y superficialidad. Como dice Jager en su entrevista, "Queste operazioni sono una modifica del paesaggio e rappresentano un forte shock per chi vive un quartiere quotidianamente, sopratutto se queste persone non hanno un ampio bagaglio culturale". Se trata del llamado "museo al aire libre" que está originándose en espacios urbanos y rurales tras la proliferación de intervenciones comisionadas $\mathrm{o}$, simplemente, toleradas desde instituciones, asociaciones y/o eventos privados. Como comenta García Bayón en su entrevista respecto a su experiencia en Bilbao y Vitoria, 
«la fórmula más contemporánea de una nueva burocracia estética ha sido concebir la totalidad de la ciudad como un museo al aire libre, en coherencia con nuestra cultura del ocio». No exenta del proceso de gentrificación, se trata de una democratización a veces mal entendida que provoca que espacios y determinados barrios de las ciudades hayan resurgido popular y mediáticamente con la ingenua satisfacción de quienes ahí viven o se pasean.

Salvo algunas excepciones, las comunidades de vecinos dan su "visto bueno" a proyectos con artistas-héroes que dicen hablar de la memoria del lugar, dándoles permiso para reproducir sus propias imágenes y poder así ser reconocidas por todos y todas. Un especial momento de popularidad al que pocos pueden resistirse. Curiosamente, la perversión se da en lugares históricos o en la periferia donde — según Di Lullo en su entrevista - "I muri hanno mutato il loro colore, fino ad allora stabilito da delibere comunali, attraverso la creatività degli artisti che di volta in volta si approcciavano a essi". De ahí que -como prosigue García Bayón en su entrevista del anexo- en la última década el concepto mural se esté desbordando, y comience a ser invasivo y utilizado como herramienta para la turistificación. "Spesso si parla di riqualificazione attraverso l'arte" — apunta Jager en su entrevista- questo binomio "arte e riqualificazione" è un potente strumento di comunicazione politica". Precisamente con respecto a ese valor público, De Lullo reivindica la necesidad de cierta mediación entre aquello que aparece en la calle y la ciudadanía para reducir la distancia que suele haber entre lo que hacen los profesionales del arte y aquellos y aquellas que se lo encuentran, sin limitarse a lo estético y superficial (entrevista en anexo). Dicho esto, ¿dónde queda la función y las posibilidades del arte de educar a la sociedad? ¿Cuál es el equilibrio entre un proyecto ciertamente reflexivo y transformador y otro complaciente y fácil para que la ciudadanía «lo entienda»? Y es que el concepto de "ciudad como museo" suena — según Gómez en su entrevista - "a una especie de utopía situacionista en continuo movimiento que, aunque atractiva, no está exenta de riesgos. (...) Parece que este tipo de intervenciones parecen estar realmente planteadas para ser contempladas desde un avión o por Google Maps que para la gente de a pie, obligando a un gran desgaste a los artistas que los llevan a cabo". De ahí que algunos artistas y escritores lleven ya tiempo reflexionando acerca de la función real de aquello que producen con respecto a la proporción de imágenes y mensajes emitidos y los espacios involucrados. El mismo E1000 opina que "las intervenciones tienen que ser libres y de carácter ciudadano. De otra forma, estamos capitalizando el espacio público al mismo nivel que la publicidad". Como apunta De Lullo en su entrevista, quizá contemplar la cantidad y la caducidad de las intervenciones, así como formatos alternativos a los de los murales sea, hoy por hoy, uno de los objetivos primordiales de la práctica artística en el espacio y la esfera públicas para evitar la excesiva transformación del entorno de quienes lo habitamos. Los límites de la peligrosidad están ahí —según FARE
ALA - y todo depende de cómo se piensa esa ciudadmuseo (entrevista en anexo). Gestionar lo que aparece en el espacio público no deja de ser una situación compleja para individuos, colectivos y gobiernos. "La ciudad es un terreno de juego para quien quiera tomársela de forma lúdica o experiencial, pero no un museo ni un lienzo en blanco. Un nuevo escenario que no tiene que ver con eso $y$, por lo tanto, necesitado de otra denominación" (entrevista a E1000 en el anexo) [figura 3].

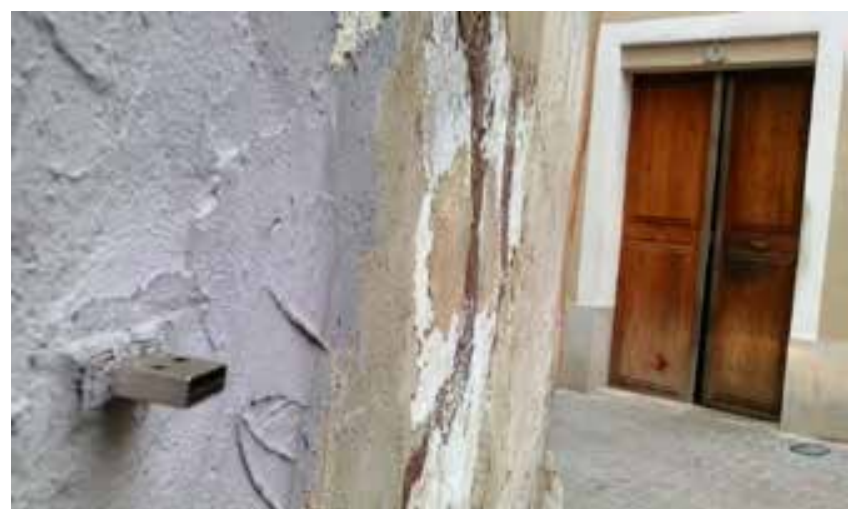

Figura 3.- Dead Drops. Intervención de Aram Bartholl. Palma (Baleares). Fotografía del autor.

\section{Conclusiones}

¿Qué necesita el Street Art en estos momentos y qué papel juega ahí el museo institucional? De entrada, muchos son los eventos, certámenes, festivales y exposiciones que surgen como comisariados cuando únicamente se organiza, selecciona y gestiona. Paralelamente, muchos artistas y colectivos urbanos - participando o no del sistema-critican, sin más, ese tipo de oficialización como si de malos y buenos se tratara. ¿Qué están aportando realmente a la ciudad, a los artistas y al propio fenómeno del arte urbano este tipo de iniciativas? Tras coleccionar, fetichizar, mercantilizar y formalizar este tipo de práctica artística, aparecen museos y exposiciones que, más que incorporar debate y mostrar el estado de la cuestión a la sociedad, muestran trabajos espectaculares de gran ejecución técnica y de crítica inocua con los que satisfacer el wow de un público deseoso de pautas para simplemente reconocer lo que se encuentra por la calle y, sobre todo, en las redes. Esta "aceptación" del arte urbano parece también venir bien al sector. $Y$ es que, tras el efecto mediático y la popularidad alcanzada por este fenómeno, la presupuesta transgresión y el efecto crítico y contracultural del discurso esencial del arte urbano probablemente se esté perdiendo a ojos de tantos ciudadanos y ciudadanas. «No debería ser difícil, pues, aceptar que su introducción en un museo o galería no normaliza necesariamente esta forma de arte. En este sentido, "depende de comisarios y artistas crear condiciones a través de las cuales la "ferocidad" del arte urbano no aparezca "domesticada" en las paredes institucionales" (Baldini 2016: 110). La capacidad de autocrítica de los profesionales —artistas, comisarios $\mathrm{u}$ otros- que se planteen actuar no debe subestimar la 
desaparición del potencial de denuncia y compromiso de algunas obras a causa del consumo feroz del trabajo de sus autores en las redes y otros medios de comunicación. Es casi como el inocuo efecto de algo a lo que ya estamos acostumbrados a ver. Presencial o virtualmente hablando, lo estético y lo amable se superpone a cualquier otra intención (cuando la hay). Ya no "leemos" un Blu o un Banksy, nos basta con reconocerlos, saber de sus hazañas, fotografiarnos cuando encontramos sus trabajos $y$ consumirlos como un producto cultural más. De ahí, que, muchos proyectos expositivos sobre arte urbano se articulen vacíos de contenido y sin intención alguna de educar a ese gran público [9]. Algo que no ha dejado de ocurrir en otros momentos históricos del arte pero que, aun así, no deja de sorprender por el empeño y el purismo de determinados artistas en ver cualquier iniciativa desde «dentro» como peligrosa y enemiga para aquellos que "trabajan" en la calle. Así pues, no se trata tanto de dónde se exhiben esos trabajos sino de cómo desarticular determinados discursos neutros y complacientes [figura 4].

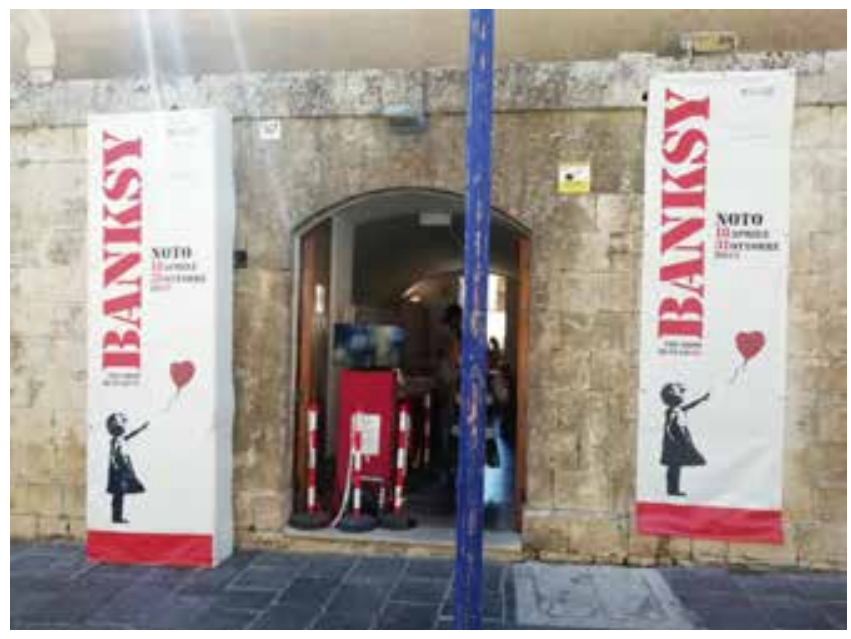

Figura 4.- Detalle del proyecto "Banksy. The Show Must Go On". Noto, Italia, 2019. Fotografía del autor.

Con respecto a esa lucha absurda dentro del sector generada sobre todo desde el proyecto de Ciancabilla, Corcoran y Omodeo en Bolonia en 2016_, "¿hasta qué punto esa forma de guerrilla es eficaz? (...) Es decir, esa proliferación de imágenes inútiles, la lenta retirada de las mejores fuerzas, la anestesia general del lenguaje... ¿qué va a ser del arte urbano? ¿Decoración, ilustración, protesta, vacío, mediocridad? ¿O vocación social, cambio, revalorización? Y si la ilegalidad perdura, ¿cómo se reconcilia con el "aburguesamiento" natural con el que, más tarde o más temprano, cada cultura o forma de arte revolucionaria se encuentra?" (Marsala 2016). Es fundamental, pues, encontrar nuevas fórmulas para llevar el arte urbano a espacios expositivos pues la ciudadanía es un público que pide ser informado sobre esta práctica artística, a menudo espectacular, que irrumpe en su día a día. Intentar ser radicalmente coherentes es complejo y quizá absurdo e inoperativo. Ello no implica dejar de tener presentes más que nunca ciertas premisas básicas. Ciertas preguntas que cualquier profesional del arte urbano debe hacerse hoy frente a determinadas acciones en y fuera de la calle. Los hay que - como FARE ALA en su entrevistareconocen cierto riesgo para los artistas al poderse sentir atados por la dinámica institucional y perder parte de su autonomía creativa, a la vez que asumen que el resultado será siempre un pálido reflejo de la complejidad espacial, temporal y relacional que una práctica artística urbana en general debería activar. En cualquier caso, Street ArtBanksy\&CO. L'arte allo stato urbano abrió y activó en 2016 desde Bolonia un debate internacional que sigue vigente y tras el cual muchos profesionales del arte urbano están deliberando presencialmente y por escrito. $Y$ las instituciones, como parte de su servicio público, deben escuchar esos otros latidos urbanos e intentar crear, con la ayuda de profesionales, un relato colaborativo, abierto y transparente respecto a determinadas cuestiones. A pesar de todo ello y superando las diferencias entre museólogos y museófobos al respecto, ambiciosos proyectos expositivos como el recién Beyond The Streets siguen irrumpiendo con fuerza en el panorama internacional para plantear lecturas interesantes no exentas de contradicciones, pues determinadas consignas como "utilizar la calle como un gran lienzo" e "Intervenir o Morir" han dejado ya de ser sostenibles. Y es que plantearse satisfacer al gran público, ambicionar y sobrevivir con cierta dignidad profesional a la vez que plantear reflexiones profesionales sobre el estado de la cuestión son tres ítems nada fáciles de equilibrar. Dentro o fuera del museo, quizá los retos hoy sean otros [10] [figura 5].

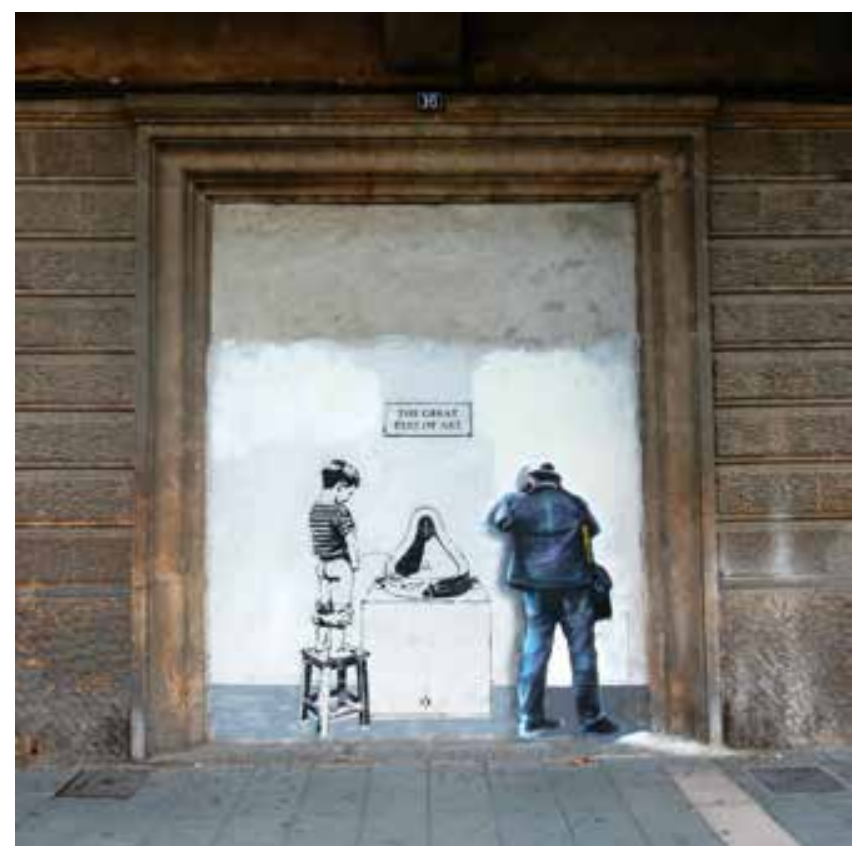

Figura 5.- The great pees of art. Intervención de ORB (2014), intervenida por el artista Dimitry Levochkin. Palma (Baleares). Foto: Street Art Mallorca. 
Por so no todo concluye en la práctica del arte. Una mediación consciente desde el minuto cero puede contribuir a la apertura de nuestra mirada. De ahí la necesidad de enfrentarnos a ello e integrar todos estos procesos desde todos los ámbitos de la cultura. A la pregunta, "Do street art shows have the capacity to bring in new audiences? To engage people who would not usually go to a museum?" -Omodeo responde- "Museums can also be used as a tool to teach people new ways of looking at their cities and to consider the role of art in their everyday lives" (Omodeo 2019: 95). Y es que la mediación supone, en esencia, arbitrar un conflicto (Fontdevila 2018: 179) y ese conflicto viene definido como una situación de desacuerdo de actitudes o comportamientos entre personas o colectivos. Micro o macro situaciones que se dan en la esfera pública y que nos rebotan horizontal y verticalmente. Pero un conflicto es también un elemento de relación en las sociedades actuales. Darle visibilidad es fundamental para comprender su importancia y para entender muchas de las dinámicas que tienen lugar en las sociedades contemporáneas. Más allá, pues, de pretender resolverlos, los conflictos piden negociación. Al percibirlos nos sentimos en un primer momento revueltos, cuestionados y desubicados de nuestra zona de confort, en un desequilibrio que nos obliga a trabajar sobre los límites de nuestra capacidad de resiliencia. Ignorar el conflicto o enterrarlo presupone entenderlo como algo negativo. Enfrentarse a él nos conduce a revisar procesos.

\section{Notas}

[1] Información del MACBA sobre el seminario organizado sobre el proyecto en 2016.

[2] Preguntas de David G.TORRES en el texto del catálogo de la exposición «Punk. Sus rastros en la creación contemporánea».

[3] Cuenta Omodeo en el programa INFLVENCERS:“Primeramente, quisiera hacer evolucionar la mirada de la gente sobre esta cultura. (...) El descubrimiento principal de esta exposición es el de explicar esta cultura a todos. Otro de los objetivos es dejar claro a los comisarios, a las instituciones, a los artistas que este arte es percibido hoy como patrimonio artístico y que tendremos que hacer selecciones al respecto durante los próximos años". A la pregunta, ¿Cómo ve el hecho de trasladar los objetos del Arte Urbano al interior de un museo? -Omodeo responde-"Pienso que ha llegado el momento de afrontar este tema y esta exposición es una llamada a todos los que quieran expresar su propia opinión al respecto. Yo quiero que se discuta este punto porque es fundamental. Hasta hace seis meses, nadie pensaba en el hecho de que los graffiti son hoy percibidos como patrimonio artístico ni en cómo hacer que sobrevivan. Los artistas que pintan en la calle no pensaban que tras algunos años habría alguno que querría quitar de la pared estas piezas para llevárselas dentro de un museo. Ahora parece que todos tienen claro este aspecto".

[4] Conversación telefónica con Christian Omodeo el 1-8-19.
[5] María Acaso comenta las diferencias de actuación entre las meta y las micro narrativas visuales, y las trampas de unas y otras en sus propias dinámicas y manifestaciones. Con pocos medios, reivindicando una constante autoría y desenmascarando las estructuras de poder como principal objetivo contradiscursivo, las micronarrativas corren el riesgo de ser fagocitadas por las metanarrativas que los grandes poderes fácticos emiten. Aun así, algunas micronarrativas utilizan y "se cuelan" en canales propios de las metanarrativas para mejorar su efectividad y alcance críticos.

[6] En 1972, Hugo Martínez -estudiante de sociología del City College de Nueva York- invitó a miembros de UGA (United Graffiti Artists) a reunirse en el City College y trabajar en sus talleres. De esas reuniones surgió el colectivo y la que se considera la primera exhibición indoor de graffiti. Más allá del impacto que supuso y de lo histórico del hecho en sí, parece ser que el proyecto se reducía a transferir trabajos de los miembros de UGA sobre tela.

[7] Baldini responde en un blog a los argumentos y ataques de Pietro M. con respecto a la polémica de Blu en SABC. (2016). "Il metodo oltre l'arte: quando il silenzio non è assenso". https:// medium.com/@pier m/il-metodo-oltre-l-arte-quando-ilsilenzio-non-\%C3\%A8-assenso-a7409dcedb5e [Consulta: 19-8$19]$.

[8] En su texto Muri addomesticati? Street Art, musei e ribellione, Baldini proporciona varias declaraciones de artistas y otros profesionales que subrayan el antagonismo entre arte urbano $y$ arte contemporáneo, argumentando acto seguido la ingenuidad de esas afirmaciones.

[9] A partir de la reciente "intervención" sobre una pieza del palermitano TVBOY por parte de un simpatizante de la Lega Nord italiana en la ciudad siciliana de Taormina, el profesor universitario de Legislación de Bienes Culturales y de Derecho Giovanni Maria Riccio diserta sobre el concepto de autoría en "Street art e zelo dei militanti politici. II murale con Carola Rackete deturpato a Taormina".

[10] Un ejemplo de ello es la reciente muestra de Banksy en el Museo Civico S.Chiara de la localidad siciliana de Noto. "Banksy. The Show Must Go On" supone la exhibición de un conjunto de piezas del autor pertenecientes a una colección privada de Nueva York. Un show expositivo que utiliza claramente el reclamo turístico del enigmático autor de Bristol en una selección "fácil" de su trabajo más popular y reconocible. Eso sí, un atractivo y morboso mensaje se reproduce en la primera hoja del catálogo: la exposición no está autorizada por el artista. https://www. instagram.com/banksy noto/ [Consulta: 23-8-19]

[11] Con partners varios, el reciente proyecto expositivo "Beyond The Streets" es, cuando menos, significativo por las connotaciones de su título. Comisariada por el especialista Roger Gastman, el proyecto explora la necesidad — colectiva, individual, anónimade "tomar" la calle desde muchos puntos de vista, y de cómo esta acción rebota en ese otro lugar común que es la esfera pública. Abordando el graffiti y el arte urbano desde la perspectiva de la cultura popular, el proyecto incluye disciplinas como la música y el tatuaje. (LA, 2018/NYC, 2019). https://beyondthestreets.com/ 
blogs/news/beyond-the-streets-nyc-press-release [Consulta: 178-19]

\section{Bibliografía}

ACASO, M. (2006). Esto no son las Torres Gemelas. Madrid. Ed. Catarata.

BALDINI, A. (2016) Muri addomesticati? Street Art, musei e rebellione. "Street Art. Banksy\&CO. L'arte allo stato urbano". Bologna. Bononia University Press.

CUOGHI E CORSELLO. http://cuoghicorsello.blogspot.com/ [Consulta: 25-5-19

FERNÁNDEZ PORTA, E. Charla en el seminario «PUNK. Sus rastros en el arte contemporáneo» (2a sesión MACBA Streaming). $\quad$ https://www.youtube.com/watch?time continue $=2931 \& \mathrm{v}=5 \mathrm{SgKPQ} 73 f 60$ [Consulta: $29-7-19]$.

FONTDEVILA, O. (2018). El público como mediador. Raw Material, Comisarios: David Armengol, David G. Torres y Martí Peran. Fabra i Coats. Centre d'Art Contemporani de Barcelona. Barcelona. http://oriolfontdevila.net/ca/the-public-as-mediator/

FONTDEVILA, O. (2015). Esdevenir públic. Premi Internacional a la Innovació Cultural Convocatòria 2014-2015: Públic/s. Barcelona. http://oriolfontdevila.net/wp-content/uploads/2019/08/ ESDEVENIR-PUBLIC.pdf

G.TORRES, D. (2016) Rastros de una actitud punk en el arte contemporáneo. En Punk. Sus rastros en la creación contemporánea. MACBA/CA2M/ARTIUM. https://issuu.com/ ca2m/docs/catalogo punk web/1?e=8774396/12412366

GRIMMEAU, A. (2011). Dehors. Le graffiti à Bruxelles. Musée d'Ixelles. Bruselas. CFC-Éditions.

MARSALA, H. (18-3-2016). Morte alla Street Art? Cuoghi Corsello criticano Blu, en Art Tribune. https://www.artribune. com/attualita/2016/03/morte-alla-street-art-cuoghi-corsellocriticano-blu/ [Consulta: 24-7-19]

MAZZUCCHELLI, F. (2017) Street(icono)clashes. Blu vs Genus Bononiae: un caso di iconoclastia urbana. Ocula Magazine, 18. Cinzia Bianchi y Silvia Viti (Coord.) https://www.ocula.it/files/ OCULA-18-VITI-OMODEO-Street-art-come-patrimonio.pdf [Consulta: 25-8-19].

METROPOLITAN MUSEUM OF ART (MET). (2013) Nueva York. https://www.metmuseum.org/exhibitions/listings/2013/punk [Consulta: 27-7-19]

MORILLA, S. (2018) Ce n'est pas une ville. Docencia de las prácticas artísticas frenteal muro del procomún, la ciudad instrumentalizada y el arte desmemoriado. Mural Street Art Conservation. n॰8. Observatorio de Arte Urbano. http://observatoriodearteurbano. org/wordpress/wp-content/uploads/2015/08/mural 8.pdf [Consulta: 27-7-19]
MUSEU D'ART CONTEMPORANI DE BARCELONA (MACBA). (2016) Barcelona. https://www.macba.cat/ca/seminari-punk [Consulta: 28-7-19]

OMODEO, Ch. (2016). L'arte allo stato urbano. Street Art. Banksy\&CO. L'arte allo stato urbano. Bologna. Bononia University Press.

OMODEO, Ch. (2019). Christian Omodeo: vandal curator? Nuart Journal, Vol. 1, Núm.2. https://nuartjournal.com/wp-content/ uploads/2019/04/Nuart-Journal vol1-no2-18 Omodeo.pdf [Consulta: 27-7-19]

OMODEO, Ch. (2016).INFLVENCERS. Directed \& Produced by Good Guy Boris. https://www.youtube.com/watch?v=YF0dblcAop8 [Consulta: 27-7-19]

PALLARÈS, J. (2017) Con vello público (y II). Sentadas al sol entre artistas y comisarios. Mural Street Art Conservation, n5. Observatorio de Arte Urbano http://observatoriodearteurbano. org/wordpress/wp-content/uploads/2015/08/MURAL 5.pdf [Consulta: 27-7-19]

RICCIO, G.M. (2019) Street art e zelo dei militanti politici. Il murale con Carola Rackete deturpato a Taormina. Art Tribune. https:// www.artribune.com/arti-visive/street-urban-art/2019/08/ street-art-e-zelo-dei-militanti-politici-il-murale-con-carolarackete-deturpato-a-taormina/?utm source $=$ Newsletter $\% 20$ Artribune\&utm campaign $=5$ e 283 b 273 b-\&utm medium =email\&utm term $=0$ dc515150dd-5e283b273b$154075821 \& \mathrm{ct}=\mathrm{t} \% 28 \% 29 \& \mathrm{goal}=0$ dc5 $15150 \mathrm{dd}-$ 5e283b273b-154075821 [Consulta: 13-8-19]

SCHACTER, R. Street Art is a Period. Period (Or, classificatory confusion and intermural art). https://www.academia. edu/31498254/Street Art is a Period. Period Or classificatory confusion and intermural art [Consulta: 27-719]

VITI, S. (2017) «Street Art come patrimonio. Quale musealizzazione?». Entrevista a Christian Omodeo en Street Art: Iconoclastia e istituzionalizzazione, en Ocula Magazine, 18. Número coordinado por Cinzia Bianchi y Silvia Viti. https:// www.ocula.it/files/OCULA-18-VITI-OMODEO-Street-art-comepatrimonio.pdf [Consulta: 27-7-19]

WU MING. (12-3-2016). Street Artist. Blu Is Erasing All The Murals He Painted in Bologna. https://www.wumingfoundation.com/ giap/che-cose-la-wu-ming-foundation/ [Consulta: 21-7-19]. https://www.wumingfoundation.com/giap/2016/03/streetartist-blu-is-erasing-all-the-murals-he-painted-in-bologna/ [Consulta: 10-8-19]

WU MING. (21-3-2017). Un anno senza Blu. https://www. wumingfoundation.com/giap/2017/03/un-anno-senza-blu/ [Consulta: 10-8-19] 


\section{Autor/es}

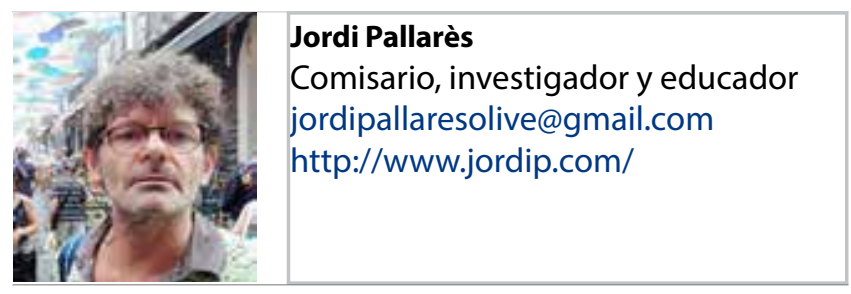

Comisario, investigador y educador visual. Trabaja en aquellas prácticas artísticas y/o reivindicativas que utilizan la esfera pública (y todos aquellos posibles espacios de autorrepresentación) con el objetivo de provocar reacciones en diferentes comunidades de individuos, en la misma ciudadanía. Sobre el público del espacio público. Como proyectos curatoriales, destacan en los últimos dos años: Sobreexposicions $i$ cures con Ampparito (Nau Bostik, Barcelona. 2019), Funàmbuls con Xavier Eltono (Casal Solleric, Palma. 2018), MUCU con Ignacio Bosch (CEART, Madrid. 2017), PEEP SHOW con Mawatres, Santiago Morilla, Aimar Pérez Galí y Pau Sampera (Arts Santa Mònica, Barcelona. 2017) o BLACK FACES con Grip Face (SC Gallery, Bilbao. 2017). Generando mesas redondas y espacios de discusión como Tuenti Urban Art Academy (2018-2019), forma parte de TAULA (Associació d'Educadores Culturals de Mallorca) y es socio-fundador de INDAGUE (Asociación Española de Investigadores y Difusores de Graffiti y Arte Urbano). 

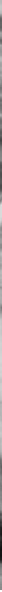

\title{
Repensando el arte público. New York city's Percent for Art Program
}

\author{
Sergio Pardo López
}

Resumen: En los últimos treinta años el número de nuevos programas e iniciativas de arte público se ha incrementado exponencialmente tanto en Estados Unidos como a nivel internacional. El aumento de iniciativas que promueven esta disciplina y la falta de rigurosidad en sus procesos de selección y gestión dificultan la consecución de piezas de arte público exitosas. El siguiente artículo presenta y evalúa diferentes aspectos que facilitan la concepción de piezas de arte público con garantías a través del Percent for Art Program, de la Concejalía de Cultural de Nueva York, programa pionero en la disciplina en Estados Unidos.

Palabras clave: Percent for Art Program, New York, Arte Público, Cultural Policies

\section{Rethiking public art. New York city's Percent For Art Program}

Abstract: In the last thirty years the number of new public art programs and initiatives has increased exponentially both in the United States and internationally. The increase in initiatives that promote this discipline and the lack of rigor in their selection and management processes make it difficult for these programs to achieve public success. The following article presents and evaluates the conception of public art pieces through the Percent for Art Program, of the Department of Cultural Affairs of New York City, a pioneering program in the United States.

Key words: Percent for Art Program, New York, Public Art, Cultural Policies

\section{Introducción}

En palabras de la filósofa de origen alemán Hilde Hein "la presencia de arte al aire libre, bien en una terminal de autobuses o en la recepción de un hotel no hace que el arte sea automáticamente público, al igual que no por el mero hecho de introducir un tigre en una jaula lo podremos llegar a domesticar". (Hilde 1996:4). En las últimas décadas, la presencia de piezas de arte público como resultado de iniciativas aisladas o enmarcadas en programas específicos ha aumentado exponencialmente tanto dentro de nuestras fronteras como a nivel internacional. Sin embargo, la falta de transparencia, la carencia de procesos de selección rigurosos o el descuido en la posterior gestión - en parte de estas iniciativas - ha tenido a corto plazo la consecuencia global de un empobrecimiento de la disciplina.

El éxito del arte público radica en gran parte en la adecuada combinación de tres componentes principales: la elección de propuestas y, por ende, de sus creadores que despierten gran interés artístico, una correcta comprensión del espacio, así como su vinculación con el entorno en donde se ubicará la pieza. Estos tres ejes son esenciales a la hora de responder a la idea principal que debe estar detrás de cualquier proceso de arte en 
el espacio público: ¿Qué debe lograr la presencia de la futura obra? Respuesta que tiene que ver con el mensaje, sus destinatarios y su propósito. Entender y responder correctamente a las premisas de cada proyecto facilita, por tanto, la aceptación del elemento en el lugar y busca construir un sentimiento de pertenencia y empoderamiento por parte de aquellos que vivirán y disfrutarán de la misma. Así bien, esta amalgama de factores ha de llevarse a cabo teniendo siempre presente la valía artística del proyecto y su potencial para enriquecer, expandir y fortificar la disciplina y la trama urbana de nuestras ciudades.

Es hora de hacer un alto en el camino a fin de ahondar en una profunda reflexión sobre esta materia en aras de establecer y determinar unas directrices que no pretendan alentar y llevar a cabo programas que produzcan meramente obras anodinas sin ningún vínculo con sus destinatarios, cuyo único propósito sea favorecer la imagen del patrocinador o artista e, incluso, inundar de imágenes vacuas las plataformas digitales. Es momento de seleccionar trabajos en procesos abiertos, por profesionales expertos en el campo concreto, teniendo siempre presentes las disciplinas en juego: medio ambiente, arquitectura, demografía e idea de permanencia en el tiempo; lo que junto con el proceso creativo del artista lleve a generar una pieza específica para el lugar. Hoy todos los agentes implicados deben promover políticas y programas que escuchen a las partes actoras, que las hagan partícipes en el proceso de selección para que una vez pasado el testigo la obra no sea entendida como un elemento extraño.

\section{Pasado y presente del arte público en EEUU}

En los Estados Unidos la idea contemporánea de introducir arte en el espacio público surge con el denominado Federal Art Project (FAP), creado por el presidente Franklin D. Roosevelt en 1935 a fin de fomentar la industria creativa y crear oportunidades para pintores, muralistas, escultores y artistas gráficos. El proyecto (renombrado en 1939 como Works Progress Administration; WPA) es el germen de los programas de arte público surgidos a finales de la década de los 50 y, por tanto, del centenar de programas que existen en la actualidad: locales, estatales o federales, y que se subvencionan a cargo de un porcentaje del presupuesto de construcción de las obras públicas (Grieve, 2009). Como definió el primer director del FAP, el curador e historiador Holder Cahill,(1880-1960) la visión de la iniciativa era servir como herramienta para incorporar el arte, los artistas y su proceso creativo en la vida cotidiana de las comunidades de todo el país.

A través de la FAP/WAP [1] unos diez mil artistas produjeron alrededor de trescientos cuarenta mil dibujos, pinturas y obras esculpidas, muchas de las cuales aún son visibles en edificios públicos de todo el país (Hapke, 2008:113). Sin embargo, durante este tiempo el arte público no se entendió como la intersección entre el arte, el espacio y la comunidad. Fue la influencia de un movimiento de arte contemporáneo —durante la década de 1980, el arte participativo y las ideas de Jane Jacobs, "community development must be locally informed, human-centric, and holistic" (Jacobs, 1961) - lo que ayudó a configurar la práctica actual del arte público en Estados Unidos.

Este nuevo enfoque artístico fue capaz de abordar elementos que parecían difíciles de manejar en proyectos institucionales durante los años setenta y ochenta. El arte participativo se centró en un compromiso directo con los espectadores a lo largo del proceso creativo, permitiéndoles ser además creadores y editores. Se plantearon nuevas preguntas: ¿en qué medida el trabajo $y$ el proceso de un artista tienen que estar vinculados al contacto directo con la comunidad? A diferencia del arte participativo, en el arte público no existe un enfoque único para lograr el objetivo deseado. La pieza ha de surgir como respuesta del creador al entorno y condicionantes del proyecto, permitiendo a las partes implicadas participar de manera directa o indirecta, dependiendo del proceso creativo del artista, con el fin de producir obras que además de su intrínseco valor estético, cumplan otros propósitos: fomentar sentimiento de comunidad/identidad, mejorar el espacio urbano, abordar problemas sociales, fomentar el cambio social, aportar un valor educativo o favorecer el desarrollo económico. Como señala la historiadora británica Claire Bishop "una obra de arte público se concibe como incompleta si no hay interacción directa o indirecta por parte de los espectadores". Debe entenderse que, como en el arte participativo, la importancia artística debe estar vinculada a la construcción de vínculos sociales a través del significado y la actividad de la comunidad (Bishop 2006).

\section{Percent for Art Program. NYC Department of Cultural Affairs}

En 1982, mientras Nueva York salía de una recesión económica, el alcalde de la ciudad Edward I. Koch inició el Percent for Art Program, posteriormente aprobado por el Ayuntamiento y dependiente de la Concejalía de Cultura de la ciudad. A partir de entonces un uno por ciento (2) del presupuesto de todos los proyectos de construcción de obra nueva o renovaciones financiadas por la ciudad se destina a obras de arte público, realizadas de manera específica para dichos espacios y su entorno. El Programa comenzó en 1983 con el desarrollo de un procedimiento para determinar los proyectos más adecuados, así como con la implantación de un proceso de selección equitativo llevado a cabo por profesionales del sector, abierto al público y con gran participación de la comunidad. Cerca de 430 proyectos han sido completados desde el inicio del programa, alcanzando un montante de noventa millones de dólares destinados a arte público. A lo largo del programa han participado 
entre otros artistas Alice Aycock, Sol Lewitt, Chakaia Booke, Lawrence Weiner o Ursula von Rydingsvard. Desde el año 2002 casi 140 proyectos han sido completados y en la actualidad el programa cuenta con 126 en curso que alcanzan la suma de 23.9 millones de dólares- y serán destinados a la realización de futuras piezas para la ciudad de Nueva York, obras que llevarán la firma de artistas como Hank Willis Thomas, Mierle Laderman Ukeles o Sara Ouhaddou.

\section{Proceso}

Fases del proceso:

1. Licitación del proyecto

2. Comisariado de Artistas

3. Primer panel de selección

4. Segundo panel de selección. Presentación de propuestas

5. Fabricación

6. Instalación

\section{Licitación del proyecto y Comisariado de Artistas}

Cada proyecto comienza en el momento de la licitación de la construcción y a partir de ahí se inserta en paralelo el trabajo de arquitectos, paisajistas e ingenieros en comunión con el artista. Durante la primera fase el equipo del programa lleva a cabo diferentes reuniones con las partes implicadas: técnicos, miembros de las concejalías involucradas en el proyecto, futuros usuarios del espacio y cohabitantes de la obra, a fin de entender las expectativas y posibles finalidades de la obras. Así mismo, el proyecto es presentado en la Junta de Distrito a fin de involucrar a la comunidad y generar diálogo. Tras un estudio pormenorizado de los condicionantes, el equipo del programa realiza un comisariado de artistas - aproximadamente cuarenta por proyecto - fundamentado únicamente en la trayectoria de los candidatos y su potencial para el proyecto en cuestión, solo teniendo en cuenta su trabajo previo y proceso creativo. Como novedad, factores como la procedencia, el momento en su carrera artística, el valor de mercado o su experiencia previa con la ejecución de obras de arte en el espacio público son del todo irrelevantes, por lo que cualquier artista, con independencia de su trayectoria y ubicación puede postularse como posible candidato.

La selección de artistas es el resultado por tanto de un trabajo interno de comisariado de los miembros del programa, los cuales hacen uso de la base de datos de artistas de la Concejalía de Cultura. Cualquier creador interesado en participar, tanto nacional como internacional, puede postularse durante todo el año a través del portal habilitado y enviar la información necesaria a fin de ser considerado para futuros proyectos [figura 1].

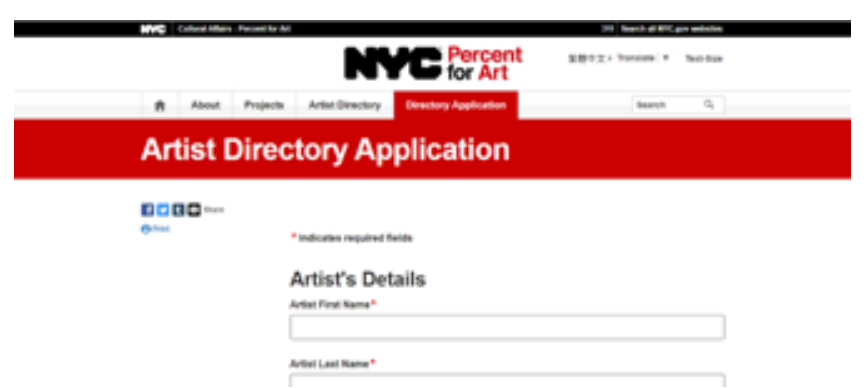

Figura 1.- Captura de pantalla del registro de artistas del Percent for Art Program, accesible dentro de la página web de la Concejalía de Cultural de la ciudad de Nueva York. https://www1.nyc. gov/site/dclapercentforart/contact/contact.page [última consulta:2-11-2019]

\section{Primer y segundo panel de selección}

En las dos fases inmediatamente posteriores de este proceso, del que saldrá el artista elegido, todas las decisiones serán tomadas por técnicos: curadores externos, artistas, críticos especializados en la materia, historiadores, y responsables del programa. Decisiones que tendrán en cuenta los comentarios y puntos de vista de todo aquel que quiera participar, siendo las sesiones abiertas a la participación del público en general. Para cada proyecto, el equipo del programa selecciona los miembros del jurado que participaran en ambos paneles. Los criterios de selección tienen en cuenta la trayectoria del profesional, experiencia en procesos de arte público y su conocimiento del entorno en donde se ubicará la pieza.

\section{Composición el jurado:}

Presidente del jurado: director o miembro del Percent for Art Program

- Panelistas con derecho a voto

- Representante del Percent for Art Program

- Representante de la Sponsor Agency [3]

- Representante de la Design Agency [4]

- 3-4 profesionales externos: artistas, críticos de arte, historiadores o curadores.

- Panelistas Asesores

- Arquitectos, paisajistas, urbanistas, ingenieros

- Representantes de la Public Design Commission [5]

- Representantes políticos: Ayuntamiento, Junta de Distrito

- Organizaciones locales

- Público general

Durante el Primer Panel de Selección el cometido es cribar la lista de cuarenta artistas preseleccionados a cuatro o cinco finalistas, atendiendo a su proceso y potencial creativo. Para ello se presenta a los panelistas diez obras de cada artista acompañado de un Artist Statement [6]. Después de visualizar el trabajo de los artistas a considerar, se abre la ronda de discusión que va seguida por diversas rondas de votación, facilitando la participación de cualquier asistente en la sala a presentar sus alegaciones y puntos de vista. Los 
técnicos con derecho a voto, por tanto, basan su decisión en base tanto a su experiencia y criterio profesional como a los argumentos compartidos por los asistentes y el debate generado durante el proceso.

Tras la selección y posterior comunicado a los finalistas, se organiza en las semanas posteriores una Orientación Artística en donde el equipo del Percent for Art Program, arquitectos, miembros de la comunidad y demás actores involucrados, comparten la información necesaria para la realización de la propuesta específica remunerada por parte de los finalistas. Desde este momento los creadores cuentan con dos meses para desarrollar la idea y contarán con el apoyo de los técnicos Percent for Art Program, que visitarán a los creadores al menos una vez en sus estudios o por a través de videoconferencia un mes antes de la presentación de las propuestas, y demás profesionales involucrados en el proyecto.

El segundo panel de selección o de entrevistas, igualmente abierto al público, el mismo comité escuchará de viva voz durante media hora, ya de manera presencial o por videoconferencia, la presentación por parte de cada uno de los finalistas seleccionados. Debido a la variedad geográfica de los artistas y condicionantes del idioma, la presentación puede ser llevada a cabo por un representante (galerista, miembro del estudio del artista, etc. con la ayuda de intérpretes facilitados por la Concejalía. Tras las presentaciones, al igual que en la primera fase de selección, se abre la ronda de debate y diversas votaciones que tendrán como resultado la selección del artista y proyecto a realizar.

\section{Fabricación e Instalación}

Una vez seleccionada la pieza, comienza la fase de desarrollo de la propuesta, que permitirá al artista(s) definir la idea y abordar tanto aspecto artístico, conceptuales y técnicos con la ayuda de las partes implicadas en el proceso. Siempre que la obra y el proceso creativo a desarrollar lo permitan, se podrán llevar a cabo talleres o actividades en relación a la futura obra, temática y medio artístico, a fin de seguir fomentando el sentimiento de pertenencia y propiedad por parte de la comunidad para con la futura pieza de arte público.

En tal sentido, la visión del Percent for Art Program y su por ende su proceso busca que las piezas seleccionadas pretendan ser una herramienta de expresión y transformación de la comunidad mediante una creación artística colectiva y participativa, surgida del entendimiento de las necesidades, así como de una ubicación concreta y sus adherencias sociales, funcionales, simbólicas y estéticas. Los proyectos de arte público realizados por el programa de Nueva York se materializan en multitud de medios, tamaños, localizaciones y técnicas. Si bien parte de la colección de la ciudad incluye murales, mosaicos y esculturas que se suelen asociar más fácilmente con la concepción más tradicional de "arte público", los proyectos del Percent for Art Program pretenden reflexionar con una visión contemporánea sobre la trama urbana en la que se insertan. Obras como Alterview de Natasha Johns-Messenger que versa sobre las diferentes percepciones de la realidad; Your Voices de Janet Zweig, que funciona como elemento de conexión entre docentes y estudiantes en un colegio público del Bronx; Peace Clock de la artista noruega Lina Viste Grønli, repensando la idea del monumento o memorial con su escultura cinética frente a las Naciones Unidas; o una lámpara de LED, Shakespeare Machine de Ben Rubin que se ha convertido en el icono del vestíbulo del Public Theater, constituyen ejemplos claros de lo que tratan de conseguir. [figura 2]

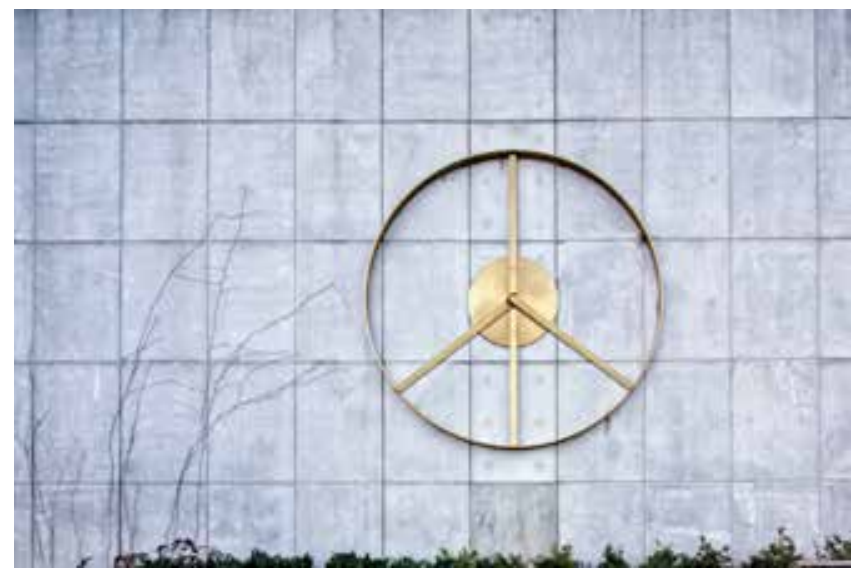

Figura 2.- Obra titulada Peace Clock, realizada en 2019 por la artista Lina Viste Grønli y ubicada en la Trygve Lie Plaza, enfrente de las Naciones Unidas en Manhattan. La pieza en su concepción busca reflexionar sobre cómo ha de abordarse el monumento contemporáneo, buscando conceptos atemporales y transversales en la diversidad de los espectadores, para una mayor relevancia en el tiempo del legado de la persona al que se busca honrar. Peace Clock es una pieza de arte público cinética ubicada delante de las Naciones Unidas que forma el símbolo de la paz dos veces al día (04:30 y 16:30) como tributo a Trygve Lie, primer Secretario General de la organización y promotor de la campaña de desarme nuclear. Concejalía de Cultura de la Ciudad de Nueva York

Tras más de treinta y cinco años de recorrido, el programa neoyorquino sigue marcando la hoja de ruta del arte público en América, y ha logrado sentar unas bases sólidas en cuanto a la necesidad de crear una colección pública con unos criterios abiertos, desde una organización profesionalizada que tiene como objetivo conseguir una muestra contextualizada en su tiempo y lugar, siendo conscientes de que las obras seleccionadas pueden llegar a ser reconocidas como patrimonio cultural. El programa y su proceso han sido adaptados, parcial o totalmente, por otras ciudades americanas, como por ejemplo Seattle o Chicago, y tomado como modelo de referencia por parte de instituciones internacionales con amplio recorrido en la materia, como los de Melbourne y Oslo. 


\section{Algunas de las obras seleccionadas}

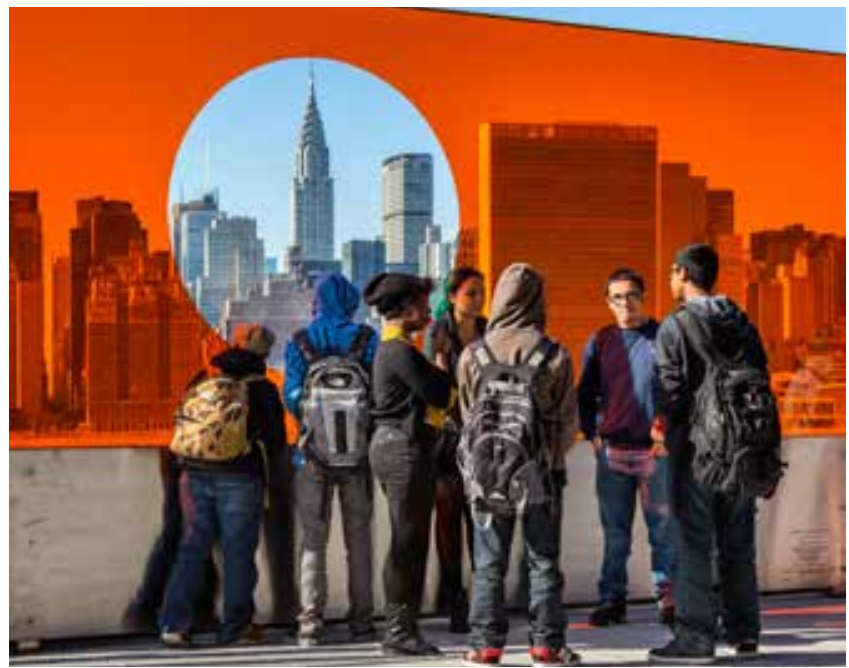

Figura 3.- Artista: Natasha Johns-Messenger; Título: Alterview; Localización: HS/ IS 404, Hunters Point, Queen; Créditos de foto: NYC Department of Cultural Affairs; Breve descripción: Ubicada en la azotea de un instituto público en Queens, la pieza versa sobre las diferentes percepciones de la realidad dependiendo desde donde se miren las cosas.

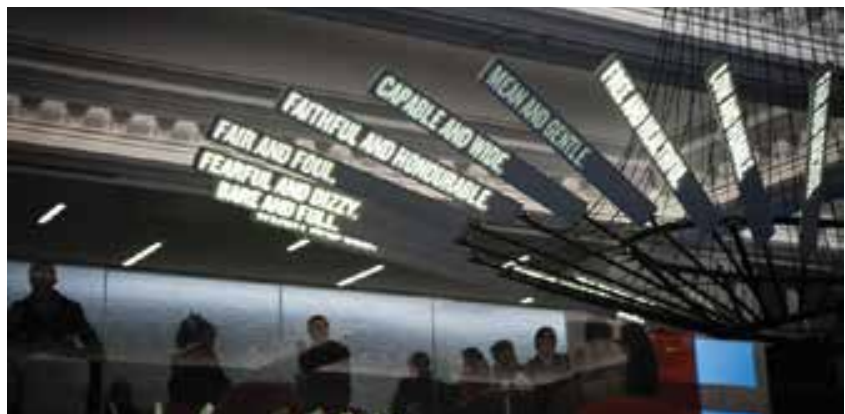

Figura 4.- Artista: Ben Rubin; Título: Shakespeare Machine; Localización: Public Theater, Manhattan; Créditos de foto: NYC Department of Cultural Affairs; Breve descripción: Obra que muestra una selección cambiante de frases de los textos de Shakespeare en el espacio que rinde tributo a su obra y se ha convertido en el icono del teatro público de Nueva York.

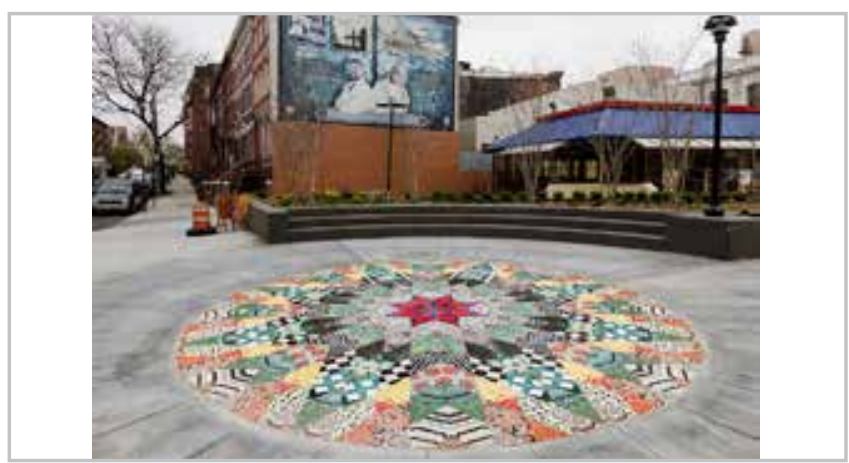

Figura 5.- Artista: Ellen Harvey; Título: Mathematical Star, Localización: Marcy Plaza, Brooklyn; Créditos de foto: NYCDepartment of Cultural Affairs; Breve descripción: Pieza de arte público que funciona en diversos niveles. Por un lado el mosaico recoge la historia del barrio a través de la tradición patchwork incorporando 18 patrones diferentes que hacen referencia a lugares de especial importancia para la comunidad, y por otro genera un nuevo hito con identidad propia. La pieza hoy en día es activada por diferentes organizaciones locales que trabajan con mujeres tras cumplir sus condenas y los hijos de están que han nacido y vivido en prisión, para fomentar sentimiento de identidad y pertenencia en su barrio.

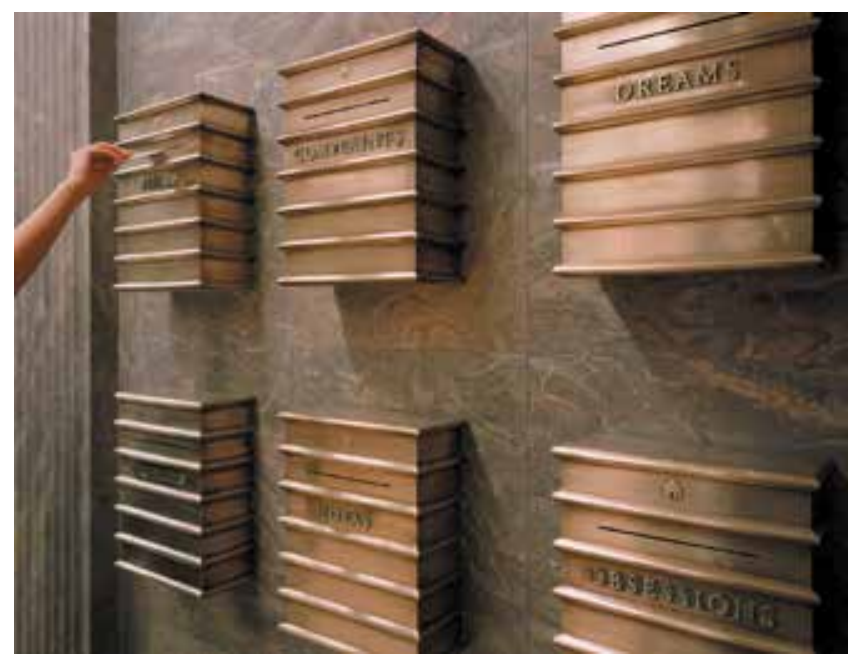

Figura 6.- Artista: Janet Zweig; Título: Your Voices; Localización: Walton High School, Bronx; Créditos de foto: NYC Department of Cultural Affairs; Breve descripción: Obra con un componente participativo que funciona como elemento de conexión entre docentes y estudiantes en un colegio público del Bronx.

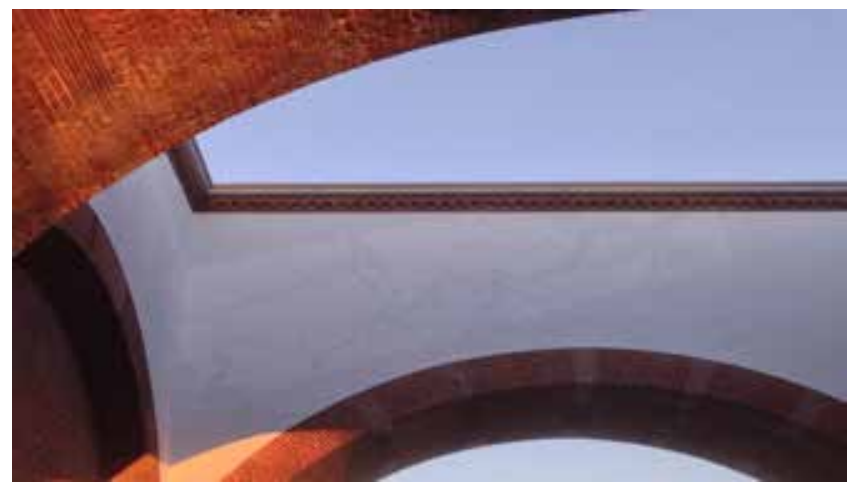

Figura 7.- Artista: Mary Temple; Título: Double Sun; Localización: McCarren Pool, Brooklyn; Créditos de foto: Sergio Pardo López; Breve descripción: Murales que celebran con dos sutiles trampantojos a la entrada del centro deportivo la historia del barrio, los meses de verano y parte de la vegetación perdida del parque.

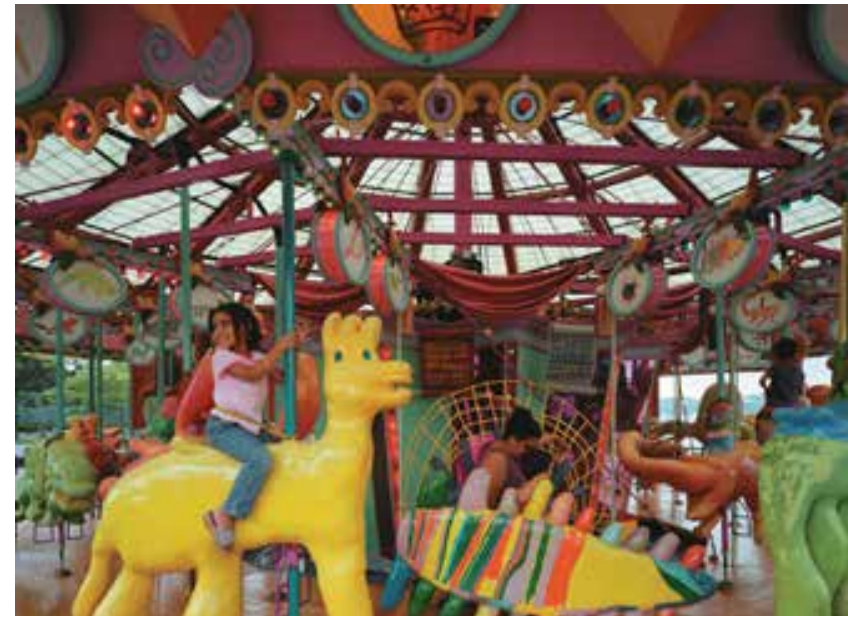

Figura 8.- Artista: Milo Mottola; Título: Totally Kid Carousel; Localización: Riverbank State Park, Manhattan; Créditos de foto: NYC Department of Cultural Affairs. Breve descripción: Pieza creada por el artista con el propósito de revitalizar un parque en desuso y que incorpora el trabajo realizado por el artista con los niños de la zona a fin de generar un sentimiento de propiedad. 


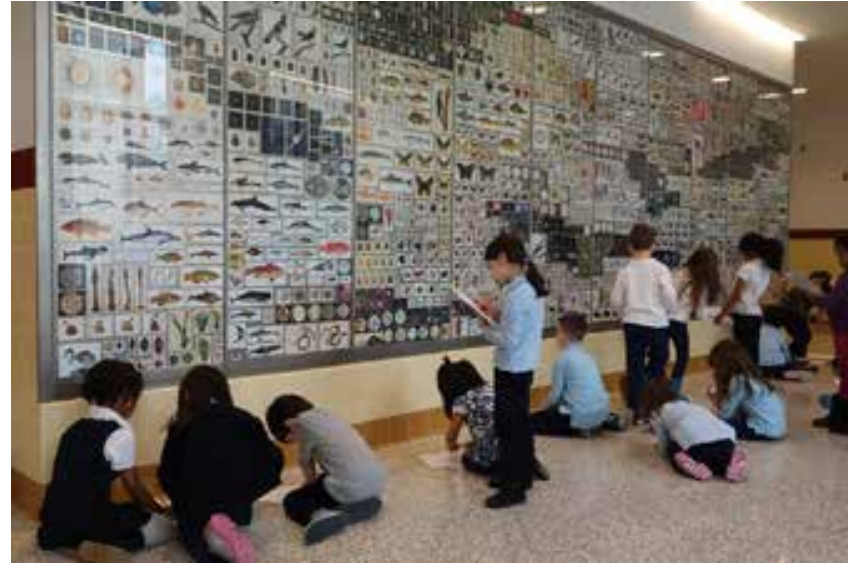

Figura 9.- Artista: Penelope Umbrico; Título: Cabinet 15262013; Localización: PS IS 71, Staten Island; Créditos de foto: NYC Department of Cultural Affairs; Breve descripción: Obra que pretende ser un contrapunto a la sobreexposición de imágenes de la web y presenta en esta enciclopedia de pared o gabinete de curiosidades un complejo mundo de imágenes, grabados y objetos que pretenden incitar a la investigación y el descubrimiento.

\section{Conclusión}

Tanto en sus inicios como en la actualidad, la promoción del sector creativo y la descentralización de la cultura en los cinco barrios de la ciudad de Nueva York siguen facilitando el acceso y visibilidad a piezas artísticas en suelo público y haciendo de esta práctica un catalizador para el diálogo, el compromiso social y el desarrollo económico en cada rincón.

Iniciativas como la expuesta deberían hacer reflexionar sobre el estado del arte público y sobre la inclusión de herramientas similares en las políticas públicas actuales. Generar debate y controversia a fin de revisar lo que actualmente se está haciendo al respecto en otras latitudes y establecer una hoja de ruta que tenga como objetivo principal la correcta integración de arte contemporáneo en el entramado urbano, permitiendo a las generaciones presentes y futuras cuestionarse la forma en la que vemos, escuchamos, pensamos y nos comportamos.

\section{Algunas respuestas:}

\section{- ¿Cómo se seleccionan los barrios en los que se sitúan las obras?}

Los proyectos del Percent for Art Program están vinculados a las obras a realizar en los cinco barrios de la ciudad. El programa busca mantener un ratio equitativo en las diferentes áreas y primar todo proyecto que tenga un mayor impacto para la comunidad y su entorno.

\section{— ¿Hay cesión de derechos de autor al Ayuntamiento?}

Las piezas que conforman la colección del Percent for Art
Program son propiedad de la ciudad la cual se reserva el derecho de utilizar imágenes para promocionar la iniciativa y el programa, no pudiendo hacerlo con fines comerciales. El autor(es) tiene libertad para utilizar imágenes de la obra incluyendo fines comerciales.

\section{- ¿Se catalogan las obras?}

Las obras se encuentran catalogadas dentro del registro de la colección del Percent for Art Program de la Concejalía de Cultura.

\section{$-¿$ Qué vinculación posterior existe del Ayuntamiento con los artistas?}

Los artistas mantienen una vinculación con el programa y participan en cualquier menester que tenga que ver o se relacione con su pieza, principalmente en lo concerniente a futuras restauraciones de la obra o por motivos divulgativo o informativos.

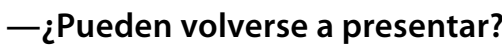

Si bien se busca fomentar la diversidad y dar oportunidad a nuevos creadores, los artistas pueden volver a ser considerados tras cinco años desde la instalación de su última obra.

\section{Notas}

[1] El Federal Art Project posteriormente renombrado Works Progress Administration fue el primer intento de patrocinio de las artes por parte del gobierno de los Estados Unidos, y el más extenso e influyente desde la Gran Depresión de la década de 1930 durante la administración del presidente Franklin D. Roosevelt. El éxito del programa fue en gran medida resultado de su primer director, Holder Cahill, (1880-1960), curador, escritor y gestor cultural, que vio el potencial para el desarrollo cultural a través de lo que sería un programa de ayudas para artistas.

[2] El presupuesto para cada proyecto, proveniente del 1\% del presupuesto de construcción del edificio, espacio u obra civil, y se desglosa de la siguiente forma: Desglose del presupuesto del $1 \%$.

a. 20\% Honorarios del Artista. Cantidad a recibir por el artista(s) por idear la pieza de arte público. Dicho porcentaje no incluye los honorarios de fabricación en caso de que sea realizado por el propio artista(s).

b. $60 \%$ Instalación y Fabricación. Cantidad destinada a la producción y posterior ubicación de la pieza en el lugar.

c. $10 \%$ Gastos Generales. Cantidad destinada a partidas no relacionadas directamente con la producción de la pieza: seguros, documentación, viajes... 
d. $10 \%$ Contingencia. Cantidad destinada a hacer frente a imprevisto o fluctuaciones de precios durante el periodo previo a la instalación de la pieza.

e. Sponsor Agency. Concejalía que gestionará el espacio: Departamento de Parques, Departamento de Transportes, Departamento de Educación... El representante ha de ser un técnico en arte público.

f. Sponsor Agency. Concejalía que financia la obra. En su mayoría esta figura recae en el Department of Design and Construction (Departamento de Obras Públicas) o el New York City Economic Development Coorporation. El representante ha de ser un técnico en arte público.

g. Public Design Commission de la Ciudad de Nueva York, conocida legalmente como la Art Commission es la agencia del gobierno de la Ciudad de Nueva York que revisa obras permanentes de arquitectura, paisajismo y arte que serán ubicadas en suelo público de la ciudad. La Comisión está compuesta por 11 miembros que sirven pro-bono y se reúnen una vez al mes para revisar y votar proyectos presentados por agencias de la Ciudad. Los miembros incluyen un arquitecto, arquitecto paisajista, pintor, escultor y tres miembros independientes, así como representantes del Brooklyn Museum, el Metropolitan Museum, la Biblioteca Pública de Nueva York y Alcaldía.

h. Artist Statement o Declaración de Artista es la descripción del proceso creativo de un artista. El breve escrito tiene como finalidad informar, facilitar la comprensión de la obra y presentar las bases para un mejor entendimiento del trabajo; es por tanto un texto de naturaleza didáctica, descriptiva o reflexiva.

\section{Bibliografía}

HEIN, H. (1996). What is Public Art? Time, Place, and Meaning. Journal of Aesthetics and Art Criticism 54: 1-7

VICTORIA GRIEVE, (2009). The Federal Art Project and the Creation of the Middlebrow Culture. Chicago: University of Illinois.

HAPKE, LAURA (2008). Labor's canvas: American workingclass history and the WPA art of the 1930s. Newcastle: Cambridge Scholars. 113

JACOBS, JANE JACOBS (1961)The death and life of great American cities. New York: Random House.

CLAIRE BISHOP (2006) ed. Participation. London: Whitechapel.

\section{Autor/es}

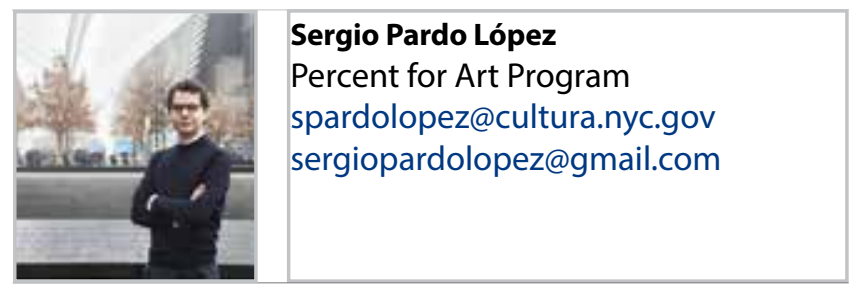

Director de Proyectos del Percent for Art Program de la Concejalía de Cultural de la Ciudad de Nueva York. Arquitecto Superior por la ETSAM de Madrid, visitante del Illinois Institute of Technology (beca Rafael del Pino), MBA Cultural por New York University (beca Fulbright), y ctual doctorando en el programa de Arquitectura, Diseño, Moda y Sociedad de la Universidad Politécnica de Madrid, ha venido desarrollando una trayectoria vinculada al mundo del arte desde una óptica multidisciplinar. En tal sentido ha participado en el comisariado de proyectos en prestigiosas instituciones como la Colección Peggy Guggenheim de Venecia, el Pabellón de España en la 10 Bienal de Arquitectura de Venecia, la Fundación Canal de Isabel II, la Casa Encendida de Madrid o la gestión de la Colección Lola Garrido. Ha sido conferenciante invitado en diversos foros como: Cornell University, New York University, Universidad de Navarra o Christie's. 

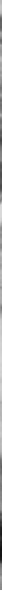

\title{
Arte Urbano en colecciones públicas y privadas. El caso del fondo artístico de la UPV
}

\author{
Mercedes Sánchez Pons
}

Resumen: El arte urbano desde hace ya décadas viene siendo objeto de estudio, interés y deseo. Instituciones, iniciativas sociales y particulares han promovido su producción en un entorno determinado bajo intereses muy variados, incitando de algún modo también el deseo de colección. En este texto analizamos un caso concreto insertándolo en este contexto global, el de las intervenciones de artistas urbanos realizadas en la Universitat Politècnica de València bajo convocatorias como el festival anual Poliniza, actualmente Poliniza-Dos, que se celebra desde el año 2006, Tuenti Urban Art o el proyecto Murales interactivos: Mujeres de Ciencia. La asimilación de alguna de estas obras en el paisaje interno del campus ha llevado a plantear su inclusión en el catálogo del fondo de arte de la universidad, bajo una colección determinada, cuya existencia y posible denominación no están exentas de controversia.

Palabras clave: conservación-restauración, arte urbano, muralismo, colección artística, Universitat Politècnica de València, festival Poliniza-Dos, Tuenti Urban Art

\section{Street art in public and private collections. Street Art artist's interventions in the art collection of the Universitat Politècnica de València}

Abstract: Urban art has been the subject of scholarly study, commercial interest and public controversy for decades. Institutions, social initiatives and individuals have promoted their production in varied environments, also prompting the desire for collection by formal institutions. In this text we analyze a specific case, that of the work of urban artists carried out at the Polytechnic University of Valencia under such initiatives as the annual Poliniza festival, currently Poliniza-Dos, which has been held since 2006; Tuenti Urban Art; and the project Interactive Murals: Women of Science. The assimilation of some of these works into the internal landscape of the campus has led to its inclusion in the catalog of the art collection of the university, an innovation that is not exempt from controversy.

Key words: street art conservation, muralism, collection, Polytechnical University of Valencia, Festival Poliniza-Dos, Tuenti Urban Art

\section{Introducción y objetivos}

El interés por el arte urbano, en cualquiera de sus formas y derivaciones ha ido creciendo de forma exponencial y de manera muy significativa en los últimos años. No es extraño, por contradictorio que pueda resultar a priori, que estamentos públicos y privados, colectivos sociales e individuos, expertos o no, se interesen en reunir piezas, ya sea de forma virtual o física, bajo perspectivas diferentes, con afán investigador, promotor, especulador o curioso. La Universitat Politècnica de València (UPV) fue pionera en 2006 en apostar por este tipo de manifestación cultural y darle cabida en el ámbito académico, organizando el festival de arte urbano Poliniza, ahora Poliniza-dos, concebido como un foro de encuentro entre artistas que trabajaban en la calle, estudiantes e investigadores y gestores culturales, que ya habían demostrado a través de sus trabajos la importancia de lo que estaba ocurriendo. No fue sencillo abrir los muros de la universidad para ello y por eso es importante destacar el empeño personal del entonces vicerrector de Alumnado y Cultura, Joan Peiró, del director del Área de Actividades Culturales, David Pérez, así como del que ha sido comisario del festival en la mayoría de sus ediciones Juan Canales. [figuira 1] 


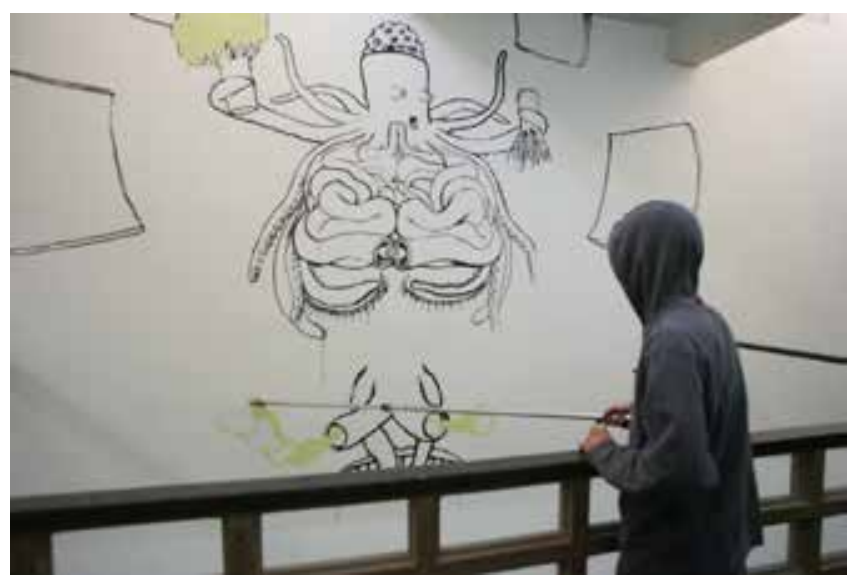

Figura 1.- Blu interviniendo un muro de la Facultad de Bellas Artes de la Universitat Politècnica de València durante la primera edición del festival Poliniza, en el 2006. Fotografía Kike Sempere para Poliniza 2006.

Su existencia ha determinado, sin duda, la deriva de la producción local de las calles valencianas (Canales, 2006; Sánchez-Pons, 2016a) y también ha contribuido al desarrollo y difusión de numerosos trabajos de investigación en este ámbito.

Catorce años después, la presencia de festivales relacionados con el arte urbano en el panorama local, nacional e internacional es incontable y también la misma UPV ha participado en otros eventos, fruto de los cuales encontramos otros muros de la universidad intervenidos.

El desarrollo de este estudio surge a partir de una pregunta que formula la actual directora del área de Fondo Artístico y Patrimonio (FAP), Susana Martín: ¿Deberíamos generar una colección específica de arte urbano con los muros aún pintados del festival Poliniza y otros eventos similares desarrollados en la UPV? ¿Cómo podría denominarse? Desde la creación de esta área se ha trabajado notablemente en la organización del fondo artístico de la UPV con la intención de — dada su naturaleza pública — posibilitar el acceso, disfrute y conocimiento de todo tipo de público. Gracias al trabajo realizado desde el Vicerrectorado de Alumnado, Cultura y Deporte, y en concreto desde dicha área, las obras que lo conforman se encuentran registradas y catalogadas, contando en la actualidad con cuatro museos reconocidos, que pueden ser visitados, así como ocho colecciones específicas muy diferentes. Fue durante ese trabajo de ordenación cuando surgió la duda expuesta anteriormente, sobre cómo y dónde incluir los murales generados durante algunas de las ediciones del festival de arte urbano, visibles todavía, así como los tres últimos creados en otros eventos recientes, en concreto los realizados en 2017 y 2018 respectivamente por PICHIAVO y Dulk, con motivo del evento Tuenti Urban Art [1] y el pintado por Lula Goce en el muro del Rectorado, a raíz del proyecto Murales interactivos, Mujeres de Ciencia. [figura 2]

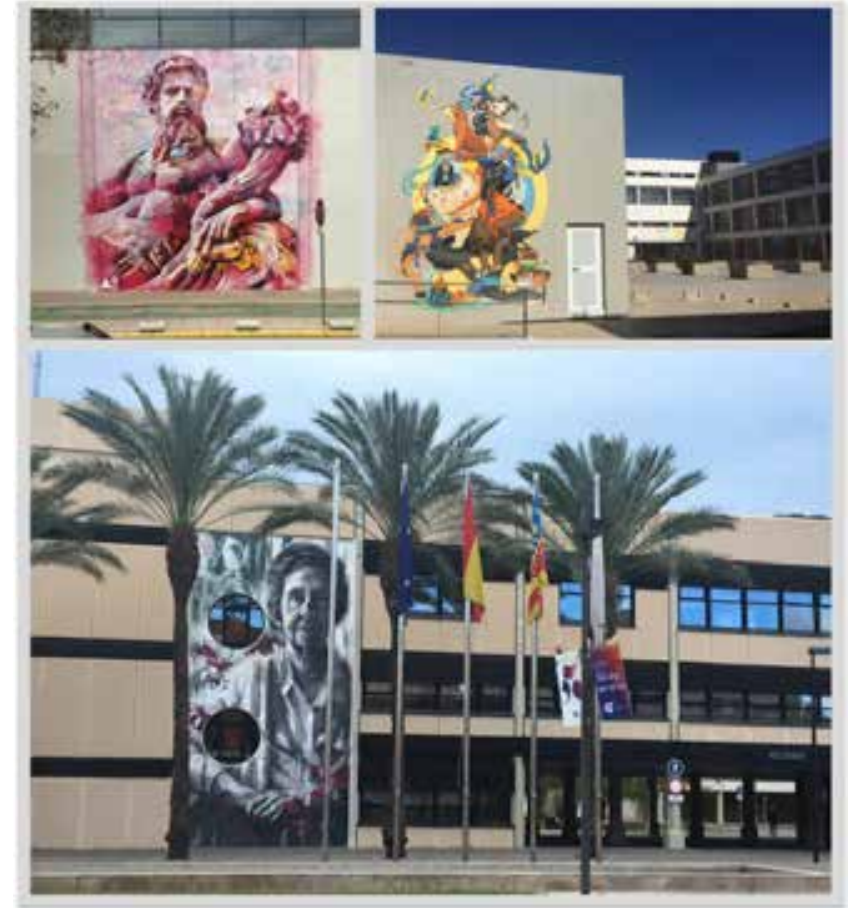

Figura 2.- Intervenciones murales de PICHIAVO y Dulk para Tuenti Urban Art y Lula Goce para Murales interactivos. Mujeres de Ciencia. Todos en el campus de Vera de la UPV.

Contestar a esta pregunta ha llevado al desarrollo de este trabajo, cuyo objetivo fundamental es, por tanto, el de llegar a una propuesta argumentada que ofrezca una respuesta al planteamiento realizado. Partimos de la hipótesis de que estas obras, junto con las que se han ido haciendo en las sucesivas ediciones, conforman un conjunto específico que podría constituir una colección concreta dentro del fondo de arte institucional y por tanto puede ser ordenada, presentada y difundida como tal.

Puesto que el término "arte urbano" lo encontramos ya en distintos tipos de colecciones artísticas la metodología seguida para contextualizar este caso se ha basado en el estudio de las diferentes formas que se dan de coleccionar obras acuñadas bajo ese término, a partir del análisis de ejemplos concretos representativos, llegando a establecer cuatro tipologías. A continuación, se analiza el caso de la UPV considerando las características de las intervenciones, la forma de participación y selección, el volumen de obras generado, el tiempo inicial previsto de permanencia y su modificación, el ámbito legal establecido, su significación en el fondo artístico y su posible relevancia en el entorno y el contexto internacional

\section{Concepto de Colección y ejemplos de tipologías de presencia de arte urbano en colecciones de arte}

El afán por "coleccionar" está en la esencia de la actividad humana y se ha practicado desde siempre con toda clase 
de objetos, incluidos aquellos considerados artísticos o culturales. La intención de reunir, seleccionar, clasificar, ordenar y en algunos casos mostrar, es intrínseca a la idea de generar una colección, ya sea de sellos, elementos etnográficos o de obras de arte.

El concepto de colección artística está íntimamente ligado a la idea de museo y discurso expositivo, pero no es exclusivo de este ámbito, ya que en muchos casos las colecciones tienen un carácter privado y no existe voluntad de mostrar el conjunto reunido a la sociedad, por lo que según el contexto la definición específica del término puede ser diferente al modificar también sus características y finalidad.

El deseo de poseer o el reconocimiento de un interés y valor, ya sea cultural o económico, son motores muy diferentes presentes en la generación de las primeras colecciones privadas. Estas son anteriores y origen, en algunos casos, de la formación de los primeros grandes museos entendidos como templos de la cultura, que tanto auge tuvieron durante el siglo XIX y principios del $X X$. Hoy en día esta relación continúa siendo importante y tal y como afirma Glenn D. Lowry, director del MoMA, el coleccionismo privado juega un papel fundamental en el cumplimiento de funciones de los museos contemporáneos (García, 2016).

Desde las últimas décadas del pasado siglo se viene cuestionando el sentido del museo, las colecciones que alberga y su función social (Crimp 1993; Danto,1999). De hecho, aún hoy resulta difícil ofrecer una definición para el término en la que las distintas asociaciones que forman parte del International Council of Museums (ICOM) se sientan representadas. Hace años que se viene trabajando en la actualización de la que incluyen sus estatutos, adaptándola a la realidad diversa del siglo $\mathrm{XXI}$, pero la propuesta presentada en la convención celebrada durante septiembre de 2019 en Tokio no ha permitido llegar a un acuerdo en cuanto a la redacción, por lo que se mantiene vigente el texto precedente:

"un museo es una institución sin fines lucrativos, permanente, al servicio de la sociedad y de su desarrollo, abierta al público, que adquiere, conserva, investiga, comunica y expone el patrimonio material e inmaterial de la humanidad y su medio ambiente con fines de educación, estudio y recreo."[3]

Esta entidad, a la vista de sus estatutos entiende que una colección museográfica está constituida por bienes culturales, que tiene bajo custodia legal la institución a la que pertenece, que también es responsable de su conservación, consta de un inventario y hay una exposición al público bajo un objetivo determinado, relacionado con la transmisión de un conocimiento. Además considera que tanto el patrimonio inmaterial y los objetos que lo definan, así como el patrimonio natural, pueden formar parte de una colección museográfica, expandiendo el ámbito del museo más allá de un recinto cerrado contenedor de objetos.

Desde el punto de vista legal para que un conjunto ordenado de bienes culturales se reconozca como colección museográfica en España deberá reunir un nivel de cumplimiento de requisitos organizativos y funciones, no coincidente en todos los aspectos a las directrices que recoge y propone el ICOM, e incluso con matices también entre comunidades autónomas. [4]

En concreto en la Comunidad Valenciana se pueden obtener dos reconocimientos diferentes, como museo o como colección museográfica, siendo necesario cumplir una serie de funciones y requisitos distintos, centrándose dicha diferencia en la infraestructura y medios disponibles para su mantenimiento y apertura al público.[5]

Desde la visión más inclusiva de la definición general, no sólo la vinculada a un museo, una colección puede ser pública o privada y con ánimo lucrativo o no y puede tener una finalidad dirigida hacia otros o quedar encerrada en sí misma. Lo que sí es necesario es que ese agrupamiento forme un conjunto coherente, es decir, que exista una selección y no una mera acumulación y que esta se haga bajo una lógica concreta, ya sea un criterio científico o cualquier otra motivación particular, lo que también le otorgará una relevancia específica según el contexto en el que sea considerada. Si se trata de una colección privada, sin reconocimiento legal, el criterio de selección quedara al arbitrio particular; si es institucional y sufragada con fondos públicos deberá responder a una intención de ofrecer esa reunión organizada de testimonios materiales o inmateriales de la vida humana a la sociedad actual y futura, ofreciendo información suficiente sobre la misma $y$, por tanto, asegurando también su conservación, en cualquiera de sus formas posibles.

El arte urbano no está exento de generar la inquietud de ser coleccionado, a partir de cualquiera de las motivaciones descritas, pudiendo llegar a formar parte de colecciones públicas o privadas, materiales o inmateriales, de forma legal o ilegal, moral o inmoral, con o sin el consentimiento del autor de la obra.

No es objeto de este estudio definir qué obras son o no arte urbano, aunque del análisis de ejemplos realizado subyace la pertinencia y necesidad de difusión de diferentes estudios al respecto (Berti, 2009; Abarca, 2016; Schacter, 2016; Gayo, 2016), puesto que el término sigue siendo utilizado en todo tipo de contextos, tanto para obras legales e ilegales que se hacen en la calle y para la calle, como para otras que se conciben y realizan para el espacio privado. Los artistas son los mismos y todo es arte contemporáneo, pero afirmar que todo aquello realizado por artistas que hacen arte urbano es arte urbano es delicado. 
Bajo esa generalidad de colección de arte urbano, o arte urbano que forma parte de una colección, encontramos numerosos ejemplos de naturaleza diversa, que vienen sucediendo desde hace ya décadas y que pasamos a explicar agrupados en cuatro tipologías.

-Tipología 1: colecciones que incluyen obras legales, adquiridas a partir de una transacción comercial con una galería o con el propio artista.

Así se conformó una de las colecciones de arte urbano más significativas, la que reunió el artista Martin Wong y que donó tras su muerte, en 1994, al museo de la ciudad de Nueva York. Son obras compradas en las décadas de los 80 y 90 del pasado siglo, directamente a los artistas y en algunos casos a galerías que, ya entonces, mostraban y distribuían piezas de escritores de grafiti y creadores significativos (Mc. Cormick, Corcoran, 2013). El artista las reunió, seleccionándolas, con la finalidad de poseerlas y conservarlas, su cesión al museo denota una apreciación y un deseo de que pervivan y puedan ser ofrecidas de nuevo al público.

Desde entonces, y en particular en los últimos años, las galerías especializadas se han multiplicado en el panorama internacional y resulta sencillo adquirir una obra de un artista que gana renombre haciendo arte urbano, en un rango de precios muy amplio. Esto lleva tanto a que se generen colecciones privadas, como a que se adquieran obras individuales.

Ya en 2013 se organizó en París un encuentro entre coleccionistas particulares para comprar y debatir sobre la compra-venta de arte urbano en el Hôtel des ventes Drouot, Collectionneurs et Street Art [6]. Igualmente, la cuarta edición de la feria internacional de nuevo arte contemporáneo, Urvanity, en Madrid, no hace sino corroborar el auge en la adquisición de este tipo de producto [7]. Goyo Villasevil, de Swinton Gallery, hace una interesante reflexión, recogida en el artículo de Fernando Díaz de Quijano (2018) para elcultural.com, en torno a los tipos de coleccionistas actuales de arte urbano, distinguiendo entre los que buscan generar una colección de arte contemporáneo representativa de una época, y esto incluye adquirir obras de artistas urbanos, y los que compran arte urbano como reacción al circuito del arte, entre los que estarían los aficionados, que también pueden optar a adquirir algo que les gusta, dada la variedad de productos y precios, y que, tal y como señala Seleka Muñoz, de Delimbo, adquieren lo que les gusta porque lo conocen tras haberlo visto en la calle.

Desde muchos puntos de vista esto no podría considerarse arte urbano, sino obras de artistas que hacen arte urbano, que en ningún caso podrían entenderse como descontextualizadas, puesto que han sido creadas para este fin. [figura 3 y figura 4]

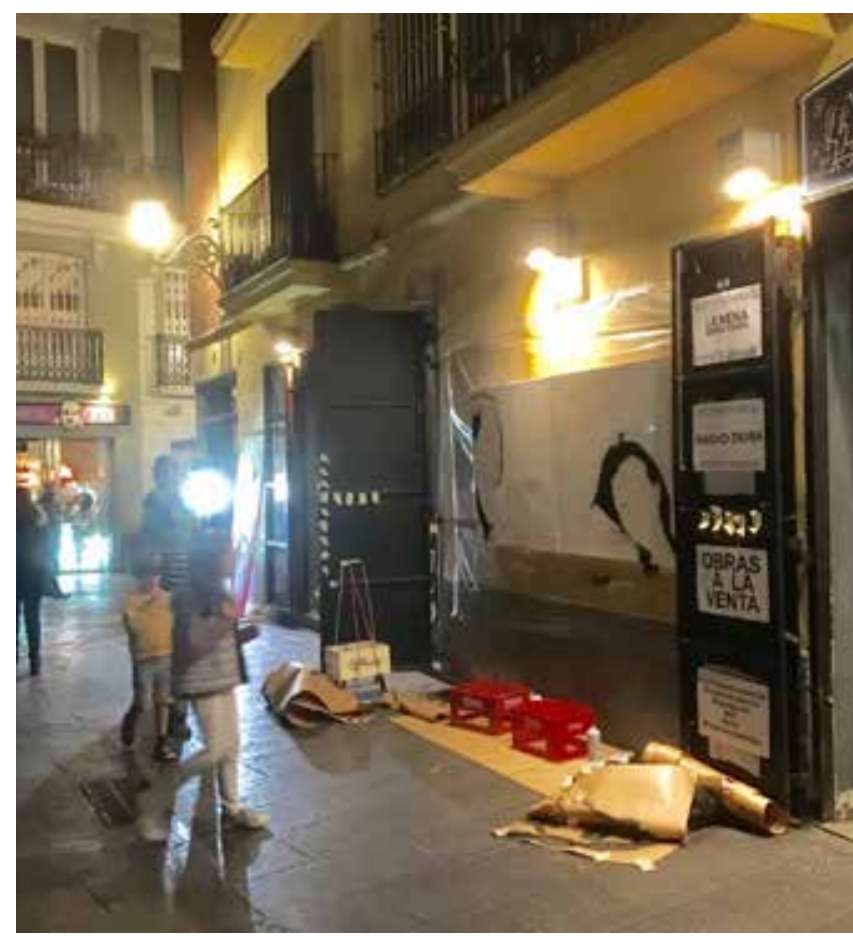

Figura 3.- Exhibición de pintura con espray y plantillas de La Nena Wapa-Wapa y Nacho Durá en el Barrio del Carmen de Valencia. En los carteles vemos cómo se autodenominan artista urbana y artista urbano respectivamente y cómo las obras que realizan se ponen a la venta.

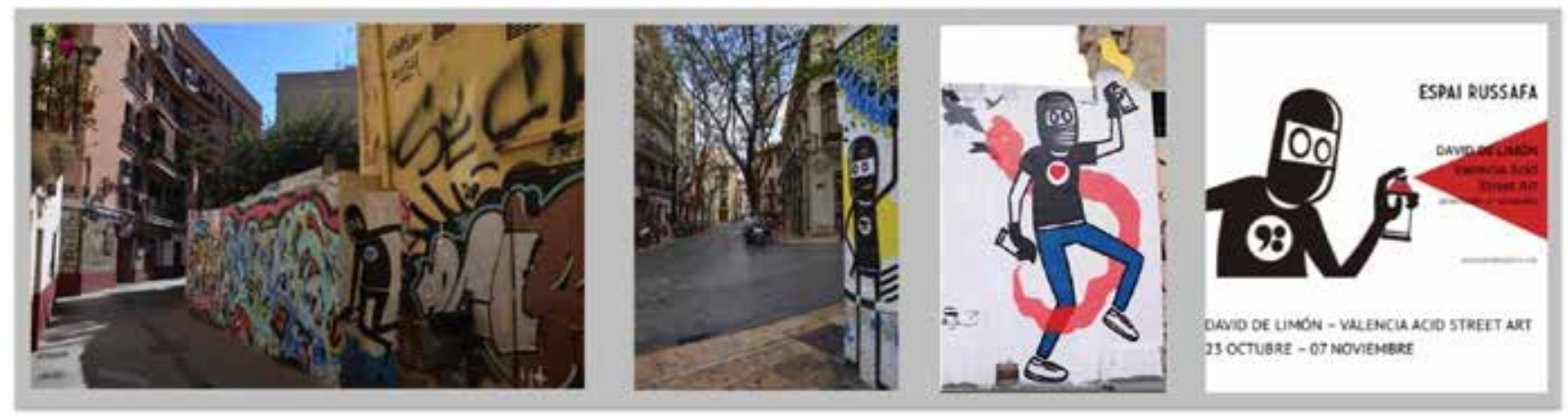

Figura 4.- Ninja de David de Limón en tres situaciones diferentes: utilizado como bombing icónico (ilegal) por la ciudad de Valencia; en los muros autorizados durante un festival organizado en el que el artista participa por invitación y en la galería Espai Russafa. 
-Tipología 2: colecciones específicas, o piezas que pasan a formar parte de una colección, extraídas del entorno urbano, con o sin consentimiento del artista y del dueño del muro.

En esta tipología estarían los múltiples ejemplos de piezas de Banksy arrancadas de los muros y vendidas o subastadas para coleccionistas privados, gracias a la autorización de los propietarios del muro, aunque no del artista, como las que realiza el grupo Sincura Art. Sin embargo, todas las mostradas en la exposición "Guerra, capitalismo y libertad", comisariada por Stefano Antonelli y organizada por Terzo Pilastro en el Palazzo Cipolla en Roma en septiembre de 2017, procedentes de colecciones privadas, pertenecerían a la tipología anterior, por el modo en el que fueron creadas y concebidas.

También podríamos incluir el controvertido arranque de ciertos fragmentos de intervenciones murales del artista italiano Blu, sin su consentimiento, en las fachadas de los edificios abandonados de Casaralta y Cavolani, en Bolonia, para formar parte de la exposición Street Art. Bansky\&CO. L'arte allo stato urbano [8]. Los comisarios de la misma, Christian Omodeo y Luca Ciancabilla, defienden activamente su actuación, bajo la perspectiva de la necesidad de salvaguardar testimonios materiales de una parte tan significativa del arte contemporáneo actual:

"(...) E ben vengano le critiche. Ben venga il dibattito, sé constructivo sul pericolo "collezionistico" o su quello del possibile "sfrutamento economico", sugli abusi e l'eccesso di zelo, sui "danni" materici che povrebbe o potrebbe comportare l'operazione di stacco, sulle inevitabili derive filosofiche ed etiche che la possibile musealizzazione e quindi decontestualizzazione dell'opera d'arte destinata in origine a un determinato ambiente o luogo comportano.

(...) Ben vengano le opinione differenti, le incomprensioni, se riusciremo a salvare anche solo pochi frammenti, pochi lacerti di un'epoca che un giorno sarà ricordata nei libri di storia dell'arte e della cultura come quella che vide operare fra le strade della città del mondo Blu, Banksy, Obey, Os Gemeos, Blek le Rat, Dado, Cuogli Corsello, Rusty. Se saremo capaci di lasciare a posteriori delle tracceconcreta di questa grande storia. Se porteremo con noi delle prove tangibili della materia che dava forma all'idea e del paessaggio del tempo su di essa. (...)" (Ciancabilla, 2016)

Como es sabido, este argumento enfureció al propio artista, y a otros muchos, generando un acalorado debate en diversos foros, como el sostenido durante la mesa redonda organizada en la Openwalls Conference de Barcelona, en octubre de ese mismo año, "¿Conservar el arte urbano?" [figura 5]. Aquella decisión supuso, como mínimo, la pérdida irremediable e inmediata del resto de muros pintados por Blu en la ciudad de Bolonia, ya que fueron eliminados por el propio artista en respuesta al hecho. Este caso ha seguido analizándose desde muchos puntos de vista, manteniendo abierto el debate en torno a la legitimidad y motivación de la actuación de Blu (Mazzucchelli, 2017; Martini 2017).

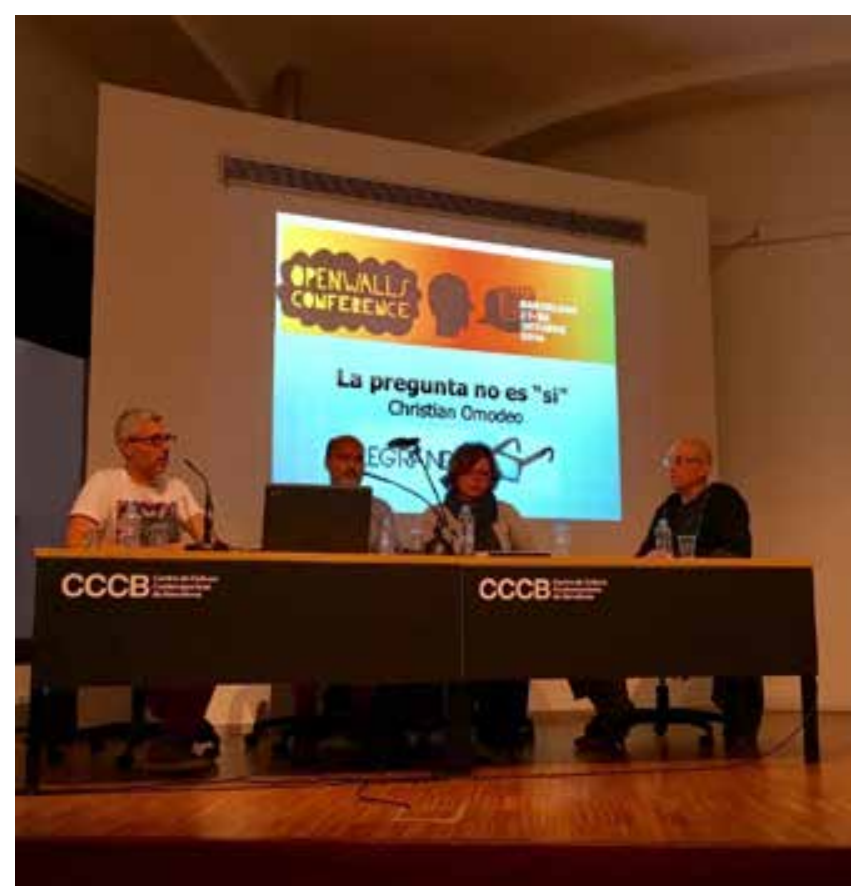

Figura 5.- . Intervención de Christian Omodeo durante la mesa redonda "Conservar el arte urbano?" organizada por el OpenWalls en el Centre de Cultura Contemporania de Barcelona en octubre de 2016. Le acompañan Javier Abarca, Elena García Gayo y el artista Jorge Rodríguez Gerada.

Es importante señalar también, en relación a la tipología anteriormente descrita, que en esta misma muestra se incluían préstamos de otras piezas de arte urbano procedentes de colecciones públicas, como de la mencionada colección Martin Wong, y también privadas, como de la colección Reinning, de Hamburgo, la Jacques et Thierry de París o la de Daniele Perra Parian.

Además de estos casos con gran repercusión mediática, es inevitable que individuos anónimos extraigan del entorno obras que admiran para generar una colección particular, sin el consentimiento del artista, pero con la misma excusa de mantener un testimonio material de algo que aprecian y no quieren que se pierda. Un ejemplo interesante es el que se muestra en la entrevista y reportaje que realiza Michael Stahl (2017) a Tommy, nombre falso de un joven de Nueva York que hace este tipo de práctica. En él se incluyen fotografías del proceso que sigue, así como de obras que guarda de SacSix, Cost y otros y también se recoge su opinión y motivación a la hora de realizarlo. Además, se incluye la respuesta de algunos de estos artistas, como Cost, respecto a este comportamiento, quien se muestra reacio, como la mayoría de ellos, a aceptarlo, ya que, aunque se siente apreciado, también considera que se está robando una parte de sí mismo.

También es conocida la existencia de piezas que, tras ser extraídas ilegalmente del entorno urbano, se ponen a la venta, con una motivación lucrativa, en plataformas como ebay [figura 6] 


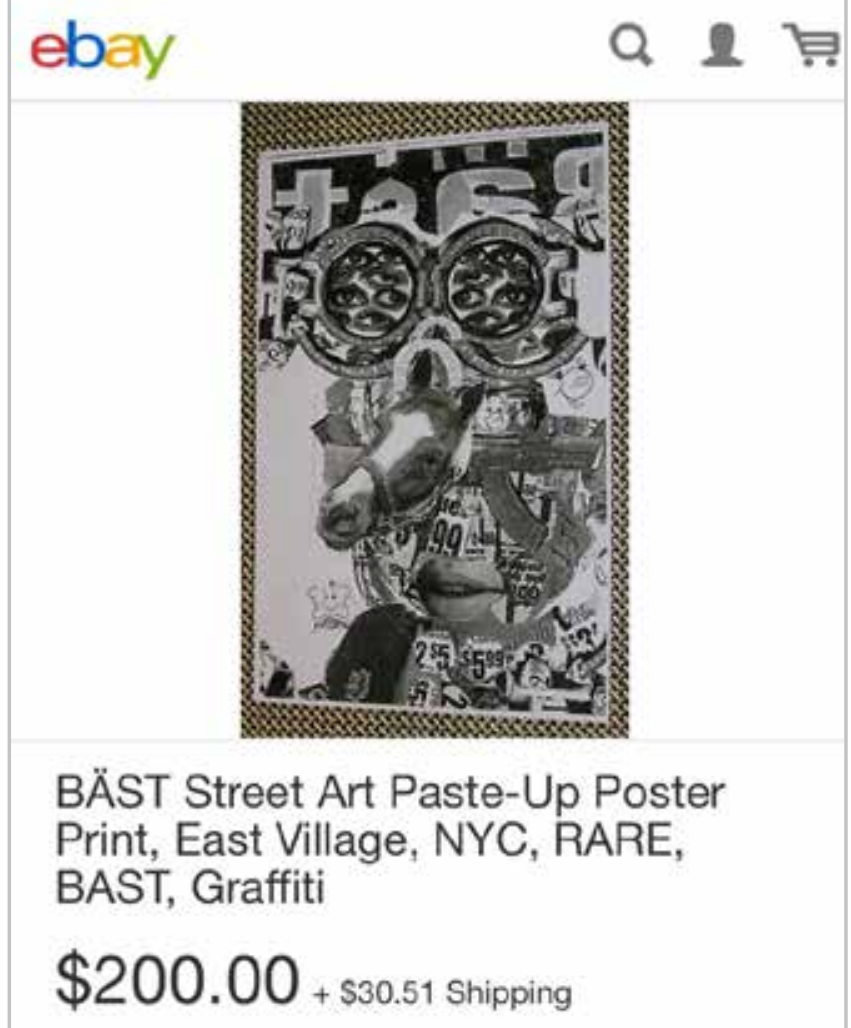

Est. Delivery Sat, Sep 14 - Thu, Sep 19

Longtime member $\quad$ Fast and safe shipping

Figura 6.- Ejemplo de Paste up a la venta en ebay. https://www. ebay.es/itm/BAST-Street-Art-Paste-Up-Poster-Print-East-VillageNYC-RARE-BAST-Graffiti/183928344735?hash=item2ad2fbd09f: g:ILMAAOSwrfRcP1yg [última consulta:2-11-2019]

Otras veces, sin embargo, es el artista quien participa en el juego de abandonar la obra y descubrir su futuro desafiando incluso al espectador, como por ejemplo el autodenominado artista urbano y ensayista MRBT62, que utiliza el icono The Photographer, realizándolo en diversos soportes y formatos e insertándolo en diferentes lugares urbanos y rurales. A través de sus cuentas en redes sociales incita al juego de "abandono-localización-nueva vida", recibiendo imágenes e historias del objeto recuperado y su nuevo emplazamiento, muchas veces en una colección privada y anónima. [figura 7] Así lo recoge en diversas entradas, como esta del 28 de agosto de este año 2019 en su cuenta de Facebook:

"Hoy (me) ha ocurrido dos veces. Sí, dos veces. Nuevamente alguien que no conozco, \#macnoler, me ha enviado una imagen de "the photographer" enmarcada. Una postal impresa con el nuevo icono de "the photographer", ubicada sutilmente en la Subida del Toledano, en la ciudad vieja y "abandonada a su suerte". Ese "después" pocas veces es conocido.

Gracias!!!!!!!
Saber que ese es el "después" es la recompensa a una actitud continua de desapego. Uno tiene la propiedad intelectual de su obra siempre, pero la posesión de las piezas está entregada ya en el mismo acto de pegar el azulejo, de adherir un paste up o fijar una postal con una bolita removible" (The Photographer, 2019)
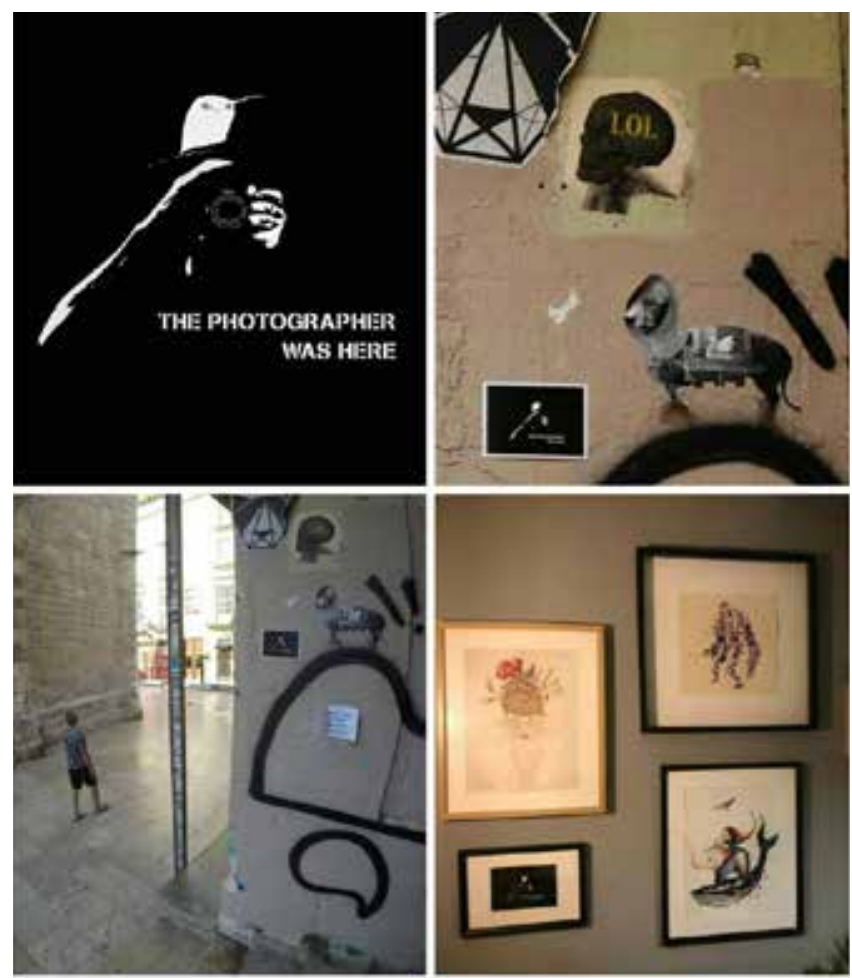

Figura 7.- Montaje de The Photographer en el que muestra la pegatina con su nuevo icono en la calle donde la colocó y una fotografía de la misma, extraída de ese lugar por un admirador enmarcada junto a otras obras. https://m.facebook.com/story. php?story fbid $=1322668197895482 \& i d=719861748176133$ [última consulta:2-11-2019]

Las obras apropiadas del modo descrito en los ejemplos rara vez pasan a formar parte de los fondos de un museo o colección estatal, ya que la cuestión legal sobre su propiedad es realmente controvertida y no sería fácilmente justificable desde los principios reflejados en el código ético del ICOM (2017). Sin embargo, a través de diferentes tipos de transacciones sí pasan a manos de coleccionistas privados de diferentes categorías.

Su extracción del emplazamiento original supone su inmediata descontextualización, cosa que, por otra parte, sucede también con la mayoría de los objetos presentes en un museo y que la museografía trata de solventar a partir del discurso expositivo que se establece en cada caso.

-Tipología 3: obras legales comisariadas y promovidas por ayuntamientos, instituciones públicas y asociaciones privadas en el espacio común, sobre muros privados o públicos autorizados. 
Ejemplos de colecciones que se mantienen en su contexto original podemos encontrarlos en numerosas ocasiones en localidades que, con motivaciones diferentes, plantean un festival con el cual, además de la experiencia que supone el propio evento durante su celebración, se genera un elenco de obras que quedan después sobre sus muros y calles. Los artistas son invitados o seleccionados bajo las bases del certamen en cada edición y sus obras pasan a formar un conjunto coherente, bajo la lógica de los organizadores del evento.

Sería imposible señalar la infinidad de festivales de arte urbano que se celebran y cada uno de ellos, con criterios más o menos discutibles, hace su propia selección de participantes que, a su vez, van generando esos conjuntos de obras "efímeras", cuyo tiempo estimado de vida queda en manos de la propia organización y su duración final está también a expensas de otros factores difícilmente controlables, como el clima, emplazamiento o uso del espacio, como ya se ha señalado en otras ocasiones (Gayo, 2015; Sánchez, 2016b).

Un caso singular, que merece la pena ser destacado es el de Fanzara, una pequeña localidad de Castellón, y su Museo Inacabado de Arte Urbano (MIAU) [9]. Su historia ha sido presentada en muchas ocasiones en foros especializados y también en todo tipo de reportajes divulgativos. Sus muros comienzan a intervenirse en 2014 con la intención de favorecer la convivencia entre vecinos enfrentados por la fricción política. Gracias al empeño de los organizadores y al interés altruista de los artistas que quisieron participar, hoy constituye uno de los proyectos de arte urbano más singulares y auténticos que podemos encontrar en el panorama internacional, que ha logrado generar una identidad propia alternativa para la comunidad de esa localidad, en la que su colección juega un papel determinante. Ellos lo denominan Museo y es innegable que lo que se ve en sus calles es una colección de arte urbano reconocida y reconocible por cualquier experto, para la que además ofrecen visitas guiadas para diferentes tipos de público, con una destacable calidad, cumpliendo así muchos de los requisitos establecidos por ICOM y por la legislación de la Comunidad Valenciana [figura 8].

Como ejemplo contrapuesto y también muy representativo podemos citar el de Wynwood, en Miami, donde, al igual que en otros muchos eventos, la especulación inmobiliaria también forma parte del motor organizador de estas iniciativas. Jessica Goldman Srebnick, jefa ejecutiva de Goldman Properties, a quién pertenece el conjunto de muros de ese particular barrio, reconoce que invitando a los artistas a pintar en ellos "coleccionan su arte" (Sullivan, 2016)

Entre ambos ejemplos hay un sinfín de casos diferentes con motivaciones y desarrollos muy distintos y específicos.

Esta tercera tipología se caracteriza porque las obras se encuentran en su contexto original y el concepto

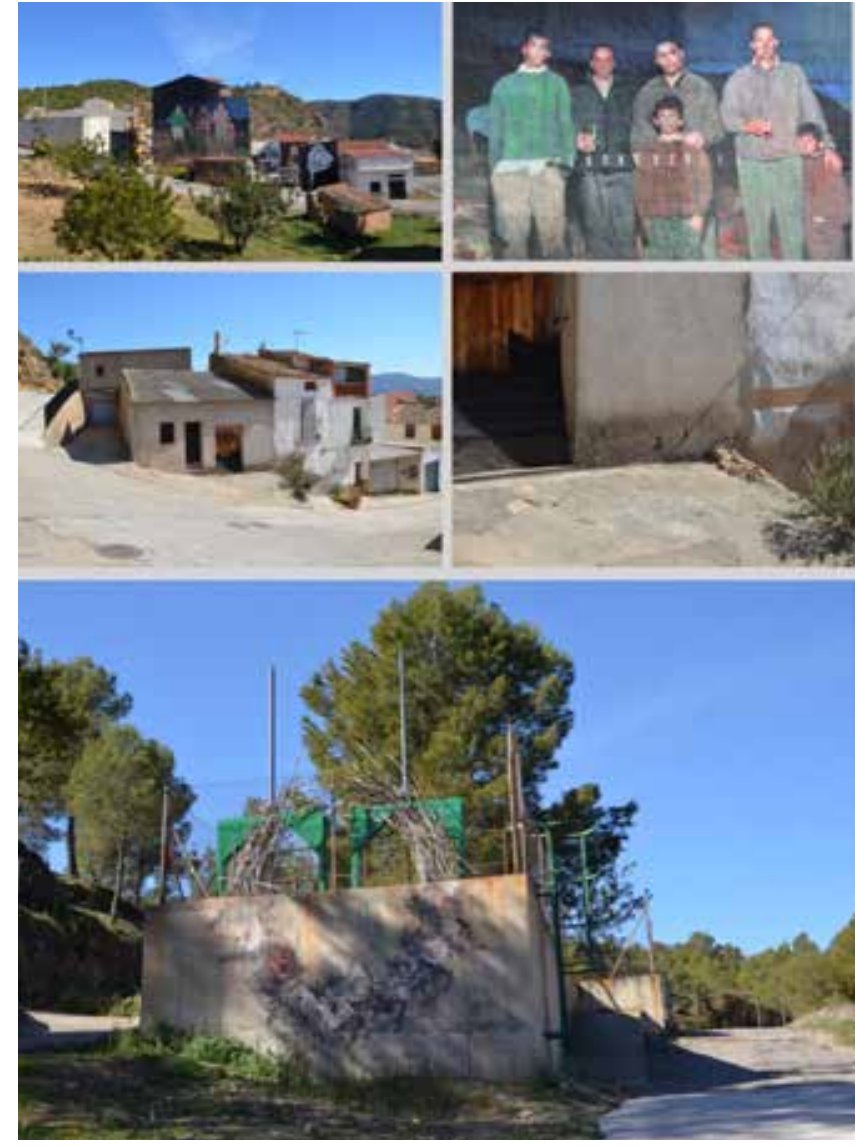

Figura 8.- Intervenciones de Axel Void, Suso 33 y Borondo en el MIAU Fanzara.

de colección cumple algunas de las características enunciadas: selección ordenada bajo un criterio y posibilidad de ser mostrada, pero en demasiados casos queda mucho por considerar en cuanto a cómo asegurar un mantenimiento en los parámetros de tiempo para los que han sido creadas, en el tipo de información que se ofrece al visitante para un conocimiento adecuado y en cómo ésta es conservada para su estudio y disfrute por generaciones futuras.

\section{—Tipología 4: cibercolecciones de arte urbano}

Otro modelo muy distinto, con ciertas ventajas y también carencias importantes es el de las cibercolecciones, realizadas tanto por expertos como por aficionados y que podemos encontrar en forma de webs estáticas o interactivas, junto con apps, que realizan su propia selección y agrupación de piezas bajo un criterio determinado, ya sea objetivo y argumentado o personal y aleatorio.

Hoy en día proliferan las recopilaciones hechas por aficionados, expertos, investigadores, gestores culturales, empresas que persiguen un fin comercial o las que realizan los propios artistas y muestran en sus redes sociales. Sin embargo, a nivel institucional no se abordan iniciativas que realicen propuestas coherentes. 
En esta modalidad se pierde gran parte del contexto, pero sobre todo la experiencia en toda su compleja extensión, tal y como destaca Javier Abarca (2015) en una reflexión que realiza sobre las posibilidades de conservar el arte urbano. Aún con todo sigue siendo una de las vías más realistas para conservar y poder explicar en un futuro su evolución. Además, ese modo que tienen los artistas de mostrar su obra y compartirla en un espacio común, más allá de lo físico, también forma parte de la esencia evolutiva del movimiento; probablemente el arte urbano sin internet no sería lo mismo ni siquiera para los artistas, que son los primeros que entienden el registro inicial (y en algunos casos posterior) como parte esencial de su proceso creativo.

\section{El Fondo de Arte y Patrimonio de la UPV}

Este año la Universitat Politècnica de València cumple 50 años y como organismo público, durante este tiempo el compromiso con su comunidad y con la sociedad ha ido evolucionando para adaptarse a las necesidades actuales. Una parte esencial de este enfoque se recoge bajo el lema CULTURA UPV. Este compromiso surge para ofrecer una visión crítica, innovadora y universal del pensamiento, las artes y la ciencia; $y$, por otro lado, para conservar y divulgar su patrimonio cultural e industrial albergado en sus museos y colecciones. [10]

Para su desarrollo se estructuran dos áreas específicas: la de Actividades Culturales y el Fondo de Arte y Patrimonio (FAP).

El FAP se crea en la década de los noventa del pasado siglo y en la actualidad está constituido por más de tres mil piezas de diversa naturaleza, que se distribuyen entre los campus de Vera, Gandía y Alcoy. Son fruto de adquisiciones, donaciones y depósitos y constituyen un vasto patrimonio artístico, documental e industrial que, como institución pública, pertenece a la sociedad.

Como explicábamos en la introducción, la labor de registro, documentación y ordenación realizada desde el FAP ha posibilitado que en la actualidad existan cuatro museos que cumplen con las exigencias legales que marca la comunidad valenciana y que, por tanto, cuentan con dicho reconocimiento: el Museo Campus Escultòric de la UPV (MUCAES UPV); el Museo de Informática; el Museo de las Telecomunicaciones y el Museo del Juguete. Todos ellos ofrecen información accesible y organizada, orientada a la didáctica y la investigación y permiten concertar visitas organizadas adaptadas a distintos colectivos. Además, cuenta con ocho colecciones específicas de diferente tipo de patrimonio cultural: pintura contemporánea; escultura contemporánea; obra gráfica; fotografía contemporánea; libros de artista; estatuaria clásica del siglo XVIII; mapas de la Fundación Giménez Lorente y la colección de maquinaria industrial. Las obras artísticas pueden ser también consultadas a partir del motor de búsqueda por autor de la base de datos, a la que se accede de forma abierta desde la web institucional. Las intervenciones murales procedentes de los distintos eventos vinculados con el arte urbano, sin embargo, no aparecen registradas en ninguna colección concreta en la base de datos, ni pueden ser localizadas a través de este sistema.

\section{Intervenciones de Arte Urbano en la UPV}

En los catorce años de existencia del festival Poliniza, Poliniza-Dos, además de los libros, exposiciones fotográficas, documentales, mesas redondas, conferencias y demás actividades generadas alrededor del mismo, se han producido más de doscientas obras e intervenciones que han ocupado los muros y espacios más significativos y visibles de la universidad. [figura 9]

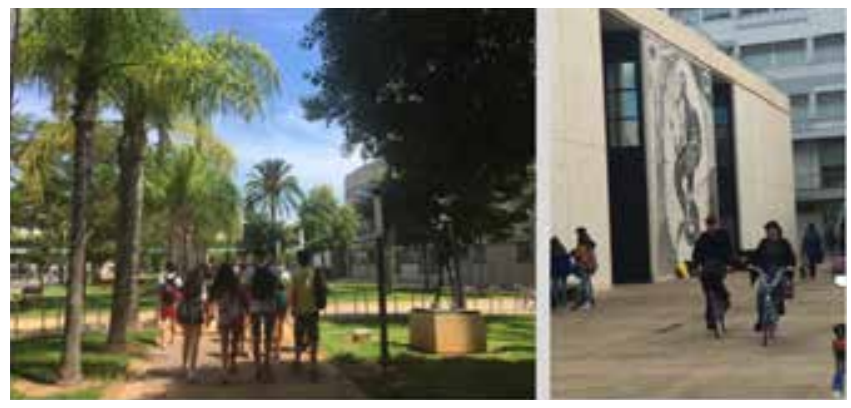

Figura 9.- Tanto las obras del Campus Escultoric (colección reconocida como museo MUCAES UPV), como los murales e intervenciones de las distintas ediciones del Poliniza forman parte del paisaje interno del campus de la universidad.

Desde su inicio se consideró necesario mostrar el carácter universal de este tipo de manifestación artística, conjugando la participación a través de invitación directa de artistas emergentes y consolidados de cualquier procedencia, junto con una fase de concurso, abierta a recibir propuestas de todo tipo, locales, nacionales e internacionales.

Como es sabido, los muros son reutilizados edición tras edición, por lo que el tiempo esperado de exposición y posible visita es de un año. Sin embargo, alguna de estas obras, bajo el criterio de la dirección del festival, se mantienen por un tiempo indeterminado en los muros de la universidad. En concreto, a fecha de hoy, además de las intervenciones de la última edición de mayo de 2019, encontramos, con diferentes estados de conservación, las de: Ferran Gisbert y Luca Zamoc (edición 2014); Luca Zamoc (edición 2014); Escif (edición 2015); BYG (edición 2016); Eltono (edición 2016); Vero Rivera (edición 2017); Alexis Díaz (edición 2017); The Empty Bell (edición 2018); Colectivo ArteyActivismofem (edición 2018); José Pizarro (edición 2018); Franco Fasoli (edición 2018); Elim Chal (edición 2018) [figura 10] 


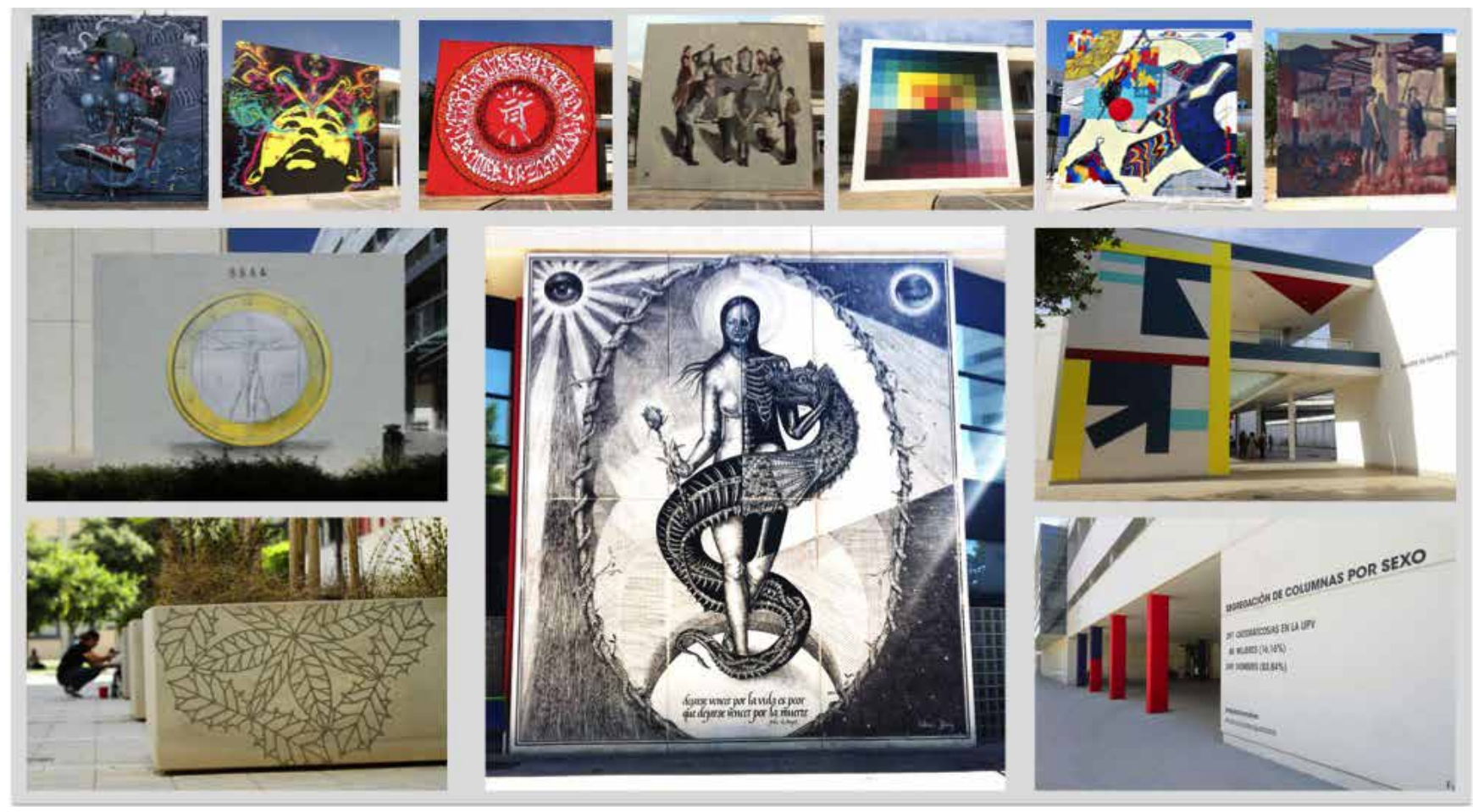

Figura 9.- Arriba muro reutilizado en sucesivas ediciones del festival Poliniza y Poliniza-Dos y abajo algunas de las intervenciones que perviven todavía en el campus y que exceden el tiempo estimado de vida de un año entre ediciones, en concreto: Escif 2015; Alexis Díaz 2017; Eltono 2016; Vero Rivera 2017 y el colectivo ArteyActivismoFem 2018.

Las obras realizadas en estos años, tanto las que permanecen, como las que han sido sustituidas, constituyen un conjunto único y particular. En la web oficial del festival se recogen las distintas ediciones, en la que se presenta información relevante desde 2014, a través de un menú común con los siguientes campos: presentación; artistas; programa; murales; menudopoliniza; fotografías del proceso y enlace a la edición anterior [11]. De las ediciones anteriores a esa fecha quedan textos, noticias y álbumes fotográficos de obras y procesos, realizados por Kike Sempere. Además, de algunas ediciones se publicaron catálogos específicos y uno conmemorativo en 2015, a los diez años del inicio del festival, que incluye al menos una imagen de cada una de las obras realizadas.

Como se ha explicado, además de las obras producidas durante el festival existen otros muros intervenidos, fruto de eventos distintos: los dos murales realizados por PICHIAVO y Dulk, a raíz de la propuesta de Tuenti Urban Art y un tercero en el que Lula Goce retrata a Margarita Salas en el muro principal del edificio del Rectorado para el proyecto Murales interactivos, Mujeres de Ciencia. Éstos tampoco están recogidos en las bases de datos del Fondo de Arte y Patrimonio, aunque sí se incluyen dentro del mapa de obras de la web del Poliniza, pese a no haber sido realizadas durante el festival.

La importancia del legado de obras generado y la potencial lectura de su evolución justificaría su organización como colección del fondo patrimonial de la UPV. Se considera que podría formar parte del fondo artístico de la universidad, puesto que se ha invertido dinero público en su generación, y los artistas han firmado contratos que regulan su participación. A nuestro parecer estas obras, tanto las que se mantienen, como las ya sustituidas o tapadas constituyen una colección, puesto que hay una selección organizada de las mismas, bajo un criterio científico, realizada por un grupo de expertos y cuya lectura ordenada constituye un discurso de la evolución en el tiempo del arte urbano en unos años cruciales de su desarrollo.

\section{Conclusiones: propuesta de colección}

Como hemos comprobado, es un hecho que el arte urbano, entendido en su contexto más inclusivo, ha pasado a formar parte de colecciones artísticas, en su mayoría privadas. La mayor parte de las veces son obras de artistas que hacen arte urbano, pero son piezas realizadas ad-hoc para un circuito interno. Cuando no es de este modo es muy poco habitual que el artista esté de acuerdo con la inclusión de su obra en una colección concreta, aunque en algunas ocasiones puede llegar a aceptarlo, como una consecuencia lógica de utilizar la calle. Todavía no existe una jurisprudencia clara al respecto y los derechos morales del artista siguen en litigio con los de la propiedad privada. Los casos referidos a "museos" o"colecciones in situ" corresponden casi siempre a obras legales y comisionadas, que podrían ser consideradas en su mayoría como un tipo de arte público o neomuralismo.

Existe un vacío institucional por parte de los responsables de la gestión del patrimonio cultural público por conservar, al menos como colecciones inmateriales $y$, por tanto, documentar con conocimiento, criterio, lógica y orden lo que 
sucede en las calles de nuestras ciudades, quedando al amparo de iniciativas particulares que, con trabajos de investigación independientes, ligados o no a instituciones públicas, van generando un corpus de información que permitirá hacer lecturas parciales de estos movimientos en un futuro.

A nuestro parecer, en el caso de la UPV queda suficientemente argumentada la posibilidad de proponer la constitución de una colección institucional específica, que pueda ser difundida y promocionada como tal, de carácter inmaterial, que recoja testimonios, información relevante sobre procesos, artistas y obras, ofrecida de un modo común y organizado y con algunas muestras materiales temporales y permanentes de este tipo de producciones. Una posible denominación podría ser la de Colección de intervenciones de artistas urbanos en la UPV, puesto que, al margen de si las obras pueden o no ser consideradas como arte urbano, los artistas han sido invitados a participar en su realización por su consideración como referentes en este tipo de prácticas.

Queda pordefiniryestudiar los dispositivos decomunicación con el público más adecuados para la misma, así como el posible establecimiento de un tesauro que favorezca la clasificación ordenada de las obras, bajo una terminología específica y reconocible que ayude a entender y transmitir socialmente su relevancia y realidad.

\section{Notas}

[1] https://www.tuenti.es/urban-art/ [última consulta: 12-5-2019]

[2] Proyecto impulsado por la UPV y el centro de innovación Las Naves, del Ayuntamiento deValencia para promover la visibilidad de las mujeres en la ciencia a través de retratos murales que conectan con una app en la que se obtienen datos sobre la científica retratada y que obtuvo el premio al mejor proyecto de divulgación científica de 2019 por la Red Nacional de Unidades de Cultura Científica de la Innovación (UCC+i)

[3] https://icom.museum/en/ [última consulta: 6-9-2019]

[4] https://www.culturaydeporte.gob.es/dam/jcr:9de6095895ee-4562-b3c9-ac28c70cd5e2/Museos y Colecciones Museograficas Metodologia 2002.pdf [última consulta: 8-9-2019]

[5] https://www.gva.es/es/inicio/procedimientos?id proc=164 (última consulta: 2-9-2019)

[6] https://www.drouot.com/news/actuDetaillee/8965 [última consulta: 13-8-2019]

[7] https://urvanity-art.com [última consulta: 21-9-2019]

[8] Exposición realizada en el Palazzo Pepoli, del Museo della Storia di Bologna, del 18 de marzo al 28 de junio de 2016, financiada por Fondazione Casa di Risparmio in Bologna, Genus Bononiae y el grupo Arthemisa. Los arranques fueron realizados por el equipo de Campillo Tarozzi, Marco Pasqualicchio y Nicola Giordano, a petición de los comisarios de la exposición

[9] https://miau32.wixsite.com/miaufanzara-2016 [última consulta: 17-9-2019]

[10] http://cultura.upv.es/conocenos/cas/index.html [última consulta: 3-2-2019]

[11] http://www.upv.es/poliniza/ [última consulta: 3-2-2019]

\section{Bibliografía}

ABARCA, J. (2015). "Conservar o no conservar el arte urbano", en Mural SAC, n०2, Observatorio de Arte Urbano, http:// observatoriodearteurbano.org/wordpress/wp-content/ uploads/2015/08/mural 2-compressed.pdf [última consulta: 2-11-2019]

ABARCA, J. (2016). "From street art to murals, what have we lost?", en Pedro Soares Neves (ed.): Street Art \& Urban Creativity Scientific Journal Vol 2, №2. Lisboa.

BERTI, G. (2009). Pioneros del Graffiti en España. Valencia: Servicio editorial de la Universitat Politècnica de València.

CANALES, J. (2006). "Urban Art en el Barrio del Carmen de Valencia“ en el /Congreso Arte Entorno, La ciudad Sentida, pp.121-133. Valencia, España: Centro de Investigación Arte y Entorno CIAE, Universitat Politècnica de València .

CIANCABILLA, L. (2016). "Del distacco dei "graffiti", en Street Art Bansky\&CO. L'Arte allo stato urbano, Bolonia University Press, Bolonia.

CRIMP, D. (1993). On the Museum's ruin, MIT Press, Londres.

DANTO, A. (1999). Después del fin del arte, Paidós, Barcelona.

DESVALLÉES, A; MAIRESSE, F. (2010). Key concepts of museology, ICOM, en http://icom.museum/professional-standards/keyconcepts-of-muesology/ [última consulta:2-11-2019]

DÍAZ DE QUIJANO, F. (2018), “De la calle a la galería” en El Cultural, https://elcultural.com/Arte-urbano-de-la-calle-a-la-galeria [última consulta:2-11-2019]

FELIU, J. (2017). “Miau Fanzara. Un arañazo al destino” en Diferents. Revista de museus no. 2, pp. 30-45, Universitat Jaume I, http://www.erevistes.uji.es/index.php/diferents/article/viewFile/3915/3181 [última consulta: 2-11-2019]

GARCíA, A. (2016). "Las colecciones privadas hacen museos públicos", en https://elpais.com/cultura/2016/02/24/ actualidad/1456341448 689974.html [última consulta: 2-11-2019]

GARCÍA GAYO, E. (2015). "Arte urbano, muralismo posefímero". $16^{a}$ Jornada de Conservación de Arte Contemporáneo (pp 42-54), Madrid, España: Museo Nacional Centro de Arte Reina Sofía. 
GARCÍA GAYO, E. (2016). "Etapas del Arte Urbano. Aportaciones para un protocolo de conservación", en Ge-Conservación, n¹0 (pp.97-108). http://ge-iic.com/ojs/index.php/revista/article/ view/408/327 [última consulta:2-11-2019]

ICOM (2017) Código de deontología del ICOM para los museos, https://icom.museum/wp-content/uploads/2018/07/ICOMcodigo-Es-web-1.pdf [última consulta:2-11-2019]

Mc. CORMICK, C.; CORCORAN, S. (2013) City as Canvas: New York City Graffiti from the Martin Wong Collection, Skira Rizzoli, Nueva York.

MAZZUCCHELLI, F. (2017). Street(icono)clashes. "Blu vs Genus Bononiae: un caso di iconoclastia urbana" en Ocula 18. 22-42. 10.12977/ocula75.

MARTINI, M. (2017). "A Street-art Tragedy: Erasure Practices form Artistic Euthanasia to Articide", en Ocula. Semiotic Eye on Media, no18, pp. 7-21, DOI: 10.12977/ocula74

SÁNCHEZ PONS, M. (2016a). “Arte urbano en el centro histórico de Valencia: El Barrio del Carmen", en $2^{\circ}$ Encuentro de Arte Urbano URBARTE, producción, conservación, restauración, investigación, ENCRyM, https://m.youtube.com/watch?v=Nbrt90cssWc [última consulta:2-11-2019]

SÁNCHEZ PONS, M. (2016b). “El conservador-restaurador ante la conservación de arte urbano", en $2^{\circ}$ Encuentro de Arte Urbano URBARTE, producción, conservación, restauración, investigación, ENCRyM, https://m.youtube.com/watch?v=Nbrt90cssWc [última consulta:2-11-2019]

SCHACTER, R. (2016). "Street Art os a period. Or the emergence of Intermural Art", en Hiperallergic, https://hyperallergic. com/310616/street-art-is-a-period-period-or-the-emergence-ofintermural-art/ [última consulta:2-11-2019]

STAHL, M. (2017). This graffiti fanboy steals priceless street art under the cloak of darkness. On the prowl with the Thomas Crown of the New York streets. http://www.narratively.com/this-graffiti-fanboysteals-priceless-street-art-under-the-cloack-of-darkness/ [última consulta:2-11-2019]

SULLIVAN, P. (2016), “Collecting Street Art: have room on your wall for a wall?", en The NY York Times, www.nytimes.com/2016/07/09/ your-money/collecting-street-art-have-room-on-your-wall-for-awall.html? $\quad r=0$ [última consulta:2-11-2019]

THE PHOTOGRAPHER (2019) https://m.facebook.com/story. php? story fbid $=1322668197895482 \& i d=719861748176133$ [última consulta:2-11-2019]

VICERRECTORADO DE CULTURA (2015). $10 \times 10$ POLINIZA. Editorial Universitat Politècnica de València. http://hdl.handle. net/10251/50571. [última consulta:2-11-2019]

\section{Autor/es}

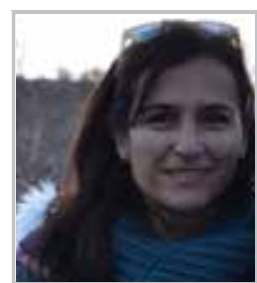

Mercedes Sánchez Pons

Universitat Politècnica de València

mersanpo@crbc.upv.es

Doctora por la Universitat Politécnica de Valencia, en el programa de Conservación y Restauración de Bienes Culturales en 2002 y Licenciada en Bellas Artes con la especialidad de Restauración. Desde 2003 es profesora titular del Departamento de Conservación y Restauración de Bienes Culturales de la UPV en los títulos de Grado y Máster. Responsable desde 2006 de la asignatura de máster Conservación y Restauración de Murales Contemporáneos ha dirigido numerosas tesis de grado y máster en relación a este tema. Forma parte del Grupo de Investigación Taller de análisis e intervención en Pinturas Murales del Instituto de Restauración del Patrimonio de la UPV. Ha dirigido y participado en numerosos proyectos de investigación, catalogación e intervención de pinturas murales, nacionales e internacionales, destacando entre los más recientes la restauración de los murales de la iglesia de San Nicolás en Valencia y el Proyecto Europeo Ewaglos: european ilustrated glossary of conservation terms for wall painting and architectural surfaces. Es también coeditora y autora del volumen Conservation Issues in Modern and Contemporary Murals (Cambridge Scholars Publishing, 2015). En la actualidad ejerce el cargo de Directora del Área de Alumnado de la Universitat Politècnica de València. 

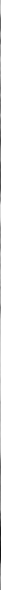

\title{
Museos de arte urbano. Estado de la cuestión
}

\author{
Rosa Senserrich-Espuñes, Elena García Gayo
}

\begin{abstract}
Resumen: El concepto de "museo de arte urbano" se está utilizando en la actualidad para denominar una múltiple variedad de espacios de naturaleza muy diversa sin demasiados lazos en común. Así pues, existen museos de arte urbano creados desde una perspectiva más tradicional, es decir, espacios-contenedores cerrados, con la obra concentrada dentro de sus paredes, en contraposición a otros, más innovadores, ubicados en espacios abiertos o con la obra dispersa por la ciudad. También existen museos desligados de toda materialidad, que se desarrollan exclusivamente en el espacio virtual. La voluntad inicial de los creadores de estos espacios es también muy variada, y persigue objetivos que van desde el querer ser considerados como anti-museos a integrarse en la red existente de museos de arte contemporáneo.
\end{abstract}

Esta recopilación pretende ser un catálogo de iniciativas que sirva de complemento a los artículos del presente monográfico, que facilite un estudio ordenado y pormenorizado de las iniciativas existentes. Para lograr entender cómo llegan a fundirse dos propuestas tan divergentes, museo y arte urbano, es necesario analizar los motivos que llevan a los gestores de estos espacios a identificarlos así.

Palabras clave: arte urbano, museo de arte urbano, gestión cultural del arte urbano, arte público, urban art

\section{Street Art museums. The state of the art}

Abstract: The concept of "urban art museum" is currently being used to describe a wide variety of spaces of a very diverse nature without too many ties in common. Thus, there are urban art museums created from a more traditional perspective, that is, enclosed spaces, with the work concentrated within its walls, as opposed to others, more innovative, located in open spaces or with works scattered throughout the city. There are also museums that lack any type of materiality, and that exist exclusively in the virtual space. The initial vision of the creators of these spaces is also extremely varied and pursues objectives that range from wanting to be considered as antimuseums to integration into the existing network of contemporary art museums.

This compilation aims to be a catalog of initiatives that complements the articles in this monograph, to facilitate an orderly and detailed study of existing initiatives. To understand how divergent entities come to merge, museums and urban art, it is necessary to analyze the reasons that lead the creators of these spaces to identify them in their own way.

Key words: street art, street art museum, cultural management of street art, public art, urban art

\section{Introducción}

Los museos de arte urbano han revolucionado en ciertos aspectos la idea tradicional de museo como espacio expositivo, no solo respecto a las obras, sino también en la forma de presentarlas a través de la experiencia provocada en el público durante su visita. Se observa una gran variedad de puntos de vista en cuanto a la percepción y oferta de disfrute de las colecciones, por lo que, en primer lugar, es necesario identificar cual es la definición del término arte urbano o street art que afecta a las diferentes alternativas, para entender después sus objetivos.
En lo que respecta a la presentación de las obras, algunos basan sus planteamientos museísticos y culturales en el uso de nuevas tecnologías a través de apps y realidad aumentada o virtual, transformando la materialidad de las mismas y completando su significado con una experiencia que va más allá de lo representado. Un ejemplo es el Museo di Arte Aumentata - MAUA, en Italia. [1] [figura 1]

Otros se acogen a la denominación de museos online y existen exclusivamente en la realidad virtual, sin una ubicación concreta, recopilando y clasificando imágenes 
de piezas de la calle y superando la calidad efímera al que están sujetas las obras de la calle. Es el caso de The Museum of Urban Art - tMoUA fundado en 2012 por el artista y fotógrafo inglés Lord K2. [2] [figura 2]

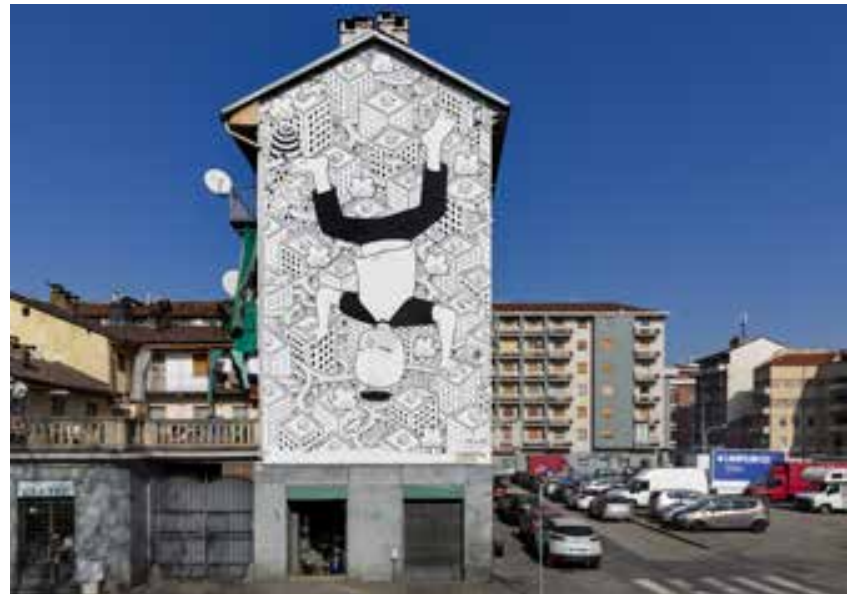

Figura 1. Let's break it down, mural del artista italiano Millo, pintado en Turín el año 2014. Para visualizar cómo el gigante de Millo cobra vida, enmarcar la imagen con la aplicación Bepart. Foto $\odot$ A.Lincetto, A.lammarino / Realidad aumentada $\odot$ M.Repetto - MAUA (IT)

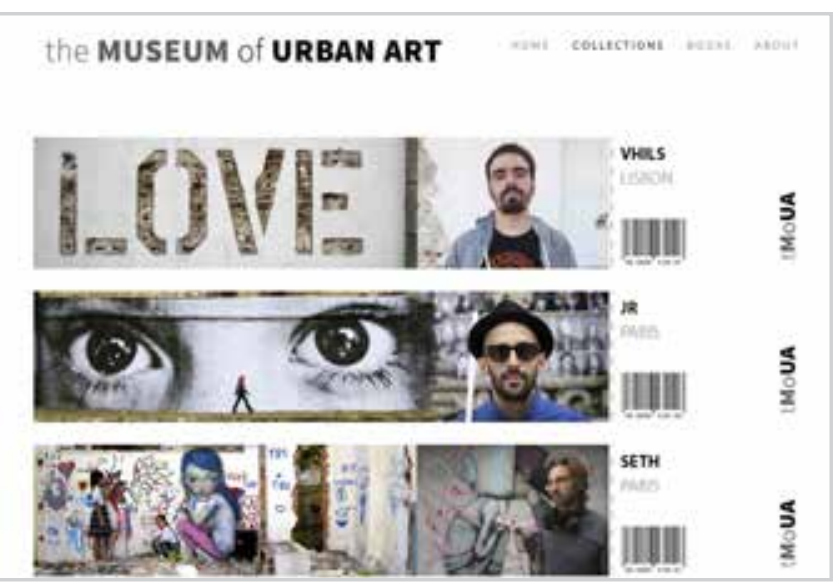

Figura 2. Imagen de la organización de la información en la web del museo online tMoUA. Clicando en una de las fichas, se ingresa en las colecciones de cada artista. Foto @ Leon K2 Archivo tMoUA

El criterio de conservación de las colecciones es variable $y$, aunque no existe una red de museos de arte urbano organizada que los defina, la mayoría identifican sus obras con un arte perecedero, siendo estos límites difusos y modificables. Para su clasificación, es imprescindible introducir aspectos que tengan relación con los objetos expuestos, ya sea a través de la didáctica, del hilo conductor que va a unir unas piezas con otras, del contexto o, al contrario, de las contradicciones de la propia descontextualización y musealización.

En cuanto al contenido, se han encontrado algunos museos que llevan a cabo acciones de tipo activista, con propuestas de comisariado rompedoras y nada habituales. Este es el caso de The Street Museum of Art - SMoA de Brooklyn (NY), fundado en 2012 en las calles de ese barrio neoyorquino. [3]

Militante, también, es el Museo dell'Altro e dell'Altrove di Metropoliz - MAAM de Roma, ubicado en los suburbios del este de la ciudad. EI MAAM es un museo inmerso en una ocupación habitacional que alberga, desde el año 2009, a más de doscientos migrantes y trabajadores temporales de todo el mundo bajo la amenaza constante de un desalojo forzoso. [figura 3]

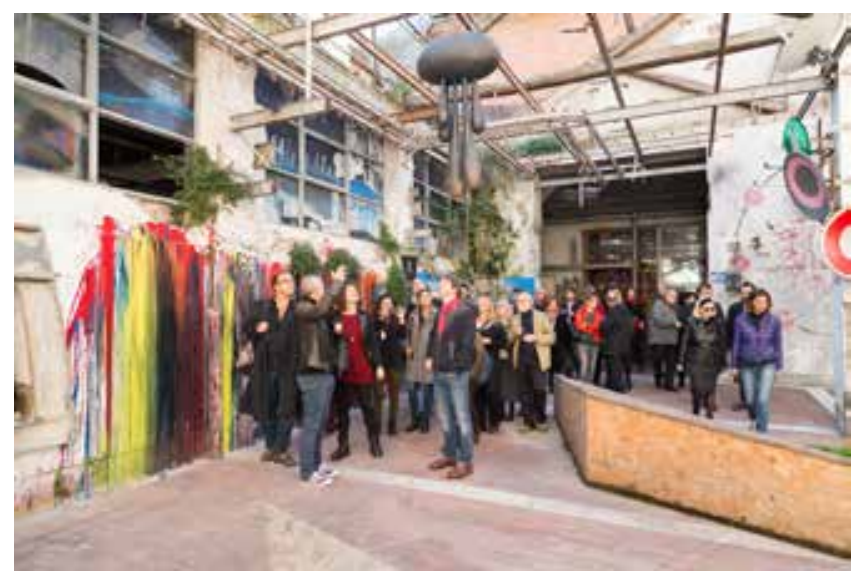

Figura 3. Visita guiada al MAAM di Metropoliz del vicealcalde de Roma, Sr.Luca Bergamo, y su equipo. Foto $\odot$ Giorgio Sacher - MAAM (IT)

Otros ejemplos con vocación activista son los llamados museos "a cielo abierto" de Latinoamérica, donde la mayoría de los murales reivindican justicia con las luchas del pueblo, se pintan de forma colaborativa con la comunidad y utilizan el arte como herramienta de transformación social, como es el caso del Museo a Cielo Abierto en La Pincoya, Chile. [4] [figura 4] [Tabla 1]

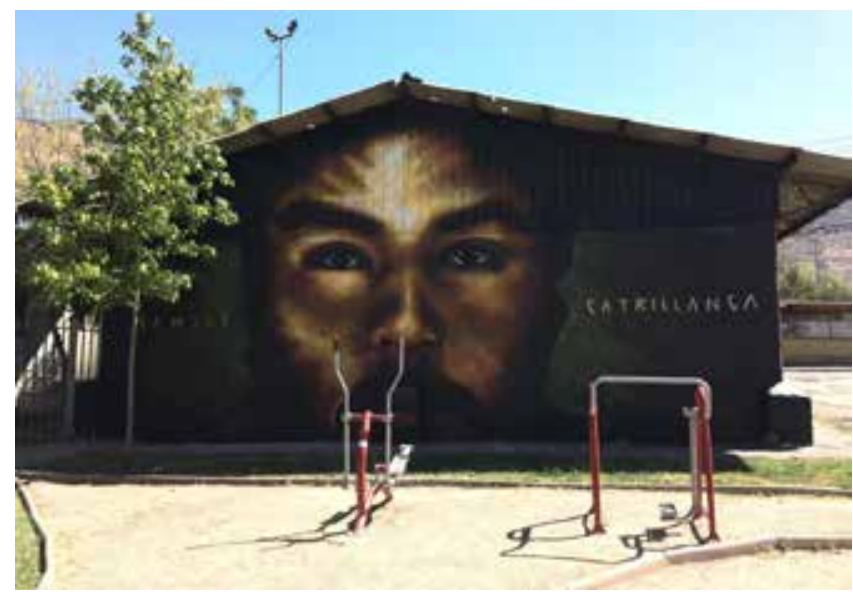

Figura 4. Mural en honor al comunero mapuche Camilo Catrillanca (1994-2018) asesinado por la represión estatal. Pintado en 2018 por el artista chileno Rodrigo Estoy, dentro de la convocatoria "Bombardeo muralista por Camilo Catrillanca". Foto (c) José Bustos - Museo en La Pincoya (CL) 
Asimismo, se hace indispensable el análisis de estas intervenciones desde el punto de vista de un patrimonio histórico artístico efímero que llega desde cauces diferentes a los oficiales, con el reto que esto supone para la industria cultural preestablecida, ya que debe asumirlos como parte de la evolución de la sociedad actual. Todo este mundo heterogéneo ha contribuido a crear lo que con el tiempo se percibe como una oferta artística que procede de la gestión de una actividad, ya sea pública o privada, que en muchas ocasiones resulta deudora de subvenciones y en la cual las instituciones aún no han encontrado una fórmula ajustada para posicionarse y asumir fórmulas de promoción artística local estables.

Es interesante resaltar que los implicados en todos estos proyectos multidisciplinares del siglo XXI son profesionales que proceden del mundo de la antropología, arquitectura, museología, bellas artes, de la historia del arte y de la gestión cultural. Además, es también de vital importancia destacar el papel del ámbito publicitario, siempre en liza con la escena artística más reivindicativa centrada en las posibles promociones presentes en ferias y galerías. Finalmente, la prensa presenta al mundo un producto terminado desde su particular óptica mediática, en el que todos estos puntos de vista aportan un significado diferente a la misma terminología.

\section{Metodología}

Para abordar un tipo de manifestación artística como es la del arte actual en el espacio público, es necesario hacer una primera relación a través de su principal pilar, que es la información que procede de la difusión a través de internet. Así pues, los medios utilizados para desarrollar el estudio que se deriva de este artículo no pueden ser otros que los que ofrece la propia red digital: artículos de prensa, notas para difusión, catálogos de exposiciones, entrevistas [5], redes sociales [6] y un sinfín de recursos puestos a libre disposición por los propios interesados.

El planteamiento inicial consiste en localizar aquellos espacios que han enlazado los términos "museo" (ICOM, 2019) y "arte urbano" en sus propuestas. Por razones prácticas, en este artículo no se han incluido los museos de arte contemporáneo que, cada vez con más frecuencia, ingresan en sus colecciones piezas artísticas procedentes de la calle o que realizan exposiciones ocasionales dedicadas al arte urbano y/o al graffiti, como es el caso de la TATE MODERN de Londres, del MACRO de Roma o del MOCO de Amsterdam -entre otros- y cuyo análisis pormenorizado merecería capítulo aparte. Seguramente, aquí tampoco figuran todos los museos de arte urbano que existen en la actualidad, ya que el objetivo es presentar algunos ejemplos que sirvan de introducción al estado de la cuestión [relación de museos en Tabla 1].

El concepto de museo basado en la idea de conservación de una colección artística es el tema que presenta más dudas para los que han asumido esta confusa unión de etiquetas, al igual que el concepto de arte urbano interpretado como expresión artística relacionada con la actividad de las ciudades y los ciudadanos (Tielve, 2000:112-118). Al avanzar en esta metodología, sobrevienen otros espacios que no se denominan museos, como son algunas galerías de arte urbano [7], asociaciones que promueven el arte en la calle [8] o espacios expositivos seleccionados para albergar muestras temporales [9] que, teniendo las mismas bases y utilizando unos recursos similares, sugieren un cambio de punto de vista, aunque los objetivos sean parecidos.

Estas variantes un tanto inconexas que se pueden observar cuando se analiza en conjunto la tipología de espacios existente tiene que ver, probablemente, con el público al que van dirigidos y al deseo de asimilación social de las iniciativas. Unos pretenden mantener una imagen de rebeldía, frente a otros que se muestran desde la más sobria institucionalización. Los museos menos numerosos, pero con más presencia urbana, son los que están soportados por una estructura económica compleja en la que participa capital público y privado, partes interesadas en producir cambios en el tejido social, cultural, y posiblemente económico, en el que se inscriben.

Para crear una primera clasificación sería preciso centrarse en el estudio del contexto, el contenido y los lazos que unen las propuestas a los visitantes, así como el análisis de sus proyectos museográficos, ya sean contemplativos, inmersivos o participativos (Derosas, 2017:99-108) y su presentación final, material o virtual (Mancini, 2013).

\section{Material expositivo: el contenido}

Los museos de arte urbano calificados como contenedores, es decir, como espacios generalmente cerrados que albergan contenido artístico en su interior, se construyen habitualmente con una mezcla de obras de diferentes procedencias, cuyo discurso puede resultar chocante cuando se une a la concepción de lo "urbano", ya que la mayoría de ellas sufren una descontextualización. En ocasiones, se exhiben obras arrancadas de la calle junto con piezas de características aparentemente similares y creadas ex profeso, o se combinan esculturas e instalaciones tomadas del espacio público con otro tipo de obras no urbanas, cuyos autores pueden ser los mismos que hacen habitualmente arte urbano. Estos museos juegan con esa dualidad, aunque las obras tengan una carga conceptual diferente.

Podría ser ésta una de las razones por las que algunos gestores, ante este hecho y para dar cierta coherencia a sus colecciones, han bautizado a sus proyectos como "museos de arte urbano y contemporáneo", combinando así las dos etiquetas. Éste es el caso del MUCA de Munich, del MARCC de Cascais o del URBAN NATION de Berlín, entre otros (relación de museos en Tabla 1). Aún con todo, esta denominación continúa siendo un tanto inexacta, pues el 
arte procedente de la calle, cuando entra en un museo, se convierte automáticamente en otra cosa, diferente. Según palabras del Manifiesto del artista italiano Mr. Savethewall: "Street Art without Street is 'just' Art. Il luogo più autentico per la sua valorizzazione è la strada, il vero museo a cielo aperto" [10] (Corriere di Como, 2018). De estas frases se desprende que, para este artista, y para la mayoría de seguidores de esta manifestación artística llamada arte urbano, el único museo reconocible como street art es aquel que se sitúa a cielo abierto, el de la calle, aunque esto pudiera sonar tan incongruente como el poner un zoo en la jungla (entrevista a SAN en anexo).

Si se compara el contenido de los museos de arte urbano que existen en su contexto con el de los museos de arte urbano-contenedores, la variedad de objetos expuestos disminuye drásticamente. En estos casos, y salvo contadas excepciones, la tipología mural es la más numerosa y constituye la materia sobre la que plantear un recorrido conceptual basado en su capacidad expresiva. Con ello, se pretende trazar una línea que discurra, por una parte, por cada obra independiente y por otra, por un discurso compartido con el resto de piezas.

El hecho de analizar una colección de elementos artísticos situados en el espacio público no es tarea fácil, por la cantidad de influencias de su entorno, lo que conduce previamente a fijar una metodología que ordene las diferentes formas de transitar la exposición, sin olvidar que estará en función del contenido.

Con respecto al papel del espectador, se pueden distinguir cuatro grandes grupos:

1. Exposiciones estáticas. El espectador es un sujeto pasivo, mero observador.

2. Dinámicas. El observador es un sujeto activo, participativo.

3. El espectador visita las obras desde su casa porque tienen una dimensión virtual.

4. El espectador es el verdadero protagonista y se comunica con el artista. En este caso, la conexión en contexto urbano es a través de colectivos sociales o asociaciones vecinales.

Los promotores, que generalmente ejercen de comisarios, eligen a los artistas, a los colectivos de artistas y/o a las obras, mediante festivales o convocatorias periódicas, y son también los responsables de generar una estructura de funcionamiento específica que les permite ir añadiendo piezas. Esta estructura está totalmente supeditada a la intencionalidad de cada convocatoria.

En la mayoría de propuestas existentes, las obras se incluyen $o$ se encargan a artistas a los que se conoce por su repercusión mediática, su participación en redes sociales y por estar en permanente actividad a lo largo del mundo. Sin embargo, también se dan propuestas más territoriales, como los museos militantes "a cielo abierto", algunos museos de arte en su contexto, como el Goya
Street Art Museum - GSAM en Fuendetodos [11] [figura 5] $\mathrm{u}$ otros museos-contenedores de carácter más local, como el Musée Romeo's d'Art Urbain de Montreal [12] [figura 6]. En estos ejemplos, las obras se encargan a artistas de la comunidad, porque normalmente involucran iniciativas de las personas que conforman esa sociedad (relación de museos en Tabla 1).

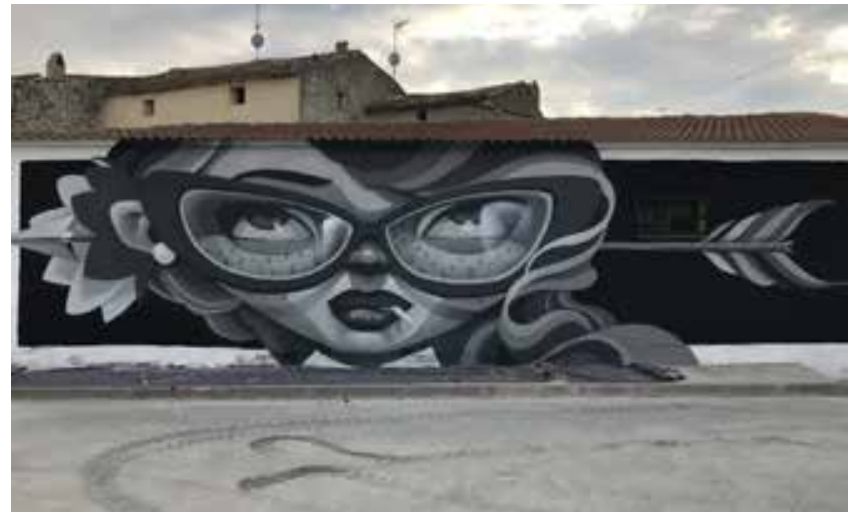

Figura 5. El bienestar y la tranquilidad, mural del artista zaragozano Danjer, pintado en Fuendetodos durante la Semana de Goya 2017. Foto @ Felipe Díaz - GSAM (ES)

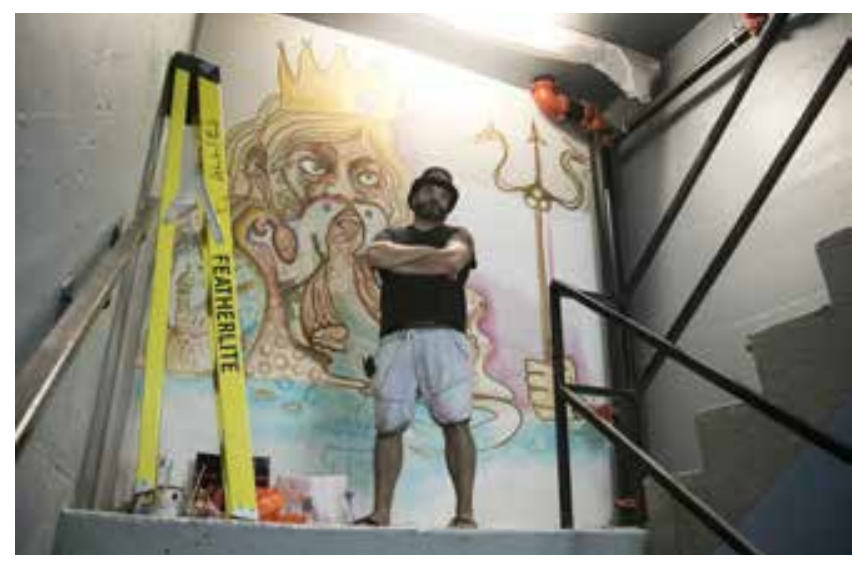

Figura 6. Poseidon, mural del artista quebequés Santerre, pintado en un rellano de la escalera de este singular museo, inaugurado en septiembre de 2018 por la firma ROMEO'S Gin. Foto $\odot$ ROMEO'S Gin (CA)

\section{El contexto y el continente}

En general, los museos de arte urbano no se ubican en espacios del centro de la ciudad muy turistificados. Tampoco suelen ser necesarios para capturar al público, situándose al lado de museos consolidados y con una afluencia de visitantes asegurada. Tan solo en contadas ocasiones, en las que se persiguen intereses comerciales, es necesario conseguir una alta visibilidad para la promoción de aspectos diferentes a la mera exhibición artística. Estos museos son normalmente el fruto de iniciativas particulares o colectivas que dan vida a espacios en desuso y que buscan fortalecer el tejido social de un barrio a través del arte urbano. En la mayoría de los museos-contenedores, este espíritu de regeneración tampoco suele estar ligado a la 
creación de un impactante edificio vanguardista que facilite la renovación de la imagen de una zona degradada, es decir, no tienen nada que ver con el llamado "efecto Guggenheim" (Luque, 2018:377-398). Como un aspecto común destacable de estos museos hay que mencionar la voluntad didáctica de contar a la comunidad cómo se ha desarrollado el arte relacionado con el entorno urbano de su localidad.

En las manifestaciones artísticas desarrolladas en el espacio público, el contexto es una parte de vital importancia y resulta alterado constantemente, incluso, por los propios visitantes. Según la modalidad de proyecto, el continente forma parte de la obra, contextualizándola, y puede ser tan diferente como los siguientes ejemplos: espacios virtuales, cubos asépticos, edificios que cambian su funcionalidad -al menos parcialmente-, lugares cotidianos en ciudades y localidades o rincones destinados a otras funciones $y$ a la espera de nuevos usos. Entre todas estas casuísticas de museos, abundan los espacios de la propia ciudad y escenarios industriales o portuarios, como el Museu de Arte Urbana do Porto - MAUP, en Río de Janeiro [13] [figura 7], cuyos murales aportan color a las tradicionales paredes blancas del puerto metropolitano. Su estética, alejada claramente del convencionalismo de un museo, pretende acercarse a la del graffiti y del street art.

Otros museos han sido creados con la finalidad de revitalizar el contexto urbano de los emplazamientos donde se sitúan, como por ejemplo el MAU o el MAUA, en Italia. EI MAU Museo d'Arte Urbana de Turín se fundó con el objetivo de crear un asentamiento artístico permanente al aire libre no lejos del centro de la ciudad. El núcleo originario está ubicado en el Borgo Vecchio Campidoglio, un distrito de clase trabajadora de fines de 1800, de casitas bajas y con una fuerte actividad artesanal, comercial y social. Este ambiente favorece la relación de comunidad entre los habitantes y el tipo de asentamiento propuesto, convirtiéndolo en un "pueblo en la ciudad". A partir del año 2014, el MAU salió del Campidoglio para realizar más de setenta obras en otros barrios de Turín.

El MAUA - Museo di Arte Aumentata, se inició gracias a una convocatoria financiada por el Municipio de Milán en el

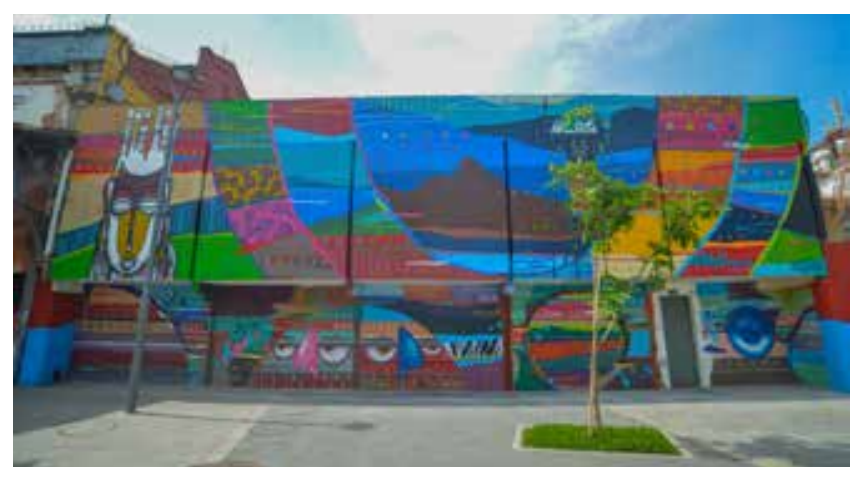

Figura 7. Mural del artista carioca André Lourenço da Silva, aka Kajaman, pintado en el Boulevard Olímpico de Río de Janeiro durante 2018. Foto $\odot$ Douglas Dobby - MAUP (BR) año 2016, en la que se seleccionaron catorce proyectos culturales entre más de ciento cincuenta propuestas encaminadas a dar vida a las zonas periféricas de la ciudad. Se trata de un proyecto participativo en cuya creación han contribuido cientos y cientos de personas, como artistas callejeros, creativos digitales, estudiantes y residentes de los distintos barrios seleccionados. Después del éxito de Milán en el 2017, la realidad aumentada se trasladó a las ciudades de Palermo y Turín. En la web del museo se ofrecen también tours guiados, en diferentes idiomas, para poder disfrutar de la experiencia presencial y de la realidad aumentada de los diferentes proyectos murales.

Un museo que destaca por su titánica labor realizada tanto en el contexto como en el continente es el MAAM - Museo dell'Altro e dell' Altrove di Metropoliz, de Roma. Desde el año 2012, el sitio ocupado por migrantes y personas sin recursos en la antigua fábrica de salami Fiorucci tomó una dirección artística experimental, asumiendo el nombre de MAAM, y hoy alberga más de quinientas obras de arte urbano, desde murales hasta instalaciones, que ayudan a dignificar y apoyar los proyectos de vida de las personas que lo habitan. Se puede visitar un día concreto a la semana, previa reserva.

En la definición oficial de "museo" existente hasta nuestros días, conceptos como el contenido y el discurso museográfico priman sobre el continente, aunque en algunos de los museos de nueva creación que se plantean en este artículo es precisamente al revés, ya que su ubicación y entorno urbano es fundamental. Entre las numerosas propuestas que se están debatiendo en la actualidad con el fin de actualizar la definición de museo, merece la pena destacar la importancia que algunos otorgan a las redes que, como espacios culturales, se establecen con el exterior (Thomas, 2019). Asimismo, sería interesante considerar el planteamiento contextual que ofrecen estos nuevos museos, ya que abre un sinfín de posibilidades en su configuración.

\section{Financiación y titularidad}

La financiación de los museos de arte urbano es también diversa, igual que sus diferentes propuestas, y va desde la opción más simple, como la financiación privada, hasta las más complejas, en las que participan capitales compartidos a partes proporcionales. Un ejemplo de financiación sencilla -por la libertad que implica la no dependencia de otros agentes- son los museos de arte urbano online, normalmente sostenidos por el propio creador o creadores.

En los llamados museos "a cielo abierto" de Latinoamérica, de carácter local y reivindicativo, son las mismas personas que forman la comunidad las que gestionan los recursos para llevar a cabo las iniciativas, muchas veces en solitario y otras, con la ayuda del gobierno del municipio o la nación, a través de fondos concursables para proyectos específicos. Una manera de proceder similar es el de los museos autogestionados en Europa, como el Street Art 
Museum Amsterdam - SAMA, que se mueven gracias a la aprobación de propuestas presentadas al ayuntamiento de la ciudad, de proyectos de crowdfunding impulsados por el equipo curatorial o gracias a los ingresos procedentes de las actividades ofrecidas por la asociación creadora, generalmente visitas y tours guiados.

En el caso de los museos de arte urbano-contenedores, que requieren de una infraestructura más compleja, se puede afirmar que casi todos cuentan con una regla en común, y es que tienen solucionada su financiación, procedente de iniciativas institucionales o privadas similares en organización y que pueden aparecer unidas en un porcentaje variable, como es el caso del Urban Nation de Berlín [14] o el Museu de Arte Urbana e Contemporânea de Cascais - MARCC (relación de museos en Tabla 1). En algunos casos se crean sociedades en las que empresas inmobiliarias son parte importante, y en éstos, existe un riesgo importante de discriminación territorial por 'gentrificación'
(Abarca, 2009:53-64) u otras problemáticas éticas o sociales que confrontan la exposición de las obras para el público con los objetivos principales y reales de la creación de tales espacios, pues muchas veces el factor económico es la motivación principal de la empresa patrocinadora, algo que ha cambiado de forma importante la fisonomía de muchas ciudades. [15]

De este modo, la financiación de las obras puede ser directa o indirecta y la titularidad de las colecciones no siempre es clara, porque depende en gran medida del origen del proyecto -muchas veces las colecciones se nutren de depósitos temporales de los propios artistas-. Esta titularidad va a marcar la definición del tipo de museo-galería o centro de arte, sea público o privado y lo enmarcará en propuestas ejecutadas dentro de un determinado esquema, que será más o menos libre y/o más o menos convencional (entrevistas en anexo de gestores de eventos relacionados con el tema). [16]

Tabla 1.- Localización territorial de museos - arte urbano

\begin{tabular}{|c|c|c|c|c|}
\hline No & Acrónimo & Nombre & Localización & Web \\
\hline \multicolumn{5}{|c|}{ MUSEOS DE ARTE URBANO - CONTENEDORES } \\
\hline 01 & ART 42 & ART 42 Urban Art Museum & Paris. FR & http://www.art-42.fr \\
\hline 02 & GASAM & The Graffiti \& Street Art Museum of Texas & Houston. US & http://thegasamtexas.org \\
\hline 03 & MAAM & Museo dell'Altro i dell'Altrove di Metropoliz & Roma. IT & http://goo.gl/flA1Ho \\
\hline 04 & MARUM & Museo de Arte Urbano de México & Querétaro. MX & $(*)$ \\
\hline 05 & MAU & Museo Arte Urbano - MAU & Callao. PE & $\begin{array}{l}\text { https://www.facebook.com/mu- } \\
\text { seoarteurbano/ }\end{array}$ \\
\hline 06 & MAUSA & Musée d'Art Urbain et du Street Art - Les Forges & $\begin{array}{l}\text { Toulouse-le-Château } \\
\text { (Jura). FR }\end{array}$ & $\begin{array}{l}\text { https://www.instagram.com/ } \\
\text { mausa.officiel/?hl=es }\end{array}$ \\
\hline 07 & MAUSA & Musée des Arts Urbains et du Street Art - Vauban & $\begin{array}{l}\text { Neuf-Brisach (L'Alsace). } \\
\text { FR }\end{array}$ & https://mausa.fr/ \\
\hline 08 & MoSA & Museum of Street Art - New York Bowery Hotel & $\begin{array}{lll}\text { citizenM New } & \text { York } \\
\text { Bowery - Lower } & \text { East } \\
\text { Side, New York. US } & \\
\end{array}$ & $\begin{array}{l}\text { www.citizenm.com/mosa/expe- } \\
\text { rience-mosa }\end{array}$ \\
\hline 09 & & Amsterdam Street Art Museum in NDSM area & $\begin{array}{l}\text { Amsterdam-Noord (an- } \\
\text { tiguo almacén astillero). } \\
\text { NL }\end{array}$ & $(*)$ \\
\hline 10 & & ROMEO'S Museum - Musée d'Art Urbain & Mile-End, Montreal. CA & $\begin{array}{l}\text { https://romeosgin.com/romeos- } \\
\text { museum/ }\end{array}$ \\
\hline 11 & & STREET ART MUSEUM & East Saint Petersburg. RU & http://www.streetartmuseum.ru \\
\hline \multicolumn{5}{|c|}{ MUSEOS DE ARTE URBANO EN EL CONTEXTO } \\
\hline 12 & GSAM & Goya Street Art Museum & Fuendetodos. ES & $\begin{array}{l}\text { http://goyastreetartmuseum. } \\
\text { com/ }\end{array}$ \\
\hline 13 & MAU & Museo d'Arte Urbana & Torino. IT & http://www.museoarteurbana.it \\
\hline 14 & MAUA & Museo di Arte Urbana Aumentata & $\begin{array}{l}\text { Milano - Palermo - Tori- } \\
\text { no. IT }\end{array}$ & https://mauamuseum.com/ \\
\hline 15 & MAUP & Museu de Arte Urbana do Porto & Rio de Janeiro. BR & http://maup.rio/ \\
\hline 16 & MIAU & Museo inacabado de arte urbano & Fanzara. ES & http://www.miaufanzara.org \\
\hline 17 & SAMA & Street Art Museum Amsterdam & $\begin{array}{l}\text { Amsterdam Nieuw- } \\
\text { West, Amsterdam West } \\
\text { and Schiphol Airport. NL }\end{array}$ & $\begin{array}{l}\text { https://www.streetartmuseu- } \\
\text { mamsterdam.com/ }\end{array}$ \\
\hline 18 & SMoA & The Street Museum of Art & $\begin{array}{l}\text { New York - London - } \\
\text { Montreal (US-GB-CA) }\end{array}$ & $\begin{array}{l}\text { http://www.streetmuseumofart. } \\
\text { org }\end{array}$ \\
\hline
\end{tabular}




\section{MUSEOS ARTE URBANO ON-LINE}

\begin{tabular}{|l|l|l|l|l|}
\hline 19 & tMoUA & The Museum of Urban Art & web & http://www.tmoua.org \\
\hline 20 & UMA & Urban Museum of Art & Valencia. ES & http://umavalencia.blogspot \\
\hline
\end{tabular}

MUSEOS DE ARTE URBANO Y CONTEMPORÁNEO

\begin{tabular}{|c|c|c|c|c|}
\hline 21 & MARCC & $\begin{array}{l}\text { Museo de Arte Urbana e Contemporânea de Cas- } \\
\text { cais }\end{array}$ & Cascais. PT & $\begin{array}{l}\text { https://bairrodosmuseus.cascais. } \\
\text { pt/list/museu/museu-de-arte- } \\
\text { urbana-e-contemporanea-de- } \\
\text { cascais?section=0 }\end{array}$ \\
\hline 22 & MUCA & Museum of Urban and Contemporary Art & Munich. DE & https://www.muca.eu/ \\
\hline 23 & UN & $\begin{array}{l}\text { URBAN NATION Museum for Urban Contemporary } \\
\text { Art }\end{array}$ & Berlín. DE & https://urban-nation.com/ \\
\hline 2 & & Museoal Aire Libre dePintura MuralContemporánea & Fuenlabrada. ES & $(*)$ \\
\hline
\end{tabular}

MUSEOS DE ARTE “A CIELO ABIERTO” , "OPEN AIR”

\begin{tabular}{|c|c|c|c|c|}
\hline 25 & & ARTE A LA VISTA. MUSEO URBANO & Rosario. AR & $\begin{array}{l}\text { https://www.rosario.gob.ar/web/ } \\
\text { ciudad/cultura/museos/museo- } \\
\text { urbano-arte-a-la-vista }\end{array}$ \\
\hline 26 & & Dundas Street West Open Air Museum & Toronto. CA & $\begin{array}{l}\text { https://www.dundaswest.mu- } \\
\text { seum/ }\end{array}$ \\
\hline 27 & MOPA & Museum of Public Art & $\begin{array}{l}\text { Baton Rouge, Louisiana. } \\
\text { US }\end{array}$ & $\begin{array}{l}\text { http://www.museumofpublicart. } \\
\text { org/ }\end{array}$ \\
\hline 28 & & Museo a Cielo Abierto de Teruel & $\begin{array}{l}\text { Barrio de San Miguel, } \\
\text { Teruel. ES }\end{array}$ & $\begin{array}{l}\text { https://www.instagram.com/mu } \\
\text { seoacieloabiertoteruel/?fbclid=l } \\
\text { wAR3iBL8 qHKdGt g49BhHJXj } \\
\text { Ky2HFCu7hj11rZRVWcX8Z7nN- } \\
\text { t4XVS3-FTc }\end{array}$ \\
\hline 29 & & Museo a Cielo Abierto de Valparaíso & Valparaíso. CL & $\begin{array}{l}\text { http://ucv.altavoz.net/prontus } \\
\text { unidacad/site/edic/base/port/in- } \\
\text { glescieloabierto.html }\end{array}$ \\
\hline 30 & & Museo a Cielo Abierto en La Pincoya & $\begin{array}{l}\text { Población Pablo Neru- } \\
\text { da, Santiago de Chile. CL }\end{array}$ & $\begin{array}{l}\text { https://museoacieloabiertoenla- } \\
\text { pincoya.wordpress.com/ }\end{array}$ \\
\hline 31 & & Museo a Cielo Abierto en San Miguel & $\begin{array}{l}\text { Villa San Miguel, Santia- } \\
\text { go de Chile. CL }\end{array}$ & $\begin{array}{l}\text { https://www.museoacieloabier- } \\
\text { toensanmiguel.cl/ }\end{array}$ \\
\hline 32 & & Museo a Cielo Abierto en Sauce & $\begin{array}{l}\text { Localidad de Sauce - Ca- } \\
\text { nelones. UY }\end{array}$ & $(*)$ \\
\hline 33 & & Museo a Cielo Abierto La Legua & $\begin{array}{l}\text { Población La Legua Es- } \\
\text { peranza, Santiago de } \\
\text { Chile. CL }\end{array}$ & $\begin{array}{l}\text { https://www.facebook.com/pa- } \\
\text { ges/Museo-a-Cielo-Abierto-La- } \\
\text { Legua/922289187979588 }\end{array}$ \\
\hline 34 & & Museo al Aire Libre de Vigo & Vigo. ES & $(*)$ \\
\hline 35 & PSA & PUERTO STREET ART & $\begin{array}{l}\text { Puerto de la Cruz -Tene- } \\
\text { rife. ES }\end{array}$ & $\begin{array}{l}\text { http://visitpuertodelacruz.es/ } \\
\text { puerto-street-art/ }\end{array}$ \\
\hline
\end{tabular}

PROYECTOS CON VOLUNTAD ANUNCIADA DE SER FUTUROS MUSEOS DE ARTE PÚBLICO

\begin{tabular}{|c|c|c|c|}
\hline 36 & BOULEVARD PARIS 13 & Paris. FR & $\begin{array}{l}\text { https://www.youtube.com } / \\
\text { watch?v=urKXvZiJSAY\&t=14s }\end{array}$ \\
\hline 37 & $\begin{array}{l}\text { TITANES } \\
\text { (Silo Mural project) }\end{array}$ & $\begin{array}{l}\text { Calzada de Calatrava, } \\
\text { Ciudad Real, Corral de } \\
\text { Calatrava, Herencia, La } \\
\text { Solana, Manzanares, } \\
\text { Malagón, Porzuna y Vi- } \\
\text { llanueva de los Infantes } \\
\text { (La Mancha). ES }\end{array}$ & https://iamtitanes.com/ \\
\hline 38 & VINARÒS ART URBÀ & Vinaroz. ES & $\begin{array}{l}\text { http://www.instagram.com/vina- } \\
\underline{\text { ros art urba }}\end{array}$ \\
\hline
\end{tabular}

(*) museos que todavía no tienen web propia 


\section{Conclusión}

Queda pendiente, pues, una revisión pormenorizada de las iniciativas sujetas a una descripción más detallada. Sirvan estos apuntes de estructura para facilitar el análisis de las particularidades del material expositivo, localización, financiación y titularidad de estos museos. La presente propuesta de estudio se centra en la unión de los términos "museo" y "arte urbano", y quedan al margen las propuestas de "galería" que tienen una acepción diferente, aunque su apariencia sea similar.

También conviene aclarar que, por omisión de aspectos relacionados con la definición de museo pronunciada por el ICOM, se desprenden todas aquellas premisas que estos museos no cumplen, puesto que el $95 \%$ se entienden como galerías de exposiciones temporales, y la didáctica de sus exposiciones como una exhibición desordenada de objetos. Aun así, en algunas de las propuestas se han podido identificar intereses puntuales relacionados con la práctica habitual de un museo, como la creación de una colección pública, la investigación, la conservación de la memoria y también la conservación-preservación de las obras. Se debería seguir profundizando en estos aspectos y plantear, en un futuro, la adopción de medidas encaminadas a mejorar los planes básicos de conservación preventiva, como el uso y fomento de la investigación de materiales (soportes, pinturas o protecciones pasivas), el seguimiento de los procesos de envejecimiento y la documentación de las piezas. Todos estos aspectos y actividades en torno a las obras contribuirían a la consolidación de estos espacios tan singulares y a tejer redes con la comunidad.

Hay que alertar de que la información vertida en internet, entrevistas y declaraciones promocionales, pueden quedar una simple declaración de intenciones, y que algunos de los museos con los que se ha intentado contactar no han acabado de facilitar la consulta. Aún con todo, las propuestas a las que se hace referencia más arriba son:

- El museo al aire libre de Valparaíso (CL), creado por la Pontificia Universidad Católica de Valparaíso de acuerdo con el Municipio, e inaugurado en 1992. Cuenta con veinte murales de pintores chilenos ubicados en la parte baja del cerro Bellavista. La universidad promueve la constante restauración de los murales deteriorados.

- El Museo d'Arte Urbana - MAU, de Torino (IT), creado en el año 1995, está reconocido como Museo de interés ciudadano y, desde el año 2001, integrado al circuito de la «Carta Musei». Las obras se encuentran en continuo cambio, restauración y creación, gracias a los proyectos promovidos periódicamente por la asociación fundadora. [figuras 8 a-b]

- El Street Art Museum de Amsterdam - SAMA (NL) es un ecomuseo en el contexto, fundado en el año 2011. Su misión es crear, explorar, documentar y preservar un creciente movimiento democrático del street art. Cuenta con un equipo curatorial que está entrando en una etapa de valoración de los criterios de preservación, documentación y archivo de la colección. Recientemente ha realizado algunas experiencias con 3D y realidad virtual para preservar la memoria de algunas piezas de street art en riesgo de desaparición inminente. [figuras $9 \mathrm{a}-\mathrm{b}$ ]

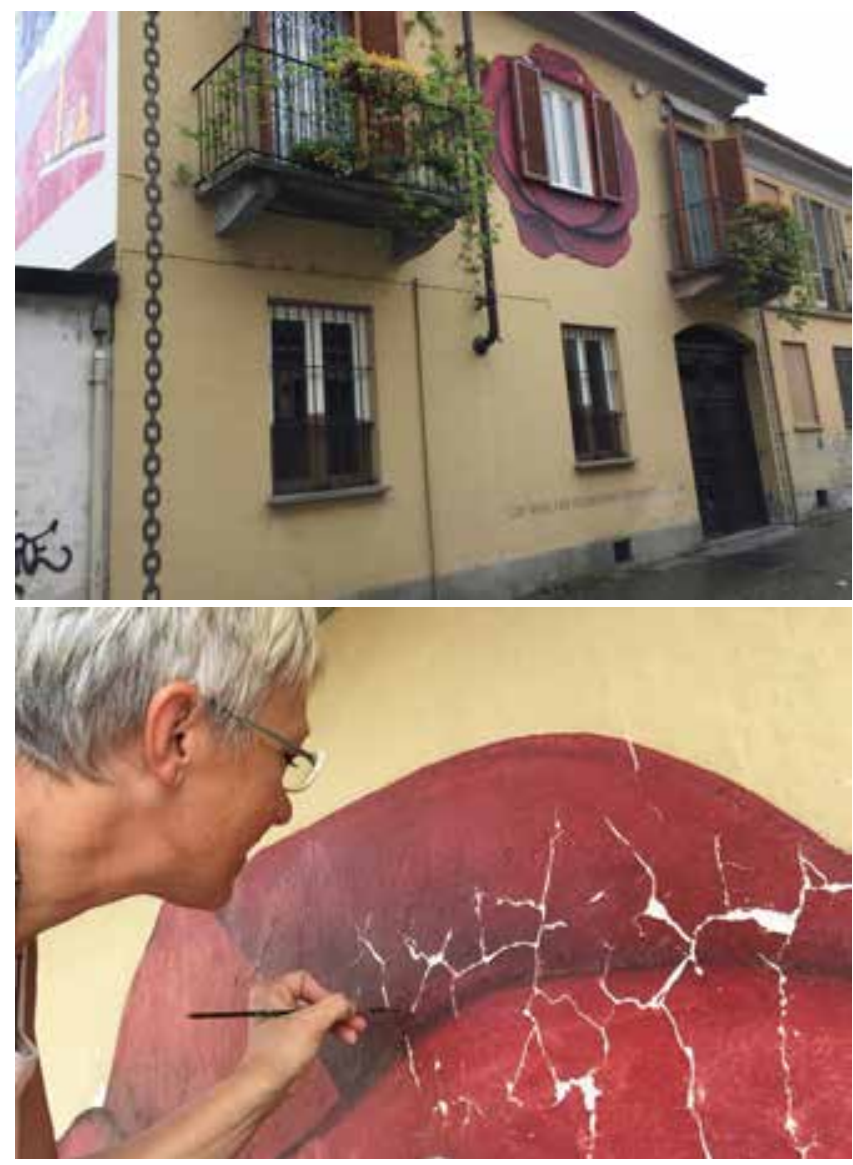

Figura 8 a-b. Cor lesu, mural de la artista italiana Roberta Fanti, pintado en 2007 y con importantes alteraciones debidas a su exposición a la intemperie (a). Ha sido restaurado en otoño de 2019 por Rita Pontarollo, de Art Deco Snc, en colaboración con el artista Vito Navolio (b). Fotos @ Rita Pontarollo - Archivo MAU (IT)

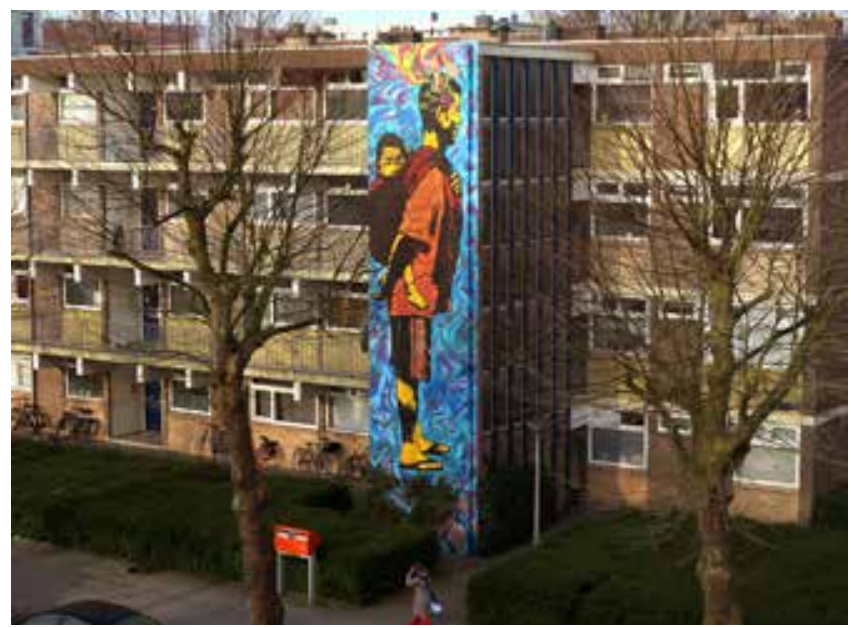

Figura 9 a. Fatherhood, mural pintado en 2015 por el artista colombiano Stinkfish para la localidad popular de Nieuw-West Amsterdam. Foto $\odot$ SAMA (NL) 


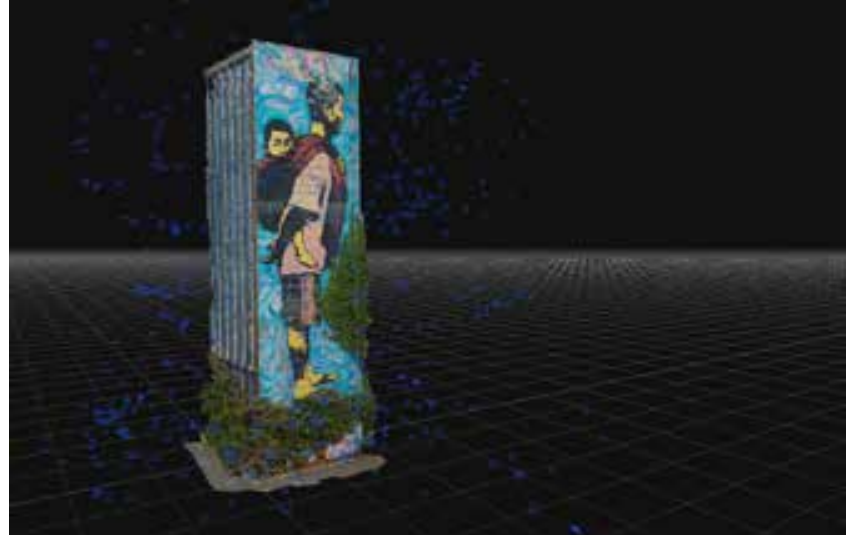

Figura 9 b. Modelo 3D del mural, reconstruido con fotogrametría y utilizado para crear una experiencia de realidad virtual 360, con el fin de preservar la imagen y memoria de la obra, ante su desaparición programada para finales de 2019. Modelo 3D (c) Gabriele Romagnoli - SAMA (NL)

- El museo al aire libre Puerto Street Art - PSA se puso en marcha en 2016, bajo la iniciativa de una plataforma de trabajo multidisciplinar coordinada por el Área de Cultura del Ayuntamiento de Puerto de la Cruz, en Tenerife (ES). Actualmente está integrado en la red de museos de la ciudad, y agrupa obras de artistas internacionales en diferentes "salas virtuales" clasificadas según su tipología (murales, esculturas, etc.), pudiéndose visitar tanto online como presencialmente. Su plan de conservación se circunscribe a la preparación óptima del soporte antes de la intervención y a un documento que se firma con la comunidad de propietarios, en el que se indica que están obligados a mantener las obras durante ocho años, tiempo estimado de vida media de los murales sometidos a la acción del sol y a la cercanía del mar. [figura 10]

-EIMuseum for Urban Contemporary Art-URBAN NATION, de Berlín (DE) abrió sus puertas en 2017. Entre sus finalidades, anunció la creación de una colección y la documentación y conservación de las obras promocionadas; aunque

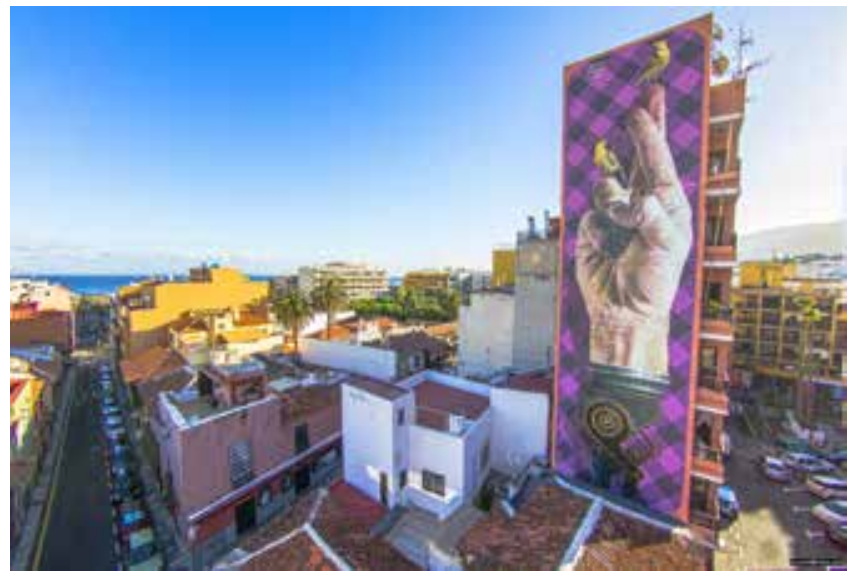

Figura 10. . Hay canarios... y canarios, mural pintado en octubre de 2015 en Puerto de la Cruz (Tenerife) por el artista argentino Martín Ron. https://goo.gl/maps/PWaYmCVAmG2wJdb5A Foto (c) Alejandro Amador - PSA (ES) desde su creación no ha demostrado que así sea, y en la inauguración de la Biennale de septiembre de 2019, su directora y principal impulsora, Yasha Young, anunció su despedida, poniendo especial énfasis en lo positivas que fueron las residencias temporales de artistas en el museo y que esta sería una meta prioritaria en proyectos personales futuros [17]. Son, por lo tanto, las residencias temporales de artistas, una de las novedades de este tipo de museo-galería, y la posibilidad de justificar inversiones en investigación a partir de las experiencias de los artistas.

Para finalizar, la única premisa común en casi todos los museos de arte urbano-contenedores (exceptuando los de vertiente más activista), es la de ser muestras abiertas en las que prima una percepción de sorpresa primaria y un tanto sensacionalista, dirigida a una oferta de turismo alternativo, y la percepción que se intenta transmitir es la de ser la colección más grande, la primera, la más novedosa o la más visitada.

En contraposición, los museos de arte urbano en contexto u open air están creados en su mayoría para fortalecer el vínculo del arte con la sociedad, a un nivel popular y no elitista, y son los únicos que pueden soportar, con menos contradicciones, las etiquetas de "museo" y "arte urbano", al no favorecer la descontextualización. Aspectos pendientes de análisis son la garantía de libertad en el proceso creativo y el respeto a la motivación de los artistas que, unidos a la espontaneidad, caracterizan las intervenciones. Por esta razón, desde el punto de vista de la organización museística y obviando las carencias de las estrictas normas del ICOM, la posibilidad de ofrecer fórmulas diferentes, inspiradas en la exposición de arte en espacios urbanos, debería tenerse en cuenta a la hora de plantear la nueva definición de museo.

Los museos de arte online constituyen también un interesante ejemplo de documentación y preservación de la memoria de muchas obras de la calle y cumplen al 100\% uno de los principales papeles a los que algunas propuestas de redefinición actual de museo hacen referencia: el de ser redes abiertas al exterior y totalmente accesibles para cualquier persona, es decir, fomentan la democratización del arte.

\section{Notas}

[1]. MAUA es un museo al aire libre de libre acceso gracias al mapa en la aplicación Bepart, descargable de forma gratuita para Android y iOS en: https://play.google.com/store/apps/ details?id=com.Bepart.BepartApp

[2]. El tMoUA es una galería de arte visual online dedicada a exhibir arte urbano y graffiti. Documenta, de una manera ordenada y visualmente estética, las obras seleccionadas y preserva, de esta manera, su memoria. Según su creador, «la virtualidad es la única forma que permite superar las barreras del tiempo y espacio propias del arte urbano». 
[3]. Hasta el año 2016, el SMoA ha llevado a cabo iniciativas de comisariado ilegal, utilizando la misma táctica de guerrilla del street art y de la cultura del graffiti. Sus proyectos han reevaluado el modelo vigente de los museos de arte contemporáneo, explorando las relaciones que los artistas compartían con sus entornos urbanos.

[4]. La crítica social siempre va contra las normas establecidas y sería necesario un análisis en profundidad de los museos en los que se percibe ese ejercicio para facilitar una posible autocrítica desde la propia institución.

[5]. La célebre fotógrafa de graffiti Martha Cooper sostiene que todos los museos de arte urbano están incompletos. También comenta que no ha oído nunca a nadie, en ninguna parte del mundo, hablar de alguno de ellos como un referente. Para más información, vean la "Entrevista a Martha Cooper", realizada por Elena García Gayo en abril de 2019 y publicada en este monográfico.

[6]. Aunque hay muchas redes sociales, se impone la influencia de Instagram, y tal como señala Martha Cooper: "si desaparece Instagram, desaparece todo".

[7]. La Galería de Arte Urbana - GAU de Lisboa, inaugurada en octubre de 2008, es uno de los primeros ejemplos en institucionalizarse y constituye un modelo para muchas galerías que vinieron después. http://gau.cm-lisboa.pt/galeria.html

[8]. La Asociación Le M.U.R. (Modulable, Urbain, Réactif) de París, se fundó en marzo de 2003 en torno al artista Jean Faucheur y se dedica a la promoción del arte contemporáneo y, más particularmente, del arte urbano. Situada en el corazón del distrito 11, Le M.U.R. promueve prácticas regulares con un panel de publicidad ubicado en la esquina de las calles St. Maur y Oberkampf, creando un puente entre el barrio y el arte callejero.

[9]. Beyond the streets' es el nombre de las dos muestras mediáticas en torno a la evolución del street art y graffiti, celebradas en Los Ángeles 2018 y Nueva York 2019.

[10]. El Manifiesto 'Street Art is Dead', lanzado en diciembre de 2018 por el artista italiano de Como, Pierpaolo Perreta, aka Mr. Savethewall, se puede seguir en su página de Facebook: https://www.facebook.com/www.savethewall.it/ posts/2012549602131655

[11]. El objetivo principal del GSAM es la revitalización de la localidad de Fuendetodos (Zaragoza) a través de la reinterpretación, en clave de arte urbano, de las obras de su ilustre hijo, don Francisco de Goya y Lucientes.

[12]. El Musée Romeo's acoge veinticuatro murales de artistas de Montreal en las cajas de escalera de dos inmuebles que forman el museo de arte urbano patrocinado por una marca de ginebra montrealesa. Nicolas Duvernois, fundador y presidente de la compañía de licores de Quebec Duvernois (Pur Vodka y Romeo's Gin) está detrás de la idea del museo, con el fin de democratizar el arte. Por esta razón, decidió ubicarlo en dos edificios con mucha afluencia de público, para que la gente pudiera ver arte en su vida cotidiana.

[13]. El MAUP, primer museo de arte urbano a cielo abierto de Río de Janeiro (2018), reúne unos cincuenta murales de grandes dimensiones ubicados en la zona portuaria. Los murales que vayan desapareciendo con el tiempo serán sustituidos por otros. EL MAUP cuenta con una plataforma digital que facilita la búsqueda rápida de cada una de las obras catalogadas, con el nombre del artista, la imagen, el título del mural, la fecha y la técnica empleada.

[14]. El Urban Nation es una Fundación pública cuya financiación fundamental procede de una inmobiliaria. Sobre este museo, vean el artículo de Sandra Gracia Melero "Berlín: todo un paradigma en el pasado, presente y futuro del arte urbano", publicado en este monográfico.

[15]. Son innumerables los artículos dedicados a la gentrificación que ha sufrido la ciudad de Málaga (entre otras), en la que han tomado parte las obras artísticas patrocinadas por el Centro de Arte Contemporáneo.

[16]. Las entrevistas contenidas en el anexo de este monográfico ofrecen más información sobre la gestión de Parees Fest (Oviedo), $B$-Murals (Barcelona) y Asalto (Zaragoza), festivales pioneros en España que han creado una metodología expositiva propia.

[17]. URBAN NATION Biennale 19: https://urban-nation.com/ event/urban-nation-biennale-2019/. La inauguración de la Biennale, el 13 de septiembre, fue retransmitida en directo a través de Instagram por algunos de los asistentes.

\section{Bibliografía}

ABARCA, J. (2009). Arte en el espacio público: barrios artísticos y revitalización urbana / coord. por Blanca Fernández Quesada, Jesús Pedro Lorente Lorente. Zaragoza: Prensas universitarias.

DEROSAS CONTRERAS, D. (2017). "Museo Inacabado de Arte Urbano (MIAU). Musealización del paisaje urbano", Didácticas Específicas, 17, ISNN 1989 - 5240.

LUQUE, L. (2018). "La ciudad contemporánea: problemas y tendencias. Perspectivas institucionales, sociales y artísticas", Sémata. Ciencias Sociais e Humanidades, 30, ISSN 1137-9669.

TIELVE GARCÍA, N. (2000). "La ciudad y el arte. Los nuevos comportamientos artísticos ante el escenario urbano", Ábaco, Revista de Cultura y Ciencias sociales, 23, ISSN 0213-6252.

CORRIERE DI COMO (2018).“'L'arte di strada è morta', parola di Savethewall". https://www.corrieredicomo.it/larte-di-strada-emorta-parola-di-savethewall/ [consulta 14/10/2019]

ICOM (2019). "La Conferencia General Extraordinaria pospone el voto sobre una nueva definición de museo", en ICOM Consejo Internacional de Museos. https://icom.museum/es/news/la- 
conferencia-general-extraordinaria-pospone-el-voto-sobre-unanueva-definicion-de-museo/ [consulta 22/09/2019]

MANCINI, F. (2013). Hacia una museología participativa: Análisis de experiencias participativas basadas en las TIC aplicadas a los museos. Tesis doctoral. Universitat Oberta de Catalunya. http:// openaccess.uoc.edu/webapps/o2/bitstream/10609/25961/1/ Tesi\%20Doctoral\%20Federica\%20Mancini.pdf [consulta 26/09/2019]

THOMAS, N. (2019). "What are museums really for?", en Apollo. The International Art Magazine. https://www.apollo-magazine.com/ defining-museums-in-the-21st-century/ [consulta 23/09/2019] ..

\section{Autor/es}

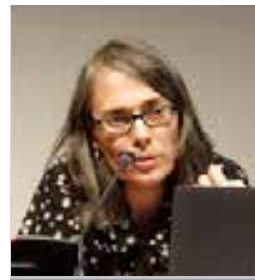

\section{Rosa Senserrich Espuñes}

Grupo de Investigación Consolidado "Conservación-Restauración del Patrimonio". Universidad de Barcelona rosa.senserrich@gmail.com

Licenciada en Bellas Artes por la Universidad de Barcelona (UB) con la especialidad de Restauración (1987). Ha ejercido como técnico superior en conservación-restauración de pintura mural y decoraciones arquitectónicas, trabajando para diferentes instituciones y museos en Cataluña y Aragón. En paralelo, ha combinado su profesión con la docencia, siendo contratada como profesora asociada por la Universidad de Barcelona (2010-17), dentro del Departamento de Artes y ConservaciónRestauración de la Facultad de Bellas Artes, como responsable de la asignatura de Grado Tratamientos aplicados a la pintura mural, y de Máster Pintura mural: entre el contexto arquitectónico y el museístico. Actualmente se dedica a la investigación independiente, y es miembro de la asociación de Conservadores y Restauradores de Cataluña (CRAC), del grupo de trabajo de Arte Urbano perteneciente al grupo español del International Institute for Conservation of historic and artistic Works (GEIIC) y del comité científico de la revista digital "Mural Street Art Conservation", creada por el Observatorio de Arte Urbano en 2015.

https://www.researchgate.net/profile/Rosa Senserrich/ research

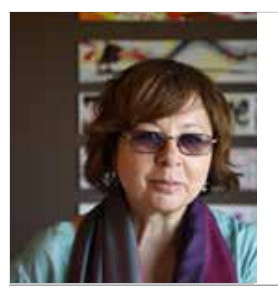

\section{Elena García Gayo}

Diputación Provincial de Ciudad Real

elenagayo@gmail.com

Titulada en Conservación Restauración de Bienes Culturales por la ESCRBC de Madrid. Conservadora-Restauradora del Servicio de Patrimonio Cultural de la Diputación Provincial de Ciudad Real. Paralelamente, es coordinadora de los grupos de trabajo, y del de Arte Urbano, del grupo español del International Institute for Conservation, GEIIC, desde 2015. Colabora con la

Comisión de Seguimiento del Plan Nacional de Conservación del Patrimonio Cultural del siglo XX en representación del GEIIC. Crea y administra el Observatorio de Arte Urbano. Dirige y edita la revista digital especializada Mural Street Art Conservation. Coordinó el primer monográfico anexo al n¹0, Arte Urbano: Conservación y Restauración de intervenciones contemporáneas, de la revista digital ge-conservación, en 2016. http://observatoriodearteurbano.org https://independent.academia.edu/EGayo 


\section{Artistas}

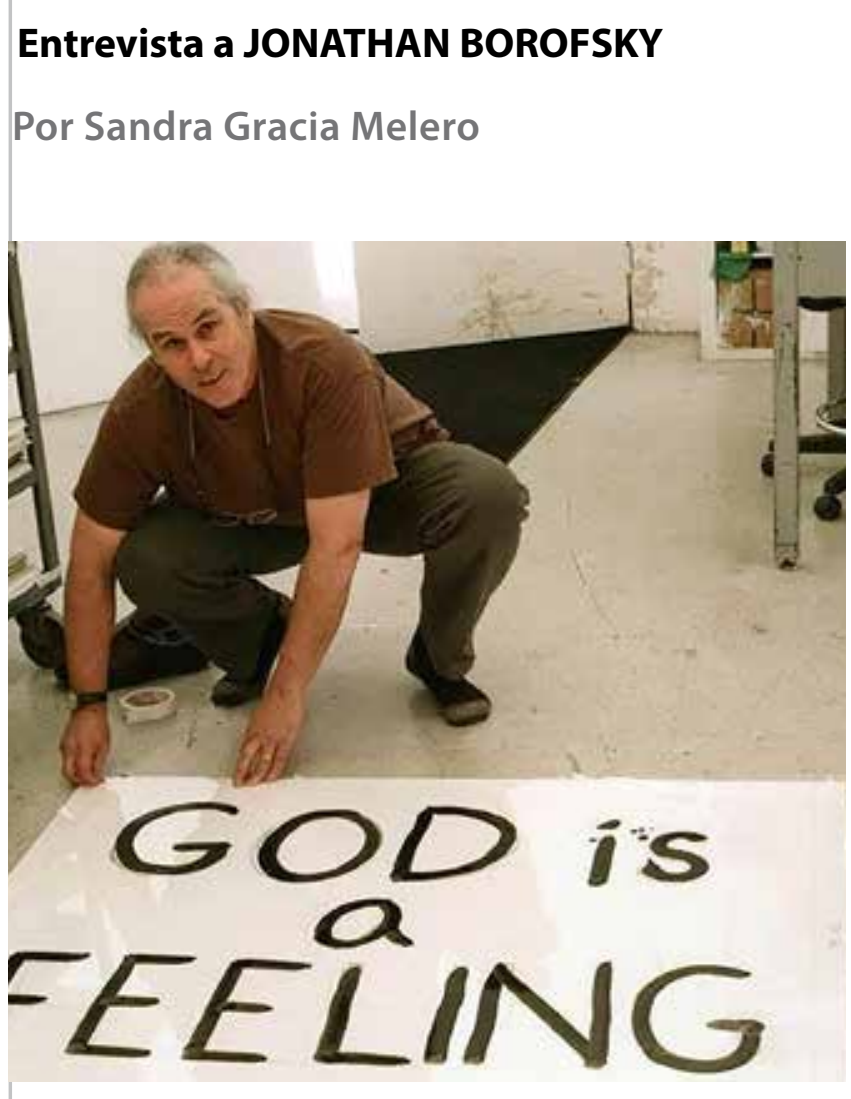

\section{How did you become a part of the Zeitgeist exhibition at the Martin-Gropius-Bau?}

I was invited by the directors of the exhibition: Norman Rosenthal and Christos M. Joachimides.

\section{What did you want to convey with your works in that} exhibition? Did you have complete creative freedom? My first suggestion to the organisers was for me to place a large 2-sided banner/sign on the roof of the GropiusBau facing both east and west. The banner, reading "Alles ist Eins", could be seen and read from the ground from both sides. This idea was turned down, so I went back to working in the room that I had already been given, but I wanted to do more: I was able to negotiate placing a silhouette of a man wearing a hat and carrying a briefcase in the skylight of the main space. This image, Man With a Briefcase, was an image that I used many times in the past to imply different meanings... In this case, my use of the image - either coincidentally or subconsciously related to the work Joseph Beuys was preparing in the main space directly below.
Jonathan Borofsky (Boston, 1942) se gradúa en Bellas Artes por la Universidad de Carnegie-Mellon en 1964 y obtiene un título de Máster en Arte y Arquitectura en la Universidad de Yale en 1966. Fue profesor en la Escuela de Artes Visuales de Nueva York hasta 1977. Influenciado por su mentor Sol Lewitt, la obra de Borofsky se relaciona con conceptos como la numerología, el trabajo o el universo, siendo sus obras más afamadas las grandes esculturas públicas de los Hammering Man en ciudades como Frankfurt, Kassel, Los Ángeles, Washington D.C., Nueva York o Seúl.

En 1982 es invitado por el Martin-Gropius-Bau de Berlín a participar en una exposición temporal colectiva titulada Zeitgeist, convirtiéndose en uno de los primeros artistas que intervienen en el Muro de Berlín.

Algunas de sus obras se conservan en colecciones como las del Museum of Modern Art de Nueva York, la Tate Gallery, la National Gallery of Art de Washington D.C. o el Kunstmuseum Basel de Basilea.

How did you live the social and political situation at that moment?

I did several things when I was there:

1. The Red Ruby Room - this is the room that I was assigned to work in. It was a corner room on third or fourth floor that had windows overlooking both East Berlin from one window, and the grounds of the former torture chambers of the Gestapo from the other window. I painted many red rubies (my symbol for the heart) on the walls of this room to help heal the situation that I viewed from these windows. This ruby symbol was used on some of the big posters for the exhibition. And, finally, in this Ruby Room, I suspended a realistic life-size figure appearing to fly out the window and over the wall below into East Berlin.

2. As I mentioned, I placed a giant silhouette in the overhead skylight - some people connected this man wearing a hat and flying overhead to Beuys' own personal history.

3. I painted the image of the Running Man on the wall. I 
also painted the words "KARMA: What you think and do comes back to you" on a different section of the wall.

4. I stood a small, painted red ruby (cut out of cardboard) on the ground where the pile of dirt which marked the grounds of the former torture chambers of the Gestapo. For the opening, which was at night, I placed a flashlight on the ground facing up at the ruby so that it could be seen in the distance as people walked into the building. It also was meant as a healing prayer.

\section{What kind of art/graffiti interventions were made on the wall at that time?}

The wall had occasional, small graffiti tags that were done quickly.

\section{Did you have permission from the authorities to intervene? Did you have any problems painting on the wall?}

No, I did not have permission to paint on the wall. As I already mentioned, my attempt to confront the political situation directly there with the banner was turned down. After that, I did subtly inquire with a few people what it would take to blow a hole in the wall... but, after some discussion, it became apparent that the concrete was much too thick, it would be dangerous to people, and it would potentially blow out the windows of nearby buildings - including the museum next door! So, I decided to paint the image of the Running Man, an image that I had painted many times before in different locations again, with different meanings depending on where it was placed. The Running Man, with his expression of angst or urgency or even fear, is my own self portrait.

The Running Man image was painted on the wall in one evening. I had two assistants from the Gropius-Bau helping me. One helped me with the ladder. The other served as a lookout for any British soldiers that might be patrolling. Actually, I used an overhead projector to project the Running Man image onto the wall (we ran an extension cord all the way from the museum!), and it took approximately two hours to complete. About halfway through the painting of the image, my lookout signalled that the British patrol ( 3 men in a jeep carrying assault rifles) was coming in our direction, so the three of us hid in nearby bushes. The soldiers got out of their open jeep, and began to inspect the strange ladder we had hastily left leaning against the wall. They were obviously concerned that someone might be using it to jump over the wall - either in or out of West Berlin! It was at this moment that I decided it would be best to reveal ourselves. I explained (not quite truthfully) that we had been given permission by the Gropius-Bau to do this work as part of their exhibition. I further explained that we were almost done, and asked if they could let me finish. They said okay, but that we shouldn't be there the next time they came around!
Do you remember what kind of materials you used? What is your opinion about the conservation and restoration of the Berlin's Wall Running Man? And what do you think about its modifications over time (bubble "Ick stand uff Berlin")?

I don't remember the materials used - whatever black and white house paint I could get ahold of. I've assumed that the work had been destroyed when the wall came down

Entrevista por escrito Fecha: 07 de octubre de 2019 


\title{
Entrevista a GONZALO BORONDO
}

\author{
Por Elena García Gayo
}

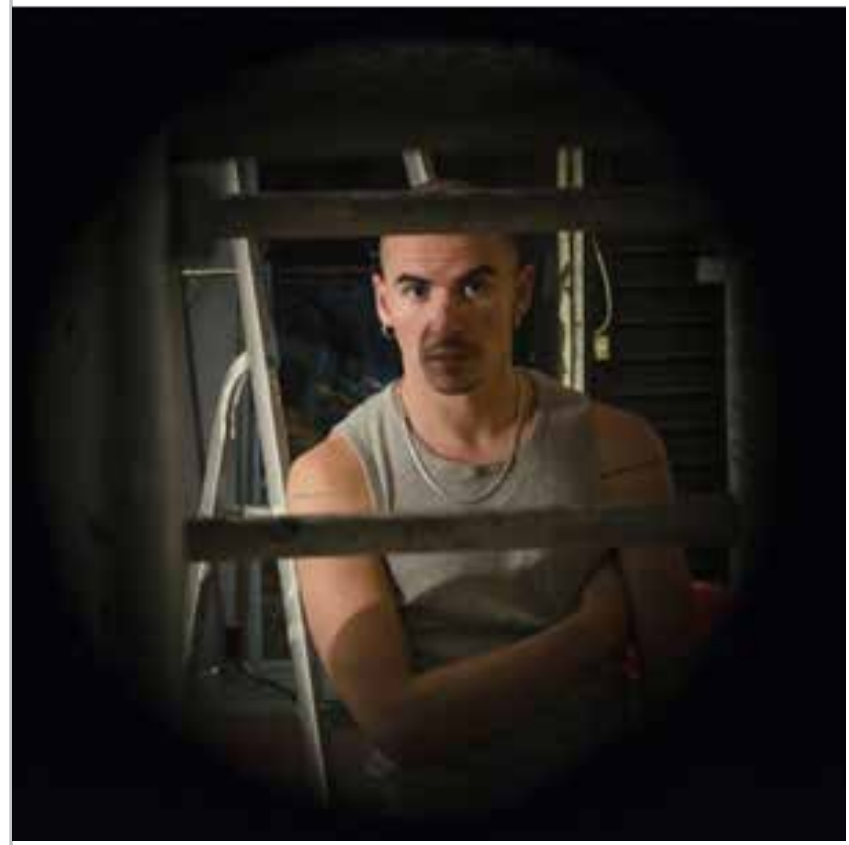

Gonzalo Borondo (Valladolid 1989). Realiza su formación superior entre las Facultades de Bellas Artes de Madrid y Roma. Ha desarrollado la creación desde la pintura y a través de la expresión en el espacio público. Experimenta en una variada gama de soportes y tipologías como: mural, instalaciones o la experiencia última, una escenografía de ópera. La experimentación es la base de su investigación artística, centrada en ampliar los recursos de la pintura a múltiples soportes como el vidrio, paja, cerámica o madera. Entiende su trabajo como una práctica estética que lleva implícita la posibilidad de obtener varias lecturas a través del paso del tiempo, que es algo destacable de su obra mural urbana. Reinterpreta los espacios desde una actitud comprometida con su entorno, consciente de la posibilidad de trascendencia y visibilidad de sus intervenciones

\section{¿Cómo afrontas el comienzo de cada proyecto, qué requisitos deben tener?}

Supongo que más allá del modo en que comienza un proyecto (por invitación o por iniciativa propia) lo que considero importante es la actitud y la intención con la que se afronta una propuesta. Siempre premio la investigación, el reto personal, la potencia comunicativa y de diálogo con el espacio y con el público. El espacio es el principal protagonista y el que decide cómo canalizar mi creatividad y cómo adaptarla al contexto.

Actualmente me interesa trabajar en lugares y propuestas que se encuentren al margen de "lo convencional". En mi caso, la convención funcionó como límite y ruptura, como motor para activar la creatividad. Siento que la inserción del arte en ambientes inesperados invita a un público más amplio a interactuar con la obra, introduciéndola en el ámbito de la vida cotidiana y no exclusivamente en el circuito del arte. Lo conseguimos así o habrá que transformar las instituciones.

\section{¿Cómo afrontas la documentación de tus obras?}

Considero que muchos de mis últimos trabajos tienen la característica de ser 'infotografiables', en el sentido en el que su traducción al lenguaje fotográfico y bidimensional no se acerca en absoluto a la atmósfera esperada, porque hago uso de elementos como el sonido, las videoproyecciones o el contexto, que completan el trabajo plástico y no son perceptibles desde un único punto de vista.
Mi trabajo comienza con el "proceso de recolección", en el cual realizo una inmersión en el territorio que acogerá la obra y acumulo información, conversaciones, experiencias y materiales que a menudo reciclo. Trabajo con lo que hay, lo que encuentro lo traduzco a través de mi universo personal y mantengo siempre presente el genius loci (espíritu del lugar) del espacio natural o arquitectónico. En este sentido dibujo, y la escritura o la fotografía son sólo algunos de los primeros ladrillos desde los que nace el resto.

En cifras numéricas (1-2-3) ¿cómo valorarías la importancia del proceso creativo, el "durante"? y en comparación, ¿la de la obra final?

Creo que uno de los grandes errores que cometemos a menudo es el de cuantificar con números las realidades, de una forma subjetiva, las notas durante los estudios, el coeficiente intelectual o los actuales likes... Considero que esto genera una competitividad sin sentido, cuantificando lo "incontable", introduciendo"lo humano" en el ámbito de producción de un sistema liberalista. Dicho esto, para mí, el proceso de desarrollo es lo más importante, porque supone mi batalla interna y, es gracias a ella, que me desarrollo con cada proyecto. Es fundamental desde un punto de vista personal y no tiene nada que ver, necesariamente, con el resultado final. Por otra parte, la obra terminada, que es lo que va a recibir el público, tiene un valor indiscutiblemente mayor ya que es lo que presento al mundo y en su fase final no sólo concierne a mi autocrecimiento. 


\section{¿Hasta qué punto admites injerencias en tus obras comisionadas?}

La necesidad de adaptación es probablemente uno de los orígenes de la creatividad, además de ser inevitables los contratiempos que, en muchos casos, se desvelan como factores que enriquecen la obra. El límite y la necesidad de superarlos es un motor muy fuerte en mi búsqueda artística, por lo que al final forma casi parte de la creación, de mi lenguaje y, por lo tanto, de la obra en sí. Por otro lado, la experiencia me ha hecho entender que ciertas condiciones no pueden más que favorecer el resultado de la obra. Las condiciones que considero fundamentales son la claridad y transparencia con el contratante desde un principio, a través de un contrato formal y sobre todo mi máxima independencia y libertad "total" de decisión en la parte creativa.

\section{¿Te planteas tu trabajo como parte de una comunicación con el público?}

El público es un factor fundamental de la obra, al fin y al cabo no existe obra sin espectador, y es por ello que me siento con el deber de intentar acercarme a un público más vasto sin que esto condicione la integridad de la obra, así que, procuro que contenga varios niveles de lectura, desde los más básicos o inmediatos hasta los más poético y filosóficos que quizás lleguen a un público más especializado o afín a mi obra.

Con esto no quiero decir que mi intención sea la de mandar un mensaje unidireccional a través de la obra, sino más bien de abrirme a otras dimensiones mentales, sugerir atmósferas que puedan promover reflexiones a partir de la experiencia sensorial.

Creo en la capacidad transformadora del arte para modificar el espacio físico y de lo que puede aportar para la gente que lo habita o frecuenta.

Incluir una visión personal en el espacio de todos es política en su base, además, más allá de esto y como de algún modo explicaba anteriormente, la actitud y la intención de buscar lo "anticonvencional" es también una manera de hacer política, de abrir posibilidades en la sociedad y facilitar el cambio. Esto funciona como crítica en sí misma, muestra a la vez una necesidad y una posibilidad diferentes a lo preestablecido. En cualquier caso, siempre he dicho que mi intención final no es la de hacer política o crear polémica sino la de desarrollar una poética que pueda hablarnos del mundo de un modo menos inmediato y a su vez más profundo.

Inevitablemente toda obra nace de una experiencia personal aunque, en mi caso, intente alejarme lo más posible de las referencias personales. Me interesa más incluir conceptos universales o temáticas que todos compartimos traduciéndolas a través de un lenguaje propio.

\section{¿Hablamos de materiales?}

Al estar las obras supeditadas a su contexto, no evito los límites plásticos introduciendo todo tipo de materiales y lenguajes que puedan enriquecer la obra sin aferrarme a lo conocido, es más, en este momento la investigación con lo inexplorado me estimula más que el profundizar lo que ya se y sé que funciona. Creo que uno no se forma como artista con sus descubrimientos, sino con su necesidad infinita de búsqueda.

Es obvio que hay materiales y técnicas más afines a mi proceso y por los que siento una particular predilección: el cristal, los materiales naturales o transparentes, los grandes formatos, la animación pictórica o el video..., pero todos ellos dependen del concepto y el lugar, y marcan mucho la decisión de usarlos o no. En este sentido, me gusta trabajar con materiales y técnicas que encuentro en el contexto donde voy a realizar la obra. La búsqueda y el descubrimiento de nuevos modos de trabajar siempre me estimula.

En el caso de los murales he comenzado a trabajar con pinturas al silicato que tienen una mayor garantía de perdurabilidad pero, más allá de las obras públicas y permanentes, priorizo la realización y la capacidad de impacto de la obra sin plantearme mucho su futuro. Siento que este no depende del todo de mí y de los esfuerzos que en ello pueda invertir. Digamos que me urge más el hacer y el transmitir que el conservar.

\section{Antes de empezar tu obra ¿te planteas utilizar técnicas/ materiales de carácter más o menos efímero, para que tu obra se degrade y se pierda lo antes posible?}

Desde hace varios años llevo intentando trabaja con la transformación casual que puede ejercer el tiempo sobre una obra. Junto al ge-IIC he comenzado a llevar a cabo algunas investigaciones sobre el modo en que se deterioran algunos materiales en una pintura mural, de modo que la transformación de los mismos modifique el contenido plástico y a su vez genere nuevas lecturas del sujeto. Me atrae la idea de mantener una constante "sorpresa" para quien vive la obra diariamente, hacer una pintura "viva", que contraste con los orígenes conceptuales de la misma. Siento que este es un proceso que acaba de comenzar, pero mi intención es la de profundizar en ello y seguir estudiando distintos métodos de innovación en busca de la autotransformación de la imagen.

Se podría decir que me interesa conocer las causas de degradación material de las obras en la medida en que estas me puedan ayudar a incrementar las posibilidades plásticas y el "pseudo-control" de su transformación, o al menos asegurarse cierto tipo de resultados.

\section{¿Qué opinión tienes de los museos de arte urbano?}

Los conozco y tengo obra en varios de ellos. Por un lado, veo positivo el que se apoye y se abra el camino a artistas 
que no provienen del circuito convencional del arte contemporáneo, legitimando la calidad de su trabajo, por otra parte, considero que no es necesario legitimarlos de ese modo y que en muchos casos están desnaturalizando lo que era especial y característico en ellos, como puede ser su capacidad de diálogo con el contexto. Al final termina sucediendo muy a menudo que se premia a quien utiliza soportes más convencionales, en lugar de potenciar la transformación de la urbe o de quien de modo espontáneo actúa en ella como principal práctica artística.Tengo obras en museos y algunas colecciones interesantes pero, lo cierto, es que desde hace algunos años tiendo a no realizar mucha obra en soportes portátiles o vendibles. No me gusta la idea de la obra de arte como objeto, se que esta es su manera de sobrevivir al tiempo (principalmente gracias al mercado que existe detrás de ellas) pero actualmente me interesa más la idea de la obra de arte como contenido cultural en sí mismo, sin necesidad de funcionar como objeto de intercambio sino como una experiencia creada en el espectador.

\section{¿Te planteas si alguna de tus obras va a sobrevivir mu- cho tiempo?}

Más que sobrevivir en el sentido físico, me pregunto cómo algunas de ellas puedan llegar a envejecer, a nivel estético-conceptual. Son muchos los ejemplos de obras que en su momento fueron muy aclamadas por la crítica y que, a cambio, el paso del tiempo les ha hecho un flaco favor, obras que a día de hoy han perdido todo interés.

Supongo que mi ambición sería más la de que la obra pueda seguir comunicando en un futuro, y no tanto si se mantendrá en perfectas condiciones. Inevitablemente, una cosa lleva a la otra, sin conservación no podrá haber juicios futuros, pero como ya comentaba procuro concentrarme en la obra en sí, el resto se escapa a mi posibilidad de gestión.

\section{¿Qué importancia le das a las redes sociales en tu obra?}

Hasta hace poco más bien ninguna, he sido siempre muy cauto al respecto y nunca las he utilizado de manera personal. Creo que a día de hoy es casi inevitable que la presencia de estas redes no interfiera en el trabajo de un artista, la realidad virtual está legitimándose por encima de la material y considero que se está transformando el modo de gestar las obras en muchos casos, aunque no siempre lo haga de manera negativa. Se producen y consumen obras de un modo que podrían casi entrar más en la categoría de entretenimiento que en la de cultura, pero al fin y al cabo estas son hijas de su tiempo.

Uno de los mensajes que me gustaría estar acertado en transmitir con mi trabajo es el de vivir el espacio físico, que a través de él se pueda prestar más atención al presente que nos circunda. Por eso me ha interesado siempre el espacio público y la experiencia inmersiva que dialoga con el contexto. Tanto el proceso como el resultado son fruto de esa atención al espacio y el presente. Lo menciono porque creo que este "mensaje" es totalmente contrario al que nos proponen las redes sociales $y$, probablemente, es este el motivo que me ha llevado a observarlas siempre con cierto recelo. En este momento estoy utilizando Instagram para crear un archivo de trabajos online que pueda servir de plataforma para quien quiera profundizar en mi trabajos, antiguos o recientes. A pesar de utilizar para ello una red social como plataforma no pretendo usarlo para interactuar de un modo convencional, sino como un espacio de difusión de contenidos.

\section{Si una de tus obras desaparece materialmente y sobre- vive digitalmente fuera de tu alcance ¿qué te planteas?}

Mis obras desaparecen continuamente, incluso yo mismo las pierdo, así que estoy bastante acostumbrado. A su vez, me gusta la idea de que exista un archivo, ya sea analógico o digital — de hecho actualmente tengo una persona trabajando en ello exclusivamente-. Creo que puede ser importante para mí mismo, para entender mi proceso y los pasos que he dado. A veces me olvido de lo que ya sabía y es fundamental mirar al pasado para hablarle al futuro. Todo termina escapando a nuestro control, y esta realidad forma parte de la existencia, por eso he decidido entrar en algunas redes sociales y en la medida de mis posibilidades controlar la calidad de los contenidos.

Entrevista por escrito. Fecha: 28 de agosto de 2019 


\title{
Entrevista a ANTONIO LAGUNA
}

\author{
Por Elena García Gayo
}

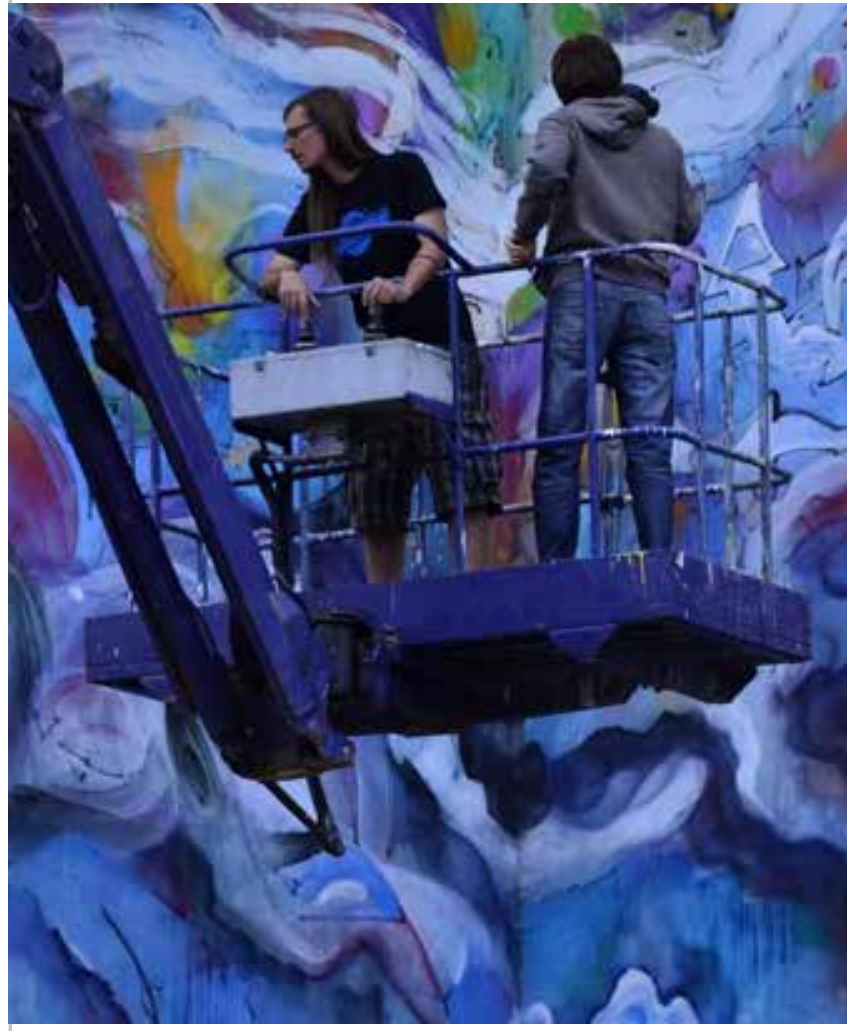

Siempre estuve rodeado de familiares que pintaban y no recuerdo cuando empecé yo a hacerlo. En primaria mis compañeros me hicieron sospechar que había algo interesante en las líneas que trazaba porque conseguía caramelos a cambio de algunos dibujos. En el instituto ya pintaba encargos para conocidos y en 1995, influido por la cultura hip hop que veía a través de reportajes, películas y pinturas callejeras de Madrid, empecé a pintar en un pueblo de ocho mil habitantes, en las paredes vírgenes de La Mancha; en Almagro. En 1998 es cuando empiezo a alejarme de los esquemas establecidos que la pintura callejera manejaba en aquel tiempo y comienzo a trabajar el mural como si de un lienzo se tratara, mezclando pintura plástica con aerosol y tratando de no preocuparme por "agradar" a un posible espectador con mis resultados. A partir del 2004 salgo de España gracias a la pintura mural, dejando atrás mi oficio de cámara en cine y televisión, y a disfrutar del final de esa gran "primera oleada" del'Street Art', hasta aproximadamente el final de la segunda ola que sitúo en 2014. En mi faceta creativa, pinto de manera no remunerada casi a diario y en cualquier superficie que puedo encontrar ahí fuera. Y de manera remunerada, actualmente, trabajo como ilustrador en publicaciones, dibujo'storyboards'. Volví al cine, en esta ocasión a través de la pintura, formando parte de diferentes equipos de arte y también con diferentes funciones, y cuando no queda más remedio hago pintura mural decorativa para ingresar algo de dinero y recordarme a mí mismo que nunca seré libre.

\section{Háblame del proceso creativo y de cómo te enfrentas a un proyecto.}

Diría que más de un $90 \%$ de la pintura mural que he llevado a cabo en toda mi vida es independiente y personal. Lo que he generado a través de festivales o instituciones es fruto de casualidades o circunstancias ajenas a mí, porque nunca lo he buscado.

Siempre he estado ligado al mundo del audiovisual, así que, he tenido el equipo necesario para captar y documentar mis piezas. En la mayoría de las ocasiones es también mi forma de hacerlas perdurar "algo más" en el tiempo. Y cuando trabajo con más gente, con amigos, también recurro al video para tener una buena documentación del tiempo que tuvimos en común.

Tengo una deuda conmigo mismo de empezar a hacer bocetos y prepararme el concepto antes de empezar a pintar, pero he aprendido mucho de mi forma básica de atacar una superficie. Me gusta hacerlo sin plan ni idea previa, en definitiva, sin una visión general. El viaje por el desconocimiento es lo apasionante para mí y hace que nunca sea un trabajo. En 2006, por ejemplo, tuve la posibilidad de pintar por primera vez el silo de Almagro [figura 1] que, con sus casi treinta metros de altura, en su día, fue probablemente el mural pintado en exterior más alto de España. Lo hice sólo y quizás debí haberme planteado algo antes, pero fue un freestyle en toda regla, y de principio a fin. Últimamente estoy intentado subvertir mi forma de enfrentarme a los trabajos. En algunas épocas de mi vida también he llevado conmigo al muro un 'mood board' con mis referentes, aunque solo sea para que ellos me hablaran desde el bolsillo.

El edificio del silo sirvió como fondo teatral para la obra que cerró la 29a edición del Festival Internacional de Teatro de Almagro y, aunque ya existían muchas referencias de pintura de calle en la zona, la obra geolocalizó a Almagro a nivel de murales y empezó a ser interesante también en este aspecto.

En esta obra no hubo presupuesto para pintura ni para mi trabajo, solo para la grúa. Pinté con lo que tenía a mano, con pintura plástica de interior, y esto hizo que partes de la pieza envejecieran prematuramente pasando por varias fases de color muy interesantes para mi. Fué un regalo que hice a mi pueblo y a mi mismo.

\section{¿Puedes comentar la segunda intervención del silo?}

En esta segunda ocasión, la idea partió del Ayuntamiento, la Diputación y de la Junta de Comunidades de Castilla- La Mancha [figura 2]. 


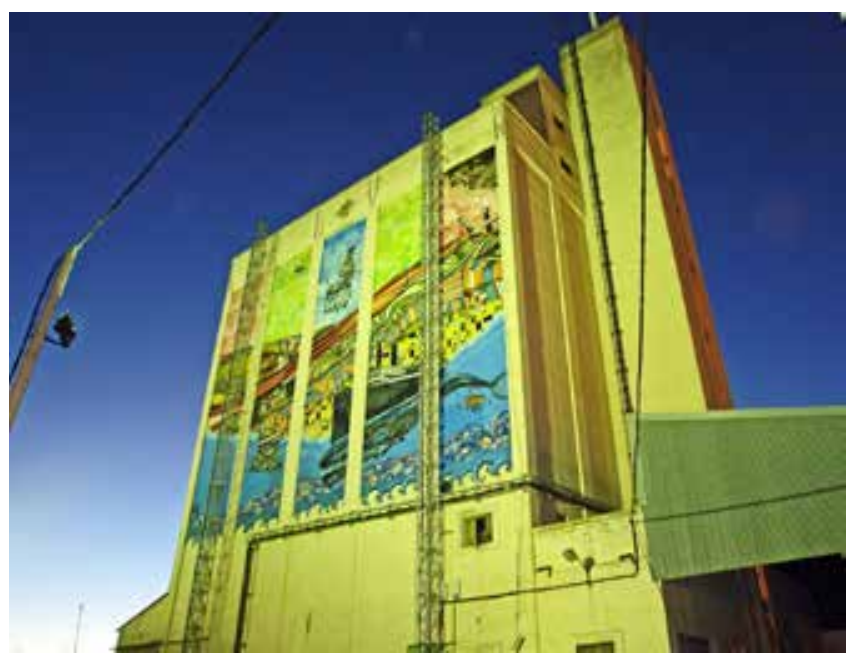

Figura 1.- Silo de Almagro. 2006

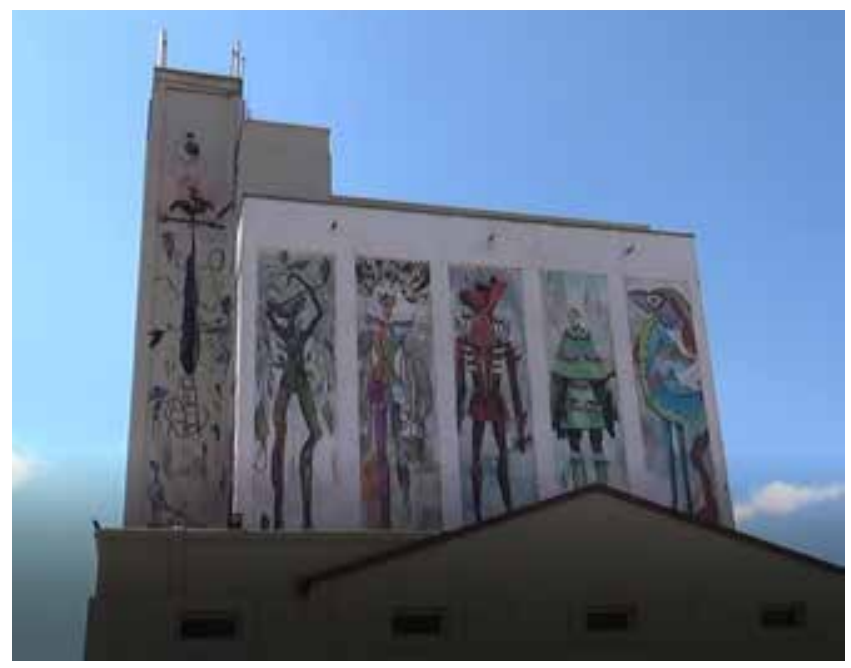

Figura 2.- Silo de Almagro. 2018

A nivel del color, trabajé con tonos más apagados y compactos que en la primera ocasión, a sabiendas de lo que hacía y cómo virarían los diferentes tonos, en la alianza del sol y la climatología... A partir de 2018 el silo es un espacio escénico más del festival y también sala de conciertos, por lo tanto, ese lugar tiene un entorno totalmente dinamizado durante todo el año, gracias a esta rehabilitación exterior e interior, y un nuevo espacio de paseo.

En cifras numéricas (1-2-3) ¿cómo valorarías la importancia del proceso creativo, el "durante", y en comparación la de la obra final?

El proceso creativo es el 3 porque, para mí, representa los aspectos de la vida que uno quiere experimentar constantemente. El resultado a veces es un 1, y otras, un número negativo.

\section{¿Hasta qué punto admites injerencias en tus obras} comisionadas?

Solo admito "carencias" e injerencias en materiales, porque la verdad es que me da igual con qué pintar. Si falta, por ejemplo, la grúa, por falta de medios, vale, pero si la falta de medios es por avaricia no puedo evitar expresarlo en el muro. En cuanto a injerencias temáticas, solo lo he experimentado en experiencias que han sufrido otros compañeros.

\section{¿Teplanteas tu trabajo como parte de una comunicación con el público?}

Sólo en parte y a veces. Somos los espectadores los que conectamos o no con un posible mensaje y lo que percibimos rara vez conecta con la idea del creador. Hablar no basta para comunicarse. En parte, lo que pinto, es el sitio de mi recreo, con las formas y colores que quiero que me acompañen, $y$, en parte, hay una autocrítica que ha ido creciendo en sinceridad con el paso de los años.

Mis obras preferidas son aquellas en las que el lugar respira y se percibe como protagónico por encima de la pieza pintada. Las arquitecturas invisibles, vírgenes y quebradas, me hacen pintar con los cinco sentidos.

\section{¿Cómo eliges los materiales y qué técnicas desarrollas? ¿Te gusta investigar?}

Las técnicas son compartidas en la medida de lo posible en ambos medios. Utilizo mejores calidades en el material de la obra que hago en el estudio, esa es toda la diferencia. Las técnicas que me permiten crear las líneas generales de la obra son las que más libertad me proporcionan, hasta el punto de que algún día mis obras finalizarán en ese punto. Cada técnica tiene la capacidad de definir un estado de ánimo. En cuanto a materiales, me adapto a lo que se me ofrece y si hay "posibles", la opción es clara, la mayor calidad posible.

El hilo conductor que da unidad a lo que pinto, lo encuentro como mínimo a medio camino del trabajo, en muchas ocasiones en el tramo final. En exterior suelo trabajar con pinturas en mal estado y con bases diluidas principalmente. Si la pieza perdura mínimamente en el tiempo se obtienen variantes de las pinturas muy interesantes.

Uso lo aprendido en pintura de escenografía y a veces lo llevo cabo en mi trabajo personal, para, por ejemplo, craquelar y "deshacer" las bases de las que parto en mis murales. Pruebo mezclando materiales que se usan tradicionalmente para otras cosas y voy aprendiendo sobre la marcha, como siempre. No me importa mucho conocer las causas de degradación de la pintura, los años te dan ese tipo de información. Es un aprendizaje natural.

\section{Lo primero que te viene a la cabeza cuando escuchas la palabra 'museo' es...}

Excursión escolar. Aunque, por una parte, es una salvaguarda de cuestiones importantes $y$, por otra, de flores de un día. 
¿Qué te sugiere el concepto "museo de arte urbano"?

Blanqueo de dinero, inversión; o ambas.

¿Conoces personalmente alguno de los llamados 'museos de arte urbano' que existen en la actualidad? ¿Tienes obra en alguno de ellos?

Si, el que iba a ser el primero. Hubo propuesta formal y negativa también formal.

Las más importantes, para mí, son las colecciones privadas de cada uno de mis amigos.

Tengo obra en algún museo, quizá de los que no tienen una relevancia especial.

Que sean disfrutadas, es todo lo que puedo desear para mi trabajo de estudio, donde estén no me importa. Por ejemplo, no me planteo si van a vivir mucho, les doy el mejor acabado posible y que las circunstancias y el tiempo decidan.

¿Sientes que el 'crear para la calle' y el 'crear para exponer' son acciones creativas complementarias o son independientes y no tienen relación?

Cada hacedor tiene sus pautas, virtudes y limitaciones. Yo respeto mi obra, incluso en las que no pude dar el $100 \%$. El lugar donde acaban, sea una fogata de una nave o una fogata dentro del MOMA, no me afecta, creo que no soy yo quien lo tiene que decidir.

Mi visión es, que pintar dentro puede ser tan salvaje y personal como fuera del espacio blanco, si el grado de libertad que puedes llegar a tener es total.

Ante cualquier imposición, pauta, norma o "pero" ... la expresión artística puede llegar a ser un trabajo como cualquier otro y el resultado variará entre una "mierda decorativa más" y una "puta mierda decorativa más".

\section{¿Qué importancia le das al espacio virtual?}

He estado fuera de ellas hasta hace dos años, me sirven para mantenerme en contacto con el "personal" y mostrar algunas cuestiones que nadie va a ver en persona. Si borro mi Instagram mañana nada cambiará para mí o mi obra.

Si desaparece alguna de mis obras y aparece en la red, creo que no hay nada que plantearse, cada día eso le sucede a alguna de ellas, está asumido casi desde que empecé.

¿Consideras que las obras que se escapan a tu control, virtualmente hablando, siguen siendo tuyas?

Lo que hice, mío es. Aunque tú lo monetices y como ajeno a tí otros lo consuman - tu nombre exista y el mío no- sigue siendo mío.
Virtualmente ¿aceptas de buen grado variaciones sobre tus obras?

Siempre que haya contacto con el sujeto que modifica, por mí, todo ok
Entrevista por escrito.

Almagro 05 de septiembre de 2019 


\title{
Entrevista a A DOS JOTAS. www.dosjotas.org
}

\author{
Por Elena García Gayo
}

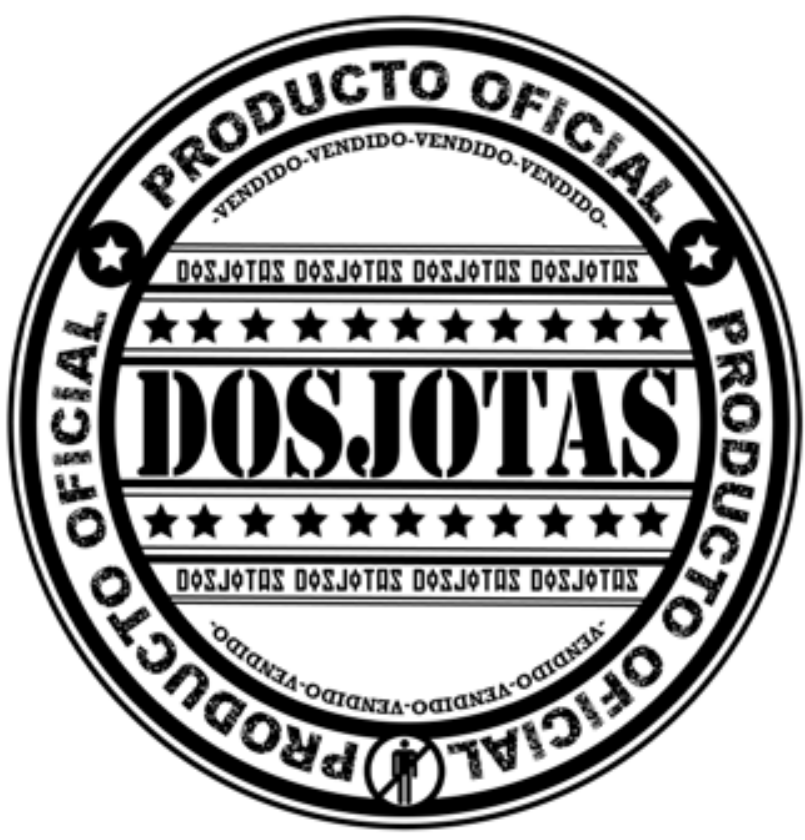

\section{¿Cómo afrontas tu trabajo?}

Mi trabajo es principalmente individual e independiente, aunque también he participado en festivales $y$ convocatorias, $y$ en actividades institucionales. Me parece fundamental poder hacer las dos cosas. En mi caso por el cariz de mis intervenciones suele tener más peso la faceta activista que la institucional. Durante el proceso creativo suelo usar fotografía y alguna vez video. Dependiendo de la intervención, suelo escribir más que dibujar, siempre le doy mucha importancia al proceso creativo, creo que es la parte más importante de un proyecto.

En cifras numéricas (1-10) ¿cómo valorarías la importancia del proceso creativo, el "durante"? Y en comparación, ¿la de la obra final?

9, el proceso creativo lo es todo, la obra final es la consecuencia de ese proceso, sin él no existiría la obra. Todas las obras que realizo dependen del contexto en el que están, sin él no tendrían sentido. Suelo trabajar partiendo de situaciones o circunstancias que existen en

el entorno urbano o en la sociedad, y suelen depender de su contexto.

No suelo tener injerencias en mis trabajos, cuando participo de algo comisionado pido total libertad, si no, no participo, porque entiendo que para crear hay que tener total libertad tanto conceptual como técnica, si no la intervención se convertiría en un encargo decorativo.

Siempre, mi trabajo va dirigido al público e intento crear reflexiones por pequeñas que sean, sin público, el trabajo no tiene sentido, porque hay una crítica social, política o institucional, que siempre está presente en mis proyectos.

\section{¿Con qué materiales sueles trabajar?}

No tengo unos materiales específicos con los que trabajo, suelen variar dependiendo del proyecto. Cada intervención necesita una técnica específica diferente para explicar lo que quiero contar con ella. Cuando el trabajo es subvencionado pido los materiales que necesito. Ahora estoy trabajando con materiales adhesivos. 
Normalmente parto de un tema, empiezo a investigar, a buscar información, con el fin de poder desarrollar un proyecto coherente y compacto. Creo que la idea de lo efímero da fuerza y apoya al arte urbano, sobre todo actualmente.

Tengo obras en la calle que perduran desde 2007, algunas se han degradado, otras no, el principal problema suele ser que las obras ilegales no duran demasiado gracias a las instituciones. Por otro lado, creo que cuando perduran en el tiempo — se degradan o son intervenidas por otras personas- comienzan a tener más fuerza y significado dentro de la ciudad.

Lo primero que te viene a la cabeza cuando escuchas la palabra 'museo' es....

Un cubo blanco lleno de objetos descontextualizados, un contenedor sin contenido.

¿Qué te sugiere el concepto "museos de arte urbano"?

Creo que son palabras contrarias, un museo, por lo general, es un espacio cerrado, el arte urbano, como su nombre indica, pertenece a la calle. Creo que más bien sería un museo con obras de artistas urbanos, pero no de arte urbano.

¿Tienes alguna obra en alguna colección de especial relevancia?

No.

\section{¿Tienes alguna obra en la colección de algún museo? ¿te gustaría?}

No. Me gustaría que una de las obras realizadas específicamente para una sala o la documentación de una obra de calle estuvieran en una colección, pero no la obra que está en la calle.

¿Te planteas si alguna de tus obras va a sobrevivir mucho tiempo?

No.

¿Sientes que el 'crear para la calle' y el 'crear para un espacio que conserve tu producción' son, para ti, acciones creativas complementarias, 0 son independientes y no tienen relación?

Son totalmente complementarias

Podrías identificar alguno de los puntos que separa el hecho de 'crear para la calle' y 'crear para un espacio expositivo' y que el público en general no suele diferenciar claramente.

Principalmente el contexto, una cosa es el espacio urbano y otra una sala de exposiciones, la comunicación y los modos de hacer cambian totalmente.

¿Qué importancia le das a las redes sociales en tu obra?

Cada vez menos, en el inicio de las redes sociales era algo muy importante, permitía que tu obra viajara en segundos por todo el mundo y llegara a un número de gente inimaginable, en la actualidad, sobre todo "caralibro", están hechas para sacar dinero, el algoritmo que rige este tipo de redes está hecho para pagar y si no pagas no existes.

Si una de tus obras desaparece materialmente y sobrevive digitalmente fuera de tu alcance ¿cómo te lo planteas?

Ya ha pasado, y es parte de lo interesante de las obras efímeras, desaparecen físicamente pero siempre queda un escrito un documento que da vida a esa obra más allá de su cuerpo material, en cualquier momento puede volver a cobrar sentido en la red fuera de las manos del artista, me parece que es algo muy interesante y que enriquece la obra.

¿Consideras que las obras que se escapan a tu control, virtualmente hablando, siguen siendo tuyas?

No suelo considerar ni las obras de calle como mías, ya que ni las firmo. Creo que el término "ARTISTA", puesto tantas veces en crisis, ha de seguir siendo cuestionado.

Virtualmente ¿aceptas de buen grado variaciones sobre tus obras?

En general no me importa, excepto si son usadas con ánimo de lucro o por alguna institución.

Entrevista por escrito. Fecha: 8 de abril de 2019 


\section{Entrevista a NURIA MORA}

Por Elena García Gayo

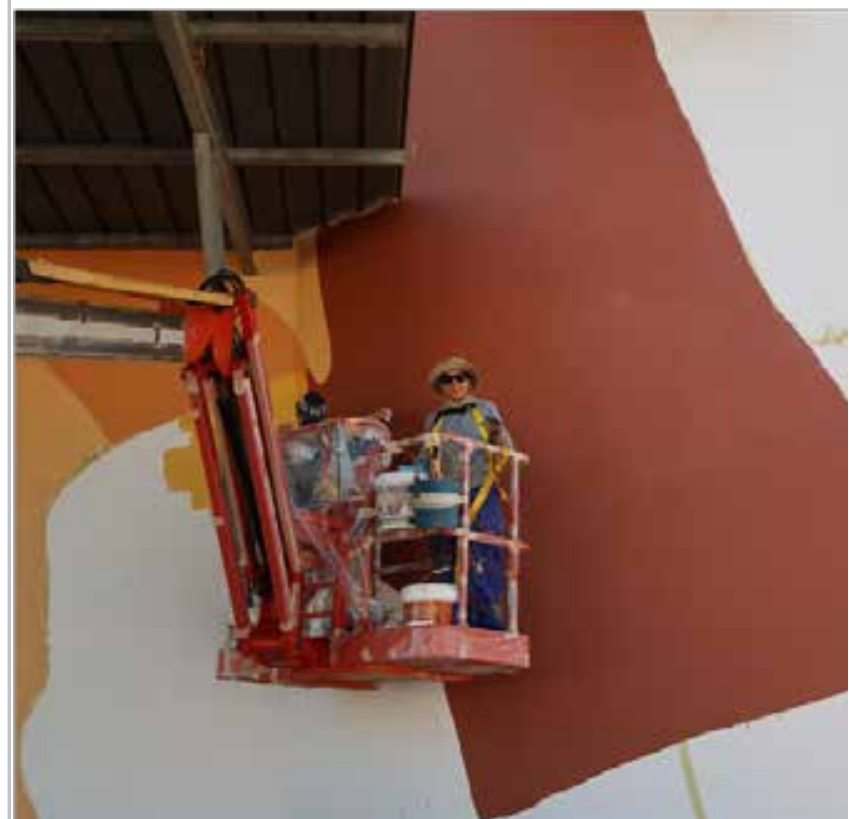

Nuria Mora ha formado parte del proyecto "Titanes", que ha sido comisariado por el artista Oscar San Miguel, Okuda, a través de la IAM Gallery, por encargo de la asociación Laborvalía. El proyecto, que implica el pintado y reinterpretación de varios silos de la provincia de Ciudad Real, ha sido subvencionado por la Diputación Provincial y se lleva a cabo desde el mes de abril y a lo largo del año 2019.

\section{¿Cómo afrontas materialmente el trabajo mural y concretamente el silo de Manzanares?}

Trabajar de forma independiente en la calle es una cosa y en el estudio es otra. Cuando estoy en la calle de manera autogestionada lo hago de una forma y si trabajo en la calle con un equipo de producción detrás y de forma legal, comisionada, suele ser de otra.

En el caso de los silos de Manzanares, qué es un proyecto llevado a cabo por una entidad pública como es la Diputación Provincial de Ciudad Real, tenemos toda una serie de personas que nos asisten. Cuando llegamos, ya teníamos el soporte perfectamente preparado y blanqueado. No se ha dado una imprimación como puedes dar a lo mejor en una obra de estudio, pero estaba preparado con pintura plástica y hemos pintado trazando directamente en el muro del silo y pintando, también, con pintura plástica. De momento, estamos usando rodillos y sobre eso añadiremos algunos detalles con espray y a pincel.

\section{¿Documentas los pasos que vas dando?}

No, no. Es una documentación general, el principio y el final. Durante el proceso vamos haciendo fotos, pero no tiene nada que ver con la técnica...

¿Cuando son encargos, sueles tener injerencias de la organización, te imponen los materiales?
Si, no los elegimos nosotros. Nos dan la pintura y elegimos los colores de espray, por ejemplo, porque la marca suele ser un sponsor o una colaboración que es ajena a mi petición.

\section{¿Tienes normalmente comunicación con el público cuando cuando pintas en la calle?}

Cuando pinto en la calle hay una interacción más directa con el público, cuando pinto de manera ilegal, porque estás en una escala más asequible y como un ciudadano cualquiera que está realizando algo. Cuando estás en un contexto como éste, que trabajas en altura, entonces, hay muy poca oportunidad. Hay unos tiempos que cumplir, con lo cual, tienes diez días para pintar y son diez días, ni uno más ni uno menos, entonces, hay poco tiempo para interactuar y atender a la gente. Sin embargo, si lo estás haciendo por amor al arte, de manera espontánea, se pueden dar todo tipo de situaciones y posibilidades.

\section{En el caso del silo ¿has tenido en cuenta que es un elemento singular del siglo XX?}

Si, la verdad es que yo algunas veces los dejaría tal cual, porque algunas propuestas me generan conflicto. Pienso que no es necesario intervenir. Te proponen que hagas un ejercicio muralístico y de entrada yo voy con reservas, porque me produce demasiado respeto y porque creo que está mejor así, sin pintar, que estableciendo un diálogo con ellos, con la pintura, que no necesitan ser pintados. Me genera conflicto la historia, pero este caso forma parte de 
un proyecto más grande y me interesaba estar dentro de él y además no soy yo sola como artista, sino que lo llevamos a cabo con el colectivo Equipo Plástico. Cuando trabajamos en equipo, realizamos obras que tienen que ver con el lugar y con nuestra experiencia con el lugar, y por ahí le vi un poco más de sentido.

Los silos forman parte del perfil de estas pequeñas localidades, al ser edificios muy altos, y vosotros estáis interviniendo el de Manzanares de una manera que lo camufla en el paisaje, no sobresale tanto como antes.

Si, es nuestra intención. Hemos hecho fotos aéreas de la zona, con drones, y hemos visto los colores que los rodean. Hemos analizado cómo es el paisaje alrededor y qué tipos de texturas se dan para mimetizarlo con el lugar. Se trata de jugar con el concepto: el grano que se traía de la tierra a los silos, ahora vuelve a reconocerse en el edificio en el que se almacenaba.

\section{Sobre el proceso creativo en contexto urbano, arquitectónico ¿qué diferencias ves aquí?}

Es lo que te comentaba antes, que me genera a veces mucho conflicto. Cuando empecé a pintar en la calle, de manera ilegal, elegía el lugar en el que quería pintar porque me interesaba establecer un diálogo con ese lugar, en este caso todo ese primer planteamiento desaparece. Por eso también me genera conflicto y que además a esto se le llame arte urbano, quería hacer un inciso en este punto, porque lo que antes se entendía como arte urbano era diferente a lo que hoy en día se entiende por arte urbano. Si tecleas arte urbano en Internet aparecerán grandes medianeras esponsorizadas por entidades privadas o públicas y con unos espacios para los artistas y los gestores. Todo enorme. Lo que se entendía cuando yo empecé, hace veinte años, eran obras autofinanciadas por los artistas, hechas de manera ilegal y espontánea. Era en cierta forma un ejercicio de crítica social y económica que en este caso se convierte en un ejercicio de muralismo más que de crítica social, porque no se presta. No quiero decir que una cosa sea peor y otra mejor, sino que es diferente y en este caso estamos hablando de un silo comisionado por una entidad pública y con un sponsor detrás. Me gusta decirlo, y entonces creo que no se le debe llamar arte urbano. Quizá es meterme en camisa de once varas, ponerme a definir algo que no me corresponde como artista. Pero si que puedo aportar mi experiencia y para mí esto es un ejercicio mural.

Hay una voluntad, que no es desconocimiento, es una voluntad de que sellame a todo arte urbano porque el sistema se apropia de todo lo que funciona y es independiente.

Ha pasado con todo tipo de prácticas artísticas y creativas, que salen de una manera independiente y fresca y el sistema rápidamente las quiere domesticar y se las apropia, como pasó con el punk. El caso es que aún hay artistas, Eltono, Nano o yo..., que seguimos todavía, aunque en menor medida que como lo hacíamos antes, pero seguimos haciendo también "arte urbano" de manera espontánea, ilegal y autofinanciada, con lo cual, es muy injusto llamar a todo lo mismo porque no lo es y sobre todo, porque se da también el caso de la aplicación de una doble moral, en la que grandes ayuntamientos y grandes marcas que te llaman para que trabajes para ellos, cuando lo haces de manera ilegal, te multan.

\section{¿Consideras que tu obra es efímera? ¿Te planteas cúanto puede durar?}

En el trabajo en la calle pongo mucho interés, sobre todo en la elección del lugar, en plantear un diálogo con el soporte y con la manera de establecer una conexión con el público al que va a llegar, pero, además, la parte más mágica, la más importante, es el momento y el lugar. Una vez terminada esta acción en la que el artista cruza esa línea absurda (porque cuando estamos hablando de saltarse la legalidad, estamos hablando de cambiar el color de una pared, no de matar a alguien) y da un paso adelante y dice: esto lo hago y lo ejecuto y es así. Estás tomando unas decisiones, viendo todas las reglas que prohíben pintar en ese lugar, y se establece una acción que solamente puedes llevar a cabo con esa rebeldía contra el sistema que te lo impide. El momento de la acción, para mí, es lo más importante. Creo que importa casi más que la pintura resultante, el que salgan voces de un individuo hablando a toda una sociedad de una manera independiente, eso me parece mucho más potente y político que a lo mejor escribir tácitamente "Rajoy es un $\mathrm{m}^{* * * * \prime}$ o cualquier otro tipo de eslogan.

\section{¿Entonces, en esos casos, se invierte la importancia del proceso?}

Es el momento en el que tú estás creando y tienes conciencia de la obra. Me interesa el proceso, el cómo llego a hacer eso y el porqué para conseguir un resultado. Lo que pasa después, está completamente fuera de mí control y fuera también de mi interés, no me interesa tanto. Cuido el proceso porque soy muy maniática, lo cuido muchísimo, pero creo que es más interesante todo lo anterior que el resultado final, que es el producto de toda esa investigación, un ejercicio previo. Estar en la calle, la acción, y preparar todo, es lo más importante. Es una forma de estar en el mundo.

\section{¿Cuándo yo menciono la palabra museo, que piensas?}

Bueno, me parece un lugar en el que clasificar y ordenar cosas y enseñarlo. Un ejercicio museístico, en principio, me parece interesante. Hay un montón de cosas que no habríamos aprendido sin ir a los museos, en contra de lo que pensaba el Movimiento Moderno en los años 20, que creían que era un lugar de cosas muertas y naturalezas muertas. Yo pienso que son lugares interesantes. Lo que me crea conflicto es intentar hacer un ejercicio de museo con algo que es una voz independiente, es decir, ahora se están dando mucho estos safaris urbanos en el que hay una persona que se dedica a hacer un recorrido por distintos lugares y explicar a la gente por qué está ahí y quien lo ha hecho, muchas veces desde 
su propia interpretación, sin un pensamiento riguroso. Estás dando una lección de curadoría sin contar con los artistas. En el caso que me afecta, a mí no me interesa hablar sobre mí, sino que la gente saque sus propias conclusiones y que sea un lugar de libre interpretación y de reflexión, o incluso de silencio y de descanso. Entonces si se hace un ejercicio de museo, con todas estas huellas que yo he ido dejando. Entiendo que a la gente le guste entender y clasificar. Esto también son consideraciones que están lejos de mis competencias.

\section{¿Los Safaris están haciendo un cierto comisariado?}

$\mathrm{Si}$, porque esto se hace sin el consentimiento de los artistas. Es un negocio muy nuevo, en el que se ha visto rápidamente un ejercicio empresarial. Se hacen estos safaris urbanos y al mismo tiempo buscan financiación para comisionar grandes medianeras para los barrios. Llaman a unos artistas que les interesa que estén y no a otros. En mi caso, por ejemplo, es bastante sintomático, porque soy una de las personas que más ha intervenido en el centro de la ciudad de Madrid, que es mi ciudad, y no tengo ninguna medianera en mi propia ciudad. Así que, estoy viendo claramente que existe alguien que hace un filtro de una labor poco rigurosa, porque no está representada la escena.

\section{¿Tienen sentido los museos de arte urbano?}

El museo de arte urbano tiene sentido en cuanto a la documentación que se pueda salvaguardar en esas cápsulas del tiempo de las que estamos hablando y creo que se puede documentar, pero siempre teniendo en cuenta que es la mirada sesgada de un documentador ajeno al movimiento. No son las fotos de la fiesta de Halloween. Todos estos expertos del arte urbano, todos, desde el perfil más amable, popular y tolerante, al más talibán, tienen una mirada de comisario.

El arte urbano es algo completamente espontáneo, que surge en la calle de una manera libre y sin normas preestablecidas, que son las que sí tiene el sistema del arte -del cual yo también participo-. No creo que haya que tener una mirada cerrada en cuanto a teorías, porque se elaboran grandes teorías en torno a esto para construir grandes discursos, pero se está dejando de lado muchas veces la propia voluntad del artista. Por ejemplo, en mi caso, no me interesa que se explique mi obra más allá de las pocas notas que doy. Es una obra abstracta, que tiene la motivación de estar en ese lugar concreto y creo que es el espectador el que tiene que reflexionar hasta donde llegue; uno se quedará en la superficie y otro hará una tesis doctoral.

Creo que es una llamada al librepensamiento, pero estamos contribuyendo a crear un sistema igual que el que el arte urbano crítica. Estamos otra vez cayendo en la misma trampa. Que un museo documente y guarde información para otra generación futura, me parece bien, pero siempre que sea una mirada plural y abierta. El problema viene cuando no están todos los que son, ni son todos los que están.
Si esto se plantea sobre selecciones y analizamos las huellas que se van dejando, pasaría a la posteridad Banksy, la obra de Blu que en Bolonia se sacó a la fuerza de la calle, obras de colecciones particulares que algunos vais vendiendo y poco más.

Hay una gran falta de rigor crítico. Igual que hay críticos de arte contemporáneo, no hay críticos de arte urbano que puedan llegar a ordenar un poco la escena. Las personas que se dedican a divulgar el arte urbano tienen muchísimas lagunas y lo digo porque están hablando de mi propia vida, así que, puedo hablar con conocimiento de causa.

Si te soy sincera, se puede, pero no va a ser arte urbano. Una obra de arte urbano, el de la calle, llevada a vídeo y fotos será la documentación de esa obra, no será la obra.

\section{Entonces, ¿las obras en galería tienen algo que tú ves esencial y diferente y que no se está mencionando?}

Cuando empecé a trabajar en la calle, que además tuvimos un éxito muy lento y éramos muy jóvenes -y un poquito inocentes-, lo hacíamos desde el prisma de la diversión, la crítica y una manera inocente de estar en sociedad.

De repente, nos pusieron el foco encima y nos dio el ataque de un "sí somos algo" y nos interesamos mucho en averiguar si estábamos haciendo algo que a la gente le importaba. En ese momento se nos planteó la posibilidad de trabajar con galerías en museos e instituciones y Eltono y yo -que éramos pareja- decidimos desarrollar una obra en paralelo que dialogara con la obra de la calle mediante distintas artimañas, la de las pancartas como piezas que se completaban entre la calle y la galería. Intentábamos hacer que todo el flujo de espectadores de un lado conviviera con el flujo de espectadores de otro y se realizaban obras incompletas en la calle que se completaban en la galería, o al revés, precisamente por ese conflicto que hay entre algo que es comercial, aunque lo hacíamos de una manera gratuita, espontánea y altruista.

Cuando vas madurando, también va creciendo en paralelo toda la escena y empiezan a difuminarse todas esas fronteras, y ahora, arte urbano es hasta una subasta de Sothebys.

En ese momento, Eltono y yo nos separamos y empecé a trabajar de manera casi obsesiva en la calle, en un montón de soportes y de una forma en la que no había trabajado antes. De una manera muy independiente, dando casi la espalda a lo que hacía en la calle, pero sientes como de repente se funde todo con un montón de lazos internos.

Ahora, estoy desarrollando una serie de papeles que vienen de todas esas texturas que he ido pintando durante años en la calle, se puede hacer casi como un mapping de mi vida y ver que de alguna manera se está filtrando todo en esta obra de galería, aunque no mencionó para nada la calle.

Mi actividad en galería es completamente paralela a la 
independiente y abordo el objeto artístico que se expone con experiencias de la calle. Por ejemplo, las esculturas de las boyas vienen de unos viajes en Vespa que hice durante tres años al sur de Portugal, a Baleares y Oporto, en el que iba recogiendo unos aisladores térmicos de cerámica -de los de la luz- y los convertía en objetos escultóricos que eran presentados, además, en una galería. Con lo cual, el nexo de unión con la calle en ese viaje era poético y conceptual, pero no era obvio lo que iba a llevar a cabo. No todas estas acciones me han llevado a la galería y, sin embargo, en mi trabajo de calle he mantenido esta voluntad de diálogo abstracto con la calle.

En lo que he podido conocer de tu trabajo, eres una artista de la que es imprescindible conocer el trabajo desarrollado en la calle para entender lo que haces en galería.

Claro, porque si no te falta una pieza, te falta información. Para mí es fundamental esa voluntad de hacer un ejercicio conceptual, "esto es por esto, por esto, por esto, y esto no me interesa". Me gusta más la belleza como idea y volver a esos objetos estéticos sugerentes. Por supuesto que hay una historia detrás, un concepto y algo que subyace, pero no es lo más importante que quiero dejar, porque esa experiencia estética la elijo para expresarme sin palabras, no necesito explicar una obra, así que, intento siempre difuminar todas esas huellas, pero el que conoce mi trayectoria sabe perfectamente que puede hacer un ejercicio de traslación. De hecho, las cerámicas que estoy haciendo ahora vienen de toda esta voluntad. He estado rescatando asadores eléctricos de cerámica y llegué a un punto en que se me agotaron y dando vueltas, saqué moldes, aprendí a hacer moldes y los hago de objetos cotidianos para construir otras esculturas. Ahora es como un chicle elástico que nunca termino de estirar.

\section{¿Cómo ha cambiado tu vida las redes sociales? ¿Cómo las usas?}

Creo que hay que mantener una zona privada. Intento no salir mucho, dentro de lo normal, tampoco me escondo. No pasa nada si alguien me etiqueta en alguna foto, pero todos estos trucos y atajos que se hacen para conseguir más visibilidad y más likes, como el de explotar tu imagen personal con el selfie o explotar tu casa, tu vida o tu cotidianidad, intento evitarlos y centrarme en mi obra y en lo que importa, que es la obra. También, por otro lado, me aburre soberanamente, creo que es como ver la televisión en los 90 y que es procrastinar, porque estás viendo y viendo y viendo y viendo, y es lo que un robot te dice que tienes que ver, porque ni siquiera lo estás eligiendo tú, es como hacer zapping en los 90.

Cuando tú buscabas algo, antes, tenías la necesidad de documentarte. Hacías una selección y buscabas y seguías un blog, seguías a un artista, su web, y te suscribías. Ahora es una actividad completamente pasiva y, además, trabajas gratis para una gran corporación, es decir, para Facebook y para que a su vez te venda en base a esa propaganda que te interesa. Soy una chica del siglo XXI y sé que si no estoy pues perderé muchas oportunidades interesantes, pero, quiero tener una relación sana con ellas, no enfermiza.

\section{¿Hay obras que desaparecen materialmente y aparecen en Internet y lejos de tu control? ¿Qué piensas?}

Una vez termino, recojo las pinturitas y me voy a mi casa. Mi trabajo está hecho, el resto no lo puedo controlar. La gente usa las obras como perfiles y las tunea, es la vida.

Cuando no existían estas plataformas y llegaba uno y te pintaba encima, pues mira, ha durado lo que ha durado. La propiedad intelectual no se pierde nunca, pero tú estás en la calle grabando y puedes utilizar esa grabación para vender unas zapatillas, y al autor, aunque no le gusten las zapatillas, no puede decir nada. 


\title{
Entrevista a DANIEL MUÑOZ. SAN http://www.eseaene.com/
}

\author{
Por Elena García Gayo
}

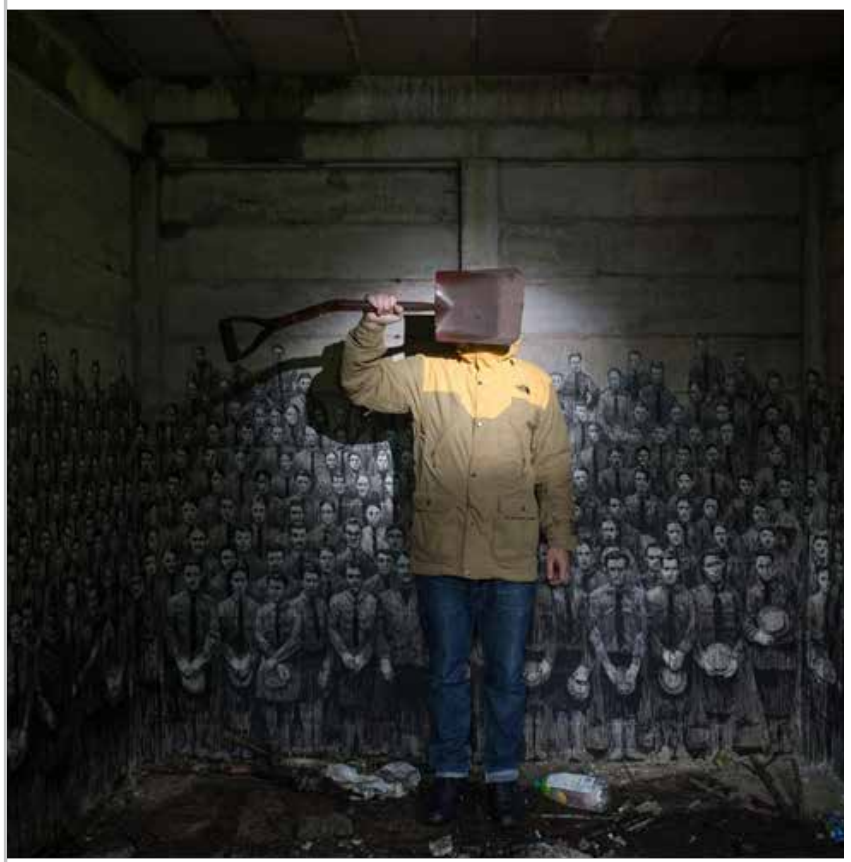

San ha formado parte del proyecto "Titanes", que ha sido comisariado por el artista Oscar San Miguel, Okuda, a través de la IAM Gallery por encargo de la asociación Laborvalia. El proyecto, que implica el pintado y reinterpretación de varios silos de la provincia de Ciudad Real, ha sido subvencionado por la Diputación Provincial y se lleva a cabo desde el mes de abril y a lo largo del año 2019.

\section{¿Cómo te planteas tu trabajo en el espacio urbano?}

Me considero un artista. No porque la etiqueta concreta de lo "urbano" me parezca mal, entiendo que es más una demanda de la sociedad, pero es una clasificación un poco absurda. Vivo en un pueblo y algunas cosas las pinto en corrales, que no es entorno urbano. Creo, que tiene mucha relación con el hip hop y me parece que es una etiqueta heredada. Lo urbano, por lo que sea, suena bien, pero no considero que sea arte urbano, hacer cosas en la calle. La gente me dice, "lo que tú haces es más contemporáneo, es arte contemporáneo". Es una etiqueta temporal, en realidad, esto es contemporáneo y esto es street, y no le ves diferencia. El arte es arte y da igual dónde esté y quien o cómo lo haga.

A la hora de trabajar, en el 99,9 por ciento de los casos, soy escrupulosísimo con el espacio, a nivel contextual, que quiere decir: a nivel histórico arquitectónico y urbanístico, a nivel estético, a nivel incluso de la luz (de la futura fotografía) o de la propia percepción. Mis obras, hablan de todo eso. Es el material con el que trabajo y al final las capas de pintura son lo de menos.

Documento los pasos que voy dando y los aprovecho para seguir avanzando. En el punto en el que estoy ahora, la línea que une las diferentes piezas que hago, que están separadas y distantes en el espacio y son diferentes porque están hechas en contextos diferentes, esa matriz que se crea, es el resultado de muchas experiencias a lo largo de los años. Las obras hablan del tiempo, de la degradación, de todos esos procesos mentales que he vivido y con la documentación que he generado he llegado a construir algo muy sólido. Lo que podrían ser inicialmente anécdotas han terminado por convertirse en algo más consistente que llega a dar forma a mi obra.

\section{¿Qué crees que es más importante, el proceso creativo o la obra final?}

La obra final es sobre todo un detonante para que la gente, el público entre en el proceso, pero empieza a la inversa, porque ven la obra terminada y de ahí empiezan a analizar lo que ha pasado. Siguen mi recorrido y tienen que llegar hasta el inicio, incluso con otra interpretación. Todos los elementos que se conjugan en una de mis piezas están hablando del proceso. De lo que interviene en la mirada, de la historia, de la construcción, del lenguaje. El proceso, que serían las pautas a seguir, el orden que intentas controlar en el pensamiento, el ciclo que sigue una idea; todos esos conductos por los que transito mentalmente, intento provocarlos y que la gente pase por lo mismo que he pasado yo. Esto es lo que me mueve y se refleja en mi trabajo.

Uno de los pilares más importantes de mis obras es sobre la regularización de mi trabajo. Del arte público y de cómo se pueden mantener unos patrones para que esa insolencia, rebeldía (un poco adolescente) y su espontaneidad, representada en algunas de mis obras, no se pierda. De cómo una de esas obras insolentes puede llegar a ser inaugurada por el presidente de una comunidad autónoma. Incluir toda 
esa fricción, ese conflicto que genera, forma parte de mi trabajo. He pintado piezas en las que he "vacilado", en sentido figurado, a los que me han contratado. Lo cobro y me voy, no soy el Ché Guevara. Trato de ponerme a tiro, en el disparador. El artista no es un ente superior y mis errores también están en las piezas, incluso mis errores a nivel organizativo. Puedo contestar mejor con ejemplos. En Galicia hice tres obras que se titulaban "cómo tachar cinco pintadas de una calle". Entonces, elegí una pared que tenía una serie de maderas clavadas, como un antiguo encofrado que había quedado en el solar, y lo que hice fue fotografiar cinco pintadas de niños, de adolescentes de las que había por calle, de esas de "te quiero María", y las reproduje en esa madera, detrás. Sobre lo que yo pretendía reflexionar es sobre el hecho de que los festivales muchas veces son festivales antigraffiti, no tapé las pintadas, las fotografié y las preservé detrás. Es evidente que se intenta tapar ese espíritu casi virgen y adolescente. La organización siempre me sugiere algo y yo juego con esa idea hasta que consigo hacerla mía, añadiendo esas otras connotaciones que subyacen y que consigo detectar.

El proceso creativo es una herramienta de pensamiento y las obras que están en la calle no terminan cuando yo me voy, siguen evolucionando y no se pueden dar por terminadas tan rápido porque se puede interactuar con ellas, no están en una casa y sobre un sofá, pueden tacharse. Nunca mueren. No puedo decir que el proceso sea llegar a ejecutar una línea mágica, sino que el proceso nunca termina, aunque el resultado final salga de mi control.

La gente que me conoce me recrimina que en mis obras hay demasiadas claves. Es una cosa que tengo que aprender a mejorar para ser más explícito, tratar de no meter tantas capas. Porque las ideas son muy sencillas, pero tengo mucha herencia de la pintura clásica narrativa y todo eso al final acaba entorpeciendo y me pasa factura. Soy demasiado críptico en muchos casos.

Con respecto a la técnica y los materiales con los que sueles trabajar ¿tienes materiales y técnicas habituales?

$\mathrm{Si}$, trabajo con acrílicos. Con materiales que se degradan muy rápido y también hablan de eso las piezas, además de la monumentalidad, de la regularización del arte por parte de las instituciones. Hago piezas que se degradan enseguida. Son muy fuertes, porque inicialmente brillan mucho y luego desaparecen. Son obras muy efímeras. Esto, lo que hace, es que fuerza a comenzar de nuevo el proceso, la vida.

No lo provoco completamente a propósito, pero mis obras tienen un componente importante de dibujo. Para dibujar necesito diluir la pintura, y cuanto más se diluye sabes que va a resistir menos, que van a ser dos veranos y se irá al "garete". Al ver como esas piezas iban degradándose, como la pintura se iba deconstruyendo, a la inversa, hasta desaparecer, me empezó a interesar mucho la idea. A nivel discursivo me sirve, pero reconozco que fue un accidente. Esto me provoca nuevas ideas, pero no me resulta fácil llegar a materializarlas técnicamente.
El tema de la permanencia también me interesa mucho relacionarlo con Internet, porque ¿qué significa que algo es efímero? Desde que han nacido las redes sociales, Internet, y todo esto, hace que al final el tiempo físico esté en cuestión en nuestro día a día. Hacer una escultura en bronce para una rotonda me parece que tiene una función muy diferente ahora que en 1960. Creo que el arte público también tiene que tener, o debería, un cuestionamiento sobre lo físico. Si yo hago una obra y no me gusta la puedo modificar, la subo a la red y eso es lo que la gente guardará en su memoria. La idea de la memoria también está muy presente en lo que hago.

\section{Las redes sociales son una herramienta fundamental para los artistas ¿Cómo te ves el que tus obras sean alteradas?}

Que sueltes una obra a la red y se ponga a navegar, es lo más maravilloso que tiene esto. Porque estás construyendo una idea a raíz de una imagen que se va a modificar. Un crítico de arte, o quien sea que al final llega a los canales de esa obra, y se pone a hacer un discurso sobre eso, es que está fuera de mi control... Las obras que salen de mi control pueden llegar a ser manipuladas, las de internet y las de la calle, y eso forma parte de su construcción. Si comparto algo que he hecho en mi casa, con el brasero puesto y la música, eso tiene otro cariz, porque el resultado es algo más introspectivo, no sé si narcisista es la palabra adecuada para esto. Si tú eres consciente de que la obra está en la calle, la apropiación te la tomas de otra manera, no es que no sea tuya, sigue siendo tuya, pero también es un poco de más gente. Suena muy romántico, lo sé, pero es que es así.

Los memes, por ejemplo, los gifs, son una serie de formatos nuevos que influyen en el arte contemporáneo. Antonio López hizo un chiste sobre la pintura que hizo de los Reyes, es otro enfoque, pero a fin de cuentas está hablando sobre la pintura.

Hay muchos artistas que han trabajado con la reproducción de las imágenes, video y fotografía. Desde Duchamp esto ha perdido sentido.

\section{¿Qué piensas si yo te digo la palabra museo?}

Que es una herramienta para albergar y gestionar la cultura. Desde la antropología a los trajes de sevillana. Es una nevera.

\section{¿Y si te digo museo de arte urbano?}

¿Cómo meter algo salvaje en una vitrina? Es aplicable siempre que haya un cuestionamiento de la propia idea de museo. Si no entra ese elemento crítico, no interesa. Por eso no llega a cuajar dentro del sistema del arte, porque no se admite así.

Lo de museo, no creo que tenga sentido ahora mismo, al menos para mí, no lo tiene. Lo primero que se tendría que reconsiderar para exponer arte urbano es este fenómeno del street art. Y no podría ser sin contar, como sea, con 
Internet, porque es escaparate, motor y casi hasta discurso. Conozco tres fórmulas de exponer el tema "museo": Una, es el cubo blanco para meter todo. Eso tenía sentido hasta finales del siglo veinte, hasta las performances. Es un relato de la historia del arte. Pero es que lo nuestro no comparte esa voluntad de permanencia y es más difícil de encajar en el concepto de museo. Aunque tuviera que estar...

La segunda, las fórmulas de "museo al aire libre", son como poner un zoo en la jungla.

Pompeya es una ciudad no es un museo, no hay que decir qué es para entenderlo.

La tercera posibilidad, que ya se está haciendo, se trata de que la propia idea de ser expuesto en un museo sea el elemento discursivo, y hacerlo a través de residencias, para que los artistas trabajen sobre esa idea. El propio conflicto debe estar en el discurso. Y conseguir que la crítica forme parte de las obras.

\section{¿Tienes obras en museos?}

Si, si tengo. $Y$ he vendido a coleccionistas. No hablaban de este conflicto, pero ahora ya sí.

Intento hacer obras efímeras para instituciones. Son un catálogo de problemas, que son los que he tenido yo.

También he participado en ferias y lo he hecho con dibujos enmarcados que criticaban a esa misma propuesta en la que estaban.

\section{¿Cómo te has planteado el trabajo del silo de Manzanares?}

Loveo como un mural.Es una obra ejecutada en colaboración con Spok, así que no puedo hablar sólo en primera persona, porque hay un proceso colaborativo. Habla de la amistad y es una celebración de los quince años que llevamos juntos, realmente planteamos temas muy personales. Tenemos una relación un poco macarra con el edificio, en el que hemos colgado nuestras medallas. Habla a través de la exaltación del ego, de la competición. Las obras hablan a muchos niveles. El contexto social, que yo tengo muy presente, aquí no está tan trabajado, está menos reflejado porque la obra no es solo mía. El estar dentro de un proyecto social, como es el de Laborvalía, por la inclusión de capacidades diferentes, ha resultado muy interesante. Hemos intentado transmitir un mensaje muy optimista, aunque yo no suelo serlo tanto, yo soy más hacia dentro.

Conozco muy bien el ámbito agrario porque el silo de mi pueblo se hizo prácticamente para el trabajo que generaba mi abuelo, que trabajaba como contratado de una gran explotación agraria, y consiguió organizar a mucha gente y tenían una producción elevadísima. Mi padre también trabajó en lo mismo. Los pueblos o pedanías que rodean al mío son pueblos de colonización, con esa misma función social de trabajar la tierra en la misma época histórica en la que se crearon los silos. Así que, si, todo eso se ha tenido en cuenta, porque el sentido político subyace. El oro de las medallas, por ejemplo, es todo lo contrario al trigo, y opuesto al valor del pan. Evidentemente, hay vapores de ideas que subyacen, aunque no se hayan reflejado de forma más detallada.
Entrevista en vídeo. 30"

Fecha: Abril, 2019

Manzanares, Ciudad Real 


\title{
Entrevista a OKUDA
}

\author{
Por Elena García Gayo
}

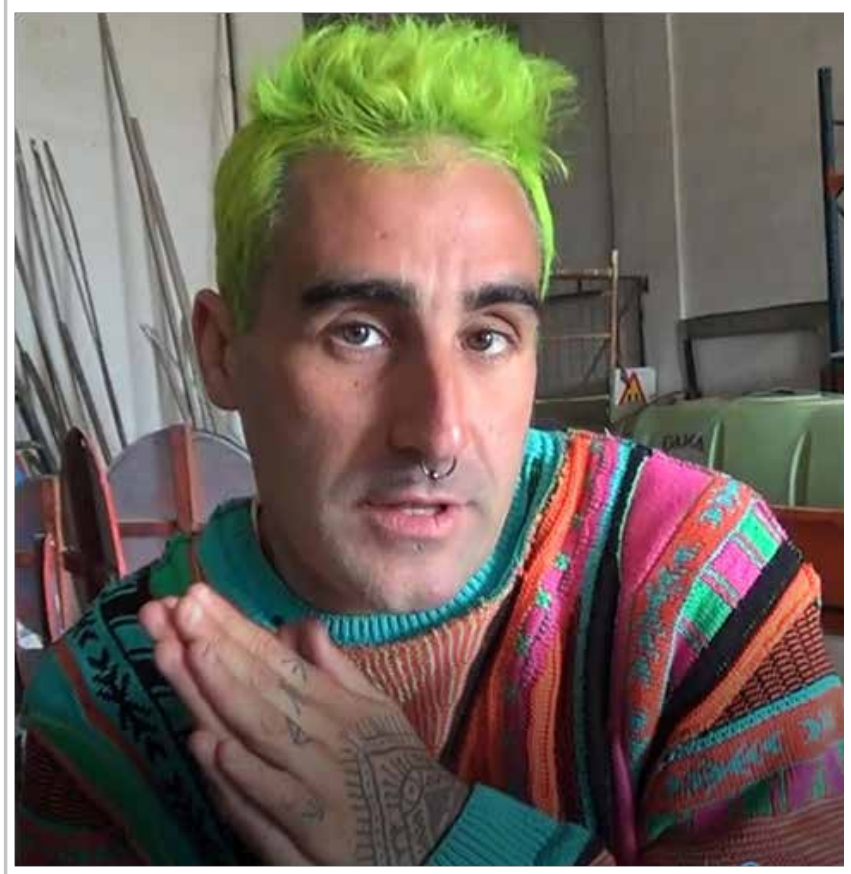

Oscar San Miguel, Okuda, ha comisariado el proyecto "Titanes" a través de la IAM Gallery por encargo de la asociación Laborvalía. El proyecto, que implica el pintado y reinterpretación de varios silos de la provincia de Ciudad Real, ha sido subvencionado por la Diputación Provincial y se lleva a cabo desde el mes de abril y a lo largo del año 2019.

¿Qué puedes decir sobre tu proceso creativo en general y el proyecto de los silos para el proyecto Titanes en particular?

Normalmente no me gusta hacer bocetos. Pero todo depende. Si te encuentras con un trabajo para un gobierno que necesita confirmar lo que vas a hacer, porque tienen una responsabilidad ante los ciudadanos, entonces, los hago. Por ejemplo, en una ocasión nos propusieron que fueran los ciudadanos los que eligieran lo que se iba a pintar. En esos casos no tengo más remedio. Pero no me gusta hacer bocetos. Suelo llegar al lugar, me empapo del entorno y hago lo que creo oportuno ese día. Porque, al final, la creación depende mucho del estado de ánimo y me gusta mantener la vida, el impulso. Marco la composición general y luego voy poco a poco a lo particular. El avance de la obra me va dictando el siguiente paso y el siguiente, y así lo voy componiendo sobre la marcha.

\section{¿Vas documentando esos pasos?}

No, para nada. Estoy super inmerso en la creación. En Instagram lo que hago mucho es desnudarme, metafóricamente hablando, enseño lo que hago, tanto en el estudio como en las obras en el espacio público. Intento mostrar los procesos desde el inicio hasta el final, pero de una forma muy espontánea y en la que se ve cada paso. Aunque no lo hago con el fin de documentar, creo que se ve bastante bien lo que hago.
¿El proceso creativo empieza con la ejecución material, directamente?

Si, por supuesto, es disfrutar el proceso desde el principio, por eso no hago bocetos previos, pinto al mismo tiempo y uno el proceso de creación a la propia producción de la obra. La idea va tomando forma durante el trabajo, está en la transformación y lo importante es el resultado final, porque es la conclusión de todo ese esfuerzo.

\section{¿En el hecho de que te contraten, admites condiciones o normalmente no te las ponen?}

Lo principal, para los proyectos que llevo a cabo, es que se respete una total libertad de creación y en cuanto a la técnica, con la que más rápido y mejor trabajo es el espray, porque se adapta a mi lenguaje. Por ejemplo, si pintara con acrílico o con cualquier otro material necesitaría seis o siete capas para conseguir un negro. En cambio, con el espray vas directo. Y además, hay ciento y pico colores distintos -imagínate lo que sería tener que hacerlos-. No los mezclo, uso varias gamas de diferentes marcas, si necesito no depender de una gama única. Y sobre todo, porque no tengo que perder tiempo en crear colores. Hoy en día hay millones de colores que puedes elegir, y lo importante del esmalte sintético, por eso lo uso, es que me da mucha rapidez en el trabajo. Puedo ir abocetando y produciendo a la vez porque puedo ir cubriendo con el espray. Un amarillo tapa a un negro perfectamente. 


\section{¿Tienes algún intercambio de opiniones con el público durante la ejecución de las obras en el espacio público?}

Depende del lugar, a veces sí. Si son edificios muy altos no, paso arriba mucho tiempo y no tengo casi comunicación con nadie. En este caso de los silos, pues sí, porque estamos entre amigos y hay más artistas invitados. Sí que hay más comunicación, que puede inspirarme o darme ideas o transformar, en cierta medida, aunque sea mínimamente, mi obra.

\section{¿Cómo te influye el contexto urbano?}

Pues, mucho, porque no es lo mismo estar aquí en una grúa oyendo sólo pájaros y ver esta llanura de prados, las distintas geometrías que forman las "mini montañas", que estar en una gran ciudad. Evidentemente, no me transmite lo mismo esto que Toronto, donde tu edificio compite con todos los demás, o en Hong Kong... aunque, he de decir que también me encanta. Me gusta vivir en ese contraste porque mi vida es eso. Estoy enganchado a los cambios. A cambiar de entorno cada semana.

Ahora vengo de Hong Kong, de presentar mi última exposición -he pintado un busto para la ciudad, una experiencia muy interesante- y al día siguiente me veo aquí que es todo campo llano, imagínate el bombardeo de información que hay en Hong Kong -aparte del arte que es una maravilla-y de repente pájaros y llanura...

¿Cómo abordas la intervención de unos edificios como estos, que son pura ingeniería, a los que Ilaman las catedrales del siglo XX y están cargados de historia?

Empecé a pintar en la calle en lugares abandonados que a nadie le interesaban y eso me permitía estar tranquilo, porque nadie me molestaba. Eran mi estudio. Así que, aquí me siento como si volviera a los inicios. Al final, es dar vida a espacios que no la tienen. Y si te fijas, ves que lo que nos muestra la modernidad es que las cosas que valen mucho ahora al poco tiempo no valen nada. Ves como se abandonan edificios como este y de repente vuelven a tener una nueva vida. Por ejemplo, en Detroit, una gran capital de Estados Unidos en la que se fue al garete la industria -la SEAT, la Ford, con fábricas enormes- y hasta la gente se fue de allí. Solo quedaban yonquis. Abandonada. Es una paradoja, porque, por un lado, ves fábricas abandonadas y por otro, mucha gente sin casa. Artistas sin estudio, cuando hay espacios como éste para usarlos. Si las instituciones lo pensaran, algunas necesidades se podrían cubrir, y se solucionarían algunos problemas.

\section{Los silos surgen en el siglo XIX a partir del Grain Elevator de Buffalo, en US. Los diseños arquitectónicos remiten a unas necesidades concretas del siglo $X X$ ¿Le has dado importancia a esto al comisariar la reinterpretación de estos espacios?}

No, no le he dado importancia, la verdad. La forma y dimensiones del edificio me parece que ya son suficientemente importantes, y sobre todo, porque están en medio de la nada. Son como gigantes dormidos en la naturaleza. $Y$ las formas son cómodas para pintar. Me gusta, sobre todo, desde que pinté la iglesia skate, que sean muros totalmente planos o, si es un edificio completo, que arquitectónicamente conserve ornamentos y todo lo que le caracterice. Este de Calzada de Calatrava, es de líneas rectas. Casi soviético.

\section{Y el silo de Calzada de Calatrava ¿cómo te lo has planteado?}

Ha sido uno de los trabajos más difíciles de ejecución, por la dificultad que tienes de acceso a los muros y porque es difícil encontrar aquí grúas de cuarenta metros. Me lo planteo como un todo. Ya hace años que me planteo las intervenciones como un todo, no como un solo lienzo, aunque eso me guste también y me resulte muy cómodo, pero desde la experiencia de la iglesia de Llanera, en Asturias, lo que me plantearon fue transformar espacios completos. Lo abordo como si fuera, casi, como proveer de piel a una escultura.

\section{¿Me puedes hablar de estos elementos geométricos que} se repiten en tus obras? ¿Cómo se pueden interpretar?

Este silo, de Calzada de Calatrava, tiene una inspiración en la comunidad autónoma. Un don Quijote futurista y un Sancho Panza convertido e inspirado en los templarios, que es una historia que he conocido hace poco y me ha interesado mucho.

Un personaje de Almodóvar tocando la guitarra. Es decir, he traducido a mi mundo de formas y colores esas ideas, unos personajes que por separado me resultan muy inspiradores, por su importancia y trascendencia, los he unido y traducido en unas líneas simples.

Soy muy seguidor de Almodóvar y su obra y creo que era el momento y el lugar adecuados para recrear estos personajes de sus películas.

Vamos a hablar de la técnica y materiales, desde el punto de vista de la planificación, es decir, lo que haces para que las obras perduren en el tiempo.

Esa es la lucha de todos los artistas en la historia del arte. Si las obras pertenecen a una colección potente, tienen cuidado de que perdure en el tiempo porque tienen la responsabilidad ante la humanidad de lo que les pase. Pero, cuando te contratan, a veces, los propios responsables están en una situación laboral temporal, porque cambian los que mandan $y$, sinceramente, a ellos no sé hasta qué punto les interesa la cultura y el arte o que estas obras perduren. Creo que nada. Entonces, la responsabilidad, si se suple, es de todos. Aunque, hay que tener en cuenta que se trabaja en la calle y al final las condiciones meteorológicas y los materiales que se usan tienen una fecha de caducidad, pero sí que hay ocasiones, por ejemplo, en el caso de unas esculturas que hicimos en Boston, en que se exigía responsabilidad de permanencia 
y de durabilidad, para tenerlas en perfecto estado, como el primer día. Y para eso hay que dar instrucciones de cómo hacerlo, que se deben usar colores concretos y unos códigos de manejo del color que se tienen que aplicar si se desgastan. El hecho de que en los colegios se den clases sobre teoría del color sobre mi obra, esa información, tarde o temprano, llegará a las universidades y se usarán los materiales más actuales y adaptados para la restauración. Muchas obras de arte contemporáneo no se tienen en cuenta desde el punto de vista de la durabilidad de las obras de arte, son muy efímeras, no es una novedad.

Creo, que si describiera unas reglas sobre cómo quiero que se restauren mis obras, se facilitará en un futuro la manera de hacerlo. Lo pensaré.

\section{¿Cómo evolucionan, cómo se degradan los materiales que usas?}

En la calle se deterioran con más facilidad y lo tienes más en cuenta, pero normalmente pones más atención a lo que quieres contar que a los materiales. Aunque, por ejemplo, en el estudio utilizo colores fluorescentes porque me encantan y aunque parecen muy fáciles de usar, no es cierto, son lo más difícil del mundo, pero se que no hay que usarlos en la calle porque son muy degradables, se van a los pocos meses, entonces, hay ciertas limitaciones que yo mismo me pongo, por mi propia experiencia.

\section{¿Si te digo la palabra museo, qué te sugiere?}

Me sugiere realizar muestras, exposiciones o instalaciones que no van a ser para la venta y esto me motiva mucho, es decir, que sean para la experiencia y para hacer que el público pueda formar parte de mi obra. Es lo que he hecho en mis últimas exposiciones. Me permitieron usar el espacio para crear obras que no eran para vender y fue muy interesante, porque era para que la gente tuviera una experiencia concreta. Me motiva mucho que los museos me propongan cosas como esa.

\section{¿Qué te sugiere que existan museos de arte urbano? Ya hay unos cuantos.}

$\mathrm{Si}$, algunos son simplemente unos murales en la calle y dicen que son museo. Es un poco raro. Tengo obra en el Urban Nation de Berlín y he tenido obras en alguna que otra exposición temporal de varios museos. En exposiciones particulares sí que tengo más. Me interesa dejar obras en grandes colecciones y para la posteridad, porque es lo que quedará. Es diferente a lo que se hace en la calle.

\section{¿Qué diferencia hay entre una intervención en la calle y una obra de estudio?}

En el estudio es un trabajo más íntimo, más profundo, hay un mensaje y tienes la posibilidad de trabajar con una serie de obras que juntas forman parte de un todo. Me gusta mucho plantear exposiciones con una idea concreta, como una serie.
En las exposiciones me gusta mezclar escultura pintura y bordado, y para la calle lo que prefiero es jugar con la arquitectura y con los formatos, es decir, transformar el skyline de las ciudades. Jugar con el espacio.

\section{¿Has participado con algún arquitecto para hacer una obra compartida?}

No, pero me gustaría que esta opción se diera de una forma frecuente, porque al final los arquitectos y los artistas que trabajan en el espacio público deberían comunicarse y hacer cosas juntos. No he hecho ninguna colaboración integral, clara, de transformar un edificio, pero sí que estoy ahora en esa clave como siguiente paso. Quiero llevar la escultura hasta un punto de vista arquitectónico, es decir, hacer cabezas de animales que puedan ser habitables; estoy un poco en esta onda.

\section{¿Qué importancia tienen las redes sociales en lo que haces?}

El concepto de artista y su camino para llegar al público ha cambiado mucho en los últimos años; lo que hace falta para llegar al mercado del arte ha cambiado totalmente y esto se ha producido por las redes sociales, por eso mismo yo he cambiado un poco las reglas en mi forma de trabajar. Siento que no he tomado el camino habitual para llegar al mercado del arte, ni siquiera para llegar al público, por lo tanto, al final lo que tienes es "tú público" y "tú mercado" y tienes la capacidad de hacer magia porque no dependes de nadie, ni de hacer amigos, y ni siquiera estás en manos de marchantes. Aunque, yo participo de ese mercado, lo que necesito lo tengo en mi equipo, ellos se encargan de la relación con galerías y museos y aunque trabajo con una de las más antiguas de España, la galería Kreisler, soy consciente de que las normas han cambiado y la forma de entender el mercado también. Me siento muy orgulloso de abanderar esto porque, aunque haya llegado al mercado de culo, ahí estoy. Al final es la ley de la oferta y la demanda.

\section{Las obras desaparecen de la calle y siguen vivas en la red ¿Qué piensas si dejan de pertenecerte porque navegan libres?}

Es la magia de Internet. Las obras siempre te van a pertenecer, están en el mundo virtual para verlas. Vengo de pintar en el espacio público y aunque hago obras de estudio y se venden para que perduren, tienes asumido que las obras desaparecerán. Aunque, los edificios que pinto ya no desaparecen tan fácilmente... Ya no me gusta que desaparezcan algunas cosas. Con la falla que hice para las fiestas de Valencia, que se iba a quemar y ya se sabía que iba a desaparecer, volví a revivir ese espíritu efímero.

Calzada de Calatrava. Ciudad Real Entrevista en vídeo. 30" Fecha: abril, 2019 


\title{
Entrevista a SIXE PAREDES https://www.sixeparedes.com/
}

\author{
Por Elena García Gayo
}

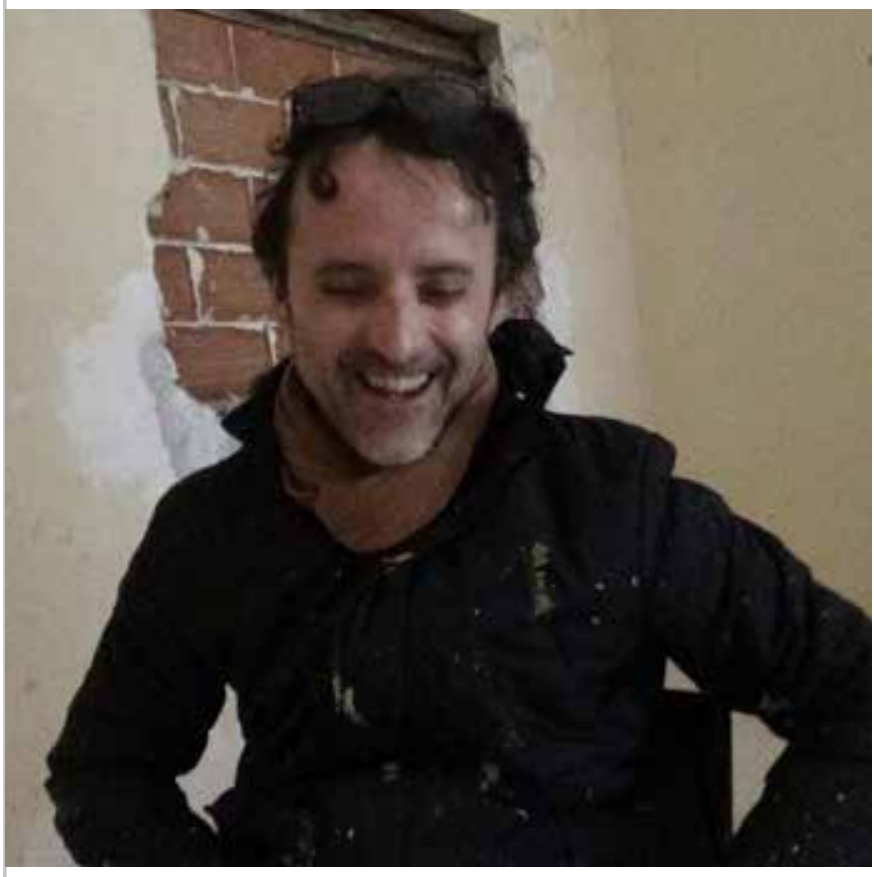

Sixe ha formado parte del proyecto "Titanes", que ha sido comisariado por el artista Oscar San Miguel, Okuda, a través de la IAM Gallery, por encargo de la asociación Laborvalía. El proyecto, que implica el pintado y reinterpretación de varios silos de la provincia de Ciudad Real, ha sido subvencionado por la Diputación Provincial y se lleva a cabo desde el mes de abril y a lo largo del año 2019.

\section{Me gustaría saber cómo te enfrentas a una nueva obra.}

Habitualmente suelo pintar solo, pero también lo hago con este colectivo, formo parte del Equipo Plástico, con el que me resulta muy interesante trabajar. Solo y con ellos, porque de las dos formas aprendes. Cuando trabajas solo ya tienes un procedimiento y método tuyos y cuando compartes un mural te olvidas de tu trabajo personal y encuentras unas aptitudes diferentes. Habitualmente, cuando pinto en la calle lo hago solo, sin encargo y de forma ilegal.

Últimamente llevo dos años con obras de estudio preparando exposiciones, salgo menos fuera, al extranjero. Me gusta profundizar en otro tipo de soportes y otro tipo de materiales.

Desde que tuve oportunidad de tener un estudio, desde 2002, trabajo mucho allí. Llevo la calle y el estudio en paralelo.

Cuando son encargos, para el Equipo, recibimos fotos de los muros, de las localizaciones y se puede generar un proyecto a partir de una idea, que es sobre lo que se trabaja. Muchas veces la arquitectura es diferente a como la has imaginado a partir de la foto y tienes que cambiar cosas o adaptar lo que pensabas hacer. Es decir, que, aunque tengas una idea definida nunca es definitiva. Cada vez que se pinta en la calle pueden pasar infinidad de cosas con las que no contabas y tienes que adaptarte.

Sea lo que sea intento documentarme siempre, averiguar qué pasa en ese lugar donde voy a ir a pintar. He trabajado en algunos muros intentando transportar la naturaleza. Edificios rodeados de cemento, entre los que hay muy pocos parques. En la serie que he llamado "El espíritu de la Montaña" traté de trasladar esa naturaleza, el espíritu de la Madre Naturaleza, a las ciudades, para que con esa certeza se despierte la conciencia de que venimos de ella y tenemos que respetarla.

En ese proceso previo de documentación hago bocetos, un preparatorio en el que desarrollo varias ideas para convencerme yo primero y después poderlo presentar, para que haya una conexión con la gente que va a convivir con el mural. Tu te vas, pero la gente se queda. Es importante que lo que se pinta se adapte al lugar.

¿Cómo es el acercamiento a una obra como la de los silos del proyecto Titanes de Ciudad Real, que son enormes obras de ingeniería de una época muy definida en la historia de España?

Lo primero, desde el respeto. Siempre se intenta que lo que se hace tenga sentido y quede bien. Que la gente lo pueda entender, porque es un edificio histórico y tiene un significado también para ellos. Es importante tenerlo en cuenta. En este silo que he pintado con el Equipo Plástico estuvimos documentándonos sobre el lugar y salieron varias ideas y una de ellas era la región, Castilla-La Mancha, una tierra plana. Nos planteamos cómo llevar esa visión de planicie a un edificio tridimensional. Esa era la idea base para empezar. 


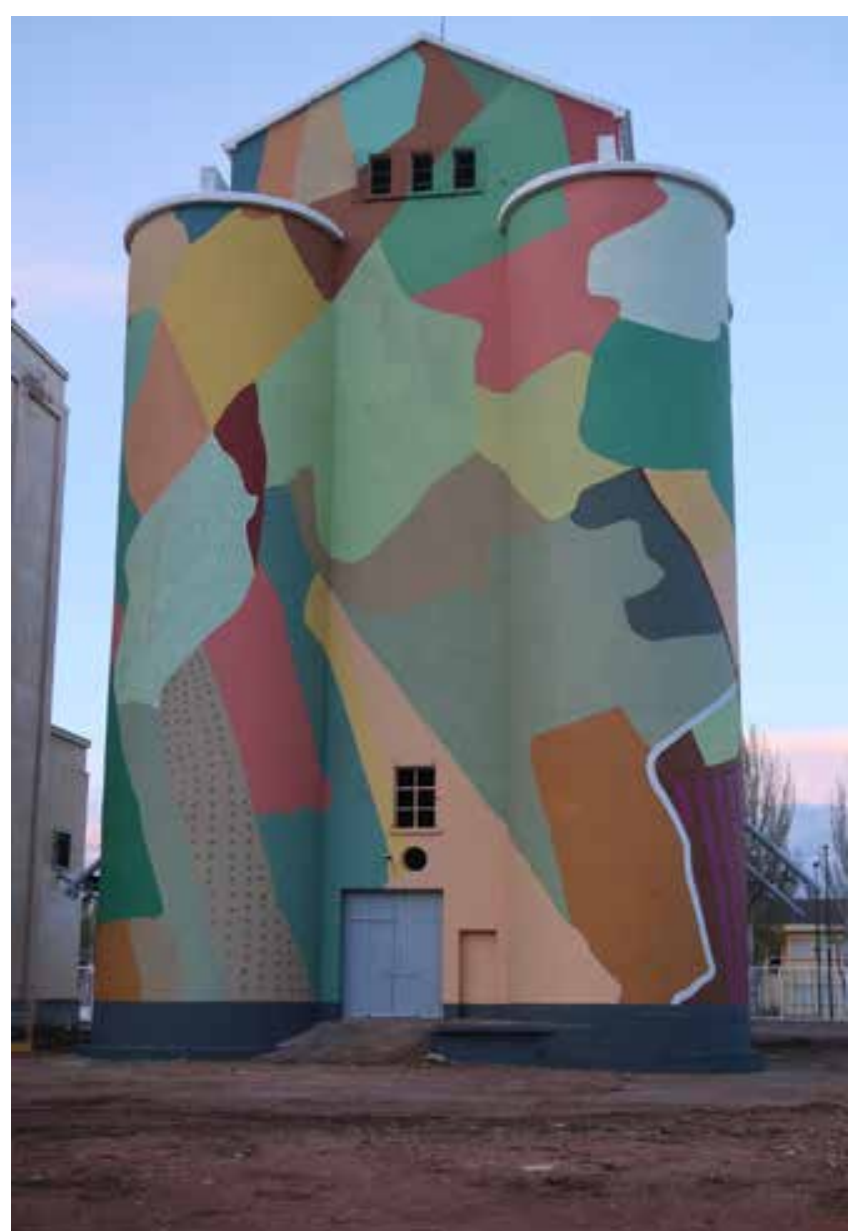

Figura 1.- Silo de Manzanares reinterpretado por el Equipo Plástico, imagen durante el proceso. Abril.

El edificio, al pintarlo, aparece un poco camuflado en el paisaje, como contraste a esa masa plana y blanca inicial. Esta nueva visión es como una segunda vida que lo mantendrá vivo durante un tiempo. Después, si la comunidad se cansara, que todo puede pasar, se puede volver a pintar.

\section{¿Al definir lo que haces dirías que interpretas o que críticas al sistema?}

No interpreto nada. Tengo un estilo muy personal, soy autodidacta y he desarrollado lo que yo llamo "abstracción numérica" y expreso así el hecho de que los seres humanos terminemos siendo cifras. No nos cuentan como seres humanos. Tenemos el valor que alcance el número en el que estemos definidos. A lo largo de la historia somos sólo una cifra numérica. También esto viene un poco de la época de la crisis económica en la que nos marearon con cifras que nadie entendía.

Hay murales en los que la gente puede entender algo y otros que generan una cierta inquietud y es eso lo que te conmueve. Cada persona ve una cosa diferente, y es también muy interesante porque se crean murales abiertos a la imaginación. Para mí, pintar una cara definida no deja lugar para imaginar nada.

\section{¿Con qué materiales trabajas en la calle?}

En la calle con espray y pintura plástica, para que perdure, es lo que utilizo.

Algunas veces vuelvo y los veo envejecer. A los que les da el sol los ves desaparecer antes. Hay sitios en los que llueve más que en otros y envejecen peor. Solo los observo, no elijo el muro en los encargos y no puedo hacer nada.

Casi siempre intento utilizar buenos materiales y en ocasiones he pedido barnices con filtro ultravioleta, pero casi nadie lo usa porque encarecen los murales. Creo que se debería hacer una ficha con cada uno de los murales que se pinta y relacionar los materiales que se han usado, porque si se deciden conservar, si se decide que forman parte del patrimonio artístico de ese lugar facilitaría la restauración. Ahora está arrancando esto de forma más generalizada, porque después de tantos años en los que se están haciendo murales, alguno habrá que se llegue a conservar, la gente lo va a querer. Tener una lista de los materiales que se han usados puede ser interesante para hacer las pruebas que sean necesarias en cada caso. Creo que facilitaría las cosas.

\section{Ya que hablas de Restauración ¿te planteas algún criterio para restaurar tus obras en cuanto a los materiales que se deben utilizar?}

Si, me gustaría que se usaran lo mismos materiales y que quedara lo más invisible posible, que no se notara la diferencia. Que la apariencia final sea la misma.

\section{¿Qué te viene a la cabeza si te digo la palabra museo...?}

Me vienen dos ideas diferentes: algo abierto y algo cerrado. El museo al que tienes que entrar para ver arte, es una, pero hoy en día se entiende también como algo abierto a través de las obras que se ven fuera y esto hace que la gente también tenga más interés por ver lo que hay dentro.

Esa relación de dentro y fuera es muy interesante, me interesa mucho. En 2008 pinté en la fachada de la Tate Modern de Londres y aquello fue un antes y un después. Fue muy interesante para mi ver que un museo tan importante te invitaba a pintar en el exterior para que la gente pudiera ver arte fuera, en su propia fachada. Fue un hito en el muralismo y muchos museos se dieron cuenta de las posibilidades de lo que hacíamos.

Ahora ya hay muchas iniciativas, muchos museos de arte urbano, con tantas muestras en interior como en exterior.

\section{¿Qué es entonces un museo de arte urbano?}

El arte urbano es de la calle. Lleva consigo otro lenguaje para poder trabajar en un espacio expositivo, que se pueda trasladar a un sitio cerrado. Algo tiene que cambiar. No puede ser lo mismo. El artista debe tener varios lenguajes. 
No se puede acometer igual una fachada enorme que un muro dentro de un museo.

¿Crees que para entender tu obra de galería hay que conocer lo que haces en la calle?

Si, porque hay unas similitudes y un hilo conductor. Se puede identificar. Son complementarias, no necesariamente iguales. Por ejemplo, hago cerámica y tejidos. Los tejidos no tienen nada que ver con la pintura que hago en la calle. Conserva los colores, elementos, pero no eslo mismo. Es una"transmutación" que va de una visión plana a otra tridimensional.

Hice una serie a la que llamé "futurismo ancestral" que es una descomposición, una alteración de unos elementos figurativos abstractos que llegan a la abstracción total. Las obras son diferentes.

\section{¿Tienes alguna obra en algún museo?}

Si, claro, tengo obras en la Fundació Vila Casas, en Cataluña, y en el MIMA de Bruselas (Millennium Iconoclast Museum of Art). Y en Fanzara, en el MIAU (Museo Inacabado de Arte Urbano).

No sólo hago murales en la calle, pero no todos los días estoy en la calle, trabajo mucho en el estudio, últimamente mucho más en el taller.

\section{¿Cómo valoras la actividad en las redes sociales?}

Es muy interesante. Es un nuevo campo con el que trabajar. Es muy importante para la difusión de tu trabajo y tener una buena conexión internacional. Que todo el mundo pueda ver lo que haces. Es un elemento importante en la actualidad. No le veo nada negativo.

\section{¿Y el hecho de que estén tus obras en la red y que dejen de pertenecerte?}

Siempre me van a pertenecer, quien quiera utilizarlas tendrá que pagar un canon. Soy del VEGAP (Visual Entidad de Gestión de Artistas Plásticos) y velan por mis intereses, por el uso de mi trabajo. Se han dado casos del uso de mis obras y por eso cobro royalties cada año.

Las obras en la red siguen vivasy si siguen vivas te pertenecen, nadie las puede utilizar sin tu permiso. Si tú has cedido los derechos de imagen, sí, pero si no, siempre son tuyas.

Sólo una vez se ha dado el caso de que una gran compañía como Telefónica alteró una de mis obras para utilizarla, lo denuncié y gané. Es claro, aunque desaparezca la materia original, la imagen de tu obra en Internet existe y te pertenece. 


\section{Entrevista a SPOK}

Por Elena García Gayo

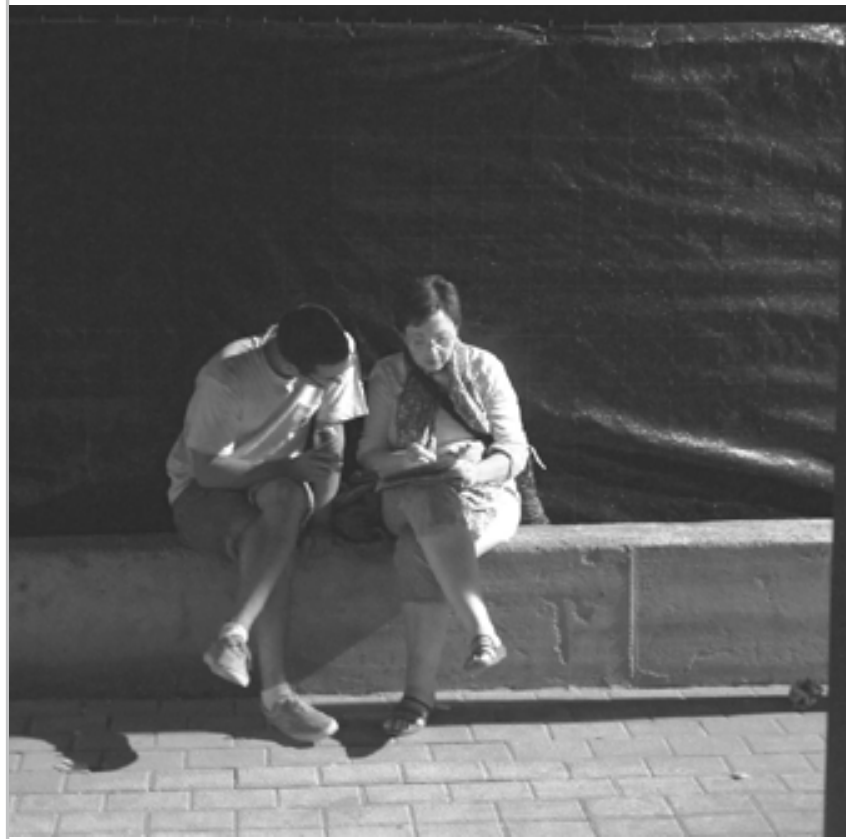

Spok ha formado parte del proyecto "Titanes", que ha sido comisariado por el artista Oscar San Miguel, Okuda, a través de la IAM Gallery, por encargo de la asociación Laborvalía. EI proyecto, que implica el pintado y reinterpretación de varios silos de la provincia de Ciudad Real, ha sido subvencionado por la Diputación Provincial y se lleva a cabo desde el mes de abril y a lo largo del año 2019.

Spok nace y reside en Madrid. Empieza a pintar graffiti en 1989. Entre 1994 y 2003, pinta trenes y muros y representa a la crew local TBC. Se gradúa en Bellas Artes. Participó en la ya mítica exposición "Street Art at Tate Modern", de Londres, comisariada por Cedar Lewisohn (mayo-agosto 2008). Ha viajado por medio mundo pintando murales.

\section{¿Puedes comentar lo que estás haciendo ahora?}

Últimamente participo en eventos organizados más que pintar por mi cuenta, me refiero a que hago menos arte urbano y pinto más muros. Sigo haciendo graffiti. Los muros solo organizados y también obras de estudio. En el silo de Manzanares, en el que colaboré con San, teníamos una idea general. Estuvimos viendo la zona. Hicimos bocetos y al llegar vimos que no nos inspiraba lo mismo. Eso suele pasar. Te cambia la idea. Los bocetos siempre se quedan cortos. Ahora, me quedo con ganas de añadir más cosas, pero el tiempo no lo permite. Hay un tiempo acordado para la grúa. Se podría terminar más, no digo mejor, sino añadir más significados y más "capas".

¿Tuvisteis en cuenta la particularidad de los silos, aquellos edificios que provienen de los grain elevator americanos que aparecen en la España de los cincuenta, en una situación política complicada?

Lo que tuvimos en cuenta, sobre todo, desde el punto de partida, fue suépoca. No tanto suaportación arquitectónica como edificio de ingeniería sino a nivel social. El marco de la época en la que se inscribe su edificación, a fin de cuentas, el resto, es una coincidencia temporal, pero es la época de Franco y el hecho de que España fuera una autarquía. Íbamos a hacer otra cosa que tenía más que ver con los símbolos a nivel político, pero luego decidimos que no, porque no queríamos crear ningún conflicto.
De hecho, pensábamos jugar con el conflicto, con una bandera de España en blanco y negro que rodeara el edificio. La bandera "más grande" de España. No se iba a entender, pero dijimos, uf, espérate... Al final como esto son cosas políticas y juegas en los límites, aunque no haya realmente límites - pero juegas con la percepción de la gente- habría sido muy interesante, porque sin forzar más que esa sutileza, sin hacer daño a nadie, habría diferentes reacciones. La grandeza de generar un espacio tan grande como este, que está completamente fuera de la escala de su entorno (...) habríamos tenido que pelearnos con los matices del lenguaje (...). Si esto hubiera sido un proyecto totalmente libre, seguro que habríamos hecho eso. Tiene también un toque de humor, un poco de absurdo, simbólico y "casa" bien con lo que es esto. Estilo "brutalista". Va todo muy ad hoc con el tipo de construcción [Figura 1].

Al final, decidimos cambiar el tema un poco, aunque es parecido, en realidad, hablamos casi de lo mismo, pero en vez de hacer lo que hacen otras personas de las que participan, que es darle una sola "capa" para decorarlo, nosotros hemos pretendido no tocar su forma ni su color, respetar su identidad y colocarle cosas encima.

Hemos hecho varios homenajes distintos basados en el recuerdo de las medallas que, para nosotros, son la unión con la infancia. Las medallas que nos daban de pequeños cuando participábamos en una carrera, aunque llegaras el último. Ese trofeo. 


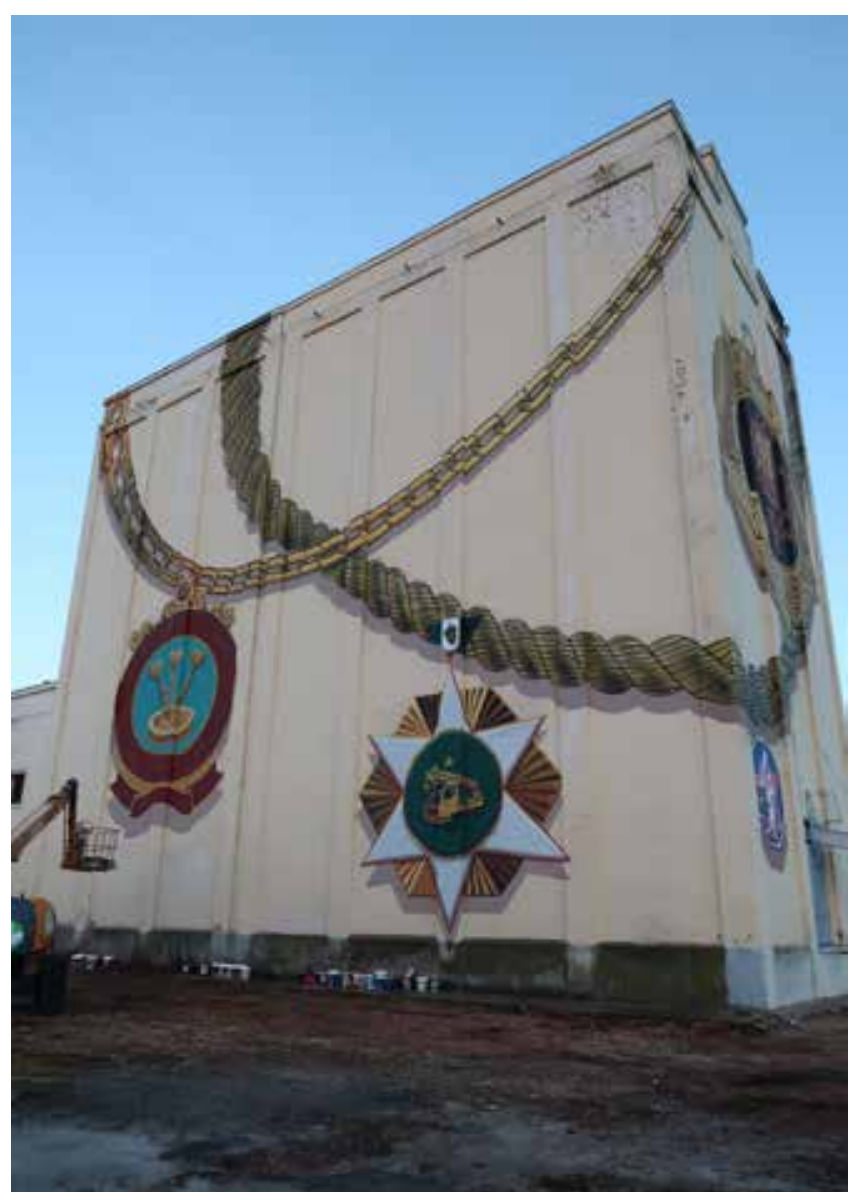

Figura 1.- Silo de Manzanares, Ciudad Real. Reinterpretado por Sok y San (ver entrevista)

El graffiti es una actividad en la que empiezas cuando eres un niño y "todavía tienes un pie en ella", pues, nos hemos hecho un homenaje a nosotros mismos a través de "no tocar" la identidad del silo y de colgar nuestras medallas en él.

En el frontal, hemos recordado un mural que Dani y yo pintamos hace quince años en el primer evento muralista que se hizo en España, el Urban Art de Ingenio, en Gran Canaria, era una cosa muy absurda que nadie había hecho y ahora volvemos a pintar juntos. La pieza funciona a varios niveles.

\section{¿Haces bocetos o cómo funciona el proceso creativo en tu obra?}

Compongo los bocetos en digital, busco imágenes en internet y las conecto. De cada fase hay algo en lo que disfrutas, en algunas obras más que en otras por cuestiones como la grúa o el tiempo. Así que, lo pasas mal y bien al tiempo. A veces intentas generar una idea y no eres capaz, no lo disfrutas (...) Es toda una dualidad. Hay que tener en cuenta que hemos pasado de hacer las cosas $100 \%$ porque queríamos, a hacerlas empujados, también $100 \%$, por las circunstancias y porque quieres hacer cosas que te lleven a otros lugares.
Profesionalizarse, quita la magia inicial, pero es el signo de los tiempos. Te haces mayor y la vida se acelera, a no ser que seas un absoluto privilegiado y puedas hacer todas las cosas por pasión, pero eso induce a la locura. Es un equilibrio inestable.

\section{¿Buscas la conexión con el público?}

¿Qué público? Hay muchos tipos de público, el que no se va a enterar de nada, hagas lo que hagas, aunque lo pongas muy claro, porque siempre va a pesar más su propio bagaje cultural y sus intenciones, y su educación, con respecto a este tipo de actividades. Es complicado establecer un lenguaje que llegue a todo el mundo. Es mejor tener tu lenguaje, tu vocabulario y que lo entienda la gente que quieres que lo entienda.

Esto lo puede ver la gente de aquí, pero a través de Internet es dónde lo ve mi público, la gente que me sigue. No es realmente para la gente del pueblo. Hay que intentar que lo que se pinta lo puedan "digerir" sin que les afecte de una manera negativa. Ese es el punto que hay que tener en cuenta. Aunque cada uno interprete lo que quiera. Gustará más a unos que a otros. Yo quiero llegar a mis seguidores, a la gente de mi entorno y mi contexto.

\section{¿Te interesa el contexto en las obras que pintas?}

Sí, siempre. Todo lo que hago tiene que ver con la realidad social o el espacio, aunque sea de una manera un poco abstracta y muy personal. Siempre he tenido esa vinculación. Hay gente que pinta a su estilo y lo suelta ahí, le da igual todo. Yo, a pesar de que el público al que me dirijo es el que te he dicho, tengo muy en cuenta dónde están situadas las obras.

\section{¿Eliges los materiales?}

La pintura es siempre pintura. El espray lo tienes a mano, porque es más fácil usarlo. La pintura plástica la utilizo mucho, pero, si no hay, me adapto.

Se que si das una capa de espray en un año está fuera; si le das dos, dura un poco más. No busco materiales perdurables en exterior. No van a durar, haga lo que haga, por los materiales que se utilizan. Si usas materiales inorgánicos durará más, pero hay una limitación de colores. Da igual, si se estropea se pinta otro.

Es difícil hacer el seguimiento de las cosas que haces. A no ser que vayas a pintar y te encuentres algo tuyo y te fijas en "el rojo" y dices, pues ha durado (...) Pinté en Cancún un mural y le di nueve capas al rojo y parece que dura. He usado el flúor, que dura muy poco y le di una capa de barniz, pero es que duran muy poco...

\section{¿Te interesa innovar?}

Me lo planteo, pero es difícil. Lo intento, pero no lo 
consigo. Porque tienes que tener tiempo, no puedes improvisar. Estamos en una dinámica de trabajos rápidos y tienes que ir a lo seguro. Si, me gustaría liberarme y cambiar totalmente, poder hacer otras cosas (...). Es una pena.

\section{Si te digo Museo...}

Pienso en El Prado (...) Me sugiere una realidad artística de siglos pasados.

\section{¿Y si te digo Museo de Arte Urbano?}

Ni pies ni cabeza. Realmente no sé qué significa. Son términos "yuxtapuestos" que se juntan tan sólo porque el lenguaje te lo permite, pero eso no significa que tenga algún sentido. Ya el propio término "arte urbano" genera conflicto, porque no todo el mundo que pinta en la calle hace street art. Son muralistas, pero no hacen street art. La mayoría de cosas que ves en la calle, para mí, no es street art. Así que, si le añades "museo" (...) museo es una caja donde se conserva. No tiene sentido que las cosas que pones en la calle se guarden en un sitio porque el contexto no es el mismo. No tiene sentido. Sólo se podría preservar esa memoria a través de fotos. Es arte efímero y no se puede encapsular la realidad. Tiene que partir de la propia intención de la obra para que eso llegue a tener sentido.

Esto es un tipo de arte digital que ha urgido de las posibilidades que ofrece Internet y ha explotado por las posibilidades de la red, que es la manera en que nos comunicamos, no de los museos. Si es necesario tener un espacio físico al que puedas llamar museo de street art donde conservar ese espacio y un tiempo concreto, en realidad lo que se necesita es un servidor de datos. No hace falta tener las obras materialmente, ni conservar nada para que sean objetos de su tiempo, porque eso no tiene sentido. La componente efímera del street art no la puedes "redefinir". Lo que más lo identifica es esa característica temporal. Sólo se pueden conservar las ideas. Los soportes serán los medios digitales que utilices.

Las obras desaparecen materialmente y pasan a ser obras digitales que ya no puedes controlar, no te pertenecen.

Siempre me pertenecerán. Igual que "el pensador" le pertenece a Rodin, por más que la gente lo tenga en su casa. Se pueden dar dos casos de pertenencia diferente. Te pertenece y también forma parte del subconsciente colectivo, al tiempo. La conversión en digital es su seguro de vida. A nadie se le ocurre hoy en día hacer una obra sin una foto después. Para Goya o Velázquez la realidad era ese cuadro, yo, desde que pinto, hago fotos a mis obras. Si no le haces una foto no existe. Lo que certifica que esa obra existe es la imagen digital no la obra, que puede desaparecer.
Tanto el graffiti como el arte en general, que no deja de ser todo un reflejo de lo mismo, pervive a través de la imagen (analógica o digital). Si hablamos de algo efímero que se convierte en digital (...) creo que nos metemos en un debate filosófico (...)

¿Crees que los caminos del arte contemporáneo y actual Ilegarán a juntarse, se llegará a reconocer el arte urbano?

Ya está. Hay asignaturas en universidades. Hace años, que tenemos los ejemplos de las asignaturas que impartían e imparten Javier Abarca y Santiago Morilla. Plenamente representado en la universidad, diría yo, que es el reflejo de las necesidades de la sociedad. Y las nuevas generaciones no es que lo demanden, es que ellos no tienen ninguna duda. Para ellos es arte porque lo han visto desde pequeños. Más allá del debate que surja entre adultos, las nuevas generaciones lo han vivido y lo veían ya construido y lo tendrán en su memoria como algo hecho.

¿Cómo percibes la restauración de todas estas obras, porque están surgiendo másteres en universidades de todo el mundo sobre el tema y es inminente que se implante algún tipo de especialización?

Llegará un momento que se obligue a pintar con silicatos. Pintar con espray no tendrá ningún sentido (...). Es algo que habla de la inmediatez, de lo efímero, de la ciudad líquida, y eso no lo puedes asir. Se harán algunas cosas, como hicisteis con el graffiti de Montera de Muelle, porque están ahí y siempre hay excepciones, pero ahora que pinta todo el mundo por todas partes, ya da igual.

\section{¿Tienes algún criterio para la restauración de tus obras, si llegara el caso?}

$\mathrm{Si}$, retoques invisibles, que se quedaran igual, que la restauración no se notara, me da igual los materiales que se usen. 


\section{Entrevista a SUSO33. www.suso33.com}

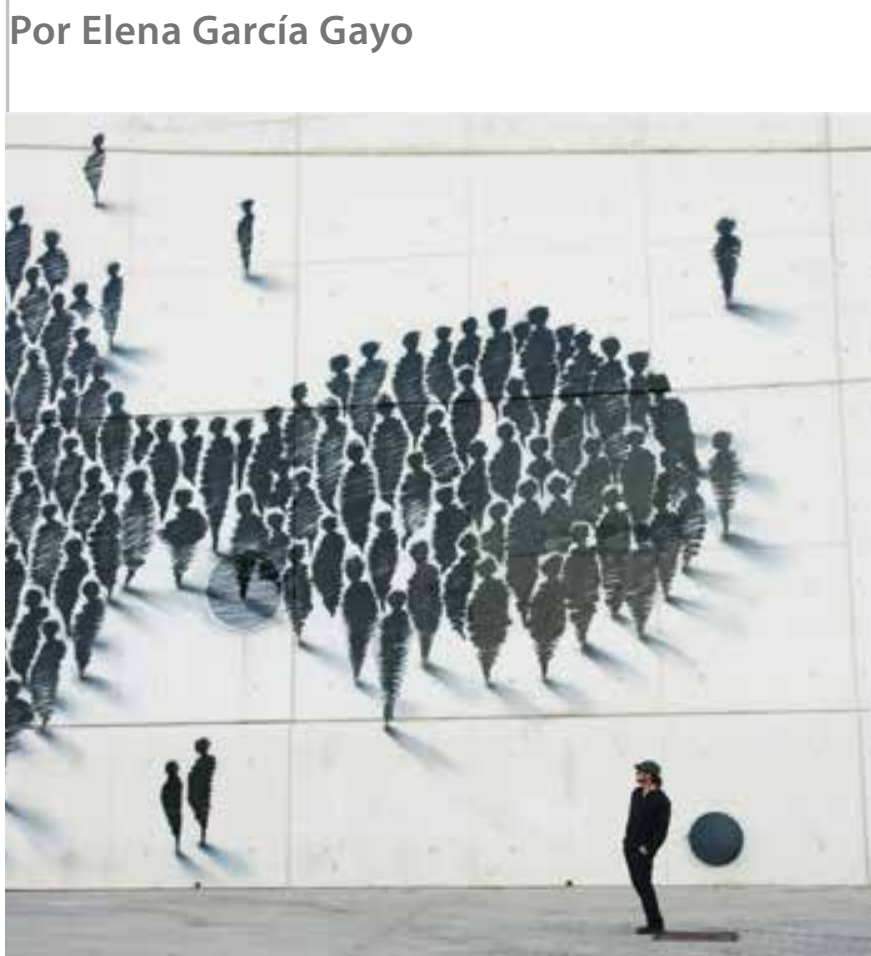

La pintura en movimiento, entendida como gesto y huella del cuerpo es la esencia de mi trabajo. Partiendo del graffiti llevo más de tres décadas experimentando con pintura de acción, muralismo, performance, instalación y videoarte. Concibo ambientes efímeros, en la calle o en la naturaleza, que de alguna manera homenajean la memoria de los espacios y sus habitantes. La luz siempre es protagonista, sea al aire libre (valorando los condicionantes naturales) o en el escenario, usando nuevas tecnologías. En cuanto a mis temáticas, quizá hablo de la soledad, de la deshumanización de la sociedad... de la búsqueda de libertad de expresión... y en algunas series (como las Pinturas Negras) de una cierta vía espiritual.

\section{¿Te consideras artista urbano?}

En la actualidad me da cierto reparo afirmar que soy un "artista urbano", porque provengo del graffiti y eso te marca mucho. Cuando comencé a los 11 años, no existía el término "arte urbano". Quizás podía usarse Street Art pero era otra cosa. Del graffiti clásico evolucioné haciendo iconos ("la plasta" es el más conocido) y más tarde "ausencias" que dialogan con el contexto, no priorizando la imposición y apropiación de los espacios del graffiti. Luego seguí haciendo intervenciones urbanas además de ejercicios de happenings y performance, incluso algo parecido al "arte de acción" y finalmente trabajo también como muralista contemporáneo. En resumen: antes no estaba el camino tan claro como ahora y no era una evolución diseñada sino un camino desconocido a explorar y abrir. Me gusta decir, ya que para mí el contexto de la ciudad donde se interviene es tan importante, que hago "arte humano" más que "arte urbano".

\section{Durante el proceso creativo, ¿documentas los pasos que se van sucediendo hasta la conclusión de la obra?}

Suelo documentar con vídeo y fotografías los proyectos complejos (mayormente los legales pues se puede rodar de forma tranquila, simultáneamente a la ejecución). Las piezas libres en la calle o en la naturaleza, a veces las fotografío a posteriori u otra gente hace fotos y me las envía o sube a redes, pero no me obsesiona tenerlas todas registradas pues su esencia es efímera. Si son intervenciones autónomas y sin permiso no hago boceto alguno. Si es una intervención legal comisionada, primero trazo algún dibujo muy sencillo a mano donde ya está la idea principal y con eso trabajo. Si es una obra de gran envergadura sí realizo un diseño en ordenador, fundamentalmente para mostrar la idea, comunicarme con mi equipo y planificar la producción; aunque siempre estoy abierto a la inspiración del momento.

\section{¿Cómo valorarías la importancia del proceso creativo con respecto a la obra finalizada? (del 1 al 3)}

El proceso creativo es clave para mí. Le doy la nota máxima. Lo es todo. Todo lo que ocurre desde que estudio la propuesta es parte de la obra y el momento de ejecución es en algunos casos un tipo de arte corporal o danza, de ahí que en ese momento deba estar muy concentrado y aunque en obras enormes tenga ayudantes, nunca es una mera ejecución del boceto. Siempre improviso y decido cosas sobre la marcha dentro de ese trance de la ejecución. En las piezas comisionadas hay "condiciones previas" y trato de plantear de inicio un proyecto que se adapte a las condiciones. Otra cosa es que a posteriori se intente influir o modificar lo que planteo y eso no suelo admitirlo.

La pintura en la calle siempre es comunicación con el público que recibe la obra sin haber ido a buscarla. Es habitual que el público exprese su opinión durante el proceso de ejecución, pues en la calle estás muy expuesto 
(esto a veces es satisfactorio y otras, complejo de llevar) y también a posteriori cuando la obra convive con ellos cada día en sus barrios y recibes sus comentarios. En mi caso, estas constantes experiencias de comunicación con el público me han inspirado obras en las que la gente propone y yo ejecuto "como un mero transmisor" Por ejemplo: "Lanzadera de palabras" (2007) o "CORTEN!" (2010).

En concreto en "Lanzadera de palabras" (2007), realizada en la fachada del Círculo de Bellas Artes de Madrid el 22 de septiembre de 2007 para La Noche en Blanco, ataviado con el traje de la plasta, a modo de "cuerpo-plotter", escribí en el exterior las frases dictadas por la gente, mostradas sin censura alguna. Abría el debate de la privación de expresión en el contexto urbano, y permitía entender el valor del graffiti y del Street Art como canales de pensamiento libre en la calle.

\section{¿Cuál crees que es el papel del artista en la sociedad actual?}

El artista ofrece nuevas formas de mirar y las comparte con la gente. Expresa su mundo interior que puede tocar a otras personas, transformarlas o hacerlas pensar. Mas que un arte político panfletario me interesa una poética abierta y ambigua que conecta con la gente, quizás con la más desfavorecida... y hablar del dolor que implica vivir, de la soledad interior... de la importancia de la libertad de expresión...

\section{¿Cómo seleccionas los materiales?}

Experimento continuamente con materiales: con los clásicos del grafiti (las marcas me piden continuamente probar el primero todas las novedades, para ayudarles a mejorar el producto), como con los materiales de la pintura clásica y con los de la escenografía (he trabajado mucho pintando decorados e imitando texturas). También experimento con tecnologías (grafiti con luz) Realidad Virtual, video, agua, tiempo...

Las condiciones precarias que implica hacer arte efímero no me han permitido elegir materiales de durabilidad como me hubiera gustado para algunas piezas, pero si he preparado a veces los muros con capas de refuerzo o los telones si eran obras destinadas a perdurar. Recuerdo que hace años en superficies metálicas daba una imprimación antioxidante y mis colegas me decían que estaba loco.

\section{A la inversa: ¿te planteas utilizar técnicas/materiales de carácter efímero, para que tu obra se degrade y se pierda lo antes posible?}

Sí, uso muchos materiales efímeros para que se pierdan y desaparezcan. Tengo toda una serie de trabajos de pintura con agua, controlando el secado paulatino según el sol los árboles... (Es una serie que empecé en Escocia. Las piezas se registran en vídeo y materialmente no queda nada). Por ejemplo, Watermotion (2014) es una serie pintando con agua sobre la pared de mi casa en Dufftown. Experimentaba ayudado por el movimiento de las nubes, el sol, los árboles, los pájaros... y esos dibujos se registraban en auto vídeos. Bocetos vertiginosos que formaban manchas de agua que se fundían con la sombra de mis brazos, etc.

Y también he realizado muchas intervenciones en murales con pintura de colores que sé que desaparecerán con el sol, jugando con la idea de transformación, para obtener una forma distinta a la de partida.

\section{En la actualidad, ¿estás trabajando con alguna técnica/ materiales de resultados imprevistos?}

Experimento continuamente para ver qué ocurre. He trabajado mucho sobre soportes con hongos que pasado el tiempo han ido creciendo y expandiendo y cambiando el color y la forma de la superficie. Estas intervenciones son de dos tipos principalmente: 1 . Con ligera intervención de pintura y 2 . Con raspando y limpiando de la superficie.

\section{¿Has podido verificar en alguno de tus trabajos cómo se están comportando con el tiempo los materiales utilizados? ¿los sigues?}

En escenografía es habitual probar texturas y experimentar todo el tiempo, y en piezas en la calle he podido ver a lo largo de años como algunas obras se transformaban según el soporte y material usado.

Precisamente, algunas de estas intervenciones en la calle las he documentado a lo largo de los años para ver cómo se iban transformando; comprobando, por ejemplo, cómo crecen las humedades... o como la gente las interviene encima.... Tengo una serie de pinturas en la que documento el paso de las cuatro estaciones: en el registro se aprecia como las plantas trepadoras de hoja caduca van llenando de hojas el muro cada año, primero con brotes y luego con hojas verdes y después con hojas rojas hasta que finalmente se caen y el ciclo empieza otra vez. En Madrid tengo varias así sin permiso y en Ámsterdam, por ejemplo, tengo un gran mural de varias plantas.

\section{¿Te interesa conocer las causas de degradación de los materiales que utilizas?}

Sí me interesaría conocer las causas de la degradación y saber más de conservación y tener más en cuenta este aspecto en mi obra pues ofrece posibilidades si conoces realmente las técnicas.

\section{Lo primero que te viene a la cabeza cuando escuchas la palabra'museo' es....}

La palabra "museo" me sugiere un lugar donde guardar y conservar la memoria. También la idea de algo "encerrado", institucional ... de espacio interior. 
La expresión "museo de arte urbano" resulta de primeras un poco contradictoria porque, por una parte, sugiere "guardar, conservar o encerrar arte efímero", pero si identificamos "museo" con "memoria", lo que se puede entender es que se quiere preservar el legado del arte urbano.

¿Conoces personalmente alguno de los llamados 'museos de arte urbano' que existen en la actualidad? ¿Tienes obra en alguno de ellos?

Conozco el "Street Art Museum" de Amsterdam https:// www.streetartmuseumamsterdam.com/ donde participé haciendo un mural en las calles de Ámsterdam, pero desconozco su labor como museo.

Y en el MIAU, Museo Inacabado de Arte Urbano, http://www. isupportstreetart.com/partnership/15868/ donde también tengo obra, pero no las conservan ni creo que documenten de un modo riguroso. Intuyo que en ambos casos se usa el término "museo" pero no hay una labor completa de estudio y conservación de las piezas.

\section{¿Tienes alguna obra en alguna colección de especial relevancia?}

Si te refieres aquí a colecciones privadas, tengo una pieza de videoarte en la Fundación Sorigué de videoarte en Lleida.

\section{¿Tienes alguna obra en la colección de algún museo?}

En Artium (Vitoria) tengo un cuadro de gran formato (de $2 \mathrm{~m}$ $\times 5 \mathrm{~m}$ ) de la serie caligramas, que estuvo en el hall de entrada una larga temporada y luego acabó en oficinas y solo lo pueden ver los que trabajan pues está en el pasillo de las oficinas.

Para el 25 aniversario del Guernica hice un mural en el Museo Reina Sofía, que después el museo cedió al Museo de Arte Urbano de Leganés. Allí lo pusieron en condiciones muy deficitarias: por ejemplo, atornillaron los focos de luz sobre el cuadro por la cara pintada. El Museo Reina Sofía nunca reclamó la obra y se quedó en Leganés. Yo la reclamé durante años, pero no me hicieron caso. Cuando hicimos la exposición del CEART se pidió oficialmente para la muestra y tuve que hacer una solicitud por escrito al Ayuntamiento de Leganés y solo así la encontraron y me la dejaron para mi retrospectiva, después de la cual se olvidaron de la obra.

Es curioso que en su momento el Museo Reina Sofía anunció el evento y la pieza "a bombo y platillo" pero luego se desentendió. Quizás porque no considera arte las piezas de arte urbano que encarga. Lo mismo ocurrió con otra pieza en Canarias.

Mi reflexión es que, si los museos tradicionales que tienen experiencia en conservación se desentienden de las piezas de arte urbano, es casi comprensible que los nuevos museos de arte urbano - que ni siquiera tienen esta preparaciónni se lo planteen y cuiden poco las piezas.

\section{¿Te planteas si alguna de tus obras va a sobrevivir mucho tiempo?}

No me lo planteo porque la esencia de mi obra es efímera, pero eso no quiere decir que no me gustaría que algunas duraran para que pudieran relacionarse con personas de generaciones futuras. Además, creo que algunas de ellas se acercan al sentir colectivo de muchas cosas que hemos vivido en otra época y podrían servir para comunicar emociones, por ejemplo, el mural de Tetuán en la Plaza del Poeta Leopoldo de Luis (Madrid). Este sí me gustaría que se conservara, por ejemplo, pues es el colofón de muchas décadas pintando de forma libre en esa zona, hablando de la gente, de sus vidas, del abandono de sus casas... hasta que las derribaron.

\section{¿Sientes que el 'crear para la calle' y el 'crear para exponer" son acciones creativas complementarias o que son independientes y no tienen relación?}

Hay artistas de los denominados "urbanos" que sí entienden de un modo separado la obra en la calle y "la obra de estudio". En mi caso, aun siendo formas de trabajar muy distintas, existe siempre una continuidad. Aunque me lo han pedido constantemente las galerías - nunca he realizado cuadros "decorativos" con los motivos y formas reconocibles que pinto en la calle- solo para vender. Siempre he elaborado proyectos galerísticos concretos que tuvieran que ver con la acción pictórica e incluyendo la reflexión sobre las contradicciones del "dentro y fuera".

Te pondré tres ejemplos que sirvan de reflexión, de piezas "para exponer", aunque hay muchos otros proyectos:

1. Susouvenirs (2011): collages sobre papel, de pequeño tamaño, a modo de obra gráfica seriada, en los que con una firma se legitima la fotografía documental de una intervención libre en el espacio público. Se trata de una estrategia irónica pues estas intervenciones públicas ilegales no pueden venderse ni ser reconocidas en su autoría.

2. "Pinturas negras escenográficas" (2015): ironizan sobre los muros de pinturas negras que hago en la naturaleza. Las pinturas negras originales son una serie de intervenciones pictóricas que empecé en septiembre de 2014 en cincuenta grandes muros de la destilería de Dufftown (Escocia). En estos murales trabajaba con las manchas que el paso del tiempo había dejado, interviniendo con mínimos trazos de pintura junto a los hongos, la humedad o el propio deterioro de la piedra. Pues bien, consciente de la dificultad de trasladar al espacio expositivo la energía de estas obras de exterior, construí una pintura negra escenográfica con forma de pata de gallo teatral reforzando la idea de decorado.

3. “Poesía Fosilizada” (2009), acción realizada en Salamanca, para la galería Adora Calvo. Pinté en el exterior una serie de lienzos con frases provenientes de la lectura que hacía 
la gente, megáfono en mano, del "manual de buenas prácticas en las artes visuales". Poco a poco los lienzos se cubrieron con capas de palabras de colores, y fueron introducidos por el público dentro de la galería, aludiendo a la poca capacidad de los artistas urbanos para decidir sobre su obra en espacios expositivos.

¿Podrías identificar alguno de los puntos que separa el hecho de 'crear para la calle' y 'crear para un espacio expositivo' y que el público en general no suele diferenciar?

Crear para la calle implica crear en relación con un paisaje urbano determinado que hay que tener en cuenta: calles, edificios, gamas de color, perspectivas, climatología, hábitos de los transeúntes... historia y memoria del lugar y de sus habitantes. En un espacio cerrado puedes crear sin tanta responsabilidad, pues solo hay que tener en cuenta el espacio interior. Crear para la calle supone que el público se va a encontrar con la obra durante su recorrido de la ciudad, en su vida cotidiana y ahí está la magia y la responsabilidad de esa comunicación

Te diría que quizá la verdadera diferencia no es tanto crear para la calle o crear para exponer sino pintar con o sin permiso. Son energías muy diferentes. A diferencia de pintar lienzos, que te permite trabajar en "la paz" y volver a empezar, la pintura de trenes, por ejemplo, solo te ofrece una oportunidad y los resultados quedan a la vista de todos. Este determinismo ambiental le da al graffiti su fuerza vital.

Trabajar en el espacio público incorporando el tiempo real, sin ensayos, sin producción previa, implica elegir el proceso e incluir la incertidumbre.

\section{¿Qué importancia le das a las redes sociales en tu obra?}

En la actualidad, el arte urbano y el tan prolífico «nuevo muralismo» no se entienden sin la fotografía y sin la difusión en las redes sociales. El graffiti, en la época analógica, cuando no todo el mundo tenía un capturador de imágenes en el bolsillo, gracias a Henry Chalfant viajó en el espacio y en el tiempo a través de la fotografía y de la televisión. Eso representó el gran cambio; su libro y sus películas.

Las redes las uso para comunicar mis proyectos, estar enterado de los proyectos de otros artistas y a veces para seguir la evolución de mis piezas en cualquier parte del mundo, pues la gente las fotografía y etiqueta; pero en general uso poco las redes.

Si una de tus obras desaparece materialmente y sobrevive digitalmente fuera de tu alcance ¿cómo te lo planteas?

No sé si te refieres a temas de autoría o a temas emocionales. En cuanto a mi relación personal con la obra, estoy acostumbrado a que desaparezcan pues es la esencia del graffiti y suelen quedar solo fotografías de nuestras obras.

¿Consideras que las obras que se escapan a tu control, virtualmente hablando, siguen siendo tuyas?

En relación a la autoría, no se duda de la autoría de una pieza porque ya no exista, si existe un registro en fotografía y vídeo. De igual manera que se mantiene la autoría de una pieza teatral o de una performance, aunque sean efímeras, se debe mantener la autoría del arte de la calle. Igual que se mantiene la autoría de un cuadro perdido o destruido de Picasso o Velázquez, se debe mantener la del arte urbano desaparecido.

En todo caso, los temas de derechos de autor, por el condicionante de la legalidad e ilegalidad en el que estas piezas están envueltas, son complejos. En los últimos años estoy colaborando con un amigo abogado experto en temas de derechos de autor para pensar sobre estos asuntos y analizar los casos dudosos según la legislación. He organizado varias mesas redondas etc. sobre ello.

\section{Virtualmente ¿aceptas de buen grado variaciones sobre tus obras?}

Si te refieres a fotografiar mi obra y usarla en otro contexto y mezclarla con otras cosas, no me parece interesante pues se pierde el sentido y la razón de las piezas y confunde al público. Otra cosa es que exista colaboración con algún artista que dialogue con mi pieza y amplíe su significado.

La colaboración y el trabajo en equipo son claves en el graffiti y debería este aspecto ser más estudiado, pues rompe con la idea de artista omnipresente y todopoderoso que ha difundido la historia del arte tradicional, que de alguna manera continúa presenten en el arte urbano, pero no el graffiti que es mucho más colectivo.

Para conocer mejor mi obra a nivel teórico se puede leer el libro que escribió Susana Blas, con motivo de mi antológica en el CEART en 2015, editado por el CEART y La Fábrica.

Entrevista por escrito agosto 2019

Madrid 


\title{
Entrevista a VERMIBUS https://vermibus.com/
}

\author{
Por Elena García Gayo
}

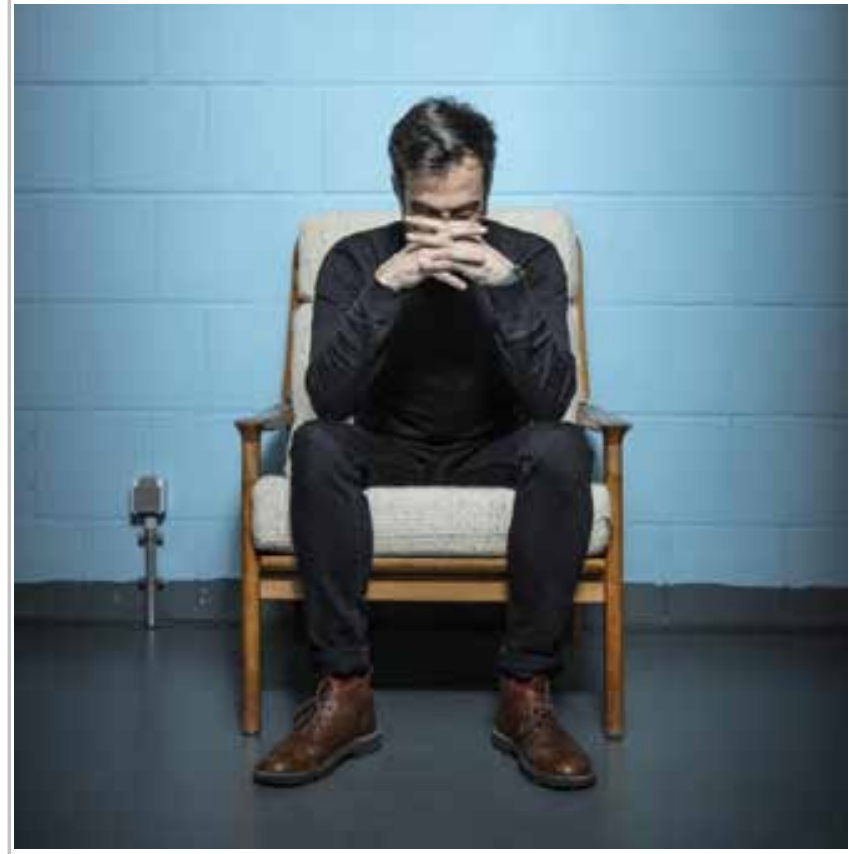

Empecé pintando graffiti en 1998. Cuando llegué a Madrid en 2003, para diferenciarme de los demás, empecé a pintar muñecos en lugar de letras y a experimentar con distintas técnicas, plantillas, posters pegados en la pared etc. Con un estilo muy parecido a lo que se hacía en Barcelona por esa época y no tanto en Madrid.

Estudié ilustración, diseño publicitario y algo de fotografía, lo cual me facilitó mis primeros trabajos como ilustrador y como fotógrafo para una agencia de publicidad.

En 2011, al mudarme a Berlín, empecé como Vermibus, personalidad que me ha facilitado trabajar desde un punto de vista artístico, investigador, apropiativo y reivindicativo, el cual he ido desarrollando desde entonces.

\section{¿Cómo explicarías tu punto de vista dentro de la escena artística urbana?}

El "arte urbano" desde esa acepción tan general que parece predominar ahora, me sugiere una escena donde la mediocridad es norma. Los blogs más influyentes del streetart publican tanto obras de altísima calidad como obras mediocres, memes o juegos visuales y resultones en busca del like y para ganar "followers". Supongo que para tener más influencia y gestionar más proyectos.

La gente consume ese contenido más que el contenido de calidad, que es menos atractivo de ver, porque necesita un pensamiento más crítico y cierta información previa para entenderlo. En la escena del arte urbano hay de todo, incluída muchísima mediocridad, en los creadores, en los influencers y en los consumidores.

Honestamente, no sé muy bien de quien es la culpa, me parecer que tiene que ver con el momento, de exceso de información, y el sistema en el que vivimos.

La manera de producir, promover y consumir cultura está centrada en resultados efectistas más que en la calidad de las propuestas y esto es especialmente visible en el street art actual. Supongo que por eso ha pasado de ser un instrumento en contra del sistema a ser una pieza del engranaje del entretenimiento capitalista. Me considero artista y activista, por eso, porque creo que son dos términos más "estables" a largo plazo. Podría considerarme Adbuster, también, ya que dentro de la escena del "arte urbano" o "streetart" es lo que más se asemeja a la etiqueta original. Pero, como todo cambia demasiado rápido, me quedo con artista/activista, apropiacionista.

\section{¿Durante el proceso creativo, documentas los pasos que se van sucediendo hasta la conclusión de la obra?}

Documento gran parte de mi trabajo de distintas maneras: de forma puramente personal, con fotografías analógicas o apuntes en cuadernos de notas y hojas sueltas. Con documentación externa, como las fotografías de otros artistas (fotógrafos). De forma independiente, generando documentación para el social media y, también, con intención artística, con videos que acaban convirtiéndose en obras finales por sí mismos.

También conservo los artículos impresos que se publican sobre mi obra, junto al resto de la publicación para poder entender el contexto en el que se mencionaron, al igual que las preguntas y respuestas que envié a los medios.

Ahora, he empezado a producir bocetos digitales, para darle forma a ideas en formato de instalación. Para pinturas, por el contrario, siempre son improvisadas. Las ideas que van surgiendo para dar forma a diferentes proyectos, por lo general, se desarrollan en función de lo que me va interesando en cada momento. Casi nunca 
tomo notas y todas las ideas se desarrollan a través de largas conversaciones con gente de mi confianza. Así, voy perfilando las posibilidades y si se pueden llevar a cabo o no y van tomando forma.

\section{¿Cómo valorarías la importancia del proceso creativo} con respecto a la obra finalizada? (del 1 al 3)

\section{El durante, 2. La obra}

\section{¿Cómo se va desarrollando la idea, en tu caso?}

Las ideas se producen de una forma muy racional y analítica, el proceso de creación es más libre e intuitivo. Pero todo depende de si el proyecto es personal o comisionado.

Si es personal, la idea empieza a tomar forma sin considerar los límites y acaba cuando consigo llevarla hasta una línea que ya no es posible atravesar. entonces, encuentra su razón de ser y se materializa en un punto intermedio. Si no lo consigo, acabo descartándola por completo.

Si es un proyecto comisionado hay situaciones en las que no me queda más remedio que admitir injerencias externas. Siempre y cuando no sobrepasen los límites éticos que me he fijado, me adapto a la situación. En ningún caso permito o colaboro con marcas para hacer publicidad, especialmente en el espacio público. Admito sugerencias, pero principalmente por un tema legal.

La elección del lugar en el que se van a localizar, depende del proyecto. En unos importa más que en otros.

\section{¿Te planteas tu trabajo como parte de una comunicación con el público?}

La obra es principalmente una comunicación unilateral, por lo que no considero que sea una conversación con el público sino más bien con la industria. Es una respuesta a su mensaje, por lo tanto, la conversación está ahí. El público lo que ve es un "debate", pero hasta que este no se pronuncia no es parte del mismo. Para resolver ese problema he empezado a dar charlas sobre lo que hago en las que, a pesar de ser un monólogo sobre mi obra, gran parte de la presentación es contestar a las preguntas del público, algo que me resulta muy enriquecedor porque es cuando pones a prueba algunas de las cosas que has preparado y percibes en la forma que son recibidas. Ahí es donde hago partícipe a gente anónima y todas las preguntas son contestadas con la mayor honestidad posible. Por otra parte, he empezado a dar workshops para que la gente tome la iniciativa y aporte su punto de vista sobre la "contra publicidad".

\section{¿Cuál crees que es el papel del artista en la sociedad actual?}

Si nos referimos a papel como "responsabilidad", el artista no tiene ningún tipo de responsabilidad. La responsabilidad es un tema personal, unos deciden tenerla y otros no.
Dicho esto, creo que la responsabilidad del artista debería ser avanzar teóricamente y técnicamente en los caminos de sus antecesores, sean cuales sean sus referencias.

Si nos referimos a papel como "función", la función del artista no ha cambiado mucho respecto a épocas anteriores. El arte es un reflejo de la sociedad actual y puede ser usado como documentación, didáctica, o como una mera reflexión sobre el contexto socio-político de la misma. Eso, o para decorar, para quitar el eco de una habitación, como moneda de cambio para especuladores, como lavado de imagen...

\section{¿Qué materiales y técnicas usas?}

Al principio compraba distintos tipos de disolventes comerciales, en distintos países, con la esperanza de encontrar diferentes composiciones en base a las regulaciones locales (Alemania, España, Italia, Francia y Polonia) básicamente, por una falta de conocimiento sobre las particularidades de los compuestos de los mismos. Prueba-error y adaptación a lo que encontraba. En 2017 empecé a trabajar con especialistas en diferentes materias y a tomarme más en serio los materiales, cómo los utilizo y las consecuencias que pueden tener sobre los soportes.

He tenido épocas en las que la técnica y su perdurabilidad no ha sido una prioridad para mi (especialmente al principio). Han sido momentos en los que la necesidad expresiva era muy intensa, muy intuitiva, tenía la necesidad de tener resultados inmediatos, que lo que hacía fluyera, sin tener una parte racional presente. Pero, al ver que había barnices que daban problemas muy rápidamente empecé a preocuparme más por los materiales que compraba, hasta el punto en el que me fue imprescindible informarme mejor para hacer mejoras, de cara a implementar en mi obra una conservación preventiva.

Uno de los cambios más interesantes fue el de simplificar las mezclas de disolventes y cambiar las marcas comerciales por otras más afines y controlables. Ahora, estoy en un punto intermedio, en el que si necesito usar un disolvente comercial lo hago de forma puntual, para algo en particular, porque ya sé exactamente el resultado que busco, y lo uso sin que la preocupación - de si va a durar o no - me paralice. Mi trabajo de la calle se pierde muy rápidamente, por lo que mis esfuerzos se centran en conservar lo máximo posible de lo que llega a las galerías.

Todos los disolventes dan resultados imprevistos dependiendo del papel, la tinta etc. Estoy empezando a usar un disolvente nuevo con el que imagino que tendré resultados diferentes. No sigo de forma estructurada el envejecimiento de mis obras, aunque sé que algunas de las primeras han cambiado con el tiempo. El papel se ha oxidado, se ha vuelto más amarillo, dependiendo de la iluminación que haya tenido.

Sobre los colores, como no he pautado el seguimiento, no guardo patrones de los colores originales de las obras, no 
puedo comparar y averiguar si han perdido intensidad o no. Me interesa saber qué es lo que pasará con mis obras, pero me da miedo que el resultado no me guste. Si me planteo que mi obra va a desaparecer en poco tiempo me preocupa y me lleva a no querer hacerla.

¿Lo primero que te viene a la cabeza cuando escuchas la palabra 'museo' es...?

Un espacio público donde proteger, dar a conocer, conservar, catalogar y categorizar obras de arte para futuras sociedades, con la intención de explicar cómo era la nuestra.

\section{¿Qué te sugiere el concepto"museos de arte urbano"?}

Lo que he comentado antes, pero creo que debe ser arte producido o pensado para el espacio urbano y llevado a otro contexto. Los artistas deben tener que ver con el arte urbano y, las obras, ser capaces de explicar lo que se hace de forma independiente en el espacio público.

¿Conoces personalmente alguno de los llamados 'museos de arte urbano' que existen en la actualidad? ¿Tienes obra en alguno de ellos?

Sí, el de Amsterdam, Berlín y Munich. Desde septiembre de 2019 tendré una en el Urban Nation, para la Biennale.

¿Tienes alguna obra en alguna colección de especial relevancia?

En Völkingen Hutte tengo una obra que, creo, es fija. En Calais tengo una obra hasta noviembre de este año.

¿Tienes alguna obra en la colección de algún museo?

Doné una obra al museo de Wiesbaden.

¿Te planteas si alguna de tus obras va a sobrevivir mucho tiempo?

Espero que lo máximo posible.

¿Sientes que el 'crear para la calle' y el 'crear para exponer son acciones creativas complementarias o que son independientes y no tienen relación?

Absolutamente complementarias.

¿Podrías identificar alguno de los puntos que separa el hecho de 'crear para la calle' y 'crear para un espacio expositivo' y que veas que el público no suele diferenciar?

Intención, legalidad, recursos y libertad de actuación. La intención de usar el espacio público de forma autogestionada tiene una finalidad y posibilidades distintas. Trabajar con permiso normalmente te da más tiempo para pensar y preparar la obra con variables más estables. Por ejemplo, fotografiar una obra instalada en la calle puede dar reflejos difíciles de evitar en la documentación, cuando resulta que la documentación es imprescindible para la supervivencia de la obra.

¿Qué importancia le das a las redes sociales en tu producción?

En los tiempos que corren, le doy mucha menos importancia de la que debería.

Principalmente las uso como difusión de mi trabajo, presentación de obras a gente que no podrá verlas de otra manera, documentación de la evolución de mi trabajo y promoción de cara a futuros clientes. A veces he seguido un plan estratégico, pero sin demasiada consistencia ni una finalidad. Creo que las redes sociales están haciendo mucho mal, tanto al arte como al consumo del mismo.

Si una de tus obras desaparece materialmente y sobrevive digitalmente fuera de tu alcance ¿cómo te lo planteas?

Esto ya ocurre y de muchas maneras. Las obras vendidas a coleccionistas privados desaparecen de alguna manera del alcance del resto del público, siendo en formato digital la única manera que hay de volver a verlas. Las obras instaladas en el espacio público, una vez retirada —al margen de si se conservan o se destruyen - la obra final, que es la obra instalada, desaparece. Solo sobrevive en su versión digital.

Por otra parte, recientemente he estado eliminando todo rastro de mi antiguo trabajo como ilustrador y como fotógrafo, obras y cuentas en las antiguas redes sociales (flickr, fotolog, etc) estoy intentando que no quede ni una obra online de mi periodo anterior a Vermibus, y al ser absolutamente desconocido, por aquel entonces, está siendo fácil. Si quisiera hacerlo ahora, sería mucho más difícil o imposible. No es en absoluto mi intención, pero quien sabe en un futuro.

En principio me parece bien que mis obras sobrevivan digitalmente, creo que es la única manera de hacerlas llegar a varias generaciones, pero quien sabe, quizás haya un apagón tecnológico y lo único que sobreviva sean los originales o las reproducciones.

¿Consideras que las obras que se escapan a tu control, virtualmente hablando, siguen siendo tuyas?

Esencialmente es eso mismo lo que ocurre. Todo lo que no esté bajo mi control escapa del mismo. Todo el contenido online es susceptible de ser descargado por cualquiera, en ese caso supongo que los unos y los ceros pasan a ser de la otra persona. Lo que no pasan a ser son los derechos de autor, a pesar de que hoy en día estos llegan a ser borrosos porque rara vez se reclaman.

No me gusta que se modifique mi obra con filtros o recortes para encajar estas en un artículo o en un espacio 
determinado. Sí que estoy a favor de que alguien, con una intención artística, utilice mi obra para crear otra, siempre y cuando no la haga pasar por mía. ¿Cómo podría estar yo en contra?

El problema de la documentación digital es una constante, en cuanto a los cambios de calidad. Una foto de una cámara digital de 2003 no cumple los parámetros de calidad que se exige hoy en día. No se puede hacer prácticamente nada con ella. Supongo que en los próximos quince años la documentación tendrá los mismos problemas; de compatibilidad, de estándares de calidad, de transición de digital a analógico, para imprimir una foto, por ejemplo.

Entrevista por escrito

Fecha: 19 de agosto 2019 


\section{Gestores Culturales}

\section{Entrevista a XAVIER BALLAZ, creador de difusor y gestor del proyecto cultural B-MURALS}

\section{Por Rosa Senserrich-Espuñes}

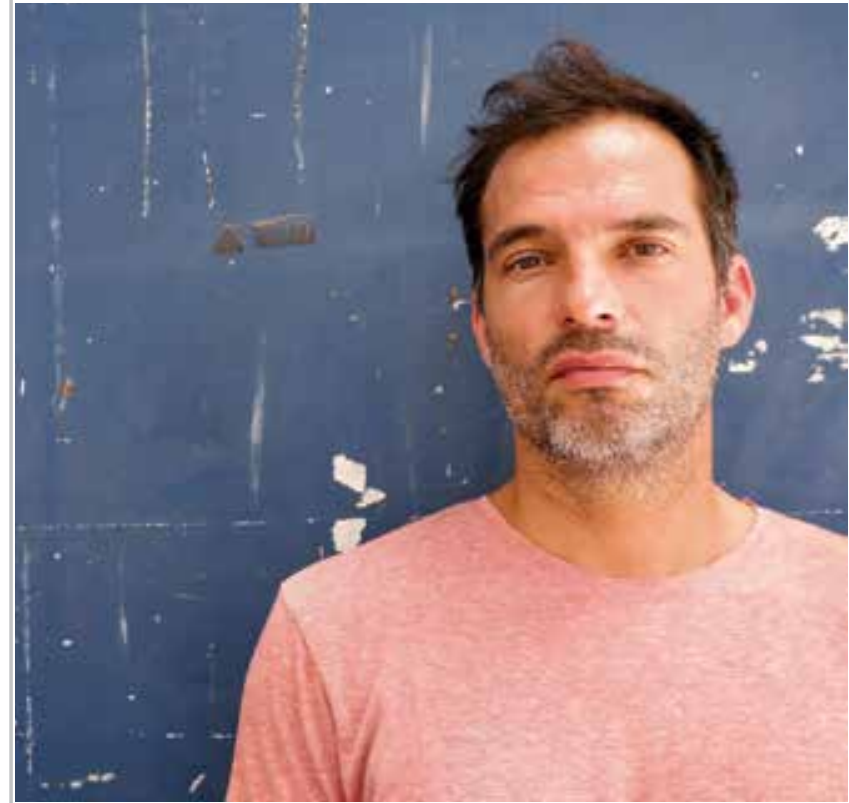

Xavier Ballaz en la Nau Bostik. Foto @ Fer Alcalá - B-MURALS
Una mañana de principios de julio y la Nau Bostik de Barcelona, el marco ideal para entrevistar a Xavier Ballaz, educador y gestor cultural con una larga trayectoria relacionada con proyectos de arte urbano en el espacio público y muralismo contemporáneo.

A través de estas preguntas, vamos desvelando la evolución de su trayectoria hasta llegar al momento en el que se encuentra, inmerso de lleno en la construcción del proyecto $B$-Murals, que lleva ya seis meses de andadura y de buenas producciones desde que ganó el premio Lluís Carulla 2018.

\section{Xavier, ¿puedes recordarnos cómo fueron los inicios y la evolución de Difusor?}

Difusor es la entidad que creamos en el año 2006 como respuesta a una ordenanza cívica del Ayuntamiento de Barcelona en la que se prohibía pintar de manera libre en las calles de la ciudad. A partir de ese momento, nos pusimos a trabajar y a negociar con los responsables del municipio, con el objetivo de posibilitar que en Barcelona se pudiera pintar. Como la implantación de la orden era muy reciente, el consistorio no quiso ceder espacios de manera libre, pues suponemos que quería tener el control del flujo de actividad que se llevara a cabo. En la práctica, esta decisión supuso una externalización de facto de algo que, a la larga, debería acabar siendo un servicio para la ciudadanía, pero... ¡no vayamos tan rápido!

En aquel momento, pensamos que una manera de poder atender esta demanda sería a través de un sistema automatizado y anónimo, en el que el distrito en cuestión tuviera información de cuándo se realizarían las pintadas y en dónde, pero no por quién. A finales del 2007 pudimos abrir el primer muro. Desde entonces, hemos pasado por diferentes fases y proyectos para llegar al punto en el que nos encontramos actualmente.

En primer lugar, el festival Difusor 2007, que, como hemos apuntado, dio pie al primer proyecto piloto de habilitación de espacios para intervenciones artísticas en la vía pública, a través de un sistema de permisos on line, la Galeria Oberta. Barcelona fue pionera en este sentido, ya que en casi ninguna ciudad de Europa existía un sistema abierto y sistematizado de acceso a muros para pintar. En todas ellas tenías que hablar con alguna entidad o institución mediadora, lo cual suponía que tenían que aprobarte la propuesta previamente. En algunos casos, disponían de espacios de libre acceso, pero completamente desregulados. Dada la imposibilidad de habilitar este tipo de espacios en Barcelona, nuestra aportación fundamental fue crear este sistema de permisos on line, donde todo era mucho más rápido, más directo y más horizontal. Este proyecto estuvo operativo durante un par de años, del 2008 al 2011, en el perímetro del Parque 
de las Aguas, en el Distrito de Horta-Guinardó (Ballaz, 2019), hasta que cambió de ubicación y se amplió a tres distritos. Con este cambio, dejó la nomenclatura de Galeria Oberta y pasó a llamarse Open Walls.

Durante el proceso de creación e implementación del proyecto Open Walls, fuimos viendo el modo de gestionar la creatividad independiente en el espacio público de otras ciudades a través de las normativas y leyes existentes en cada lugar. Esto nos permitió plantear toda una serie de iniciativas que nos parecían relevantes a nivel internacional, con el propósito de hacer pedagogía en Barcelona. Nos estaba costando mucho desarrollar nuestros planteamientos y pensamos que, mostrando como se hacía en otros sitios, contribuiríamos a abrir el abanico de posibilidades en nuestra ciudad.

De este festival -la Open Walls Conference- se hicieron cinco ediciones. La primera tuvo lugar en el año 2011 y fue la más modesta. Con el tiempo, y a medida que el proyecto se iba consolidando, conseguimos pintar en gran formato. Para ello, tuvimos que poner en marcha toda una serie de protocolos previos, juntamente con el Institut de Cultura de Barcelona (ICUB), para poder estandarizar la información que cada distrito exigía a la hora de solicitar un proyecto, y que, hasta ese momento, era bastante dispar. Así pues, la labor que se realizó en el marco de la edición de 2014, bajo el nombre de Transversal, consistió en la organización de una serie de mesas de trabajo en las que participaron diversos agentes, como el ICUB, algunos técnicos de distrito y diferentes ayuntamientos y entidades, lo que permitió estandarizar la información que se pedía.

Las cinco ediciones del festival Open Walls Conference fueron bastante descentralizadas, pues en cada ocasión se buscaba trabajar en un distrito distinto. De este modo se favorecía la función pedagógica antes comentada, pero tenía el problema de que al público le costaba identificar el festival -y a Difusor- con una localización determinada. Esto lo resolvimos llevando la última edición, la del 2016, aquí, a la Nau Bostik, lo que nos dio pie a arrancar con el proyecto $B$-Murals, que actualmente es el que nos ocupa más tiempo dentro de la entidad.

\section{Háblanos del punto de partida y objetivos del proyecto B-Murals}

Cómo hemos comentado, $B$-Murals viene de la trayectoria de Difusor, del festival Open Walls Conference 2016 realizado en la Nau Bostik, que nos acoge y nos permite plantear un centro artístico de creación especializado en arte urbano, con diversos objetivos. Hasta ahora, aparte de los proyectos educativos, habíamos funcionado básicamente en el formato de festival, pero nos dimos cuenta que ese formato tenía una serie de hándicaps que creemos que, trabajando desde un espacio físico dedicado al arte, podremos ir resolviendo. En esta nueva etapa apostamos por actuar de una manera más pausada, por medio de unas residencias que permitan a los artistas invitados profundizar un poco más a cómo lo suelen hacer desde el formato de festival. Las diferentes líneas de trabajo de B-Murals pueden agruparse en tres:

Por un lado está el soporte a la creación, bien a través de residencias o a través de producciones artísticas de personas a las que invitamos, o mediante la realización de exposiciones de artistas que están empezando, que posiblemente han tenido una primera exposición colectiva, pero nunca una individual.

Los espacios que gestionamos en B-Murals, dentro de la Nau Bostik, nos permiten disponer de un espacio principal, que es el lugar de trabajo y también de exposición de la residencia artística, y de otro espacio polivalente o secundario, que se utiliza para otro tipo de muestras, y que ahora, por ejemplo, está destinado a la exposición "Videncia y evidencia", del artista valenciano Gambin Rot. Aparte, contamos también con los muros exteriores de la nave para la producción de toda una serie de intervenciones artísticas.

Después, hay toda una línea de transformación social. Se trata de un aspecto que ya habíamos venido trabajando desde los inicios de Difusor, aunque, como hemos dicho, con el formato de festival no era fácil articular proyectos con una cierta duración en el territorio. Desde $B$-Murals, esperamos que esta faceta mejore considerablemente, como ya lo ha hecho en los proyectos más sociales impulsados desde Difusor. De hecho, nos hemos acercado bastante a los resultados esperados en las dos residencias realizadas hasta la fecha. La primera se llevó a cabo en diciembre 2018, con el artista argentino Elian Chali, que trabajó conjuntamente con la Escola 30 Passos -que tiene su sede cerca de la Nau Bostik- y con la escuela de formación de educadores Bemen-3, planteando un proyecto didáctico para que niños de P5 experimentaran entorno el significado de la pintura mural. De esa manera, entendemos que estamos formando públicos, haciendo pedagogía sobre lo que es el arte urbano en el territorio, y estamos acercando la cultura, a través de los murales, a un barrio donde no existen tantos equipamientos culturales. Pero la idea no es solamente ser un referente educativo en temas artísticos en el barrio, sino también a nivel de ciudad, mediante propuestas educativas que, desde siempre, hemos impulsado desde Difusor, y que podrían tener una relación con B-Murals y su territorio. Así pues, dependiendo del proyecto o de la ubicación, las centraremos aquí, en la Nau Bostik, o las centraremos en el equipamiento con el que entonces estemos trabajando.

Por ejemplo, en relación a esta línea de transformación social en otras partes de la ciudad, sólo en el primer trimestre de 2019, Difusor ha realizado diversos proyectos formativos en la zona norte, a través del Plà de Barris, con una serie de actividades relacionadas con la temática de género. Se colaboró intensamente con una formadora especializada en el tema, que estableció toda una serie de dinámicas, de charlas y de debates con los alumnos del taller. Como resultado, se elaboró un fanzine realizado desde la perspectiva de género. Asimismo, el trabajo efectuado por 
los chicos y chicas del taller fue recogido por tres muralistas que crearon, junto con los alumnos, una serie de murales -uno en cada barrio- que reflejaban las reflexiones de estos chavales.

Más allá de la ciudad también se han llevado a cabo talleres para diferentes tipos de público, como alumnos de primaria y secundaria, principalmente.

Otro aspecto importante para nosotros es la reflexión, la creación de una línea de pensamiento. Estamos realizando comunicaciones y Podcast que se podrán consultar en la web, donde se recogerán, por ejemplo, todas las charlas que han tenido lugar durante las jornadas de presentación 'B-MURALS Festival \& Conferences', celebradas entre el 3 y el 8 de junio de 2019. También contaremos con la producción de un fanzine, que en estos momentos se está acabando de elaborar, que explicará la obra de la exposición 'Sobreexposiciones y Comisariados' del artista madrileño Ampparito, con la que B-Murals ha inaugurado estas jornadas. Este fanzine se ha efectuado con la colaboración del artista y del comisario de la exposición, Jordi Pallarés. Posiblemente algunas de las conferencias de las jornadas se publicarán en papel. Es nuestra voluntad ir creando un bagaje, un cajón donde poder recurrir a los temas que se vayan tratando, con la vocación de ser una base de datos, un fondo para pensar y reflexionar.

En resumen, el objetivo de B-Murals es consolidar un espacio de creación y reflexión sobre el arte urbano desde el barrio barcelonés de La Sagrera, con vistas a que pueda ser una referencia de toda la labor realizada por nosotros y/o propuesta por otros agentes del territorio, como las entidades, los vecinos y las escuelas del barrio. Y además, consolidarlo también como un centro de referencia mural del grafitti y de las artes visuales en el espacio público de la ciudad de Barcelona.

\section{¿Cómo se financia un proyecto como B-Murals?}

El proyecto B-Murals ganó, a finales del año 2018, el premio que otorga la fundación Lluís Carulla a proyectos de emprendimiento cultural, lo que ha supuesto un impulso importante para el equipo de Difusor. Esta dotación económica nos ha permitido arrancar y plantearnos la profesionalización, así como una cierta estabilidad y proyección de futuro con este trabajo. De todos modos, para tirar adelante un espacio de estas características y atender la infraestructura que necesitan las producciones que realizamos, los recursos procedentes del premio Lluís Carulla no son suficientes. La financiación recibida por la fundación, unos 60.000 euros (menos impuestos) deberá repartirse entre los 18 meses de duración previstos, pero, para ser sostenible, el proyecto no puede basarse sólo en eso.

Por esta razón, además, planteamos una propuesta de financiación a tres bandas: Una parte procedente de la financiación privada, principalmente a través de sponsors.
La firma Montana Colors SL, que se ha implicado desde un primer momento con Difusor, nos está ayudando también en este momento, convirtiéndose en nuestro principal sponsor. Pero estamos buscando la manera de incorporar a más patrocinadores, especialmente vinculados al territorio y al arte. Somos conscientes que debemos escoger bien con quién colaboramos, ya que nuestro trabajo está relacionado con el espacio público y es necesario mirar qué hacemos para que todo tenga sentido.

Otra parte sería la financiación pública, mediante subvenciones. La verdad es que estamos a la espera de la implicación del Ayuntamiento de Barcelona y del Departamento de Cultura de la Generalitat de Catalunya.

La última parte sería de aportación propia, a través del financiamiento que pudiéramos generar desde Difusor, con los proyectos que realizamos externamente. Ésta es una fórmula que pienso que equilibra un poco la relación de fuerzas y que nos permite a todos sentirnos cómodos y acompañados.

\section{¿Nos puedes comentar algunos aspectos particulares de las residencias de artista, las exposiciones y las intervenciones en la Nau Bostik?}

Está previsto que las residencias artísticas de $B$-Murals sean tres al año. La forma de acceso varía en cada una de las convocatorias. En la primera, $B$-Murals invita a un comisario externo, que se encarga de llevar la residencia del artista; en la segunda, el acompañamiento y gestión de la misma va a cargo de Difusor, y en el tercer caso, la elección del artista se produce a partir de una convocatoria con jurado.

El formato de las residencias es siempre, más o menos, el mismo: el artista viene a la Nau-Bostik, trabaja las semanas que necesita (normalmente de una a cuatro) y produce la obra, que posteriormente es expuesta y dinamizada a través de publicaciones, visitas y explicaciones.

Las exposiciones funcionan por convocatoria abierta. Este verano se lanzó la primera, para comenzar el ciclo a partir de otoño 2019, con una exposición que substituirá a la de Gambin Rot que hay en este momento.

Aún estamos decidiendo la manera de sistematizar el proceso de gestión de las intervenciones en el espacio exterior de la Nau Bostik, pues existe mucha demanda que nos está costando asimilar. En principio, la idea es poder ir invitando a artistas, pero siendo lo suficientemente flexibles para que si hay alguien que pasa por Barcelona y tiene interés en participar, o alguien de aquí que tiene un proyecto serio y necesita un espacio como éste para producirlo, poder facilitarle los muros externos de la nave para su intervención. En este caso, pretendemos que sea un espacio artístico que tenga cierta durabilidad y recorrido, a diferencia de otras paredes de Barcelona, donde los murales libres duran una semana o menos. 


\section{¿Pretendéis hacer una colección con todos los murales que tenéis en las fachadas de la Nau Bostik?}

Los murales que hay en las paredes exteriores de la Nau Bostik son efímeros. La idea es que tengan cierta durabilidad, pero no los conservaremos largo tiempo, ya que nacen con fecha de caducidad. Otra cosa son los murales que comisariamos en el espacio público de la ciudad.

¿Tenéis programada esta caducidad? Es decir, cuando un artista pinta un mural, ¿sabéis cuánto va a durar?

Posiblemente los murales tengan una duración de uno o dos años, aunque esto puede variar. Evidentemente, los situados a más altura, como el de Elian Chali o el de Sixe, tendrán más duración, pero no hay voluntad de mantenerlos a largo plazo. Dejamos abierta la posibilidad que la fachada se cubra una y otra vez.

¿Existe la voluntad de catalogar las obras que se van creando en este espacio exterior de la Nau Bostik?

Sí, hay un archivo y una base de datos sencilla, con una ficha y fotos, donde se refleja el nombre del artista, la fecha de ejecución y los materiales empleados. Normalmente esta documentación no incluye vídeos.

Hablemos del copyright y los derechos de autor... sabemos que el artista conserva siempre el derecho moral de sus creaciones, pero ¿cómo se gestionan los derechos de explotación en B-Murals?

Un gran tema... La Nau Bostik es un espacio un poco complejo, en el que, aparte de nosotros, hay más profesionales que trabajan en otros ámbitos: se hacen rodajes, sesiones de fotos, etc. A veces, la gestión del copyright se complica por este motivo.

Lo que estamos empezando a hacer al respecto es pedir a los o las artistas que firmen un documento a través del cual nos ceden los derechos de explotación, de modo que, cuando hay alguna oportunidad de explotar estos derechos, el interlocutor somos nosotros. Lo que se acuerde con quien desee hacer uso de esos derechos será hablado con una única entidad, Difusor, y no con 40 o 50 artistas diferentes -de lo que tendríamos que encargarnos nosotros-, lo que agiliza la comunicación y las posibilidades de viabilidad económica, sobre todo para la Nau Bostik, proyecto completamente autogestionado. En el documento que se firma, se establece un porcentaje que queda para la gestión del proyecto y otro porcentaje -que aproximadamente son tres cuartas partes del precio que se acuerde- para el creador de la obra. Por lo tanto, a través de la firma del contrato, el o la artista está en condiciones de recibir una compensación económica cada vez que exista un uso de explotación de su obra.

¿Cuál es el papel de las redes sociales en la difusión de este proyecto?
Este es un tema que tenemos que acabar de afinar. De $B$-Murals existe, aún en construcción, un sitio web, y también hay una página de Facebook y un perfil en Instagram. En estas redes, lo que aparece es la información relativa a $B$-Murals, y las noticias más relevantes también las replicamos en las redes de Difusor. En B-Murals aparecen todos los detalles de las actividades en la sede de la Nau Bostik, y en Difusor, los proyectos generales que realizamos. De todas maneras, como en Difusor tenemos muchos más seguidores, la idea es replicar allí algunas de las informaciones.

¿Realizáis visitas guiadas relativas al proyecto B-Murals? ¿Tenéis folletos 0 algún tipo de información para las personas que os visitan?

De momento, tenemos visitas guiadas bajo demanda. Establecimos un calendario de talleres familiares que se realizaban una vez al mes y en los que se explicaba un poco el proyecto. De manera parecida, tenemos el propósito de establecer un calendario para las visitas guiadas, pero, de momento, funcionamos a demanda.

En cuanto a folletos informativos, contamos con todo lo que se ha producido en relación a las exposiciones.

¿Qué piensas de la posibilidad de conservación de algunas creaciones murales comisariadas?

Como hemos comentado antes, dentro del proyecto $B$-Murals no nos planteamos conservar los murales, pero sí que lo planteamos en las producciones que quedan fuera de la Nau Bostik, en el entorno urbano. De hecho, Difusor ya ha comisariado algunos de los murales de gran tamaño, como "Panorama”, que Jorge Rodríguez-Gerada pintó para el centro cívico de Sant Martí, en el barrio barcelonés de La Verneda, durante la $4^{\mathrm{a}}$ edición de la Open Walls Conference. El mural se ejecutó con la técnica del silicato para asegurar una mayor duración en el tiempo, excepto los detalles, que fueron realizados al carboncillo, y evidentemente, la diferencia del estado de conservación de las dos técnicas se puede apreciar claramente. Por este motivo, con este mural sí que nos planteamos en algún momento retocar las partes más afectadas y volverlo a proteger.

La utilización de materiales adecuados que favorezcan la conservación de las obras es un tema delicado, porque hacer murales con idea de perdurabilidad es caro y requiere de unas condiciones de trabajo que no son a las que podemos acceder ahora mismo. Crear medianeras con esta cualidad requeriría, sobre todo, de una apuesta fuerte por parte del Ayuntamiento de Barcelona, que es quien después se queda con las obras y quien las puede rentabilizar. Por lo tanto, este cambio implicaría el hecho de que, poco a poco, vayamos accediendo a unas mejores condiciones de trabajo que nos permitan realizar murales con vistas a maximizar su durabilidad. Pintar con una pintura para exteriores adecuada, por ejemplo, o cuidar la preparación de la pared, dando un tratamiento previo, son algunas de las cosas que actualmente no podemos asumir en muchos de 
los proyectos que producimos o acompañamos, puesto que solamente contamos con los presupuestos procedentes de subvenciones para actividades culturales.

\section{¿Con qué crees que guarda más relación el proyecto $B$-Murals, con un centro de exposiciones, con una galería o con un museo?}

Los museos no suelen tener la rentabilidad económica como uno de sus principios. El proyecto B-Murals cuesta dinero $y$, por esta razón, hemos de encontrar maneras de rentabilizar la inversión, porque de lo contrario no sería sostenible. No podemos mantener el proyecto únicamente con un premio, que tiene una fecha de caducidad, con unos sponsors o con las pequeñas aportaciones que podamos ir haciendo nosotros a partir de proyectos propios.

Así pues, nuestra vocación es hacer un espacio que fomente la creación en unas condiciones adecuadas para los artistas, de manera que éstos puedan crear, pero que también esta producción artística tenga asociada una serie de dispositivos a través de los cuales podamos ir generando ingresos, como con la producción de obra seriada, o que alguna de las obras que forman parte de la colección se quede para el fondo del proyecto, y, en un momento dado, se pueda vender. $\mathrm{O}$ sea, buscar un modelo híbrido que nos aporte esos ingresos que necesitamos para la sostenibilidad del proyecto.

Ballaz, X. (21.06.2019). B-Murals: Dinámica Cultural y Arte Urbano en Barcelona [On-line] https://www.allcitycanvas. com/b-murals-cultura-y-arte-urbano-en-barcelona?fbclid= IwAR3N4VIPIjGTWXKQ-Rn93e3cHOCalxB5QXJDbDVpGFSY $\underline{\text { hZoUlc9n9ztZPGY }}$

Transcripción de la entrevista Nau Bostik (Barcelona), fecha: 5 de Julio de 2019. 


\section{Entrevista a EDUARD CRESPO y LAURA LARA gestores de PAREES FEST. Oviedo}

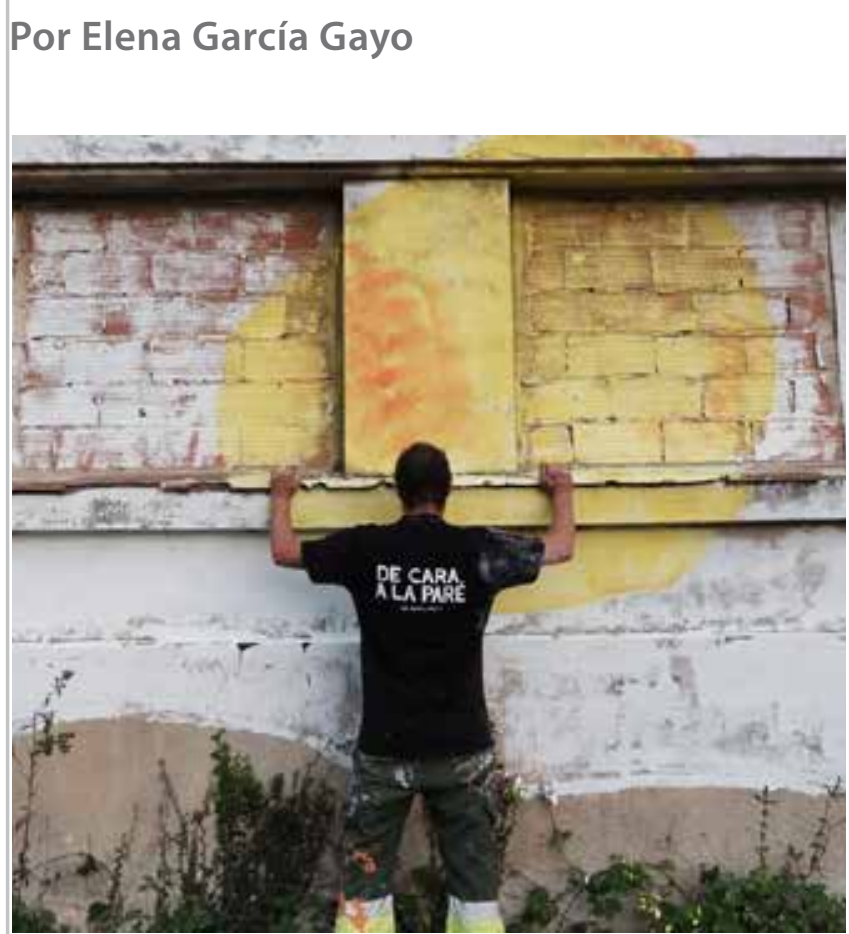

ENTREVISTA A LOS GESTORES DE PAREES FEST. OVIEDO. PROYECTO RELACIONADO CON EXPRESIONES ARTÍSTICAS DESARROLLADAS EN EL ESPACIO PÚBLICO.

Eduard Crespo. Diseñador gráfico. Coordinador general y Comisario de Parees Fest. Laura Lara, licenciada en Bellas Artes Coordinadora y Responsable de procesos creativos.

\section{¿Cómo fueron los comienzos de Parees Fest?}

Parees empezó tras un gobierno del PP de muchos años en Oviedo y que trajo un cambio político del que salió un tripartito de socialistas, IU y Somos Oviedo (Podemos). En la situación cultural de la ciudad, en aquel momento, se daba mucha importancia a la colocación de esculturas en el espacio público de personajes diferentes, a modo de monumentos y sin un hilo conductor definido. No había nada de pintura pero sí un cierto interés y como teníamos experiencia en este tema se presentó un proyecto para intentar cambiar esa situación.

La organización sale de Difusor, que es una asociación artística y cultural que surgió en Barcelona como reacción a la normativa de tolerancia cero que existía en aquel momento en el ayuntamiento y para encontrar vías de diálogo entre la institución y los artistas. Al poco tiempo, se empezaron a buscar muros para poder pintar, se hicieron convocatorias, charlas y conferencias sobre el tema y se estableció una negociación.

Todos los años se vuelve a presentar un proyecto que ha llegado a tener una dotación económica anual de 75.000€. Con respecto a los medios que se necesitan para llevar a cabo un proyecto de este tipo, se tiene muy en cuenta trabajar con empresas locales, asturianas.

\section{¿Entendéis esto como un proyecto de arte público?}

Las expectativas son trabajar para la ciudadanía con una nueva mirada a la ciudad, generar un diálogo e intentar ver, desde nuestro punto de vista muralista, lo que se puede aportar a la ciudad. Dependemos del apoyo del ayuntamiento para desarrollar esta faceta artística desde el punto de vista de servicio público.

Por eso, todos los murales están conectados con el territorio. Los hemos dividido en tres grupos:

- Muralismo Participativo, que tiene una relación directa con el territorio y sus pobladores, en el que el artista trabaja en contacto directo con el tejido social, vinculandose con los colectivos y los/as propios vecinos/as.

- Muralismo Contextualizado, que se caracteriza por crear una relación indirecta con el territorio y sus pobladores, son los que, tras proponer y explorar con el artista un tema vinculado con el contexto, entra en contacto con agentes locales vinculados a la propuesta. Con la información que nos facilitan y las reuniones, vía videoconferencia, entre los/ las artistas y estos agentes locales, se elabora el material que servirá de apoyo e inspiración para la elaboración del boceto.

- Y Muralismo Comunitario, que establece una relación directa y activa con el territorio y sus pobladores. Son murales en los que los ciudadanos se convierten en los propios creadores del mural de forma activa, dejando de ser simplemente usuarios del espacio público. A través del formato taller (se ha realizado Taller de Pintura Mural para familias y también Talleres de Pintura Mural para personas mayores) se crea un diálogo entre el artista y los participantes donde la autoría de la obra se convierte en colectiva. 


\section{¿Tenéis en cuenta la posible gentrificación posterior que se puede generar de vuestras acciones?}

$\mathrm{Si}$, se tiene muy en cuenta. Como elemento importante para evitar en cierta medida esa gentrificación nacida de los procesos culturales, son los mencionados procesos de conexión con el territorio. De manera que la ciudadanía se sienta vinculada e identificada con los murales, que formen parte del tejido social y los sientan suyos.

Esto facilita que se evite el muralismo gentrificante enfocado al turismo y a la ciudad como "Parque Temático". El Festival apuesta por un muralismo vinculado al contexto, que dé voz a la ciudadanía, que cree referentes identitarios y que narre parte de la memoria colectiva y la cultura popular.

Por otro lado, partimos de lo que podríamos llamar la Zona Cero, que es el centro histórico, dónde no se puede pintar, y a partir de ahí vamos buscando espacios en los alrededores. No importa la zona sino que podamos ir alternándolas. Algunos barrios son más amables para pintar y otros son más reticentes. Algunos tienen más medianeras que otros. Intentamos tener una noción visual del territorio sobre un mapa y desde ahí se equilibran las intervenciones. No nos fijamos en el estrato social dominante en cada zona, si es un barrio trabajador o residencial, sólo vemos donde hay espacios vacíos. Intentamos que queden repartidas las intervenciones y así esa posible gentrificación queda dispersa.

\section{¿Cómo se hace la selección de artistas?}

LapeculiaridaddelPareesFestsonsusprocesosparticipativos, y esto hace que se necesite hacer una investigación previa y delicada de cada artista, estilo y tendencia para que puedan encajar dentro de esos parámetros del festival. Se realiza una investigación y estudio constante de la tendencia muralística y se analizan a los/las artistas y su obra a fondo. Por otro lado, ponemos mucho en valor dar la oportunidad a artistas que no hayan trabajado previamente los grandes formatos murales. $Y$ también vincular la escena artística local y dar espacio a un/a creador/a asturiano/a.

\section{¿Cómo abordáis los temas referentes a la técnica y materiales? ¿La conservación y reutilización de espacios?}

Hemos hecho muros de pequeño y gran formato, los pequeños son vandalizados y se ha decidido hacer solo grandes. Intentamos investigar al máximo en materiales y cómo se aplican. Nuestra intención es que duren lo más posible y usamos cartas de colores garantizados sobre los que se aplican productos protectores, por ejemplo, del sol. Los muros no se reutilizan, alguno se pinta encima, si se ve la posibilidad. Los que quedan vandalizados a pie de calle han quedado así. No se ha solucionado. Vamos un poco sobre nuestra propia experiencia de tres años. Hemos comprobado que los colores con pintura plástica se conservan muy bien con el paso del tiempo. En estos tres años no ha habido cambios significativos.

\section{¿Hay expectativas de generar una documentación didáctica que se pueda llevar a espacios expositivos tradicionales?}

El arte mural sólo puede existir dentro del contexto donde se desarrolla, el espacio público. Por ello, por ahora no hemos sentido la necesidad de vincularlo con los espacios expositivos. Los procesos son intrínsecos a los murales, son su alma mater. Cuando ese proceso está bien planteado, se puede sentir y leer en el propio mural, por lo que no hay una intención de registrarlos y exponerlos.

Editamos un catálogo. En él se recogen las fotos de las obras, ubicaciones y se explica cada proceso con la intención de que se pueda entender de manera más profunda cómo se han hecho los murales. Sus anécdotas, quien formó parte y dar a conocer a los artistas.

Por ejemplo, nos parece muy interesante todo el proceso participativo que el equipo de Mediadoras diseñó para la intervención de Colectivo Licuado. El mural trataba el tema de la mujer en la música y la cultura popular asturiana. Para profundizar en ello, se convocaron reuniones con el Colectivo Nun tamos toes, grupo de mujeres pandereteras que cantan canciones reivindicativas con ritmos tradicionales y con el Colectivo de baile tradicional Folk Queer que bailando hace una revisión desde la perspectiva de género de los roles y papeles del hombre y la mujer en el baile asturiano. También pudieron conocer el Espacio del Centro Social La Llegra, vinculado a la recuperación y reivindicación de la cultura popular asturiana. Todas esas vivencias y encuentros dieron lugar al mural de Las Pandereteiras. O el mural de Olloniego sobre el tema de la minería. Olloniego es una localidad con un fuerte pasado minero, situada a $10 \mathrm{~km}$ de Oviedo. Por ello se eligió esa temática, un medio de vida que atraviesa la historia y forma parte de la identidad asturiana. Es interesante mencionar que esta localidad, ubicada en el epicentro del concejo en el que se circunscribe Oviedo, ha sufrido cierto abandono desde las instituciones en lo que se refiere al reconocimiento de la labor minera. Quizás por eso, es un territorio orgulloso de sus orígenes y sus habitantes se sienten muy identificados con la historia minera de su entorno. Por todo ello, valoramos que sería muy interesante realizar un mural que dejase recogida la historia minera del lugar.

\section{¿Qué es lo más importante, cuál es la esencia de Parees Fest?}

El proceso, sin ninguna duda, la obra final es casi una anécdota de todo ello.

Lo que da sentido a la iniciativa es el "desde dónde" los artistas generan esa obra. 


\title{
Entrevista a LUIS GARCÍA ALEMÁN Festival asalto. Zaragoza
}

\author{
Por Sandra García Melero y Carlota Santabárbara Morera
}

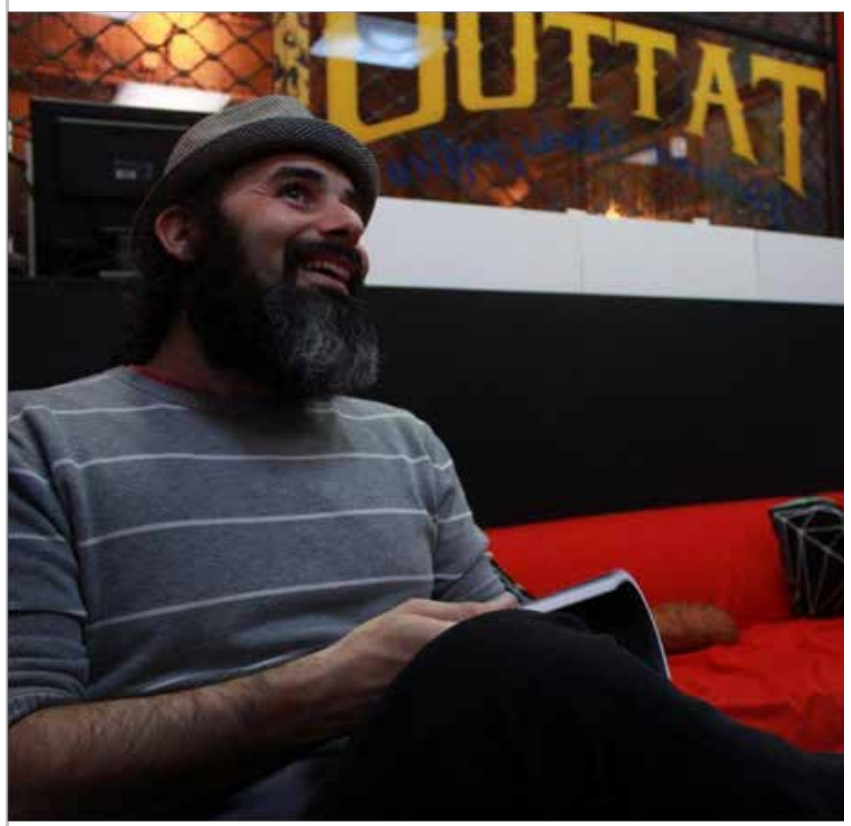

El grupo motor de Asalto somos cuatro personas: Alfredo Martínez, Sergio Beltrán, Isabel Tris y Luis Gracía, somos los cuatro diseñadores, nos conocimos diseñando. Sergio y yo nos conocimos en clase y por las noches salíamos a la calle y pintábamos juntos.

\section{¿Qué es Asalto y cuándo surge?}

Hacia el año 2000, cuando todavía no se hablaba del Street art, hacíamos vandalismo con mensaje, stencils. Conocíamos a gente del ámbito de la cultura, de la escuela de arte de Zaragoza y coincidió que se retomó desde el ayuntamiento de Zaragoza el Ciclo Frontera, un festival de arte contemporáneo que se hacía ya en los años 70 y 80 . En la primera edición del 2004, nos invitaron a hacer una intervención colectiva de arte urbano. Fue una valla publicitaria e invitamos a gente local y nacional del mundo del stencil, con carácter berlinés. Resultó bastante fresco, porque el resto eran vallas publicitarias impresas y pegadas. Ese fue nuestro primer contacto con Zaragoza cultural. La valla se titulaba "Válidos", una reivindicación del arte en la calle como arte válido igual que lo eran otras intervenciones artísticas en este ciclo. Tras esta experiencia, los comisarios y la coordinación del festival nos propusieron hacerlo pero a mayor escala, invitando a gente del arte urbano que intervinieran en otros soportes. $Y$ así surgió el primer Asalto, invitamos a gente sobretodo nacional o residente en España, como Boris Hopper. Se movían entre el graffiti y el arte urbano vandálico, pero buscábamos su parte más amable (vandal con tiza o con rotuladores en cosas más delicadas), nosotros no veníamos propiamente del graffiti, nos gustaban más estas cosas. Les parecía muy curioso que les invitáramos a intervenir en un festival de arte. Vino Suso, Zeta, Sixe... y chavales a los que invitábamos a pintar.

En la Segunda Frontera intervinimos en el edificio vacío de lo que ahora es Puerta Cinegia, a modo de "museo porque se trataba de un espacio interior, con artistas locales como
Enrique Radigales. Pero al traer a personas del arte urbano fue inevitable que se nos desparramaran por las calles, y pasó que en la calle Estebanes, sobre todo en los solares adyacentes empezaron a intervenir.

\section{¿Por lo tanto se trataban de intervenciones que de alguna manera fueron imprevistas?}

Imprevisto y descontrolado, primero porque tampoco queríamos controlarlo y segundo porque no había parámetros todavía. Vimos que era muy interesante lo que pasó en el edificio, incluso hubo performance con Tosen, pero nos gustó más lo que pasó en las calles. Por ejemplo, Boris Hopper hizo una instalación con cajas de cartón, que duró como hora y media porque el servicio de limpieza la retiró. Pero supimos que esa era la línea que nos gustaba, en la calle con cosas que duren o no. El festival gustó, y le acompañó una época boyante durante los años 2006 al 2008, Cultura y Ayuntamiento invirtieron dinero y estaban interesados en la frescura del proyecto Asalto. Fuimos cogiendo fuerza, en el tercer Asalto empezábamos a tener entidad propia pero siempre bajo el paraguas del festival de arte de la Frontera. Pasado 2008, hubo una hecatombe cultural y la Frontera desapareció, ese año el Asalto tampoco se hizo porque se concentró todo en la Expo del Agua del 2008. En 2009 realizamos el cuarto Asalto como programa independiente. Se realizó en las riberas del Ebro para reivindicarlas desde la ciudadanía un festival sin murales, más escultórico.

Al principio Asalto era muy naif, invitábamos a gente que nos gustaba, con ciertos parámetros estéticos e intenciones. No 
habíamos invitado nunca a gente del graffiti puro porque no había entendimiento y queríamos mostrar otras cosas. Poco a poco hemos evolucionado y visto que podían pasar cosas, nuestra dirección actual quince años después, consideramos el arte urbano como un método de transformación, no como herramienta, pero sí como una manera más de cambio.

\section{¿Consideráis el arte urbano como agente de transformación social?}

Sí, ahora primamos eso, obviamente son 15 años, siempre decimos que valoramos la excelencia artística porque al final es un festival de arte contemporáneo, pero si es un muro espectacular con una técnica increíble pero no satisface por las necesidades el entorno y el contexto, no dialoga con lo que pasa en la calle, no nos vale.

\section{¿Busca eso la externalización del Asalto a otros barrios que no son el centro?}

Eso fue a partir de dos vías. En primer lugar, es que llegó un momento en el que ya no quedaban muros en el casco histórico. Aunque las medianeras tienen cierto vacío legal y se pueden intervenir, también hemos hecho pequeño-medio formato. Con pequeño formato hemos tenido algún muro bajo la excusa de esta protección se llegó a borrar y a repintar de nuevo. Por el barrio de las Armas hay de Boa Mistura, por ejemplo. También hemos hecho mucha cosa efímera. Conocemos la problemática, pero fueron unos años en los que en Cultura había cierta permisibilidad. El casco histórico llegó un momento que estaba saturado de murales, era una zona fácil para intervenir porque era muy turística.

Comenzamos a hacer actuaciones en los barrios de San José, en la Arrabal, y empezamos a ver que la respuesta en los barrios era muy buena y lo agradecían, había más cercanía con los vecinos y los artistas, más diálogo, y nos gustó.

Antes de que llegara el siguiente cambio político, que tenían la idea de descentrificación, ya queríamos seguir con esta idea, que los barrios demandaban cultura y que se pueden generar cambios y actitudes, apostamos por intervenir en los barrios y el primero fue el barrio de Delicias.

\section{¿Cuáles serían por tanto los objetivos del Festival Asalto, La transformación social, esa honestidad con el entorno?}

Transformar como tal suena un poco pretencioso. Sabemos que el arte genera cambios y movimiento, en el barrio de las Armas sí que se ha notado ese cambio y ha durado en el tiempo. Intervinimos en un solar que se utilizaba para tirar escombros y que al tener narcopisos cercanos era una zona donde los heroinómanos se pinchaban, quisimos limpiarlo e intervenirlo con murales y ahora es un espacio transparente. Lo que generó que ciertas fundaciones solicitaran que no sólo fuera un solar vacío, los vecinos reclamaban un jardín o zona verde, y de ahí surgió el circo social. Quizás al final hubiera terminado pasando, pero lo limpiamos, lo pintamos y visualizamos este espacio. Esto para nosotros sí que fue un hito importante. Los drogadictos se desplazaron, los narcopisos siguen aquí. Por entonces, hace como 7 años, la heroína empezó a desaparecer de por aquí, aunque ahora está volviendo. En el barrio del Oliver también, gente de clase obrera, ven que merece la pena. Se dignifica, se desarrolla el orgullo de pertenencia, el poder explicar el barrio a través de los murales, del retrato de dos niñas del colegio, una gitana y una negra que juegan juntas... Sus vidas siguen igual pero su barrio es un poco diferente.

\section{¿Tenéis como objetivo concreto visibilizar a los artistas?}

Somos conscientes que nos hemos ablandado. Nos gustan artistas más potentes y duros de lo que a veces traemos, también por querernos adaptar a los espacios. Aunque hablamos con artistas top y siempre nos gusta tenerlos aquí, también apostamos por gente que despunta y que nos recomiendan, y nos ha ido bien. Teníamos aquí a Scif o a Blu cuando empezaron, el poder tener ese buen contacto hasta ahora, siendo que han llegado a lo más alto, es muy valioso. Hay que apostar por gente y forzamos a que los artistas pinten todos en la misma semana, así se generan relaciones entre ellos y un artista joven pueda comer y preguntarle al Niño de las pinturas. Nosotros lo habríamos agradecido en nuestro momento. De ahí viene también la pregunta de ¿y los artistas locales emergentes? Nos volvemos locos, porque para ser una ciudad con el festival más veterano de España, no hay artistas urbanos. Intentamos y luchamos por rescatar a gente del graffiti más de nuestra quinta, porque los jóvenes que pintan graffiti ahora son otra cosa.

\section{¿Cómo Isaac Mahow?}

Isaac viene del grafiti pero estudió diseño con nosotros y tiene una mentalidad diferente. Esa quinta, gente que realmente quiere probar cosas nuevas. La gente joven con la que estamos trabajando ahora casi todos vienen de la ilustración. Pintar en la calle engancha y es gente creativa pero no hay cantera, no se experimenta. Para eso abrimos La Galería urbana, pero fracasó estrepitosamente. Tenemos un festival que puede abrirnos puertas, pero no hay cantera. Con Mebes colaboramos en una edición, coincidimos en Madrid también en Mulafest, hay buena relación. Una vez a través de una intermediaria le invitamos, pero se vio un poco abrumado.

Algunos artistas nos han dicho que no al festival por cuestión de calendario, aunque con Blu nos pasó que rechazó la invitación porque ya se había salido de los circuitos de festivales, no quería saber nada del tema. Le gusta que le hayan respetado las obras aquí pero con cariño nos dijo que no quería volver, ahora huye de lo mediático.

\section{¿Cuál es la subvención del proyecto y las colaboraciones?}

Los primeros años éramos parte de un gran festival que tenían un gran presupuesto. Nos asignaban una cantidad para que invitáramos a los artistas que escogiéramos. Por entonces a los artistas se les pagaba siempre los gastos aunque en la primera edición no se les pagó por realizar las obras, a partir 
de la segunda y tercera ya sí. Sin tener ni idea ni cómo ni cuánto. Había dotación para ello. El festival es el 90-95\% el Ayuntamiento de Zaragoza.

En cuanto a las colaboraciones privadas, tan sólo patrocinio en especias. Las marcas como Montana ${ }^{\circledR}$ nos esponsoriza desde los inicios con material. Las grúas no son patrocinios, a veces te pueden dar un par de días extra pero, aunque nos consta que en otros festivales sí que patrocinan, en este caso no. Suelen ser sobre todo las casas de pinturas, que nos regalan mucho material o nos lo dejan a precio de coste. Ha habido años que sí que han entrado marcas específicas, un año una marca de zapatillas, otro Eastpack ${ }^{\circledR}$, porque nos traía a algún artista. También si quieren más visibilidad en el festival, cómo incrustar un logo, sí que es por un feed pero normalmente nos puede llegar para cubrir cuestiones como las visitas guiadas o bolsas. El $90-95 \%$ es institucional. En el momento en el que el rumbo político cambie, no habrá Asalto. La gente nos dice que ya tenemos mucha entidad y que políticamente sería un riesgo no continuar, pero nunca se sabe, pueden bajar mucho el presupuesto. Es nuestra incertidumbre y nuestro miedo, que dependemos de la institución.

\section{¿Y qué nos puedes contar de Asalto en Alfamén?}

En Alfamén estamos trabajando directamente con el alcalde, él fue el que nos llamó. Reside en Zaragoza y le gustó mucho la transformación del Gancho. Nos pidió presupuesto y lo propuso en el Ayuntamiento y salió para adelante. Este ha sido el tercer año aunque parece que no va a continuar porque ha habido cambio político bastante radical. Aunque el pueblo está encantado y esperamos que pueda hacer presión.

Otros pueblos se han interesado también al ver el ejemplo de Asalto en Alfamén pero muchos no cuentan con que se necesita un presupuesto para ello. Este ejemplo es muy enriquecedor, los artistas viven en el pueblo con los vecinos, incluso en sus casas. Se genera tal sinergia que las despedidas son duras.

El primer año que estuvimos en Alfamén coincidió que también estuvimos en Fuendetodos, aunque había poco presupuesto. Cosas sueltas nos van pidiendo, como un skate park pequeño, más una labor de comisariado. Aunque entre este año y el que viene va a salir algún pueblo más.

\section{En relación a esto todas las polémicas que surgen en barrios como Lavapiés, que el arte urbano o el muralismo gentrifica}

Eso es muy "neoliberal", quejarse al artista y no al que te sube el alquiler. Conocemos casos como el de Miami de cómo a través de murales han arrasado toda una zona y desplazado a los vecinos para crear un nuevo barrio lleno de hoteles.

\section{Volviendo a lo general, ha habido en general aceptación, pero también rechazo}

Sí, el rechazo generalmente ha venido puntualmente por gente muy radicalizada que todo le parece mal o gente del grafiti puro y duro, sobre todo los primeros años. Al fin y al cabo, estamos trabajando en su contexto y espacio, y lo estamos legalizando, colaborando a que esto sea cultura mainstream, lo ven como un intrusismo de gente que no viene del grafiti puro. Al principio, éramos los "modernos" y firmaban encima de los muros pero poco a poco esta gente madura y les traes artistas como Cris Mcabe que viene del grafiti y que tiene un modelo de spray con su nombre, que lo han visto en las revistas y eso genera respeto.

A nivel social de rechazo de los vecinos ha ocurrido pocas veces y de manera anecdótica. Un mural que tuvimos que borrar, la araña de Smithe. Una vecina en contra, con toda la comunidad a favor. Costo más repintar la pared que lo que había costado traer al artista de México. A nosotros nos gustó a nivel mediático, el apoyo y el revuelo que se montó por borrar una medianera. A partir de ahí muchas comunidades se preocupan de qué pasa si hay que arreglar la fachada, como lo que ha pasado con el mural de Rosh, realmente siempre que pintamos partimos con que lo que queremos es que dure por lo menos un mes, tampoco pensamos en que dure para la eternidad. En este caso se tenía que restaurar la fachada y ya está.

¿Cuáles son los requisitos mínimos para participar? ¿Buscáis a los artistas o son ellos los que se ofrecen?

Ha habido de todo, sobre todo había ediciones en las que abríamos convocatoria, por ejemplo, intervenciones escultóricas en la calle, así descubres cosas nuevas, como nos pasó con Ampparito, algo muy diferente. Después cuando empezó a crecer el Asalto llegaban muchas, y había un gran trabajo de criba, así que decidimos cerrar las convocatorias. Sobre todo, empezamos a trabajar más partiendo del muro concreto y comisariado para escoger qué artista encaja más ahí, no abrir una convocatoria. Lo bueno es que al día podemos recibir como 5 propuestas, muchas de latinoamericanos que quieren de cara al verano hacer la gira por Europa. De ahí vamos guardando los que nos van interesando. Ahora trabajamos más el comisariado, por ejemplo, en frente de ese cole quieres que haya algo muy colorista y blandito, ya sabes a qué artista buscar. Si necesitáramos algo diferente sí que abriríamos convocatoria porque no conocemos a toda la gente que pinta, hay artistas muy interesantes por descubrir.

A la hora de valorar, el primer corte es estético, pero no es el $100 \%$. Hay artistas que estéticamente no son la locura, pero sí que van a trabajar muy bien con los chavales por ejemplo y les va a satisfacer y aprender, como un docente. Las propuestas te entran por los ojos, y luego analizas la metodología y si te gusta, adelante.

\section{Directrices externas para hacer colección ¿Os marcan desde el ayuntamiento alguna línea a seguir?}

No, pero se están dando cuenta sobre todo en ferias europeas que, cuando se les acaban los argumentos clásicos turísticos, 
sacan el as del festival Asalto. Hablándolo con una técnica de turismo, del plano del festival Asalto ha desaparecido mucha obra, como el 70\%. Desde Cultura no nos han dado nunca directrices, pero ahora se dan cuenta desde Turismo que se está perdiendo mucho patrimonio, que seguimos defendiendo que somos una ciudad con muchos murales, pero ya no queda tanto. Hay murales muy bonitos en barrios periféricos, pero claro, esto es más incómodo para el turista. Yo creo que si se pusieran las pilas van a empezar a darse cuenta de que hay que volver también al centro. Los murales de aquí están ya muy deteriorados, el de Blu antes tenía color y ahora es blanco (tiene 15 años), el de Ino está velado ya.

\section{En cuanto a murales o intervenciones de otra naturaleza}

Lo efímero, en el momento en el que queda registrado de manera fotográfica o por video, si desaparece ya ha quedado para incluirlo en un catálogo o en la web.

\section{¿Copyright? ¿los artistas conservan la propiedad intelectual de las obras?}

Desde nuestro punto de vista, obviamente. Contractualmente no firmamos nada a ese nivel.

No nos ceden derecho de reproducción de sus obras, pero nunca lo hemos pedido, no nos parece honesto. Por ejemplo, el mural de Boa Mistura del Pilar fue un símbolo para la comunidad Erasmus, nos pidieron poder hacer camisetas con el, les preguntamos a Boa Mistura. La cosa es que no sea pecuario, no nos parecería tan bien si se quieren hacer postales para vender. Siempre recurrimos a ellos porque tenemos claro que, aunque una obra la recibe un cliente siempre será la propiedad intelectual del artista.

\section{¿Cuál es el uso de las redes sociales del festival Asalto?}

Dadas de altas tenemos Facebook, Instagram y Twitter, aunque lo que más se usa es Instagram. En el mundo de hoy y audiovisual Instagram funciona muy bien. Facebook hay una horquilla de edades más jóvenes que ya no lo usan y Twitter sobre todo se mueve mucho durante el evento.

\section{¿Hay visitas guiadas, folletos, etc.?}

$\mathrm{Si}$, las visitas guiadas tienen mucho éxito. Son grupos pequeños y se agotan enseguida. Al principio surgió porque lo demandaba la gente, ahora ya contamos todo el proceso, mucho más.

Estas están abiertas a todo el mundo, pero por ejemplo si estáis en un barrio concreto, hacemos visitas con los propios vecinos, muchas veces con las asociaciones de vecinos, con los colegios...

La visitas siempre se ciñen al momento del festival, aunque durante el año también surgen a centros educativos por encargo. Un año también decidimos abrirlas durante un tiempo a ver cómo funcionan, pero creemos que merece más la pena durante el festival, no tienen tanto tirón durante el año, aunque quizás con una campaña publicitaria más potente sí.

¿Os ha hecho alguna propuesta desde Turismo de Zaragoza, tal y como tienen otras rutas, introducir esta?

No, están contentos repartiendo mapas. Nos consta que se hacen visitas guiadas un poco piratillas, pero bueno, están en la calle, mientras no te inventes mucho la historia... Más que por rentabilizar lo vemos como una forma de mantener el interés por el arte urbano en Zaragoza fuera de las fechas del Asalto. Es algo que tenemos pendiente y ver si lo regularizamos o no.

El coste de las visitas contempla lo que nos cuesta la guía y las bolsas que se obsequian.

\section{¿Os habéis planteado colocar códigos QR en los murales?}

Si, de hecho, el fenómeno cartela en el séptimo festival ya lo hicimos. Alguna queda, muy analógica. A nivel tecnológico sí que llevamos tiempo pensando en ofrecer algo que al pasar te aporte información, sobre murales que ya no están, etc. Llevamos fantaseando con eso muchos años, incluso nos han llegado propuestas de mapas interactivos, pero nunca ha terminado de cuajar. Es interesante pero también hay que gestionar qué información se da, controlar muchas cosas.

\section{En cuanto a la conservación, ¿qué materiales utilizan los} artistas? ¿os planteáis que sean duraderos?

Los gestionamos y se los conseguimos nosotros. Buscamos la máxima calidad para exterior. Sobre todo, en los últimos años (antes pintabas con lo que podías), preferimos prevenir que conservar. Preferimos con brigadas profesionales preparar bien la pared, imprimar y aplicar materiales de máxima calidad y que dure lo que tenga que durar.

\section{¿Trabajáis con pinturas al silicato?}

No, casi todo a día de hoy es imprimación con una especie de látex para tapar el poro y en algunos como el de Aryz que damos un anti vandálico al final, un barniz que se queda mate. El pigmento del spray no dura nada, así que en ocasiones le damos protección UVI.

\section{¿Veis que los artistas se preocupen por el tipo de material} y su conservación?

Por lo general les interesa sobretodo que corra bien la pintura y que cubra. En muchas ocasiones incluso venden obra, pero no se preocupan de si va a perdurar en el tiempo. Algún artista si, Elian (argentino) por ejemplo se preocupa de las obras que vende, pero no tanto de las que hace en la calle. Suelen dar por hecho que es efímero, unos porque entienden la situación de lo efímero y otros porque en cuanto tienen una buena foto ya no les importa lo que pase.

¿Hay algún seguimiento de la conservación de los muros? ¿Hacéis seguimiento fotográfico de la conservación? 
Por ejemplo, en el mural de Ino sí que hubo seguimiento porque el artista había experimentado con pintura negra de calidad, pero en forma de veladuras muy diluidas, y quería saber su conservación para seguir utilizándola o no. Michel Wert con el que hemos trabajo en los depósitos de Ámbar, más o menos trabaja en estos tonos pero también tiene grises (mezcla con blanco). En este proyecto, al ser comisariado tiene un tratamiento más exhaustivo para que dure en el tiempo, barniz, antioxidante, los negros son de muy buena calidad con tinta china... También pensamos que el conservar o restaurar una obra es mucho más costoso seguramente. Nosotros nos basamos en la experiencia que tenemos y en ver qué materiales han durado más a lo largo del tiempo.

\section{¿Realmente no hay interés en la conservación?}

No hay preocupación. Interés sí que hay en ver qué materiales se conservan mejor. Queremos que perduren lo más posible y dentro de naturaleza.

¿Tenéis un Top 10 de murales que os gustaría o tenéis interés que se conserven? Por ejemplo, el conejo de Roa o el Blu...

Más que nosotros es el barrio, por ejemplo, con el conejo. Por un lado, nos parece interesante como la ciudad, que es un ser vivo se coma las cosas. Podemos llamar al año que viene a Roa y vuelve y tendremos otras cosas. Sí que es cierto, tuvimos este debate en Valencia con los del Poliniza, que una vez que dejas ahí la obra de quien es. Nosotros queremos que dure más, pero si desaparece no pasa nada, el artista muchas veces piensa igual, pero ¿qué pasa cuando el vecino o el barrio considera que ya es un icono y que no puede desaparecer?

\section{¿Habéis decidido o planteado en alguna ocasión repintarlos?}

Hemos repintado en una ocasión porque fue nuestro único fracaso como comisarios. En este mural de las armas donde hay una calavera de Boa Mistura, el año anterior vino un artista griego que lo que hacía era espectacular pero aquí vino de vacaciones, a experimentar y dejó una cosa que no era ni de certamen de iniciación de centro cívico, muy por debajo del nivel del festival. En tal caso se borró.

Pero el artistas nunca volvería a repintarlo para recuperarlo, casi preferimos que blanqueara el muro y que hiciera otro. Porque no somos nada melancólicos en ese aspecto, las cosas tienen su ritmo y su proceso. Si la obra desaparece, desaparece, esto es una cosa que está en la calle. Nosotros cuando empezamos con esto veníamos del mural del MACBA, que de un día para otro cambiaba entero, venimos de esa cultura. Muy del graffiti. Lo vemos muy natural y también lo contrario muy conservador.

\section{¿Os opondríais si la comunidad de vecinos decidiera restaurarlo?}

Ahí hay un debate, si quiere la comunidad de vecinos para nosotros es un encargo. Ya no es un festival de arte urbano, son ellos los que encargan que quiere algo concreto, algo que también hacemos. Si es la institución la que pone el dinero sí, si es la comunidad de vecinos sería ella quien tendría que buscar la financiación.

Consideramos que ya no es un asunto del artista, de hecho, seguro que Roa no lo repintaría. Depende del perfil, Boa Mistura empatiza mucho con el entorno y con la gente y lo haría por el cariño, pero otros como Roa diría que "te pinto otro donde quieras"

En cuanto al concepto museo-galería, ¿podrías relacionar Asalto con un museo, un centro de exposiciones o una galería?

Se han hecho exposiciones efímeras, con obras que se han perdido o que permanecen bajo capas que se han ido superponiendo de pintura. Asalto no tiene una intención de permanencia como sí lo tiene un museo que conserva una colección. En ocasiones sí que nos hemos referido a Zaragoza como un museo de arte urbano, pero es mero lenguaje, en esencia no es nuestra intención. Nos gusta más la idea de "patrimonio". En un momento dado en el Casco Antiguo había una gran cantidad de murales y daba gusto pasear.

Con respecto a la investigación, catalogación, generáis información ¿la almacenáis, guardáis, archiváis?

Si, en todas las ediciones generamos un catálogo impreso para conservar la memoria. En un principio era para darle empaque al proyecto, entidad, como actividad artística. Es cierto que hasta los últimos años no nos hemos tomado muy en serio en generar buen archivo fotográfico, pero nos gustaría hacer algo especial y recoger las ediciones en un catálogo.

\section{¿Qué opináis de musealizar el arte urbano?}

Generar rutas, cartelas, sensibilizar, informar del mensaje de los murales, eso nos gusta. El proyecto es muy personal y familiar, y transmitir lo que pasa en el Asalto nos resulta muy difícil. Los que hacen las visitas guiadas son siempre personas que viven todo el proceso del festival, que están dentro. En la calle a ese nivel me parece interesante (la primera vez lo vi en Lisboa). Pero esto es arte contextual, no tiene ningún sentido meterlo en un museo. Ya no sería arte urbano. Coger obras de la calle y meterlas en un museo es una aberración. Coger la técnica o el artista que haga obra para un museo es interesante pero ya es otra cosa. Un espacio museístico te permite hacer lo que quieras, en la calle muchas veces estas limitado por el muro el entorno...

\section{¿Pero siempre con carácter efímero o también generar obra que perdure para coleccionar?}

Nosotros mismos tenemos bastantes obras originales, pero no lo consideramos arte urbano. Son obras generadas por artistas urbanos de los que su universo visual nos parece interesante y nos gusta. 


\section{¿Consideráis las obras de arte urbano del Asalto, arte contemporáneo?}

Sí en cuanto a la temporalidad. Ahora se dice mucho el nuevo arte contemporáneo... Esto es un debate muy largo. Muchos no tienen una formación artística y otros vienen del graffiti puro y duro, mucho abandonan muy frustrados, las escuelas de bellas artes porque les encorsetan por su academicismo y terminan por dejarlo. Es muy generoso decir que todo lo que hay en la calle es arte. Yo vengo del diseño, Cruz Novillo decía que el diseñador ve la diana y tira el dardo al centro de la diana, y el artista tira el dardo y luego pinta la diana alrededor. Para mí el arte urbano puro y duro, el street art, tiene que buscar algo más que el hecho artístico o satisfacer tu ego artístico.

\section{¿Tiene que ser activista?}

Si, llámalo activismo. Digamos que cierto activismo o "solucionar" cierta problemática mediante herramientas artísticas, un poco lo que hacemos los diseñadores, utilizamos la composición, el color, para solucionar algo, para mi ese es el arte urbano. Como venimos del diseño quizás le vemos esa vinculación estética. Si viene un artista y hace una obra en la calle que es muy artística pero que solo le interesa a él, pues no lo consideramos arte urbano. Para mí en el momento en el que un mural tiene un carácter social, se relaciona con el medio, ahí ya no creo que sea solo muralismo, lo considero arte urbano. Somos peculiares en relación a otros festivales, no buscamos el mural porque sí.

\section{¿Cómo ha cambiado el festival desde sus inicios?}

Ya no existe tanta sorpresa, y nosotros sí que seguimos buscándola, si no hay activismo o relación, o un espacio singular o colectivo determinado, con el entorno es difícil que siga sorprendiendo. Si no es así, es un barrio con muchos murales y ya está.

En el tema de paridad, por ejemplo, el año pasado casi lo conseguimos. En el mundo del muralismo hay mujeres pero en menor porcentaje y suelen estar muchos más solicitadas. En Latinoamérica hay un festival sólo de mujeres.

El festival Asalto se ha consolidado como uno de los festivales de arte urbano nacionales con más trayectoria en el panorama nacional, ampliando sus miras al ámbito rural siguen valorando la intervención plástica en el espacio urbano como agente de transformación social y diálogo, más allá del mero decorativismo imperante hoy en día en otros proyectos artísticos similares.

Entrevista

Fecha: 29 de mayo de 2019 


\title{
Entrevista a ANTONELLA DI LULLO
}

\author{
Por Jordi Pallarès
}

ENTREVISTAS PARA EL ARTÍCULO:

MUSEIZAR EL ARTE URBANO. PREGUNTAS, RELATOS Y COMPLEJOS TRAS STREET ART-BANKSY \& CO.

Antonella Di Lullo Comisaria romana con una amplia experiencia en festivales y proyectos de arte urbano indoor y outdoor. (correo electrónico el 25-8-19)

https://www.out-door.it/ [consulta 4-11-2019]

https://www.artribune.com/attualita/2013/09/street-art-a-roma-parte-loutdoor-festival/ [consulta 4-11-2019]

\section{Cosa ne pensi di «la città come museo» con riferimento alla Street Art? Cosa succede si un'opera de quelle che si mostrano scompare o non rimane come prima?}

Negli ultimi tempi il rapporto tra street art e città è profondamente mutato: nei primi anni del nuovo millennio, in moltissime città sparse per il mondo, gli interventi artistici legati a questo movimento si sono susseguiti e moltiplicati velocemente, con tempistiche e modalità differenti. Le periferie delle città, luogo prediletto di questa pratica, sono diventate famosi musei a cielo aperto. I muri hanno mutato il loro colore, fino ad allora stabilito da delibere comunali, attraverso la creatività degli artisti che di volta in volta si approcciavano a essi. La definizione "città come museo" potrebbe quindi essere calzante: basti pensare ai numerosi quartieri trasformati in art district in tutto il mondo, ma nello storytelling contemporaneo il termine è stato talvolta abusato, quasi anche per dare una legittimazione a quello che stava accadendo. A mio parere quello che è mancato, rispetto alla dimensione museale, è la funzione didascalica in loco. Molto spesso i muri non sono sufficientemente accompagnati da importanti informazioni, quali ad esempio il nome dell'artista e l'interpretazione dell'opera. Questa mia considerazione potrebbe sembrare molto accademica, ma spesso le opere di street art sono indissolubilmente legate al luogo, lo raccontano e lo enfatizzano. Perciò se esso non viene raccontato si rischia una lettura puramente estetica e superficiale.

La percezione comune fa riferimento a quegli anni di inizio secolo perché in essi vi è stata una veloce diffusione del fenomeno che ha permesso al grande pubblico e al cittadino di imparare a conoscere questa forma d'arte, gli artisti, le loro pratiche e le loro terminologie. Seppure sia passato un tempo relativamente breve, mi sembra che l'attenzione verso i muri (e si badi bene non verso la street art) si sia affievolita in favore di altri progetti e grandi mostre -più o meno discutibili- che attraggono il grande pubblico verso i musei.

In generale non ho più la percezione che avevo fino a qualche anno $\mathrm{fa}$, di continui cantieri che celano la realizzazione di grandi muri. Noto che molti artisti della scena si sono spostati verso altri lidi: progetti diversi, sicuramente più ambiziosi e sperimentali. Questo non vuol dire che la pratica del muro sia finita o che gli artisti abbiamo perso interesse verso di esso, ma che ora hanno nuove possibilità di confrontarsi con superfici, materiali e progetti eterogenei. Con un riferimento diretto alla città di Roma, dove vivo e continuo a lavorare come curatrice di diversi progetti tra i quali l'Outdoor Festival, posso affermare che la pratica della realizzazione di muri si sia molto ridotta, dopo aver ricevuto un'attenzione da parte del pubblico e delle istituzioni molto alta.

Quello che ho sicuramente notato è che gli artisti dopo anni di pratiche legali, cioè muri più o meno commissionati, sono tornati a "lavorare da soli", o hanno implementato nuovamente questa pratica, con interventi per lo più di poster art, quindi di ridotte dimensioni e di veloce affissione, in punti più o meno strategici e assolutamente illegali. Quasi una risposta, un reset completo, o meglio, un tornare alle loro primissime esperienze. Opere quindi effimere e temporanee, destinate a scomparire. Anche se in generale questi aggettivi appena citati fanno parte del vocabolario della street art, per diversissimi motivi questo tipo di opere scompaiono: il palazzo su cui è stata dipinta un'opera viene demolito, le vernici utilizzate non reggono il passaggio del tempo e quindi l'opera si deteriora. L'artista stesso ha pensato l'opera come effimera, oppure per risposta ridipinge il suo muro. Infine le opere possono scomparire per motivi che stento a digerire come puri fini commerciali con lo stacco delle opere dal muro oppure per censura politica o religiosa. E' un'arte molto veloce nella sua genesi, nella sua realizzazione e nel suo consumo, possiamo solo mestamente consolarci con le testimonianze fotografiche, anche se chi lo dice che anche questa pratica non sia parte insita del movimento?

Si parla tantissimo adesso di musei di Street Art, cosa ne pensi di questo concetto? Gran parte di questi musei sono privati. Pensi che le istituzione pubbliche hanno l'obbligazione e I'sfida di raccontare questo fenomeno dal museo a i cittadini o è meglio lasciarlo nel suo stato «urbano»?

Lavorando da diversi anni a stretto contatto con numerosi artisti, quello che è emerso, durante confronti e costruzioni di progetti, è stata la costante necessità da parte di questi ultimi di esprimersi qualunque fosse la superficie e lo 
spazio a loro disposizione. Soprattutto con l'esperienza dell' Outdoor Festival, a partire dal 2014 in poi, quando il festival si è trasformato: dopo 3 edizioni in strada e numerosi muri realizzati, abbiamo avuto la necessità di confrontarci con spazi chiusi da tempo, custodi di una storia ben precisa che emergeva e che aveva la necessità di essere raccontata. $\mathrm{Ci}$ sembrava che la strada non fosse più sufficiente. I supporti, i materiali e i luoghi potevano essere illimitati per lo sviluppo di un'idea. Riflettevo inoltre su quali sarebbero potute essere le diverse evoluzioni di questo movimento, dove si stava andando e come poteva essere raccontato il periodo appena trascorso. Portare in spazi chiusi queste pratiche artistiche per me significava portare una certa attitudine all'arte e al lavoro che accomuna questi artisti. Per molti di loro trovarsi in grandi spazi chiusi dove le pareti invece di una erano quattro rappresentava una sfida che tutti volevano affrontare e con la quale volevano confrontarsi.

Per quel che riguarda il «contenitore» museo, in questo periodo a mio avviso deve affrontare delle sfide e porsi degli obbiettivi ben precisi nei confronti del pubblico e dell'arte che contiene e che vuole sostenere. $E^{\prime}$ un discorso che a mio parere si deve applicare a tutte le tipologie di museo contemporaneo. Se da una parte il museo non può certo dimenticare la sua funzione divulgativa, deve contemporaneamente essere promotore e sostenitore di nuovi artisti e progetti. E' proprio tra questi tre poli - storico, di ricerca e di promozione-che il museo deve oggi trovare un suo bilanciamento. Nello specifico per quei musei dedicati alla street art, non sono contraria. Sicuramente sembra paradossale portare all'interno opere prelevate dalla strada se non per i soli scopi di conservazione e divulgazione. Chiaramente le modalità devono essere chiare e concordate con l'artista. E' certamente un argomento che porta con sè numerosi questioni aperte, dubbi ed interrogativi sulle modalità di azione.

I musei sia privati che pubblici in questo preciso momento, a mio parere, devono quindi lavorare sulle due direttrici apparentemente divergenti: da una parte non devono dimenticare la storia del movimento, ponendosi delle domande sulla sua evoluzione e approfondendo i nodi principali della sua storia, come ad esempio il fatto che in un certo periodo molti artisti si siano trovati in strada con la medesima voglia di esprimersi nello spazio pubblico. Sicuramente un obbligo ed una sfida. Senza dimenticare il lavoro di numerosi fotografi e video maker che hanno saputo raccontare quello che stava accadendo (in moltissimi casi anche gli artisti stessi che hanno fotografato le loro opere); quello che abbiamo oggi a disposizione è un immenso archivio che può raccontarci delle storie. Bisogna solo saperlo interrogare. Dall'altra i musei devono saper sostenere il lavoro degli artisti, facendosi promotori e finanziatori di progetti e sperimentazione, cercando di capire e intuire la direzione di questo movimento e quali saranno le sue evoluzioni future. Deve sapere cioè racchiudere al suo interno il passato, il presente e il futuro del movimento, non ponendosi come statico contenitore, ma sottolineando e promuovendo la dinamicità di questo contenuto.

La street art e il movimento del writing, in un preciso momento, hanno beneficiato dell'evoluzione e della diffusione di internet: piattaforme social volte alla condivisione, che hanno permesso la diffusione di artisti, opere e pratiche in ambiti talvolta distanti da essi. Dallo schermo del computer ci si poteva comodamente meravigliare dei muri che venivano dipinti nell'altro capo del mondo, si poteva conoscere nuovi artisti e le infinite sfumature che questi due movimenti avevano al loro interno. La reale problematica che questo fenomeno ha portato è stata quella di una esposizione troppo superficiale delle opere: il contesto circostante in moltissimi casi non veniva menzionato, e scompariva appiattendosi, sembrando un muro anonimo proveniente da una qualsiasi città del mondo. Fortunatamente nel corso degli anni sono nati degli strumenti che hanno sempre di più permesso l'approfondimento e la divulgazione di queste pratiche contrastando il fenomeno dell'esibizione superficiale dei social: veri e propri archivi digitali che cresceranno nel tempo in grado di fornire una conoscenza e una riflessione più dettagliata. .

\section{Entrevista a E1000}

Por Jordi Pallarès

Es un artista urbano ubicado en Madrid que combina sus intervenciones en el espacio público con exhibiciones en galerías y centros culturales. (Correo electrónico el 22-8-19) https://www.instagram.com/e1000 / [consulta 4-11-2019]]

Se habla mucho ahora de museos de Arte Urbano, ¿qué piensas sobre este concepto?

Creo que a veces nos enredamos en el concepto porque necesitamos etiquetar las cosas de forma distinta continuamente para sentirnos seguros y conocedores, cuando lo importante es que nos entendamos. Creo que pueden existir museos con trabajos de artistas que desarrollen su trabajo en la calle pero el $50 \%$ de la esencia del arte urbano es el entorno donde se desenvuelve. Y es imposible crearle un espacio porque ya lo tiene.

Gran parte de estos museos son de carácter privado. ¿Piensas que las instituciones públicas tienen la obligación y el reto de explicar este fenómeno desde el museo a la ciudadanía o es mejor dejarlo en su estado «urbano»? 
En mi opinión es mejor dejarlo en su estado natural aunque en ocasiones se hagan representaciones de algo que sucede en otra esfera. Una serie de condicionantes (climatología, ubicación, su parte espontánea...) hará que siempre se quede en una representación de lo que sucede en otro lugar. Creo que la parte de la documentación y estudiarlo desde el interés es una función que puede ser de carácter más institucional.

Como artista, ¿cómo crees que se debe abordar un proyecto indoor sobre una práctica artística que surge y tiene sentido en la calle? ¿Cómo hay que tratar lo efímero y la autoría en esos casos?

Esto se lleva haciendo mucho tiempo en el mundo del arte, la diferencia es que esto ha nacido para la calle pero no con la idea de ser puesto en interior, por eso creo que es imprescindible ser consecuente con el trabajo en la calle. Es importante no centrarse únicamente en la parte estética e intentar transmitir también la experiencia, que para mi es uno de los pilares de este movimiento. Están por un lado en entorno, que es el punto de partida, por otro lado la experiencia de la ejecución y de la recepción del espectador y la pieza que es lo que se debería adaptar a los anteriores factores.

¿Cuál es tu opinión acerca de la «la ciudad como museo»con respecto al Arte Urbano? ¿Cuál podría ser el impacto de este tipo de "museos" en la propia ciudad y en la vida de quienes la habitan? ¿Tiene que haber límites en las intervenciones?

La ciudad es una ciudad, un terreno de juego para quien quiera tomársela de forma lúdica o experiencia, pero no creo que sea un museo ni un lienzo blanco, es un nuevo escenario que no tiene que ver con eso, y por lo tanto necesitaría otra denominación. En mi opinión las intervenciones tienen que ser libres y de carácter ciudadano, de otra forma estamos capitalizando el espacio público al mismo nivel que la publicidad.

\title{
Entrevista a FARE ALA
}

\author{
Por Jordi Pallarès
}

Es un colectivo artístico multidisciplinar ubicado en Palermo (Italia). Según su web “nasce dall'incontro di diversi artisti accomunati dall'esigenza di creare un luogo aperto di discussione sul rapporto fra pratica artistica e dimensione sociale e politica dello spazio urbano".(Correo electrónico el 21-8-19). http://www.fareala.com/p/about-noi.html [consulta 4-11-2019]

\section{Si parla tantissimo adesso di musei di Street Art, cosa ne pensate di questo concetto?}

Pensiamo che musealizzare la street art significhi -almeno in apparenza- snaturare una pratica che nasce nello spazio urbano spostandola in uno del tutto lontano dalla strada. Lontano da ciò che per noi rimane, o deve tornare a essere, il luogo centrale del conflitto e delle lotte. Con questo non vogliamo dire che tutta la street art o l'arte in generale abbiano o debbano necessariamente avere un carattere critico o politico. Tuttavia ci sono dei casi che fanno riflettere. La street art che rimane in strada, infatti, non sempre ha questo carattere politico o critico e anzi può accadere esattamente il contrario. Oggi vediamo infatti interventi di street art realizzati in strada che aprono, aiutano, o spingono processi di gentrificazione e trasformazione dello spazio urbano in senso genuinamente capitalista. Non è un caso se spesso a certe pratiche di street art si accompagni un lessico inquietante riferito ai quartieri o alle aree urbane: è il caso dell'espressione «rigenerazione urbana», «riqualificazione» o, peggio, del termine "decoro urbano» che conducono questi interventi ad essere - in modo consapevole o meno - un «cavallo di troia» che facilita la mutazione urbana dettata dalle politiche capitaliste, securitarie e di controllo. Una piccola riflessione linguistica in tal senso: il termine rigenerazione, riferito ai quartieri dove si intende intervenire, ha come presupposto non detto che questi spazi siano «degenerati» o defunti e che dunque andrebbero in qualche modo "rigenerati" dall'arte. Ciò pensiamo che sia sufficiente per capire la posizione problematica e il giudizio che, più o meno inavvertitamente, animano certe pratiche di street art.

Gran parte di questi musei sono privati. Pensate che le istituzioni pubbliche hanno l'obbligo e la sfida di raccontare questo fenomeno a i cittadini?

Sì, pensiamo che le istituzioni pubbliche debbano raccogliere la sfida di raccontare la street art ai cittadini. Molto però dipende dalle modalità di narrazione di queste pratiche e dal rapporto tra spazio museale e spazio urbano che sottendono o attivano. Se si tratta di semplici mostre indoor di street art, come se ne vedono molte in giro, non pensiamo possano restituire allo spettatore la complessità sociale e relazionale dello spazio urbano dove nasce l'opera e della quale quest'ultima dovrebbe nutrirsi. Operazioni di questo tipo - che semplicemente spostano opere di street in uno spazio indoor - proprio per questa ragione, oltre che per la trasformazione delle opere in pezzi vendibili sul mercato, rasentano per noi il grottesco. Esperienze diverse potrebbero rappresentare delle modalità interessanti. Pensiamo a progetti istituzionali che invitano gli artisti a lavorare in strada e che, allo stesso tempo, aprono riflessioni sui problemi posti dalla restituzione nello spazio museale dell'esperienza condotta nello spazio urbano. In generale, rimane però un rischio per l'artista: quello di ritrovarsi 
«schiacciato» all'interno delle dinamiche istituzionali e di perdere parte dell'autonomia creativa.

Senza pretendere una risposta assoluta, come si può affrontare un progetto indoor di una pratica artistica che esce e ha senso in strada?

Pensiamo che sia molto difficile restituire una pratica artistica nata in strada - che non solo è decisamente site specific ma spesso anche «time specific» - allinterno di un altro spazio, esterno o interno che sia. Il risultato sarebbe sempre un pallido riflesso della complessità spaziale, temporale e relazionale che una pratica artistica urbana in generale dovrebbe attivare.

Sono passati tre anni della polemica mostra in Bologna. Come si può lavorare l'effimero e l'autoria nel spazio pubblico in un museo o centro culturale?

Crediamo che l'idea di organizzare una mostra staccando opere dai muri della città con l'intento/scusa di preservare alcuni pezzi di street art dagli effetti del tempo -peraltro su inizativa di poteri forti (e per giunta senza chiedere consenso agli artisti) come accaduto a Bologna qualche anno fa- sia un'operazione che non sapremmo definire altrimenti se non come rivoltante. Iniziative come queste, che rubano le opere di street alla strada per consegnarle al mercato, sottendono una visione della città e dell'arte - e quindi della vita - come ambiti di accumulazione privata e profitto e snaturano totalmente gli interventi degli artisti.

Cosa ne pensate di «la città come museo» con riferimento alla Street Art? Quale potrebbe essere l'impatto de questi «musei» nella città e la vita di cittadini?

Tutto dipende dalle modalità e, in questo caso, dalla maniera in cui si pensa la «città come museo». Se questo concetto si traduce in un percorso che conduce i cittadini a vedere una serie di opere (magari dal carattere decorativo o spettacolare) o deve essere uno dei tanti percorsi di consumo turistico o di intrattenimento che affollano le nostre città, è inutile dire che ai nostri occhi l'impatto che si realizza è non solo poco interessante ma addirittura pericoloso.

\title{
Entrevista a SERGIO GARCÍA BAYÓN
}

\author{
Por Jordi Pallarès
}

Responsable de un proyecto surgido en 2008 en Bilbao, SC GAllery exhibe, representa y gestiona a artistas internacionales que desarrollan su trabajo en el espacio público. (Correo electrónico el 21-8-19) https://www.scgallery.es/ [consulta 4-11-2019]

Se habla mucho ahora de museos de Arte Urbano, ¿qué piensas sobre este concepto?

Los museos son espacios importantes dentro de la infraestructura de cualquier país y desde el punto de vista social. Ya sean públicos o privados, con ánimo de lucro o sin él, la finalidad de los museos es la de conservar, adquirir, investigar, transmitir información, exponer o exhibir.... El arte urbano ha protagonizado una gran aceptación global en estas dos últimas décadas, con diferentes exposiciones museísticas - Street art en la Tate Modern 2008, Art in the Streets, en el Moca de Los Angeles 2011, City as canvas en el City Museum de NY 2014, "Deambular" del artista Eltono en Artium, Henry Chaflan en el Ceart de Fuenlabrada 2019, etc-. El arte urbano necesita conservadores que posibiliten la transmisión y preservación de la historia del movimiento artístico, la evolución y la realización de nuevos proyectos.

En la última década han surgido algunos museos relacionados con este movimiento artístico (Mima Museum Bélgica, Berlín), es lógico que suceda. Ahora bien, algunos tan solo exhiben objetos de artistas que están relacionados con el movimiento urbano y para nada ofrecen ni el contexto ni las prácticas del arte urbano.

Gran parte de estos museos son de carácter privado. ¿Piensas que las instituciones públicas tienen la obligación y el reto de explicar este fenómeno desde el museo a la ciudadanía o es mejor dejarlo en su estado «urbano»?

Es cierto que la gran mayoría de los denominados museos de arte urbano son privados y la instituciones públicas en general dejan a un lado esta corriente artística. Creo que es importante que las instituciones públicas se impliquen con conocimiento, es necesario para poder acercar a la ciudadanía este fenómeno artístico. Es un debate complejo en el cual se deben adquirir una serie de bases sobre las condiciones del arte y en este país no se han dado. Ya veremos qué nos depara en un futuro próximo.

Como galerista y responsable de proyectos públicos, ¿cómo crees que se debe abordar un proyecto indoor sobre una práctica artística que surge y tiene sentido en la calle? ¿Cómo hay que tratar lo efímero y la autoría en esos casos?

En muy pocas ocasiones desde SC Gallery hemos realizado proyectos outdoor para finalmente exhibirlos dentro de la galería o museo. El arte no puede obviar su contexto, ya que le otorga todo su significado; de esta forma, el arte público no puede tampoco olvidar la arquitectura, el urbanismo, la cultura y, en definitiva, la idiosincrasia de la audiencia a la que se dirige. En este caso, desde SC Gallery junto a los artistas y 
comisarios invitados, hemos estudiado rigurosamente todas las propuestas que han acabado mostrándose en la galería o museo. Principalmente ofreciendo documentación y alguna obra, objeto, relacionada con el trabajo de calle. Son dos escenarios distintos y es bastante complejo compaginarlos en un tipo de proyecto outdoor \& indoor y no desvirtuarlo. Esta coherencia entre la obra y su entorno es esencial para conocer el contexto y su alcance.

\section{¿Cuál es tu opinión acerca del concepto «la ciudad como museo» con respecto al Arte Urbano? ¿Cuál podría ser el impacto de este tipo de «museos» en la propia ciudad y en la vida de quienes la habitan? ¿Tiene que haber límites en las intervenciones?}

Por una parte, pienso que la fórmula más contemporánea de una nueva burocracia estética ha sido concebir la totalidad de la ciudad como un museo al aire libre, en coherencia con nuestra cultura del ocio. Con las diferentes intervenciones, estamos reactivando el debate en torno al Arte Público, creo que esto es muy interesante. Extendiendo su alcance y su comprensión al de las transformaciones sufridas por las propias ciudades.
Para canalizar este y otro tipo de propuestas, es necesario que exista una comprensión de la cultura como servicio público, al mismo tiempo que como patrimonio. Estas ideas de arte público, más allá de su potencial estético, exigen y adquieren la responsabilidad de repensar nuestras ciudades, nuestro tejido social, nuestras necesidades más básicas. Muros que nadie mira y de repente adquieren un valor artístico. Sin tener que visitar museos o galerías de arte, el ciudadano de a pie, tiene un contacto con el arte. Siempre me ha interesado esta idea. Democratizar el arte de algún modo. Sí que es cierto que en la última década el concepto mural está desbordando su significado y comienza a ser invasivo y utilizado como herramienta para la turistificación de una ciudad o barrio. Creo que debe de existir una especie de gabinete (arquitectos, urbanistas, artista, críticos de arte, etc) que valore el impacto de los grandes murales y se actúe con valores y respeto hace el entorno, vecin@s, etc. El arte es también un servicio público, además de una industria y un objeto de colección o museizado. No debemos olvidarlo. Por ello las intervenciones murales, instalaciones, performances, etc. deben de estar en relación con el espacio público y formar parte de la urbe.

\title{
Entrevista a JAUME GÓMEZ
}

\author{
Por Jordi Pallarès
}

Es investigador y editor especializado en subculturas y cultura de masas. Es también el actual presidente de INDAGUE, Asociación Española de Investigadores y Difusores de Graffiti y Arte Urbano. (Correo electrónico el 22-7-19). https://indagueblog.wordpress. com/ [consulta 4-11-2019]

\section{Es parla tantíssim ara de museus d'art urbà, què en penses sobre aquest concepte?}

Els museus d'Art urbà, com a concepte de Museu són un nou fenomen que és fruit de l'assoliment cultural i maduració estètica i conceptual de dos fenòmens annexes: graffiti i art urbà. El desenvolupament dels projectes de museus d'art urbà en l'actualitat naixen impulsats gairebé per dos fronts diferents: per aquells que ja gestionen galeries o bé impulsen iniciatives de festivals i tours de graffiti i art urbà; o des de la base d'aquests moviments.

En el concepte és clau la mirada més enllà del carrer desenvolupada des de finals dels anys setanta pels primers escriptors de graffiti i artistes urbans en generar obra "apropiable" per a galeristes de Nova York com Sidney Janis Gallery i Razor Gallery o per europeus com Yaki Kornblit a Ámsterdam i la Medusa Gallery de Roma a meitat dels anys 80. Més enllà de poderoses col-leccions generades en aquests anys com la de Sam Esses a Nova York, el primer intent de crear un museu com a tal va ocórrer el 1989 quan I' artista Martin Wong va crear un espai únic a un àtic de l'East Village que va denominar "«Museum of American Graffiti" amb obra d'escriptors de graffiti com Dondi, Sharp, Lee Quiñones i artistes urbans com Keith Haring. Al 1994, aquesta col•lecció va ser donada al Museum of City of New York on es va fer una sala per a aquest «Museum of American Graffiti». Per tant, des del 1994 aquesta idea de museu "d'art urbà". Dead Drops. Intervención de Aram Bartholl. Palma, 2010. Foto del autor. públic ja existeix.

Amb l'expansió global del fenomen, i després del desastre de les galeries en venta i promoció de graffiti i art urbà apropiable entre 1986 i l' any 2000, en l'última dècada s'ha anat generant un gran èxit cultural d'aquests llenguatges i s'ha creat un nou pùblic. Això ha activat tot un sistema de l'art que és pràcticament privat perquè aquests llenguatges no tenien cabuda en l'àmbit públic. De fet, ha estat impulsat per galeristes, la gran majoria pròxims a artistes urbans i escriptors de graffiti, les col-leccions dels quals han anat creixent $i$ transformant-se en museus. Un bon exemple fóra l'evolució de l'Alice Gallery en el MIMA a Brussel•les, tot i la coexistència d'ambdós espais.

Els llenguatges també han madurat. Ja no es pot parlar sols de «graffiti art» o «art urbà» apropiable en format llenç, serigrafia o instal•lacíó. De fet, el més interessant a nivell estratègic i creatiu prové d'una reacció de discursos de numerosos artistes que 
ara treballen en terrenys híbrids, seleccionant trets del graffiti i l'art urbà per generar noves idees, estratègies i llenguatges, tal com manifesta el nou concepte d'Art Intermural. En una part petita, aquesta reacció busca, d'una forma subtil, una mena «d'adaptació molesta» dins dels espais interiors o tradicionals de l'art, donant-li's però una volta àcida i crítica.

\section{Gran part d'aquests museus són privats. Creus que les institucions públiques tenen l'obligació i el repte d'explicar aquest fenomen des del museu a la ciutadania?}

Jo mateix vaig advertir i proposar el passat juny -dins de un cicle de conferències- a un responsable de l'Ajuntament de Barcelona la possibilitat de crear un museu d'Art Urbà públic i donar eixida a la que segurament será una necessitat. Però, sobretot, donant eixida al que és una gran oportunitat, donat la quantitat d'artistes que treballen els llenguatges del graffiti i l'art urbà a Barcelona i Catalunya. En la meua opinió, és una obligació lògica i natural. Hi ha més artistes que mai, més venda, més galeries, més «consum» i públic expectant d'obra, espais, venda i difussió cultural d'aquests fenòmens. Per tant, s'haurà de començar a pensar en què no es pot deixar en mans privades tota aquesta tasca cultural. $A$ més a més, està ocorrent un fenomen ben conegut en l'àmbit tradicional de l'art i és que les obres de més qualitat i valor històric estan quedant en mans privades. Els més hàbils col-leccionistes i especuladors ja fa temps, especialment a partir de 2004, que han anat treballant en la venda d'obres i, fins i tot, de lots a subhastes en cases tradicionals com Sotheby's o espais com Artprices que reflexen aquests moviments. És a dir, la tasca pública quan arribi, ja ho farà amb molts anys de retard i, per tant, sospite que més d'un museu públic acabarà nodrint-se d'obres d'aquestes col•leccions privades a preus molt cars. De fet, molts col•leccionistes van néixer també en aquest àmbit per especular. Aquests girs estan arrodonint el camí habitual de l'especulació de l'art, ara en aquests llenguatges que es venen com frescos inous, però que ja duen mig segle sacsejant els límits de la cultura popular i de l'art tradicional per les seues arrels subculturals i activistes. En definitiva, el que ocorrerà els pròxims anys amb la creació de nous museus pùblics d'Art Urbà és que s'acabarà reproduint la rèplica del sistema de l'art tradicional dins aquests àmbits, copiant les seues estratègies, patrocinadors, canals i interessos. Hi ha molts riscos i molts beneficis culturals en tota aquesta tasca.

\section{Sense pretendre una resposta absoluta, com s'hauria abordar segons el teu parer un projecte indoor d'una pràctica artística que sorgeix i té sentit al carrer? Com creus que s'haurien de treballar els conceptes d'efímer i d'autoria?}

Ja hem escrit diferents investigadors sobre aquests procesos d'integració outdoor cap a indoor. El que ocorre en aquest procés és que el graffiti i també l'art urbà pateixen una descontextualització i re-contextualització que modifica radicalment el seu discurs: en part perden el component de joc, d'experiència a l'espai urbà, perden el gest exploratori, actitudinal i el sentit alliberador o catàrtic també. Si s'ha que pagar entrades en aquests museus o galeries, aquests llenguatges perden la gratuïtat intrínseca del seu paper al carrer. Les obres a l'interior tampoc competeixen per l'espai públic, ni estan en competència amb altres accions a l'entorn i, per últim, no cotitzen com "accions" dins dels marcs de la subcultura o de les escenes d'art urbà. Per tant, són obres que passen a un nou plànol que convé treballar. Fins ara, de forma consensuada, les dos estratègies més bàsiques d'integració d'aquestes pràctiques outdoor han estat la traslació mural exterior per interior i la transformació dels llenguatges, motius i recursos en format llenç. Per a mi, aquestes estratègies ja no funcionen gaire, excepte per a les obres clàssiques dels 80 estil Futura 2000, i en alguns casos contemporanis com ara determinades obres d'artistes com Felipe Pantone. EI format llenç pareix que s'està esgotant, especialment per al llenguatge més pur del graffiti. A més, la fórmula clàssica del mural interior pareix que també. Especialment, l'art intermural està buscant fòrmules híbrides per fugir d'aquests esquemes a favor d'una gran perfomativitat tècnica i discursiva.

Sembla ser que el concepte d'efímer és clau a l'hora de treballar aquests dos llenguatges que ho són per idiosincràcia. Malgrat això, la gran part de formats en què es presenten obres de graffiti i art urbà als museus són apropiables i no especialment efímers. A més, com a peces museables, comprades, taxades i exposades en mesures de seguretat cap al gran pùblic estan projectades en una clara voluntat no efímera. Pel contrari, el caràcter efímer d'aquests llenguatges també presenta nous avantatges que els llenguatges tradicionals no tenen. Per exemple, permetre als museus tenir obra renovable i així poder programar moltes exposicions temporals en una clara dinàmica consumible d'imatges, pròpia d'aquests temps. En aquestos casos, és habitual el recurs d'intervencions en «format mural» que solen vestir tant l'interior com l'exterior dels museus, tant per a exposicions úniques d'art urbà en museus d'art contemporani com podria ser el Moca de Los Angeles en mostres com «Art on the Streets», com en renovacions contínues de murals efímers estil «Urban Nation» de Berlin.

Si jo tingués que gestionar un museu d'Art Urbà, intentaria assolir una col-lecció permanent d'obres, però seria realment complexegestionarla conservació de intervencionsmuralistes, donat que l'espai quedaria viciat per a noves exposicions. És un tema complexe de respondre, perquè a l'hora de projectar exposicions tant artistes urbans com escriptors de graffiti necessiten trencar els marcs i intervenir els murs. Per a ells i elles és clau, és innat. Per tant, tenir noves exposicions obligaria a repintar contínuament com habitualment passa a tots els museus. Per altra banda, generar una col•lecció permanent també suposaria crear un èlit d'artistes i escriptors de graffiti dins del museu. És a dir, crear un nou status fora de la subcultura, per a ells fora de la tradicional economia de prestigi de la subcultura. Aquest fenomen que ja va ocórrer a meitat dels anys 80 i que avui és global, no serà mai superat per la pròpia subcultura de base del moviment en el cas del graffiti. Per tant, a l'hora de generar un museu amb obres d'art d'escriptors de graffiti intentaria mantenir fidelitat a certes estructures. Açò sona infantil i utòpic però el respecte al caràcter i essència de la subcultura del graffiti estaria molt present al meu museu. 
Respecte al concepte d'autoria -exceptuant algunes obres més pròximes a l'artivisme- és una idea que està especialment marcada al món del graffiti i l'art urbà, en què la signatura i l'estil propi són requisits bàsics, a pesar de la potència del concepte col-laboratiu d'aquestes pràctiques. Hi ha certs creadors que estan precisament treballant en conceptes de dissolució de la firma, estil reconeixible, tècnica mural i, fins i tot, reaccionant al concepte d'autoria com a via de creació de nous discursos paral-lels a aquests llenguatges. De la mateixa manera, el pùblic i el mercat reclamen el caràcter icònic de l'autoria. Per exemple, «un verdader Banksy». Per tant, com a la resta de pràctiques artístiques, és una cosa indissoluble a aquestes pràctiques. Un tema diferent és parlar sobre els drets d'autor i reproducció d'obres al carrer. Jo mateix he sofert que obres creades per mi han estat emprades com backgrounds d'espots publicitaris de cotxes, partits polítics o usades per fotògrafs com a escenaris. Des d'un punt de vista radical, el que està al carrer és públic i, per tant, no té autoría legal. Però ocorre que, de forma comuna, especialment fotògrafs, editorials, webs i algunes empreses es lucren publicant fotografies d'obres o copiant recursos d'obres del carrer. És molt important respectar els escriptors i els artistes, i és relativament fàcil demanar-los permís per a publicar el seus continguts. És una qüestió de respecte i, és clar, no és habitual en aquells que busquen lucrar-se.

Què en penses de "la ciutat com a museu» respecte a l'Art Urbà? Quin pot arribar a ser, segons el teu parer, l'impacte d'aquests «museus» en les ciutats (i pobles) i en la vida dels ciutadans i ciutadanes?

La ciutat com a museu sona a una mena d'utopia situacionista en continu moviment, i sona atractiva però no exempta de riscos. La ciutat com a museu es un terme que s'està emprant especialment en ciutats que des del món del graffiti, i de major forma il•legal, van anar des dels anys 90 bricolant espais murals de renovació i que els darrers anys han assolit una gran activitat muralista també en el camp de l'art urbà. Els espais bricolats per aquesta pràctica no solien sobrepassar els 6 metres d'alçada, de tal manera que eren espais que parlaven als ciutadans. Podem parlar de Berlin, València o Lisboa com a bons exemples. En aquestes ciutats, i de forma natural i progressiva, els habitants han anat assimilant i convivint amb aquests fenòmens de manera que, en part, els senten com a "museus". Però, especialment i des de 2007, de forma extensa, numerosos curadors han aparegut a tot arreu gestionant immensos festivals que deixen gigantescos murals als centres urbans de tot el món i això està tenint un impacte i també una tasca d'homogenització cultural, de globalització. De forma recurrent, aquests bells murals aplasten al ciutadà, no li parlen de tu a tu, ni permeten cap poètica, ni alimenten un joc de recerca i sorpresa com l'art urbà de principi de segle. Pareix que estan més bé plantejats per a ser vistos desde l'avió o per Googlemaps que per la gent a peu de carrer, i obliguen a un gran desgast als artistes que els fan. En bona mesura, la imposició d'aquests enormes formats dins de l' art urbà ha estat per pròpia competició entre els seus participants per un millor posicionament mediàtic. A mi, aquest format propi del concepte de ciutat com a museu no em fascina realment. La ciutat museu perfecta és aquella en la que, de forma contínua, els seus habitants alliberen espais per a la pràctica del graffiti, de l'art urbà i de moltes altres pràctiques culturals col•laboratives. I en aquesta tasca d'alliberar espais, les autoritats tenen molt a dir. De fet, fins i tot poden construir espais per a la pràctica, però això ja és utòpic.

\title{
Entrevista a GREG JAGER
}

\author{
Por Jordi Pallarès
}

Es un artista urbano romano que desarrolla su trabajo a nivel internacional, combinando espacios indoor y outdoor. (Correo electrónico el 18-8-19) https://gregjager.com/ [consulta 4-11-2019]

\section{Si parla tantissimo adesso di musei di Street Art, cosa ne pensi di questo concetto?}

II «museo» nella sua formula più canonica è un'istituzione che nasce con l'obiettivo di preservare e tutelare l'arte prodotta in un determinato periodo storico, al fine di poterla tramandare. I musei hanno direttori, comitati scientifici, collezioni stabili.

L'arte urbana è al contrario un fenomeno che nasce per essere effimero, fuori da qualsiasi contesto istituzionale (altrimenti non sarebbe urbana).

Penso che esperimenti di musealizzazione (se pur effimeri), di quella cultura che noi siamo abituati a catalogare come «Urban», sono i nuovi vettori culturali spinti dalla cooperazione di energie provenienti da background comuni. Piattaforme che offrono esperienze immersive a 360 gradi, laboratori, talk, incontri con le scuole.

Ho il piacere di citare alcuni esempi:

- Monumenta Leipzig https://www.brooklynstreetart. com/2018/10/03/monumenta-large-scale-icon-celebratesthe-intelligence-of-many-in-leipzig/

- Mima, Bruxelles http://www.mimamuseum.eu/

- Artmossphere, Moscow http://2018.artmossphere.com/

Credo sia fisiologico che una sottocultura prima o poi emerga e si confronti con la società.

Gran parte di questi musei sono privati. Pensi che le istituzione pubbliche hanno l'obbligazione e I'sfida di 


\section{raccontare questo fenomeno dal museo a i cittadini o è meglio lasciarlo nel suo stato «urbano»?}

Le istituzioni devono lavorare al servizio dell'arte e hanno l'obbligo di intervenire supportando con agevolazioni sia economiche che tecniche (finanziando, aprendo spazi, agevolando la mobilità internazionale), sempre nel rispetto dei processi creativi e della curatela. Solo in questo modo si può offrire ai cittadini un contenuto genuino e puro.

Come artista, come pensi che si deve affrontare un progetto indoor di una pratica artistica che esce e ha senso in strada? Come trattare l'effimero e l'autoria?

Per cinquant'anni, i graffiti e la street art hanno sfidato le convenzioni e stimolato il dibattito sulle nostre percezioni di ciò che costituisce l'arte. Mentre il genere entra nel suo sesto decennio, ci poniamo di fronte a nuove interpretazioni di dove si trovano oggi la street art e i graffiti.

Vorrei citare Raphael Schacter (Insegnante di antropologia presso I'UCL di Londra) che introduce, puntuale come un orologgio svizzero, il concetto di «Intermural Art». Questo concetto dell'arte che attraversa le pareti è molto interessante. rappresenta un cambiamento radicale in un momento chiave in cui la strada è satura di interventi murali (legali e illegali) e questa saturazione ha completamente svuotato di significato e potenza comunicativa tutto ciò che viene prodotto in strada. Quindi, mentre molti artisti di strada e di graffiti stanno ancora sfidando le ortodosse regole della sfera pubblica, altri hanno formato un movimento di avanguardia che articola influenze di graffiti, street e arte contemporanea.

Per quanto mi riguarda, come portatore di ciò che chiamo «estetica radicale», la relazione con spazi indoor concede sicuramente maggiore possibilità dal punto di vista della sperimentazione e dello stimolo creativo. Inoltre si instaura un intimo rapporto con lo spettatore che può essere guidato in una contemplazione spirituale.

\section{Cosa ne pensi di «la città come museo» con riferimento alla Street Art? Quale potrebbe essere l'impatto de questi «musei» nella città e la vita di cittadini?}

Sicuramente l'impatto nella vita dei cittadini è forte. Queste operazioni sono una modifica del paesaggio e rappresentano un forte shock per chi vive un quartiere quotidianamente, sopratutto se queste persone non hanno un ampio bagaglio culturale. Non è un caso che la "musealizzazione" avvenga sempre in quartieri con gravi problemi o con situazioni marginali. Spesso si parla di riqualificazione attraverso l'arte. Secondo me questo binomio «arte e riqualificazione» è un potente strumento di comunicazione politica. Ma non è attraverso l'arte che si risolvono problemi spesso complessi. Questi interventi artistici dovrebbero essere parte di una visione più ampia di governance del territorio. Purtroppo spesso non è così. 


\section{Investigadores de arte urbano y graffiti}

\section{Entrevista a CRAIG CASTLEMAN}

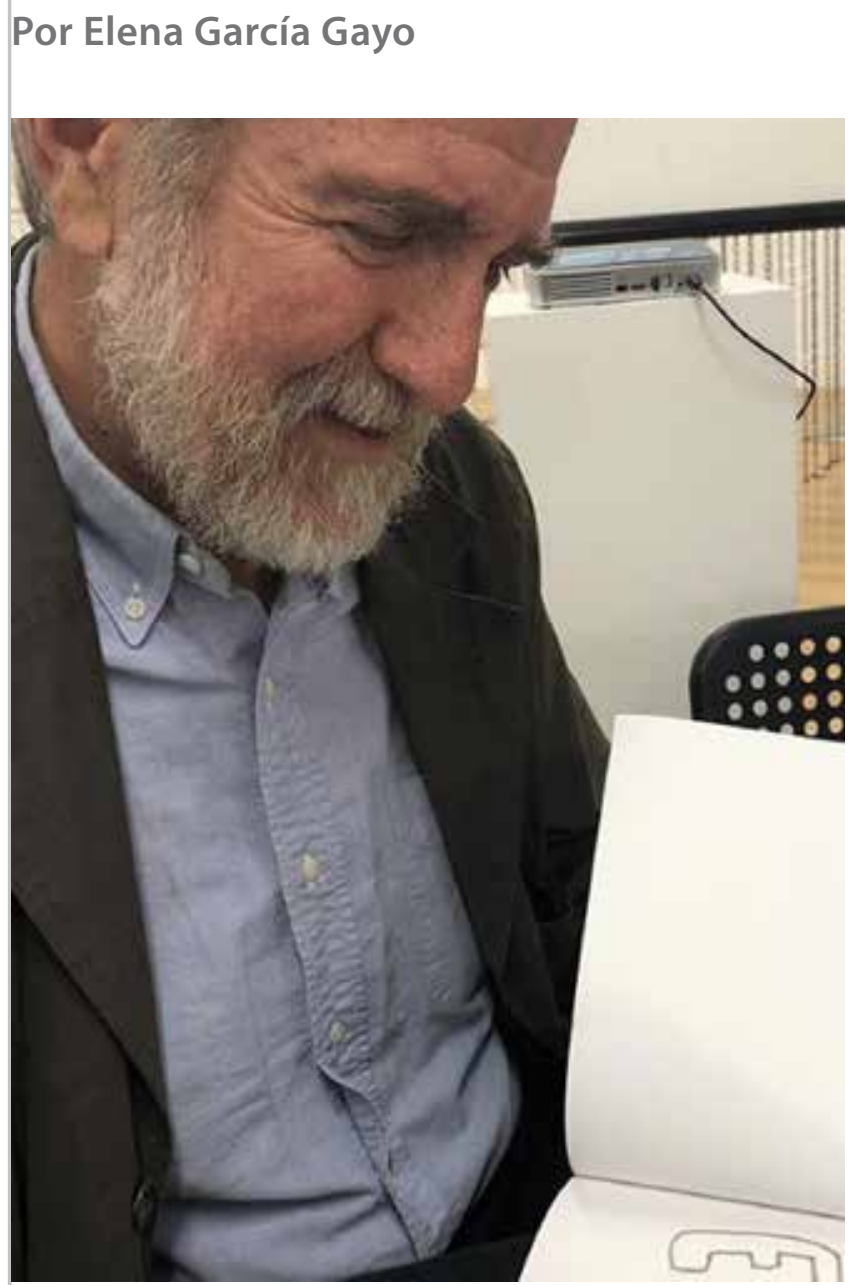

Craig Castleman (Washington DC, 1953) es Doctor en Educación por la Columbia University de Nueva York. Fue profesor en la High School of Art and Design en Midtown Manhattan, donde dio clases a una generación de estudiantes entusiasmados por el graffiti que le abrirían las puertas de un mundo singular, entre ellos figuras destacadas como Bama, Tracy 168, Phase 2, Futura 2000, Iz the Wiz o Lee. En 1979 defendió la primera tesis doctoral sobre el Subway Graffiti, posteriormente publicada en 1982 por MIT Press bajo el título de "Getting Up. Subway Graffiti in New York". A partir de 1983, después de una conferencia en el prestigioso Urban Center, Castleman se retira de la escena. Decide pasar a un segundo plano, dedicándose a su actividad de profesor de secundaria y otras actividades de carácter social. Treinta años después, en 2013, reaparece públicamente en México, con motivo de la reedición de su libro por la editorial Capitán Swing, en 2012. En 2019 ha sido invitado a España para impartir un ciclo de conferencias en Madrid, Barcelona, Valencia, Málaga y Granada, por la asociación de Investigadores y Difusores de Graffiti y Arte Urbano, INDAGUE, y de la fundación CONTORNO URBANO, con el objetivo de recuperar su figura, homenajear el legado de su obra por su valor pionero en la comprensión y difusión del Graffiti Movement, y reivindicar el papel de los investigadores dedicados a analizar y dejar testimonio de este fenómeno en diferentes partes del mundo y desde diferentes prismas disciplinares. (via INDAGUE) https://indagueblog. wordpress.com/2019/03/06/craig-castleman-tour-mayo-2019/

\section{¿Cómo fue tu acercamiento a esos primeros pulsos del graffiti?}

Enseñé inglés e inglés como segundo idioma en escuelas del centro de la ciudad durante más de cuarenta años, pero incluso en los años setenta, al comienzo de mi carrera, sabía que los estudiantes no pueden aprender a leer y escribir a menos que tengan un auténtico interés en el material que se les da. A mis alumnos de la High School of Art and Design de Manhattan les apasionaba el graffiti, por lo que se sumergieron con gran energía en el proyecto de escribir un libro, al que llamaron "Nasty Stuff', que expresaba ese entusiasmo.

Como maestro novato, recibí a los alumnos que nadie más quería, aquellos con problemas de comportamiento y aprendizaje, aunque nunca vi ninguna evidencia de ese problema en mis clases. De hecho, los estudiantes que escribieron el libro, que luego adapté como disertación doctoral y posteriormente como libro, "Getting Up", fue escrito por estudiantes que en su mayoría se me presentaron como "profundamente disléxicos" y con "trastorno del comportamiento" a punto de ser expulsados. Su entusiasmo por el proyecto, que les brindó la oportunidad de demostrar que eran artistas y estudiosos del arte, no vándalos sin conocimientos, hizo que se enorgullecieran más de sus habilidades, que se reflejaban en todo su trabajo. Cada "disléxico" resultó ser un lector y escritor entusiasta (al menos sobre el tema del graffiti) y sus "problemas de comportamiento" desaparecieron. Ninguno de mis alumnos fue expulsado, porque sabían 
que tenían que aprobar todas las materias para poder completar su libro de graffiti.

En años posteriores, escribieron libros sobre otros temas de interés para ellos, incluidos el rap, el break dance, touch dozens -traducido tocar docenas- un juego verbal que fue un precursor del rap, y muchas otras manifestaciones de la vida y la cultura urbana. En cuarenta años sólo tuve un estudiante que era verdaderamente y profundamente disléxico y el libro de ese año, sobre la vida de carnaval en la ciudad, le gustó tanto que hizo una película; siempre hay compensaciones a las discapacidades, en su caso, no podía leer pero tenía una memoria fotográfica impresionante y una gran imaginación visual, por lo que contribuyó al proyecto de ese año, el estudio de ferias y carnavales urbanos, con un video sobre la Fiesta de San Genaro. Fue maravilloso, ganó una beca para la Escuela de Cine de la Universidad de Nueva York y ha trabajado como experto de forma continua, como director y productor en largometrajes y programas de televisión. Así de importante es el poder del entusiasmo para superar obstáculos.

\section{¿Qué diferencias y similitudes hay entre el espíritu del graffiti actual y el de los 80 ?}

Creo que el espíritu, el entusiasmo, el amor al arte y la pasión por hacer el mundo más bello es idéntico a lo largo de los cincuenta años del movimiento del graffiti. La diferencia es que los materiales utilizados para crear graffiti ahora son mucho más sofisticados y permiten al artista realizar efectos con los que los escritores de los años setenta sólo podían soñar. Es increíble para mí ver qué poco han cambiado algunas cosas en medio siglo y que los escritores de graffiti son infinitamente creativos, valientes, generosos y de espíritu público como sus antepasados de hace medio siglo.

\section{Hiciste la tesis doctoral sobre el graffiti cuando empezaba a crearse como un movimiento internacional. Desde su punto de vista ¿qué medios actuales cree que le habría podido facilitar esa documentación que generó?}

Tuve la mejor de las ayudas possible. Mi tesis doctoral fue, en gran parte, escrita por escritores de graffiti, policías, trabajadores del metro y funcionarios públicos. No contenía material teórico, ni análisis, ni crítica de arte; era estrictamente descriptivo y se basaba en miles de horas de observación y entrevistas. Solo necesité que varios escritores participaran en mi defensa de disertación y mis examinadores y mentores les dieron crédito, si no un título, por sus percepciones y experiencia.

\section{El graffiti nació de un movimiento de adolescentes ¿Cuál era tu motivación?}

Me gustan los niños, su entusiasmo por la vida y el aprendizaje me parece que es intoxicante, como una droga a la que soy adicto. Aunque, gran parte de esa audacia, creatividad y emoción es suprimida por la sociedad, particularmente por las escuelas, todavía está allí, debajo de la superficie, y finalmente florece con un poco de estímulo. No hay mejor sensación que ver a un grupo de adolescentes cínicos, miserables y enojados que de repente se vuelven tan emocionados, alegres y llenos de esperanza como los niños de una guardería, si se les da la oportunidad. Por supuesto, el graffiti comenzó como un movimiento adolescente, ¿quién más habría tenido la energía y el valor para enfrentarse al sistema de metro de la ciudad de Nueva York a pesar de los arrestos, las palizas, las amenazas y la amarga oposición, sin lograr ser doblegado? ¿Y todo por la idea de convertir feos trenes en hermosos y llamativos vagones?

\section{¿Crees que el graffiti se debe analizar desde la política, cuestionando la propiedad privada?}

La política del graffiti siempre ha sido un"toma y daca". En lugar de ver este increíble arte libre como un activo, como lo hizo gran parte del público, los políticos optaron por verlo como vandalismo y crimen y una afrenta a su poder. Demasiado. Si por aquel entonces se hubieran proporcionado espacios, materiales y estímulo a los escritores en lugar de represión, multas y cárcel, hoy no habría "problema de graffiti". Después de todo, nuestros espacios públicos nos pertenecen a todos, no son las posesiones privadas de los ricos y poderosos. Si el público diera su opinión, nuestras ciudades se llenarían de hermosos murales, trenes y autobuses pintados de colores y maravillosas obras de arte en todas partes. Y creo que los escritores de graffiti respetarían la propiedad privada porque sería un desperdicio pintar murales para aquellos que no los aprecian. Además, con lugares públicos para desarrollar y demostrar su dominio, creo que muchas personas pagarían de buena gana para que su propiedad privada se hiciera más bella. Podemos ver eso en la calle 125, donde Franco se ha ganado la vida durante medio siglo pintando puertas de seguridad con sus increíbles murales de la vida de Harlem y la historia afroamericana. También podemos verlo en las miles de puertas de seguridad pintadas en las ciudades españolas que dan vida a las calles aburridas e incluso hostiles después de que las tiendas hayan cerrado.

\section{¿Ahora hay un movimiento de asimilación y se utiliza el graffiti como medio para enseñar dibujo. ¿Crees que el graffiti tiene un papel importante en la integración social?}

No soy un maestro de arte, pero espero que los maestros de arte (de los cuales tenemos muy pocos en las escuelas de EE. UU., ya que el arte y la música han sido eliminados de los planes de estudios) usen el graffiti como un medio para alentar a los estudiantes a desarrollar estilos propios y únicos. Muchas de las primeras innovaciones en el arte del graffitise desarrollaron, aunque sin el consentimiento de los maestros, en las escuelas públicas de Nueva York. En la High School of Art and Design, por ejemplo, las clases de Diseño incluyeron el estudio de técnicas con aerógrafo, que se aplicaron directamente al uso de pintura en aerosol del graffiti. La combinación de colores, goteos controlados, esquemas y otras técnicas se pusieron a prueba en clases de arte antes de que aparecieran en los trenes. Estoy encantado y francamente asombrado al ver que el movimiento que comenzó en los subterráneos de la ciudad de Nueva York ha persistido y florecido internacionalmente. 
Realmente me gusta el término "integración social", porque ese fue precisamente el motivo que subyace de los esfuerzos de los primeros escritores. Estaban desesperados por escapar de los guetos, pobres, de clase media e incluso de los ricos, donde se encontraron atrapados, y con esta vía de escape pudieron viajar y conocer a otros artistas de la ciudad. Era la primera vez que los adolescentes en Nueva York lograban convertirse en verdaderos cosmopolitas; ir a todas partes y disfrutar de la fama auténtica que se extendía más allá de sus vecindarios. Ahora vemos el mismo impulso por conectar escritos de gran tamaño, a través del trabajo y la reputación de los escritores de graffiti, que se extienden a través de los cinco continentes y por todo el mundo.

Ahora hay museos de arte urbano y en alguno se contempla la exposición de graffiti, aunque para ello son arrancados de la calle. ¿Crees que el graffiti fuera de su contexto se puede entender?

Sé muy poco acerca de las aplicaciones comerciales y del graffiti en museos, galerías o publicidad, pero espero que haya permitido a algunos escritores ganarse la vida practicando su arte. Defino el graffiti como "arte libre" y eso abarca desde un tag en un buzón hasta un Picasso o la Sagrada Familia en Barcelona, cualquier tipo de manifestación artística que el público pueda disfrutar de forma gratuita. Eso no significa que el arte producido con fines de lucro no sea tan bello o creativo o significativo, solo que, en mi definición, no es "graffiti" sino arte comercial de "estilo graffiti". Creo que es tan valioso como auténtico, significativo, cuando es producido por artistas que están sinceramente comprometidos por hacer que el mundo sea más hermoso, ya sea en un tren, en una pared o en una puerta de seguridad, en una galería o en museo. En otras palabras, si el artista entiende el graffiti y lo ama, entonces creo que otros pueden entenderlo y apreciarlo en cualquier contexto.

\section{Entónces, llevándolo al extremo ¿cree que el graffiti se puede considerar arte urbano?}

Creo que todo el arte urbano es graffiti, en cuanto a que tiene "elementos comunes", porque de una forma u otra crece a partir de la mezcla cultural, de una energía vital, y de los peligros y los muchos problemas inherentes a la vida urbana. Ya sea porque los artistas reaccionan a la vida de la ciudad pintando murales, haciendo tags, escribiendo poemas en las paredes del baño o plantillas con declaraciones políticas, si su trabajo muestra una apreciación por la diversidad y la increíble vitalidad de la vida urbana, es arte urbano $y$, si se ofrece generosamente y libremente para todos, es graffiti.

Entrevista por escrito, en inglés y español.

Fecha: Julio de 2019 


\title{
Entrevista a MARTHA COOPER
}

\author{
Por Elena García Gayo
}

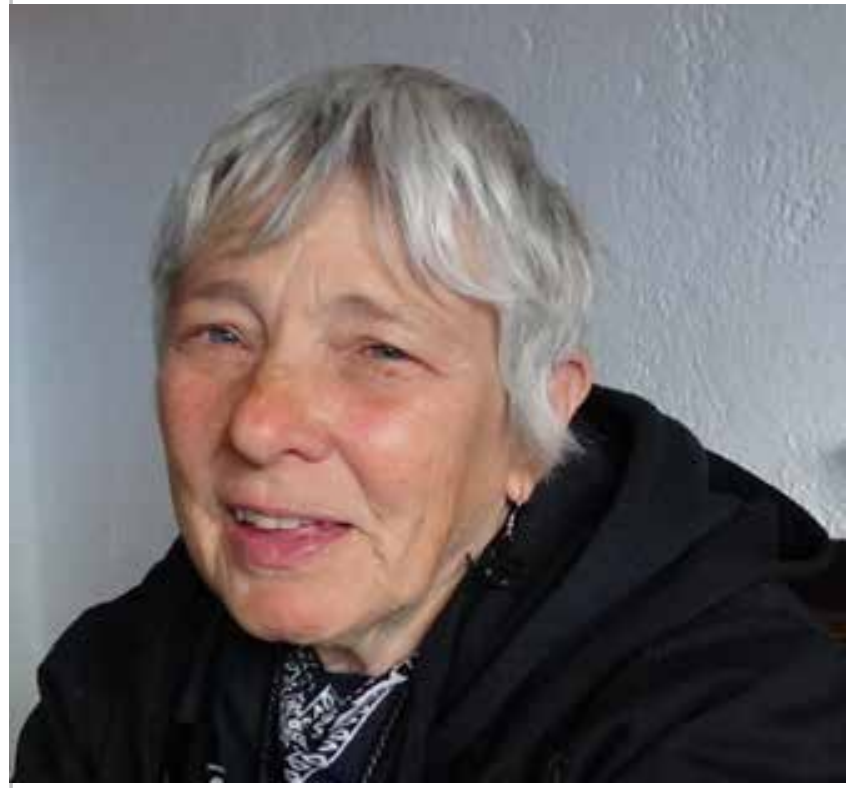

Martha Cooper nace en Baltimor en 1942 y vive en Nueva York. Licenciada en Antropología por la Universidad de Oxford trabaja para el New York Post y recorre las calles en busca de crónicas para publicar. Es así es como desde la lente de una fotógrafa antropóloga llegó a documentar y a interesarse por el mundo del graffiti y la cultura hip hop de los años 70 hasta la actualidad. "A mí lo que realmente me ha interesado siempre es la vida de la gente y su forma de expresarse". Martha es una leyenda para el graffiti y publica varios libros como The hip hop files photographs 1979-1984 o Subway art (1984) imprescindibles para conocer este mundo vital de la subcultura, tanto en su etapa inicial como en su evolución. Hoy sigue en activo, con 50 años de experiencias que la llevan a viajar por todo el mundo con su cámara.

Foto de la entrevista en Campo de Criptana, Ciudad Real, abril de 2019

\section{¿Qué diferencias y similitudes ves entre el espíritu del graffiti actual y el de los 80 ?}

Bueno, cuando los estaba fotografiando por primera vez en los 80 era algo muy underground. Una de las cosas que me parecía más interesante es que nadie entendía en absoluto qué era el graffiti, nadie entendía lo importante que era para aquellos jóvenes el hecho de escribir su apodo, simplemente veían garabatos en la pared. Especialmente en el metro, incluso, se sentían atacados, pensaban que escribían insultos y "cosas" negativas sobre la gente, cuando simplemente ponían sus apodos. Nadie lo entendía. Ahora, ya, mucha gente entiende lo que es el graffiti y lo que significa escribir tu nombre por la ciudad, lo que no quiere decir que a todo el mundo le guste. Ahora ya no es tan underground. Han pasado tres o cuatro generaciones, estamos hablando de hace cuarenta años, así que, los que eran jóvenes ya no lo son tanto y donde quiera que vayas hay revisores de metro que son ex grafiteros, hay policías que son ex grafiteros. Y la gente que está a favor o en contra de los grafitis a menudo ha crecido como grafitero y ellos lo entienden desde dentro, y obviamente eso no lo tenías antes. Antes era algo secreto, ya no lo es.

\section{¿Qué relación ves con los museos?}

Bien, yo diría que los museos de arte contemporáneo importantes han rechazado acoger los grafitis como algo que pondrían en sus museos y de hecho no se encuentran piezas de graffiti en los museos de arte moderno, y aun así se pueden encontrar grafitis increíbles. Los museos de arte moderno no quieren incluirlos dentro del arte contemporáneo. Para mí, algunos, son más arte contemporáneo que muchas otras cosas que veo, y solo estoy hablando de letras, letras en las paredes. Hay muchas galerías en las que se pinta y muchas subastas de grafiti pintados sobre lienzos, pero para mí no son tan interesantes. Graffiti y lienzo son como dos temas incompatibles, pero eso, los lienzos es lo que se tendría que poner en un museo, a no ser que se pintara la pared..

Esto también ha cambiado mucho porque se están vendiendo grafitis, se está haciendo dinero con ello, especialmente aquellos primeros grafiteros, de los que alguno se ha hecho muy famoso. Por ejemplo Dondi, al cual fotografié y que desafortunadamente murió, vendió una única obra antigua por, creo, unos 240 mil dólares. Es increíble y eso eleva el precio también para aquellos primeros grafiteros. Esta es la mentalidad de los coleccionistas, eso no quiere decir que los primeros grafiteros fueran mejores que los actuales, pero sus precios son más altos porque fueron los pioneros. Actualmente ya hay un mercado relacionado con los grafitis.

Una de las cosas que más me gustaba del graffiti era que se hacía"arte" para los demás, no para venderlo, ¿ves la diferencia? Ahora, está ese sentimiento de que si se pinta en un lienzo se puede vender $y$, originalmente, no se pensaba así. Ellos tenían su propio arte. Solo lo hacían para sus compañeros, para otros grafiteros. Tenían sus propios criterios y decidían qué era bueno y qué no, y no podías vender un trozo que estuviera en un vagón de Metro. Ahora la gente bromea diciendo que ojalá hubieran cogido un trozo de tren para venderlo, porque el dinero está involucrado y es lo que marca la diferencia, es lo que ha cambiado. Tampoco estoy en contra de este enfoque 
porque creo que un artista necesita dinero para vivir y poder ganarse la vida como artista.

\section{¿Piensas que la fotografía continúa siendo un medio ideal para documentar el street art?}

¿Qué otro medio hay? Considero que la fotografía fija es una parte para tener un video, pero creo que el mejor enfoque es la combinación de fotografía y una publicación. Si tomas una fotografía y no la combinas con un buen archivo de piezas (...). El sistema de archivado se convierte en algo verdaderamente importante.

La documentación es una cosa y el archivado de material y publicación es otra. Quiero decir, que, una de las cosas importantes es que hay mucha información sobre el "arte en el metro" y la gente puede verla. Instagram, por ejemplo, es interesante pero quién sabe si dentro de veinte años seguirá existiendo. Puedes mirar a través del hashtag "graffiti" muchas fotos seguidas, pero eso no tiene interés. Dentro de veinte o treinta años estará superado, aunque haya habido una increíble documentación. Hay grafiteros que son muy buenos fotógrafos, porque se han convertido en buenos fotógrafos al tener que documentar sus piezas. En aquellos días yo era la única persona con una cámara y me convertí en alguien importante para ellos porque querían las fotos; porque esa era su prueba de que habían pintado un tren. No tenían su propia cámara y si la tenían era de esas de cartón pequeñas y baratas.

\section{Hace tiempo me comentaste que te hubiera gustado que se conservara un vagón de Metro de los primeros.}

$\mathrm{Si}$, reflexiono mucho sobre ello, pero ya no se puede hacer nada. Estoy trabajando, o mejor, quiero trabajar, en organizar una base de datos donde la gente consulte fotos y, quizás, sin permiso para reproducirlas, pero al menos que estén recopiladas en algún lugar. Un museo sería el sitio perfecto, para que de alguna manera se pudiera centralizar esa descarga de Instagram o dónde los artistas enviaran sus imágenes... no sé...

\section{¿Ya hay algo de esto en la biblioteca de Martha Cooper en el Urban Nation Museum de Berlín?}

Si, en Urban Nation he empezado una biblioteca y he hablado con Christian Omodeo, porque Christian me ayuda, y hemos hablado muchas veces sobre este tipo de cosas, pero verdaderamente aún no se ha empezado.

Estamos todos de acuerdo en que hay que hacer algo y somos conscientes del problema, aunque no haya una solución viable, aún. Hay miles de fotos que pueden desaparecer en un momento. Estoy trabajando con Jaime Rojo y Steven Harrington, de Brooklyn Street Art, que como sabes es un blog donde se publica diariamente sobre Street Art de todo el mundo. Quizás la solución pasaría por juntar a la gente que está preocupada por este tema y ver qué se puede hacer entre todos.

\section{¿No sería posible hacer esto en el Urban Nation?}

En el Urban Nation no están mis negativos todavía, porque ellos no tienen medios para almacenarlos como se debería. Todavía no. Ahora mismo estoy recopilando material impreso, todo tipo de publicaciones, libros, ensayos que la gente ha escrito, incluso, en formato electrónico, para intentar tener una base de datos interesante, porque la gente me escribe diciendo que ha escrito artículos y hay muchos académicos que están escribiendo trabajos serios sobre graffiti y street art y me gustaría que todo eso entrara en la biblioteca, pero ¿dónde poner todo ese material físicamente? No lo sé. ¿Y las diapositivas y los negativos? No lo sé aún, porque no todo está digitalizado.

Falla la financiación. Y que no todas las fotos son buenas, ¿entiendes? Por ejemplo, Roger Gastman, que ha comisariado la exposición Beyond the Streets en Los Ángeles y en Nueva York, en junio de este año, me comentó "quiero publicar un libro" y yo pondría el material fotográfico "con fotos que no has publicado antes" me dijo, y pensé que no me quedarían fotos muy buenas sin publicar, porque siempre repaso todas mis fotografías y selecciono las que para mí son buenas "como fotografías". Así que, él buscó entre mi material, entre todas las cajas y diapositivas que tengo. Encontró unas outtakes, que son lo que nosotros, los fotógrafos, llamamos "las imágenes de desecho", y resulta, que finalmente decidimos hacer un libro con las imágenes desechadas. Así que, al menos ahora, tenemos un puñado de fotos que no habían sido publicadas.

Este libro puede servir para que alguien lo mire y encuentre la manera en la que se escribía una letra en particular, es algo que no está relacionado con la fotografía, porque lo que se encontraría son detalles que antes a lo mejor no se valoraban. A veces hay cosas interesantes en una foto de un graffiti que fotografié en los 80 y no es una buena foto. Así que, eso es lo que ha pasado, y con ese material publicó el libro y vendió muchos ejemplares sobre la historia del graffiti. Gastman es una persona que de verdad sabe de graffiti. Él es quien me presentó a Taki 183, que está considerado el primer grafitero de Nueva York.

\section{¿Cómo conociste a Henry Chalfant?}

Nos conocimos por medio de los grafiteros. En esos momentos los dos estábamos interesados en publicar un libro y decidimos hacerlo juntos sobre grafitis, sabíamos muy poco sobre el tema, por entonces, así que decidimos unirnos. Él tenía los trenes, muchos negativos de trenes, y yo el contexto, porque había hecho fotos a los trenes como fondo de las fotos. Teníamos dos tipos diferentes de fotografías por separado, así que, las unimos, porque no pensábamos que fuera interesante la documentación de forma individual.

Henry tiene todas esas fotografías digitalizadas y miles solo de trenes, y eso es fantástico. No sé dónde las está guardando. No sé qué está haciendo con ellas, pero sé que las tiene.

Desde tu punto de vista de fotógrafa, ¿notas que esa 


\section{documentación podría mejorar con algún medio complementario?}

Una de las cosas de las que se habla $-\mathrm{y}$ me encanta esta idea- es el sistema que proponen los del Insta Graffiti. Son una pareja de Brasil que tiene ese usuario en Instagram, con más de un millón de seguidores, y ellos trabajan desarrollando un sistema novedoso, por lo que he oído hablar, pero me parece que aún no han encontrado financiación. Es un sistema de realidad virtual mediante el cual mientras tu miras una pared, puedes ver todas las capas que hay en esa misma pared en diferentes fechas. Recopilan fotos de gente. En la pared se escanea el código QR con el dispositivo móvil, a través del cual se visualizan las capas que se tengan documentadas delante del muro y se ven sucesivamente. Lo quieren hacer en paredes de todo el mundo y la gente mandaría fotografías para poner, así, la siguiente capa en esa pared. Creo que es una "gran"idea. Me encantaría que se llevara a cabo, por ejemplo, en la pared de la calle Houston en Nueva York, donde se pinta cada tres meses. Es la pared que pintó Keith Haring, y sería bonito ir y ver el espectáculo de diapositivas de las diferentes paredes y que cada una pudiera tener posibilidad de comentarse. Creo que esta es una buena idea.

También se podrían utilizar esas gafas virtuales, pero no estoy muy puesta en toda esta nueva tecnología, recuérdalo. Aunque creo entender la idea y me interesa, porque si un muro se derriba sería posible recuperar lo que había antes. Si era simplemente un muro y ahora es un bloque de apartamentos, sería muy interesante ver esa transformación. Es como guardar virtualmente la memoria de un lugar. Y si eso se empezará en alguna parte, estoy segura de que la gente enviaría sus fotos. Si se conociera esta posibilidad, la gente lo buscaría, creo que los artistas especialmente dirían "ey, he pintado esa pared" y enviarían sus piezas. Me gusta esa idea.

\section{Ahora se empieza a pensar que el street art está muerto porque se ha convertido en un tipo de pintura institucional.}

Sabes, hay muchos tipos de muros: paredes conservadas, paredes autorizadas, ilegales, y la verdad, yo estoy interesada en todo tipo de paredes. Y me gusta la idea de las ilegales pero las legales como la de Houston en Nueva York -que he fotografiado muchas veces- es muy agradable de ver. Yo no diría que está muerto, ¿sabes?

Por ejemplo, este proyecto de los silos de Ciudad Real, es un proyecto permitido, no es ilegal y es muy interesante porque está trayendo el arte a pequeñas localidades. Para algunos jóvenes que viven en estos pueblos es la primera vez que ven algo así.

Hace unos días estaba con Okuda y había una escuela cruzando la calle y los chicos gritaban "¡Okuda, Okuda!", era tan hermoso oirles, desde lejos podíamos escucharles; Okuda se había convertido en un superhéroe para ellos. Y quizás alguno de ellos tiene talento artístico y era la primera vez que veía a un artista trabajando. Yo no diría que está muerto, se puede decir que ha evolucionado.
He estado en Tahití cuatro veces, y en Honolulu también. Vas a lugares en los que pensarías por ejemplo “¿por qué alguien quiere pintar una pared aquí en Tahití?" $Y$, sin embargo, allí, los turistas están apoyando el proyecto. Bien, ¿crees que un turista iría a Tahití a ver grafitis o street art, que esto puede ser una atracción turística? Es algo que me asombra, pensar que alguien pueda viajar tan lejos... Yo pensaba en Tahití, en las playas, que se supone que son inmaculadas y preciosas, y resulta que llevan cinco o seis años -de los que yo he ido cuatro- y es un proyecto muy grande, éste de Tahití.

En Wynwood, Miami, hay unas paredes conservadas que han pintado artistas como Okuda y muchos otros artistas, de un gran nivel. Sería el lugar perfecto para ver esa evolución documental que te comentaba antes, porque ese mismo sitio, exacto, lo he fotografiado durante diez años. Pues, ahí, traen a diez artistas cada año y pintan estos muros y hay multitud de gente. Es algo parecido a Disney World, es simplemente increíble, la cantidad de gente que va. Las familias van para pasar el fin de semana, usan los muros como si fueran el telón de fondo de sus fotos y ves a mucha gente, de pie, delante de la pared y haciéndose fotos. Es increíble. Y posan con sus bebés. De hecho, creo que es muy agradable, me gusta.

Swoon hizo un mural con una madre dando el pecho a su bebé y las madres venían y le daban el pecho delante del mural. Los niños crecerán y verán la foto delante del mural y si tienen alguna habilidad artística podrían sentirse estimulados por esa primera relación con el arte. Me gusta la parte interactiva de estas convocatorias y la parte de la fotografía, evidentemente, porque veo a esos niños pequeños con pequeñas cámaras fotografiando a sus padres delante de la pared. Quizá sean fotógrafos algún día. Creo que es una actividad mucho más sana que ir a Disneyland, que ir a un parque de atracciones. Hay gente que se ríe de esto, pero a mí me gusta.

\section{Ya hay alrededor de treinta museos en el mundo que se denominan "museo de street art" ¿Que crees que les falta y qué les sobra?}

He estado en unos cuantos, no sé si he estado en los treinta... Sabes, a todos les falta algo. Si los comparas, vamos a decir, por ejemplo, con el museo de Historia Natural de Nueva York, que tiene muchas salas de antropología, la mayoría de estos museos tienen exposiciones serias. Viéndolo de una forma objetiva, para mí, los museos de arte urbano son más parecidos a galerías, donde los artistas llevan obras, quizás están organizados sin pensar en lo que la propia obra significa. Comparados con otros museos, encuentro sus exposiciones "flojas".

Sabes, son exposiciones de arte pero no tienen un planteamiento museográfico y algunos de ellos creo que, de hecho, venden las obras, lo cual no me parece que sea apropiado, creo que necesitarían cuidar más el contenido y tener una colección cuidada y permanente. Muchos de 
ellos no tienen colecciones permanentes. ¿Hay treinta museos? Eso son muchos museos.

EGG: Los que se denominan a sí mismos como museos de arte urbano, si, ronda esa cifra.

M.C: A todos les falta algo. No he escuchado a nadie que haya alabado a ninguno de ellos en ninguna parte del mundo, por ser un museo con un buen despliegue. Por ejemplo, creo que el Urban Nation tiene el edificio, pero no tiene una unidad expositiva, no hay un discurso sobre la historia del grafiti y el street art. Además, creo que no tiene ninguna exposición en este momento. No he estado recientemente, así que, no lo sé...Ellos tienen salas para poner lienzos. Para mí, los lienzos, aunque pueden ser interesantes, sirven para ver ejemplos del trabajo de un determinado artista, pero, verdaderamente, no se puede llamar a un lienzo street art. Imagino que ese es el problema de estos museos, que lo que exponen del artista no es lo que hace en la calle, les falta el contexto, y especialmente para el graffiti. Cuando haces un graffiti ilegal, por la noche, por ejemplo, tienes que ser rápido porque la policía puede aparecer. Así que, es algo rápido y fresco y a veces en el lienzo es muy (...) se esfuerzan mucho en el lienzo y se pierde la espontaneidad. Es difícil crear un museo de arte callejero y mantenerlo como si fuera de la calle. ¿Qué le falta? Le falta la calle. Supongo que eso es lo que diría, si me lo preguntas.

\section{¿Crees que se llegarán a restaurar murales?}

Creo que no lo tenemos todavía claro, pero habrá conservadores en el futuro que sabrán plantearlo y hacerlo. Yo no soy parte en esto, porque no creo estar dentro de la historia del street art, no tengo una visión completa, solo conozco una pequeña parte, la que he visto $y$, como puedes ver, he olvidado muchas cosas, pero hay algunas exhibiciones increíbles por ahí. Y tienen todo tipo de medios interactivos y digitales muy modernos. Tendrán que descubrir una aplicación... pero no seré yo.

\section{El graffiti y arte urbano están totalmente asumidos por la cultura oficial...}

Si. Esto es lo que está sucediendo. El proyecto de los silos de Ciudad Real, del que hablábamos, ha llegado a cada una de esas localidades en las que hay un silo. Los alcaldes están de acuerdo con el diseño y provee a los artistas con fondos públicos. Ya lo han hecho, así que, para mí, ésto es un hecho...y algunos de estos artistas son grafiteros. En uno de los edificios hay un graffiti....déjame que lo busque...me encanta éste (muestra una foto del silo de Manzanares con las medallas del silo de San y Spok y se interesa por el contenido representado en las medallas, que se le explica. Las entrevistas de San y Spok están también en este monográfico).

¿Cuál sería, a tu modo de ver, el papel que tendrían que desempeñar las nuevas generaciones que gestionarán

\section{el fenómeno cultural del arte urbano?}

Habrá cientos de fotógrafos haciendo fotos de estos murales, eso está claro. En Instagram habrá hashtag que reúnan la información de las obras, y hace falta encontrar la manera de llevar esas fotos a archivos.

Hay que hacerlo cuanto antes, mientras todo está en nuestra memoria, porque la historia se desvanece. La documentación es muy importante, es nuestra historia. Hay que pensar cómo hacerlo y creo que es importante. Dentro de cincuenta años no quedará nada de estos murales porque no se van a mantener, no lo hará nadie, no se puede, es demasiado caro.

Quizás Montana, que donó dinero para esto de los silos, pero no lo volverán a hacer en su aniversario, dentro de otros diez años, (bromea).

La conservación, preservación, juega un papel muy importante y no hay suficiente gente que piense en eso. Están demasiado ocupados haciendo pinturas nuevas, pero no en pensar cómo preservar y mantener las que hay.

Entrevista en vídeo, 40".

Campo de Criptana, Ciudad Real. 10 de abril de 2019 Traducción: Pilar Ramiro Rueda 


\section{Entrevista a JAVIER ABARCA}

Por Elena García Gayo

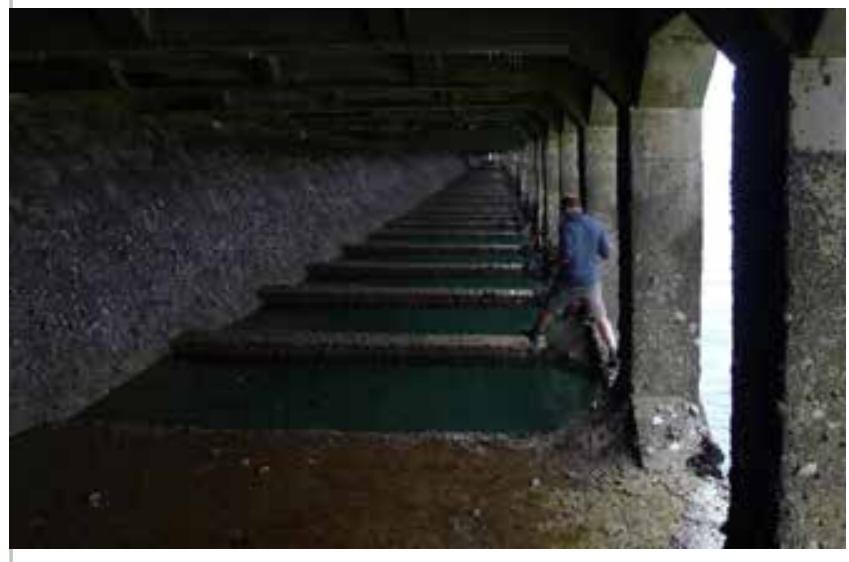

Empezaste a documentar y estudiar el arte urbano hace ya algunos años ¿Qué crees que ha cambiado a lo largo de estas dos décadas?

Ha cambiado todo, harían falta varias páginas para explicarlo. El arte urbano pequeño e independiente ha desaparecido en gran medida. A cambio tenemos una versión institucionalizada, que tiene muy poco que ver con la original, en forma de grandes murales y exposiciones.

\section{¿Cómo definirías su evolución?}

Básicamente como comercialización.

\section{¿Hay algún medio actual que facilite la documentación?}

Sin duda internet, y ahora mismo Instagram, es el medio que más está facilitando la documentación, y sobre todo la circulación de esta.

\section{¿Cuáles son las claves que mejor definen el arte urbano?}

Depende de a qué nos refiramos con ese término. Si usamos la acepción de hace diez y quince años, las claves que definen el arte urbano son el juego con el contexto, el trabajo a escala humana, la modulación de la dimensión temporal de las obras, la propagación de las obras a través del espacio y el tiempo, la exploración de los márgenes, la libertad de contenidos y la comunicación de tú a tú con el público.

¿Crees que el arte urbano se debe analizar desde una posición política?

Quienes lo analizamos podemos entenderlo en esos términos, en cualquier caso, aunque no haya contenido político explícito, porque incidir en el espacio público es por definición hacer política, más aún cuando se hace sin permiso.
Javier Abarca (Madrid 1973) es doctor en Bellas Artes y trabaja como investigador y docente freelance especializado en graffiti y arte urbano. Figura principal de la primera generación del graffiti español, impartió entre 2006 y 2015 una asignatura sobre graffiti y arte urbano en la Facultad de Bellas Artes de la Universidad Complutense de Madrid en Aranjuez. Publica desde 2008 la web Urbanario. Es fundador y director de la feria editorial Unlock y del congreso Tag Conference. Trabaja en docencia, crítica, comisariado y dirección de eventos en España y Europa.

\section{¿Qué piensas de la apropiación institucional de la etiqueta} de arte urbano?

Esa apropiación es negativa sobre todo por la confusión que crea. Es esperable que existan versiones institucionalizadas de las cosas, pero, en el caso del arte urbano, la versión original y la institucionalizada son tan radicalmente distintas que referirse a las dos con el mismo término lleva a muchos equívocos.

Ahora hay museos de arte urbano y algunas obras son arrancadas de la calle para exponerlas en ellos ¿Crees que el arte urbano fuera de su contexto se puede entender?

Una obra sacada de su contexto puede ayudar un poco a entender lo que pasó realmente, pero solo un poco.

\section{¿Es posible una didáctica institucional del arte urbano?} Como cualquier otra corriente cultural, es susceptible de ser objeto de estudio y docencia.

Llevándolo al extremo ¿qué piensas de la generalización en la que se considera el graffiti como arte urbano?

Estos términos son confusos, no existe consenso en cuanto a sus significados. Lo que está claro es que la cultura del graffiti de tradición neoyorquina tiene poco que ver con lo que se suele llamar arte urbano. A no ser que con "arte urbano" nos refiramos a cualquier forma de arte ejecutado sin permiso en la calle.

Entrevista por escrito Fecha: Agosto de 2019 


\section{(1)}

\section{Entrevista a FERNANDO FIGUEROA SAAVEDRA}

\section{Por Elena García Gayo}

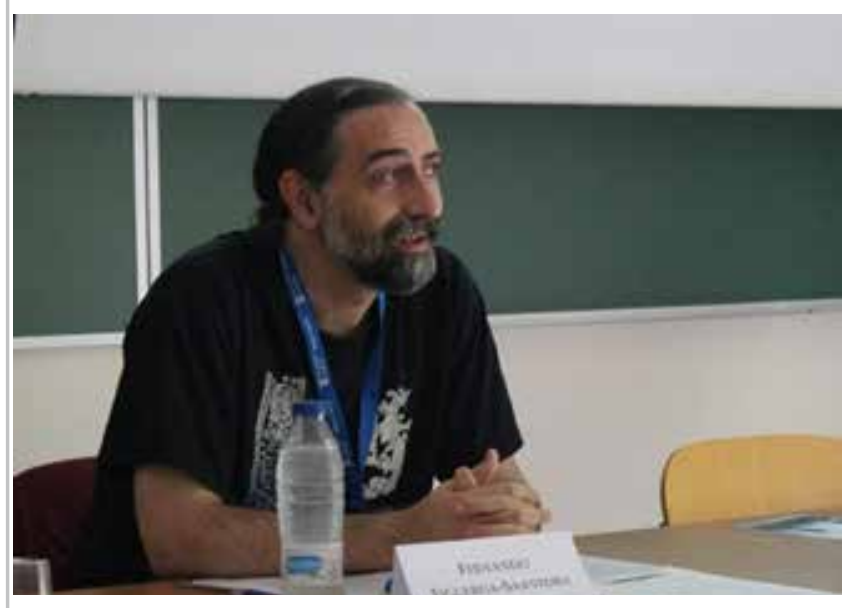

\section{Empezaste a documentar y estudiar el graffiti hace ya} algunos años ¿Crees que ha cambiado la motivación?

Ha habido en el graffiti un cambio sustancial de las finalidades o de los mecanismos para obtener un resultado, aunque el motor inicial sea el mismo: sentirse poderoso, alcanzar notoriedad $\mathrm{u}$ obtener respeto. Esto responde a cambios socioculturales que han alterado valores $y$ contravalores, y que influyen a las nuevas generaciones o a la sociedad en general (fortalecimiento de una mentalidad materialista y competitiva, absorción económica de la subcultura, intensificación espectacular de los hitos colectivos, monetización de la productividad, afán de lucro, imperancia de la exposición mediática, etc.) y a que la iniciación se produce de un modo más tardío, lo que redefine el horizonte psicoevolutivo de los participantes, alterando la vivencia como rito de paso, como práctica liberada del circuito de consumo, la concepción aventurera del autodescubrimiento de la autonomía, el apego afectivo con el territorio o la comunidad mediante hitos emocionales muy intensos, la socialización como exploración emancipada de la autoridad, etc.

Antes, ser escritor era un modo de construirse como persona por medio de la vinculación con una pandilla, la exploración del entorno urbano propio y la consciencia de pertenecer a una subcultura como modo de vida al margen o enfrentado a las reglas de la sociedad adulta, dirigido a buscar la verdad, a ser auténtico. El nuevo estado de cosas modifica el papel de la pandilla, incluso del territorio o el significado de lo auténtico, como ejes vertebrales del graffiti como subcultura. La consciencia de pertenecer a ella deja de descansar en compartir un tipo de actitudes y experiencias para dar paso al consumo de una cultura material prefijada, una senda predeterminada y previsible de acciones u hábitos y unos acontecimientos permitidos o patrocinados que te hagan sentir diferente o especial, pero no singular.
Doctor en Historia del Arte por la UCM (1999), redactor jefe de la revista Negativos (2007-2009) y actualmente vicepresidente de la asociación Indague. Publicaciones destacadas: Madrid Graffiti (2002), Graphitfragen (2006), Firmas, muros y botes (2014), El grafiti de firma (2014) o Grafiti y civilización, vol. I (2017). Co-promotor de la Plataforma Muelle (2010), la Asociación Indague (2016) o el Castleman Tour (2019).

La iniciación tardía trastoca lo que en su momento sería una invocación de libertad, por ejemplo, haciendo que se viva como una evocación, una ritualización que reconduce el espíritu revolucionario hacia un espíritu de resistencia. El aspecto de promoción profesional o de generar un negocio era antes escasa o nula, y en ningún caso era prioritaria, porque la mercantilización no era determinante en la meritocracia marginal y de raíz adolescente del graffiti, incluso era un símbolo del enemigo. Ahora es una pretensión estimada y apetecida por las nuevas generaciones que se integran a una relectura de la subcultura capitalizada y espectacularizada, y arraiga desde la convicción de que la vivencia adulta es unívoca. Hasta la introducción, iniciación y formación del graffiti ya se distancia de las calles y sus modos de interrelación directa, interfiriendo Internet o las instituciones, que acaparan esa función, mediante cursos, talleres, convocatorias, tutoriales, reservas o concesiones territoriales...

No obstante, esta absorción se logra alimentando el motor más básico: la búsqueda de la fama, aunque no es el mismo concepto de fama que existía en las sociedades preconsumistas. La notoriedad frente a una comunidad y también la búsqueda de un sentimiento de poder y un respeto social descansan ahora en la exposición a través de los medios y en la participación en la industria-mercado. Del valor de la proeza callejera y por consiguiente de la singularidad personal entre la masa urbana de quien aspira a personificar al héroe popular, se ha pasado a la acumulación cuantitativa, la irradiación mediática y el rédito económico de la espectacularidad que erige al ídolo de masas.

\section{Si tuvieras que definir los cambios del graffiti ¿los definirías como una evolución?}

Se puede considerar una evolución, pero no en términos de progreso emancipatorio o de reconocimiento de la originalidad de sus valores y su viabilidad en el rediseño 
de los modos de participación sociales. Se ha maltratado, ninguneado o manipulado su autenticidad. Los escritores se han adaptado a las circunstancias, pero con el coste de dejarse malear a conveniencia de los poderes económicos y políticos. Su fortaleza como modelo alternativo de vivencia cultural se ha visto traicionada o mistificada, plegándose al dictado de los requisitos del sistema, en gran medida por quebrarse o no existir una comprensión de su espíritu vital, una memoria histórica y hasta una conciencia histórica de su devenir.

En las primeras fases los escritores tenían fe en cambiar el juicio social y consideraban viable que se llegase a permitir grafitear libremente, sobre todo si se exploraba lo artístico y social. Era el mismo sueño de aquellos que querían normalizar y que no se ilegalizase tocar, bailar o actuar en la calle, resaltando sus valores positivos como vertebradores culturales del sentimiento de comunidad o embellecedores o humanizadores del paisaje o la vida misma. Ahora pocos piensan en fundir arte y vida, pocos creen en que descriminalizar el graffiti sea posible, y se pliegan a la idea establecida de que habrá un graffiti legal y un graffiti ilegal, de que o se ajusta uno al rol de delincuente o al de profesional artístico o social o no podrá ser. Cuando la idea inicial era normalizar el graffiti y que cualquiera pudiese pintar libremente sin pagar ni cobrar por lo que ya de por sí era una satisfacción con sus recompensas morales.

En ese orden su desarrollo puede considerarse la prueba de un fracaso propio y de un éxito de los mecanismos de absorción sistémica, al fijar como normalidad la dicotomía delito-arte. Las sucesivas muertes del graffiti, no obstante, muestran una inercia de resistencia compaginada con el deseo de diseñar otros modos de ver, hacer y sentir la cultura humana al margen de lo establecido, que siguen ahí latentes y buscando maneras de concretarse. Estamos en un proceso abierto que anuncia replanteamientos críticos permanentes.

\section{Hiciste la tesis doctoral sobre el graffiti entre 1995 y 1999. Desde tu punto de vista ¿qué medios actuales crees que te habrían podido facilitar esa documentación que generaste?}

El uso de la fotografía o el vídeo digital hubiera podido ampliar la cantidad de registros fotográficos. Internet también estaba en pañales y había muy pocos sitios de referencia para obtener información, que solía ser descriptiva y estereotipada. Ahora es más fácil y barato obtener y hacer circular información, acceder a colegas, a archivos y a informantes, pero el ritmo acelerado de Internet genera mucha morralla o una brecha entre la realidad tangible y su retrato mediático. Se trata de una distorsión que sobrepone una imagen espectacular, fragmentaria y sesgada respecto a lo visible a pie de calle. Por lo demás, todo lo que parece más fácil ahora se hacía igual antes con otros medios, quizás más "artesanos", pero no más claros y ricos en aportes.

¿Crees que el graffiti se debe analizar desde la política, cuestionando la propiedad privada o desde la competición con sus iguales?
No es tanto cuestionar la propiedad privada como establecer un debate que proponga nuevos y diversos modelos de entender la propiedad. Sus implicaciones políticas implícitas o explícitas afectan a la concepción oficial de los tipos establecidos de propiedad y los cauces establecidos de participación y co-construcción social. Este cuestionamiento suelen protagonizarlo habitualmente los adolescentes en todas las culturas, y de un modo práctico, no sólo especulativo, siendo lícita su evaluación positiva. Pero estas pautas se han ido estigmatizando como antisociales por intereses de protección de la estructura social imperante, a menos que se encaucen dentro del circuito de renovación económica.

Respecto a verlo como una competición entre iguales para destacar, de índole marginal, es lógico dentro de su esfera subcultural, al margen de su interés por ocupar el espacio o influir en el mundo establecido y redefinir la realidad que conforma. Depende mucho de la sensación de impermeabilidad del entramado cultural, de aguante del aparato social. Si la cultura se cierra a sus demandas e influjo, es imposible que suponga la invención de una aportación nueva que llegue a asumirse como costumbre o tradición por todo el cuerpo social, porque se ha logrado una apertura y ampliación de la mentalidad social.

Ambas ideas no son una disyuntiva, pueden ir de la mano. No obstante, si el graffiti reivindica una propiedad esa es la suya misma como manifestación cultural y el desarrollo del derecho de acción de los individuos sobre el espacio que habita o explora, que más bien se traduce en una ocupación del espacio-tiempo en términos de posesión o derecho de uso, no como reclamación de la condición de propietarios de un soporte o un territorio.

\section{Ahora hay un movimiento de asimilación y se utiliza el graffiti como medio para enseñar dibujo. ¿Crees que el graffiti tiene un papel importante en la integración social?}

Es llamativo que algo que te estigmatiza socialmente sea empleado como mecanismo de integración social. Cuando se hace eso es que hay una trampa en algún lado. O se ha producido una alteración que mistifica a conveniencia el proceso, para adaptarlo a lo que se necesita, o se ha estado pervirtiendo la percepción y el juicio sobre un fenómeno que no era tan malo como se pintaba.

Si apostamos por lo primero, es una prueba de su absorción utilitaria o de un juego conceptual de captación, a favor de eliminar lo engorroso políticamente, para dejar solo lo aceptable en términos de beneficio sistémico, sin perder atractivo frente a un público fascinado por el graffiti como imaginario de lo rebelde, prohibido o exclusivo. Simplemente sirve como gancho para ciertos sectores con el que se evoca lo alternativo sin serlo, y en vez de abrir mentalmente la posibilidad de articular nuevos procesos culturales lo que se alimenta y engrosa es el repertorio técnico, de motivos y de estilos gráficos dentro de un desarrollo convencional de las artes plásticas y el diseño. Viene a reforzar el sistema instituido de formación y cualificación profesional que nutre 
el mercado o el aparato de control, reafirmando la legitimidad y capacitación legitimadora del aparato político-económico.

\section{Ahora hay museos de arte urbano y en alguno de ellos se contempla el graffiti, para eso son arrancados de la calle $i$ Crees que el graffiti fuera de su contexto se puede entender?}

Si no se acompaña de un aparato explicativo adecuado que informe al espectador acerca de su contexto original, es imposible, lo más que puede hacer es reproyectar su idea preconcebida $y$, si acaso, enriquecerla con nuevas especulaciones. A menos que este tenga un contacto directo con el fenómeno en su entorno natural es raro que se solventen las distorsiones de una recreación mental distanciada de la realidad. La más grave distorsión ha sido siempre desgajarlo de sus actores, de las comunidades y de los paisajes que las han visto nacer y que, frecuentemente, son sus destinatarios, que jamás son entes estáticos, pero eso no hace más que incidir en el sentido dinámico del graffiti como proceso regenerativo. Es un acto-objeto que forma parte de un proceso en un contexto.

No obstante, hoy por hoy existe un tipo de producción pensada para su "vivencia" a través de las plataformas digitales. Eso también hay que tenerlo en cuenta.

\section{Llevándolo al extremo ¿crees que el graffiti se puede considerar arte urbano?}

Cuando alcanza una dimensión artística sí. Así se entendió cuando se pasóa producciones más elaboradas quelas simples firmas, como las masterpieces, aunque parezca algo ingenuo. Este término de arte urbano ya se aplicó tempranamente precisamente sobre esta vertiente artística del graffiti. Es un arte urbano que puede ir desde una dimensión gráfica y plástica hasta una dimensión procesual o performativa, desde el leitmotiv del nombre hasta la portavocía de una comunidad o la representación del imaginario más personal.

Entrevista por escrito.

Fecha: Agosto 2019 


\title{
Conservadores Restauradores
}

\section{Entrevista a MARIA CHATZIDAKIS}

\author{
Por Elena García Gayo
}

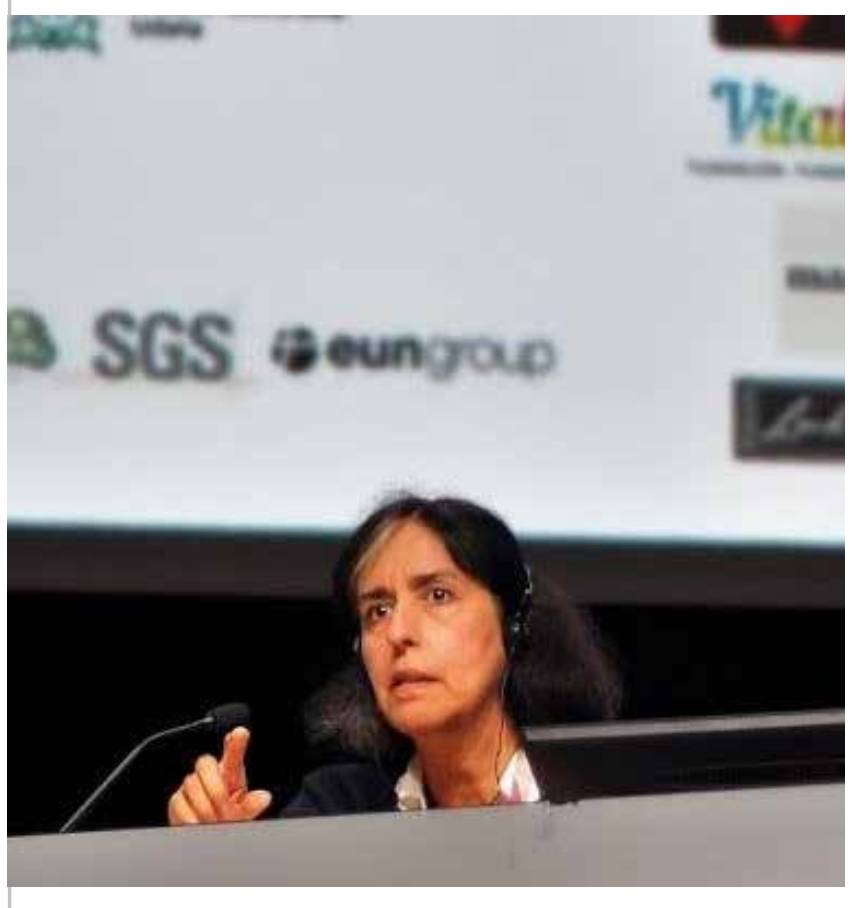

\section{Comoconservadora-restauradora, ¿cómo has percibido el surgimiento del arte urbano en tu entorno?}

El arte urbano, el graffiti y los murales públicos son formas de expresión en el entorno público que plantean un diálogo con el arte, la política y el activismo social. También ofrecen una gran oportunidad para estudiar y analizar el ciclo de vida de una obra de arte. Podemos observar los procesos de deterioro y el papel que juega el medio ambiente natural y humano sobre la obra. Antes de planificar la conservación, debemos comprender el significado de la obra de arte y su relación con la comunidad y su papel para la sociedad.

Para mí, fue la mejor forma de revisar los principios y la ética de la conservación. El diálogo entre el pasado restaurado y esta pátina contemporánea, que es el arte urbano y el graffiti, me planteó una discusión muy interesante que requería de una mayor investigación y colaboración.
Maria Chatzidakis es profesora de conservación de pinturas murales, incluyendo conservación de arte urbano, graffiti y murales públicos, en el Departamento de Conservación de Antigüedades y Obras de Arte de la Universidad de West Attica. Licenciada en Conservación de Obras de Arte por la T.E.I. de Atenas y máster en Informática Cultural y Gestión de Patrimonio. Tras treinta años de experiencia laboral en conservación de pinturas murales, pigmentos históricos, pinturas sobre paneles y objetos etnográficos, sus intereses de investigación se centran en el área de conservación de pinturas murales, murales públicos, arte urbano y graffiti, centrándose en la ética, documentación y terminología de la conservación de patrimonio desde el ámbito de la educación. Es miembro del Instituto Internacional de Conservación (CII); la Red Internacional de Conservación del Arte Contemporáneo (INCCA) y cofundadora del grupo de conservadores de arte urbano (St.A.Co.). mchatz@uniwa.gr

St.A.CO.: https://www.facebook.com/staco.street.art.conservators/

Somos muy afortunados porque tenemos la oportunidad de conocer en detalle los materiales y técnicas empleados por el artista en su trabajo, en el caso del arte urbano. Por lo tanto, es importante recopilar esta información porque nos ayudará a elegir materiales y métodos de conservación efectivos, pero también a vincular ciertos deterioros con materiales defectuosos para evitar los mismos problemas en el futuro.

Es importante que el artista esté de acuerdo con la decisión de preservar su trabajo. Además, deberíamos explicar de antemano qué es la conservación y qué pretendemos hacer. Dado que estamos tratando con arte público, obviamente el público y la comunidad son los afectados directos. Su participación es necesaria desde el principio para determinar los valores que se intentarán preservar. La participación de la comunidad es la medida preventiva más importante, ya que su interés protegerá las obras de arte. 
¿Crees que la brecha entre las diversas instituciones del arte urbano es entendida cuando la etiqueta de "arte urbano" es utilizada con objetivos políticos?

Las organizaciones e instituciones oficiales muestran incomodidad cuando tienen que decidir sobre arte urbano. Es demasiado tarde para ellos. No estoy segura de si el arte urbano necesita instituciones. Quizás las instituciones necesiten arte urbano. Por otro lado, el arte urbano es un acto político. Es el arte público el que intenta ganar espacio público y pedir un diálogo. Pero en otras ocasiones, también se puede tratar un arte decorativo que conduce a la gentrificación. Tal vez la pregunta sería, si las organizaciones oficiales pueden entender y tratar de proteger un movimiento nuevo y activo o si solo son capaces de ocuparse de obras antiguas y desaparecidas.

En tu opinión, ¿cuál debería ser el enfoque de las actividades de conservación en un entorno tan agresivo como el de la calle?

De hecho, el ambiente agresivo de la calle es un factor clave en las intervenciones de conservación. Por ello el modo de actuar es único en cada caso. En concreto existen dos posibilidades completamente opuestas, según el tiempo y las circunstancias específicas. Por un lado, cuando tenemos que realizar intervenciones de "rescate" en condiciones difíciles debido al tiempo, la ubicación y la condición, debamos actuar de manera rápida y efectiva. Tomando decisiones rápidas, y utilizando únicamente los materiales disponibles. Pero, en general, preferimos actuar con calma y bien organizados, realizando las intervenciones mínimas necesarias. Trabajando con la comunidad, explicando a los transeúntes más curiosos e incluso organizando programas educativos para explicar por qué intentamos mantener estas obras de arte efímeras. Nos interesa que la conservación sea una alternativa a ese entorno tan cambiante. Nuestras intervenciones alargan ligeramente la presencia de estas obras de arte en la calle, pero además pueden sernos de gran ayuda tanto para la comunidad como para ampliar nuestro conocimiento en ciencias y prácticas de conservación.

Creo que las autoridades públicas deberían encargarse de la documentación y el seguimiento de las obras de arte públicas en su área. Las instituciones educativas, las escuelas y otras organizaciones pueden ayudar también con esto. Teniendo en cuenta los requisitos mínimos de documentación y permitiendo que se gestionen en un entorno digital.

No es fácil considerar el arte urbano como una obra de arte con límites específicos. El arte urbano es site-specific. Por lo general, es un proyecto que evoluciona poco a poco, al que se le añaden posters, firmas, pinturas, etc. en su conjunto. Por lo tanto, existen determinados criterios y modos de actuar y deben ser específicos para cada caso concreto. público deben conservarse, ¿cómo debe llevarse a cabo? ¿Alguna consideración en cuanto a un enfoque más respetuoso?

No se lleva a cabo de la misma forma en que la conservación tradicional intenta mantener las obras de arte que han sido afectadas por el tiempo. Los procesos típicos de conservación, documentación y diagnóstico son casi los mismos, pero debemos tratar de comprender cuáles son los valores que queremos mantener. Debemos estar en contacto con los artistas e involucrar a la comunidad y al público. Es un gran problema, y se deben convocar reuniones específicas dedicadas a ello.

¿Es positivo o negativo preservar las obras creadas para la calle, ya que sus creadores suelen ser artistas muy jóvenes y su futuro en el mundo del arte no es del todo claro?

¿Y qué? Estamos tratando de mantener estos trabajos únicamente porque creemos que tiene valor para la comunidad, la sociedad o incluso para los conservadores, como estudios de caso interesantes. No estamos necesariamente buscando al próximo Basquiat.

¿Qué importancia le das al uso de las redes sociales para difundir noticias sobre las actividades de conservación de arte desarrolladas en el espacio público?

¡Es muy importante! Las redes sociales son importantes herramientas profesionales. Nos ayudan a mantenernos informados sobre nuevas obras de arte en todo el mundo, sobre artistas, materiales, proyectos y promueven la colaboración y la comunicación. Muchas discusiones y colaboraciones han tenido lugar a través de ellos, incluso la nuestra...

Creo que deberíamos aprovechar la oportunidad de colaborar y comunicarnos a través de las redes sociales. Es la única forma de mantenerse en contacto con los temas que nos interesan. Construir esta red es un paso importante para la conservación del arte público.

Entrevista por escrito Fecha: septiembre de 2019

Si consideras que algunas de las obras del espacio 


\section{Entrevista a WILL SHANK}

Por Rosa Gasol y Rosa Senserrich

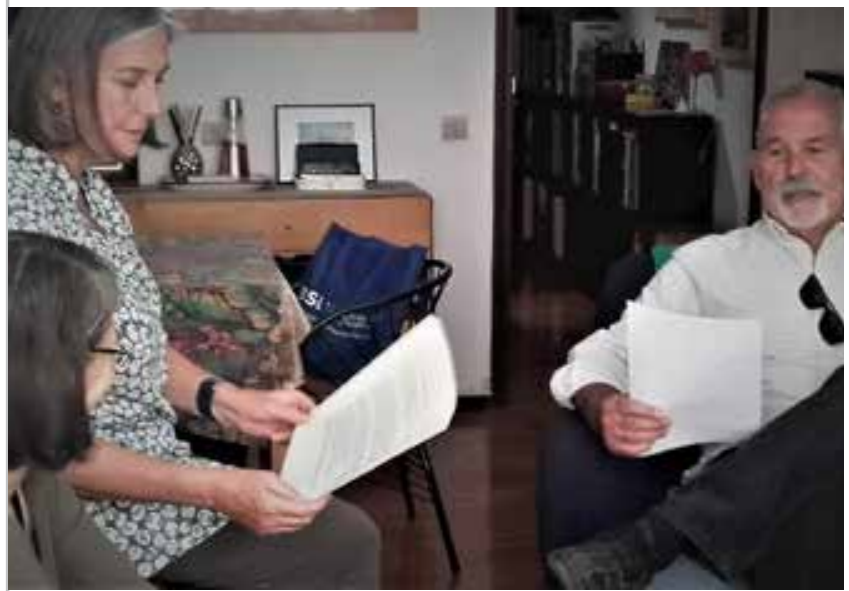

Will Shank, estudioso y conservador-restaurador de arte urbano, ha trabajado en el Museo de Arte Moderno de San Francisco en EEUU durante quince años, siendo jefe del Departamento de Conservación. A partir del año 2000 realiza su actividad profesional de manera independiente desde Barcelona.

A través del contacto con los artistas que trabajaban en la calle a finales de los años 90, empieza su interés y fascinación por el arte urbano, y su actividad profesional como conservador de museo se fue orientando hacia esta disciplina. Es co-fundador de la organización estadounidense Rescue Public Murals, con la misión de salvar murales de la comunidad principalmente de zonas deprimidas económicamente, desde la década de 1960 hasta la actualidad. La constatación de que ya no se conservan murales de los años sesenta y muy pocos de los setenta, le impulsó a luchar por la preservación de los que todavía quedaban. Ha dirigido proyectos curatoriales tanto en América como en Europa, colaborando con diversos profesionales para estudiar y preservar obras de artistas conocidos como Keith Haring, creadas en los años 80. Actualmente está estudiando una importante colección de esculturas al aire libre del artista de vanguardia franco-estadounidense Niki de Saint Phalle, fechadas entre 198090 y conservados en el exterior.

\section{La creación de la obra y el trabajo de los artistas urbanos}

Desde el punto de vista de la preservación de la obra, cree que no hay nada más importante que construir un cuerpo sólido de conocimiento del proceso creativo del artista, ya sea de obra pintada sobre lienzo o bien de los artistas contemporáneos que trabajan en la calle. Las fuentes primarias son una base importantísima para conocer de primera mano las técnicas que utilizan y las entrevistas a los artistas se configuran como un método fundamental de trabajo. Recientemente ha participado en Chicago haciendo entrevistas a artistas y en una masterclass en Porto facilitando el diálogo entre un grupo internacional de restauradores y varios muralistas portugueses.

Por lo que respecta al público, si una obra de arte urbano debe tener algún valor para la comunidad en la que se encuentra, el público debe tener un papel activo en las decisiones que se toman acerca de la ubicación y el contenido de la obra. Idealmente se le debería hacer partícipe de algún modo, ya que si las obras no son aceptadas en el barrio es más fácil que sean vandalizadas.

\section{Experiencias con técnicas y materiales usados en exteriores}

No todas las obras de arte en la calle pueden o deben ser preservadas. El ambiente es, de hecho, poco favorable para la durabilidad de las obras de arte por muchas razones. Pero si una obra de arte callejero es reconocida por las partes interesadas con un valor social, artístico, histórico o bien como valor único, se deben hacer esfuerzos para preservarla, ya sea física o virtualmente. Hay diferentes formas de preservar, como centrarse en la documentación, que equivale a proteger algo que por su naturaleza es efímero y es muy relevante en arte urbano.

Enumera algunas de sus experiencias con pinturas de exterior, algunas efectuadas con materiales no estables, reutilizados desde el ámbito de la decoración. Por ejemplo, cita varios casos de la técnica pictórica de las obras de Keith Haring sobre las que ha trabajado: en Pisa la obra Tuttomondo de 1989 es una emulsión acrílica y fue la última obra pública exterior de Haring, en la que Will Shank intervino durante 2011-12; en París, el Hôpital Necker des Enfants Malades, fue pintado en 1987 con una resina vinílica, y destaca los problemas surgidos con el color negro a causa de la temperatura. Esta obra ha sido estudiada e intervenida por colegas de Versalles y el Laboratoire de Recherche des Monuments Historiques (LRMH) entre 2011-17. Recientemente en Ámsterdam cita una obra al óleo con una resina alquídica, en estudio actualmente. 
Opiniones sobre la manera de difundir, conservar, catalogar, investigar y exponer obras pensadas para la calle

Hay diferentes formas de comisionar y exhibir el arte callejero, algunas más exitosas que otras. Considera que la creación de "Museos de arte urbano" es un oxímoron, no le gusta la idea y le parece ridícula. Las pinturas son de artistas que trabajan en la calle, pero si se crean para un museo no son "arte urbano" por naturaleza. Para él, las soluciones más exitosas para comisariar el arte callejero son el tipo de festivales temporales como el Poliniza de Valencia o la creación permanente de murales comisionados, como el Festival Avant-Garde en Tudela, que cada año crea y deja para la ciudad nuevas obras de arte. Finalmente debería hablarse de "Rutas de arte urbano" puesto que la terminología es incongruente si se usa la palabra museo en cualquier manifestación.

En términos de preservación, cada caso es diferente, dependiendo de las intenciones del artista, así como de la comprensión de los diversos interesados como la institución que encarga el trabajo, la comunidad que vive con él, etc.

Las instituciones podrían asumir el registro o catalogación de obras en el espacio público con la finalidad de proteger alguna de ellas. En la práctica, el registro lo están llevando a cabo las entidades que realizan rutas de arte urbano de forma voluntaria. Algunas obras de arte deben ser conservadas, en este sentido cita al grupo St.A.CO. en Atenas, que vigila y monitorea los murales que existen e interviene en ellos con la participación de estudiantes.

Dependiendo de cada caso, una obra de arte callejero debe ser conservada o no. Hay que tener en cuenta el tipo de valor que se le atribuye: valor histórico, valor estético, valor de novedad o valor social. Considera que se deben tomar decisiones inteligentes sobre la preservación y establecer prioridades, teniendo en cuenta que hay que seleccionar, puesto que no es posible conservarlo todo.

\section{Experiencia y opinión sobre el espacio virtual}

Recibió el Premio a la Promoción de la Conservación del Instituto Americano para la Conservación en 2010, debido a su interés en aumentar la conciencia pública sobre el trabajo a menudo oculto de los conservadores en los museos y en la esfera pública. Desde entonces, la omnipresencia de las redes sociales ha facilitado mucho la difusión de dicha información, y debemos hacer todo lo posible por explotar estos medios y compartir información con el público sobre nuestra profesión.

\section{Conservación de las obras in situ vs. traslados}

En cuanto al traslado o arranque de las obras de arte desde la calle a un ambiente interior $u$ otro no original, no está a favor de esta práctica. El arte callejero pierde el contexto cuando se reubica, y se convierte inherentemente en un objeto"precioso". Espera que la época de las exitosas macroexposiciones de arte callejero en museos tradicionales (por ejemplo, Né Dans La Rue, de la Fondation Cartier de París de 2009, Street Art, Tate Modern de Londres, 2008, Art in the Streets, MoCA Los Angeles, 2011, etc.) haya llegado a su fin a partir de la polémica exposición de Bolonia Street Art: Banksy \& Co. en 2016, que enojó tanto al muralista Blu, que, como respuesta, llegó a destruir sus propias obras en Bolonia. Cree que las exhibiciones populares de Haring y Basquiat son diferentes porque, aunque estos artistas trabajaron en la calle y en el metro, también crearon obras de arte destinadas a ser expuestas en ambientes más tradicionales.

Transcripción de la entrevista realizada Barcelona Fercha: 30 de Mayo de 2019 


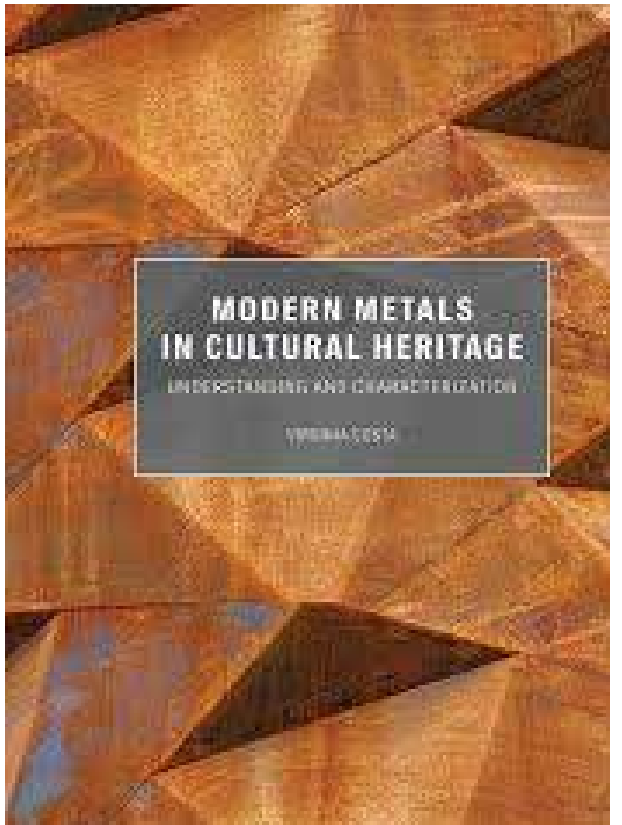

\section{Modern Metals in Cultural Heritage: Understanding and Characterization}

\author{
Virginia Costa \\ Editor: Getty Publications \\ Imprint: Getty Conservation Institute, 2019
}

ISBN: 978-1-60606-605-8

Páginas: 136

Idioma: Inglés

\begin{abstract}
A menudo la información acerca de los procesos de fabricación y degradación de metales, así como la química que rige estos materiales, son manuales técnicos de difícil lectura para aquellos profesionales que no estén familiarizados con una terminología muy académica. El libro Modern Metals in Cultural Heritage es, como bien dice en su introducción, "un puente entre la información técnica publicada y las personas a cargo del patrimonio metálico".
\end{abstract}

La autora, Virginia Costa, es una reconocida especialista en el análisis y conservación de metales que ha trabajado como asesora de multitud de instituciones por todo el mundo. En este libro resume los aspectos más relevantes de las propiedades de los metales y describe los avances técnicos en metalurgia dentro de su contexto histórico.

El uso de materiales en escultura contemporánea ha ido muy a la par con los avances tecnológicos en la historia. En el caso de los materiales metálicos, las nuevas aleaciones diseñadas para automoción, construcción, ingeniería civil o aeroespacial, han servido de base a los artistas para su proceso de creación y la investigación en nuevos materiales en el arte. La salvaguarda de estas obras comienza a estar en riesgo, y en muchos casos el riesgo aumentará con el paso de los años. Comprender el comportamiento de estos materiales es un paso esencial para su correcta conservación; en este aspecto, este libro proporciona información química y metalúrgica para el entendimiento de los procesos de degradación de los metales más utilizados en arte contemporáneo.
El libro se divide en tres partes que a su vez constan de varios capítulos. En la primera parte se hace una revisión de las propiedades químicas del enlace metálico y sus características microestructurales. Por medio de gran cantidad de ilustraciones, describe de forma amena y didáctica las propiedades mecánicas de los metales y los procesos de corrosión. La segunda parte del libro se centra en las aleaciones más utilizadas en arte contemporáneo: aleaciones de aluminio, cobre, titanio, zinc, y hierro (aceros inoxidables y aceros patinables). Describe de manera muy técnica y muy asequible los procesos de fabricación y corrosión, y las propiedades y aplicaciones de las distintas aleaciones. No incluye información sobre técnicas de conservación de obras contemporáneas, aunque finaliza cada sección con una breve bibliografía de intervenciones en estas obras para aquellos que quieran continuar con la lectura. La tercera parte del libro describe los distintos métodos de recubrimientos metálicos y recubrimientos de conversión. Esta última parte resulta muy interesante para todo tipo de profesionales que trabajen con metales ya que resume la información de forma clara y muy bien ilustrada, lo cual no es común en este tipo de literatura. Quizás uno de los aspectos más destacables del libro es que cada capítulo se cierra con un apartado sobre caracterización, con información de gran utilidad y que solo puede proporcionar quien ha acumulado más de cuarenta años de experiencia en el trabajo con metales.

El libro es un manual técnico sobre metalurgia que proporciona información de forma concisa y muy precisa sobre las principales características de los materiales metálicos. Los contenidos están muy bien explicados, 
con gran cantidad de ilustraciones. Su lectura no es sencilla pero sí agradecida. Muy recomendable para aquellos restauradores y conservadores que quieran adentrarse un poco más en la química de los metales y sus aleaciones.

Ana Crespo lbañez Investigadora en formación (FPI) CENIM-CSIC 


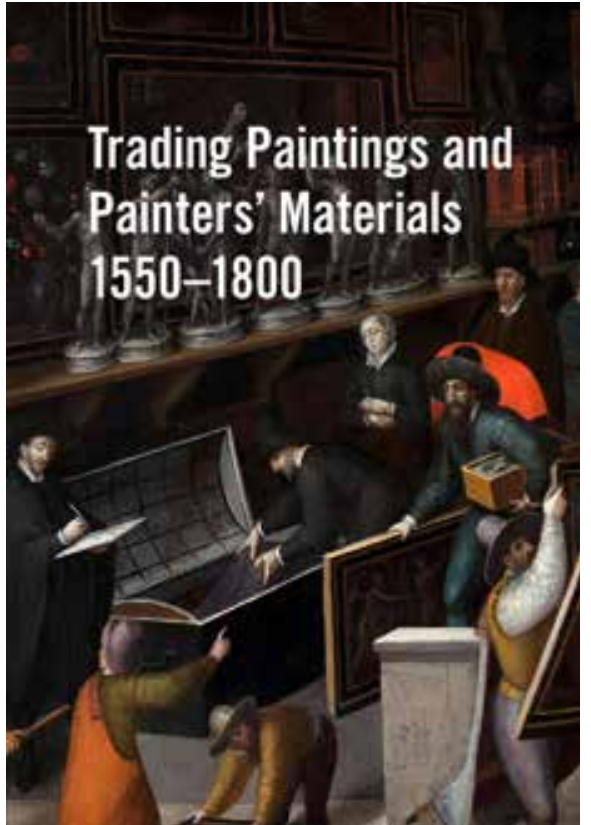

\section{Trading Paintings and Painters' Materials 1550 - 1800}

Anne Haack Christensen y Angela Jager, eds.

Londres, Archetype Publications / CATS, 2019

ISBN-9781909492714

IDimensiones: $210 \times 297 \mathrm{~mm}$

Páginas: 170

Idioma: Inglés
El Centro para Estudios Tecnológicos de Arte y Conservación (CATS) de Copenhague lleva varios años organizando unos congresos bianuales internacionales sobre investigación en técnicas artísticas y conservación, cuyas actas están siendo publicadas periódicamente por la editorial Archetype. La más reciente es esta sobre el comercio de pinturas y materiales de pintores entre 1550 y 1800 que recoge las ponencias de su cuarto y penúltimo congreso, celebrado en el Museo Nacional de Dinamarca del 21 al 22 de junio de 2018.

CATS es un centro de investigación que surge en 2011 al asociarse tres instituciones danesas, el Museo Estatal de Kunst, el Museo Nacional de Dinamarca (NMD) y la Escuela de Conservación (KADK) de la Real Academia Danesa de Bellas Artes, Arquitectura, Diseño y Conservación, con el fin de compartir y complementar las instalaciones científicas donde se realizan las investigaciones en diferentes proyectos nacionales e internacionales y se ofrecen servicios de análisis a clientes privados y públicos, además de organizar conferencias, talleres y congresos. El principal campo de interés de CATS es la historia técnica del arte, en el que se funden orientaciones interdisciplinares de la historia del arte, de la historia cultural, de las ciencias naturales y de la conservación.

El tema elegido en esté congreso de 2018 y publicado este año de 2019, el comercio y pintura y materiales pictóricos entre 1550 y 1800 , es objeto en los últimos tiempos de una atención cada vez mayor tanto en el mundo de la historia del arte como de la conservación. Las investigaciones sobre fuentes primarias que se están realizando conectan la información vinculada a los aspectos socioeconómicos del arte, a la tecnología de las obras y a su conservación, y con este enfoque se está construye una base de conocimiento fundamental para entender las redes de comunicación artística de cada época e interpretar los análisis científicos de laboratorio.

Antecedente de este congreso fue el que se celebró hace unos años en la Galería Nacional de Londres, Trade in Artists' Materials. Markets and Commerce in Europe to 1700, organizado conjuntamente con el Instituto Courtauld. Las actas se publicaron en una magnífica edición a cargo de Jo Kirby, Susie Nash y Joanna Cannon, en la que se incluyeron estudios claves para el conocimiento de este tipo de tráfico y mercadería.

El artículo de apertura de esta nueva publicación es de Jo Kirby, actualmente conservadora científica emérita de la Galería Nacional, quien introdujo el congreso de Copenhague con una conferencia magistral sobre aspectos globales del comercio de materiales artísticos en los siglos XVI al XVIII. Abre también la publicación la conferencia de Sandra van Ginhoven, investigadora del Instituto de Investigación Getty (GRI), un excelente trabajo sobre el comercio trasatlántico de los mercaderes flamencos entre Europa y los territorios americanos.

Otros artículos se centran más en el mercado danés de arte y materiales pictóricos de los siglos XVII al XVIII, algunos más generales, y otros enfocados en herramientas particulares como las esponjas, o la actividad comercial de algún artista. También se incluyen otros estudios más específicos, como por ejemplo la circulación de influencias artísticas a través del paisaje entre Alemania 
e Inglaterra, un interesante trabajo sobre el mercado de materiales en Londres entre 1600 y 1880, una ciudad que ejerció liderazgo mundial a partir del siglo XVIII en este tipo de industria y comercio, o el existente en Quebec a finales de esta centuria. Llama la atención un artículo apasionante que describe los hallazgos arqueológicos de un barco comerciante naufragado en la costa dálmata en 1583, cargado de pigmentos y otros materiales artísticos precedentes de Venecia, el mercado de materiales artísticos europeo más importante de la Edad Moderna. En las investigaciones subacuáticas han podido identificar bermellón, tierras rojas, ocres, lacas, albayalde o minio entre otros. De Italia se incluye el descubrimiento insólito de azul egipcio en una pintura del pintor Ferrarés del siglo $\mathrm{XVI}$.

La única contribución relativa al mundo hispano es la de Julia Brandt, Corinna Gramatke e Isabel Wagner sobre los estudios técnicos realizados sobre esculturas guaraníes de las Reducciones jesuíticas del Paraguay. El estudio procede de un interesante proyecto en el que la estudiosa alemana Corinna Gramatke ha volcado sus investigaciones sobre la circulación de materiales entre América y Europa en el siglo XVIII a partir de los fondos documentales jesuíticos.

Sería deseable que desde nuestro ámbito geográfico e histórico, con su enorme riqueza documental, se fomenten estudios de este tipo que amplíen el conocimiento de la circulación de materiales artísticos en las rutas comerciales y su influencia en el uso por parte de los artistas de uno y otro lado del Atlántico.

Rocío Bruquetas Galán

Museo de América. España 
www.revista@ge-iic.com

Edición digital del GEIIC 